\title{
The Savannah River Site's Groundwater Monitoring Program Second Quarter 1999 (April through June 1999)
}

by

J. B. Hutchison

Westinghouse Savannah River Company

Savannah River Site

Aiken, South Carolina 29808

AFR EIVED

Exploration Resources, Inc.

GA USA

JAN 102000

OSTI

DOE Contract No. DE-AC09-96SR18500

This paper was prepared in connection with work done under the above contract number with the U.S. Department of Energy. By acceptance of this paper, the publisher and/or recipient acknowledges the U.S.

Government's right to retain a nonexclusive, royalty-free license in and to any copyright covering this paper, along with the right to reproduce and to authorize others to reproduce all or part of the copyrighted paper. 


\section{THEENVIRONMENTAL PROTECTION DEPARTMENT ENIVIRONMENTAL MONITORING SECTIION}

\section{The Savañnah River Site's Groundwater Mónitoring Program}

\section{SEGOND QUARTER 1999 (U) (April through June 1999 )}

Westinghoüse Savannah River Company Savânnah River Site Aiken $\mathrm{SC} 29808$
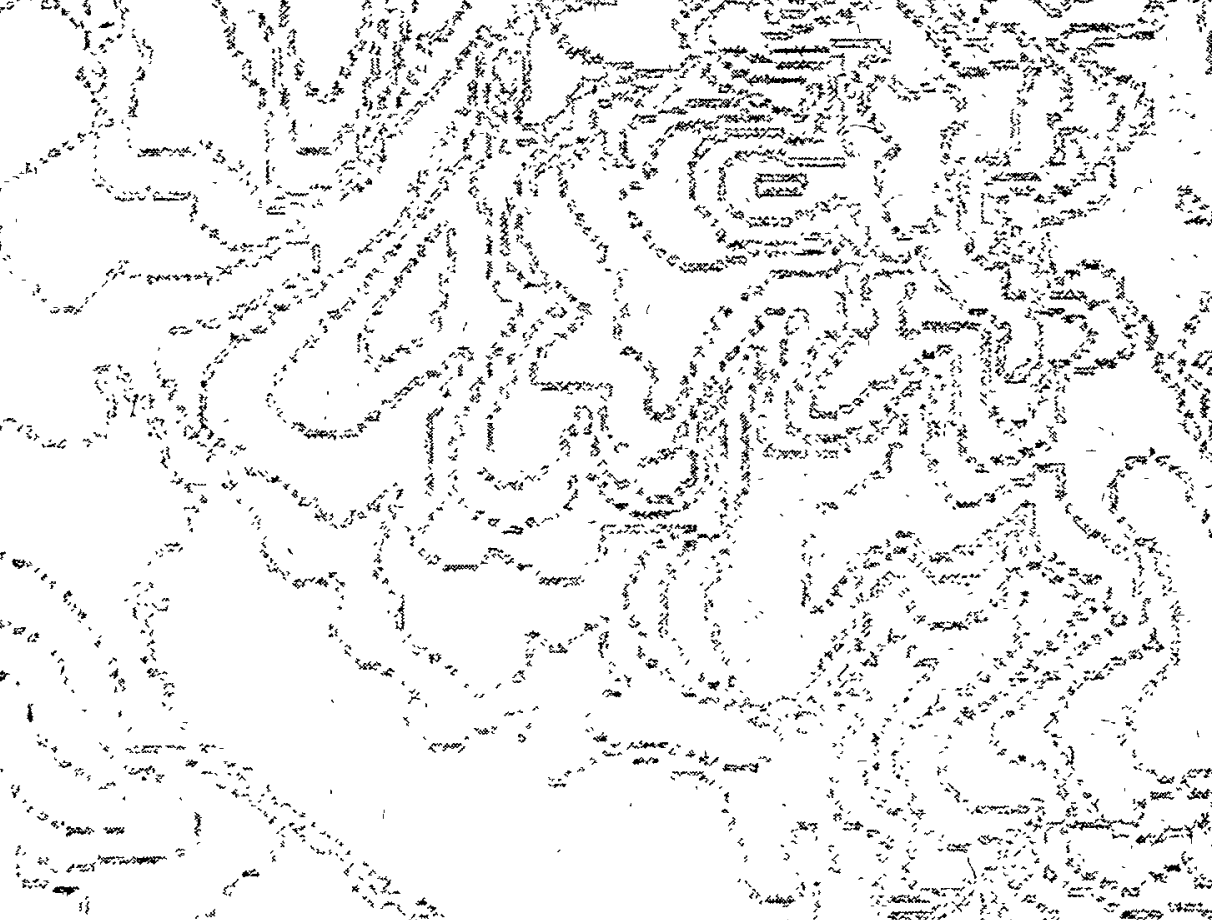

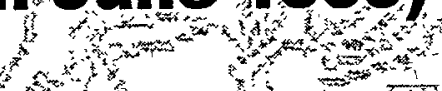
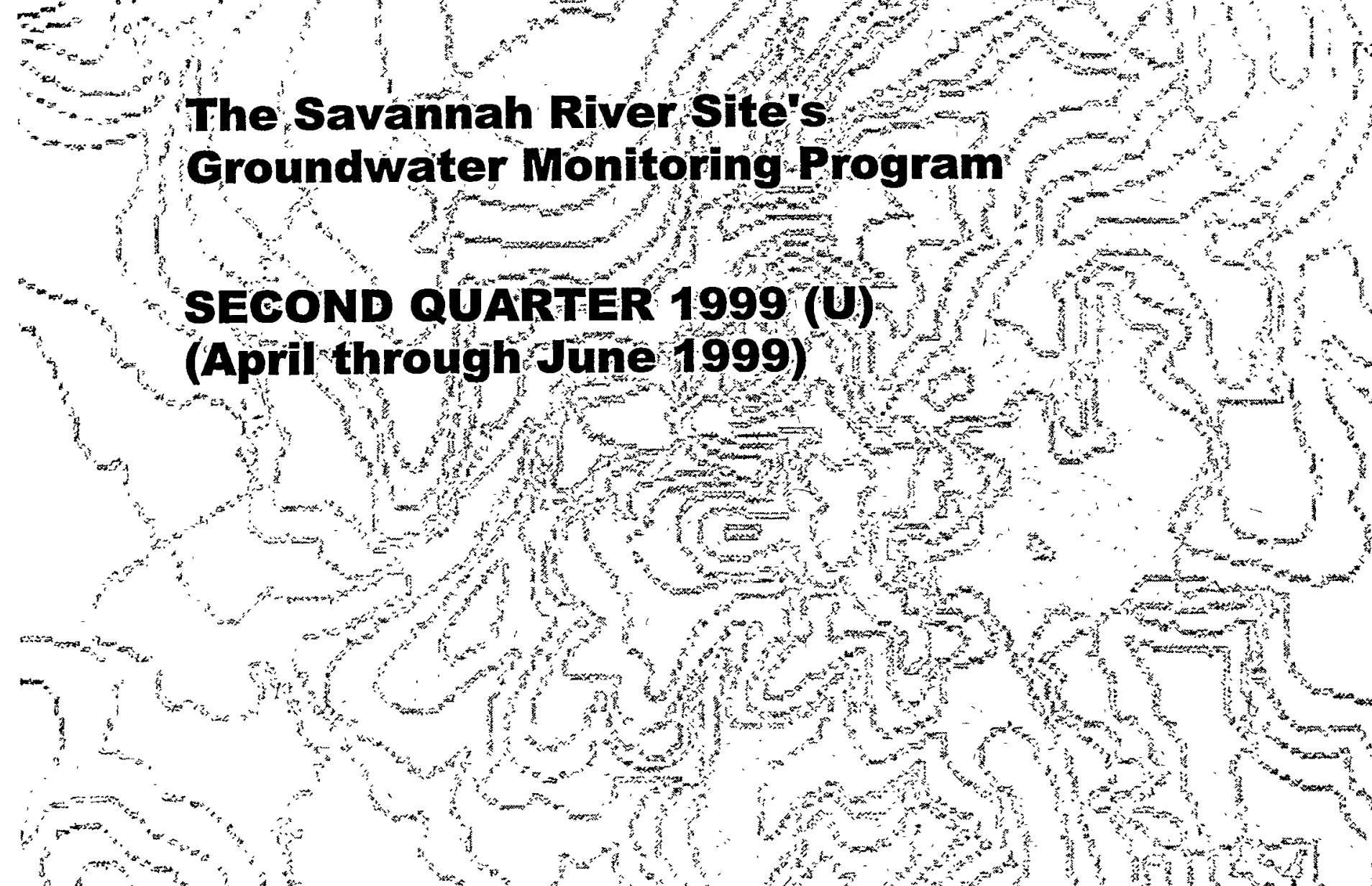


\title{
THE ENVIRONMENTAL PROTECTION DEPARTMENT ENVIRONMENTAL MONITORING SECTION
}

\author{
The Savannah River Site's \\ Groundwater Monitoring Program
}

\section{SECOND QUARTER 1999 (U) (April through June 1999)}

\author{
Environmental Protection Department \\ Westinghouse Savannah River Company \\ Aiken, SC \\ and \\ Exploration Resources, Inc. \\ Athens, GA \\ Reviewed and approved by . \\ Jay Hutchison \\ EPD/EMS Groundwater Coordinator \\ Cover graphics supplied by R.A. Hiergesell \\ Savannah River Technology Center \\ Environmental Sciences Section \\ Publication Date: November 1999 \\ Westinghouse Savannah River Company \\ Savannah River Site \\ Aiken, SC 29808
}

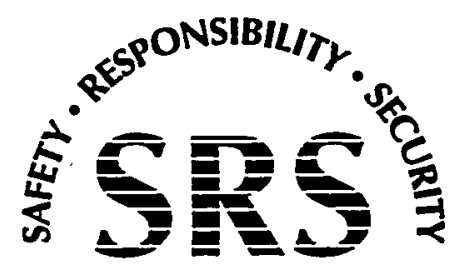

SAVANNAH RIVER SITE

Prepared for the U.S. Department of Energy under Contract No. AB60294N 


\section{This Quarter at a Glance ...}

Executive Summany table of all analytes detected at or above Flag 2 criteria

Flagging Criteria - standards for flagging results

Sample Scheduling-description of the sampling schedule

Fiold Notes-comments from the field-data books

Analytical Data Review-discrepancies in each laboratory's analytical data; laboratory-specific methods and estimated quantitation limits

Quality Control Samples - discussion of the quality of the analytical data in terms of precision, accuracy, representativeness, comparability, and completeness

Site Index - table of the well series and their site locations; also discusses the history of the sites

Appendices:

A. Water-Level Data-tables listing field data obtained for hydrogeologic studies

B. Analytical Resuits-tables listing the quarter's analytical results and field data

C. Sampling Blanks Results-tables listing all analytical results for sampling blanks for the quarter

$\bullet \bullet$

The following is a key to the numbered areas of the Savannah River Site.

Site

100 Areas-Reactors

200 Areas-Separations

300 Areas - Reactor Materials

400 Area Heavy Water.

600 Areas-General

700 Area-Administration

\section{Function}

To operate and support the reactors

To separate and purify the product from fuel and target assemblies; to process waste

To fabricate new fuel and target assemblies from raw materials

To produce steam and electrical power, to process heavy water

Other (general)

To provide administrative and support services

\section{DISCLAIMER}

This report was prepared as an account of work sponsored by an agency of the United States Government. Neither the United States Government nor any agency thereof, nor any of their employees, makes any warranty, express or implied, or assumes any legal liability or responsibility for the accuracy, completeness, or usefulness of any information, apparatus, product or process disclosed, or represents that its use would not infringe privately owned rights. Reference herein to any specific commercial product, process or service by trade name, trademark, manufacturer, or otherwise does not necessarily constitute or imply its endorsement, recommendation, or favoring by the United States Government or any agency thereof. The views and opinions of authors expressed herein do not necessarily state or reflect those of the United States Government or any agency thereof.

This report has been reproduced directly from the best available copy.

Available for sale to the public, in paper, from: U.S. Department of Commerce, National Technical Information Service, 5285 Port Royal Road, Springfield, VA 22161, phone: (800) 553-6847

fax: (703) 605-6900

email: orders@ntis.fedworld.gov

online ordering: http://www.ntis.gov/ordering.htm

Available electronically at http://www.doe.gov/bridge

Available for a processing fee to U.S. Department of Energy and its contractors, in paper, from: U.S. Department of Energy, Office of Scientific and Technical Information, P.O. Box 62, Oak Ridge, TN 37831-0062, phone: (865) 576-8401

fax: (865) 576-5728

email: reports@adonis.osti.gov 


\section{DISCLAIMER}

Portions of this document may be illegible in electronic image products. Images are produced from the best available original document. 


\section{Contents}

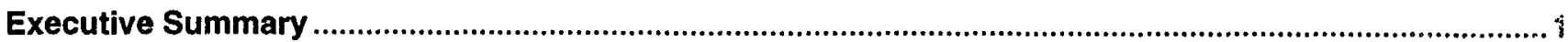

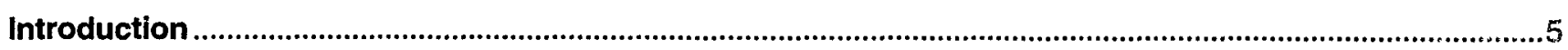

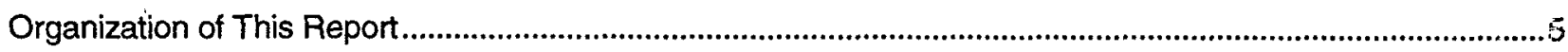

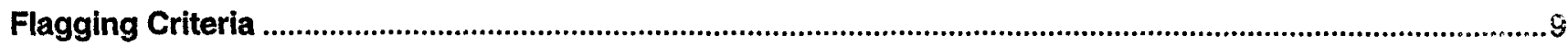

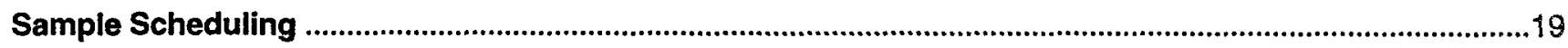

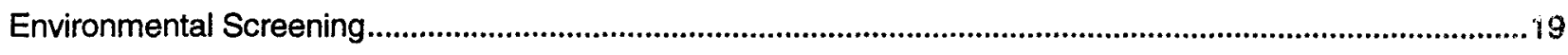

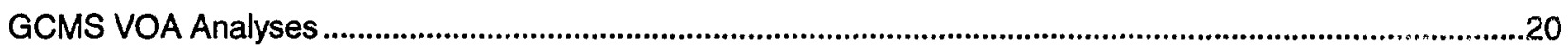

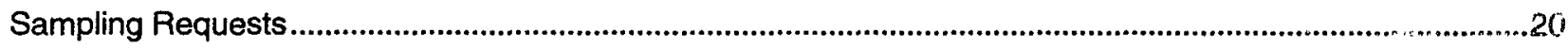

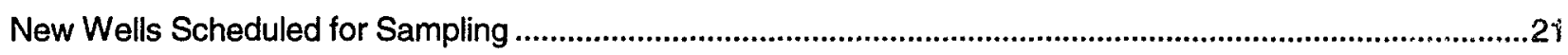

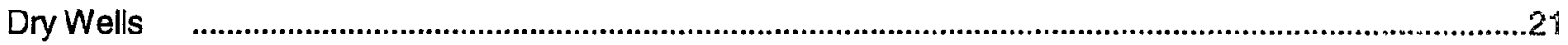

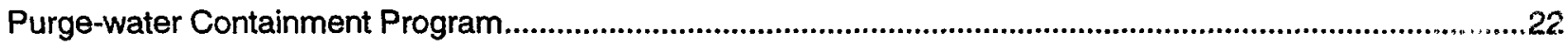

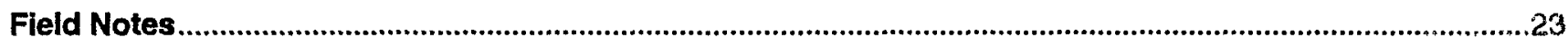

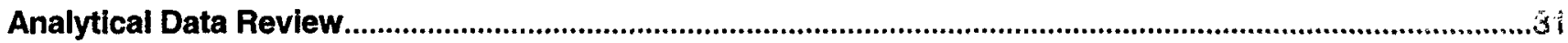

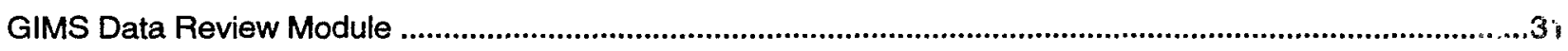

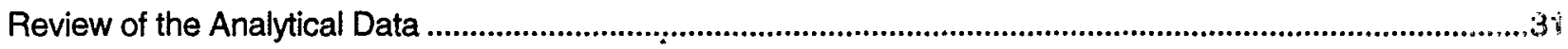

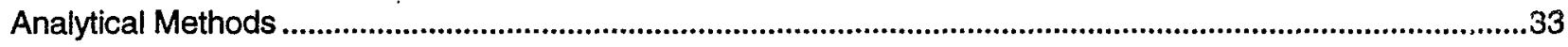

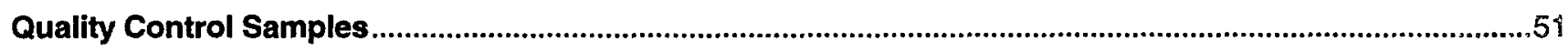

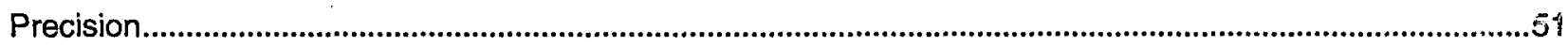

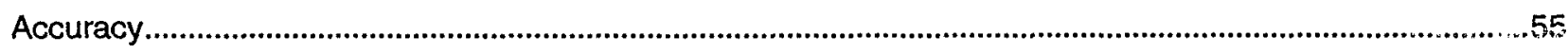

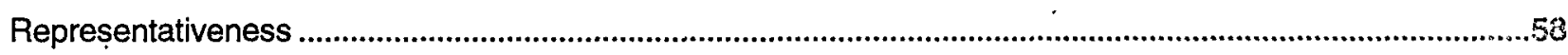

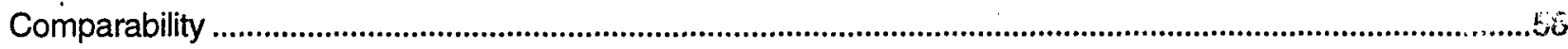

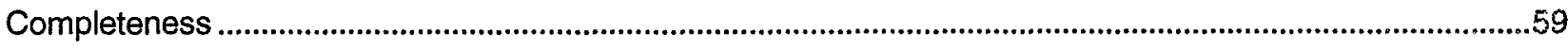

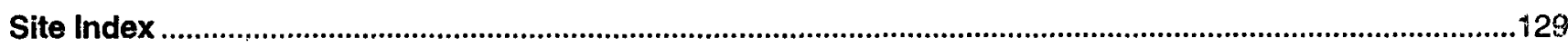

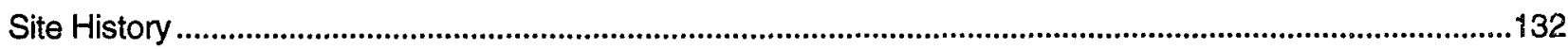

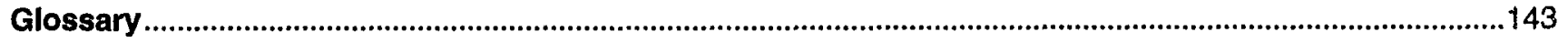


References

Appendix A. Water-Level Data

A-1

Appendix B. Analytical Results.

B-1

Appendix C. Sampling Blanks Results

C-1

Appendix D. Analytical and Sampling Blanks Results for MSB Wells

D-1 


\section{LIST OF FIGURES}

Page

Figure 1. Areas and Locations Monitored for Groundwater Quality ......................................................7

Figure 2. Separations and Waste Management Areas Monitored for Groundwater Quality .....................8

Figure 3. Three Types of Groundwater Monitoring Wellheads .................................................................23

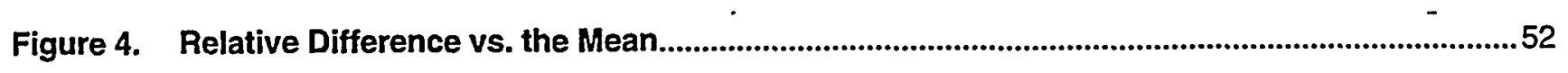

Figure 5. Relationship between $w_{i}$ and Analyte Concentration ...............................................................53 Figure 6. Effect of a Linear-Weight Function on the MRDadj...............................................................53 


\section{LIST OF TABLES}

Table 1. Analytes above Flag 2 Criteria 1

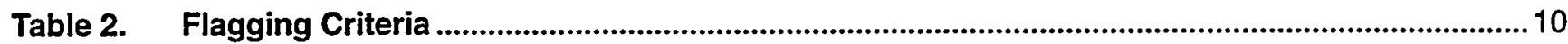

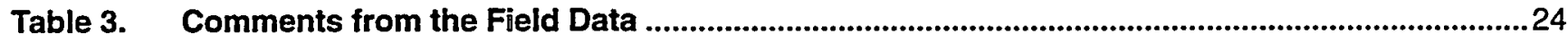

Table 4. EX Samples with High Analytical Results as Compared to Historical Data .............................34

Table 5. GE Samples with High Analytical Results as Compared to Historical Data .............................34

Table 6. GE Samples with Low Analytical Results as Compared to Historical Data.............................34

Table 7. GP Samples with High Analytical Results as Compared to Historical Data ............................34

Table 8. WA Samples with High Analytical Results as Compared to Historical Data ............................35

Table 9. TM Samples with High Analytical Results as Compared to Historical Data.............................35

Table 10. Methods and Estimated Quantitation Limits Used by EX .....................................................35

Table 11. Methods and Estimated Quantitation Limits Used by GE...................................................38

Table 12. Methods and Estimated Quantitation Limits Used by WA ..................................................43

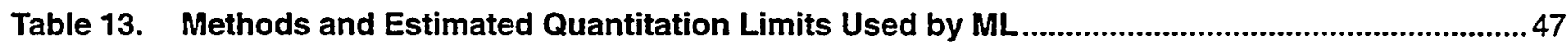

Table 14. Methods and Estimated Quantitation Limits Used by GP ...................................................48

Table 15. Methods and Estimated Quantitation Limits Used by TM .........................................................49

Table 16. Wells Providing Blind Replicate Samples and Associated Blanks .......................................59

Table 17. Analytes Not Showing Measurable Concentrations above Estimated Quantitation Limits in Any Replicated or Duplicated Samples for GE, WA, EX, and ML .................................60

Table 18. Analytes Not Showing Measurable Concentrations above Estimated Quantitation Limits in Any Replicated or Duplicated Samples for GP and TM .................................................63

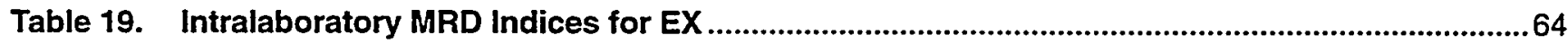

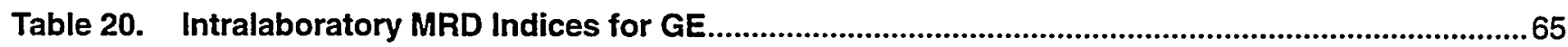

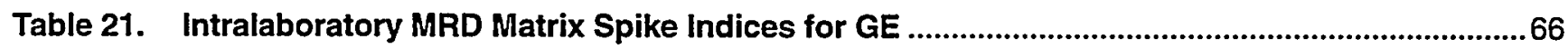

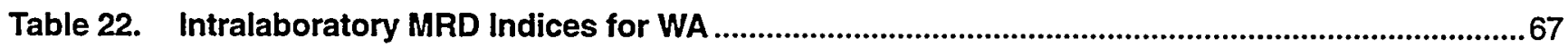

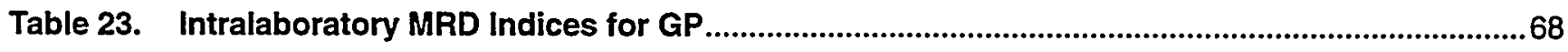

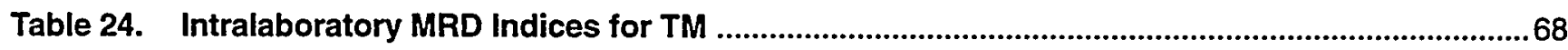

Table 25. Interiaboratory MRD and ttest Results for Analytes with at Least One Pair of Results above the RDL for EX and WA 
Table 26. Interlaboratory MRD and t-test Results for Analytes with at Least One Pair of Results above the RDL for GE and WA.

Table 27. Interlaboratory MRD and ttest Results for Analytes with at Least One Pair of Results above the RDL for GP and TM

Table 28. EX Samples and Blind Replicates Yielding Results Where One Is More Than Twice Another.

Table 29. EX Samples and Laboratory Duplicates Yielding Results Where One Is More Than Twice Another

Table 30. WA Samples and Blind Replicates Yielding Results Where One Is More Than Twice Another.

Table 31. WA Samples and Laboratory Duplicates Yielding Results Where One Is More Than Twice Another.

Table 32. GP Samples and Blind Replicates Yielding Results Where One Is More Than Twice Another

Table 33. GP Samples and Laboratory Duplicates Yielding Results Where One Is More Than Twice Another.

Table 34. TM Samples and Laboratory Duplicates Yielding Results Where One Is More Than Twice Another.

Table 35. Analytes with One Laboratory's Result Greater Than Twice the Result from the Other Laboratory between EX and WA

Table 36. Analytes with One Laboratory's Result Greater Than Twice the Result from the Other Laboratory between GE and WA.

Table 37. Analytes with One Laboratory's Result Greater Than Twice the Result from the Other Laboratory between GP and TM 72

Table 38. Quality Control Standards for Selected Analyses for EX ..........................................................73

Table 39. Quality Control Standards for Selected Analyses for GE..........................................................75

Table 40. Quality Control Standards for Selected Analyses for WA ........................................................78

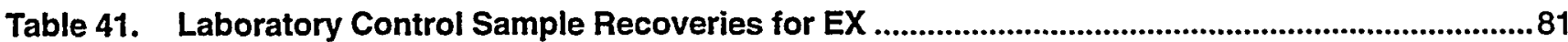

Table 42. Laboratory Control Sample Recoveries for GE .......................................................................82

Table 43. Laboratory Control Sample Recoveries for WA ............................................................................85

Table 44. Laboratory Control Sample Recoveries for ML ............................................................................87

Table 45. Laboratory Control Sample Recoveries for GP ......................................................................87

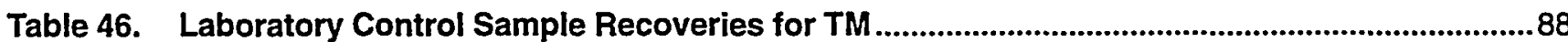

Table 47. Surrogate Recoveries for EX

\section{Contents}


Table 48. Surrogate Recoveries for GE

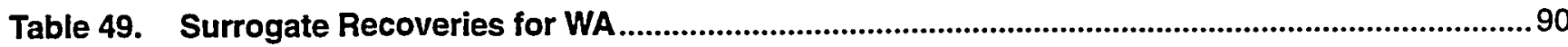

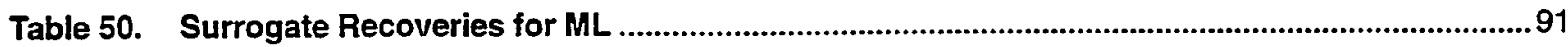

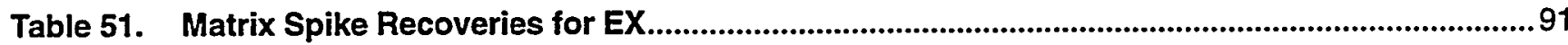

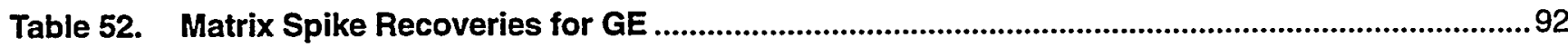

Table 53. Matrix Spike Recoveries for WA

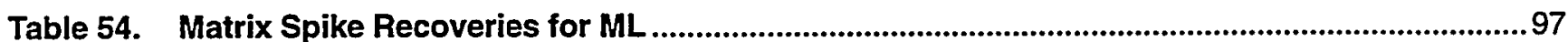

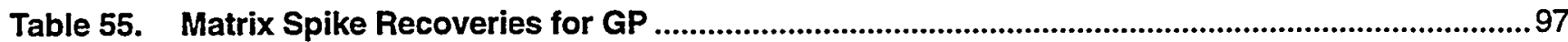

Table 56. Analytes Detected in Method Blanks for EX

Table 57. Analytes Detected in Method Blanks for GE.........................................................................101

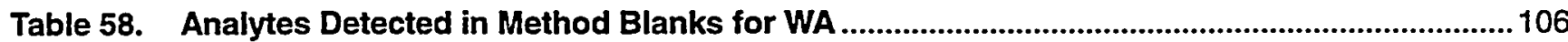

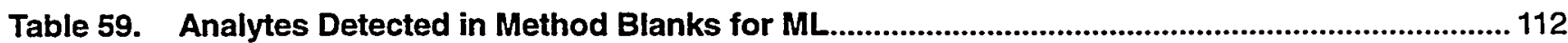

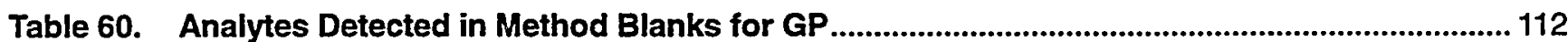

Table 61. Analytes Detected in Method Blanks for TM......................................................................114

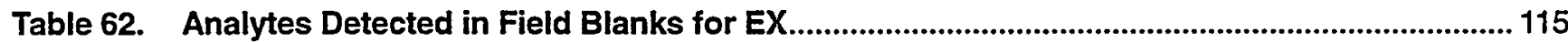

Table 63. Analytes Detected in Field Blanks for GE .......................................................................116

Table 64. Analytes Detected in Field Blanks for WA

Table 65. Analytes Detected in Field Blanks for GP ...................................................................... 122

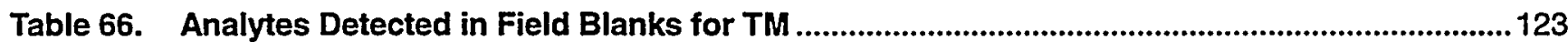

Table 67. Analytes Detected in Trip Blanks for EX

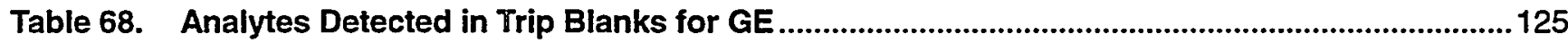

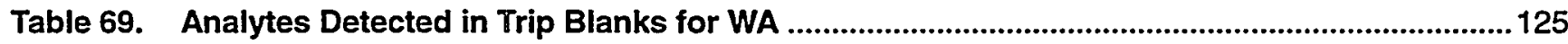

Table 70. Analytes Detected in Trip Blanks for ML

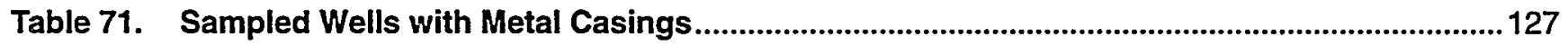

Table 72. Wells That Had Turbidity Greater Than 15 NTU..............................................................128

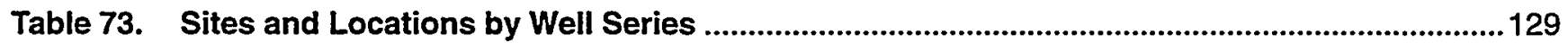




\section{Executive Summary}

The Environmental Protection Department/Environmental Monitoring Section (EPD/EMS) administers the Savannah River Site's (SRS) Groundwater Monitoring Program. During second quarter 1999, EPD/EMS conducted extensive sampling of monitoring wells.

EPD/EMS has established two sets of flagging criteria to assist in managing sample results. The flagging criteria do not define contamination levels; instead, they aid personnel in sample scheduling, data interpretation, and trend identification. Since 1991, the flagging criteria have been based on the U.S. Environmental Protection Agency (EPA) drinking water standards and on method detection limits. A detailed explanation of the flagging criteria is presented in the Flagging Criteria section of this document. Analytical results from second quarter 1999 are included in this report, which is distributed to all site custodians.

One or more analytes exceeded Flag 2 criteria during second quarter 1999 in 45 monitoring well series. Analytes exceeded the current Flag 2 criteria for the first time since 1984 in 5 of those 45 monitoring well series.

Table 1, organized alphabetically by well series, lists those well series with analytical results above Flag 2 criteria during second quarter 1999. Results from all laboratory analyses that underwent the standard verification and validation process are used to generate this table. Specific conductance and $\mathrm{pH}$ data from field measurements also are included in this table.

Table 1. Analytes above Flag 2 Criteria

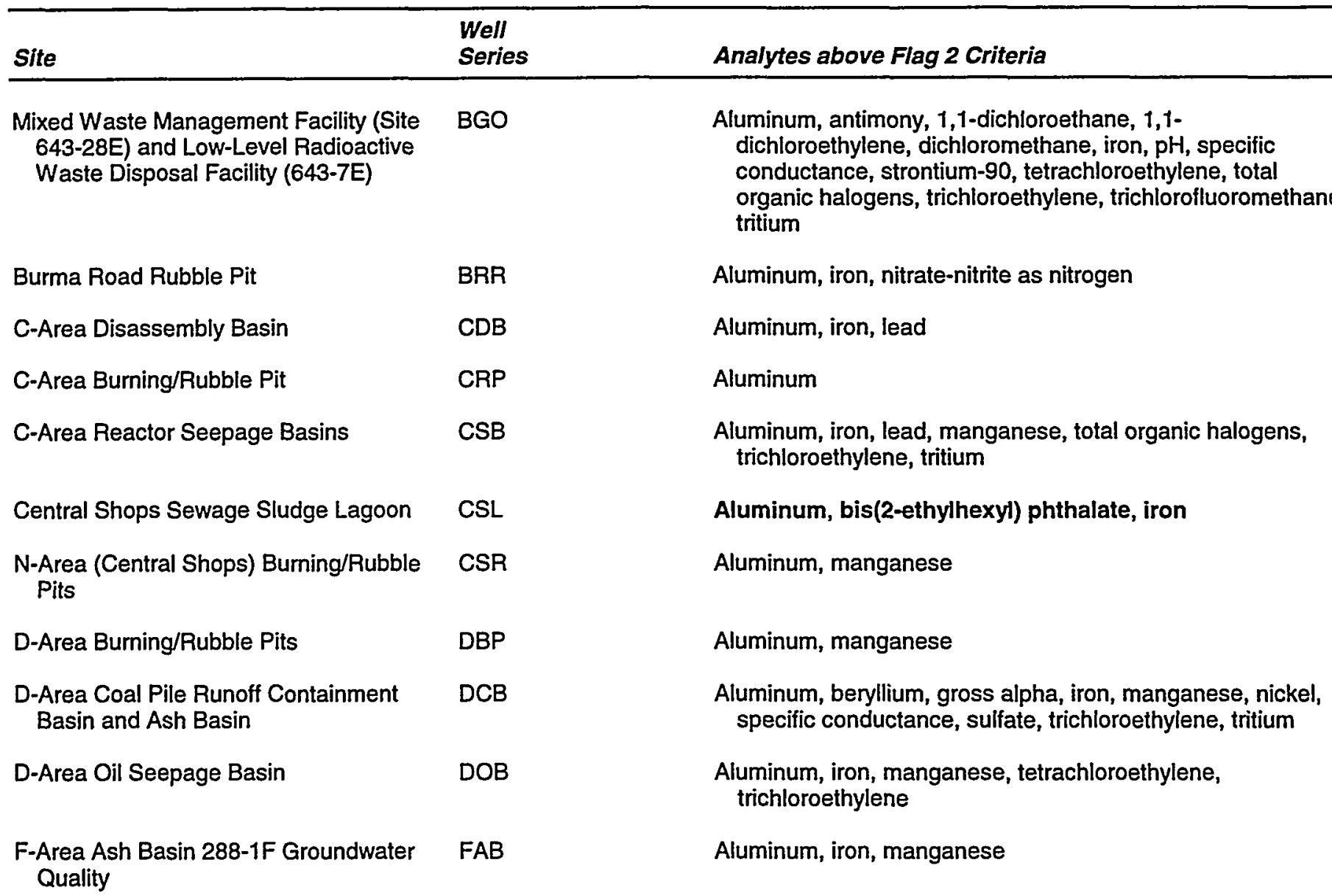




\begin{tabular}{|c|c|c|}
\hline Site & $\begin{array}{l}\text { Well } \\
\text { Series }\end{array}$ & Analytes above Flag 2 Criteria \\
\hline F-Area Burning/Rubble Pits & FBP & $\begin{array}{l}\text { Aluminum, iron, manganese, nitrate-nitrite as nitrogen, } \\
\text { tetrachloroethylene, trichloroethylene }\end{array}$ \\
\hline $\begin{array}{l}\text { F-Area Coal Pile Runoff Containment } \\
\text { Basin }\end{array}$ & FCB & Aluminum, iron, lead \\
\hline $\begin{array}{l}\text { F-Area Seepage Basins Remediation } \\
\text { Extraction Well }\end{array}$ & FEX & $\begin{array}{l}\text { Aluminum, americium-241, cadmium, cobalt, curium-243/244, } \\
\text { gross alpha, iodine-129, manganese, nonvolatile beta, } \\
\text { radium-226, specific conductance, strontium-90, uranium- } \\
233 / 234, \text { uranium-238, uranium }\end{array}$ \\
\hline $\begin{array}{l}\text { F-Area Seepage Basins Remediation } \\
\text { Injection Tank }\end{array}$ & FIN & $\begin{array}{l}\text { Aluminum, iodine-129, manganese, specific conductance, } \\
\text { uranium-233/234, uranium-238 }\end{array}$ \\
\hline F-Area Retention Basin & FRB & Iron, manganese \\
\hline F-Area Seepage Basins & FSB & $\begin{array}{l}\text { Aluminum, cadmium, gross alpha, iron, lead, nitrate-nitrite as } \\
\text { nitrogen, nonvolatile beta, } \mathrm{pH} \text {, specific conductance, tritium }\end{array}$ \\
\hline F-Area Inactive Process Sewer Line & FSL & $\begin{array}{l}\text { Aluminum, cadmium, gross alpha, iron, lead, nitrate-nitrite as } \\
\text { nitrogen, nonvolatile beta, tritium }\end{array}$ \\
\hline H-Area Tank Farm Operable Unit & HAA & $\mathrm{pH}$, specific conductance \\
\hline H-Area HP-52 Outfall & HHP & Iron, manganese \\
\hline $\begin{array}{l}\text { H-Area Seepage Basins Remediation } \\
\text { Injection Tank }\end{array}$ & HIN & Aluminum, iodine-129, mercury \\
\hline Old H-Area Retention Basin & HR3 & Aluminum, manganese, nitrate-nitrite as nitrogen, tritium \\
\hline H-Area Seepage Basins & HSB & $\begin{array}{l}\text { Aluminum, gross alpha, mercury, nitrate-nitrite as nitrogen, } \\
\text { nonvolatile beta, } \mathrm{pH} \text {, specific conductance, tritium }\end{array}$ \\
\hline H-Area Inactive Process Sewer Line & HSL & Nonvolatile beta, tritium \\
\hline H-Area Warner's Pond & HWP & Iron, manganese, nonvolatile beta, tritium \\
\hline K-Area Bingham Pump Outage Pits & KBP & Aluminum, iron, manganese \\
\hline K-Area Coal Pile Runoff Basin & KCB & Aluminum, gross alpha, iron, radium-226 \\
\hline K-Area Disassembly Basin & $\mathrm{KDB}$ & Tritium \\
\hline L-Area Research Wells & LAW & Tritium \\
\hline L-Area Bingham Pump Outage Pit & LBP & Aluminum, iron, $\mathrm{pH}$ \\
\hline L-Area Disassembly Basin & LDB & Tritium \\
\hline Interim Sanitary Landfill & LFW & $\begin{array}{l}\text { Aluminum, benzene, chloroethene, 1,3-dichlorobenzene, 1,4- } \\
\text { dichlorobenzene, dichlorodifluoromethane, 1,1- } \\
\text { dichloroethane, 1,1-dichloroethylene, dichloromethane, } \\
\text { iron, mercury, tetrachloroethylene, trichloroethylene, } \\
\text { trichlorofluoromethane, tritium }\end{array}$ \\
\hline B-Area Microbiology Wells & $\mathrm{P}$ & Aluminum, iron \\
\hline P-Area Bingham Pump Outage Pit & PBP & Aluminum \\
\hline P-Area Reactor Seepage Basins & PSB & lodine-129 \\
\hline
\end{tabular}




\begin{tabular}{|c|c|c|}
\hline Site & $\begin{array}{l}\text { Well } \\
\text { Series }\end{array}$ & Analytes above Flag 2 Criteria \\
\hline \multicolumn{3}{|c|}{$\cdot$} \\
\hline R-Area Bingham Pump Outage Pit & RBP & Aluminum, iron, tetrachloroethyiene \\
\hline AM-Area Recovery Well Network & RWM & Tetrachloroethylene, trichloroethylene \\
\hline \multicolumn{2}{|c|}{ S-Area Defense Waste Processing Facility SBG } & Tetrachloroethylene, trichloroethylene \\
\hline TNX Burying Groumd & TBG & $\begin{array}{l}\text { Aluminum, carbon tetrachloride, cis-1,2-dichloroethylene, } \\
\text { gross alpha, iron, manganese, mercury, nitrate as nitrogen, } \\
\text { tetrachloroethylene, trichloroethylene }\end{array}$ \\
\hline TNX-Area Operable Unit & TCM & Aluminum, gross alpha, iron, manganese, trichloroethylene \\
\hline TNX-Area Operable Unit & TIR & $\begin{array}{l}\text { Aluminum, carbon tetrachloride, gross alpha, manganese, } \\
\text { mercury, nitrate as nitrogen, trichloroethylene }\end{array}$ \\
\hline TNX-Area Assessment Wells & TNX & $\begin{array}{l}\text { Aluminum, carbon tetrachloride, iron, manganese, } \\
\text { tetrachloroethylene, trichloroethylene }\end{array}$ \\
\hline TNX-Area Recovery Wells & TRW & $\begin{array}{l}\text { Aluminum, carbon tetrachloride, iron, manganese, } \\
\text { trichloroethylene }\end{array}$ \\
\hline Old TNX Seepage Basin & XSB & Aluminum, iron, trichloroethylene \\
\hline New TNX Seepage Basin & YSB & Aluminum, iron \\
\hline
\end{tabular}

Note: The groundwater samples are unfiltered. Therefore, the results for metals are for total recoverable metals. Analytes in bold were detected at levels above the current Flag 2 criteria for the first time since 1984. 
NOTES 


\section{Introduction}

This report summarizes the Groundwater Monitoring Program conducted by SRS during second quarter 1999. It includes the analytical data, field data, data review, quality control, and other documentation for this program; provides a record of the program's activities; and serves as an official record of the analytical results.

EPD/EMS is responsible for providing drilling, sampling, and analytical and data management support for the SRS Groundwater Monitoring Program at approximately 135 waste sites in 17 areas at SRS (see figures 1 and 2 at the end of this section). The majority of this monitoring is required by U.S. Department of Energy (DOE) orders and by federal and state regulations administered by the USEPA and the South Carolina Department of Health and Environmental Control (SCDHEC). The Groundwater Monitoring Program includes the following activities:

- installation, maintenance, and abandonment of monitoring wells

- environmental soil borings

- development of sampling and analytical schedules

- collection and analysis of groundwater samples

- review of analytical and other data

- maintenance of the databases containing groundwater monitoring data

- quality assurance (QA) evaluations of laboratory performance

- reports of results to waste-site facility custodians and the Environmental Protection Department

The custodian of each waste site is responsible for informing EPD/EMS of sampling and analytical requirements and special requests for the sampling schedule, assisting in review of the data, and making any decisions regarding groundwater monitoring at the waste site.

Each custodian receives a copy of this report. Each custodian also receives site-specific data on request, including the following:

- a computer printout of the analytical data for the current quarter and for the previous seven quarters, designed to assist in identifying trends

- a computer printout of analytical results at or above Flag 1 and Flag 2 criteria for the quarter, designed to assist in identifying elevated constituents

\section{ORGANIZATION OF THIS REPORT}

This report is divided into sections that focus on specific aspects of the SRS Groundwater Monitoring Program. The Executive Summary section presents a listing by waste site and well series of all analytes detected at or above Flag 2 criteria during the quarter. Analytes detected at or above Flag 2 criteria for the first time since 1984 are indicated in bold type.

The Flagging Criteria section lists flagging criteria for analytes and provides a short description of how the criteria were derived. The Sample Scheduling section discusses the preparation of the sampling schedule and the criteria for analyte selection. 
During sample collection, samplers write comments in the field logbooks that may be pertinent to the analysis of samples. Many of the comments concern wells that went dry during sampling or water that appeared colored, turbid, or aerated. These comments are included in the Field Notes section.

Samples are analyzed by the EPD/EMS (EM Lab or EM) Radiological Laboratory at SRS and by one or more offsite laboratories. During second quarter 1999, EMAX Laboratories, Inc. (EX), of Torrance, CA; General Engineering Laboratories (GE), of Charleston, SC; and Recra LabNet Philadelphia (WA), of Lionville, PA, were the primary off-site laboratories. Radionuclide analyses were conducted by Environmental Physics, Inc. (GP), a subcontractor for GE, and Thermo NUtech (TM), a subcontractor for WA. The GE Mobile Laboratory (ML) performed on-site analyses of volatile and semivolatile organics and metals analyses. The Analytical Data Review section contains three subsections. The GIMS Data Review Module subsection discusses automated data management activities at EPD/EMS. The Review of the Analytical Data subsection includes a discussion of discrepancies in each laboratory's analytical data, including results that were considerably higher or lower than previous results. This subsection also includes information about the analytical narratives that were used as reference materials throughout the data validation process. The Analytical Methods subsection lists the methods the laboratories used for measuring concentrations of each analyte.

The Quality Control Samples section contains five subsections and discusses the analytical data in terms of the following indicators of data quality: precision, accuracy, representativeness, comparability, and completeness. The Precision subsection explains the replicate analysis program, gives the statistical methods used for comparison, and lists the results of the comparisons between the replicate and duplicate analyses. The Accuracy subsection examines the relationship between an observed value and an accepted reference value and/or the measure of the over- or underestimation of reported concentrations. The Representativeness subsection describes how groundwater samples can be affected to produce results that may be biased positively or negatively. The Comparability subsection discusses whether the laboratories use the same standardized procedures for sample preparation and analysis, whether the reporting units are the same, and whether similar quantitation limits were obtained. The Completeness section evaluates the amount of useable data that resulted from the data collection.

The Site Index section lists and gives a description of the sites associated with each well series, as well as historical information for the sites. A list of terms, abbreviations, and acronyms used in this report can be found in the Glossary section. References cited are included in the References section.

The Water-Level Data section (Appendix A) includes concurrent water elevations obtained in AM and other areas; these data are used by SRS personnel in hydrogeologic studies. The Analytical Results section (Appendix $B$ ) includes tables listing the verified and validated analytical results from all laboratories and field data for all wells sampled during the quarter. The tables appear in alphabetical order by well name. The Sampling Blanks Results section (Appendix C) contains tables listing the analytical results of laboratory tests on sampling blanks. The Analytical and Sampling Blanks Results for MSB Wells section (Appendix D) contains laboratory analytical results and field data for five MSB wells sampled during the quarter, as well as the analytical results of laboratory tests on sampling blanks from the project. These results are not included in the Analytical Results section (Appendix B) because they did not undergo the standard verification and validation process. 


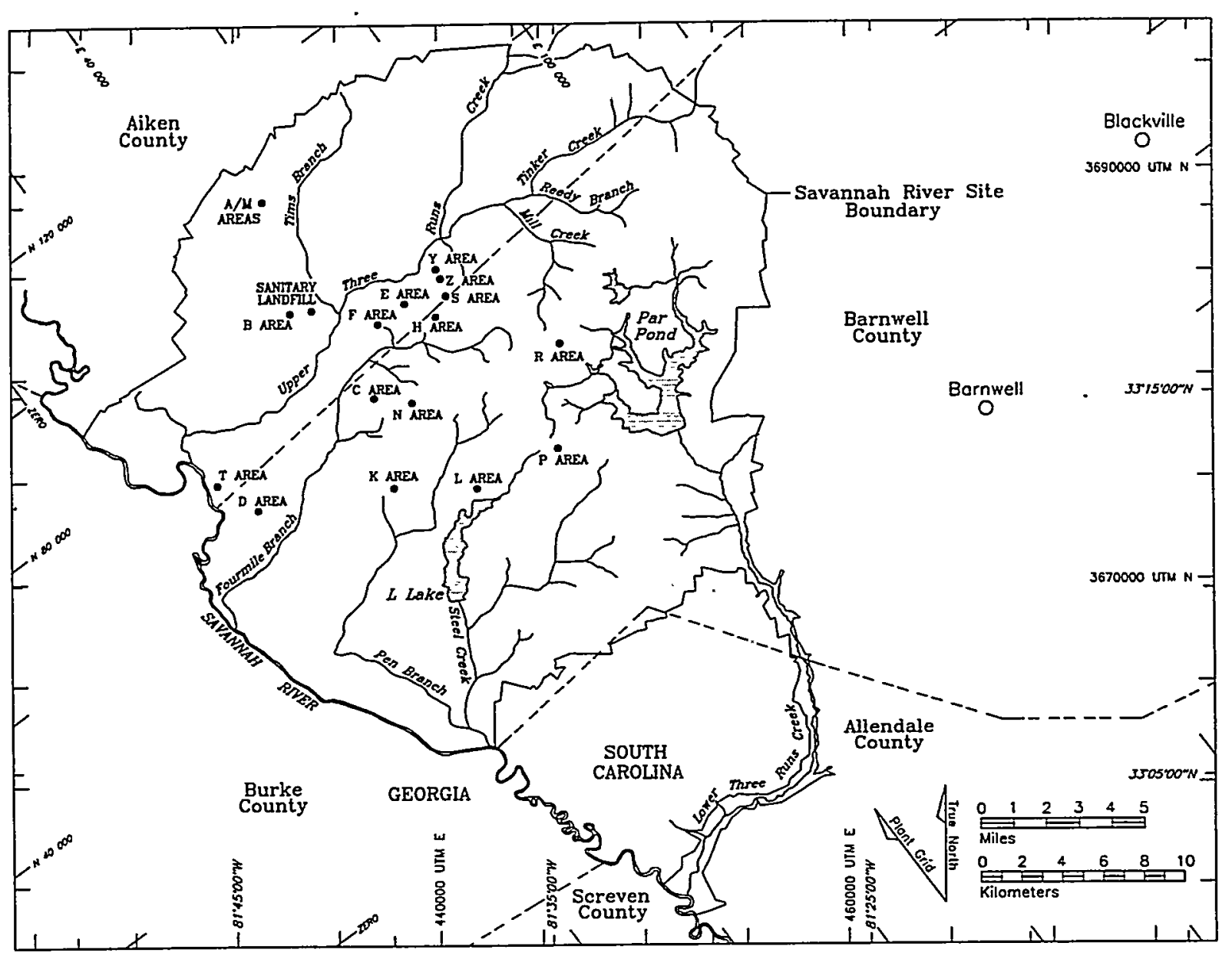

Figure 1. Areas and Locations Monitored for Groundwater Quality 


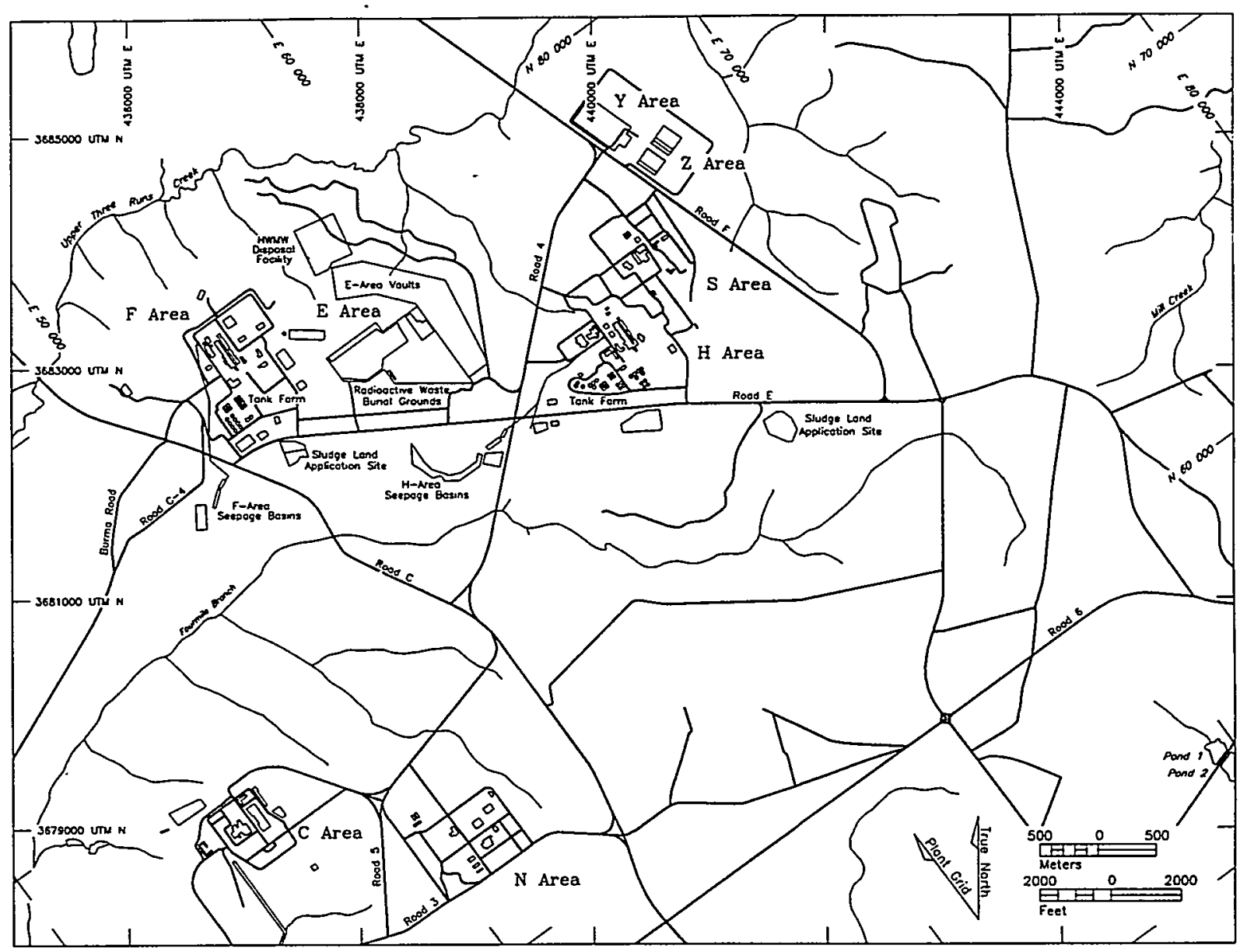

Figure 2. Separations and Waste Managoment Aroas Monitored for Groundwater Quality 


\section{Flagging Criteria}

Analytes in the data tables are assigned flagging levels $(0,1$, or 2$)$ depending on their concentrations in a groundwater sample. The flagging levels dictate the scheduling and frequency of groundwater sampling. Beginning fist quarter 1992, flagging criteria were established for all of the constituents currently being analyzed as part of the EPD/EMS Groundwater Monitoring Program, except for certain aesthetic constituents, indicator parameters, major cations, and common laboratory contaminants and cleaners, which can be analyzed by special request. The flagging criteria in table 2 were determined as follows:

Flag 0: Analytical results below Flag 1 and constituents having no flagging criteria were classified as Flag 0.

Flag 1: The Flag 1 criterion for a constituent was set as one-half of the EPA final primary drinking water standard, the EPA proposed primary drinking water standard, or the EPA secondary drinking water standard for that constituent. If a constituent did not have an EPA drinking water standard, the Flag 1 criterion was set as five times a recently published 90 th percentile detection limit obtained by one of the primary laboratories.

Flag 2: The Flag 2 criterion for a constituent was set as the EPA final primary drinking water standard, the EPA proposed primary drinking water standard, or the EPA secondary drinking water standard for that constituent. If a constituent did not have a drinking water standard, the Flag 2 criterion was set as 10 times a recently published 90th percentile detection limit obtained by one of the primary laboratories.

The following acronyms are used as abbreviated sources in the flagging criteria table. Complete information concerning documents cited can be found in the References section of this report.

APHA - American Public Health Association.

APHA Method-A specific analytical method for testing constituent levels in a sample as established by the APHA, American Water Works Association, and Water Pollution Control Federation. See American Public Health Association et al. in References.

EPA-U.S. Environmental Protection Agency.

EPA Method - A specific analytical method for testing constituent levels. Descriptions of these methods can be found in the EPA publications Methods for Chemical Analysis of Water and Wastes (1983) and Test Methods for Evaluating Solid Waste (1986b) and in the 1991 Code of Federal Regulations, Title 40, Part 136. See Environmental Protection Agency in References.

EPD/EMS - The Environmental Protection Department/Environmental Monitoring Section at the Savannah River Site.

PDWS - Primary Drinking Water Standards.

SCDHEC — South Carolina Department of Health and Environmental Control.

SDWS - Secondary Drinking Water Standards. 


\begin{tabular}{|c|c|c|c|c|}
\hline Analyte & Unit & Flag 1 & Flag 2 & Sourcet \\
\hline Acenaphthene & $\mu g / L$ & 5.1 & 10.2 & EPA Method 8270 \\
\hline Acenaphthylene & $\mu g / L$ & 5.1 & 10.2 & EPA Method 8270 \\
\hline Acetone & $\mu g / L$ & 500 & 1,000 & Set by EPD/EMS \\
\hline Acetonitrile (Methyl cyanide) & $\mu g / L$ & 50 & 100 & EPA Method 8240 \\
\hline Acetophenone & $\mu g / L$ & 85 & 170 & EPA Method 8270 \\
\hline 2-Acetylaminofluorene & $\mu g / L$ & 81 & 162 & EPA Method 8270 \\
\hline Acrolein & $\mu g / L$ & 166.5 & 333 & EPA Method 8240 \\
\hline Acrylonitrile & $\mu g / L$ & 250 & 500 & EPA Method 8240 \\
\hline Actinium-228 & $\mu \mathrm{Ci} / \mathrm{mL}$ & $1.64 \mathrm{E}-06$ & 3.27E-06 & Proposed PDWS (EPA, 1991c) \\
\hline Alachlor & $\mu g / L$ & 1.0 & 2.0 & Final PDWS (EPA, 1997a) \\
\hline Aldicarb & $\mu g / L$ & 1.5 & 3.0 & Final PDWS (EPA, 1997a) \\
\hline Aldicarb sulfone & $\mu g / L$ & 1.0 & 2.0 & Final PDWS (EPA, 1997a) \\
\hline Aldicarb sulfoxide & $\mu g / L$ & 2.0 & 4.0 & Final PDWS (EPA, 1997a) \\
\hline Aldrin & $\mu g / L$ & 0.4 & 0.8 & EPA Method 8080 \\
\hline Alkalinity (as $\mathrm{CaCO}_{3}$ ) & & No flag & No flag & Set by EPD/EMS \\
\hline Allyl chloride & $\mu g / L$ & 416.5 & 833 & EPA Method 8240 \\
\hline Aluminum & $\mu g / L$ & 25 & 50 & SDWS (EPA, 1997b) \\
\hline Aluminum, dissolved & $\mu g / L$ & 25 & 50 & SDWS (EPA, 1997b) \\
\hline Aluminum, total recoverable & $\mu g / L$ & 25 & 50 & SDWS (EPA, 1997b) \\
\hline Americium-241 & $\mu \mathrm{Ci} / \mathrm{mL}$ & 3.17E-09 & 6.34E-09 & Proposed PDWS (EPA, 1991c) \\
\hline Americium-243 & $\mu \mathrm{Ci} / \mathrm{mL}$ & 3.19E-09 & 6.37E-09 & Proposed PDWS (EPA, 1991c) \\
\hline 4-Aminobiphenyl & $\mu g / L$ & 81 & 162 & EPA Method 8270 \\
\hline Ammonia & $\mu g / L$ & 250 & 500 & APHA Method 417B \\
\hline Ammonia nitrogen & $\mu g / L$ & 500 & 1,000 & EPA Method 350.1 \\
\hline Aniline & $\mu g / L$ & 81 & 162 & EPA Method 8270 \\
\hline Anthracene & $\mu g / L$ & 5.1 & 10.2 & EPA Method 8270 \\
\hline Antimony & $\mu g / L$ & 3.0 & 6.0 & Final PDWS (EPA, 1997a) \\
\hline Antimony, dissolved & $\mu g / L$ & 3.0 & 6.0 & Final PDWS (EPA, 1997a) \\
\hline Antimony, total recoverable & $\mu g / L$ & 3.0 & 6.0 & Final PDWS (EPA, 1997a) \\
\hline Antimony-124 & $\mu \mathrm{Ci} / \mathrm{mL}$ & 3.0E-08 & $6.0 E-08$ & $\begin{array}{l}\text { Interim Final PDWS (EPA, } \\
\text { 1977) }\end{array}$ \\
\hline Antimony-125 & $\mu \mathrm{Ci} / \mathrm{mL}$ & 1.5E-07 & 3.0E-07 & $\begin{array}{l}\text { Interim Final PDWS (EPA, } \\
\text { 1977) }\end{array}$ \\
\hline Aramite & $\mu g / L$ & 81 & 162 & EPA Method 8270 \\
\hline Arsenic & $\mu g / L$ & 25 & 50 & Final PDWS (EPA, 1997a) \\
\hline Arsenic, dissolved & $\mu g / L$ & 25 & 50 & Final PDWS (EPA, 1997a) \\
\hline Arsenic, total recoverable & $\mu g / L$ & 25 & 50 & Final PDWS (EPA, 1997a) \\
\hline Asbestos & Fibers/L & $3,500,000$ & $7,000,000$ & Final PDWS (EPA, 1997a) \\
\hline Atrazine & $\mu g / L$ & 1.5 & 3.0 & Final PDWS (EPA, 1997a) \\
\hline Azobenzene & $\mu g / L$ & 50 & 100 & EPA Method 625 \\
\hline Barium & $\mu g / L$ & 1,000 & 2,000 & Final PDWS (EPA, 1997a) \\
\hline Barium, dissolved & $\mu g / L$ & 1,000 & 2,000 & Final PDWS (EPA, 1997a) \\
\hline Barium, total recoverable & $\mu \mathrm{g} / \mathrm{L}$ & 1,000 & 2,000 & Final PDWS (EPA, 1997a) \\
\hline Barium-133 & $\mu \mathrm{C} / \mathrm{mL}$ & $7.60 \mathrm{E}-07$ & $1.52 E-06$ & Proposed PDWS (EPA, 1991c) \\
\hline Barium-140 & $\mu \mathrm{Ci} / \mathrm{mL}$ & $4.5 E-08$ & $9.0 E-08$ & $\begin{array}{l}\text { Interim Final PDWS (EPA, } \\
\text { 1977) }\end{array}$ \\
\hline Benzene & $\mu g / L$ & 2.5 & 5.0 & Final PDWS (EPA, 1997a) \\
\hline alpha-Benzene hexachloride & $\mu g / L$ & 0.15 & 0.3 & EPA Method 8080 \\
\hline beta-Benzene hexachloride & $\mu g / L$ & 0.25 & 0.5 & EPA Method 8080 \\
\hline delta-Benzene hexachloride & $\mu g / L$ & 0.25 & 0.5 & EPA Method 8080 \\
\hline Benzidine & $\mu g / L$ & 83.5 & 167 & EPA Method 8270 \\
\hline Benzo[a]anthracene & $\mu g / L$ & 0.05 & 0.1 & Proposed PDWS (EPA, 1990) \\
\hline Benzo[b]fluoranthene & $\mu g / L$ & 0.1 & 0.2 & Proposed PDWS (EPA, 1990) \\
\hline Benzo[ $k$ ffluoranthene & $\mu g / L$ & 0.1 & 0.2 & Proposed PDWS (EPA, 1990) \\
\hline Benzoic acid & $\mu g / L$ & 5.0 & 10 & EPA Method 8270 \\
\hline Benzo $[g, h, i]$ perylene & $\mu g / L$ & 5.1 & 10.2 & EPA Method 8270 \\
\hline Benzo[a]pyrene & $\mu g / L$ & 0.1 & 0.2 & Final PDWS (EPA, 1997a) \\
\hline 1,4-Benzoquinone & $\mu g / L$ & 50 & 100 & EPA Method 8270 \\
\hline Benzyl alcohol & $\mu g / L$ & 5.0 & 10 & EPA Method 8270 \\
\hline
\end{tabular}




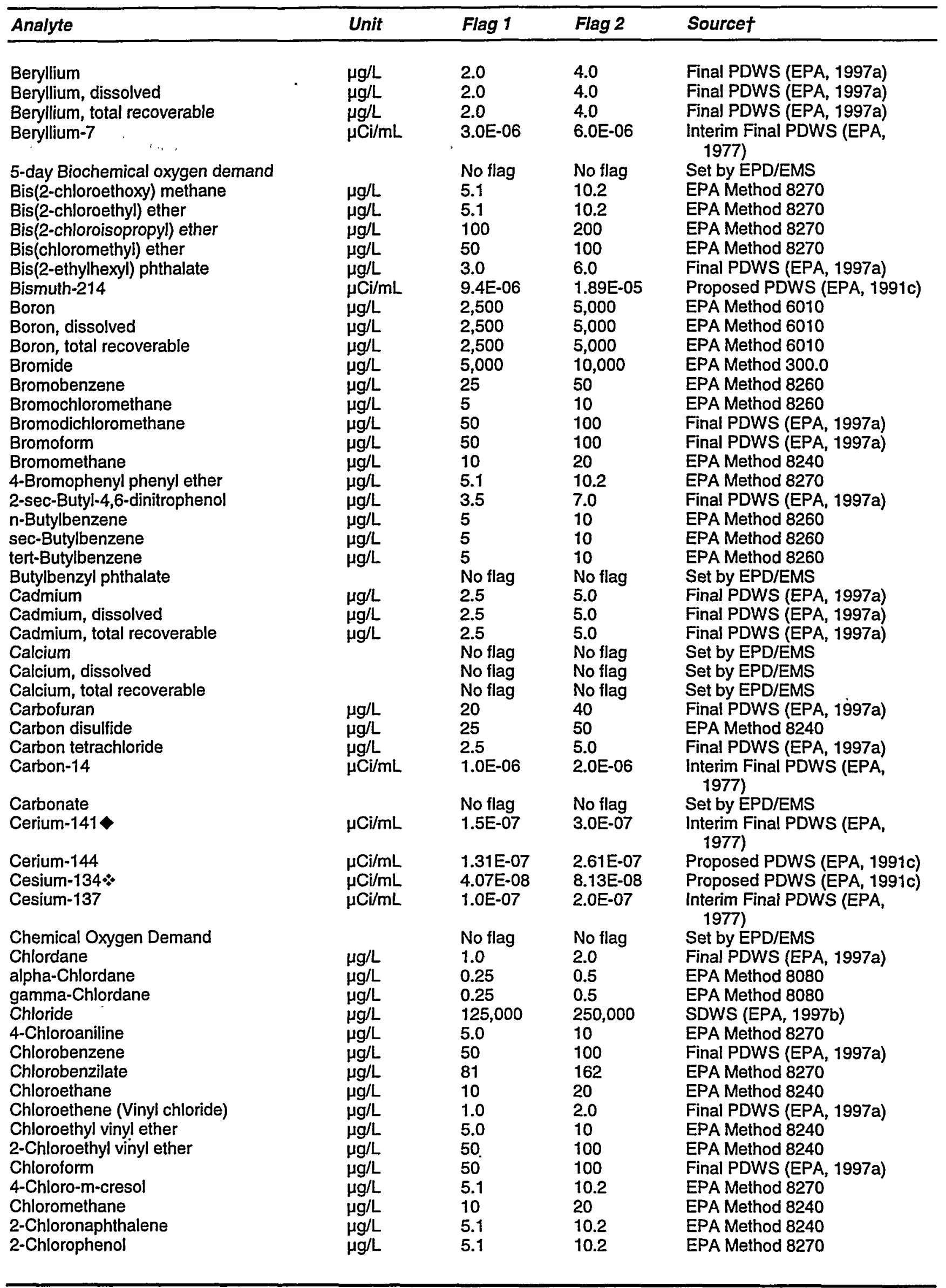




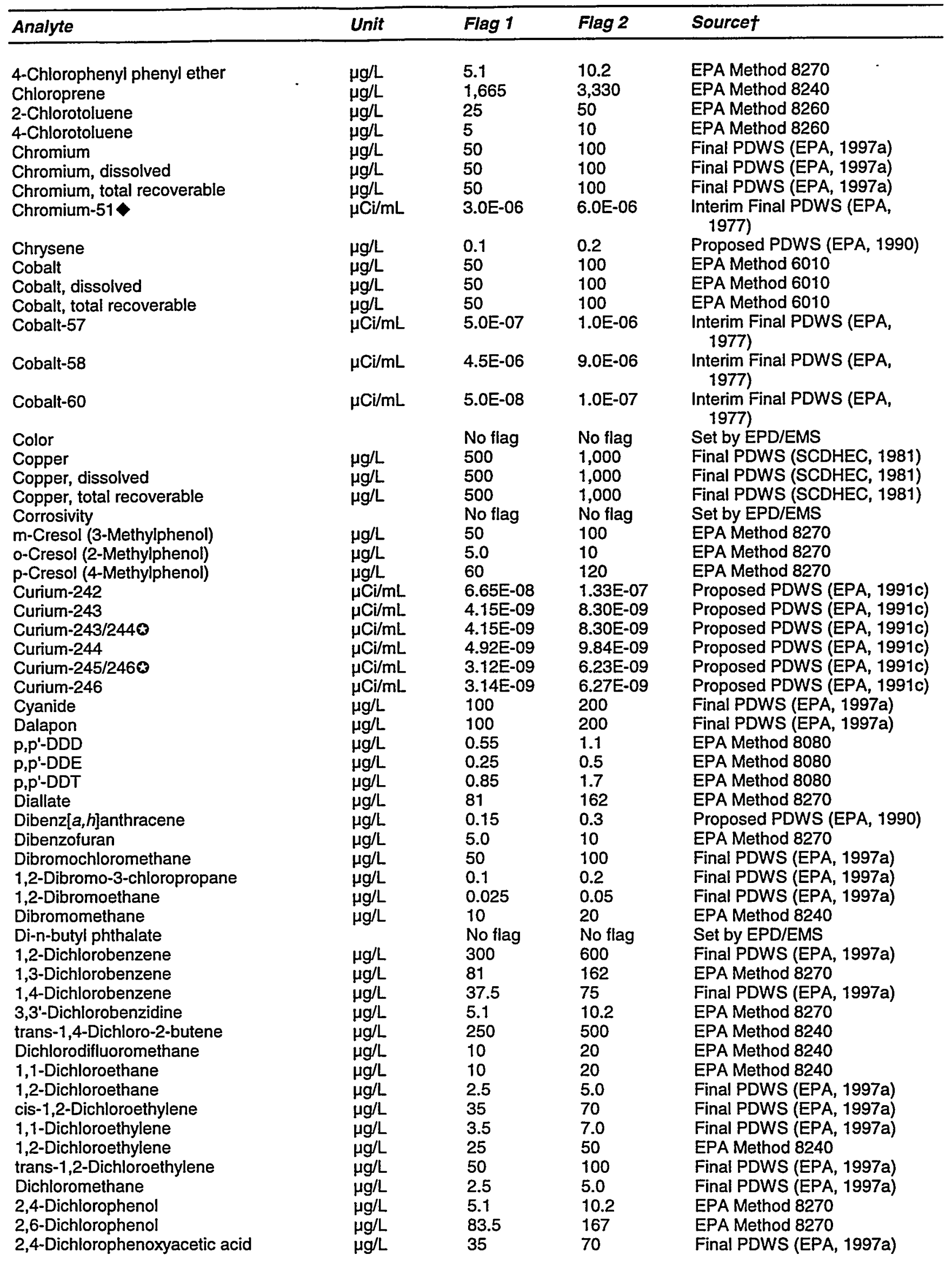




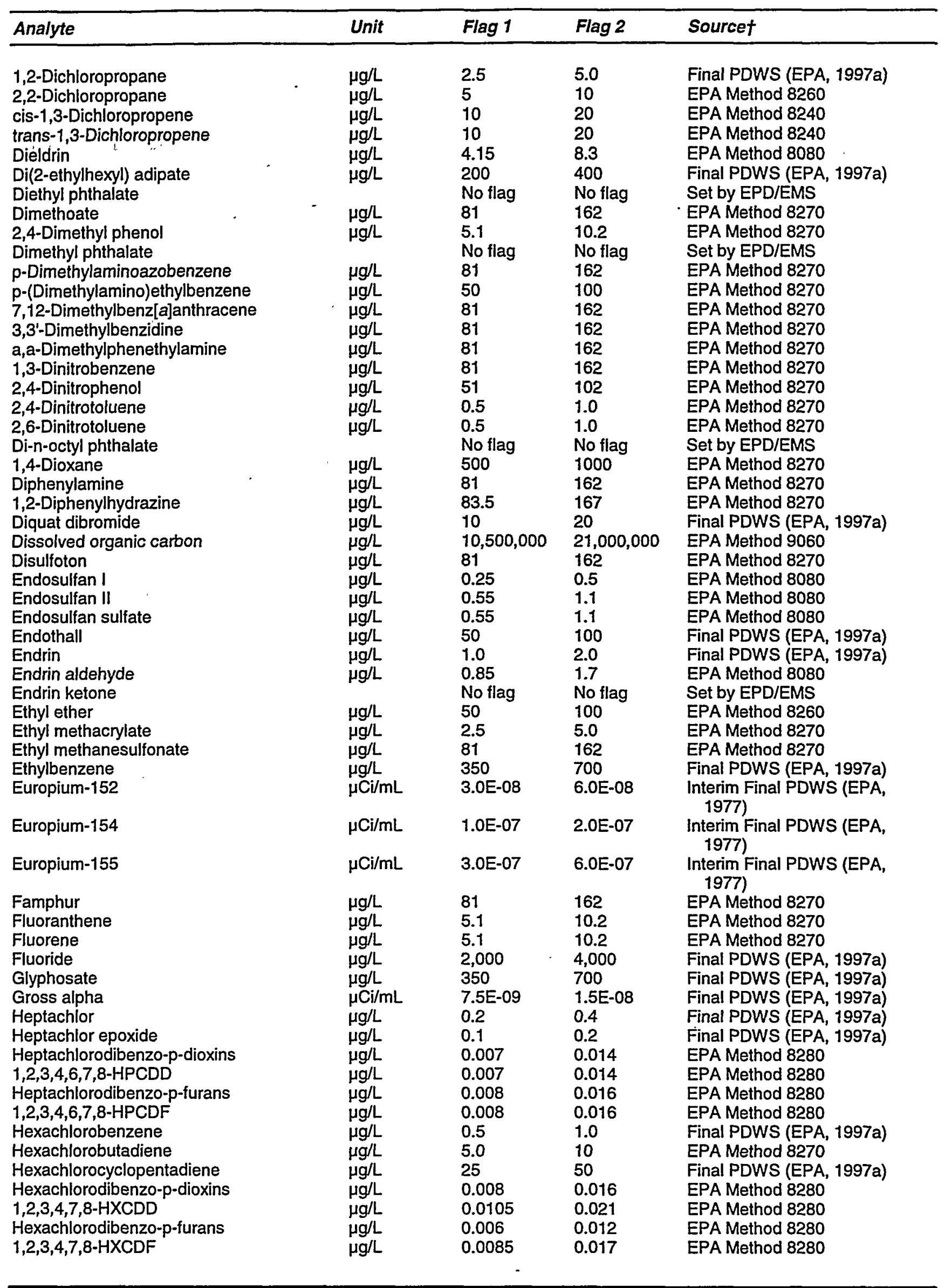




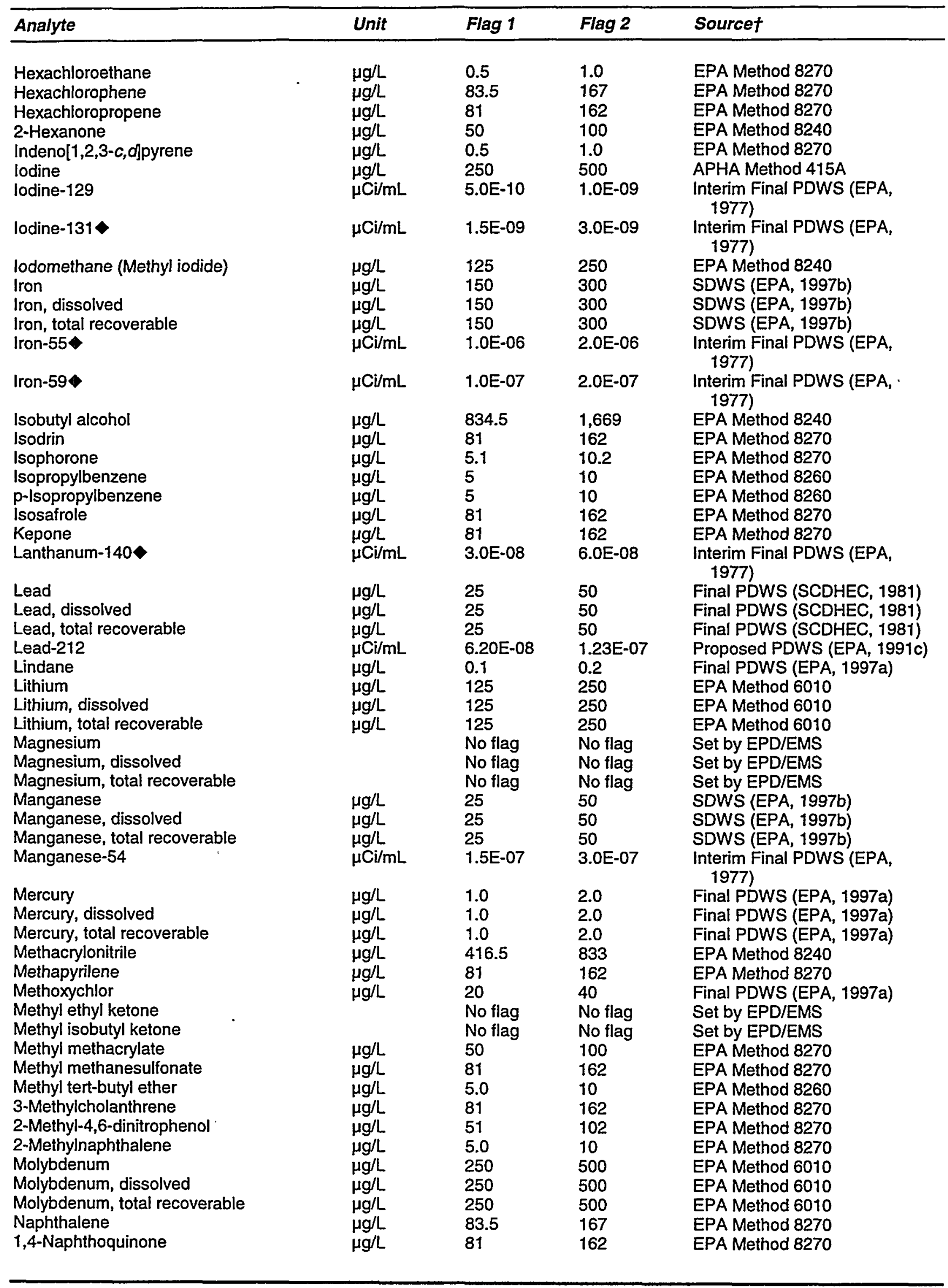




\begin{tabular}{|c|c|c|c|c|}
\hline Analyte & Unit & Flag 1 & Flag 2 & Sourcet \\
\hline 1-Naphthylamine & $\mu g / L$ & 81 & 162 & EPA Method 8270 \\
\hline 2-Naphthylamine & $\mu \mathrm{g} / \mathrm{L}$ & 81 & 162 & EPA Method 8270 \\
\hline Neptunium-237 & $\mu \mathrm{Ci} / \mathrm{mL}$ & 3.53E-09 & 7.06E-09 & Proposed PDWS (EPA, 1991c) \\
\hline Neptunium-239 & $\mu \mathrm{Ci} / \mathrm{mL}$ & $8.40 E-07$ & $1.68 \mathrm{E}-06$ & Proposed PDWS (EPA, 1991C) \\
\hline Nickel & $\mu g / L$ & 50 & 100 & Final PDWS (EPA, 1997a) \\
\hline Nickel, dissolved & $\mu g / L$ & 50 & 100 & Final PDWS (EPA, 1997a) \\
\hline Nickel, total recoverable & $\mu g / L$ & 50 & 100 & Final PDWS (EPA, 1997a) \\
\hline Nickel-59 & $\mu \mathrm{Ci} / \mathrm{mL}$ & $1.5 \mathrm{E}-07$ & $3.0 \mathrm{E}-07$ & $\begin{array}{l}\text { Interim Final PDWS (EPA, } \\
\text { 1977) }\end{array}$ \\
\hline Nickel-63 & $\mu \mathrm{Ci} / \mathrm{mL}$ & 2.5E-08 & 5.0E-08 & $\begin{array}{l}\text { Interim Final PDWS (EPA, } \\
1977 \text { ) }\end{array}$ \\
\hline Niobium-95 & $\mu \mathrm{Ci} / \mathrm{mL}$ & 1.5E-07 & $3.0 E-07$ & $\begin{array}{l}\text { Interim Final PDWS (EPA, } \\
1977 \text { ) }\end{array}$ \\
\hline Nitrate as nitrogen & $\mu g / L$ & 5,000 & 10,000 & Final PDWS (EPA, 1997a) \\
\hline Nitrate-nitrite as nitrogen & $\mu g / L$ & 5,000 & 10,000 & Final PDWS (EPA, 1997a) \\
\hline Nitrite as nitrogen & $\mu g / L$ & 500 & 1,000 & Final PDWS (EPA, 1997a) \\
\hline m-Nitroaniline & $\mu g / L$ & 5.0 & 10 & EPA Method 8270 \\
\hline o-Nitroaniline & $\mu g / L$ & 5.0 & 10 & EPA Method 8270 \\
\hline p-Nitroaniline & $\mu g / L$ & 5.0 & 10 & EPA Method 8270 \\
\hline Nitrobenzene & $\mu g / L$ & 5.1 & 10.2 & EPA Method 8270 \\
\hline Nitrogen by Kjeldahl method & $\mu g / L$ & 500 & 1,000 & EPA Method 351.2 \\
\hline 2-Nitrophenol & $\mu g / L$ & 5.1 & 10.2 & EPA Method 8270 \\
\hline 4-Nitrophenol & $\mu g / L$ & 5.1 & 10.2 & EPA Method 8270 \\
\hline 4-Nitroquinoline-1-oxide & $\mu g / L$ & 81 & 162 & EPA Method 8270 \\
\hline N-Nitrosodi-n-butylamine & $\mu g / L$ & 81 & 162 & EPA Method 8270 \\
\hline N-Nitrosodiethylamine & $\mu g / L$ & 81 & 162 & EPA Method 8270 \\
\hline N-Nitrosodimethylamine & $\mu g / L$ & 83.5 & 167 & EPA Method 8270 \\
\hline $\mathrm{N}$-Nitrosodiphenylamine & $\mu g / L$ & 5.1 & 10.2 & EPA Method 8270 \\
\hline N-Nitrosodipropylamine & $\mu g / L$ & 5.1 & 10.2 & EPA Method 8270 \\
\hline N-Nitrosomethylethylamine & $\mu \mathrm{g} / \mathrm{L}$ & 81 & 162 & EPA Method 8270 \\
\hline N-Nitrosomorpholine & $\mu g / L$ & 81 & 162 & EPA Method 8270 \\
\hline N-Nitrosopiperidine & $\mu g / L$ & 81 & 162 & EPA Method 8270 \\
\hline N-Nitrosopyrrolidine & $\mu g / L$ & 81 & 162 & EPA Method 8270 \\
\hline 5-Nitro-o-toluidine & $\mu g / L$ & 81 & 162 & EPA Method 8270 \\
\hline Nonvolatile beta & $\mu \mathrm{Ci} / \mathrm{mL}$ & 2.5E-08 & 5.0E-08 & $\begin{array}{l}\text { Interim Final PDWS (EPA, } \\
1977 \text { ) }\end{array}$ \\
\hline Octachlorodibenzo-p-dioxins & $\mu g / L$ & 0.0085 & 0.017 & EPA Method 8280 \\
\hline Octachlorodibenzo-p-furans & $\mu g / L$ & 0.0065 & 0.013 & EPA Method 8280 \\
\hline Odor & & No flag & No flag & Set by EPD/EMS \\
\hline Oil \& grease & $\mu \mathrm{g} / \mathrm{L}$ & 8,350 & $16,700^{\circ}$ & EPA Method 413.1 \\
\hline Oxamyl & $\mu g / L$ & 100 & 200 & Final PDWS (EPA, 1997a) \\
\hline Parathion & $\mu g / L$ & 0.4 & 0.8 & EPA Method 8080 \\
\hline Parathion methyl & $\mu g / L$ & 0.4 & 0.8 & EPA Method 8080 \\
\hline PCB 1016 & $\mu g / L$ & 0.25 & 0.5 & Final PDWS (EPA, 1997a) \\
\hline PCB 1221 & $\mu g / L$ & 0.25 & 0.5 & Final PDWS (EPA, 1997a) \\
\hline PCB 1232 & $\mu \mathrm{g} / \mathrm{L}$ & 0.25 & 0.5 & Final PDWS (EPA, 1997a) \\
\hline PCB 1242 & $\mu g / L$ & 0.25 & 0.5 & Final PDWS (EPA, 1997a) \\
\hline PCB 1248 & $\mu g / L$ & 0.25 & 0.5 & Final PDWS (EPA, 1997a) \\
\hline PCB 1254 & $\mu g / L$ & 0.25 & 0.5 & Final PDWS (EPA, 1997a) \\
\hline PCB 1260 & $\mu g / L$ & 0.25 & 0.5 & Final PDWS (EPA, 1997a) \\
\hline PCB 1262 & $\mu g / L$ & 0.25 & 0.5 & Final PDWS (EPA, 1997a) \\
\hline Pentachlorobenzene & $\mu g / L$ & 81 & 162 & EPA Method 8270 \\
\hline Pentachlorodibenzo-p-dioxins & $\mu g / L$ & 0.008 & 0.016 & EPA Method 8280 \\
\hline $1,2,3,7,8-P C D D$ & $\mu g / L$ & 0.0075 & 0.015 & EPA Method 8280 \\
\hline Pentachlorodibenzo-p-furans & $\mu g / L$ & 0.0085 & 0.017 & EPA Method 8280 \\
\hline $1,2,3,7,8-P C D F$ & $\mu g / L$ & 0.0085 & 0.017 & EPA Method 8280 \\
\hline Pentachloroethane & $\mu g / L$ & 81 & 162 & EPA Method 8270 \\
\hline Pentachloronitrobenzene & $\mu g / L$ & 81 & 162 & EPA Method 8270 \\
\hline Pentachlorophenol & $\mu g / L$ & 0.5 & 1.0 & Final PDWS (EPA, 1997a) \\
\hline $\mathrm{pH}$ & $\mathrm{pH}$ & 8.0 & 10 & Set by EPD/EMSS \\
\hline $\mathrm{pH}$ & $\mathrm{pH}$ & 4.0 & 3.0 & Set by EPD/EMS \\
\hline Phenacetin & $\mu g / L$ & 81 & 162 & EPA Method 8270 \\
\hline
\end{tabular}




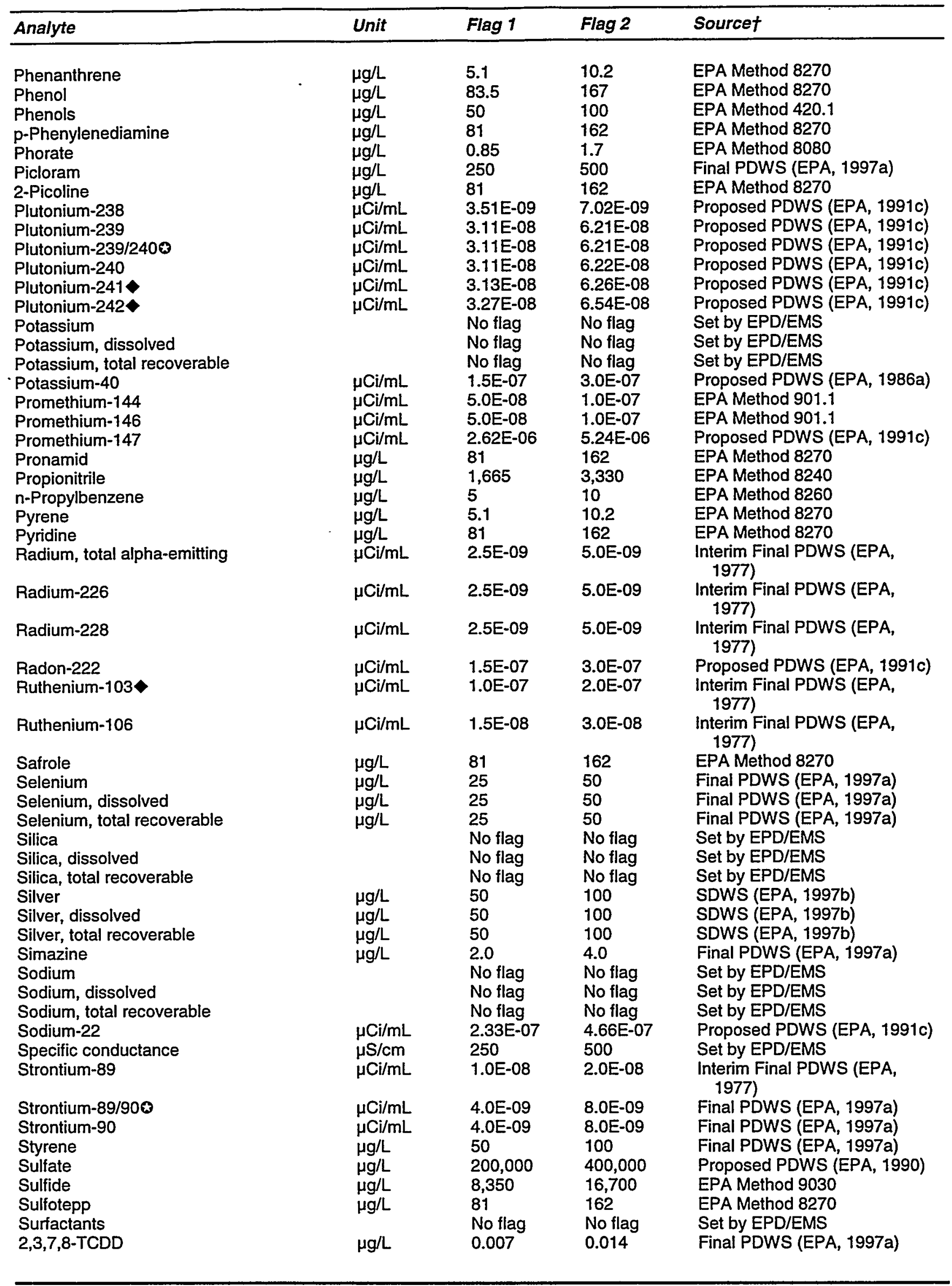




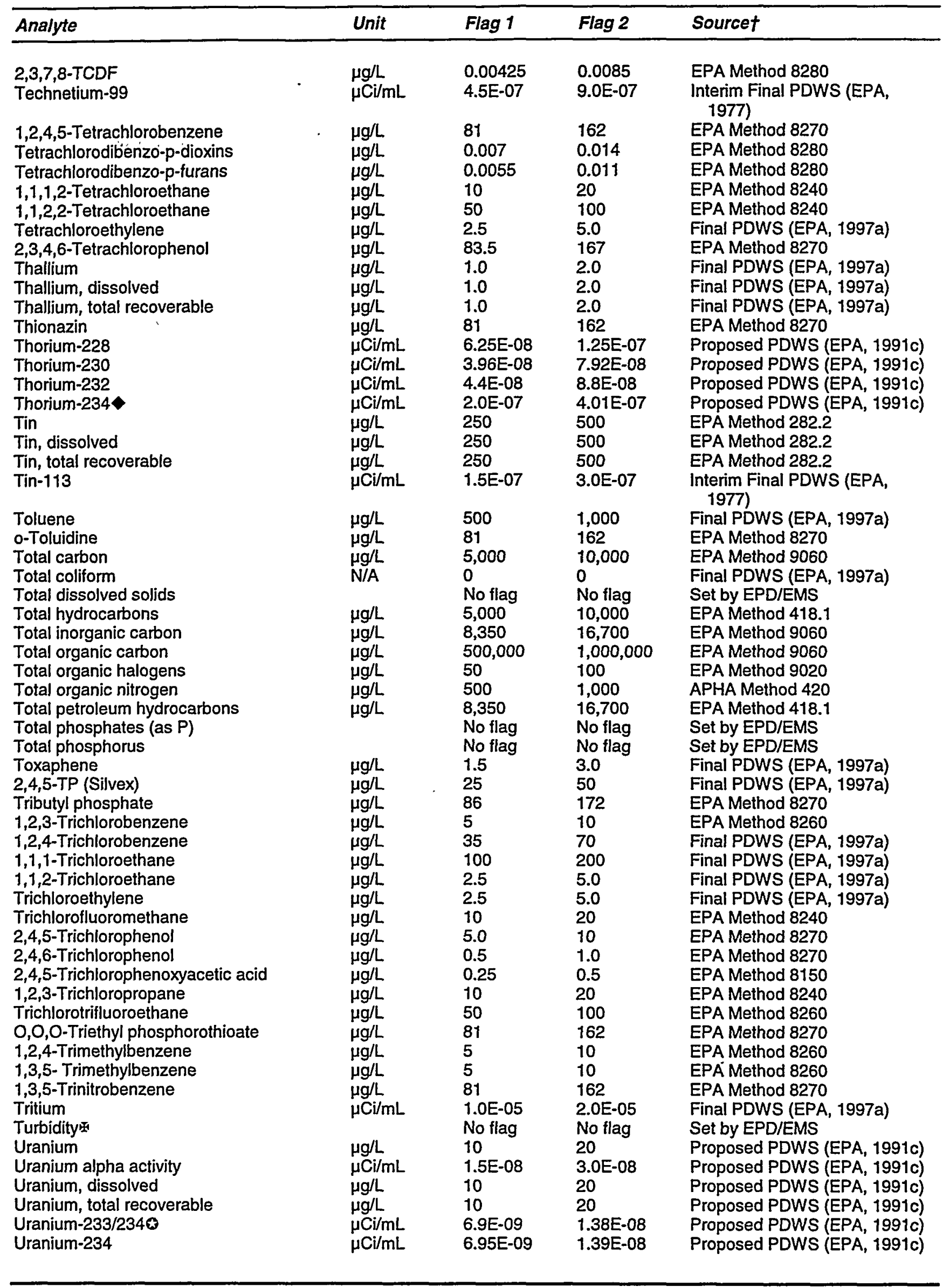




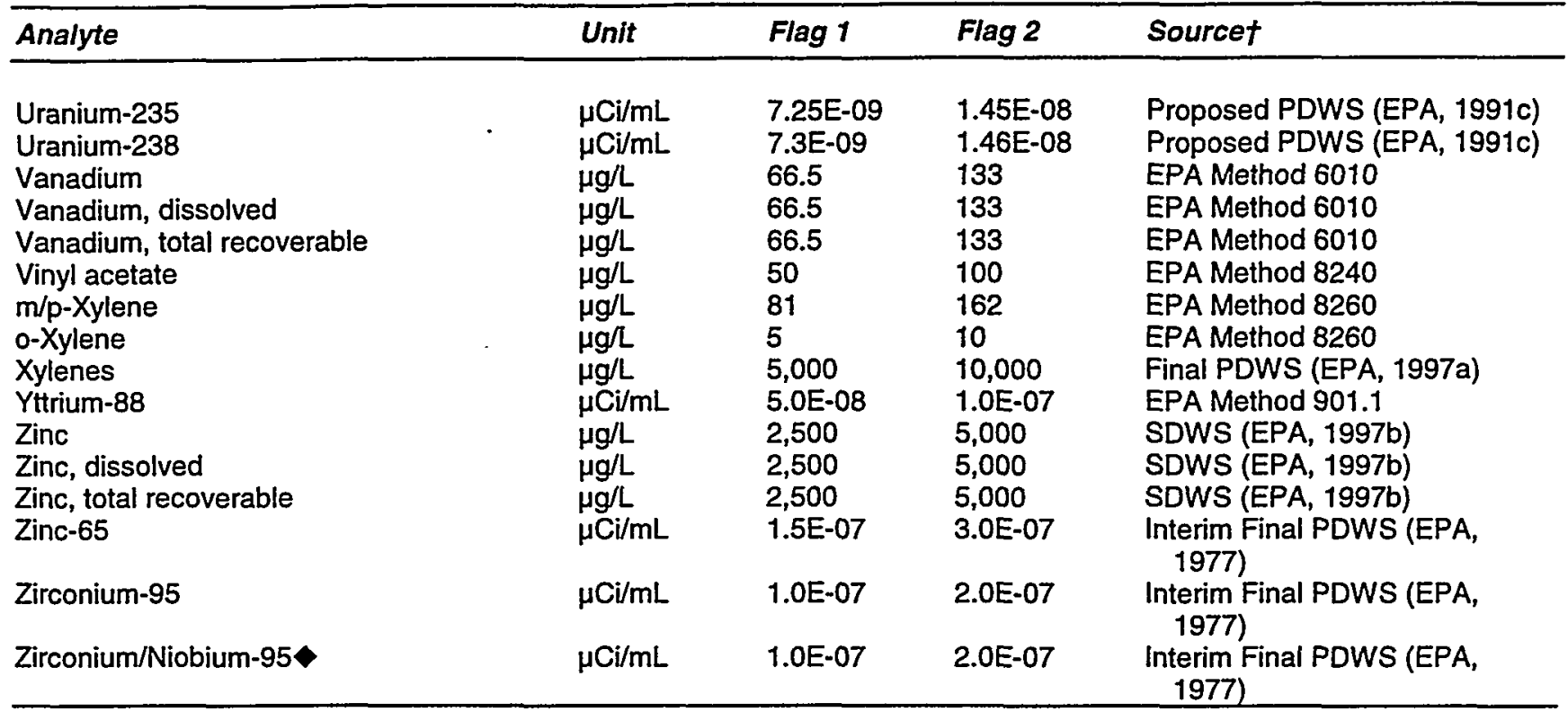

t Analytical methods are discussed in the Analytical Data Review section of this document; references for dated sources are in the References section.

-EMS discontinued monitoring this radionuclide because it is inappropriate for the SRS Groundwater Monitoring Program.

* EPD/EMS set this flagging criterion using the 1991 proposed PDWS because the final PDWS in 1977 may have been in error.

When radionuclide analyses are combined, the lower DWS of the two isotopes is used for flagging.

The primary maximum contaminant level range for turbidity is 1-5 NTU, which is inappropriate for the SRS Groundwater Monitoring Program.

Note: Beginning fourth quarter 1992, samples were no longer filtered at the wells. Therefore, the methods for analyzing metals now include a digestion step. Beginning fourth quarter 1993, the laboratories were required to report all metals as total recoverable metals. Flagging criteria remain unchanged. 


\section{Sample Scheduling}

Scheduling of sampling and analyses for the SRS Groundwater Monitoring Program conducted by EPD/EMS is based on several factors. Environmental screening is scheduled on a regular basis. Additional scheduling is based on previous flagging levels, regulatory requirements, and special requests that fall within the scope of the Groundwater Monitoring Program. This information is used to generate The Savannah River Site's Groundwater Monitoring Program 1999 Sampling Schedule.

A breakdown by laboratory of the total number of analyses performed during second quarter 1999 follows:

Laboratory
EMAX Laboratories, Inc.
Environmental Physics
General Engineering Laboratories
Recra LabNet Philadelphia
Thermo NUtech
Mobile Lab

Laboratory

EMAXLaboratc

General Engineering Laboratories

Thermo NUtech

Mobile Lab

\author{
Number of Analyses \\ 9,908 \\ 2,834 \\ 8,676 \\ 13,630 \\ 1,269 \\ 141
}

\section{ENVIRONMENTAL SCREENING}

New wells designated as screening program wells are scheduled initially for four quarters of environmental screening. Environmental-screening constituents, which include indicator parameters, groundwater quality characteristics, and some drinking water characteristics, are listed below. After the initial four quarters of analyses for new wells, environmental screening is scheduled once every three years for wells identified as environmental-screening program wells. The wells are sampled only for the environmental-screening constituents that have not been analyzed within the past three years.

Beginning in 1996, EPD/EMS changed its policy concerning quarterly field measurements. Only wells scheduled by request or wells identified for environmental screening receive field measurements.

\section{Environmental-Screening Constituents}

$\begin{array}{llll}\text { Aluminum } & \mathrm{pH} & \text { Well condition } & \text { Mercury } \\ \text { Arsenic } & \text { Phenolphthalein alkalinity } & \text { Fluoride } & \text { Nitrate-nitrite as nitrogen } \\ \text { Barium } & \text { Program } & \text { Gross alpha } & \text { Nonvolatile beta } \\ \text { Boron } & \text { Sampling method } & \text { Iron } & \text { Selenium } \\ \text { Cadmium } & \text { Site code } & \text { Lead } & \text { Silver } \\ \text { Chloride } & \text { Specific conductance } & \text { Lithium } & \text { Sodium } \\ \text { Chromium } & \text { Stabilized (Yes or No) } & \text { Major ions } & \text { Sulfate } \\ \text { Field measurements } & \text { Time } & \text { Calcium } & \text { Total dissolved solids } \\ \text { Air temperature } & \text { Total alkalinity } & \text { Magnesium } & \text { Total organic carbon } \\ \text { Date } & \text { Turbidity } & \text { Potassium } & \text { Total organic halogens } \\ \text { Depth to water } & \text { Volume purged } & \text { Silica } & \text { Total phosphates (as P) } \\ \text { Flow rate } & \text { Water temperature } & \text { Manganese } & \text { Tritium }\end{array}$

\section{Scheduling Based on Flagging Levels}

Only the flagging criteria for environmental screening and GC VOA (see Glossary) are used to trigger scheduling. Wells are grouped for scheduling by monitoring site or by the investigation for which they are sampled. Specitic criteria for Flag 1 and Flag 2 designations are found in the Flagging Criteria section of this report. 
Beginning in 1996, only wells in the environmental-screening program were scheduled by flagging criteria once a year. Constituents classified as Flag 0 in each well series are scheduled for analyses only by custodian request or as part of the triennial environmental-screening program. If an analytical result for an environmentalscreening or GC VOA analysis in any well exceeds Flag 2 or Flag 1, the environmental-screening wells in the same monitoring series are sampled and analyzed for that constituent once a year. If a constituent falls below Flag 2 for three consecutive sampling events, the individual well's flag is reduced from Flag 2 status to Flag 1 or Flag 0 status, depending on the results, and the well is scheduled according to the lower flag. If a constituent falls below Flag 1 for three consecutive sampling events, the individual well's flag is reduced from Flag 1 status to Flag 0 status, and the flagging-based sampling ceases.

If an environmental-screening or GC VOA constituent has ever been flagged in a well series, it automatically is flagged for all new wells of that series that are designated as environmental-screening wells. The rules previously referred to also apply to removal of a flag from a new well.

When one or more of the five constituents in the GC VOA suite are flagged, the entire suite is scheduled for analysis. The GC VOA suite includes the following: carbon tetrachloride, chloroform, tetrachloroethylene, 1,1,1-trichloroethane, and trichloroethylene.

The following constituents are exceptions to the flagging rules but still receive analyses by custodian request or during triennial environmental-screening analyses:

- Specific conductance and $\mathrm{pH}$, two indicator constituents, have flagging criteria but do not trigger the scheduling mechanism.

- No flags are set for the following indicator parameters and major cations: alkalinity, 5-day biochemical oxygen demand, calcium, carbonate, chemical oxygen demand, magnesium, potassium, silica, sodium, total dissolved solids, total phosphates (as P), and total phosphorus.

- Aesthetic analyses such as color, odor, corrosivity, Eh, turbidity, and surfactants will not be assigned flagging criteria but may be analyzed by special request.

- Common laboratory contaminants and cleaners including phthalates, dichloromethane (methylene chloride), ketones, and toluene are not assigned flagging criteria unless they have primary drinking water standards. These constituents may be analyzed by special request.

\section{GCMS VOA ANALYSES}

All wells are reviewed for total organic halogens (TOH) results twice a year. GCMS VOA (see Glossary) is scheduled once for individual wells that are designated as environmental-screening wells, have had two results for TOH greater than $10 \mu \mathrm{g} / \mathrm{L}$ (excluding the first TOH analysis), and have never received GCMS VOA analysis.

\section{SAMPLING REQUESTS}

Many analyses are scheduled at the request of various SRS groups. The person or group requesting an analysis must submit a formal sampling request form to EPD/EMS. If the request is within the scope of the Groundwater Monitoring Program, and if provision for the analysis has been made in the current laboratory contract, the analysis is added to the sampling schedule. Likewise, if a sampling request should be deleted, the originator of the request must submit a deletion form.

\section{Regulatory Requirements}

All regulatory sampling requirements, such as those mandated by the Resource Conservation and Recovery Act (RCRA), are scheduled by request.

\section{Changes in Sampling}

For changes in sampling for second quarter 1999, please refer to The Savannah River Site's Groundwater Monitoring Program 1999 Sampling Schedule. 
The following RCRA Facility Investigation/Remedial Investigation (RFI/RI) and South Carolina Department of Health and Environmental Control (SCDHEC) projects were in process during second quarter 1999:

- F- and H-Area Seepage Basins

- F- and H-Area Water Treatment Unit Injection Tanks

- M-Area Hazardous Waste Management Facility

- Mixed Waste Management Facility

- Old Burial Ground

- Sanitary Landfill

\section{CERCLA Projects}

The following Comprehensive Environmental Response, Compensation, and Liability Act (CERCLA) projects were either in process or new during second quarter 1999:

- C-Area Reactor Seepage Basin

- Central Shops Sewage Sludge Lagoon

- 488-D Ash Basin and D-Area Coal Pile Runoff Basin Operable Unit

- D-Area Burning/Rubble Pits

- D-Area Oil Seepage Basin

- K-Area Coal Pile Runoff Containment Basin

- P-Area Reactor Seepage Basin

- R-Area Reactor Seepage Basin

- Silverton Road Waste Unit

- TNXArea

\section{NEW WELLS SCHEDULED FOR SAMPLING}

The following wells were scheduled for sampling for the first time during second quarter 1999: wells CSL 21D, 22D, 23D, 24D, 25D, 26D, and 27D; DCB 33A; and TNX 61D, 61M, 61S, 65D, 65M, 65S, 66D, 66M, 66S, 72D, $72 \mathrm{M}$, and $72 \mathrm{~S}$. All data collected from them were subjected to standard verification and validation processes and are presented in the Analytical Results table in Appendix B of this report. In addition, wells MSB 90C, 90TB, 91C, 91TB, and 92C were scheduled for sampling for the first time during second quarter. Data collected from these wells were not subjected to standard verification and validation processes and are therefore presented separately in the Analytical and Sampling Blanks Results for MSB Wells table presented in Appendix D of this report.

\section{DRY WELLS}

Chains for the following wells were returned for second quarter 1999 because the wells were dry: TNX 61D, $61 \mathrm{M}, 61 \mathrm{~S}, 65 \mathrm{M}, 65 \mathrm{~S}, 66 \mathrm{D}, 66 \mathrm{M}, 66 \mathrm{~S}, 72 \mathrm{D}, 72 \mathrm{M}$, and $72 \mathrm{~S}$. All of these wells were placed on the schedule for sampling during third quarter 1999. 


\section{PURGE-WATER CONTAINMENT PROGRAM}

Beginning in 1991, a purge-water containment program was partially implemented to dispose properly of the water purged from certain wells before sampling. According to the Investigation-Derived Waste Management Plan (WSRC, 1995), additional wells were identified for purge-water treatment at the M-1 Air Stripper and the $\mathrm{F}$ - and $\mathrm{H}$-Area Effluent Treatment Facility. The program has been implemented, and no well that was scheduled for analysis as part of the Groundwater Monitoring Program during second quarter 1999 was not sampled. 


\section{Field Notes}

A sampler may visit a well to collect field data, collect samples, and/or measure depth to water. A well may be visited multiple times during a quarter for any combination of these reasons. Field measurements generally include air temperature, depth to water prior to pumping, dissolved oxygen, Eh (REDOX potential), flow rate, $\mathrm{pH}$, phenolphthalein alkalinity, specific conductance, total alkalinity, turbidity, volume of water purged prior to sampling, and water temperature.

EPD/EMS personnel and RCS Corporation of Aiken, SC, performed well visitations during second quarter 1999. Each sampler maintained a field notebook. These notebooks are in the second quarter 1999 section of the EPD/EMS Groundwater Monitoring Library. All well visitations were routine during second quarter 1999, except as indicated in table 3 . The table includes samplers' comments on conditions that may affect the samples or the data-collection process. The majority of wells sampled during second quarter 1999 were pumped. Bailed wells are listed in table 66 in the Quality Control Samples section.

If a well pumps or is bailed dry during purging and is revisited and sampled within 24 hours, this is considered one sampling event yielding a single set of field and analytical data. For such wells, table 3 lists the volume purged before the well went dry during the first visitation. The Analytical Results section gives the total amount of water purged from each well in one sampling event.

Comments about dry wells and continuously pumping wells are in the Analytical Results section.
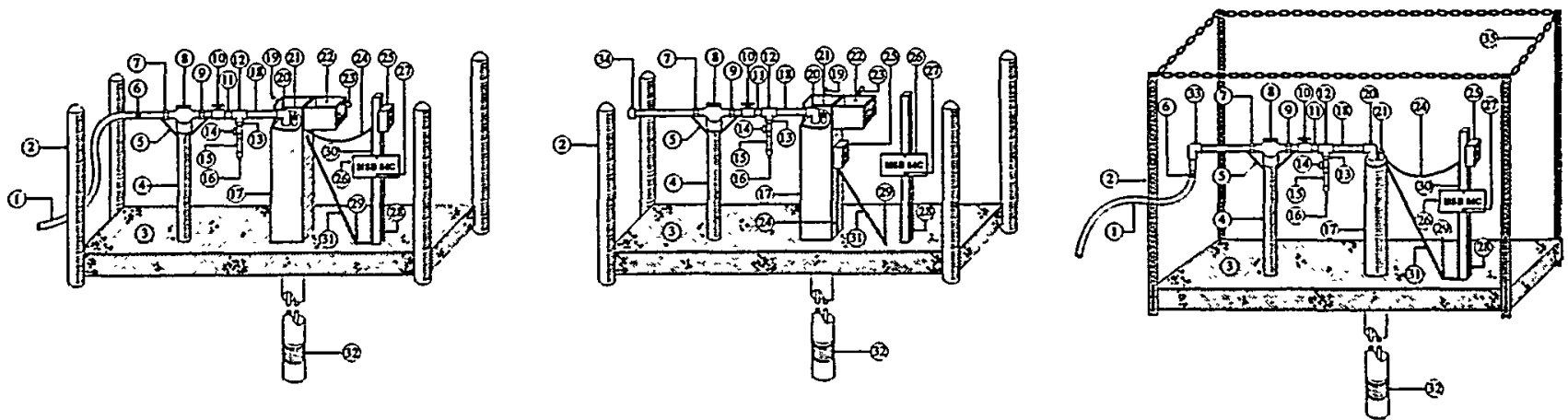

\footnotetext{
1. Water discharge hose

2. Protective or delineator post

3. Concrete pad

4. Fowmeter support post

5. Flowmeter tie down

6. Hose clamp

7. Fowmeter connector
}
8. Flowmeter
9. Flowmeter connector
10. Gate or ball valve
11. Nipple
12. Sampling tee
13. Bushing
14. Sample cock
15. Sample nipple
16. Sample nipple cap
17. Protective casing
18. Nipple
19. Hasp
20. Riser pipe elbow
21. Liquid level pipe cap

22. Protective casing lid

23. Lock

24. Electrical conduit

25. Electrical box

26. Well identification sign

27. Sign bolt

28. Mounting post
29. Grounding rod 30. Grounding wire

31. Security cable

32. Pump

33. Elbow

34. Quick disconnec

35. Yellow chain

Figure 3. Three Types of Groundwater Monitoring Wellheads 
Table 3. Comments from the Field Data

\begin{tabular}{|c|c|c|}
\hline Well & Date & Comments \\
\hline \multicolumn{3}{|l|}{ BGO Series } \\
\hline \multirow[t]{2}{*}{ BGO 2D } & $05 / 18 / 99$ & $\begin{array}{l}\text { No water in standpipe; pump not receiving power, unable } \\
\text { to sample }\end{array}$ \\
\hline & $06 / 21 / 99$ & No water in standpipe \\
\hline $\mathrm{BGO} 3 \mathrm{C}$ & $05 / 18 / 99$ & Dry after $19 \mathrm{gal}$ \\
\hline BGO 4D & $05 / 18 / 99$ & Dry after 3 gal \\
\hline BGO 5C & $05 / 18 / 99$ & Dry after $24 \mathrm{gal}$ \\
\hline BGO $5 D$ & $05 / 24 / 99$ & Dry after $8 \mathrm{gal}$ \\
\hline BGO $6 B$ & $05 / 18 / 99$ & Dry after $39 \mathrm{gal}$ \\
\hline BGO 6D & $05 / 24 / 99$ & Dry after $9 \mathrm{gal}$ \\
\hline \multirow[t]{3}{*}{ BGO BAR } & $05 / 18 / 99$ & $\begin{array}{l}\text { Not sampled due to mechanical problems; needs } \\
\text { maintenance }\end{array}$ \\
\hline & 06/04/99 & $\begin{array}{l}\text { Dry after } 42 \text { gal; flow rate too slow for meter to spin; all } \\
\text { samples not collected }\end{array}$ \\
\hline & 06/07/99 & $\begin{array}{l}\text { No water to surface; unable to sample, needs } \\
\text { maintenance }\end{array}$ \\
\hline BGO 10C & $05 / 17 / 99$ & Dry after 38 gal \\
\hline BGO 10DR & 05/06/99 & Dry after $3 \mathrm{gal}$ \\
\hline BGO 13DR & $05 / 20 / 99$ & Dry after 6 gal \\
\hline BGO 14CR & $05 / 25 / 99$ & Dry after $14 \mathrm{gal}$ \\
\hline $\mathrm{BGO} 16 \mathrm{~B}$ & $05 / 18 / 99$ & Dry after 43 gal \\
\hline BGO 16D & $05 / 18 / 99$ & Dry after 3 gal \\
\hline \multirow{4}{*}{ BGO 2OD } & $05 / 20 / 99$ & Dry after $14 \mathrm{gal}$ \\
\hline & $04 / 14 / 99$ & Dry after 9 gal \\
\hline & 05/19/99 & Dry after $9 \mathrm{gal}$ \\
\hline & $06 / 14 / 99$ & Dry after $7 \mathrm{gal}$ \\
\hline $\begin{array}{l}\text { BGO 21D } \\
\text { BGO 24D }\end{array}$ & $05 / 19 / 99$ & Dry after 7 gal \\
\hline \multirow{4}{*}{ BGO 33D } & $05 / 19 / 99$ & Dry after 7 gal \\
\hline & $\begin{array}{l}04 / 13 / 99 \\
05 / 17 / 99\end{array}$ & $\begin{array}{l}\text { Dry after } 7 \text { gal } \\
\text { Dry after } 8 \text { gal }\end{array}$ \\
\hline & $06 / 14 / 99$ & Dry after 6 gal \\
\hline & $06 / 15 / 99$ & Dry after 2 gal; pumped dry while trying to lower turbidity \\
\hline \multirow[t]{3}{*}{ BGO 34D } & $04 / 13 / 99$ & Dry after 8 gal \\
\hline & $05 / 17 / 99$ & Dry after $10 \mathrm{gal}$ \\
\hline & $06 / 14 / 99$ & Dry after $10 \mathrm{gal}$ \\
\hline \multirow[t]{3}{*}{ BGO 35D } & $04 / 13 / 99$ & Dry after $5 \mathrm{gal}$ \\
\hline & 05/17/99 & Dry after 6 gal \\
\hline & $06 / 14 / 99$ & Dry after $6 \mathrm{gal}$ \\
\hline \multirow[t]{3}{*}{ BGO 36D } & $04 / 13 / 99$ & Dry after $7 \mathrm{gal}$ \\
\hline & $05 / 17 / 99$ & Dry after $7 \mathrm{gal}$ \\
\hline & $06 / 14 / 99$ & Dry after $7 \mathrm{gal}$ \\
\hline \multirow[t]{3}{*}{ BGO $37 D$} & $04 / 13 / 99$ & Dry after $4 \mathrm{gal}$ \\
\hline & $05 / 20 / 99$ & Dry after $5 \mathrm{gal}$ \\
\hline & $06 / 14 / 99$ & Dry after 4 gal \\
\hline \multirow[t]{3}{*}{ BGO 38D } & $04 / 13 / 99$ & Dry after 8 gal \\
\hline & $05 / 17 / 99$ & Dry after $7 \mathrm{gal}$ \\
\hline & $06 / 14 / 99$ & Dry after 9 gal \\
\hline \multirow[t]{3}{*}{ BGO 39D } & $04 / 14 / 99$ & Dry after $5 \mathrm{gal}$ \\
\hline & $05 / 17 / 99$ & Dry after 4 gal \\
\hline & $06 / 14 / 99$ & Dry after $4 \mathrm{gal}$ \\
\hline \multirow[t]{3}{*}{ BGO 49D } & 04/13/99 & Dry after 7 gal; no water in standpipe \\
\hline & $05 / 17 / 99$ & Dry after $8 \mathrm{gal}$; no water in standpipe \\
\hline & $06 / 14 / 99$ & Dry after 6 gal; no water in standpipe \\
\hline \multirow[t]{2}{*}{ BGO 51D } & $04 / 14 / 99$ & Dry after $1 \mathrm{gal}$ \\
\hline & $\begin{array}{l}05 / 18 / 99 \\
06 / 14 / 99\end{array}$ & $\begin{array}{l}\text { Dry after } 2 \text { gal } \\
\text { Dry after } 1 \mathrm{gal}\end{array}$ \\
\hline
\end{tabular}




\begin{tabular}{|c|c|c|}
\hline Well & Date & Comments' \\
\hline BGO 52D & $\begin{array}{l}04 / 14 / 99 \\
05 / 19 / 99 \\
06 / 14 / 99\end{array}$ & $\begin{array}{l}\text { Dry after } 2 \mathrm{gal} \\
\text { Dry after } 1 \mathrm{gal} \\
\text { Dry after } 1 \mathrm{gal}\end{array}$ \\
\hline \multicolumn{3}{|c|}{ BRR Series } \\
\hline BRR 5D & $06 / 07 / 99$ & Dry after $6 \mathrm{gal}$ \\
\hline \multicolumn{3}{|c|}{ CCB Series } \\
\hline $\operatorname{CCB} 4$ & 06/08/99 & $\begin{array}{l}\text { Not sampled due to mechanical problems; needs } \\
\text { maintenance }\end{array}$ \\
\hline \multicolumn{3}{|c|}{ CDB Series } \\
\hline $\begin{array}{l}\text { CDB } 1 \\
\text { CDB } 2\end{array}$ & $\begin{array}{l}06 / 08 / 99 \\
06 / 08 / 99\end{array}$ & $\begin{array}{l}\text { Dry after } 12 \mathrm{gal} \\
\text { Dry after } 18 \mathrm{gal}\end{array}$ \\
\hline \multicolumn{3}{|c|}{ CMP Series } \\
\hline CMP 11D & $06 / 08 / 99$ & Dry after 6 gal \\
\hline \multicolumn{3}{|c|}{ CRP Series } \\
\hline $\begin{array}{l}\text { CRP 5D } \\
\text { CRP 11D }\end{array}$ & $\begin{array}{l}06 / 08 / 99 \\
06 / 04 / 99\end{array}$ & $\begin{array}{l}\text { Dry after } 2 \text { gal } \\
\text { Well partially removed; not sampled }\end{array}$ \\
\hline \multicolumn{3}{|c|}{ CSB Series } \\
\hline $\begin{array}{l}\operatorname{CSB} 1 A \\
\operatorname{CSB} 2 A\end{array}$ & $\begin{array}{l}06 / 08 / 99 \\
06 / 08 / 99\end{array}$ & $\begin{array}{l}\text { Dry after } 8 \mathrm{gal} \\
\text { Dry after } 6 \mathrm{gal} \text {; flowmeter broken }\end{array}$ \\
\hline \multicolumn{3}{|c|}{ CSD Series } \\
\hline CSD 1D & 06/08/99 & $\begin{array}{l}\text { Not sampled due to mechanical problems; needs } \\
\text { maintenance }\end{array}$ \\
\hline \multicolumn{3}{|c|}{ CSL Series } \\
\hline $\begin{array}{l}\operatorname{CSL} 25 \\
\operatorname{CSL} 26 \\
\operatorname{CSL} 27\end{array}$ & $\begin{array}{l}04 / 13 / 99 \\
04 / 13 / 99 \\
04 / 13 / 99 \\
04 / 15 / 99\end{array}$ & $\begin{array}{l}\text { Dry after } 6 \text { gal } \\
\text { Pump overloads box; unable to sample } \\
\text { Dry after } 2 \text { gal } \\
\text { Dry after } 2 \text { gal }\end{array}$ \\
\hline \multicolumn{3}{|c|}{ DBP Series } \\
\hline DBP 1 & 04/13/99 & Flowmeter broken, flow rate estimated \\
\hline \multicolumn{3}{|c|}{ DCB Series } \\
\hline DCB 27 & $\begin{array}{l}05 / 10 / 99 \\
05 / 12 / 99\end{array}$ & $\begin{array}{l}\text { Could not sample because turbidity would not fall below } \\
15 \text { NTU } \\
\text { Well could not stabilize due to turbidity, sample was } \\
\text { pulled at } 33.0 \text { NTU }\end{array}$ \\
\hline DCB 30 & $\begin{array}{l}05 / 10 / 99 \\
05 / 11 / 99 \\
05 / 12 / 99\end{array}$ & $\begin{array}{l}\text { Dry after } 4 \mathrm{gal} \\
\text { Dry after } 12 \text { gal } \\
\text { Dry after } 1 \mathrm{gal} \text {; high turbidity }\end{array}$ \\
\hline \multicolumn{3}{|c|}{ DOB Series } \\
\hline DOB 12 & 06/03/99 & Flowmeter stopped working; purged through sample port \\
\hline \multicolumn{3}{|c|}{ FAB Series } \\
\hline $\begin{array}{l}\text { FAB } 2 \\
\text { FAB } 3\end{array}$ & $\begin{array}{l}06 / 10 / 99 \\
06 / 10 / 99 \\
06 / 15 / 99\end{array}$ & $\begin{array}{l}\text { Dry after } 13 \text { gal } \\
\text { Dry after } 9 \text { gal } \\
\text { Dry after } 12 \text { gal }\end{array}$ \\
\hline
\end{tabular}

\section{Field Notes}




\begin{tabular}{|c|c|c|}
\hline Well & Date & Comments \\
\hline FAB 4 & 06/10/99 & Dry after $38 \mathrm{gal}$ \\
\hline \multicolumn{3}{|l|}{ FBP Series } \\
\hline $\begin{array}{l}\text { FBP 3A } \\
\text { FBP 6D } \\
\text { FBP 10D }\end{array}$ & $\begin{array}{l}06 / 14 / 99 \\
06 / 14 / 99 \\
06 / 15 / 99\end{array}$ & $\begin{array}{l}\text { Well not sampled because pump is broken } \\
\text { Dry after } 5 \text { gal } \\
\text { High turbidity }\end{array}$ \\
\hline \multicolumn{3}{|l|}{ FCB Series } \\
\hline FCB 5 & $06 / 15 / 99$ & Dry after $5 \mathrm{gal}$ \\
\hline \multicolumn{3}{|l|}{ FSB Series } \\
\hline $\begin{array}{l}\text { FSB } 78 C \\
\text { FSB } 79\end{array}$ & $\begin{array}{l}04 / 09 / 99 \\
04 / 07 / 99\end{array}$ & $\begin{array}{l}\text { Dry after } 18 \mathrm{gal} \\
\text { Pump broken, control box display "Ground Fault;" unable } \\
\text { to sample }\end{array}$ \\
\hline FSB 87D & $\begin{array}{l}04 / 06 / 99 \\
04 / 26 / 99\end{array}$ & $\begin{array}{l}\text { No water in standpipe; needs maintenance, unable to } \\
\text { sample } \\
\text { No water in standpipe }\end{array}$ \\
\hline FSB 9OD & $04 / 08 / 99$ & $\begin{array}{l}\text { Dry after } 5 \text { gal; no water in standpipe } \\
\text { No water in standpipe }\end{array}$ \\
\hline $\begin{array}{l}\text { FSB 91C } \\
\text { FSB 93D } \\
\text { FSB 94C } \\
\text { FSB 97D } \\
\text { FSB 98C } \\
\text { FSB 98D } \\
\text { FSB106D }\end{array}$ & $\begin{array}{l}04 / 06 / 99 \\
04 / 12 / 99 \\
04 / 09 / 99 \\
04 / 07 / 99 \\
04 / 05 / 99 \\
05 / 04 / 99 \\
04 / 12 / 99 \\
04 / 19 / 99 \\
04 / 20 / 99\end{array}$ & $\begin{array}{l}\text { Dry after } 30 \mathrm{gal} \\
\text { Dry after } 3 \mathrm{gal} \\
\text { Dry after } 8 \mathrm{gal} \\
\text { Dry after } 9 \mathrm{gal} \\
\text { Unable to sample; ground fault occurred } \\
\text { Dry after } 5 \mathrm{gal} \\
\text { Dry after } 2 \mathrm{gal} \text {; no water in standpipe } \\
\text { Dry after } 1 \mathrm{gal} \text {; no water in standpipe } \\
\text { Dry after } 5 \mathrm{gal} \text {; no water in standpipe; purged } 5 \mathrm{gal} \\
\text { through sample port to lower turbidity }\end{array}$ \\
\hline $\begin{array}{l}\text { FSB107D } \\
\text { FSB108D } \\
\text { FSB113A } \\
\text { FSB115C } \\
\text { FSB116D } \\
\text { FSB117D }\end{array}$ & $\begin{array}{l}04 / 26 / 99 \\
04 / 08 / 99 \\
04 / 12 / 99 \\
04 / 05 / 99 \\
04 / 05 / 99 \\
04 / 06 / 99 \\
04 / 09 / 99\end{array}$ & $\begin{array}{l}\text { Dry after } 1 \mathrm{gal} \text {; no water in standpipe } \\
\text { Unable to sample; control box displays "Ground Fault" } \\
\text { Dry after } 8 \mathrm{gal} \\
\text { Dry after } 40 \mathrm{gal} \\
\text { Dry after } 18 \mathrm{gal} \\
\text { Dry after } 1 \mathrm{gal} \\
\text { Riser-pipe elbow broken; well was repaired same day and } \\
\text { sampled }\end{array}$ \\
\hline $\begin{array}{l}\text { FSB119D } \\
\text { FSB120A } \\
\text { FSB120D } \\
\text { FSB121DR }\end{array}$ & $\begin{array}{l}04 / 08 / 99 \\
04 / 09 / 99 \\
04 / 06 / 99 \\
04 / 06 / 99 \\
04 / 07 / 99\end{array}$ & $\begin{array}{l}\text { Dry after } 7 \mathrm{gal} \\
\text { High turbidity, all samples collected } \\
\text { Dry after } 41 \mathrm{gal} \\
\text { Dry after } 8 \mathrm{gal} \\
\text { Dry after } 10 \mathrm{gal}\end{array}$ \\
\hline \multicolumn{3}{|l|}{ FSL Series } \\
\hline $\begin{array}{l}\text { FSL 1D } \\
\text { FSL 2D } \\
\text { FSL 4D } \\
\text { FSL 7D } \\
\text { FSL 8D } \\
\text { FSL 9D }\end{array}$ & $\begin{array}{l}04 / 28 / 99 \\
04 / 12 / 99 \\
04 / 12 / 99 \\
04 / 07 / 99 \\
04 / 07 / 99 \\
04 / 07 / 99\end{array}$ & $\begin{array}{l}\text { Dry after } 1 \mathrm{gal} \\
\text { Dry after } 7 \mathrm{gal} \\
\text { Dry after } 1 \mathrm{gal} \\
\text { Dry after } 1 \mathrm{gal} \\
\text { Dry after } 2 \mathrm{gal} \\
\text { Dry after } 6 \mathrm{gal}\end{array}$ \\
\hline \multicolumn{3}{|l|}{ HR3 Series } \\
\hline HR3 14DU & 06/02/99 & Dry after $7 \mathrm{gal}$ \\
\hline
\end{tabular}




\begin{tabular}{|c|c|c|}
\hline Well & Date & Comments \\
\hline \multicolumn{3}{|c|}{ HSB Series } \\
\hline $\begin{array}{l}\text { HSB 68 } \\
\text { HSB 68C } \\
\text { HSB 70C } \\
\text { HSB 71C } \\
\text { HSB 84A }\end{array}$ & $\begin{array}{l}04 / 12 / 99 \\
04 / 26 / 99 \\
04 / 26 / 99 \\
04 / 26 / 99 \\
04 / 13 / 99\end{array}$ & $\begin{array}{l}4 \text { gal purged through sample port to lower turbidity } \\
\text { Dry after } 19 \text { gal } \\
\text { Dry after } 25 \text { gal } \\
\text { Dry after } 20 \text { gal } \\
\text { Box was overloading and tripping breaker, unable to } \\
\text { sample }\end{array}$ \\
\hline HSB 84B & $04 / 13 / 99$ & $\begin{array}{l}\text { Flowmeter broken, will not spin; estimated flow rate in } 3 \text { - } \\
\text { gal pail at } 2.5 \text { gal per min }\end{array}$ \\
\hline $\begin{array}{l}\text { HSB 84C } \\
\text { HSB 85B } \\
\text { HSB102D }\end{array}$ & $\begin{array}{l}04 / 13 / 99 \\
04 / 21 / 99 \\
04 / 13 / 99\end{array}$ & $\begin{array}{l}\text { Dry after } 14 \mathrm{gal} \\
\text { Dry after } 45 \mathrm{gal} \\
\text { Dry after } 3 \text { gal; not enough water volume to make meter } \\
\text { spin, volume purged estimated }\end{array}$ \\
\hline $\begin{array}{l}\text { HSB107D } \\
\text { HSB108D }\end{array}$ & $\begin{array}{l}04 / 13 / 99 \\
04 / 13 / 99\end{array}$ & $\begin{array}{l}\text { Flowmeter broken, volume purged estimated } \\
\text { Flow rate too slow for meter to spin, volume purged } \\
\text { estimated }\end{array}$ \\
\hline $\begin{array}{l}\text { HSB109C } \\
\text { HSB109D } \\
\text { HSB110C } \\
\text { HSB112E } \\
\text { HSB113D } \\
\text { HSB114D } \\
\text { HSB115D }\end{array}$ & $\begin{array}{l}04 / 19 / 99 \\
04 / 13 / 99 \\
04 / 19 / 99 \\
04 / 26 / 99 \\
04 / 20 / 99 \\
04 / 20 / 99 \\
04 / 20 / 99 \\
04 / 21 / 99\end{array}$ & $\begin{array}{l}\text { Flowmeter broken, flow rate and volume purged estimated } \\
\text { Dry after } 1 \text { gal; no water in standpipe } \\
\text { Dry after } 13 \mathrm{gal} \\
\text { Dry after } 4 \mathrm{gal} \text {, no water in standpipe } \\
\text { Dry after } 2 \mathrm{gal} \\
\text { No power to the pump, unable to sample } \\
\text { Dry after } 2 \mathrm{gal} \\
\text { Purged } 10 \mathrm{gal} \text { through sample port to lower turbidity }\end{array}$ \\
\hline $\begin{array}{l}\text { HSB123A } \\
\text { HSB126D } \\
\text { HSB129C } \\
\text { HSB132C } \\
\text { HSB136C } \\
\text { HSB137C } \\
\text { HSB138D } \\
\text { HSB139C } \\
\text { HSB141A } \\
\text { HSB141D } \\
\text { HSB142D } \\
\text { HSB147D } \\
\text { HSB148C } \\
\text { HSB148D } \\
\text { HSB150D } \\
\text { HSB152D }\end{array}$ & $\begin{array}{l}04 / 21 / 99 \\
04 / 19 / 99 \\
04 / 26 / 99 \\
04 / 20 / 99 \\
04 / 26 / 99 \\
04 / 26 / 99 \\
04 / 22 / 99 \\
04 / 26 / 99 \\
04 / 15 / 99 \\
04 / 15 / 99 \\
04 / 15 / 99 \\
04 / 22 / 99 \\
04 / 21 / 99 \\
04 / 21 / 99 \\
04 / 21 / 99 \\
04 / 23 / 99\end{array}$ & $\begin{array}{l}\text { Dry after } 21 \mathrm{gal} \\
\text { Dry after } 8 \mathrm{gal} \\
\text { Dry after } 28 \mathrm{gal} \\
\text { Dry after } 41 \mathrm{gal} \\
\text { Dry after } 22 \mathrm{gal} \\
\text { Dry after } 26 \mathrm{gal} \\
\text { Dry after } 4 \mathrm{gal} \\
\text { Dry after } 27 \mathrm{gal} \\
\text { Dry after } 84 \mathrm{gal} \\
\text { Dry after } 22 \mathrm{gal} \\
\text { Dry after } 2 \mathrm{gal} \\
\text { Dry after } 7 \mathrm{gal} \\
\text { Dry after } 22 \mathrm{gal} \\
\text { Dry after } 4 \mathrm{gal} \\
\text { Dry after } 12 \mathrm{gal} \\
\text { Dry after } 4 \mathrm{gal} ; \text { no water in standpipe }\end{array}$ \\
\hline \multicolumn{3}{|c|}{ HSL Series } \\
\hline HSL 7D & $04 / 23 / 99$ & Dry after 5 gal \\
\hline \multicolumn{3}{|l|}{ IDP Series } \\
\hline IDP 10 & $06 / 30 / 99$ & No water in standpipe; pump is broken, unable to sample \\
\hline \multicolumn{3}{|c|}{ KBP Series } \\
\hline $\begin{array}{l}\text { KBP 1D } \\
\text { KBP 2D }\end{array}$ & $\begin{array}{l}06 / 17 / 99 \\
06 / 16 / 99\end{array}$ & $\begin{array}{l}\text { Dry after } 5 \text { gal } \\
\text { Dry after } 1 \text { gal }\end{array}$ \\
\hline \multicolumn{3}{|c|}{ KСB Series } \\
\hline KCB 5 & $05 / 13 / 99$ & Dry after $6 \mathrm{gal}$ \\
\hline \multicolumn{3}{|c|}{ KDB Series } \\
\hline KDB 1 & $\begin{array}{l}04 / 27 / 99 \\
05 / 21 / 99 \\
06 / 21 / 99\end{array}$ & $\begin{array}{l}\text { Dry after } 5 \text { gal; purged } 1 \text { gal through sample port } \\
\text { Dry after } 15 \mathrm{gal} \\
\text { Dry after } 16 \mathrm{gal}\end{array}$ \\
\hline
\end{tabular}




\begin{tabular}{|c|c|c|}
\hline Well & Date & Comments \\
\hline $\begin{array}{l}\mathrm{KDB} 3 \\
\mathrm{KDB} 4\end{array}$ & $\begin{array}{l}04 / 27 / 99 \\
05 / 21 / 99 \\
06 / 21 / 99 \\
04 / 27 / 99\end{array}$ & $\begin{array}{l}\text { Dry after } 17 \mathrm{gal} \\
\text { Dry after } 15 \mathrm{gal} \\
\text { Dry after } 19 \mathrm{gal} \\
\text { Dry after } 4 \mathrm{gal} \text {; no water in standpipe; depth to water not } \\
\text { recorded, tape hit top of pump; purged } 1 \mathrm{gal} \text { through } \\
\text { sample port }\end{array}$ \\
\hline KDB 5 & $\begin{array}{l}05 / 21 / 99 \\
06 / 21 / 99 \\
04 / 27 / 99 \\
05 / 21 / 99 \\
06 / 21 / 99\end{array}$ & $\begin{array}{l}\text { Dry after } 5 \mathrm{gal} \text {; no water in standpipe; flowmeter does not } \\
\text { work } \\
\text { Dry after } 5 \mathrm{gal} \text {; no water in standpipe } \\
\text { Dry after } 7 \mathrm{gal} \\
\text { Dry after } 7 \mathrm{gal} \\
\text { Dry after } 8 \mathrm{gal}\end{array}$ \\
\hline \multicolumn{3}{|c|}{ LBP Series } \\
\hline LBP 1D & $06 / 16 / 99$ & Dry after 2 gal \\
\hline \multicolumn{3}{|c|}{ LDB Series } \\
\hline LDB 1 & $04 / 27 / 99$ & $\begin{array}{l}\text { Dry after } 20 \text { gal; flowmeter on backwards, will repair after } \\
\text { sampling } \\
\text { Well not samoled needs plumbina }\end{array}$ \\
\hline LDB 2 & $\begin{array}{l}04 / 27 / 99 \\
05 / 21 / 99 \\
06 / 21 / 99\end{array}$ & $\begin{array}{l}\text { Dry after } 24 \mathrm{gal} \\
\text { Dry after } 18 \mathrm{gal} \\
\text { Dry after } 23 \mathrm{gal}\end{array}$ \\
\hline LDB 3 & $04 / 27 / 99^{\circ}$ & $\begin{array}{l}\text { Well not accessible, roped off for walking path } \\
\text { construction, unable to sample }\end{array}$ \\
\hline LDB 4 & $\begin{array}{l}04 / 27 / 99 \\
05 / 21 / 99 \\
06 / 21 / 99\end{array}$ & $\begin{array}{l}\text { Dry after } 6 \mathrm{gal} \\
\text { Dry after } 7 \mathrm{gal} \\
\text { Dry after } 8 \text { gal }\end{array}$ \\
\hline
\end{tabular}

LFW Series

LFW 30

05/05/99

$06 / 07 / 99$

LFW 60D

$06 / 07 / 99$

RSA Series

RSA 7

$05 / 14 / 99$

05/26/99

$05 / 27 / 99$

$06 / 16 / 99$

RSA 8

$05 / 13 / 99$

$05 / 14 / 99$

$06 / 16 / 99$

Pipe broken, unable to sample

Dry after $16 \mathrm{gal}$

Dry after 6 gal

RSD Series

RSD 1

$05 / 13 / 99$

$05 / 14 / 99$

$06 / 16 / 99$

RSD 3

$05 / 13 / 99$

$06 / 16 / 99$

No water in standpipe; wrong plug for electrical box, unable to sample

Dry after 2 gal; no water in standpipe

No water in standpipe

Dry after 4 gal; no water in standpipe

Dry after 6 gal; no water in standpipe

No water in standpipe

Dry after 10 gal; no water in standpipe

Dry after $17 \mathrm{gal}$

Dry after $5 \mathrm{gal}$

Dry after 6 gal; well went dry after 1 gal trying to lower turbidity

Dry after $29 \mathrm{gal}$

Dry after $4 \mathrm{gal}$

RSE Series

RSE 1A

$05 / 14 / 99$

$06 / 16 / 99$

RSE 2

$05 / 13 / 99$

$06 / 16 / 99$

Dry after $6 \mathrm{gal}$

Pump will not operate; unable to sample

Dry after $8 \mathrm{gal}$

Dry after $6 \mathrm{gal}$ 


\begin{tabular}{|c|c|c|}
\hline Well & Date & Comments \\
\hline RSE 7 & $\begin{array}{l}05 / 13 / 99 \\
06 / 16 / 99\end{array}$ & $\begin{array}{l}\text { Dry after } 2 \text { gal } \\
\text { Dry after } 7 \mathrm{gal} \text {; well want dry after } 1 \mathrm{gal} \text { trying to lower } \\
\text { turbidity }\end{array}$ \\
\hline ASE 8 & $\begin{array}{l}05 / 13 / 99 \\
06 / 16 / 99\end{array}$ & $\begin{array}{l}\text { Dry after } 20 \mathrm{gal} \\
\text { Dry after } 12 \mathrm{gal}\end{array}$ \\
\hline \multicolumn{3}{|c|}{ RWM Series } \\
\hline $\begin{array}{l}\text { RWM } 1 \\
\text { RWM } 2 \\
\text { RWM } 3 \\
\text { RWM } 7 \\
\text { RWM } 8 \\
\text { RWM } 9 \\
\text { RWM } 12\end{array}$ & $\begin{array}{l}04 / 14 / 99 \\
05 / 17 / 99 \\
06 / 14 / 99 \\
05 / 17 / 99 \\
06 / 14 / 99 \\
04 / 14 / 99 \\
06 / 14 / 99 \\
06 / 14 / 99 \\
05 / 17 / 99 \\
06 / 14 / 99 \\
06 / 14 / 99\end{array}$ & $\begin{array}{l}\text { No water in standpipe } \\
\text { No water in standpipe } \\
\text { No water in standpipe } \\
\text { No water in standpipe } \\
\text { No water in standpipe } \\
\text { No water in standpipe } \\
\text { No water in standpipe } \\
\text { Flowmeter not working } \\
\text { Well not operating, unable to sample } \\
\text { Well not running, unable to sample } \\
\text { Flowmeter not working }\end{array}$ \\
\hline \multicolumn{3}{|c|}{ SRW Series } \\
\hline $\begin{array}{l}\text { SRW } 8 \\
\text { SRW } 18 \\
\text { SRW } 19\end{array}$ & $\begin{array}{l}05 / 06 / 99 \\
05 / 10 / 99 \\
05 / 12 / 99 \\
05 / 06 / 99 \\
05 / 10 / 99\end{array}$ & $\begin{array}{l}\text { No water in standpipe } \\
\text { Samples not collected due to high turbidity } \\
\text { High turbidity } \\
\text { Dry after } 3 \text { gal } \\
\text { Purged through sample port due to high turbidity }\end{array}$ \\
\hline \multicolumn{3}{|c|}{ TBG Series } \\
\hline $\begin{array}{l}\text { TBG } 3 \\
\text { TBG } 6\end{array}$ & $\begin{array}{l}05 / 07 / 99 \\
05 / 07 / 99\end{array}$ & $\begin{array}{l}\text { Dry after } 10 \mathrm{gal} \\
\text { Dry after } 13 \mathrm{gal}\end{array}$ \\
\hline \multicolumn{3}{|l|}{ TIR Series } \\
\hline $\begin{array}{l}\text { TIR 1L } \\
\text { TIR 1M } \\
\text { TIR } 1 \mathrm{U}\end{array}$ & $\begin{array}{l}05 / 03 / 99 \\
05 / 03 / 99 \\
05 / 07 / 99\end{array}$ & $\begin{array}{l}\text { Sampled with disposable hand-held pump } \\
\text { Sampled with disposable hand-held pump } \\
\text { Sampled with disposable hand-held pump }\end{array}$ \\
\hline \multicolumn{3}{|c|}{ TNX Series } \\
\hline $\begin{array}{l}\text { TNX 1D } \\
\text { TNX 2D } \\
\text { TNX 3D } \\
\text { TNX 4D } \\
\text { TNX 5D } \\
\text { TNX 6D } \\
\text { TNX 7D } \\
\text { TNX 14D } \\
\text { TNX 16D } \\
\text { TNX 18D } \\
\text { TNX 20B } \\
\text { TNX 20D } \\
\text { TNX 24D } \\
\text { TNX 26D } \\
\\
\text { TNX 61D } \\
\text { TNX 61M } \\
\text { TNX 61S } \\
\text { TNX 65D } \\
\text { TNX 65M } \\
\text { TNX 65S } \\
\text { TNX 66D }\end{array}$ & $\begin{array}{l}05 / 04 / 99 \\
05 / 04 / 99 \\
05 / 07 / 99 \\
05 / 04 / 99 \\
05 / 04 / 99 \\
05 / 04 / 99 \\
05 / 04 / 99 \\
05 / 03 / 99 \\
05 / 03 / 99 \\
05 / 03 / 99 \\
05 / 03 / 99 \\
05 / 03 / 99 \\
05 / 05 / 99 \\
05 / 03 / 99 \\
06 / 09 / 99 \\
06 / 17 / 99 \\
06 / 29 / 99 \\
06 / 29 / 99 \\
06 / 29 / 99 \\
06 / 29 / 99 \\
06 / 29 / 99 \\
06 / 29 / 99 \\
06 / 29 / 99\end{array}$ & $\begin{array}{l}\text { Dry after } 12 \mathrm{gal} \\
\text { Dry after } 5 \mathrm{gal} \\
\text { Dry after } 3 \mathrm{gal} \\
\text { Dry after } 6 \mathrm{gal} \\
\text { Dry after } 5 \mathrm{gal} \\
\text { Dry after } 3 \mathrm{gal} \\
\text { Dry after } 11 \mathrm{gal} \\
\text { Sampled with disposable hand-held pump } \\
\text { Sampled with disposable hand-held pump } \\
\text { Sampled with disposable hand-held pump } \\
\text { Sampled with disposable hand-held pump } \\
\text { Sampled with disposable hand-held pump } \\
\text { Purged through sample port due to high turbidity } \\
\text { Sampled with disposable hand-held pump } \\
\text { Disposable pump stopped working, well not sampled } \\
\text { Sampled with disposable hand-held pump } \\
\text { Dry after } 1 \text { gal } \\
\text { Dry after } 1 \text { gal } \\
\text { Not enough water to come to surface } \\
\text { Dry after } 1 \text { gal } \\
\text { No water to surface } \\
\text { Well is dry } \\
\text { No water to surface }\end{array}$ \\
\hline
\end{tabular}

\section{Field Notes}


Well

TNX 66M

TNX 66S

TNX 72D

TNX 72M

TNX 72S

TRW Series

TRW 3

XSB Series

XSB 3A
$04 / 22 / 99$

05/17/99

\section{Date}

$06 / 29 / 99$

$06 / 29 / 99$

$06 / 28 / 99$

$06 / 29 / 99$

$06 / 28 / 99$

$06 / 28 / 99$
Comments

No water to surface

No water to surface

Dry after less than $0.5 \mathrm{gal}$

Not enough water to come to surface

Not enough water to come to surface

No water in standpipe (dry)

No water in standpipe; probe came up dry No water in standpipe

No water in standpipe 


\section{Analytical Data Review}

The SRS Groundwater Monitoring Program evaluates all data systematically to provide high-quality data for reporting on the environmental monitoring and cleanup efforts at SRS. Data verification and validation are continuous, interactive processes, usually completed within 60 days after the last data are received for a quarter.

EX, GE, and WA, the primary contracting laboratories for sample analyses, performed all analyses with the following exceptions:

- The EM Lab at SRS conducted total-activity analyses of samples for shipping clearance. The EM Lab also conducted tritium analyses of samples from specified well series. Data from the EM Lab for second quarter 1999 were not available in time for publication in this report.

- GE subcontracted radionuclide analyses to GP, and WA subcontracted radionuclide analyses to TM. GP and TM conducted gross alpha, nonvolatile beta, tritium, and selected radionuclide analyses.

- ML performed on-site analyses of volatile and semivolatile organics and metals.

\section{GIMS DATA REVIEW MODULE}

The Geochemical Information Management System (GIMS) is a combination of hardware, software, data, and procedures that supports EPD/EMS' data management activities. The GIMS Data Review Module provides automated data loading, validation and verification functions, data editing, determination of data review status, report generation, and data review $Q A$. The data editing program allows users to correct errors in loaded analytical, field, and shipping data. When the review process is complete, data are loaded into the permanent production database tables in GIMS and are available sitewide.

\section{REVIEW OF THE ANALYTICAL DATA}

EPD/EMS reviews analytical data from the laboratories for errors and unusual results before releasing the data for use. The laboratories are asked to review and comment on suspect data.

Typical errors identified during data loading into GIMS include incorrect sample dates, run dates, and sample identifications; incorrectly entered analytical units, methods, and corresponding detection limits; and incorrect dilution factor calculations.

Analytical results that appear different from historical data collected since 1991 are brought to the attention of the appropriate laboratory. Thus, the laboratory is able to identify problems with some of the analyses, including incorrect dilution factor calculations and data entry errors. EPD/EMS corrects data files after receiving written notification from the laboratory. Specific details concerning the corrections are entered in the EMS Groundwater Monitoring Program Changes to the Database Logbook.

Samples that exceeded holding times are indicated by an EPA STORET code $Q$ in the analytical results tables (see Appendix B for further information). The EPA STORET code $V$ is used to indicate sample results associated with method laboratory blanks at the preparation step that are elevated above the instrument detection limit. Samples that were preserved incorrectly are marked with a YEPA STORET code in the analytical results tables (see Appendix B and Appendix D). Usually, the $Y$ indicates that the sample coolers were not cold enough. An EMS code I indicates that a sample's matrix spike recovery was not within control limits.

To determine if a new analytical result for a sampling site is similar to or relatively higher or lower than historical results, new results for each well are compared to its historical results using the following procedure: 
- GIMS calculates the mean of the historical results and the mean of the historical results above detection for all analytes in the wells being compared. The historical results that are below their detection limit value are considered at their detection limits for the purpose of the calculation. The process eliminates any false high values due to diluted samples.

- GIMS factors in trends in the data calculated from the previous eight sampling events. If no previous data are available for a particular well/analyte combination, the program includes previous results from other wells in the same vicinity.

- Results greater than 10 times the calculated mean of the previous results are marked as "high."

Results (or their detection limits if the results are below detection) less than 10 percent of the calculated mean of the previous results are marked as "low."

GIMS flags the potentially anomalous results for review. The data reviewer examines the results and takes into account individual historical values, variations of certain values, general trends in the data, and data in the prep batch associated with the current result. The data reviewer eliminates results if anomalous historical results have skewed the calculated mean. Another data reviewer inspects and confirms that the results marked as anomalous are properly identified. Anomalous results are presented to the lab for review and comment. Results significantly high or low compared with historical data are rerun by the lab.

\section{Review of the Analytical Narratives}

EPD/EMS reviews the analytical narratives received from the laboratories, which are used as reference materials throughout the data validation process. Any discrepancies between the narratives and the analytical or chain-of-custody (COC) data must be resolved by the laboratories. The narratives include the following types of problems: QA samples that do not meet the criteria specified by the analytical method, problems with matrix interference, sample-specific adjustments to the method caused by high concentrations of some analytes, problems with sample preservation and holding time, instrument calibration problems, and contaminated blanks. The narratives also include additional information about $\mathrm{COC}$ and analytical data.

The three primary laboratories (EX, GE, and WA) and ML differ in their analytical suite assignments for certain constituents. Thus, some analytes may not be analyzed by all laboratories. See the Sample Scheduling and Field Notes sections of this report for more information on wells scheduled but not sampled this quarter.

\section{Review of EX's Analytical Data}

A technical review of the quarter's analytical data identified at least one reported result for each of the analyses in table 4 as high compared with historical data. A review of the laboratory records did not reveal any problems with the analyses.

A technical review of the quarter's analytical data identified no reported results as low compared with historical data.

\section{Rieview of GE's Analytical Data}

A technical review of the quarter's analytical data identified at least one reported result for each of the analyses in table 5 as high compared with historical data. A review of the laboratory records did not reveal any problems with the analyses.

A technical review of the quarter's analytical data identified at least one reported result for each of the analyses in table 6 as low as compared with historical data. A review of the laboratory records did not reveal any problems.

\section{Review of GP's Analytical Data}

A technical review of the quarter's analytical data identified at least one reported result for each of the analyses in table 7 as high compared with historical data. A review of the laboratory records did not reveal any problems other than those listed below. 
GP results for several wells were rejected due to low abundance for the following analytes: Ac-228 and Cs-134. GP results for several wells were rejected due to interference for the following analytes: $K-40, R u-106,1-129$, and $\mathrm{Zn}-65$

A technical review of the quarter's analytical data identified no reported results as low compared with historical data.

\section{Review of WA's Analytical Data}

A technical review of the quarter's analytical data identified at least one reported result for each of the analyses in table 8 as high as compared with historical data. A review of the laboratory records did not reveal any problems.

A technical review of the quarter's analytical data identified no reported results as low compared with historical data.

\section{Review of TM's Analytical Data}

A technical review of the quarter's analytical data identified at least one reported result for each of the analyses in table 9 as high as compared with historical data. A review of the laboratory records did not reveal any problems.

A technical review of the quarter's analytical data identified no reported results as low compared with historical data.

\section{ANALYTICAL METHODS}

Sample analyses performed for EPD/EMS during second quarter 1999 were conducted using EPA and other methods as noted in tables 10-15 at the end of this section. EX, GE, and WA performed most of the analyses conducted during the quarter. Their methods and estimated quantitation limits (EQLs) are listed in table 10 for EX, table 11 for GE, and table 12 for WA.

ML performed some on-site analyses of volatile and semivolatile organics and metals. Their methods and EQLs are listed in table 13. GP and TM performed the radionuclide analyses during second quarter 1999. Radionuclide methods generally are modified by the laboratories performing the analyses. Their methods and EQLs are listed in table 14 for GP and table 15 for TM.

The EM Lab conducted selected radionuclide analyses of samples required by the Groundwater Monitoring Program. The total activity method used by the EM Lab is an in-house method based on applicable EPA, DOE, or other procedures. Methods used by EPD/EMS for testing other radioisotopes also are in-house analytical methods. The EM Lab radioactivity determinations are typically reported as the absolute concentrations calculated from the analytical tests.

If the laboratories used more than one analytical method for an analyte, the methods are listed in the tables in descending order according to frequency of use. Generally, the method listed first was used for at least half of the analyses. 
Table 4. EX Samples with High Analytical Results as Compared to Historical Data

\begin{tabular}{ll}
\hline Analyte & Well(s) \\
\hline & \\
Chloroethene (Vinyl chloride) & FSB 93C \\
1,3-Dichlorobenzene & LFW 58D†, LFW 60C \\
1,1 -Dichloroethane & FSB 93C† \\
Ethylbenzene & FSB 93C \\
Iron & DOB 7, LFW 62D, LFW 63D \\
Toluene & FSB 93C \\
\hline
\end{tabular}

$\dagger$ The questioned value was at least 10 times higher than historical data. Because holding times had not been exceeded, the laboratory was asked to reanalyze the sample.

Table 5. GE Samples with High Analytical Results as Compared to Historical Data

\begin{tabular}{ll}
\hline Analyte & Well(s) \\
\hline & \\
Calcium & HIN600TK \\
Iron & FSB119D, FSB123D \\
Nitrate-nitrite as nitrogen & HSB 70C \\
Zinc & FIN 2TK \\
\hline
\end{tabular}

$\dagger$ The questioned value was at least 10 times higher than historical data. Because insufficient sample was left, the laboratory was not asked to reanalyze the sample.

Table 6. GE Samples with Low Analytical Results as Compared to Historical Data

Analyte Well(s)

Nitrate-nitrite as $\mathrm{N}$

Specific conductance

FSB103C†

HSB 83A†

$\dagger$ The questioned value was at least 10 times higher than historical data. Because holding times had been exceeded, the laboratory was not asked to reanalyze the sample.

Table 7. GP Samples with High Analytical Results as Compared to Historical Data

\begin{tabular}{ll}
\hline Analyte & Well(s) \\
\hline & HSB 85At \\
Nonvolatile beta & FSB 87D \\
Tritium & FIN 2TK \\
Uranium-235 & P \\
\hline
\end{tabular}

$\dagger$ The questioned value was at least 10 times higher than historical data. Because insufficient sample was left, the laboratory was not asked to reanalyze the sample.

- The questioned value was at least 10 times higher than historical data. The laboratory was not asked to reanalyze the sample. 
Table 8. WA Samples with High Analytical Results as Compared to Historical Data

\begin{tabular}{ll}
\hline Analyte & Well(s) \\
\hline Aluminum & BGO 15D, DCB 12, PSB 7At \\
Iron & BGO 15D, BGO 16AR, KBP 2D \\
Manganese & DCB 12 \\
\hline
\end{tabular}

† The questioned value was at least 10 times higher than historical data. Because holding times had been exceeded, the laboratory was asked to reanalyze the sample.

\section{Table 9. TM Samples with High Analytical Results as Compared to Historical Data}

\begin{tabular}{ll}
\hline Analyte & Well(s) \\
\hline & \\
Gross alpha & BGO 35D \\
Nonvolatile beta & BGO 51D \\
Strontium-90 & BGO 14AR \\
Tritium & BGO 20B, BGO 37C†, LDB 4† \\
\hline
\end{tabular}

$\dagger$ The questioned value was at least 10 times higher than historical data. Because holding times had not been exceeded, the laboratory was asked to reanalyze the sample.

Table 10. Methods and Estimated Quantitation Limits Used by EX

\begin{tabular}{|c|c|c|c|}
\hline Analyte & Unit & Method & Minimum/Maximum EQLs \\
\hline $\begin{array}{l}\text { Acenaphthene } \\
\text { Acenaphthylene } \\
\text { Acetone } \\
\text { Acetonitrile } \\
\text { Acrolein } \\
\text { Acrylonitrile } \\
\text { Aldrin } \\
\text { Allyl chloride } \\
\text { Aluminum } \\
\text { Anthracene } \\
\text { Antimony } \\
\text { Arsenic } \\
\text { Barium } \\
\text { Benzene } \\
\text { alpha-Benzene hexachloride } \\
\text { beta-Benzene hexachloride } \\
\text { delta-Benzene hexachloride } \\
\text { Benzidine } \\
\text { Benzo[a]anthracene } \\
\text { Benzo[b]fluoranthene } \\
\text { Benzo[k]fluoranthene } \\
\text { Benzo[g,h,i]perylene } \\
\text { Benzo[a]pyrene } \\
\text { Beryllium } \\
\text { Bis(2-chloroethoxy) methane } \\
\text { Bis(2-chloroethyl) ether } \\
\text { Bis(2-chloroisopropy]) ether } \\
\text { Bis(2-ethylhexyl) phthalate } \\
\text { Boron } \\
\text { Bromodichloromethane }\end{array}$ & $\begin{array}{l}\mu g / L \\
\mu g / L \\
\mu g / L \\
\mu g / L \\
\mu g / L \\
\mu g / L \\
\mu g / L \\
\mu g / L \\
\mu g / L \\
\mu g / L \\
\mu g / L \\
\mu g / L \\
\mu g / L \\
\mu g / L \\
\mu g / L \\
\mu g / L \\
\mu g / L \\
\mu g / L \\
\mu g / L \\
\mu g / L \\
\mu g / L \\
\mu g / L \\
\mu g / L \\
\mu g / L \\
\mu g / L \\
\mu g / L \\
\mu g / L \\
\mu g / L \\
\mu g / L \\
\mu g / L\end{array}$ & $\begin{array}{l}\text { EPA8270C } \\
\text { EPA8270C } \\
\text { EPA8260B } \\
\text { EPA8260B } \\
\text { EPA8260B } \\
\text { EPA8260B } \\
\text { EPA8081A } \\
\text { EPA8260B } \\
\text { EPA6010B } \\
\text { EPA8270C } \\
\text { EPA6010B } \\
\text { EPA6010B } \\
\text { EPA6010B } \\
\text { EPA8260B } \\
\text { EPA8081A } \\
\text { EPA8081A } \\
\text { EPA8081A } \\
\text { EPA8270C } \\
\text { EPA8270C } \\
\text { EPA8270C } \\
\text { EPA8270C } \\
\text { EPA8270C } \\
\text { EPA8270C } \\
\text { EPA6010B } \\
\text { EPA8270C } \\
\text { EPA8270C } \\
\text { EPA8270C } \\
\text { EPA8270C } \\
\text { EPA6010B } \\
\text { EPA8260B }\end{array}$ & $\begin{array}{l}10.0 \\
10.0 \\
10.0 / 50.0 \\
500 / 2,500 \\
50.0 / 250 \\
50.0 / 250 \\
0.1 \\
10.0 / 50.0 \\
200 \\
10.0 \\
100 \\
10.0 \\
10.0 \\
5.0 / 1,200 \\
0.1 \\
0.1 \\
0.1 \\
10.0 \\
10.0 \\
10.0 \\
10.0 \\
10.0 \\
10.0 \\
10.0 \\
10.0 \\
10.0 \\
10.0 \\
10.0 \\
100 \\
5.0 / 1,200\end{array}$ \\
\hline
\end{tabular}




\begin{tabular}{|c|c|c|c|}
\hline Analyte & Unit & Method & Minimum/Maximum EQLs \\
\hline $\begin{array}{l}\text { Bromoform } \\
\text { Bromomethane } \\
\text { 4-Bromophenyl phenyl ether } \\
\text { Butylbenzyl phthalate } \\
\text { Cadmium } \\
\text { Calcium } \\
\text { Carbon disulfide } \\
\text { Carbon tetrachloride } \\
\text { Chemical oxygen demand } \\
\text { alpha-Chlordane } \\
\text { gamma-Chlordane } \\
\text { Chloride } \\
\text { Chlorobenzene } \\
\text { 4-Chloro-m-cresol } \\
\text { Chloroethane } \\
\text { Chloroethene } \\
\text { 2-Chloroethyl vinyl ether } \\
\text { Chloroform } \\
\text { Chloromethane } \\
\text { 2-Chloronaphthalene } \\
\text { 2-Chlorophenol } \\
\text { 4-Chlorophenyl phenyl ether } \\
\text { Chloroprene } \\
\text { Chromium } \\
\text { Chrysene } \\
\text { Cobalt } \\
\text { Copper } \\
\text { Cyanide } \\
\text { p,p'-DDD } \\
\text { p,p'-DDE } \\
\text { p,p'-DDT } \\
\text { Dibenz[a,h]anthracene } \\
\text { Dibromochloromethane } \\
\text { 1,2-Dibromo-3-chloropropane } \\
\text { 1,2-Dibromoethane } \\
\text { Dibromomethane } \\
\text { Di-n-butyl phthalate } \\
\text { 1,2-Dichlorobenzene } \\
\text { 1,3-Dichlorobenzene } \\
\text { 1,4-Dichlorobenzene } \\
\text { 3,3'-Dichlorobenzidine } \\
\text { trans-1,4-Dichloro-2-butene } \\
\text { Dichlorodifluoromethane } \\
\text { 1,1-Dichloroethane } \\
\text { 1,2-Dichloroethane } \\
\text { 1,1-Dichloroethylene } \\
\text { 1,2-Dichloroethylene } \\
\text { cis-1,2-Dichloroethylene } \\
\text { trans-1,2-Dichloroethylene } \\
\text { Dichloromethane } \\
\text { 2,4-Dichlorophenol } \\
\text { 1,2-Dichloropropane } \\
\text { cis-1,3-Dichloropropene } \\
\text { trans-1,3-Dichloropropene } \\
\text { Dieldrin } \\
\text { Diethyl phthalate } \\
\text { 2,4-Dimethyl phenol } \\
\text { Dimethyl phthalate } \\
\text { 2,4-Dinitrophenol } \\
\text { ing }\end{array}$ & $\begin{array}{l}\mu g / L \\
\mu g / L \\
\mu g / L \\
\mu g / L \\
\mu g / L \\
\mu g / L \\
\mu g / L \\
\mu g / L \\
\mu g / L \\
\mu g / L \\
\mu g / L \\
\mu g / L \\
\mu g / L \\
\mu g / L \\
\mu g / L \\
\mu g / L \\
\mu g / L \\
\mu g / L \\
\mu g / L \\
\mu g / L \\
\mu g / L \\
\mu g / L \\
\mu g / L \\
\mu g / L \\
\mu g / L \\
\mu g / L \\
\mu g / L \\
\mu g / L \\
\mu g / L \\
\mu g / L \\
\mu g / L \\
\mu g / L \\
\mu g / L \\
\mu g / L \\
\mu g / L \\
\mu g / L \\
\mu g / L \\
\mu g / L \\
\mu g / L \\
\mu g / L \\
\mu g / L \\
\mu g / L \\
\mu g / L \\
\mu g / L \\
\mu g / L \\
\mu g / L \\
\mu g / L \\
\mu g / L \\
\mu g / L \\
\mu g / L \\
\mu g / L \\
\mu g / L \\
\mu g / L \\
\mu g / L \\
\mu g / L \\
\mu g / L \\
\mu g / L \\
\mu g / L \\
\mu g / L \\
\mu g / L \\
\mu g / L \\
\mu g / L\end{array}$ & $\begin{array}{l}\text { EPA8260B } \\
\text { EPA8260B } \\
\text { EPA8270C } \\
\text { EPA8270C } \\
\text { EPA6010B } \\
\text { EPA6010B } \\
\text { EPA8260B } \\
\text { EPA8260B } \\
\text { EPA8021B } \\
\text { EPA410.4 } \\
\text { EPA8081A } \\
\text { EPA8081A } \\
\text { EPA300.0 } \\
\text { EPA8260B } \\
\text { EPA8270C } \\
\text { EPA8260B } \\
\text { EPA8260B } \\
\text { EPA8260B } \\
\text { EPA8260B } \\
\text { EPA8021B } \\
\text { EPA8260B } \\
\text { EPA8270C } \\
\text { EPA8270C } \\
\text { EPA8270C } \\
\text { EPA8260B } \\
\text { EPA6010B } \\
\text { EPA8270C } \\
\text { EPA6010B } \\
\text { EPA6010B } \\
\text { EPA9014 } \\
\text { EPA8081A } \\
\text { EPA8081A } \\
\text { EPA8081A } \\
\text { EPA8270C } \\
\text { EPA8260B } \\
\text { EPA8260B } \\
\text { EPA8260B } \\
\text { EPA8260B } \\
\text { EPA8270C } \\
\text { EPA8260B } \\
\text { EPA8260B } \\
\text { EPA8260B } \\
\text { EPA8270C } \\
\text { EPA8260B } \\
\text { EPA8260B } \\
\text { EPA8260B } \\
\text { EPA8260B } \\
\text { EPA8260B } \\
\text { EPA8260B } \\
\text { EPA8021B } \\
\text { EPA8260B } \\
\text { EPA8260B } \\
\text { EPA8260B } \\
\text { EPA8270C } \\
\text { EPA8260B } \\
\text { EPA8260B } \\
\text { EPA8260B } \\
\text { EPA8081A } \\
\text { EPA8270C } \\
\text { EPA8270C } \\
\text { EPA8270C } \\
\text { EPA8270C }\end{array}$ & $\begin{array}{l}5.0 / 1,200 \\
5.0 / 1,200 \\
10.0 \\
10.0 \\
10.0 \\
1,000 \\
5.0 / 25.0 \\
5.0 / 1,200 \\
1.0 / 100 \\
10,000 \\
0.1 \\
0.1 \\
200 \\
5.0 / 1,200 \\
10.0 \\
10.0 / 2,500 \\
5.0 / 1,200 \\
5.0 / 1,200 \\
5.0 / 1,200 \\
1.0 / 100 \\
5.0 / 1,200 \\
10.0 \\
10.0 \\
10.0 \\
50.0 / 250 \\
10.0 \\
10.0 \\
20.0 \\
20.0 \\
10.0 \\
0.2 \\
0.2 \\
0.2 \\
10.0 \\
5.0 / 1,200 \\
5.0 / 25.0 \\
5.0 / 25.0 \\
5.0 / 25.0 \\
10.0 \\
5.0 / 25.0 \\
5.0 / 25.0 \\
5.0 / 25.0 \\
10.0 \\
20.0 / 100 \\
5.0 / 25.0 \\
5.0 / 1,200 \\
5.0 / 1,200 \\
5.0 / 1,200 \\
1.0 \\
1.0 / 100 \\
5.0 / 25.0 \\
5.0 / 1,200 \\
5.0 / 1,250 \\
10.0 \\
5.0 / 1,200 \\
5.0 / 1,200 \\
5.0 / 1,200 \\
0.2 \\
10.0 \\
10.0 \\
10.0 \\
25.0 \\
0 \\
0.0 \\
0\end{array}$ \\
\hline
\end{tabular}




\begin{tabular}{|c|c|c|c|}
\hline Analyte & Unit & Method & Minimum/Maximum EQLs \\
\hline $\begin{array}{l}\text { 2,4-Dinitrotoluene } \\
\text { 2,6-Dinitrotoluene } \\
\text { Di-n-octyl phthalate } \\
\text { 1,4-Dioxane } \\
\text { 1,2-Diphenylhydrazine } \\
\text { Endosulfan sulfate } \\
\text { Endosulfan I } \\
\text { Endosulfan II } \\
\text { Endrin } \\
\text { Endrin aldehyde } \\
\text { Ethyl methacrylate } \\
\text { Ethylbenzene } \\
\text { Fluoranthene } \\
\text { Fluorene } \\
\text { Heptachlor } \\
\text { Heptachlor epoxide } \\
\text { Hexachlorobenzene } \\
\text { Hexachlorobutadiene } \\
\text { Hexachlorocyclopentadiene } \\
\text { Hexachloroethane } \\
\text { 2-Hexanone } \\
\text { Indeno[1,2,3-c,d]pyrene } \\
\text { lodomethane } \\
\text { Iron } \\
\text { Isobutyl alcohol } \\
\text { Isophorone } \\
\text { Lead } \\
\text { Lindane } \\
\text { Magnesium } \\
\text { Manganese } \\
\text { Mercury } \\
\text { Methacrylonitrile } \\
\text { 2-Methyl-4,6-dinitrophenol } \\
\text { Methyl ethyl ketone } \\
\text { Methyl isobutyl ketone } \\
\text { Methyl methacrylate } \\
\text { Naphthalene } \\
\text { Nickel } \\
\text { Nitrate as nitrogen } \\
\text { Nitrate-nitrite as nitrogen } \\
\text { m-Nitroaniline } \\
\text { Nitrobenzene } \\
\text { 2-Nitrophenol } \\
\text { 4-Nitrophenol } \\
\text { N-Nitrosodimethylamine } \\
\text { N-Nitrosodiphenylamine } \\
\text { N-Nitrosodipropylamine } \\
\text { PCB 1016 } \\
\text { PCB 1221 } \\
\text { PCB 1232 } \\
\text { PCB 1242 } \\
\text { PCB 1248 } \\
\text { PCB 1254 } \\
\text { PCB 1260 } \\
\text { Pentachloroethane } \\
\text { Pentachlorophenol } \\
\text { pH } \\
\text { Phenanthrene } \\
\text { Phenol } \\
\text { Potassium } \\
\text { Propionitrile } \\
\text { Pyrene } \\
\text { Pyene }\end{array}$ & 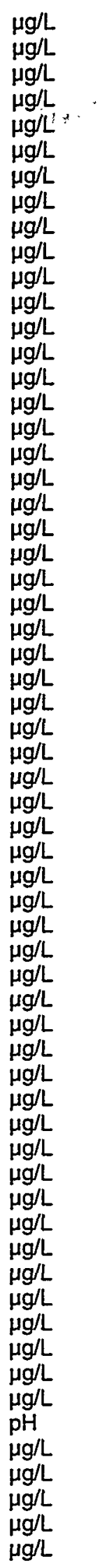 & $\begin{array}{l}\text { EPA8270C } \\
\text { EPA8270C } \\
\text { EPA8270C } \\
\text { EPA8260B } \\
\text { EPA8270C } \\
\text { EPA8081A } \\
\text { EPA8081A } \\
\text { EPA8081A } \\
\text { EPA8081A } \\
\text { EPA8081A } \\
\text { EPA8260B } \\
\text { EPA8260B } \\
\text { EPA8270C } \\
\text { EPA8270C } \\
\text { EPA8081A } \\
\text { EPA8081A } \\
\text { EPA8270C } \\
\text { EPA8270C } \\
\text { EPA8270C } \\
\text { EPA8270C } \\
\text { EPA8260B } \\
\text { EPA8270C } \\
\text { EPA8260B } \\
\text { EPA6010B } \\
\text { EPA8260B } \\
\text { EPA8270C } \\
\text { EPA6010B } \\
\text { EPA8081A } \\
\text { EPA6010B } \\
\text { EPA6010B } \\
\text { EPA7470A } \\
\text { EPA8260B } \\
\text { EPA8270C } \\
\text { EPA8260B } \\
\text { EPA8260B } \\
\text { EPA8260B } \\
\text { EPA8270C } \\
\text { EPA6010B } \\
\text { EPA300.0 } \\
\text { EPA300.0 } \\
\text { EPA8270C } \\
\text { EPA8270C } \\
\text { EPA8270C } \\
\text { EPA8270C } \\
\text { EPA8270C } \\
\text { EPA8270C } \\
\text { EPA8270C } \\
\text { EPA8082 } \\
\text { EPA8082 } \\
\text { EPA8082 } \\
\text { EPA8082 } \\
\text { EPA8082 } \\
\text { EPA8082 } \\
\text { EPA8082 } \\
\text { EPA8260B } \\
\text { EPA8270C } \\
\text { EPA150.1 } \\
\text { EPA8270C } \\
\text { EPA8270C } \\
\text { EPA6010B } \\
\text { EPA8260B } \\
\text { EPA8270C }\end{array}$ & $\begin{array}{l}10.0 \\
10.0 \\
10.0 \\
1,000 / 5,000 \\
10.0 \\
0.2 \\
0.1 \\
0.2 \\
0.2 \\
0.2 \\
5.0 / 25.0 \\
5.0 / 1,200 \\
10.0 \\
10.0 \\
0.1 \\
0.1 \\
10.0 \\
10.0 \\
10.0 \\
10.0 \\
5.0 / 25.0 \\
10.0 \\
5.0 / 25.0 \\
200 \\
1,500 / 7,500 \\
10.0 \\
10.0 / 100 \\
0.1 \\
1,000 \\
10.0 \\
0.5 \\
500 / 2,500 \\
25.0 \\
10.0 / 50.0 \\
5.0 / 25.0 \\
50.0 / 250 \\
10.0 \\
50.0 \\
100 / 500 \\
100 / 500 \\
25.0 \\
10.0 \\
10.0 \\
25.0 \\
25.0 \\
10.0 \\
10.0 \\
2.0 \\
2.0 \\
1.0 \\
1.0 \\
1.0 \\
1.0 \\
1.0 \\
200 / 1,000 \\
25.0 \\
0.0 \\
10.0 \\
10.0 \\
5,000 \\
500 / 2,500 \\
10.0 \\
\\
\end{array}$ \\
\hline
\end{tabular}




\begin{tabular}{|c|c|c|c|}
\hline Analyte & Unit & Method & Minimum/Maximum EQLs \\
\hline $\begin{array}{l}\text { Selenium } \\
\text { Silver } \\
\text { Sodium } \\
\text { Specific conductance } \\
\text { Styrene } \\
\text { Sulfate } \\
\text { 1,1,1,2-Tetrachloroethane } \\
\text { 1,1,2,2-Tetrachloroethane } \\
\text { Tetrachloroethylene } \\
\text { Thallium } \\
\text { Toluene } \\
\text { Total organic carbon } \\
\text { Toxaphene } \\
\text { 1,2,4-Trichlorobenzene } \\
\text { 1,1,1-Trichloroethane } \\
\text { 1,1,2-Trichloroethane } \\
\text { Trichloroethylene } \\
\text { Trichlorofluoromethane } \\
2,4,6-\text { Trichlorophenol } \\
1,2,3-\text { Trichloropropane } \\
\text { Vanadium } \\
\text { Vinyl acetate } \\
\text { Xylenes } \\
\text { Zinc }\end{array}$ & $\begin{array}{l}\mu g / L \\
\mu g / L \\
\mu g / L \\
\mu S / \mathrm{cm} \\
\mu g / L \\
\mu g / L \\
\mu g / L \\
\mu g / L \\
\mu g / L \\
\mu g / L \\
\mu g / L \\
\mu g / L \\
\mu g / L \\
\mu g / L \\
\mu g / L \\
\mu g / L \\
\mu g / L \\
\mu g / L \\
\mu g / L \\
\mu g / L \\
\mu g / L \\
\mu g / L \\
\mu g / L \\
\mu g / L \\
\mu g / L \\
\mu g / L \\
\mu g / L\end{array}$ & $\begin{array}{l}\text { EPA6010B } \\
\text { EPA6010B } \\
\text { EPA6010B } \\
\text { EPA120.1 } \\
\text { EPA8260B } \\
\text { EPA300.0 } \\
\text { EPA8260B } \\
\text { EPA8260B } \\
\text { EPA8260B } \\
\text { EPA8021B } \\
\text { EPA6010B } \\
\text { EPA8260B } \\
\text { EPA9060 } \\
\text { EPA8081A } \\
\text { EPA8270C } \\
\text { EPA8260B } \\
\text { EPA8021B } \\
\text { EPA8260B } \\
\text { EPA8260B } \\
\text { EPA8021B } \\
\text { EPA8260B } \\
\text { EPA8270C } \\
\text { EPA8260B } \\
\text { EPA6010B } \\
\text { EPA8260B } \\
\text { EPA8260B } \\
\text { EPA6010B } \\
\end{array}$ & $\begin{array}{l}10.0 \\
20.0 \\
1,000 \\
1.0 \\
5.0 / 25.0 \\
200 \\
5.0 / 25.0 \\
5.0 / 1,200 \\
5.0 / 1,200 \\
1.0 / 100 \\
10.0 \\
5.0 / 1,200 \\
5,000 \\
1.0 \\
10.0 \\
5.0 / 1,200 \\
1.0 / 100 \\
5.0 / 1,200 \\
5.0 / 1,200 \\
1.0 / 100 \\
5.0 / 1,200 \\
25.0 \\
5.0 / 25.0 \\
10.0 \\
20.0 / 100 \\
10.0 / 50.0 \\
20.0 \\
\end{array}$ \\
\hline
\end{tabular}

Table 11. Methods and Estimated Quantitation Limits Used by GE

\begin{tabular}{|c|c|c|c|}
\hline Analyte & Unit & Method & Minimum/Maximum EQLs \\
\hline $\begin{array}{l}\text { Acenaphthene } \\
\text { Acenaphthylene } \\
\text { Acetone } \\
\text { Acetophenone } \\
\text { 2-Acetylaminofluorene } \\
\text { Aldrin } \\
\text { Alkalinity (as } \mathrm{CaCO}_{3} \text { ) } \\
\text { Aluminum } \\
\text { 4-Aminobiphenyl } \\
\text { Aniline } \\
\text { Anthracene } \\
\text { Antimony } \\
\text { Aramite } \\
\text { Arsenic } \\
\text { Barium } \\
\text { Benzene } \\
\text { alpha-Benzene hexachloride } \\
\text { beta-Benzene hexachloride } \\
\text { delta-Benzene hexachloride } \\
\text { Benzidine } \\
\text { Benzo[a]anthracene } \\
\text { Benzo[b]fluoranthene }\end{array}$ & $\begin{array}{l}\mu g / L \\
\mu g / L \\
\mu g / L \\
\mu g / L \\
\mu g / L \\
\mu g / L \\
m e q / L \\
\mu g / L \\
\mu g / L \\
\mu g / L \\
\mu g / L \\
\mu g / L \\
\mu g / L \\
\mu g / L \\
\mu g / L \\
\mu g / L \\
\mu g / L \\
\mu g / L \\
\mu g / L \\
\mu g / L \\
\mu g / L \\
\mu g / L \\
\mu g / L \\
\mu g / L \\
\mu g / L \\
\mu g / L\end{array}$ & $\begin{array}{l}\text { EPA8270C } \\
\text { EPA8270C } \\
\text { EPA8260B } \\
\text { EPA8270C } \\
\text { EPA8270C } \\
\text { EPA8081A } \\
\text { EPA310.1 } \\
\text { EPA6020 } \\
\text { EPA6010B } \\
\text { EPA8270C } \\
\text { EPA8270C } \\
\text { EPA8270C } \\
\text { EPA6010B } \\
\text { EPA6020 } \\
\text { EPA8270C } \\
\text { EPA6010B } \\
\text { EPA6020 } \\
\text { EPA6010B } \\
\text { EPA6020 } \\
\text { EPA8260B } \\
\text { EPA8081A } \\
\text { EPA8081A } \\
\text { EPA8081A } \\
\text { EPA8270C } \\
\text { EPA8270C } \\
\text { EPA8270C }\end{array}$ & $\begin{array}{l}9.8 / 10.4 \\
9.8 / 10.4 \\
5.0 / 500 \\
10.0 / 10.4 \\
10.0 / 10.4 \\
0.016 / 0.0206 \\
1,000 \\
15.0 / 150 \\
50.0 \\
10.0 / 10.4 \\
10.0 / 10.4 \\
9.8 / 10.4 \\
10.0 \\
0.2 / 2.0 \\
10.0 / 10.4 \\
5.0 \\
3.0 \\
5.0 \\
2.0 \\
1.0 / 100 \\
0.016 / 0.0206 \\
0.016 / 0.0206 \\
0.016 / 0.0206 \\
49.0 / 50.0 \\
9.8 / 10.4 \\
9.8 / 10.4\end{array}$ \\
\hline
\end{tabular}




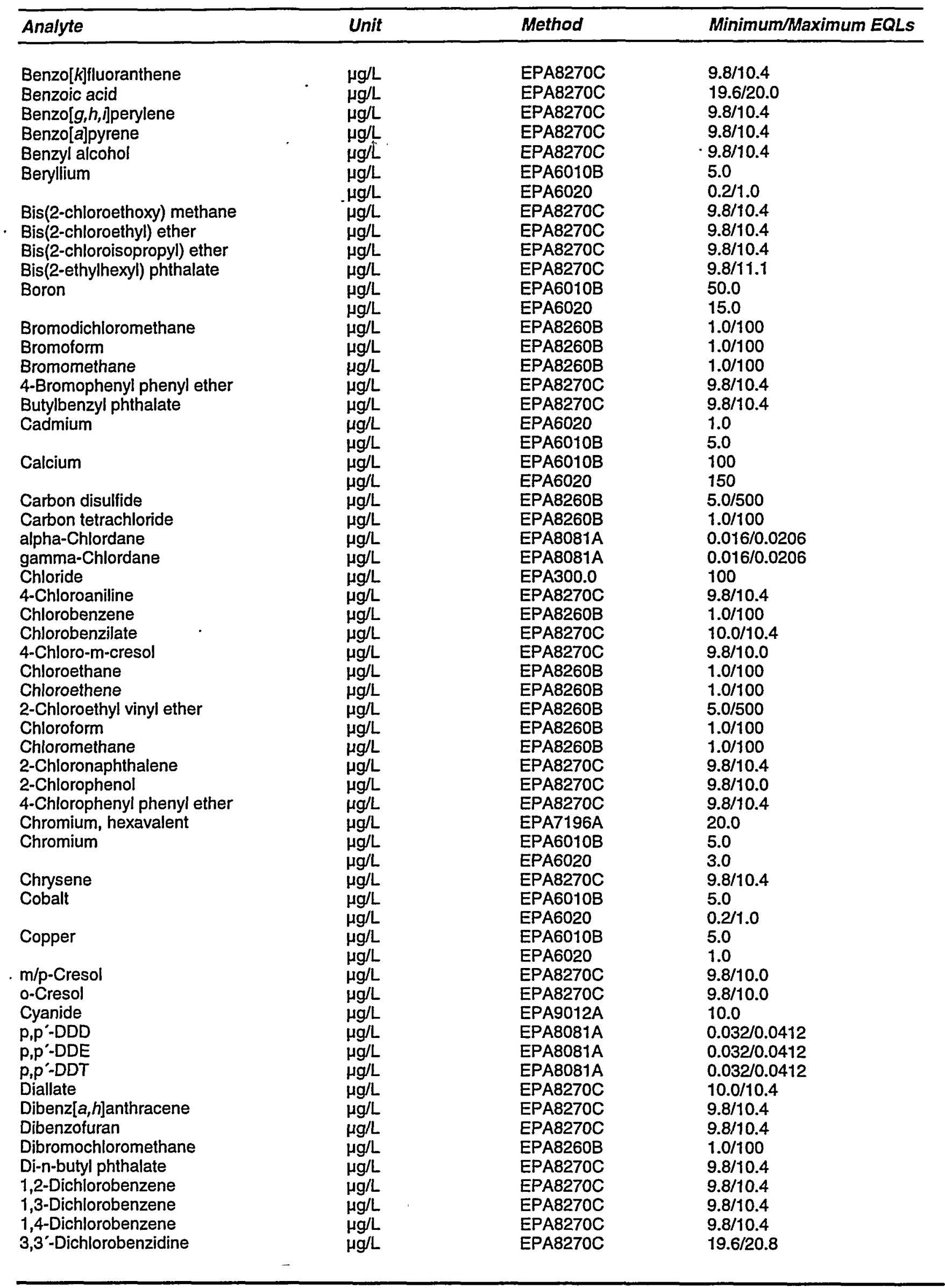




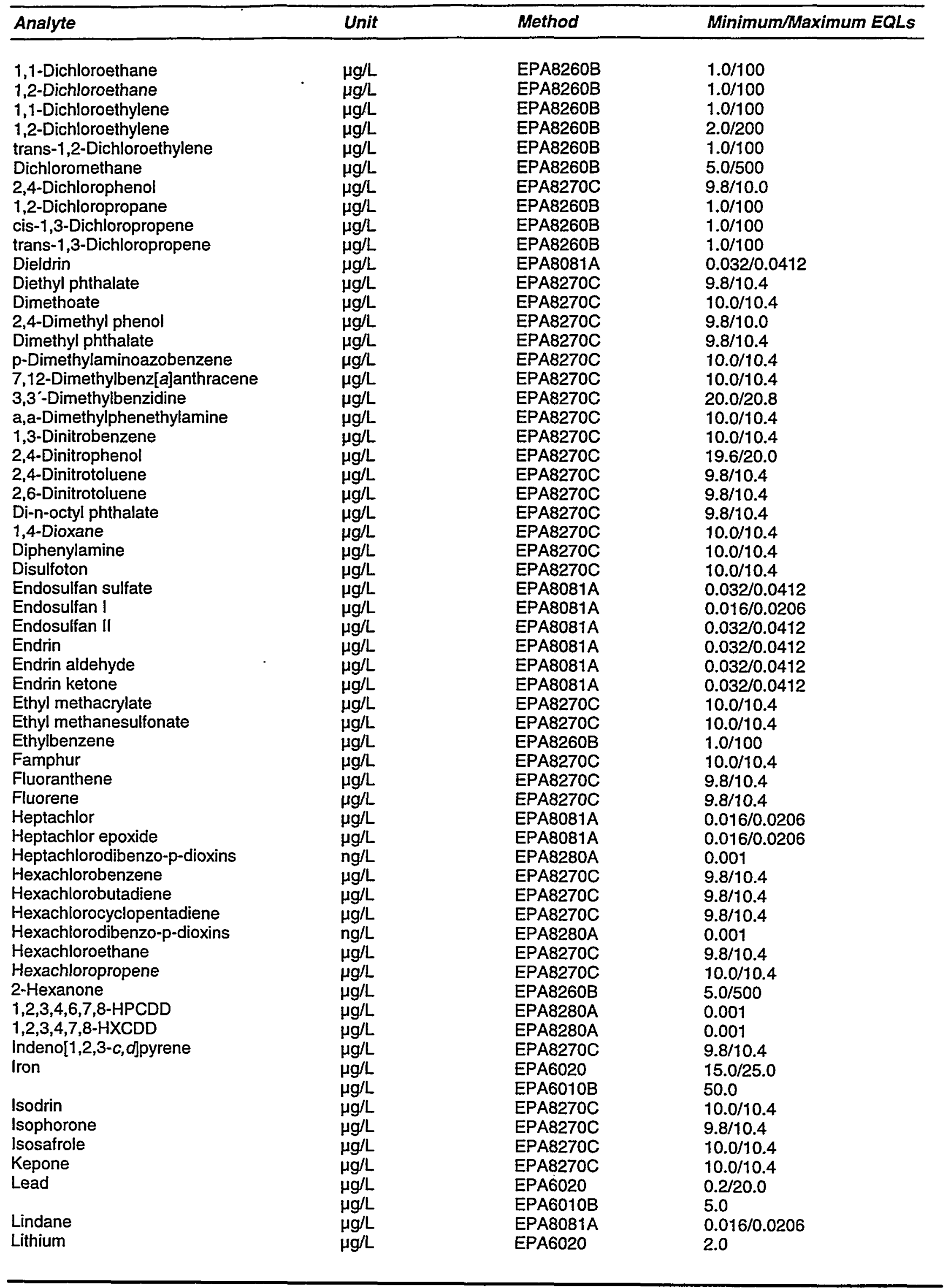




\begin{tabular}{|c|c|c|c|}
\hline Analyte & Unit & Method & Minimum/Maximum EQLs \\
\hline $\begin{array}{l}\text { Magnesium } \\
\text { Manganese } \\
\text { Mercury } \\
\text { Methapyrilene } \\
\text { Methoxychlor } \\
\text { 2-Methyl-4,6-dinitrophenol } \\
\text { Methyl ethyl ketone } \\
\text { Methyl isobutyl ketone } \\
\text { Methyl methanesulfonate } \\
\text { 3-Methylcholanthrene } \\
\text { 2-Methylnaphthalene } \\
\text { Molybdenum } \\
\text { Naphthalene } \\
\text { 1,4-Naphthoquinone } \\
\text { 1-Naphthylamine } \\
\text { 2-Naphthylamine } \\
\text { Nickel } \\
\text { Nitrate-nitrite as nitrogen } \\
\text { m-Nitroaniline } \\
\text { O-Nitroaniline } \\
\text { p-Nitroaniline } \\
\text { Nitrobenzene } \\
\text { 2-Nitrophenol } \\
\text { 4-Nitrophenol } \\
\text { 4-Nitroquinoline-1-oxide } \\
\text { N-Nitrosodi-n-butylamine } \\
\text { N-Nitrosodiethylamine } \\
\text { N-Nitrosodimethylamine } \\
\text { N-Nitrosodiphenylamine } \\
\text { N-Nitrosodipropylamine } \\
\text { N-Nitrosomethylethylamine } \\
\text { N-Nitrosomorpholine } \\
\text { N-Nitrosopiperidine } \\
\text { N-Nitrosopyrrolidine } \\
\text { 5-Nitro-o-toluidine } \\
\text { Octachlorodibenzo-p-dioxin } \\
\text { PCB 1016 } \\
\text { PCB 1221 } \\
\text { PCB 1232 } \\
\text { PCB 1242 } \\
\text { PCB 1248 } \\
\text { PCB 1254 } \\
\text { PCB 1260 } \\
\text { 1,2,3,7,8-PCDD } \\
\text { Pentachlorobenzene } \\
\text { Pentachlorodibenzo-p-dioxins } \\
\text { Pentachloroethane } \\
\text { Pentachloronitrobenzene } \\
\text { Pentachlorophenol } \\
\text { pH } \\
\text { Phenacetin } \\
\text { Phenanthrene } \\
\text { Phenol } \\
\text { Phenols } \\
\text { p-Phenylenediamine } \\
\text { 2-Picoline } \\
\text { Potassium } \\
\text { Pronamid } \\
\text { Prol }\end{array}$ & $\begin{array}{l}\mu g / L \\
\mu g / L \\
\mu g / L \\
\mu g / L \\
\mu g / L \\
\mu g / L \\
\mu g / L \\
\mu g / L \\
\mu g / L \\
\mu g / L \\
\mu g / L \\
\mu g / L \\
\mu g / L \\
\mu g / L \\
\mu g / L \\
\mu g / L \\
\mu g / L \\
\mu g / L \\
\mu g / L \\
\mu g / L \\
\mu g / L \\
\mu g / L \\
\mu g / L \\
\mu g / L \\
\mu g / L \\
\mu g / L \\
\mu g / L \\
\mu g / L \\
\mu g / L \\
\mu g / L \\
\mu g / L \\
\mu g / L \\
\mu g / L \\
\mu g / L \\
\mu g / L \\
\mu g / L \\
\mu g / L \\
\mu g / L \\
\mu g / L \\
\mu g / L \\
\mu g / L \\
\mu g / L \\
\mu g / L \\
\mu g / L \\
\mu g / L \\
\mu g / L \\
\mu g / L \\
\mu g / L \\
n g / L \\
\mu g / L \\
\mu g / L \\
\mu g / L \\
p H \\
\mu g / L \\
\mu g / L \\
\mu g / L \\
\mu g / L \\
\mu g / L \\
\mu g / L \\
\mu g / L \\
\mu g / L \\
\mu g / L\end{array}$ & $\begin{array}{l}\text { EPA6010B } \\
\text { EPA6020 } \\
\text { EPA6010B } \\
\text { EPA6020 } \\
\text { EPA7470A } \\
\text { EPA8270C } \\
\text { EPA8081A } \\
\text { EPA8270C } \\
\text { EPA8260B } \\
\text { EPA8260B } \\
\text { EPA8270C } \\
\text { EPA8270C } \\
\text { EPA8270C } \\
\text { EPA6020 } \\
\text { EPA8270C } \\
\text { EPA8270C } \\
\text { EPA8270C } \\
\text { EPA8270C } \\
\text { EPA6010B } \\
\text { EPA6020 } \\
\text { EPA353.1 } \\
\text { EPA8270C } \\
\text { EPA8270C } \\
\text { EPA8270C } \\
\text { EPA8270C } \\
\text { EPA8270C } \\
\text { EPA8270C } \\
\text { EPA8270C } \\
\text { EPA8270C } \\
\text { EPA8270C } \\
\text { EPA8270C } \\
\text { EPA8270C } \\
\text { EPA8270C } \\
\text { EPA8270C } \\
\text { EPA8270C } \\
\text { EPA8270C } \\
\text { EPA8270C } \\
\text { EPA8270C } \\
\text { EPA8280A } \\
\text { EPA8082 } \\
\text { EPA8082 } \\
\text { EPA8082 } \\
\text { EPA8082 } \\
\text { EPA8082 } \\
\text { EPA8082 } \\
\text { EPA8082 } \\
\text { EPA8280A } \\
\text { EPA8270C } \\
\text { EPA8280A } \\
\text { EPA8270C } \\
\text { EPA8270C } \\
\text { EPA8270C } \\
\text { EPA9040B } \\
\text { EPA8270C } \\
\text { EPA8270C } \\
\text { EPA8270C } \\
\text { EPA9066 } \\
\text { EPA8270C } \\
\text { EPA8270C }\end{array}$ & $\begin{array}{l}10.0 \\
3.0 / 10.0 \\
10.0 \\
0.2 / 5.0 \\
0.2 \\
10.0 / 10.4 \\
0.16 / 0.206 \\
9.8 / 10.0 \\
10.0 / 1,000 \\
5.0 / 500 \\
10.0 / 10.4 \\
10.0 / 10.4 \\
9.8 / 10.4 \\
0.5 \\
9.8 / 10.4 \\
10.0 / 10.4 \\
10.0 / 10.4 \\
10.0 / 10.4 \\
5.0 \\
2.0 \\
50.0 / 10,000 \\
9.8 / 10.4 \\
9.8 / 10.4 \\
9.8 / 10.4 \\
9.8 / 10.4 \\
9.8 / 10.0 \\
9.8 / 10.0 \\
10.0 / 10.4 \\
10.0 / 10.4 \\
10.0 / 10.4 \\
10.0 / 10.4 \\
9.8 / 10.4 \\
9.8 / 10.4 \\
10.0 / 10.4 \\
10.0 / 10.4 \\
10.0 / 10.4 \\
10.0 / 10.4 \\
10.0 / 10.4 \\
0.001 \\
0.1 / 0.115 \\
0.1 / 0.115 \\
0.1 / 0.115 \\
0.1 / 0.115 \\
0.1 / 0.115 \\
0.1 / 0.115 \\
0.1 / 0.115 \\
0.001 \\
10.0 / 10.4 \\
0.001 \\
10.0 / 10.4 \\
10.0 / 10.4 \\
19.6 / 20.0 \\
0.1 \\
10.0 / 10.4 \\
9.8 / 10.4 \\
9.8 / 10.0 \\
5.0 \\
20.0 / 20.8 \\
10.0 / 10.4 \\
100 \\
15.0 / 300 \\
1001 / 104\end{array}$ \\
\hline
\end{tabular}




\begin{tabular}{|c|c|c|c|}
\hline Analyte & Unit & Method & Minimum/Maximum EQLs \\
\hline Pyrene & $\mu g / L$ & EPA8270C & $9.8 / 10.4$ \\
\hline Pyridine & $\mu g / L$ & EPA8270C & $10.0 / 10.4$ \\
\hline Safrole & $\mu g / L$ & EPA8270C & $10.0 / 10.4$ \\
\hline \multirow[t]{2}{*}{ Selenium } & $\mu g / L$ & EPA6010B & 5.0 \\
\hline & $\mu g / L$ & EPA6020 & 5.0 \\
\hline \multirow[t]{2}{*}{ Silver } & $\mu g / L$ & EPA6010B & 5.0 \\
\hline & $\mu g / L$ & EPA6020 & 1.0 \\
\hline \multirow[t]{2}{*}{ Sodium } & $\mu g / L$ & EPA6010B & $100 / 500$ \\
\hline & $\mu g / L$ & EPA6020 & $250 / 2,500$ \\
\hline Specific conductance & $\mu \mathrm{S} / \mathrm{cm}$ & EPA9050A & 1.0 \\
\hline Strontium & $\mu g / L$ & EPA6020 & 10.0 \\
\hline Styrene & $\mu g / L$ & EPA8260B & $1.0 / 100$ \\
\hline Sulfate & $\mu g / L$ & EPA300.0 & $200 / 10,000$ \\
\hline Sulfotepp & $\mu g / L$ & EPA8270C & $10.0 / 10.4$ \\
\hline $2,3,7,8-T C D D$ & $\mu g / L$ & EPA8280A & 0.001 \\
\hline $1,2,4,5-$ Tetrachlorobenzene & $\mu g / L$ & EPA8270C & $10.0 / 10.4$ \\
\hline Tetrachlorodibenzo-p-dioxins & $\mathrm{ng} / \mathrm{L}$ & EPAB280A & 0.001 \\
\hline $1,1,2,2$-Tetrachloroethane & $\mu g / L$ & EPA8260B & $1.0 / 100$ \\
\hline Tetrachloroethylene & $\mu g / L$ & EPA8260B & $1.0 / 100$ \\
\hline \multirow[t]{2}{*}{ Thallium } & $\mu g / L$ & EPA6010B & 5.0 \\
\hline & $\mu g / L$ & EPA6020 & $0.5 / 2.5$ \\
\hline Thionazin & $\mu g / L$ & EPAB270C & $10.0 / 10.4$ \\
\hline \multirow[t]{2}{*}{ Tin } & $\mu g / L$ & EPA6020 & 5.0 \\
\hline & $\mu g / L$ & EPA6010B & 100 \\
\hline Titanium & $\mu g / L$ & EPA6020 & 10.0 \\
\hline Toluene & $\mu g / L$ & EPA8260B & $1.0 / 100$ \\
\hline o-Toluidine & $\mu g / L$ & EPA8270C & $10.0 / 10.4$ \\
\hline Total dissolved solids & $\mu g / L$ & EPA160.1 & 10,000 \\
\hline Total organic carbon & $\mu g / L$ & EPA9060 & 5,000 \\
\hline Total organic halogens & $\mu g / L$ & EPA9020B & $10.0 / 100$ \\
\hline Toxaphene & $\mu g / L$ & EPA8081A & $0.8 / 1.03$ \\
\hline 1,2,4-Trichlorobenzene & $\mu g / L$ & EPAB270C & $9.8 / 10.4$ \\
\hline 1,1,1-Trichloroethane & $\mu g / L$ & EPA8260B & $1.0 / 100$ \\
\hline 1,1,2-Trichloroethane & $\mu g / L$ & EPA8260B & $1.0 / 100$ \\
\hline Trichloroethylene & $\mu g / L$ & EPA8260B & $1.0 / 100$ \\
\hline Trichlorofluoromethane & $\mu g / L$ & EPA8260B & $5.0 / 500$ \\
\hline 2,4,5-Trichlorophenol & $\mu g / L$ & EPAB270C & $9.8 / 10.0$ \\
\hline 2,4,6-Trichlorophenol & $\mu g / L$ & EPA8270C & $9.8 / 10.0$ \\
\hline $0,0,0$-Triethyl phosphorothioate & $\mu g / L$ & EPA8270C & $10.0 / 10.4$ \\
\hline $1,3,5$-Trinitrobenzene & $\mu g / L$ & EPA8270C & $10.0 / 10.4$ \\
\hline Uranium & $\mu g / L$ & EPA6020 & 2.0 \\
\hline Vanadium & $\mu g / L$ & EPA6010B & 5.0 \\
\hline & $\mu g / L$ & EPA6020 & $10.0 / 100$ \\
\hline Vinyl acetate & $\mu g / L$ & EPA8260B & $5.0 / 500$ \\
\hline Xylenes & $\mu g / L$ & EPA8260B & $2.0 / 200$ \\
\hline Zinc & $\mu g / L$ & EPA6010B & 5.0 \\
\hline & $\mu g / L$ & EPA6020 & 10.0 \\
\hline
\end{tabular}

Note: The groundwater samples are unfiltered; thus, the methods for metals are for total recoverable metals. Method 6010 is an inductively coupled plasma atomic emission spectroscopy method for metals determination and is published for RCRA determinations. 
Table 12. Methods and Estimated Quantitation Limits Used by WA

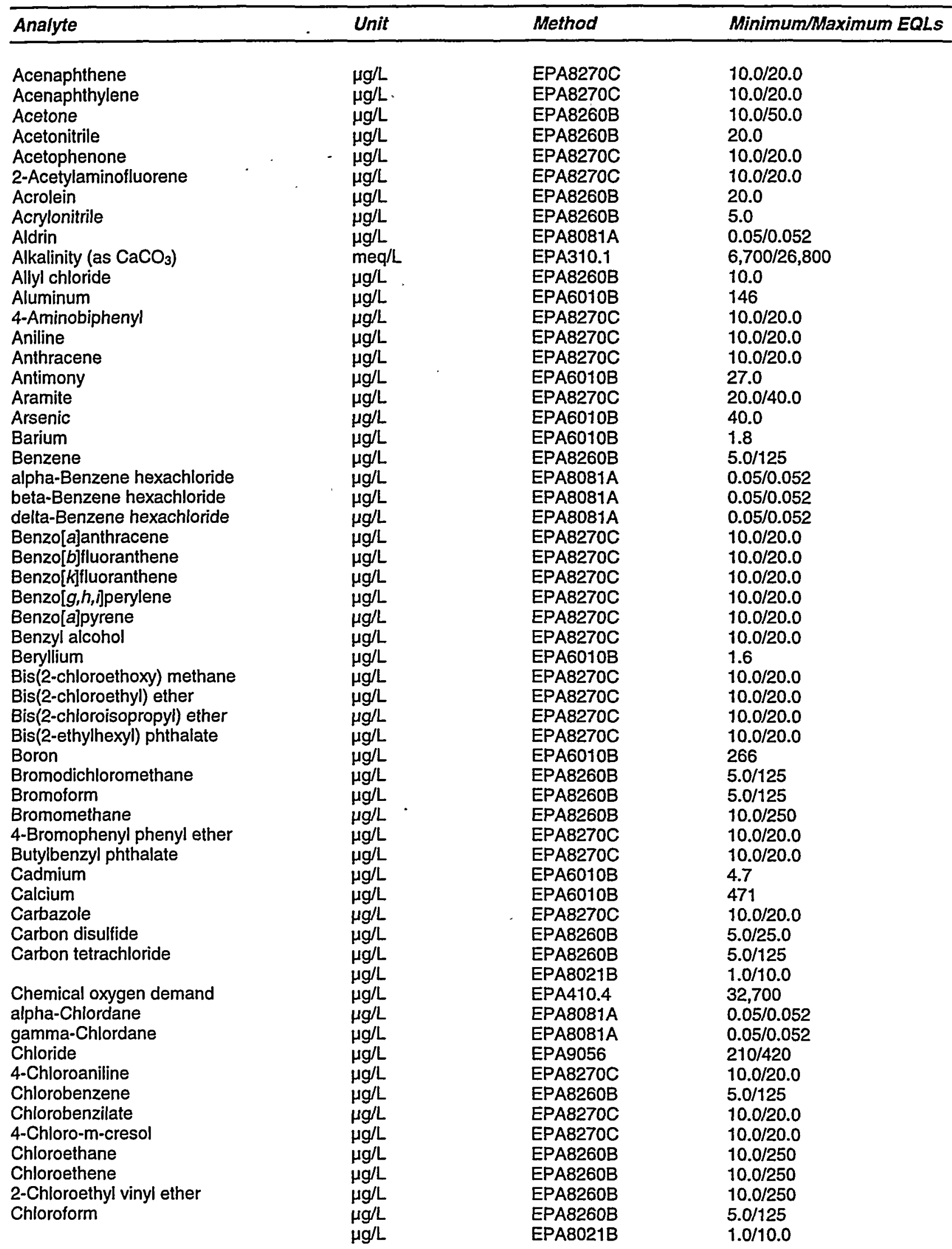




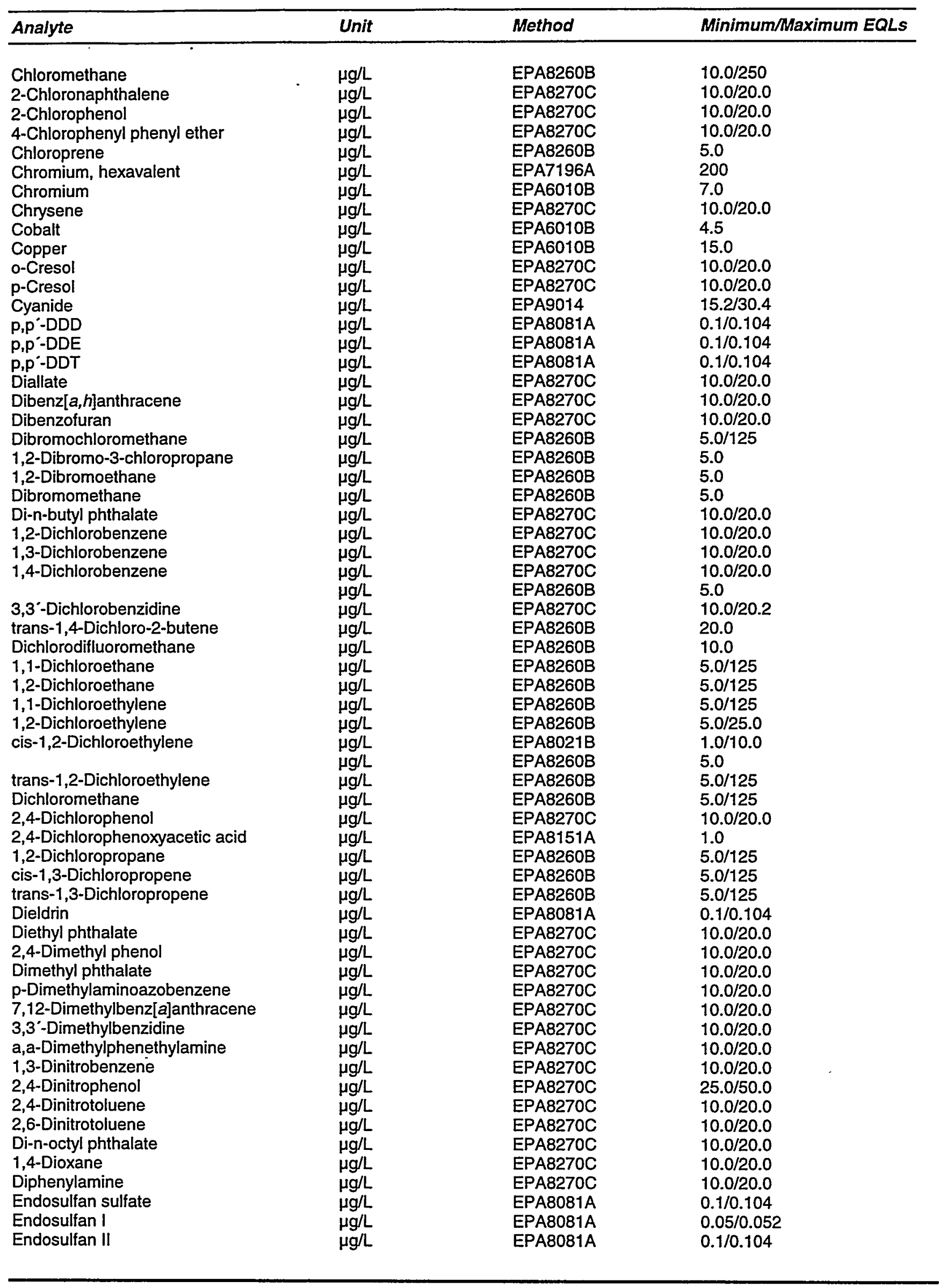




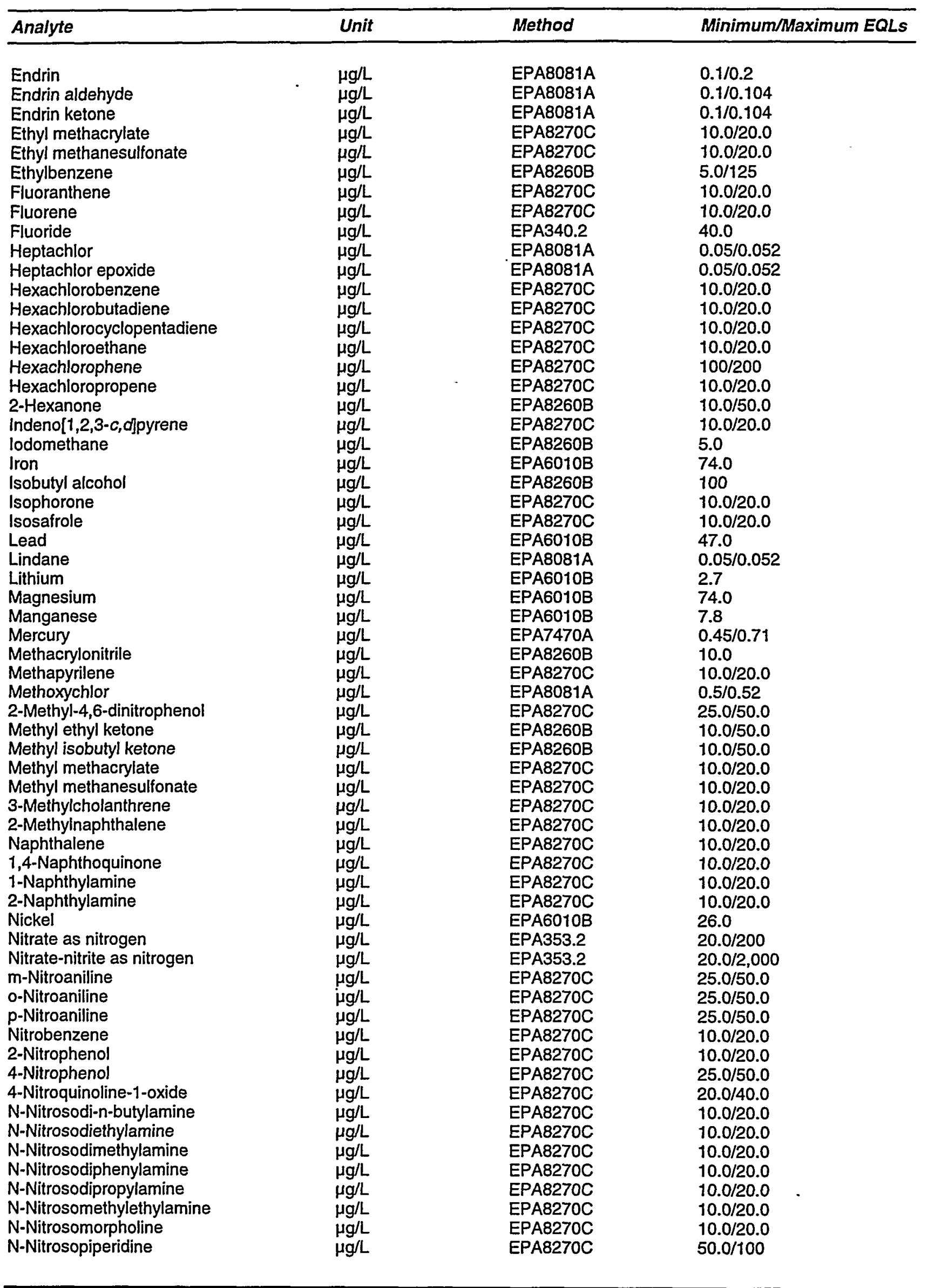




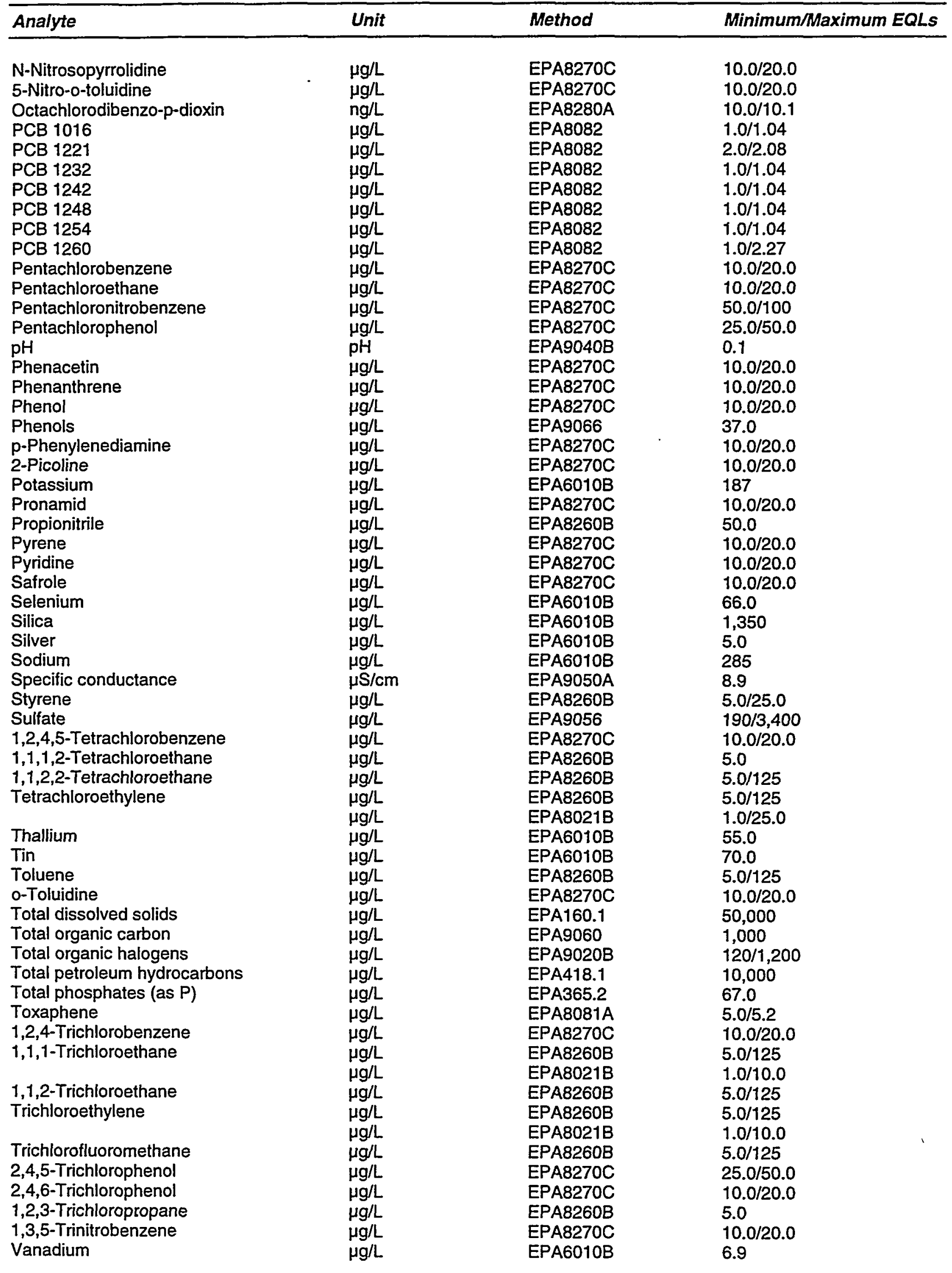




\begin{tabular}{llll}
\hline Analyte & Unit & Method & Minimum/Maximum EQLs \\
\hline Vinyl acetate & $\mu g / \mathrm{L}$ & EPA8260B & $10.0 / 50.0$ \\
Xylenes & $\mu g / \mathrm{L}$ & EPA8260B & $5.0 / 125$ \\
Zinc & $\mu g / \mathrm{L}$ & EPA6010B & 53.0 \\
\hline
\end{tabular}

Note: The groundwater samples are unfiltered; thus, the methods for metals are for total recoverable metals. Method 200.7 is an inductively coupled plasma atomic emission spectroscopy method for metals determination and is published for Safe Drinking Water Act investigations.

Table 13. Methods and Estimated Quantitation Limits Used by ML

\begin{tabular}{|c|c|c|c|}
\hline Analyte & Unit & Method & Minimum/Maximum EQLs \\
\hline Acetone & $\mu g / L$ & EPA8260B & 5.0 \\
\hline Benzene & $\mu \mathrm{g} / \mathrm{L}$ & EPA8260B & 1.0 \\
\hline Bromodichloromethane & $\mu \mathrm{g} / \mathrm{L}$ & EPA8260B & 1.0 \\
\hline Bromoform & $\mu g / L$ & EPA8260B & 1.0 \\
\hline Bromomethane & $\mu g / L$ & EPA8260B & 1.0 \\
\hline Carbon disulfide & $\mu g / L$ & EPA8260B & 5.0 \\
\hline Carbon tetrachloride & $\mu \mathrm{g} / \mathrm{L}$ & EPA8260B & 1.0 \\
\hline Chlorobenzene & $\mu g / L$ & EPA8260B & 1.0 \\
\hline Chloroethane & $\mu g / L$ & EPA8260B & 1.0 \\
\hline Chloroethene & $\mu g / L$ & EPA8260B & 1.0 \\
\hline Chloroform & $\mu g / L$ & EPA8260B & 1.0 \\
\hline Chloromethane & $\mu \mathrm{g} / \mathrm{L}$ & EPA8260B & 1.0 \\
\hline Dibromochloromethane & $\mu g / L$ & EPA8260B & 1.0 \\
\hline 1,1-Dichloroethane & $\mu g / L$ & EPA8260B & 1.0 \\
\hline 1,2-Dichloroethane & $\mu g / L$ & EPA8260B & 1.0 \\
\hline 1,1 -Dichloroethylene & $\mu g / L$ & EPA8260B & 1.0 \\
\hline 1,2-Dichloroethylene & $\mu g / L$ & EPA8260B & 1.0 \\
\hline cis-1,2-Dichloroethylene & $\mu g / L$ & EPA8260B & 1.0 \\
\hline trans-1,2-Dichloroethylene & $\mu g / L$ & EPA8260B & 1.0 \\
\hline Dichloromethane & $\mu g / L$ & EPA8260B & 1.0 \\
\hline 1,2-Dichloropropane & $\mu g / L$ & EPA8260B & 1.0 \\
\hline cis-1,3-Dichloropropene & $\mu g / L$ & EPA8260B & 1.0 \\
\hline trans-1,3-Dichloropropene & $\mu g / L$ & EPA8260B & 1.0 \\
\hline Ethylbenzene & $\mu g / L$ & EPA8260B & 1.0 \\
\hline 2-Hexanone & $\mu g / L$ & EPA8260B & 5.0 \\
\hline Methyl ethyl ketone & $\mu \mathrm{g} / \mathrm{L}$ & EPA8260B & 5.0 \\
\hline Methyl isobutyl ketone & $\mu g / L$ & EPA8260B & 5.0 \\
\hline Styrene & $\mu g / L$ & EPA8260B & 1.0 \\
\hline $1,1,2,2$-Tetrachloroethane & $\mu g / L$ & EPA8260B & 1.0 \\
\hline Tetrachloroethylene & $\mu g / L$ & EPA8260B & 1.0 \\
\hline Toluene & $\mu g / L$ & EPA8260B & 1.0 \\
\hline 1,1,1-Trichloroethane & $\mu g / L$ & EPA8260B & 1.0 \\
\hline 1,1,2-Trichloroethane & $\mu g / L$ & EPA8260B & 1.0 \\
\hline Trichloroethylene & $\mu g / L$ & EPA8260B & 1.0 \\
\hline Vinyl acetate & $\mu g / L$ & EPA8260B & 5.0 \\
\hline Xylenes & $\mu g / L$ & EPA8260B & 1.0 \\
\hline
\end{tabular}


Table 14. Methods and Estimated Quantitation Limits Used by GP

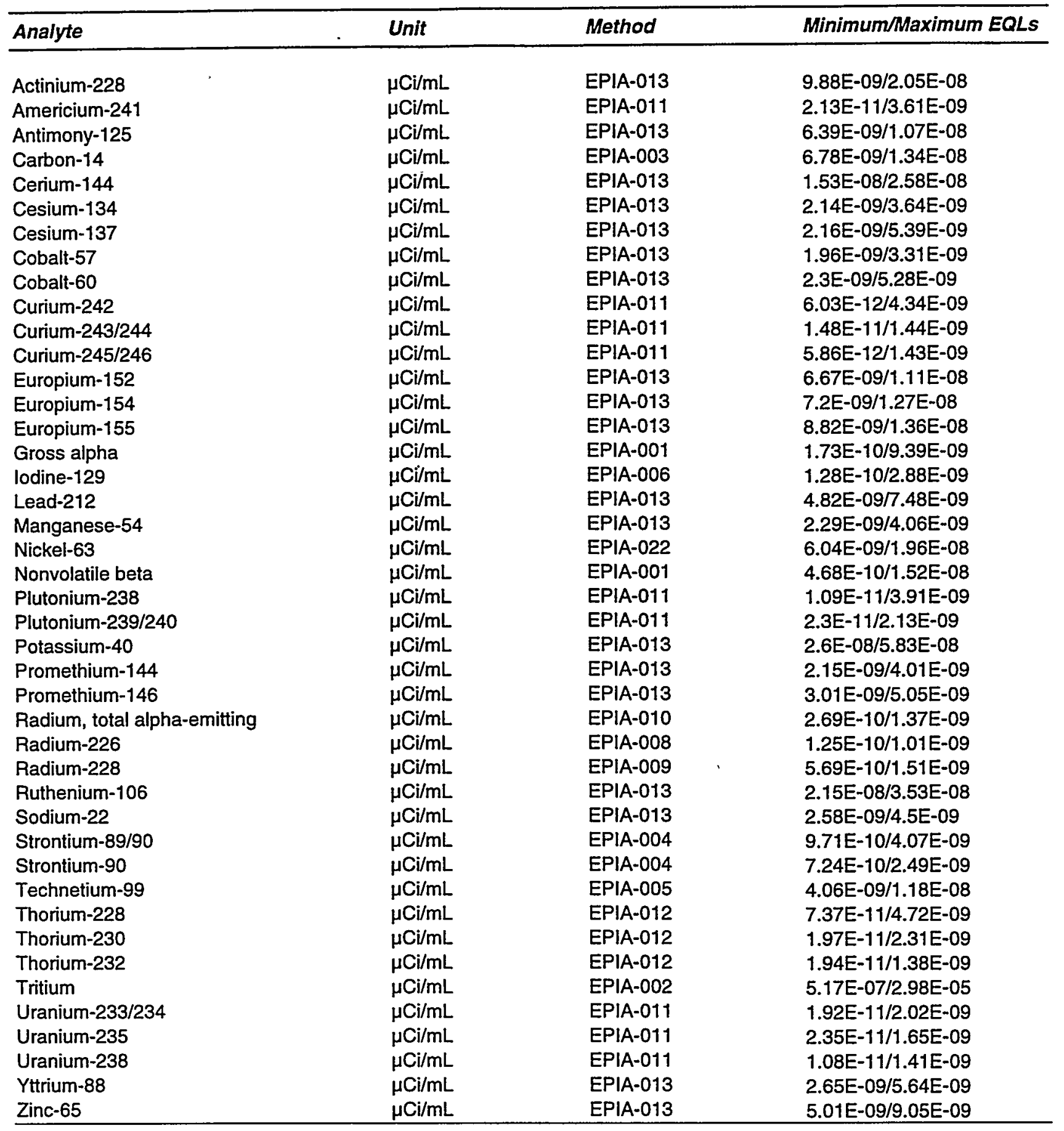


Table 15. Methods and Estimated Quantitation Limits Used by TM

\begin{tabular}{|c|c|c|c|}
\hline Analyte & Unit & Method & Minimum/Maximum EQLs \\
\hline Actinium-228 & $\mu \mathrm{Ci} / \mathrm{mL}$ & EPA901.1MOD & $1.687 \mathrm{E}-08 / 2.637 \mathrm{E}-08$ \\
\hline Antimony-124 & $\mu \mathrm{Ci} / \mathrm{mL}$ & EPA901.1MOD & 4.97E-09/5.57E-09 \\
\hline Antimony-125 & $\mu \mathrm{Ci} / \mathrm{mL}$ & EPA901.1MOD & $1.089 \mathrm{E}-08 / 1.408 \mathrm{E}-08$ \\
\hline Barium-133 & $\mu \mathrm{Ci} / \mathrm{mL}$ & EPA901.1MOD & 4.5E-09/6.67E-09 \\
\hline Cerium-144 & $\mu \mathrm{Ci} / \mathrm{mL}$ & EPA901.1MOD & 2.498E-08/2.769E-08 \\
\hline Cesium-134 & $\mu \mathrm{Ci} / \mathrm{mL}$ & EPA901.1MOD & 4.63E-09/5.51E-09 \\
\hline Cesium-137 & $\mu \mathrm{Ci} / \mathrm{mL}$ & EPA901.1MOD & 4.32E-09/6.95E-09 \\
\hline Cobalt-57 & $\mu \mathrm{Ci} / \mathrm{mL}$ & EPA901.1MOD & 3.41E-09/3.5E-09 \\
\hline Cobalt-58 & $\mu \mathrm{Ci} / \mathrm{mL}$ & EPA901.1MOD & 4.18E-09/6.51E-09 \\
\hline Cobalt -60 & $\mu \mathrm{Ci} / \mathrm{mL}$ & EPA901.1MOD & 4.79E-09/7.23E-09 \\
\hline Europium-152 & $\mu \mathrm{Ci} / \mathrm{mL}$ & EPA901.1MOD & $3.116 E-08 / 4.394 E-08$ \\
\hline Europium-154 & $\mu \mathrm{Ci} / \mathrm{mL}$ & EPA901.1MOD & $1.269 \mathrm{E}-08 / 1.976 \mathrm{E}-08$ \\
\hline Europium-155 & $\mu \mathrm{Ci} / \mathrm{mL}$ & EPA901.1MOD & $1.004 \mathrm{E}-08 / 1.359 \mathrm{E}-08$ \\
\hline Gross alpha & $\mu \mathrm{Ci} / \mathrm{mL}$ & EPA900.0MOD & $1.1 E-10 / 2.527 E-08$ \\
\hline lodine-129 & $\mu \mathrm{Ci} / \mathrm{mL}$ & EPA902.0MOD & 2.15E-09/1.072E-08 \\
\hline Lead-212 & $\mu \mathrm{Ci} / \mathrm{mL}$ & EPA901.1MOD & 5.75E-09/8.18E-09 \\
\hline Manganese-54 & $\mu \mathrm{Ci} / \mathrm{mL}$ & EPA901.1MOD & 4.27E-09/6.98E-09 \\
\hline Neptunium-239 & $\mu \mathrm{Ci} / \mathrm{mL}$ & EPA901.1MOD & $6.193 E-08 / 1.092 E-07$ \\
\hline Nonvolatile beta & $\mu \mathrm{Ci} / \mathrm{mL}$ & EPA900.0MOD & $2.6 \mathrm{E}-10 / 9.42 \mathrm{E}-09$ \\
\hline Potassium-40 & $\mu \mathrm{Ci} / \mathrm{mL}$ & EPA901.1MOD & $5.141 \mathrm{E}-08 / 6.072 \mathrm{E}-08$ \\
\hline Promethium-144 & $\mu \mathrm{Ci} / \mathrm{mL}$ & EPA901.1MOD & $4.88 \mathrm{E}-09 / 6.55 \mathrm{E}-09$ \\
\hline Promethium-146 & $\mu \mathrm{Ci} / \mathrm{mL}$ & EPA901.1MOD & 7.93E-09/1.076E-08 \\
\hline Radium, total alpha-emitting & $\mu \mathrm{Ci} / \mathrm{mL}$ & EPA903.0MOD & 4.3E-10/1.27E-09 \\
\hline Radium-226 & $\mu \mathrm{Ci} / \mathrm{mL}$ & EPA903.0MOD & $1.6 E-10 / 3.9 E-10$ \\
\hline Radium-228 & $\mu \mathrm{Ci} / \mathrm{mL}$ & EPA904.0MOD & $9.4 E-10 / 1.95 E-09$ \\
\hline Ruthenium-106 & $\mu \mathrm{Ci} / \mathrm{mL}$ & EPA901.1MOD & $3.903 \mathrm{E}-08 / 5.714 \mathrm{E}-08$ \\
\hline Sodium-22 & $\mu \mathrm{Ci} / \mathrm{mL}$ & EPA901.1MOD & 4.55E-09/7.07E-09 \\
\hline Strontium-90 & $\mu \mathrm{Ci} / \mathrm{mL}$ & EMLSR02MOD & 5.5E-10/4.19E-09 \\
\hline Technetium-99 & $\mu \mathrm{Ci} / \mathrm{mL}$ & EICHROMTC1MOD & 1.34E-09/1.412E-08 \\
\hline $\operatorname{Tin}-113$ & $\mu \mathrm{Ci} / \mathrm{mL}$ & EPA901.1MOD & 4.93E-09/6.58E-09 \\
\hline Tritium & $\mu \mathrm{Ci} / \mathrm{mL}$ & EPA906.0MOD & $3.8 \mathrm{E}-07 / 3.3415 \mathrm{E}-04$ \\
\hline Yttrium-88 & $\mu \mathrm{Ci} / \mathrm{mL}$ & EPA901.1MOD & $4.24 \mathrm{E}-09 / 5.57 \mathrm{E}-09$ \\
\hline Zinc-65 & $\mu \mathrm{Ci} / \mathrm{mL}$ & EPA901.1MOD & 9.82E-09/1.39E-08 \\
\hline Zirconium-95 & $\mu \mathrm{Ci} / \mathrm{mL}$ & EPA901.1MOD & 7.95E-09/1.103E-08 \\
\hline
\end{tabular}


NOTES 


\section{Quality Control Samples}

This section discusses the analytical data in terms of the following indicators of data quality: precision, accuracy, representativeness, comparability, and completeness. Precision is determined from the field and laboratory duplicate or replicate analyses and indicates the consistency of field and laboratory techniques. Accuracy is determined from the quality control standards, laboratory control samples or blank spikes, surrogates, matrix spikes, and the results of method, field, and trip blanks and indicates the ability of the laboratory to generate correct results. (Equipment blanks are used to evaluate the effectiveness of the cleaning procedures used in the field.) Representativeness is the determination of how well the sample reflects the site's characteristics. Comparability expresses the confidence with which data from different laboratories are considered to be equivalent. Completeness measures the amount of useable data resulting from the data collection activity.

\section{PRECISION}

Precision is a measure of the repeatability of a measurement and is evaluated from the results of duplicate samples and splits. Blind replicates, or field replicates, measure the repeatability of the sampling and analytical techniques, and laboratory duplicates measure the ability of the laboratory to reproduce a result. Split samples measure whether two laboratories using comparable procedures obtain equivalent results. Low precision can be caused by poor instrument performance, poor operator technique, inconsistent application of method protocols, laboratory environment, time between analyses, or by a difficult, heterogeneous sample matrix.

\section{Replicate and Duplicate Analyses of Samples}

Blind replicate and duplicate samples are analyzed to establish the precision of scheduled analyses. The replicate and duplicate analytical results are used to generate Mean Relative Difference (MRD) indices, which are used to evaluate the laboratories' performances.

The primary laboratories EX, GE, and WA, performed all analyses with the following exceptions: GP and TM performed radionuclide analyses for EX, GE, and WA; and ML performed some on-site volatile and semivolatile organics and metals analyses.

For intralaboratory comparisons, generally $10 \%$ of the samples are analyzed in duplicate. In addition, EPD/EMS sends blind replicates of approximately $5 \%$ of the total samples to the laboratories for analysis. The results of the blind replicate analyses are used for both intralaboratory and interlaboratory comparisons.

All second quarter 1999 analytical results that have undergone verification and validation are included in the Analytical Results section (Appendix B); those that have not are in the Analytical and Sampling Blank Results for MSB Wells section (Appendix D) of this report. Results from duplicate samples are included in the main table for a given well and sample date. Results from analyses of replicate samples and duplicate analyses of the replicates are reported in a second table for the same well and sample date.

Table 16 lists the well names, sample dates, and associated blanks for wells used as blind replicates for EX, GE, WA, and ML.

Certain analytes were not present in concentrations above estimated quantitation limits in any well samples having replicates or duplicates. These analytes are not considered in further evaluation of replicate and duplicate analyses and are listed in tables 17 and 18. See tables 10-15 for the estimated quantitation limits that are applicable this quarter.

\section{Intralaboratory Comparisons}

Intralaboratory comparisons are of two types: in-house duplicates and blind replicates. The MRD was developed by R.C. Tuckfield of the Applied Statistics Group at the Savannah River Technology Center, in conjunction with M.M. Khalil of EPD/EMS, to assess the reproducibility of identical chemical analyses. For both intralabora- 
tory comparisons, the MRD is defined as the average absolute difference between an original sample and its duplicate or blind replicate, expressed as a percentage of the mean of those two values. It is calculated as

$$
\operatorname{MRD}=\left\{\frac{\sum_{i=1}^{n}\left(\left|x_{i}-y_{i}\right| /\left[\left(x_{i}+y_{i}\right) / 2\right]\right)}{n}\right\} \times 100
$$

where

$$
\begin{aligned}
x_{i}= & \text { an analyte's mean concentration } \\
& \text { in a water sample for the } i^{\text {th }} \text { well, }
\end{aligned}
$$

For the in-house duplicate comparisons, the quantities $x_{i}$ and $y_{i}$ represent the results for the original sample and the in-house duplicate, respectively. For the blind replicate comparisons, $x_{i}$ and $y_{i}$ represent the results for the known sample and the EPD blind replicate, respectively. Generally, the closer the original results and their replicate or duplicate results are to each other, the lower the MRD.

\section{An Adjusted Mean Relative Difference}

A drawback to the MRD statistic occurs when $x_{i}$ and $y_{i}$ are close to zero. This drawback can be illustrated by determining the relative difference (RD) for the $i^{\text {th }}$ well or sample as follows:

$$
\begin{gathered}
\mathrm{RD}_{i}=\frac{\left|x_{i}-y_{i}\right|}{z_{i}} \\
\text { where } z_{i}=\left(\frac{x_{i}+y_{i}}{2}\right)
\end{gathered}
$$

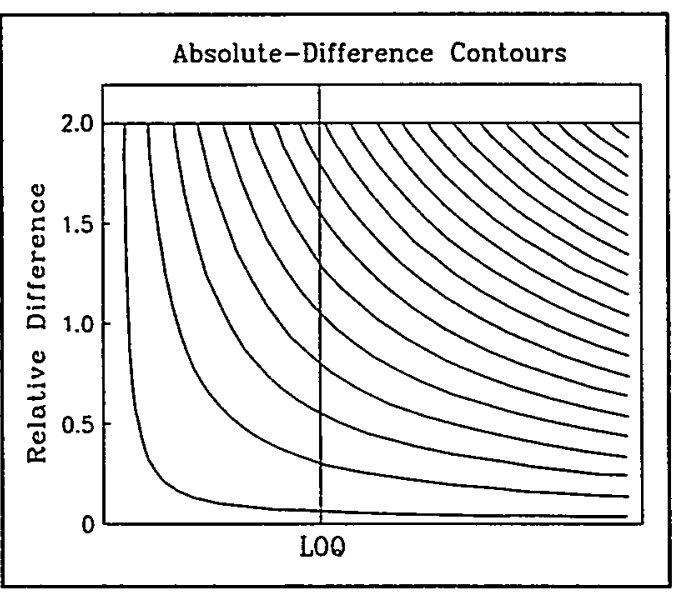

Figure 4. Relative Difference vs. the Mean 
The $\mathrm{RD}_{i}$ is an individual term in the MRD calculation for the $i^{\text {th }}$ replicated sample. For example, if $x_{i}=99$ and $y_{i}$ $=101$, then $\mathrm{RD}_{i}=2 \%$. However, if $x_{i}=3$ and $y_{i}=1$, then $\mathrm{RD}_{i}=100 \%$. Both situations have the same absolute difference, but the latter situation has a much larger relative difference. The effect can be shown by graphing the relative difference vs. the mean $\left(z_{i}\right)$ and marking contours for constant levels of absolute difference (figure 4). The first contour, in the lower left corner of the figure, represents the smallest absolute difference. The last contour, in the upper right corner of the figure, represents the largest absolute difference.

The inordinate inflation of the MRD when $x_{i}$ and $y_{i}$ are near zero is of particular concern when the results are below the limit of quantitation (LOQ). Briefly, the LOQ is defined by L.H. Keith (1991) as 10 times the instrument signal standard deviation $(\sigma)$ for blank samples. For perspective, the limit of detection is defined as $3 \sigma$.

The reproducibility of analytical results less than the LOQ is considered by environmental chemists to be questionable. In this situation, the $\mathrm{RD}_{j}$ may reflect variation more in the measuring device itself than in the measuring process. However, the MRD can be a useful statistic if adjusted so that results below the LOQ have less influence than more reproducible results above the LOQ.

The simplest adjustment to the MRD to reduce the influence of analyte concentrations near zero is to weight each $R_{D_{i}}$ in the calculation by an amount, $w_{i}$, that reflects its proximity to the LOQ value. Figure 5 shows the relationship between $w_{i}$ and analyte concentration. This relationship is a linear-weight function.

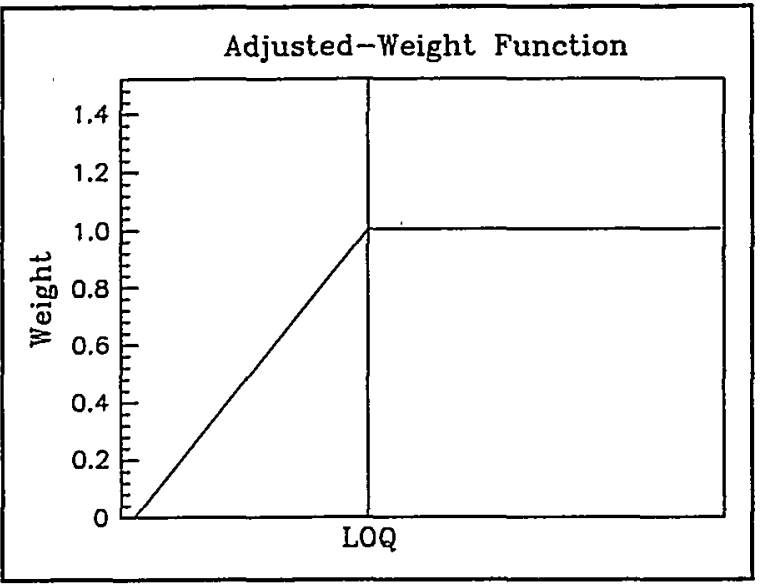

\section{Figure 5. Rolationship botwoen $\mathrm{w}_{\mathrm{l}}$ and Analyto Concentration}

Figure 6 shows the computer simulation results for the effect of a linear-weight function on the now-adjusted MRD (MRDadj), developed by Tuckfield and Khalil, again by determining constant contours of absolute difference. Below the LOQ, all samples with the same absolute difference are given the same adjusted RD value. Above the $L O Q$, the unadjusted RD is preserved because the weight function is unity when $z_{i}$ is greater than the LOQ.

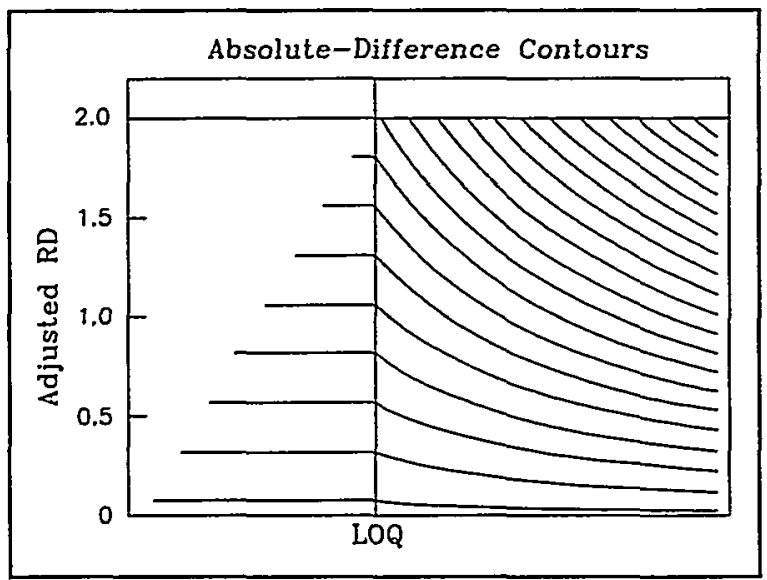

Figure 6. Effect of a Linear-Weight Function on the MRDadj 
The MRDadj, then, has the following form:

$$
\begin{gathered}
\text { MRDadj }=\frac{\sum_{i=1}^{n} w_{i} \mathrm{RD}_{i}}{n}, \\
\text { where } \mathrm{w}_{i}= \begin{cases}\frac{z_{i}}{\mathrm{LOQ}} & ; \text { if } z_{i}<\mathrm{LOQ} \\
1 & ; \text { otherwise. }\end{cases}
\end{gathered}
$$

This adjustment has several advantages. For example, the weight function reflects the chemist's view of the reliability of the measurement. If analyses are conducted on different equipment (i.e., with different LOQs), the precision of the equipment is included automatically in the MRD. Data from more precise equipment are given more influence. Also, no data are removed from the computation completely, so the sample size $(n)$ is not affected.

\section{Normalizing Data to the Reference Detection Limit}

Because some detection limits may be anomalously high (because of dilution or other effects, for example), it is necessary to use a reference detection limit (RDL) in the MRD calculations. This is set as the 90th percentile value of the detection limits of the not-detected samples. All the results less than the RDL are adjusted up to that value. Results that are detection limit values above the RDL are eliminated from the MRD index calculations. By definition, fewer than $10 \%$ of the detection limit values are above the RDL. The intralaboratory MRD indices are listed in tables 19-24. Table 21 provides the intralaboratory MRD matrix spike indicies for GE.

\section{Interlaboratory Comparisons}

For interlaboratory comparisons, the MRD is calculated as the average absolute difference between the laboratories for the $i^{\text {th }}$ well expressed as a percentage of the mean of both laboratories. For these comparisons, $x_{i}$ and $y_{i}$ represent the mean analyte concentrations for the $i^{\text {th }}$ well; $x_{i}$ represents the mean from one laboratory, and $y_{i}$ represents the mean from the other. The means are calculated from the known sample results and the EPD blind replicate results.

\section{Choosing an RDL}

For interlaboratory comparisons, a new RDL must be established for calculation of the MRD. The interlaboratory RDL is chosen as the 90th percentile value from the combined array of non-detected sample results from both laboratories.

\section{Normalizing Data to the RDL}

All results less than the RDL are adjusted to the new RDL value. Detection limit values above the RDL are eliminated from the MRD index comparison and from the $t$-tests. By definition, fewer than $10 \%$ of the detection limit values are above the RDL. In addition to the interlaboratory MRD calculations, paired $t$-tests are performed to see if the difference between the mean concentrations of an analyte from the same well reported by each laboratory is significant. The t-test tests the null hypothesis that there is no significant difference in the concentrations reported by the two laboratories. The MRD and the $t$-test results for analytes with at least one pair of results above the interlaboratory RDL are listed in tables $25-27$.

Analytes with significance-of-probability values less than .050 (tables 25-27) indicate a probability of less than $5 \%$ that the results for that analyte are the same from both laboratories.

\section{Presentation of the Replicate and Duplicate Analyses}

in tables 25-27, high MRDs (greater than or equal to 20) appear in bold type. Low MRDs (less than or equal to .050) appear in bold italic type. 
Table 28 lists analytes and wells for which samples and blind replicates analyzed by EX yielded results where one was more than twice another.

Table 29 lists analytes and wells for which samples and laboratory duplicates analyzed by EX yielded results where one was more than twice another.

Table 30 lists analytes and wells for which samples and blind replicates analyzed by WA yielded results where one was more than twice another.

Table 31 lists analytes and wells for which samples and laboratory duplicates analyzed by WA yielded results where one was more than twice another.

Table 32 lists analytes and wells for which samples and blind replicates analyzed by GP yielded results where one was more than twice another.

Table 33 lists analytes and wells for which samples and laboratory duplicates analyzed by GP yielded results where one was more than twice another.

Table 34 lists analytes and wells for which samples and laboratory duplicates analyzed by TM yielded results where one was more than twice another.

Tables 35-37 list analytes and wells where a result from one laboratory was more than twice the corresponding result from the other laboratory.

See the Analytical Methods subsection of the Analytical Data Review section of this report for more information.

\section{ACCURACY}

Accuracy is defined as the closeness of agreement between an observed value and an accepted reference value or as a measure of the over- or underestimation of reported concentrations. Accuracy is especially important when the concentration of concern approaches the detection limit and/or the action limit. When the concentration is underestimated near the detection limit, the analyte may be present but reported as not detected; near the action limit, the analyte may be at a concentration that would require remediation, but the remediation would not be performed. When the concentration is overestimated near the detection limit, the analyte may not be present but reported as detected; near the action limit, the analyte may not be at a concentration that would require remediation, but the remediation would be performed. Quality control standards, performance evaluation studies, laboratory control samples, surrogate and matrix spikes, and method blanks are used to evaluate accuracy.

\section{Quality Control Standards}

During second quarter 1999, EPD/EMS conducted quality assessments of EX, GE, and WA laboratories. Each laboratory received a set of certified environmental quality control standards from Environmental Resource Associates (ERA) of Arvada, CO (lot numbers 435, 574, 580, 581, 585, 587, 3214, 3427, 8913, 9980, $9983,9985,13028$, and 21028). Each laboratory's results were compared with the ERA-certified values and performance acceptance limits (PALS). The PALS are listed as guidelines for acceptable analytical results given the limitations of the EPA methods used to determine these parameters. The PALs closely approximate the $95 \%$ confidence interval. EX, GE, and WA all returned results for second quarter 1999 quality control assessments. The laboratories' results and the certified values and limits are listed in tables 38-40.

EX, GE, and WA analyzed total petroleum hydrocarbons by the infrared method and grease and oil by the gravimetric method. The laboratories were requested to report $\mathrm{m}$-cresol and $\mathrm{p}$-cresol as $\mathrm{m} / \mathrm{p}$-cresol and $\mathrm{m}$-xylene and $\mathrm{p}$-xylene as $\mathrm{m} / \mathrm{p}$-xylene because current analytical methods do not allow them to separate these analytes reliably.

Of 107 analyses reported by EX, 101, or $94.4 \%$, were within the PALs. Of the 107 analyses reported by GE, 105 , or $98.1 \%$, were within the PALs. Of 107 analyses reported by WA, 93 , or $86.9 \%$, were within the PALs. During second quarter 1999, WA experienced a problem with the laboratory equipment used to conduct 
analytical method EPA8081 for pesticides, PCBs, and toxaphene. Except for the analyses using analytical method EPA8081, 96.7\% of the analyses reported by WA during second quarter 1999 were within the PALs.

\section{Laboratory Control Samples}

Laboratory control samples are used to monitor the performance of all steps in the analysis process, including sample preparation, and are used to identify problems with the analytical procedure. Laboratory control samples are deionized water that is spiked with the target analyte, digested, and analyzed with the regular samples for inorganic parameters. Blank spikes are organic-free water that is spiked with selected target analytes, extracted, and analyzed with the regular samples for organic parameters. The spiking solutions for laboratory control samples are obtained from the EPA or a third-party supplier, or they are prepared in the laboratory with chemicals from a different source than the calibration standards. All laboratory control standards are validated to EPA standards, as detailed in the EGG Operating Handbook, section 1.800, Analytical Data Qualification.

The percent recovery $(\% \mathrm{R})$ for laboratory control samples or blank spikes is calculated as

$$
\% R=\frac{\text { Observed concentration }}{\text { Known concentration }} \times 100
$$

Tables 41-46 list the statistical information for the percent recovery for laboratory control samples by analyte for EX, GE, WA, ML, GP, and TM. The Qualified Out of Range column provides the number of laboratory control samples or blank spikes that had percent recoveries outside the acceptance limits compared to the total number analyzed; the other columns provide the mean recovery, standard deviation, and the minimum and maximum recoveries.

\section{Surrogates}

Surrogates are analytes not normally found in environmental samples that are used to spike all samples, QC samples, and calibration standards for organic analyses. Surrogates are added prior to analysis for VOAs (volatile organic analyses) and prior to extraction for semivolatiles, pesticides, and herbicides. Low surrogate recovery is a measure of the effect of the sample matrix, high analyte concentration, or laboratory error. High surrogate recovery usually indicates instrument or sample preparation errors. All surrogates are validated to EPA standards, as detailed in the WSRC EGG Operating Handbook, section 1.800, Analytical Data Qualification.

Tables $47-50$ list the statistical information for the percent recovery for the surrogates by analyte for $E X, G E$, WA, and ML. The Qualified Out of Range column gives the number of surrogates that had percent recoveries outside the acceptance limits compared to the total number analyzed; the other columns provide the mean recovery, standard deviation, and the minimum and maximum recoveries.

\section{Matrix Spikes}

Matrix spikes are used to evaluate the effect of the sample matrix on the analytical procedure. Matrix spikes are prepared by adding a known quantity of the target analyte to at least $5 \%$ of the samples prior to sample preparation. For the inorganic analyses, all target analytes are spiked. For the organic analyses, selected target analytes are used in the spiking solution. Results from the matrix spike are used to evaluate the extent of matrix interference and to determine the bias of the procedure for the sample matrix. Matrix spikes have the same recovery limits as laboratory control samples. 
The percent recovery for matrix spikes is calculated as

$$
\% R=\frac{S S R-S R}{S A} \times 100
$$

where

$$
\begin{aligned}
& \% R=\text { percent recovery } \\
& \text { SSR }=\text { spiked sample result } \\
& \text { SR }=\text { sample result, and } \\
& S A=\text { spike added. }
\end{aligned}
$$

Percent bias in tables 51-55 is the difference between $100 \%$ and the mean recovery; a negative value indicates that the mean recovery was below $100 \%$. If the bias is consistently positive, the laboratory may be overestimating the concentration of the analyte, and if the bias is consistently negative, the laboratory may be underestimating the concentration of the analyte. Results close to the quantitation and action limits should be closely examined, and their use in decision-making should be carefully considered.

Matrix spikes are rejected if the concentration of the analyte in the sample is more than four times the amount of the spike. Results for matrix spikes are provided in tables 51-55 for EX, GE, WA, ML, and GP. The Qualified Out of Range column provides the number of matrix spikes that had percent recoveries outside the acceptance limits compared to the total number analyzed; the other columns provide the mean recovery, standard deviation, percent bias, and the minimum and maximum recoveries.

\section{Method Blanks}

Method blanks, or laboratory blanks, are used to determine the existence and magnitude of contamination problems resulting from the analytical process. Method blanks are deionized water to which all reagents are added in the same proportions used in sample processing. When method blanks have detectable concentrations of the analytes, the laboratory must determine the cause and take corrective action to eliminate the contamination.

Tables 56-61 list the statistical information for analytes detected in method blanks for EX, GE, WA, ML, GP, and TM. The Frequency of Detection column provides the number of method blanks analyzed for each analyte during the quarter that had detectable concentrations compared to the total number that were analyzed. The other columns list the mean result, standard deviation, and minimum and maximum results.

\section{Field Blanks}

Field blanks (called QA blanks in the tables) are used to identify possible sources of contamination from the processing and shipping of samples. Field blanks are sample bottles filled with deionized water prior to well sampling; the bottles are not opened at the sampling site. The field blanks are sent along with, and analyzed in the same manner as, the samples. Positive results from field blanks can result from analytical bias, contaminated sample bottles, contaminated deionized water, or contamination during shipping or analysis. The results from all samples in the sample delivery group are evaluated by the laboratory and data validators to determine the cause of the contamination and the corrective action to be taken.

Tables 62-66 list the statistical information for the field blanks by analyte for EX, GE, WA, GP, and TM. The Frequency of Detection column gives the number of field blanks analyzed for each analyte during the quarter that had detectable concentrations compared to the total number analyzed. The other columns list the mean result, standard deviation, and minimum and maximum results.

\section{Quality Control Samples}




\section{Trip Blanks}

Trip blanks are vials of deionized water sent to the laboratory for volatiles analysis with each shipping cooler containing volatiles samples. Trip blanks are used to check for contamination resulting from shipping, primarily due to the breaking of the vial's seal because of depressurization during air transport. Trip blanks are used also to test the laboratories' reliability. The blanks are prepared by adding preservative to a $40 \mathrm{~mL}$ vial, filling it completely with deionized water, and sealing the top with a teflon-lined septum cap. The results from all samples in the sample delivery group are evaluated by the laboratory and data validators to determine the cause of the contamination and the corrective action to be taken.

Tables 67-70 list the statistical information for the analytes detected in trip blanks by EX, GE, WA, and ML. The Frequency of Detection column gives the number of trip blanks analyzed for each analyte during the quarter that had detectable concentrations compared to the total number analyzed. The other columns list the mean result, standard deviation, and minimum and maximum results.

\section{Equipment Blanks or Rinsates}

Equipment blanks (called EPT blanks in the tables) or rinsates are used to determine if sampling equipment that has been cleaned in the field is contaminated. Prior to sampling, deionized water is poured over or pumped through portions of the sampling equipment that come in contact with the sample. If the equipment blank is contaminated, the field cleaning procedure must be evaluated to determine the cause of the contamination. Results for all samples collected with equipment cleaned in the field must be evaluated to determine whether the contamination is isolated or generalized.

No information about equipment blanks was provided for second quarter 1999.

\section{Blanks Results}

The blanks results tables in Appendix $\mathrm{C}$ list the dates, field measurements, and analytical results for the sampling blanks. See Appendix B for a key to the abbreviations used in the tables.

\section{REPRESENTATIVENESS}

A representative sample is a sample that can be expected to exhibit the average properties of the population being sampled. Representativeness for groundwater samples can be affected by using a bailer to collect the sample from the well, metal casings in the well, and turbidity (suspended particulates) in the sample. The results may be biased positively or negatively.

If a well is bailed, VOAs are biased negatively due to aeration of the sample in the sampling process. No wells were bailed during second quarter 1999.

For metal casings, the bias for metals can be positive or negative depending on whether the casing is releasing or absorbing metals. Table 71 lists the wells with metal casings that were sampled during second quarter 1999.

If turbidity is greater than 15 NTU, the metals can be biased positively or negatively, and the radionuclidesparticularly those that are determined by gamma spectroscopy-can be masked due to self-absorption. Table 72 lists the wells that had turbidity results greater than 15 NTU during second quarter 1999.

\section{COMPARABILITY}

Comparability is evaluated by confirming that the laboratories used the same standardized procedures for sample preparation and analysis, that the reporting units are the same, and that similar quantitation limits were obtained. The analytical methods, reporting units, and EQLs reported by each laboratory are given in tables 1015 in the Analytical Data Review section. Tables 35-37 list the analytes and wells where a result from one laboratory was more than twice the corresponding result from the other laboratory. 


\section{COMPLETENESS}

Completeness is evaluated by comparing the wells scheduled for sampling with the wells sampled and comparing the requested analyses. with the analytical data received. The number of wells sampled and the requested analyses are determined from the chains of custody. The laboratories performed all requested analyses on samples from wells that could be sampled. See the Sample Scheduling, Field Notes, Analytical Results, and Analytical and Sampling Blanks Results for MSB Wells sections of this report for more information on wells scheduled but not sampled this quarter.

Table 16. Wells Providing Blind Replicate Samples and Associated Blanks

\begin{tabular}{|c|c|c|c|}
\hline Well & $\begin{array}{l}\text { Sample } \\
\text { Date }\end{array}$ & Replicate & $\begin{array}{l}\text { Associated } \\
\text { Blank }\end{array}$ \\
\hline $\begin{array}{l}\text { BGO 14AR } \\
\text { BGO 15D } \\
\text { BGO 20B } \\
\text { BGO 39C } \\
\text { BGO 52C } \\
\text { CSL 26D } \\
\text { DBP 4 } \\
\text { DOB 2 } \\
\text { FSB 76A } \\
\text { FSB 78B } \\
\text { FSB 87A } \\
\text { FSB 93C } \\
\text { FSB 98AR } \\
\text { HSB 83A } \\
\text { HSB 86B } \\
\text { HSB118A } \\
\text { HSB120A } \\
\text { HSB127C } \\
\text { HSB131C } \\
\text { HSB140A } \\
\text { KCB 3 } \\
\text { LFW 10A } \\
\text { LFW 61D } \\
\text { P 26B } \\
\text { PSB 2A } \\
\text { RSD 3 } \\
\text { RSE 7 } \\
\text { RWM 3 } \\
\text { RWM 8 } \\
\text { RWM 11 } \\
\text { SBG 4 } \\
\text { SRW 9 } \\
\text { TRW 4 } \\
\text { TNX61M } \\
\text { XSB 4D }\end{array}$ & $\begin{array}{l}05 / 25 / 99 \\
05 / 24 / 99 \\
04 / 14 / 99 \\
05 / 17 / 99 \\
06 / 14 / 99 \\
04 / 14 / 99 \\
04 / 13 / 99 \\
06 / 03 / 99 \\
04 / 05 / 99 \\
04 / 15 / 99 \\
04 / 06 / 99 \\
04 / 06 / 99 \\
04 / 15 / 99 \\
04 / 19 / 99 \\
04 / 16 / 99 \\
04 / 22 / 99 \\
04 / 23 / 99 \\
04 / 21 / 99 \\
04 / 23 / 99 \\
04 / 23 / 99 \\
05 / 12 / 99 \\
06 / 03 / 99 \\
06 / 07 / 99 \\
05 / 04 / 99 \\
05 / 21 / 99 \\
05 / 14 / 99 \\
06 / 17 / 99 \\
04 / 14 / 99 \\
\text { Canceled } \\
06 / 14 / 99 \\
05 / 20 / 99 \\
05 / 10 / 99 \\
05 / 17 / 99 \\
\text { Canceled } \\
05 / 05 / 99\end{array}$ & $\begin{array}{l}\text { QA 43B } \\
\text { QA 45B } \\
\text { QA 25B } \\
\text { QA 27B } \\
\text { QA 29B } \\
\text { QA 57B } \\
\text { QA 61B } \\
\text { QA 37B } \\
\text { QA 1B } \\
\text { QA 3B } \\
\text { QA 5B } \\
\text { QA 7B } \\
\text { QA 9B } \\
\text { QA 11B } \\
\text { QA 13B } \\
\text { QA 15B } \\
\text { QA 17B } \\
\text { QA 19B } \\
\text { QA 21B } \\
\text { QA 23B } \\
\text { QA 67B } \\
\text { QA 47B } \\
\text { QA 49B } \\
\text { QA 51B } \\
\text { QA 39B } \\
\text { QA 63B } \\
\text { QA 64B } \\
\text { QA 31B } \\
\text { QA 35B } \\
\text { QA 59B } \\
\text { QA 41B } \\
\text { QA 53B } \\
\text { QA 55B }\end{array}$ & $\begin{array}{l}\text { QA 44B } \\
\text { QA 46B } \\
\text { QA 26B } \\
\text { QA 28B } \\
\text { QA 30B } \\
\text { QA 58B } \\
\text { QA 62B } \\
\text { QA 38B } \\
\text { QA 2B } \\
\text { QA 4B } \\
\text { QA 6B } \\
\text { QA 8B } \\
\text { QA 10B } \\
\text { QA 12B } \\
\text { QA 14B } \\
\text { QA 16B } \\
\text { QA 28B } \\
\text { QA 20B } \\
\text { QA 22B } \\
\text { QA 24B } \\
\text { QA 68B } \\
\text { QA 48B } \\
\text { QA 50B } \\
\text { QA 52B } \\
\text { Not applicable } \\
\text { QA 64B } \\
\text { QA 66B } \\
\text { Not applicable } \\
\text { Not applicable } \\
\text { Not applicable } \\
\text { Not applicable } \\
\text { QA 54B } \\
\text { QA 56B }\end{array}$ \\
\hline
\end{tabular}




\begin{tabular}{|c|c|c|c|c|}
\hline Analyte & $\frac{\text { Number of Analyses }}{G E}$ & WA & $E X$ & $M L$ \\
\hline Acenaphthene & 5 & 8 & - & - \\
\hline Acenaphthylene & 5 & 8 & - & - \\
\hline Acetonitrile & - & 2 & 6 & - \\
\hline Acetophenone & 1 & 4 & - & - \\
\hline 2-Acetylaminofluorene & $i$ & 4 & - & - \\
\hline Acrolein & - & 2 & 6 & - \\
\hline Acrylonitrile & - & 2 & 6 & - \\
\hline Aldrin & 4 & 3 & - & - \\
\hline Allyl chloride & - & 2 & 6 & - \\
\hline 4-Aminobiphenyl & 1 & 4 & - & - \\
\hline Aniline & 1 & 4 & - & - \\
\hline Anthracene & 5 & 8 & - & - \\
\hline Antimony & 6 & 17 & 2 & - \\
\hline Aramite & 1 & 4 & - & - \\
\hline Benzene & 7 & 41 & 20 & - \\
\hline alpha-Benzene hexachloride & 4 & 3 & - & - \\
\hline beta-Benzene hexachloride & 4 & 3 & - & - \\
\hline delta-Benzene hexachloride & 4 & 3 & - & - \\
\hline Benzidine & 4 & - & - & - \\
\hline Benzo[a]anthracene & 5 & 8 & - & - \\
\hline Benzo[b]fluoranthene & 5 & 8 & - & - \\
\hline Benzo[ $k$ ffluoranthene & 5 & 8 & - & - \\
\hline Benzoic acid & 4 & - & - & - \\
\hline Benzo[g,h,i]perylene & 5 & 8 & - & - \\
\hline Benzo[a]pyrene & 5 & 8 & - & - \\
\hline Benzyl alcohol & 5 & 4 & - & - \\
\hline Beryllium & 6 & 6 & 2 & - \\
\hline Bis(2-chloroethoxy) methane & 5 & 8 & - & - \\
\hline Bis(2-chloroethyl) ether & 5 & 8 & - & - \\
\hline Bis(2-chloroisopropyl) ether & 5 & 8 & - & - \\
\hline Bis(2-ethylhexyl) phthalate & 7 & 10 & - & - \\
\hline Bromodichloromethane & 7 & 41 & 20 & - \\
\hline Bromoform & 7 & 41 & 20 & - \\
\hline Bromomethane & 7 & 41 & 20 & - \\
\hline 4-Bromophenyl phenyl ether & 5 & 8 & - & - \\
\hline Butylbenzyl phthalate & 5 & 8 & - & - \\
\hline Cadmium & 17 & 30 & 6 & - \\
\hline Carbazole & - & 4 & - & - \\
\hline Carbon disulfide & 4 & 6 & 8 & - \\
\hline alpha-Chlordane & 4 & 3 & - & - \\
\hline gamma-Chlordane & 4 & 3 & - & - \\
\hline 4-Chloroaniline & 5 & 8 & - & - \\
\hline Chlorobenzene & 7 & 41 & 20 & - \\
\hline Chlorobenzilate & 1 & 4 & - & - \\
\hline 4-Chloro-m-cresol & 4 & 4 & - & - \\
\hline Chloroethane & 7 & 41 & 20 & - \\
\hline 2-Chloroethyl vinyl ether & 3 & 35 & 12 & - \\
\hline Chloromethane & 7 & 41 & 20 & - \\
\hline 2-Chloronaphthalene & 5 & 8 & - & - \\
\hline 2-Chlorophenol & 4 & 4 & - & - \\
\hline 4-Chlorophenyl phenyl ether & 5 & 8 & - & - \\
\hline Chloroprene & - & 2 & 6 & - \\
\hline Chromium, hexavalent & 8 & 2 & - & - \\
\hline Chrysene & 5 & 8 & - & - \\
\hline Cobalt & 4 & 5 & 2 & - \\
\hline Copper & 6 & 17 & 2 & - \\
\hline $\mathrm{m} / \mathrm{p}$-Cresol & 4 & - & - & - \\
\hline
\end{tabular}




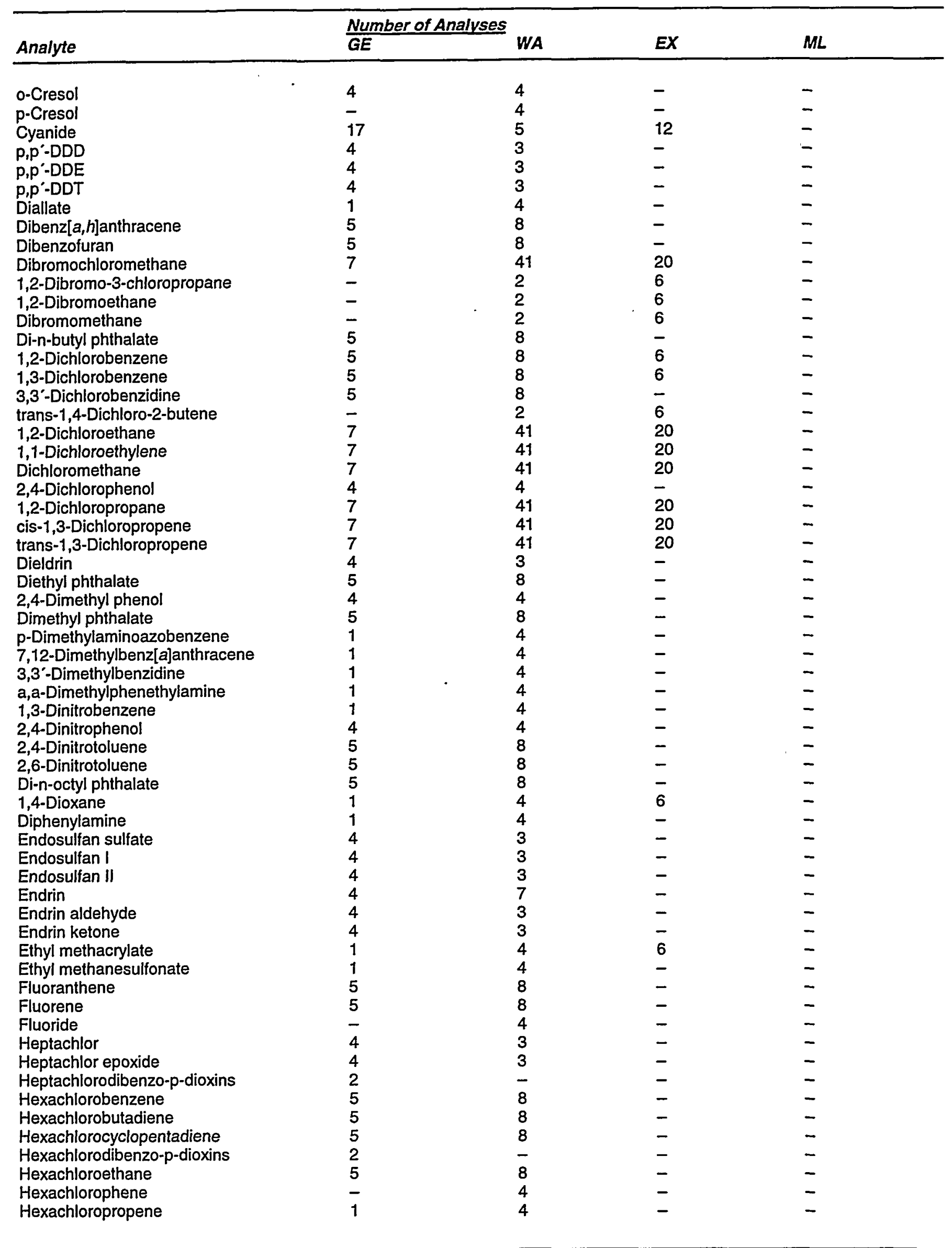




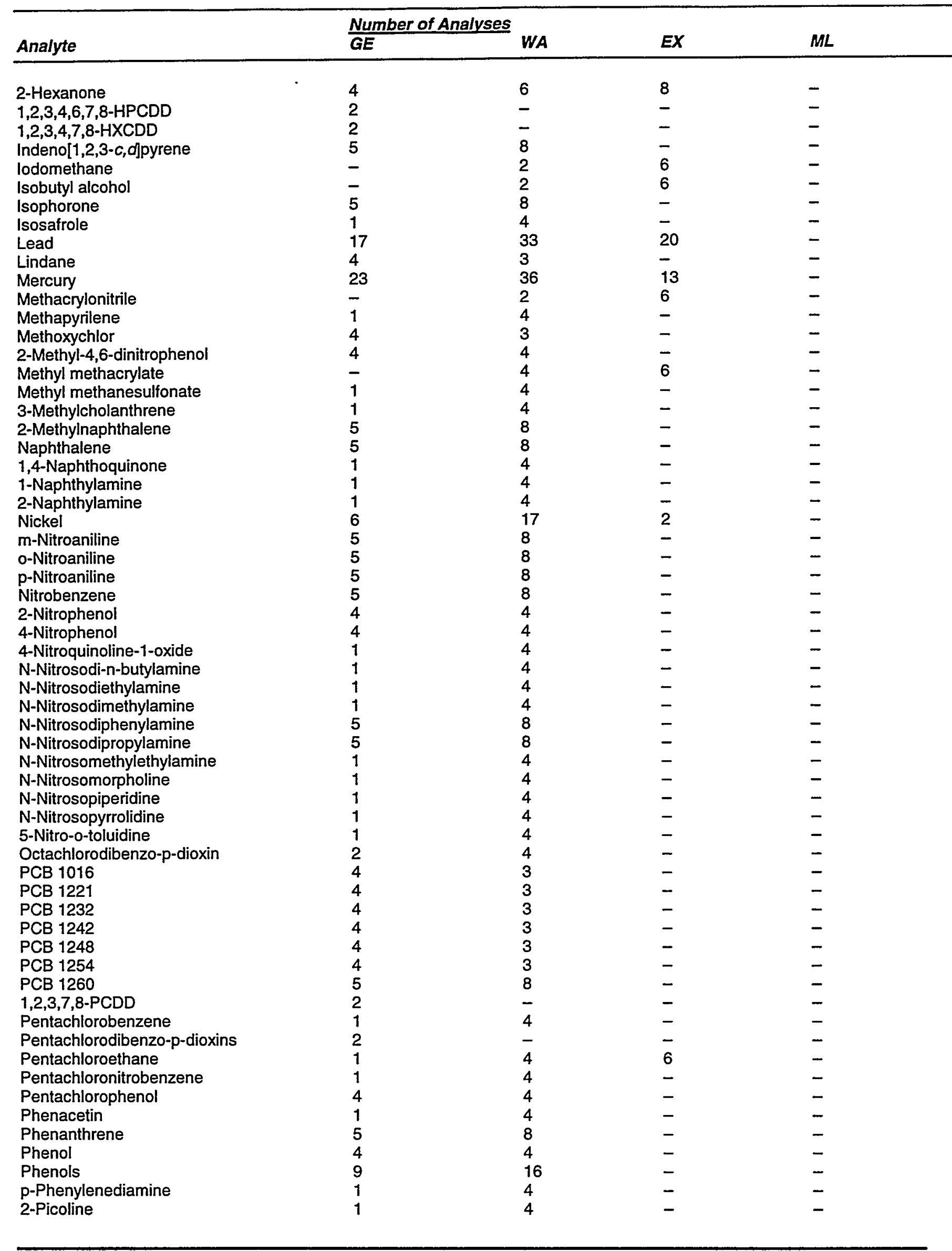




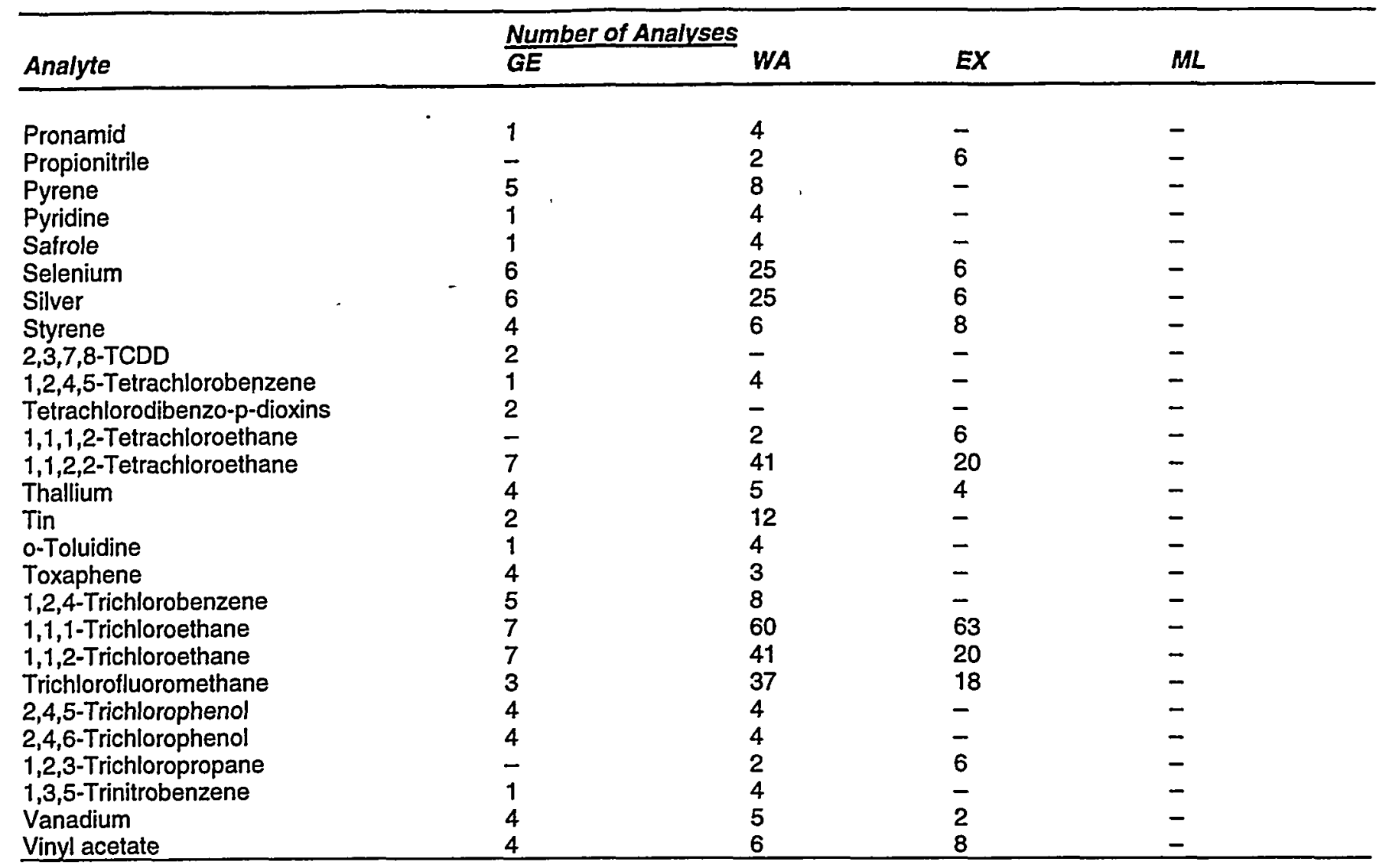

- No replicate or duplicate analyses were performed.

Table 18. Analytes Not Showing Measurable Concentrations above Estimated Quantitation Limits in Any Replicated or Duplicated Samples for GP and TM

\begin{tabular}{lll}
\hline & Number of Analyses & $T M$ \\
\cline { 2 - 3 } Analyte & GP & - \\
Americium-241 & 8 & 4 \\
Antimony-124 & - & 4 \\
Antimony-125 & 20 & 4 \\
Barium-133 & - & 4 \\
Cerium-144 & 20 & 4 \\
Cesium-134 & 20 & 4 \\
Cesium-137 & 20 & 4 \\
Cobalt-57 & 20 & 4 \\
Cobalt-58 & - & 4 \\
Cobalt-60 & 20 & - \\
Curium-242 & 8 & - \\
Curium-243/244 & 8 & - \\
Curium-245/246 & 8 & 4 \\
Europium-152 & 20 & 4 \\
Europium-154 & 20 & 4 \\
Europium-155 & 20 & 4 \\
Lead-212 & 20 & 4 \\
Manganese-54 & 20 & 4 \\
Neptunium-239 & - & - \\
Nickel-63 & 6 & - \\
Plutonium-238 & 8 &
\end{tabular}




\begin{tabular}{lll}
\hline & Number of Analyses & $T M$ \\
\cline { 2 - 3 } Analyte & GP & - \\
\hline Plutonium-239/240 & 8 & 4 \\
Promethium-146 & 20 & 4 \\
Sodium-22 & 20 & - \\
Thorium-228 & 8 & - \\
Thorium-230 & 8 & - \\
Thorium-232 & 8 & 4 \\
Tin-113 & - & 4 \\
Yttrium-88 & 20 & 4 \\
Zirconium-95 & - & \\
\hline
\end{tabular}

- No replicate or duplicate analyses were performed.

Table 19. Intralaboratory MRD Indices for EX

\begin{tabular}{|c|c|c|c|c|c|c|c|}
\hline \multirow[b]{2}{*}{ Analyte } & \multirow[b]{2}{*}{$R D L$} & \multicolumn{3}{|c|}{ In-house Duplicates } & \multicolumn{3}{|c|}{ Blind Replicates } \\
\hline & & $\begin{array}{l}\text { Number of } \\
\text { Dup. Pairs }\end{array}$ & MRD & MRDadj & $\begin{array}{l}\text { Number of } \\
\text { Dup. Pairs }\end{array}$ & MRD & MRDadj \\
\hline Acetone & $50 \mu \mathrm{g} / \mathrm{L}$ & 0 & - & - & 3 & 2.30 & 2.00 \\
\hline Aluminum & $200 \mu \mathrm{g} / \mathrm{L}$ & 0 & - & - & 6 & 0.00 & 0.00 \\
\hline Arsenic & $17 \mu \mathrm{g} / \mathrm{L}$ & 0 & - & - & 3 & 0.00 & 0.00 \\
\hline Barium & $10 \mu \mathrm{g} / \mathrm{L}$ & 0 & - & - & 4 & 0.75 & 0.75 \\
\hline Boron & $100 \mu \mathrm{g} / \mathrm{L}$ & 0 & - & - & 3 & 0.64 & 0.64 \\
\hline Calcium & $\dagger$ & 0 & - & - & 1 & 3.33 & 3.33 \\
\hline Carbon tetrachloride & $50 \mu \mathrm{g} / \mathrm{L}$ & 1 & 0.00 & 0.00 & 9 & 0.00 & 0.00 \\
\hline Chemical oxygen demand & $10,000 \mu \mathrm{g} / \mathrm{L}$ & $i$ & 0.00 & 0.00 & 1 & 53.90 & 22.80 \\
\hline Chloride & $200 \mu g / L$ & 1 & 0.00 & 0.00 & 1 & 1.42 & 1.42 \\
\hline Chloroethene & $250 \mu \mathrm{g} / \mathrm{L}$ & 0 & - & - & 6 & 0.00 & 0.00 \\
\hline Chloroform & $50 \mu \mathrm{g} / \mathrm{L}$ & 1 & 0.00 & 0.00 & 9 & 0.00 & 0.00 \\
\hline Chromium & $10 \mu \mathrm{g} / \mathrm{L}$ & 0 & - & - & 3 & 0.00 & 0.00 \\
\hline 1,4-Dichlorobenzene & $25 \mu \mathrm{g} / \mathrm{L}$ & 0 & - & - & 2 & 3.85 & 1.20 \\
\hline Dichlorodifluoromethane & $25 \mu \mathrm{g} / \mathrm{L}$ & 0 & - & - & 2 & 2.17 & 1.20 \\
\hline 1,1-Dichloroethane & $250 \mu \mathrm{g} / \mathrm{L}$ & 0 & - & - & 6 & 0.00 & 0.00 \\
\hline 1,2-Dichloroethylene & $1.0 \mu \mathrm{g} / \mathrm{L}$ & 0 & - & - & 1 & 0.00 & 0.00 \\
\hline cis-1,2-Dichloroethylene & $5.0 \mu \mathrm{g} / \mathrm{L}$ & 1 & 118.37 & 87.00 & 5 & 0.00 & 0.00 \\
\hline trans-1,2-Dichloroethylene & $250 \mu \mathrm{g} / \mathrm{L}$ & 0 & - & - & 5 & 0.00 & 0.00 \\
\hline Ethylbenzene & $250 \mu \mathrm{g} / \mathrm{L}$ & 0 & - & _- & 6 & 0.00 & 0.00 \\
\hline Iron & $200 \mu \mathrm{g} / \mathrm{L}$ & 0 & - & - & 6 & 3.76 & 2.38 \\
\hline Magnesium & $\dagger$ & 0 & - & - & 1 & 4.76 & 4.76 \\
\hline Manganese & $10 \mu \mathrm{g} / \mathrm{L}$ & 0 & - & - & 4 & 0.89 & 0.45 \\
\hline Methyl ethyl ketone & $50 \mu \mathrm{g} / \mathrm{L}$ & 0 & - & - & 3 & 3.17 & 3.17 \\
\hline Methyl isobutyl ketone & $25 \mu \mathrm{g} / \mathrm{L}$ & 0 & - & - & 3 & 0.00 & 0.00 \\
\hline Nitrate as nitrogen & $100 \mu \mathrm{g} / \mathrm{L}$ & 6 & 1.61 & 1.14 & 3 & 1.74 & 1.74 \\
\hline Nitrate-nitrite as nitrogen & $500 \mu \mathrm{g} / \mathrm{L}$ & 1 & 0.00 & 0.00 & 1 & 4.26 & 1.44 \\
\hline $\mathrm{pH}$ & $t$ & 1 & 0.36 & 0.36 & 1 & 3.25 & 3.25 \\
\hline Potassium & $5,000 \mu \mathrm{g} / \mathrm{L}$ & 0 & - & - & 1 & 0.00 & 0.00 \\
\hline Sodium & $\dagger$ & 0 & - & - & 1 & 15.38 & 15.38 \\
\hline Specific conductance & $t$ & 1 & 0.00 & 0.00 & 1 & 0.95 & 0.95 \\
\hline Sulfate & $200 \mu \mathrm{g} / \mathrm{L}$ & 1 & 0.00 & 0.00 & $i$ & 0.81 & 0.81 \\
\hline Tetrachloroethylene & $50 \mu \mathrm{g} / \mathrm{L}$ & 1 & 0.00 & 0.00 & 9 & 1.00 & 0.40 \\
\hline Toluene & $250 \mu \mathrm{g} / \mathrm{L}$ & 0 & - & - & 6 & 0.00 & 0.00 \\
\hline Total organic carbon & $\dagger$ & 0 & - & - & 1 & 34.15 & 34.15 \\
\hline Trichloroethylene & $5.0 \mu \mathrm{g} / \mathrm{L}$ & 1 & 120.00 & 120.00 & 9 & 19.33 & 19.33 \\
\hline
\end{tabular}




\begin{tabular}{|c|c|c|c|c|c|c|c|}
\hline \multirow[b]{2}{*}{ Analyte } & \multirow[b]{2}{*}{$R D L$} & \multicolumn{3}{|c|}{ In-house Duplicates } & \multicolumn{3}{|c|}{ Blind Replicates } \\
\hline & & $\begin{array}{l}\text { Number of } \\
\text { Dup. Pairs }\end{array}$ & MRD & MRDadj & $\begin{array}{l}\text { Number of } \\
\text { Dup. Pairs }\end{array}$ & $M R D$ & MRDadj \\
\hline Xylenes & $50 \mu \mathrm{g} / \mathrm{L}$ & 0 & - & - & 3 & 0.00 & 0.00 \\
\hline Zinc & $20 \mu \mathrm{g} / \mathrm{L}$ & 0 & - & - & 1 & 0.00 & 0.00 \\
\hline
\end{tabular}

$\dagger$ No detection limit, or no replicate or duplicate results below detection limit.

- No replicate or duplicate analyses could be calculated.

Note: An MRD of 0.00 indicates no difference between any of the pairs of results used in calculating the MRD. MRD results greater than or equal to 20 appear in bold.

Table 20. Intralaboratory MRD Indices for GE

\begin{tabular}{|c|c|c|c|c|c|c|c|}
\hline \multirow[b]{2}{*}{ Analyte } & \multirow[b]{2}{*}{$R D L$} & \multicolumn{3}{|c|}{ In-house Duplicates } & \multicolumn{3}{|c|}{ Blind Replicates } \\
\hline & & $\begin{array}{l}\text { Number of } \\
\text { Dup. Pairs }\end{array}$ & MRD & MRDadj & $\begin{array}{l}\text { Number of } \\
\text { Dup. Pairs }\end{array}$ & MRD & MRDadj \\
\hline Acetone & $100 \mu g / L$ & 0 & - & - & 2 & 0.00 & 0.00 \\
\hline Alkalinity (as $\mathrm{CaCO}_{3}$ ) & $3,570 \mu \mathrm{g} / \mathrm{L}$ & 2 & 0.45 & 0.45 & 0 & - & - \\
\hline Aluminum & $50.0 \mu \mathrm{g} / \mathrm{L}$ & 0 & - & - & 8 & 4.78 & 2.06 \\
\hline Arsenic & $5.0 \mu \mathrm{g} / \mathrm{L}$ & 0 & - & - & 2 & 0.00 & 0.00 \\
\hline Barium & $+\infty$ & 0 & - & - & 2 & 3.43 & 3.43 \\
\hline Boron & $50.0 \mu \mathrm{g} / \mathrm{L}$ & 0 & - & - & 0 & - & - \\
\hline Calcium & $t$ & 0 & - & - & 2 & 2.39 & 2.39 \\
\hline Carbon tetrachloride & $20.0 \mu \mathrm{g} / \mathrm{L}$ & 0 & - & - & 2 & 0.00 & 0.00 \\
\hline Chloride & $\dagger$ & 2 & 1.32 & 1.32 & 0 & - & - \\
\hline Chloroethene & $20.0 \mu \mathrm{g} / \mathrm{L}$ & 0 & - & - & 2 & 0.00 & 0.00 \\
\hline Chloroform & $20.0 \mu \mathrm{g} / \mathrm{L}$ & 0 & - & - & 2 & 0.00 & 0.00 \\
\hline Chromium & $5.0 \mu \mathrm{g} / \mathrm{L}$ & 0 & - & - & 3 & 0.00 & 0.00 \\
\hline 1,4-Dichlorobenzene & $10.4 \mu \mathrm{g} / \mathrm{L}$ & 0 & - & - & 2 & 0.00 & 0.00 \\
\hline 1,1-Dichloroethane & $20.0 \mu \mathrm{g} / \mathrm{L}$ & 0 & - & - & 2 & 0.00 & 0.00 \\
\hline 1,2-Dichloroethylene & $40.0 \mu \mathrm{g} / \mathrm{L}$ & 0 & - & - & 2 & 0.00 & 0.00 \\
\hline trans-1,2-Dichloroethylene & $1.0 \mu \mathrm{g} / \mathrm{L}$ & 0 & - & - & 0 & - & - \\
\hline Ethylbenzene & $20.0 \mu \mathrm{g} / \mathrm{L}$ & 0 & - & - & 2 & 0.00 & 0.00 \\
\hline Iron & $79.8 \mu \mathrm{g} / \mathrm{L}$ & 0 & - & - & 8 & 1.65 & 1.36 \\
\hline Lithium & $2.0 \mu \mathrm{g} / \mathrm{L}$ & 0 & - & - & 0 & - & - \\
\hline Magnesium & $t$ & 0 & - & - & 2 & 2.76 & 2.76 \\
\hline Manganese & $t$ & 0 & - & - & 2 & 7.54 & 7.54 \\
\hline Methyl ethyl ketone & $200 \mu \mathrm{g} / \mathrm{L}$ & 0 & - & - & 2 & 0.00 & 0.00 \\
\hline Methyl isobutyl ketone & $100 \mu \mathrm{g} / \mathrm{L}$ & 0 & - & - & 2 & 0.00 & 0.00 \\
\hline Nitrate-nitrite as nitrogen & $50.0 \mu \mathrm{g} / \mathrm{L}$ & 31 & 2.51 & 2.18 & 12 & 7.95 & 5.14 \\
\hline $\mathrm{pH}$ & $t$ & 37 & 0.19 & 0.19 & 13 & 1.11 & 1.11 \\
\hline Potassium & $t$ & 0 & - & - & 2 & 5.42 & 5.42 \\
\hline Sodium & $t$ & 0 & - & - & 2 & 23.29 & 23.29 \\
\hline Specific conductance & $t$ & 36 & 0.61 & 0.61 & 12 & 2.33 & 2.33 \\
\hline Sulfate & $t$ & 4 & 1.01 & 1.01 & 0 & - & - \\
\hline Tetrachloroethylene & $20.0 \mu \mathrm{g} / \mathrm{L}$ & 0 & ـ & - & 2 & 0.00 & 0.00 \\
\hline Toluene & $20.0 \mu \mathrm{g} / \mathrm{L}$ & 0 & - & - & 2 & 0.00 & 0.00 \\
\hline Total dissolved solids & $t$ & 3 & 2.91 & 2.91 & 0 & - & - \\
\hline Total organic carbon & $5,000 \mu \mathrm{g} / \mathrm{L}$ & 2 & 0.00 & 0.00 & 0 & - & - \\
\hline
\end{tabular}




\begin{tabular}{lllllllll}
\hline & & \multicolumn{3}{c}{ In-house Duplicates } & & \multicolumn{3}{c}{ Blind Replicates } \\
Analyte & RDL & $\begin{array}{l}\text { Number of } \\
\text { Dup. Pairs }\end{array}$ & MRD & MRDadj & $\begin{array}{l}\text { Number of } \\
\text { Dup. Pairs }\end{array}$ & MRD & MRDadj \\
\hline Total organic halogens & $10.0 \mu \mathrm{g} / \mathrm{L}$ & 3 & 4.26 & 3.20 & 1 & 39.72 & 39.72 \\
Trichloroethylene & $1.0 \mu \mathrm{g} / \mathrm{L}$ & 0 & - & - & 2 & 3.46 & 3.46 \\
Xylenes & $40.0 \mu \mathrm{g} / \mathrm{L}$ & 0 & - & - & 2 & 0.00 & 0.00 \\
Zinc & $5.0 \mu \mathrm{g} / \mathrm{L}$ & 0 & - & - & 2 & 10.19 & 10.19 \\
\hline
\end{tabular}

$\dagger$ No detection limit, or no replicate or duplicate results below detection limit.

- No replicate or duplicate analyses could be calculated.

Note: An MRD of 0.00 indicates no difference between any of the pairs of results used in calculating the MRD. MRD results greater than or equal to 20 appear in bold.

Table 21. Intralaboratory MRD Matrix Spike Indices for GE

\begin{tabular}{|c|c|c|c|c|}
\hline \multirow[b]{2}{*}{ Analyte } & \multirow[b]{2}{*}{$R D L$} & \multirow{2}{*}{$\begin{array}{l}\text { Number of } \\
\text { Dup. Pairs }\end{array}$} & \multicolumn{2}{|c|}{ In-house Duplicates } \\
\hline & & & $M R D$ & MRDadj \\
\hline Acenaphthene & $t$ & 10 & 9.67 & 9.67 \\
\hline Aldrin & $t$ & 8 & 7.67 & 7.67 \\
\hline Benzene & $t$ & 12 & 4.85 & 4.85 \\
\hline Chlorobenzene & $t$ & 12 & 6.71 & 6.71 \\
\hline 4-Chloro-m-cresol & $t$ & 10 & 11.71 & 11.71 \\
\hline 2-Chlorophenol & $t$ & 10 & 9.73 & 9.73 \\
\hline $\mathrm{p}, \mathrm{p}^{\prime}-\mathrm{DDT}$ & $t$ & 8 & 11.53 & 11.53 \\
\hline 1,4-Dichlorobenzene & $t$ & 10 & 11.22 & 11.22 \\
\hline 1,1-Dichloroethylene & $t$ & 12 & 4.07 & 4.07 \\
\hline Dieldrin & $t$ & 8 & 5.53 & 5.53 \\
\hline 2,4-Dinitrotoluene & $t$ & 10 & 9.99 & 9.99 \\
\hline Endrin & $t$ & 8 & 8.80 & 8.80 \\
\hline Heptachlor & $t$ & 8 & 8.19 & 8.19 \\
\hline Lindane & $t$ & 8 & 7.67 & 7.67 \\
\hline 4-Nitrophenol & $t$ & 10 & 11.71 & 11.71 \\
\hline N-Nitrosodipropylamine & $t$ & 10 & 8.69 & 8.69 \\
\hline PCB 1260 & $t$ & 8 & 5.97 & 5.97 \\
\hline Pentachlorophenol & $t$ & 10 & 9.29 & 9.29 \\
\hline Phenol & $t$ & 10 & 10.88 & 10.88 \\
\hline Pyrene & $t$ & 10 & 10.26 & 10.26 \\
\hline Toluene & $t$ & 12 & 4.95 & 4.95 \\
\hline 1,2,4-Trichlorobenzene & $t$ & 10 & 9.82 & 9.82 \\
\hline Trichloroethylene & $t$ & 14 & 4.53 & 4.53 \\
\hline
\end{tabular}

$\dagger$ No detection limit, or no replicate or duplicate results below detection limit.

Note: An MRD of 0.00 indicates no difference between any of the pairs of results used in calculating the MRD. 


\begin{tabular}{|c|c|c|c|c|c|c|c|}
\hline \multirow[b]{2}{*}{ Analyte } & \multirow[b]{2}{*}{$R D L$} & \multicolumn{3}{|c|}{ In-house Duplicates } & \multicolumn{3}{|c|}{ Blind Replicates } \\
\hline & & $\begin{array}{l}\text { Number of } \\
\text { Dup. Pairs }\end{array}$ & MRD & MRDadj & $\begin{array}{l}\text { Number of } \\
\text { Dup. Pairs }\end{array}$ & $M R D$ & MRDadj \\
\hline Acetone & $50.0 \mu \mathrm{g} / \mathrm{L}$ & 1 & 0.00 & 0.00 & 0 & - & - \\
\hline Alkalinity $\left(\right.$ as $\mathrm{CaCO}_{3}$ ) & $13,400 \mu \mathrm{g} / \mathrm{L}$ & 6 & 1.45 & 1.45 & 2 & 3.86 & 3.86 \\
\hline Aluminum & $146 \mu \mathrm{g} / \mathrm{L}$ & 9 & 1.81 & 1.46 & 3 & 20.43 & 9.66 \\
\hline Arsenic & $40.0 \mu \mathrm{g} / \mathrm{L}$ & 9 & 0.00 & 0.00 & 3 & 0.00 & 0.00 \\
\hline Barium & $3.9 \mu \mathrm{g} / \mathrm{L}$ & 9 & 4.69 & 3.56 & 2 & 32.58 & 32.58 \\
\hline Boron & $266 \mu \mathrm{g} / \mathrm{L}$ & 7 & 0.00 & 0.00 & 2 & 0.00 & 0.00 \\
\hline Calcium & $t$ & 5 & 1.40 & 1.40 & 0 & - & - \\
\hline Carbon tetrachloride & $10.0 \mu \mathrm{g} / \mathrm{L}$ & 15 & 0.00 & 0.00 & 6 & 0.00 & 0.00 \\
\hline Chemical oxygen demand & $32,700 \mu \mathrm{g} / \mathrm{L}$ & 1 & 0.00 & 0.00 & 0 & - & - \\
\hline Chloride & $t$ & 4 & 2.84 & 2.84 & 0 & - & - \\
\hline Chloroethene & $50.0 \mu \mathrm{g} / \mathrm{L}$ & 8 & 0.00 & 0.00 & 5 & 0.00 & 0.00 \\
\hline Chloroform & $5.0 \mu \mathrm{g} / \mathrm{L}$ & 16 & 0.11 & 0.11 & 6 & 0.00 & 0.00 \\
\hline Chromium & $7.0 \mu \mathrm{g} / \mathrm{L}$ & 9 & 0.00 & 0.00 & 3 & 0.00 & 0.00 \\
\hline 1,4-Dichlorobenzene & $20.0 \mu \mathrm{g} / \mathrm{L}$ & 3 & 0.00 & 0.00 & 1 & 0.00 & 0.00 \\
\hline Dichlorodifluoromethane & $10.0 \mu \mathrm{g} / \mathrm{L}$ & 0 & - & - & 0 & - & - \\
\hline 1,1-Dichloroethane & $25.0 \mu \mathrm{g} / \mathrm{L}$ & 9 & 0.14 & 0.09 & 5 & 0.00 & 0.00 \\
\hline 1,2-Dichloroethylene & $25.0 \mu \mathrm{g} / \mathrm{L}$ & 1 & 0.00 & 0.00 & 0 & - & - \\
\hline cis-1,2-Dichloroethỳlene & $1.0 \mu \mathrm{g} / \mathrm{L}$ & 8 & 0.67 & 0.67 & 1 & 4.71 & 4.71 \\
\hline trans-1,2-Dichloroethylene & $50.0 \mu \mathrm{g} / \mathrm{L}$ & 8 & 0.00 & 0.00 & 5 & 0.00 & 0.00 \\
\hline Ethylbenzene & $50.0 \mu \mathrm{g} / \mathrm{L}$ & 9 & 0.00 & 0.00 & 5 & 0.00 & 0.00 \\
\hline Iron & $74.0 \mu \mathrm{g} / \mathrm{L}$ & 9 & 3.53 & 2.12 & 2 & 2.38 & 0.87 \\
\hline Lithium & $3.0 \mu \mathrm{g} / \mathrm{L}$ & 7 & 0.37 & 0.14 & 2 & 6.14 & 6.14 \\
\hline Magnesium & $t$ & 5 & 1.07 & 1.07 & 0 & - & - \\
\hline Manganese & $7.8 \mu \mathrm{g} / \mathrm{L}$ & 5 & 0.63 & 0.59 & 1 & 2.27 & 2.27 \\
\hline Methyl ethyl ketone & $50.0 \mu \mathrm{g} / \mathrm{L}$ & 2 & 64.03 & 53.40 & 0 & - & - \\
\hline Methyl isobutyl ketone & $50.0 \mu \mathrm{g} / \mathrm{L}$ & 1 & 0.00 & 0.00 & 0 & - & - \\
\hline Nitrate as nitrogen & $t$ & 2 & 0.75 & 0.75 & 0 & - & - \\
\hline Nitrate-nitrite as nitrogen & $43.0 \mu \mathrm{g} / \mathrm{L}$ & 5 & 1.14 & 1.14 & 0 & - & - \\
\hline $\mathrm{pH}$ & $\dagger$ & 7 & 0.49 & 0.49 & 0 & - & - \\
\hline Potassium & $187 \mu \mathrm{g} / \mathrm{L}$ & 5 & 0.44 & 0.44 & 0 & - & - \\
\hline Silica & $t$ & 3 & 1.44 & 1.44 & 0 & - & - \\
\hline Sodium & $\dagger$ & 5 & 0.44 & 0.44 & 0 & - & - \\
\hline Specific conductance & $t$ & 3 & 0.28 & 0.28 & 0 & - & - \\
\hline Sulfate & $t$ & 10 & 4.52 & 4.52 & 2 & 9.35 & 9.35 \\
\hline Tetrachloroethylene & $10.0 \mu \mathrm{g} / \mathrm{L}$ & 15 & 0.00 & 0.00 & 6 & 0.00 & 0.00 \\
\hline Toluene & $50.0 \mu \mathrm{g} / \mathrm{L}$ & 9 & 0.00 & 0.00 & 5 & 0.00 & 0.00 \\
\hline Total dissolved solids & $50,000 \mu \mathrm{g} / \mathrm{L}$ & 14 & 3.29 & 1.84 & 2 & 44.75 & 24.30 \\
\hline Total organic carbon & $1,000 \mu \mathrm{g} / \mathrm{L}$ & 3 & 4.39 & 2.20 & 2 & 22.18 & 8.55 \\
\hline Total organic halogens & $120 \mu \mathrm{g} / \mathrm{L}$ & 12 & 0.00 & 0.00 & 3 & 0.81 & 0.33 \\
\hline Total phosphates (as P) & $67.0 \mu \mathrm{g} / \mathrm{L}$ & 2 & 5.17 & 2.69 & 0 & - & - \\
\hline Trichloroethylene & $5.0 \mu \mathrm{g} / \mathrm{L}$ & 17 & 0.99 & 0.82 & 6 & 0.72 & 0.72 \\
\hline Xylenes & $25.0 \mu \mathrm{g} / \mathrm{L}$ & 8 & 0.00 & 0.00 & 5 & 0.00 & 0.00 \\
\hline Zinc & $53.0 \mu \mathrm{g} / \mathrm{L}$ & 6 & 0.00 & 0.00 & 2 & 0.00 & 0.00 \\
\hline
\end{tabular}

$\dagger$ No detection limit, or no replicate or duplicate results below detection limit.

- No replicate or duplicate analyses could be calculated.

Note: An MRD of 0.00 indicates no difference between any of the pairs of results used in calculating the MRD. MRD results greater than or equal to 20 appear in bold. 


\begin{tabular}{|c|c|c|c|c|c|c|c|}
\hline \multirow[b]{2}{*}{ Analyte } & \multirow[b]{2}{*}{$R D L$} & \multicolumn{3}{|c|}{ In-house Duplicates } & \multicolumn{3}{|c|}{ Blind Replicates } \\
\hline & & $\begin{array}{l}\text { Number of } \\
\text { Dup. Pairs }\end{array}$ & MRD & MRDadj & $\begin{array}{l}\text { Number of } \\
\text { Dup. Pairs }\end{array}$ & MRD & MRDadj \\
\hline Actinium-228 & $1.58 \mathrm{E}-08 \mu \mathrm{Ci} / \mathrm{mL}$ & 7 & 1.05 & 0.33 & 2 & 0.00 & 0.00 \\
\hline Carbon-14 & 8.95E-09 $\mu \mathrm{Ci} / \mathrm{mL}$ & 10 & 10.79 & 6.79 & 5 & 18.84 & 10.66 \\
\hline Gross alpha & $1.15 \mathrm{E}-09 \mu \mathrm{Ci} / \mathrm{mL}$ & 29 - & 12.96 & 7.28 & 17 & 12.53 & 7.81 \\
\hline lodine-129 & 1.43E-09 $\mu \mathrm{Ci} / \mathrm{mL}$ & 7 & 14.21 & 13.91 & 2 & 0.00 & 0.00 \\
\hline Nonvolatile beta & 1.52E-09 $\mu \mathrm{Ci} / \mathrm{mL}$ & 29 & 6.13 & 4.19 & 16 & 26.00 & 14.84 \\
\hline Potassium-40 & 4.94E-08 $\mu \mathrm{Ci} / \mathrm{mL}$ & 7 & 0.00 & 0.00 & 2 & 0.00 & 0.00 \\
\hline Promethium-144 & 3.83E-09 $\mu \mathrm{Ci} / \mathrm{mL}$ & 8 & 0.00 & 0.00 & 1 & 0.00 & 0.00 \\
\hline $\begin{array}{l}\text { Radium, total alpha- } \\
\text { emitting }\end{array}$ & 1.37E-09 $\mu \mathrm{Ci} / \mathrm{mL}$ & 8 & 3.14 & 2.00 & 2 & 0.00 & 0.00 \\
\hline Radium-226 & $9.31 \mathrm{E}-10 \mu \mathrm{Ci} / \mathrm{mL}$ & 8 & 4.35 & 2.90 & 1 & 64.79 & 64.79 \\
\hline Radium-228 & $1.18 \mathrm{E}-09 \mu \mathrm{Ci} / \mathrm{mL}$ & 6 & 0.00 & 0.00 & 1 & 33.43 & 30.00 \\
\hline Ruthenium-106 & 3.52E- $08 \mu \mathrm{Ci} / \mathrm{mL}$ & 7 & 0.00 & 0.00 & 2 & 0.00 & 0.00 \\
\hline Strontium-89/90 & 2.11E-09 $\mu \mathrm{Ci} / \mathrm{mL}$ & 4 & 31.17 & 20.12 & 0 & - & - \\
\hline Strontium-90 & 2.25E-09 $\mu \mathrm{Ci} / \mathrm{mL}$ & 8 & 1.84 & 1.84 & 4 & 0.00 & 0.00 \\
\hline Technetium-99 & $1.18 \mathrm{E}-08 \mu \mathrm{Ci} / \mathrm{mL}$ & 5 & 20.51 & 10.22 & 1 & 0.00 & 0.00 \\
\hline Tritium & $6.68 \mathrm{E}-07 \mu \mathrm{Ci} / \mathrm{mL}$ & 22 & 4.43 & 3.98 & 14 & 18.70 & 18.24 \\
\hline Uranium-233/234 & $1.82 \mathrm{E}-09 \mu \mathrm{Ci} / \mathrm{mL}$ & 5 & 0.98 & 0.98 & 1 & 0.00 & 0.00 \\
\hline Uranium-235 & $9.62 \mathrm{E}-10 \mu \mathrm{Ci} / \mathrm{mL}$ & 4 & 5.64 & 3.43 & 1 & 0.00 & 0.00 \\
\hline Uranium-238 & 1.38E-09 $\mu \mathrm{Ci} / \mathrm{mL}$ & 5 & 3.28 & 3.28 & 1 & 0.00 & 0.00 \\
\hline Zinc-65 & $8.06 \mathrm{E}-09 \mu \mathrm{Ci} / \mathrm{mL}$ & 7 & 11.92 & 6.14 & 2 & 0.00 & 0.00 \\
\hline
\end{tabular}

- No replicate or duplicate analyses could be calculated.

Note: An MRD of 0.00 indicates no difference between any of the pairs of results used in calculating the MRD. MRD results greater than or equal to 20 appear in bold.

Table 24. Intralaboratory MRD Indices for TM

\begin{tabular}{|c|c|c|c|c|c|c|c|}
\hline \multirow[b]{2}{*}{ Analyte } & \multirow[b]{2}{*}{$R D L$} & \multicolumn{3}{|c|}{ In-house Duplicates } & \multicolumn{3}{|c|}{ Blind Replicates } \\
\hline & & $\begin{array}{l}\text { Number of } \\
\text { Dup. Pairs }\end{array}$ & $M R D$ & MRDadj & $\begin{array}{l}\text { Number of } \\
\text { Dup. Pairs }\end{array}$ & MRD & MRDadj \\
\hline Actinium-228 & 2.637E-08 $\mu \mathrm{Ci} / \mathrm{mL}$ & 2 & 0.00 & 0.00 & 0 & - & - \\
\hline Gross alpha & $1.62 \mathrm{E}-09 \mu \mathrm{Ci} / \mathrm{mL}$ & 48 & 7.17 & 4.35 & 8 & 7.06 & 3.50 \\
\hline lodine-129 & $1.072 \mathrm{E}-08 \mu \mathrm{Ci} / \mathrm{mL}$ & 1 & 0.00 & 0.00 & 0 & - & - \\
\hline Nonvolatile beta & $2.09 \mathrm{E}-09 \mu \mathrm{Ci} / \mathrm{mL}$ & 46 & 16.56 & 9.41 & 6 & 0.00 & 0.00 \\
\hline Potassium-40 & $6.072 \mathrm{E}-08 \mu \mathrm{Ci} / \mathrm{mL}$ & 2 & 0.00 & 0.00 & 0 & - & - \\
\hline Promethium-144 & $6.55 \mathrm{E}-09 \mu \mathrm{Ci} / \mathrm{mL}$ & 2 & 0.00 & 0.00 & 0 & - & - \\
\hline $\begin{array}{l}\text { Radium, total alpha- } \\
\text { emitting }\end{array}$ & $9.0 \mathrm{E}-10 \mu \mathrm{Ci} / \mathrm{mL}$ & 3 & 42.03 & 24.00 & 1 & 48.75 & 35.67 \\
\hline Radium-226 & $\dagger$ & 1 & 18.68 & 18.68 & 0 & - & - \\
\hline Radium-228 & $t$ & 1 & 18.10 & 18.10 & 0 & - & - \\
\hline Ruthenium-106 & $5.714 \mathrm{E}-08 \mu \mathrm{Ci} / \mathrm{mL}$ & 2. & 0.00 & 0.00 & 0 & - & - \\
\hline Strontium-90 & 2.69E-09 $\mu \mathrm{Ci} / \mathrm{mL}$ & 3 & 15.50 & 12.64 & 0 & - & - \\
\hline Technetium-99 & $1.412 \mathrm{E}-08 \mu \mathrm{Ci} / \mathrm{mL}$ & 1 & 0.00 & 0.00 & 0 & - & - \\
\hline
\end{tabular}




\begin{tabular}{lllllllll}
\hline & & \multicolumn{2}{c}{ In-house Duplicates } & \multicolumn{3}{c}{ Blind Replicates } \\
Analyte & RDL & $\begin{array}{l}\text { Number of } \\
\text { Dup. Pairs }\end{array}$ & MRD & MRDadj & $\begin{array}{l}\text { Number of } \\
\text { Dup. Pairs }\end{array}$ & MRD & MRDadj \\
\hline Tritium & $5.6 \mathrm{E}-07 \mu \mathrm{Ci} / \mathrm{mL}$ & 54 & 5.83 & 5.53 & 5 & 4.32 & 3.60 \\
Zinc-65 & $1.39 \mathrm{E}-08 \mu \mathrm{Ci} / \mathrm{mL}$ & 2 & 0.00 & 0.00 & 0 & - & - \\
\hline
\end{tabular}

$\dagger$ No detection limit, or no replicate or duplicate results below detection limit.

- No replicate or duplicate analyses could be calculated.

Note: An MRD of 0.00 indicates no difference between any of the pairs of results used in calculating the MRD. MRD results greater than or equal to 20 appear in bold.

Table 25. Interlaboratory MRD and t-test Results for Analytes with at Least One Pair of Results above the RDL for EX and WA

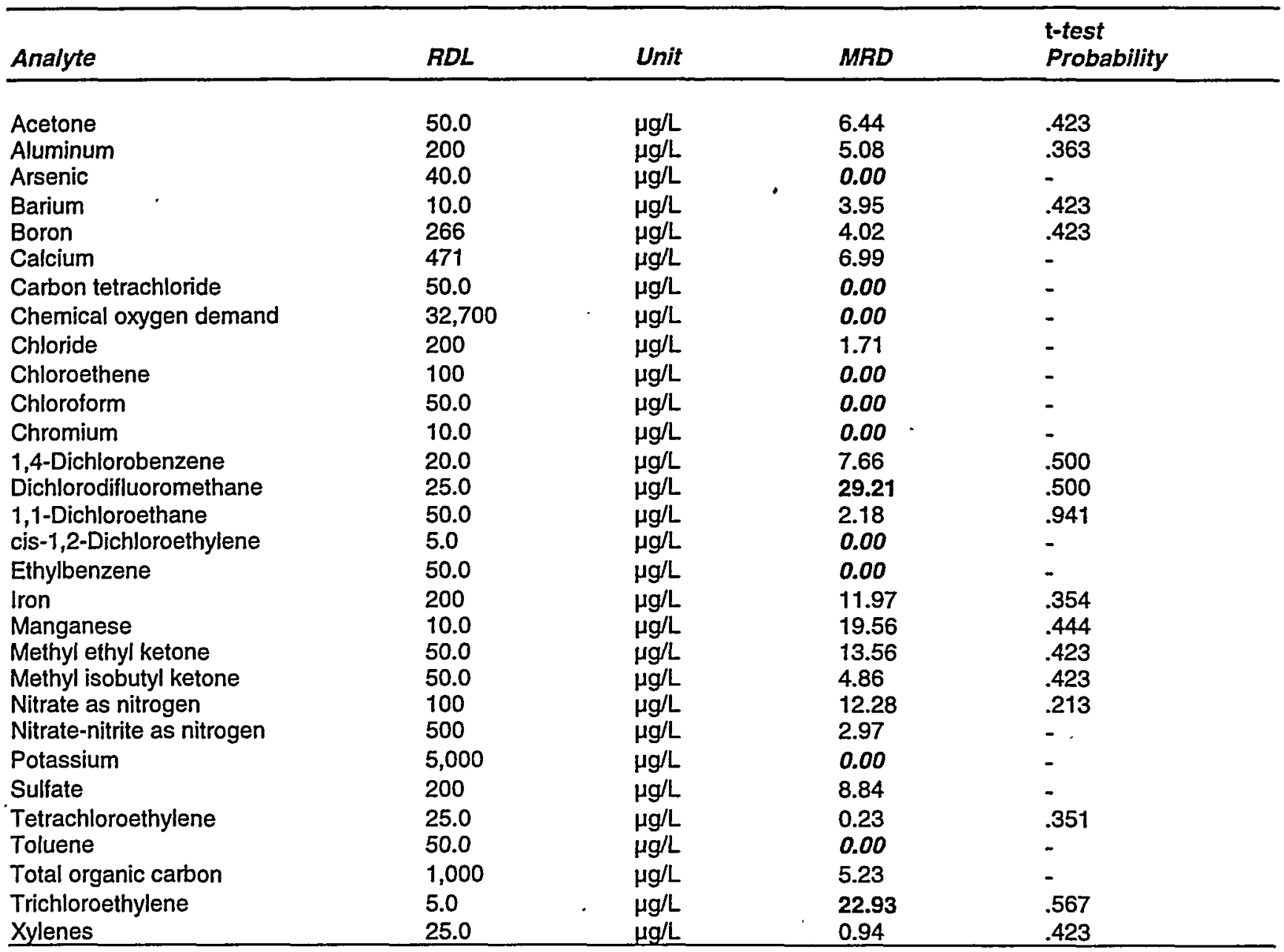

- Could not calculate because there are no differences between pairs.

Note: Values less than .050 indicate a probability of less than 1 in 20 that the results for that analyte are the same from both laboratories. MRD results greater than or equal to 20 appear in bold; less than or equal to .050 , in bold italic. 
Table 26. Interlaboratory MRD and t-test Results for Analytes with at Least One Pair of Results above the RDL for GE and WA

\begin{tabular}{|c|c|c|c|c|}
\hline Analyte & $R D L$ & Unit & MRD & $\begin{array}{l}\text { t-test } \\
\text { Probability }\end{array}$ \\
\hline Alkalinity (as $\mathrm{CaCO}_{3}$ ) & 13,400 & $\mu g / L$ & 2.19 & .500 \\
\hline Aluminum & 146 & $\mu g / L$ & 10.34 & .313 \\
\hline Calcium & 471 & $\mu g / L$ & 20.47 & .163 \\
\hline Chloroform & 5.0 & $\mu g / L$ & 0.00 & - \\
\hline 1,1-Dichloroethane & 5.0 & $\mu g / L$ & 0.00 & - \\
\hline 1,2-Dichloroethylene & 40.0 & $\mu g / L$ & 0.00 & - \\
\hline trans-1,2-Dichloroethylene & 5.0 & $\mu g / L$ & 0.00 & - \\
\hline Iron & 74.0 & $\mu g / L$ & 26.71 & .238 \\
\hline Lithium & 3.0 & $\mu g / L$ & 3.48 & .500 \\
\hline Manganese & 7.8 & $\mu g / L$ & 7.89 & .429 \\
\hline Methyl ethyl ketone & 200 & $\mu g / L$ & 0.00 & - \\
\hline Nitrate-nitrite as nitrogen & 50.0 & $\mu g / L$ & 6.10 & .743 \\
\hline Potassium & 187 & $\mu g / L$ & 4.87 & .354 \\
\hline Tetrachloroethylene & 5.0 & $\mu g / L$ & 11.58 & .391 \\
\hline Toluene & 25.0 & $\mu g / L$ & 0.00 & - \\
\hline Total dissolved solids & 50,000 & $\mu g / L$ & 27.74 & .500 \\
\hline Total organic carbon & 5,000 & $\mu g / L$ & 0.00 & - \\
\hline Total organic halogens & 120 & $\mu g / L$ & 11.86 & .500 \\
\hline Trichloroethylene & 5.0 & $\mu g / L$ & 4.22 & .607 \\
\hline Zinc & 53.0 & $\mu g / L$ & 2.79 & .391 \\
\hline
\end{tabular}

- Could not calculate because there are no differences between pairs.

Note: Values less than .050 indicate a probability of less than 1 in 20 that the results for that analyte are the same from both laboratories. MRD results greater than or equal to 20 appear in bold; less than or equal to .050 , in bold italic.

Table 27. Interlaboratory MRD and t-test Results for Analytes with at Least One Pair of Results above the RDL for GP and TM

\begin{tabular}{lllll}
\hline Analyte & $R D L$ & Unit & MRD & \multicolumn{1}{c}{$\begin{array}{l}\text { t-test } \\
\text { Probability }\end{array}$} \\
\hline Actinium-228 & & & & - \\
Gross alpha & $1.99 \mathrm{E}-08$ & $\mu \mathrm{Ci} / \mathrm{mL}$ & 0.00 & .880 \\
lodine-129 & $1.52 \mathrm{E}-09$ & $\mu \mathrm{Ci} / \mathrm{mL}$ & 6.23 & - \\
Nonvolatile beta & $8.55 \mathrm{E}-09$ & $\mu \mathrm{Ci} / \mathrm{mL}$ & 0.00 & .040 \\
Potassium-40 & $2.05 \mathrm{E}-09$ & $\mu \mathrm{Ci} / \mathrm{mL}$ & 24.62 & - \\
Promethium-144 & $5.784 \mathrm{E}-08$ & $\mu \mathrm{Ci} / \mathrm{mL}$ & 0.00 & - \\
Radium, total alpha-emitting & $5.0 \mathrm{E}-09$ & $\mu \mathrm{Ci} / \mathrm{mL}$ & 0.00 & .234 \\
Radium-226 & $1.37 \mathrm{E}-09$ & $\mu \mathrm{Ci} / \mathrm{mL}$ & 23.55 & - \\
Radium-228 & $9.31 \mathrm{E}-10$ & $\mu \mathrm{Ci} / \mathrm{mL}$ & 63.42 & - \\
Ruthenium-106 & $1.18 \mathrm{E}-09$ & $\mu \mathrm{Ci} / \mathrm{mL}$ & 18.63 & - \\
Strontium-90 & $4.246 \mathrm{E}-08$ & $\mu \mathrm{Ci} / \mathrm{mL}$ & 0.00 & .423 \\
Technetium-99 & $2.44 \mathrm{E}-09$ & $\mu \mathrm{Ci} / \mathrm{mL}$ & 33.30 & -
\end{tabular}




\begin{tabular}{lllll}
\hline Analyte & RDL & Unit & MRD & $\begin{array}{l}\text { t-test } \\
\text { Probability }\end{array}$ \\
\hline & & & & \\
Tritium & $6.59 \mathrm{E}-07$ & $\mu \mathrm{Ci} / \mathrm{mL}$ & 23.27 & .438 \\
Zinc-65 & $1.035 \mathrm{E}-08$ & $\mu \mathrm{Ci} / \mathrm{mL}$ & 0.00 & - \\
\hline
\end{tabular}

+ No detection limit, or no replicate or duplicate results below detection limit.

- Could not calculate because there are no differences between pairs.

Note: Values less than .050 indicate a probability of less than 1 in 20 that the results for that analyte are the same from both laboratories. MRD results greater than or equal to 20 appear in bold; less than or equal to .050 , in bold italic.

Table 28. EX Samples and Blind Replicates Yielding Results Where One Is More Than Twice Another

\begin{tabular}{ll}
\hline Analyte & Wells \\
\hline Trichloroethylene & XSB 4D \\
\hline
\end{tabular}

Table 29. EX Samples and Laboratory Duplicates Yielding Results Where One Is More Than Twice Another

\begin{tabular}{ll}
\hline Analyte & Wells \\
\hline cis-1,2-Dichloroethylene & TIR 1U \\
Trichloroethylene & TIR 1U \\
\hline
\end{tabular}

Table 30. WA Samples and Blind Replicates Yielding Results Where One Is More Than Twice Another

\begin{tabular}{ll}
\hline Analyte & Wells \\
\hline Total dissolved solids & BGO 14AR \\
\hline
\end{tabular}

Table 31. WA Samples and Laboratory Duplicates Vielding Results Where One Is More Than Twice Another

Analyte Wells

Methyl ethyl ketone

LFW 61D 
Table 32. GP Samples and Blind Replicates Yielding Results Where One Is More Than Twice Another

Analyte

Nonvolatile beta

Tritium

\section{Wells}

FSB 98AR, HSB118A

FSB 78B

Table 33. GP Samples and Laboratory Duplicates Yielding Results Where One Is More Than Twice Another

\begin{tabular}{ll}
\hline Analyte & Wells \\
\hline lodine-129 & FIN 2TK \\
Zinc-65 & FEX 1TK \\
\hline
\end{tabular}

Table 34. TM Samples and Laboratory Duplicates Yielding Results Where One Is More Than Twice Another

Analyte Wells

Nonvolatile beta

FSB 98AR, HSB127C

Table 35. Analytes with One Laboratory's Result Greater Than Twice the Result from the Other Laboratory between EX and WA

\begin{tabular}{ll}
\hline Analyte & Wells \\
\hline Manganese & P 26B \\
Trichloroethylene & XSB 4D \\
\hline
\end{tabular}

Table 36. Analytes with One Laboratory's Result Greater Than Twice the Result from the Other Laboratory between GE and WA

\begin{tabular}{ll}
\hline Analyte & Wells \\
\hline Iron & BGO 15D, KCB 3 \\
\hline
\end{tabular}

Table 37. Analytes with One Laboratory's Result Greater Than Twice the Result from the Other Laboratory between GP and TM

\begin{tabular}{ll}
\hline Analyte & Wells \\
\hline & \\
Nonvolatile beta & FSB 78B, HSB118A, HSB127C, HSB131C \\
Strontium-90 & BGO 14AR \\
Tritium & BGO 20C, FSB 76A \\
\hline
\end{tabular}

\section{Quality Control Samples}


Table 38. Quality Control Standards for Selected Analyses for EX

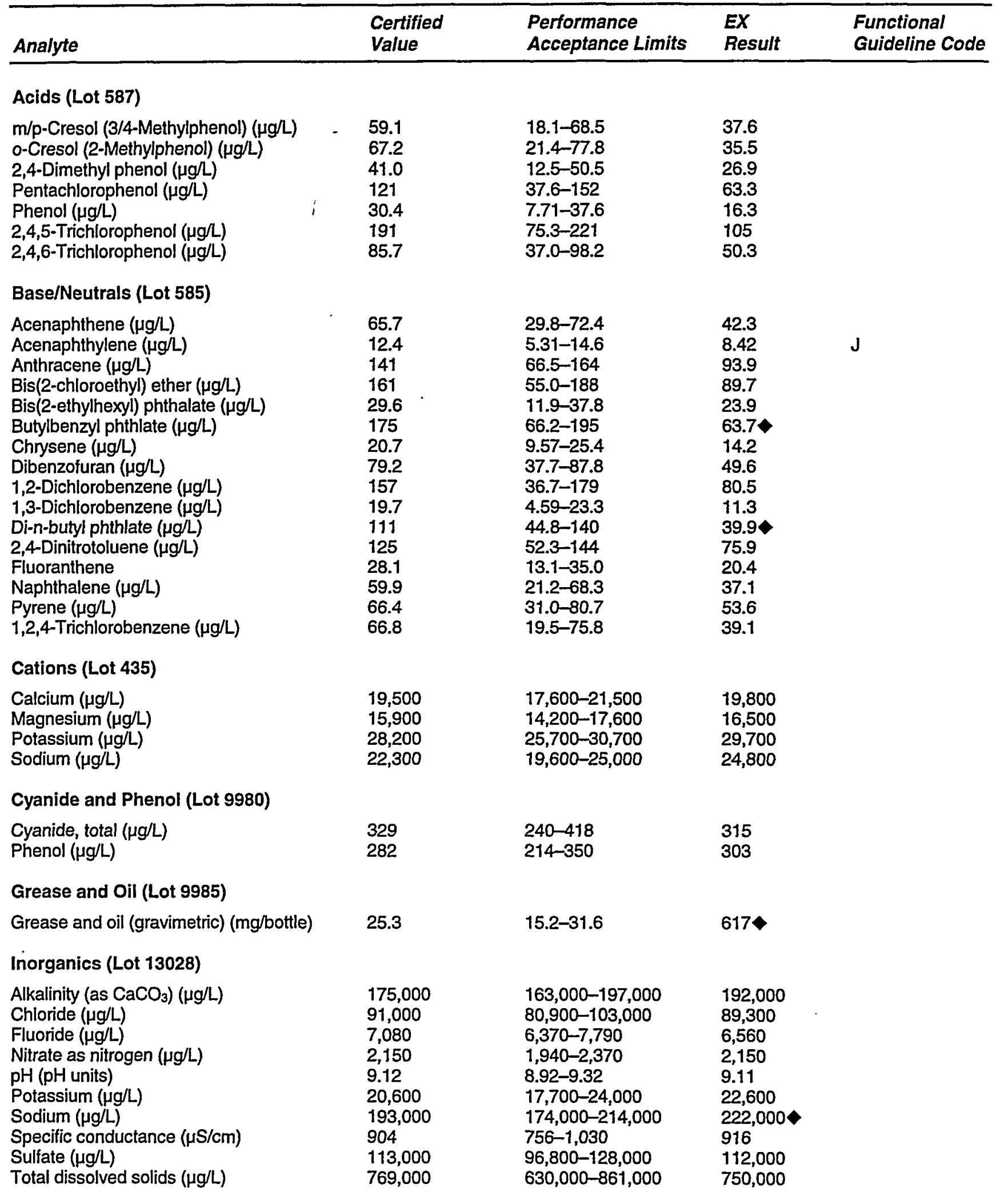




\begin{tabular}{lllll}
\hline & Certified & Performance & EX & Functional \\
Analyte & Value & Acceptance Limits & Result & Guideline Code \\
\hline
\end{tabular}

Nutrients (Lot 9980)

Ammonia as nitrogen $(\mu \mathrm{g} / \mathrm{L})$

6,290

2,220

7,970

$5,280-7,300$

6,500

Nitrate-nitrite as nitrogen $(\mu \mathrm{g} / \mathrm{L})$

$1,980-2,460$

2,230

Total phosphates (as P) ( $\mu g / L)$

$6,770-9,170$

8,090

PCBs (Lot 574)

PCB $1248(\mu g / L)$

1.02

$0.545-1.27$

0.720

Pesticides (Lot 580)

Aldrin $(\mu \mathrm{g} / \mathrm{L})$

6.09

alpha-Benzene hexachloride $(\mu g / L)$

3.12

2.20

beta-Benzene hexachloride $(\mu g / L)$

3.34

1.12

5.71

4,4'-DDD $(\mu g / L)$

4,4'-DDE ( $\mu g / L)$

1.90

4,4'-DDT ( $\mu g / L)$

6.82

3.44

Dieldrin $(\mu g / L)$

0.453

Heptachlor $(\mu g / L)$

2.51

Heptachlor epoxide $(\mu g / L)$

4.36

Methoxychlor ( $\mu g / L)$

7.10

$3.16-7.50$

5.10

$1.74-3.97$

2.40

$1.17-2.78$

2.00

$2.02-4.14$

3.00

$0.780-1.34$

1.10

$3.51-7.41 \quad 6.00$

$1.11-2.38 \quad 1.80$

$3.96-8.57 \quad 6.50$

$2.13-4.45 \quad 3.40$

$\begin{array}{ll}0.284-0.585 & 0.520\end{array}$

$1.14-3.11 \quad 1.90$

$2.69-5.33 \quad 4.10$

$\begin{array}{ll}4.05-9.56 & 7.70\end{array}$

Pesticides/Herbicides (Lot 21028)

2-sec-Butyl-4,6-dinitrophenol $(\mu g / L)$

$0.482-1.90$

$2.43-7.28$

$0.610-1.83$

$0.3004 J$

2,4,5-TP (Silvex) ( $\mu g / L)$

1.22

Total Petroleum Hydrocarbons (Lot 8913)

Total petroleum hydrocarbons, infrared 139

88.6-181

187 (mg/bottle)

6.60

Trace Metals (Lot 9983)

Aluminum $(\mu \mathrm{g} / \mathrm{L})$

Antimony $(\mu g / L)$

500

77.8

Arsenic $(\mu g / L)$

133

Barium $(\mu g / L)$

Beryllium ( $\mu \mathrm{g} / \mathrm{L})$

778

122

Boron $(\mu g / L)$

Cadmium ( $\mu g / L)$

410

62.2

Chromium $(\mu g / L)$

611

Cobalt $(\mu g / L)$

322

133

Copper $(\mu g / L)$

Iron $(\mu \mathrm{g} / \mathrm{L})$

733

Lead $(\mu g / L)$

Manganese $(\mu g / L)$

Mercury ( $\mu \mathrm{g} / \mathrm{L})$

211

644

4.67

Molybdenum ( $\mu g / L)$

351

Nickel $(\mu g / L)$

249

Selenium $(\mu g / L)$

66.7

88.9

Silver $(\mu g / L)$

789

410-590

$58.4-97.3$

99.8-157

638-918

4.60

1.50

$100-144$

$336-513 \quad 501$

$51.0-73.4 \quad 58.3$

$501-721$

264-380 354

109-157 142

601-865 785

173-249 206

$528-760 \quad 668$

$3.50-5.84 \quad 4.35$

288-414 356

204-294 263

$50.0-78.7 \quad 63.8$

$\begin{array}{ll}72.9-105 & 90.7\end{array}$

$647-931 \quad 830$ 


\begin{tabular}{|c|c|c|c|c|}
\hline Analyte & $\begin{array}{l}\text { Certified } \\
\text { Value }\end{array}$ & $\begin{array}{l}\text { Performance } \\
\text { Acceptance Limits }\end{array}$ & $\begin{array}{l}\text { EX } \\
\text { Result }\end{array}$ & $\begin{array}{l}\text { Functional } \\
\text { Guideline Code }\end{array}$ \\
\hline $\begin{array}{l}\text { Thallium }(\mu g / L) \\
\text { Vanadium }(\mu g / L) \\
\text { Zinc }(\mu g / L)\end{array}$ & $\begin{array}{l}54.4 \\
356 \\
606\end{array}$ & $\begin{array}{l}40.8-68.0 \\
292-420 \\
497-715\end{array}$ & $\begin{array}{l}52.0 \\
374 \\
612\end{array}$ & \\
\hline \multicolumn{5}{|l|}{ Turbidity (Lot 3427) } \\
\hline Turbidity (NTU) & 3.36 & $2.86-3.93$ & 3.60 & \\
\hline \multicolumn{5}{|l|}{ Volatiles (Lot 581) } \\
\hline $\begin{array}{l}\text { Acetone }(\mu g / L) \\
\text { Benzene }(\mu g / L) \\
\text { Bromodichloromethane }(\mu g / L) \\
\text { Bromoform }(\mu g / L) \\
\text { Carbon tetrachloride }(\mu g / L) \\
\text { Chlorobenzene }(\mu g / L) \\
\text { Chloroform }(\mu g / L) \\
\text { Dibromochloromethane }(\mu g / L) \\
\text { 1,2-Dichlorobenzene }(\mu g / L) \\
\text { 1,3-Dichlorobenzene }(\mu g / L) \\
\text { 1,4-Dichlorobenzene }(\mu g / L) \\
\text { 1,2-Dichloroethane }(\mu g / L) \\
\text { 1,1-Dichloroethylene }(\mu g / L) \\
\text { Dichloromethane }(m e t h y l e n e \text { chloride) }(\mu g / L) \\
\text { Ethylbenzene }(\mu g / L) \\
\text { 4-Methyl-2-pentanone }(M I B K)(\mu g / L) \\
\text { Styrene }(\mu g / L) \\
\text { Tetrachloroethylene }(\mu g / L) \\
\text { Toluene }(\mu g / L) \\
1,1,1-\text { Trichloroethane }(\mu g / L) \\
\text { Trichloroethylene }(\mu g / L) \\
\text { m/p-Xylene }(\mu g / L)\end{array}$ & $\begin{array}{l}150 \\
50.0 \\
60.0 \\
85.1 \\
94.5 \\
20.1 \\
75.5 \\
67.3 \\
21.5 \\
119 \\
41.8 \\
47.9 \\
100 \\
65.3 \\
15.3 \\
89.9 \\
24.9 \\
110 \\
62.8 \\
40.0 \\
19.4 \\
36.6\end{array}$ & $\begin{array}{l}75.2-233 \\
38.7-62.3 \\
46.1-74.8 \\
62.2-110 \\
69.4-118 \\
15.7-24.1 \\
58.0-92.3 \\
52.4-83.0 \\
16.3-26.4 \\
91.0-143 \\
31.4-50.9 \\
37.4-60.2 \\
65.5-127 \\
46.2-85.1 \\
11.4-17.9 \\
52.0-123 \\
17.3-30.3 \\
81.2-133 \\
48.4-75.8 \\
28.9-47.7 \\
14.4-23.5 \\
23.7-46.1\end{array}$ & $\begin{array}{l}100 \\
50.0 \\
67.0 \\
87.0 \\
97.0 \\
21.0 \\
75.0 \\
68.0 \\
22.0 \\
120 \\
45.0 \\
47.0 \\
104 \\
61.0 \\
16.0 \\
78.0 \\
25.0 \\
115 \\
67.0 \\
41.0 \\
20.0 \\
40.0\end{array}$ & \\
\hline
\end{tabular}

Result is out of range.

$\mathrm{J}$ The analytical result is an estimated quantity.

Table 39. Quality Control Standards for Selected Analyses for GE

\begin{tabular}{lllll}
\hline Analyte & $\begin{array}{l}\text { Certified } \\
\text { Value }\end{array}$ & $\begin{array}{l}\text { Performance } \\
\text { Acceptance Limits }\end{array}$ & $\begin{array}{l}\text { GE } \\
\text { Result }\end{array}$ & $\begin{array}{l}\text { Functional } \\
\text { Guideline Code }\end{array}$ \\
\hline
\end{tabular}

Acids (Lot 587)

$\mathrm{m} / \mathrm{p}$-Cresol (3/4-Methylphenol) $(\mu \mathrm{g} / \mathrm{L})$

o-Cresol (2-Methylphenol) ( $\mu \mathrm{g} / \mathrm{L}) \quad 67.2$

2,4-Dimethyl phenol $(\mu \mathrm{g} / \mathrm{L}) \quad 41.0$

Pentachlorophenol $\left(\mu g^{\prime} L\right)$

Phenol $(\mu \mathrm{g} / \mathrm{L}) \quad 30.4$

2,4,5-Trichlorophenol $(\mu \mathrm{g} / \mathrm{L}) \quad 191$

2,4,6-Trichlorophenol $(\mu \mathrm{g} / \mathrm{L}) \quad 85.7$

$18.1-68.5 \quad 32.5$

$21.4-77.8 \quad 38.1$

12.5-50.5 27.6

$37.6-152 \quad 104$

$\begin{array}{lll}7.71-37.6 & 7.60 & \end{array}$

$75.3-221 \quad 110$

Base/Neutrals (Lot 585)

Acenaphthene $(\mu g / L)$

Acenaphthylene $(\mu \mathrm{g} / \mathrm{L}) \quad 12.4$

Anthracene $(\mu g / L)$ (141

Bis(2-chloroethyl) ether $(\mu g / L) \quad 161$

Bis(2-ethylhexyl) phthalate ( $\mu g / L)$

$29.8-72.4 \quad 47.4$

$\begin{array}{lll}5.31-14.6 & 9.80 & \mathrm{~J}\end{array}$

66.5-164 117

$55.0-188 \quad 91.7$

$\begin{array}{ll}11.9-37.8 & 25.6\end{array}$ 


\begin{tabular}{|c|c|c|c|c|}
\hline Analyte & $\begin{array}{l}\text { Certified } \\
\text { Value }\end{array}$ & $\begin{array}{l}\text { Performance } \\
\text { Acceptance Limits }\end{array}$ & $\begin{array}{l}\text { GE } \\
\text { Result }\end{array}$ & $\begin{array}{l}\text { Functional } \\
\text { Guideline Code }\end{array}$ \\
\hline $\begin{array}{l}\text { Butylbenzyl phthlate }(\mu g / L) \\
\text { Chrysene }(\mu g / L) \\
\text { Dibenzofuran }(\mu g / L) \\
\text { 1,2-Dichlorobenzene }(\mu g / L) \\
\text { 1,3-Dichlorobenzene }(\mu g / L) \\
\text { Di-n-butylphthlate }(\mu g / L) \\
\text { 2,4-Dinitrotoluene }(\mu g / L) \\
\text { Fluoranthene } \\
\text { Naphthalene }(\mu g / L) \\
\text { Pyrene }(\mu g / L) \\
\text { 1,2,4-Trichlorobenzene }(\mu g / L)\end{array}$ & $\begin{array}{l}175 \\
20.7 \\
79.2 \\
157 \\
19.7 \\
111 \\
125 \\
28.1 \\
59.9 \\
66.4 \\
66.8\end{array}$ & $\begin{array}{l}66.2-195 \\
9.57-25.4 \\
37.7-87.8 \\
36.7-179 \\
4.59-23.3 \\
44.8-140 \\
52.3-144 \\
13.1-35.0 \\
21.1-68.3 \\
31.0-80.7 \\
19.5-75.8\end{array}$ & $\begin{array}{l}138 \\
16.9 \\
57.6 \\
90.6 \\
10.7 \\
90.0 \\
92.8 \\
26.8 \\
36.2 \\
51.2 \\
39.3\end{array}$ & \\
\hline \multicolumn{5}{|l|}{ Cations (Lot 435) } \\
\hline $\begin{array}{l}\text { Calcium }(\mu g / L) \\
\text { Magnesium }(\mu g / L) \\
\text { Potassium }(\mu g / L) \\
\text { Sodium }(\mu g / L)\end{array}$ & $\begin{array}{l}19,500 \\
15,900 \\
28,200 \\
22,300\end{array}$ & $\begin{array}{l}17,600-21,500 \\
14,200-17,600 \\
25,700-30,700 \\
19,600-25,000\end{array}$ & $\begin{array}{l}19,000 \\
14,900 \\
27,500 \\
22,500\end{array}$ & \\
\hline \multicolumn{5}{|l|}{ Cyanide and Phenol (Lot 9980) } \\
\hline $\begin{array}{l}\text { Cyanide, total ( } \mu g / L) \\
\text { Phenol ( } \mu g / L)\end{array}$ & $\begin{array}{l}329 \\
282\end{array}$ & $\begin{array}{l}240-418 \\
214-350\end{array}$ & $\begin{array}{l}286 \\
254\end{array}$ & \\
\hline \multicolumn{5}{|l|}{ Grease and Oil (Lot 9985) } \\
\hline $\begin{array}{l}\text { Grease and oil (gravimetric) (mg/bottle) } \\
\text { Inorganics (Lot 13028) }\end{array}$ & 25.3 & $15.2-31.6$ & 26.0 & \\
\hline $\begin{array}{l}\left.\text { Alkalinity (as } \mathrm{CaCO}_{3}\right)(\mu g / L) \\
\text { Chloride }(\mu g / L) \\
\text { Fluoride }(\mu g / L) \\
\text { Nitrate as nitrogen }(\mu g / L) \\
\text { pH (pH units) } \\
\text { Potassium }(\mu g / L) \\
\text { Sodium }(\mu g / L) \\
\text { Specific conductance }(\mu \mathrm{S} / \mathrm{cm}) \\
\text { Sulfate }(\mu g / L) \\
\text { Total dissolved solids }(\mu g / L)\end{array}$ & $\begin{array}{l}175,000 \\
91,000 \\
7,080 \\
2,150 \\
9.12 \\
20,600 \\
193,000 \\
904 \\
113,000 \\
769,000\end{array}$ & $\begin{array}{l}163,000-197,000 \\
80,900-103,000 \\
6,370-7,790 \\
1,940-2,370 \\
8.92-9.32 \\
17,700-24,000 \\
174,000-214,000 \\
756-1,030 \\
96,800-128,000 \\
630,000-861,000\end{array}$ & $\begin{array}{l}174,000 \\
89,200 \\
6,960 \\
1,960 \\
9.30 \\
20,700 \\
189,000 \\
1,030 \\
107,000 \\
704,000\end{array}$ & \\
\hline \multicolumn{5}{|l|}{ Nutrients (Lot 9980) } \\
\hline $\begin{array}{l}\text { Ammonia as nitrogen }(\mu \mathrm{g} / L) \\
\text { Nitrate-nitrite as nitrogen }(\mu \mathrm{g} / \mathrm{L}) \\
\text { Total phosphates (as } P)(\mu \mathrm{g} / \mathrm{L})\end{array}$ & $\begin{array}{l}6,290 \\
2,220 \\
7,970\end{array}$ & $\begin{array}{l}5,280-7,300 \\
1,980-2,460 \\
6,770-9,170\end{array}$ & $\begin{array}{l}6,000 \\
2,260 \\
8,820\end{array}$ & \\
\hline \multicolumn{5}{|l|}{ PCBs (Lot 574) } \\
\hline PCB $1248(\mu g / L)$ & 1.02 & $0.545-1.27$ & 0.820 & \\
\hline \multicolumn{5}{|l|}{ Pesticides (Lot 580) } \\
\hline $\begin{array}{l}\text { Aldrin }(\mu g / L) \\
\text { alpha-Benzene hexachloride }(\mu g / L) \\
\text { beta-Benzene hexachloride }(\mu g / L) \\
\text { alpha-Chlordane }(\mu g / L) \\
\text { gamma-Chlordane }(\mu g / L) \\
4,4^{\prime}-D D D(\mu g / L) \\
4,4^{\prime}-D D E(\mu g / L) \\
4,4^{\prime}-D D T(\mu g / L) \\
\text { Dieldrin }(\mu g / L) \\
\text { Endrin }(\mu g / L) \\
\text { Heptachlor }(\mu g / L)\end{array}$ & $\begin{array}{l}6.09 \\
3.12 \\
2.20 \\
3.34 \\
1.12 \\
5.71 \\
1.90 \\
6.82 \\
3.44 \\
0.453 \\
2.51\end{array}$ & $\begin{array}{l}3.16-7.50 \\
1.74-3.97 \\
1.17-2.78 \\
2.02-4.14 \\
0.780-1.34 \\
3.51-7.41 \\
1.11-2.38 \\
3.96-8.57 \\
2.13-4.45 \\
0.284-0.585 \\
1.14-3.11\end{array}$ & $\begin{array}{l}5.16 \\
2.54 \\
1.99 \\
3.10 \\
1.10 \\
5.60 \\
1.94 \\
6.58 \\
3.08 \\
0.520 \\
2.22\end{array}$ & \\
\hline
\end{tabular}




\begin{tabular}{|c|c|c|c|c|}
\hline Analyte & $\begin{array}{l}\text { Certified } \\
\text { Value }\end{array}$ & $\begin{array}{l}\text { Performance } \\
\text { Acceptance Limits } \\
\end{array}$ & $\begin{array}{l}\text { GE } \\
\text { Result } \\
\end{array}$ & $\begin{array}{l}\text { Functional } \\
\text { Guideline Code }\end{array}$ \\
\hline $\begin{array}{l}\text { Heptachlor epoxide }(\mu g / L) \\
\text { Methoxychlor }(\mu g / L)\end{array}$ & $\begin{array}{l}4.36 \\
7.10\end{array}$ & $\begin{array}{l}2.69-5.33 \\
4.05-9.56\end{array}$ & $\begin{array}{l}3.94 \\
7.91\end{array}$ & \\
\hline \multicolumn{5}{|l|}{ Pesticides/Herbicides (Lot 21028) } \\
\hline $\begin{array}{l}\text { 2-sec-Butyl-4,6-dinitrophenol ( } \mu g / L) \\
\text { 2,4-Dichlorophenoxyacetic acid ( } \mu g / L) \\
\text { 2,4,5-TP (Silvex) }(\mu g / L)\end{array}$ & $\begin{array}{l}1.47 \\
4.85 \\
1.22\end{array}$ & $\begin{array}{l}0.482-1.90 \\
2.43-7.28 \\
0.610-1.83\end{array}$ & $\begin{array}{l}0.504 \\
5.20 \\
1.05\end{array}$ & \\
\hline \multicolumn{5}{|l|}{ Total Petroleum Hydrocarbons (Lot 8913) } \\
\hline $\begin{array}{l}\text { Total petroleum hydrocarbons, infrared } \\
\text { (mg/bottle) }\end{array}$ & 139 & $88.6-181$ & 129 & \\
\hline \multicolumn{5}{|l|}{ Toxaphene (Lot 3214) } \\
\hline Toxaphene $(\mu g / L)$ & 6.15 & $3.38-8.92$ & 5.09 & \\
\hline \multicolumn{5}{|l|}{ Trace Metals (Lot 9983) } \\
\hline $\begin{array}{l}\text { Aluminum }(\mu g / L) \\
\text { Antimony }(\mu g / L) \\
\text { Arsenic }(\mu g / L) \\
\text { Barium }(\mu g / L) \\
\text { Beryllium }(\mu g / L) \\
\text { Boron }(\mu g / L) \\
\text { Cadmium }(\mu g / L) \\
\text { Chromium }(\mu g / L) \\
\text { Cobalt }(\mu g / L) \\
\text { Copper }(\mu g / L) \\
\text { Iron }(\mu g / L) \\
\text { Lead }(\mu g / L) \\
\text { Manganese }(\mu g / L) \\
\text { Mercury }(\mu g / L) \\
\text { Molybdenum }(\mu g / L) \\
\text { Nickel }(\mu g / L) \\
\text { Selenium }(\mu g / L) \\
\text { Silver }(\mu g / L) \\
\text { Strontium }(\mu g / L) \\
\text { Thallium }(\mu g / L) \\
\text { Vanadium }(\mu g / L) \\
\text { Zinc }(\mu g / L)\end{array}$ & $\begin{array}{l}500 \\
77.8 \\
133 \\
778 \\
122 \\
410 \\
62.2 \\
611 \\
322 \\
133 \\
733 \\
211 \\
644 \\
4.67 \\
351 \\
249 \\
66.7 \\
88.9 \\
789 \\
54.4 \\
356 \\
606\end{array}$ & $\begin{array}{l}410-590 \\
58.4-97.3 \\
99.8-157 \\
638-918 \\
100-144 \\
336-513 \\
51.0-73.4 \\
501-721 \\
264-380 \\
109-157 \\
601-865 \\
173-249 \\
528-760 \\
3.50-5.84 \\
288-414 \\
204-294 \\
50.0-78.7 \\
72.9-105 \\
647-931 \\
40.8-68.0 \\
292-420 \\
497-715\end{array}$ & $\begin{array}{l}539 \\
75.9 \\
135 \\
770 \\
121 \\
443 \\
62.0 \\
604 \\
337 \\
132 \\
703 \\
207 \\
635 \\
4.50 \\
348 \\
253 \\
68.1 \\
81.3 \\
758 \\
55.1 \\
357 \\
610\end{array}$ & . \\
\hline \multicolumn{5}{|l|}{ Turbidity (Lot 3427) } \\
\hline Turbidity (NTU) & 3.36 & $2.86-3.93$ & 3.35 & \\
\hline \multicolumn{5}{|l|}{ Volatiles (Lot 581) } \\
\hline $\begin{array}{l}\text { Acetone }(\mu g / L) \\
\text { Benzene }(\mu g / L) \\
\text { Bromodichloromethane }(\mu g / L) \\
\text { Bromoform }(\mu g / L) \\
\text { Carbon tetrachloride }(\mu g / L) \\
\text { Chlorobenzene }(\mu g / L) \\
\text { Chloroform }(\mu g / L) \\
\text { Dibromochloromethane }(\mu g / L) \\
1,2 \text {-Dichlorobenzene }(\mu g / L) \\
\text { 1,3-Dichlorobenzene }(\mu g / L) \\
\text { 1,4-Dichlorobenzene }(\mu g / L) \\
1,2 \text {-Dichloroethane }(\mu g / L) \\
1,1-\text { Dichloroethylene }(\mu g / L) \\
\text { Dichloromethane }(m e t h y l e n e \text { chloride) }(\mu g / L) \\
\text { Ethylbenzene }(\mu g / L)\end{array}$ & $\begin{array}{l}150 \\
50.0 \\
60.0 \\
85.1 \\
94.5 \\
20.1 \\
75.5 \\
67.3 \\
21.5 \\
119 \\
41.8 \\
47.9 \\
100 \\
65.3 \\
15.3\end{array}$ & $\begin{array}{l}75.2-233 \\
38.7-62.3 \\
46.1-74.8 \\
62.2-110 \\
69.4-118 \\
15.7-24.1 \\
58.0-92.3 \\
52.4-83.0 \\
16.3-26.4 \\
91.0-143 \\
31.4-50.9 \\
37.4-60.2 \\
65.5-127 \\
46.2-85.1 \\
11.4-17.9\end{array}$ & $\begin{array}{l}63.6 \\
51.6 \\
59.7 \\
95.7 \\
97.8 \\
20.0 \\
73.0 \\
65.4 \\
20.8 \\
128 \\
42.6 \\
46.6 \\
118 \\
69.4 \\
13.7\end{array}$ & \\
\hline
\end{tabular}




\begin{tabular}{lllll}
\hline Analyte & $\begin{array}{l}\text { Certified } \\
\text { Value }\end{array}$ & $\begin{array}{l}\text { Performance } \\
\text { Acceptance Limits }\end{array}$ & $\begin{array}{l}\text { GE } \\
\text { Result }\end{array}$ & $\begin{array}{l}\text { Functional } \\
\text { Guideline Code }\end{array}$ \\
\hline & & & & \\
4-Methyl-2-pentanone (MIBK) $(\mu g / L)$ & 89.9 & $52.0-123$ & 79.7 & \\
Styrene $(\mu g / L)$ & 24.9 & $17.3-30.3$ & 21.3 & \\
Tetrachloroethylene $(\mu \mathrm{g} / \mathrm{L})$ & 110 & $81.2-133$ & 115 & \\
Toluene $(\mu g / L)$ & 62.8 & $48.4-75.8$ & 63.3 & \\
1,1,1-Trichloroethane $(\mu \mathrm{g} / \mathrm{L})$ & 40.0 & $28.9-47.7$ & 42.2 \\
Trichloroethylene $(\mu \mathrm{g} / \mathrm{L})$ & 19.4 & $14.4-23.5$ & 17.1 & \\
m/p-Xylene $(\mu \mathrm{g} / \mathrm{L})$ & 36.6 & $23.7-46.1$ & 33.9 & \\
\hline
\end{tabular}

Result is out of range.

$\mathrm{J}$ The analytical result is an estimated quantity.

Table 40. Quality Control Standards for Selected Analyses for WA

\begin{tabular}{lllll}
\hline & Certified & Performance & WA & Functional \\
Analyte & Value & Acceptance Limits & Result & Guideline Code \\
\hline
\end{tabular}

\section{Acids (Lot 587)}

m/p-Cresol (3/4-Methylphenol) ( $\mu \mathrm{g} / \mathrm{L})$

o-Cresol (2-Methylphenol) $(\mu \mathrm{g} / \mathrm{L})$

2,4-Dimethyl phenol $(\mu g / L)$

Pentachlorophenol ( $\mu \mathrm{g} / \mathrm{L})$

Phenol ( $\mu g /$ L)

2,4,5-Trichlorophenol $(\mu \mathrm{g} / \mathrm{L})$

2,4,6-Trichlorophenol $(\mu \mathrm{g} / \mathrm{L})$

$\begin{array}{llll}59.1 & 18.1-68.5 & 47.4 \\ 67.2 & 21.4-77.8 & 48.6 \\ 41.0 & 12.5-50.5 & 28.0 & \\ 121 & 37.6-152 & 23.4 \triangleleft & \text { J } \\ 30.4 & 7.71-37.6 & 22.8 \\ 191 & 75.3-221 & 151 \\ 85.7 & 37.0-98.2 & 64.9 & \end{array}$

\section{Base/Neutrals (Lot 585)}

Acenaphthene ( $\mu \mathrm{g} / \mathrm{L})$

Acenaphthylene $(\mu g / L)$

Anthracene $(\mu g / L)$

Bis(2-chloroethyl) ether ( $\mu \mathrm{g} / \mathrm{L}$ )

Bis(2-ethylhexyl) phthalate $(\mu g / L)$

Butylbenzylphthlate $(\mu g / L)$

Chrysene ( $\mu g / L)$

Dibenzofuran $(\mu g / L)$

1,2-Dichlorobenzene $(\mu g / L)$

1,3-Dichlorobenzene ( $\mu \mathrm{g} / \mathrm{L})$

Di-n-butyl phthlate $(\mu g / L)$

2,4-Dinitrotoluene $(\mu g / L)$

Fluoranthene

Naphthalene $(\mu \mathrm{g} / \mathrm{L})$

Pyrene $(\mu \mathrm{g} / \mathrm{L})$

1,2,4-Trichlorobenzene $(\mu g / L)$

45.3

$5.31-14.6 \quad 8.28$

66.5-164

115

$55.0-188$

$11.9-37.8$

$66.2-195$

$9.57-25.4$

$37.7-87.8$

$36.7-179$

$4.59-23.3$

$44.8-140$

52.3-144

13.1-35.0

$21.1-68.3$

$31.0-80.7$

$19.5-75.8$

104

24.5

121

15.5

53.4

82.5

9.11

78.3

84.4

18.3

36.1

51.6

43.3

Cations (Lot 435)

Calcium $(\mu g / L)$

19,500

15,900

Magnesium $(\mu g / L)$

28,200

Sodium $(\mu g / L)$

22,300

$\begin{array}{ll}17,600-21,500 & 20,000 \\ 14,200-17,600 & 16,000 \\ 25,700-30,700 & 28,500 \\ 19,600-25,000 & 21,700\end{array}$

Cyanide and Phenol (Lot 9980)

Cyanide, total $(\mu g / L)$ 


\begin{tabular}{|c|c|c|c|c|}
\hline Analyte & $\begin{array}{l}\text { Certified } \\
\text { Value }\end{array}$ & $\begin{array}{l}\text { Performance } \\
\text { Acceptance Limits }\end{array}$ & $\begin{array}{l}\text { WA } \\
\text { Result }\end{array}$ & $\begin{array}{l}\text { Functional } \\
\text { Guideline Code }\end{array}$ \\
\hline \multicolumn{5}{|l|}{ Grease and Oil (Lot 9985) } \\
\hline $\begin{array}{l}\text { Grease and oil (gravimetric) (mg/bottle) } \\
\text { Inorganics (Lot 13028) }\end{array}$ & 25.3 & $15.2-31.6$ & 20.6 & \\
\hline $\begin{array}{l}\left.\text { Alkalinity (as } \mathrm{CaCO}_{3}\right)(\mu g / L) \\
\text { Chloride }(\mu g / L) \\
\text { Fluoride }(\mu g / L) \\
\text { Nitrate as nitrogen }(\mu g / L) \\
\text { pH (pH units) } \\
\text { Potassium }(\mu g / L) \\
\text { Sodium }(\mu g / L) \\
\text { Specific conductance }(\mu \mathrm{S} / \mathrm{cm}) \\
\text { Sulfate }(\mu g / L) \\
\text { Total dissolved solids }(\mu g / L)\end{array}$ & $\begin{array}{l}175,000 \\
91,000 \\
7,080 \\
2,150 \\
9.12 \\
20,600 \\
193,000 \\
904 \\
113,000 \\
769,000\end{array}$ & $\begin{array}{l}163,000-197,000 \\
80,900-103,000 \\
6,370-7,790 \\
1,940-2,370 \\
8.92-9.32 \\
17,700-24,000 \\
174,000-214,000 \\
756-1,030 \\
96,800-128,000 \\
630,000-861,000\end{array}$ & $\begin{array}{l}178,000 \\
91,400 \\
5,970 \\
2,100 \\
9.15 \\
24,100 \\
182,000 \\
872 \\
112,000 \\
729,000\end{array}$ & \\
\hline \multicolumn{5}{|l|}{ Nutrients (Lot 9980) } \\
\hline $\begin{array}{l}\text { Ammonia as nitrogen }(\mu g / L) \\
\text { Nitrate-nitrite as nitrogen }(\mu g / L) \\
\text { Total phosphates (as } P)(\mu g / L)\end{array}$ & $\begin{array}{l}6,290 \\
2,220 \\
7,970\end{array}$ & $\begin{array}{l}5,280-7,300 \\
1,980-2,460 \\
6,770-9,170\end{array}$ & $\begin{array}{l}6,450 \\
2,160 \\
7,980\end{array}$ & \\
\hline \multicolumn{5}{|l|}{ PCBs (Lot 574) } \\
\hline PCB $1248(\mu g / L)$ & 1.02 & $0.545-1.27$ & 1.35 & \\
\hline \multicolumn{5}{|l|}{ Pesticides (Lot 580 ) } \\
\hline $\begin{array}{l}\text { Aldrin }(\mu g / L) \\
\text { alpha-Benzene hexachloride }(\mu g / L) \\
\text { beta-Benzene hexachloride }(\mu g / L) \\
\text { alpha-Chlordane }(\mu g / L) \\
\text { gamma-Chlordane }(\mu g / L) \\
4,4^{\prime}-D D D(\mu g / L) \\
4,4^{\prime}-D D E(\mu g / L) \\
4,4^{\prime}-D D T(\mu g / L) \\
\text { Dieldrin }(\mu g / L) \\
\text { Endrin }(\mu g / L) \\
\text { Heptachlor }(\mu g / L) \\
\text { Heptachlor epoxide }(\mu g / L) \\
\text { Methoxychlor }(\mu g / L)\end{array}$ & $\begin{array}{l}6.09 \\
3.12 \\
2.20 \\
3.34 \\
1.12 \\
5.71 \\
1.90 \\
6.82 \\
3.44 \\
0.453 \\
2.51 \\
4.36 \\
7.10\end{array}$ & $\begin{array}{l}3.16-7.50 \\
1.74-3.97 \\
1.17-2.78 \\
2.02-4.14 \\
0.780-1.34 \\
3.51-7.41 \\
1.11-2.38 \\
3.96-8.57 \\
2.13-4.45 \\
0.284-0.585 \\
1.14-3.11 \\
2.69-5.33 \\
4.05-9.56\end{array}$ & $\begin{array}{l}<0.100 \\
<0.050 \\
<0.050 \\
<0.050 \\
1.11 \\
<0.100 \\
2.03 \\
<0.100 \\
<0.100 \\
0.650 \\
<0.050 \\
<0.050 \\
7.86\end{array}$ & \\
\hline \multicolumn{5}{|l|}{ Pesticides/Herbicides (Lot 21028) } \\
\hline $\begin{array}{l}\text { 2-sec-Butyl-4,6-dinitrophenol }(\mu g / L) \\
\text { 2,4-Dichlorophenoxyacetic acid }(\mu g / L) \\
2,4,5-T P \text { (Silvex) }(\mu g / L)\end{array}$ & $\begin{array}{l}1.47 \\
4.85 \\
1.22\end{array}$ & $\begin{array}{l}0.482-1.90 \\
2.43-7.28 \\
0.610-1.83\end{array}$ & $\begin{array}{l}1.28 \\
5.59 \\
1.12\end{array}$ & \\
\hline \multicolumn{5}{|l|}{ Total Petroleum Hydrocarbons (Lot 8913) } \\
\hline $\begin{array}{l}\text { Total petroleum hydrocarbons, infrared } \\
\text { (mg/bottle) }\end{array}$ & 139 & $88.6-181$ & 140 & $\mathbf{J}$ \\
\hline Toxaphene (Lot 3214) & & & & \\
\hline Toxaphene $(\mu g / L)$ & 6.15 & $3.38-8.92$ & $<10.0 \%$ & \\
\hline
\end{tabular}




\begin{tabular}{|c|c|c|c|c|}
\hline Analyte & $\begin{array}{l}\text { Certified } \\
\text { Value }\end{array}$ & $\begin{array}{l}\text { Performance } \\
\text { Acceptance Limits }\end{array}$ & $\begin{array}{l}\text { WA } \\
\text { Result }\end{array}$ & $\begin{array}{l}\text { Functional } \\
\text { Guideline Code }\end{array}$ \\
\hline \multicolumn{5}{|l|}{ Trace Metals (Lot 9983) } \\
\hline $\begin{array}{l}\text { Aluminum }(\mu g / L) \\
\text { Antimony }(\mu g / L) \\
\text { Arsenic }(\mu g / L) \\
\text { Barium }(\mu g / L) \\
\text { Beryllium }(\mu g / L) \\
\text { Boron }(\mu g / L) \\
\text { Cadmium }(\mu g / L) \\
\text { Chromium }(\mu g / L) \\
\text { Cobalt }(\mu g / L) \\
\text { Copper }(\mu g / L) \\
\text { Iron }(\mu g / L) \\
\text { Lead }(\mu g / L) \\
\text { Manganese }(\mu g / L) \\
\text { Mercury }(\mu g / L) \\
\text { Molybdenum }(\mu g / L) \\
\text { Nickel }(\mu g / L) \\
\text { Selenium }(\mu g / L) \\
\text { Silver }(\mu g / L) \\
\text { Strontium }(\mu g / L) \\
\text { Thallium }(\mu g / L) \\
\text { Vanadium }(\mu g / L) \\
\text { Zinc }(\mu g / L)\end{array}$ & $\begin{array}{l}500 \\
77.8 \\
133 \\
778 \\
122 \\
410 \\
62.2 \\
611 \\
322 \\
133 \\
733 \\
211 \\
644 \\
4.67 \\
351 \\
249 \\
66.7 \\
88.9 \\
789 \\
54.4 \\
356 \\
606\end{array}$ & $\begin{array}{l}410-590 \\
58.4-97.3 \\
99.8-157 \\
638-918 \\
100-144 \\
336-513 \\
51.0-73.4 \\
501-721 \\
264-380 \\
109-157 \\
601-865 \\
173-249 \\
528-760 \\
3.50-5.84 \\
288-414 \\
204-294 \\
50.0-78.7 \\
72.9-105 \\
647-931 \\
40.8-68.0 \\
292-420 \\
497-715\end{array}$ & $\begin{array}{l}555 \\
76.2 \\
135 \\
769 \\
123 \\
444 \\
63.6 \\
616 \\
341 \\
133 \\
740 \\
216 \\
660 \\
4.70 \\
360 \\
257 \\
71.9 \\
88.3 \\
761 \\
56.6 \\
360 \\
612\end{array}$ & \\
\hline \multicolumn{5}{|l|}{ Turbidity (Lot 3427) } \\
\hline Turbidity (NTU) & 3.36 & $2.86-3.93$ & 3.22 & \\
\hline \multicolumn{5}{|l|}{ Volatiles (Lot 581) } \\
\hline $\begin{array}{l}\text { Acetone }(\mu g / L) \\
\text { Benzene }(\mu g / L) \\
\text { Bromodichloromethane }(\mu g / L) \\
\text { Bromoform }(\mu g / L) \\
\text { Carbon tetrachloride }(\mu g / L) \\
\text { Chlorobenzene }(\mu g / L) \\
\text { Chloroform }(\mu g / L) \\
\text { Dibromochloromethane }(\mu g / L) \\
\text { 1,2-Dichlorobenzene }(\mu g / L) \\
\text { 1,3-Dichlorobenzene }(\mu g / L) \\
\text { 1,4-Dichlorobenzene }(\mu g / L) \\
\text { 1,2-Dichloroethane }(\mu g / L) \\
\text { 1,1-Dichloroethylene }(\mu g / L) \\
\text { Dichloromethane }(m e t h y l e n e ~ c h l o r i d e)(\mu g / L) \\
\text { Ethylbenzene }(\mu g / L) \\
\text { 4-Methyl-2-pentanone }(\mathrm{MIBK})(\mu g / L) \\
\text { Styrene }(\mu g / L) \\
\text { Tetrachloroethylene }(\mu g / L) \\
\text { Toluene }(\mu g / L) \\
\text { 1,1,1-Trichloroethane }(\mu g / L) \\
\text { Trichloroethylene }(\mu g / L) \\
\text { m/p-Xylene }(\mu g / L)\end{array}$ & $\begin{array}{l}150 \\
50.0 \\
60.0 \\
85.1 \\
94.5 \\
20.1 \\
75.5 \\
67.3 \\
21.5 \\
119 \\
41.8 \\
47.9 \\
100 \\
65.3 \\
15.3 \\
89.9 \\
24.9 \\
110 \\
62.8 \\
40.0 \\
19.4 \\
36.6 \\
\end{array}$ & $\begin{array}{l}75.2-233 \\
38.7-62.3 \\
46.1-74.8 \\
62.2-110 \\
69.4-118 \\
15.7-24.1 \\
58.0-92.3 \\
52.4-83.0 \\
16.3-26.4 \\
91.0-143 \\
31.4-50.9 \\
37.4-60.2 \\
65.5-127 \\
46.2-85.1 \\
11.4-17.9 \\
52.0-123 \\
17.3-30.3 \\
81.2-133 \\
48.4-75.8 \\
28.9-47.7 \\
14.4-23.5 \\
23.7-46.1 \\
\end{array}$ & $\begin{array}{l}122 \\
51.0 \\
56.2 \\
83.2 \\
90.0 \\
19.2 \\
70.3 \\
62.1 \\
17.8 \\
107 \\
38.7 \\
46.0 \\
93.7 \\
52.2 \\
12.2 \\
94.3 \\
18.7 \\
96.7 \\
61.1 \\
36.5 \\
16.2 \\
33.7 \\
\end{array}$ & \\
\hline
\end{tabular}

Result is out of range.

$\therefore$ Not enough information to determine if result is within performance acceptance limits.

$\mathrm{J}$ The analytical result is an estimated quantity. 
Table 41. Laboratory Control Sample Recoveries for EX

\begin{tabular}{|c|c|c|c|c|c|}
\hline Analyte & $\begin{array}{l}\text { Qualified } \\
\text { Out of Ranget }\end{array}$ & $\begin{array}{l}\text { Mean } \\
\text { Recovery (\%) }\end{array}$ & $\begin{array}{l}\text { Standard } \\
\text { Deviation }\end{array}$ & $\begin{array}{l}\text { Minimum } \\
\text { Recovery (\%) }\end{array}$ & $\begin{array}{l}\text { Maximum } \\
\text { Recovery (\%) }\end{array}$ \\
\hline \multicolumn{6}{|l|}{ EPA120.1 } \\
\hline Specific conductance & $0 / 2$ & 108 & 0.0 & 108 & 108 \\
\hline \multicolumn{6}{|l|}{ EPA300.0 } \\
\hline Chloride & $0 / 2$ & 97.5 & 0.71 & 97.0 & 98.0 \\
\hline Nitrate as nitrogen & $0 / 14$ & 106 & 2.62 & 100 & 109 \\
\hline Nitrate-nitrite as nitrogen & $0 / 3$ & 104 & 0.58 & 103 & 104 \\
\hline Sulfate & $0 / 4$ & 96.5 & 0.58 & 96.0 & 97.0 \\
\hline \multicolumn{6}{|l|}{ EPA410.4 } \\
\hline Chemical oxygen demand & $1 / 3$ & 67.3 & 50.7 & 9.0 & 101 \\
\hline \multicolumn{6}{|l|}{ EPA6010B } \\
\hline Aluminum & $0 / 17$ & 106 & 4.18 & 98.0 & 114 \\
\hline Antimony & $0 / 4$ & 98.0 & 5.83 & 92.0 & 103 \\
\hline Arsenic & $0 / 9$ & 102 & 2.39 & 98.0 & 105 \\
\hline Barium & $0 / 10$ & 105 & 3.89 & 100 & 112 \\
\hline Beryllium & $0 / 4$ & 103 & 2.94 & 100 & 106 \\
\hline Boron & $0 / 9$ & 110 & 3.49 & 106 & 116 \\
\hline Cadmium & $0 / 9$ & 103 & 4.01 & 97.0 & 109 \\
\hline Calcium & $0 / 2$ & 108 & 0.71 & 107 & 108 \\
\hline Chromium & $0 / 9$ & 105 & 4.93 & 96.0 & 111 \\
\hline Cobalt & $0 / 2$ & 109 & 0.0 & 109 & 109 \\
\hline Copper & $0 / 4$ & 99.3 & 0.50 & 99.0 & 100 \\
\hline Iron & $0 / 17$ & 107 & 4.53 & 98.0 & 116 \\
\hline Lead & $0 / 21$ & 100 & 4.46 & 95.0 & 112 \\
\hline Magnesium & $0 / 2$ & 107 & 0.71 & 106 & 107 \\
\hline Manganese & $0 / 11$ & 108 & 2.97 & 104 & 114 \\
\hline Nickel & $0 / 4$ & 101 & 3.77 & 97.0 & 104 \\
\hline Potassium & $0 / 2$ & 105 & 0.71 & 104 & 105 \\
\hline Selenium & $0 / 9$ & 106 & 2.39 & 102 & 109 \\
\hline Silver & $0 / 9$ & 105 & 4.21 & 99.0 & 111 \\
\hline Sodium & $0 / 2$ & 102 & 0.0 & 102 & 102 \\
\hline Thallium & $0 / 6$ & 105 & 2.07 & 102 & 107 \\
\hline Vanadium & $0 / 2$ & 103 & 0.0 & 103 & 103 \\
\hline Zinc & $0 / 4$ & 102 & 3.51 & 98.0 & 105 \\
\hline \multicolumn{6}{|l|}{ EPA7470A } \\
\hline Mercury & $0 / 32$ & 102 & 4.37 & 96.0 & 111 \\
\hline \multicolumn{6}{|l|}{ EPA8021B } \\
\hline Carbon tetrachloride & $0 / 14$ & 107 & 9.31 & 92.0 & 123 \\
\hline Chloroform & $0 / 14$ & 108 & 8.55 & 96.0 & 126 \\
\hline cis-1,2-Dichloroethylene & $0 / 14$ & 109 & 7.95 & 97.0 & 122 \\
\hline Tetrachloroethylene & $1 / 14$ & 112 & 12.4 & 93.0 & 140 \\
\hline 1,1,1-Trichloroethane & $0 / 14$ & 107 & 9.08 & 94.0 & 125 \\
\hline Trichloroethylene & $1 / 14$ & 107 & 10.5 & 90.0 & 128 \\
\hline \multicolumn{6}{|l|}{ EPA8081A } \\
\hline Aldrin & $0 / 2$ & 61.5 & 21.9 & 46.0 & 77.0 \\
\hline$p, p^{\prime}-D D T$ & $0 / 2$ & 118 & 7.78 & 112 & 123 \\
\hline Dieldrin & $0 / 2$ & 91.0 & 17.0 & 79.0 & 103 \\
\hline Endrin & $0 / 2$ & 94.5 & 20.5 & 80.0 & 109 \\
\hline Heptachlor & $0 / 2$ & 64.5 & 21.9 & 49.0 & 80.0 \\
\hline Lindane & $1 / 2$ & 64.0 & 24.0 & 47.0 & 81.0 \\
\hline \multicolumn{6}{|l|}{ EPA8082 } \\
\hline РСВ 1260 & $0 / 2$ & 93.5 & 2.12 & 92.0 & 95.0 \\
\hline
\end{tabular}




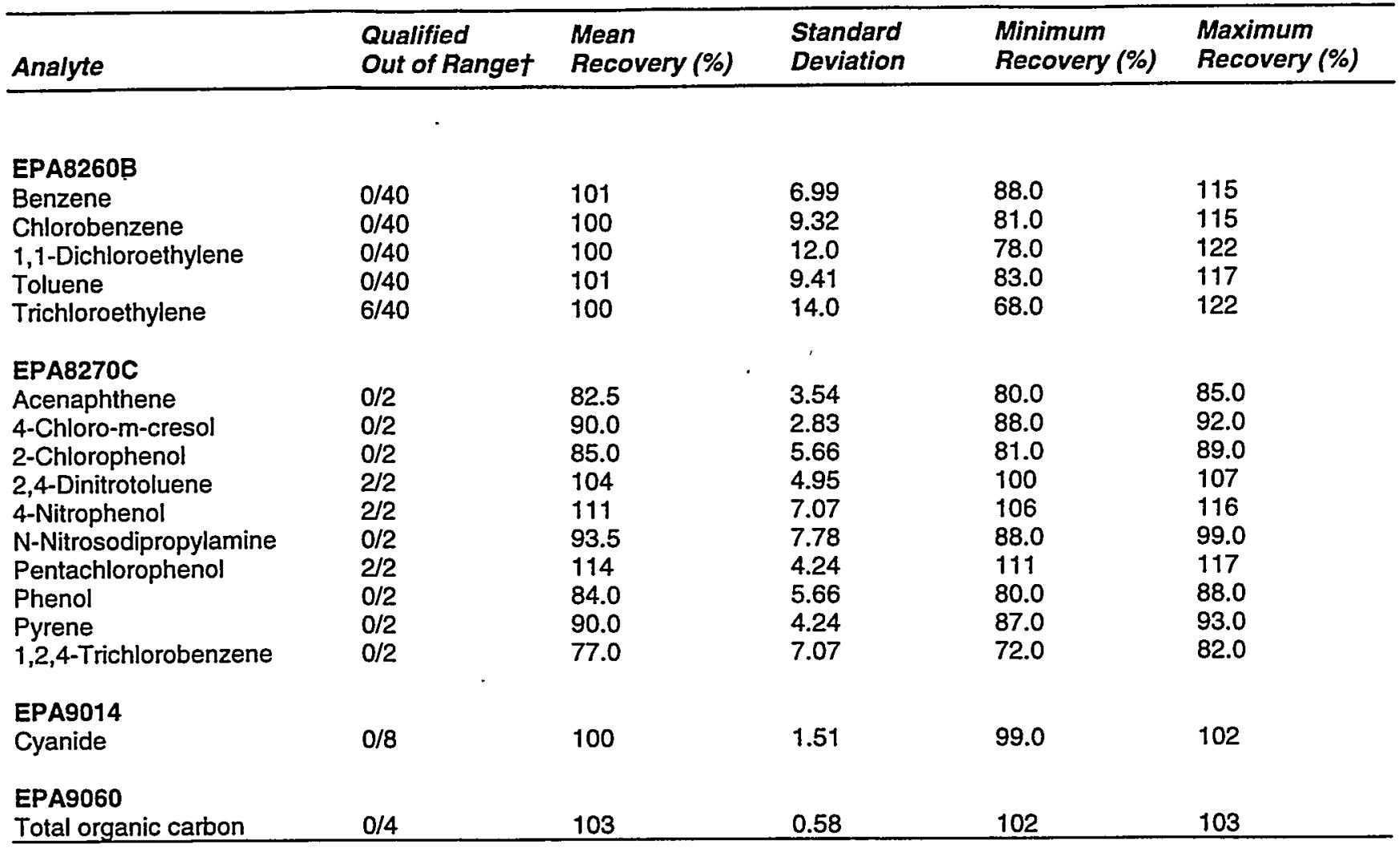

$\dagger \quad$ Number of batches qualified that exhibit poor laboratory control sample and blank spike recovery due to interference compared to the total number of batches containing laboratory control samples and blank spikes.

Note: $A$ value of 0 is reported as 0.0 .

Table 42. Laboratory Control Sample Recoveries for GE

\begin{tabular}{|c|c|c|c|c|c|}
\hline Analyte & $\begin{array}{l}\text { Qualified } \\
\text { Out of Ranget }\end{array}$ & $\begin{array}{l}\text { Mean } \\
\text { Recovery (\%) }\end{array}$ & $\begin{array}{l}\text { Standard } \\
\text { Deviation }\end{array}$ & $\begin{array}{l}\text { Minimum } \\
\text { Recovery (\%) }\end{array}$ & $\begin{array}{l}\text { Maximum } \\
\text { Recovery (\%) }\end{array}$ \\
\hline \multicolumn{6}{|l|}{ EPA160.1 } \\
\hline Total dissolved solids & $0 / 2$ & 102 & 0.71 & 101 & 102 \\
\hline \multicolumn{6}{|l|}{ EPA300.0 } \\
\hline Chloride & $0 / 1$ & 98.3 & - & 98.3 & 98.3 \\
\hline Sulfate & $0 / 2$ & 99.2 & 0.35 & 98.9 & 99.4 \\
\hline \multicolumn{6}{|l|}{ EPA310.1 } \\
\hline Alkalinity (as $\mathrm{CaCO}_{3}$ ) & $0 / 3$ & 99.6 & 3.27 & 95.9 & .102 \\
\hline \multicolumn{6}{|l|}{ EPA353.1 } \\
\hline Nitrate-nitrite as nitrogen & $0 / 20$ & 99.8 & 4.06 & 94.0 & 107 \\
\hline \multicolumn{6}{|l|}{ EPA6010B } \\
\hline Aluminum & $0 / 12$ & 100 & 4.06 & 92.2 & 106 \\
\hline Antimony & $0 / 8$ & 102 & 4.99 & 92.7 & 106 \\
\hline Arsenic & $0 / 8$ & 100 & 5.41 & 91.1 & 106 \\
\hline Barium & $0 / 8$ & 97.9 & 2.58 & 93.3 & 101 \\
\hline Beryllium & $0 / 10$ & 100 & 3.94 & 93.5 & 105 \\
\hline Boron & $0 / 2$ & 100 & 1.34 & 99.1 & 101 \\
\hline Cadmium & $0 / 8$ & 98.7 & 4.44 & 91.7 & 105 \\
\hline
\end{tabular}




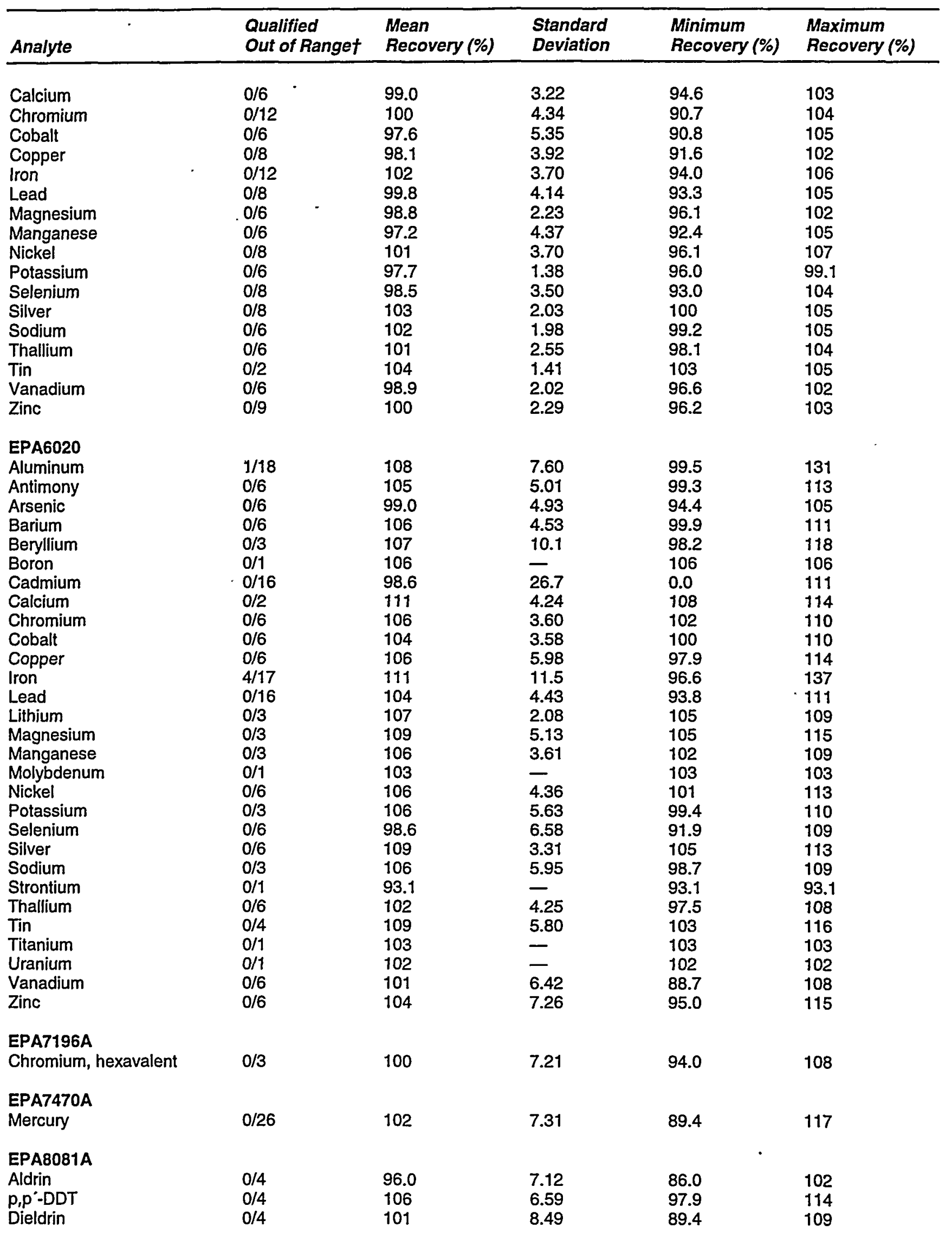




\begin{tabular}{|c|c|c|c|c|c|}
\hline Analyte & $\begin{array}{l}\text { Qualified } \\
\text { Out of Ranget }\end{array}$ & $\begin{array}{l}\text { Mean } \\
\text { Recovery (\%) }\end{array}$ & $\begin{array}{l}\text { Standard } \\
\text { Deviation }\end{array}$ & $\begin{array}{l}\text { Minimum } \\
\text { Recovery (\%) }\end{array}$ & $\begin{array}{l}\text { Maximum } \\
\text { Recovery (\%) }\end{array}$ \\
\hline $\begin{array}{l}\text { Endrin } \\
\text { Heptachlor } \\
\text { Lindane }\end{array}$ & $\begin{array}{l}1 / 4 \\
0 / 4 \\
0 / 4\end{array}$ & $\begin{array}{l}116 \\
105 \\
102\end{array}$ & $\begin{array}{l}7.94 \\
7.51 \\
6.19\end{array}$ & $\begin{array}{l}104 \\
97.3 \\
94.1\end{array}$ & $\begin{array}{l}122 \\
112 \\
108\end{array}$ \\
\hline $\begin{array}{l}\text { EPA8082 } \\
\text { PCB } 1260\end{array}$ & $0 / 5$ & 69.0 & 11.4 & 57.0 & 80.0 \\
\hline $\begin{array}{l}\text { EPA8260B } \\
\text { Benzene } \\
\text { Chlorobenzene } \\
\text { 1,1-Dichloroethylene } \\
\text { Toluene } \\
\text { Trichloroethylene }\end{array}$ & $\begin{array}{l}0 / 20 \\
0 / 20 \\
0 / 20 \\
0 / 20 \\
0 / 22\end{array}$ & $\begin{array}{l}94.8 \\
97.0 \\
103 \\
94.9 \\
96.2\end{array}$ & $\begin{array}{l}5.90 \\
5.29 \\
8.38 \\
5.49 \\
8.15\end{array}$ & $\begin{array}{l}84.4 \\
83.1 \\
88.6 \\
80.2 \\
83.0\end{array}$ & $\begin{array}{l}110 \\
105 \\
117 \\
105 \\
112\end{array}$ \\
\hline $\begin{array}{l}\text { EPA8270C } \\
\text { Acenaphthene } \\
\text { 4-Chloro-m-cresol } \\
\text { 2-Chlorophenol } \\
\text { 1,4-Dichlorobenzene } \\
\text { 2,4-Dinitrotoluene } \\
\text { 4-Nitrophenol } \\
\text { N-Nitrosodipropylamine } \\
\text { Pentachlorophenol } \\
\text { Phenol } \\
\text { Pyrene } \\
\text { 1,2,4-Trichlorobenzene }\end{array}$ & $\begin{array}{l}0 / 11 \\
0 / 10 \\
0 / 10 \\
0 / 11 \\
2 / 11 \\
0 / 10 \\
0 / 11 \\
4 / 10 \\
0 / 10 \\
0 / 11 \\
0 / 11\end{array}$ & $\begin{array}{l}74.2 \\
82.6 \\
67.9 \\
59.3 \\
92.1 \\
30.6 \\
78.4 \\
99.2 \\
31.3 \\
88.4 \\
62.3\end{array}$ & $\begin{array}{l}5.07 \\
6.72 \\
5.36 \\
7.66 \\
10.1 \\
8.86 \\
10.6 \\
14.7 \\
4.76 \\
7.22 \\
8.64\end{array}$ & $\begin{array}{l}64.9 \\
73.8 \\
60.9 \\
50.6 \\
76.8 \\
15.5 \\
61.4 \\
70.7 \\
24.0 \\
80.7 \\
51.4\end{array}$ & $\begin{array}{l}79.6 \\
94.7 \\
75.3 \\
71.3 \\
113 \\
47.7 \\
92.2 \\
118 \\
38.3 \\
102 \\
75.7\end{array}$ \\
\hline $\begin{array}{l}\text { EPA9012A } \\
\text { Cyanide }\end{array}$ & $0 / 8$ & 91.8 & 6.14 & 80.0 & 99.3 \\
\hline $\begin{array}{l}\text { EPA9020B } \\
\text { Total organic halogens }\end{array}$ & $1 / 4$ & 84.6 & 15.9 & 63.9 & 99.5 \\
\hline $\begin{array}{l}\text { EPA9040B } \\
\mathrm{pH}\end{array}$ & $0 / 28$ & 99.9 & 0.25 & 99.6 & 101 \\
\hline $\begin{array}{l}\text { EPA9050A } \\
\text { Specific conductance }\end{array}$ & $0 / 22$ & 105 & 2.97 & 101 & 110 \\
\hline $\begin{array}{l}\text { EPA9060 } \\
\text { Total organic carbon }\end{array}$ & $0 / 2$ & 105 & 0.0 & 105 & 105 \\
\hline $\begin{array}{l}\text { EPA9066 } \\
\text { Phenols }\end{array}$ & $0 / 6$ & 102 & 3.39 & 98.2 & 107 \\
\hline
\end{tabular}

$\dagger$ Number of batches qualified that exhibit poor laboratory control sample and blank spike recovery due to interference compared to the total number of batches containing laboratory control samples and blank spikes.

- Standard deviation cannot be determined.

Note: $A$ value of 0 is reported as 0.0 . 
Table 43. Laboratory Control Sample Recoveries for WA

\begin{tabular}{|c|c|c|c|c|c|}
\hline Analyte & $\begin{array}{l}\text { Qualified } \\
\text { Out of Ranget }\end{array}$ & $\begin{array}{l}\text { Mean } \\
\text { Recovery (\%) }\end{array}$ & $\begin{array}{l}\text { Standard } \\
\text { Deviation }\end{array}$ & $\begin{array}{l}\text { Minimum } \\
\text { Recovery (\%) }\end{array}$ & $\begin{array}{l}\text { Maximum } \\
\text { Recovery (\%) }\end{array}$ \\
\hline \multicolumn{6}{|l|}{ EPA160.1 } \\
\hline Total dissolved solids & $0 / 32$ & 99.7 & 2.48 & 95.0 & 104 \\
\hline \multicolumn{6}{|l|}{ EPA310.1 } \\
\hline Alkalinity (as $\mathrm{CaCO}_{3}$ ) & $0 / 12$ & 102 & 3.98 & 98.8 & 110 \\
\hline \multicolumn{6}{|l|}{ EPA340.2 } \\
\hline Fluoride & $0 / 8$ & 98.9 & 3.26 & 92.9 & 104 \\
\hline \multicolumn{6}{|l|}{ EPA353.2 } \\
\hline Nitrate as nitrogen & $0 / 6$ & 99.3 & 0.81 & 97.8 & 100 \\
\hline Nitrate-nitrite as nitrogen & $0 / 18$ & 99.1 & 2.0 & 95.8 & 102 \\
\hline \multicolumn{6}{|l|}{ EPA365.2 } \\
\hline Total phosphates (as P) & $0 / 8$ & 99.4 & 1.92 & 96.7 & 102 \\
\hline \multicolumn{6}{|l|}{ EPA410.4 } \\
\hline Chemical oxygen demand & $0 / 2$ & 108 & 0.0 & 108 & 108 \\
\hline \multicolumn{6}{|l|}{ EPA418.1 } \\
\hline Total petroleum hydrocarbons & $0 / 2$ & 98.1 & 1.13 & 97.3 & 98.9 \\
\hline \multicolumn{6}{|l|}{ EPA6010B } \\
\hline Aluminum & $0 / 21$ & 98.7 & 1.99 & 96.4 & 102 \\
\hline Antimony & $0 / 10$ & 97.5 & 1.72 & 95.1 & 100 \\
\hline Arsenic & $0 / 19$ & 98.6 & 1.63 & 96.3 & 101 \\
\hline Barium & $0 / 17$ & 97.3 & 2.63 & 91.8 & 100 \\
\hline Beryllium & $0 / 4$ & 98.9 & 2.10 & 97.8 & 102 \\
\hline Boron & $0 / 11$ & 94.8 & 1.79 & 92.3 & 97.0 \\
\hline Cadmium & $0 / 18$ & 99.3 & 2.63 & 96.8 & 106 \\
\hline Calcium & $0 / 10$ & 99.2 & 0.87 & 98.0 & 101 \\
\hline Chromium & $0 / 18$ & 99.3 & 1.47 & 97.0 & 102 \\
\hline Cobalt & $0 / 3$ & 98.8 & 3.64 & 96.7 & 103 \\
\hline Copper & $0 / 10$ & 97.8 & 2.38 & 92.7 & 100 \\
\hline Iron & $0 / 20$ & 100 & 1.79 & 97.2 & 103 \\
\hline Lead & $0 / 19$ & 98.8 & 2.16 & 96.1 & 103 \\
\hline Lithium & $0 / 12$ & 102 & 2.08 & 97.3 & 104 \\
\hline Magnesium & $0 / 10$ & 100 & 2.71 & 98.0 & 105 \\
\hline Manganese & $0 / 14$ & 101 & 1.28 & 99.9 & 103 \\
\hline Nickel & $0 / 11$ & 96.6 & 1.98 & 94.6 & 100 \\
\hline Potassium & $0 / 10$ & 97.8 & 2.62 & 93.9 & 103 \\
\hline Selenium & $0 / 19$ & 98.4 & 1.59 & 95.4 & 100 \\
\hline Silica & $0 / 6$ & 97.3 & 0.77 & 96.8 & 98.8 \\
\hline Silver & $0 / 17$ & 99.3 & 1.10 & 97.0 & 101 \\
\hline Sodium & $0 / 11$ & 96.8 & 1.65 & 95.1 & 99.8 \\
\hline Thallium & $0 / 3$ & 101 & 3.23 & 99.4 & 105 \\
\hline $\operatorname{Tin}$ & $0 / 7$ & 98.8 & 0.73 & 98.2 & 100 \\
\hline Vanadium & $0 / 3$ & 100 & 1.62 & 99.2 & 102 \\
\hline Zinc & $0 / 10$ & 97.4 & 1.15 & 96.0 & 99.4 \\
\hline \multicolumn{6}{|l|}{ EPA7196A } \\
\hline Chromium, hexavalent & $0 / 2$ & 103 & 0.0 & 103 & 103 \\
\hline \multicolumn{6}{|l|}{ EPA7470A } \\
\hline Mercury & $0 / 15$ & 103 & 1.87 & 101 & 107 \\
\hline
\end{tabular}

\section{Quality Control Samples}




\begin{tabular}{|c|c|c|c|c|c|}
\hline Analyte & $\begin{array}{l}\text { Qualified } \\
\text { Out of Ranget }\end{array}$ & $\begin{array}{l}\text { Mean } \\
\text { Recovery (\%) }\end{array}$ & $\begin{array}{l}\text { Standard } \\
\text { Deviation }\end{array}$ & $\begin{array}{l}\text { Minimum } \\
\text { Recovery (\%) }\end{array}$ & $\begin{array}{l}\text { Maximum } \\
\text { Recovery (\%) }\end{array}$ \\
\hline $\begin{array}{l}\text { EPA8021B } \\
\text { Carbon tetrachloride } \\
\text { Chloroform } \\
\text { cis-1,2-Dichloroethylene } \\
\text { Tetrachloroethylene } \\
\text { 1,1,1-Trichloroethane } \\
\text { Trichloroethylene }\end{array}$ & $\begin{array}{l}0 / 12 \\
0 / 12 \\
0 / 10 \\
0 / 10 \\
0 / 12 \\
0 / 12\end{array}$ & $\begin{array}{l}98.8 \\
98.2 \\
95.2 \\
98.7 \\
96.8 \\
95.7\end{array}$ & $\begin{array}{l}8.78 \\
8.65 \\
10.6 \\
10.1 \\
8.94 \\
7.71\end{array}$ & $\begin{array}{l}83.5 \\
83.3 \\
79.6 \\
83.8 \\
81.9 \\
85.1\end{array}$ & $\begin{array}{l}113 \\
113 \\
112 \\
110 \\
114 \\
108\end{array}$ \\
\hline $\begin{array}{l}\text { EPA8081A } \\
\text { Aldrin } \\
\text { p,p'-DDT } \\
\text { Dieldrin } \\
\text { Endrin } \\
\text { Heptachlor } \\
\text { Lindane }\end{array}$ & $\begin{array}{l}0 / 2 \\
0 / 2 \\
0 / 2 \\
1 / 3 \\
0 / 2 \\
0 / 3\end{array}$ & $\begin{array}{l}55.0 \\
105 \\
93.0 \\
114 \\
65.0 \\
91.7\end{array}$ & $\begin{array}{l}7.07 \\
4.24 \\
4.24 \\
6.93 \\
0.0 \\
5.77\end{array}$ & $\begin{array}{l}50.0 \\
102 \\
90.0 \\
110 \\
65.0 \\
85.0\end{array}$ & $\begin{array}{l}60.0 \\
108 \\
96.0 \\
122 \\
65.0 \\
95.0\end{array}$ \\
\hline $\begin{array}{l}\text { EPA8082 } \\
\text { PCB } 1254\end{array}$ & $0 / 2$ & 83.0 & 1.91 & 81.6 & 84.3 \\
\hline $\begin{array}{l}\text { EPA8151A } \\
\text { 2,4-Dichlorophenoxyacetic } \\
\text { acid }\end{array}$ & $0 / 1$ & 107 & - & 107 & 107 \\
\hline $\begin{array}{l}\text { EPA8260B } \\
\text { Benzene } \\
\text { Chlorobenzene } \\
\text { 1,1-Dichloroethylene } \\
\text { cis-1,2-Dichloroethylene } \\
\text { Tetrachloroethylene } \\
\text { Toluene } \\
\text { Trichloroethylene }\end{array}$ & $\begin{array}{l}0 / 17 \\
0 / 17 \\
0 / 17 \\
0 / 2 \\
0 / 2 \\
0 / 17 \\
0 / 17\end{array}$ & $\begin{array}{l}98.5 \\
97.9 \\
85.5 \\
101 \\
99.2 \\
98.8 \\
94.8\end{array}$ & $\begin{array}{l}7.13 \\
6.59 \\
9.29 \\
0.0 \\
0.0 \\
7.26 \\
8.54\end{array}$ & $\begin{array}{l}86.1 \\
87.9 \\
73.8 \\
101 \\
99.2 \\
89.9 \\
76.6\end{array}$ & $\begin{array}{l}113 \\
109 \\
106 \\
101 \\
99.2 \\
112 \\
111\end{array}$ \\
\hline $\begin{array}{l}\text { EPA8270C } \\
\text { Acenaphthene } \\
\text { Bis(2-ethylhexyl) phthalate } \\
\text { 4-Chloro-m-cresol } \\
\text { 2-Chlorophenol } \\
\text { 1,4-Dichlorobenzene } \\
\text { 2,4-Dinitrotoluene } \\
\text { 4-Nitrophenol } \\
\text { N-Nitrosodipropylamine } \\
\text { Pentachlorophenol } \\
\text { Phenol } \\
\text { Pyrene } \\
\text { 1,2,4-Trichlorobenzene }\end{array}$ & $\begin{array}{l}0 / 2 \\
0 / 1 \\
0 / 1 \\
0 / 1 \\
0 / 2 \\
1 / 2 \\
1 / 1 \\
0 / 2 \\
0 / 1 \\
0 / 2 \\
0 / 2 \\
0 / 2\end{array}$ & $\begin{array}{l}83.4 \\
79.8 \\
60.6 \\
63.9 \\
57.1 \\
87.0 \\
100 \\
62.7 \\
89.9 \\
64.8 \\
83.2 \\
60.9\end{array}$ & $\begin{array}{l}7.92 \\
- \\
- \\
15.3 \\
38.2 \\
- \\
24.4 \\
- \\
2.83 \\
33.7 \\
16.9\end{array}$ & $\begin{array}{l}77.8 \\
79.8 \\
60.6 \\
63.9 \\
46.3 \\
60.0 \\
100 \\
45.4 \\
89.9 \\
62.8 \\
59.3 \\
48.9\end{array}$ & $\begin{array}{l}89.0 \\
79.8 \\
60.6 \\
63.9 \\
67.9 \\
114 \\
100 \\
79.9 \\
89.9 \\
66.8 \\
107 \\
72.8\end{array}$ \\
\hline $\begin{array}{l}\text { EPA8280A } \\
\text { Octachlorodibenzo-p-dioxin }\end{array}$ & $0 / 1$ & 89.0 & - & 89.0 & 89.0 \\
\hline $\begin{array}{l}\text { EPA9014 } \\
\text { Cyanide }\end{array}$ & $0 / 8$ & 96.1 & 5.73 & 88.9 & 107 \\
\hline $\begin{array}{l}\text { EPA9020B } \\
\text { Total organic halogens }\end{array}$ & $0 / 94$ & 99.4 & 4.18 & 90.1 & 108 \\
\hline $\begin{array}{l}\text { EPA9050A } \\
\text { Specific conductance }\end{array}$ & $0 / 12$ & 98.5 & 3.07 & 96.0 & 104 \\
\hline
\end{tabular}




\begin{tabular}{|c|c|c|c|c|c|}
\hline Analyte & $\begin{array}{l}\text { Qualified } \\
\text { Out of Ranget }\end{array}$ & $\begin{array}{l}\text { Mean } \\
\text { Recovery (\%) }\end{array}$ & $\begin{array}{l}\text { Standard } \\
\text { Deviation }\end{array}$ & $\begin{array}{l}\text { Minimum } \\
\text { Recovery (\%) }\end{array}$ & $\begin{array}{l}\text { Maximum } \\
\text { Recovery (\%) }\end{array}$ \\
\hline \multicolumn{6}{|l|}{ EPA9056 } \\
\hline Chloride & $0 / 4$ & 92.3 & 0.97 & 91.5 & 93.5 \\
\hline Sulfate & $0 / 12$ & 94.1 & 1.76 & 91.5 & 96.1 \\
\hline \multicolumn{6}{|l|}{ EPA9060 } \\
\hline Total organic carbon & $0 / 26$ & 100 & 2.89 & 93.0 & 105 \\
\hline \multicolumn{6}{|l|}{ EPA9066 } \\
\hline Phenols & $0 / 10$ & 96.9 & 4.19 & 93.6 & 108 \\
\hline
\end{tabular}

$\dagger$ Number of batches qualified that exhibit poor laboratory control sample and blank spike recovery due to interference compared to the total number of batches containing laboratory control samples and blank spikes.

- Standard deviation cannot be determined.

Note: A value of 0 is reported as 0.0

Table 44. Laboratory Control Sample Recoveries for $M L$

\begin{tabular}{llllll}
\hline Analyte & $\begin{array}{l}\text { Qualified } \\
\text { Out of Ranget }\end{array}$ & $\begin{array}{l}\text { Mean } \\
\text { Recovery (\%) }\end{array}$ & $\begin{array}{l}\text { Standard } \\
\text { Deviation }\end{array}$ & $\begin{array}{l}\text { Minimum } \\
\text { Recovery (\%) }\end{array}$ & $\begin{array}{l}\text { Maximum } \\
\text { Recovery (\%) }\end{array}$ \\
\hline EPA8260B & & & & & \\
Benzene & $0 / 1$ & 104 & - & 104 & 104 \\
Chlorobenzene & $0 / 1$ & 102 & - & 102 & 102 \\
1,1-Dichloroethylene & $0 / 1$ & 92.4 & - & 92.4 & 92.4 \\
Toluene & $0 / 1$ & 101 & - & 101 & 101 \\
Trichloroethylene & $0 / 1$ & 101 & 101 & 101 \\
\hline
\end{tabular}

+ Number of batches qualified that exhibit poor laboratory control sample and blank spike recovery due to interference compared to the total number of batches containing laboratory control samples and blank spikes.

- Standard deviation cannot be determined.

Table 45. Laboratory Control Sample Recoveries for GP

\begin{tabular}{llllll}
\hline Analyte & $\begin{array}{l}\text { Qualified } \\
\text { Out of Ranget }\end{array}$ & $\begin{array}{l}\text { Mean } \\
\text { Recovery (\%) }\end{array}$ & $\begin{array}{l}\text { Standard } \\
\text { Deviation }\end{array}$ & $\begin{array}{l}\text { Minimum } \\
\text { Recovery (\%) }\end{array}$ & $\begin{array}{l}\text { Maximum } \\
\text { Recovery (\%) }\end{array}$ \\
\hline $\begin{array}{l}\text { EPIA-001 } \\
\text { Gross alpha } \\
\text { Nonvolatile beta }\end{array}$ & $0 / 27$ & 98.9 & 7.79 & 83.2 & 118 \\
$\begin{array}{l}\text { EPIA-002 } \\
\text { Tritium }\end{array}$ & $1 / 27$ & 107 & 7.43 & 88.7 & 123 \\
$\begin{array}{l}\text { EPIA-003 } \\
\text { Carbon-14 }\end{array}$ & $1 / 23$ & 98.6 & 6.31 & 77.8 & 110 \\
$\begin{array}{l}\text { EPIA-004 } \\
\text { Strontium-89/90 }\end{array}$ & $1 / 11$ & 97.7 & 8.24 & 76.0 & 105 \\
Strontium-90 & $0 / 4$ & & & & \\
$\begin{array}{l}\text { EPIA-005 } \\
\text { Technetium-99 }\end{array}$ & $3 / 10$ & 94.7 & 9.27 & 85.6 & 105 \\
& $0 / 5$ & 89.8 & 9.56 & 77.2 & 102 \\
\hline
\end{tabular}




\begin{tabular}{|c|c|c|c|c|c|}
\hline Analyte & $\begin{array}{l}\text { Qualified } \\
\text { Out of Ranget }\end{array}$ & $\begin{array}{l}\text { Mean } \\
\text { Recovery (\%) }\end{array}$ & $\begin{array}{l}\text { Standard } \\
\text { Deviation }\end{array}$ & $\begin{array}{l}\text { Minimum } \\
\text { Recovery (\%) }\end{array}$ & $\begin{array}{l}\text { Maximum } \\
\text { Recovery (\%) }\end{array}$ \\
\hline $\begin{array}{l}\text { EPIA-006 } \\
\text { lodine-129 }\end{array}$ & $1 / 7$ & 110 & 8.51 & 99.3 & 125 \\
\hline $\begin{array}{l}\text { EPIA-008 } \\
\text { Radium-226 }\end{array}$ & $0 / 8$ & 98.6 & 8.51 & 89.9 & 111 \\
\hline $\begin{array}{l}\text { EPIA-009 } \\
\text { Radium-228 }\end{array}$ & $3 / 7$ & 100 & 17.4 & 76.8 & 124 \\
\hline $\begin{array}{l}\text { EPIA-010 } \\
\text { Radium, total alpha-emitting }\end{array}$ & $0 / 8$ & 88.5 & 4.43 & 82.4 & 94.8 \\
\hline $\begin{array}{l}\text { EPIA-011 } \\
\text { Americium-241 } \\
\text { Curium-243/244 } \\
\text { Plutonium-239/240 } \\
\text { Uranium-238 }\end{array}$ & $\begin{array}{l}0 / 4 \\
0 / 4 \\
0 / 5 \\
1 / 7\end{array}$ & $\begin{array}{l}104 \\
114 \\
93.1 \\
90.2\end{array}$ & $\begin{array}{l}9.48 \\
6.55 \\
9.86 \\
10.3\end{array}$ & $\begin{array}{l}97.8 \\
104 \\
81.4 \\
75.8\end{array}$ & $\begin{array}{l}118 \\
118 \\
107 \\
104\end{array}$ \\
\hline $\begin{array}{l}\text { EPIA-012 } \\
\text { Thorium-232 }\end{array}$ & $0 / 4$ & 93.7 & 9.66 & 83.6 & 106 \\
\hline $\begin{array}{l}\text { EPIA-013 } \\
\text { Cesium-137 }\end{array}$ & $0 / 8$ & 102 & 4.73 & 97.4 & 111 \\
\hline $\begin{array}{l}\text { EPIA-022 } \\
\text { Nickel-63 } \\
\end{array}$ & $1 / 2$ & 81.9 & 4.17 & 78.9 & 84.8 \\
\hline
\end{tabular}

$\dagger$ Number of batches qualified that exhibit poor laboratory control sample and blank spike recovery due to interference compared to the total number of batches containing laboratory control samples and blank spikes.

Table 46. Laboratory Control Sample Recoveries for TM

\begin{tabular}{|c|c|c|c|c|c|}
\hline Analyte & $\begin{array}{l}\text { Qualified } \\
\text { Out of Ranget }\end{array}$ & $\begin{array}{l}\text { Mean } \\
\text { Recovery (\%) }\end{array}$ & $\begin{array}{l}\text { Standard } \\
\text { Deviation }\end{array}$ & $\begin{array}{l}\text { Minimum } \\
\text { Recovery (\%) }\end{array}$ & $\begin{array}{l}\text { Maximum } \\
\text { Recovery (\%) }\end{array}$ \\
\hline \multicolumn{6}{|l|}{ EICHROMTC1MOD } \\
\hline Technetium-99 & $0 / 1$ & 108 & - & 108 & 108 \\
\hline \multicolumn{6}{|l|}{ EMLSR02MOD } \\
\hline Strontium-90 & $1 / 3$ & 93.7 & 18.0 & 73.0 & 106 \\
\hline \multicolumn{6}{|l|}{ EPA900.0MOD } \\
\hline Gross alpha & $7 / 55$ & 102 & 13.1 & 70.1 & 130 \\
\hline Nonvolatile beta & $1 / 51$ & 97.9 & 9.11 & 65.3 & 119 \\
\hline \multicolumn{6}{|l|}{ EPA901.1MOD } \\
\hline Cesium-137 & $0 / 2$ & 96.8 & 0.27 & 96.6 & 97.0 \\
\hline Cobalt-60 & $0 / 2$ & 95.2 & 0.42 & 94.9 & 95.5 \\
\hline \multicolumn{6}{|l|}{ EPA902.0MOD } \\
\hline lodine-129 & $0 / 1$ & 88.3 & - & 88.3 & 88.3 \\
\hline \multicolumn{6}{|l|}{ EPA903.0MOD } \\
\hline Radium, total alpha-emitting & $0 / 4$ & 105 & 2.58 & 102 & 108 \\
\hline Radium-226 & $0 / 2$ & 97.8 & 5.44 & 93.9 & 102 \\
\hline
\end{tabular}




\begin{tabular}{|c|c|c|c|c|c|}
\hline Analyte & $\begin{array}{l}\text { Qualified } \\
\text { Out of Ranget }\end{array}$ & $\begin{array}{l}\text { Mean } \\
\text { Recovery (\%) }\end{array}$ & $\begin{array}{l}\text { Standard } \\
\text { Deviation }\end{array}$ & $\begin{array}{l}\text { Minimum } \\
\text { Recovery (\%) }\end{array}$ & $\begin{array}{l}\text { Maximum } \\
\text { Recovery (\%) }\end{array}$ \\
\hline \multicolumn{6}{|l|}{ EPA904.0MOD } \\
\hline Radium-228 & $0 / 2$ & 92.6 & 0.54 & 92.2 & 93.0 \\
\hline \multicolumn{6}{|l|}{ EPA906.0MOD } \\
\hline Tritium & $2 / 57$ & 96.6 & 8.36 & 80.8 & 123 \\
\hline
\end{tabular}

$\dagger$ Number of batches qualified that exhibit poor laboratory control sample and blank spike recovery due to interference compared to the total number of batches containing laboratory control samples and blank spikes.

- Standard deviation cannot be determined.

Table 47. Surrogate Recoveries for EX

\begin{tabular}{llllll}
\hline Analyte & $\begin{array}{l}\text { Qualified } \\
\text { Out of Ranget }\end{array}$ & $\begin{array}{l}\text { Mean } \\
\text { Recovery (\%) }\end{array}$ & $\begin{array}{l}\text { Standard } \\
\text { Deviation }\end{array}$ & $\begin{array}{l}\text { Minimum } \\
\text { Recovery (\%) }\end{array}$ & $\begin{array}{l}\text { Maximum } \\
\text { Recovery (\%) }\end{array}$ \\
\hline $\begin{array}{l}\text { EPA8021B } \\
\text { p-Bromofluorobenzene }\end{array}$ & $57 / 126$ & 113 & & & \\
& & 11.9 & 82.0 & 135 \\
EPA8081A & & & & \\
Decachlorobiphenyl & $0 / 3$ & 104 & 3.21 & 100 & 106 \\
Tetrachloro-m-xylene & $0 / 3$ & 59.3 & 11.0 & 47.0 & 68.0 \\
EPA8082 & & & & \\
Decachlorobiphenyl & $0 / 3$ & 102 & 2.52 & 100 & 105 \\
Tetrachloro-m-xylene & $0 / 3$ & 62.3 & 6.03 & 56.0 & 68.0 \\
& & & & & \\
EPA8260B & & & & & \\
p-Bromofluorobenzene & $6 / 203$ & 98.5 & 6.07 & 80.0 & 123 \\
1,2-Dichloroethane-d4 & $4 / 203$ & 93.7 & 8.11 & 71.0 & 119 \\
Toluene-d8 & $27 / 203$ & 101 & 8.07 & 81.0 & 129 \\
EPA8270C & & & & & \\
2-Fluorobiphenyl & $0 / 3$ & 82.0 & 6.93 & 74.0 & 86.0 \\
2-Fluorophenol & $0 / 3$ & 79.0 & 6.24 & 74.0 & 86.0 \\
Nitrobenzene-d5 & $0 / 3$ & 78.7 & 12.7 & 65.0 & 90.0 \\
Phenol-d5 & $0 / 3$ & 80.0 & 5.57 & 75.0 & 86.0 \\
p-Terphenyl-d14 & $0 / 3$ & 83.0 & 4.36 & 78.0 & 86.0 \\
2.4,6-Tribromophenol (surr) & $0 / 3$ & 111 & 16.7 & 92.0 & 121 \\
\hline
\end{tabular}

$\dagger$ Number of batches qualified that exhibit poor surrogate recovery due to interference compared to the total number of batches containing surrogates.

Table 48. Surrogate Recoveries for GE

\begin{tabular}{llllll}
\hline Analyte & $\begin{array}{l}\text { Qualified } \\
\text { Out of Ranget }\end{array}$ & $\begin{array}{l}\text { Mean } \\
\text { Recovery (\%) }\end{array}$ & $\begin{array}{l}\text { Standard } \\
\text { Deviation }\end{array}$ & $\begin{array}{l}\text { Minimum } \\
\text { Recovery (\%) }\end{array}$ & $\begin{array}{l}\text { Maximum } \\
\text { Recovery (\%) }\end{array}$ \\
\hline EPA8081A & & & & & \\
Decachlorobiphenyl & $0 / 31$ & 81.4 & 18.2 & 44.4 & 116 \\
Dibutylchlorendate & $0 / 1$ & 95.6 & -13.1 & 95.6 & 95.6 \\
Tetrachloro-m-xylene & $0 / 32$ & 87.8 & 63.8 & 121
\end{tabular}




\begin{tabular}{|c|c|c|c|c|c|}
\hline Analyte & $\begin{array}{l}\text { Qualified } \\
\text { Out of Ranget }\end{array}$ & $\begin{array}{l}\text { Mean } \\
\text { Recovery (\%) }\end{array}$ & $\begin{array}{l}\text { Standard } \\
\text { Deviation }\end{array}$ & $\begin{array}{l}\text { Minimum } \\
\text { Recovery (\%) }\end{array}$ & $\begin{array}{l}\text { Maximum } \\
\text { Recovery (\%) }\end{array}$ \\
\hline \multicolumn{6}{|l|}{ EPA8082 } \\
\hline Decachlorobiphenyl & $0 / 31$ & 64.0 & 13.4 & 41.4 & 85.5 \\
\hline Tetrachloro-m-xylene & $0 / 36$ & 60.6 & 12.4 & 33.0 & 82.5 \\
\hline \multicolumn{6}{|l|}{ EPA8260B } \\
\hline p-Bromofluorobenzene & $21 / 108$ & 90.9 & 5.15 & 78.7 & 103 \\
\hline Dibromofluoromethane & $14 / 108$ & 90.8 & 5.46 & 76.6 & 103 \\
\hline Toluene-d8 & $24 / 108$ & 93.7 & 8.69 & 78.7 & 113 \\
\hline \multicolumn{6}{|l|}{ EPA8270C } \\
\hline 2-Fluorobiphenyl & $2 / 77$ & 61.0 & 11.7 & 19.7 & 81.6 \\
\hline 2-Fluorophenol & $0 / 43$ & 41.6 & 6.58 & 26.8 & 55.9 \\
\hline Nitrobenzene-d5 & $2 \longdiv { 7 7 }$ & 59.4 & 12.5 & 18.4 & 88.2 \\
\hline Phenol-d6 & $0 / 43$ & 29.5 & 5.94 & 17.7 & 45.9 \\
\hline p-Terphenyl-d14 & $2 / 77$ & 78.4 & 15.3 & 23.8 & 105 \\
\hline 2,4,6-Tribromophenol (surr) & $0 / 43$ & 70.2 & 11.6 & 49.4 & 98.6 \\
\hline
\end{tabular}

$\dagger \quad$ Number of batches qualified that exhibit poor surrogate recovery due to interference compared to the total number of batches containing surrogates.

- Standard deviation cannot be determined.

Table 49. Surrogate Recoveries for WA

\begin{tabular}{|c|c|c|c|c|c|}
\hline Analyte & $\begin{array}{l}\text { Qualified } \\
\text { Out of Ranget }\end{array}$ & $\begin{array}{l}\text { Mean } \\
\text { Recovery (\%) }\end{array}$ & $\begin{array}{l}\text { Standard } \\
\text { Deviation }\end{array}$ & $\begin{array}{l}\text { Minimum } \\
\text { Recovery (\%) }\end{array}$ & $\begin{array}{l}\text { Maximum } \\
\text { Recovery (\%) }\end{array}$ \\
\hline \multicolumn{6}{|l|}{ EPA8021B } \\
\hline Bromochloromethane & $0 / 90$ & 104 & 12.5 & 70.4 & 124 \\
\hline \multicolumn{6}{|l|}{ EPA8081A } \\
\hline $\begin{array}{l}\text { Decachlorobiphenyl } \\
\text { Tetrachloro-m-xylene }\end{array}$ & $\begin{array}{l}0 / 19 \\
0 / 20\end{array}$ & $\begin{array}{l}93.5 \\
58.9\end{array}$ & $\begin{array}{l}7.04 \\
15.3\end{array}$ & $\begin{array}{l}79.0 \\
35.0\end{array}$ & $\begin{array}{l}104 \\
95.0\end{array}$ \\
\hline \multicolumn{6}{|l|}{ EPA8082 } \\
\hline $\begin{array}{l}\text { Decachlorobiphenyl } \\
\text { Tetrachloro-m-xylene }\end{array}$ & $\begin{array}{l}0 / 19 \\
2 / 19\end{array}$ & $\begin{array}{l}91.9 \\
48.6\end{array}$ & $\begin{array}{l}4.06 \\
16.0\end{array}$ & $\begin{array}{l}85.0 \\
20.0\end{array}$ & $\begin{array}{l}100 \\
75.0\end{array}$ \\
\hline \multicolumn{6}{|l|}{ EPA8151A } \\
\hline 2,4-Dichlorophenylacetic acid & $0 / 1$ & 89.8 & 一 & 89.8 & 89.8 \\
\hline \multicolumn{6}{|l|}{ EPA8260B } \\
\hline $\begin{array}{l}\text { p-Bromofluorobenzene } \\
\text { 1,2-Dichloroethane-d4 } \\
\text { Toluene-d8 }\end{array}$ & $\begin{array}{l}0 / 217 \\
2 / 217 \\
1 / 217\end{array}$ & $\begin{array}{l}96.2 \\
95.6 \\
99.6\end{array}$ & $\begin{array}{l}3.92 \\
7.38 \\
3.17\end{array}$ & $\begin{array}{l}88.0 \\
78.0 \\
91.0\end{array}$ & $\begin{array}{l}112 \\
120 \\
113\end{array}$ \\
\hline \multicolumn{6}{|l|}{ EPA8270C } \\
\hline 2-Fluorobiphenyl & $0 / 25$ & 73.5 & 10.3 & 52.3 & 104 \\
\hline 2-Fluorophenol & $0 / 9$ & 65.2 & 7.27 & 54.0 & 76.9 \\
\hline Nitrobenzene-d5 & $0 / 25$ & 74.7 & 7.21 & 59.0 & 89.2 \\
\hline Phenol-d5 & $0 / 9$ & 52.9 & 23.4 & 19.1 & 81.8 \\
\hline p-Terphenyl-d14 & $0 / 25$ & 81.7 & 12.3 & 40.7 & 104 \\
\hline 2,4,6-Tribromophenol (surr) & $0 / 9$ & 83.3 & 21.8 & 51.8 & 111 \\
\hline
\end{tabular}




\begin{tabular}{llllll}
\hline Analyte & $\begin{array}{l}\text { Qualified } \\
\text { Out of Ranget }\end{array}$ & $\begin{array}{l}\text { Mean } \\
\text { Recovery (\%) }\end{array}$ & $\begin{array}{l}\text { Standard } \\
\text { Deviation }\end{array}$ & $\begin{array}{l}\text { Minimum } \\
\text { Recovery (\%) }\end{array}$ & $\begin{array}{l}\text { Maximum } \\
\text { Recovery (\%) }\end{array}$ \\
\hline $\begin{array}{l}\text { EPAB280A } \\
\text { Carbon 13-labeled OCDD }\end{array}$ & $0 / 11$ & 85.9 & 7.87 & 75.0 & 100 \\
\hline
\end{tabular}

$\dagger$ Number of batches qualified that exhibit poor surrogate recovery due to interference compared to the total number of batches containing surrogates.

- Standard deviation cannot be determined.

Table 50. Surrogate Recoveries for ML

\begin{tabular}{llllll}
\hline Analyte & $\begin{array}{l}\text { Qualified } \\
\text { Out of Ranget }\end{array}$ & $\begin{array}{l}\text { Mean } \\
\text { Recovery (\%) }\end{array}$ & $\begin{array}{l}\text { Standard } \\
\text { Deviation }\end{array}$ & $\begin{array}{l}\text { Minimum } \\
\text { Recovery (\%) }\end{array}$ & $\begin{array}{l}\text { Maximum } \\
\text { Recovery (\%) }\end{array}$ \\
\hline & & & & & \\
EPA8260B & & & & & \\
p-Bromofluorobenzene & $0 / 6$ & 106 & 0.98 & 105 & 107 \\
Dibromofluoromethane & $0 / 6$ & 104 & 1.03 & 103 & 106 \\
Toluene-d8 & $0 / 6$ & 110 & 0.0 & 110 & 110 \\
\hline
\end{tabular}

+ Number of batches qualified that exhibit poor surrogate recovery due to interference compared to the total number of batches containing surrogates.

Note: A value of 0 is reported as 0.0 .

Table 51. Matrix Spike Recoveries for EX

\begin{tabular}{|c|c|c|c|c|c|c|}
\hline Analyte & $\begin{array}{l}\text { Qualified } \\
\text { Out of Ranget }\end{array}$ & $\begin{array}{l}\text { Mean } \\
\text { Recovery (\%) }\end{array}$ & $\begin{array}{l}\text { Standard } \\
\text { Deviation }\end{array}$ & Bias (\%) & $\begin{array}{l}\text { Minimum } \\
\text { Recovery (\%) }\end{array}$ & $\begin{array}{l}\text { Maximum } \\
\text { Recovery (\%) }\end{array}$ \\
\hline \multicolumn{7}{|l|}{ EPA300.0 } \\
\hline Chloride & $0 / 1$ & 115 & - & 15.0 & 115 & 115 \\
\hline Nitrate as nitrogen & $0 / 6$ & 112 & 4.0 & 12.0 & 106 & 117 \\
\hline Nitrate-nitrite as nitrogen & $0 / 1$ & 104 & - & 4.0 & 104 & 104 \\
\hline Sulfate & $0 / 1$ & 80.0 & - & -20.0 & 80.0 & 80.0 \\
\hline \multicolumn{7}{|l|}{ EPA410.4 } \\
\hline Chemical oxygen demand & $0 / 1$ & 118 & - & 18.0 & 118 & 118 \\
\hline \multicolumn{7}{|l|}{ EPA6010B } \\
\hline Aluminum & $0 / 22$ & 106 & 3.37 & 6.0 & 102 & 112 \\
\hline Antimony & $0 / 2$ & 105 & 1.41 & 5.0 & 104 & 106 \\
\hline Arsenic & $0 / 8$ & 106 & 2.56 & 6.0 & 102 & 109 \\
\hline Barium & $0 / 12$ & 105 & 2.68 & 5.0 & 100 & 109 \\
\hline Beryllium & $0 / 2$ & 107 & 0.71 & 7.0 & 106 & 107 \\
\hline Boron & $0 / 12$ & 107 & 5.15 & 7.0 & 100 & 117 \\
\hline Cadmium & $0 / 8$ & 106 & 3.06 & 6.0 & 103 & 111 \\
\hline Calcium & $0 / 2$ & 107 & 0.71 & 7.0 & 106 & 107 \\
\hline Chromium & $0 / 8$ & 108 & 3.91 & 8.0 & 104 & 114 \\
\hline Cobalt & $0 / 2$ & 110 & 0.71 & 10.0 & 109 & 110 \\
\hline Copper & $0 / 2$ & 104 & 0.71 & 4.0 & 103 & 104 \\
\hline Iron & $0 / 22$ & 106 & 6.68 & 6.0 & 81.0 & 114 \\
\hline Lead & $0 / 22$ & 99.7 & 5.23 & -0.30 & 91.0 & 112 \\
\hline Magnesium & $0 / 2$ & 109 & 0.71 & 9.0 & 108 & 109 \\
\hline Manganese & $0 / 16$ & 105 & 2.25 & 5.0 & 101 & 109 \\
\hline Nickel & $0 / 2$ & 105 & 0.71 & 5.0 & 104 & 105 \\
\hline Potassium & $0 / 2$ & 111 & 0.71 & 11.0 & 110 & 111 \\
\hline
\end{tabular}




\begin{tabular}{|c|c|c|c|c|c|c|}
\hline Analyte & $\begin{array}{l}\text { Qualified } \\
\text { Out of Ranget }\end{array}$ & $\begin{array}{l}\text { Mean } \\
\text { Recovery (\%) }\end{array}$ & $\begin{array}{l}\text { Standard } \\
\text { Deviation }\end{array}$ & Bias (\%) & $\begin{array}{l}\text { Minimum } \\
\text { Recovery (\%) }\end{array}$ & $\begin{array}{l}\text { Maximum } \\
\text { Recovery (\%) }\end{array}$ \\
\hline Selenium & $0 / 8$ & 110 & 3.16 & 10.0 & 106 & 114 \\
\hline Silver & $0 / 8$ & 109 & 2.88 & 9.0 & 105 & 113 \\
\hline Sodium & $0 / 2$ & 105 & 0.0 & 5.0 & 105 & 105 \\
\hline Thallium & $0 / 4$ & 106 & 3.11 & 6.0 & 103 & 110 \\
\hline Vanadium & $0 / 2$ & 104 & 0.71 & 4.0 & 103 & 104 \\
\hline Zinc & $0 / 2$ & 105 & 0.71 & 5.0 & 104 & 105 \\
\hline \multicolumn{7}{|l|}{ EPA7470A } \\
\hline Mercury & $0 / 16$ & 102 & 9.33 & 2.0 & 78.0 & 115 \\
\hline \multicolumn{7}{|l|}{ EPAB021B } \\
\hline Carbon tetrachloride & $0 / 16$ & 103 & 10.6 & 3.0 & 82.0 & 115 \\
\hline Chloroform & $0 / 16$ & 107 & 11.2 & 7.0 & 86.0 & 124 \\
\hline cis-1,2-Dichloroethylene & $0 / 16$ & 108 & 8.90 & 8.0 & 89.0 & 118 \\
\hline Tetrachloroethylene & $0 / 16$ & 109 & 13.5 & 9.0 & 82.0 & 129 \\
\hline 1,1,1-Trichloroethane & $0 / 16$ & 104 & 10.6 & 4.0 & 83.0 & 115 \\
\hline Trichloroethylene & $0 / 16$ & 90.8 & 21.7 & -9.20 & 53.0 & 124 \\
\hline \multicolumn{7}{|l|}{ EPA8260B } \\
\hline Benzene & $0 / 18$ & 104 & 7.86 & 4.0 & 89.0 & 113 \\
\hline Chlorobenzene & $0 / 18$ & 97.9 & 7.10 & -2.10 & 88.0 & 113 \\
\hline 1,1-Dichloroethylene & $0 / 18$ & 100 & 12.4 & 0.0 & 81.0 & 117 \\
\hline Toluene & $0 / 18$ & 101 & 7.63 & 1.0 & 87.0 & 115 \\
\hline Trichloroethylene & $0 / 18$ & 101 & 9.55 & 1.0 & 87.0 & 116 \\
\hline \multicolumn{7}{|l|}{ EPA9014 } \\
\hline Cyanide & $0 / 4$ & 99.0 & 2.31 & -1.0 & 97.0 & 101 \\
\hline \multicolumn{7}{|l|}{ EPA9060 } \\
\hline Total organic carbon & $0 / 2$ & 101 & 1.41 & 1.0 & 100 & 102 \\
\hline
\end{tabular}

$\dagger$ Number of batches qualified that exhibit poor spike recovery due to interference compared to the total number of batches containing spikes.

- Standard deviation cannot be determined.

Note: $A$ value of 0 is reported as 0.0 .

Table 52. Matrix Spike Recoveries for GE

\begin{tabular}{|c|c|c|c|c|c|c|}
\hline Analyte & $\begin{array}{l}\text { Qualified } \\
\text { Out of Ranget }\end{array}$ & $\begin{array}{l}\text { Mean } \\
\text { Recovery (\%) }\end{array}$ & $\begin{array}{l}\text { Standard } \\
\text { Deviation }\end{array}$ & Bias (\%) & $\begin{array}{l}\text { Minimum } \\
\text { Recovery (\%) }\end{array}$ & $\begin{array}{l}\text { Maximum } \\
\text { Recovery (\%) }\end{array}$ \\
\hline \multicolumn{7}{|l|}{ EPA300.0 } \\
\hline Chloride & $0 / 2$ & 91.4 & 0.85 & -8.60 & 90.8 & 92.0 \\
\hline Sulfate & $0 / 4$ & 101 & 7.28 & 1.0 & 93.3 & 109 \\
\hline \multicolumn{7}{|l|}{ EPA310.1 } \\
\hline Alkalinity (as $\mathrm{CaCO}_{3}$ ) & $0 / 2$ & 98.4 & 7.92 & -1.60 & 92.8 & 104 \\
\hline \multicolumn{7}{|l|}{ EPA353.1 } \\
\hline Nitrate-nitrite as nitrogen & $0 / 31$ & 105 & 6.17 & 5.0 & 94.0 & 117 \\
\hline \multicolumn{7}{|l|}{ EPA6010B } \\
\hline Aluminum & $0 / 10$ & 99.3 & 5.46 & -0.70 & 92.7 & 110 \\
\hline Antimony & $0 / 4$ & 102 & 3.85 & 2.0 & 98.4 & 106 \\
\hline Arsenic & $0 / 6$ & 97.7 & 8.40 & -2.30 & 89.7 & 108 \\
\hline Barium & $0 / 4$ & 96.5 & 3.54 & -3.50 & 93.0 & 99.7 \\
\hline
\end{tabular}




\begin{tabular}{|c|c|c|c|c|c|c|}
\hline Analyte & $\begin{array}{l}\text { Qualified } \\
\text { Out of Ranget }\end{array}$ & $\begin{array}{l}\text { Mean } \\
\text { Recovery (\%) }\end{array}$ & $\begin{array}{l}\text { Standard } \\
\text { Deviation }\end{array}$ & Bias (\%) & $\begin{array}{l}\text { Minimum } \\
\text { Recovery (\%) }\end{array}$ & $\begin{array}{l}\text { Maximum } \\
\text { Recovery (\%) }\end{array}$ \\
\hline $\begin{array}{l}\text { Beryllium } \\
\text { Cadmium } \\
\text { Calcium } \\
\text { Chromium } \\
\text { Cobalt } \\
\text { Copper } \\
\text { Iron } \\
\text { Lead } \\
\text { Magnesium } \\
\text { Manganese } \\
\text { Nickel } \\
\text { Potassium } \\
\text { Selenium } \\
\text { Silver } \\
\text { Sodium } \\
\text { Thallium } \\
\text { Vanadium } \\
\text { Zinc }\end{array}$ & $\begin{array}{l}0 / 8 \\
0 / 4 \\
0 / 4 \\
0 / 10 \\
0 / 4 \\
0 / 4 \\
0 / 10 \\
0 / 4 \\
0 / 4 \\
0 / 6 \\
0 / 4 \\
0 / 4 \\
0 / 4 \\
0 / 4 \\
0 / 4 \\
0 / 4 \\
0 / 4 \\
0 / 6\end{array}$ & $\begin{array}{l}102 \\
101 \\
102 \\
99.5 \\
101 \\
96.4 \\
112 \\
102 \\
102 \\
97.2 \\
102 . \\
95.5 \\
100 \\
102 \\
98.7 \\
100 \\
99.0 \\
101\end{array}$ & $\begin{array}{l}6.20 \\
8.94 \\
2.98 \\
6.86 \\
9.24 \\
5.66 \\
25.5 \\
8.73 \\
3.68 \\
8.24 \\
10.5 \\
2.61 \\
8.38 \\
3.65 \\
3.84 \\
7.07 \\
6.15 \\
4.86\end{array}$ & $\begin{array}{l}2.0 \\
1.0 \\
2.0 \\
-0.50 \\
1.0 \\
-3.60 \\
12.0 \\
2.0 \\
2.0 \\
-2.80 \\
2.0 \\
-4.50 \\
0.0 \\
2.0 \\
-1.30 \\
0.0 \\
-1.0 \\
1.0\end{array}$ & $\begin{array}{l}91.2 \\
91.4 \\
98.9 \\
89.3 \\
90.4 \\
89.4 \\
94.2 \\
92.1 \\
98.3 \\
90.7 \\
90.1 \\
92.2 \\
90.3 \\
98.8 \\
94.8 \\
91.6 \\
91.4 \\
95.4\end{array}$ & $\begin{array}{l}109 \\
109 \\
105 \\
107 \\
109 \\
101 \\
161 \\
110 \\
105 \\
108 \\
111 \\
97.8 \\
107 \\
106 \\
102 \\
107 \\
104 \\
106\end{array}$ \\
\hline $\begin{array}{l}\text { EPA6020 } \\
\text { Aluminum } \\
\text { Antimony } \\
\text { Arsenic } \\
\text { Barium } \\
\text { Beryllium } \\
\text { Boron } \\
\text { Cadmium } \\
\text { Calcium } \\
\text { Chromium } \\
\text { Cobalt } \\
\text { Copper } \\
\text { Iron } \\
\text { Lead } \\
\text { Lithium } \\
\text { Magnesium } \\
\text { Manganese } \\
\text { Molybdenum } \\
\text { Nickel } \\
\text { Potassium } \\
\text { Selenium } \\
\text { Silver } \\
\text { Sodium } \\
\text { Strontium } \\
\text { Thallium } \\
\text { Tin } \\
\text { Titanium } \\
\text { Uranium } \\
\text { Vanadium } \\
\text { Zinc }\end{array}$ & $\begin{array}{l}0 / 30 \\
0 / 6 \\
0 / 6 \\
0 / 6 \\
0 / 4 \\
0 / 2 \\
0 / 2 \\
0 / 2 \\
0 / 6 \\
0 / 6 \\
0 / 6 \\
0 / 2 \\
0 / 28 \\
0 / 2 \\
0 / 4 \\
0 / 4 \\
0 / 2 \\
0 / 6 \\
0 / 4 \\
0 / 6 \\
0 / 6 \\
0 / 4 \\
0 / 2 \\
0 / 6 \\
0 / 2 \\
0 / 2 \\
0 / 2 \\
0 / 6\end{array}$ & $\begin{array}{l}-340 \\
107 \\
95.0 \\
114 \\
96.3 \\
111 \\
94.2 \\
133 \\
99.0 \\
98.1 \\
96.4 \\
99.4 \\
100 \\
99.5 \\
-692 \\
120 \\
107 \\
95.5 \\
85.8 \\
95.8 \\
105 \\
88.6 \\
95.2 \\
96.1 \\
107 \\
102 \\
117 \\
100 \\
-86.2\end{array}$ & $\begin{array}{l}1,600 \\
5.49 \\
7.42 \\
15.2 \\
10.4 \\
1.41 \\
28.4 \\
43.8 \\
4.86 \\
5.31 \\
3.61 \\
21.0 \\
4.13 \\
2.19 \\
914 \\
20.0 \\
0.71 \\
5.15 \\
14.8 \\
2.28 \\
4.13 \\
9.60 \\
3.25 \\
4.63 \\
2.12 \\
0.71 \\
4.95 \\
5.47 \\
285\end{array}$ & $\begin{array}{c}-440 \\
7.0 \\
-5.0 \\
14.0 \\
-3.70 \\
11.0 \\
-5.80 \\
33.0 \\
-1.0 \\
-1.90 \\
-3.60 \\
-0.60 \\
0.0 \\
-0.50 \\
-792 \\
20.0 \\
7.0 \\
-4.50 \\
-14.2 \\
-4.20 \\
5.0 \\
-11.4 \\
-4.80 \\
-3.90 \\
7.0 \\
2.0 \\
17.0 \\
0.0 \\
-186\end{array}$ & $\begin{array}{l}-7,580 \\
99.4 \\
86.0 \\
97.7 \\
84.6 \\
110 \\
-5.61 \\
102 \\
91.9 \\
90.9 \\
91.1 \\
50.3 \\
90.0 \\
97.9 \\
-1,750 \\
92.0 \\
106 \\
86.8 \\
69.8 \\
93.3 \\
101 \\
79.1 \\
92.9 \\
89.9 \\
105 \\
101 \\
113 \\
93.1 \\
-466\end{array}$ & $\begin{array}{l}210 \\
113 \\
105 \\
133 \\
106 \\
112 \\
109 \\
164 \\
104 \\
105 \\
102 \\
150 \\
110 \\
101 \\
87.0 \\
139 \\
107 \\
101 \\
98.8 \\
99.8 \\
110 \\
101 \\
97.5 \\
101 \\
108 \\
102 \\
120 \\
106 \\
101\end{array}$ \\
\hline $\begin{array}{l}\text { EPA7196A } \\
\text { Chromium, hexavalent }\end{array}$ & $0 / 3$ & 100 & 7.0 & 0.0 & 95.0 & 108 \\
\hline $\begin{array}{l}\text { EPA7470A } \\
\text { Mercury }\end{array}$ & $0 / 34$ & $\dot{99.9}$ & 6.35 & -0.10 & 85.5 & 116 \\
\hline $\begin{array}{l}\text { EPA8081A } \\
\text { Aldrin } \\
\text { p,p'-DDT } \\
\text { Dieldrin } \\
\text { Endrin }\end{array}$ & $\begin{array}{l}0 / 8 \\
0 / 8 \\
0 / 8 \\
0 / 8\end{array}$ & $\begin{array}{l}91.0 \\
96.2 \\
91.8 \\
107\end{array}$ & $\begin{array}{l}8.74 \\
12.0 \\
12.4 \\
15.5\end{array}$ & $\begin{array}{l}-9.0 \\
-3.80 \\
-8.20 \\
7.0\end{array}$ & $\begin{array}{l}80.7 \\
70.1 \\
79.7 \\
77.2\end{array}$ & $\begin{array}{l}107 \\
110 \\
114 \\
128\end{array}$ \\
\hline
\end{tabular}




\begin{tabular}{|c|c|c|c|c|c|c|}
\hline Analyte & $\begin{array}{l}\text { Qualified } \\
\text { Out of Ranget }\end{array}$ & $\begin{array}{l}\text { Mean } \\
\text { Recovery (\%) }\end{array}$ & $\begin{array}{l}\text { Standard } \\
\text { Deviation }\end{array}$ & Bias (\%) & $\begin{array}{l}\text { Minimum } \\
\text { Recovery (\%) }\end{array}$ & $\begin{array}{l}\text { Maximum } \\
\text { Recovery (\%) }\end{array}$ \\
\hline $\begin{array}{l}\text { Heptachlor } \\
\text { Lindane }\end{array}$ & $\begin{array}{l}0 / 8 \\
0 / 8\end{array}$ & $\begin{array}{l}109 \\
97.5\end{array}$ & $\begin{array}{l}10.4 \\
12.4\end{array}$ & $\begin{array}{l}9.0 \\
-2.50\end{array}$ & $\begin{array}{l}96.3 \\
81.4\end{array}$ & $\begin{array}{l}127 \\
118\end{array}$ \\
\hline $\begin{array}{l}\text { EPA8082 } \\
\text { PCB } 1260\end{array}$ & $0 / 10$ & 72.5 & 4.40 & -27.5 & 65.0 & 77.0 \\
\hline $\begin{array}{l}\text { EPA8260B } \\
\text { Benzene } \\
\text { Chlorobenzene } \\
\text { 1,1-Dichloroethylene } \\
\text { Toluene } \\
\text { Trichloroethylene }\end{array}$ & $\begin{array}{l}0 / 12 \\
0 / 12 \\
0 / 12 \\
0 / 12 \\
0 / 14\end{array}$ & $\begin{array}{l}98.0 \\
95.4 \\
105 \\
93.6 \\
97.5\end{array}$ & $\begin{array}{l}9.57 \\
6.45 \\
12.7 \\
8.39 \\
14.3\end{array}$ & $\begin{array}{c}-2.0 \\
-4.60 \\
5.0 \\
-6.40 \\
-2.50\end{array}$ & $\begin{array}{l}82.9 \\
80.3 \\
85.8 \\
75.6 \\
80.2\end{array}$ & $\begin{array}{l}117 \\
104 \\
130 \\
106 \\
129\end{array}$ \\
\hline $\begin{array}{l}\text { EPA8270C } \\
\text { Acenaphthene } \\
\text { 4-Chloro-m-cresol } \\
\text { 2-Chlorophenol } \\
\text { 1,4-Dichlorobenzene } \\
\text { 2,4-Dinitrotoluene } \\
\text { 4-Nitrophenol } \\
\text { N-Nitrosodipropylamine } \\
\text { Pentachlorophenol } \\
\text { Phenol } \\
\text { Pyrene } \\
\text { 1,2,4-Trichlorobenzene }\end{array}$ & $\begin{array}{l}0 / 12 \\
0 / 10 \\
0 / 10 \\
0 / 12 \\
0 / 12 \\
0 / 10 \\
0 / 12 \\
0 / 10 \\
0 / 10 \\
0 / 12 \\
0 / 12\end{array}$ & $\begin{array}{l}54.7 \\
59.4 \\
51.5 \\
46.4 \\
62.7 \\
39.2 \\
52.7 \\
70.7 \\
31.8 \\
76.3 \\
49.3\end{array}$ & $\begin{array}{l}6.78 \\
8.11 \\
6.57 \\
7.40 \\
10.5 \\
7.49 \\
10.2 \\
13.1 \\
5.13 \\
11.2 \\
8.15\end{array}$ & $\begin{array}{l}-45.3 \\
-40.6 \\
-48.5 \\
-53.6 \\
-37.3 \\
-60.8 \\
-47.3 \\
-29.3 \\
-68.2 \\
-23.7 \\
-50.7\end{array}$ & $\begin{array}{l}45.6 \\
49.1 \\
44.4 \\
37.4 \\
43.9 \\
26.8 \\
43.2 \\
46.2 \\
25.5 \\
60.4 \\
39.1\end{array}$ & $\begin{array}{l}65.3 \\
68.5 \\
61.7 \\
56.6 \\
74.8 \\
50.5 \\
70.5 \\
90.4 \\
39.0 \\
89.8 \\
59.8\end{array}$ \\
\hline $\begin{array}{l}\text { EPA9012A } \\
\text { Cyanide }\end{array}$ & $0 / 7$ & 88.1 & 3.64 & -11.9 & 82.3 & 94.7 \\
\hline $\begin{array}{l}\text { EPA9020B } \\
\text { Total organic halogens }\end{array}$ & $0 / 3$ & 106 & 2.08 & 6.0 & 104 & 108 \\
\hline $\begin{array}{l}\text { EPA9060 } \\
\text { Total organic carbon }\end{array}$ & $0 / 2$ & 96.2 & 13.9 & -3.80 & 86.3 & 106 \\
\hline $\begin{array}{l}\text { EPA9066 } \\
\text { Phenols } \\
\end{array}$ & $0 / 4$ & 98.0 & 3.75 & -2.0 & 95.1 & 103 \\
\hline
\end{tabular}

+ Number of batches qualified that exhibit poor spike recovery due to interference compared to the total number of batches containing spikes.

Note: $A$ value of 0 is reported as 0.0 .

Table 53. Matrix Spike Recoveries for WA

\begin{tabular}{|c|c|c|c|c|c|c|}
\hline Analyte & $\begin{array}{l}\text { Qualified } \\
\text { Out of Ranget }\end{array}$ & $\begin{array}{l}\text { Mean } \\
\text { Recovery (\%) }\end{array}$ & $\begin{array}{l}\text { Standard } \\
\text { Deviation }\end{array}$ & Bias (\%) & $\begin{array}{l}\text { Minimum } \\
\text { Recovery (\%) }\end{array}$ & $\begin{array}{l}\text { Maximum } \\
\text { Recovery (\%) }\end{array}$ \\
\hline \multicolumn{7}{|l|}{ EPA310.1 } \\
\hline Alkalinity $\left(\mathrm{as} \mathrm{CaCO}_{3}\right.$ ) & $0 / 5$ & 103 & 1.95 & 3.0 & 102 & 106 \\
\hline \multicolumn{7}{|l|}{ EPA340.2 } \\
\hline Fluoride & $0 / 2$ & 89.9 & 3.54 & -10.1 & 87.4 & 92.4 \\
\hline \multicolumn{7}{|l|}{ EPA353.2 } \\
\hline Nitrate as nitrogen & $0 / 2$ & 96.4 & 6.51 & -3.60 & 91.8 & 101 \\
\hline Nitrate-nitrite as nitrogen & $0 / 5$ & 99.7 & 5.02 & -0.30 & 94.7 & 106 \\
\hline
\end{tabular}




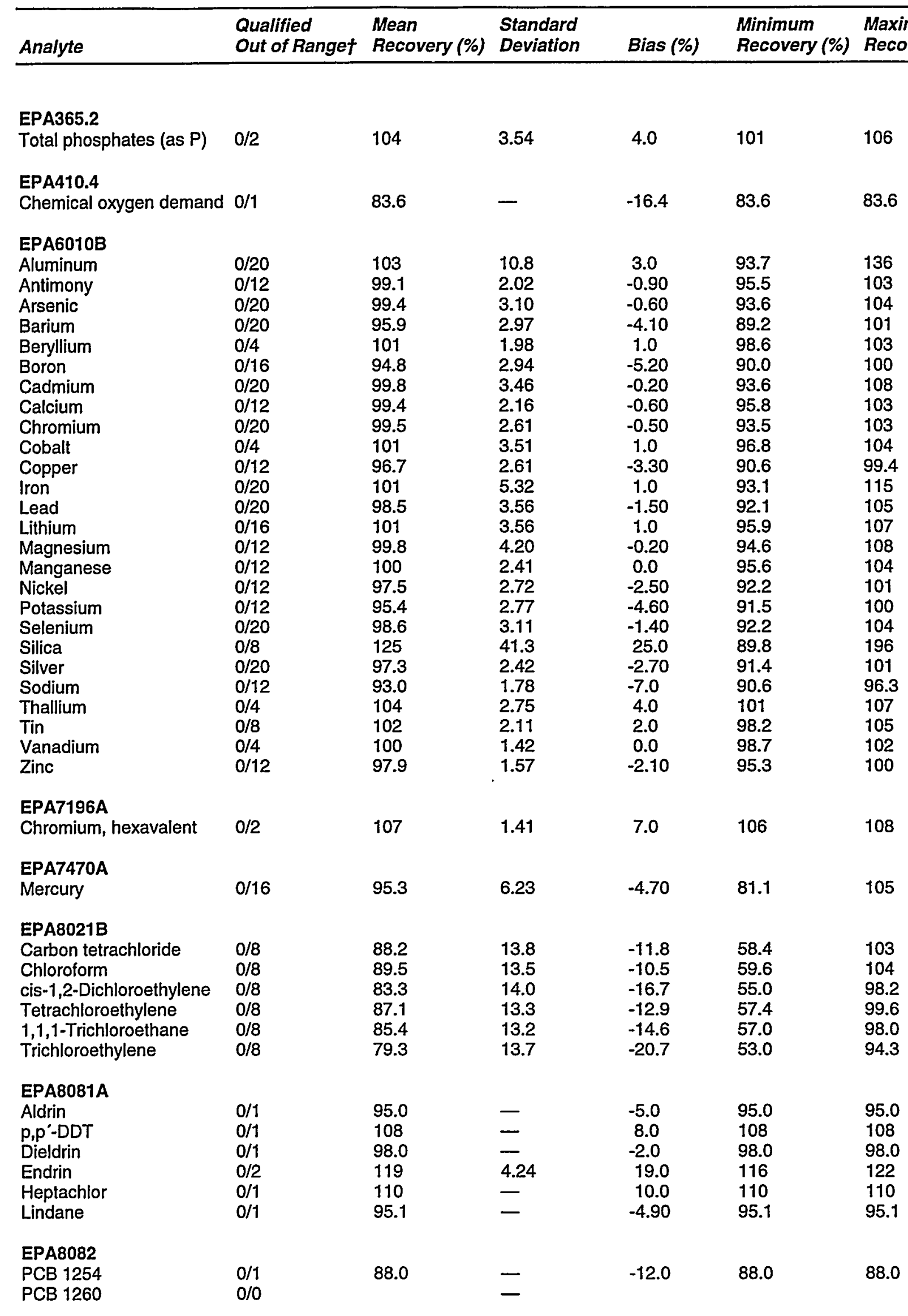




\begin{tabular}{|c|c|c|c|c|c|c|}
\hline Analyte & $\begin{array}{l}\text { Qualified } \\
\text { Out of Ranget }\end{array}$ & $\begin{array}{l}\text { Mean } \\
\text { Recovery (\%) }\end{array}$ & $\begin{array}{l}\text { Standard } \\
\text { Deviation }\end{array}$ & Bias (\%) & $\begin{array}{l}\text { Minimum } \\
\text { Recovery (\%) }\end{array}$ & $\begin{array}{l}\text { Maximum } \\
\text { Recovery (\%) }\end{array}$ \\
\hline \multicolumn{7}{|l|}{ EPA8260B } \\
\hline Benzene & $0 / 9$ & 95.9 & 6.94 & -4.10 & 85.4 & 107 \\
\hline p-Bromofluorobenzene & $0 / 1$ & 94.0 & - & -6.0 & 94.0 & 94.0 \\
\hline Chlorobenzene & $0 / 9$ & 93.7 & 3.99 & -6.30 & 85.7 & 97.9 \\
\hline 1,2-Dichloroethane-d4 & $0 / 1$ & 99.0 & - & -1.0 & 99.0 & 99.0 \\
\hline 1,1-Dichloroethylene & $0 / 9$ & 84.0 & 5.23 & -16.0 & 76.9 & 93.4 \\
\hline Toluene & $0 / 9$ & 94.9 & 3.61 & -5.10 & 88.2 & 100 \\
\hline Toluene-d8 & $0 / 1$ & 101 & - & 1.0 & 101 & 101 \\
\hline Trichloroethylene & $0 / 9$ & 98.5 & 22.7 & -1.50 & 76.4 & 157 \\
\hline \multicolumn{7}{|l|}{ EPA8270C } \\
\hline Acenaphthene & $0 / 3$ & 72.4 & 10.2 & -27.6 & 61.1 & 80.8 \\
\hline Bis(2-ethylhexyl) phthalate & $0 / 1$ & 79.3 & - & -20.7 & 79.3 & 79.3 \\
\hline 4-Chloro-m-cresol & $0 / 2$ & 57.6 & 18.7 & -42.4 & 44.4 & 70.8 \\
\hline 2-Chlorophenol & $0 / 2$ & 65.2 & 11.0 & -34.8 & 57.4 & 72.9 \\
\hline 1,4-Dichlorobenzene & $0 / 3$ & 53.2 & 15.5 & -46.8 & 35.8 & 65.6 \\
\hline 2,4-Dinitrotoluene & $0 / 3$ & 67.0 & 4.79 & -33.0 & 63.7 & 72.5 \\
\hline 4-Nitrophenol & $0 / 2$ & 45.6 & 9.69 & -54.4 & 38.7 & 52.4 \\
\hline N-Nitrosodipropylamine & $0 / 3$ & 78.2 & 9.81 & -21.8 & 67.2 & 86.1 \\
\hline Pentachlorophenol & $0 / 2$ & 49.8 & 6.51 & -50.2 & 45.2 & 54.4 \\
\hline Phenol & $0 / 2$ & 67.8 & 9.69 & -32.2 & 60.9 & 74.6 \\
\hline Pyrene & $0 / 3$ & 80.0 & 2.05 & -20.0 & 77.6 & 81.2 \\
\hline 1,2,4-Trichlorobenzene & $0 / 3$ & 57.7 & 17.1 & -42.3 & 38.8 & 72.2 \\
\hline \multicolumn{7}{|l|}{ EPA8280A } \\
\hline $\begin{array}{l}\text { Octachlorodibenzo-p- } \\
\text { dioxin }\end{array}$ & $0 / 1$ & 84.0 & - & -16.0 & 84.0 & 84.0 \\
\hline \multicolumn{7}{|l|}{ EPA9014 } \\
\hline Cyanide & $0 / 3$ & 91.4 & 10.8 & -8.60 & 79.0 & 98.6 \\
\hline \multicolumn{7}{|l|}{ EPA9020B } \\
\hline Total organic halogens & $0 / 7$ & 102 & 8.23 & 2.0 & 93.4 & 118 \\
\hline \multicolumn{7}{|l|}{ EPA9056 } \\
\hline Chloride & $0 / 4$ & 97.3 & 10.8 & -2.70 & 81.3 & 104 \\
\hline Sulfate & $0 / 10$ & 103 & 5.42 & 3.0 & 96.3 & 115 \\
\hline \multicolumn{7}{|l|}{ EPA9060 } \\
\hline Total organic carbon & $0 / 4$ & 103 & 2.22 & 3.0 & 101 & 106 \\
\hline \multicolumn{7}{|l|}{ EPA9066 } \\
\hline Phenols & $0 / 6$ & 97.3 & 5.89 & -2.70 & 89.0 & 107 \\
\hline
\end{tabular}

$\dagger$ Number of batches qualified that exhibit poor spike recovery due to interference compared to the total number of batches containing spikes.

- Standard deviation cannot be determined.

Note: A value of 0 is reported as 0.0 . 
Table 54. Matrix Spike Recoveries for ML

\begin{tabular}{lllllll}
\hline Analyte & $\begin{array}{l}\text { Qualified } \\
\text { Out of Ranget }\end{array}$ & $\begin{array}{l}\text { Mean } \\
\text { Recovery (\%) }\end{array}$ & $\begin{array}{l}\text { Standard } \\
\text { Deviation }\end{array}$ & Bias (\%) & $\begin{array}{l}\text { Minimum } \\
\text { Recovery (\%) }\end{array}$ & $\begin{array}{l}\text { Maximum } \\
\text { Recovery (\%) }\end{array}$ \\
\hline EPA8260B & & & & & & \\
Benzene & $0 / 2$ & 106 & 2.83 & 6.0 & 104 & 108 \\
Chlorobenzene & $0 / 2$ & 102 & 0.0 & 2.0 & 102 & 102 \\
1,1-Dichloroethylene & $0 / 2$ & 93.3 & 0.28 & -6.70 & 93.1 & 93.5 \\
Toluene & $0 / 2$ & 103 & 0.71 & 3.0 & 102 & 103 \\
Trichloroethylene & $0 / 2$ & 103 & 3.54 & 3.0 & 100 & 105 \\
\hline
\end{tabular}

$\dagger$ Number of batches qualified that exhibit poor spike recovery due to interference compared to the total number of batches containing spikes.

Note: $A$ value of 0 is reported as 0.0 .

Table 55. Matrix Spike Recoveries for GP

\begin{tabular}{|c|c|c|c|c|c|c|}
\hline Analyte & $\begin{array}{l}\text { Qualified } \\
\text { Out of Ranget }\end{array}$ & $\begin{array}{l}\text { Mean } \\
\text { Recovery (\%) }\end{array}$ & $\begin{array}{l}\text { Standard } \\
\text { Deviation }\end{array}$ & Bias (\%) & $\begin{array}{l}\text { Minimum } \\
\text { Recovery (\%) }\end{array}$ & $\begin{array}{l}\text { Maximum } \\
\text { Recovery (\%) }\end{array}$ \\
\hline \multicolumn{7}{|l|}{ EPIA-001 } \\
\hline Gross alpha & $0 / 27$ & 99.2 & 11.2 & -0.80 & 80.0 & 124 \\
\hline Nonvolatile beta & $0 / 27$ & 109 & 9.18 & 9.0 & 92.1 & 122 \\
\hline \multicolumn{7}{|l|}{ EPIA-002 } \\
\hline Tritium & $0 / 22$ & 91.6 & 23.9 & -8.40 & 30.4 & 145 \\
\hline \multicolumn{7}{|l|}{ EPIA-003 } \\
\hline Carbon-14 & $0 / 11$ & 100 & 6.49 & 0.0 & 94.1 & 118 \\
\hline \multicolumn{7}{|l|}{ EPIA-004 } \\
\hline Strontium-89/90 & $0 / 4$ & 104 & 12.8 & 4.0 & 88.2 & 118 \\
\hline Strontium-90 & $0 / 10$ & 90.2 & 10.4 & -9.80 & 76.8 & 105 \\
\hline \multicolumn{7}{|l|}{ EPIA-005 } \\
\hline Technetium-99 & $0 / 5$ & 103 & 4.29 & 3.0 & 99.4 & 110 \\
\hline \multicolumn{7}{|l|}{ EPIA-006 } \\
\hline lodine-129 & $0 / 7$ & 103 & 7.77 & 3.0 & 91.3 & 115 \\
\hline \multicolumn{7}{|l|}{ EPIA-008 } \\
\hline Radium-226 & $0 / 8$ & 94.8 & 8.71 & -5.20 & 83.3 & 107 \\
\hline \multicolumn{7}{|l|}{ EPIA-009 } \\
\hline Radium-228 & $0 / 7$ & 106 & 12.1 & 6.0 & 83.2 & 119 \\
\hline \multicolumn{7}{|l|}{ EPIA-010 } \\
\hline $\begin{array}{l}\text { Radium, total alpha- } \\
\text { emitting }\end{array}$ & $0 / 8$ & 90.6 & 6.46 & -9.40 & 76.2 & 96.6 \\
\hline \multicolumn{7}{|l|}{ EPIA-011 } \\
\hline Americium-241 & $0 / 4$ & 113 & 5.94 & 13.0 & 105 & 118 \\
\hline Curium-243/244 & $0 / 4$ & 111 & 7.46 & 11.0 & 105 & 122 \\
\hline Plutonium-239/240 & $0 / 4$ & 90.5 & 8.74 & -9.50 & 82.7 & 103 \\
\hline Uranium-238 & $0 / 5$ & 89.8 & 13.5 & -10.2 & 75.7 & 108 \\
\hline
\end{tabular}




\begin{tabular}{lllllll}
\hline Analyte & $\begin{array}{l}\text { Qualified } \\
\text { Out of Ranget }\end{array}$ & $\begin{array}{l}\text { Mean } \\
\text { Recovery (\%) }\end{array}$ & $\begin{array}{l}\text { Standard } \\
\text { Deviation }\end{array}$ & Bias (\%) & $\begin{array}{l}\text { Minimum } \\
\text { Recovery (\%) }\end{array}$ & $\begin{array}{l}\text { Maximum } \\
\text { Recovery (\%) }\end{array}$ \\
\hline $\begin{array}{l}\text { EPIA-012 } \\
\text { Thorium-232 }\end{array}$ & $0 / 4$ & 91.4 & 6.14 & -8.60 & 85.0 & 97.8 \\
$\begin{array}{l}\text { EPIA-013 } \\
\text { Cesium-137 }\end{array}$ & $0 / 8$ & 100 & 5.84 & 0.0 & 90.6 & 108 \\
$\begin{array}{l}\text { EPIA-022 } \\
\text { Nickel-63 }\end{array}$ & $0 / 3$ & 81.9 & 5.82 & -18.1 & 77.6 & 88.5 \\
\hline
\end{tabular}

$\dagger$ Number of batches qualified that exhibit poor spike recovery due to interference compared to the total number of batches containing spikes.

Note: A value of 0 is reported as 0.0 .

Table 56. Analytes Detected in Method Blanks for EX

\begin{tabular}{|c|c|c|c|c|}
\hline Analyte & $\begin{array}{l}\text { Frequency } \\
\text { of Detectiont }\end{array}$ & Mean Result & $\begin{array}{l}\text { Standard } \\
\text { Deviation }\end{array}$ & Minimum/Maximum Results \\
\hline \multicolumn{5}{|l|}{ EPA300.0 } \\
\hline Chloride & $0 / 1$ & 200 & - & $200 / 200 \mu \mathrm{g} / \mathrm{L}$ \\
\hline Nitrate as nitrogen & $0 / 7$ & 100 & 0.0 & $100 / 100 \mu \mathrm{g} / \mathrm{L}$ \\
\hline Nitrate-nitrite as nitrogen & $0 / 1$ & 100 & - & $100 / 100 \mu \mathrm{g} / \mathrm{L}$ \\
\hline Sulfate & $0 / 1$ & 200 & - & $200 / 200 \mu \mathrm{g} / \mathrm{L}$ \\
\hline \multicolumn{5}{|l|}{ EPA410.4 } \\
\hline Chemical oxygen demand & $0 / 1$ & 10,000 & - & $10,000 / 10,000 \mu \mathrm{g} / \mathrm{L}$ \\
\hline \multicolumn{5}{|l|}{ EPA6010B } \\
\hline Aluminum & $0 / 11$ & 200 & 0.0 & $200 / 200 \mu \mathrm{g} / \mathrm{L}$ \\
\hline Antimony & $0 / 2$ & 100 & 0.0 & $100 / 100 \mu \mathrm{g} / \mathrm{L}$ \\
\hline Arsenic & $1 / 5$ & 9.14 & 1.92 & $5.70 / 10.0 \mu \mathrm{g} / \mathrm{L}$ \\
\hline Barium & $0 / 6$ & 10.0 & 0.0 & $10.0 / 10.0 \mu \mathrm{g} / \mathrm{L}$ \\
\hline Beryllium & $0 / 2$ & 10.0 & 0.0 & $10.0 / 10.0 \mu \mathrm{g} / \mathrm{L}$ \\
\hline Boron & $0 / 7$ & 100 & 0.0 & $100 / 100 \mu \mathrm{g} / \mathrm{L}$ \\
\hline Cadmium & $0 / 5$ & 10.0 & 0.0 & $10.0 / 10.0 \mu \mathrm{g} / \mathrm{L}$ \\
\hline Calcium & $0 / 1$ & 1,000 & - & $1,000 / 1,000 \mu \mathrm{g} / \mathrm{L}$ \\
\hline Chromium & $0 / 5$ & 10.0 & 0.0 & $10.0 / 10.0 \mu \mathrm{g} / \mathrm{L}$ \\
\hline Cobalt & $0 / 1$ & 20.0 & - & $20.0 / 20.0 \mu \mathrm{g} / \mathrm{L}$ \\
\hline Copper & $0 / 2$ & 20.0 & 0.0 & $20.0 / 20.0 \mu \mathrm{g} / \mathrm{L}$ \\
\hline Iron & $1 / 11$ & 183 & 57.0 & $11.0 / 200 \mu \mathrm{g} / \mathrm{L}$ \\
\hline Lead & $0 / 13$ & 23.8 & 33.8 & $10.0 / 100 \mu \mathrm{g} / \mathrm{L}$ \\
\hline Magnesium & $0 / 1$ & 1,000 & - & $1,000 / 1,000 \mu \mathrm{g} / \mathrm{L}$ \\
\hline Manganese & $0 / 8$ & 10.0 & 0.0 & $10.0 / 10.0 \mu \mathrm{g} / \mathrm{L}$ \\
\hline Nickel & $0 / 2$ & 50.0 & 0.0 & $50.0 / 50.0 \mu \mathrm{g} / \mathrm{L}$ \\
\hline Potassium & $0 / 1$ & 5,000 & - & $5,000 / 5,000 \mu \mathrm{g} / \mathrm{L}$ \\
\hline Selenium & $1 / 5$ & 8.88 & 2.51 & $4.39 / 10.0 \mu \mathrm{g} / \mathrm{L}$ \\
\hline $\begin{array}{l}\text { Silver } \\
\text { S }\end{array}$ & $0 / 5$ & 20.0 & 0.0 & $20.0 / 20.0 \mu \mathrm{g} / \mathrm{L}$ \\
\hline Sodium & $0 / 1^{\circ}$ & 1,000 & - & $1,000 / 1,000 \mu \mathrm{g} / \mathrm{L}$ \\
\hline Thallium & $1 / 3$ & 8.72 & 2.22 & $6.16 / 10.0 \mu \mathrm{g} / \mathrm{L}$ \\
\hline Vanadium & $0 / 1$ & 10.0 & - & $10.0 / 10.0 \mu \mathrm{g} / \mathrm{L}$ \\
\hline Zinc & $0 / 2$ & 20.0 & 0.0 & $20.0 / 20.0 \mu \mathrm{g} / \mathrm{L}$ \\
\hline \multicolumn{5}{|l|}{ EPA7470A } \\
\hline Mercury & $0 / 16$ & 0.50 & 0.0 & $0.50 / 0.50 \mu \mathrm{g} / \mathrm{L}$ \\
\hline
\end{tabular}




\begin{tabular}{|c|c|c|c|c|}
\hline Analyte & $\begin{array}{l}\text { Frequency } \\
\text { of Detectiont }\end{array}$ & Mean Result & $\begin{array}{l}\text { Standard } \\
\text { Deviation }\end{array}$ & Minimum/Maximum Results \\
\hline \multicolumn{5}{|l|}{ EPA8021B } \\
\hline Carbon tetrachloride & $0 / 7$ & 1.0 & 0.0 & $1.0 / 1.0 \mu \mathrm{g} / \mathrm{L}$ \\
\hline Chloroform & $0 / 7$ & 1.0 & 0.0 & $1.0 / 1.0 \mu \mathrm{g} / \mathrm{L}$ \\
\hline cis-1,2-Dichloroethylene & $0 / 7$ & 1.0 & 0.0 & $1.0 / 1.0 \mu \mathrm{g} / \mathrm{L}$ \\
\hline Tetrachloroethylene & $0 / 7$ & 1.0 & 0.0 & $1.0 / 1.0 \mu \mathrm{g} / \mathrm{L}$ \\
\hline 1,1,1-Trichloroethane & $0 / 7$ & 1.0 & 0.0 & $1.0 / 1.0 \mu \mathrm{g} / \mathrm{L}$ \\
\hline Trichloroethylene & $0 / 7$ & 1.0 & 0.0 & $1.0 / 1.0 \mu \mathrm{g} / \mathrm{L}$ \\
\hline \multicolumn{5}{|l|}{ EPA8081A } \\
\hline Aldrin & $0 / 1$ & 0.10 & - & $0.10 / 0.10 \mu \mathrm{g} / \mathrm{L}$ \\
\hline alpha-Benzene hexachloride & $0 / 1$ & 0.10 & - & $0.10 / 0.10 \mu \mathrm{g} / \mathrm{L}$ \\
\hline beta-Benzene hexachloride & $0 / 1$ & 0.10 & - & $0.10 / 0.10 \mu \mathrm{g} / \mathrm{L}$ \\
\hline delta-Benzene hexachloride & $0 / 1$ & 0.10 & - & $0.10 / 0.10 \mu \mathrm{g} / \mathrm{L}$ \\
\hline alpha-Chlordane & $0 / 1$ & 0.10 & - & $0.10 / 0.10 \mu \mathrm{g} / \mathrm{L}$ \\
\hline gamma-Chlordane & $0 / 1$ & 0.10 & - & $0.10 / 0.10 \mu \mathrm{g} / \mathrm{L}$ \\
\hline$p, p^{\prime}-D D D$ & $0 / 1$ & 0.20 & - & $0.20 / 0.20 \mu \mathrm{g} / \mathrm{L}$ \\
\hline$p, p^{\prime}-D D E$ & $0 / 1$ & 0.20 & - & $0.20 / 0.20 \mu g / L$ \\
\hline$p, p^{\prime}-D D T$ & $0 / 1$ & 0.20 & - & $0.20 / 0.20 \mu \mathrm{g} / \mathrm{L}$ \\
\hline Dieldrin & $0 / 1$ & 0.20 & - & $0.20 / 0.20 \mu \mathrm{g} / \mathrm{L}$ \\
\hline Endosulfan sulfate & $0 / 1$ & 0.20 & - & $0.20 / 0.20 \mu \mathrm{g} / \mathrm{L}$ \\
\hline Endosulfan I & $0 / 1$ & 0.10 & - & $0.10 / 0.10 \mu \mathrm{g} / \mathrm{L}$ \\
\hline Endosulfan II & $0 / 1$ & 0.20 & - & $0.20 / 0.20 \mu \mathrm{g} / \mathrm{L}$ \\
\hline Endrin & $0 / 1$ & 0.20 & - & $0.20 / 0.20 \mu \mathrm{g} / \mathrm{L}$ \\
\hline Endrin aldehyde & $0 / 1$ & 0.20 & - & $0.20 / 0.20 \mu \mathrm{g} / \mathrm{L}$ \\
\hline Heptachlor & $0 / 1$ & 0.10 & - & $0.10 / 0.10 \mu g / L$ \\
\hline Heptachlor epoxide & $0 / 1$ & 0.10 & - & $0.10 / 0.10 \mu \mathrm{g} / \mathrm{L}$ \\
\hline Lindane & $0 / 1$ & 0.10 & - & $0.10 / 0.10 \mu g / L$ \\
\hline Toxaphene & $0 / 1$ & 1.0 & - & $1.0 / 1.0 \mu \mathrm{g} / \mathrm{L}$ \\
\hline \multicolumn{5}{|l|}{ EPA8082 } \\
\hline PCB 1016 & $0 / 1$ & 2.0 & - & $2.0 / 2.0 \mu \mathrm{g} / \mathrm{L}$ \\
\hline PCB 1221 & $0 / 1$ & 2.0 & - & $2.0 / 2.0 \mu \mathrm{g} / \mathrm{L}$ \\
\hline PCB 1232 & $0 / 1$ & 1.0 & - & $1.0 / 1.0 \mu \mathrm{g} / \mathrm{L}$ \\
\hline PCB 1242 & $0 / 1$ & 1.0 & - & $1.0 / 1.0 \mu \mathrm{g} / \mathrm{L}$ \\
\hline PCB 1248 & $0 / 1$ & 1.0 & - & $1.0 / 1.0 \mu \mathrm{g} / \mathrm{L}$ \\
\hline PCB 1254 & $0 / 1$ & 1.0 & - & $1.0 / 1.0 \mu \mathrm{g} / \mathrm{L}$ \\
\hline PCB 1260 & $0 / 1$ & 1.0 & - & $1.0 / 1.0 \mu \mathrm{g} / \mathrm{L}$ \\
\hline \multicolumn{5}{|l|}{ EPA8260B } \\
\hline Acetone & $0 / 6$ & 10.0 & 0.0 & $10.0 / 10.0 \mu \mathrm{g} / \mathrm{L}$ \\
\hline Acetonitrile & $0 / 4$ & 500 & 0.0 & $500 / 500 \mu \mathrm{g} / \mathrm{L}$ \\
\hline Acrolein & $0 / 5$ & 50.0 & 0.0 & $50.0 / 50.0 \mu \mathrm{g} / \mathrm{L}$ \\
\hline Acrylonitrile & $0 / 5$ & 50.0 & 0.0 & $50.0 / 50.0 \mu \mathrm{g} / \mathrm{L}$ \\
\hline Allyl chloride & $0 / 4$ & 10.0 & 0.0 & $10.0 / 10.0 \mu \mathrm{g} / \mathrm{L}$ \\
\hline Benzene & $0 / 20$ & 5.0 & 0.0 & $5.0 / 5.0 \mu \mathrm{g} / \mathrm{L}$ \\
\hline Bromodichloromethane & $0 / 20$ & 5.0 & 0.0 & $5.0 / 5.0 \mu \mathrm{g} / \mathrm{L}$ \\
\hline Bromoform & $0 / 20$ & 5.0 & 0.0 & $5.0 / 5.0 \mu \mathrm{g} / \mathrm{L}$ \\
\hline Bromomethane & $0 / 20$ & 5.0 & 0.0 & $5.0 / 5.0 \mu \mathrm{g} / \mathrm{L}$ \\
\hline Carbon disulfide & $0 / 6$ & 5.0 & 0.0 & $5.0 / 5.0 \mu \mathrm{g} / \mathrm{L}$ \\
\hline Carbon tetrachloride & $0 / 20$ & 5.0 & 0.0 & $5.0 / 5.0 \mu \mathrm{g} / \mathrm{L}$ \\
\hline Chlorobenzene & $0 / 20$ & 5.0 & 0.0 & $5.0 / 5.0 \mu \mathrm{g} / \mathrm{L}$ \\
\hline Chloroethane & $0 / 20$ & 10.0 & 0.0 & $10.0 / 10.0 \mu \mathrm{g} / \mathrm{L}$ \\
\hline Chloroethene & $0 / 20$ & 5.0 & 0.0 & $5.0 / 5.0 \mu \mathrm{g} / \mathrm{L}$ \\
\hline 2-Chloroethyl vinyl ether & $0 / 14$ & 5.0 & 0.0 & $5.0 / 5.0 \mu \mathrm{g} / \mathrm{L}$ \\
\hline Chloroform & $0 / 20$ & 5.0 & 0.0 & $5.0 / 5.0 \mu \mathrm{g} / \mathrm{L}$ \\
\hline Chloromethane & $0 / 20$ & 5.0 & 0.0 & $5.0 / 5.0 \mu \mathrm{g} / \mathrm{L}$ \\
\hline Chloroprene & $0 / 4$ & 50.0 & 0.0 & $50.0 / 50.0 \mu \mathrm{g} / \mathrm{L}$ \\
\hline Dibromochloromethane & $0 / 20$ & 5.0 & 0.0 & $5.0 / 5.0 \mu \mathrm{g} / \mathrm{L}$ \\
\hline 1,2-Dibromo-3-chloropropane & $0 / 4$ & 5.0 & 0.0 & $5.0 / 5.0 \mu \mathrm{g} / \mathrm{L}$ \\
\hline 1,2-Dibromoethane & $0 / 4$ & 5.0 & 0.0 & $5.0 / 5.0 \mu \mathrm{g} / \mathrm{L}$ \\
\hline Dibromomethane & $0 / 4$ & 5.0 & 0.0 & $5.0 / 5.0 \mu \mathrm{g} / \mathrm{L}$ \\
\hline
\end{tabular}




\begin{tabular}{|c|c|c|c|c|}
\hline Analyte & $\begin{array}{l}\text { Frequency } \\
\text { of Detectiont }\end{array}$ & Mean Result & $\begin{array}{l}\text { Standard } \\
\text { Deviation }\end{array}$ & Minimum/Maximum Results \\
\hline 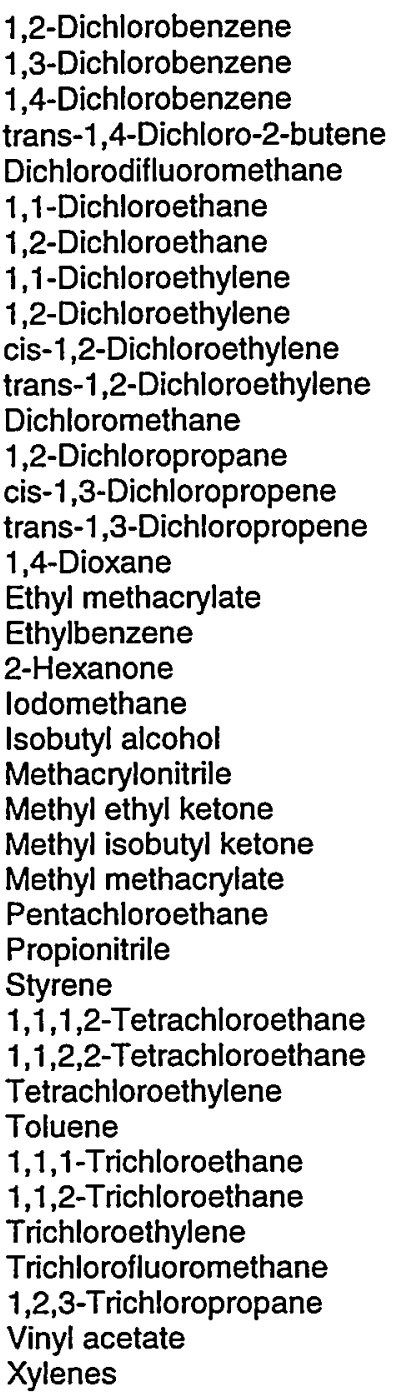 & $\begin{array}{l}0 / 5 \\
0 / 5 \\
0 / 5 \\
0 / 4 \\
0 / 4 \\
0 / 20 \\
0 / 20 \\
0 / 20 \\
0 / 2 \\
0 / 4 \\
0 / 18 \\
0 / 20 \\
0 / 20 \\
0 / 20 \\
0 / 20 \\
0 / 4 \\
0 / 4 \\
0 / 20 \\
0 / 6 \\
0 / 4 \\
0 / 4 \\
0 / 4 \\
0 / 6 \\
0 / 6 \\
0 / 4 \\
0 / 4 \\
0 / 4 \\
0 / 6 \\
0 / 4 \\
0 / 20 \\
0 / 20 \\
0 / 20 \\
0 / 21 \\
0 / 20 \\
0 / 20 \\
0 / 18 \\
0 / 4 \\
0 / 6 \\
0 / 6\end{array}$ & $\begin{array}{l}5.0 \\
5.0 \\
5.0 \\
20.0 \\
5.0 \\
5.0 \\
5.0 \\
5.0 \\
1.0 \\
5.0 \\
5.0 \\
5.0 \\
5.0 \\
5.0 \\
5.0 \\
1,000 \\
5.0 \\
5.0 \\
5.0 \\
5.0 \\
1,500 \\
500 \\
10.0 \\
5.0 \\
50.0 \\
200 \\
500 \\
5.0 \\
5.0 \\
5.0 \\
5.0 \\
5.0 \\
5.0 \\
5.0 \\
5.0 \\
5.0 \\
5.0 \\
20.0 \\
10.0\end{array}$ & $\begin{array}{l}0.0 \\
0.0 \\
0.0 \\
0.0 \\
0.0 \\
0.0 \\
0.0 \\
0.0 \\
0.0 \\
0.0 \\
0.0 \\
0.0 \\
0.0 \\
0.0 \\
0.0 \\
0.0 \\
0.0 \\
0.0 \\
0.0 \\
0.0 \\
0.0 \\
0.0 \\
0.0 \\
0.0 \\
0.0 \\
0.0 \\
0.0 \\
0.0 \\
0.0 \\
0.0 \\
0.0 \\
0.0 \\
0.0 \\
0.0 \\
0.0 \\
0.0 \\
0.0 \\
0.0 \\
0.0\end{array}$ & $\begin{array}{l}5.0 / 5.0 \mu \mathrm{g} / \mathrm{L} \\
5.0 / 5.0 \mu \mathrm{g} / \mathrm{L} \\
5.0 / 5.0 \mu \mathrm{g} / \mathrm{L} \\
20.0 / 20.0 \mu \mathrm{g} / \mathrm{L} \\
5.0 / 5.0 \mu \mathrm{g} / \mathrm{L} \\
5.0 / 5.0 \mu \mathrm{g} / \mathrm{L} \\
5.0 / 5.0 \mu \mathrm{g} / \mathrm{L} \\
5.0 / 5.0 \mu \mathrm{g} / \mathrm{L} \\
1.0 / 1.0 \mu \mathrm{g} / \mathrm{L} \\
5.0 / 5.0 \mu \mathrm{g} / \mathrm{L} \\
5.0 / 5.0 \mu \mathrm{g} / \mathrm{L} \\
5.0 / 5.0 \mu \mathrm{g} / \mathrm{L} \\
5.0 / 5.0 \mu \mathrm{g} / \mathrm{L} \\
5.0 / 5.0 \mu \mathrm{g} / \mathrm{L} \\
5.0 / 5.0 \mu \mathrm{g} / \mathrm{L} \\
1,000 / 1,000 \mu \mathrm{g} / \mathrm{L} \\
5.0 / 5.0 \mu \mathrm{g} / \mathrm{L} \\
5.0 / 5.0 \mu \mathrm{L} / \mathrm{L} \\
5.0 / 5.0 \mu \mathrm{g} / \mathrm{L} \\
5.0 / 5.0 \mu \mathrm{g} / \mathrm{L} \\
1,500 / 1,500 \mu \mathrm{g} / \mathrm{L} \\
500 / 500 \mu \mathrm{g} / \mathrm{L} \\
10.0 / 10.0 \mu \mathrm{g} / \mathrm{L} \\
5.0 / 5.0 \mu \mathrm{g} / \mathrm{L} \\
50.0 / 50.0 \mu \mathrm{g} / \mathrm{L} \\
200 / 200 \mu \mathrm{g} / \mathrm{L} \\
500 / 500 \mu \mathrm{g} / \mathrm{L} \\
5.0 / 5.0 \mu \mathrm{g} / \mathrm{L} \\
5.0 / 5.0 \mu \mathrm{g} / \mathrm{L} \\
5.0 / 5.0 \mu \mathrm{g} / \mathrm{L} \\
5.0 / 5.0 \mu \mathrm{g} / \mathrm{L} \\
5.0 / 5.0 \mu \mathrm{g} / \mathrm{L} \\
5.0 / 5.0 \mu \mathrm{g} / \mathrm{L} \\
5.0 / 5.0 \mu \mathrm{g} / \mathrm{L} \\
5.0 / 5.0 \mu \mathrm{g} / \mathrm{L} \\
5.0 / 5.0 \mu \mathrm{g} / \mathrm{L} \\
5.0 / 5.0 \mu \mathrm{g} / \mathrm{L} \\
20.0 / 20.0 \mu \mathrm{g} / \mathrm{L} \\
10.0 / 10.0 \mu \mathrm{g} / \mathrm{L}\end{array}$ \\
\hline $\begin{array}{l}\text { EPA8270C } \\
\text { Acenaphthene } \\
\text { Acenaphthylene } \\
\text { Anthracene } \\
\text { Benzidine } \\
\text { Benzo[a]anthracene } \\
\text { Benzo[b]fluoranthene } \\
\text { Benzo[kflluoranthene } \\
\text { Benzo[g,h,i]perylene } \\
\text { Benzo[a]pyrene } \\
\text { Bis(2-chloroethoxy) methane } \\
\text { Bis(2-chloroethyl) ether } \\
\text { Bis(2-chloroisopropyl) ether } \\
\text { Bis(2-ethylhexyl) phthalate } \\
\text { 4-Bromophenyl phenyl ether } \\
\text { Butylbenzyl phthalate } \\
\text { 4-Chloro-m-cresol } \\
\text { 2-Chloronaphthalene } \\
\text { 2-Chlorophenol } \\
\text { 4-Chlorophenyl phenyl ether } \\
\text { Chrysene }\end{array}$ & $\begin{array}{l}0 / 1 \\
0 / 1 \\
0 / 1 \\
0 / 1 \\
0 / 1 \\
0 / 1 \\
0 / 1 \\
0 / 1 \\
0 / 1 \\
0 / 1 \\
0 / 1 \\
0 / 1 \\
0 / 1 \\
0 / 1 \\
0 / 1 \\
0 / 1 \\
0 / 1 \\
0 / 1 \\
0 / 1 \\
0 / 1\end{array}$ & $\begin{array}{l}10.0 \\
10.0 \\
10.0 \\
10.0 \\
10.0 \\
10.0 \\
10.0 \\
10.0 \\
10.0 \\
10.0 \\
10.0 \\
10.0 \\
10.0 \\
10.0 \\
10.0 \\
10.0 \\
10.0 \\
10.0 \\
10.0 \\
10.0\end{array}$ & $\begin{array}{l}= \\
= \\
= \\
= \\
= \\
= \\
= \\
= \\
= \\
= \\
=\end{array}$ & $\begin{array}{l}10.0 / 10.0 \mu \mathrm{g} / \mathrm{L} \\
10.0 / 10.0 \mu \mathrm{g} / \mathrm{L} \\
10.0 / 10.0 \mu \mathrm{g} / \mathrm{L} \\
10.0 / 10.0 \mu \mathrm{g} / \mathrm{L} \\
10.0 / 10.0 \mu \mathrm{g} / \mathrm{L} \\
10.0 / 10.0 \mu \mathrm{g} / \mathrm{L} \\
10.0 / 10.0 \mu \mathrm{g} / \mathrm{L} \\
10.0 / 10.0 \mu \mathrm{g} / \mathrm{L} \\
10.0 / 10.0 \mu \mathrm{g} / \mathrm{L} \\
10.0 / 10.0 \mu \mathrm{g} / \mathrm{L} \\
10.0 / 10.0 \mu \mathrm{g} / \mathrm{L} \\
10.0 / 10.0 \mu \mathrm{g} / \mathrm{L} \\
10.0110 .0 \mu \mathrm{g} / \mathrm{L} \\
10.0110 .0 \mu \mathrm{h} / \mathrm{L} \\
10.0 / 10.0 \mu \mathrm{g} / \mathrm{L} \\
10.0 / 10.0 \mu \mathrm{g} / \mathrm{L} \\
10.0 / 10.0 \mu \mathrm{g} / \mathrm{L} \\
10.0 / 10.0 \mu \mathrm{g} / \mathrm{L} \\
10.0 / 10.0 \mu \mathrm{g} / \mathrm{L} \\
10.0110 .0 \mu \mathrm{g} / \mathrm{L}\end{array}$ \\
\hline
\end{tabular}




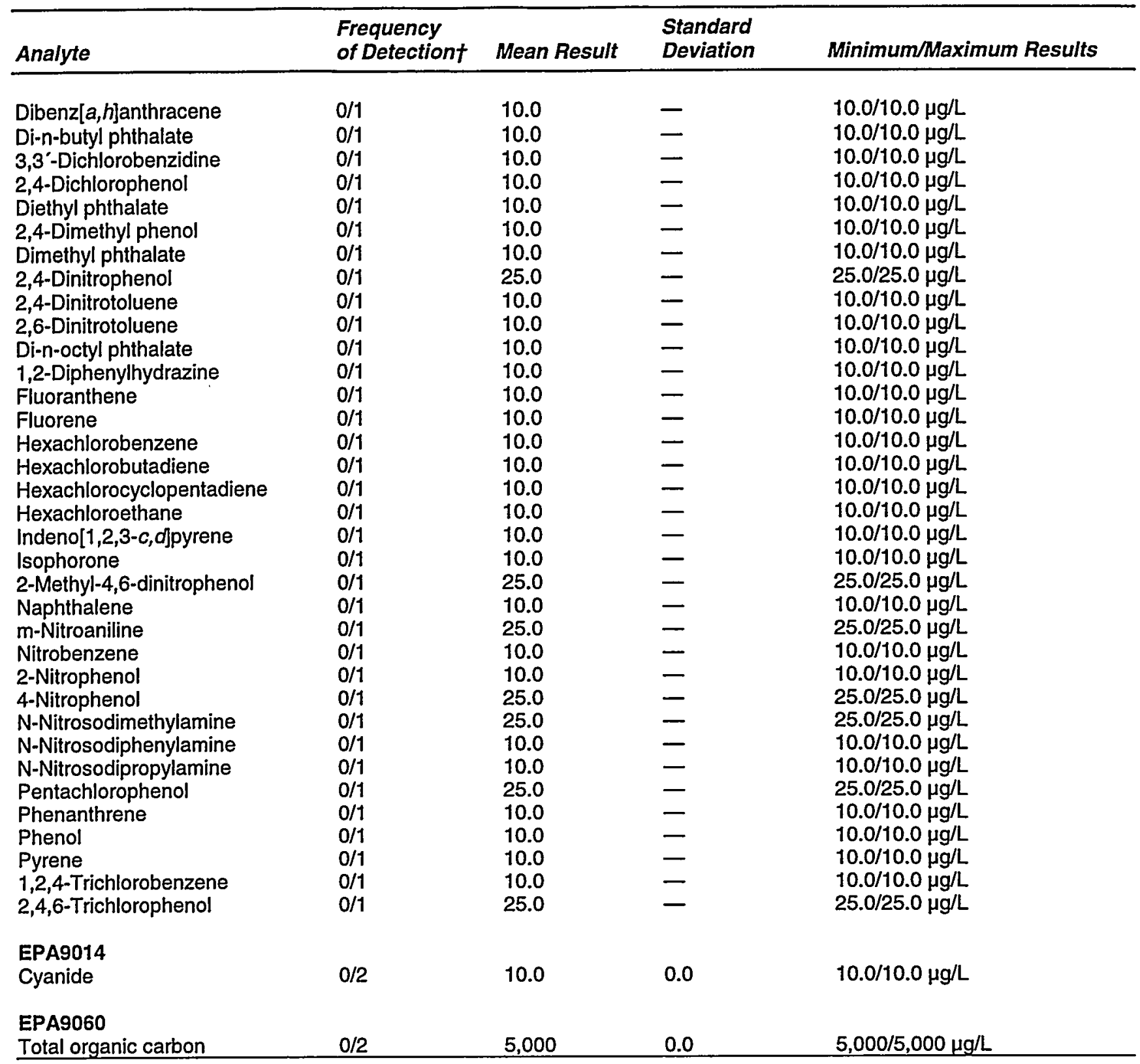

+ Number of times analyte was detected compared to the total number of method blanks for the analyte.

- Standard deviation cannot be determined.

Note: If the analyte was not detected in the method blank(s), detection limit information appears in the Mean Result and Minimum/Maximum Results columns.

Table 57. Analytes Detected in Method Blanks for GE

\begin{tabular}{lllll}
\hline Analyte & $\begin{array}{l}\text { Frequency } \\
\text { of Detectiont }\end{array}$ & Mean Result & $\begin{array}{l}\text { Standard } \\
\text { Deviation }\end{array}$ & Minimum/Maximum Results \\
\hline $\begin{array}{llll}\text { EPA160.1 } \\
\text { Total dissolved solids }\end{array}$ & $0 / 3$ & 10,000 & 0.0 & $10,000 / 10,000 \mu \mathrm{g} / \mathrm{L}$
\end{tabular}




\begin{tabular}{|c|c|c|c|c|}
\hline Analyte & $\begin{array}{l}\text { Frequency } \\
\text { of Detectiont }\end{array}$ & Mean Result & $\begin{array}{l}\text { Standard } \\
\text { Deviation }\end{array}$ & Minimum/Maximum Results \\
\hline \multicolumn{5}{|l|}{ EPA300.0 } \\
\hline Chloride & $1 / 1$ & 45.0 & - & $45.0 / 45.0 \mu \mathrm{g} / \mathrm{L}$ \\
\hline Sulfate & $1 / 3$ & 155 & 77.9 & $65.0 / 200 \mu \mathrm{g} / \mathrm{L}$ \\
\hline \multicolumn{5}{|l|}{ EPA353.1 } \\
\hline Nitrate-nitrite as nitrogen & $8 / 19$ & 36.8 & 16.7 & $10.0 / 50.0 \mu \mathrm{g} / \mathrm{L}$ \\
\hline \multicolumn{5}{|l|}{ EPA6010B } \\
\hline Aluminum & $2 / 7$ & 39.9 & 17.3 & $12.8 / 50.0 \mu g / L$ \\
\hline Antimony & $1 / 5$ & 8.87 & 2.54 & $4.33 / 10.0 \mu \mathrm{g} / \mathrm{L}$ \\
\hline Arsenic & $0 / 5$ & 5.0 & 0.0 & $5.0 / 5.0 \mu \mathrm{g} / \mathrm{L}$ \\
\hline Barium & $1 / 5$ & 4.21 & 1.76 & $1.07 / 5.0 \mu \mathrm{g} / \mathrm{L}$ \\
\hline Beryllium & $0 / 6$ & 5.0 & 0.0 & $5.0 / 5.0 \mu \mathrm{g} / \mathrm{L}$ \\
\hline Boron & $0 / 1$ & 50.0 & - & $50.0 / 50.0 \mu \mathrm{g} / \mathrm{L}$ \\
\hline Cadmium & $0 / 5$ & 5.0 & 0.0 & $5.0 / 5.0 \mu \mathrm{g} / \mathrm{L}$ \\
\hline Calcium & $1 / 4$ & 113 & 26.5 & $100 / 153 \mu \mathrm{g} / \mathrm{L}$ \\
\hline Chromium & $0 / 7$ & 5.0 & 0.0 & $5.0 / 5.0 \mu \mathrm{g} / \mathrm{L}$ \\
\hline Cobalt & $0 / 4$ & 5.0 & 0.0 & $5.0 / 5.0 \mu \mathrm{g} / \mathrm{L}$ \\
\hline Copper & $1 / 5$ & 4.28 & 1.61 & $1.40 / 5.0 \mu \mathrm{g} / \mathrm{L}$ \\
\hline Iron & $0 / 7$ & 50.0 & 0.0 & $50.0 / 50.0 \mu \mathrm{g} / \mathrm{L}$ \\
\hline Lead & $0 / 5$ & 5.0 & 0.0 & $5.0 / 5.0 \mu \mathrm{g} / \mathrm{L}$ \\
\hline Magnesium & $2 / 4$ & 8.54 & 1.71 & $6.75 / 10.0 \mu \mathrm{g} / \mathrm{L}$ \\
\hline Manganese & $0 / 4$ & 10.0 & 0.0 & $10.0 / 10.0 \mu \mathrm{g} / \mathrm{L}$ \\
\hline Nickel & $0 / 5$ & 5.0 & 0.0 & $5.0 / 5.0 \mu \mathrm{g} / \mathrm{L}$ \\
\hline Potassium & $1 / 4$ & 82.0 & 36.0 & $28.1 / 100 \mu \mathrm{g} / \mathrm{L}$ \\
\hline Selenium & $0 / 5$ & 5.0 & 0.0 & $5.0 / 5.0 \mu \mathrm{g} / \mathrm{L}$ \\
\hline Silver & $1 / 5$ & 4.20 & 1.79 & $1.0 / 5.0 \mu \mathrm{g} / \mathrm{L}$ \\
\hline Sodium & $0 / 4$ & 400 & 200 & $100 / 500 \mu g / L$ \\
\hline Thallium & $0 / 4$ & 5.0 & 0.0 & $5.0 / 5.0 \mu \mathrm{g} / \mathrm{L}$ \\
\hline Tin & $0 / 1$ & 100 & - & $100 / 100 \mu \mathrm{g} / \mathrm{L}$ \\
\hline Vanadium & $0 / 4$ & 5.0 & 0.0 & $5.0 / 5.0 \mu \mathrm{g} / \mathrm{L}$ \\
\hline Zinc & $2 / 6$ & 6.08 & 1.69 & $5.0 / 8.61 \mu g / L$ \\
\hline \multicolumn{5}{|l|}{ EPA6020 } \\
\hline Aluminum & $2 / 16$ & 25.3 & 34.1 & 13.7/150 $\mu \mathrm{g} / \mathrm{L}$ \\
\hline Antimony & $2 / 5$ & 1.32 & 0.93 & $0.30 / 2.0 \mu \mathrm{g} / \mathrm{L}$ \\
\hline Arsenic & $0 / 5$ & 3.0 & 0.0 & $3.0 / 3.0 \mu \mathrm{g} / \mathrm{L}$ \\
\hline Barium & $0 / 5$ & 2.0 & 0.0 & $2.0 / 2.0 \mu \mathrm{g} / \mathrm{L}$ \\
\hline Beryllium & $0 / 3$ & 0.47 & 0.46 & $0.20 / 1.0 \mu \mathrm{g} / \mathrm{L}$ \\
\hline Boron & $0 / 1$ & 15.0 & - & $15.0 / 15.0 \mu \mathrm{g} / \mathrm{L}$ \\
\hline Cadmium & $0 / 14$ & 1.0 & 0.0 & $1.0 / 1.0 \mu \mathrm{g} / \mathrm{L}$ \\
\hline Calcium & $0 / 2$ & 150 & 0.0 & $150 / 150 \mu g / L$ \\
\hline Chromium & $2 / 5$ & 2.29 & 0.97 & $1.20 / 3.0 \mu \mathrm{g} / \mathrm{L}$ \\
\hline Cobalt & $1 / 5$ & 0.88 & 0.28 & $0.38 / 1.0 \mu \mathrm{g} / \mathrm{L}$ \\
\hline Copper & $1 / 5$ & 0.89 & 0.26 & $0.43 / 1.0 \mu \mathrm{g} / \mathrm{L}$ \\
\hline Iron & $0 / 15$ & 23.7 & 3.52 & $15.0 / 25.0 \mu \mathrm{g} / \mathrm{L}$ \\
\hline Lead & $3 / 14$ & 1.56 & 0.74 & $0.20 / 2.0 \mu \mathrm{g} / \mathrm{L}$ \\
\hline Lithium & $0 / 2$ & 2.0 & 0.0 & $2.0 / 2.0 \mu \mathrm{g} / \mathrm{L}$ \\
\hline Magnesium & $0 / 3$ & 7.67 & 4.04 & $3.0 / 10.0 \mu \mathrm{g} / \mathrm{L}$ \\
\hline Manganese & $0 / 3$ & 3.40 & 2.77 & $0.20 / 5.0 \mu \mathrm{g} / \mathrm{L}$ \\
\hline Molybdenum & $1 / 1$ & 0.12 & 一 & $0.12 / 0.12 \mu \mathrm{g} / \mathrm{L}$ \\
\hline Nickel & $0 / 5$ & 2.0 & 0.0 & $2.0 / 2.0 \mu \mathrm{g} / \mathrm{L}$ \\
\hline Potassium & $0 / 3$ & 205 & 165 & $15.0 / 300 \mu \mathrm{g} / \mathrm{L}$ \\
\hline Selenium & $0 / 5$ & 5.0 & 0.0 & $5.0 / 5.0 \mu \mathrm{g} / \mathrm{L}$ \\
\hline Silver & $0 / 5$ & 1.0 & 0.0 & $1.0 / 1.0 \mu \mathrm{g} / \mathrm{L}$ \\
\hline Sodium & $0 / 3$ & 250 & 0.0 & $250 / 250 \mu \mathrm{g} / \mathrm{L}$ \\
\hline Strontium & $0 / 1$ & 10.0 & - & $10.0 / 10.0 \mu \mathrm{g} / \mathrm{L}$ \\
\hline Thallium & $1 / 5$ & 0.43 & 0.17 & $0.13 / 0.50 \mu \mathrm{g} / \mathrm{L}$ \\
\hline Tin & $0 / 4$ & 5.0 & 0.0 & $5.0 / 5.0 \mu \mathrm{g} / \mathrm{L}$ \\
\hline Titanium & $0 / 1$ & 10.0 & - & $10.0 / 10.0 \mu \mathrm{g} / \mathrm{L}$ \\
\hline
\end{tabular}




\begin{tabular}{|c|c|c|c|c|}
\hline Analyte & $\begin{array}{l}\text { Frequency } \\
\text { of Detectiont }\end{array}$ & Mean Result & $\begin{array}{l}\text { Standard } \\
\text { Deviation }\end{array}$ & Minimum/Maximum Results \\
\hline Uranium & $1 / 1$ & 0.05 & - & $0.05 / 0.05 \mu g / L$ \\
\hline Vanadium & $0 / 5$ & 10.0 & 0.0 & $10.0 / 10.0 \mu \mathrm{g} / \mathrm{L}$ \\
\hline Zinc & $0 / 5$ & 10.0 & 0.0 & $10.0 / 10.0 \mu \mathrm{g} / \mathrm{L}$ \\
\hline \multicolumn{5}{|l|}{ EPA7196A } \\
\hline Chromium, hexavalent & $0 / 3$ & 20.0 & 0.0 & $20.0 / 20.0 \mu \mathrm{g} / \mathrm{L}$ \\
\hline \multicolumn{5}{|l|}{ EPA7470A } \\
\hline Mercury & $3 / 20$ & 0.18 & 0.05 & $0.04 / 0.20 \mu \mathrm{g} / \mathrm{L}$ \\
\hline \multicolumn{5}{|l|}{ EPA8081A } \\
\hline Aldrin & $0 / 4$ & 0.02 & 0.00 & $0.02 / 0.02 \mu g / L$ \\
\hline alpha-Benzene hexachloride & $0 / 4$ & 0.02 & 0.00 & $0.02 / 0.02 \mu \mathrm{g} / \mathrm{L}$ \\
\hline beta-Benzene hexachloride & $0 / 4$ & 0.02 & 0.00 & $0.02 / 0.02 \mu \mathrm{g} / \mathrm{L}$ \\
\hline delta-Benzene hexachloride & $0 / 4$ & 0.02 & 0.00 & $0.02 / 0.02 \mu \mathrm{g} / \mathrm{L}$ \\
\hline alpha-Chlordane & $0 / 4$ & 0.02 & 0.00 & $0.02 / 0.02 \mu \mathrm{g} / \mathrm{L}$ \\
\hline gamma-Chlordane & $0 / 4$ & 0.02 & 0.00 & $0.02 / 0.02 \mu \mathrm{g} / \mathrm{L}$ \\
\hline$p, p^{\prime}-D D D$ & $0 / 4$ & 0.04 & 0.00 & $0.03 / 0.04 \mu \mathrm{g} / \mathrm{L}$ \\
\hline$p, p^{\circ}-D D E$ & $0 / 4$ & 0.04 & 0.00 & $0.03 / 0.04 \mu \mathrm{g} / \mathrm{L}$ \\
\hline$p, p^{\circ}=D D T$ & $0 / 4$ & 0.04 & 0.00 & $0.03 / 0.04 \mu \mathrm{g} / \mathrm{L}$ \\
\hline Dieldrin & $0 / 4$ & 0.04 & 0.00 & $0.03 / 0.04 \mu \mathrm{g} / \mathrm{L}$ \\
\hline Endosulfan sulfate & $0 / 4$ & 0.04 & 0.00 & $0.03 / 0.04 \mu \mathrm{g} / \mathrm{L}$ \\
\hline Endosulfan I & $0 / 4$ & 0.02 & 0.00 & $0.02 / 0.02 \mu \mathrm{g} / \mathrm{L}$ \\
\hline Endosulfan II & $0 / 4$ & 0.04 & 0.00 & $0.03 / 0.04 \mu \mathrm{g} / \mathrm{L}$ \\
\hline Endrin & $0 / 4$ & 0.04 & 0.00 & $0.03 / 0.04 \mu \mathrm{g} / \mathrm{L}$ \\
\hline Endrin aldehyde & $0 / 4$ & 0.04 & 0.00 & $0.03 / 0.04 \mu \mathrm{g} / \mathrm{L}$ \\
\hline Endrin ketone & $0 / 4$ & 0.04 & 0.00 & $0.03 / 0.04 \mu \mathrm{g} / \mathrm{L}$ \\
\hline Heptachlor & $0 / 4$ & 0.02 & 0.00 & $0.02 / 0.02 \mu \mathrm{g} / \mathrm{L}$ \\
\hline Heptachlor epoxide & $0 / 4$ & 0.02 & 0.00 & $0.02 / 0.02 \mu \mathrm{g} / \mathrm{L}$ \\
\hline Lindane & $0 / 4$ & 0.02 & 0.00 & $0.02 / 0.02 \mu \mathrm{g} / \mathrm{L}$ \\
\hline Methoxychlor & $0 / 4$ & 0.19 & 0.02 & $0.16 / 0.20 \mu \mathrm{g} / \mathrm{L}$ \\
\hline Toxaphene & $0 / 4$ & 0.95 & 0.10 & $0.80 / 1.0 \mu \mathrm{g} / \mathrm{L}$ \\
\hline \multicolumn{5}{|l|}{ EPA8082 } \\
\hline PCB 1016 & $0 / 4$ & 0.10 & 0.0 & $0.10 / 0.10 \mu \mathrm{g} / \mathrm{L}$ \\
\hline PCB 1221 & $0 / 4$ & 0.10 & 0.0 & $0.10 / 0.10 \mu \mathrm{g} / \mathrm{L}$ \\
\hline PCB 1232 & $0 / 4$ & 0.10 & 0.0 & $0.10 / 0.10 \mu \mathrm{g} / \mathrm{L}$ \\
\hline РСВ 1242 & $0 / 4$ & 0.10 & 0.0 & $0.10 / 0.10 \mu \mathrm{g} / \mathrm{L}$ \\
\hline PCB 1248 & $0 / 4$ & 0.10 & 0.0 & $0.10 / 0.10 \mu \mathrm{g} / \mathrm{L}$ \\
\hline РСВ 1254 & $0 / 4$ & 0.10 & 0.0 & $0.10 / 0.10 \mu \mathrm{g} / \mathrm{L}$ \\
\hline PCB 1260 & $0 / 5$ & 0.10 & 0.0 & $0.10 / 0.10 \mu \mathrm{g} / \mathrm{L}$ \\
\hline \multicolumn{5}{|l|}{ EPA8260B } \\
\hline Acetone & $0 / 12$ & 46.3 & 143 & $5.0 / 500 \mu \mathrm{g} / \mathrm{L}$ \\
\hline Benzene & $0 / 19$ & 6.21 & 22.7 & $1.0 / 100 \mu \mathrm{g} / \mathrm{L}$ \\
\hline Bromodichloromethane & $0 / 19$ & 6.21 & 22.7 & $1.0 / 100 \mu \mathrm{g} / \mathrm{L}$ \\
\hline Bromoform & $0 / 19$ & 6.21 & 22.7 & $1.0 / 100 \mu \mathrm{g} / \mathrm{L}$ \\
\hline Bromomethane & $0 / 19$ & 6.21 & 22.7 & $1.0 / 100 \mu \mathrm{g} / \mathrm{L}$ \\
\hline Carbon disulfide & $0 / 12$ & 46.3 & 143 & $5.0 / 500 \mu \mathrm{g} / \mathrm{L}$ \\
\hline Carbon tetrachloride & $0 / 19$ & 6.21 & 22.7 & $1.0 / 100 \mu \mathrm{g} / \mathrm{L}$ \\
\hline Chlorobenzene & $0 / 19$ & 6.21 & 22.7 & $1.0 / 100 \mu \mathrm{g} / \mathrm{L}$ \\
\hline Chloroethane & $0 / 19$ & 6.21 & 22.7 & $1.0 / 100 \mu \mathrm{g} / \mathrm{L}$ \\
\hline Chloroethene & $0 / 19$ & 6.21 & 22.7 & $1.0 / 100 \mu \mathrm{g} / \mathrm{L}$ \\
\hline 2-Chloroethyl vinyl ether & $0 / 14$ & 40.4 & 132 & $5.0 / 500 \mu \mathrm{g} / \mathrm{L}$ \\
\hline Chloroform & $0 / 19$ & 6.21 & 22.7 & $1.0 / 100 \mu \mathrm{g} / \mathrm{L}$ \\
\hline Chloromethane & $0 / 19$ & 6.21 & 22.7 & $1.0 / 100 \mu \mathrm{g} / \mathrm{L}$ \\
\hline Dibromochloromethane & $0 / 19$ & 6.21 & 22.7 & $1.0 / 100 \mu \mathrm{g} / \mathrm{L}$ \\
\hline 1,1-Dichloroethane & $0 / 19$ & 6.21 & 22.7 & $1.0 / 100 \mu \mathrm{g} / \mathrm{L}$ \\
\hline 1,2-Dichloroethane & $0 / 19$ & 6.21 & 22.7 & $1.0 / 100 \mu \mathrm{g} / \mathrm{L}$ \\
\hline 1,1-Dichloroethylene & $0 / 19$ & 6.21 & 22.7 & $1.0 / 100 \mu \mathrm{g} / \mathrm{L}$ \\
\hline 1,2-Dichloroethylene & $0 / 12$ & 18.5 & 57.2 & $2.0 / 200 \mu \mathrm{g} / \mathrm{L}$ \\
\hline
\end{tabular}




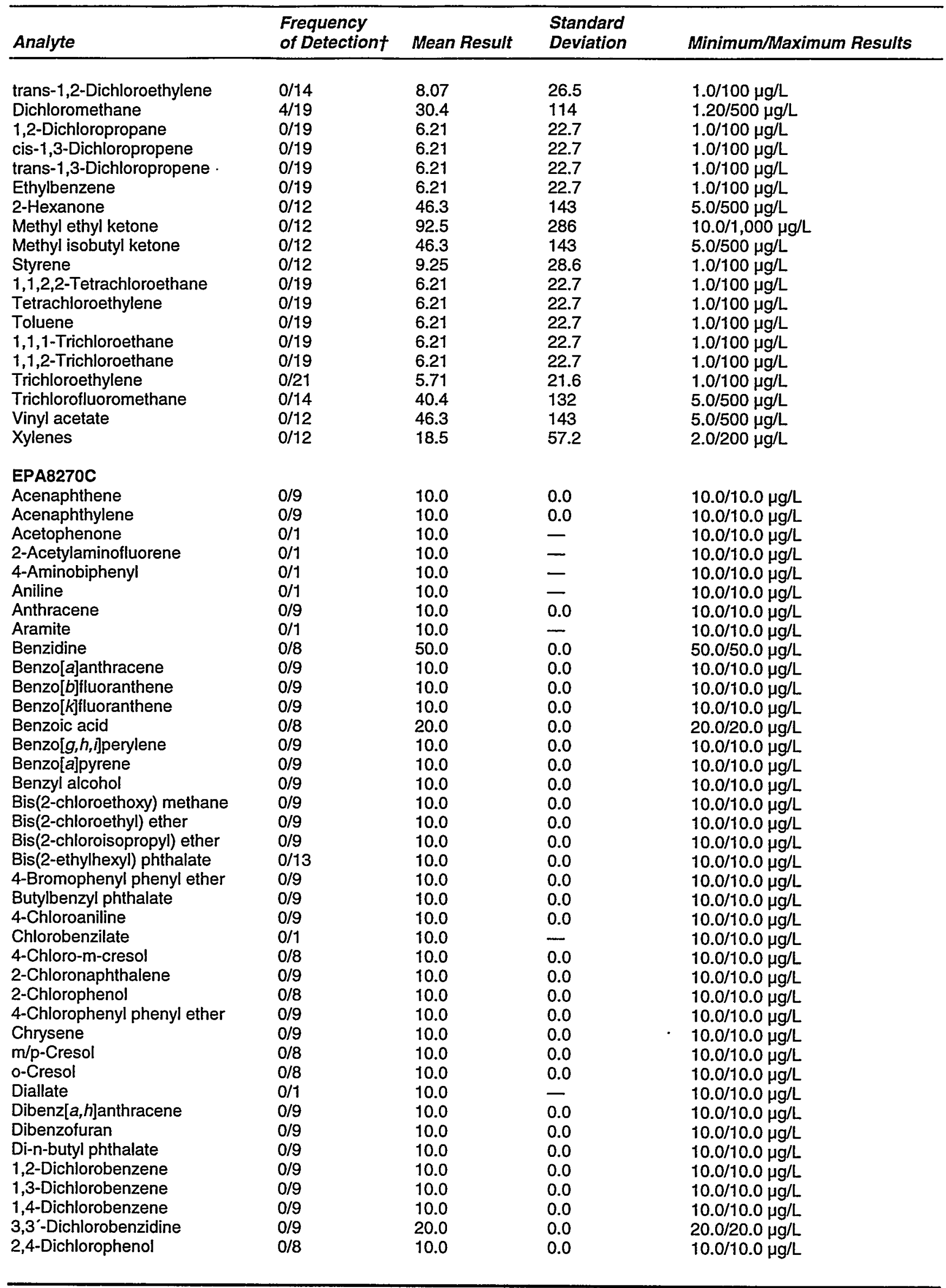




\begin{tabular}{|c|c|c|c|c|c|}
\hline Analyte & $\begin{array}{l}\text { Frequency } \\
\text { of Detectiont }\end{array}$ & Mean Result & $\begin{array}{l}\text { Standard } \\
\text { Deviation }\end{array}$ & Minimum/Maximum & Results \\
\hline Diethyl phthalate & $0 / 9$ & 10.0 & 0.0 & $10.0 / 10.0 \mu \mathrm{g} / \mathrm{L}$ & \\
\hline Dimethoate & $0 / 1$ & 10.0 & 一 & 10.0/10.0 $\mu \mathrm{g} / \mathrm{L}$ & \\
\hline 2,4-Dimethyl phenol & $0 / 8$ & 10.0 & 0.0 & 10.0/10.0 $\mu \mathrm{g} / \mathrm{L}$ & \\
\hline Dimethyl phthalate & $0 / 9$ & 10.0 & 0.0 & $10.0 / 10.0 \mu \mathrm{g} / \mathrm{L}$ & $;:$ \\
\hline p-Dimethylaminoazobenzene & $0 / 1$ & 10.0 & - & $10.0 / 10.0 \mu \mathrm{g} / \mathrm{L}$ & \\
\hline 7,12-Dimethylbenz[a]anthracene & $0 / 1$ & 10.0 & - & $10.0 / 10.0 \mu \mathrm{g} / \mathrm{L}$ & \\
\hline 3,3'-Dimethylbenzidine & $0 / 1$ & 20.0 & 一 & $20.0 / 20.0 \mu \mathrm{g} / \mathrm{L}$ & \\
\hline a,a-Dimethylphenethylamine & $0 / 1$ & 10.0 & - & $10.0 / 10.0 \mu g / L$ & \\
\hline 1,3-Dinitrobenzene & $0 / 1$ & 10.0 & - & 10.0/10.0 $\mu \mathrm{g} / \mathrm{L}$ & \\
\hline 2,4-Dinitrophenol & $0 / 8$ & 20.0 & 0.0 & 20.0/20.0 $\mu \mathrm{g} / \mathrm{L}$ & \\
\hline 2,4-Dinitrotoluene & $0 / 9$ & 10.0 & 0.0 & $10.0 / 10.0 \mu \mathrm{g} / \mathrm{L}$ & \\
\hline 2,6-Dinitrotoluene & $0 / 9$ & 10.0 & 0.0 & $10.0 / 10.0 \mu \mathrm{g} / \mathrm{L}$ & \\
\hline Di-n-octyl phthalate & $0 / 9$ & 10.0 & 0.0 & $10.0 / 10.0 \mu \mathrm{g} / \mathrm{L}$ & \\
\hline 1,4-Dioxane & $0 / 1$ & 10.0 & - & $10.0 / 10.0 \mu \mathrm{g} / \mathrm{L}$ & \\
\hline Diphenylamine & $0 / 1$ & 10.0 & - & $10.0 / 10.0 \mu \mathrm{g} / \mathrm{L}$ & \\
\hline Disulfoton & $0 / 1$ & 10.0 & 一 & $10.0 / 10.0 \mu \mathrm{g} / \mathrm{L}$ & \\
\hline Ethyl methacrylate & $0 / 1$ & 10.0 & 一 & $10.0 / 10.0 \mu \mathrm{g} / \mathrm{L}$ & \\
\hline Ethyl methanesulfonate & $0 / 1$ & 10.0 & - & $10.0 / 10.0 \mu \mathrm{g} / \mathrm{L}$ & \\
\hline Famphur & $0 / 1$ & 10.0 & - & $10.0 / 10.0 \mu \mathrm{g} / \mathrm{L}$ & \\
\hline Fluoranthene & $0 / 9$ & 10.0 & 0.0 & 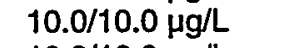 & \\
\hline Fluorene & $0 / 9$ & 10.0 & 0.0 & 10.0/10.0 $\mu \mathrm{g} / \mathrm{L}$ & \\
\hline Hexachlorobenzene & $0 / 9$ & 10.0 & 0.0 & $10.0 / 10.0 \mu \mathrm{g} / \mathrm{L}$ & \\
\hline Hexachlorobutadiene & $0 / 9$ & 10.0 & 0.0 & 10.0/10.0 $\mu \mathrm{g} / \mathrm{L}$ & \\
\hline Hexachlorocyclopentadiene & $0 / 9$ & 10.0 & 0.0 & $10.0 / 10.0 \mu \mathrm{g} / \mathrm{L}$ & \\
\hline Hexachloroethane & $0 / 9$ & 10.0 & 0.0 & $10.0 / 10.0 \mu \mathrm{g} / \mathrm{L}$ & \\
\hline Hexachloropropene & $0 / 1$ & 10.0 & 一 & $10.0 / 10.0 \mu \mathrm{g} / \mathrm{L}$ & \\
\hline Indeno $[1,2,3-c, 0]$ pyrene & $0 / 9$ & 10.0 & 0.0 & $10.0 / 10.0 \mu \mathrm{g} / \mathrm{L}$ & \\
\hline Isodrin & $0 / 1$ & 10.0 & - & 10.0/10.0 $\mu \mathrm{g} / \mathrm{L}$ & \\
\hline Isophorone & $0 / 9$ & 10.0 & 0.0 & $10.0 / 10.0 \mu \mathrm{g} / \mathrm{L}$ & \\
\hline Isosafrole & $0 / 1$ & 10.0 & - & $10.0 / 10.0 \mu \mathrm{g} / \mathrm{L}$ & \\
\hline Kepone & $0 / 1$ & 10.0 & - & $10.0 / 10.0 \mu \mathrm{g} / \mathrm{L}$ & \\
\hline Methapyrilene & $0 / 1$ & 10.0 & - & $10.0 / 10.0 \mu \mathrm{g} / \mathrm{L}$ & \\
\hline 2-Methyl-4,6-dinitrophenol & $0 / 8$ & 10.0 & 0.0 & $10.0 / 10.0 \mu \mathrm{g} / \mathrm{L}$ & \\
\hline Methyl methanesulfonate & $0 / 1$ & 10.0 & - & $10.0 / 10.0 \mu \mathrm{g} / \mathrm{L}$ & \\
\hline 3-Methylcholanthrene & $0 / 1$ & 10.0 & - & $10.0 / 10.0 \mu \mathrm{g} / \mathrm{L}$ & \\
\hline 2-Methylnaphthalene & $0 / 9$ & 10.0 & 0.0 & $10.0 / 10.0 \mu \mathrm{g} / \mathrm{L}$ & \\
\hline Naphthalene & $0 / 9$ & 10.0 & 0.0 & $10.0 / 10.0 \mu g / L$ & \\
\hline 1,4-Naphthoquinone & $0 / 1$ & 10.0 & - & $10.0 / 10.0 \mu \mathrm{g} / \mathrm{L}$ & \\
\hline 1-Naphthylamine & $0 / 1$ & 10.0 & - & $10.0 / 10.0 \mu \mathrm{g} / \mathrm{L}$ & \\
\hline 2-Naphthylamine & $0 / 1$ & 10.0 & - & $10.0 / 10.0 \mu \mathrm{g} / \mathrm{L}$ & \\
\hline m-Nitroaniline & $0 / 9$ & 10.0 & 0.0 & $10.0 / 10.0 \mu \mathrm{g} / \mathrm{L}$ & \\
\hline o-Nitroaniline & $0 / 9$ & 10.0 & 0.0 & $10.0 / 10.0 \mu \mathrm{g} / \mathrm{L}$ & \\
\hline p-Nitroaniline & $0 / 9$ & 10.0 & 0.0 & $10.0 / 10.0 \mu \mathrm{g} / \mathrm{L}$ & \\
\hline Nitrobenzene & $0 / 9$ & 10.0 & 0.0 & 10.0/10.0 $\mu \mathrm{g} / \mathrm{L}$ & \\
\hline 2-Nitrophenol & $0 / 8$ & 10.0 & 0.0 & $10.0 / 10.0 \mu \mathrm{g} / \mathrm{L}$ & \\
\hline 4-Nitrophenol & $0 / 8$ & 10.0 & 0.0 & $10.0 / 10.0 \mu \mathrm{g} / \mathrm{L}$ & \\
\hline 4-Nitroquinoline-1-oxide & $0 / 1$ & 10.0 & - & $10.0 / 10.0 \mu \mathrm{g} / \mathrm{L}$ & \\
\hline N-Nitrosodi-n-butylamine & $0 / 1$ & 10.0 & - & $10.0 / 10.0 \mu \mathrm{g} / \mathrm{L}$ & \\
\hline $\mathrm{N}$-Nitrosodiethylamine & $0 / 1$ & 10.0 & 一 & $10.0 / 10.0 \mu \mathrm{g} / \mathrm{L}$ & \\
\hline N-Nitrosodimethylamine & $0 / 1$ & 10.0 & - & $10.0 / 10.0 \mu \mathrm{g} / \mathrm{L}$ & \\
\hline N-Nitrosodiphenylamine & $0 / 9$ & 10.0 & 0.0 & $10.0 / 10.0 \mu \mathrm{g} / \mathrm{L}$ & \\
\hline $\mathrm{N}$-Nitrosodipropylamine & $0 / 9$ & 10.0 & 0.0 & $10.0 / 10.0 \mu \mathrm{g} / \mathrm{L}$ & \\
\hline $\mathrm{N}$-Nitrosomethylethylamine & $0 / 1$ & 10.0 & - & $10.0 / 10.0 \mu \mathrm{g} / \mathrm{L}$ & \\
\hline N-Nitrosomorpholine & $0 / 1$ & 10.0 & - & $10.0 / 10.0 \mu \mathrm{g} / \mathrm{L}$ & \\
\hline N-Nitrosopiperidine & $0 / 1$ & 10.0 & 一 & $10.0 / 10.0 \mu \mathrm{g} / \mathrm{L}$ & \\
\hline N-Nitrosopyrrolidine & $0 / 1$ & 10.0 & 一 & $10.0 / 10.0 \mu \mathrm{g} / \mathrm{L}$ & \\
\hline 5-Nitro-o-toluidine & $0 / 1$ & 10.0 & - & $10.0 / 10.0 \mu \mathrm{g} / \mathrm{L}$ & \\
\hline Pentachlorobenzene & $0 / 1$ & 10.0 & - & $10.0 / 10.0 \mu \mathrm{g} / \mathrm{L}$ & \\
\hline Pentachloroethane & $0 / 1$ & 10.0 & - & $10.0 / 10.0 \mu \mathrm{g} / \mathrm{L}$ & \\
\hline Pentachloronitrobenzene & $0 / 1$ & 10.0 & - & $10.0 / 10.0 \mu \mathrm{g} / \mathrm{L}$ & \\
\hline Pentachlorophenol & $0 / 8$ & 20.0 & 0.0 & $20.0 / 20.0 \mu \mathrm{g} / \mathrm{L}$ & \\
\hline
\end{tabular}




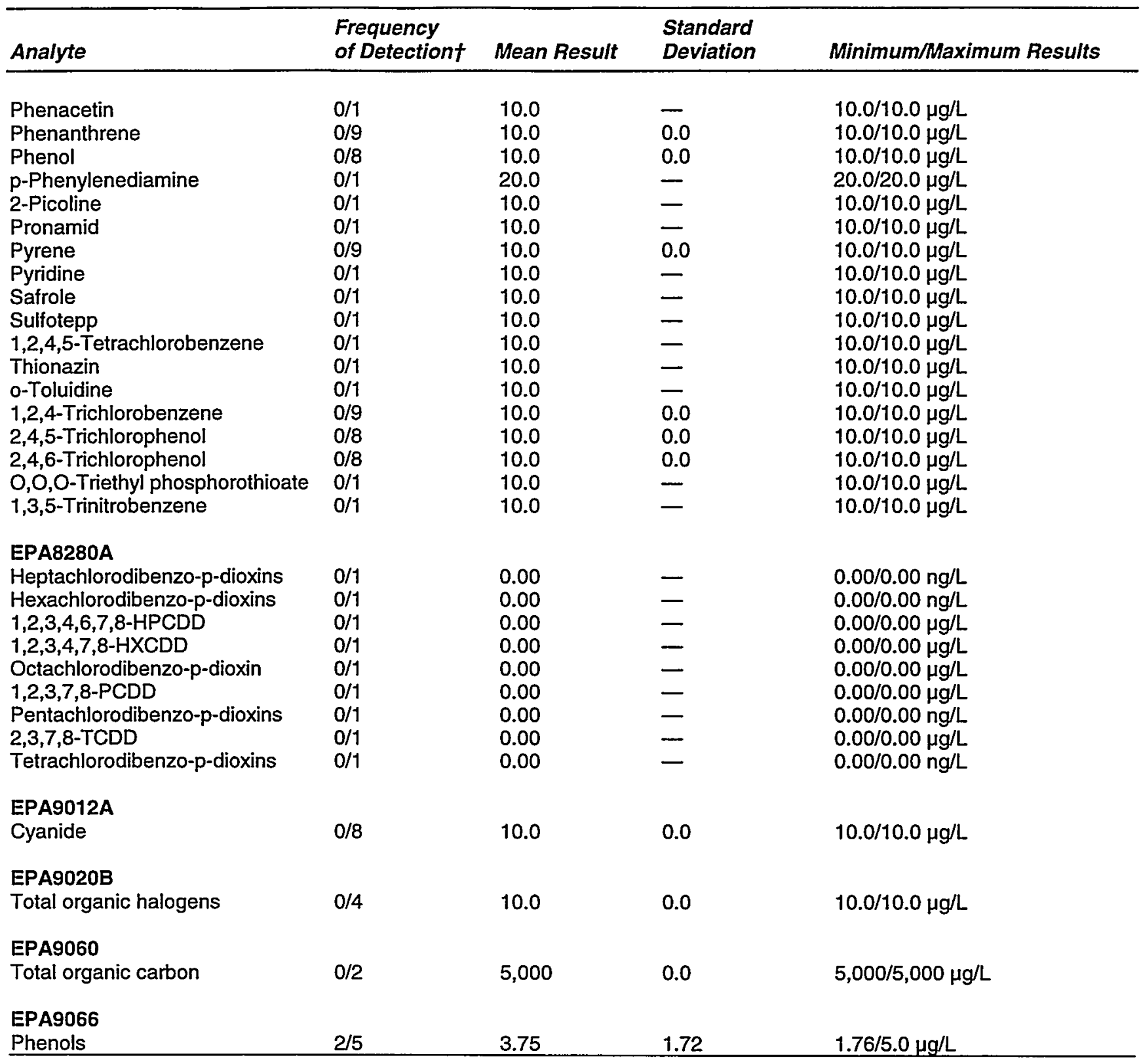

$\dagger$ Number of times analyte was detected compared to the total number of method blanks for the analyte.

- Standard deviation cannot be determined.

Notes: A value of 0 is reported as 0.0 .

Numbers less than 0.004 are reported as 0.00 .

If the analyte was not detected in the method blank(s), detection limit information appears in the Mean Result and Minimum/Maximum Results columns.

Table 58. Analytes Detected in Method Blanks for WA

\begin{tabular}{lllll}
\hline Analyte & $\begin{array}{l}\text { Frequency } \\
\text { of Detectiont }\end{array}$ & Mean Result & $\begin{array}{l}\text { Standard } \\
\text { Deviation }\end{array}$ & Minimum/Maximum Results \\
\hline $\begin{array}{l}\text { EPA160.1 } \\
\text { Total dissolved solids }\end{array}$ & $0 / 16$ & 50,000 & 0.0 & $50,000 / 50,000 \mu \mathrm{g} / \mathrm{L}$ \\
\hline
\end{tabular}




\begin{tabular}{|c|c|c|c|c|}
\hline Analyte & $\begin{array}{l}\text { Frequency } \\
\text { of Detectiont }\end{array}$ & Mean Result & $\begin{array}{l}\text { Standard } \\
\text { Deviation }\end{array}$ & Minimum/Maximum \\
\hline \multicolumn{5}{|l|}{ EPA310.1 } \\
\hline Alkalinity (as $\mathrm{CaCO}_{3}$ ) & $0 / 6$ & 6.70 & 0.0 & $6.70 / 6.70 \mathrm{meq} / \mathrm{L}$ \\
\hline \multicolumn{5}{|l|}{ EPA340.2 } \\
\hline Fluoride & $4 / 4$ & 18.2 & 4.95 & 14.4/24.8 $\mu \mathrm{g} / \mathrm{L}$ \\
\hline \multicolumn{5}{|l|}{ EPA353.2 } \\
\hline Nitrate as nitrogen & $1 / 3$ & 15.3 & 8.08 & $6.0 / 20.0 \mu g / L$ \\
\hline Nitrate-nitrite as nitrogen & $1 / 9$ & 18.0 & 6.0 & $2.0 / 20.0 \mu \mathrm{g} / \mathrm{L}$ \\
\hline \multicolumn{5}{|l|}{ EPA365.2 } \\
\hline Total phosphates (as P) & $0 / 4$ & 67.0 & 0.0 & $67.0 / 67.0 \mu \mathrm{g} / \mathrm{L}$ \\
\hline \multicolumn{5}{|l|}{ EPA410.4 } \\
\hline Chemical oxygen demand & $0 / 1$ & 32,700 & 一 & $32,700 / 32,700 \mu \mathrm{g} / \mathrm{L}$ \\
\hline \multicolumn{5}{|l|}{ EPA418.1 } \\
\hline Total petroleum hydrocarbons & $0 / 1$ & 10,000 & - & $10,000 / 10,000 \mu \mathrm{g} / \mathrm{L}$ \\
\hline \multicolumn{5}{|l|}{ EPA6010B } \\
\hline Aluminum & $5 / 21$ & 117 & 53.1 & $20.1 / 146 \mu \mathrm{g} / \mathrm{L}$ \\
\hline Antimony & $0 / 10$ & 27.0 & 0.0 & $27.0 / 27.0 \mu \mathrm{g} / \mathrm{L}$ \\
\hline Arsenic & $0 / 19$ & 40.0 & 0.0 & $40.0 / 40.0 \mu g / L$ \\
\hline Barium & $12 / 17$ & 0.87 & 0.66 & $0.20 / 1.80 \mu \mathrm{g} / \mathrm{L}$ \\
\hline Beryllium & $0 / 4$ & 1.60 & 0.0 & $1.60 / 1.60 \mu \mathrm{g} / \mathrm{L}$ \\
\hline Boron & $0 / 11$ & 266 & 0.0 & $266 / 266 \mu g / L$ \\
\hline Cadmium & $0 / 18$ & 4.70 & 0.0 & 4.70/4.70 $\mu \mathrm{g} / \mathrm{L}$ \\
\hline Calcium & $0 / 10$ & 471 & 0.0 & $471 / 471 \mu g / L$ \\
\hline Chromium & $2 / 19$ & 6.34 & 1.97 & $0.75 / 7.0 \mu \mathrm{g} / \mathrm{L}$ \\
\hline Cobalt & $2 / 3$ & 2.03 & 2.14 & $0.79 / 4.50 \mu \mathrm{g} / \mathrm{L}$ \\
\hline Copper & $3 / 9$ & 11.4 & 5.90 & $1.50 / 15.0 \mu \mathrm{g} / \mathrm{L}$ \\
\hline Iron & $11 / 24$ & 47.9 & 29.9 & $11.8 / 74.0 \mu \mathrm{g} / \mathrm{L}$ \\
\hline Lead & $0 / 19$ & 47.0 & 0.0 & $47.0 / 47.0 \mu \mathrm{g} / \mathrm{L}$ \\
\hline Lithium & $3 / 12$ & 2.39 & 0.57 & $1.20 / 2.70 \mu \mathrm{g} / \mathrm{L}$ \\
\hline Magnesium & $2 / 10$ & 62.4 & 24.5 & $15.8 / 74.0 \mu \mathrm{g} / \mathrm{L}$ \\
\hline Manganese & $0 / 14$ & 7.80 & 0.0 & $7.80 / 7.80 \mu \mathrm{g} / \mathrm{L}$ \\
\hline Nickel & $0 / 11$ & 26.0 & 0.0 & $26.0 / 26.0 \mu \mathrm{g} / \mathrm{L}$ \\
\hline Potassium & $4 / 11$ & 127 & 83.4 & $18.7 / 187 \mu g / L$ \\
\hline Selenium & $0 / 19$ & 66.0 & 0.0 & $66.0 / 66.0 \mu \mathrm{g} / \mathrm{L}$ \\
\hline Silica & $0 / 6$ & 1,350 & 0.0 & $1,350 / 1,350 \mu \mathrm{g} / \mathrm{L}$ \\
\hline Silver & $0 / 17$ & 5.0 & 0.0 & $5.0 / 5.0 \mu \mathrm{g} / \mathrm{L}$ \\
\hline Sodium & $4 / 11$ & 194 & 126 & $30.9 / 285 \mu \mathrm{g} / \mathrm{L}$ \\
\hline Thallium & $0 / 3$ & 55.0 & 0.0 & $55.0 / 55.0 \mu \mathrm{g} / \mathrm{L}$ \\
\hline Tin & $1 / 6$ & 60.3 & 23.8 & $11.6 / 70.0 \mu \mathrm{g} / \mathrm{L}$ \\
\hline Vanadium & $0 / 3$ & 6.90 & 0.0 & $6.90 / 6.90 \mu \mathrm{g} / \mathrm{L}$ \\
\hline Zinc & $0 / 10$ & 53.0 & 0.0 & $53.0 / 53.0 \mu \mathrm{g} / \mathrm{L}$ \\
\hline \multicolumn{5}{|l|}{ EPA7196A } \\
\hline Chromium, hexavalent & $0 / 1$ & 200 & - & $200 / 200 \mu \mathrm{g} / \mathrm{L}$ \\
\hline \multicolumn{5}{|l|}{ EPA7470A } \\
\hline Mercury & $0 / 15$ & 0.63 & 0.12 & $0.45 / 0.71 \mu \mathrm{g} / \mathrm{L}$ \\
\hline \multicolumn{5}{|l|}{ EPA8021B } \\
\hline Carbon tetrachloride & $0 / 12$ & 1.0 & 0.0 & $1.0 / 1.0 \mu g / L$ \\
\hline Chloroform & $0 / 12$ & 1.0 & 0.0 & $1.0 / 1.0 \mu \mathrm{g} / \mathrm{L}$ \\
\hline cis-1,2-Dichloroethylene & $0 / 10$ & 1.0 & 0.0 & 1.0/1.0 $\mu \mathrm{g} / \mathrm{L}$ \\
\hline Tetrachloroethylene & $0 / 10$ & 1.0 & 0.0 & $1.0 / 1.0 \mu \mathrm{g} / \mathrm{L}$ \\
\hline
\end{tabular}




\begin{tabular}{|c|c|c|c|c|}
\hline Analyte & $\begin{array}{l}\text { Frequency } \\
\text { of Detectiont }\end{array}$ & Mean Result & $\begin{array}{l}\text { Standard } \\
\text { Deviation }\end{array}$ & Minimum/Maximum Results \\
\hline 1,1,1-Trichloroethane & $0 / 12$ & 1.0 & 0.0 & $1.0 / 1.0 \mu g / L$ \\
\hline Trichloroethylene & $0 / 12$ & 1.0 & 0.0 & $1.0 / 1.0 \mu \mathrm{g} / \mathrm{L}$ \\
\hline \multicolumn{5}{|l|}{ EPA8081A } \\
\hline Aldrin & $0 / 2$ & 0.05 & 0.0 & $0.05 / 0.05 \mu \mathrm{g} / \mathrm{L}$ \\
\hline alpha-Benzene hexachloride & $0 / 2$ & 0.05 & 0.0 & $0.05 / 0.05 \mu \mathrm{g} / \mathrm{L}$ \\
\hline beta-Benzene hexachloride & $0 / 2$ & 0.05 & 0.0 & $0.05 / 0.05 \mu \mathrm{g} / \mathrm{L}$ \\
\hline delta-Benzene hexachloride & $0 / 2$ & 0.05 & 0.0 & $0.05 / 0.05 \mu \mathrm{g} / \mathrm{L}$ \\
\hline alpha-Chlordane & $0 / 2$ & 0.05 & 0.0 & $0.05 / 0.05 \mu \mathrm{g} / \mathrm{L}$ \\
\hline gamma-Chlordane & $0 / 2$ & 0.05 & 0.0 & $0.05 / 0.05 \mu g / L$ \\
\hline$p, p^{\prime}-D D D$ & $0 / 2$ & 0.10 & 0.0 & $0.10 / 0.10 \mu \mathrm{g} / \mathrm{L}$ \\
\hline$p, p-D D E$ & $0 / 2$ & 0.10 & 0.0 & $0.10 / 0.10 \mu \mathrm{g} / \mathrm{L}$ \\
\hline p,p'-DDT & $0 / 2$ & 0.10 & 0.0 & $0.10 / 0.10 \mu \mathrm{g} / \mathrm{L}$ \\
\hline Dieldrin & $0 / 2$ & 0.10 & 0.0 & $0.10 / 0.10 \mu \mathrm{g} / \mathrm{L}$ \\
\hline Endosulfan sulfate & $0 / 2$ & 0.10 & 0.0 & $0.10 / 0.10 \mu \mathrm{g} / \mathrm{L}$ \\
\hline Endosulfan I & $0 / 2$ & 0.05 & 0.0 & $0.05 / 0.05 \mu \mathrm{g} / \mathrm{L}$ \\
\hline Endosulfan II & $0 / 2$ & 0.10 & 0.0 & $0.10 / 0.10 \mu \mathrm{g} / \mathrm{L}$ \\
\hline Endrin & $0 / 3$ & 0.10 & 0.0 & $0.10 / 0.10 \mu \mathrm{g} / \mathrm{L}$ \\
\hline Endrin aldehyde & $0 / 2$ & 0.10 & 0.0 & $0.10 / 0.10 \mu \mathrm{g} / \mathrm{L}$ \\
\hline Endrin ketone & $0 / 2$ & 0.10 & 0.0 & $0.10 / 0.10 \mu \mathrm{g} / \mathrm{L}$ \\
\hline Heptachlor & $0 / 2$ & 0.05 & 0.0 & $0.05 / 0.05 \mu \mathrm{g} / \mathrm{L}$ \\
\hline Heptachlor epoxide & $0 / 2$ & 0.05 & 0.0 & $0.05 / 0.05 \mu \mathrm{g} / \mathrm{L}$ \\
\hline Lindane & $0 / 3$ & 0.05 & 0.0 & $0.05 / 0.05 \mu \mathrm{g} / \mathrm{L}$ \\
\hline Methoxychlor & $0 / 2$ & 0.50 & 0.0 & $0.50 / 0.50 \mu \mathrm{g} / \mathrm{L}$ \\
\hline Toxaphene & $0 / 2$ & 5.0 & 0.0 & $5.0 / 5.0 \mu \mathrm{g} / \mathrm{L}$ \\
\hline \multicolumn{5}{|l|}{ EPA8082 } \\
\hline PCB 1016 & $0 / 2$ & 1.0 & 0.0 & $1.0 / 1.0 \mu \mathrm{g} / \mathrm{L}$ \\
\hline PCB 1221 & $0 / 2$ & 2.0 & 0.0 & $2.0 / 2.0 \mu \mathrm{g} / \mathrm{L}$ \\
\hline PCB 1232 & $0 / 2$ & 1.0 & 0.0 & $1.0 / 1.0 \mu \mathrm{g} / \mathrm{L}$ \\
\hline PCB 1242 & $0 / 2$ & 1.0 & 0.0 & $1.0 / 1.0 \mu \mathrm{g} / \mathrm{L}$ \\
\hline PCB 1248 & $0 / 2$ & 1.0 & 0.0 & $1.0 / 1.0 \mu \mathrm{g} / \mathrm{L}$ \\
\hline PCB 1254 & $0 / 2$ & 1.0 & 0.0 & $1.0 / 1.0 \mu \mathrm{g} / \mathrm{L}$ \\
\hline PCB 1260 & $0 / 3$ & 1.0 & 0.0 & $1.0 / 1.0 \mu \mathrm{g} / \mathrm{L}$ \\
\hline \multicolumn{5}{|l|}{ EPA8151A } \\
\hline 2,4-Dichlorophenoxyacetic acid & $0 / 1$ & 1.0 & - & $1.0 / 1.0 \mu \mathrm{g} / \mathrm{L}$ \\
\hline \multicolumn{5}{|l|}{ EPA8260B } \\
\hline Acetone & $1 / 8$ & 9.59 & 1.16 & $6.73 / 10.0 \mu \mathrm{g} / \mathrm{L}$ \\
\hline Acetonitrile & $0 / 4$ & 20.0 & 0.0 & $20.0 / 20.0 \mu \mathrm{g} / \mathrm{L}$ \\
\hline Acrolein & $0 / 4$ & 20.0 & 0.0 & $20.0 / 20.0 \mu \mathrm{g} / \mathrm{L}$ \\
\hline Acrylonitrile & $0 / 4$ & 5.0 & 0.0 & $5.0 / 5.0 \mu \mathrm{g} / \mathrm{L}$ \\
\hline Allyl chloride & $0 / 4$ & 10.0 & 0.0 & $10.0 / 10.0 \mu \mathrm{g} / \mathrm{L}$ \\
\hline Benzene & $0 / 35$ & 5.0 & 0.0 & $5.0 / 5.0 \mu \mathrm{g} / \mathrm{L}$ \\
\hline Bromodichloromethane & $0 / 35$ & 5.0 & 0.0 & $5.0 / 5.0 \mu \mathrm{g} / \mathrm{L}$ \\
\hline Bromoform & $0 / 35$ & 5.0 & 0.0 & $5.0 / 5.0 \mu \mathrm{g} / \mathrm{L}$ \\
\hline Bromomethane & $2 / 35$ & 9.60 & 1.64 & $3.05 / 10.0 \mu \mathrm{g} / \mathrm{L}$ \\
\hline Carbon disulfide & $0 / 8$ & 5.0 & 0.0 & $5.0 / 5.0 \mu \mathrm{g} / \mathrm{L}$ \\
\hline Carbon tetrachloride & $0 / 35$ & 5.0 & 0.0 & $5.0 / 5.0 \mu \mathrm{g} / \mathrm{L}$ \\
\hline Chlorobenzene & $0 / 35$ & 5.0 & 0.0 & $5.0 / 5.0 \mu \mathrm{g} / \mathrm{L}$ \\
\hline Chloroethane & $0 / 35$ & 10.0 & 0.0 & $10.0 / 10.0 \mu \mathrm{g} / \mathrm{L}$ \\
\hline Chloroethene & $0 / 35$ & 10.0 & 0.0 & $10.0 / 10.0 \mu \mathrm{g} / \mathrm{L}$ \\
\hline 2-Chloroethyl vinyl ether & $0 / 29$ & 10.0 & 0.0 & $10.0 / 10.0 \mu \mathrm{g} / \mathrm{L}$ \\
\hline Chloroform & $0 / 35$ & 5.0 & 0.0 & $5.0 / 5.0 \mu \mathrm{g} / \mathrm{L}$ \\
\hline Chloromethane & $1 / 35$ & 9.79 & 1.26 & $2.54 / 10.0 \mu \mathrm{g} / \mathrm{L}$ \\
\hline Chloroprene & $0 / 4$ & 5.0 & 0.0 & $5.0 / 5.0 \mu \mathrm{g} / \mathrm{L}$ \\
\hline Dibromochloromethane & $0 / 35$ & 5.0 & 0.0 & $5.0 / 5.0 \mu \mathrm{g} / \mathrm{L}$ \\
\hline 1,2-Dibromo-3-chloropropane & $0 / 4$ & 5.0 & 0.0 & $5.0 / 5.0 \mu \mathrm{g} / \mathrm{L}$ \\
\hline 1,2-Dibromoethane & $0 / 4$ & 5.0 & 0.0 & $5.0 / 5.0 \mu \mathrm{g} / \mathrm{L}$ \\
\hline Dibromomethane & $0 / 4$ & 5.0 & 0.0 & $5.0 / 5.0 \mu \mathrm{g} / \mathrm{L}$ \\
\hline
\end{tabular}




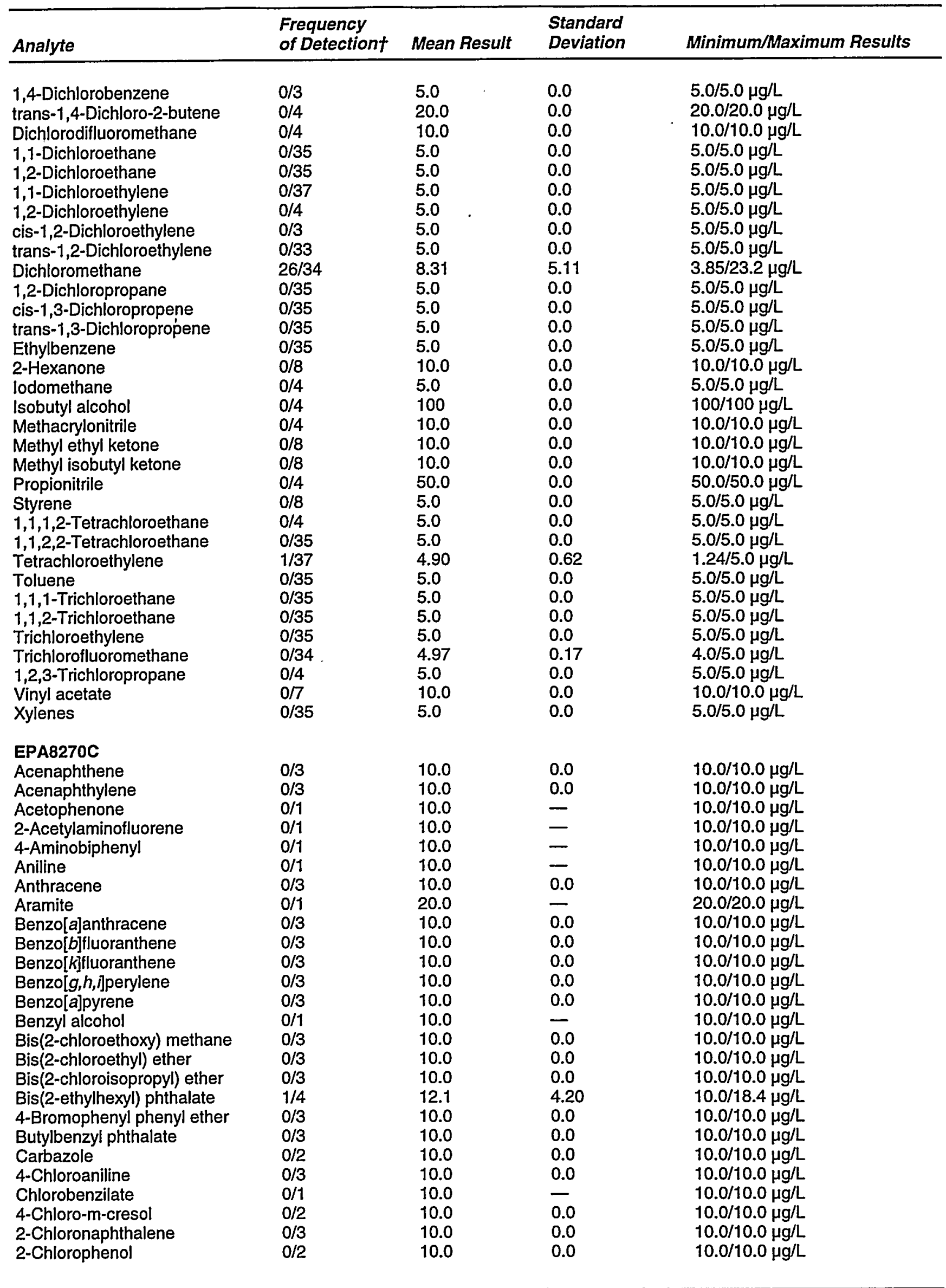




\begin{tabular}{|c|c|c|c|c|}
\hline Analyte & $\begin{array}{l}\text { Frequency } \\
\text { of Detectiont }\end{array}$ & Mean Result & $\begin{array}{l}\text { Standard } \\
\text { Deviation }\end{array}$ & Minimum/Maximum Results \\
\hline 4-Chlorophenyl phenyl ether & $0 / 3$ & 10.0 & 0.0 & $10.0 / 10.0 \mu \mathrm{g} / \mathrm{L}$ \\
\hline Chrysene & $0 / 3$ & 10.0 & 0.0 & $10.0 / 10.0 \mu \mathrm{g} / \mathrm{L}$ \\
\hline o-Cresol & $0 / 2$ & 10.0 & 0.0 & $10.0 / 10.0 \mu \mathrm{g} / \mathrm{L}$ \\
\hline p-Cresol & $0 / 2$ & 10.0 & 0.0 & $10.0 / 10.0 \mu \mathrm{g} / \mathrm{L}$ \\
\hline Diallate & $0 / 1$ & 10.0 & - & $10.0 / 10.0 \mu \mathrm{g} / \mathrm{L}$ \\
\hline Dibenz $[a, h]$ anthracene & $0 / 3$ & 10.0 & 0.0 & $10.0 / 10.0 \mu \mathrm{g} / \mathrm{L}$ \\
\hline Dibenzofuran & $0 / 3$ & 10.0 & 0.0 & $10.0 / 10.0 \mu \mathrm{g} / \mathrm{L}$ \\
\hline Di-n-butyl phthalate & $0 / 3$ & 10.0 & 0.0 & $10.0 / 10.0 \mu \mathrm{g} / \mathrm{L}$ \\
\hline 1,2-Dichlorobenzene & $0 / 3$ & 10.0 & 0.0 & $10.0 / 10.0 \mu g / L$ \\
\hline 1,3-Dichlorobenzene & $0 / 3$ & 10.0 & 0.0 & $10.0 / 10.0 \mu \mathrm{g} / \mathrm{L}$ \\
\hline 1,4-Dichlorobenzene & $0 / 3$ & 10.0 & 0.0 & $10.0 / 10.0 \mu \mathrm{g} / \mathrm{L}$ \\
\hline 3,3-Dichlorobenzidine & $0 / 3$ & 16.7 & 5.77 & $10.0 / 20.0 \mu \mathrm{g} / \mathrm{L}$ \\
\hline 2,4-Dichlorophenol & $0 / 2$ & 10.0 & 0.0 & $10.0 / 10.0 \mu \mathrm{g} / \mathrm{L}$ \\
\hline Diethyl phthalate & $0 / 3$ & 10.0 & 0.0 & $10.0 / 10.0 \mu \mathrm{g} / \mathrm{L}$ \\
\hline 2,4-Dimethyl phenol & $0 / 2$ & 10.0 & 0.0 & $10.0 / 10.0 \mu \mathrm{g} / \mathrm{L}$ \\
\hline Dimethyl phthalate & $0 / 3$ & 10.0 & 0.0 & $10.0 / 10.0 \mu \mathrm{g} / \mathrm{L}$ \\
\hline p-Dimethylaminoazobenzene & $0 / 1$ & 10.0 & - & $10.0 / 10.0 \mu \mathrm{g} / \mathrm{L}$ \\
\hline 7,12-Dimethylbenz[a]anthracene & $0 / 1$ & 10.0 & - & $10.0 / 10.0 \mu \mathrm{g} / \mathrm{L}$ \\
\hline 3,3-Dimethylbenzidine & $0 / 1$ & 10.0 & - & $10.0 / 10.0 \mu \mathrm{g} / \mathrm{L}$ \\
\hline a,a-Dimethylphenethylamine & $0 / 1$ & 10.0 & - & $10.0 / 10.0 \mu \mathrm{g} / \mathrm{L}$ \\
\hline 1,3-Dinitrobenzene & $0 / 1$ & 10.0 & - & $10.0 / 10.0 \mu \mathrm{g} / \mathrm{L}$ \\
\hline 2,4-Dinitrophenol & $0 / 2$ & 25.0 & 0.0 & $25.0 / 25.0 \mu \mathrm{g} / \mathrm{L}$ \\
\hline 2,4-Dinitrotoluene & $0 / 3$ & 10.0 & 0.0 & $10.0 / 10.0 \mu \mathrm{g} / \mathrm{L}$ \\
\hline 2,6-Dinitrotoluene & $0 / 3$ & 10.0 & 0.0 & $10.0 / 10.0 \mu \mathrm{g} / \mathrm{L}$ \\
\hline Di-n-octyl phthalate & $0 / 3$ & 10.0 & 0.0 & $10.0 / 10.0 \mu g / L$ \\
\hline 1,4-Dioxane & $0 / 1$ & 10.0 & - & $10.0 / 10.0 \mu g / L$ \\
\hline Diphenylamine & $0 / 1$ & 10.0 & - & $10.0 / 10.0 \mu \mathrm{g} / \mathrm{L}$ \\
\hline Ethyl methacrylate & $0 / 1$ & 10.0 & 一 & $10.0 / 10.0 \mu \mathrm{g} / \mathrm{L}$ \\
\hline Ethyl methanesulfonate & $0 / 1$ & 10.0 & - & $10.0 / 10.0 \mu \mathrm{g} / \mathrm{L}$ \\
\hline Fluoranthene & $0 / 3$ & 10.0 & 0.0 & $10.0 / 10.0 \mu \mathrm{g} / \mathrm{L}$ \\
\hline Fluorene & $0 / 3$ & 10.0 & 0.0 & $10.0 / 10.0 \mu \mathrm{g} / \mathrm{L}$ \\
\hline Hexachlorobenzene & $0 / 3$ & 10.0 & 0.0 & $10.0 / 10.0 \mu \mathrm{g} / \mathrm{L}$ \\
\hline Hexachlorobutadiene & $0 / 3$ & 10.0 & 0.0 & $10.0 / 10.0 \mu g / L$ \\
\hline Hexachlorocyclopentadiene & $0 / 3$ & 10.0 & 0.0 & $10.0 / 10.0 \mu \mathrm{g} / \mathrm{L}$ \\
\hline Hexachloroethane & $0 / 3$ & 10.0 & 0.0 & $10.0 / 10.0 \mu \mathrm{g} / \mathrm{L}$ \\
\hline Hexachlorophene & $0 / 1$ & 100 & - & $100 / 100 \mu \mathrm{g} / \mathrm{L}$ \\
\hline Hexachloropropene & $0 / 1$ & 10.0 & - & $10.0 / 10.0 \mu \mathrm{g} / \mathrm{L}$ \\
\hline Indeno $[1,2,3-c, d]$ pyrene & $0 / 3$ & 10.0 & 0.0 & $10.0 / 10.0 \mu \mathrm{g} / \mathrm{L}$ \\
\hline Isophorone & $0 / 3$ & 10.0 & 0.0 & $10.0 / 10.0 \mu \mathrm{g} / \mathrm{L}$ \\
\hline Isosafrole & $0 / 1$ & 10.0 & - & $10.0 / 10.0 \mu \mathrm{g} / \mathrm{L}$ \\
\hline Methapyrilene & $0 / 1$ & 10.0 & - & $10.0 / 10.0 \mu \mathrm{g} / \mathrm{L}$ \\
\hline 2-Methyl-4,6-dinitrophenol & $0 / 2$ & 25.0 & 0.0 & $25.0 / 25.0 \mu \mathrm{g} / \mathrm{L}$ \\
\hline Methyl methacrylate & $0 / 1$ & 10.0 & - & $10.0 / 10.0 \mu \mathrm{g} / \mathrm{L}$ \\
\hline Methyl methanesulfonate & $0 / 1$ & 10.0 & - & $10.0 / 10.0 \mu \mathrm{g} / \mathrm{L}$ \\
\hline 3-Methyicholanthrene & $0 / 1$ & 10.0 & - & $10.0 / 10.0 \mu \mathrm{g} / \mathrm{L}$ \\
\hline 2-Methylnaphthalene & $0 / 3$ & 10.0 & 0.0 & $10.0 / 10.0 \mu \mathrm{g} / \mathrm{L}$ \\
\hline Naphthalene & $0 / 3$ & 10.0 & 0.0 & $10.0 / 10.0 \mu \mathrm{g} / \mathrm{L}$ \\
\hline 1,4-Naphthoquinone & $0 / 1$ & 10.0 & - & $10.0 / 10.0 \mu \mathrm{g} / \mathrm{L}$ \\
\hline 1-Naphthylamine & $0 / 1$ & 10.0 & - & $10.0 / 10.0 \mu \mathrm{g} / \mathrm{L}$ \\
\hline 2-Naphthylamine & $0 / 1$ & 10.0 & - & $10.0 / 10.0 \mu \mathrm{g} / \mathrm{L}$ \\
\hline m-Nitroaniline & $0 / 3$ & 25.0 & 0.0 & $25.0 / 25.0 \mu \mathrm{g} / \mathrm{L}$ \\
\hline o-Nitroaniline & $0 / 3$ & 25.0 & 0.0 & $25.0 / 25.0 \mu g / L$ \\
\hline p-Nitroaniline & $0 / 3$ & 25.0 & 0.0 & $25.0 / 25.0 \mu \mathrm{g} / \mathrm{L}$ \\
\hline Nitrobenzene & $0 / 3$ & 10.0 & 0.0 & $10.0 / 10.0 \mu \mathrm{g} / \mathrm{L}$ \\
\hline 2-Nitrophenol & $0 / 2$ & 10.0 & 0.0 & $10.0 / 10.0 \mu \mathrm{g} / \mathrm{L}$ \\
\hline 4-Nitrophenol & $0 / 2$ & 25.0 & 0.0 & $25.0 / 25.0 \mu \mathrm{g} / \mathrm{L}$ \\
\hline 4-Nitroquinoline-1-oxide & $0 / 1$ & 20.0 & - & $20.0 / 20.0 \mu \mathrm{g} / \mathrm{L}$ \\
\hline N-Nitrosodi-n-butylamine & $0 / 1$ & 10.0 & - & $10.0 / 10.0 \mu \mathrm{g} / \mathrm{L}$ \\
\hline N-Nitrosodiethylamine & $0 / 1$ & 10.0 & - & $10.0 / 10.0 \mu \mathrm{g} / \mathrm{L}$ \\
\hline N-Nitrosodimethylamine & $0 / 1$ & 10.0 & - & $10.0 / 10.0 \mu \mathrm{g} / \mathrm{L}$ \\
\hline N-Nitrosodiphenylamine & $0 / 3$ & 10.0 & 0.0 & $10.0 / 10.0 \mu \mathrm{g} / \mathrm{L}$ \\
\hline
\end{tabular}




\begin{tabular}{|c|c|c|c|c|}
\hline Analyte & $\begin{array}{l}\text { Frequency } \\
\text { of Detectiont }\end{array}$ & Mean Result & $\begin{array}{l}\text { Standard } \\
\text { Deviation }\end{array}$ & Minimum/Maximum Results \\
\hline $\begin{array}{l}\text { N-Nitrosodipropylamine } \\
\text { N-Nitrosomethylethylamine } \\
\text { N-Nitrosomorpholine } \\
\text { N-Nitrosopiperidine } \\
\text { N-Nitrosopyrrolidine } \\
\text { 5-Nitro-o-toluidine } \\
\text { Pentachlorobenzene } \\
\text { Pentachloroethane } \\
\text { Pentachloronitrobenzene } \\
\text { Pentachlorophenol } \\
\text { Phenacetin } \\
\text { Phenanthrene } \\
\text { Phenol } \\
\text { p-Phenylenediamine } \\
\text { 2-Picoline } \\
\text { Pronamid } \\
\text { Pyrene } \\
\text { Pyridine } \\
\text { Safrole } \\
\text { 1,2,4,5-Tetrachlorobenzene } \\
\text { o-Toluidine } \\
\text { 1,2,4-Trichlorobenzene } \\
\text { 2,4,5-Trichlorophenol } \\
\text { 2,4,6-Trichlorophenol } \\
\text { 1,3,5-Trinitrobenzene }\end{array}$ & $\begin{array}{l}0 / 3 \\
0 / 1 \\
0 / 1 \\
0 / 1 \\
0 / 1 \\
0 / 1 \\
0 / 1 \\
0 / 1 \\
0 / 1 \\
0 / 2 \\
0 / 1 \\
0 / 3 \\
0 / 3 \\
0 / 1 \\
0 / 1 \\
0 / 1 \\
0 / 3 \\
0 / 1 \\
0 / 1 \\
0 / 1 \\
0 / 1 \\
0 / 3 \\
0 / 2 \\
0 / 2 \\
0 / 1\end{array}$ & $\begin{array}{l}10.0 \\
10.0 \\
10.0 \\
50.0 \\
10.0 \\
10.0 \\
10.0 \\
10.0 \\
50.0 \\
25.0 \\
10.0 \\
10.0 \\
10.0 \\
10.0 \\
10.0 \\
10.0 \\
10.0 \\
10.0 \\
10.0 \\
10.0 \\
10.0 \\
10.0 \\
25.0 \\
10.0 \\
10.0\end{array}$ & $\begin{array}{l}0.0 \\
= \\
= \\
= \\
= \\
\overline{-} \\
\frac{0.0}{0.0} \\
0.0 \\
= \\
\overline{0} \\
= \\
\overline{-} \\
\overline{0} \\
0.0 \\
0.0 \\
0.0\end{array}$ & $\begin{array}{l}10.0 / 10.0 \mu g / L \\
10.0 / 10.0 \mu g / L \\
10.0 / 10.0 \mu g / L \\
50.0 / 50.0 \mu g / L \\
10.0 / 10.0 \mu g / L \\
10.0 / 10.0 \mu g / L \\
10.0 / 10.0 \mu g / L \\
10.0 / 10.0 \mu g / L \\
50.0 / 50.0 \mu g / L \\
25.0 / 25.0 \mu g / L \\
10.0 / 10.0 \mu g / L \\
10.0 / 10.0 \mu g / L \\
10.0 / 10.0 \mu g / L \\
10.0 / 10.0 \mu g / L \\
10.0 / 10.0 \mu g / L \\
10.0 / 10.0 \mu g / L \\
10.0 / 10.0 \mu g / L \\
10.0 / 10.0 \mu g / L \\
10.0 / 10.0 \mu g / L \\
10.0 / 10.0 \mu g / L \\
10.0 / 10.0 \mu g / L \\
10.0 / 10.0 \mu g / L \\
25.0 / 25.0 \mu g / L \\
10.0 / 10.0 \mu g / L \\
10.0 / 10.0 \mu g / L\end{array}$ \\
\hline $\begin{array}{l}\text { EPA8280A } \\
\text { Octachlorodibenzo-p-dioxin }\end{array}$ & $0 / 1$ & 2.60 & - & $2.60 / 2.60 \mathrm{ng} / \mathrm{L}$ \\
\hline $\begin{array}{l}\text { EPA9014 } \\
\text { Cyanide }\end{array}$ & $0 / 4$ & 15.2 & 0.0 & $15.2 / 15.2 \mu \mathrm{g} / \mathrm{L}$ \\
\hline $\begin{array}{l}\text { EPA9020B } \\
\text { Total organic halogens }\end{array}$ & $0 / 48$ & 120 & 0.0 & $120 / 120 \mu g / L$ \\
\hline $\begin{array}{l}\text { EPA9050A } \\
\text { Specific conductance }\end{array}$ & $0 / 6$ & 8.90 & 0.0 & $8.90 / 8.90 \mu \mathrm{S} / \mathrm{cm}$ \\
\hline $\begin{array}{l}\text { EPA9056 } \\
\text { Chloride } \\
\text { Sulfate }\end{array}$ & $\begin{array}{l}0 / 4 \\
2 / 10\end{array}$ & $\begin{array}{l}210 \\
296\end{array}$ & $\begin{array}{l}0.0 \\
93.2\end{array}$ & $\begin{array}{l}210 / 210 \mu g / L \\
119 / 340 \mu g / L\end{array}$ \\
\hline $\begin{array}{l}\text { EPA9060 } \\
\text { Total organic carbon }\end{array}$ & $4 / 13$ & 730 & 422 & $114 / 1,000 \mu \mathrm{g} / \mathrm{L}$ \\
\hline $\begin{array}{l}\text { EPA9066 } \\
\text { Phenols }\end{array}$ & $0 / 5$ & 37.0 & 0.0 & $37.0 / 37.0 \mu \mathrm{g} / \mathrm{L}$ \\
\hline
\end{tabular}

$\dagger$ Number of times analyte was detected compared to the total number of method blanks for the analyte.

- Standard deviation cannot be determined.

Note: If the analyte was not detected in the method blank(s), detection limit information appears in the Mean Result and Minimum/Maximum Results columns. 
Table 59. Analytes Detected in Method Blanks for ML

\begin{tabular}{|c|c|c|c|c|}
\hline Analyte & $\begin{array}{l}\text { Frequency } \\
\text { of Detectiont }\end{array}$ & Mean Result & $\begin{array}{l}\text { Standard } \\
\text { Deviation }\end{array}$ & Minimum/Maximum Results \\
\hline \multicolumn{5}{|l|}{ EPA8260B } \\
\hline Acetone & $1 / 1$ & 5.70 & - & $5.70 / 5.70 \mu \mathrm{g} / \mathrm{L}$ \\
\hline Benzene & $0 / 1$ & 1.0 & - & $1.0 / 1.0 \mu \mathrm{g} / \mathrm{L}$ \\
\hline Bromodichloromethane & $0 / 1$ & 1.0 & - & $1.0 / 1.0 \mu \mathrm{g} / \mathrm{L}$ \\
\hline Bromoform & $0 / 1$ & 1.0 & - & $1.0 / 1.0 \mu \mathrm{g} / \mathrm{L}$ \\
\hline Bromomethane & $0 / 1$ & 1.0 & - & $1.0 / 1.0 \mu \mathrm{g} / \mathrm{L}$ \\
\hline Carbon disulfide & $0 / 1$ & 5.0 & - & $5.0 / 5.0 \mu \mathrm{g} / \mathrm{L}$ \\
\hline Carbon tetrachloride & $0 / 1$ & 1.0 & - & $1.0 / 1.0 \mu \mathrm{g} / \mathrm{L}$ \\
\hline Chlorobenzene & $0 / 1$ & 1.0 & - & $1.0 / 1.0 \mu \mathrm{g} / \mathrm{L}$ \\
\hline Chloroethane & $0 / 1$ & 1.0 & - & $1.0 / 1.0 \mu \mathrm{g} / \mathrm{L}$ \\
\hline Chloroethene & $0 / 1$ & 1.0 & - & $1.0 / 1.0 \mu \mathrm{g} / \mathrm{L}$ \\
\hline Chloroform & $0 / 1$ & 1.0 & - & $1.0 / 1.0 \mu \mathrm{g} / \mathrm{L}$ \\
\hline Chloromethane & $0 / 1$ & 1.0 & - & $1.0 / 1.0 \mu \mathrm{g} / \mathrm{L}$ \\
\hline Dibromochloromethane & $0 / 1$ & 1.0 & - & $1.0 / 1.0 \mu \mathrm{g} / \mathrm{L}$ \\
\hline 1,1 -Dichloroethane & $0 / 1$ & 1.0 & - & $1.0 / 1.0 \mu \mathrm{g} / \mathrm{L}$ \\
\hline 1,2-Dichloroethane & $0 / 1$ & 1.0 & - & $1.0 / 1.0 \mu \mathrm{g} / \mathrm{L}$ \\
\hline 1,1-Dichloroethylene & $0 / 1$ & 1.0 & - & $1.0 / 1.0 \mu \mathrm{g} / \mathrm{L}$ \\
\hline 1,2-Dichloroethylene & $0 / 1$ & 1.0 & - & $1.0 / 1.0 \mu \mathrm{g} / \mathrm{L}$ \\
\hline cis-1,2-Dichloroethylene & $0 / 1$ & 1.0 & - & $1.0 / 1.0 \mu \mathrm{g} / \mathrm{L}$ \\
\hline trans-1,2-Dichloroethylene & $0 / 1$ & 1.0 & - & $1.0 / 1.0 \mu \mathrm{g} / \mathrm{L}$ \\
\hline Dichloromethane & $1 / 1$ & 2.63 & - & $2.63 / 2.63 \mu \mathrm{g} / \mathrm{L}$ \\
\hline 1,2-Dichloropropane & $0 / 1$ & 1.0 & - & $1.0 / 1.0 \mu \mathrm{g} / \mathrm{L}$ \\
\hline cis-1,3-Dichloropropene & $0 / 1$ & 1.0 & - & $1.0 / 1.0 \mu \mathrm{g} / \mathrm{L}$ \\
\hline trans-1,3-Dichloropropene & $0 / 1$ & 1.0 & - & $1.0 / 1.0 \mu \mathrm{g} / \mathrm{L}$ \\
\hline Ethylbenzene & $0 / 1$ & 1.0 & - & $1.0 / 1.0 \mu \mathrm{g} / \mathrm{L}$ \\
\hline 2-Hexanone & $0 / 1$ & 5.0 & - & $5.0 / 5.0 \mu \mathrm{g} / \mathrm{L}$ \\
\hline Methyl ethyl ketone & $0 / 1$ & 5.0 & - & $5.0 / 5.0 \mu \mathrm{g} / \mathrm{L}$ \\
\hline Methyl isobutyl ketone & $0 / 1$ & 5.0 & - & $5.0 / 5.0 \mu \mathrm{g} / \mathrm{L}$ \\
\hline Styrene & $0 / 1$ & 1.0 & - & $1.0 / 1.0 \mu \mathrm{g} / \mathrm{L}$ \\
\hline $1,1,2,2$-Tetrachloroethane & $0 / 1$ & 1.0 & - & $1.0 / 1.0 \mu \mathrm{g} / \mathrm{L}$ \\
\hline Tetrachloroethylene & $0 / 1$ & 1.0 & - & $1.0 / 1.0 \mu \mathrm{g} / \mathrm{L}$ \\
\hline Toluene & $0 / 1$ & 1.0 & - & $1.0 / 1.0 \mu \mathrm{g} / \mathrm{L}$ \\
\hline 1,1,1-Trichloroethane & $0 / 1$ & 1.0 & - & $1.0 / 1.0 \mu \mathrm{g} / \mathrm{L}$ \\
\hline 1,1,2-Trichloroethane & $0 / 1$ & 1.0 & - & $1.0 / 1.0 \mu \mathrm{g} / \mathrm{L}$ \\
\hline Trichloroethylene & $0 / 1$ & 1.0 & - & $1.0 / 1.0 \mu \mathrm{g} / \mathrm{L}$ \\
\hline Vinyl acetate & $0 / 1$ & 5.0 & - & $5.0 / 5.0 \mu \mathrm{g} / \mathrm{L}$ \\
\hline Xylenes & $0 / 1$ & 1.0 & - & $1.0 / 1.0 \mu \mathrm{g} / \mathrm{L}$ \\
\hline
\end{tabular}

$\dagger$ Number of times analyte was detected compared to the total number of method blanks for the analyte.

- Standard deviation cannot be determined.

Note: If the analyte was not detected in the method blank(s), detection limit information appears in the Mean Result and Minimum/Maximum Results columns.

Table 60. Analytes Detected in Method Blanks for GP

\begin{tabular}{lllll}
\hline Analyte & $\begin{array}{l}\text { Frequency } \\
\text { of Detectiont }\end{array}$ & Mean Result & $\begin{array}{l}\text { Standard } \\
\text { Deviation }\end{array}$ & Minimum/Maximum Results \\
\hline EPIA-001 & & & & \\
Gross alpha & $0 / 27$ & $1.09 \mathrm{E}-10$ & $2.00 \mathrm{E}-10$ & $-2.69 \mathrm{E}-10 / 5.30 \mathrm{E}-10 \mu \mathrm{Ci} / \mathrm{mL}$ \\
Nonvolatile beta & $0 / 27$ & $1.79 \mathrm{E}-10$ & $3.62 \mathrm{E}-10$ & $-4.58 \mathrm{E}-10 / 7.86 \mathrm{E}-10 \mu \mathrm{Ci} / \mathrm{mL}$
\end{tabular}




\begin{tabular}{|c|c|c|c|c|}
\hline Analyte & $\begin{array}{l}\text { Frequency } \\
\text { of Detectiont }\end{array}$ & Mean Result & $\begin{array}{l}\text { Standard } \\
\text { Deviation }\end{array}$ & Minimum/Maximum Results \\
\hline \multicolumn{5}{|l|}{ EPIA-002 } \\
\hline Tritium & $0 / 23$ & $-2.13 E-08$ & $1.69 E-07$ & $-3.10 \mathrm{E}-07 / 3.22 \mathrm{E}-07 \mu \mathrm{Ci} / \mathrm{mL}$ \\
\hline \multicolumn{5}{|l|}{ EPIA-003 } \\
\hline Carbon-14 & $0 / 11$ & $1.87 \mathrm{E}-09$ & $4.54 \mathrm{E}-09$ & $-5.66 \mathrm{E}-09 / 7.04 \mathrm{E}-09 \mu \mathrm{Ci} / \mathrm{mL}$ \\
\hline \multicolumn{5}{|l|}{ EPIA-004 } \\
\hline Strontium-89/90 & $0 / 4$ & $4.60 \mathrm{E}-10$ & $2.22 E-10$ & 2.33E-10/6.50E-10 $\mu \mathrm{Ci} / \mathrm{mL}$ \\
\hline Strontium-90 & $0 / 10$ & $1.09 E-10$ & $5.27 \mathrm{E}-10$ & $-4.42 \mathrm{E}-10 / 9.14 \mathrm{E}-10 \mu \mathrm{Ci} / \mathrm{mL}$ \\
\hline \multicolumn{5}{|l|}{ EPIA-005 } \\
\hline Technetium-99 & $0 / 5$ & $-1.71 E-09$ & 2.73E-09 & $-4.61 \mathrm{E}-09 / 1.96 \mathrm{E}-09 \mu \mathrm{Ci} / \mathrm{mL}$ \\
\hline \multicolumn{5}{|l|}{ EPIA-006 } \\
\hline lodine-129 & $0 / 7$ & $3.44 \mathrm{E}-10$ & $2.68 E-10$ & $1.01 \mathrm{E}-10 / 8.85 \mathrm{E}-10 \mu \mathrm{Ci} / \mathrm{mL}$ \\
\hline \multicolumn{5}{|l|}{ EPIA-008 } \\
\hline Radium-226 & $0 / 8$ & $2.24 \mathrm{E}-10$ & $8.79 E-11$ & $5.21 \mathrm{E}-11 / 3.60 \mathrm{E}-10 \mu \mathrm{Ci} / \mathrm{mL}$ \\
\hline \multicolumn{5}{|l|}{ EPIA-009 } \\
\hline Radium-228 & $0 / 7$ & $-7.46 E-10$ & 1.23E-09 & $-2.80 \mathrm{E}-09 / 2.44 \mathrm{E}-10 \mu \mathrm{Ci} / \mathrm{mL}$ \\
\hline \multicolumn{5}{|l|}{ EPIA-010 } \\
\hline Radium, total alpha-emitting & $0 / 8$ & $-6.25 E-11$ & $2.26 \mathrm{E}-10$ & $-3.00 \mathrm{E}-10 / 4.00 \mathrm{E}-10 \mu \mathrm{Ci} / \mathrm{mL}$ \\
\hline \multicolumn{5}{|l|}{ EPIA-011 } \\
\hline Americium-241 & $0 / 4$ & $8.23 E-12$ & $1.09 \mathrm{E}-11$ & $-2.19 \mathrm{E}-12 / 1.92 \mathrm{E}-11 \mu \mathrm{Ci} / \mathrm{mL}$ \\
\hline Curium-242 & $0 / 4$ & $1.68 \mathrm{E}-11$ & $2.24 \mathrm{E}-11$ & 0.0/4.73E-11 $\mu \mathrm{Ci} / \mathrm{mL}$ \\
\hline Curium-243/244 & $0 / 4$ & $-4.00 E-12$ & $1.42 E-11$ & $-2.38 \mathrm{E}-11 / 9.74 \mathrm{E}-12 \mu \mathrm{Ci} / \mathrm{mL}$ \\
\hline Curium-245/246 & $1 / 4$ & $1.15 \mathrm{E}-11$ & $1.32 \mathrm{E}-11$ & $0.0 / 3.03 \mathrm{E}-11 \mu \mathrm{Ci} / \mathrm{mL}$ \\
\hline Plutonium-238 & $0 / 4$ & $2.89 \mathrm{E}-11$ & $4.18 \mathrm{E}-11$ & $0.0 / 8.87 \mathrm{E}-11 \mu \mathrm{Ci} / \mathrm{mL}$ \\
\hline Plutonium-239/240 & $0 / 4$ & $1.35 \mathrm{E}-11$ & $2.91 \mathrm{E}-11$ & $-4.91 \mathrm{E}-12 / 5.69 \mathrm{E}-11 \mu \mathrm{Ci} / \mathrm{mL}$ \\
\hline Uranium-233/234 & $1 / 6$ & $3.12 \mathrm{E}-11$ & $6.64 \mathrm{E}-11$ & $-3.75 \mathrm{E}-12 / 1.66 \mathrm{E}-10 \mu \mathrm{Ci} / \mathrm{mL}$ \\
\hline Uranium-235 & $0 / 6$ & $7.00 \mathrm{E}-12$ & $7.64 \mathrm{E}-12$ & $-2.31 \mathrm{E}-12 / 1.60 \mathrm{E}-11 \mu \mathrm{Ci} / \mathrm{mL}$ \\
\hline Uranium-238 & $1 / 6$ & $1.43 \mathrm{E}-11$ & $1.41 \mathrm{E}-11$ & 5.32E-12/4.26E-11 $\mu \mathrm{Ci} / \mathrm{mL}$ \\
\hline \multicolumn{5}{|l|}{ EPIA-012 } \\
\hline Thorium-228 & $0 / 4$ & 1.17E-12 & $1.69 E-11$ & $-1.22 \mathrm{E}-11 / 2.35 \mathrm{E}-11 \mu \mathrm{Ci} / \mathrm{mL}$ \\
\hline Thorium-230 & $0 / 4$ & $2.08 \mathrm{E}-11$ & $9.62 \mathrm{E}-12$ & 6.55E-12/2.77E-11 $\mu \mathrm{Ci} / \mathrm{mL}$ \\
\hline Thorium-232 & $0 / 4$ & $2.62 E-12$ & $6.16 \mathrm{E}-12$ & $-1.34 \mathrm{E}-12 / 1.18 \mathrm{E}-11 \mu \mathrm{Ci} / \mathrm{mL}$ \\
\hline \multicolumn{5}{|l|}{ EPIA-013 } \\
\hline Actinium-228 & $0 / 8$ & 5.46E-09 & 2.80E-09 & $-1.44 \mathrm{E}-10 / 8.09 \mathrm{E}-09 \mu \mathrm{Ci} / \mathrm{mL}$ \\
\hline Antimony-125 & $0 / 8$ & $-5.58 E-10$ & 2.43E-09 & $-4.76 \mathrm{E}-09 / 3.08 \mathrm{E}-09 \mu \mathrm{Ci} / \mathrm{mL}$ \\
\hline Cerium-144 & $0 / 8$ & $-6.16 \mathrm{E}-10$ & 2.98E-09 & $-4.47 \mathrm{E}-09 / 4.47 \mathrm{E}-09 \mu \mathrm{Ci} / \mathrm{mL}$ \\
\hline Cesium-134 & $0 / 8$ & $2.72 E-10$ & $8.59 E-10$ & $-7.01 \mathrm{E}-10 / 1.44 \mathrm{E}-09 \mu \mathrm{Ci} / \mathrm{mL}$ \\
\hline Cesium-137 & $0 / 8$ & $-5.81 E-10$ & $7.76 \mathrm{E}-10$ & -1.87E-09/5.45E-10 $\mu \mathrm{Ci} / \mathrm{mL}$ \\
\hline Cobalt-57 & $0 / 8$ & $2.18 \mathrm{E}-11$ & $6.80 \mathrm{E}-10$ & $-1.11 \mathrm{E}-09 / 8.30 \mathrm{E}-10 \mu \mathrm{Ci} / \mathrm{mL}$ \\
\hline Cobalt-60 & $0 / 8$ & 3.33E-10 & $1.08 \mathrm{E}-09$ & $-1.29 \mathrm{E}-09 / 2.10 \mathrm{E}-09 \mu \mathrm{Ci} / \mathrm{mL}$ \\
\hline Europium-152 & $0 / 8$ & $9.36 \mathrm{E}-10$ & $3.51 E-09$ & $-3.89 \mathrm{E}-09 / 7.07 \mathrm{E}-09 \mu \mathrm{Ci} / \mathrm{mL}$ \\
\hline Europium-154 & $0 / 8$ & $1.98 \mathrm{E}-10$ & $3.90 E-09$ & $-5.87 \mathrm{E}-09 / 7.04 \mathrm{E}-09 \mu \mathrm{Ci} / \mathrm{mL}$ \\
\hline Europium-155 & $0 / 8$ & $-1.61 E-09$ & 2.17E-09 & $-4.73 \mathrm{E}-09 / 1.30 \mathrm{E}-09 \mu \mathrm{Ci} / \mathrm{mL}$ \\
\hline Lead-212 & $0 / 8$ & $3.00 \mathrm{E}-09$ & $1.84 \mathrm{E}-09$ & 3.29E-10/5.78E-09 $\mu \mathrm{Ci} / \mathrm{mL}$ \\
\hline Manganese-54 & $0 / 8$ & $-2.27 E-11$ & $6.55 \mathrm{E}-10$ & $-1.17 \mathrm{E}-09 / 7.16 \mathrm{E}-10 \mu \mathrm{Ci} / \mathrm{mL}$ \\
\hline Potassium-40 & $3 / 8$ & $3.15 E-08$ & $2.22 E-08$ & 4.07E-09/7.24E-08 $\mu \mathrm{Ci} / \mathrm{mL}$ \\
\hline Promethium-144 & $0 / 8$ & $2.96 \mathrm{E}-10$ & $1.81 E-09$ & $-1.55 \mathrm{E}-09 / 3.82 \mathrm{E}-09 \mu \mathrm{Ci} / \mathrm{mL}$ \\
\hline
\end{tabular}




\begin{tabular}{lllll}
\hline Analyte & $\begin{array}{l}\text { Frequency } \\
\text { of Detectiont }\end{array}$ & Mean Result & $\begin{array}{l}\text { Standard } \\
\text { Deviation }\end{array}$ & Minimum/Maximum Results \\
\hline Promethium-146 & $0 / 8$ & $-4.95 \mathrm{E}-10$ & $1.64 \mathrm{E}-09$ & $-2.28 \mathrm{E}-09 / 1.54 \mathrm{E}-09 \mu \mathrm{Ci} / \mathrm{mL}$ \\
Ruthenium-106 & $0 / 8$ & $2.43 \mathrm{E}-09$ & $2.77 \mathrm{E}-09$ & $-1.08 \mathrm{E}-09 / 6.13 \mathrm{E}-09 \mu \mathrm{Ci} / \mathrm{mL}$ \\
Sodium-22 & $0 / 8$ & $8.84 \mathrm{E}-11$ & $1.39 \mathrm{E}-09$ & $-2.10 \mathrm{E}-09 / 2.51 \mathrm{E}-09 \mu \mathrm{Ci} / \mathrm{mL}$ \\
Yttrium-88 & $0 / 8$ & $2.97 \mathrm{E}-10$ & $9.92 \mathrm{E}-10$ & $-8.18 \mathrm{E}-10 / 1.97 \mathrm{E}-09 \mu \mathrm{Ci} / \mathrm{mL}$ \\
Zinc-65 & $0 / 8$ & $-5.32 \mathrm{E}-10$ & $8.31 \mathrm{E}-10$ & $-1.93 \mathrm{E}-09 / 8.68 \mathrm{E}-10 \mu \mathrm{Ci} / \mathrm{mL}$ \\
& & & & \\
EPIA-022 & $0 / 2$ & $-4.19 \mathrm{E}-09$ & $5.66 \mathrm{E}-09$ & $-8.19 \mathrm{E}-09 /-1.88 \mathrm{E}-10 \mu \mathrm{Ci} / \mathrm{mL}$ \\
Nickel-63 & &
\end{tabular}

$\dagger$ Number of times analyte was detected compared to the total number of method blanks for the analyte.

Note: If the analyte was not detected in the method blank(s), detection limit information appears in the Mean Result and Minimum/Maximum Results columns.

Table 61. Analytes Detected in Method Blanks for TM

\begin{tabular}{|c|c|c|c|c|}
\hline Analyte & $\begin{array}{l}\text { Frequency } \\
\text { of Detectiont }\end{array}$ & Mean Result & $\begin{array}{l}\text { Standard } \\
\text { Deviation }\end{array}$ & Minimum/Maximum Results \\
\hline \multicolumn{5}{|l|}{ EICHROMTC1MOD } \\
\hline Technetium-99 & $0 / 1$ & $6.40 E-10$ & 一 & $6.40 \mathrm{E}-10 / 6.40 \mathrm{E}-10 \mu \mathrm{Ci} / \mathrm{mL}$ \\
\hline \multicolumn{5}{|l|}{ EMLSR02MOD } \\
\hline Strontium-90 & $1 / 3$ & 3.37E-10 & $6.81 E-10$ & $-1.10 \mathrm{E}-10 / 1.12 \mathrm{E}-09 \mu \mathrm{Ci} / \mathrm{mL}$ \\
\hline \multicolumn{5}{|l|}{ EPA900.0MOD } \\
\hline Gross alpha & $2 / 55$ & $-2.07 E-11$ & $1.69 \mathrm{E}-10$ & $-2.60 \mathrm{E}-10 / 7.90 \mathrm{E}-10 \mu \mathrm{Ci} / \mathrm{mL}$ \\
\hline Nonvolatile beta & $1 / 51$ & $-2.15 E-10$ & 4.49E-10 & $-9.90 \mathrm{E}-10 / 2.09 \mathrm{E}-09 \mu \mathrm{Ci} / \mathrm{mL}$ \\
\hline \multicolumn{5}{|l|}{ EPA901.1MOD } \\
\hline Cesium-137 & $0 / 2$ & 1.69E-09 & 1.81E-09 & 4.10E-10/2.97E-09 $\mu \mathrm{Ci} / \mathrm{mL}$ \\
\hline Cobalt-60 & $0 / 2$ & $-3.25 E-10$ & 9.83E-10 & $-1.02 \mathrm{E}-09 / 3.70 \mathrm{E}-10 \mu \mathrm{Ci} / \mathrm{mL}$ \\
\hline \multicolumn{5}{|l|}{ EPA902.0MOD } \\
\hline lodine-129 & $0 / 1$ & $2.90 E-10$ & 一 & $2.90 \mathrm{E}-10 / 2.90 \mathrm{E}-10 \mu \mathrm{Ci} / \mathrm{mL}$ \\
\hline \multicolumn{5}{|l|}{ EPA903.0MOD } \\
\hline Radium, total alpha-emitting & $0 / 4$ & $6.25 E-11$ & $2.21 E-10$ & $-1.10 \mathrm{E}-10 / 3.80 \mathrm{E}-10 \mu \mathrm{Ci} / \mathrm{mL}$ \\
\hline Radium-226 & $0 / 2$ & $1.05 E-10$ & $9.19 \mathrm{E}-11$ & 4.00E-11/1.70E-10 $\mu \mathrm{Ci} / \mathrm{mL}$ \\
\hline \multicolumn{5}{|l|}{ EPA904.0MOD } \\
\hline Radium-228 & $0 / 2$ & $2.50 \mathrm{E}-10$ & $2.55 E-10$ & 7.00E-11/4.30E-10 $\mu \mathrm{Ci} / \mathrm{mL}$ \\
\hline \multicolumn{5}{|l|}{ EPA906.0MOD } \\
\hline Tritium & $1 / 57$ & $4.93 \mathrm{E}-08$ & 2.01E-07 & $-3.50 \mathrm{E}-07 / 1.08 \mathrm{E}-06 \mu \mathrm{Ci} / \mathrm{mL}$ \\
\hline
\end{tabular}

$\dagger$ Number of times analyte was detected compared to the total number of method blanks for the analyte.

- Standard deviation cannot be determined.

Note: If the analyte was not detected in the method blank(s), detection limit information appears in the Mean Result and Minimum/Maximum Results columns. 
Table 62. Analytes Detected in Field Blanks for EX

\begin{tabular}{|c|c|c|c|c|}
\hline Analyte & $\begin{array}{l}\text { Frequency } \\
\text { of Detectiont }\end{array}$ & Mean Result & $\begin{array}{l}\text { Standard } \\
\text { Deviation }\end{array}$ & Minimum/Maximum Results \\
\hline $\begin{array}{l}\text { EPA120.1 } \\
\text { Specific conductance }\end{array}$ & $1 / 1$ & 2.23 & 一 & $2.23 / 2.23 \mu \mathrm{S} / \mathrm{cm}$ \\
\hline $\begin{array}{l}\text { EPA150.1 } \\
\mathrm{pH}\end{array}$ & $2 / 2$ & 5.56 & 0.01 & $5.55 / 5.57 \mathrm{pH}$ \\
\hline $\begin{array}{l}\text { EPA300.0 } \\
\text { Chloride } \\
\text { Nitrate as nitrogen } \\
\text { Nitrate-nitrite as nitrogen } \\
\text { Sulfate }\end{array}$ & $\begin{array}{l}0 / 2 \\
0 / 3 \\
0 / 2 \\
1 / 2\end{array}$ & $\begin{array}{l}200 \\
100 \\
500 \\
153\end{array}$ & $\begin{array}{l}0.0 \\
0.0 \\
0.0 \\
67.2\end{array}$ & $\begin{array}{l}200 / 200 \mu \mathrm{g} / \mathrm{L} \\
100 / 100 \mu \mathrm{g} / \mathrm{L} \\
500 / 500 \mu \mathrm{g} / \mathrm{L} \\
105 / 200 \mu \mathrm{g} / \mathrm{L}\end{array}$ \\
\hline $\begin{array}{l}\text { EPA410.4 } \\
\text { Chemical oxygen demand }\end{array}$ & $0 / 1$ & 10,000 & - & $10,000 / 10,000 \mu \mathrm{g} / \mathrm{L}$ \\
\hline $\begin{array}{l}\text { EPA6010B } \\
\text { Aluminum } \\
\text { Antimony } \\
\text { Arsenic } \\
\text { Barium } \\
\text { Beryllium } \\
\text { Boron } \\
\text { Cadmium } \\
\text { Calcium } \\
\text { Chromium } \\
\text { Cobalt } \\
\text { Copper } \\
\text { Iron } \\
\text { Lead } \\
\text { Magnesium } \\
\text { Manganese } \\
\text { Nickel } \\
\text { Potassium } \\
\text { Selenium } \\
\text { Silver } \\
\text { Sodium } \\
\text { Thallium } \\
\text { Vanadium } \\
\text { Zinc }\end{array}$ & $\begin{array}{l}0 / 6 \\
0 / 1 \\
0 / 3 \\
0 / 4 \\
0 / 1 \\
0 / 1 \\
0 / 3 \\
0 / 3 \\
0 / 1 \\
0 / 3 \\
0 / 1 \\
0 / 1 \\
2 / 6 \\
0 / 6 \\
0 / 1 \\
1 / 4 \\
0 / 1 \\
0 / 1 \\
0 / 3 \\
0 / 3 \\
0 / 1 \\
0 / 2 \\
0 / 1 \\
0 / 1\end{array}$ & $\begin{array}{l}200 \\
100 \\
10.0 \\
10.0 \\
10.0 \\
100 \\
10.0 \\
1,000 \\
10.0 \\
20.0 \\
20.0 \\
113 \\
10.0 \\
1,000 \\
8.18 \\
50.0 \\
5,000 \\
10.0 \\
20.0 \\
1,000 \\
10.0 \\
10.0 \\
20.0\end{array}$ & $\begin{array}{l}0.0 \\
0.0 \\
0.0 \\
\frac{-}{0.0} \\
0.0 \\
\frac{0}{0.0} \\
\frac{-}{-} \\
\frac{95.3}{0.0} \\
\frac{3.65}{-} \\
\frac{-}{0.0} \\
\frac{0.0}{0.0} \\
\frac{-}{-}\end{array}$ & $\begin{array}{l}200 / 200 \mu \mathrm{g} / \mathrm{L} \\
100 / 100 \mu \mathrm{g} / \mathrm{L} \\
10.0 / 10.0 \mu \mathrm{g} / \mathrm{L} \\
10.0 / 10.0 \mu \mathrm{g} / \mathrm{L} \\
10.0 / 10.0 \mu \mathrm{g} / \mathrm{L} \\
100 / 100 \mu \mathrm{g} / \mathrm{L} \\
10.0 / 10.0 \mu \mathrm{g} / \mathrm{L} \\
1,000 / 1,000 \mu \mathrm{g} / \mathrm{L} \\
10.0 / 10.0 \mu \mathrm{g} / \mathrm{L} \\
20.0 / 20.0 \mu \mathrm{g} / \mathrm{L} \\
20.0 / 20.0 \mu \mathrm{g} / \mathrm{L} \\
19.0 / 200 \mu \mathrm{g} / \mathrm{L} \\
10.0 / 10.0 \mu \mathrm{g} / \mathrm{L} \\
1,000 / 1,000 \mu \mathrm{g} / \mathrm{L} \\
2.70 / 10.0 \mu \mathrm{g} / \mathrm{L} \\
50.0 / 50.0 \mu \mathrm{g} / \mathrm{L} \\
5,000 / 5,000 \mu \mathrm{g} / \mathrm{L} \\
10.0 / 10.0 \mu \mathrm{g} / \mathrm{L} \\
20.0 / 20.0 \mu \mathrm{g} / \mathrm{L} \\
1,000 / 1,000 \mu \mathrm{g} / \mathrm{L} \\
10.0 / 10.0 \mu \mathrm{g} / \mathrm{L} \\
10.0 / 10.0 \mu \mathrm{g} / \mathrm{L} \\
20.0 / 20.0 \mu \mathrm{g} / \mathrm{L}\end{array}$ \\
\hline $\begin{array}{l}\text { EPA7470A } \\
\text { Mercury }\end{array}$ & $1 / 6$ & 0.46 & 0.10 & $0.25 / 0.50 \mu \mathrm{g} / \mathrm{L}$ \\
\hline $\begin{array}{l}\text { EPA9014 } \\
\text { Cyanide }\end{array}$ & $0 / 2$ & 10.0 & 0.0 & $10.0 / 10.0 \mu \mathrm{g} / \mathrm{L}$ \\
\hline $\begin{array}{l}\text { EPA9060 } \\
\text { Total organic carbon }\end{array}$ & $0 / 1$ & 5,000 & - & $5,000 / 5,000 \mu \mathrm{g} / \mathrm{L}$ \\
\hline
\end{tabular}

$\dagger$ Number of times analyte was detected compared to the total number of field blanks for the analyte.

- Standard deviation cannot be determined.

Note: If the analyte was not detected in the field blank(s), detection limit information appears in the Mean Result and Minimum/Maximum Results columns. 
Table 63. Analytes Detected in Field Blanks for GE

\begin{tabular}{|c|c|c|c|c|}
\hline Analyte & $\begin{array}{l}\text { Frequency } \\
\text { of Detectiont }\end{array}$ & Mean Result & $\begin{array}{l}\text { Standard } \\
\text { Deviation }\end{array}$ & Minimum/Maximum Results \\
\hline \multicolumn{5}{|l|}{ EPA353.1 } \\
\hline Nitrate-nitrite as nitrogen & $7 / 14$ & 28.6 & 19.6 & $10.0 / 50.0 \mu \mathrm{g} / \mathrm{L}$ \\
\hline \multicolumn{5}{|l|}{ EPA6010B } \\
\hline Aluminum & $0 / 3$ & 50.0 & 0.0 & $50.0 / 50.0 \mu \mathrm{g} / \mathrm{L}$ \\
\hline Antimony & $0 / 2$ & 10.0 & 0.0 & $10.0 / 10.0 \mu \mathrm{g} / \mathrm{L}$ \\
\hline Arsenic & $0 / 2$ & 5.0 & 0.0 & $5.0 / 5.0 \mu \mathrm{g} / \mathrm{L}$ \\
\hline Barium & $0 / 2$ & 5.0 & 0.0 & $5.0 / 5.0 \mu \mathrm{g} / \mathrm{L}$ \\
\hline Beryllium & $0 / 3$ & 5.0 & 0.0 & $5.0 / 5.0 \mu \mathrm{g} / \mathrm{L}$ \\
\hline Cadmium & $0 / 2$ & 5.0 & 0.0 & $5.0 / 5.0 \mu \mathrm{g} / \mathrm{L}$ \\
\hline Calcium & $0 / 2$ & 100 & 0.0 & $100 / 100 \mu g / L$ \\
\hline Chromium & $0 / 3$ & 5.0 & 0.0 & $5.0 / 5.0 \mu \mathrm{g} / \mathrm{L}$ \\
\hline Cobalt & $0 / 2$ & 5.0 & 0.0 & $5.0 / 5.0 \mu \mathrm{g} / \mathrm{L}$ \\
\hline Copper & $0 / 2$ & 5.0 & 0.0 & $5.0 / 5.0 \mu \mathrm{g} / \mathrm{L}$ \\
\hline Iron & $0 / 3$ & 50.0 & 0.0 & $50.0 / 50.0 \mu \mathrm{g} / \mathrm{L}$ \\
\hline Lead & $0 / 2$ & 5.0 & 0.0 & $5.0 / 5.0 \mu \mathrm{g} / \mathrm{L}$ \\
\hline Magnesium & $0 / 2$ & 10.0 & 0.0 & $10.0 / 10.0 \mu \mathrm{g} / \mathrm{L}$ \\
\hline Manganese & $0 / 2$ & 10.0 & 0.0 & $10.0 / 10.0 \mu \mathrm{g} / \mathrm{L}$ \\
\hline Nickel & $0 / 2$ & 5.0 & 0.0 & $5.0 / 5.0 \mu \mathrm{g} / \mathrm{L}$ \\
\hline Potassium & $0 / 2$ & 100 & 0.0 & $100 / 100 \mu \mathrm{g} / \mathrm{L}$ \\
\hline Selenium & $0 / 2$ & 5.0 & 0.0 & $5.0 / 5.0 \mu \mathrm{g} / \mathrm{L}$ \\
\hline Silver & $0 / 2$ & 5.0 & 0.0 & $5.0 / 5.0 \mu \mathrm{g} / \mathrm{L}$ \\
\hline Sodium & $0 / 2$ & 500 & 0.0 & $500 / 500 \mu g / L$ \\
\hline Thallium & $0 / 2$ & 5.0 & 0.0 & $5.0 / 5.0 \mu \mathrm{g} / \mathrm{L}$ \\
\hline Vanadium & $0 / 2$ & 5.0 & 0.0 & $5.0 / 5.0 \mu \mathrm{g} / \mathrm{L}$ \\
\hline Zinc & $0 / 2$ & 3.50 & 2.13 & $1.99 / 5.0 \mu \mathrm{g} / \mathrm{L}$ \\
\hline \multicolumn{5}{|l|}{ EPA6020 } \\
\hline Aluminum & $0 / 5$ & 15.0 & 0.0 & 15.0/15.0 $\mu g / L$ \\
\hline Cadmium & $0 / 5$ & 0.86 & 0.31 & $0.31 / 1.0 \mu \mathrm{g} / \mathrm{L}$ \\
\hline Iron & $1 / 5$ & 26.3 & 2.95 & $25.0 / 31.6 \mu \mathrm{g} / \mathrm{L}$ \\
\hline Lead & $0 / 5$ & 1.36 & 0.88 & $0.37 / 2.0 \mu \mathrm{g} / \mathrm{L}$ \\
\hline \multicolumn{5}{|l|}{ EPA7196A } \\
\hline Chromium, hexavalent & $0 / 2$ & 20.0 & 0.0 & $20.0 / 20.0 \mu \mathrm{g} / \mathrm{L}$ \\
\hline \multicolumn{5}{|l|}{ EPA7470A } \\
\hline Mercury & $0 / 9$ & 0.20 & 0.0 & $0.20 / 0.20 \mu \mathrm{g} / \mathrm{L}$ \\
\hline \multicolumn{5}{|l|}{ EPA8081A } \\
\hline Aldrin & $0 / 2$ & 0.02 & 0.00 & $0.02 / 0.02 \mu \mathrm{g} / \mathrm{L}$ \\
\hline alpha-Benzene hexachloride & $0 / 2$ & 0.02 & 0.00 & $0.02 / 0.02 \mu \mathrm{g} / \mathrm{L}$ \\
\hline beta-Benzene hexachloride & $0 / 2$ & 0.02 & 0.00 & $0.02 / 0.02 \mu \mathrm{g} / \mathrm{L}$ \\
\hline delta-Benzene hexachloride & $0 / 2$ & 0.02 & 0.00 & $0.02 / 0.02 \mu \mathrm{g} / \mathrm{L}$ \\
\hline alpha-Chlordane & $0 / 2$ & 0.02 & 0.00 & $0.02 / 0.02 \mu \mathrm{g} / \mathrm{L}$ \\
\hline gamma-Chlordane & $0 / 2$ & 0.02 & 0.00 & $0.02 / 0.02 \mu g / L$ \\
\hline $\mathrm{p}, \mathrm{p}^{\circ}-\mathrm{DDD}$ & $0 / 2$ & 0.04 & 0.00 & $0.04 / 0.04 \mu \mathrm{g} / \mathrm{L}$ \\
\hline p,p-DDE & $0 / 2$ & 0.04 & 0.00 & $0.04 / 0.04 \mu \mathrm{g} / \mathrm{L}$ \\
\hline $\mathrm{p}, \mathrm{p}^{\circ}-\mathrm{DDT}$ & $0 / 2$ & 0.04 & 0.00 & $0.04 / 0.04 \mu \mathrm{g} / \mathrm{L}$ \\
\hline Dieldrin & $0 / 2$ & 0.04 & 0.00 & $0.04 / 0.04 \mu \mathrm{g} / \mathrm{L}$ \\
\hline Endosulfan sulfate & $0 / 2$ & 0.04 & 0.00 & $0.04 / 0.04 \mu \mathrm{g} / \mathrm{L}$ \\
\hline Endosulfan I & $0 / 2$ & 0.02 & 0.00 & $0.02 / 0.02 \mu \mathrm{g} / \mathrm{L}$ \\
\hline Endosulfan II & $0 / 2$ & 0.04 & 0.00 & $0.04 / 0.04 \mu \mathrm{g} / \mathrm{L}$ \\
\hline Endrin & $0 / 2$ & 0.04 & 0.00 & $0.04 / 0.04 \mu g / L$ \\
\hline Endrin aldehyde & $0 / 2$ & 0.04 & 0.00 & $0.04 / 0.04 \mu g / L$ \\
\hline Endrin ketone & $0 / 2$ & 0.04 & 0.00 & $0.04 / 0.04 \mu \mathrm{g} / \mathrm{L}$ \\
\hline Heptachlor & $0 / 2$ & 0.02 & 0.00 & $0.02 / 0.02 \mu \mathrm{g} / \mathrm{L}$ \\
\hline Heptachlor epoxide & $0 / 2$ & 0.02 & 0.00 & $0.02 / 0.02 \mu \mathrm{g} / \mathrm{L}$ \\
\hline
\end{tabular}




\begin{tabular}{|c|c|c|c|c|}
\hline Analyte & $\begin{array}{l}\text { Frequency } \\
\text { of Detectiont }\end{array}$ & Mean Result & $\begin{array}{l}\text { Standard } \\
\text { Deviation }\end{array}$ & Minimum/Maximum Results \\
\hline Lindane & $0 / 2$ & 0.02 & 0.00 & $0.02 / 0.02 \mu \mathrm{g} / \mathrm{L}$ \\
\hline Methoxychlor & $0 / 2$ & 0.20 & 0.00 & $0.20 / 0.20 \mu \mathrm{g} / \mathrm{L}$ \\
\hline Toxaphene & $0 / 2$ & 1.01 & 0.01 & $1.0 / 1.01 \mu g / L$ \\
\hline \multicolumn{5}{|l|}{ EPA8082 } \\
\hline PCB 1016 & $0 / 2$ & 0.10 & 0.0 & $0.10 / 0.10 \mu \mathrm{g} / \mathrm{L}$ \\
\hline PCB 1221 & $0 / 2$ & 0.10 & 0.0 & $0.10 / 0.10 \mu \mathrm{g} / \mathrm{L}$ \\
\hline PCB 1232 & $0 / 2$ & 0.10 & 0.0 & $0.10 / 0.10 \mu \mathrm{g} / \mathrm{L}$ \\
\hline PCB 1242 & $0 / 2$ & 0.10 & 0.0 & $0.10 / 0.10 \mu \mathrm{g} / \mathrm{L}$ \\
\hline PCB 1248 & $0 / 2$ & 0.10 & 0.0 & $0.10 / 0.10 \mu \mathrm{g} / \mathrm{L}$ \\
\hline PCB 1254 & $0 / 2$ & 0.10 & 0.0 & $0.10 / 0.10 \mu \mathrm{g} / \mathrm{L}$ \\
\hline PCB 1260 & $0 / 2$ & 0.10 & 0.0 & $0.10 / 0.10 \mu g / L$ \\
\hline \multicolumn{5}{|l|}{ EPA8270C } \\
\hline Acenaphthene & $0 / 2$ & 9.95 & 0.07 & $9.90 / 10.0 \mu \mathrm{g} / \mathrm{L}$ \\
\hline Acenaphthylene & $0 / 2$ & 9.95 & 0.07 & $9.90 / 10.0 \mu \mathrm{g} / \mathrm{L}$ \\
\hline Anthracene & $0 / 2$ & 9.95 & 0.07 & $9.90 / 10.0 \mu \mathrm{g} / \mathrm{L}$ \\
\hline Benzidine & $0 / 2$ & 49.8 & 0.35 & $49.5 / 50.0 \mu \mathrm{g} / \mathrm{L}$ \\
\hline Benzo[a]anthracene & $0 / 2$ & 9.95 & 0.07 & $9.90 / 10.0 \mu \mathrm{g} / \mathrm{L}$ \\
\hline Benzo[b]fluoranthene & $0 / 2$ & 9.95 & 0.07 & $9.90 / 10.0 \mu \mathrm{g} / \mathrm{L}$ \\
\hline Benzo $[k]$ fluoranthene & $0 / 2$ & 9.95 & 0.07 & $9.90 / 10.0 \mu \mathrm{g} / \mathrm{L}$ \\
\hline Benzoic acid & $0 / 2$ & 19.9 & 0.14 & $19.8 / 20.0 \mu \mathrm{g} / \mathrm{L}$ \\
\hline Benzo $[g, h, i]$ perylene & $0 / 2$ & 9.95 & 0.07 & $9.90 / 10.0 \mu \mathrm{g} / \mathrm{L}$ \\
\hline Benzo[a]pyrene & $0 / 2$ & 9.95 & 0.07 & $9.90 / 10.0 \mu \mathrm{g} / \mathrm{L}$ \\
\hline Benzyl alcohol & $0 / 2$ & 9.95 & 0.07 & $9.90 / 10.0 \mu \mathrm{g} / \mathrm{L}$ \\
\hline Bis(2-chloroethoxy) methane & $0 / 2$ & 9.95 & 0.07 & $9.90 / 10.0 \mu \mathrm{g} / \mathrm{L}$ \\
\hline Bis(2-chloroethyl) ether & $0 / 2$ & 9.95 & 0.07 & $9.90 / 10.0 \mu g / L$ \\
\hline Bis(2-chloroisopropyl) ether & $0 / 2$ & 9.95 & 0.07 & $9.90 / 10.0 \mu \mathrm{g} / \mathrm{L}$ \\
\hline Bis(2-ethylhexyl) phthalate & $2 / 3$ & 27.5 & 17.5 & $10.2 / 45.1 \mu \mathrm{g} / \mathrm{L}$ \\
\hline 4-Bromophenyl phenyl ether & $0 / 2$ & 9.95 & 0.07 & $9.90 / 10.0 \mu \mathrm{g} / \mathrm{L}$ \\
\hline Butylbenzyl phthalate & $0 / 2$ & 9.95 & 0.07 & $9.90 / 10.0 \mu \mathrm{g} / \mathrm{L}$ \\
\hline 4-Chloroaniline & $0 / 2$ & 9.95 & 0.07 & $9.90 / 10.0 \mu \mathrm{g} / \mathrm{L}$ \\
\hline 4-Chloro-m-cresol & $0 / 2$ & 9.95 & 0.07 & $9.90 / 10.0 \mu \mathrm{g} / \mathrm{L}$ \\
\hline 2-Chloronaphthalene & $0 / 2$ & 9.95 & 0.07 & $9.90 / 10.0 \mu \mathrm{g} / \mathrm{L}$ \\
\hline 2-Chlorophenol & $0 / 2$ & 9.95 & 0.07 & $9.90 / 10.0 \mu \mathrm{g} / \mathrm{L}$ \\
\hline 4-Chlorophenyl phenyl ether & $0 / 2$ & 9.95 & 0.07 & $9.90 / 10.0 \mu \mathrm{g} / \mathrm{L}$ \\
\hline Chrysene & $0 / 2$ & 9.95 & 0.07 & $9.90 / 10.0 \mu \mathrm{g} / \mathrm{L}$ \\
\hline $\mathrm{m} / \mathrm{p}$-Cresol & $0 / 2$ & 9.95 & 0.07 & $9.90 / 10.0 \mu \mathrm{g} / \mathrm{L}$ \\
\hline o-Cresol & $0 / 2$ & 9.95 & 0.07 & $9.90 / 10.0 \mu \mathrm{g} / \mathrm{L}$ \\
\hline Dibenz $[a, h]$ anthracene & $0 / 2$ & 9.95 & 0.07 & $9.90 / 10.0 \mu g / L$ \\
\hline Dibenzofuran & $0 / 2$ & 9.95 & 0.07 & $9.90 / 10.0 \mu \mathrm{g} / \mathrm{L}$ \\
\hline Di-n-butyl phthalate & $0 / 2$ & 9.95 & 0.07 & $9.90 / 10.0 \mu \mathrm{g} / \mathrm{L}$ \\
\hline 1,2-Dichlorobenzene & $0 / 2$ & 9.95 & 0.07 & $9.90 / 10.0 \mu \mathrm{g} / \mathrm{L}$ \\
\hline 1,3-Dichlorobenzene & $0 / 2$ & 9.95 & 0.07 & $9.90 / 10.0 \mu \mathrm{g} / \mathrm{L}$ \\
\hline 1,4-Dichlorobenzene & $0 / 2$ & 9.95 & 0.07 & $9.90 / 10.0 \mu \mathrm{g} / \mathrm{L}$ \\
\hline $3,3^{\prime}$-Dichlorobenzidine & $0 / 2$ & 19.9 & 0.14 & $19.8 / 20.0 \mu \mathrm{g} / \mathrm{L}$ \\
\hline 2,4-Dichlorophenol & $0 / 2$ & 9.95 & 0.07 & $9.90 / 10.0 \mu \mathrm{g} / \mathrm{L}$ \\
\hline Diethyl phthalate & $0 / 2$ & 9.95 & 0.07 & $9.90 / 10.0 \mu \mathrm{g} / \mathrm{L}$ \\
\hline 2,4-Dimethyl phenol & $0 / 2$ & 9.95 & 0.07 & $9.90 / 10.0 \mu \mathrm{g} / \mathrm{L}$ \\
\hline Dimethyl phthalate & $0 / 2$ & 9.95 & 0.07 & $9.90 / 10.0 \mu \mathrm{g} / \mathrm{L}$ \\
\hline 2,4-Dinitrophenol & $0 / 2$ & 19.9 & 0.14 & $19.8 / 20.0 \mu \mathrm{g} / \mathrm{L}$ \\
\hline 2,4-Dinitrotoluene & $0 / 2$ & 9.95 & 0.07 & $9.90 / 10.0 \mu \mathrm{g} / \mathrm{L}$ \\
\hline 2,6-Dinitrotoluene & $0 / 2$ & 9.95 & 0.07 & $9.90 / 10.0 \mu \mathrm{g} / \mathrm{L}$ \\
\hline Di-n-octyl phthalate & $0 / 2$ & 9.95 & 0.07 & $9.90 / 10.0 \mu \mathrm{g} / \mathrm{L}$ \\
\hline Fluoranthene & $0 / 2$ & 9.95 & 0.07 & $9.90 / 10.0 \mu \mathrm{g} / \mathrm{L}$ \\
\hline Fluorene & $0 / 2$ & 9.95 & 0.07 & $9.90 / 10.0 \mu \mathrm{g} / \mathrm{L}$ \\
\hline Hexachlorobenzene & $0 / 2$ & 9.95 & 0.07 & $9.90 / 10.0 \mu \mathrm{g} / \mathrm{L}$ \\
\hline Hexachlorobutadiene & $0 / 2$ & 9.95 & 0.07 & $9.90 / 10.0 \mu \mathrm{g} / \mathrm{L}$ \\
\hline Hexachlorocyclopentadiene & $0 / 2$ & 9.95 & 0.07 & $9.90 / 10.0 \mu \mathrm{g} / \mathrm{L}$ \\
\hline Hexachloroethane & $0 / 2$ & 9.95 & 0.07 & $9.90 / 10.0 \mu \mathrm{g} / \mathrm{L}$ \\
\hline Indeno $[1,2,3-c, d]$ pyrene & $0 / 2$ & 9.95 & 0.07 & $9.90 / 10.0 \mu g / L$ \\
\hline
\end{tabular}




\begin{tabular}{|c|c|c|c|c|}
\hline Analyte & $\begin{array}{l}\text { Frequency } \\
\text { of Detectiont }\end{array}$ & Mean Result & $\begin{array}{l}\text { Standard } \\
\text { Deviation }\end{array}$ & Minimum/Maximum Results \\
\hline Isophorone & $0 / 2$ & 9.95 & 0.07 & $9.90 / 10.0 \mu \mathrm{g} / \mathrm{L}$ \\
\hline 2-Methyl-4,6-dinitrophenol & $0 / 2$ & 9.95 & 0.07 & $9.90 / 10.0 \mu \mathrm{g} / \mathrm{L}$ \\
\hline 2-Methylnaphthalene & $0 / 2$ & 9.95 & 0.07 & $9.90 / 10.0 \mu \mathrm{g} / \mathrm{L}$ \\
\hline Naphthalene & $0 / 2$ & 9.95 & 0.07 & $9.90 / 10.0 \mu \mathrm{g} / \mathrm{L}$ \\
\hline m-Nitroaniline & $0 / 2$ & 9.95 & 0.07 & $9.90 / 10.0 \mu \mathrm{g} / \mathrm{L}$ \\
\hline o-Nitroaniline & $0 / 2$ & 9.95 & 0.07 & $9.90 / 10.0 \mu \mathrm{g} / \mathrm{L}$ \\
\hline p-Nitroaniline & $0 / 2$ & 9.95 & 0.07 & $9.90 / 10.0 \mu \mathrm{g} / \mathrm{L}$ \\
\hline Nitrobenzene & $0 / 2$ & 9.95 & 0.07 & $9.90 / 10.0 \mu \mathrm{g} / \mathrm{L}$ \\
\hline 2-Nitrophenol & $0 / 2$ & 9.95 & 0.07 & $9.90 / 10.0 \mu \mathrm{g} / \mathrm{L}$ \\
\hline 4-Nitrophenol & $0 / 2$ & 9.95 & 0.07 & $9.90 / 10.0 \mu \mathrm{g} / \mathrm{L}$ \\
\hline N-Nitrosodiphenylamine & $0 / 2$ & 9.95 & 0.07 & $9.90 / 10.0 \mu \mathrm{g} / \mathrm{L}$ \\
\hline N-Nitrosodipropylamine & $0 / 2$ & 9.95 & 0.07 & $9.90 / 10.0 \mu \mathrm{g} / \mathrm{L}$ \\
\hline Pentachlorophenol & $0 / 2$ & 19.9 & 0.14 & $19.8 / 20.0 \mu \mathrm{g} / \mathrm{L}$ \\
\hline Phenanthrene & $0 / 2$ & 9.95 & 0.07 & $9.90 / 10.0 \mu \mathrm{g} / \mathrm{L}$ \\
\hline Phenol & $0 / 2$ & 9.95 & 0.07 & $9.90 / 10.0 \mu \mathrm{g} / \mathrm{L}$ \\
\hline Pyrene & $0 / 2$ & 9.95 & 0.07 & $9.90 / 10.0 \mu \mathrm{g} / \mathrm{L}$ \\
\hline 1,2,4-Trichlorobenzene & $0 / 2$ & 9.95 & 0.07 & $9.90 / 10.0 \mu \mathrm{g} / \mathrm{L}$ \\
\hline 2,4,5-Trichlorophenol & $0 / 2$ & 9.95 & 0.07 & $9.90 / 10.0 \mu \mathrm{g} / \mathrm{L}$ \\
\hline 2,4,6-Trichlorophenol & $0 / 2$ & 9.95 & 0.07 & $9.90 / 10.0 \mu \mathrm{g} / \mathrm{L}$ \\
\hline \multicolumn{5}{|l|}{ EPA9012A } \\
\hline Cyanide & $0 / 3$ & 10.0 & 0.0 & $10.0 / 10.0 \mu \mathrm{g} / \mathrm{L}$ \\
\hline \multicolumn{5}{|l|}{ EPA9020B } \\
\hline Total organic halogens & $1 / 1$ & 5.04 & - & $5.04 / 5.04 \mu \mathrm{g} / \mathrm{L}$ \\
\hline \multicolumn{5}{|l|}{ EPA9040B } \\
\hline $\mathrm{pH}$ & $20 / 20$ & 5.60 & 0.56 & $4.62 / 6.71 \mathrm{pH}$ \\
\hline \multicolumn{5}{|l|}{ EPA9050A } \\
\hline Specific conductance & $19 / 19$ & 3.02 & 3.53 & $1.01 / 11.3 \mu \mathrm{S} / \mathrm{cm}$ \\
\hline
\end{tabular}

$\dagger$ Number of times analyte was detected compared to the total number of field blanks for the analyte.

- Standard deviation cannot be determined.

Notes: A value of 0 is reported as 0.0 .

Numbers less than 0.004 are reported as 0.00 .

If the analyte was not detected in the field blank(s), detection limit information appears in the Mean Result and Minimum/Maximum Results columns.

Table 64. Analytes Detected in Field Blanks for WA

\begin{tabular}{lllll}
\hline Analyte & $\begin{array}{l}\text { Frequency } \\
\text { of Detectiont }\end{array}$ & Mean Result & $\begin{array}{l}\text { Standard } \\
\text { Deviation }\end{array}$ & Minimum/Maximum Results \\
\hline EPA160.1 & & & & \\
Total dissolved solids & $0 / 4$ & 50,000 & 0.0 & $50,000 / 50,000 \mu \mathrm{g} / \mathrm{L}$ \\
& & & & \\
EPA310.1 & $2 / 3$ & 3.05 & 3.17 & $0.98 / 6.70 \mathrm{meq} / \mathrm{L}$ \\
Alkalinity (as CaCO 3 ) & & & & \\
EPA6010B & $0 / 3$ & 106 & 69.7 & $25.2 / 146 \mu \mathrm{g} / \mathrm{L}$ \\
Aluminum & $0 / 2$ & 27.0 & 0.0 & $27.0 / 27.0 \mu \mathrm{g} / \mathrm{L}$ \\
Antimony & $0 / 3$ & 40.0 & 0.0 & $40.0 / 40.0 \mu \mathrm{g} / \mathrm{L}$ \\
Arsenic & $0 / 2$ & 1.80 & 0.0 & $1.80 / 1.80 \mu \mathrm{g} / \mathrm{L}$ \\
Barium & $0 / 2$ & 266 & 0.0 & $266 / 266 \mu \mathrm{g} / \mathrm{L}$ \\
Boron & & & & \\
\hline
\end{tabular}




\begin{tabular}{|c|c|c|c|c|}
\hline Analyte & $\begin{array}{l}\text { Frequency } \\
\text { of Detectiont }\end{array}$ & Mean Result & $\begin{array}{l}\text { Standard } \\
\text { Deviation }\end{array}$ & Minimum/Maximum Results \\
\hline $\begin{array}{l}\text { Cadmium } \\
\text { Chromium } \\
\text { Copper } \\
\text { Iron } \\
\text { Lead } \\
\text { Lithium } \\
\text { Manganese } \\
\text { Nickel } \\
\text { Selenium } \\
\text { Silver } \\
\text { Tin } \\
\text { Zinc }\end{array}$ & $\begin{array}{l}0 / 2 \\
0 / 3 \\
0 / 2 \\
0 / 3 \\
0 / 2 \\
0 / 2 \\
0 / 1 \\
0 / 2 \\
0 / 2 \\
0 / 2 \\
0 / 2 \\
0 / 2\end{array}$ & $\begin{array}{l}4.70 \\
7.0 \\
15.0 \\
65.8 \\
47.0 \\
2.70 \\
7.80 \\
26.0 \\
66.0 \\
2.91 \\
70.0 \\
53.0\end{array}$ & $\begin{array}{l}0.0 \\
0.0 \\
0.0 \\
14.3 \\
0.0 \\
0.0 \\
0.0 \\
0.0 \\
2.96 \\
0.0 \\
0.0\end{array}$ & $\begin{array}{l}4.70 / 4.70 \mu \mathrm{g} / \mathrm{L} \\
7.0 / 7.0 \mu \mathrm{g} / \mathrm{L} \\
15.0 / 15.0 \mu \mathrm{g} / \mathrm{L} \\
49.3 / 74.0 \mu \mathrm{g} / \mathrm{L} \\
47.0 / 47.0 \mu \mathrm{g} / \mathrm{L} \\
2.70 / 2.70 \mu \mathrm{g} / \mathrm{L} \\
7.80 / 7.80 \mu \mathrm{g} / \mathrm{L} \\
26.0 / 26.0 \mu \mathrm{g} / \mathrm{L} \\
66.0 / 66.0 \mu \mathrm{g} / \mathrm{L} \\
0.82 / 5.0 \mu \mathrm{g} / \mathrm{L} \\
70.0 / 70.0 \mu \mathrm{g} / \mathrm{L} \\
53.0 / 53.0 \mu \mathrm{g} / \mathrm{L}\end{array}$ \\
\hline $\begin{array}{l}\text { EPA7470A } \\
\text { Mercury }\end{array}$ & $0 / 2$ & 0.70 & 0.0 & $0.70 / 0.70 \mu \mathrm{g} / \mathrm{L}$ \\
\hline $\begin{array}{l}\text { EPA8081A } \\
\text { Endrin }\end{array}$ & $0 / 1$ & 0.10 & - & $0.10 / 0.10 \mu \mathrm{g} / \mathrm{L}$ \\
\hline $\begin{array}{l}\text { EPA8082 } \\
\text { PCB } 1260\end{array}$ & $0 / 1$ & 1.03 & - & $1.03 / 1.03 \mu \mathrm{g} / \mathrm{L}$ \\
\hline $\begin{array}{l}\text { EPAB260B } \\
\text { Benzene } \\
\text { Bromodichloromethane } \\
\text { Bromoform } \\
\text { Bromomethane } \\
\text { Carbon tetrachloride } \\
\text { Chlorobenzene } \\
\text { Chloroethane } \\
\text { Chloroethene } \\
\text { 2-Chloroethyl vinyl ether } \\
\text { Chloroform } \\
\text { Chloromethane } \\
\text { Dibromochloromethane } \\
\text { 1,1-Dichloroethane } \\
\text { 1,2-Dichloroethane } \\
\text { 1,1-Dichloroethylene } \\
\text { trans-1,2-Dichloroethylene } \\
\text { Dichloromethane } \\
\text { 1,2-Dichloropropane } \\
\text { cis-1,3-Dichloropropene } \\
\text { trans-1,3-Dichloropropene } \\
\text { Ethylbenzene } \\
\text { 1,1,2,2-Tetrachloroethane } \\
\text { Tetrachloroethylene } \\
\text { Toluene } \\
\text { 1,1,1-Trichloroethane } \\
\text { 1,1,2-Trichloroethane } \\
\text { Trichloroethylene } \\
\text { Trichlorofluoromethane } \\
\text { Xylenes }\end{array}$ & $\begin{array}{l}0 / 1 \\
0 / 1 \\
0 / 1 \\
0 / 1 \\
0 / 1 \\
0 / 1 \\
0 / 1 \\
0 / 1 \\
0 / 1 \\
0 / 1 \\
0 / 1 \\
0 / 1 \\
0 / 1 \\
0 / 1 \\
0 / 1 \\
0 / 1 \\
0 / 1 \\
0 / 1 \\
0 / 1 \\
0 / 1 \\
0 / 1 \\
0 / 1 \\
0 / 1 \\
0 / 1 \\
0 / 1 \\
0 / 1 \\
0 / 1 \\
0 / 1 \\
0 / 1\end{array}$ & $\begin{array}{l}5.0 \\
5.0 \\
5.0 \\
10.0 \\
5.0 \\
5.0 \\
10.0 \\
10.0 \\
10.0 \\
5.0 \\
10.0 \\
5.0 \\
5.0 \\
5.0 \\
5.0 \\
5.0 \\
4.57 \\
5.0 \\
5.0 \\
5.0 \\
5.0 \\
5.0 \\
5.0 \\
5.0 \\
5.0 \\
5.0 \\
5.0 \\
5.0 \\
5.0\end{array}$ & $\begin{array}{l}= \\
= \\
= \\
= \\
= \\
= \\
= \\
= \\
= \\
= \\
= \\
= \\
= \\
= \\
=\end{array}$ & $\begin{array}{l}5.0 / 5.0 \mu \mathrm{g} / \mathrm{L} \\
5.0 / 5.0 \mu \mathrm{g} / \mathrm{L} \\
5.0 / 5.0 \mu \mathrm{g} / \mathrm{L} \\
10.0 / 10.0 \mu \mathrm{g} / \mathrm{L} \\
5.0 / 5.0 \mu \mathrm{g} / \mathrm{L} \\
5.0 / 5.0 \mu \mathrm{g} / \mathrm{L} \\
10.0110 .0 \mu \mathrm{g} / \mathrm{L} \\
10.0 / 10.0 \mu \mathrm{g} / \mathrm{L} \\
10.0 / 10.0 \mu \mathrm{g} / \mathrm{L} \\
5.0 / 5.0 \mu \mathrm{g} / \mathrm{L} \\
10.0 / 10.0 \mu \mathrm{g} / \mathrm{L} \\
5.0 / 5.0 \mu \mathrm{g} / \mathrm{L} \\
5.0 / 5.0 \mu \mathrm{L} / \mathrm{L} \\
5.0 / 5.0 \mu \mathrm{g} / \mathrm{L} \\
5.0 / 5.0 \mu \mathrm{g} / \mathrm{L} \\
5.0 / 5.0 \mu \mathrm{L} / \mathrm{L} \\
4.57 / 4.57 \mu \mathrm{g} / \mathrm{L} \\
5.0 / 5.0 \mu \mathrm{g} / \mathrm{L} \\
5.0 / 5.0 \mu \mathrm{g} / \mathrm{L} \\
5.0 / 5.0 \mu \mathrm{g} / \mathrm{L} \\
5.0 / 5.0 \mu \mathrm{g} / \mathrm{L} \\
5.0 / 5.0 \mu \mathrm{g} / \mathrm{L} \\
5.0 / 5.0 \mu \mathrm{g} / \mathrm{L} \\
5.0 / 5.0 \mu \mathrm{g} / \mathrm{L} \\
5.0 / 5.0 \mu \mathrm{g} / \mathrm{L} \\
5.0 / 5.0 \mu \mathrm{g} / \mathrm{L} \\
5.0 / 5.0 \mu \mathrm{g} / \mathrm{L} \\
5.0 / 5.0 \mu \mathrm{g} / \mathrm{L} \\
5.0 / 5.0 \mu \mathrm{g} / \mathrm{L}\end{array}$ \\
\hline $\begin{array}{l}\text { EPA8270C } \\
\text { Acenaphthene } \\
\text { Acenaphthylene } \\
\text { Acetophenone } \\
\text { 2-Acetylaminofluorene } \\
\text { 4-Aminobiphenyl } \\
\text { Aniline } \\
\text { Anthracene }\end{array}$ & $\begin{array}{l}0 / 1 \\
0 / 1 \\
0 / 1 \\
0 / 1 \\
0 / 1 \\
0 / 1 \\
0 / 1\end{array}$ & $\begin{array}{l}10.2 \\
10.2 \\
10.2 \\
10.2 \\
10.2 \\
10.2 \\
10.2\end{array}$ & $\begin{array}{l}z \\
\bar{z} \\
\bar{z}\end{array}$ & $\begin{array}{l}10.2 / 10.2 \mu \mathrm{g} / \mathrm{L} \\
10.2 / 10.2 \mu \mathrm{g} / \mathrm{L} \\
10.2 / 10.2 \mu \mathrm{g} / \mathrm{L} \\
10.2 / 10.2 \mu \mathrm{g} / \mathrm{L} \\
10.2 / 10.2 \mu \mathrm{g} / \mathrm{L} \\
10.2 / 10.2 \mu \mathrm{g} / \mathrm{L} \\
10.2 / 10.2 \mu \mathrm{g} / \mathrm{L}\end{array}$ \\
\hline
\end{tabular}




\begin{tabular}{|c|c|c|c|c|}
\hline Analyte & $\begin{array}{l}\text { Frequency } \\
\text { of Detectiont }\end{array}$ & Mean Result & $\begin{array}{l}\text { Standard } \\
\text { Deviation }\end{array}$ & Minimum/Maximum Results \\
\hline Aramite & $0 / 1$ & 20.4 & - & $20.4 / 20.4 \mu \mathrm{g} / \mathrm{L}$ \\
\hline Benzo[a]anthracene & $0 / 1$ & 10.2 & - & $10.2 / 10.2 \mu \mathrm{g} / \mathrm{L}$ \\
\hline Benzo[b]fluoranthene & $0 / 1$ & 10.2 & - & $10.2 / 10.2 \mu \mathrm{g} / \mathrm{L}$ \\
\hline Benzo[ $k$ ]fluoranthene & $0 / 1$ & 10.2 & - & $10.2 / 10.2 \mu \mathrm{g} / \mathrm{L}$ \\
\hline Benzo[g,h,i]perylene & $0 / 1$ & 10.2 & - & $10.2 / 10.2 \mu \mathrm{g} / \mathrm{L}$ \\
\hline Benzo[a]pyrene & $0 / 1$ & 10.2 & - & $10.2 / 10.2 \mu \mathrm{g} / \mathrm{L}$ \\
\hline Benzyl alcohol & $0 / 1$ & 10.2 & - & $10.2 / 10.2 \mu \mathrm{g} / \mathrm{L}$ \\
\hline Bis(2-chloroethoxy) methane & $0 / 1$ & 10.2 & - & $10.2 / 10.2 \mu \mathrm{g} / \mathrm{L}$ \\
\hline Bis(2-chloroethyl) ether & $0 / 1$ & 10.2 & - & $10.2 / 10.2 \mu \mathrm{g} / \mathrm{L}$ \\
\hline Bis(2-chloroisopropyl) ether & $0 / 1$ & 10.2 & - & $10.2 / 10.2 \mu \mathrm{g} / \mathrm{L}$ \\
\hline Bis(2-ethylhexyil) phthalate & $0 / 1$ & 10.2 & - & $10.2 / 10.2 \mu \mathrm{g} / \mathrm{L}$ \\
\hline 4-Bromophenyl phenyl ether & $0 / 1$ & 10.2 & - & $10.2 / 10.2 \mu \mathrm{g} / \mathrm{L}$ \\
\hline Butylbenzyl phthalate & $0 / 1$ & 10.2 & - & $10.2 / 10.2 \mu \mathrm{g} / \mathrm{L}$ \\
\hline 4-Chloroaniline & $0 / 1$ & 10.2 & - & $10.2 / 10.2 \mu \mathrm{g} / \mathrm{L}$ \\
\hline Chlorobenzilate & $0 / 1$ & 10.2 & - & $10.2 / 10.2 \mu \mathrm{g} / \mathrm{L}$ \\
\hline 2-Chloronaphthalene & $0 / 1$ & 10.2 & - & $10.2 / 10.2 \mu \mathrm{g} / \mathrm{L}$ \\
\hline 4-Chlorophenyl phenyl ether & $0 / 1$ & 10.2 & - & $10.2 / 10.2 \mu \mathrm{g} / \mathrm{L}$ \\
\hline Chrysene & $0 / 1$ & 10.2 & - & $10.2 / 10.2 \mu \mathrm{g} / \mathrm{L}$ \\
\hline Diallate & $0 / 1$ & 10.2 & - & $10.2 / 10.2 \mu \mathrm{g} / \mathrm{L}$ \\
\hline Dibenz[a,h]anthracene & $0 / 1$ & 10.2 & - & $10.2 / 10.2 \mu \mathrm{g} / \mathrm{L}$ \\
\hline Dibenzofuran & $0 / 1$ & 10.2 & - & $10.2 / 10.2 \mu \mathrm{g} / \mathrm{L}$ \\
\hline Di-n-butyl phthalate & $0 / 1$ & 10.2 & - & $10.2 / 10.2 \mu \mathrm{g} / \mathrm{L}$ \\
\hline 1,2-Dichlorobenzene & $0 / 1$ & 10.2 & - & $10.2 / 10.2 \mu \mathrm{g} / \mathrm{L}$ \\
\hline 1,3-Dichlorobenzene & $0 / 1$ & 10.2 & - & $10.2 / 10.2 \mu \mathrm{g} / \mathrm{L}$ \\
\hline 1,4-Dichlorobenzene & $0 / 1$ & 10.2 & - & $10.2 / 10.2 \mu \mathrm{g} / \mathrm{L}$ \\
\hline 3,3'-Dichlorobenzidine & $0 / 1$ & 10.2 & - & $10.2 / 10.2 \mu \mathrm{g} / \mathrm{L}$ \\
\hline Diethyl phthalate & $0 / 1$ & 10.2 & - & $10.2 / 10.2 \mu \mathrm{g} / \mathrm{L}$ \\
\hline Dimethyl phthalate & $0 / 1$ & 10.2 & - & $10.2 / 10.2 \mu \mathrm{g} / \mathrm{L}$ \\
\hline p-Dimethylaminoazobenzene & $0 / 1$ & 10.2 & - & $10.2 / 10.2 \mu \mathrm{g} / \mathrm{L}$ \\
\hline 7,12-Dimethylbenz[a]anthracene & $0 / 1$ & 10.2 & - & $10.2 / 10.2 \mu \mathrm{g} / \mathrm{L}$ \\
\hline 3,3'-Dimethylbenzidine & $0 / 1$ & 10.2 & - & $10.2 / 10.2 \mu \mathrm{g} / \mathrm{L}$ \\
\hline a,a-Dimethylphenethylamine & $0 / 1$ & 10.2 & - & $10.2 / 10.2 \mu \mathrm{g} / \mathrm{L}$ \\
\hline 1,3-Dinitrobenzene & $0 / 1$ & 10.2 & - & $10.2 / 10.2 \mu \mathrm{g} / \mathrm{L}$ \\
\hline 2,4-Dinitrotoluene & $0 / 1$ & 10.2 & - & $10.2 / 10.2 \mu \mathrm{g} / \mathrm{L}$ \\
\hline 2,6-Dinitrotoluene & $0 / 1$ & 10.2 & - & $10.2 / 10.2 \mu \mathrm{g} / \mathrm{L}$ \\
\hline Di-n-octyl phthalate & $0 / 1$ & 10.2 & - & $10.2 / 10.2 \mu \mathrm{g} / \mathrm{L}$ \\
\hline 1,4-Dioxane & $0 / 1$ & 10.2 & - & $10.2 / 10.2 \mu \mathrm{g} / \mathrm{L}$ \\
\hline Diphenylamine & $0 / 1$ & 10.2 & - & $10.2 / 10.2 \mu \mathrm{g} / \mathrm{L}$ \\
\hline Ethyl methacrylate & $0 / 1$ & 10.2 & - & $10.2 / 10.2 \mu \mathrm{g} / \mathrm{L}$ \\
\hline Ethyl methanesulfonate & $0 / 1$ & 10.2 & - & $10.2 / 10.2 \mu \mathrm{g} / \mathrm{L}$ \\
\hline Fluoranthene & $0 / 1$ & 10.2 & - & $10.2 / 10.2 \mu \mathrm{g} / \mathrm{L}$ \\
\hline Fluorene & $0 / 1$ & 10.2 & - & $10.2 / 10.2 \mu \mathrm{g} / \mathrm{L}$ \\
\hline Hexachlorobenzene & $0 / 1$ & 10.2 & - & $10.2 / 10.2 \mu \mathrm{g} / \mathrm{L}$ \\
\hline Hexachlorobutadiene & $0 / 1$ & 10.2 & - & $10.2 / 10.2 \mu \mathrm{g} / \mathrm{L}$ \\
\hline Hexachlorocyclopentadiene & $0 / 1$ & 10.2 & - & $10.2 / 10.2 \mu \mathrm{g} / \mathrm{L}$ \\
\hline Hexachloroethane & $0 / 1$ & 10.2 & - & $10.2 / 10.2 \mu \mathrm{g} / \mathrm{L}$ \\
\hline Hexachlorophene & $0 / 1$ & 102 & - & $102 / 102 \mu \mathrm{g} / \mathrm{L}$ \\
\hline Hexachloropropene & $0 / 1$ & 10.2 & - & $10.2 / 10.2 \mu \mathrm{g} / \mathrm{L}$ \\
\hline Indeno[ $[1,2,3-c, d]$ pyrene & $0 / 1$ & 10.2 & - & $10.2 / 10.2 \mu \mathrm{g} / \mathrm{L}$ \\
\hline Isophorone & $0 / 1$ & 10.2 & - & $10.2 / 10.2 \mu \mathrm{g} / \mathrm{L}$ \\
\hline Isosafrole & $0 / 1$ & 10.2 & - & $10.2 / 10.2 \mu \mathrm{g} / \mathrm{L}$ \\
\hline Methapyrilene & $0 / 1$ & 10.2 & - & $10.2 / 10.2 \mu \mathrm{g} / \mathrm{L}$ \\
\hline Methyl methacrylate & $0 / 1$ & 10.2 & - & $10.2 / 10.2 \mu \mathrm{g} / \mathrm{L}$ \\
\hline Methyl methanesulfonate & $0 / 1$ & 10.2 & - & $10.2 / 10.2 \mu \mathrm{g} / \mathrm{L}$ \\
\hline 3-Methylcholanthrene & $0 / 1$ & 10.2 & - & $10.2 / 10.2 \mu \mathrm{g} / \mathrm{L}$ \\
\hline 2-Methylnaphthalene & $0 / 1$ & 10.2 & - & $10.2 / 10.2 \mu \mathrm{g} / \mathrm{L}$ \\
\hline Naphthalene & $0 / 1$ & 10.2 & - & $10.2 / 10.2 \mu \mathrm{g} / \mathrm{L}$ \\
\hline 1,4-Naphthoquinone & $0 / 1$ & 10.2 & - & $10.2 / 10.2 \mu \mathrm{g} / \mathrm{L}$ \\
\hline 1-Naphthylamine & $0 / 1$ & 10.2 & - & $10.2 / 10.2 \mu \mathrm{g} / \mathrm{L}$ \\
\hline 2-Naphthylamine & $0 / 1$ & 10.2 & - & $10.2 / 10.2 \mu \mathrm{g} / \mathrm{L}$ \\
\hline m-Nitroaniline & $0 / 1$ & 25.5 & - & $25.5 / 25.5 \mu \mathrm{g} / \mathrm{L}$ \\
\hline
\end{tabular}




\begin{tabular}{|c|c|c|c|c|}
\hline Analyte & $\begin{array}{l}\text { Frequency } \\
\text { of Detectiont }\end{array}$ & Mean Result & $\begin{array}{l}\text { Standard } \\
\text { Deviation }\end{array}$ & Minimum/Maximum Results \\
\hline o-Nitroaniline & $0 / 1$ & 25.5 & - & $25.5 / 25.5 \mu \mathrm{g} / \mathrm{L}$ \\
\hline p-Nitroaniline & $0 / 1$ & 25.5 & - & $25.5 / 25.5 \mu g / L$ \\
\hline Nitrobenzene & $0 / 1$ & 10.2 & - & $10.2 / 10.2 \mu \mathrm{g} / \mathrm{L}$ \\
\hline 4-Nitroquinoline-1-oxide' & $0 / 1$ & 20.4 & - & $20.4 / 20.4 \mu \mathrm{g} / \mathrm{L}$ \\
\hline$N$-Nitrosodi-n-butylamine & $0 / 1$ & 10.2 & - & $10.2 / 10.2 \mu \mathrm{g} / \mathrm{L}$ \\
\hline N-Nitrosodiethylamine & $0 / 1$ & 10.2 & - & $10.2 / 10.2 \mu \mathrm{g} / \mathrm{L}$ \\
\hline $\mathrm{N}$-Nitrosodimethylamine & $0 / 1$ & 10.2 & - & $10.2 / 10.2 \mu \mathrm{g} / \mathrm{L}$ \\
\hline N-Nitrosodiphenylamine & $0 / 1$ & 10.2 & - & $10.2 / 10.2 \mu \mathrm{g} / \mathrm{L}$ \\
\hline N-Nitrosodipropylamine & $0 / 1$ & 10.2 & - & $10.2 / 10.2 \mu \mathrm{g} / \mathrm{L}$ \\
\hline N-Nitrosomethylethylamine & $0 / 1$ & 10.2 & - & $10.2 / 10.2 \mu \mathrm{g} / \mathrm{L}$ \\
\hline N-Nitrosomorpholine & $0 / 1$ & 10.2 & - & $10.2 / 10.2 \mu \mathrm{g} / \mathrm{L}$ \\
\hline N-Nitrosopiperidine & $0 / 1$ & 51.0 & - & $51.0 / 51.0 \mu \mathrm{g} / \mathrm{L}$ \\
\hline N-Nitrosopyrrolidine & $0 / 1$ & 10.2 & - & $10.2 / 10.2 \mu \mathrm{g} / \mathrm{L}$ \\
\hline 5-Nitro-o-toluidine & $0 / 1$ & 10.2 & - & $10.2 / 10.2 \mu \mathrm{g} / \mathrm{L}$ \\
\hline Pentachlorobenzene & $0 / 1$ & 10.2 & - & $10.2 / 10.2 \mu \mathrm{g} / \mathrm{L}$ \\
\hline Pentachloroethane & $0 / 1$ & 10.2 & - & $10.2 / 10.2 \mu \mathrm{g} / \mathrm{L}$ \\
\hline Pentachloronitrobenzene & $0 / 1$ & 51.0 & - & $51.0 / 51.0 \mu \mathrm{g} / \mathrm{L}$ \\
\hline Phenacetin & $0 / 1$ & 10.2 & - & $10.2 / 10.2 \mu \mathrm{g} / \mathrm{L}$ \\
\hline Phenanthrene & $0 / 1$ & 10.2 & - & $10.2 / 10.2 \mu \mathrm{g} / \mathrm{L}$ \\
\hline p-Phenylenediamine & $0 / 1$ & 10.2 & - & $10.2 / 10.2 \mu \mathrm{g} / \mathrm{L}$ \\
\hline 2-Picoline & $0 / 1$ & 10.2 & - & $10.2 / 10.2 \mu g / L$ \\
\hline Pronamid & $0 / 1$ & 10.2 & - & $10.2 / 10.2 \mu g / L$ \\
\hline Pyrene & $0 / 1$ & 10.2 & - & $10.2 / 10.2 \mu \mathrm{g} / \mathrm{L}$ \\
\hline Pyridine & $0 / 1$ & 10.2 & - & $10.2 / 10.2 \mu \mathrm{g} / \mathrm{L}$ \\
\hline Safrole & $0 / 1$ & 10.2 & - & $10.2 / 10.2 \mu \mathrm{g} / \mathrm{L}$ \\
\hline $1,2,4,5$-Tetrachlorobenzene & $0 / 1$ & 10.2 & - & $10.2 / 10.2 \mu \mathrm{g} / \mathrm{L}$ \\
\hline o-Toluidine & $0 / 1$ & 10.2 & - & $10.2 / 10.2 \mu \mathrm{g} / \mathrm{L}$ \\
\hline 1,2,4-Trichlorobenzene & $0 / 1$ & 10.2 & - & $10.2 / 10.2 \mu \mathrm{g} / \mathrm{L}$ \\
\hline $1,3,5$-Trinitrobenzene & $0 / 1$ & 10.2 & - & $10.2 / 10.2 \mu g / L$ \\
\hline \multicolumn{5}{|l|}{ EPA8280A } \\
\hline Octachlorodibenzo-p-dioxin & $0 / 1$ & 3.20 & - & $3.20 / 3.20 \mathrm{ng} / \mathrm{L}$ \\
\hline \multicolumn{5}{|l|}{ EPA9020B } \\
\hline Total organic halogens & $0 / 3$ & 120 & 0.0 & $120 / 120 \mu \mathrm{g} / \mathrm{L}$ \\
\hline \multicolumn{5}{|l|}{ EPA9056 } \\
\hline Sulfate & $1 / 2$ & 303 & 52.3 & $266 / 340 \mu g / L$ \\
\hline \multicolumn{5}{|l|}{ EPA9060 } \\
\hline Total organic carbon & $2 / 2$ & 1,140 & 302 & $923 / 1,350 \mu \mathrm{g} / \mathrm{L}$ \\
\hline \multicolumn{5}{|l|}{ EPA9066 } \\
\hline
\end{tabular}

$\dagger \quad$ Number of times analyte was detected compared to the total number of field blanks for the analyte.

- Standard deviation cannot be determined.

Note: If the analyte was not detected in the field blank(s), detection limit information appears in the Mean Result and Minimum/Maximum Results columns. 
Table 65. Analytes Detected in Field Blanks for GP

\begin{tabular}{|c|c|c|c|c|}
\hline Analyte & $\begin{array}{l}\text { Frequency } \\
\text { of Detectiont }\end{array}$ & Mean Result & $\begin{array}{l}\text { Standard } \\
\text { Deviation }\end{array}$ & Minimum/Maximum Results \\
\hline \multicolumn{5}{|l|}{ EPIA-001 } \\
\hline Gross alpha & $0 / 19$ & $1.16 \mathrm{E}-10$ & $1.74 E-10$ & $-7.93 \mathrm{E}-11 / 4.12 \mathrm{E}-10 \mu \mathrm{Ci} / \mathrm{mL}$ \\
\hline Nonvolatile beta & $0 / 18$ & $2.13 E-11$ & $2.74 \mathrm{E}-10$ & $-5.95 \mathrm{E}-10 / 3.93 \mathrm{E}-10 \mu \mathrm{Ci} / \mathrm{mL}$ \\
\hline \multicolumn{5}{|l|}{ EPIA-002 } \\
\hline Tritium & $1 / 16$ & $1.74 \mathrm{E}-05$ & 7.03E-05 & $-3.82 \mathrm{E}-07 / 2.81 \mathrm{E}-04 \mu \mathrm{Ci} / \mathrm{mL}$ \\
\hline \multicolumn{5}{|l|}{ EPIA-003 } \\
\hline Carbon-14 & $0 / 6$ & $4.83 E-11$ & 4.19E-09 & $-3.82 \mathrm{E}-09 / 7.87 \mathrm{E}-09 \mu \mathrm{Ci} / \mathrm{mL}$ \\
\hline \multicolumn{5}{|l|}{ EPIA-004 } \\
\hline Strontium-90 & $0 / 5$ & $-1.51 E-10$ & $5.27 E-10$ & $-7.20 \mathrm{E}-10 / 4.28 \mathrm{E}-10 \mu \mathrm{Ci} / \mathrm{mL}$ \\
\hline \multicolumn{5}{|l|}{ EPIA-005 } \\
\hline Technetium-99 & $0 / 1$ & $-1.57 \mathrm{E}-09$ & 一 & $-1.57 \mathrm{E}-09 /-1.57 \mathrm{E}-09 \mu \mathrm{Ci} / \mathrm{mL}$ \\
\hline \multicolumn{5}{|l|}{ EPIA-006 } \\
\hline lodine-129 & $0 / 2$ & $3.07 E-10$ & $6.29 \mathrm{E}-11$ & $2.62 \mathrm{E}-10 / 3.51 \mathrm{E}-10 \mu \mathrm{Ci} / \mathrm{mL}$ \\
\hline \multicolumn{5}{|l|}{ EPIA-008 } \\
\hline Radium-226 & $0 / 2$ & $4.69 \mathrm{E}-10$ & $4.24 \mathrm{E}-12$ & 4.66E-10/4.72E-10 $\mu \mathrm{Ci} / \mathrm{mL}$ \\
\hline \multicolumn{5}{|l|}{ EPIA-009 } \\
\hline Radium-228 & $0 / 1$ & $4.25 E-10$ & - & $4.25 \mathrm{E}-10 / 4.25 \mathrm{E}-10 \mu \mathrm{Ci} / \mathrm{mL}$ \\
\hline \multicolumn{5}{|l|}{ EPIA-010 } \\
\hline Radium, total alpha-emitting & $0 / 3$ & $-3.33 E-11$ & $3.06 \mathrm{E}-10$ & $-3.00 \mathrm{E}-10 / 3.00 \mathrm{E}-10 \mu \mathrm{Ci} / \mathrm{mL}$ \\
\hline \multicolumn{5}{|l|}{ EPIA-011 } \\
\hline Uranium-233/234 & $0 / 1$ & $2.24 \mathrm{E}-11$ & - & $2.24 \mathrm{E}-11 / 2.24 \mathrm{E}-11 \mu \mathrm{Ci} / \mathrm{mL}$ \\
\hline Uranium-235 & $0 / 1$ & 0.0 & - & $0.0 / 0.0 \mu \mathrm{Ci} / \mathrm{mL}$ \\
\hline Uranium-238 & $0 / 1$ & $2.66 E-11$ & - & $2.66 \mathrm{E}-11 / 2.66 \mathrm{E}-11 \mu \mathrm{Ci} / \mathrm{mL}$ \\
\hline \multicolumn{5}{|l|}{ EPIA-013 } \\
\hline Actinium-228 & $0 / 3$ & $6.98 \mathrm{E}-09$ & $6.08 \mathrm{E}-09$ & 3.40E-09/1.40E-08 $\mu \mathrm{Ci} / \mathrm{mL}$ \\
\hline Antimony-125 & $0 / 3$ & $6.97 \mathrm{E}-10$ & $5.53 E-09$ & $-5.18 \mathrm{E}-09 / 5.81 \mathrm{E}-09 \mu \mathrm{Ci} / \mathrm{mL}$ \\
\hline Cerium-144 & $0 / 3$ & 4.44E-09 & $4.88 \mathrm{E}-09$ & $-5.86 \mathrm{E}-10 / 9.15 \mathrm{E}-09 \mu \mathrm{Ci} / \mathrm{mL}$ \\
\hline Cesium-134 & $0 / 3$ & $-1.54 \mathrm{E}-10$ & 4.63E-10 & $-4.61 \mathrm{E}-10 / 3.78 \mathrm{E}-10 \mu \mathrm{Ci} / \mathrm{mL}$ \\
\hline Cesium-137 & $0 / 3$ & $-7.93 E-11$ & 1.23E-09 & $-1.47 \mathrm{E}-09 / 8.53 \mathrm{E}-10 \mu \mathrm{Ci} / \mathrm{mL}$ \\
\hline Cobalt-57 & $0 / 3$ & $-3.60 E-11$ & $9.15 E-10$ & $-7.32 \mathrm{E}-10 / 1.00 \mathrm{E}-09 \mu \mathrm{Ci} / \mathrm{mL}$ \\
\hline Cobalt -60 & $0 / 3$ & 4.49E-10 & $6.10 \mathrm{E}-10$ & $-2.30 \mathrm{E}-10 / 9.50 \mathrm{E}-10 \mu \mathrm{Ci} / \mathrm{mL}$ \\
\hline Europium-152 & $0 / 3$ & $6.70 E-10$ & 2.75E-09 & $-2.34 \mathrm{E}-09 / 3.05 \mathrm{E}-09 \mu \mathrm{Ci} / \mathrm{mL}$ \\
\hline Europium-154 & $0 / 3$ & $-6.63 E-10$ & $1.54 \mathrm{E}-09$ & $-2.44 \mathrm{E}-09 / 2.49 \mathrm{E}-10 \mu \mathrm{Ci} / \mathrm{mL}$ \\
\hline Europium-155 & $0 / 3$ & $-1.62 E-09$ & 3.69E-09 & $-5.49 \mathrm{E}-09 / 1.86 \mathrm{E}-09 \mu \mathrm{Ci} / \mathrm{mL}$ \\
\hline Lead-212 & $0 / 3$ & $2.56 \mathrm{E}-09$ & 1.68E-09 & 6.45E-10/3.79E-09 $\mu \mathrm{Ci} / \mathrm{mL}$ \\
\hline Manganese-54 & $0 / 3$ & $5.03 E-10$ & $1.46 E-10$ & 3.37E-10/6.12E-10 $\mu \mathrm{Ci} / \mathrm{mL}$ \\
\hline Potassium-40 & $0 / 3$ & 5.85E-09 & 8.92E-09 & $-4.04 \mathrm{E}-09 / 1.33 \mathrm{E}-08 \mu \mathrm{Ci} / \mathrm{mL}$ \\
\hline Promethium-144 & $0 / 3$ & $3.06 \mathrm{E}-10$ & $1.22 E-09$ & $-1.01 \mathrm{E}-09 / 1.39 \mathrm{E}-09 \mu \mathrm{Ci} / \mathrm{mL}$ \\
\hline Promethium-146 & $0 / 3$ & $-2.78 E-10$ & $8.78 E-10$ & $-1.06 \mathrm{E}-09 / 6.72 \mathrm{E}-10 \mu \mathrm{Ci} / \mathrm{mL}$ \\
\hline Ruthenium-106 & $0 / 3$ & $-5.19 E-09$ & 1.92E-09 & $-6.94 \mathrm{E}-09 /-3.13 \mathrm{E}-09 \mu \mathrm{Ci} / \mathrm{mL}$ \\
\hline
\end{tabular}




\begin{tabular}{lllll}
\hline Analyte & $\begin{array}{l}\text { Frequency } \\
\text { of Detectiont }\end{array}$ & Mean Result & $\begin{array}{l}\text { Standard } \\
\text { Deviation }\end{array}$ & Minimum/Maximum Results \\
\hline Sodium-22 & & & & \\
Yttrium-88 & $0 / 3$ & $-2.32 \mathrm{E}-10$ & $5.49 \mathrm{E}-10$ & $-8.65 \mathrm{E}-10 / 1.04 \mathrm{E}-10 \mu \mathrm{Ci} / \mathrm{mL}$ \\
Zinc-65 & $0 / 3$ & $1.71 \mathrm{E}-09$ & $4.12 \mathrm{E}-10$ & $1.24 \mathrm{E}-09 / 2.02 \mathrm{E}-09 \mu \mathrm{Ci} / \mathrm{mL}$ \\
\hline
\end{tabular}

$\dagger$ Number of times analyte was detected compared to the total number of field blanks for the analyte.

- Standard deviation cannot be determined.

Note: If the analyte was not detected in the field blank(s), detection limit information appears in the Mean Result and Minimum/Maximum Results columns.

Table 66. Analytes Detected in Field Blanks for TM

\begin{tabular}{|c|c|c|c|c|}
\hline Analyte & $\begin{array}{l}\text { Frequency } \\
\text { of Detectiont }\end{array}$ & Mean Result & $\begin{array}{l}\text { Standard } \\
\text { Deviation }\end{array}$ & Minimum/Maximum Results \\
\hline \multicolumn{5}{|l|}{ EPA900.0MOD } \\
\hline Gross alpha & $1 / 8$ & $2.63 E-10$ & $2.63 \mathrm{E}-10$ & $-1.30 \mathrm{E}-10 / 6.10 \mathrm{E}-10 \mu \mathrm{Ci} / \mathrm{mL}$ \\
\hline Nonvolatile beta & $0 / 6$ & $-1.27 \mathrm{E}-10$ & $1.13 E-09$ & $-2.10 \mathrm{E}-09 / 1.31 \mathrm{E}-09 \mu \mathrm{Ci} / \mathrm{mL}$ \\
\hline \multicolumn{5}{|l|}{ EPA903.0MOD } \\
\hline Radium, total alpha-emitting & $0 / 1$ & $3.60 E-10$ & 一 & $3.60 \mathrm{E}-10 / 3.60 \mathrm{E}-10 \mu \mathrm{Ci} / \mathrm{mL}$ \\
\hline $\begin{array}{l}\text { EPA906.0MOD } \\
\text { Tritium }\end{array}$ & $0 / 6$ & $267 F-08$ & $160=-07$ & $170 E_{-0} 710$ ○ीE-07 \\
\hline
\end{tabular}

$\dagger \quad$ Number of times analyte was detected compared to the total number of field blanks for the analyte.

- Standard deviation cannot be determined.

Note: If the analyte was not detected in the field blank(s), detection limit information appears in the Mean Result and Minimum/Maximum Results columns.

Table 67. Analytes Detected in Trip Blanks for EX

\begin{tabular}{lllll}
\hline Analyte & $\begin{array}{l}\text { Frequency } \\
\text { of Detectiont }\end{array}$ & Mean Result & $\begin{array}{l}\text { Standard } \\
\text { Deviation }\end{array}$ & Minimum/Maximum Results \\
\hline EPAB021B & & & & \\
Carbon tetrachloride & $0 / 5$ & 1.0 & 0.0 & $1.0 / 1.0 \mu \mathrm{g} / \mathrm{L}$ \\
Chloroform & $0 / 5$ & 1.0 & 0.0 & $1.0 / 1.0 \mu \mathrm{g} / \mathrm{L}$ \\
cis-1,2-Dichloroethylene & $0 / 5$ & 1.0 & 0.0 & $1.0 / 1.0 \mu \mathrm{g} / \mathrm{L}$ \\
Tetrachloroethylene & $0 / 5$ & 1.0 & 0.0 & $1.0 / 1.0 \mu \mathrm{g} / \mathrm{L}$ \\
1,1,1-Trichloroethane & $0 / 5$ & 1.0 & 0.0 & $1.0 / 1.0 \mu \mathrm{g} / \mathrm{L}$ \\
Trichloroethylene & $0 / 5$ & 1.0 & 0.0 & $1.0 / 1.0 \mu \mathrm{g} / \mathrm{L}$ \\
& & & & \\
EPA8260B & $0 / 4$ & 10.0 & 0.0 & $10.0 / 10.0 \mu \mathrm{gg} / \mathrm{L}$ \\
Acetone & $0 / 2$ & 500 & 0.0 & $500 / 500 \mu \mathrm{g} / \mathrm{L}$ \\
Acetonitrile & $0 / 3$ & 50.0 & 0.0 & $50.0 / 50.0 \mu \mathrm{g} / \mathrm{L}$ \\
Acrolein & $0 / 3$ & 50.0 & 0.0 & $50.0 / 50.0 \mu \mathrm{g} / \mathrm{L}$ \\
Acrylonitrile & $0 / 2$ & 10.0 & 0.0 & $10.0 / 10.0 \mu \mathrm{g} / \mathrm{L}$ \\
Allyl chloride & $0 / 11$ & 5.0 & 0.0 & $5.0 / 5.0 \mu \mathrm{g} / \mathrm{L}$ \\
Benzene & $0 / 11$ & 5.0 & 0.0 & $5.0 / 5.0 \mu \mathrm{g} / \mathrm{L}$ \\
Bromodichloromethane & & & & \\
& & & &
\end{tabular}




\begin{tabular}{|c|c|c|c|c|}
\hline Analyte & $\begin{array}{l}\text { Frequency } \\
\text { of Detectiont }\end{array}$ & Mean Result & $\begin{array}{l}\text { Standard } \\
\text { Deviation }\end{array}$ & Minimum/Maximum Results \\
\hline Bromoform & $0 / 11$ & 5.0 & 0.0 & $5.0 / 5.0 \mu \mathrm{g} / \mathrm{L}$ \\
\hline Bromomethane & $0 / 11$ & 5.0 & 0.0 & $5.0 / 5.0 \mu \mathrm{g} / \mathrm{L}$ \\
\hline Carbon disulfide & $0 / 4$ & 5.0 & 0.0 & $5.0 / 5.0 \mu \mathrm{g} / \mathrm{L}$ \\
\hline Carbon tetrachloride & $0 / 11$ & 5.0 & 0.0 & $5.0 / 5.0 \mu \mathrm{g} / \mathrm{L}$ \\
\hline Chlorobenzene & $0 / 11$ & 5.0 & 0.0 & $5.0 / 5.0 \mu \mathrm{g} / \mathrm{L}$ \\
\hline Chloroethane & $0 / 11$ & 10.0 & 0.0 & 10.0/10.0 $\mu \mathrm{g} / \mathrm{L}$ \\
\hline Chloroethene & $0 / 11$ & 5.0 & 0.0 & $5.0 / 5.0 \mu g / L$ \\
\hline 2-Chloroethyl vinyl ether & $0 / 7$ & 5.0 & 0.0 & $5.0 / 5.0 \mu \mathrm{g} / \mathrm{L}$ \\
\hline Chloroform & $0 / 11$ & 5.0 & 0.0 & $5.0 / 5.0 \mu \mathrm{g} / \mathrm{L}$ \\
\hline Chloromethane & $0 / 11$ & 5.0 & 0.0 & $5.0 / 5.0 \mu \mathrm{g} / \mathrm{L}$ \\
\hline Chloroprene & $0 / 2$ & 50.0 & 0.0 & $50.0 / 50.0 \mu g / L$ \\
\hline Dibromochloromethane & $0 / 11$ & 5.0 & 0.0 & $5.0 / 5.0 \mu \mathrm{g} / \mathrm{L}$ \\
\hline 1,2-Dibromo-3-chloropropane & $0 / 2$ & 5.0 & 0.0 & $5.0 / 5.0 \mu \mathrm{g} / \mathrm{L}$ \\
\hline 1,2-Dibromoethane & $0 / 2$ & 5.0 & 0.0 & $5.0 / 5.0 \mu \mathrm{g} / \mathrm{L}$ \\
\hline Dibromomethane & $0 / 2$ & 5.0 & 0.0 & $5.0 / 5.0 \mu \mathrm{g} / \mathrm{L}$ \\
\hline 1,2-Dichlorobenzene & $0 / 3$ & 5.0 & 0.0 & $5.0 / 5.0 \mu \mathrm{g} / \mathrm{L}$ \\
\hline 1,3-Dichlorobenzene & $0 / 3$ & 5.0 & 0.0 & $5.0 / 5.0 \mu \mathrm{g} / \mathrm{L}$ \\
\hline 1,4-Dichlorobenzene & $0 / 3$ & 5.0 & 0.0 & $5.0 / 5.0 \mu \mathrm{g} / \mathrm{L}$ \\
\hline trans-1,4-Dichloro-2-butene & $0 / 2$ & 20.0 & 0.0 & $20.0 / 20.0 \mu \mathrm{g} / \mathrm{L}$ \\
\hline Dichlorodifluoromethane & $0 / 2$ & 5.0 & 0.0 & $5.0 / 5.0 \mu g / L$ \\
\hline 1,1-Dichloroethane & $0 / 11$ & 5.0 & 0.0 & $5.0 / 5.0 \mu g / L$ \\
\hline 1,2-Dichloroethane & $0 / 11$ & 5.0 & 0.0 & $5.0 / 5.0 \mu \mathrm{g} / \mathrm{L}$ \\
\hline 1,1-Dichloroethylene & $0 / 11$ & 5.0 & 0.0 & $5.0 / 5.0 \mu g / L$ \\
\hline 1,2-Dichloroethylene & $0 / 2$ & 1.0 & 0.0 & $1.0 / 1.0 \mu \mathrm{g} / \mathrm{L}$ \\
\hline cis-1,2-Dichloroethylene & $0 / 2$ & 5.0 & 0.0 & $5.0 / 5.0 \mu g / L$ \\
\hline trans-1,2-Dichloroethylene & $0 / 9$ & 5.0 & 0.0 & $5.0 / 5.0 \mu \mathrm{g} / \mathrm{L}$ \\
\hline Dichloromethane & $2 / 11$ & 4.57 & 1.01 & $1.90 / 5.0 \mu \mathrm{g} / \mathrm{L}$ \\
\hline 1,2-Dichloropropane & $0 / 11$ & 5.0 & 0.0 & $5.0 / 5.0 \mu \mathrm{g} / \mathrm{L}$ \\
\hline cis-1,3-Dichloropropene & $0 / 11$ & 5.0 & 0.0 & $5.0 / 5.0 \mu \mathrm{g} / \mathrm{L}$ \\
\hline trans-1,3-Dichloropropene & $0 / 11$ & 5.0 & 0.0 & $5.0 / 5.0 \mu g / L$ \\
\hline 1,4-Dioxane & $0 / 2$ & 1,000 & 0.0 & $1,000 / 1,000 \mu \mathrm{g} / \mathrm{L}$ \\
\hline Ethyl methacrylate & $0 / 2$ & 5.0 & 0.0 & $5.0 / 5.0 \mu \mathrm{g} / \mathrm{L}$ \\
\hline Ethylbenzene & $0 / 11$ & 5.0 & 0.0 & $5.0 / 5.0 \mu \mathrm{g} / \mathrm{L}$ \\
\hline 2-Hexanone & $0 / 4$ & 5.0 & 0.0 & $5.0 / 5.0 \mu \mathrm{g} / \mathrm{L}$ \\
\hline lodomethane & $0 / 2$ & 5.0 & 0.0 & $5.0 / 5.0 \mu \mathrm{g} / \mathrm{L}$ \\
\hline Isobutyl alcohol & $0 / 2$ & 1,500 & 0.0 & $1,500 / 1,500 \mu \mathrm{g} / \mathrm{L}$ \\
\hline Methacrylonitrile & $0 / 2$ & 500 & 0.0 & $500 / 500 \mu g / L^{2}$ \\
\hline Methyl ethyl ketone & $0 / 4$ & 10.0 & 0.0 & $10.0 / 10.0 \mu g / L$ \\
\hline Methyl isobutyl ketone & $0 / 4$ & 5.0 & 0.0 & $5.0 / 5.0 \mu g / L$ \\
\hline Methyl methacrylate & $0 / 2$ & 50.0 & 0.0 & $50.0 / 50.0 \mu \mathrm{g} / \mathrm{L}$ \\
\hline Pentachloroethane & $0 / 2$ & 200 & 0.0 & $200 / 200 \mu \mathrm{g} / \mathrm{L}$ \\
\hline Propionitrile & $0 / 2$ & 500 & 0.0 & $500 / 500 \mu \mathrm{g} / \mathrm{L}$ \\
\hline Styrene & $0 / 4$ & 5.0 & 0.0 & $5.0 / 5.0 \mu \mathrm{g} / \mathrm{L}$ \\
\hline $1,1,1,2-$ Tetrachloroethane & $0 / 2$ & 5.0 & 0.0 & $5.0 / 5.0 \mu \mathrm{g} / \mathrm{L}$ \\
\hline $1,1,2,2$-Tetrachloroethane & $0 / 11$ & 5.0 & 0.0 & $5.0 / 5.0 \mu \mathrm{g} / \mathrm{L}$ \\
\hline Tetrachloroethylene & $0 / 11$ & 5.0 & 0.0 & $5.0 / 5.0 \mu \mathrm{g} / \mathrm{L}$ \\
\hline Toluene & $0 / 11$ & 5.0 & 0.0 & $5.0 / 5.0 \mu \mathrm{g} / \mathrm{L}$ \\
\hline $1,1,1$-Trichloroethane & $0 / 11$ & 5.0 & 0.0 & $5.0 / 5.0 \mu \mathrm{g} / \mathrm{L}$ \\
\hline 1,1,2-Trichloroethane & $0 / 11$ & 5.0 & 0.0 & $5.0 / 5.0 \mu \mathrm{g} / \mathrm{L}$ \\
\hline Trichloroethylene & $0 / 11$ & 5.0 & 0.0 & $5.0 / 5.0 \mu \mathrm{g} / \mathrm{L}$ \\
\hline Trichlorofluoromethane & $0 / 8$ & 5.0 & 0.0 & $5.0 / 5.0 \mu \mathrm{g} / \mathrm{L}$ \\
\hline 1,2,3-Trichloropropane & $0 / 2$ & 5.0 & 0.0 & $5.0 / 5.0 \mu g / L$ \\
\hline Vinyl acetate & $0 / 4$ & 20.0 & 0.0 & $20.0 / 20.0 \mu \mathrm{g} / \mathrm{L}$ \\
\hline Xylenes & $0 / 4$ & 10.0 & 0.0 & $10.0 / 10.0 \mu \mathrm{g} / \mathrm{L}$ \\
\hline
\end{tabular}

$\dagger \quad$ Number of times analyte was detected compared to the total number of trip blanks for the analyte.

Note: If the analyte was not detected in the trip blank(s), detection limit information appears in the Mean Result and Minimum/Maximum Results columns. 
Table 68. Analytes Detected in Trip Blanks for GE

\begin{tabular}{|c|c|c|c|c|}
\hline Analyte & $\begin{array}{l}\text { Frequency } \\
\text { of Detectiont }\end{array}$ & Mean Result & $\begin{array}{l}\text { Standard } \\
\text { Deviation }\end{array}$ & Minimum/Maximum Results \\
\hline \multicolumn{5}{|l|}{ EPA8260B } \\
\hline Acetone & $0 / 5$ & 5.0 & 0.0 & $5.0 / 5.0 \mu \mathrm{g} / \mathrm{L}$ \\
\hline Benzene & $0 / 11$ & 1.0 & 0.0 & $1.0 / 1.0 \mu \mathrm{g} / \mathrm{L}$ \\
\hline Bromodichloromethane & $0 / 11$ & 1.0 & 0.0 & $1.0 / 1.0 \mu \mathrm{g} / \mathrm{L}$ \\
\hline Bromoform & $0 / 11$ & 1.0 & 0.0 & $1.0 / 1.0 \mu \mathrm{g} / \mathrm{L}$ \\
\hline Bromomethane & $0 / 11$ & 1.0 & 0.0 & $1.0 / 1.0 \mu \mathrm{g} / \mathrm{L}$ \\
\hline Carbon disulfide & $0 / 5$ & 5.0 & 0.0 & $5.0 / 5.0 \mu \mathrm{g} / \mathrm{L}$ \\
\hline Carbon tetrachloride & $0 / 11$ & 1.0 & 0.0 & $1.0 / 1.0 \mu \mathrm{g} / \mathrm{L}$ \\
\hline Chlorobenzene & $0 / 11$ & 1.0 & 0.0 & $1.0 / 1.0 \mu \mathrm{g} / \mathrm{L}$ \\
\hline Chloroethane & $0 / 11$ & 1.0 & 0.0 & $1.0 / 1.0 \mu \mathrm{g} / \mathrm{L}$ \\
\hline Chloroethene & $0 / 11$ & 1.0 & 0.0 & $1.0 / 1.0 \mu \mathrm{g} / \mathrm{L}$ \\
\hline 2-Chloroethyl vinyl ether & $0 / 6$ & 5.0 & 0.0 & $5.0 / 5.0 \mu \mathrm{g} / \mathrm{L}$ \\
\hline Chloroform & $0 / 11$ & 1.0 & 0.0 & $1.0 / 1.0 \mu \mathrm{g} / \mathrm{L}$ \\
\hline Chloromethane & $0 / 11$ & 1.0 & 0.0 & $1.0 / 1.0 \mu \mathrm{g} / \mathrm{L}$ \\
\hline Dibromochloromethane & $0 / 11$ & 1.0 & 0.0 & $1.0 / 1.0 \mu \mathrm{g} / \mathrm{L}$ \\
\hline 1,1-Dichloroethane & $0 / 11$ & 1.0 & 0.0 & $1.0 / 1.0 \mu \mathrm{g} / \mathrm{L}$ \\
\hline 1,2-Dichloroethane & $0 / 11$ & 1.0 & 0.0 & $1.0 / 1.0 \mu \mathrm{g} / \mathrm{L}$ \\
\hline 1,1-Dichloroethylene & $0 / 11$ & 1.0 & 0.0 & $1.0 / 1.0 \mu \mathrm{g} / \mathrm{L}$ \\
\hline 1,2-Dichloroethylene & $0 / 5$ & 2.0 & 0.0 & $2.0 / 2.0 \mu \mathrm{g} / \mathrm{L}$ \\
\hline trans-1,2-Dichloroethylene & $0 / 6$ & 1.0 & 0.0 & $1.0 / 1.0 \mu \mathrm{g} / \mathrm{L}$ \\
\hline Dichloromethane & $6 / 11$ & 2.44 & 1.32 & $1.34 / 5.0 \mu \mathrm{g} / \mathrm{L}$ \\
\hline 1,2-Dichloropropane & $0 / 11$ & 1.0 & 0.0 & $1.0 / 1.0 \mu \mathrm{g} / \mathrm{L}$ \\
\hline cis-1,3-Dichloropropene & $0 / 11$ & 1.0 & 0.0 & $1.0 / 1.0 \mu \mathrm{g} / \mathrm{L}$ \\
\hline trans-1,3-Dichloropropene & $0 / 11$ & 1.0 & 0.0 & $1.0 / 1.0 \mu \mathrm{g} / \mathrm{L}$ \\
\hline Ethylbenzene & $0 / 11$ & 1.0 & 0.0 & $1.0 / 1.0 \mu \mathrm{g} / \mathrm{L}$ \\
\hline 2-Hexanone & $0 / 5$ & 5.0 & 0.0 & $5.0 / 5.0 \mu \mathrm{g} / \mathrm{L}$ \\
\hline Methyl ethyl ketone & $0 / 5$ & 10.0 & 0.0 & $10.0 / 10.0 \mu \mathrm{g} / \mathrm{L}$ \\
\hline Methyl isobutyl ketone & $0 / 5$ & 5.0 & 0.0 & $5.0 / 5.0 \mu \mathrm{g} / \mathrm{L}$ \\
\hline Styrene & $0 / 5$ & 1.0 & 0.0 & $1.0 / 1.0 \mu \mathrm{g} / \mathrm{L}$ \\
\hline $1,1,2,2$-Tetrachloroethane & $0 / 11$ & 1.0 & 0.0 & $1.0 / 1.0 \mu \mathrm{g} / \mathrm{L}$ \\
\hline Tetrachloroethylene & $0 / 11$ & 1.0 & 0.0 & $1.0 / 1.0 \mu \mathrm{g} / \mathrm{L}$ \\
\hline Toluene & $0 / 11$ & 1.0 & 0.0 & $1.0 / 1.0 \mu \mathrm{g} / \mathrm{L}$ \\
\hline $1,1,1-$-Trichloroethane & $0 / 11$ & 1.0 & 0.0 & $1.0 / 1.0 \mu \mathrm{g} / \mathrm{L}$ \\
\hline $1,1,2$-Trichloroethane & $0 / 11$ & 1.0 & 0.0 & $1.0 / 1.0 \mu \mathrm{g} / \mathrm{L}$ \\
\hline Trichloroethylene & $0 / 13$ & 1.0 & 0.0 & $1.0 / 1.0 \mu \mathrm{g} / \mathrm{L}$ \\
\hline Trichlorofluoromethane & $0 / 6$ & 5.0 & 0.0 & $5.0 / 5.0 \mu \mathrm{g} / \mathrm{L}$ \\
\hline Vinyl acetate & $0 / 5$ & 5.0 & 0.0 & $5.0 / 5.0 \mu \mathrm{g} / \mathrm{L}$ \\
\hline Xylenes & $0 / 5$ & 2.0 & 0.0 & $2.0 / 2.0 \mu \mathrm{g} / \mathrm{L}$ \\
\hline
\end{tabular}

+ Number of times analyte was detected compared to the total number of trip blanks for the analyte.

Note: If the analyte was not detected in the trip blank(s), detection limit information appears in the Mean Result and Minimum/Maximum Results columns.

Table 69. Analytes Detected in Trip Blanks for WA

\begin{tabular}{lllll}
\hline Analyte & $\begin{array}{l}\text { Frequency } \\
\text { of Detectiont }\end{array}$ & Mean Result & $\begin{array}{l}\text { Standard } \\
\text { Deviation }\end{array}$ & Minimum/Maximum Results \\
\hline EPA8021B & & & & \\
Carbon tetrachloride & $1 / 10$ & 1.02 & 0.06 & $1.0 / 1.20 \mu \mathrm{g} / \mathrm{L}$ \\
$\begin{array}{l}\text { Chloroform } \\
\text { cis-1,2-Dichloroethylene }\end{array}$ & $0 / 10$ & 1.0 & 0.0 & $1.0 / 1.0 \mu \mathrm{g} / \mathrm{L}$ \\
& $0 / 10$ & 1.0 & 0.0 & $1.0 / 1.0 \mu \mathrm{g} / \mathrm{L}$ \\
\hline
\end{tabular}




\begin{tabular}{|c|c|c|c|c|}
\hline Analyte & $\begin{array}{l}\text { Frequency } \\
\text { of Detectiont }\end{array}$ & Mean Result & $\begin{array}{l}\text { Standard } \\
\text { Deviation }\end{array}$ & Minimum/Maximum Results \\
\hline Tetrachloroethylene & $1 / 10$ & 1.11 & 0.35 & $1.0 / 2.10 \mu \mathrm{g} / \mathrm{L}$ \\
\hline $1,1,1$-Trichloroethane & $0 / 10$ & 1.0 & 0.0 & $1.0 / 1.0 \mu \mathrm{g} / \mathrm{L}$ \\
\hline Trichloroethylene & $0 / 10$ & 1.0 & 0.0 & $1.0 / 1.0 \mu \mathrm{g} / \mathrm{L}$ \\
\hline \multicolumn{5}{|l|}{ EPA8260B } \\
\hline Acetone & $0 / 3$ & 10.0 & 0.0 & $10.0 / 10.0 \mu \mathrm{g} / \mathrm{L}$ \\
\hline Benzene & $0 / 21$ & 5.0 & 0.0 & $5.0 / 5.0 \mu \mathrm{g} / \mathrm{L}$ \\
\hline Bromodichloromethane & $0 / 21$ & 5.0 & 0.0 & $5.0 / 5.0 \mu \mathrm{g} / \mathrm{L}$ \\
\hline Bromoform & $0 / 21$ & 5.0 & 0.0 & $5.0 / 5.0 \mu \mathrm{g} / \mathrm{L}$ \\
\hline Bromomethane & $0 / 21$ & 10.0 & 0.0 & $10.0 / 10.0 \mu \mathrm{g} / \mathrm{L}$ \\
\hline Carbon disulfide & $0 / 3$ & 5.0 & 0.0 & $5.0 / 5.0 \mu g / L$ \\
\hline Carbon tetrachloride & $0 / 21$ & 5.0 & 0.0 & $5.0 / 5.0 \mu \mathrm{g} / \mathrm{L}$ \\
\hline Chlorobenzene & $0 / 21$ & 5.0 & 0.0 & $5.0 / 5.0 \mu \mathrm{g} / \mathrm{L}$ \\
\hline Chloroethane & $0 / 21$ & 10.0 & 0.0 & $10.0 / 10.0 \mu \mathrm{g} / \mathrm{L}$ \\
\hline Chloroethene & $0 / 21$ & 10.0 & 0.0 & $10.0 / 10.0 \mu \mathrm{g} / \mathrm{L}$ \\
\hline 2-Chloroethyl vinyl ether & $0 / 18$ & 10.0 & 0.0 & $10.0 / 10.0 \mu \mathrm{g} / \mathrm{L}$ \\
\hline Chloroform & $0 / 21$ & 5.0 & 0.0 & $5.0 / 5.0 \mu g / L$ \\
\hline Chloromethane & $0 / 21$ & 10.0 & 0.0 & $10.0 / 10.0 \mu \mathrm{g} / \mathrm{L}$ \\
\hline Dibromochloromethane & $0 / 21$ & 5.0 & 0.0 & $5.0 / 5.0 \mu \mathrm{g} / \mathrm{L}$ \\
\hline 1,1-Dichloroethane & $0 / 21$ & 5.0 & 0.0 & $5.0 / 5.0 \mu \mathrm{g} / \mathrm{L}$ \\
\hline 1,2-Dichloroethane & $0 / 21$ & 5.0 & 0.0 & $5.0 / 5.0 \mu \mathrm{g} / \mathrm{L}$ \\
\hline 1,1-Dichloroethylene & $0 / 21$ & 5.0 & 0.0 & $5.0 / 5.0 \mu \mathrm{g} / \mathrm{L}$ \\
\hline 1,2-Dichloroethylene & $0 / 3$ & 5.0 & 0.0 & $5.0 / 5.0 \mu \mathrm{g} / \mathrm{L}$ \\
\hline trans-1,2-Dichloroethylene & $0 / 18$ & 5.0 & 0.0 & $5.0 / 5.0 \mu \mathrm{g} / \mathrm{L}$ \\
\hline Dichloromethane & $2 / 21$ & 6.27 & 2.14 & $4.07 / 10.9 \mu \mathrm{g} / \mathrm{L}$ \\
\hline 1,2-Dichloropropane & $0 / 21$ & 5.0 & 0.0 & $5.0 / 5.0 \mu \mathrm{g} / \mathrm{L}$ \\
\hline cis-1,3-Dichloropropene & $0 / 21$ & 5.0 & 0.0 & $5.0 / 5.0 \mu \mathrm{g} / \mathrm{L}$ \\
\hline trans-1,3-Dichloropropene & $0 / 21$ & 5.0 & 0.0 & $5.0 / 5.0 \mu \mathrm{g} / \mathrm{L}$ \\
\hline Ethylbenzene & $0 / 21$ & 5.0 & 0.0 & $5.0 / 5.0 \mu \mathrm{g} / \mathrm{L}$ \\
\hline 2-Hexanone & $0 / 3$ & 10.0 & 0.0 & $10.0 / 10.0 \mu \mathrm{g} / \mathrm{L}$ \\
\hline Methyl ethyl ketone & $0 / 3$ & 10.0 & 0.0 & $10.0 / 10.0 \mu \mathrm{g} / \mathrm{L}$ \\
\hline Methyl isobutyl ketone & $0 / 3$ & 10.0 & 0.0 & $10.0 / 10.0 \mu \mathrm{g} / \mathrm{L}$ \\
\hline Styrene & $0 / 3$ & 5.0 & 0.0 & $5.0 / 5.0 \mu g / L$ \\
\hline 1,1,2,2-Tetrachloroethane & $0 / 21$ & 5.0 & 0.0 & $5.0 / 5.0 \mu \mathrm{g} / \mathrm{L}$ \\
\hline Tetrachloroethylene & $0 / 21$ & 5.0 & 0.0 & $5.0 / 5.0 \mu g / L$ \\
\hline Toluene & $0 / 21$ & 5.0 & 0.0 & $5.0 / 5.0 \mu \mathrm{g} / \mathrm{L}$ \\
\hline 1,1,1-Trichloroethane & $0 / 21$ & 5.0 & 0.0 & $5.0 / 5.0 \mu \mathrm{g} / \mathrm{L}$ \\
\hline $1,1,2-$ Trichloroethane & $0 / 21$ & 5.0 & 0.0 & $5.0 / 5.0 \mu \mathrm{g} / \mathrm{L}$ \\
\hline Trichloroethylene & $0 / 21$ & 5.0 & 0.0 & $5.0 / 5.0 \mu \mathrm{g} / \mathrm{L}$ \\
\hline Trichlorofluoromethane & $0 / 18$ & 5.0 & 0.0 & $5.0 / 5.0 \mu \mathrm{g} / \mathrm{L}$ \\
\hline Vinyl acetate & $0 / 3$ & 10.0 & 0.0 & $10.0 / 10.0 \mu \mathrm{g} / \mathrm{L}$ \\
\hline Xylenes & $0 / 21$ & 5.0 & 0.0 & $5.0 / 5.0 \mu \mathrm{g} / \mathrm{L}$ \\
\hline
\end{tabular}

+ Number of times analyte was detected compared to the total number of trip blanks for the analyte.

Note: If the analyte was not detected in the trip blank(s), detection limit information appears in the Mean Result and Minimum/Maximum Results columns.

Table 70. Analytes Detected in Trip Blanks for ML

\begin{tabular}{lllll}
\hline Analyte & $\begin{array}{l}\text { Frequency } \\
\text { of Detectiont }\end{array}$ & Mean Result & $\begin{array}{l}\text { Standard } \\
\text { Deviation }\end{array}$ & Minimum/Maximum Results \\
\hline EPA8260B & & & & \\
Acetone & $0 / 1$ & 7.17 & - & $7.17 / 7.17 \mu \mathrm{g} / \mathrm{L}$ \\
Benzene & $0 / 1$ & 1.0 & - & $1.0 / 1.0 \mu \mathrm{g} / \mathrm{L}$ \\
Bromodichloromethane & $0 / 1$ & 1.0 & $1.0 / 1.0 \mu \mathrm{g} / \mathrm{L}$ \\
\hline
\end{tabular}




\begin{tabular}{|c|c|c|c|c|}
\hline Analyte & $\begin{array}{l}\text { Frequency } \\
\text { of Detectiont }\end{array}$ & Mean Result & $\begin{array}{l}\text { Standard } \\
\text { Deviation }\end{array}$ & Minimum/Maximum Results \\
\hline Bromoform & $0 / 1$ & 1.0 & - & $1.0 / 1.0 \mu \mathrm{g} / \mathrm{L}$ \\
\hline Bromomethane & $0 / 1$ & 1.0 & - & $1.0 / 1.0 \mu \mathrm{g} / \mathrm{L}$ \\
\hline Carbon disulfide & $0 / 1$ & 5.0 & - & $5.0 / 5.0 \mu \mathrm{g} / \mathrm{L}$ \\
\hline Carbon tetrachloride & $0 / 1$ & 1.0 & - & $1.0 / 1.0 \mu \mathrm{g} / \mathrm{L}$ \\
\hline Chlorobenzene & $0 / 1$ & 1.0 & - & $1.0 / 1.0 \mu \mathrm{g} / \mathrm{L}$ \\
\hline Chloroethane & $0 / 1$ & 1.0 & - & $1.0 / 1.0 \mu \mathrm{g} / \mathrm{L}$ \\
\hline Chloroethene & $0 / 1$ & 1.0 & - & $1.0 / 1.0 \mu \mathrm{g} / \mathrm{L}$ \\
\hline Chloroform & $0 / 1$ & 1.0 & - & $1.0 / 1.0 \mu \mathrm{g} / \mathrm{L}$ \\
\hline Chloromethane & $0 / 1$ & 1.0 & - & $1.0 / 1.0 \mu \mathrm{g} / \mathrm{L}$ \\
\hline Dibromochloromethane & $0 / 1$ & 1.0 & - & $1.0 / 1.0 \mu \mathrm{g} / \mathrm{L}$ \\
\hline 1,1-Dichloroethane & $0 / 1$ & 1.0 & - & $1.0 / 1.0 \mu \mathrm{g} / \mathrm{L}$ \\
\hline 1,2-Dichloroethane & $0 / 1$ & 1.0 & - & $1.0 / 1.0 \mu \mathrm{g} / \mathrm{L}$ \\
\hline 1,1-Dichloroethylene & $0 / 1$ & 1.0 & - & $1.0 / 1.0 \mu \mathrm{g} / \mathrm{L}$ \\
\hline 1,2 -Dichloroethylene & $0 / 1$ & 1.0 & - & $1.0 / 1.0 \mu \mathrm{g} / \mathrm{L}$ \\
\hline cis-1,2-Dichloroethylene & $0 / 1$ & 1.0 & - & $1.0 / 1.0 \mu \mathrm{g} / \mathrm{L}$ \\
\hline trans-1,2-Dichloroethylene & $0 / 1$ & 1.0 & - & $1.0 / 1.0 \mu \mathrm{g} / \mathrm{L}$ \\
\hline Dichloromethane & $0 / 1$ & 4.87 & - & $4.87 / 4.87 \mu g / L$ \\
\hline 1,2-Dichloropropane & $0 / 1$ & 1.0 & - & $1.0 / 1.0 \mu g / L$ \\
\hline cis-1,3-Dichloropropene & $0 / 1$ & 1.0 & - & $1.0 / 1.0 \mu \mathrm{g} / \mathrm{L}$ \\
\hline trans-1,3-Dichloropropene & $0 / 1$ & 1.0 & - & $1.0 / 1.0 \mu \mathrm{g} / \mathrm{L}$ \\
\hline Ethylbenzene & $0 / 1$ & 1.0 & - & $1.0 / 1.0 \mu \mathrm{g} / \mathrm{L}$ \\
\hline 2-Hexanone & $0 / 1$ & 5.0 & - & $5.0 / 5.0 \mu \mathrm{g} / \mathrm{L}$ \\
\hline Methyl ethyl ketone & $0 / 1$ & 5.0 & - & $5.0 / 5.0 \mu \mathrm{g} / \mathrm{L}$ \\
\hline Methyl isobutyl ketone & $0 / 1$ & 5.0 & - & $5.0 / 5.0 \mu \mathrm{g} / \mathrm{L}$ \\
\hline Styrene & $0 / 1$ & 1.0 & - & $1.0 / 1.0 \mu \mathrm{g} / \mathrm{L}$ \\
\hline $1,1,2,2-$ Tetrachloroethane & $0 / 1$ & 1.0 & - & $1.0 / 1.0 \mu \mathrm{g} / \mathrm{L}$ \\
\hline Tetrachloroethylene & $0 / 1$ & 1.0 & - & $1.0 / 1.0 \mu \mathrm{g} / \mathrm{L}$ \\
\hline Toluene & $0 / 1$ & 1.0 & - & $1.0 / 1.0 \mu \mathrm{g} / \mathrm{L}$ \\
\hline $1,1,1$-Trichloroethane & $0 / 1$ & 1.0 & - & $1.0 / 1.0 \mu \mathrm{g} / \mathrm{L}$ \\
\hline $1,1,2$-Trichloroethane & $0 / 1$ & 1.0 & - & $1.0 / 1.0 \mu \mathrm{g} / \mathrm{L}$ \\
\hline Trichloroethylene & $0 / 1$ & 1.0 & - & $1.0 / 1.0 \mu \mathrm{g} / \mathrm{L}$ \\
\hline Vinyl acetate & $0 / 1$ & 5.0 & - & $5.0 / 5.0 \mu \mathrm{g} / \mathrm{L}$ \\
\hline Xylenes & $0 / 1$ & 1.0 & - & $1.0 / 1.0 \mu \mathrm{g} / \mathrm{L}$ \\
\hline
\end{tabular}

$\dagger$ Number of times analyte was detected compared to the total number of trip blanks for the analyte.

- Standard deviation cannot be determined.

Note: If the analyte was not detected in the trip blank(s), detection limit information appears in the Mean Result and Minimum/Maximum Results columns.

Table 71. Sampled Wells with Metal Casings

\begin{tabular}{llll}
\hline Well & Casing & Well & Casing \\
\hline RSA 8 & Steel & RWM 13B & Carbon steel \\
RSD 1 & Steel & RWM 13C & Carbon steel \\
RSD 3 & Steel & RWM 14B & Carbon steel \\
RSE 1A & Steel & RWM 14C & Carbon steel \\
RSE 2 & Steel & RWM 15B & Carbon steel \\
RSE 7 & Steel & TNX 14D & Stainless steel \\
RSE 8 & Steel & TNX 15D & Stainless steel \\
RWM 1 & Carbon steel & TNX 16D & Stainless steel \\
RWM 3 & Carbon steel & TNX 17D & Stainless steel \\
RWM 4 & Carbon steel & TNX 18D & Stainless steel \\
RWM 5 5 & Carbon steel & TNX 19D & Stainless steel \\
RWM 6 & Carbon steel & TNX 20D & Stainless steel \\
RWM 7 & Carbon steel & &
\end{tabular}




\begin{tabular}{llll}
\hline Well & Casing & Well & Casing \\
\hline RWM 8 & Carbon steel & TNX 21D & Stainless steel \\
RWM 9 & Carbon steel & TNX 22D & Stainless steel \\
RWM 10 & Carbon steel & TNX 26D & Stainless steel \\
RWM 11 & Carbon steel & & \\
\hline
\end{tabular}

Table 72. Wells That Had Turbidity Greater Than 15 NTU

\begin{tabular}{lll}
\hline Well & Date & Results (in NTU) \\
\hline DCB 27 & $05 / 12 / 99$ & 33.0 \\
DCB 30 & $05 / 12 / 99$ & 40.9 \\
FBP 10D & $06 / 15 / 99$ & 42.5 \\
FSB119D & $04 / 09 / 99$ & 121 \\
HSB152D & $04 / 23 / 99$ & 154 \\
KDB 3 & $06 / 21 / 99$ & 15.7 \\
KDB 5 & $04 / 27 / 99$ & 18.8 \\
KDB 5 & $05 / 21 / 99$ & 51.8 \\
KDB 5 & $06 / 21 / 99$ & 18.2 \\
LDB 1 & $04 / 27 / 99$ & 18.4 \\
LDB 2 & $04 / 27 / 99$ & 17.4 \\
LDB 2 & $05 / 21 / 99$ & 31.5 \\
LDB 2 & $06 / 21 / 99$ & 16.0 \\
LDB 4 & $05 / 21 / 99$ & 22.0 \\
RSD 1 & $05 / 14 / 99$ & 32.0 \\
RSD 1 & $06 / 17 / 99$ & 61.0 \\
RSE 7 & $05 / 14 / 99$ & 34.0 \\
RSE 7 & $06 / 17 / 99$ & 35.0 \\
RWM 12 & $06 / 14 / 99$ & 46.7 \\
SRW 17DR & $05 / 05 / 99$ & 86.1 \\
SRW 18 & $05 / 12 / 99$ & 44.6 \\
TBG 6 & $05 / 07 / 99$ & 48.0 \\
TCM 3 & $05 / 06 / 99$ & 23.0 \\
TNX 21D & $05 / 03 / 99$ & \\
\hline
\end{tabular}




\section{Site Index}

Table 73 provides information about sites, locations, and well series. Some site names and locations were not available.

Table 73. Sites and Locations by Well Series

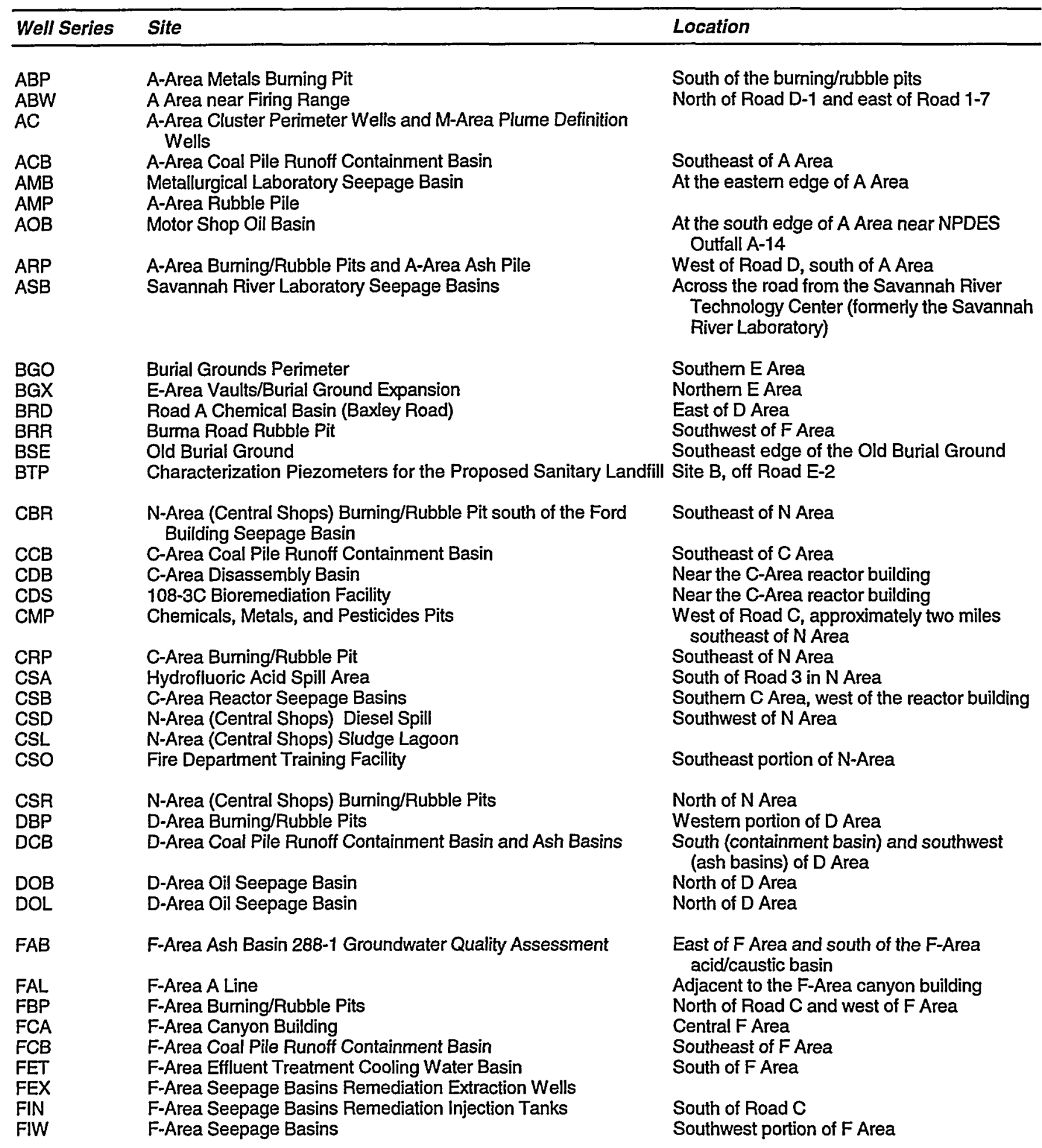




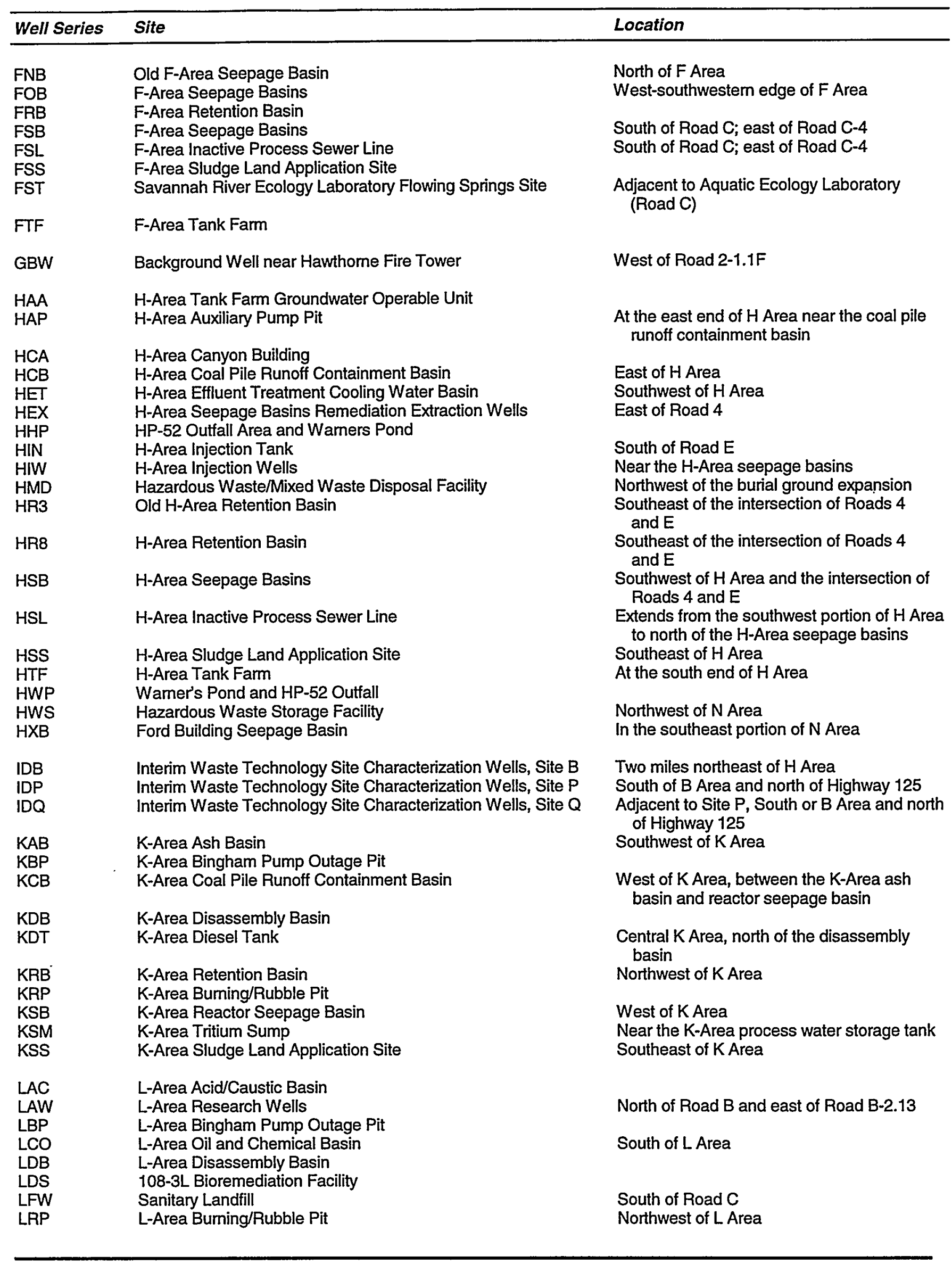




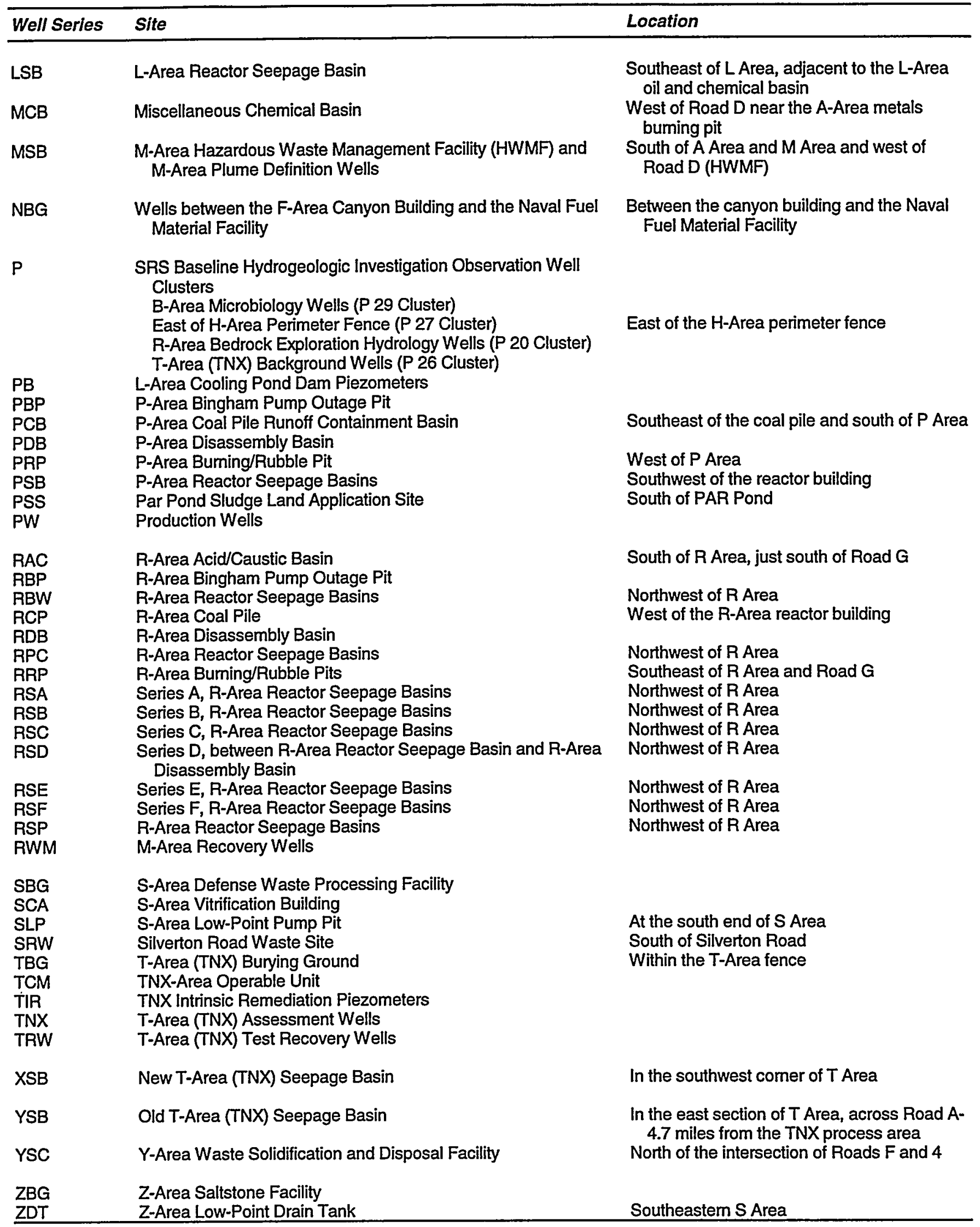




\section{SITE HISTORY}

Geographical descriptions in the text are based on true north rather than SRS grid coordinates.

The following sections describe facilities at approximately 100 locations within designated areas at SRS. The sections are arranged in the following order:

- acid/caustic basins

- burning/rubble, rubble, and metals burning pits

- coal pile runoff containment basins, ash basins, and coal piles

- disassembly basins

- seepage and retention basins

- operating buildings and facilities

- plume monitoring

- radioactive waste storage and disposal facilities

- sanitary landfill and interim sanitary landfill

- sludge application sites

- other sites

\section{Acid/Caustic Basins}

The acid/caustic basins in F Area, H Area, K Area, L Area, P Area, and R Area are unlined earthen pits (approximately 50 by 50 by 7 feet deep). These pits received dilute sulfuric acid and sodium hydroxide solutions used to regenerate ion-exchange units in power plant water purification processes at the reactor and separations areas in the center of SRS. The basins allowed mixing and neutralization of the dilute solutions before their discharge to nearby streams.

The basins were constructed between 1952 and 1955. They are uncovered, and most are dry except during periods of prolonged precipitation. The R-Area and L-Area basins were abandoned in 1964 and 1968, respectively. The other basins remained in service until 1982, when the water purification systems either were shut down or modernized. However, the $\mathrm{H}$-Area basin continued to receive steam condensate from a hose box and drainage from a chemical pad until the basin was abandoned in 1985. During July through September 1993, the F-, H-, K-, and P-Area basins were dewatered, vegetation was removed and disposed of, the basins were filled with compacted soil from the Burma Road clay pit, a grass cover was established, and the fences were reinstalled.

\section{Burning/Rubble, Rubble, and Metals Burning Pits}

From 1951 to 1973, burnable wastes-such as paper, wood, plastics, rubber, oil, degreasers, and drummed solvents-were received and burned monthly in one or more of the burning/rubble pits in the following areas: $A$, C, D, F, K, L, N, P, and R. In 1973, waste no longer was burned at the pits, which were covered with a layer of soil. Rubble wastes-including paper, wood, cans, concrete, and empty galvanized-steel barrels and drumsthen were disposed of in the pits until they reached capacity and were covered with soil. All burning/rubble pits were inactive by 1981, and all are covered except the R-Area pit, which has not been backfilled. Lithiumaluminum alloy, aluminum pieces, metal drums, other metal scraps, and plastic pipe were deposited and burned periodically in the A-Area metals burning pit, beginning about 1952. In 1974, the solid materials remaining on the site were covered with soil, and the pit was regraded. The site is inactive. 
The Burma Road rubble pit consists of two excavated earthen pits that may contain paint cans, fluorescent light fixtures, metal, concrete, lumber, poles, and glass. Unknown quantities of refuse were deposited here from approximately 1973 through 1983 . The pit is inactive and has been covered with soil.

\section{Coal Pile Runoff Containment Basins, Ash Basins, and Coal Piles}

Electricity and steam at SRS are generated by burning coal. Coal piles originally existed in the following areas: $A, C, D, F, H, K, L, P$, and $R$. The facilities generally contained a 90-day reserve of coal that was not rotated. During long-term exposure to the environment, chemical and biological oxidation of sulfur compounds in coal resulted in the formation of sulfuric acid.

The R-Area coal pile was removed in 1964, and the L-Area coal pile was removed in 1968. To achieve compliance with the National Pollutant Discharge Elimination System (NPDES) permit issued in 1977, coal pile runoff containment basins in A Area and D Area were completed in October 1978, and basins in C Area, F Area, $H$ Area, $K$ Area, and $P$ Area were completed in March 1981. The coal piles in C Area and F Area were removed in 1985. In 1991, the K-Area coal pile was reduced to a 2-inch base, and 75 percent of the P-Area coal pile was removed.

Currently, rainwater runoff from the remaining coal piles in $A, D, H, K$, and $P$ Areas flows into the coal pile runoff containment basins via gravity flow ditches and sewers. The basins allow mixing of the runoff and its seepage into the subsurface, thus preventing the entry of large surges of low-pH runoff into surface streams. The basins in $C$ and $F$ Areas also still collect runoff, although no coal remains at either location. Ash sluice water from the D-Area and K-Area powerhouses has been discharged to the D-Area ash basins and the K-Area ash basin, respectively, since 1951.

\section{F-Area Ash Basin}

The F-Area ash basin was monitored for the first time during second quarter 1994.

\section{R-Area Coal Pile}

Two wells were installed in 1990 inside the boundaries of the former coal storage area, originally for groundwater assessment in relation to the R-Area coal pile.

\section{Disassembly Basins}

The disassembly basins, also called fuel and target storage basins, are concrete-lined, open tanks of water next to the reactor rooms inside the reactor buildings in C, K, L, P, and R Areas. Irradiated assemblies (reactor fuel and target rods) were rinsed and stored in the basins prior to their shipment to the separations areas. Some radioactivity was transferred to the basin water from leaks in porous components and as a liquid or oxide corrosion film on the irradiated components.

Sand filters were used to remove radioactive particulates from the disassembly basin water. The filtered water was circulated through deionizers to remove additional constituents and was purged periodically through regenerated deionizers to the reactor seepage basins.

\section{Seepage and Retention Basins}

Seepage, retention, and settling basins have been used at SRS to store or dispose of wastewater from various operations. Seepage and retention basins in the following areas are monitored: $A, C, F, H, K, L, M, N, P, R, T$, and the Savannah River Laboratory.

\section{C-Area Reactor Seepage Basins}

These basins have received low-level radioactive purge water from the disassembly basin since 1957. 


\section{F-Area Seepage Basins and Inactive Process Sewer Line}

Beginning in 1955, the F-Area seepage basins received F-Area wastewater containing low-level radioactivity and chemicals, including chromium, mercury, nitric acid, and sodium hydroxide. Clay caps were completed in 1991 when the basins were closed.

\section{Ford Building Seepage Basin}

The Ford Building seepage basin received low-level radioactive wastewater from Ford Building operations (repairing heat exchangers) from 1964 to January 1984.

\section{H-Area Retention Basins}

A small, unlined earthen retention basin (the old $\mathrm{H}$-Area retention basin) was used from 1955 to 1973 to provide temporary emergency storage for cooling water from the chemical separations process that contained radionuclides and possible trace quantities of chemicals.

A larger, rubber-lined retention basin replaced the original basin in 1973 and still is in use for receipt of diverted cooling water or tank farm stormwater runoff.

\section{H-Area Seepage Basins and Inactive Process Sewer Line}

Starting in 1955, the $\mathrm{H}$-Area seepage basins received wastewater from $\mathrm{H}$ Area containing low-level radioactivity and chemicals, including nitric acid, mercury, and sodium hydroxide. Basin 3 has been inactive since 1962. Basins 1,2, and 4 operated from 1980 until they were taken out of service in the fourth quarter of 1988. Clay caps were completed early in 1991 when the basins were closed.

\section{K-Area Reactor Seepage Basin}

This basin has received low-level radioactive purge water from the disassembly basin since 1957.

\section{L-Area Reactor Seepage Basin}

This basin has received low-level radioactive purge water from the disassembly basin since 1957.

\section{M-Area Hazardous Waste Management Facility}

The unlined M-Area settling basin, in operation from 1958 until 1985, received wastewater containing metalcleaning solvents, depleted uranium, and other chemicals and metals from fuel fabrication processes in $M$ Area. Because surface water flowed from this basin, it is classified as a settling basin rather than a seepage basin. Water from the basin flowed through an overflow ditch to Lost Lake, a shallow upland depression. A seepage area formed adjacent to the ditch and Lost Lake. The M-Area hazardous waste management facility comprises the settling basin, overflow ditch, seepage area, and Lost Lake. A closure cap was completed on the basin during 1989/1990.

Since the beginning of a full-scale recovery system for groundwater remediation in April 1985, groundwater flow has changed markedly near this facility, and changes over time in concentrations of analytes are difficult to interpret. See the Plume Monitoring section of this chapter for more information on remediation.

\section{Metallurgical Laboratory Seepage Basin}

The Metallurgical Laboratory seepage basin received wastewater effluent from the Metallurgical Laboratory building from 1956 until 1985. Wastewater released to the basin consisted of small quantities ( 5 to 10 gallons per day) of laboratory wastes-mostly rinse water-from metallographic sample preparation (degreasing, cleaning, etching) and corrosion testing of stainless steel and nickel-based alloys. Noncontact cooling water (approximately 900 gallons per day) also was discharged. The basin has been dewatered, backfilled, and capped with low-permeability clay.

\section{New T-Area (TNX) Seepage Basin}

The new TNX seepage basin replaced the old TNX seepage basin and operated from 1980 to 1988. 


\section{Old F-Area Seepage Basin}

The old F-Area seepage basin, the first seepage basin constructed in F Area, was used for disposal of wastewater from the canyon building from November 1954 until May 1955, when it was abandoned. During operation, the seepage basin received a variety of wastewaters, including evaporator overheads, laundry wastewater, and an unknown amount of chemicals. For three months in 1969, spent nitric acid solutions used to etch depleted uranium were discharged to the basin. In 1984, low-level contaminated water was released to the basin.

\section{Old T-Area (TNX) Seepage Basin}

The old TNX seepage basin received waste from pilot-scale tests conducted at TNX from 1958 to 1980 . In 1981 , the basin wall was breached and the impounded water was drained into the adjacent wetlands. The basin then was backfilled with a sand and clay mixture, and the top was capped with clay.

\section{P-Area Reactor Seepage Basins}

These basins have received low-level radioactive purge water from the P-Area disassembly basin since 1957.

\section{R-Area Reactor Seepage Basins}

On November 8, 1957, an experimental fuel element failed during a calorimeter test in the emergency section of the R-Area disassembly basin. Following this incident, the original seepage basin received approximately $2,700 \mathrm{Ci}$ of nonvolatile beta activity, including strontium-90 and cesium-137, each of which has a half-life of about 30 years. Much of the released radioactivity was contained in that basin, which was backfilled in December 1957. Five more basins were put into operation in 1957 and 1958 to assist in containing the radioactivity.

In 1960, Basins 2 through 5 were closed and backfilled. The ground surface above Basins 1 through 5 was treated with herbicide and covered with asphalt. In addition, a kaolinite cap and dike were constructed over and around Basin 1 and the northwest end of Basin 3 to minimize lateral movement of the radioactive contamination. Basin 6, which received water directly from the disassembly basin from 1960 until 1964, was backfilled in 1977.

\section{Savannah River Laboratory Seepage Basins}

The Savannah River Laboratory seepage basins received low-level radioactive laboratory wastewater through underground drains until they were taken out of service in October 1982. Two basins were put into operation in 1954; one more was added in 1958 and another in 1960 to provide additional holding capacity.

An exception to the practice of discharging only low-level alpha or beta-gamma wastewater was made in 1971, when $0.68 \mathrm{Ci}$ of curium from a leaking separator pit in the Savannah River Laboratory radioactive waste tanks was disposed of in the basins. Approximately 34 million gallons of wastewater were discharged to the basins during their operating life.

\section{Operating Buildings and Facilities}

\section{Defense Waste Processing Facility (S-Area Vitrification Building)}

The DWPF, also known as the S-Area vitrification building or S-Area canyon, contains the process and auxiliary equipment to incorporate high-level radioactive waste into leach-resistant glass. The facility began radioactive operations in 1996.

\section{F-Area Canyon Building and A-Line Uranium Recovery Facility}

At the canyon building, irradiated product from the reactors is dissolved using nitric acid, and the desired radionuclides are separated from fission products. At the A-Line uranium recovery facility, adjacent to the canyon building, uranium oxide is produced from uranyl nitrate. 


\section{F-Area Effluent Treatment Cooling Water Basin}

The F-Area effluent treatment cooling water basin receives diverted cooling water from the separations processes. The cooling water is sent from the basin to the F-Area and $\mathrm{H}$-Area effluent treatment facility (ETF) if contaminated or to a permitted outfall if uncontaminated. The ETF, on the south side of $H$ Area, was placed in service in 1988 to treat wastewater formerly sent to the F-Area and H-Area seepage basins. In addition to cooling water, it also receives separations area stormwater runoff and condensed overheads from the evaporators in the tank farms. The treatment facility removes hazardous and radioactive contaminants from these low-level liquid wastes and concentrates them for immobilization as saltstone.

\section{H-Area Auxiliary Pump Pit}

The $\mathrm{H}$-Area auxiliary pump pit facility will pump high-level radioactive sludge and precipitate from the $\mathrm{H}$-Area tank farm to the S-Area low-point pump pit en route to the vitrification facility. When the pumps are shut down, this facility will collect the solution in a temporary holding tank via gravity flow lines.

\section{H-Area Canyon Building}

As in F Area, materials from the reactors are dissolved at the canyon building, and the desired radionuclides are separated from waste products.

\section{H-Area Effluent Treatment Cooling Water Basin}

For more information, see the F-Area Effluent Treatment Cooling Water Basin section.

\section{K-Area Tritium Sump}

A single well, installed in 1992, monitors the water table just west of the K-Area reactor. The well was placed near the K-Area process water storage tank, which stores water collected in sumps within the K-Area reactor building. Tritium activity in this sump water has been reported at greater than $5 \mathrm{Ci} / \mathrm{mL}$.

\section{N-Area Hazardous Waste Storage Facility}

Building $645-\mathrm{N}$ of the hazardous waste storage facility has been in service since 1983,645-2N since 1987, and $645-4 \mathrm{~N}$ since 1984 . Buildings $645-\mathrm{N}$ and $645-4 \mathrm{~N}$ contain hazardous waste, and building $645-2 \mathrm{~N}$ contains mixed waste (a mixture of low-level radioactive waste and hazardous waste). Wastes are stored inside the buildings in drums placed on diked concrete floors designed to contain liquid spills.

\section{Naval Fuel Material Facility}

The Naval Fuel Material Facility was used to produce HEU (highly enriched uranium) for naval reactors until shutdown in 1989. Monitoring wells in the NBG series are located between the canyon building and the Naval Fuel Material Facility.

\section{S-Area Facilities}

S-Area contains several facilities for processing high-level radioactive waste from the F-Area and $\mathrm{H}$-Area tank farms into borosilicate glass solidified within stainless steel canisters. The glass is stored temporarily in specially designed storage buildings within S Area. Eventual permanent disposal is expected to be in an offsite federal geologic repository.

\section{S-Area Low-Point Pump Pit}

The S-Area low-point pump pit receives high-level radioactive sludge and precipitate from the $\mathrm{H}$-Area tank farm and pumps it to the defense waste processing facility (DWPF) vitrification building; it also receives waste being recycled from the vitrification building back to the tank farm. As at the H-Area auxiliary pump pit, when the pumps are shut down, the sludge and precipitate remaining in the line drain back into a temporary holding tank via gravity flow lines. 


\section{Z-Area Low-Point Drain Tank}

The Z-Area low-point drain tank facility receives low-level radioactive salt solution from the $\mathrm{H}$-Area tank farm and pumps it to the Z-Area salt solution holding tank. When the H-Area pump is shut down, the low-point drain tank can collect the solution remaining in the lines via gravity flow.

\section{Z-Area Saltstone Manufacturing and Disposal Facility}

The Z-Area saltstone manufacturing and disposal facility processes and permanently disposes of low-level radioactive salt solution supernatant from the underground storage tanks at $F$ Area and $H$ Area and from ETF concentrate.

The facility began radioactive operations in June 1990. In November 1992, a tank in the Z-Area saltstone manufacturing and disposal facility overflowed, and a portion of the liquid leaked from the building into a storm drain. Approximately 2 gallons of solution reached a drainage pipe that flows into a series of sedimentation basins and eventually into McQueen Branch. Sediment samples showed small amounts of cesium-137 exceeding those amounts observed in the Savannah River, but within the activity ranges in site streams.

\section{Plume Monitoring}

\section{A Area and M Area}

In addition to the groundwater monitoring conducted at specific locations in A Area and M Area, numerous plume definition wells also monitor a 5 -square-mile area to assess the extent of volatile organic contamination. The first plume definition wells were installed soon after discovery of the contamination in June 1981.

The plume definition well network extends from the region north of SRTC, between Road 1 and the SRS boundary, south to wells near the miscellaneous chemical basin and the metals burning pit, and from Tims Branch in the east toward the Silverton Road waste site in the west. The plume encompasses approximately three square miles and consists primarily of trichloroethylene, tetrachloroethylene, and 1,1,1-trichloroethane.

\section{Separations and Waste Management Areas}

A number of wells were installed in the separations areas in 1951 and 1952 . These wells, which range from approximately 15 to 90 feet in depth, are used to measure water table elevations and monitor for radioactive constituents (gross alpha, nonvolatile beta, and tritium) in the groundwater in and around F Area and $\mathrm{H}$ Area. They have steel casings that could affect the metal concentrations in the water.

\section{Radioactive Waste Storage and Disposal Facilities}

\section{Burial Grounds}

The burial grounds have been used for storage and disposal of radioactive solid waste produced at SRS or shipped from other facilities since 1952. The original area, known as the old burial ground, contains low-level alpha and beta-gamma trenches, intermediate-level beta-gamma trenches, and alpha waste trenches. As the trenches were filled, they were covered with soil. When the old burial ground was filled in 1974, operations moved to the adjacent low-level radioactive waste disposal facility (LLRWDF).

The sections of the LLRWDF currently being operated, known as the Solid Waste Disposal Facility (SWDF), contain trenches for only radioactive waste. Concrete vaults, known as the E-Area vaults, have been constructed east and north of the LLRWDF for disposal of solid radioactive waste. The first waste was placed there in September 1994.

Mixed waste storage building 643/29E, within the boundaries of the LLRWDF, has been in use since March 1987. The adjacent mixed waste storage building, 643/43E, was completed in July 1995, and the facility began receiving waste later that same month.

Until 1965, transuranic (TRU) waste was placed in plastic bags and cardboard boxes and buried in earthen trenches. Between 1965 and 1974, lower level TRU waste was buried unencapsulated in trenches, and higher level TRU waste was buried in retrievable concrete containers or encapsulated in concrete. Since 1974, TRU 
wastes contaminated with greater than $0.01 \mathrm{Ci} / g$ have been stored in watertight containers on concrete pads with monitoring sumps. TRU waste storage pads 1-19 are on the FFA's list of RCRA-regulated units.

Since mid-1984, newly generated low-level beta-gamma waste has been placed in metal boxes or metal drums. Currently, it is disposed of in engineered trenches and covered with at least 4 feet of soil. Some wastes that do not have forms that are easily placed in containers are disposed of in shallow land-burial slit trenches.

Mixed wastes stored or disposed of within the old burial ground and portions of the LLRWDF include cadmium, lead, mercury, and tritiated pump oil. Some of the waste is contained in welded stainless steel containers or metal drums and stored within concrete cylinders. Degraded radioactive organic solvents and tritiated pump oil have been stored in 22 underground storage tanks in the old burial ground. In addition, two areas of the old burial ground were used for incineration of solvents.

The burial ground complex, comprising the old burial ground, solvent storage tanks S01-S22, and portions of the LLRWDF, is monitored by the following:

Burial Ground Expansion (E-Area Vaults)-This site is located in the northern section of E Area and is monitored by the BGX well series.

Hazardous Waste/Mixed Waste Disposal Facility - This site is northwest of the burial ground expansion and is monitored by the HMD well series.

Old Burial Ground-The old burial ground is in the southern portion of $E$ Area and is monitored by wells in the $B G$ and $B G O$ well series.

Radioactive Waste Burial Ground-The LLRWDF, which includes the mixed waste management facility (MWMF), is monitored by wells in the BGO well series.

\section{Tank Farms}

Liquid radioactive wastes are stored and processed at the tank farms, which comprise subsurface tanks containing high-level aqueous radioactive wastes in the form of sludges, supernatant liquid of varying salt concentrations, and saltcake. Approximately 129 million liters of waste are stored in the tanks.

The high-level liquid waste volume is reduced in the tank farm evaporators. Certain tanks are used for pretreatment of the wastes before they are processed at the DWPF into saltstone (low-level waste) or a glass form (high-level waste). As described earlier, saltstone manufacturing and disposal is ongoing; vitrification was tested during 1995, and the DWPF began production operations in 1996. Pretreatment processes at the tank farms include in-tank precipitation and extended sludge processing.

More information about the function of the tank farms may be found in previous sections of this chapter, including the discussions of the F-Area effluent treatment cooling water basin, the H-Area auxiliary pump pit, $S$ Area, the S-Area low-point pump pit, the DWPF, the Z-Area low-point drain tank, and the Z-Area saltstone manufacturing and disposal facility.

Because of restrictions on the disposal of purge water, monitoring wells at the tank farms are bailed and not purged.

F-Area Tank Farm-The F-Area tank farm comprises 22 subsurface tanks. In 1961, Tank 8 was overfilled, causing soil and possible groundwater contamination.

H-Area Tank Farm-The H-Area tank farm comprises 29 subsurface tanks. In 1960, Tank 16 leaked an unknown quantity (a few tens of gallons to a few hundred gallons) of waste into the soil. The tank's remaining waste was removed by 1972 .

Several other releases of waste from $\mathrm{H}$-Area tanks have occurred, including a spill of approximately 100 gallons at Tank 13 in 1983. In 1989, approximately 500 pounds of volume-reduced waste leaked from a transfer line at 
Tank 37. The leak sites have been cleaned up or stabilized to prevent the spread of contamination. Both the FArea and $\mathrm{H}$-Area sites are being monitored for gross alpha, nonvolatile beta, and tritium.

\section{Sanitary Landfill and Interim Sanitary Landfill}

The sanitary landfill began receiving waste from office, cafeteria, and industrial activities during 1974. Materials such as paper, plastics, rubber, wood, cardboard, rags, metal debris, pesticide bags, empty cans, carcasses, asbestos in bags, and sludge from the site's wastewater treatment plant are placed in unlined trenches and covered daily with soil or a fabric substitute. The original section of the landfill and its southern expansion, with a total area of approximately 54 acres, have been filled. Operations at the portion of approximately 16 acres known as the northern expansion, or the interim sanitary landfill, were discontinued in November 1994.

Sanitary landfills are intended to receive only nonradioactive, nonhazardous waste. However, until October 1992, some hazardous wastes (specifically, solvent-laden rags and wipes used for cleaning, decontamination, and instrument calibration) were buried in portions of the original 32-acre landfill and its southern expansion.

\section{Sludge Application Sites}

These sites originally were the subject of a research program using domestic sewage sludge to reclaim borrow pits and to enhance forest productivity at SRS. In 1980, sludge was applied to the following application sites: K Area, Kato Road, Lower Kato Road, Orangeburg, PAR Pond, Road F, Sandy (Lucy), Second PAR Pond Borrow Pit, and 40-Acre Hardwood. After sludge was applied to the sites, hardwoods and pines were planted to quantify the effectiveness of the sludge as a fertilizer and soil conditioner.

Sludge from Aiken and Augusta municipal wastewater treatment plants was applied to the following sites: F Area, H Area, Kato Road, Lower Kato Road, Orangeburg, Road F, Sandy (Lucy), Second PAR Pond Borrow Pit, and 40-Acre Hardwood. Wastewater sludge was applied to the K Area and PAR Pond sites in 1981 and 1988. Revegetating of the sites is continuing.

In November 1993, groundwater monitoring was discontinued at the Kato Road, Lower Kato Road, Orangeburg, Road F, Sandy (Lucy), and 40-Acre Hardwood sites because they have not received applications of sewage sludge since 1981, and historical monitoring results show no impact from sludge applications. Monitoring was canceled after first quarter 1994.

\section{H-Area Sanitary Sludge Land Application Site}

Sewage sludge from SRS sanitary wastewater treatment plants was disposed of at this 13-acre site southeast of $\mathrm{H}$ Area from November 1990 to May 1992.

\section{K-Area and PAR Pond Sludge Land Application Sites (Formerly K-Area Borrow Pit and PAR Pond Borrow Pit Sites)}

In 1981, sludge from Aiken and Augusta municipal wastewater treatment plants was applied to the K-Area and PAR Pond borrow pits. In 1988, the N-Area sanitary sewage sludge lagoon was closed, and the lagoon sludge was applied to the K Area and PAR Pond borrow pits. In 1989, the K-Area location (now called the K-Area sludge land application site) was declared a RCRA/CERCLA unit because of the presence of chlordane in the lagoon sludge applied to the site.

\section{Other Sites}

\section{B-Area Gas Station}

Elevated benzene, which could be the result of old underground gasoline or diesel storage tanks, has been detected near B Area. EMS has inspected the area and believes there may be two underground storage tanks southeast of B Area. The first suspected tank appears to be at an abandoned gas station between Kato Road and Road C-2. The second appears to be an old diesel tank in front of a storage and laboratory facility. 


\section{Baseline Hydrogeologic Investigation Observation Well Clusters}

Wells in the P series that provide baseline hydrogeologic investigation data are located in numerous locations across SRS.

\section{Chemicals, Metals, and Pesticides Pits}

The chemicals, metals, and pesticides pits were used from 1971 to 1979 to dispose of oil in drums, organic solvents, and small amounts of pesticides and metals. In 1984, the pits were excavated to form two trenches, backfilled, and capped. During excavation, most of the contaminated material (liquid in original drums, free liquid placed in drums during excavation, and contaminated soil) was moved to the hazardous waste storage facility.

\section{D-Area Oil Disposal Basin}

The D-Area oil disposal basin was constructed in 1952 and received waste oil products from D Area that were unacceptable for incineration in the powerhouse boilers. These waste oils may have contained hydrogen sulfide, chlorinated organics, or other chemicals. In 1975, the oil basin was removed from service and backfilled with soil.

\section{Interim Waste Technology Site Characterization Wells}

Characterization wells monitor interim waste technology sites $B, L, Q$, and $P$.

\section{K-Area Diesel Tank Spill}

Following the discovery in 1989 of a leaking buried diesel supply line, most of the diesel-contaminated soil was removed from this area except where continued excavation would have jeopardized the structural integrity of an underground storage tank.

\section{L-Area Acid/Caustic Basin and L-Area Oil and Chemical Basin}

From 1961 to 1979 , the L-Area oil and chemical basin received small quantities of radioactive oil and chemical waste that could not be discharged to effluent streams, regular seepage basins, or the 200 Areas' waste management systems. The waste came from throughout SRS, primarily from the reactor areas and the contaminated-equipment workshop through a pipeline known to have leaked. The basin has been inactive since 1979.

\section{M-Area Recovery Wells}

The RWM well series identifies the M-Area recovery wells. The first wells were installed in 1982 and 1983, with pumps added in 1985. Additional wells were installed in 1985, 1990, 1993, and 1996. The RWM wells pump contaminated groundwater to air strippers, which remove volatile organic compounds from the water before it is returned to the ground.

\section{Miscellaneous Chemical Basin}

The miscellaneous chemical basin, in operation by 1956 , was closed and graded in 1974. No records document the materials disposed of at this location. However, soil gas investigations revealed volatile organics in the nearsurface soils at the basin. It is assumed that the site was used for disposal of waste solvents, liquid chemical wastes, and possibly waste oil. The basin is inactive.

\section{Motor Shop Oil Basin}

This unlined basin was placed in service in 1977 to receive liquid effluent from the Motor Shop, including trace quantities of engine oil, grease, kerosene, ethylene glycol, and soap. All waste passed through an oil skimmer prior to discharge into the basin. All discharges to the basin were terminated in August 1983. The basin is inactive but collects rainwater during periods of heavy precipitation.

\section{N-Area Diesel Spill Hazardous Waste Storage Facility}

The tanks have been filled with inert material, and the pipelines have been disconnected at this site. 


\section{N-Area Fire Department Training Facility}

The fire department training facility, also known as the $\mathrm{N}$-Area burnable-oil basin, is a shallow pit surrounded by an 18-inch-high asphalt dike. It was used from 1979 to 1982 by the SRS Fire Department to train personnel in the use of firefighting equipment. After this time, the area was excavated and backfilled.

\section{N-Area Hydrofluoric Acid Spill}

It is uncertain whether a spill occurred at the hydrofluoric acid spill area or if contaminated soil or containers were buried there. The spill or burial occurred prior to 1970, and an identification sign is the only evidence that material was released.

\section{Production Wells}

The PW series wells are production wells scattered across SRS.

\section{Road A (Baxley Road) Chemical Basin}

The Road A chemical basin is reported to have received miscellaneous radioactive and chemical aqueous waste, but no records of the materials disposed of at the basin are available. The basin was closed and backfilled in 1973. The BRD well series is being monitored for environmental-screening constituents only.

\section{Silverton Road Waste Site}

The Silverton Road waste site, south of Silverton Road, was used for disposal of metal shavings, construction debris, tires, drums, tanks, and miscellaneous other items. The startup date is unknown, and no records of waste disposal activities were kept. Operations at this location ended in 1974, and the waste material is covered with soil and vegetation.

\section{TNX Burying Ground}

The TNX burying ground was created to dispose of debris from an experimental evaporator that exploded at $T$ Area in 1953. The buried material included contaminated conduit, tin, drums, structural steel, and depleted uranium. Although most of this material was excavated and sent to the LLRWDF between 1980 and 1984, an estimated $27 \mathrm{~kg}$ of uranyl nitrate remains buried at this location. See the New TNX Seepage Basin section for more information on the unit. 
NOTES

1 


\section{Glossary}

Also see p. B-1 for abbreviations and qualifiers used in the results tables in Appendix B.

2,4-D. 2,4-Dichlorophenoxyacetic acid.

absolute difference. The unsigned result of the subtraction of any two numbers.

accuracy. The degree of agreement between an observed value and an accepted reference value or a measure of the over- or underestimation of reported concentrations.

advisory range. A range of acceptable analytical results established by the provider of known samples.

aerated sample. Groundwater sample supplied or charged with air. Aeration can occur naturally or during well pumping.

aliquot. A portion of a sample being used for analysis.

analyte. Analyzed constituent.

analytical detection limit. The lowest reasonably accurate concentration of an analyte that can be detected. This value varies depending on the method, instrument, and dilution used.

APHA. American Public Health Association.

Appendix IX. A list of constituents specified by Appendix IX in the Code of Federal Regulations, Title 40, Part 264 (EPA, 1991d). Analysis for Appendix IX constituents is required by the Resource Conservation and Recovery Act (RCRA) under specified conditions.

associated samples. Samples analyzed by a laboratory in the same batch with field or laboratory blanks.

ASTM. American Society for Testing and Materials.

bail. To remove water from a well by lowering a container into the water, allowing it to fill with water, and removing it from the well.

blank. Aliquot of deionized water generated by laboratory or sampling personnel and analyzed like a groundwater sample. See equipment blank, field blank, laboratory blank, and trip blank.

blank spike. An organic-free water sample spiked with target analytes, extracted, and analyzed with the regular samples for organic parameters to monitor the performance of all steps in the analysis process.

blind replicate. A second sample taken from a well at the same time as the primary sample and sent to the laboratory for analysis as an unknown.

BNA. Base/neutral and acid extractables. Groups of organic compounds analyzed as part of the Appendix IX and Priority Pollutants suites; also, a group of compounds that can be analyzed by EPA Method 8270 .

Bq/L. Becquerels per liter. A measurement of radioactivity.

cation. Positively charged ion.

CERCLA. Comprehensive Environmental Response, Compensation, and Liability Act, commonly known as Superfund. 
certified value. The known concentration of an analyte in a referenced sample.

CFR. Code of Federal Regulations. Sections of this annual document contain EPA standards and regulations for environmental monitoring.

chain-of-custody record. A form that documents the collection, transport, analysis, and disposal of well samples.

common analyses. Common parameters tested for, and generally found, in drinking water.

comparability. An evaluation made by confirming that the laboratories used the same standardized procedures for sample preparation and analysis, that the reporting units are the same, and that similar detection and quantitation limits were obtained.

completeness. An evaluation based on a comparison of the wells scheduled for sampling to the wells sampled, also a comparison of the requested analyses to the analytical data received.

deionized water. Water from which all charged species or ionizable organic and inorganic salts have been removed.

detection limit. See analytical detection limit.

dilution factor. The mathematical factor by which a sample is diluted to bring the concentration of an analyte in the sample within the analytical range of an instrument (e.g., $1 \mathrm{~mL}$ sample $+9 \mathrm{~mL}$ solvent $=1: 10$ dilution, or a dilution factor of 10).

DL. See analytical detection limit.

DNAPL. Dense nonaqueous phase liquid.

DOE. U.S. Department of Energy.

drinking water standards. Federal primary and secondary drinking water standards, as set forth by the EPA.

duplicate. Duplicate sample; an aliquot of a primary sample.

duplicate result. A result obtained from identical analyses performed on more than one aliquot of a primary sample.

DWS. See drinking water standards.

E. A code letter used in the analytical data tables that signifies exponential notation (e.g., $3.4 \mathrm{E}+03=3.4 \times 10^{3}=$ $3,400)$.

EM. EPD/EMS Laboratory at SRS.

EMAX Laboratories. EMAX Laboratories, Inc., of Torrance, CA.

EMS. The Environmental Monitoring Section of the Environmental Protection Department at SRS.

EMS code. See qualifier.

Environmental Physics. Environmental Physics, Inc., of Charleston, SC (subcontractor for General Engineering).

environmental-screening analyses. A group of analyses that forms the core of the EPD/EMS Groundwater Monitoring Program each quarter. See the Sample Scheduling section of this report for a complete list of constituents. 
EPA. U.S. Environmental Protection Agency.

EPD. Environmental Protection Department at SRS.

EPD/EMS. Environmental Protection Department's Environmental Monitoring Section at SRS.

EQL. See estimated quantitation limit.

equipment blank. A sample of deionized water that is opened at the sampling location and poured or pumped through the sampling device. Equipment blanks are used to identify possible contaminants in the sampling equipment.

\section{ES. See QST Environmental.}

estimated quantitation limit (EQL). The lowest concentration reliably achieved within specified limits of precision and accuracy during routine laboratory operating conditions. The EQL is generally $5 x$ to $10 x$ the method detection limit (MDL); however, it may be nominally chosen within these guidelines to simplify data reporting. For many analytes, the EQL analyte concentration is selected as the lowest nonzero standard in the calibration curve.

\section{EX. See EMAX Laboratories.}

Fibers/L. Fibers per liter. A unit of measurement for asbestos.

field blank. A sample container of deionized water sent to a laboratory under an alias as a quality control check.

field qualifier. See sample interference field qualifier. Due to space limitations, sample interference field qualifiers are referred to as field qualifiers in the analytical results tables in Appendix B.

flagging criteria. Criteria established to help determine the relative concentration and testing frequency for analytes. See the Flagging Criteria section of this report for further information.

functional guideline code. See qualifier.

gamma PHA. A group of analyses performed to determine activities of gamma-emitting radionuclides.

GC. See Gulf Coast.

GC VOA. Gas chromatographic volatile organics analyses. Also used to refer to a group of volatile organic compounds that can be analyzed by gas chromatography.

GCMS VOA. Gas chromatograph/mass spectrometer volatile organics analyses. Also used to refer to a group of volatile organic compounds analyzed by gas chromatography and mass spectrometry methods.

GE. See General Engineering.

General Engineering. General Engineering Laboratories of Charleston, SC.

General Engineering Laboratories Mobile Laboratory. The Mobile Laboratory, associated with General Engineering Laboratories of Charleston, SC.

GP. See Environmental Physics.

Gulf Coast. Gulf Coast of Chicago, IL (owned by Recra).

halogen. Any of the elements of the halogen family, which consists of fluorine, chlorine, bromine, iodine, and astatine.

\section{Glossary}


herbicides/pesticides. A suite of analyses. See the Sample Scheduling section of this report for further information.

holding time. The length of time during which an analysis of a sample can be reliably performed. Holding times vary depending on which constituents are being analyzed.

interlaboratory comparisons. Comparisons conducted between two or more laboratories.

intralaboratory comparisons. Comparisons conducted within a single laboratory.

ion. An isolated electron or positron or an atom or molecule that has acquired a net electric charge by the loss or gain of one or more electrons.

laboratory blank. Deionized water or solvent sample generated by the laboratory. One blank is analyzed with each batch of samples as an in-house check of analytical procedures and equipment.

laboratory control sample. A deionized water sample that is spiked with the target analyte, digested, and analyzed with the regular samples for inorganic parameters to monitor the performance of all steps in the analysis process.

\section{MA. See Microanalytical Laboratories.}

major ions. A group of analyses performed in the EPD/EMS Groundwater Monitoring Program to determine the concentrations of calcium, magnesium, potassium, and silica ions and the alkalinity of a sample.

matrix spike. A known quantity of a target analyte added to at least $5 \%$ of the samples prior to sample preparation to evaluate the effect of the sample matrix on the analytical procedure.

MDL. See method detection limit.

mean. The arithmetic mean; a single number that typifies a set of numbers.

method detection limit (MDL). A reproducible analyte- and method-specific detection limit: the minimum concentration of a substance that can be measured and reported with $99 \%$ confidence that the analyte concentration is greater than zero.

mg/L. Milligrams per liter.

$\mu \mathrm{Ci}$. Microcurie; unit of radioactivity equivalent to $3.7 \times 10^{4}$ disintegrations per second.

$\mu \mathrm{Ci} / \mathrm{mL}$. Microcuries per milliliter.

$\mu g / L$. Micrograms per liter.

$\boldsymbol{\mu S} / \mathbf{c m}$. Microsiemens per centimeter, equivalent to micromhos per centimeter. The unit of conductance across two points, used as the measure of specific conductance in analytical data tables.

Microanalytical Laboratories. Microanalytical Laboratories, Inc., of Gainesville, FL (subcontractor for QST Environmental).

ML. See General Engineering Laboratories Mobile Laboratory.

modifier. See qualifier.

MRD. Mean relative difference. See the Quality Control Samples section of this report for further information. 
msl. Mean sea level.

NTU. Nephelometric turbidity units. The standard unit of turbidity measurement.

null hypothesis. A statement, which can be tested statistically, of no difference in a characteristic of a population or distribution.

organic. A chemical compound based on carbon chains or rings and containing hydrogen with or without oxygen, nitrogen, or other elements.

PCB. Polychlorinated biphenyl.

pCi. Picocurie; a unit of radioactivity equivalent to $3.7 \times 10^{-2}$ disintegrations per second.

pCi/L. Picocuries per liter.

pCi/mL. Picocuries per milliliter.

piezometer. An instrument used to measure the potentiometric surface of groundwater. Also, a well designed for this purpose.

plume. A volume of contaminated air or water originating at a point-source emission (e.g., a smokestack) or a waste source (e.g., a hazardous-waste disposal site).

potentiometric surface. The surface to which water in an aquifer would rise by hydrostatic pressure if unconfined.

precision. A measure of the repeatability of a measurement, evaluated from the results of duplicate samples and splits.

primary laboratory. A laboratory having a contract with EPD/EMS to perform a specific set of analyses; a primary laboratory may subcontract this work to other laboratories.

purge. To remove water from a well prior to sampling, generally by pumping or bailing. Under the EPD/EMS Groundwater Monitoring Program, two well volumes generally are purged before sampling.

QA. Quality assurance.

QC. Quality control.

QST Environmental. QST Environmental, of Gainesville, FL.

qualifier. A code used to convey additional information about an analytical result. Also called a modifier. Specific types include functional guideline codes, STORET codes, and EMS codes. See Appendix B for additional information.

radioisotopes. Radioactive isotopes.

radionuclide. A nuclide at an unstable, high-energy level that seeks a more stable, low-energy level by emitting particles of energy. Through these emissions, the nuclear configuration decays to simpler nuclides.

RCRA. See Resource Conservation and Recovery Act.

RCRA site. Solid-waste management unit under RCRA regulation.

RDL. See reference detection limit. 
Recra LabNet Philadelphia. Recra LabNet Philadelphia, of Lionville, PA.

reference detection limit (RDL). The detection limit chosen to allow comparison of several analyses with different detection limits. For the purposes of this report, the individual detection limits of at least $90 \%$ of the analyses are less than the reference detection limit. See the Quality Control Samples section of this report for further information.

relative percent difference (RPD). A commonly used estimate of precision when only two samples are available. Precision is the agreement among a set of replicate measurements without assumption of the true value. Precision is estimated by means of duplicate analyses.

replicate. Replicate sample. Used in this report to mean only those duplicate samples sent to the laboratory as unknowns. See blind replicate.

representativeness. The quality of exhibiting the average properties of the population being sampled.

Resource Conservation and Recovery Act (RCRA). Federal legislation that regulates the transport, treatment, and disposal of solid and hazardous wastes.

RFI Program. RCRA Facility Investigation Program. EPA-regulated investigation of a solid-waste management unit with regard to its potential impact on the environment.

RFIRI Program. RCRA Facility Investigation/Remedial Investigation Program. At SRS, an expansion of the RFI Program that includes CERCLA and hazardous-substance regulations.

RPD. See relative percent difference.

run date. The calendar date denoting when an analysis is performed.

sample interference field qualifier. See also field qualifier. This describes interferences encountered during sample collection that could affect analytical results. It is used to qualify analytical data based on field condition.

sample quantitation limit (SQL). The sample-specific EQL, which is the EQL multiplied by factors of concentration, dilution, aliquot size, and percent solids.

sample-specific EQL (sSEQL). The EQL multiplied by factors of concentration, dilution, aliquot size, and percent solids. Also called the SQL.

sample-specific MDL (ssMDL). The MDL multiplied by factors of concentration, dilution, aliquot size, and percent solids. For radiological analyses it is known as the sample-specific minimum detectable concentration.

sampling device. Anything used in sampling, especially portable (nondedicated) pumps and bailers. Possible source of sample contamination if not cleaned thoroughly between uses.

SCDHEC. South Carolina Department of Health and Environmental Control.

seepage basin. An excavation that receives wastewater. Designed to prevent overflow or surface runoff.

settling basin. A temporary holding basin (excavation) that receives wastewater.

significance of probability. The probability of observing a statistical value as significant as, or more significant than, the value actually observed.

site custodian. WSRC employee responsible for a site being monitored.

SQL. See sample quantitation limit. 
SRL. Savannah River Laboratory at SRS; now Savannah River Technology Center (SRTC).

SRP. Savannah River Plant; now Savannah River Site (SRS).

SRS. Savannah River Site.

SRTC. Savannah River Technology Center.

STORET. EPA national database for storage and retrieval of water quality information and monitoring data; some of the qualifiers listed in the Analytical Results section of this report (Appendix B) are based on STORET codes.

STORET code. See qualifier.

surrogate. An organic compound similar in composition and test performance to one of the analytes of interest; known quantities are used in an analysis as a quality assurance measure.

tank farm. An installation of interconnected underground tanks used for storage of high-level radioactive liquid wastes.

Thermo NUtech. Thermo NUtech, of Oak Ridge, TM (subcontractor for Recra LabNet Philadelphia and QST Environmental).

\section{TL. See Triangle Laboratories.}

TM. See Thermo NUtech.

TOC. Top of casing. The elevation of the casing at the top of a well; used as a reference for water-level measurements.

Triangle Laboratories. Triangle Laboratories, Inc., of Durham, NC (subcontractor for Environmental Science \& Engineering).

trip blank. A sample container of deionized water that is transported to the well sample location, treated as a well sample, and sent to the laboratory for analysis; trip blanks are used to check for contamination resulting from transport, shipping, and site conditions.

t-test. Statistical method used to determine if the means of groups of observations are equal.

turbidity. A measure of the concentration of sediment or suspended particles in solution.

U. Unclassified.

USDWS. U.S. Public Health Service drinking water standard.

validation and verification. The standard, in-depth review process to which laboratory analytical data are subjected before being used. The data verification process confirms that the required samples were collected and documented, the required analyses were performed on the samples, and the analytical results were reported correctly. The data validation process determines the usefulness of each analytical result based on QC and method requirements. The information evaluated during this process includes COC forms, analytical narrative summaries, and analytical result data files.

volatile organic compounds. A broad range of organic compounds, commonly halogenated, that vaporize at ambient, or relatively low, temperatures (e.g., acetone, benzene, chloroform, and methyl alcohol).

WA. See Recra LabNet Philadelphia. 
well volume. The volume of water between the well water surface and the bottom of the screen; the volume of water standing inside the well casing.

wellhead. The top of a well.

WSRC. Westinghouse Savannah River Company. 


\section{References}

American Public Health Association, American Water Works Association, and Water Pollution Control Federation. 1985. Standard Methods for the Examination of Water and Wastewater, 16th edition. Washington, DC.

American Society for Testing and Materials. 1992. Annual Book of ASTM Standards, Volume 11.02. Philadelphia, PA.

Environmental Protection Agency. 1977. National Interim Primary Drinking Water Regulations, EPA-570/9-76-003. Washington, DC.

Environmental Protection Agency. 1980. Prescribed Procedures for Measurement of Radioactivity in Drinking Water, EPA-600/4-80-032 (method 901.1). Cincinnati, OH.

Environmental Protection Agency. 1982. Methods for Organic Chemical Analysis of Municipal and Industrial Wastewater, PB83-201798 (method 625). Cincinnati, OH.

Environmental Protection Agency. 1983. Methods for Chemical Analysis of Water and Wastes, PB84-128677 (methods 200.7, 282.2, 310.1, 350.1, 351.2, 413.1, 418.1, and 420.1). Cincinnati, $\mathrm{OH}$.

Environmental Protection Agency. 1986a. RCRA Ground-Water Monitoring Technical Enforcement Guidance Document, OSWER-9950.1. Washington, DC: Office of Waste Programs Enforcement.

Environmental Protection Agency. 1986b. Test Methods for Evaluating Solid Waste, Volumes 1A, 1B, and 1C, third edition, SW-846 (methods 6010, 8080, 8150, 8240, 8270, 8280, 9020, 9030, and 9060). Washington, DC.

Environmental Protection Agency. 1988a. Laboratory Data Validation Functional Guidelines for Evaluating Organics Analyses. Washington, DC: Office of Solid Waste and Emergency Response.

Environmental Protection Agency. 1988b. Laboratory Data Validation Functional Guidelines for Inorganics Analyses, Draft. Washington, DC: Office of Solid Waste and Emergency Response.

Environmental Protection Agency. 1990. "National Primary and Secondary Drinking Water Regulations; Synthetic Organic Chemicals and Inorganic Chemicals; Proposed Rule" in Federal Register, July 25, 1990, pp.

30369-30448. Washington, DC.

Environmental Protection Agency. 1991a. "Guidelines Establishing Test Procedures for the Analysis of Pollutants" in Code of Federal Regulations, Title 40, Part 136, pp. 293-575. Washington, DC.

Environmental Protection Agency. 1991b. National Functional Guidelines for Organic Data Review, Draft. Washington, DC: Office of Solid Waste and Emergency Response.

Environmental Protection Agency. 1991c. "National Primary Drinking Water Regulations; Radionuclides; Proposed Rule" in Federal Register, July 18, 1991, pp. 33052-33127. Washington, DC.

Environmental Protection Agency. 1991d. "Standards for Owners and Operators of Hazardous Waste Treatment, Storage, and Disposal Facilities" in Code of Federal Regulations, Title 40, Part 264, App. IX, pp. 310-316.

Washington, DC.

Environmental Protection Agency. 1991e. Test Method: The Determination of Inorganic Anions in Water by Ion Chromatography Method 300.0, Revised August 1991. Cincinnati, $\mathrm{OH}$.

Environmental Protection Agency. 1991f. USEPA Contract Laboratory Program, Statement of Work (CLP SOW) for Organics Analysis, Multi-Media, Multi-Concentration, ILM03.0. Washington, DC. 
Environmental Protection Agency. 1997a. "National Primary Drinking Water Regulations" in Code of Federal Regulations, pp. 288-432. Washington, DC.

Environmental Protection Agency. 1997b. "National Secondary Drinking Water Regulations" in Code of Federal Regulations, pp. 473-474. Washington, DC.

Keith, L.H. 1991. Environmental Sampling and Analysis: A Practical Guide. Chelsea, Ml: Lewis Publishers.

South Carolina Department of Health and Environmental Control. 1981. State Primary Drinking Water Regulations, R.61-58.5. Columbia, SC.

U.S. Department of Energy. 1986. Savannah River Plant Environmental Report for 1985, Volumes I and II, DPSPU-86-30-1. Aiken, SC.

U.S. Department of Energy. 1987. Savannah River Plant Environmental Report for 1986, Volumes I and II, DPSPU-87-30-1. Aiken, SC.

U.S. Department of Energy. 1988a. Geohydrology Program Report. Aiken, SC: Environmental Division, Savannah River Operations Office.

U.S. Department of Energy. 1988b. Savannah River Plant Environmental Report for 1987, Volumes I and II, DPSPU-88-30-1. Aiken, SC.

U.S. Department of Energy. 1989a. Geoscience Implementation Plan. Aiken, SC: Environmental Division, Savannah River Operations Office.

U.S. Department of Energy. 1989b. Savannah River Site Environmental Report for 1988, Volumes I and II, WSRCRP-89-59-1. Aiken, SC.

Westinghouse Savannah River Company. Environmental Geochemistry Group Operating Handbook, Section 1.800, "Analytical Data Qualification," October 19, 1998. ESH-EMS-970437. Aiken, SC. 


\section{Appendix A. Water-Level Data}

During second quarter 1999, water-level measurements were obtained for hydrogeologic projects. Most of the data presented on the following pages were obtained as concurrent data for hydrogeologic interpretation in the $\mathrm{A} / \mathrm{M}$ and $\mathrm{F} / \mathrm{H}$ areas. Only water levels were measured for this project; no field tests of water characteristics were conducted. RCS Corporation of Aiken, SC, collected the data. 
NOTES

\section{Appendix A. Water-Level Data}




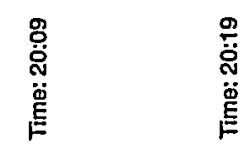

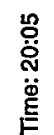

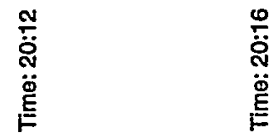

亳

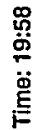
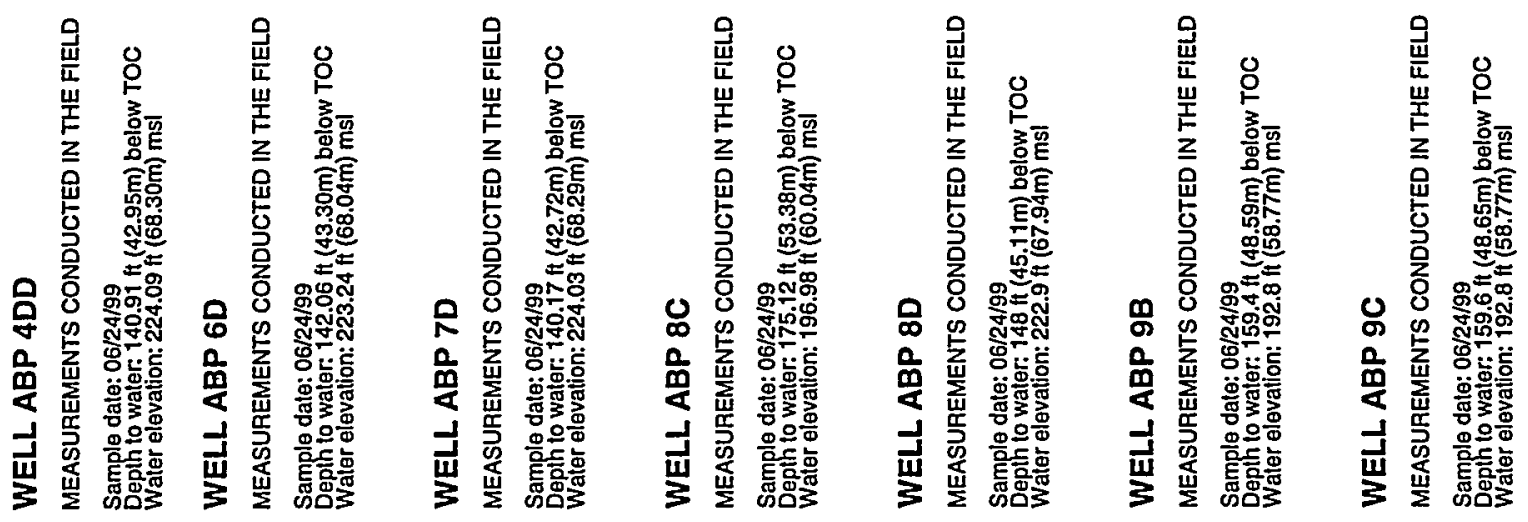

?
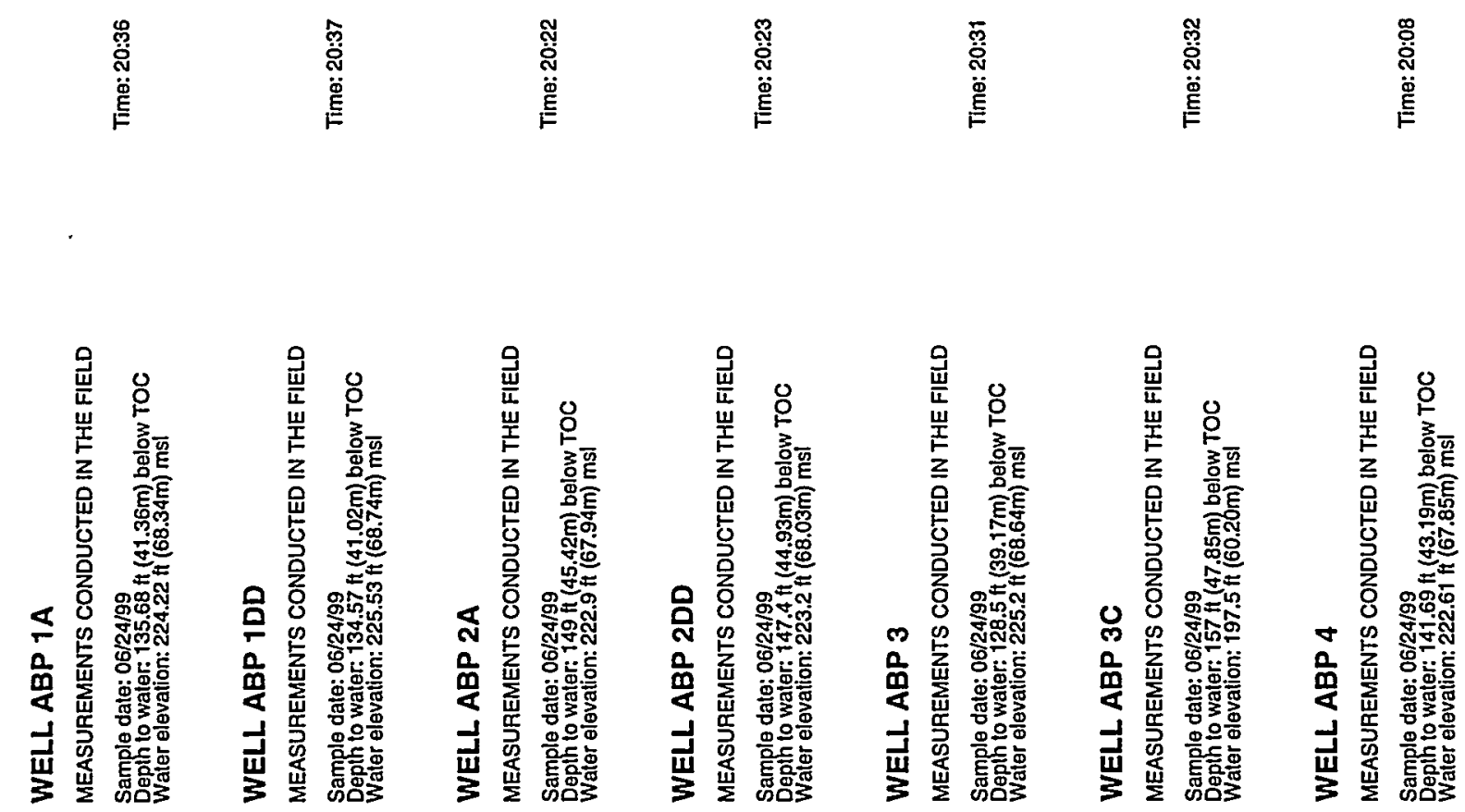


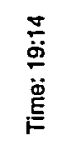

$\underset{\stackrel{n}{\ddot{\theta}}}{\stackrel{\mathscr{\omega}}{E}}$

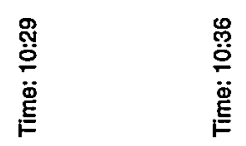

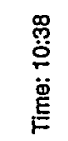

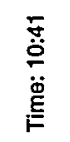

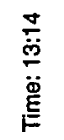
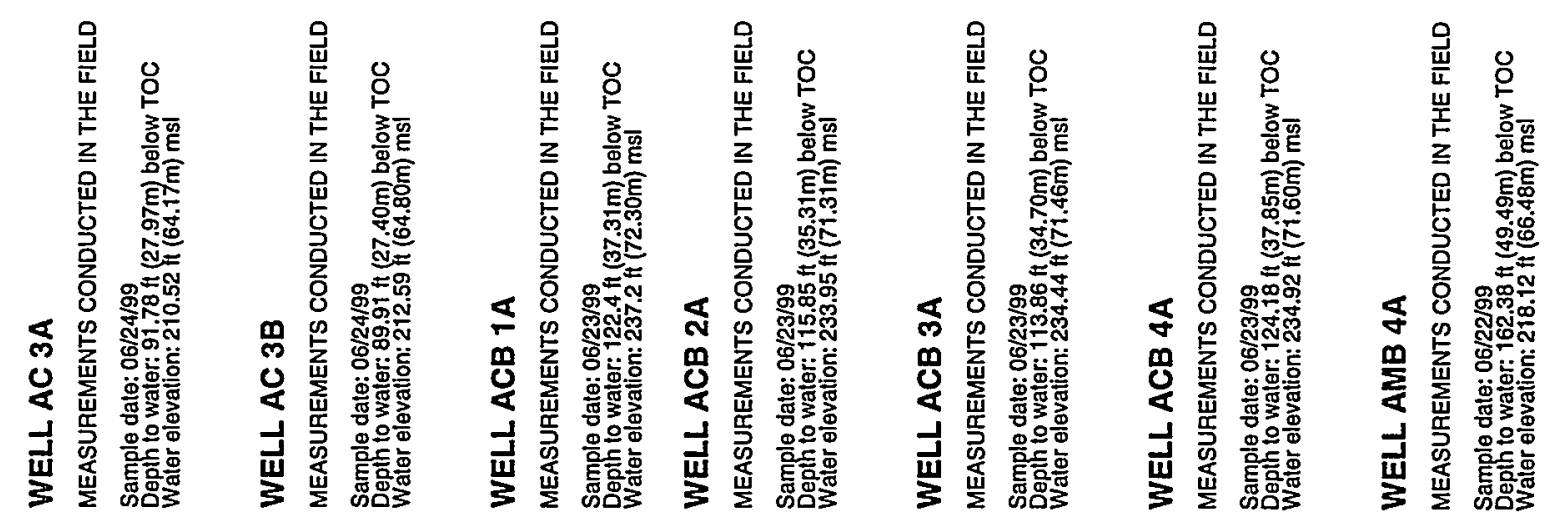

$\overline{0}$
$\stackrel{i}{*}$
$\stackrel{0}{E}$

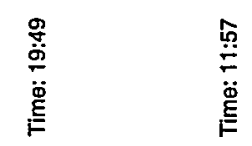

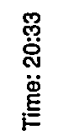

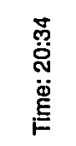

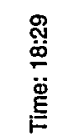

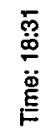
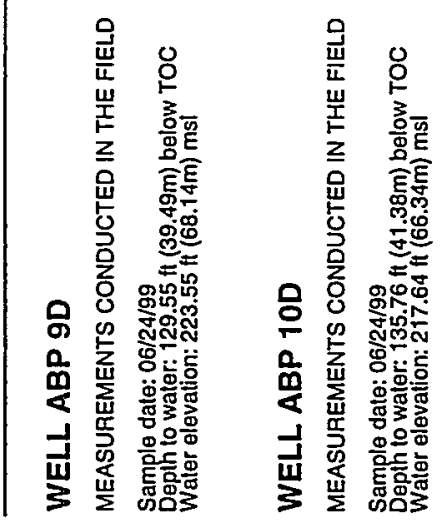

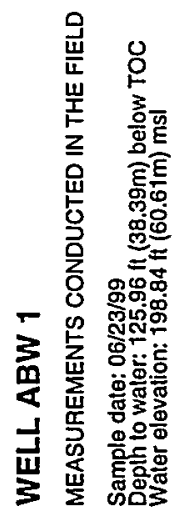
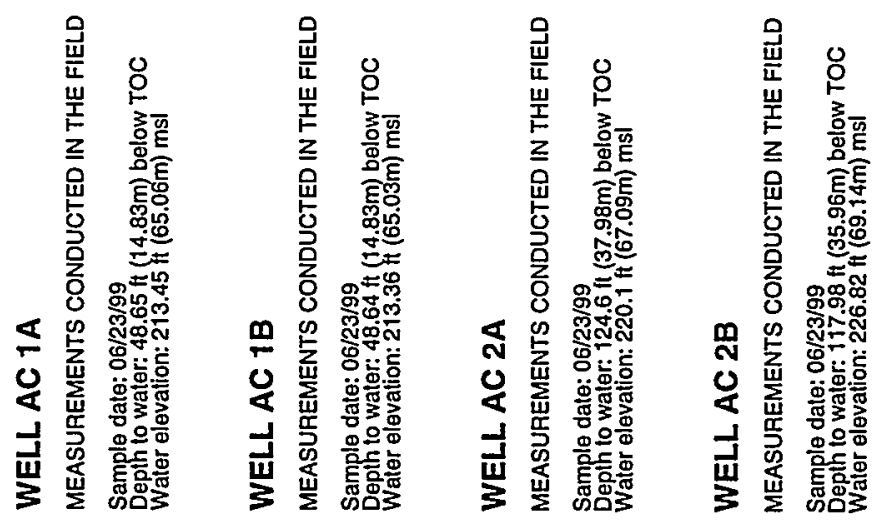


\section{WELL AMB 4B}

MEASUREMENTS CONDUCTED IN THE FIELD Sample date: 06/22/99 Wepth to water: $157.14 \mathrm{ft}(47.90 \mathrm{~m})$ below TOC

\section{WELL AMB 4D}

MEASUREMENTS CONDUCTED IN THE FIELD

Sample date: 06/22/99

Deplh to water: 149.18 (t $(45.47 \mathrm{~m}$ ) below TOC

\section{WELL AMB 5}

MEASUREMENTS CONDUCTED IN THE FIELD

Sample date: 06/22/99 1 (45.16m) below TOC

\section{WELL AMB 6}

MEASUREMENTS CONDUCTED IN THE FIELD

Sample date: 06/22/99

Depth to waler: $145.66 \mathrm{Ht}(44.40 \mathrm{~m})$ below TOC

WELL AMB 7

MEASUREMENTS CONDUCTED IN THE FIELD

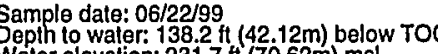

Wept

\section{WELL AMB 7A}

MEASUREMENTS CONDUCTED IN THE FIELD

Depth to water: $155.49 \mathrm{ft}(47.39 \mathrm{~m})$ below TOC
Water elevation: $218.11 \mathrm{ft}(66.48 \mathrm{~m}) \mathrm{msl}$

\section{WELL AMB 7B}

MEASUREMENTS CONDUCTED IN THE FIELD

Samplo dato: 06/20/9

Depth to water: 149.51 it (45.57m) bolow TOC
WELL AMB 8D

MEASUREMENTS CONDUCTED IN THE FIELD

Sample date: 06/22/99

Depth to waler: $138.29 \mathrm{ft}(42.15 \mathrm{~m})$ below TOC
Water elevation: $231.31 \mathrm{ft}(70.50 \mathrm{~m}) \mathrm{ms}$

Time: 12:47

\section{WELL AMB 9D}

MEASUREMENTS CONDUCTED IN THE FIELD

Sample date: 06/22/99
Depth to water: $136.57 \mathrm{ft}(41.63 \mathrm{~m})$ below TOC
Water elevation: $231.33 \mathrm{ft}(70.51 \mathrm{~m}) \mathrm{ms}$

Time: 12:50

\section{WELLL AMB 10A}

MEASUREMENTS CONDUCTED IN THE FIELD

Sample date: $06 / 22 / 99$ (t) $(45.48 \mathrm{~m})$ below TOC

Time: $13: 00$

\section{WELL AMB 10B}

MEASUREMENTS CONDUCTED IN THE FIELD

Sample date: 06/22/99

Depth to water: $144.61 \mathrm{ft}(44.08 \mathrm{~m})$ below TOC

Time: 13:01

\section{WELL AMB 10D}

MEASUREMENTS CONDUCTED IN THE FIELD

Sample date: 06/22/99

Depth to water: $133.44 \mathrm{ft}(40.67 \mathrm{~m})$ below TOC

Water elevation: $232.06 \mathrm{ft}(70.73 \mathrm{~m}) \mathrm{msl}$

Time: 13:00

\section{WELL AMB 10DD}

MEASUREMENTS CONDUCTED IN THE FIELD

Sample date: 06/22/99

Depth to water: $14.2 \mathrm{ft}(4.33 \mathrm{~m})$ below TOC

Time: 13:00

\section{WELL AMB 11B}

MEASUREMENTS CONDUCTED IN THE FIELD

Sample date: 06/22/99

Depth lo water: $142.69 \mathrm{ft}(43.49 \mathrm{~m})$ below TOC
Water elevation: $221.91 \mathrm{ft}(67.64 \mathrm{~m}) \mathrm{ms}$ 


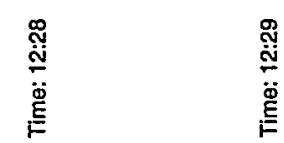

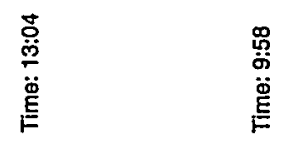

סั.

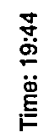

8
8
5
5
8
8
8
8
8
5

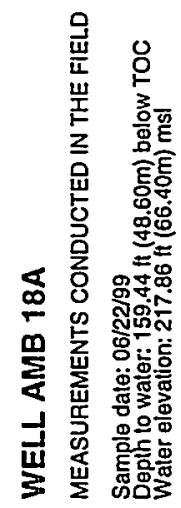
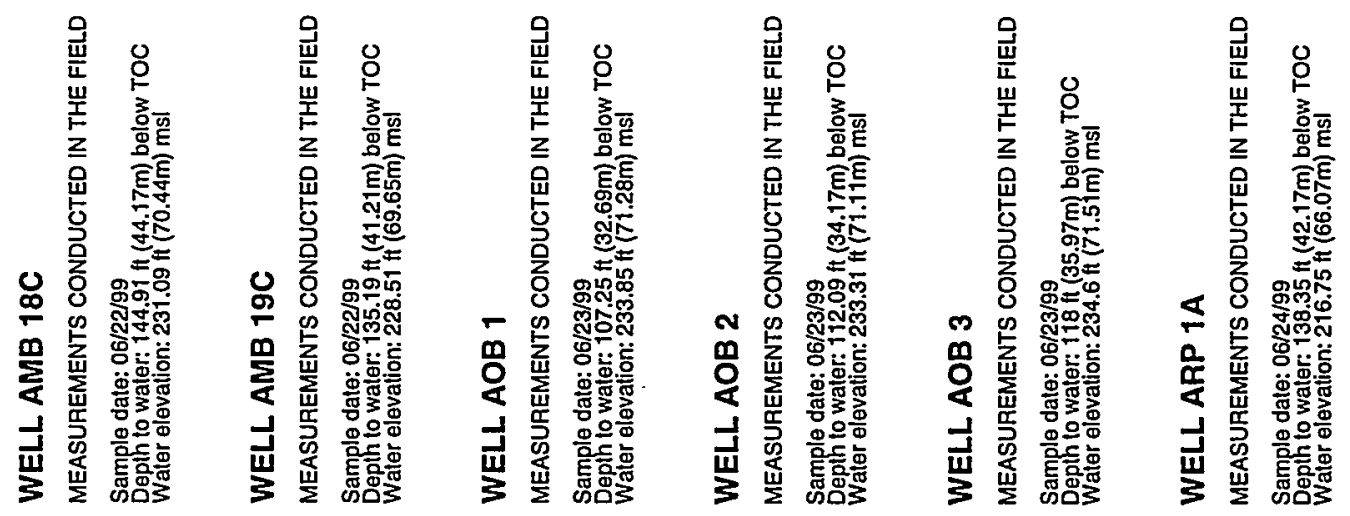

芯

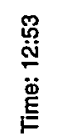

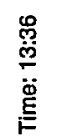

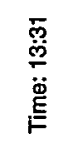

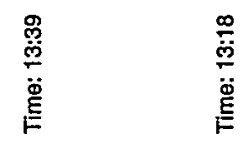
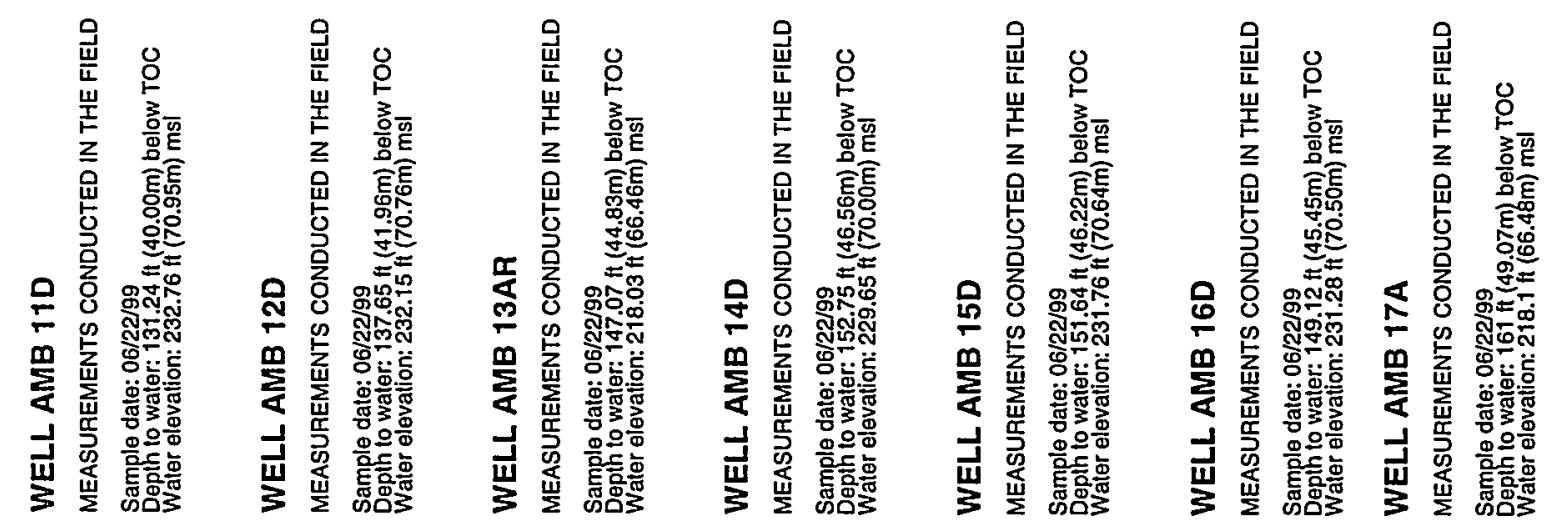


\section{WELL ARP 2}

MEASUREMENTS CONDUCTED IN THE FIELD

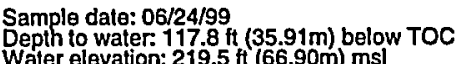

Time: 19:39

\section{WELLL ARP 3}

MEASUREMENTS CONDUCTED IN THE FIELD

Sample dala: $06 / 24 / 99$
Dephth to water: $18.2 \mathrm{ft}(36.03 \mathrm{~m})$ below TOC
Water elovation: $221.6 \mathrm{tt}(67.54 \mathrm{~m}) \mathrm{msl}$

Time: 19:37

\section{WELL ARP 4}

MEASUREMENTS CONDUCTED IN THE FIELD

Sample date: 06/24/99

Sample date: $06 / 24 / 99$
Deph 10 water: $28.98(39.31 \mathrm{~m})$ below toC
Water elevation: $219.42 \mathrm{H}(66.8 \mathrm{~m}) \mathrm{msl}$

\section{WELL ASB 1A}

MEASUREMENTS CONDUCTED IN THE FIELD

Sample date: 06/25/99

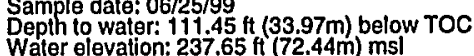

\section{WELL ASB 2AR}

MEASUREMENTS CONDUCTED IN THE FIELD

Sample date: $06 / 25 / 99$
Dephth io warer: $118.02 \mathrm{ft}(35.97 \mathrm{~m})$ below TOC
Water elevalion: $237.58 \mathrm{ft}(72.42 \mathrm{~m}) \mathrm{msl}$

\section{WELL ASB 2CR}

MEASUREMENTS CONDUCTED IN THE FIELD

Sample data: $06 / 25 / 99$
Oopth to waler: $133.95 \mathrm{ft}(40.83 \mathrm{~m})$ below TOC
Wath

WELL ASB 3AR

MEASUREMENTS CONDUCTED IN THE FIELD

Sample date: 06/25/99

Sample date: $06.25 / 99$
Dopht to water: $103.32 \mathrm{ft}(31.49 \mathrm{~m})$ below
Walter elevation: $238.28 \mathrm{tt}(72.63 \mathrm{~m}) \mathrm{msl}$
Time: 11:45

Time: 11:45

Time: 11:44

Time: 11:44
WELL ASB 3CR

MEASUREMENTS CONDUCTED IN THE FIELD

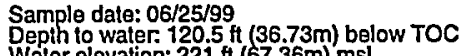

Time: 11:44

\section{WELLL ASB 4}

MEASUREMENTS CONDUCTED IN THE FIELD

Sample date: 06/23/99

Depth to warer $97.89 \mathrm{H}(29.84 \mathrm{~m})$ below TOC
Water elevation: $237.71 \mathrm{Ht}(72.45 \mathrm{~m}) \mathrm{ms}$

Time: 11:25

\section{WELL ASB 5AR}

MEASUREMENTS CONDUCTED IN THE FIELD

Sample date: 06/25/99

Wepth to water: $110.95 \mathrm{ft}(33.82 \mathrm{~m})$ below TOC

Time: 11:47

\section{WELL ASB 5C}

MEASUREMENTS CONDUCTED IN THE FIELD

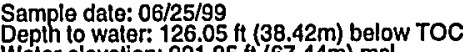

Time: 11:47

\section{WELL ASB 6A}

MEASUREMENTS CONDUCTED IN THE FIELD

Sample date: 06/25/99

Depth to water: $112.88 \mathrm{ft}(34.41 \mathrm{~m})$ below TOO

\section{WELL ASB 6AA}

MEASUREMENTS CONDUCTED IN THE FIELD

Sample date: 06/25/99

Depth to waler: $137.06 \mathrm{ft}(41.78 \mathrm{~m})$ below TOC
Water elevation: $217.14 \mathrm{ft}(66.19 \mathrm{~m}) \mathrm{msl}$

Time: 11:46

\section{WELL ASB 6C}

MEASUREMENTS CONDUCTED IN THE FIELD

Sample date: 06/25/99 $1.39 .91 \mathrm{~m})$ below TOC

Time: 11:46 


\section{WELL ASB 6TA}

MEASUREMENTS CONDUCTED IN THE FIELD

Sample dale: 06/25/99

Depth to water: 139.72 ft $(42.59 \mathrm{~m})$ below TOC

\section{WELL ASB 8}

MEASUREMENTS CONDUCTED IN THE FIELD

Sample date: $06 / 22 / 99 \mathrm{ft}(35.19 \mathrm{~m})$ below TOC

\section{WELL ASB 8A}

MEASUREMENTS CONDUCTED IN THE FIELD

Sample date: 06/22/99

Depth to waler: 131.23 it $(40.00 \mathrm{~m})$ below TOC

\section{WELL ASB 8B}

MEASUREMENTS CONDUCTED IN THE FIELD

Sample dale: $06 / 22 / 999 \mathrm{ft}(40.47 \mathrm{~m})$ below TOC

Wher

\section{WELL ASB 8C}

MEASUREMENTS CONDUCTED IN THE FIELD

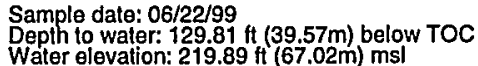

Time: 10:48

\section{WELL ASB 8TA}

MEASUREMENTS CONDUCTED IN THE FIELD

Sample date: 06/22/99

Depth to water: $134.25 \mathrm{ft}(40.92 \mathrm{~m})$ below TOC

Time: 10:43

\section{WELL ASB 9}

MEASUREMENTS CONDUCTED IN THE FIELD

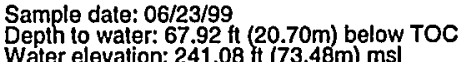

Time: 11:11

\section{WELL ASB 9B}

MEASUREMENTS CONDUCTED IN THE FIELD

Sample date: 06/23/99

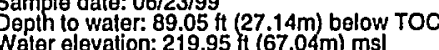

Time: 11:08

\section{WELL ASB 9C}

MEASUREMENTS CONDUCTED IN THE FIELD

Sample dale: 06/23/99
Depth to waitir: $89.71 \mathrm{ft}(27.34 \mathrm{~m})$ below TOC
Water elevation: $220.19 \mathrm{ti}(67.1 \mathrm{~m}) \mathrm{msl}$

Time: 11:08

\section{WELL ASB 10CR}

MEASUREMENTS CONDUCTED IN THE FIELD

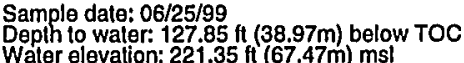

Time: 11:45

\section{WELL BGO 1D}

MEASUREMENTS CONDUCTED IN THE FIELD

Sample date: 06/24/99

Time: 11:24

\section{WELL BGO 2D}

MEASUREMENTS CONDUCTED IN THE FIELD

Sample date: 06/24/99

Water elevation: Not available

Time: 11:17

\section{WELL BGO 3A}

MEASUREMENTS CONDUCTED IN THE FIELD

Sample date: 06/24/99

Depth to water: $129.15 \mathrm{Ht}(39.37 \mathrm{~m})$ below TOC

Time: 11:16

\section{WELL BGO 3C}

MEASUREMENTS CONDUCTED IN THE FIELD

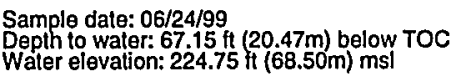




\section{WELL BGO 3DR}

MEASUREMENTS CONDUCTED IN THE FIELD

Sample dale: 06/24/99

Depth to water: $60.6 \mathrm{ft}$ (18.47m) below TOC

Time: 11:16

\section{WELL BGO 4D}

MEASUREMENTS CONDUCTED IN THE FIELD

Sample dato: 06/24/99

Water elevation: Not available

\section{WELL BGO 5C}

MEASUREMENTS CONDUCTED IN THE FIELD

Sample date: 06/24/99

Samplo date: 06/24/99

\section{WELL. BGO 5D}

MEASUREMENTS CONDUCTED IN THE FIELD

Sample date: 06/24/99

Depth to waler: 66.85 ft $(20.38 \mathrm{~m})$ below TOC
Water elevation: $229.45 \mathrm{Ht}(69.94 \mathrm{~m}) \mathrm{ms}$ |

\section{WELL BGO 6A}

MEASUREMENTS CONDUCTED IN THE FIELD

Sample date: 06/24/99

Depth to water: $126.65 \mathrm{ft}(38.60 \mathrm{~m})$ below TOC

Water elevation: $158.95 \mathrm{ft}(48.45 \mathrm{~m}) \mathrm{msl}$

\section{WELL BGO 6B}

MEASUREMENTS CONDUCTED IN THE FIELD

Sample date: 06/24/99

Water elevation: $217.55 \mathrm{Ht}(66.31 \mathrm{~m}) \mathrm{ms}$ TOC

\section{WELLL BGO 6C}

MEASUREMENTS CONDUCTED IN THE FIELD

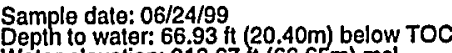

Time: 11:14
WELL BGO 6D

MEASUREMENTS CONDUCTED IN THE FIELD

Sample date: 06/24/99

Depth to water: $55.64 \mathrm{ft}(16.96 \mathrm{~m})$ below TOC
Water elevation: $229.86 \mathrm{ft}(70.06 \mathrm{~m}) \mathrm{ms}$

Time: 11:14

\section{WELLL BGO 7D}

MEASUREMENTS CONDUCTED IN THE FIELD

Sample date: 06/25/99

Depth to water: $56.63 \mathrm{ft}(17.26 \mathrm{~m})$ below TOC
Water elevation: $230.37 \mathrm{ft}(70.22 \mathrm{~m}) \mathrm{ms}$ I

Time: 11:57

\section{WELL. BGO BAR}

MEASUREMENTS CONDUCTED IN THE FIELD

Sample date: 06/25/99
Depth to water: $127.83 \mathrm{ft}(38.96 \mathrm{~m})$ below TOC

Time: $11: 57$

\section{WELL BGO 8C}

MEASUREMENTS CONDUCTED IN THE FIELD

Sample date: 06/25/99 $(20.08 \mathrm{~m})$ below TOC

Water elevation: $222.01 \mathrm{ft}(67.67 \mathrm{~m}) \mathrm{ms} \mid$

Time: 11:57

\section{WELL BGO 8D}

MEASUREMENTS CONDUCTED IN THE FIELD

Sample date: 06/25/99

Depth io water: $57.29 \mathrm{ft}(17.46 \mathrm{~m})$ below TOC

Water elevalion: 230.51 f $(70.26 \mathrm{~m}) \mathrm{ms}$

Time: 11:57

\section{BGO 9AA}

MEASUREMENTS CONDUCTED IN THE FIELD

Sample date: 06/25/99

Depth to water: $127.85 \mathrm{ft}(38.97 \mathrm{~m})$ below TOC
Water elevalion: $156.95 \mathrm{ft}(47.84 \mathrm{~m}) \mathrm{msl}$

Time: 14:15

WELL BGO 9D

MEASUREMENTS CONDUCTED IN THE FIELD

Samplodate:

Depth to water: $56.89 \mathrm{ft}(17.34 \mathrm{~m})$ below TOC

Time: 11:55 


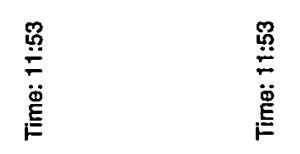

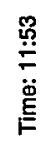

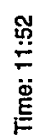

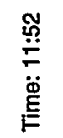

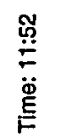



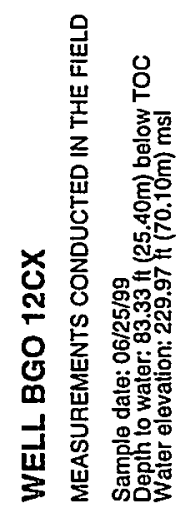

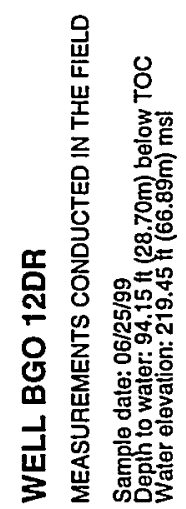

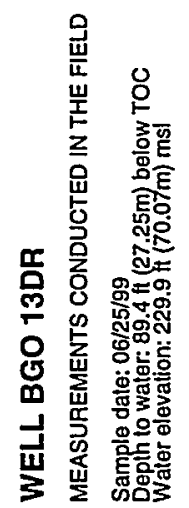

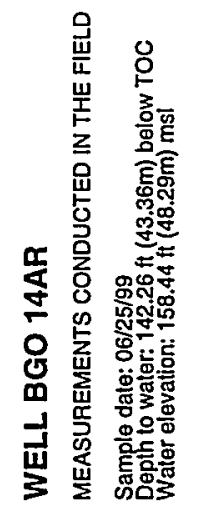
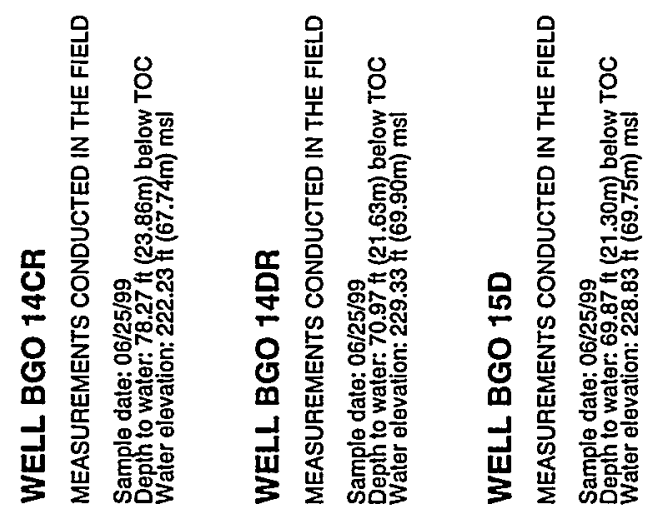

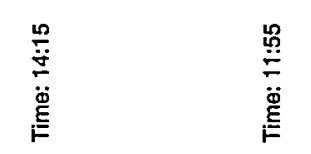

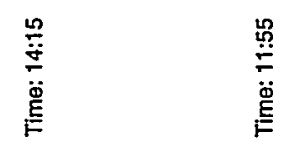

苛

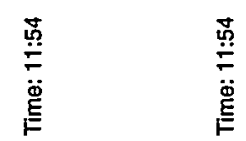

$\frac{0}{4}$

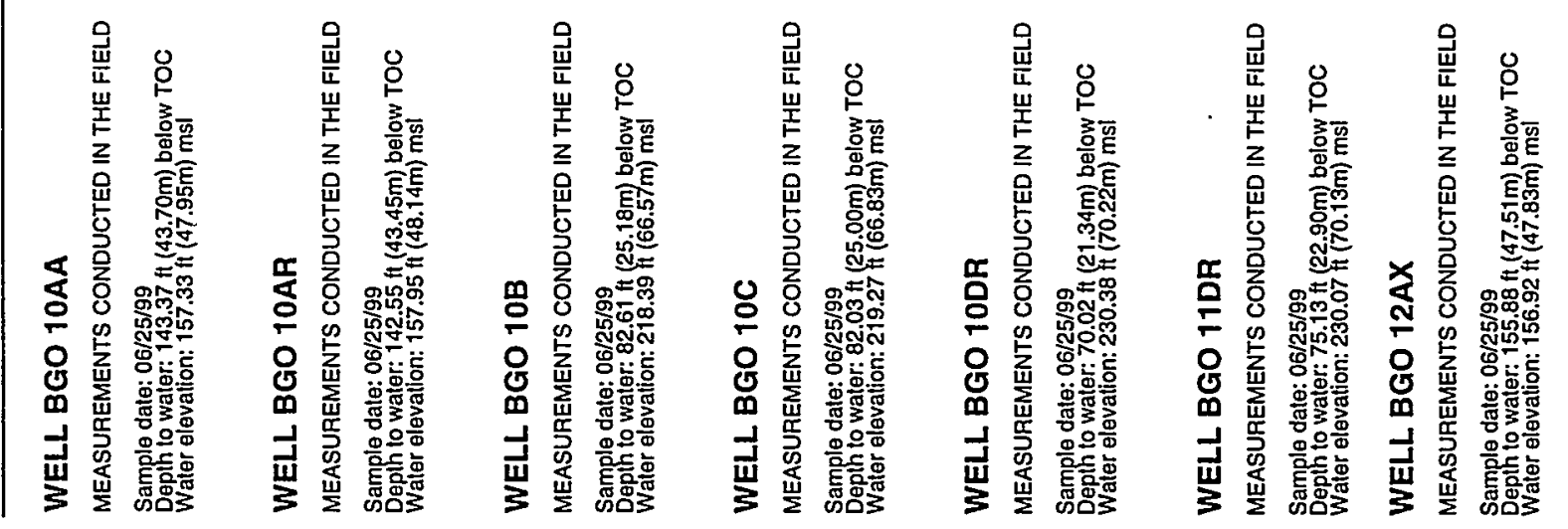




\section{WELL BGO 16AR}

MEASUREMENTS CONDUCTED IN THE FIELD

Sample date: 06/24/99

Deph to water $142.97 \mathrm{ht}(43.58 \mathrm{~m})$ below TOC

Time: 11:21

\section{WELL BGO 16B}

MEASUREMENTS CONDUCTED IN THE FIELD

Sample date: $06 / 24 / 99$
Depth to water: $884(26.82 \mathrm{~m})$ below Toc
Waler elevation: $217.1 \mathrm{ti}(66.17 \mathrm{~m}) \mathrm{ms}$

Time: 11:2

\section{WELL BGO 16D}

MEASUREMENTS CONDUCTED IN THE FIELD

Sample date: 06/24/99

Wepth to water: $74.99 \mathrm{Ht}(22.86 \mathrm{~m})$ below TOC

\section{WELL BGO 17DR}

MEASUREMENTS CONDUCTED IN THE FIELD

Sample data: 06/24/99

Deph io water: $66.95 \mathrm{ft}(21.02 \mathrm{~m})$ below TOC
Water elevalion: $230.25 \mathrm{ht}(70.18 \mathrm{~m}) \mathrm{msl}$

\section{WELL BGO 18A}

MEASUREMENTS CONDUCTED IN THE FIELD

Sample date: 06/24/99

Wepht to waier: $134.15 \mathrm{ft}(40.89 \mathrm{~m})$ below TOC

\section{WELL BGO 18D}

MEASUREMENTS CONDUCTED IN THE FIELD

Samplo data: 06/24/99

\section{WELL BGO 19DR}

MEASUREMENTS CONDUCTED IN THE FIELD

Sample date: 06/24/99

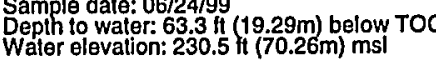

\section{WELL BGO 20A}

MEASUREMENTS CONDUCTED IN THE FIELD

Sample date: 06/24/99 Depht lo water. 121.21 fit $(36.95 \mathrm{~m})$ below TOC
Water elevation: $162.69 \mathrm{ft}(49.59 \mathrm{~m}) \mathrm{msl}$

Time: 11:18

\section{WELL BGO 20AA}

MEASUREMENTS CONDUCTED IN THE FIELD

Sample date: 06/24/99

Depht lowater: $122.31 \mathrm{ft}(37.28 \mathrm{~m})$ below TOC
Water elevation: $161.29 \mathrm{ft}(49.16 \mathrm{~m}) \mathrm{msl}$

Time: 11:18

\section{WELL BGO 20B}

MEASUREMENTS CONDUCTED IN THE FIELD

Sample date: 06/24/99

Weph to water: $56.4 \mathrm{f}(17.19 \mathrm{~m})$ below TOC

Time: 11:18

Time: 11:21

\section{WELL BGO 20C}

MEASUREMENTS CONDUCTED IN THE FIELD

Sample date: $06 / 24 / 99$.

Time: 11:19

Time: 11:20

\section{WELL BGO 20D}

MEASUREMENTS CONDUCTED IN THE FIELD

Sample date: 06/24/99

Depth to water: $51.45 \mathrm{ft}(15.68 \mathrm{~m})$ below TOC

Time: 11:18

Time: 11:20

\section{WELL BGO 21D}

MEASUREMENTS CONDUCTED IN THE FIELD

Sample date: 06/24/99

Depth to water: $52.4 \mathrm{ft}(15.97 \mathrm{~m})$ below TOC

Time: 11:20

Wathe elevalion: $233 \mathrm{tt}(71.02 \mathrm{~m}) \mathrm{ms}$
Wh

Time: 11:17

\section{WELL BGO 22DX}

MEASUREMENTS CONDUCTED IN THE FIELD

Sample date: 06/24/99

Time: 11:19 


\section{WELL BGO 23D}

MEASUREMENTS CONDUCTED IN THE FIELD

Sample date: 06/24/99

Depth to water: $54.55 \mathrm{ft}$ ( $16.63 \mathrm{~m})$ below TOC

WELL BGO 24D

MEASUREMENTS CONDUCTED IN THE FIELD

Sample date: 06/24/99

Depth to water: 57.2 ff $(17.43 \mathrm{~m})$ below TOC

Time: 11:17

\section{WELL BGO 25A}

MEASUREMENTS CONDUCTED IN THE FIELD

Sample date: 06/25/99

Depth to water: $135.55 \mathrm{ft}(41.32 \mathrm{~m})$ below TOC

WELL BGO 26A

MEASUREMENTS CONDUCTED IN THE FIELD

Sample date: 06/25/99

Sample date: $06 / 25 / 99$
Depth to water: 128.35 ft $(39.12 \mathrm{~m})$ below TOC
Water elevation: $158.85 \mathrm{Ht}(48.42 \mathrm{~m}) \mathrm{msl}$

\section{WELL BGO 26D}

MEASUREMENTS CONDUCTED IN THE FIELD

Sample date: 06/25/99

Sample date: $06 / 25 / 99$
Depth to water: $59.19 \mathrm{ft}(18.04 \mathrm{~m})$ below TOC
Water elevation: $226.31 \mathrm{ft}(68.98 \mathrm{~m}) \mathrm{msl}$

\section{WELL BGO 27D}

MEASUREMENTS CONDUCTED IN THE FIELD

Sample date: 06/25/99
Depth to water: $50.62 \mathrm{ft}(15.43 \mathrm{~m})$ below TOC
Water elevation: $225.68 \mathrm{ft}(68.79 \mathrm{~m}) \mathrm{ms}$

\section{WELL. BGO 28D}

MEASUREMENTS CONDUCTED IN THE FIELD

Sample date: 06/25/99

Depth to water: $53.06 \mathrm{ft}(16.17 \mathrm{~m})$ below TOC

Time: 11:49
WELLL BGO 29A

MEASUREMENTS CONDUCTED IN THE FIELD

Sample date: 06/25/99

Depth to water: $104.76 \mathrm{ft}(31.93 \mathrm{~m})$ below TOC

Time: 11:47

\section{WELL BGO 29C}

MEASUREMENTS CONDUCTED IN THE FIELD

Sample date: 06/25/99

Depth to waler: $43.51 \mathrm{ft}(13.26 \mathrm{~m})$ below TOC

Time: 11:47

WELL BGO 29D

MEASUREMENTS CONDUCTED IN THE FIELD

Sample date: 06/25/99

Weph to water. 40.98 it $(12.49 \mathrm{~m})$ below TOC

\section{WELL BGO 30C}

MEASUREMENTS CONDUCTED IN THE FIELD

Sample date: 06/25/99

Depth to water: $56.47 \mathrm{ft}(17.21 \mathrm{~m})$ below TOC

WELL BGO 30D

MEASUREMENTS CONDUCTED IN THE FIELD

Sample date: 06/25/99

Depth to water: $50.97 \mathrm{ft}(15.54 \mathrm{~m})$ below TOC

Time: 11:49

WELL BGO 31C

MEASUREMENTS CONDUCTED IN THE FIELD

Sample date: 06/25/9

Depth to water: $49.45 \mathrm{ft}(15.07 \mathrm{~m})$ below TOO

Time: 11:48

\section{WELL BGO 31D}

MEASUREMENTS CONDUCTED IN THE FIELD

Sample dale: 06/25/99

Depth to water: $49.05 \mathrm{ft}(14.95 \mathrm{~m})$ below TOC

Time: 11:48 
WELL BGO 32D

MEASUREMENTS CONDUCTED IN THE FIELD

Sample date: 06/25/99

Depth to water. $53.95 \mathrm{ft}(16.44 \mathrm{~m})$ below TOC
Water elevation: $227.75 \mathrm{Ht}(69.42 \mathrm{~m}) \mathrm{msl}$

\section{WELL BGO 33C}

MEASUREMENTS CONDUCTED IN THE FIELD

Sample date: 06/25/99

Depth to water: $56 \mathrm{ft}(17.07 \mathrm{~m})$ below TOC
Water elevation: $223.4 \mathrm{ft}(68.09 \mathrm{~m}) \mathrm{ms}$ l

Time: 14:24

\section{WELL BGO 33D}

MEASUREMENTS CONDUCTED IN THE FIELD

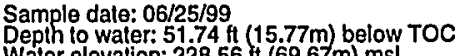

WELL BGO 34D

MEASUREMENTS CONDUCTED IN THE FIELD

Sample date: 06/25/99

Depih to water: 44.28 ft $(13.50 \mathrm{~m})$ below TOC

\section{WELL BGO 35C}

MEASUREMENTS CONDUCTED IN THE FIELD

Sample date: 06/25/99

Depth to water: $44.96 \mathrm{ft}(13.70 \mathrm{~m})$ below TOC

\section{WELL BGO 35D}

MEASUREMENTS CONDUCTED IN THE FIELD

Sample date: $06 / 25 / 99$
Depth io water: $40.9 \mathrm{Ht}(12.47 \mathrm{~m})$ below TOC
Water elevation: $232.6 \mathrm{tt}(70.90 \mathrm{~m}) \mathrm{msl}$

\section{WELL BGO 36D}

MEASUREMENTS CONDUCTED IN THE FIELD

Sample date: 06/25/99

Depth to water: $39.98 \mathrm{ft}(12.19 \mathrm{~m})$ below TOC
WELL BGO 37C

MEASUREMENTS CONDUCTED IN THE FIELD

Depth to water. $54.62 \mathrm{ft}(16.65 \mathrm{~m})$ below TOC

Waler elevation: $231.68 \mathrm{ft}(70.62 \mathrm{~m}) \mathrm{ms}$

\section{WELL BGO 37D}

MEASUREMENTS CONDUCTED IN THE FIELD

Sample date: 06/25/99

Sample date: 06/25/99

Time: 14:21

\section{WELL BGO 38D}

MEASUREMENTS CONDUCTED IN THE FIELD

Sample date: 06/25/99

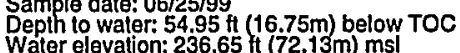

Time: 14:21

\section{WELL BGO 39A}

MEASUREMENTS CONDUCTED IN THE FIELD

Sample date: $06 / 25 / 99$ (t) $(39.33 \mathrm{~m})$ below TOC

Time: 14:20

\section{WELL BGO 39C}

MEASUREMENTS CONDUCTED IN THE FIELD

Sample date: 06/25/99

Dample date: $06 / 25 / 99$
Wath to water: $64.7 \mathrm{tt}(19.72 \mathrm{~m})$ below TOC
Water elevation: $231.7 \mathrm{ft}(70.62 \mathrm{~m}) \mathrm{ms}$

Time: 14:21

\section{WELL BGO 390}

MEASUREMENTS CONDUCTED IN THE FIELD

Sample dale: 06/25/99

Depht lo water: $60.1 \mathrm{ft}(18.32 \mathrm{~m})$ below TOC
Water elevation: $235.6 \mathrm{Ht}(71.81 \mathrm{~m}) \mathrm{ms}$

Time: 14:20

\section{WELL BGO 40D}

MEASUREMENTS CONDUCTED IN THE FIELD

Sample date: 06/25/99

Depth to water: $67.38 \mathrm{fl}(20.54 \mathrm{~m})$ below TOC

Water elevation: $221.02 \mathrm{ft}(67.37 \mathrm{~m}) \mathrm{ms}$
Time: 11:51 


\section{WELL BGO 41A}

MEASUREMENTS CONDUCTED IN THE FIELD

Sample date: 06/25/99

Sample date: 06/25/99 $14.05 \mathrm{~m})$ below TOC

\section{WELL BGO 42C}

MEASUREMENTS CONDUCTED IN THE FIELD

Sample date: 06/25/99

Wath to waler: 76.02 H $(23.17 \mathrm{~m}$ ) below TOC

\section{WELL BGO 43A}

MEASUREMENTS CONDUCTED IN THE FIELD

Sample date: 06/25/99

Depth to water: $158.15 \mathrm{ft}(48.20 \mathrm{~m})$ below TOC
Waler elevation: $156.75 \mathrm{ft}(47.78 \mathrm{~m}) \mathrm{msl}$

\section{WELL BGO 43AA}

MEASUREMENTS CONDUCTED IN THE FIELD

Sample date: 06/25/99

What

\section{WELL BGO 43CR}

MEASUREMENTS CONDUCTED IN THE FIELD

Sample date: 06/25/99

epth to water: $91.43 \mathrm{ft}(27.87 \mathrm{~m})$ below TOC

Water elevation: $223.87 \mathrm{ht}(68.24 \mathrm{~m}) \mathrm{ms}$

\section{WELL BGO 43D}

MEASUREMENTS CONDUCTED IN THE FIELD

Sample date: 06/25/99

Depth to water: $85.11 \mathrm{ft}(25.94 \mathrm{~m})$ below TOC
Water elevation: $230.19 \mathrm{ft}(70.16 \mathrm{~m}) \mathrm{msl}$

\section{WELL BGO 44A}

MEASUREMENTS CONDUCTED IN THE FIELD

Sample date: 06/25/99

Depth to water: $127.15 \mathrm{ht}(38.76 \mathrm{~m})$ below TOC

Water elevation: $158.15 \mathrm{ft}(48.20 \mathrm{~m}) \mathrm{msl}$
WELLL BGO 44AA

MEASUREMENTS CONDUCTED IN THE FIELD

Sample date: 06/25/99

epth to water: $127.05 \mathrm{ft}(38.73 \mathrm{~m})$ below TOC

Time: 11:56

\section{WELLL BGO 44B}

MEASUREMENTS CONDUCTED IN THE FIELD

Sample date: 06/25/99

Depth to water: $65.44 \mathrm{ft}(19.95 \mathrm{~m})$ below TOC
Water elevation: $219.76 \mathrm{Ht}(66.98 \mathrm{~m}) \mathrm{ms}$

\section{WELL BGO 44C}

MEASUREMENTS CONDUGTED IN THE FIELD

Sample date: 06/25/99

Depth to water: $66.05 \mathrm{ft}(20.13 \mathrm{~m})$ below TOC

WELL BGO 44D

MEASUREMENTS CONDUCTED IN THE FIELD

Sample date: 06/25/9

Deph to water: $54.7 \mathrm{t}(16.67 \mathrm{~m})$ below TOC

Time: 11:56

\section{WELL BGO 45A}

MEASUREMENTS CONDUCTED IN THE FIELD

Sample date: 06/25/99

Deplh to water: $118.65 \mathrm{ft}(36.16 \mathrm{~m})$ below TOC

\section{WELL BGO 45B}

MEASUREMENTS CONDUCTED IN THE FIELD

Sample date: 06/25/99

Depth to water: $60.78 \mathrm{H}(18.53 \mathrm{~m})$ below TOC

Time: 11:50

WELL BGO 45C

MEASUREMENTS CONDUCTED IN THE FIELD

Sample date: 06/25/99
Depth to waler: $57.11 \mathrm{ft}(17.41 \mathrm{~m})$ below TOC

Time: 11:50 
WELL BGO 45D

MEASUREMENTS CONDUCTED IN THE FIELD

Sample date: 06/25/99

me: 11:50

Weph to water: $52.81 \mathrm{ft}(16.10 \mathrm{~m})$ below TOC

\section{WELL BGO 46B}

MEASUREMENTS CONDUCTED IN THE FIELD

Sample date: 06/25/99

Depth to water: $49 \mathrm{ft}$ (14.94m) below TOC

\section{WELL BGO 46C}

MEASUREMENTS CONDUCTED IN THE FIELD

Sample date: 06/25/99

Depth to water: $47.2 \mathrm{ft}(14.39 \mathrm{~m})$ below TOC

\section{WELL BGO 46D}

MEASUREMENTS CONDUCTED IN THE FIELD

Sample date: 06/25/99

Depth to water: $41.85 \mathrm{ft}(12.76 \mathrm{~m})$ below TOC
Water elevation: $223.25 \mathrm{H}(68.05 \mathrm{~m}) \mathrm{ms}$

\section{WELL BGO 47A}

MEASUREMENTS CONDUCTED IN THE FIELD

Sample date: 08/25/90

Depth to waler: $104.95 \mathrm{ft}(31.99 \mathrm{~m})$ below TOC

\section{WELL BGO 47C}

MEASUREMENTS CONDUCTED IN THE FIELD

Sample date: 06/25/99

Depth to waler: $46.54 \mathrm{ft}(14.19 \mathrm{~m})$ below TOC

WELL BGO 47D

MEASUREMENTS CONDUCTED IN THE FIELD

Sample date: 06/25/99

Sample date: $06 / 25 / 99$
Depth to waitir. 43.4 4 (t).23m) below TOC
Water elevation: $224 \mathrm{ft}(68.28 \mathrm{~m}) \mathrm{msl}$
Time: 14:26

WELL BGO 48C

MEASUAEMENTS CONDUCTED IN THE FIELD

Sample date: 06/25/99

Wepth to water $54.85 \mathrm{ft}(1672 \mathrm{~m})$ below TOC

Water elevation: $221.75 \mathrm{ft}(67.59 \mathrm{~m}) \mathrm{ms}$

Time: 14:27

\section{WELL BGO 48D}

MEASUREMENTS CONDUCTED IN THE FIELD

Sample date: 06/25/99

Depth to waler: $52.55 \mathrm{ft}(16.02 \mathrm{~m})$ below TOC

\section{WELL BGO 49A}

MEASUREMENTS CONDUCTED IN THE FIELD

Sample date: 06/25/99

Weph to water $106.22 \mathrm{ft}(32.38 \mathrm{~m})$ below TOC

Time: 14:27

\section{WELL BGO 49C}

MEASUREMENTS CONDUCTED IN THE FIELD

Sample date: $06 / 25 / 99$
Depth to wate: $43.44 \mathrm{ft}(13.24 \mathrm{~m})$ below TOC

\section{WELL BGO 49D}

MEASUREMENTS CONDUCTED IN THE FIELD

Sample data: 06/25/99

Time: 14:28

Time: 14:26

\section{WELL BGO 50A}

MEASUREMENTS CONDUCTED IN THE FIELD

Sample dale: 06/25/99

Deph to water: $95.36 \mathrm{ft}(29.07 \mathrm{~m})$ below TOC

Water elevation: $160.04 \mathrm{ft}(48.78 \mathrm{~m}) \mathrm{ms}$ l

Time: 14:25

\section{WELL BGO 50C}

MEASUREMENTS CONDUCTED IN THE FIELD

Sample date: 06/25/99 $31.69 \mathrm{~m})$ below TOC
Time: 14:25 


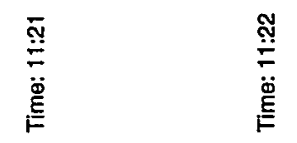

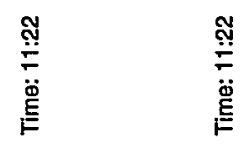

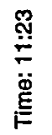

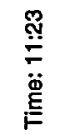

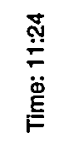
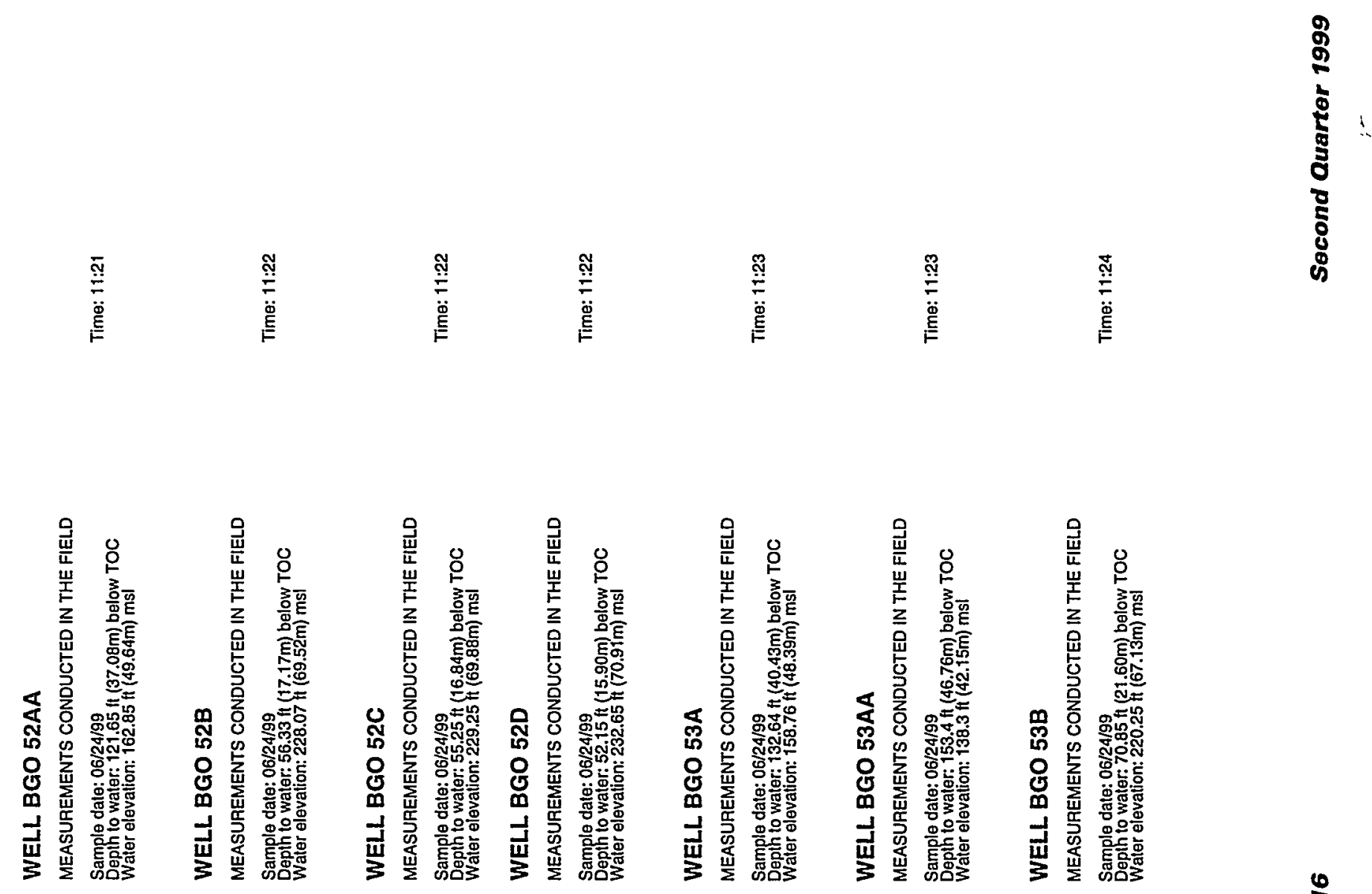

$\stackrel{\wp}{\dot{x}}$
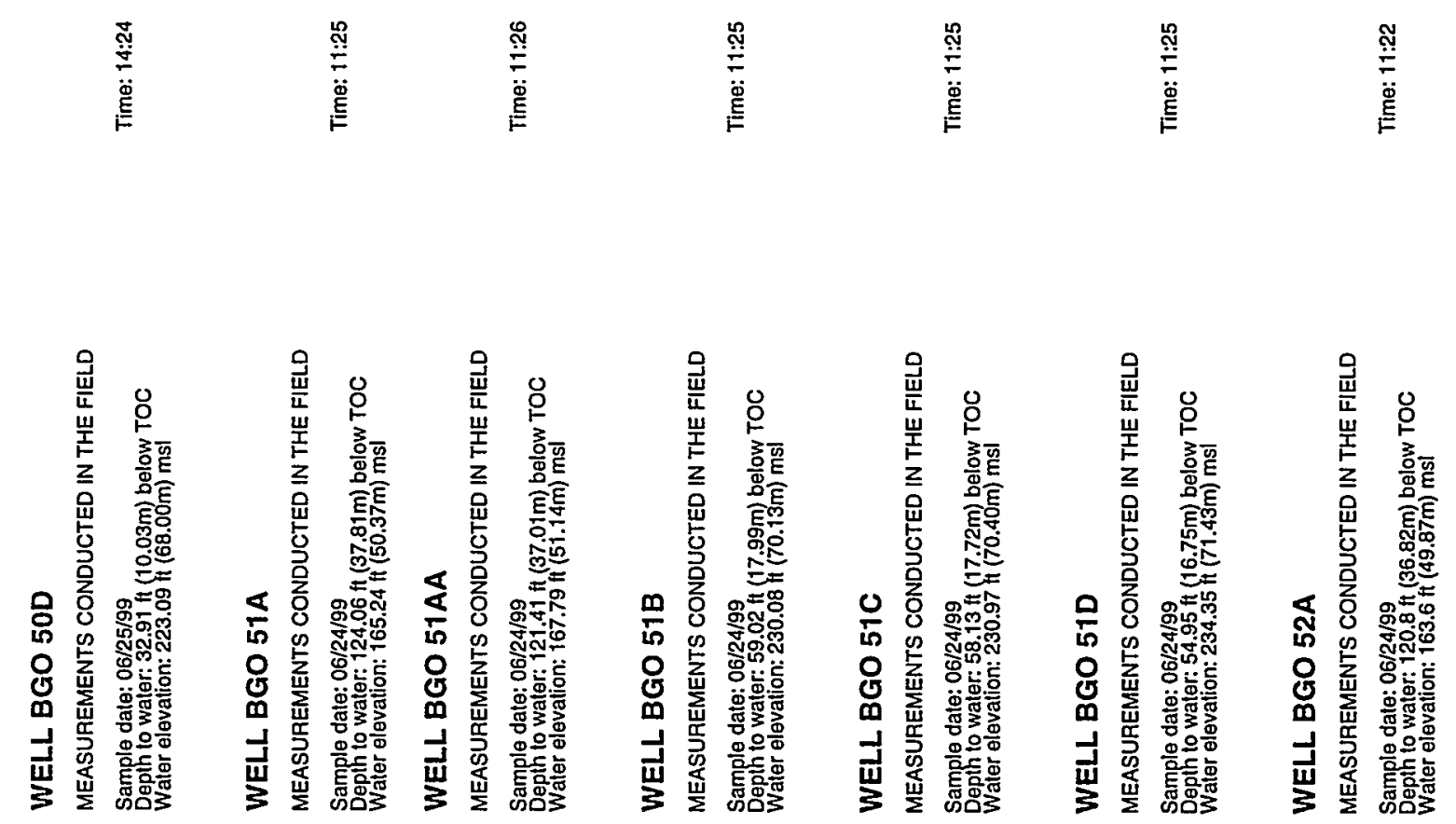


\section{WELL BGO 53C}

MEASUREMENTS CONDUCTED IN THE FIELD

Sample date: 06/24/99

Depth to water: $69.35 \mathrm{ft}(21.14 \mathrm{~m})$ below TOC

Time: 11:24

\section{WELL BGO 53D}

MEASUREMENTS CONDUCTED IN THE FIELD

Sample date: 06/24/99

Depth to water: $63.04 \mathrm{H}(19.21 \mathrm{~m})$ below TOC

\section{WELL BGX 1A}

MEASUREMENTS CONDUCTED IN THE FIELD

Sample date: 06/25/99 $(40.70 \mathrm{~m})$ below TOC

列

WELL BGX 1C

MEASUREMENTS CONDUCTED IN THE FIELD

Sample dale: 06/25/99

Depth to water: $77.12 \mathrm{ft}(23.51 \mathrm{~m})$ below TOC

WELL BGX 10

MEASUREMENTS CONDUCTED IN THE FIELD

Sample date: 06/25/99

Sample date: $06 / 25 / 99$
Depth to water: $63.05 \mathrm{ft}(19.22 \mathrm{~m})$ below TOC
Water elevation: $228.25 \mathrm{f}(69.57 \mathrm{~m}) \mathrm{ms}$

\section{WELL BGX 2B}

MEASUREMENTS CONDUCTED IN THE FIELD

Sample date: 06/25/9

Depth to water: $80.19 \mathrm{ft}(24.44 \mathrm{~m})$ below TOC
Water elevation: $211.11 \mathrm{fi}(64.35 \mathrm{~m}) \mathrm{msl}$

\section{WELL BGX 2D}

MEASUREMENTS CONDUCTED IN THE FIELD

Sample date: $06 / 25 / 99$ f

Time: 14:16
WELL BGX 3D

MEASUREMENTS CONDUCTED IN THE FIELD

Sample date: 06/25/99

Depth lo water: $77.74 \mathrm{ft}(23.70 \mathrm{~m})$ below TOC

Time: 14:17

\section{WELL BGX 4A}

MEASUREMENTS CONDUCTED IN THE FIELD

Sample date: 06/25/99

Depth to water: $136.05 \mathrm{ft}(41.47 \mathrm{~m})$ below TOC

Time: 14:17

\section{WELL BGX 4C}

MEASUREMENTS CONDUCTED IN THE FIELD

Sample date: $06 / 25 / 99$
Depth to water: $77.92 \mathrm{ft}(23.75 \mathrm{~m})$ below TOC
Water elevation: $212.88 \mathrm{tt}(64.89 \mathrm{~m}) \mathrm{ms}$

Time: 14:17

\section{WELL BGX 4D}

MEASUREMENTS CONDUCTED IN THE FIELD

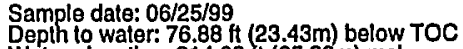

Time: 14:17

\section{WELL BGX 5D}

MEASUREMENTS CONDUCTED IN THE FIELD

Sample date: $06 / 25 / 99$
Depth to water: $77.85 \mathrm{ft}(23.73 \mathrm{~m})$ below TOC
Water elevation: $207.15 \mathrm{tt}(63.14 \mathrm{~m}) \mathrm{ms}$

Time: 14:18

\section{WELL BGX 6D}

MEASUREMENTS CONDUCTED IN THE FIELD

Sample date: 06/24/99

epth to water: 72.98 if $(22.24 \mathrm{~m})$ below TOC

Water elevation: $204.02 \mathrm{ft}(62.19 \mathrm{~m}) \mathrm{ms}$.

Time: 11:13

WELLL BGX 7D

MEASUREMENTS CONDUCTED IN THE FIELD

Sample date: 06/24/99 $22.93 m$ ) below TOC

Time: 11:13 

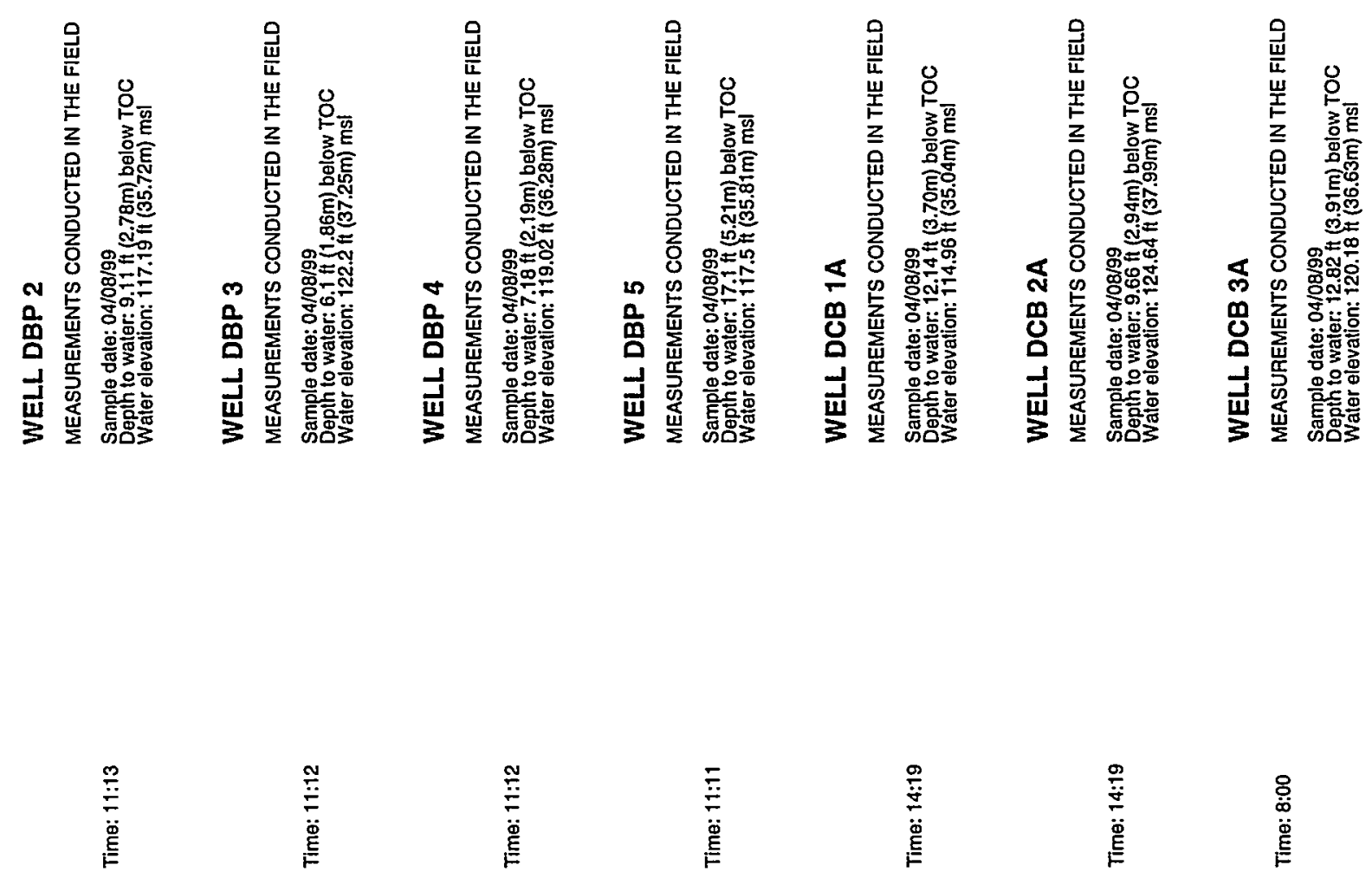

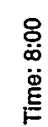
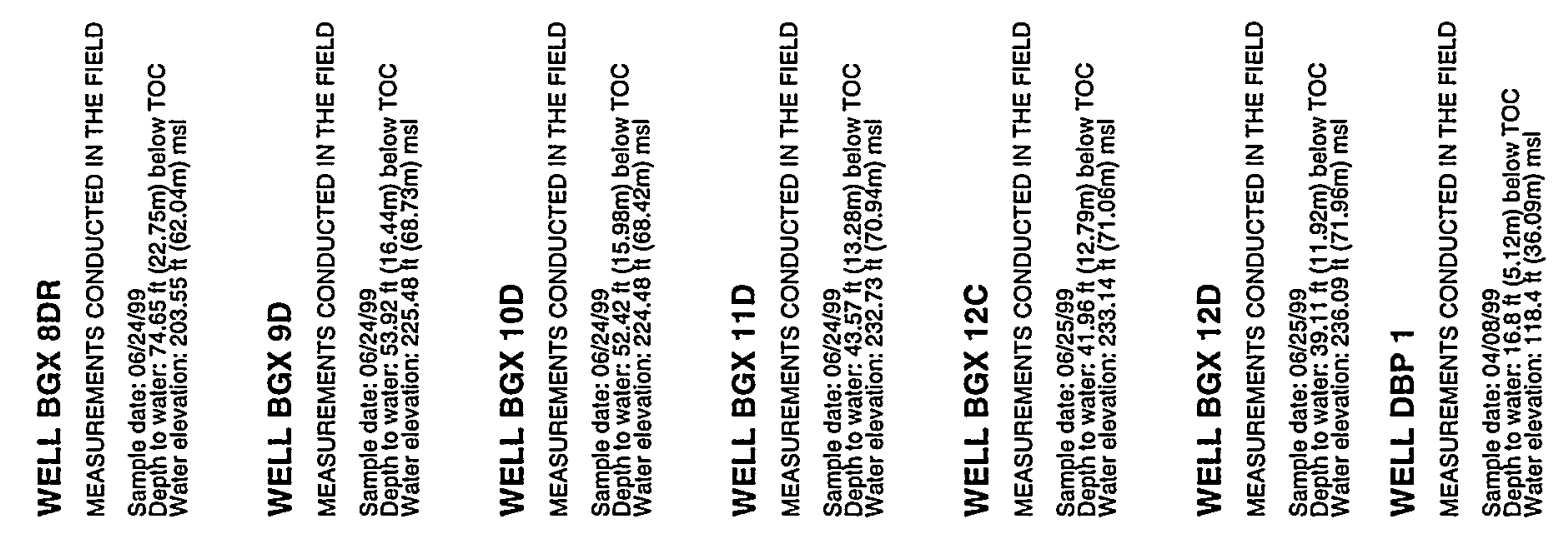


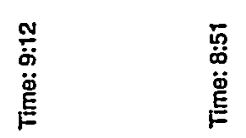

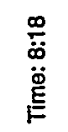

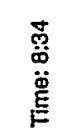

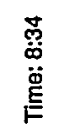

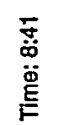

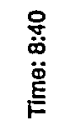

8
2
5
5
8
0
5
8
8

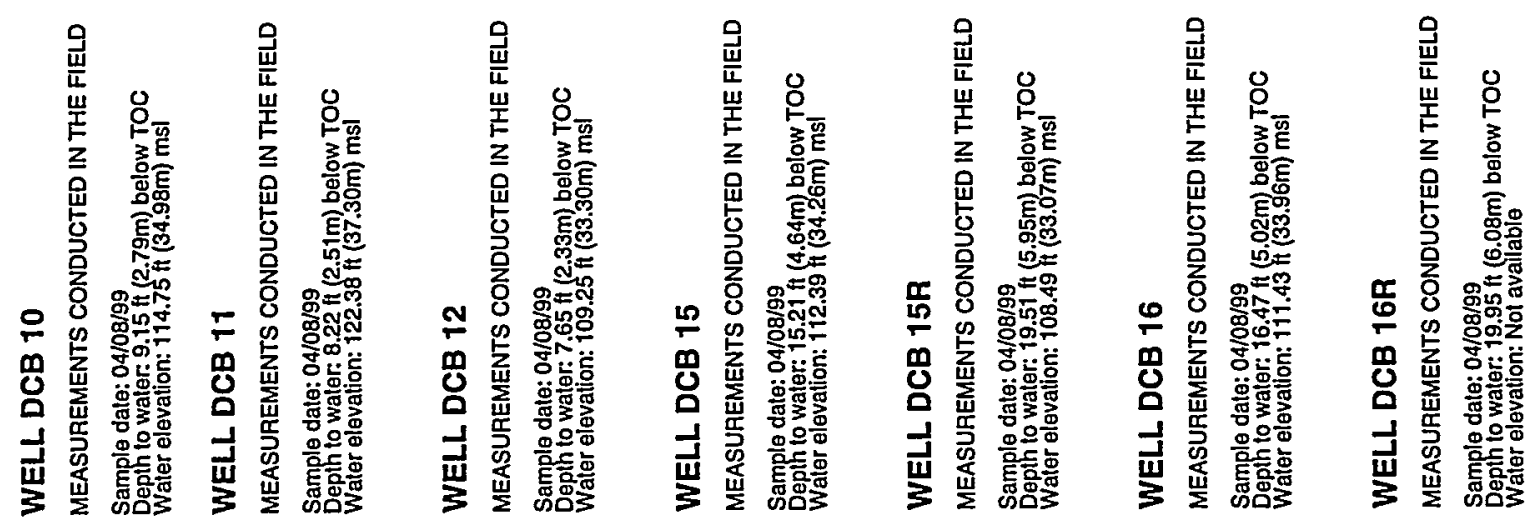

$\stackrel{9}{4}$

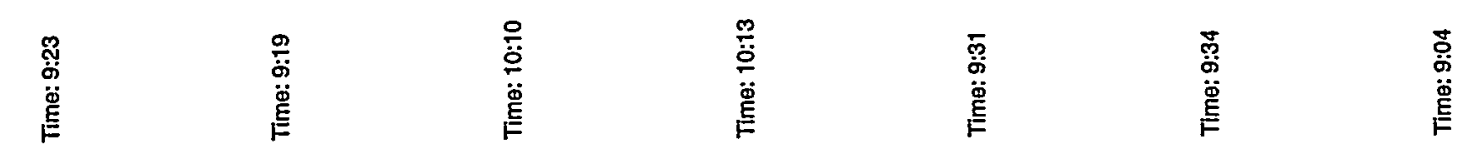

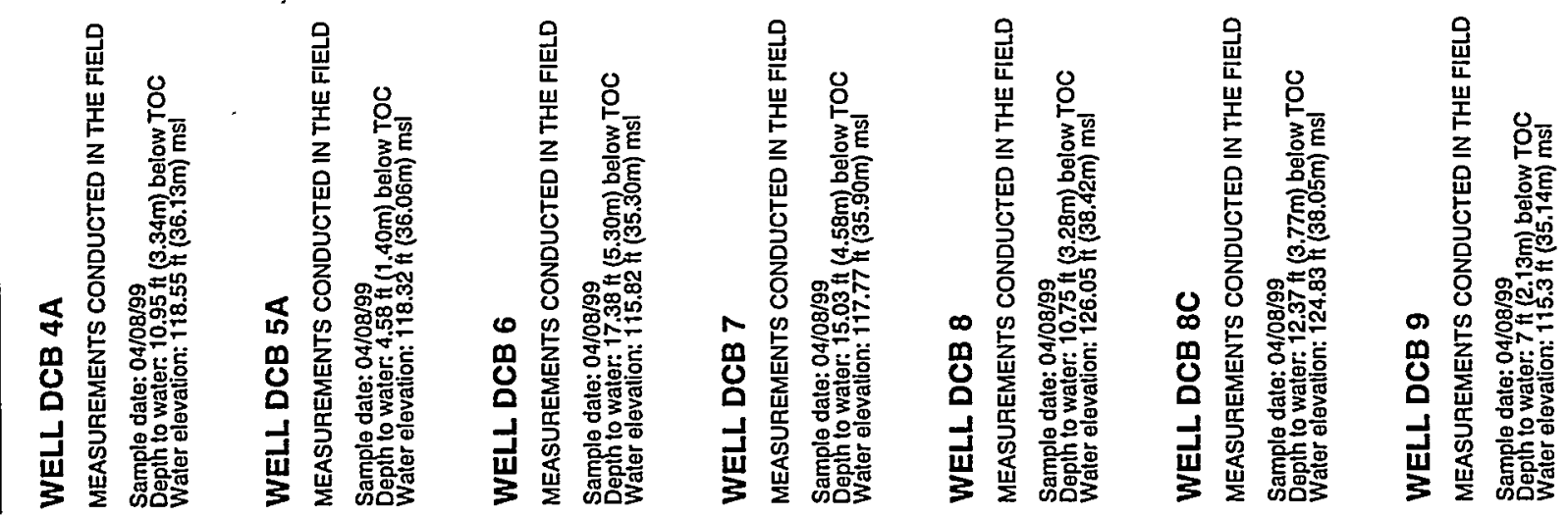

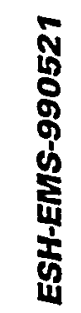




\section{WELL DCB 17A}

MEASUREMENTS CONDUCTED IN THE FIELD

Sample date: $04 / 08 / 99$
Dephth to water: $10.85 \mathrm{ft}(3.31 \mathrm{~m})$ below TOC
Water elevalion: Not available

\section{WELL DCB 17B}

MEASUREMENTS CONDUCTED IN THE FIELD

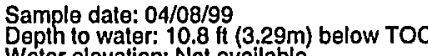

\section{WELL DCB 17C}

MEASUREMENTS CONDUCTED IN THE FIELD

Sample date: 04/08/99

Weph to waler.

\section{WELL DCB 18A}

MEASUREMENTS CONDUCTED IN THE FIELD

Sample date: $04 / 08 / 99$

water $9.019(2.75 \mathrm{~m}) 6$

\section{WELL DCB 18C}

MEASUREMENTS CONDUCTED IN THE FIELD

Sample date: 04/08/99

Depth to water: $12.65 \mathrm{ft}(3.86 \mathrm{~m})$ below TOC

Waler elevation: Not avaliable

\section{WELL DCB 19A}

MEASUREMENTS CONDUCTED IN THE FIELD

Sample date: 04/08/99

Deptr to water $9.97 \mathrm{H}$ H $(3.04 \mathrm{~m})$ below TOC
Waler elevation: $120.43 \mathrm{tt}(36.7 \mathrm{~m}) \mathrm{msl}$

\section{WELL DCB 19B}

MEASUREMENTS CONDUCTED IN THE FIELD

Sample date: 04/08/99
Depth to water: $12.45 \mathrm{ft}(3.79 \mathrm{~m})$ below TOC
WELL DCB 19C

MEASUREMENTS CONDUCTED IN THE FIELD

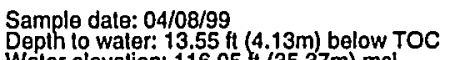

Time: 9:08

\section{WELL DCB 20A}

MEASUREMENTS CONDUCTED IN THE FIELD

Sample data: 04/08/99

Time: 13:09

\section{WELL DCB $20 B$}

MEASUREMENTS CONDUCTED IN THE FIELD

Sample date: 04/08/99

Depth to water: $14.51 \mathrm{ft}(4.42 \mathrm{~m})$ below TOC

Time: 13:09

\section{WELL DCB 20C}

MEASUREMENTS CONDUCTED IN THE FIELD

Sample date: $04 / 08 / 99$
Depth to water: $14.65 \mathrm{ft}(4.47 \mathrm{~m})$ below TOC
Water elevation: Nol available

Time: 13:09

WELL DCB 20D

MEASUREMENTS CONDUCTED IN THE FIELD

Sample dale: 04/08/99

Depth to water: $15.7 \mathrm{ft}(4.79 \mathrm{~m})$ below TOC
Water elevation: Not available

Time: 13:10

\section{WELL DCB 21A}

MEASUREMENTS CONDUCTED IN THE FIELD

Sample date: 04/08/99

Depth to water: $9.81 \mathrm{ft}(2.99 \mathrm{~m})$ below TOC

Time: 12:53

\section{WELL DCB 21B}

MEASUREMENTS CONDUCTED IN THE FIELD

Sample date: 04/08/99

Time: 12:55 


\section{WELL DCB 21C}

MEASUREMENTS CONDUCTED IN THE FIELD

Sample date: $04 / 08 / 999 \mathrm{ft}(4.27 \mathrm{~m})$ below TOC

Time: 12:55

\section{WELL DCB 22A}

MEASUREMENTS CONDUCTED IN THE FIELD

Sample date: 04/08/99

Depth to water: $12.38 \mathrm{ft}(3.77 \mathrm{~m})$ below TOC

Water elevation: Not available

\section{WELL DCB 22B}

MEASUREMENTS CONDUCTED IN THE FIELD

Sample date: 04/08/99

Depht lo water: $12.85 \mathrm{ft}(3.92 \mathrm{~m})$ below TOC
Water elevation: Not available

Time: 12:53

\section{WELL DCB 22C}

MEASUREMENTS CONDUCTED IN THE FIELD

Sample date: 04/08/99

Depth to water: 13.31 ft $(4.06 \mathrm{~m})$ below TOC

Time: 12:53

WELL DCB 23A

MEASUREMENTS CONDUCTED IN THE FIELD

Sample date: 04/08/99

Deph to water: $7.73 \mathrm{ft}(2.36 \mathrm{~m})$ below TOC

Water elevation: Not available

Timo: 13:02

\section{WELL DCB $23 B$}

MEASUREMENTS CONDUCTED IN THE FIELD

Sample date: $04 / 08 / 99$
Deph to water: 10.34 (1 $(3.15 \mathrm{~m})$ below TOC
Waler elevation: Nol available

Time: 13:03

\section{WELL DCB 23C}

MEASUREMENTS CONDUCTED IN THE FIELD

Sample date: 04/08/99

Depth to waler: $1.15 \mathrm{ft}(3.09 \mathrm{~m})$ below TOC
Water elevation: Not avallable

Time: 13:03
WELL DCB 23D

MEASUREMENTS CONDUCTED IN THE FIELD

Depth to water: $7.02 \mathrm{ft}(2.14 \mathrm{~m})$ below TOC

Time: 13:03

WELL DCB 24A

MEASUREMENTS CONDUCTED IN THE FIELD

Sample date: 04/08/99

Time: 12:57

\section{WELL DCB 24B}

MEASUREMENTS CONDUCTED IN THE FIELD

Sample date: 04/08/99

Depth to water: $6.88 \mathrm{Ht}(2.10 \mathrm{~m})$ below TOC
Water elevation: Not available

Time: 12:58

\section{WELL DCB 24C}

MEASUREMENTS CONDUCTED IN THE FIELD

Sample dale: $04 / 08 / 99$

Time: 12:58

Water to waterition: Not available
Walow TOC

\section{WELL DCB 26C}

MEASUREMENTS CONDUCTED IN THE FIELD

Sample date: 04/08/99

Wepth to water: $13 \mathrm{ft}(3.96 \mathrm{~m})$ below TOC

Time: 8:16

WELL DCB 27

MEASUREMENTS CONDUCTED IN THE FIELD

Samplo date: 04/08/99

Time: 8:24

Depth to water: $9.56 \mathrm{Ht}(2.91 \mathrm{~m})$ below TOC
Water elevallon: $107.24 \mathrm{ft}(32.69 \mathrm{~m}) \mathrm{ms}$

\section{WELLL DCB 27}

MEASUREMENTS CONDUCTED IN THE FIELD

Sample date: $04 / 08 / 99$

Depth to water: $9.56 \mathrm{H}(2.91 \mathrm{~m})$ below TOC

Time: 8:24 


\section{WELL DCB 28}

MEASUREMENTS CONDUCTED IN THE FIELD Sample date: 04/08/99

Deph to waier: 6.17t $1(1.88 \mathrm{~m})$ below TOC
Waler elevalion: $96.33 \mathrm{ti}(29.36 \mathrm{~m}) \mathrm{msl}$

\section{WELL DCB 30}

MEASUREMENTS CONDUCTED IN THE FIELD

Sample date: 04/08/99

Deph lo waier: 11.02 ft $(3.36 \mathrm{~m})$ below TOC

\section{WELL DCB 31}

MEASUREMENTS CONDUCTED IN THE FIELD

Sample date: 04/08/99

Depth to water: Not available
Water elevation: Not available

\section{WELL DCB 32A}

MEASUREMENTS CONDUCTED IN THE FIELD

Sample date: 04/08/99

Sample date: $04 / 08 / 99$
Depth to water: $20.95 \mathrm{ft}(6.39 \mathrm{~m})$ bolow TOC
Water elevation: $123.25 \mathrm{ft}(37.57 \mathrm{~m}) \mathrm{msl}$

Time: 8:09

\section{WELL DCB 33C}

MEASUREMENTS CONDUCTED IN THE FIELD

Sample date: 04/08/9

Depth to water: $9.12 \mathrm{ft}(2.78 \mathrm{~m})$ below TOC
Water elevation: $134.08 \mathrm{f}(40.87 \mathrm{~m}) \mathrm{msl}$

\section{WELL DCB 33D}

MEASUREMENTS CONDUCTED IN THE FIELD

Sample date: $04 / 08 / 99$
Depth to water: $9.13 \mathrm{ft}(2.78 \mathrm{~m})$ below TOC

\section{WELL DCB 34A}

MEASUREMENTS CONDUCTED IN THE FIELD

Sample date: 04/08/99

Depth to water: $12.4 \mathrm{ft}(3.78 \mathrm{~m})$ below TOC

\section{WELL DCB 34C}

MEASUREMENTS CONDUCTED IN THE FIELD

Sample date: 04/08/99

Time: 9:21

Weth to water: 12.11 h $(3.69 \mathrm{~m})$ below TOC

\section{WELL DCB 35A}

MEASUREMENTS CONDUCTED IN THE FIELD

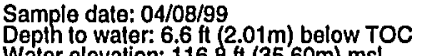

Time: 10:19

\section{WELL DCB 35C}

MEASUREMENTS CONDUCTED IN THE FIELD

Sample dale: 04/08/99

epth to water: $6.62 \mathrm{ft}(2.02 \mathrm{~m})$ below TOC

Time: 10:20

\section{WELL DCB 36A}

MEASUREMENTS CONDUCTED IN THE FIELD

Sample date: 04/08/99

Depth to water: $11.1 \mathrm{ft}(3.38 \mathrm{~m})$ below TOC
Water elevation: $123 \mathrm{it}(37.49 \mathrm{~m}) \mathrm{msl}$

Time: 9:14

\section{WELL DCB 36C}

MEASUREMENTS CONDUCTED IN THE FIELD

Sample date: 04/08/99

Depth to waler: $11.37 \mathrm{ft}(3.47 \mathrm{~m})$ below TOC

Time: 9:14

\section{WELL DCB 37A}

MEASUAEMENTS CONDUCTED IN THE FIELD

Sample date: 04/08/99

Time: 9:02

\section{WELLL DCB 37C}

MEASUREMENTS CONDUCTED IN THE FIELD

Sample date: 04/08/99

Depth to water: $12.91 \mathrm{ft}(3.94 \mathrm{~m})$ below TOC

Time: 9:02 
WELL DCB 38A

MEASUREMENTS CONDUCTED IN THE FIELD

Sample date: 04/08/99

Depth to water: Not available
Water elevation: Not available

\section{WELL DCB 38C}

MEASUREMENTS CONDUCTED IN THE FIELD

Sample date: $04 / 08 / 9$

Deph to waler: $23.42 \mathrm{ft}(7.14 \mathrm{~m})$ below TOC

\section{WELL DCB 39A}

MEASUREMENTS CONDUCTED IN THE FIELD

Sample date: $04 / 08 / 99$

\section{WELL DCB 39C}

MEASUREMENTS CONDUCTED IN THE FIELD

Sample date: 04/08/99

Sample date: $04 / 08 / 99$
Depth to water: 6.25 ft $(4.95 \mathrm{~m})$ below TOC
Water elevation: $115.85 \mathrm{Ht}(35.31 \mathrm{~m}) \mathrm{msl}$

\section{WELL DCB 40A}

MEASUREMENTS CONDUCTED IN THE FIELD

Sample date: 04/08/99

Depth to water: $15.33 \mathrm{H}(4.67 \mathrm{~m})$ below TOC
Water elevation: $120.17 \mathrm{Ht}(36.63 \mathrm{~m}) \mathrm{ms}$

\section{WELL DCB 41A}

MEASUREMENTS CONDUCTED IN THE FIELD

Sample date: 04/08/99

Waph to water: 12.79 fi $(3.90 \mathrm{~m})$ below TOC

\section{WELL DCB 41C}

MEASUREMENTS CONDUCTED IN THE FIELD

Sample date: $04 / 08 / 99$
Depth to water: $12.64 \mathrm{fl}(3.85 \mathrm{~m})$ below TOC
Wat

Time: 10:05
WELLL DCB 42A

MEASUREMENTS CONDUCTED IN THE FIELD

Sample dale: 04/08/99

Depth to water. Nol available
Water elevation: Nol available

\section{WELL DCB 42C}

MEASUREMENTS CONDUCTED IN THE FIELD

Sample dale: 04/08/99

Deph to water Not available

Time: 16:18

\section{WELL DCB 43A}

MEASUREMENTS CONDUCTED IN THE FIELD

Sample date: 04/08/99

Deph lo water: $15.92 \mathrm{ft}(4.85 \mathrm{~m})$ below TOC
Water elevalion: $118.18 \mathrm{tt}(36.02 \mathrm{~m}) \mathrm{msl}$

Time: 8:59

\section{WELL DCB 43C}

MEASUREMENTS CONDUCTED IN THE FIELD

Sample date: $04 / 08$

Wepth to water: $15.25 \mathrm{ft}(4.65 \mathrm{~m})$ below TOC

Time: 8:59

\section{WELL DCB 44A}

MEASUREMENTS CONDUCTED IN THE FIELD

Sample date: $04 / 08 / 99$
Depth 10 water: $13.11 \mathrm{ft}(4.00 \mathrm{~m})$ below TOC
Water elevation: $119.99 \mathrm{lt}(36.57 \mathrm{~m}) \mathrm{msl}$

Time: 9:59

\section{WELL DCB 44C}

MEASUREMENTS CONDUCTED IN THE FIELD

Sample date: 04/08/99

Depth to waler: $12.69 \mathrm{ft}(3.87 \mathrm{~m})$ below TOC

Time: 10:00

\section{WELL DCB 45A}

MEASUREMENTS CONDUCTED IN THE FIELD

Sample date: 04/08/99

Sample date: $04 / 08 / 99$
Depht to waler: $14 \mathrm{ft}(4.27 \mathrm{~m})$ below ToC
Waler elevation: $123.6 \mathrm{ft}(37.67 \mathrm{~m}) \mathrm{msl}$

Time: 9:54 


\section{WELL DCB 45C}

MEASUREMENTS CONDUCTED IN THE FIELD

Sample date: 04/08/99

Depth to waler: $14.1 \mathrm{tt}(4.30 \mathrm{~m})$ below TOC
Waler elevation: $124.7 \mathrm{ft}(38.01 \mathrm{~m}) \mathrm{msl}$

\section{WELL DCB 46C}

MEASUREMENTS CONDUCTED IN THE FIELD

Sample date: 04/08/99

epth to water: $21.76 \mathrm{ft}(6.63 \mathrm{~m})$ below TOC

\section{WELL DCB $47 C$}

MEASUREMENTS CONDUCTED IN THE FIELD

Sample date: 04/08/99

Depth to water: $22.33 \mathrm{H}(6.81 \mathrm{~m})$ below TOC
Water elevation: $109.07 \mathrm{Ht}(33.24 \mathrm{~m}) \mathrm{msl}$

\section{WELL DCB 48D}

MEASUREMENTS CONDUCTED IN THE FIELD

Sample date: 04/08/99

Depth to water: $14.11 \mathrm{ft}(4.30 \mathrm{~m})$ below TOC

\section{WELL DOB 1}

MEASUREMENTS CONDUCTED IN THE FIELDD

Sample date: 04/08/99

Wepth to waler: 7.44 t $(2.27 m)$ below TOC

\section{WELL DOB 2}

MEASUREMENTS CONDUCTED IN THE FIELD

Sample date: 04/08/99

Depth to water: $8.43 \mathrm{ft}(2.57 \mathrm{~m})$ below TOC

Time: 11:12

\section{WELL DOB 3}

MEASUREMENTS CONDUCTED IN THE FIELD

Sample date: 04/08/99

Depth to water: 8.4 ff $2.56 \mathrm{~m})$ below TOC
Water elevation: $144.4 \mathrm{ft}(44.01 \mathrm{~m}) \mathrm{msl}$

Time: 11:01

\section{WELL DOB 4}

MEASUREMENTS CONDUCTED IN THE FIELD

Sample dale: $04 / 08 / 99$
Depth to water: 918 th $(2.80 \mathrm{~m})$ below TOC
Water elevation: 143.82 it $(43.84 \mathrm{~m}) \mathrm{ms}$

Time: 10:55

\section{WELL DOB 5}

MEASUREMENTS CONDUCTED IN THE FIELD

Sample date: 04/08/99

Waph to water: $9.95 \mathrm{ft}(3.03 \mathrm{~m})$ below TOC

Time: 11:54

\section{WELL DOB 6}

MEASUREMENTS CONDUCTED IN THE FIELD

Sample date: 04/08/99

Depth to water: $6.51 \mathrm{H}(1.98 \mathrm{~m})$ below TOC

: $12: 02$

\section{WELL DOB 7}

MEASUREMENTS CONDUGTED IN THE FIELL

Sample date: 04/08/99

Wepth to water: $7.4 \mathrm{At}(2.26 \mathrm{~m})$ below TOC

Time: 11:38

\section{WELLL DOB 8}

MEASUREMENTS CONDUCTED IN THE FIELD

Sample date: 04/08/99

Water elevation: 144.01 if $(43.89 \mathrm{~m}) \mathrm{msl}$

Time: 10:56

\section{WELL DOB 9}

MEASUREMENTS CONDUCTED IN THE FIELD

Sample date: 04/08/99

Depth to water: $9.45 \mathrm{ft}(2.88 \mathrm{~m})$ below TOC

WELL DOB 10

MEASUREMENTS CONDUCTED IN THE FIELD

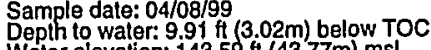

Time: 11:14 


\section{WELL DOB 11}

MEASUREMENTS CONDUCTED IN THE FIELD

Sample date: 04/08/99

Depth to water: $7.58 \mathrm{ft}(2.31 \mathrm{~m})$ below TOC

Time: 11:17

\section{WELL DOB 12}

MEASUREMENTS CONDUCTED IN THE FIELD

Sample date: 04/08/99

Depth to water: $8.81 \mathrm{th}(2.69 \mathrm{~m})$ below TOC

Time: 11:25

\section{WELL DOB 13}

MEASUREMENTS CONDUCTED IN THE FIELD

Sample date: 04/08/99 $20.62 \mathrm{~m})$ below TOC

\section{WELL DOB 14}

MEASUREMENTS CONDUCTED IN THE FIELD

Sample date: 04/08/99

Depth to waler: $8.45 \mathrm{ft}(2.58 \mathrm{~m})$ below TOC

WELL DOB 15

MEASUREMENTS CONDUCTED IN THE FIELD

Sample date: 04/08/99

Deph to water: $7.5 \mathrm{fl}(2.29 \mathrm{~m})$ below TOC
Water elevallon: $143.1 \mathrm{ft}(43.62 \mathrm{~m}) \mathrm{msl}$

\section{WELLL DOB 16}

MEASUREMENTS CONDUCTED IN THE FIELD

Sample date: 04/08/99

Deph to water: $8.03 \mathrm{sit}(2.45 \mathrm{~m})$ below TOC
Waler elevalion: $143.07 \mathrm{it}(43.61 \mathrm{~m}) \mathrm{ms}$

\section{WELL DOB 17}

MEASUREMENTS CONDUCTED IN THE FIELD

Sample date: $04 / 08 / 99$ (3.

\section{WELLL DOB 18}

MEASUREMENTS CONDUCTED IN THE FIELD

Sample date: 04/08/99

Depth to water: $16.25 \mathrm{ft}(4.95 \mathrm{~m})$ below TOC

Time: 12:39

\section{WELL DOL 1}

MEASUREMENTS CONDUCTED IN THE FIELD

Sample dale: 04/08/99

Weth to water $10.18 \mathrm{ft}(3.10 \mathrm{~m})$ below TOC

Time: 11:58

\section{WELL DOL 2}

MEASUREMENTS CONDUCTED IN THE FIELD

Sample date: $04 / 08 / 99$
Depth lo water: $9.5 \mathrm{ft}(2.90 \mathrm{~m})$ below TOC
Water elavation: $143.5 \mathrm{it}(43.74 \mathrm{~m}) \mathrm{msl}$

Time: 11:31

\section{WELL FOB 5C}

MEASUREMENTS CONDUCTED IN THE FIELD

Sample date: 06/25/99

Depth to water: $55.31 \mathrm{ft}(16.86 \mathrm{~m})$ below TOC

\section{WELL. FOB 7A}

MEASUREMENTS CONDUCTED IN THE FIELD

Sample date: 06/25/99

Time: 20:07

Depth to waler: $147 \mathrm{ft}(44.81 \mathrm{~m})$ below TOC
Water elevallon: $150.5 \mathrm{ft}(45.87 \mathrm{~m}) \mathrm{msl}$

\section{WELL FOB 7C}

MEASUREMENTS CONDUCTED IN THE FIELD

Depth to water: $88.61 \mathrm{ft}(27.01 \mathrm{~m})$ below TOC
Water elevalion: $209.29 \mathrm{tt}(63.79 \mathrm{~m}) \mathrm{ms}$

Time: 20:09

\section{WELLL FOB 9C}

MEASUREMENTS CONDUCTED IN THE FIELD

Sample date: 06/28/99

Depth to waler: $83.73 \mathrm{ft}(25.52 \mathrm{~m})$ below TOC
Water elevation: $211.07 \mathrm{Hi}(64.33 \mathrm{~m}) \mathrm{ms}$

Time: 12:37 


\section{WELL. FSB 50PD}

MEASUREMENTS CONDUCTED IN THE FIELD

Sample date: 06/25/99

Deph to water: $55.6 \mathrm{Gt}(15.73 \mathrm{~m})$ below
Water elevation: $206.4 \mathrm{tt}(62.91 \mathrm{~m}) \mathrm{ms}$

\section{WELL FSB 76}

MEASUREMENTS CONDUCTED IN THE FIELD

Sample date: 06/28/99

Wepth to water: 75.95 ft $23.15 \mathrm{~m})$ below TOC

\section{WELL FSB 76A}

MEASUREMENTS CONDUCTED IN THE FIELD

Sample date: 06/28/99

Depth to water: $138.62 \mathrm{ft}(42.25 \mathrm{~m})$ below TO

\section{WELL FSB 76B}

MEASUREMENTS CONDUCTED IN THE FIELD

Sample date: 06/28/99

Semple date: $06 / 28 / 99$
Wath to water: $142.3 \mathrm{H}(43.37 \mathrm{~m})$ below TOC
Water elevation: $151.5 \mathrm{Ht}(46.18 \mathrm{~m}) \mathrm{msl}$

Time: 12:23

\section{WELL FSB 76C}

MEASUREMENTS CONDUCTED IN THE FIELD

Sample date: 06/28/9

Depth to water: 81.03 ft $(24.70 \mathrm{~m})$ below TOC

\section{WELL FSB 77}

MEASUREMENTS CONDUCTED IN THE FIELD

Sample date: 06/28/99

Wepth to waler: $60.78 \mathrm{ft}(18.53 \mathrm{~m})$ below TOC

\section{WELL FSB 78}

MEASUREMENTS CONDUCTED IN THE FIELD

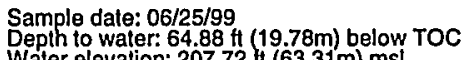

\section{WELL FSB 78A}

MEASUREMENTS CONDUCTED IN THE FIELD

Sample date: $06 / 25 / 99$
Depth 10 water: $116.7 \mathrm{ft}(35.57 \mathrm{~m})$ below TOC
Water elevation: $155.9 \mathrm{ft}(47.52 \mathrm{~m}) \mathrm{ms}$ l

Time: 21:49

\section{WELL FSB 78B}

MEASUREMENTS CONDUCTED IN THE FIELD Sample date: 06/25/99 18 ft $(36.08 \mathrm{~m})$ below TOC

Time: 21:50

\section{WELL FSB 78C}

MEASUREMENTS CONDUCTED IN THE FIELD

Sample date: $06 / 25 / 99$
Depih to water: $66.15 \mathrm{ft}(20.16 \mathrm{~m})$ below TOC
Water elevation: $207.35 \mathrm{Ht}(63.20 \mathrm{~m}) \mathrm{ms}$

Time: 21:51

WELL FSB 79

MEASUREMENTS CONDUCTED IN THE FIELD

Sample dale: 06/28/99

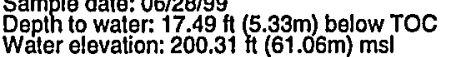

Time: 12:30

\section{WELL FSB 79A}

MEASUREMENTS CONDUCTED IN THE FIELD

Sample date: 06/28/99

Depth to water: $60.05 \mathrm{ft}(18.30 \mathrm{~m})$ below TOC

Time: 12:30

\section{WELL FSB 79B}

MEASUREMENTS CONDUCTED IN THE FIELD

Sample date: $06 / 28 / 99$
Depth to water: $59.92 \mathrm{ft}(18.26 \mathrm{~m})$ below TOC
Wat

Time: 12:31

\section{WELL FSB 79C}

MEASUREMENTS CONDUCTED IN THE FIELD

Sample date: 06/28/99

Depth to water: $22.3 \mathrm{ft}(6.80 \mathrm{~m})$ below TOC

Time: 12:31 
WELL FSB 87A

MEASUREMENTS CONDUCTED IN THE FIELD

Sample date: 06/25/99

Depth to water $134.04 \mathrm{ft}(40.86 \mathrm{~m})$ below TOC

Water elevation: $153.76 \mathrm{ft}(46.87 \mathrm{~m}) \mathrm{msl}$

\section{WELL FSB 87B}

MEASUREMENTS CONDUCTED IN THE FIELD

Sample date: 06/25/99

Wepth to water: $136.97 \mathrm{ft}(41.75 \mathrm{~m})$ below TOC

\section{WELL FSB $87 C$}

MEASUREMENTS CONDUCTED IN THE FIELD

Sample date: 06/25/99

Pepth to water: $78.83 \mathrm{Ht}(24.03 \mathrm{~m})$ below TOC

WELLL FSB 87D

MEASUREMENTS CONDUCTED IN THE FIELD

Sample date: 06/25/99

Depth to water: Not available

WELL FSB 88C

MEASUREMENTS CONDUCTED IN THE FIELD

Sample date: 06/28/99

Dephth lo water: $70.66 \mathrm{ft}(21.54 \mathrm{~m})$ below TOC
Water elevation: $212.34 \mathrm{t}(64.72 \mathrm{~m}) \mathrm{ms}$

\section{WELL FSB 88D}

MEASUREMENTS CONDUCTED IN THE FIELD

Sample date: $06 / 28 / 99$
Depth 1o water: $65.9 \mathrm{gt}(20.09 \mathrm{~m})$ below TOC
Water elevation: $216.5 \mathrm{t}(65.99 \mathrm{~m}) \mathrm{ms}$

\section{WELL FSB $89 C$}

MEASUREMENTS CONDUCTED IN THE FIELD

Sample date: $06 / 28 / 99$
Deph to waier: $69.56 \mathrm{ft}(21.20 \mathrm{~m})$ below TOC
Water elevalion: $211.74 \mathrm{H}(64.54 \mathrm{~m}) \mathrm{ms}$

Time: 12:26

Time: 21:03
WELL FSB 89D

MEASUREMENTS CONDUCTED IN THE FIELD

Sample date: 06/28/99

Depth to water: $65.37 \mathrm{ft}(19.93 \mathrm{~m})$ below TOC
Water elevation: $215.83 \mathrm{ht}(65.79 \mathrm{~m}) \mathrm{ms}$

Time: 12:27

WELL FSB 90C

MEASUREMENTS CONDUCTED IN THE FIELLD

Sample date: 06/28/99

Depth to water: $68.02 \mathrm{ft}(20.73 \mathrm{~m})$ below TOC

WELL FSB 90D

MEASUREMENTS CONDUCTED IN THE FIELD

Sample date: 06/28/99

Time: 12:28

Water elevation: Not available

\section{WELL FSB 91C}

MEASUREMENTS CONDUCTED IN THE FIELD

Sample date: 06/28/99

Depth to waler: $68.66 \mathrm{ft}(20.93 \mathrm{~m})$ below TOC
Water elevation: $210.64 \mathrm{ft}(64.20 \mathrm{~m}) \mathrm{ms}$ l

Time: 12:28

\section{WELL FSB 91D}

MEASUREMENTS CONDUCTED IN THE FIELD

Sample date: 06/28/99

Time: 12:28

\section{WELL FSB 92C}

MEASUREMENTS CONDUCTED IN THE FIELD

Sample date: 06/28/99

epth to water: $66.4 \mathrm{ft}(20.24 \mathrm{~m})$ below TOC

Time: 12:29

\section{WELL FSB 92D}

MEASUREMENTS CONDUCTED IN THE FIELD

Sample date: $06 / 28 / 99$
Depth to water: $64.35 \mathrm{H}(19.61 \mathrm{~m})$ below TOC
Water elevation: $211.55 \mathrm{Ht}(64.48 \mathrm{~m}) \mathrm{ms}$ 


\section{WELL FSB $93 C$}

MEASUREMENTS CONDUCTED IN THE FIELD

Sample date: 08/28/99
Depth to water: $67.8 \mathrm{ft}(20.67 \mathrm{~m})$ below TOC
Water elevation: 208.4 (6) $(63.52 \mathrm{~m}) \mathrm{ms}$

WELL FSB 93D

MEASUREMENTS CONDUCTED IN THE FIELD

Sample date: 06/28/99

Depth to water: $66.18 \mathrm{ft}(20.17 \mathrm{~m})$ below TOC

\section{WELL FSB $94 C$}

MEASUAEMENTS CONDUCTED IN THE FIELD

Sample date: 06/25/99
Depth to waler: 73.82 it (22.50m) below TOC

\section{WELLL FSB 94DR}

MEASUREMENTS CONDUCTED IN THE FIELD

Sample date: 06/25/99

Demplh to water: $71.68 \mathrm{ft}(21.85 \mathrm{~m})$ below TOC
Water elevation: $208.82 \mathrm{ft}(63.65 \mathrm{~m}) \mathrm{ms}$

\section{WELL FSB 95CR}

MEASUREMENTS CONDUCTED IN THE FIELD

Sample date: 06/25/99

Depth to water: 77.22 ft $(23.54 \mathrm{~m})$ below TOC

\section{WELL FSB 95DR}

MEASUREMENTS CONDUCTED IN THE FIELD

Sample date: 06/25/99
Depth to waler: $75.11 \mathrm{ft}(22.89 \mathrm{~m})$ below TOC
Water elevation: $208.99 \mathrm{tt}(63.70 \mathrm{~m}) \mathrm{ms}$

\section{WELL FSB 96AR}

MEASUREMENTS CONDUCTED IN THE FIELD

Sample date: 06/25/99

Depht to water: $128.26 \mathrm{ft}(39.09 \mathrm{~m})$ below TOC
Water elevation: $152.94 \mathrm{ft}(46.62 \mathrm{~m}) \mathrm{msl}$

\section{WELL FSB 97A}

MEASUREMENTS CONDUCTED IN THE FIELD

Sample dale: 06/25/99

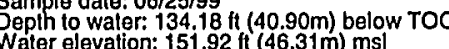

Time: 21:15

\section{WELL FSB 97C}

MEASUREMENTS CONDUCTED IN THE FIELD

Sample dale: $06 / 25 / 99$ (23.84m) below TOC

Time: 21:17

\section{WELL FSB 97D}

MEASUREMENTS CONDUCTED IN THE FIELD

Sample date: 06/25/99

epth to water: $75.75 \mathrm{H}(23.09 \mathrm{~m})$ below TOC

Water elevation: $210.25 \mathrm{ft}(64.08 \mathrm{~m}) \mathrm{ms}$ |

\section{WELL FSB 98AR}

MEASUREMENTS CONDUCTED IN THE FIELD

Sample date: 06/25/99 $\mathrm{ft}(40.48 \mathrm{~m})$ below TOC

Water elevation: $151.19 \mathrm{ft}(46.08 \mathrm{~m}) \mathrm{msl}$

Time: 20:49

\section{WELL FSB 98C}

MEASUREMENTS CONDUCTED IN THE FIELD

Sample date: 06/25/99 $2309 \mathrm{~m}$ below TOC

Water elevation: $208.73 \mathrm{tt}(63.62 \mathrm{~m}) \mathrm{ms}$ (

Time: 20:55

\section{WELL FSB 98D}

MEASUREMENTS CONDUCTED IN THE FIELD

Sample date: 06/25/99

epth to water: $72.75 \mathrm{H}(22.17 \mathrm{~m})$ below TOC

Time: 20:52

\section{WELL FSB 99A}

MEASUREMENTS CONDUCTED IN THE FIELD

Sample date: $06 / 25 / 99$ f $(41.82 \mathrm{~m})$ below TOC

Time: 20:38 


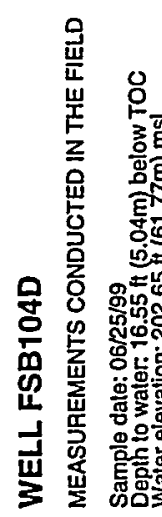
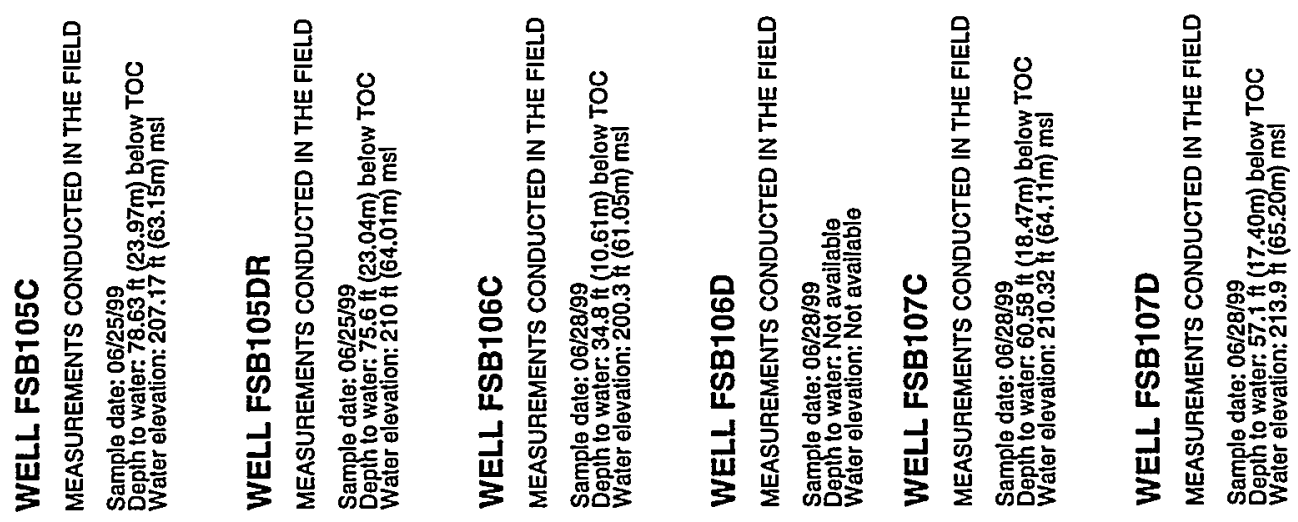

รุ
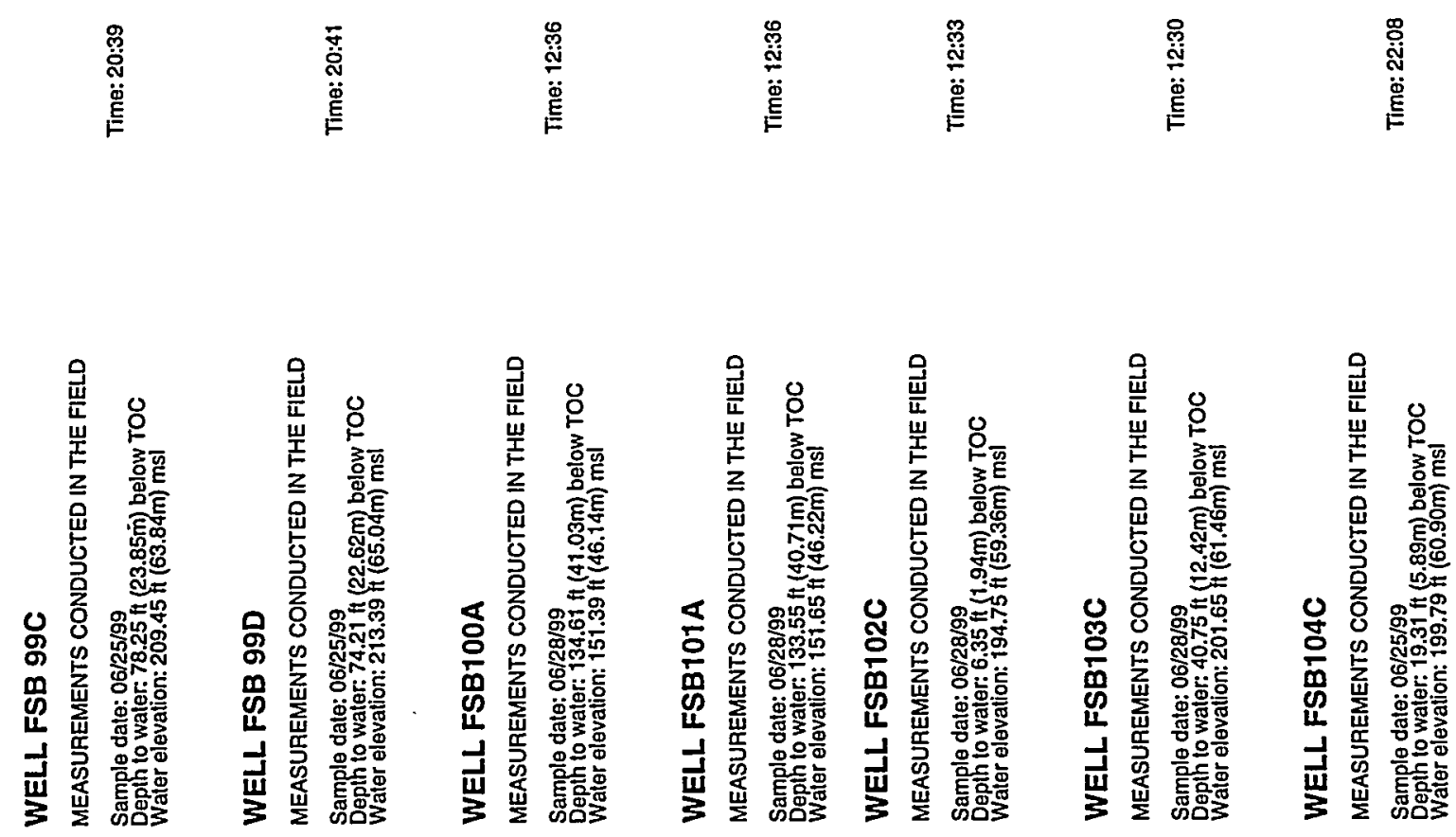


\section{WELL FSB108D}

MEASUREMENTS CONDUCTED IN THE FIELD

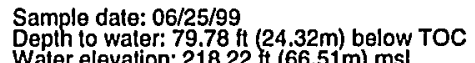

\section{WELL FSB109D}

MEASUREMENTS CONDUCTED IN THE FIELD

Sample date: 06/25/99

\section{WELL FSB110C}

MEASUREMENTS CONDUCTED IN THE FIELD

Sample date: 06/28/99
Depth to water: $34.31 \mathrm{ft}(10.46 \mathrm{~m})$ below TOC
Water elevation: $200.19 \mathrm{ft}(61.02 \mathrm{~m}) \mathrm{ms}$

\section{WELL FSB110D}

MEASUREMENTS CONDUCTED IN THE FIELD

Sample date: 06/28/99

Depth to water: $30.7 \mathrm{ft}(9.36 \mathrm{~m})$ below TOC

\section{WELL FSB111C}

MEASUREMENTS CONDUCTED IN THE FIELD

Sample date: 06/28/99

Depth to water: $64.45 \mathrm{H}$ (19.64m) below TOC

\section{WELL FSB111D}

MEASUREMENTS CONDUCTED IN THE FIELD

Sample date: 06/28/99

Depth to water: 61.12 Ht $(18.63 \mathrm{~m})$ below TOC

\section{WELL FSB112A}

MEASUREMENTS CONDUCTED IN THE FIELD

Sample date: 06/25/99

Depth to water: $76.2 \mathrm{ft}(23.23 \mathrm{~m})$ below TOC
WELL FSB112C

MEASUREMENTS CONDUCTED IN THE FIELD

Sample date: $06 / 25 / 99$

Time: 22:21

\section{WELL FSB112D}

MEASUREMENTS CONDUCTED IN THE FIELD

Sample dale: 06/25/99

Depth to water: $25.79 \mathrm{ft}(7.86 \mathrm{~m})$ below TOC

Time: 22:21

\section{WELL FSB113A}

MEASUREMENTS CONDUCTED IN THE FIELD

Sample dale: $06 / 28 / 99$

Water elevation: $159.75 \mathrm{H}(48.69 \mathrm{~m}) \mathrm{ms}$ TOC

Time: 12:34

\section{WELL FSB113C}

MEASUREMENTS CONDUCTED IN THE FIELD

Sample date:06/28/99

Depth to water: $21.3 \mathrm{ft}(6.49 \mathrm{~m})$ below TOC
Water elevation: $201.6 \mathrm{ft}(61.45 \mathrm{~m}) \mathrm{ms}$

Time: 12:34

\section{WELL FSB113D}

MEASUREMENTS CONDUCTED IN THE FIELD

Sample date: 06/28/99

Depth to water: $16.7 \mathrm{t}(5.09 \mathrm{~m})$ below TOC

Time: 12:35

WELL FSB114A

MEASUREMENTS CONDUCTED IN THE FIELD

Sample date: $06 / 28 / 99$
Depth to water: 96.65 th $(29.46 \mathrm{~m})$ below TOC
Water elevation: $155.35 \mathrm{Ht}(47.35 \mathrm{~m}) \mathrm{msl}$

Time: 12:24

WELL FSB114C

MEASUREMENTS CONDUCTED IN THE FIELD

Sample date: $06 / 28 / 99$
Depth to water: $39.41 \mathrm{ft}(12.01 \mathrm{~m})$ below TOC
Waler elevation: $212.79 \mathrm{ft}(64.86 \mathrm{~m}) \mathrm{msl}$ 


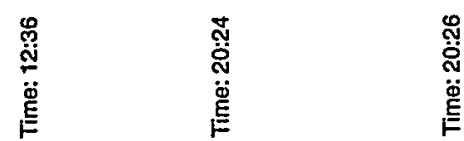

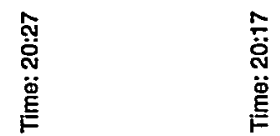

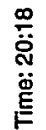

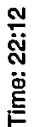

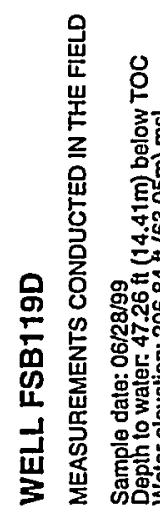
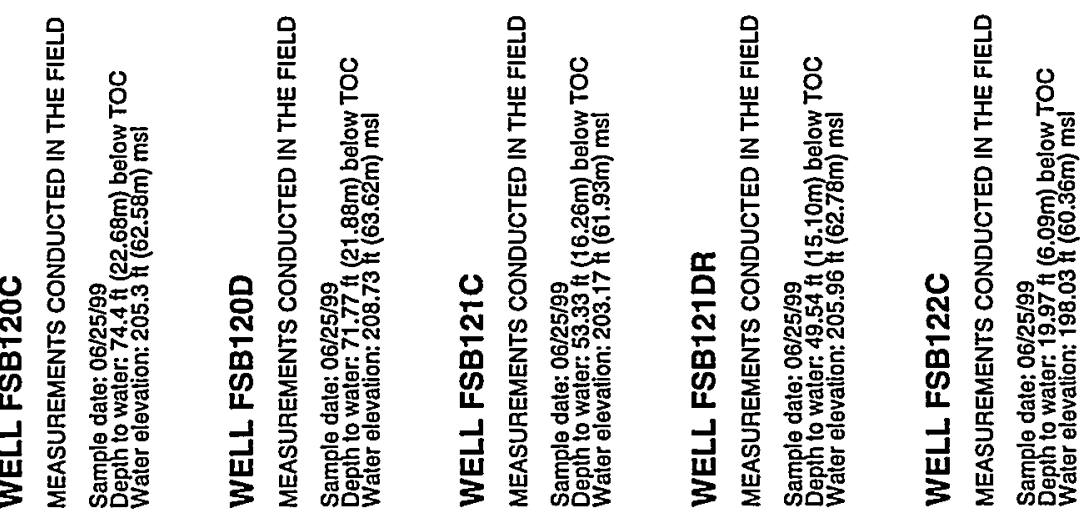

q<smiles>CC(C)C</smiles>

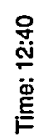

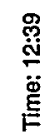

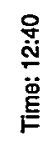

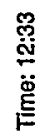

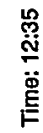
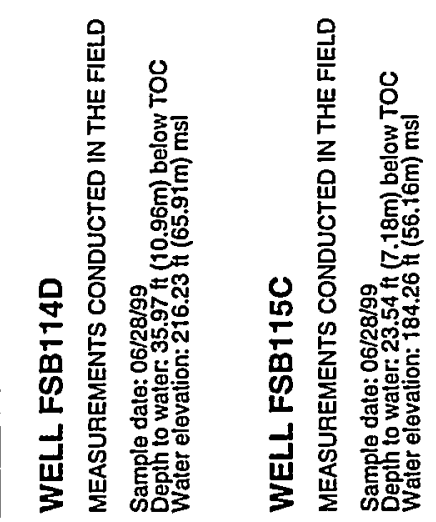

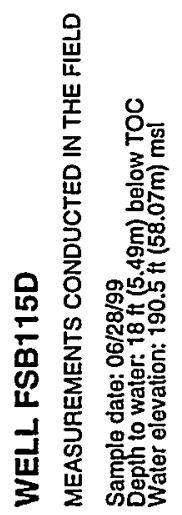

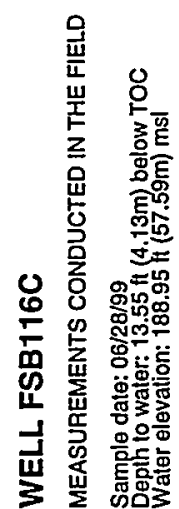

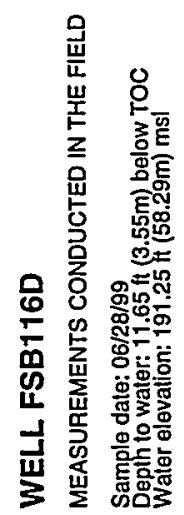

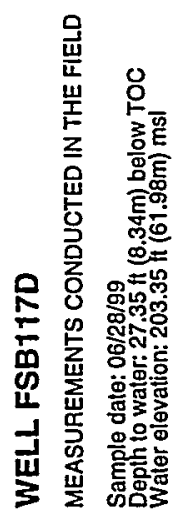

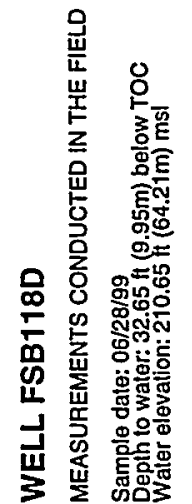




\section{WELL FSB122D}

MEASUREMENTS CONDUCTED IN THE FIELD

Sample date: 06/25/99

Depth to water: $16.31 \mathrm{ft}(4.97 \mathrm{~m})$ below TOC
Water elevation: $201.29 \mathrm{ft}(61.35 \mathrm{~m}) \mathrm{msl}$

\section{WELL FSB123C}

MEASUREMENTS CONDUCTED IN THE FIELD

Sample dale: 06/28/99

Wepth to water: 28.6 tt $(8.72 \mathrm{~m})$ below TOC

\section{WELL FSB123D}

MEASUREMENTS CONDUCTED IN THE FIELD

Sample date: 06/28/99

Depth to water: 27.15 \& $(8.28 \mathrm{~m})$ below TOC

Water elevation: $210.95 \mathrm{ft}(64.30 \mathrm{~m}) \mathrm{msl}$

\section{WELL FSB150PC}

MEASUREMENTS CONDUCTED IN THE FIELD

Sample date: 06/28/99

Depth to water: 38.61 it (11.77m) below TOC

\section{WELL FSB150PD}

MEASUREMENTS CONDUCTED IN THE FIELD

Sample date: 06/25/99

epph to water: 53.09 ft $(16.18 \mathrm{~m})$ below TOC

\section{WELL FSL 10}

MEASUREMENTS CONDUCTED IN THE FIELD

Sample date: $06 / 30 / 99$

Depth to water: $86.89 \mathrm{ft}(26.48 \mathrm{~m})$ below
Water elevation: $223.91 \mathrm{th}(68.25 \mathrm{~m}) \mathrm{msl}$

\section{WELLL FSL 2D}

MEASUREMENTS CONDUCTED IN THE FIELD

Sample date: 06/28/99

Depth to water: $81.08 \mathrm{ft}(24.71 \mathrm{~m})$ below
Water elevation: $224.72 \mathrm{tt}(68.50 \mathrm{~m}) \mathrm{msl}$
WELL FSL 3D

MEASUREMENTS CONDUCTED IN THE FIELD

Sample date: 06/28/99

Wh

Time: 12:37

\section{WELL FSL 4D}

MEASUREMENTS CONDUCTED IN THE FIELD

Sample date: 06/28/99

epth to wailer: 77.474 f $23.61 \mathrm{~m})$ below TOC

Time: 12:37

\section{WELL FSL 5D}

MEASUREMENTS CONDUGTED IN THE FIELD

Sample date: 06/28/99

Depth to water: $71.26 \mathrm{ft}(21.72 \mathrm{~m})$ below TOC

Water elevation: $220.54 \mathrm{ft}(67.22 \mathrm{~m}) \mathrm{msl}$

Time: 12:38

\section{WELLL FSL 6D}

MEASUREMENTS CONDUCTED IN THE FIELD

Sample date: $06 / 28 / 99$ (20.26m) below TOC

Water elevation: $219.74 \mathrm{Ht}(66.98 \mathrm{~m}) \mathrm{msl}$

Time: 12:38

WELLL FSL 7D

MEASUREMENTS CONDUCTED IN THE FIELD

Sample date: 06/28/99

Depth to water: $69.08 \mathrm{ft}(21.06 \mathrm{~m})$ below TOC
Water elevation: $218.52 \mathrm{ft}(66.61 \mathrm{~m}) \mathrm{msl}$

Time: 8:38

\section{WELL FSL 8D}

MEASUREMENTS CONDUCTED IN THE FIELD

Sample date: $06 / 28 / 99$ (22.38m) below TOC

Water elevation: $27.38 \mathrm{Ht}(66.26 \mathrm{~m}) \mathrm{ms}$

Time: 12:24

WELL FSL 9D

MEASUREMENTS CONDUCTED IN THE FIELD

Sample date: 06/28/99

Deph to waler: $69.4 \mathrm{ft}(21.15 \mathrm{~m})$ below TOC

Time: 12:24 
WELL FSS 1D

MEASUREMENTS CONDUCTED IN THE FIELD

Sample date: 06/28/9

Depth to water: 44.13 ft $(13.45 \mathrm{~m})$ below TOC

Time: 12:39

\section{WELL FSS 2D}

MEASUREMENTS CONDUCTED IN THE FIELD

Sample date: 06/28/99

Time: 12:38

WELL FSS 3D

MEASUREMENTS CONDUCTED IN THE FIELD

Sample date: 06/28/99 $11.89 \mathrm{~m})$ below TOC

\section{WELL FSS 4D}

MEASUREMENTS CONDUCTED IN THE FIELD

Sample date: 06/28/99 $32.35 \mathrm{~m}$ ) below TOC

Depth to water: $73.31 \mathrm{H}(22.35 \mathrm{~m})$ below TOC
Water elevation: $218.49 \mathrm{H}(66.60 \mathrm{~m}) \mathrm{ms}$

\section{WELL HIW 1MD}

MEASUREMENTS CONDUCTED IN THE FIELD

Sample date: 06/19/99

Depth to water: $37.06 \mathrm{ft}(11.30 \mathrm{~m})$ below TOC
Water elevation: $237.54 \mathrm{ft}(72.40 \mathrm{~m}) \mathrm{ms}$

\section{WELL HIW $1 M D$}

MEASUREMENTS CONDUCTED IN THE FIELD

Sample date: 06/19/99
Depth to water: $37.06 \mathrm{ft}(11.30 \mathrm{~m})$ below TOC
Water elevation: $237.54 \mathrm{ft}(72.40 \mathrm{~m}) \mathrm{ms}$

Time: 5:11

\section{WELL HIW 1PD}

MEASUREMENTS CONDUCTED IN THE FIELD

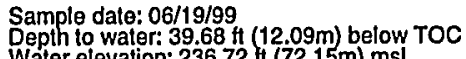

WELL HIW 1PD

MEASUREMENTS CONDUCTED IN THE FIELL

Sample date: 06/19/99

Water elevation: $236.72 \mathrm{ft}(72.15 \mathrm{~m}) \mathrm{ms}$

Time: 5:11

WELL. HIW $2 A$

MEASUREMENTS CONDUCTED IN THE FIELD

Sample date: $06 / 19 / 99$
Depth to water: $110.74 \mathrm{ft}(33.75 \mathrm{~m})$ below TOC
Water elevalion: $167.26 \mathrm{ft}(50.98 \mathrm{~m}) \mathrm{msl}$

Time: 4:58

\section{WELL HIW $2 A$}

MEASUREMENTS CONDUCTED IN THE FIELD

Sample date: $06 / 19 / 99$
Depth to water: $110.74 \mathrm{ft}(33.75 \mathrm{~m})$ below TOC
Water elevation: $167.26 \mathrm{ft}(50.98 \mathrm{~m}) \mathrm{msl}$

Time: 4:58

\section{WELL HIW 20}

MEASUREMENTS CONDUCTED IN THE FIELD

Sample date: 06/19/99

epth to waler: $44.05 \mathrm{Ht}(13.43 \mathrm{~m})$ below TOC

Time: 5:00

\section{WELLL HIW 2D}

MEASUREMENTS CONDUCTED IN THE FIELD

Sample date: 06/19/99

Wepth to water: $44.05 \mathrm{ft}(13.43 \mathrm{~m})$ below
Water elevation: $233.75 \mathrm{Ht}(71.25 \mathrm{~m}) \mathrm{ms}$

Time: 5:00

WELL HIW 2MC

MEASUREMENTS CONDUCTED IN THE FIELD

Sample date: 06/19/99

Depth to water: 39.1 th $(11.92 \mathrm{~m})$ below TOC
Water elevation: $231.8 \mathrm{ft}(70.65 \mathrm{~m}) \mathrm{ms}$

Time: 5:01

\section{WELL HIW 2MC}

MEASUREMENTS CONDUCTED IN THE FIELD

Sample date: 06/19/99

Time: 5:01 


\section{WELL HIW 3MC}

MEASUREMENTS CONDUCTED IN THE FIELD

Sample dale: $06 / 19 / 99$
Depth to water: $42.55 \mathrm{ht}(12.97 \mathrm{~m})$ below TOC
Water elevation: $231.45 \mathrm{Ht}(70.55 \mathrm{~m}) \mathrm{ms}$

\section{WELL HIW 3MC}

MEASUREMENTS CONDUCTED IN THE FIELD

Sample date: 06/19/99

Depth to water: $42.55 \mathrm{f}(12.97 \mathrm{~m})$ below TOC
Water elevation: $231.45 \mathrm{Ht}(70.5 \mathrm{~m}) \mathrm{ms}$

\section{WELL HIW 5MC}

MEASUREMENTS CONDUCTED IN THE FIELD

Sample date: 06/19/99

Depth to waler: $38.5 \mathrm{ft}(11.73 \mathrm{~m})$ below TOC

WELL HIW 5MC

MEASUREMENTS CONDUCTED IN THE FIELD

Sample date: 06/19/99

Depth to water: $38.5 \mathrm{ft}(11.73 \mathrm{~m})$ below TOC
Water elevation: $229.7 \mathrm{ft}(70.01 \mathrm{~m}) \mathrm{ms}$

\section{WELL HMD 1D}

MEASUREMENTS CONDUCTED IN THE FIELD

Sample date: 06/19/99

Depth to water: $57.2 \mathrm{ft}(17.43 \mathrm{~m})$ below TOC

Time: $8: 05$

\section{WELLL HMD 1D}

MEASUREMENTS CONDUCTED IN THE FIELD

Sample date: 06/19/99

Depth to water: 57.2 ft $(17.43 \mathrm{~m})$ below $\mathrm{TOC}$

\section{WELL HMD 1D}

MEASUREMENTS CONDUCTED IN THE FIELD

Sample date: 06/25/99

Depth to water: $57.18 \mathrm{ff}(17.43 \mathrm{~m})$ below TOC
Water elevation: $207.32 \mathrm{ft}(63.19 \mathrm{~m}) \mathrm{ms}$

Time: 14:18
WELL HMD 2D

MEASUREMENTS CONDUCTED IN THE FIELD

Sample date: 06/19/99

Time: 8:08

Depth to water: $62.64 \mathrm{ft}(19.09 \mathrm{~m})$ below TOC
Water elevation: $198.46 \mathrm{tt}(60.49 \mathrm{~m}) \mathrm{ms}$

\section{WELL HMD 2D}

MEASUREMENTS CONDUCTED IN THE FIELD

Sample date: 06/19/99

Depth to waler: $62.64 \mathrm{ft}(19.09 \mathrm{~m})$ below TOC
Water elevation: $198.46 \mathrm{ft}(60.49 \mathrm{~m}) \mathrm{ms}$ (

Time: 8:08

\section{WELL HMD 2D}

MEASUREMENTS CONDUCTED IN THE FIELD

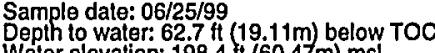

Time: $14: 18$

WELL HMD 3D

MEASUREMENTS CONDUCTED IN THE FIELD

Sample date: 06/19/99

Depth to water: $61.41 \mathrm{ft}(18.72 \mathrm{~m})$ below TOC

Time: 8:09

WELL HMD 3D

MEASUREMENTS CONDUCTED IN THE FIELD

Sample date: 06/19/99

Deth ho water: $6.41 .9 \mathrm{ft}(18.72 \mathrm{~m})$ blow
Water elevalion: $198.09 \mathrm{ft}(60.38 \mathrm{~m}) \mathrm{ms}$

Time: 8:09

WELL HMD 3D

MEASUREMENTS CONDUCTED IN THE FIELD

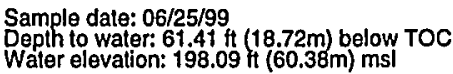

Time: 14:18

WELL HMD 4D

MEASUREMENTS CONDUCTED IN THE FIELD

Sample date: 06/19/99

Depth to water: 52.32 ft $(15.95 \mathrm{~m})$ below TOC

Time: 8:11 
WELL HMD 4D

MEASUREMENTS CONDUCTED IN THE FIELD

Sample date: 06/19/99

Depth to water $52.32 \mathrm{ft}(15.95 \mathrm{~m})$ below TOC
Water elevation: $198.58 \mathrm{Ht}(60.53 \mathrm{~m}) \mathrm{ms}$

\section{WELLL HMD 4D}

MEASUREMENTS CONDUCTED IN THE FIELD

Sample date: 06/25/99

Depth to water: $52.35 \mathrm{ft}$ (15.96m) below TOC

\section{WELL HSB 50PC}

MEASUREMENTS CONDUCTED IN THE FIELD

Sample date: $06 / 19 / 99$
Depph to water: 22.32 $\mathrm{ft}(6.80 \mathrm{~m})$ below TOC
Water elevation: 209.38 ti $(63.82 \mathrm{~m}) \mathrm{msl}$

\section{WELL HSB 50PC}

MEASUREMENTS CONDUCTED IN THE FIELD

Sample date: 06/19/99

Sample date: $06 / 19 / 99$ ( $10.0 \mathrm{~m})$ below TOC

\section{WELL HSB 65}

MEASUREMENTS CONDUCTED IN THE FIELD

Sample date: 06/19/99

Depth to waler: $37.1 \mathrm{ft}(11.31 \mathrm{~m})$ below TOC
Water elevation: $234.9 \mathrm{ft}(71.60 \mathrm{~m}) \mathrm{ms}$

\section{WELL HSB 65}

MEASUREMENTS CONDUCTED IN THE FIELD

Sample date: $06 / 19 / 99$
Depth oo waler: $37.1 \mathrm{ft}(11.31 \mathrm{~m})$ below TOC
Water elevation: $234.9 \mathrm{Ht}(71.60 \mathrm{~m}) \mathrm{ms}$

\section{WELL HSB 65A}

MEASUREMENTS CONDUCTED IN THE FIELD

Sample date: 06/19/99

Sample date: 06/19/99 $\mathrm{Heph}$ (1) waier: $102.28 \mathrm{Ht}(31.18 \mathrm{~m})$ below TOC
WELL HSB 65A

MEASUREMENTS CONDUCTED IN THE FIELD

Sample date: 06/19/99

Depth to waler: $102.28 \mathrm{Ht}(31.18 \mathrm{~m})$ below TOC
Water elevation: $171.32 \mathrm{ft}(52.22 \mathrm{~m}) \mathrm{msl}$

\section{WELL HSB 65B}

MEASUREMENTS CONDUCTED IN THE FIELD

Sample date: 06/19/99

Depth to water: $49.7 \mathrm{ft}(15.15 \mathrm{~m})$ below TOC

Time: 5:07

\section{WELL HSB 65B}

MEASUREMENTS CONDUCTEQ IN THE FIELD

Sample dale: 06/19/99

Depth to water: $49.7 \mathrm{ft}(15.15 \mathrm{~m})$ below TOC

Time: 5:07

\section{WELL HSB 65C}

MEASUREMENTS CONDUCTED IN THE FIEL.D

Sample date: $06 / 19 / 99$

Weph to water: 37.68 it (11.49m) below TOC

Time: 5:08

\section{WELL HSB 65C}

MEASUREMENTS CONDUCTED IN THE FIELD

Sample date: $06 / 19 / 99$
Depth to water: 37,68 Ht (11.49m) below TOC

Time: 5:08

Time: 5:05

\section{WELLL HSB 66}

MEASUREMENTS CONDUCTED IN THE FIEL.D

Sample date: 06/19/99

Depth to water: $69.8 \mathrm{ft}(21.28 \mathrm{~m})$ below TOC

Time: 4:54

\section{WELL HSB 66}

MEASUREMENTS CONDUCTED IN THE FIELD

Sample date: 06/19/99

Depth to water: $69.8 \mathrm{ft}(21.28 \mathrm{~m})$ below TOC

Time: 4:54 


\section{WELL HSB 67}

MEASUREMENTS CONDUCTED IN THE FIELD

Sample dale: 06/19/99

Deppht to water: $16.5 \mathrm{th}(5.03 \mathrm{~m})$ below TOC
Water elevation: $221.3 \mathrm{H}(67.45 \mathrm{~m}) \mathrm{msl}$

\section{WELL HSB 67}

MEASUREMENTS CONDUCTED IN THE FIELD

Sample date: 06/19/9

epth to water: $16.5 \mathrm{ft}(5.03 \mathrm{~m}$ ) below TOC

\section{WELL HSB 68}

MEASUREMENTS CONDUCTED IN THE FIELD

Sample date: 06/19/99

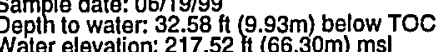

\section{WELL HSB 68}

MEASUREMENTS CONDUCTED IN THE FIELD

Sample date: 06/19/99

Depth o waler: $32.58 \mathrm{ft}(9.93 \mathrm{~m})$ below TOC

\section{WELL HSB 68A}

MEASUREMENTS CONDUCTED IN THE FIELD

Sample date: 06/19/99

Water elevation: $171.87 \mathrm{ft}(23.63 \mathrm{~m})$ below TOC

\section{WELL HSB 68A}

MEASUREMENTS CONDUCTED IN THE FIELD

Sample date: $06 / 19 / 9$

Depth to water: $77.53 \mathrm{Ht}(23.63 \mathrm{~m})$ below TOC
Water elevalion: $171.87 \mathrm{il}(52.39 \mathrm{~m}) \mathrm{msl}$

\section{WELL. HSB 68B}

MEASUREMENTS CONDUCTED IN THE FIELD

Sample date: 06/19/9

Deplh lo waler: $34.95 \mathrm{ft}(10.65 \mathrm{~m})$ below TOC
Water elevation: $215.05 \mathrm{Ht}(65.55 \mathrm{~m}) \mathrm{ms}$

\section{WELL HSB 68B}

MEASUREMENTS CONDUCTED IN THE FIELD

Sampla dato: 06/19/99

Wephrow

Time: 6:55

\section{WELL HSB 68C}

MEASUREMENTS CONDUCTED IN THE FIELD

Sample date: 06/19/99

Weth to water: $34.3 \mathrm{H}$ (1) (10.45m) below TOC

Time: 6:56

\section{WELL HSB 68C}

MEASUREMENTS CONDUCTED IN THE FIELD

Sample date: 06/19/99

Depth to waler: $34.3 \mathrm{Ht}(10.45 \mathrm{~m})$ below TOC
Waler elevation: $215.8 \mathrm{Ht}(65.78 \mathrm{~m}) \mathrm{ms}$

\section{WELL HSB 69}

MEASUREMENTS CONDUCTED IN THE FIELD

Sample dale: 06/19/9

Depth to water: 20.459 if $6.23 \mathrm{~m})$ below TOC

Time: 7:03

\section{WELL HSB 69}

MEASUREMENTS CONDUCTED IN THE FIELD

Sample date: 06/19/99

Deph to water: $20.45 \mathrm{ft}(6.23 \mathrm{~m})$ below TOC
Water elevation: $215.55 \mathrm{tt}(65.70 \mathrm{~m}) \mathrm{msl}$

Time: 7:03

\section{WELL HSB 69A}

MEASUREMENTS CONDUCTED IN THE FIELD

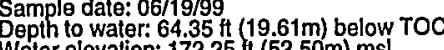

\section{WELL HSB 69A}

MEASUREMENTS CONDUCTED IN THE FIELD

Sample date: 06/19/99

Depth to water: $64.35 \mathrm{ft}(19.61 \mathrm{~m})$ below TOC

Time: 7:03 


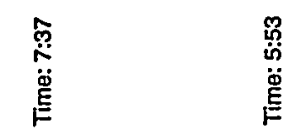

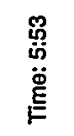

葛

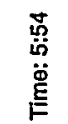

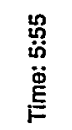

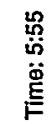
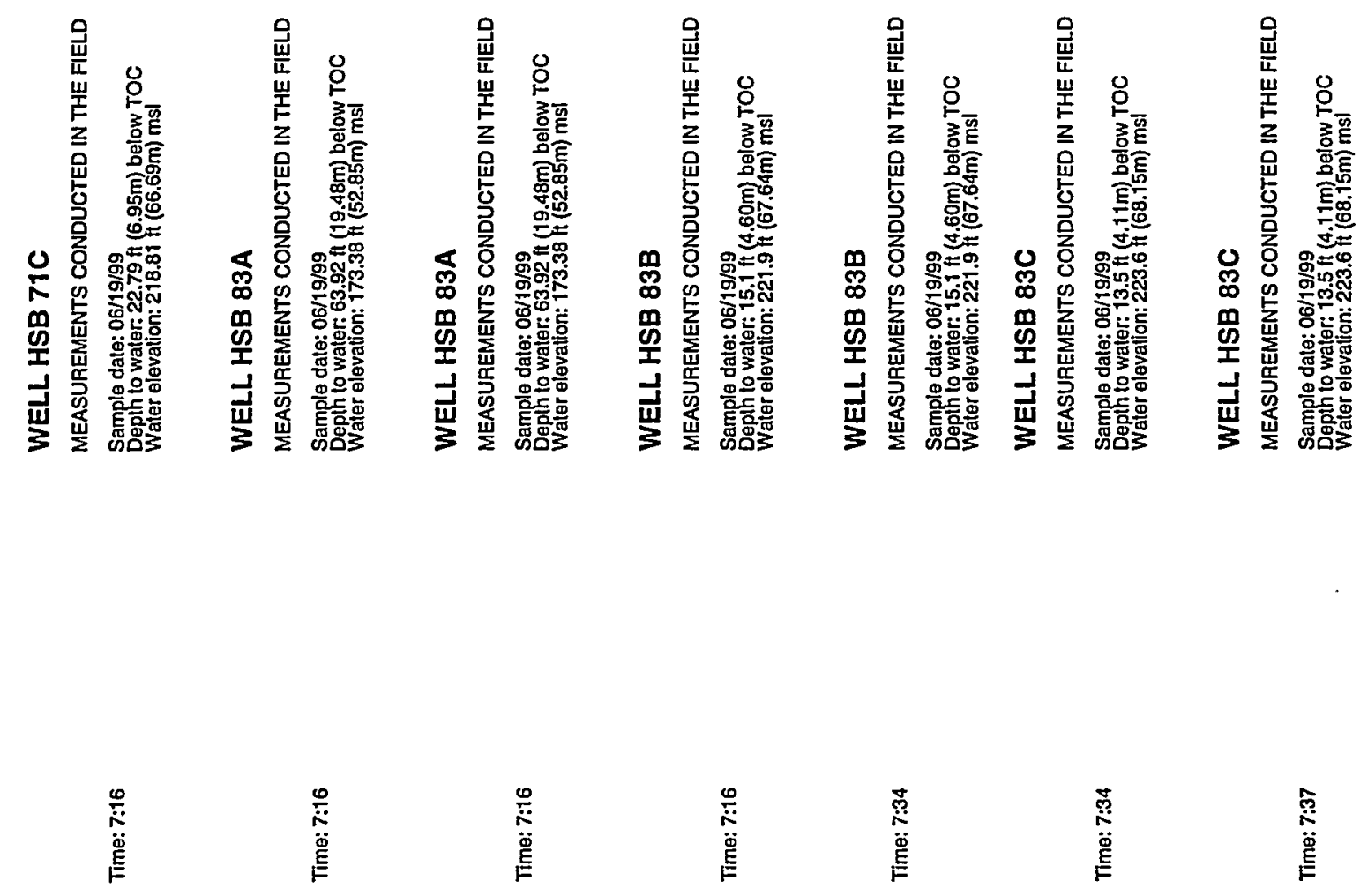

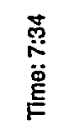

商
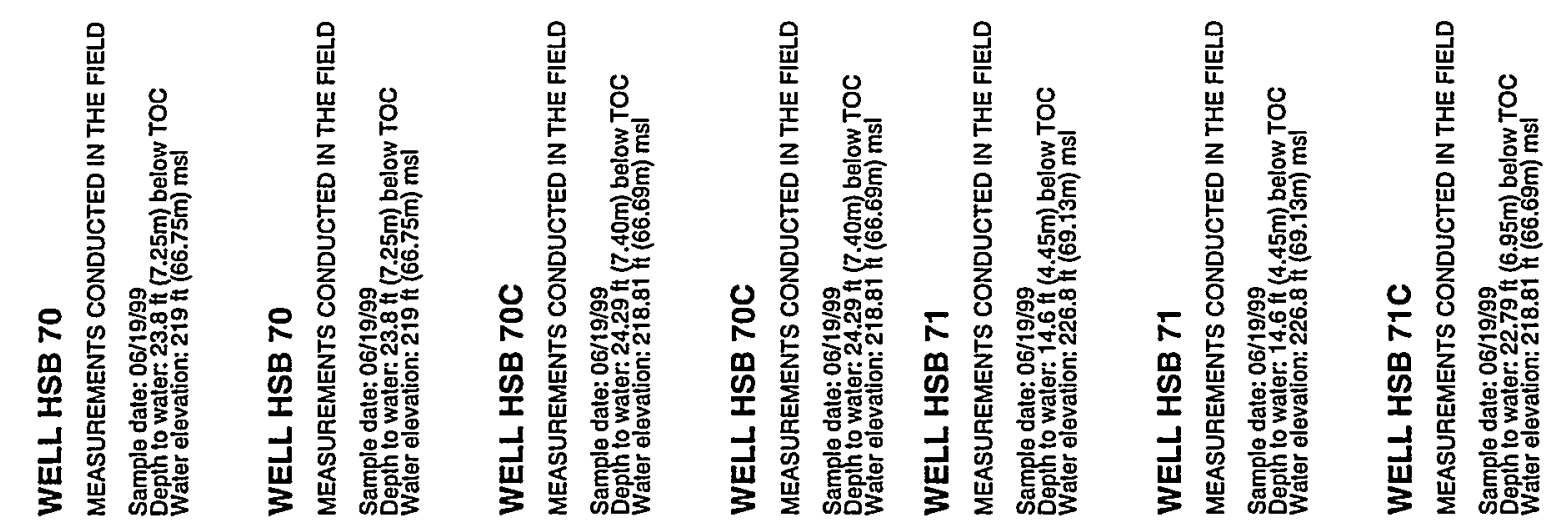


\section{WELL HSB 83D}

MEASUREMENTS CONDUCTED IN THE FIELD

Sample date: 06/19/99

Depth to water: $13.65 \mathrm{ft}(4.16 \mathrm{~m})$ below TOC

\section{WELL HSB 83D}

MEASUREMENTS CONDUCTED IN THE FIELD

Sample date: 06/19/99 $1.16 \mathrm{~m})$ below TOC

(6)

\section{WELL. HSB 84A}

MEASUREMENTS CONDUCTED IN THE FIELD

Sample date: 06/19/99

Sample date: $06 / 19 / 99$
Depth to water: $56.76 \mathrm{ft}(17.30 \mathrm{~m})$ below TOC
Water elevation: $171.94 \mathrm{li}(52.41 \mathrm{~m}) \mathrm{ms}$

Time: 7:06

\section{WELL HSB 84A}

MEASUREMENTS CONDUCTED IN THE FIELD

Sample date: 06/19/99

Depth to water: $56.76 \mathrm{ft}(17.30 \mathrm{~m})$ below TOC

\section{WELL HSB 84B}

MEASUREMENTS CONDUCTED IN THE FIELD

Sample date: 06/19/99

Depth to water: 20.4 tt $(6.22 \mathrm{~m})$ below TOC

\section{WELL HSB 84B}

MEASUREMENTS CONDUCTED IN THE FIELD

Sample date: 06/19/99

Depth to water: $20.4 \mathrm{tt}(6.22 \mathrm{~m})$ below TOC
Water elevation: $208.5 \mathrm{ft}(63.55 \mathrm{~m}) \mathrm{msl}$

Time: 7:06

WELL HSB 84C

MEASUREMENTS CONDUCTED IN THE FIELD

Sample date: 06/19/99

Depth to water: 18.12 ft $(5.52 \mathrm{~m})$ below TOC

Time: 7:07
WELL HSB $84 C$

MEASUREMENTS CONDUCTED IN THE FIELD

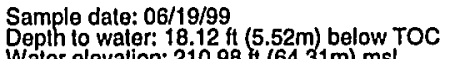

Time: 7:07

\section{WELL HSB 84D}

MEASUREMENTS CONDUCTED IN THE FIELD

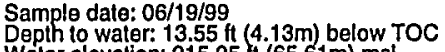

Time: 7:07

WELL HSB 84D

MEASUREMENTS CONDUCTED IN THE FIELD

Sample date: $06 / 19 / 99$
Depth to water: 13.55 $(4.13 \mathrm{~m})$ below TOC
Water elevation: $215.25 \mathrm{Ht}(65.61 \mathrm{~m}) \mathrm{msl}$

Time: 7:07

\section{WELL HSB 85A}

MEASUREMENTS CONDUCTED IN THE FIELD

Sample date: $06 / 19 / 99$
Depth to water: $125.58 \mathrm{ft}(38.28 \mathrm{~m})$ below TOC
Water elevation: $168.82 \mathrm{ft}(51.46 \mathrm{~m}) \mathrm{ms}$

Time: 7:59

\section{WELL HSB 85A}

MEASUREMENTS CONDUCTED IN THE FIELD Sample date: $06 / 19 / 99$
Depth to water: $125.58 \mathrm{ft}(38.28 \mathrm{~m})$ below TOC
Water elevation: $168.82 \mathrm{ft}(51.46 \mathrm{~m}) \mathrm{msl}$

\section{WELL HSB 85B}

MEASUREMENTS CONDUCTED IN THE FIELD

Sample date: 06/19/99

Depth to water: $61.78 \mathrm{ft}(18.83 \mathrm{~m})$ below TOC

Time: 8:00

WELL HSB 85B

MEASUREMENTS CONDUCTED IN THE FIELD

Sample date: $06 / 19 / 99$ (18.83m) below TOC

Time: 8:00 


\section{WELL HSB 85C}

MEASUREMENTS CONDUCTED IN THE FIELD

Sample date: 06/19/99

Depth to waler: $55.9 \mathrm{Ht}(17.04 \mathrm{~m})$ below TOC
Water elevation: $238.2 \mathrm{ft}(72.60 \mathrm{~m}) \mathrm{msl}$

\section{WELL HSB 85C}

MEASUREMENTS CONDUCTED IN THE FIELLD

Sample date: 06/19/9

Wepth to waler: 55.9 ff (17.04m) below TOC

\section{WELLL HSB 86A}

MEASUREMENTS CONDUCTED IN THE FIELD

Sample date: 06/19/99
Depth to water: $93.85 \mathrm{H}$ (28.61m) below TOC

\section{WELL HSB 86A}

MEASUREMENTS CONDUCTED IN THE FIELD

Sample date: 06/19/99

Sample date: 06/19/99

\section{WELL HSB 86B}

MEASUREMENTS CONDUCTED IN THE FIELD

Sample date: 06/19/99

Depth to water: $44.65 \mathrm{ft}(13.61 \mathrm{~m})$ below TOC
Water elevation: $217.25 \mathrm{ft}(66.22 \mathrm{~m}) \mathrm{msl}$

\section{WELL HSB 86B}

MEASUREMENTS CONDUCTED IN THE FIELD

Sample date: 06/19/9

Dater to water: $44.65 \mathrm{ft}(13.61 \mathrm{~m})$ below TOC

\section{WELL HSB 86C}

MEASUREMENTS CONDUCTED IN THE FIELD

Sample date: 06/19/99
Depth to water: 43.92 Ht $(13.39 \mathrm{~m})$ below TOC
WELL HSB 86C

MEASUREMENTS CONDUCTED IN THE FIELD

Sample date: 06/19/99

Depth to water: $43.92 \#(13.39 \mathrm{~m})$ below TOC

Water elevation: $218.98 \mathrm{Ht}(66.75 \mathrm{~m}) \mathrm{msl}$

Time: 3:51

\section{WELL HSB 86D}

MEASUREMENTS CONDUCTED IN THE FIELD

Sample date: 06/19/99

Depth lo water: $44.05 \mathrm{ft}(13.43 \mathrm{~m})$ below TOC

\section{WELL HSB 86D}

MEASUREMENTS CONDUCTED IN THE FIELD

Sample date: 06/19/9

Del
Depth to water: $44.05 \mathrm{ft}(13.43 \mathrm{~m})$ below TOC
Water elevation: $218.95 \mathrm{ft}(66.74 \mathrm{~m}) \mathrm{msl}$

Time: 3:52

\section{WELL HSB100C}

MEASUREMENTS CONDUCTED IN THE FIELD

Sample date: 06/19/99

Water elevation: $225.94 \mathrm{ft}(68.87 \mathrm{~m}) \mathrm{ms}$ )

Time: 4:38

\section{WELL HSB100C}

MEASUREMENTS CONDUCTED IN THE FIELD

Sample date: 06/19/99
Depth to water: $34,26 \mathrm{ft}$
W

Time: 4:38

\section{WELL HSB100D}

MEASUREMENTS CONDUCTED IN THE FIELD

Sample date: 06/19/99

Depth to water: $25.88 \mathrm{ft}(7.89 \mathrm{~m})$ below TOC

Time: 4:40

\section{WELL HSB100D}

MEASUREMENTS CONDUCTED IN THE FIELD

Sample date: 06/19/99

Sample date: $06 / 19 / 99$
Depth to water: $25.88 \mathrm{ft}(7.89 \mathrm{~m})$ below TOC
Water elevation: $234.22 \mathrm{ft}(71.3 \mathrm{~m}) \mathrm{msl}$
Time: 4:40 

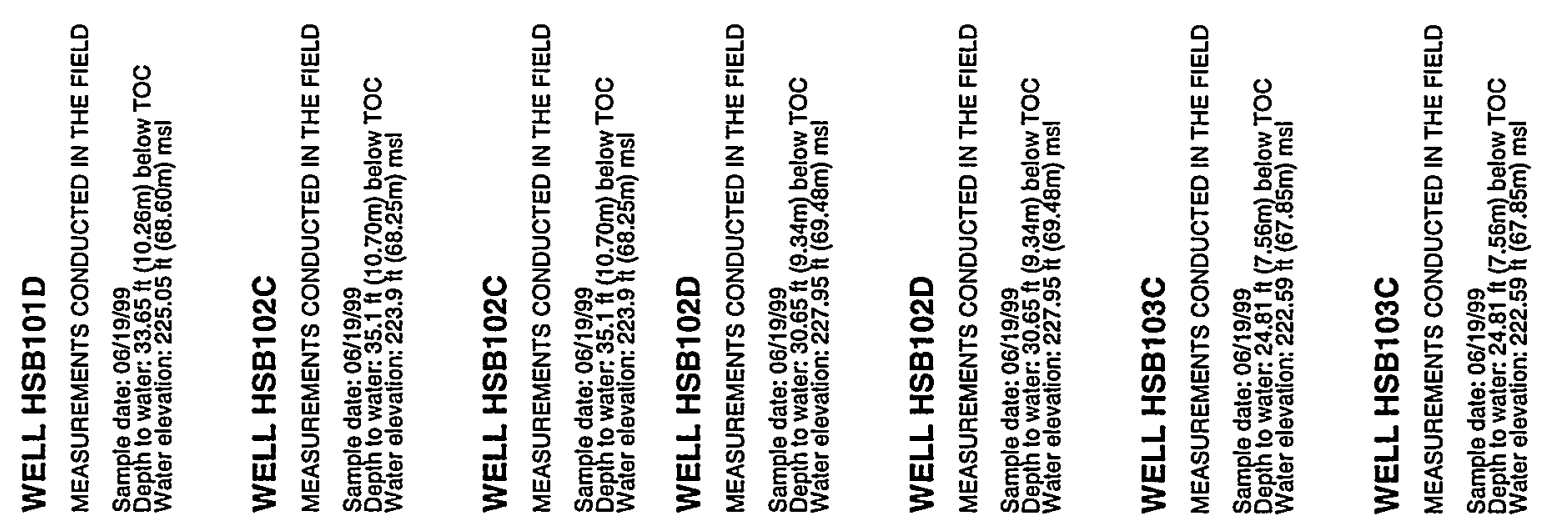

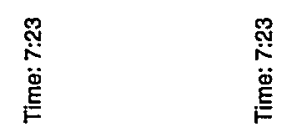

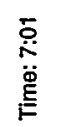

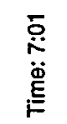

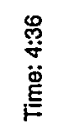

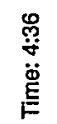

弚

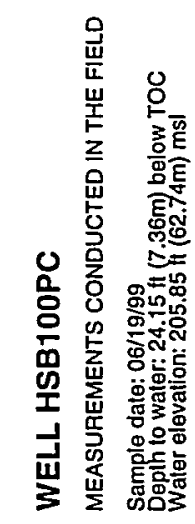

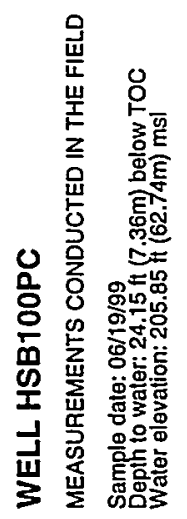

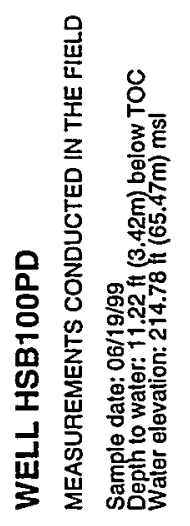

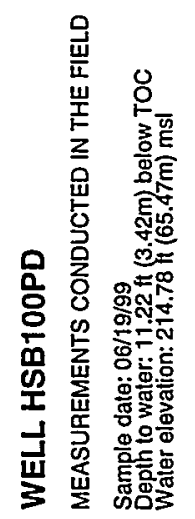
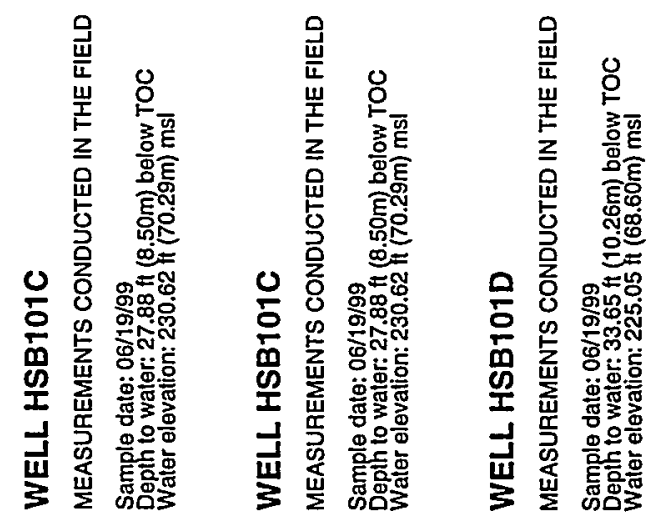


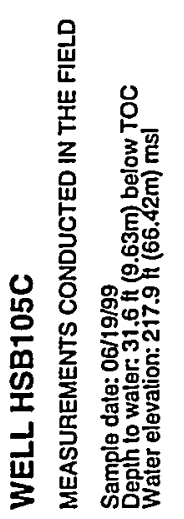
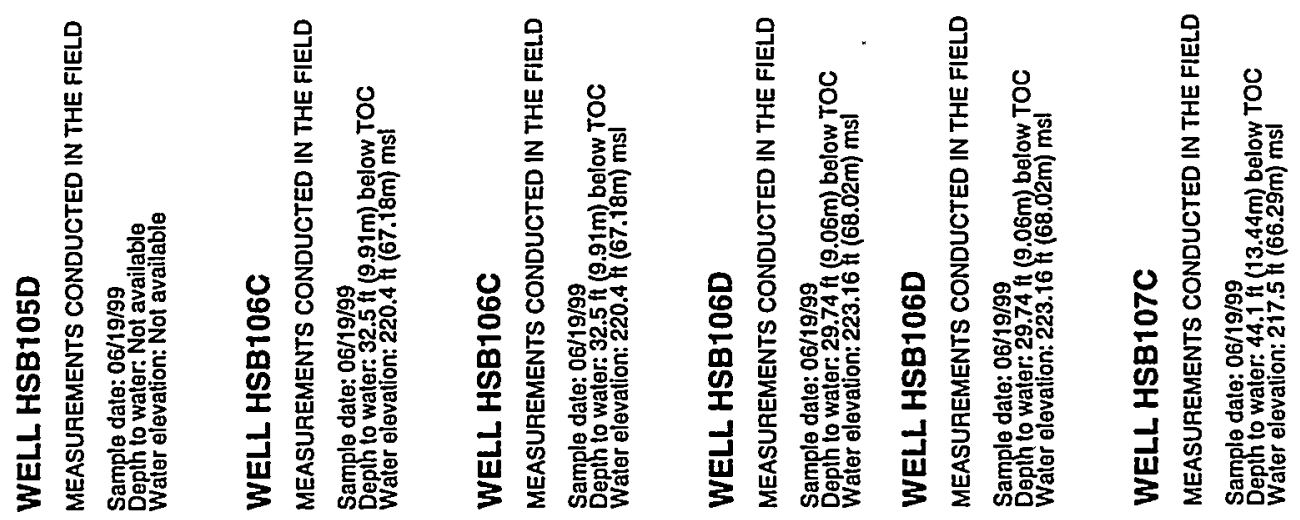

粂

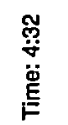

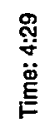

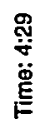

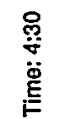

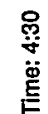

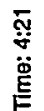
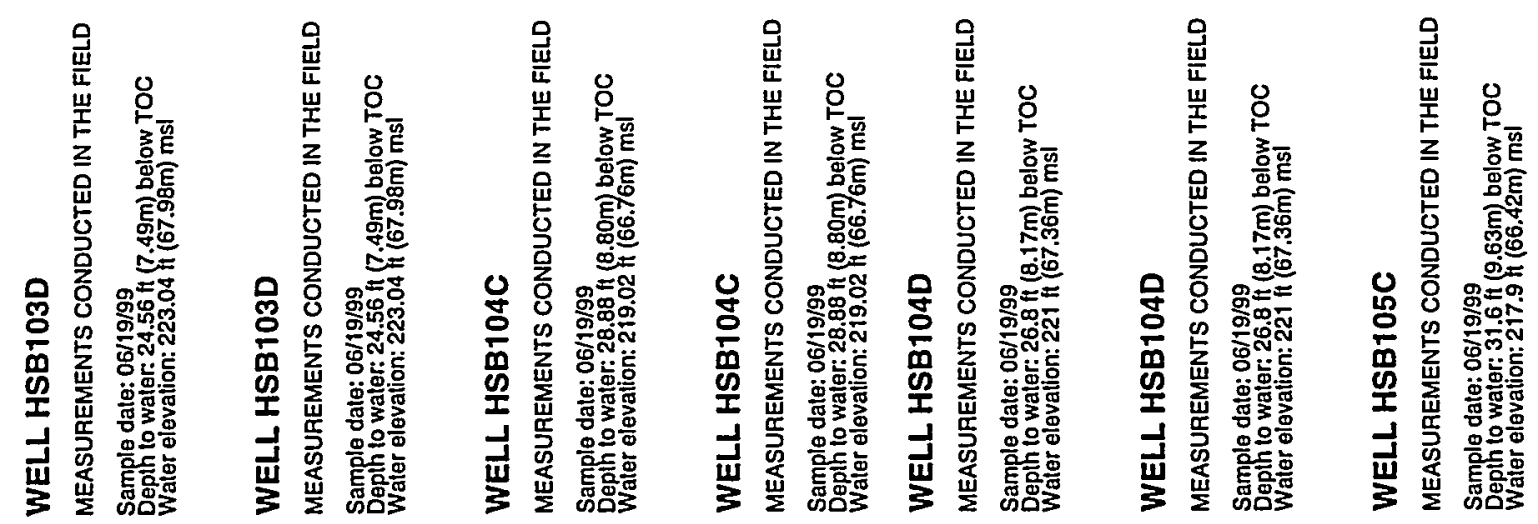


\section{WELL HSB107C}

MEASUREMENTS CONDUCTED IN THE FIELD

Sample date: 06/19/99

Depth to water: $44.1 \mathrm{ff}(13.44 \mathrm{~m})$ below TOC

Waler elevalion: $217.5 \mathrm{H}(66.29 \mathrm{~m}) \mathrm{ms}$

\section{WELL HSB107D}

MEASUREMENTS CONDUCTED IN THE FIELD

Sample dale: 06/19/99

Sample dale: $06 / 19 / 99$
Depth to water: $40.94 \mathrm{ft}(12,48 \mathrm{~m})$ below TOC
Water elevation: $221.36 \mathrm{t}(67.47 \mathrm{~m}) \mathrm{ms}$

\section{WELL HSB107D}

MEASUREMENTS CONDUCTED IN THE FIELD

Sample date: 06/19/99

Depth to water: $40.94 \mathrm{Ht}(12.48 \mathrm{~m})$ below TOC

\section{WELL HSB108C}

MEASUREMENTS CONDUCTED IN THE FIELD

Sample date: 06/19/99

Depth to water: 49.67 ft $(15.14 \mathrm{~m})$ below TOC

WELL HSB108C

MEASUREMENTS CONDUCTED IN THE FIELD

Sample date: 06/19/99

Depth to water: 49.67 it $(15.14 \mathrm{~m})$ below TOC

Waler elevation: $216.53 \quad(6,66.00 \mathrm{~m}) \mathrm{ms}$ l

\section{WELL HSB108D}

MEASUREMENTS CONDUCTED IN THE FIELD

Sample date: 06/19/99

列

Time: 4:15

\section{WELL HSB108D}

MEASUREMENTS CONDUCTED IN THE FIELO

Sample date: 06/19/99

Deplh to water: $46.3 \mathrm{ft}(14.11 \mathrm{~m})$ below TOC

\section{WELLL HSB109C}

MEASUREMENTS CONDUCTED IN THE FIELD

Sample date: 06/19/9

Deplh to water: $44.8 \mathrm{Ht}(13.66 \mathrm{~m})$ below TOC
Waler elevalion: $216.8 \mathrm{H}(66.0 \mathrm{Bm}) \mathrm{ms}$

\section{WELL HSB109C}

MEASUREMENTS CONDUCTED IN THE FIELD

Sample date: 06/19/99

Depth to waler: $44.8 \mathrm{H}(13.66 \mathrm{~m})$ below TOC
Waler elevation: $216.8 \mathrm{t}(66.08 \mathrm{~m}) \mathrm{msl}$

\section{WELL HSB109D}

MEASUREMENTS CONDUCTED IN THE FIELD

Sample date: 06/19/99

Deph to water: Not avallable

Time: 4:11

\section{WELL HSB110C}

MEASUREMENTS CONDUCTED IN THE FIELD

Sample date: 06/19/99

Depth to water: $38.8 \mathrm{ft}(11.83 \mathrm{~m})$ below TOC

Time: 4:08

\section{WELL HSB110C}

MEASUREMENTS CONDUCTED IN THE FIELD

Sample date: 06/19/99

Depth to waler: $38.8 \mathrm{ft}(11.83 \mathrm{~m})$ below TOC

Time: 4:08

\section{WELL HSB110D}

MEASUREMENTS CONDUCTED IN THE FIELD

Sample date: 06/19/99

Time: 4:08

Depht to water: $37.61 \mathrm{ft}(11.46 \mathrm{~m})$ below TOC
Water elevation: $217.99 \mathrm{H}(66.44 \mathrm{~m}) \mathrm{ms}$

\section{WELL HSB110D}

MEASUREMENTS CONDUCTED IN THE FIELD

Sample date: 06/19/99

Depth to waler: $37.61 \mathrm{ft}(11.46 \mathrm{~m})$ below TOC

Time: 4:08 


\section{WELL HSB111C}

MEASUREMENTS CONDUCTED IN THE FIELD Sample date: 06/19/99 Depth to water: $38.61 \mathrm{H}(11.77 \mathrm{~m})$ below TOC

\section{WELL HSB111C}

MEASUREMENTS CONDUCTED IN THE FIELD

Sample date: 06/19/99

Depth to water: $38.61 \mathrm{ft}(11.77 \mathrm{~m})$ below TOC

\section{WELL HSB111D}

MEASUAEMENTS CONDUCTED IN THE FIELD

Sample dale: 06/19/99

Depth to waler: $39.41 \mathrm{Ht}(12.01 \mathrm{~m})$ below TOC

\section{WELL HSB111D}

MEASUREMENTS CONDUCTED IN THE FIELD

Sample date: $06 / 19 / 99$
Depth to water: $39.41 \mathrm{ft}(12.01 \mathrm{~m})$ below TOC
Water elevalion: $216.59 \mathrm{H}(66.02 \mathrm{~m}) \mathrm{ms}$

\section{WELL HSB111E}

MEASUREMENTS CONDUCTED IN THE FIELD

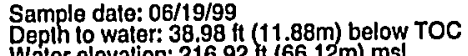

\section{WELL HSB111E}

MEASUREMENTS CONDUCTED IN THE FIELD

Sample date: 06/19/99

Sample date: 06/19/99 $11.8 \mathrm{~m})$ below TOC

\section{WELL HSB112C}

MEASUREMENTS CONDUCTED IN THE FIELD

Sample date: 06/19/99

Depth to water: $36.65 \mathrm{ft}(11.17 \mathrm{~m})$ below $\mathrm{TOC}$
Water elevalion: $218.25 \mathrm{Ht}(66.52 \mathrm{~m}) \mathrm{ms}$
WELL HSB112C

MEASUREMENTS CONDUCTED IN THE FIELD

Sample dale: 06/19/99

Time: 4:00

Wath lo water: $36.65 \mathrm{H}(11.17 \mathrm{~m})$ below TOC

\section{WELL HSB112D}

MEASUREMENTS CONDUCTED IN THE FIELD

Sample date: 06/19/99

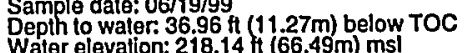

Time: 4:02

\section{WELL HSB112D}

MEASUREMENTS CONDUCTED IN THE FIELD

Sample dale: 06/19/99

Weph to water. 36.969 f $(11.27 \mathrm{~m}$ ) below TOC

Time: 4:02

\section{WELL HSB112E}

MEASUREMENTS CONDUCTED IN THE FIELD

Sample date: 06/19/99

Time: 4:02

Depth to water: Not available

\section{WELL HSB113C}

MEASUREMENTS CONDUCTED IN THE FIELD

Sample dale: 06/19/99

Depth to water: $43.35 \mathrm{ft}(13.21 \mathrm{~m})$ below TOC

\section{WELL HSB113C}

MEASUREMENTS CONDUCTED IN THE FIELD

Sample date: 06/19/99
Dephth to water: $43.35 \mathrm{ft}(13.21 \mathrm{~m})$ below TOC
Water elevalion: $217.65 \mathrm{Ht}(66.3 \mathrm{~mm}) \mathrm{msl}$

Time: 3:57

\section{WELL HSB113D}

MEASUREMENTS CONDUCTED IN THE FIELD

Sample date: 06/19/99

Wepth to waler: $43.08 \mathrm{ft}(13.13 \mathrm{~m})$ below TOC

Time: 3:58 
WELL HSB113D

MEASUREMENTS CONDUCTED IN THE FIELD

Sample date: 06/19/99

Depth to water: 43.08 ft $(13.13 \mathrm{~m})$ below TOC

\section{WELL HSB114C}

MEASUREMENTS CONDUCTED IN THE FIELD

Sample date: 06/19/99

Time: 3:54

Depth to water: Nof available
Water elevation: Not available

WELL HSB114D

MEASUREMENTS CONDUCTED IN THE FIELD

Sample date: 06/19/99

Depth to water: $45.28 \mathrm{H}(13.80 \mathrm{~m})$ below TOC
Waler elevation: $218.72 \%(66.67 \mathrm{~m}) \mathrm{ms}$ T

\section{WELL HSB114D}

MEASUREMENTS CONDUCTED IN THE FIELD

Sample date: 06/19/99

Depth to water: $45.28 \mathrm{H}(13.80 \mathrm{~m})$ below TOC
Water elevation: $218.72 \mathrm{t}(66.67 \mathrm{~m}) \mathrm{ms}$

\section{WELL HSB115C}

MEASUREMENTS CONDUCTED IN THE FIELD

Sample date: 06/49/9

Depth to water: $49.4 \mathrm{ft}(15.06 \mathrm{~m})$ below TOC
Water elevation: $219.9 \mathrm{Ht}(67.03 \mathrm{~m}) \mathrm{ms}$ )

\section{WELL HSB115C}

MEASUREMENTS CONDUCTED IN THE FIELD

Sample date: 06/19/99

Depth to water: $49.4 \mathrm{ft}(15.06 \mathrm{~m})$ below TOC

\section{WELL HSB115D}

MEASUREMENTS CONDUCTED IN THE FIELD

Sample date: 06/19/9

Depth to water: $49.3 \mathrm{ft}(15.03 \mathrm{~m})$ below TOC
Water elevation: $219.8 \mathrm{ft}(67.00 \mathrm{~m}) \mathrm{ms}$

\section{WELL HSB115D}

MEASUREMENTS CONDUCTED IN THE FIELD

Sample dale: 06/19/99

\section{WELL HSB116C}

MEASUREMENTS CONDUCTED IN THE FIELD

Sample date: 06/19/99

Time: 3:42

\section{WELL HSB116C}

MEASUREMENTS CONDUCTED IN THE FIELD

Sample date: 06/19/99

Depth to waler: $35.9 \mathrm{ft}(10.94 \mathrm{~m})$ below TOC

WELL HSB116D

MEASUREMENTS CONDUCTED IN THE FIELD

Sample date: 06/19/99 $70.79 \mathrm{~m})$ below TOC

Wepth to waler: $35.4 \pi(10.79 \mathrm{~m})$ below $\mathrm{TOC}$
Water elevation: $221.4 \mathrm{ft}(67.48 \mathrm{~m}) \mathrm{msl}$

Time: 3:43

\section{WELL HSB116D}

MEASUREMENTS CONDUCTED IN THE FIELD

Sample date: 06/19/99

Depph to wa:er: $35.4 \mathrm{ft}(10.79 \mathrm{~m})$ below TOC

Time: 3:43

\section{WELL HSB117A}

MEASUREMENTS CONDUCTED IN THE FIELD

Sample dale: $06 / 19 / 99$
Depth to water: $70.98 \mathrm{ft}(21.63 \mathrm{~m})$ below TOC
Water elevation: $166.32 \mathrm{ft}(50.69 \mathrm{~m}) \mathrm{ms}$

Time: 7:31

\section{WELL HSB117A}

MEASUREMENTS CONDUCTED IN THE FIELD

Sample date: $06 / 19 / 99$ (21.63m) below TOC

Time: 7:31 


\section{WELL HSB117C}

MEASUREMENTS CONDUCTED IN THE FIELLD

Sample dale: 06/19/99

Semple dale: $06 / 19 / 99$
Walter wale wate: $20.05 \mathrm{ht}(6.11 \mathrm{~m})$ below TOC
Wation: $217.35 \mathrm{ft}(66.25 \mathrm{~m}) \mathrm{msl}$

\section{WELL HSB117C}

MEASUREMENTS CONDUCTED IN THE FIELLD

Sample date: 06/19/99

Deph to waler: $20.05 \mathrm{ft}(6.11 \mathrm{~m})$ below TOC
Water elevation: $217.35 \mathrm{H}(66.25 \mathrm{~m}) \mathrm{msl}$

\section{WELL HSB117D}

MEASUAEMENTS CONDUGTED IN THE FIELD

Sample date: $06 / 19 / 99$
Depth to waler: $18.37 \mathrm{ht}(5.60 \mathrm{~m})$ below TOC
Water elevation: 219.23 th $(66.82 \mathrm{~m}) \mathrm{msl}$

\section{WELL HSB117D}

MEASUREMENTS CONDUCTED IN THE FIELD

Sample date: 06/19/99 $(5.60 \mathrm{~m})$ below TOC

\section{WELL HSB118A}

MEASUREMENTS CONDUCTED IN THE FIELD

Sample date: 06/19/99 $2.30 \mathrm{~m})$ below TOC

\section{WELL HSB118A}

MEASUREMENTS CONDUCTED IN THE FIELD

Sample date: 06/19/99

Depth to water: $79.73 \mathrm{ft}(24.30 \mathrm{~m})$ below TOC
Water elevation: $167.57 \mathrm{ft}(51.08 \mathrm{~m}) \mathrm{ms}$

\section{WELL HSB119A}

MEASUREMENTS CONDUCTED IN THE FIELD

Sample date: 06/19/99

Deph to waler: $90.25 \mathrm{ft}(27.51 \mathrm{~m})$ below TOC

Water elevalion: $166.85 \mathrm{ht}(50.86 \mathrm{~m}) \mathrm{ms}$ (
WELL HSB119A

MEASUREMENTS CONDUCTED IN THE FIELD

Sample date: 06/19/99

Depth lo water: $90.25 \mathrm{H}(27.51 \mathrm{~m})$ below TOC

Time: 3:41

WELL HSB120A

MEASUREMENTS CONDUCTED IN THE FIELD

Sample date: 06/19/99

Water to waler: $101.96 \mathrm{H}(31.08 \mathrm{~m})$ below TOC

\section{WELL. HSB120A}

MEASUREMENTS CONDUCTED IN THE FIELD

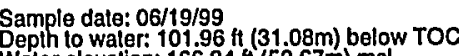

Time: 3:39

Wepter elevalion: 166.24 ff $(50.67 \mathrm{~m}) \mathrm{ms}$ )

\section{WELL HSB121A}

MEASUREMENTS CONDUCTED IN THE FIELD

Sample date: 06/19/99 $\mathrm{ft}(31.38 \mathrm{~m})$ below TOC

Time: 4:51

\section{WELL HSB121A}

MEASUREMENTS CONDUCTED IN THE FIELD

Sample date: 06/19/99

Depth to waler: $102.95 \mathrm{ft}(31.38 \mathrm{~m})$ below TOC

Time: $4: 51$

\section{WELL HSB122A}

MEASUREMENTS CONDUCTED IN THE FIELD

Sample date: 06/19/99

Time: 4:49

\section{WELLL HSB122A}

MEASUREMENTS CONDUCTED IN THE FIELD 


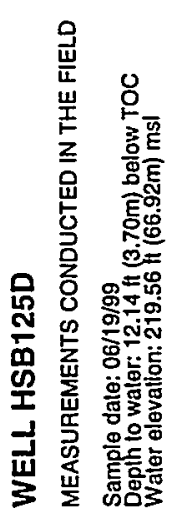
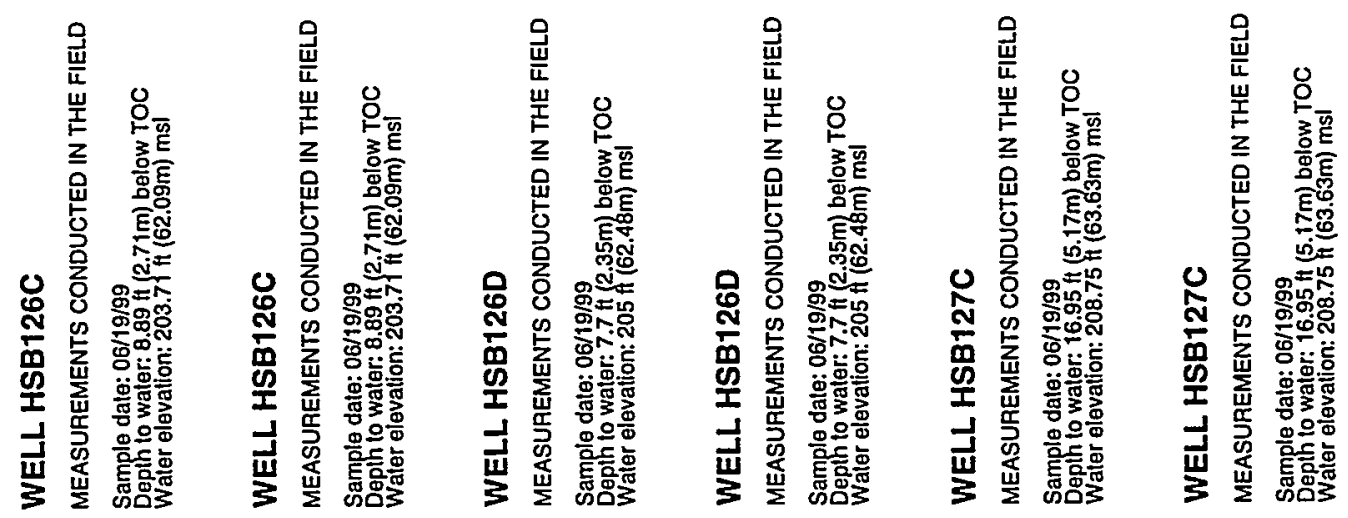

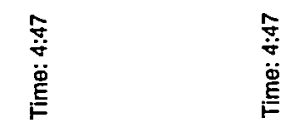

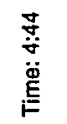

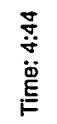

$\stackrel{8}{0}$
$\stackrel{0}{E}$
$\stackrel{\mathscr{E}}{E}$

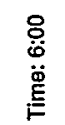

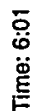
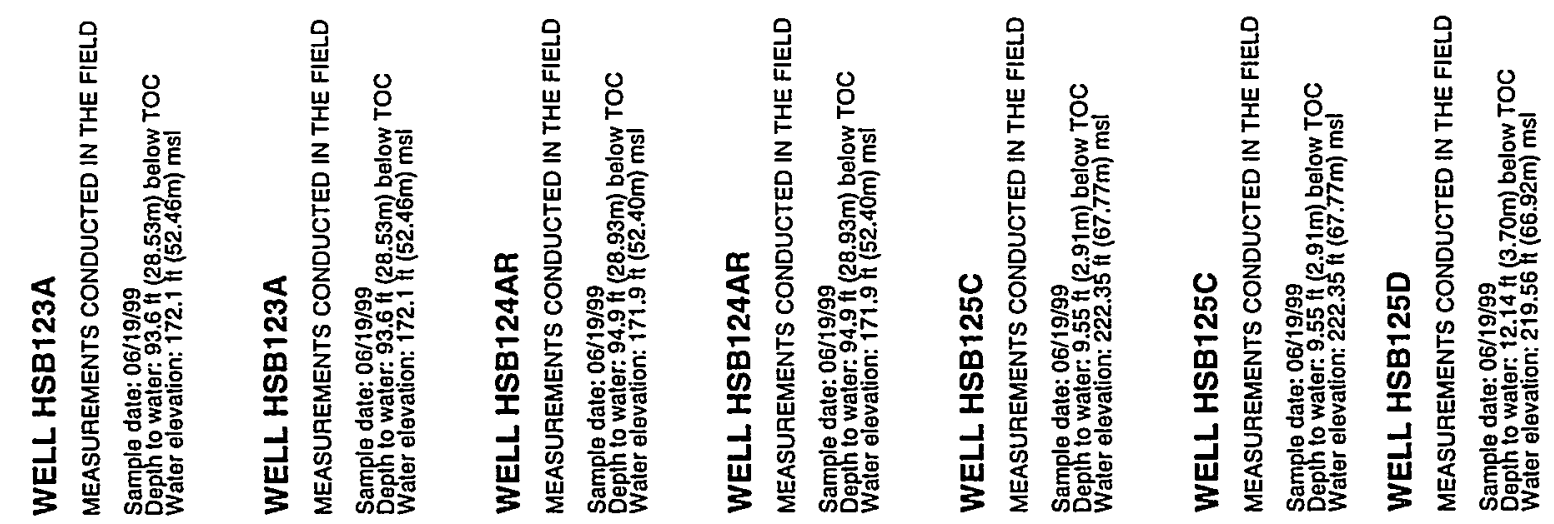
WELL. HSB127D

MEASUREMENTS CONDUCTED IN THE FIELD

Sample date: $06 / 19 / 99$
Depht to water: $1.95 \mathrm{H}$ (4.25m) below TOC
Waler elevation: $212.15 \mathrm{Ht}(64.66 \mathrm{~m}) \mathrm{msl}$

\section{WELL HSB127D}

MEASUREMENTS CONDUCTED IN THE FIEL.D

Sample date: 06/19/9

Sample date: 06/19/99

\section{WELL HSB129C}

MEASUREMENTS CONDUCTED IN THE FIELD

Sample date: 06/19/9

Depth to waler: 11.08 f $(3.38 \mathrm{~m})$ below TOC

Time: 7:26

\section{WELL. HSB129C}

MEASUREMENTS CONDUCTEO IN THE FIELD

Sample dale: 06/19/99

\section{WELL HSB129D}

MEASUREMENTS CONDUCTED IN THE FIELD

Sample date: 06/19/99

Deplh lo waler: 7.48 fl $(2.28 \mathrm{~m})$ below TOC

Time: 7:27

WELL HSB129D

MEASUREMENTS CONDUCTED IN THE FIELD

Sample date: 06/19/99
Dephth to waler: $7.48 \mathrm{H}$ (2.28m) below TOC
Waler elevation: $207.22 \mathrm{ft}(63.16 \mathrm{~m}) \mathrm{msl}$

\section{WELL HSB130C}

MEASUREMENTS CONDUCTED IN THE FIELD

Sample date: 06/19/99

Depth to water: $18.7 \mathrm{ft}(5.70 \mathrm{~m})$ below TOC
WELL HSB130C

MEASUREMENTS CONDUCTED IN THE FIELD

Sample dale: 06/19/99

Time: 6:17

\section{WELL HSB130D}

MEASUREMENTS CONDUCTED IN THE FIELD

Sample date: 06/19/99

Depth to water: 18.88 ff $(5.75 \mathrm{~m})$ below TOC
Waler alevalion: 199.72 fit $(60.88 \mathrm{~m}) \mathrm{msl}$

Time: 6:18

\section{WELL HSB130D}

MEASUREMENTS CONDUCTED IN THE FIELD

Sample dale: 06/19/99
Deph to water: $18.88 \mathrm{Ht}(5.75 \mathrm{~m})$ below TOC
Water elevation: $199.72 \mathrm{lt}(60.88 \mathrm{~m}) \mathrm{ms}$

Time: 6:18

\section{WELL. HSB131C}

MEASUREMENTS CONDUCTED IN THE FIELD

Sample date: 06/19/99

Depth to water: $8.16 \mathrm{ft}(2.49 \mathrm{~m})$ below TOC

\section{WELL HSB131C}

MEASUREMENTS CONDUCTED IN THE FIELD

Sample date: 06/19/99

Depth to water: $8.16 \mathrm{Ht}(2.49 \mathrm{~m})$ below TOC
Water elevation: $203.54 \mathrm{ft}(62.04 \mathrm{~m}) \mathrm{ms}$

Time: 6:33

\section{WELL HSB132C}

MEASUREMENTS CONDUCTED IN THE FIELD

Sample dale: 06/19/99 $20.24 \mathrm{~m}$ below TOC

Time: 5:44

\section{WELL HSB132C}

MEASUREMENTS CONDUCTED IN THE FIELD

Sample date: 06/19/99

Time: 5:44 


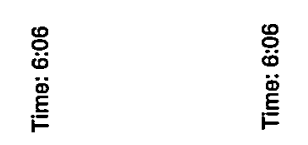

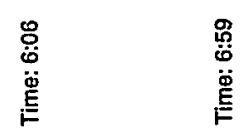

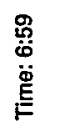

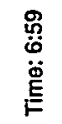

题

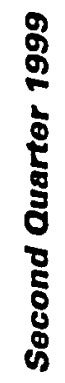
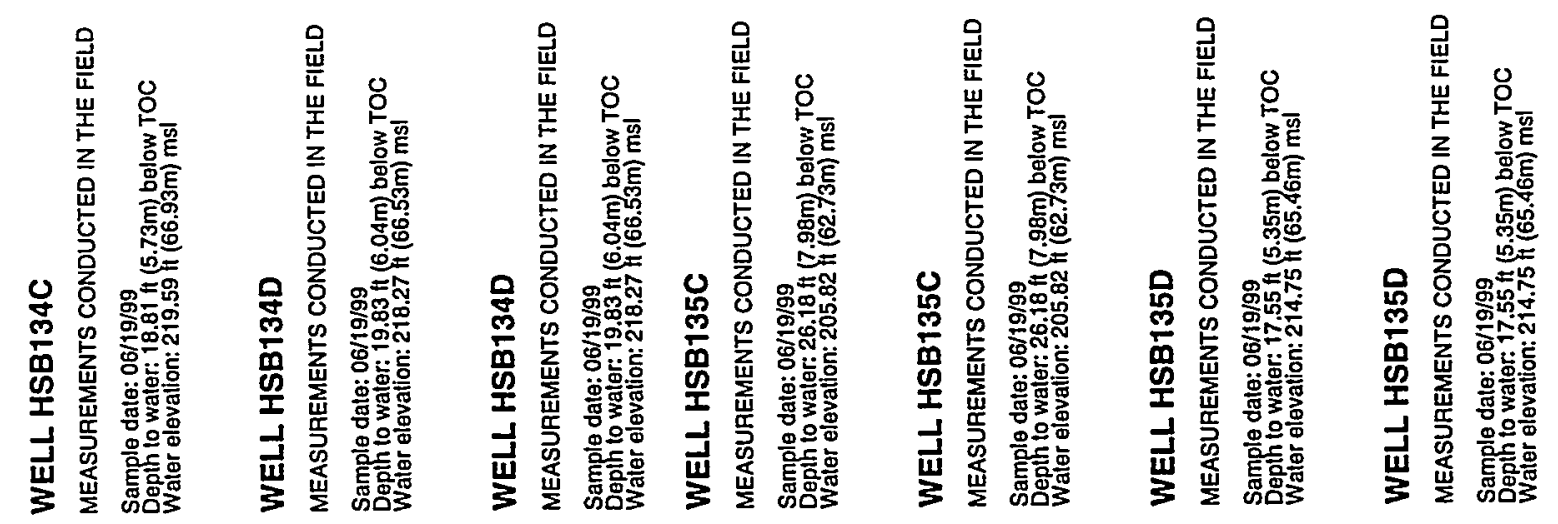

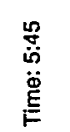

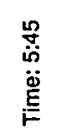

$\mathcal{P}$
$\dot{i n}$
$\ddot{\oplus}$
$\stackrel{E}{E}$
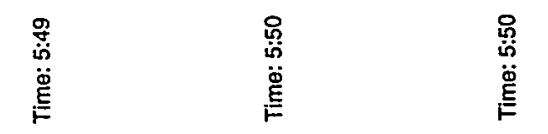

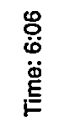
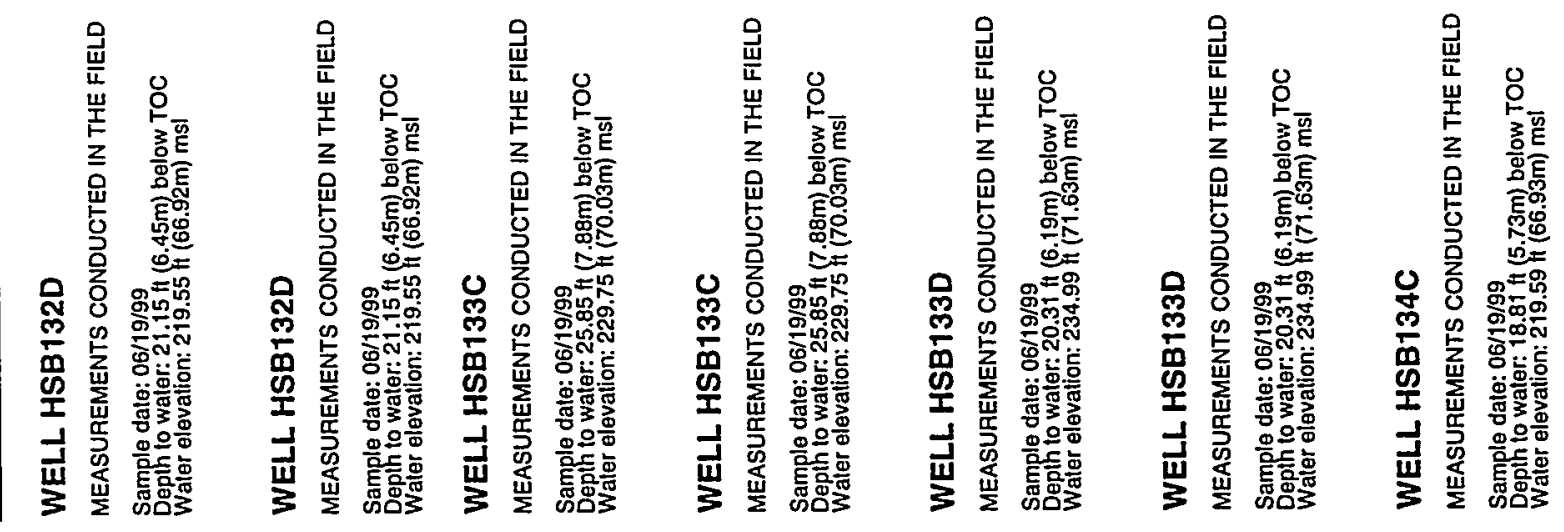

变 

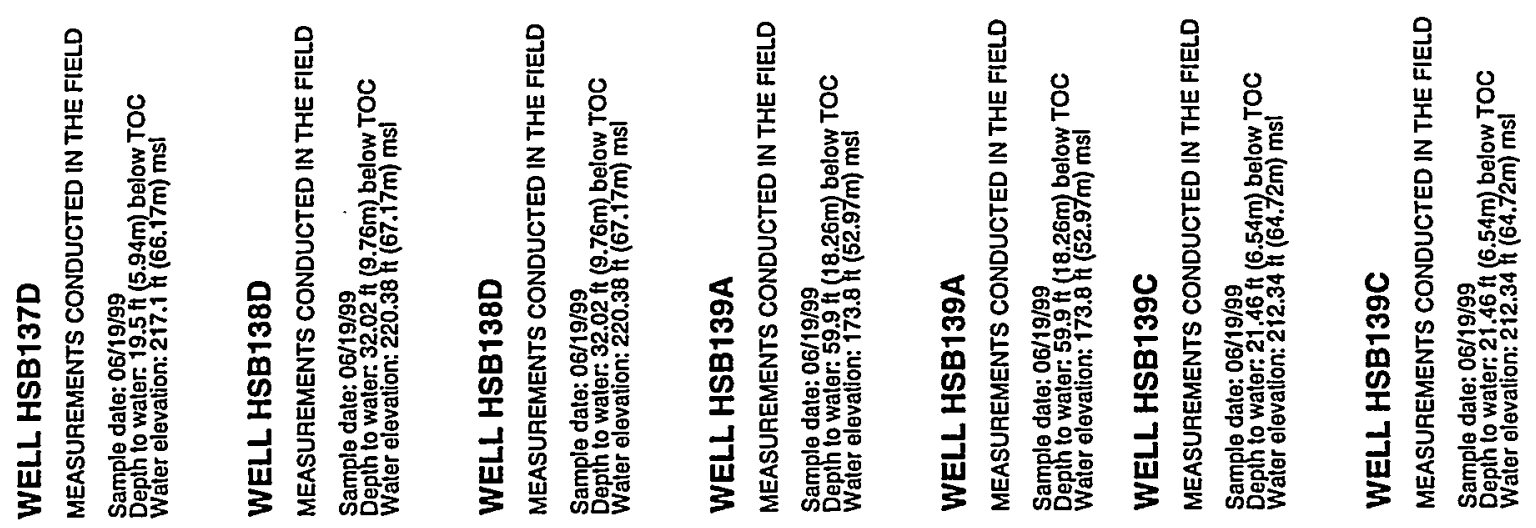

\&
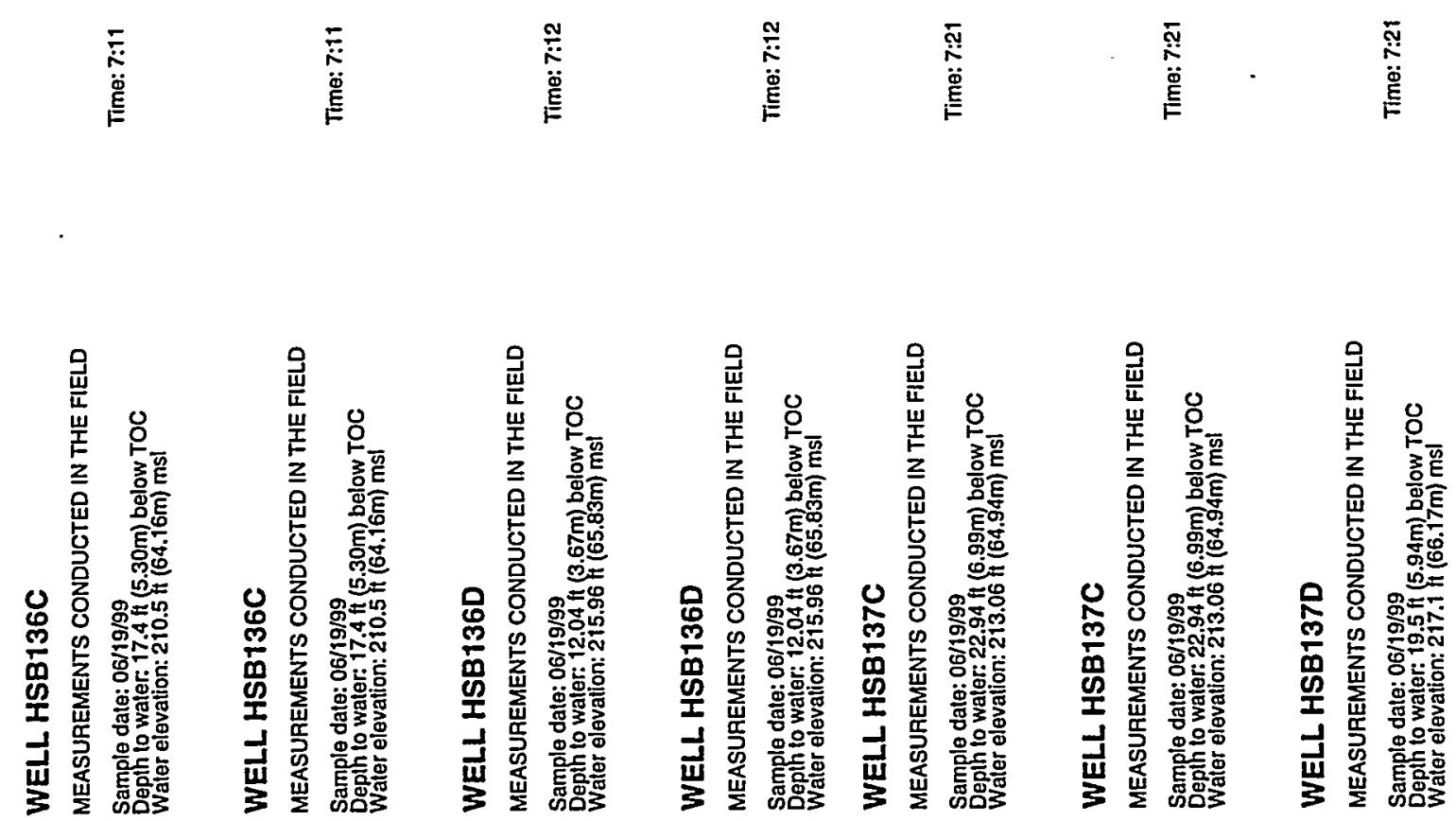


\section{WELL HSB139D}

MEASUREMENTS CONDUCTED IN THE FIELD

Sample date: 06/19/99

Sample date: $06 / 19 / 99$
Opth to water: 16.22 if $(4.94 \mathrm{~m})$ below TOC
Water elevation: 217.58 fi $(66.32 \mathrm{~m}) \mathrm{ms}$ l

\section{WELL HSB139D}

MEASUREMENTS CONDUCTED IN THE FIELD

Sample date: 06/19/99

Depth to water: 16.22 f $(4.94 \mathrm{~m})$ below TOC

Time: $6: 46$

\section{WELL HSB140A}

MEASUREMENTS CONDUCTED IN THE FIELD

Sample date: 06/19/99

\section{WELL. HSB140A}

MEASUREMENTS CONDUCTED IN THE FIELD

Sample date: 06/19/99

Depth to water: $60.4 \mathrm{H}(18.41 \mathrm{~m})$ below TOC

\section{WELL HSB140C}

MEASUREMENTS CONDUCTED IN THE FIELD

Sample date: 06/19/99

Depth to water: $30.48 \mathrm{~h}(9.29 \mathrm{~m})$ below TOC

Water elevation: $205.12 \mathrm{ft}(62.52 \mathrm{~m}) \mathrm{msl}$
Wath

\section{WELL HSB140C}

MEASUAEMENTS CONDUCTED IN THE FIELD

Sample date: 06/19/99

Depth to water: $30.48 \mathrm{Ht}(9.29 \mathrm{~m})$ below TOC

Time: 6:29

\section{WELL HSB140D}

MEASUREMENTS CONDUCTED IN THE FIELD

Sample date: 06/19/99

epth to water: $23.9 \mathrm{ft}(7.28 \mathrm{~m})$ below TOC

Time: 6:28
WELL HSB140D

MEASUREMENTS CONDUCTED IN THE FIELD

Sample date: 06/19/99

Depth to water: $23.9 \mathrm{Hi}(7.28 \mathrm{~m})$ below TOC

WELL HSB141A

MEASUREMENTS CONDUCTED IN THE FIELD

Sample date: 06/19/99

Depth to water: $79.78 \mathrm{ft}(24.32 \mathrm{~m})$ below TOC
Water elevalion: $174.82 \mathrm{ft}(53.29 \mathrm{~m}) \mathrm{ms}$

Time: 5:42

WELL HSB141A

MEASUREMENTS CONDUCTED IN THE FIELD

Sample date: 06/19/99

Water elevation: 174.78 it $(24.32 \mathrm{~m})$ below TOC

Time: 5:42

\section{WELL HSB141CR}

MEASUREMENTS CONDUCTED IN THE FIELD

Sample date: $06 / 19 / 99$
Deppth to wate: $27.7 \mathrm{Ht}(8.44 \mathrm{~m})$ below TOC
Water elevation: $226.6 \mathrm{ft}(69.07 \mathrm{~m}) \mathrm{msl}$

Time: 5:42

\section{WELL HSB141CR}

MEASUREMENTS CONDUCTED IN THE FIELD

Sample date: 06/19/99

Depth to water: $27.7 \mathrm{tt}(8.44 \mathrm{~m})$ below TOC

Time: 5:42

\section{WELL HSB141D}

MEASUREMENTS CONDUCTED IN THE FIELD

Sample date: $06 / 19 / 99$
Deph to water: $20.69 \mathrm{H}(6.31 \mathrm{~m})$ below TOC
Water elevation: $234.11 \mathrm{H}(71.36 \mathrm{~m}) \mathrm{msl}$

Time: 5:42

\section{WELL HSB141D}

MEASUREMENTS CONDUCTED IN THE FIELD

Sample date: 06/19/9

Depth to waler: $20.69 \mathrm{t}(6.31 \mathrm{~m})$ below TOC

Time: 5:42 


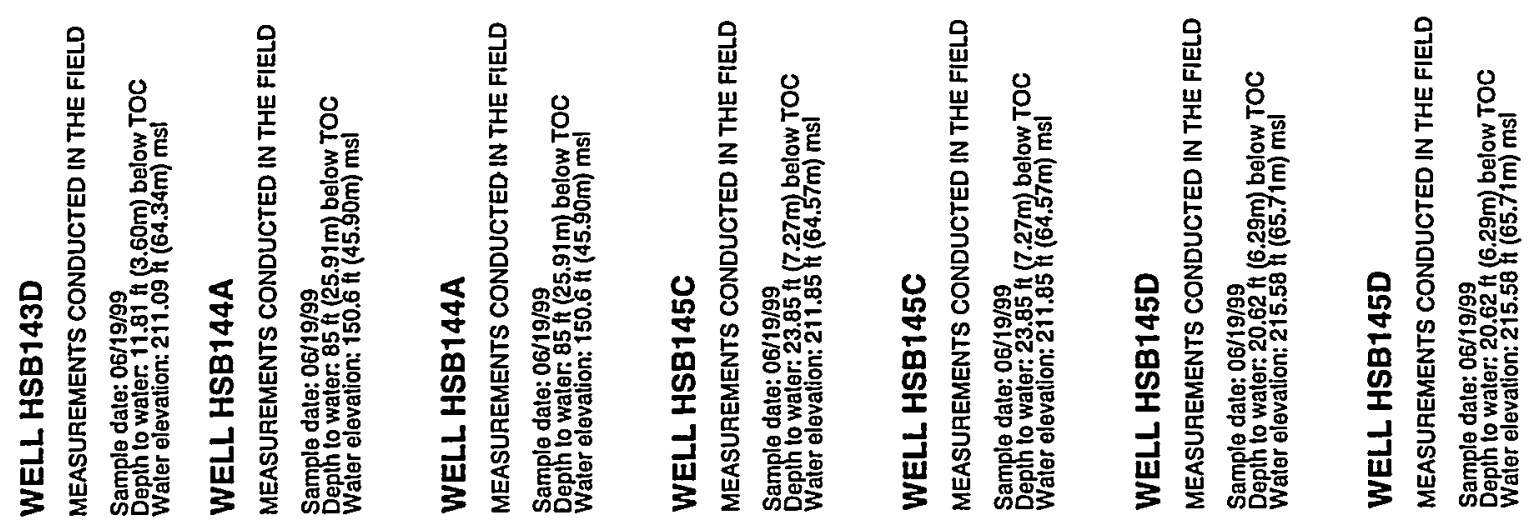<smiles>CC(C)(C)C(=O)O</smiles>

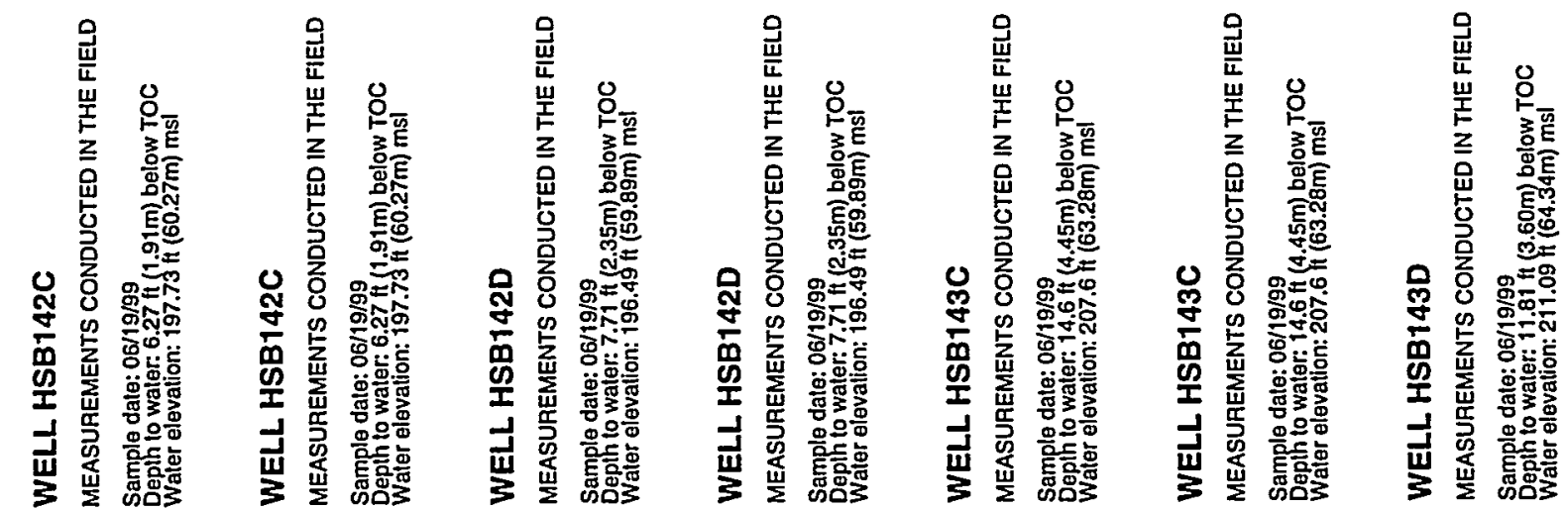




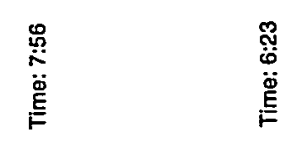

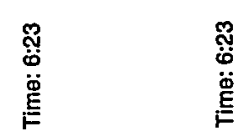

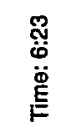

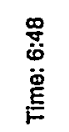

$\stackrel{\infty}{*}$
$\dot{0}$
$\dot{\oplus}$
$\stackrel{E}{E}$
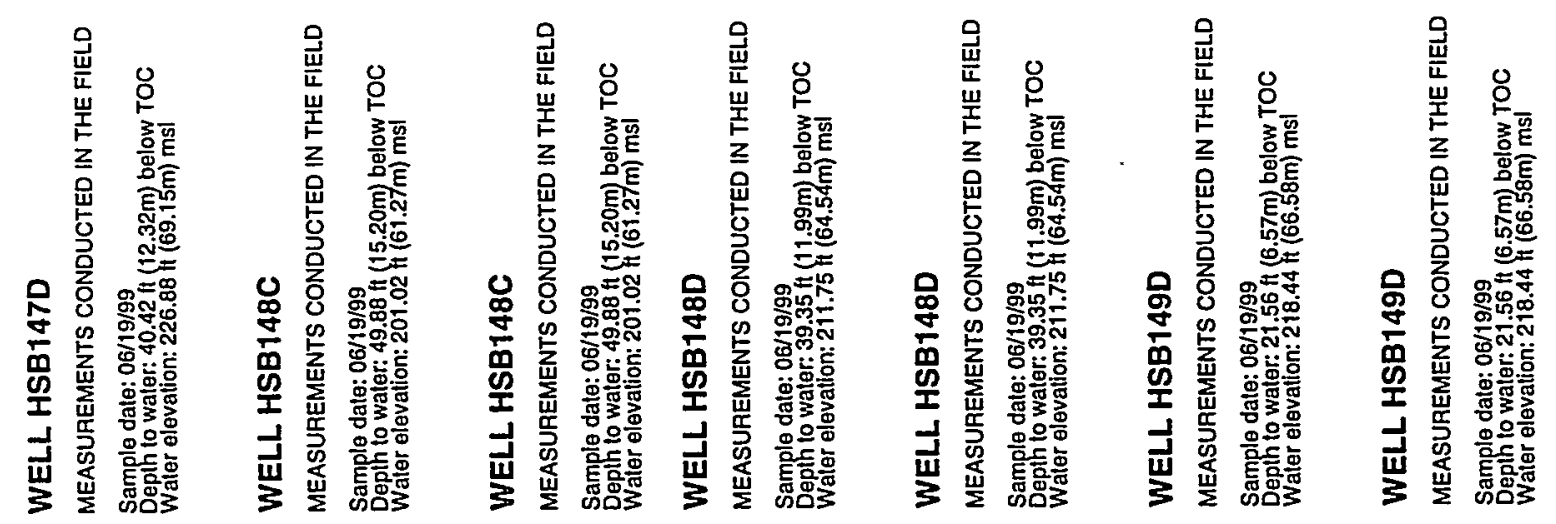

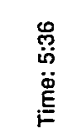

怘

怘

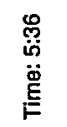

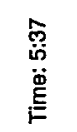

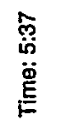

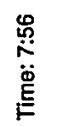

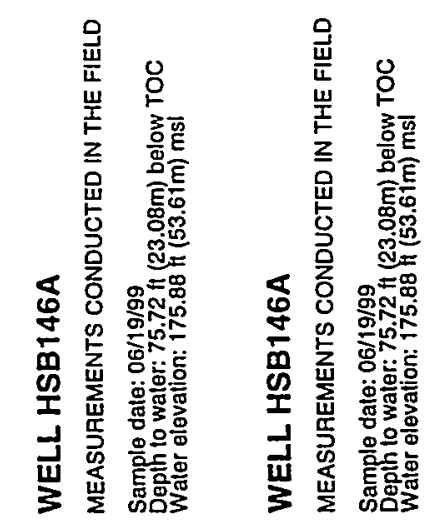

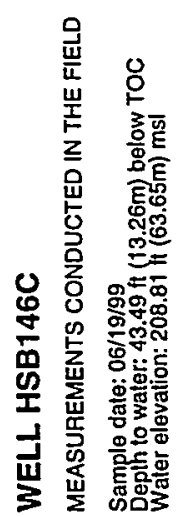

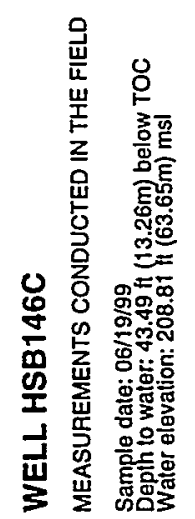

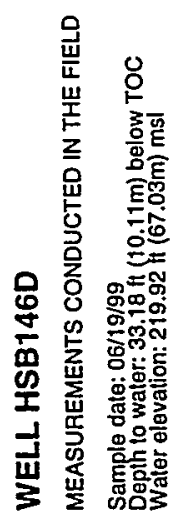
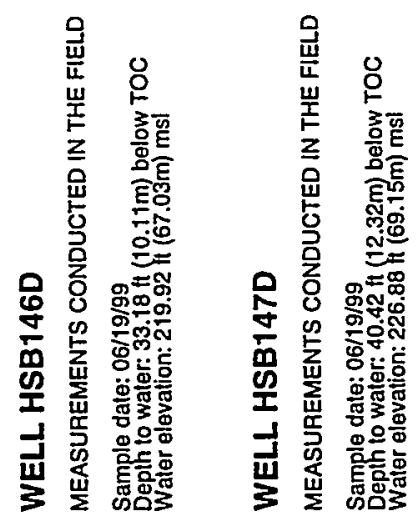


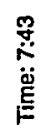

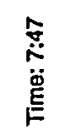

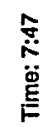

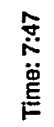

$\underset{\stackrel{Y}{*}}{\stackrel{\mathscr{*}}{E}}$

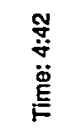



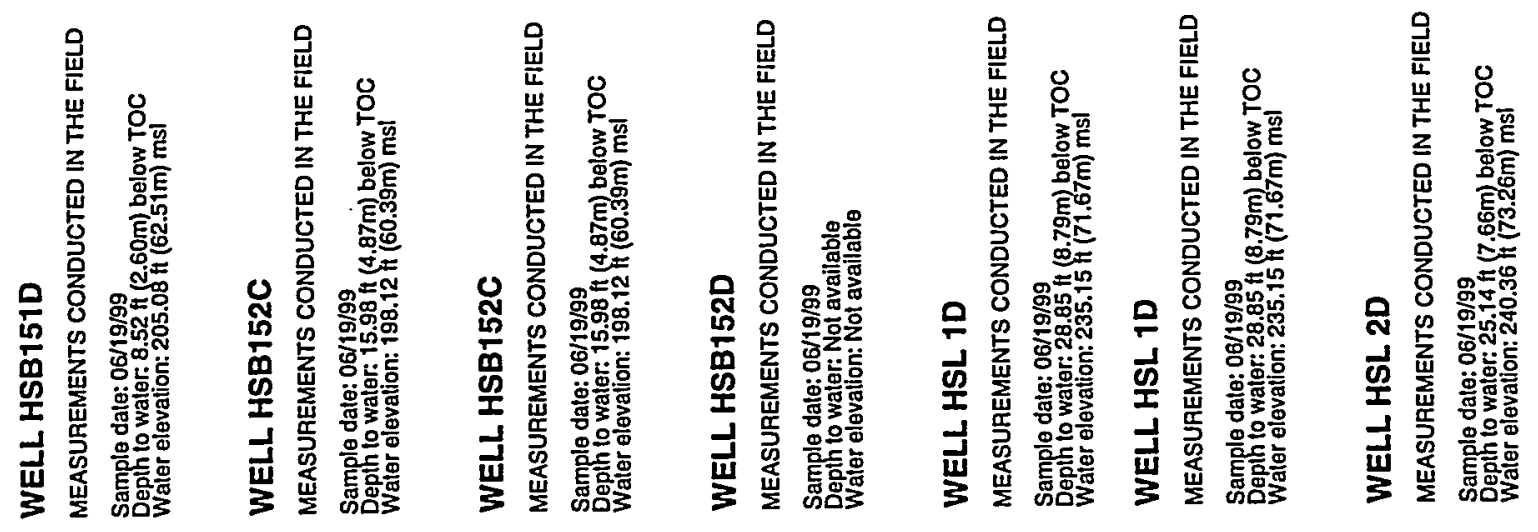

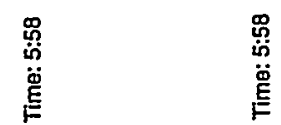

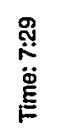

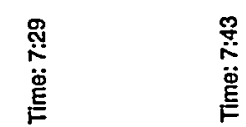

亳

疍

$\frac{8}{8}$

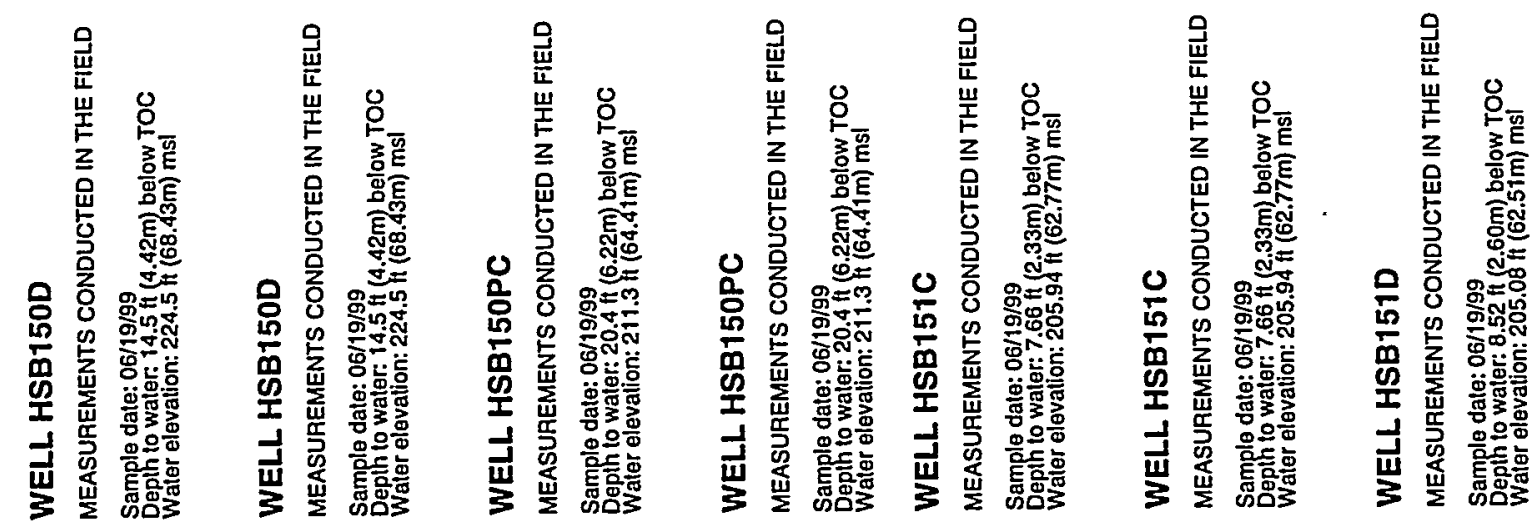



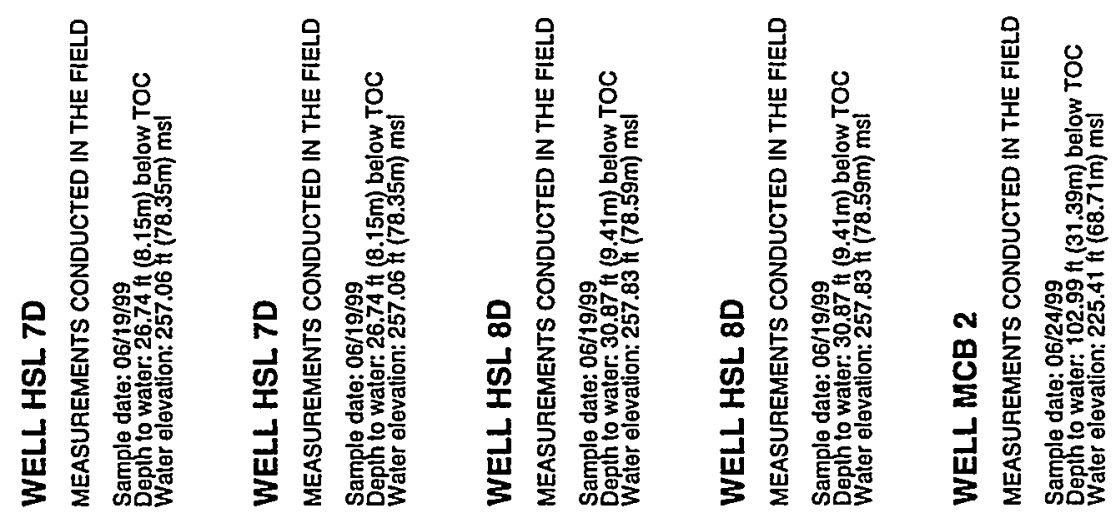

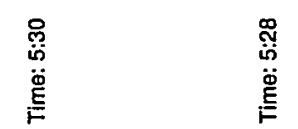

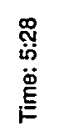

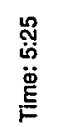

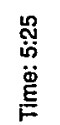

离

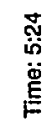
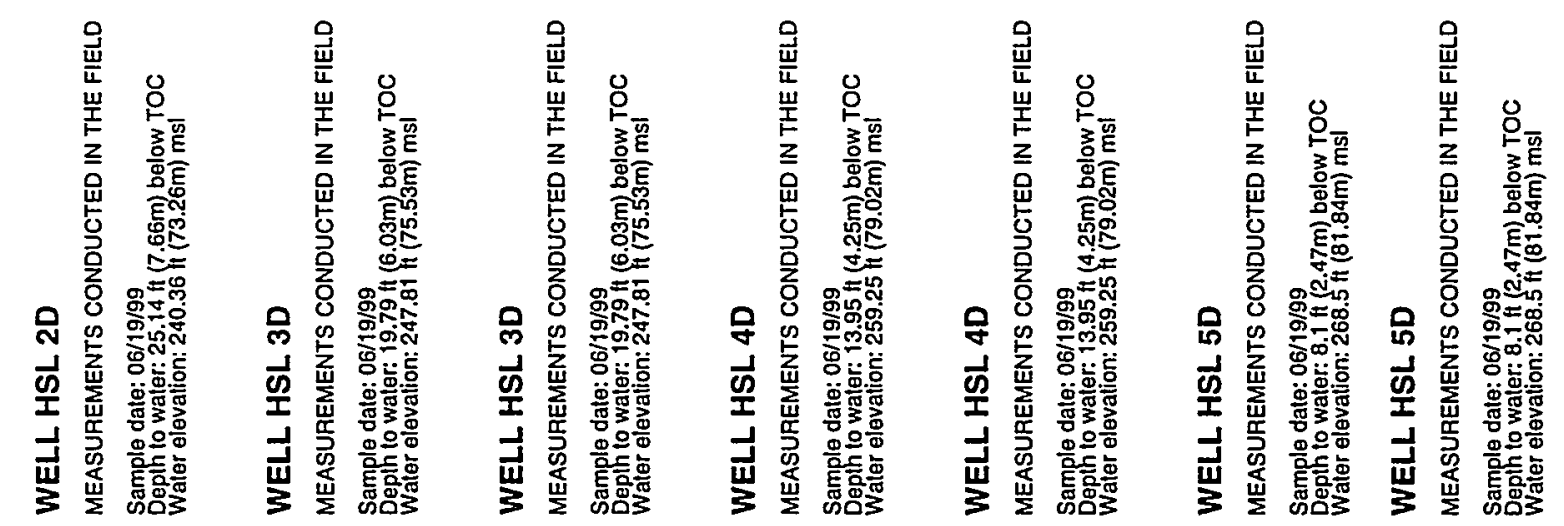


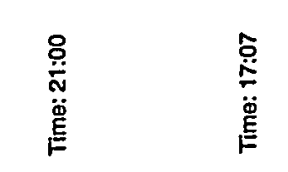

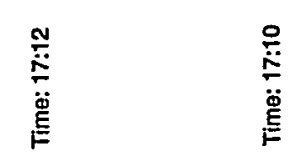

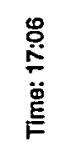

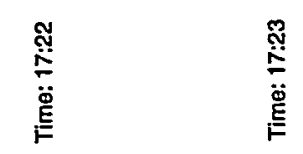
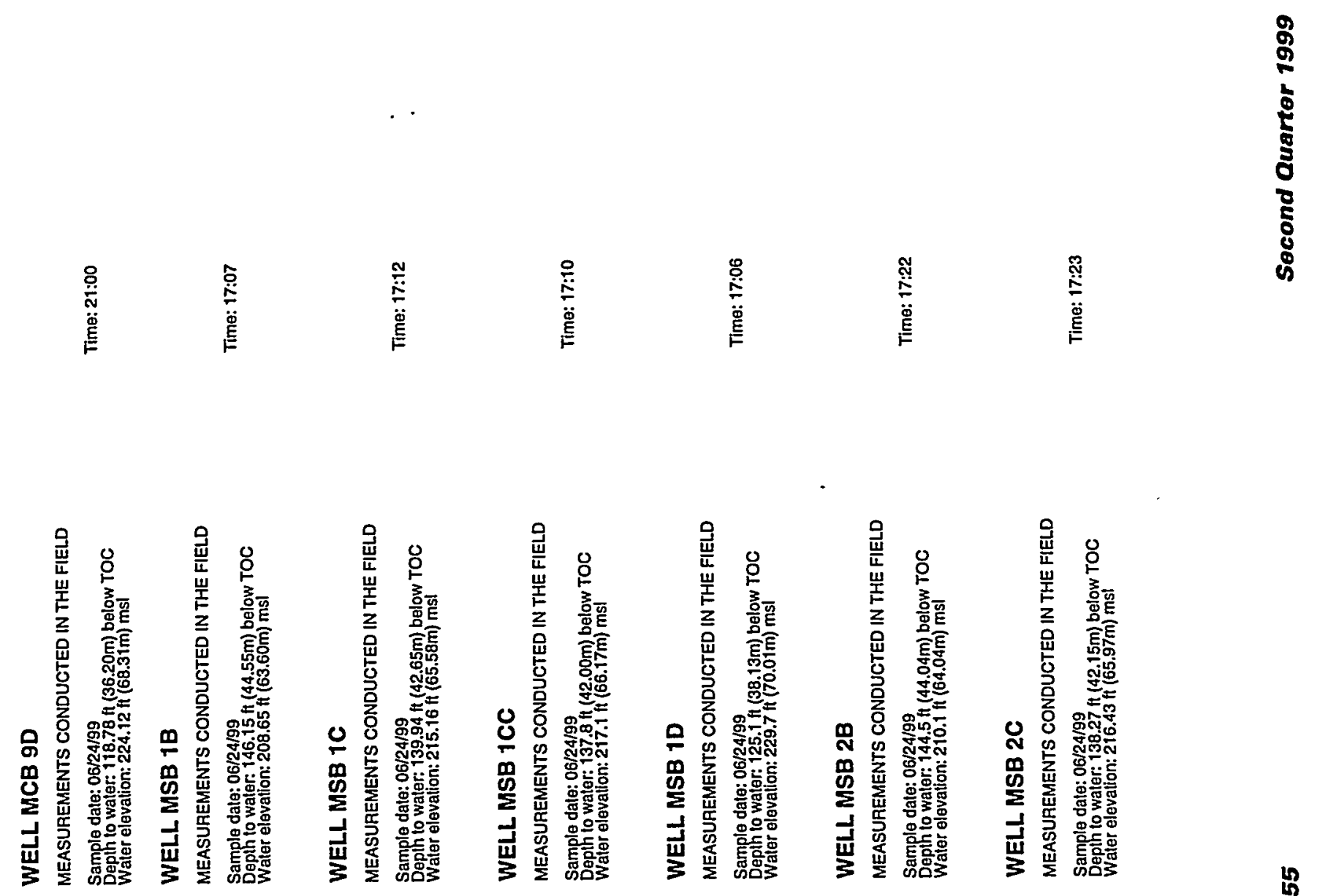

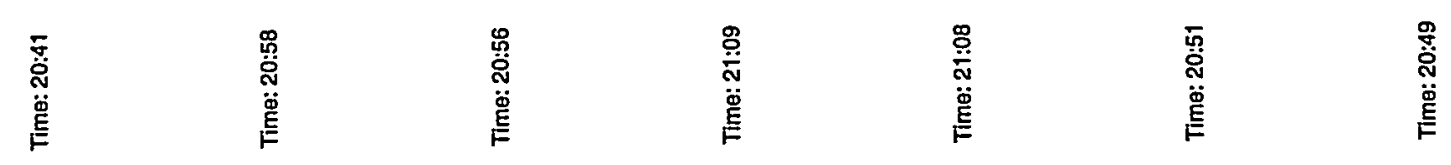

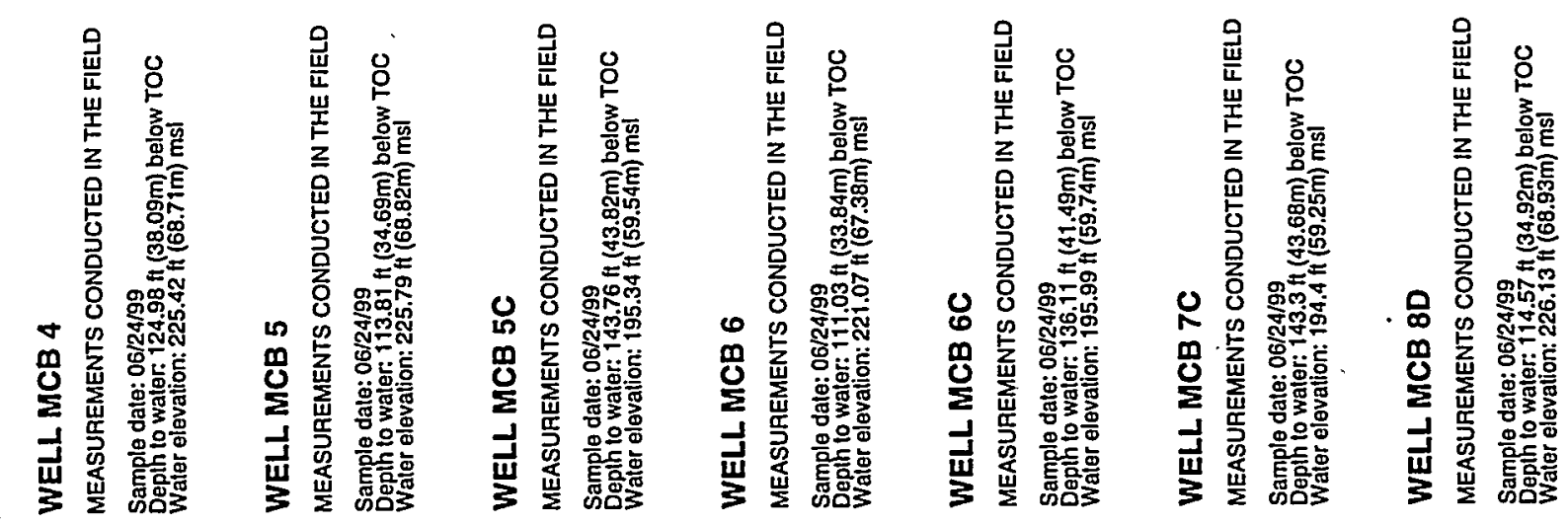




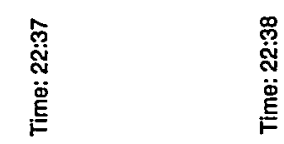

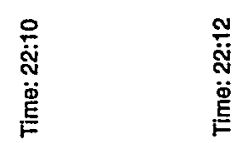

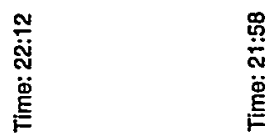

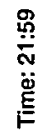

8
$\%$
5
8
8
8
8
8
5
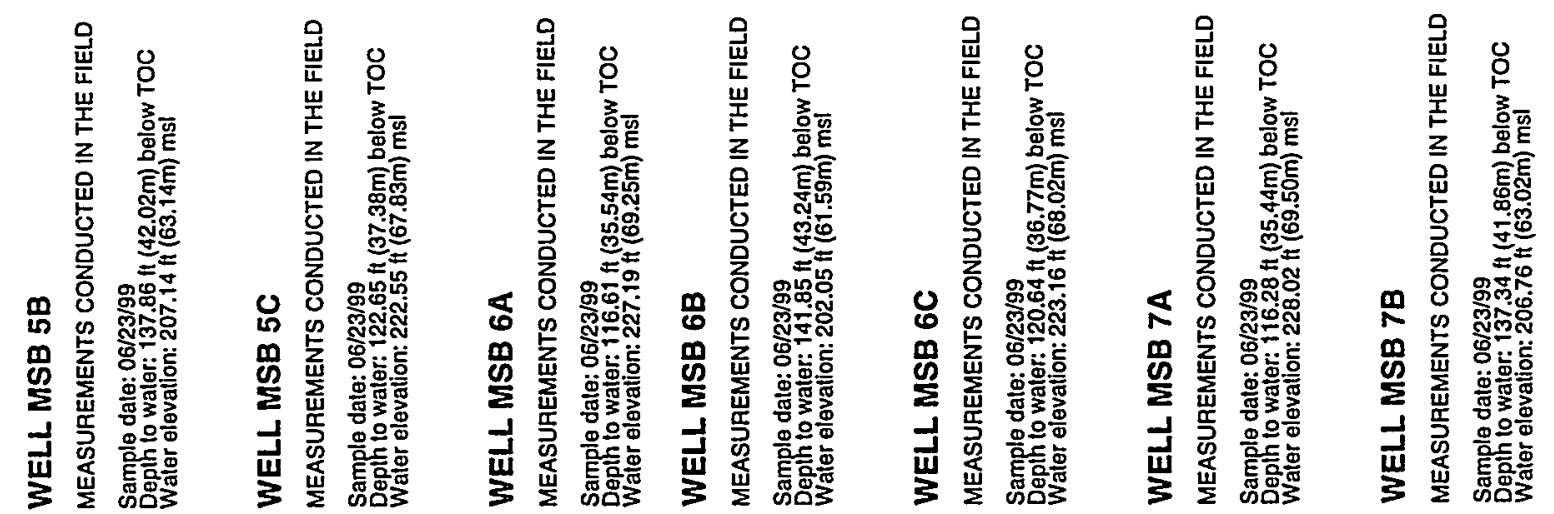

ధำ

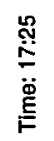

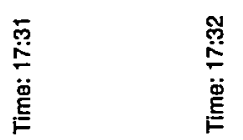

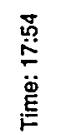

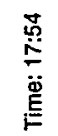

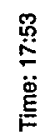

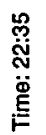
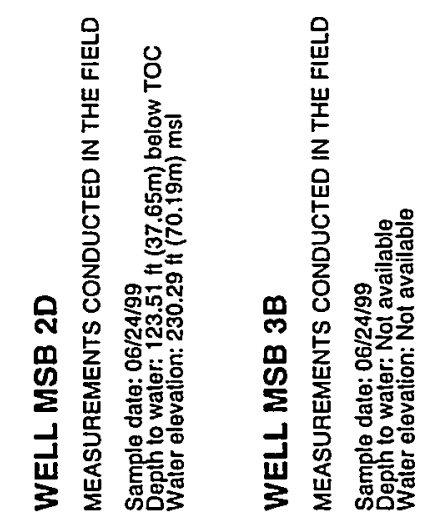

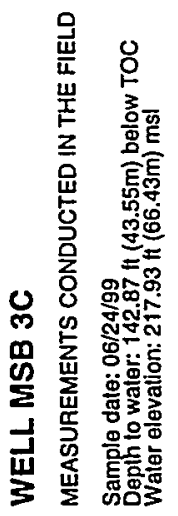
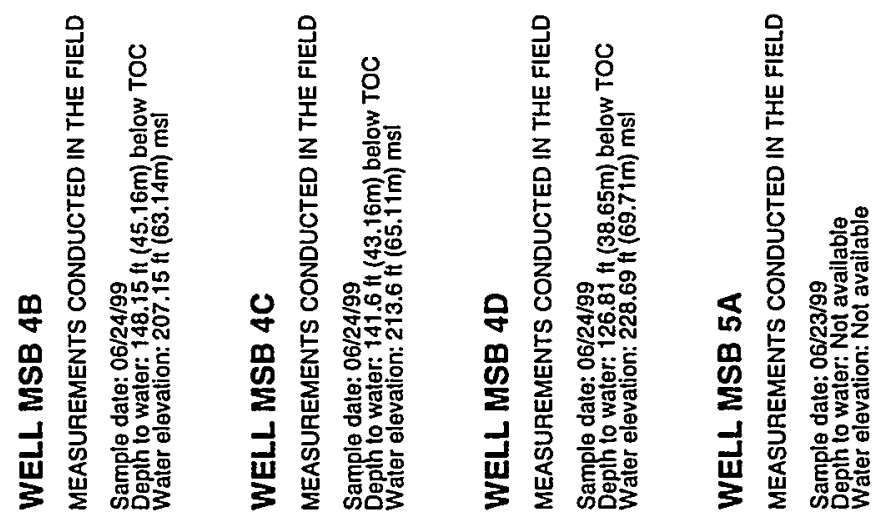

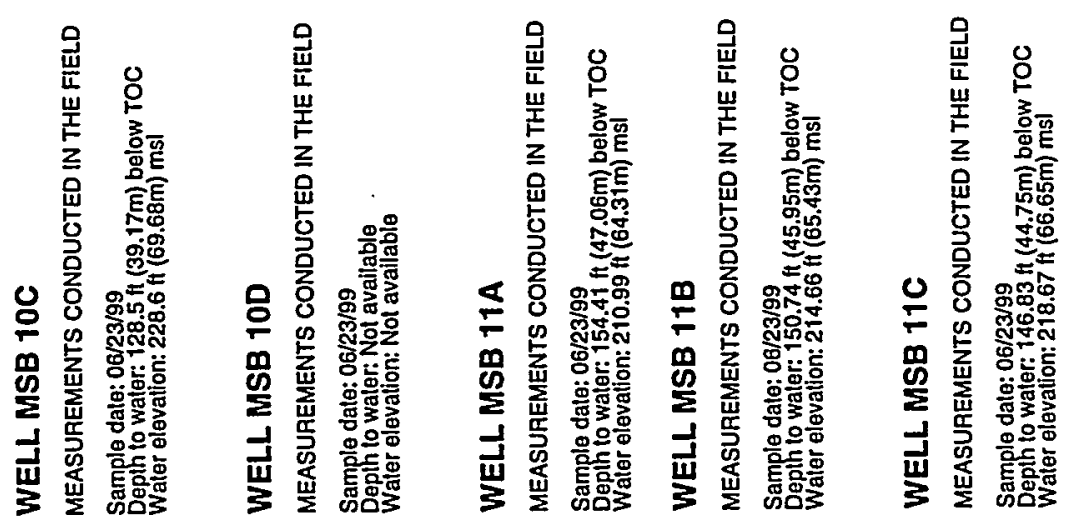

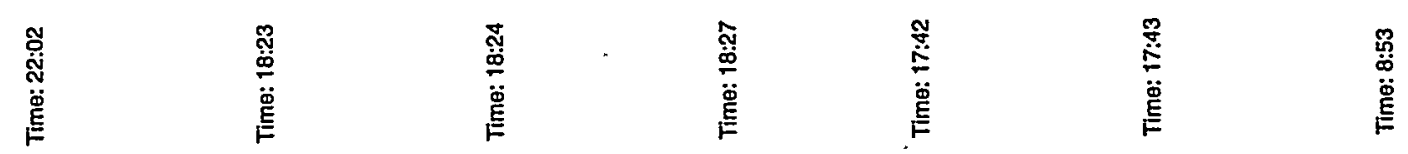

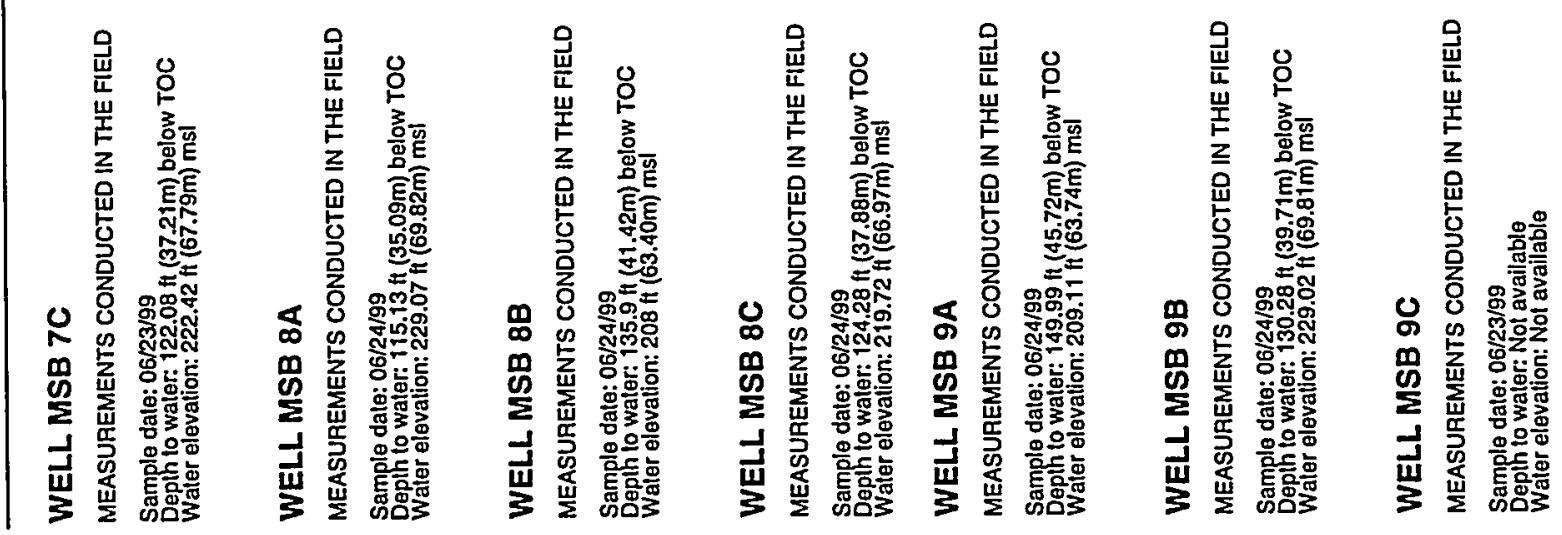




\section{WELL MSB 11D}

MEASUREMENTS CONDUCTED IN THE FIELD

Sample dale: 06/23/99

Depth to water: $136.67 \mathrm{ft}(41.66 \mathrm{~m})$ below TOC

\section{WELL MSB 11E}

MEASUREMENTS CONDUCTED IN THE FIELD

Sample date: $06 / 23 / 99$ fin $(38.31 \mathrm{~m})$ below TOC

Water elevalion: $239.51 \mathrm{ft}(73.00 \mathrm{~m}) \mathrm{msl}$

\section{WELL MSB 11F}

MEASUREMENTS CONDUCTED IN THE FIELD

Sample date: 06/23/99

Water elevalion: Not available

\section{WELLL MSB 12A}

MEASUREMENTS CONDUCTED IN THE FIELD

Sample date: $06 / 23 / 99$
Depth to water: $141.29 \mathrm{ft}(43.07 \mathrm{~m})$ below TOC
Waler elevation: $208.41 \mathrm{ft}(63.52 \mathrm{~m}) \mathrm{ms}$ )

\section{WELL MSB $12 B$}

MEASUREMENTS CONDUCTED IN THE FIELD

Sample date: 06/23/99

Sample date: 06/23/.9
Depth to water: $132.1 \mathrm{ft}(40.26 \mathrm{~m})$ below TOC
Waler elevation: $218.2 \mathrm{ft}(66.51 \mathrm{~m}) \mathrm{ms}$

\section{WELL MSB 12C}

MEASUREMENTS CONDUCTED IN THE FIELD

Sample dale: $06 / 23 / 99 \mathrm{H}(38.57 \mathrm{~m})$ below TOC

Waler elevation: $223.25 \mathrm{ft}(68.05 \mathrm{~m}) \mathrm{ms}$

Time: 23:52

\section{WELL MSB 12D}

MEASUREMENTS CONDUCTED IN THE FIELD

Sample dale: 06/23/99

Time: 23:51

\section{WELL MSB 12TA}

MEASUREMENTS CONDUCTED IN THE FIELD

Sample date: 06/23/99
Depph to water: $156.7 \mathrm{ft}(47.76 \mathrm{~m})$ below TOC

Time: 23:56

\section{WELL MSB 12TB}

MEASUREMENTS CONDUCTED IN THE FIELD

Samplo date: $06 / 23 / 99$ ft $(47.85 \mathrm{~m})$ below TOC

Time: 23:56

\section{WELL MSB 13A}

MEASUREMENTS CONDUCTED IN THE FIELD

Sample dato: 06/23/99

Deplh to waler: $140.03 \mathrm{ft}(42.68 \mathrm{~m})$ below TOC
Water elevalion: $206.67 \mathrm{ft}(62.99 \mathrm{~m}) \mathrm{msl}$

Time: 22:49

\section{WELL MSB 13B}

MEASUREMENTS CONDUCTED IN THE FIELD

Sample date: $06 / 23 / 99$
Depth to waler: $119.58 \mathrm{H}(36.45 \mathrm{~m})$ below TOC
Waler elevation: $227.52 \mathrm{ft}(69.35 \mathrm{~m}) \mathrm{msl}$

Time: 22:50

\section{WELL MSB 13C}

MEASUREMENTS CONDUCTED IN THE FIELD

Sample dale: 06/23/99 $13.9 \mathrm{f}$ ) below TOC

Time: 22:52

\section{WELL MSB 13CC}

MEASUREMENTS CONDUCTEO IN THE FIELD

Sample date: 06/23/99

Depth to water: $123 \mathrm{ft}(37.49 \mathrm{~m})$ below TOC

Time: 22:45

\section{WELL MSB 13D}

MEASUREMENTS CONDUCTED IN THE FIELD

Sample date: 06/23/99

Water elevation: $227.7 \mathrm{ft}(69.40 \mathrm{~m}) \mathrm{msl}$
Time: 22:55 


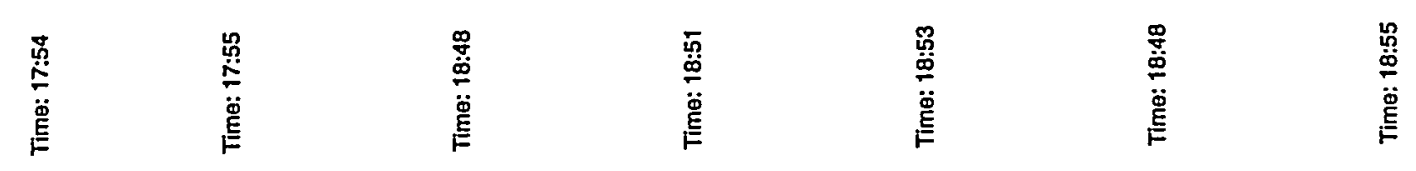
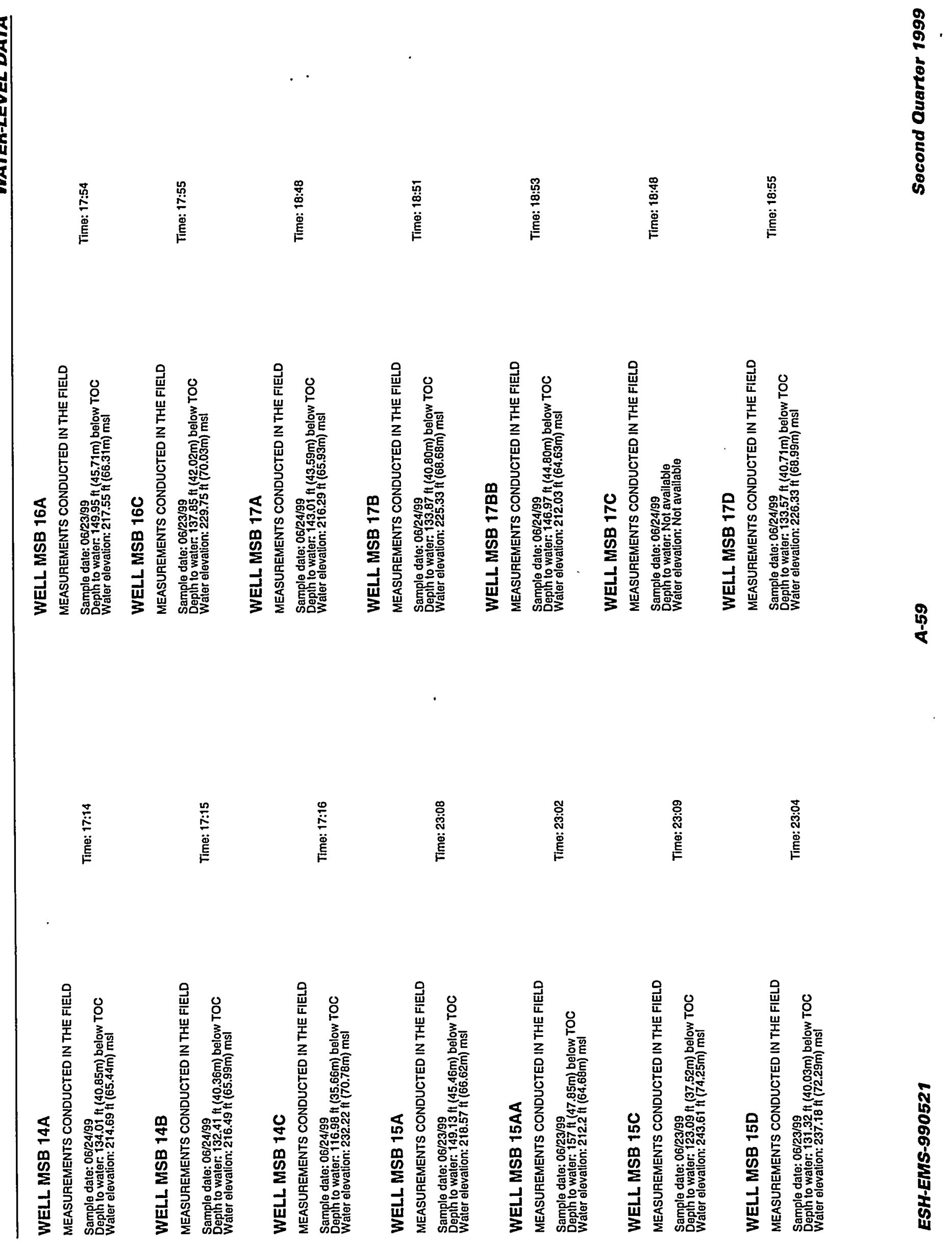

ชุำ 


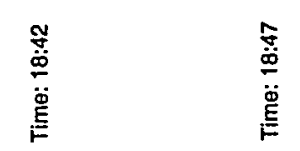

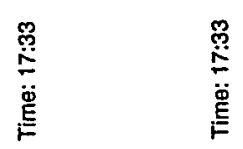

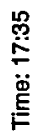

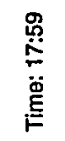

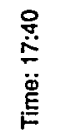
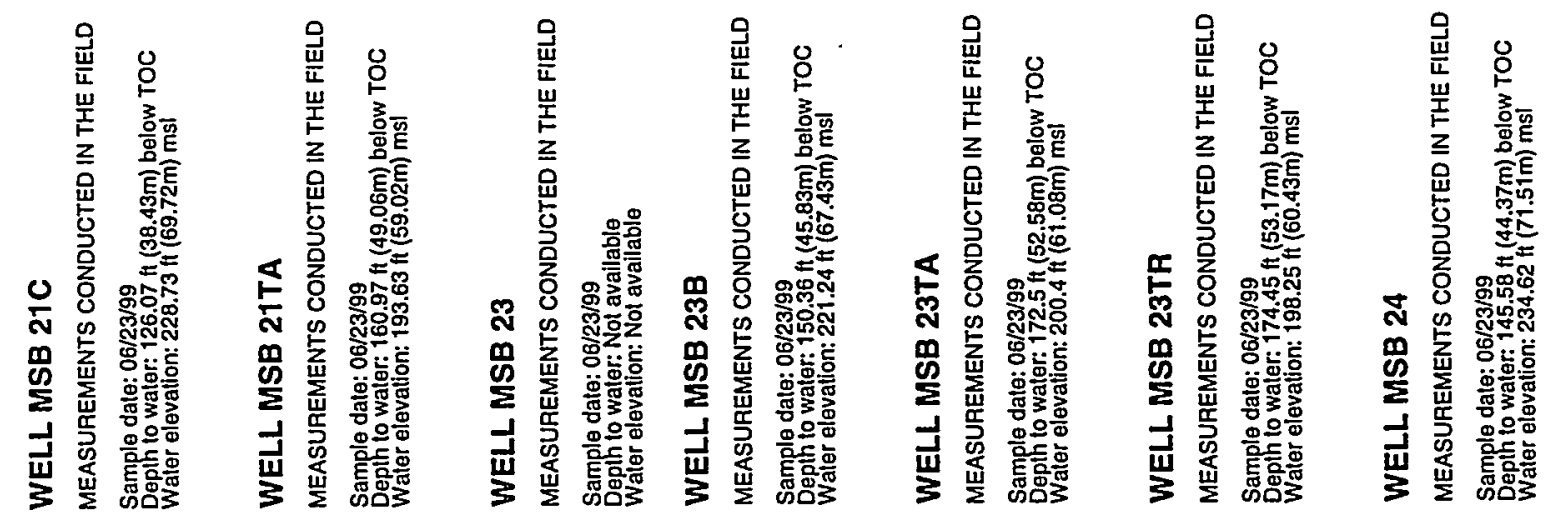

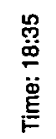

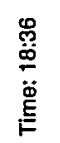

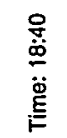

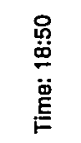

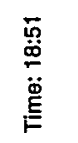

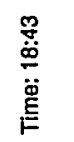

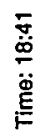

$\frac{8}{8}$

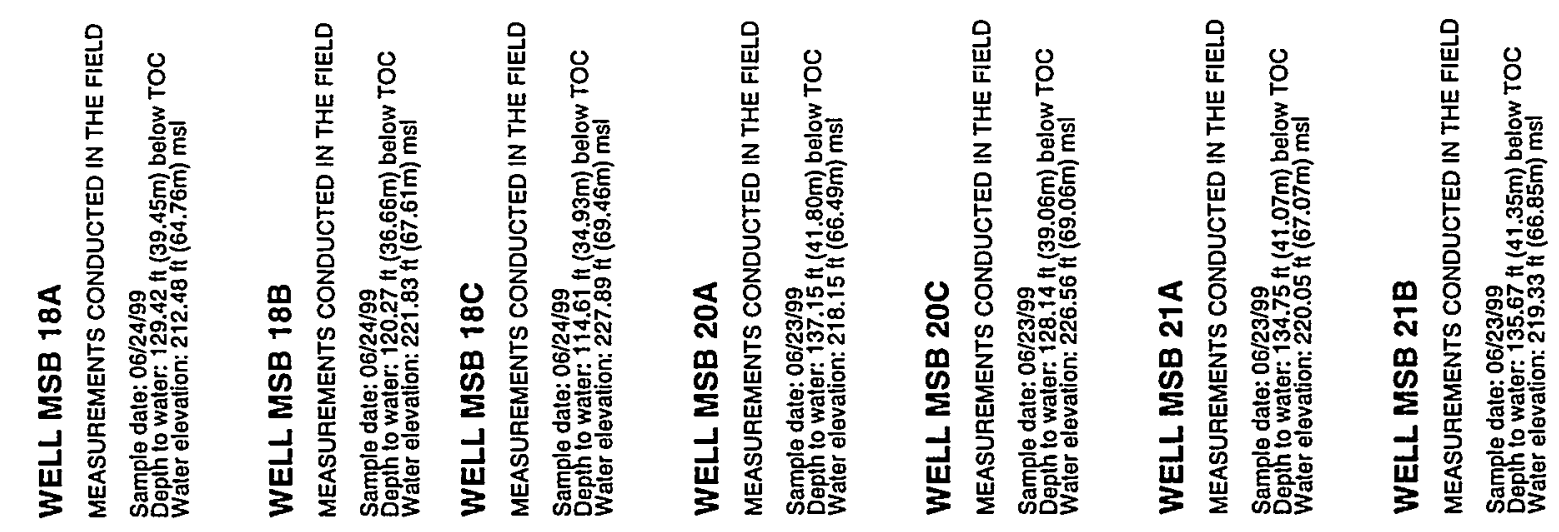


WELL MSB 24A

MEASUREMENTS CONDUCTED IN THE FIELD

Sample date: 06/23/99

Wepth to water: 157.96 $\mathrm{ft}(48.15 \mathrm{~m})$ below

Time: 17:39

\section{WELL MSB 25}

MEASUREMENTS CONDUCTED IN THE FIELD

Sample date: $06 / 23 / 99$

Wath er waler: Not available

\section{WELL MSB 25A}

MEASUREMENTS CONDUCTED IN THE FIELD

Sample date: 06/23/99

Depth to waler: 152 \# (46.33m) below TOC

\section{WELL MSB 26}

MEASUREMENTS CONDUCTED IN THE FIELD

Sample dale: 06/23/99

Depth to water: Not available
Water elevation: Not available

\section{WELL MSB 26A}

MEASUREMENTS CONDUCTED IN THE FIELD

Sample date: 06/23/99

Sample date: 06/23/99 $14.37 \mathrm{~m})$ below TOC

\section{WELL MSB 26B}

MEASUREMENTS CONDUCTED IN THE FIELD

Sample date: 06/23/99

Dephlo owale: $145.72 \mathrm{H}(44.42 \mathrm{~m})$ below TOC
Water elevation: $217.08 \mathrm{ft}(66.17 \mathrm{~m}) \mathrm{msl}$

\section{WELL MSB 27}

MEASUREMENTS CONDUCTED IN THE FIELD

Sample date: 06/23/99 $\mathrm{ft}(12.4 \mathrm{~m})$ below TOC

Time: 17:46
WELL MSB 27A

MEASUREMENTS CONDUCTED IN THE FIELD

Sample date: 06/23/99

Depth to waler: $147.2 \mathrm{H}(44.87 \mathrm{~m})$ below TOC

Time: 17:47

\section{WELL MSB 27B}

MEASUREMENTS CONDUCTED IN THE FIELD

Sample date: 06/23/99 $(46.62 \mathrm{~m})$ below TOC

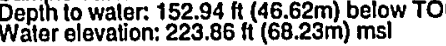

Time: 17:49

WELL MSB 27TA

MEASUREMENTS CONDUCTED IN THE FIELD

Sample date: $06 / 23 / 99$
Deplh lo water: $176.32 \mathrm{ft}(53.74 \mathrm{~m})$ below TOC
Water elevalion: $200.28 \mathrm{ft}(61.05 \mathrm{~m}) \mathrm{msl}$

Time: 17:48

WELL MSB 28

MEASUREMENTS CONDUCTED IN THE FIELD

Sample date: 06/23/99 $(138.15 \mathrm{~m})$ below TOC

Time: 18:11

\section{WELLL MSB 28A}

MEASUREMENTS CONDUCTED IN THE FIELD

Sample date: 06/23/99 $130.34 \mathrm{~m})$ below TOC

\section{WELL MSB 29A}

MEASUREMENTS CONDUCTED IN THE FIELD

Sample date: 06/22/99 4 (44.57m) below TOC

Time: $8: 52$

\section{WELL MSB 29B}

MEASUREMENTS CONDUCTED IN THE FIELD

Sample date: 06/22/99

Depth to waler: $141.38 \mathrm{nt}(43.09 \mathrm{~m})$ below TOC

Time: 8:49 


\section{WELL MSB 29C}

MEASUREMENTS CONDUCTED IN THE FIELD

Sample date: 06/22/99

Depth to water: $135.02 \mathrm{ft}(41.15 \mathrm{~m})$ below TOC

\section{WELL MSB 29D}

MEASUREMENTS CONDUCTED IN THE FIELD

Sample date: 06/22/99 $(40.56 \mathrm{~m})$ below TOC

Depth lo water: $133.07 \mathrm{ft}(40.56 \mathrm{~m})$ below
Water elevation: $231.83 \mathrm{ft}(70.66 \mathrm{~m}) \mathrm{msl}$

\section{WELL MSB 29DD}

MEASUREMENTS CONDUCTED IN THE FIELD

Sample date: $06 / 22 / 99$
Depth to waler: $132.32 \mathrm{Ht}(40.33 \mathrm{~m})$ below TOC
Water elevation: $232.08 \mathrm{ft}(70.74 \mathrm{~m}) \mathrm{msl}$

\section{WELL MSB 29TA}

MEASUREMENTS CONDUCTED IN THE FIELD

Sample date: $06 / 22 / 99 \mathrm{ft}(46.69 \mathrm{~m})$ below TOC

Depth to water: $153.18 \mathrm{ft}(46.69 \mathrm{~m})$ below

\section{WELL MSB 30A}

MEASUREMENTS CONDUCTED IN THE FIELD

Sample date: $06 / 23 / 99$

Sample date: $06 / 23 / 99$
Depth to waler: 157 f $(47.85 \mathrm{~m})$ below TOC
Waler elevation: $198 \mathrm{ft}(60.35 \mathrm{~m}) \mathrm{msl}$

\section{WELL MSB 30AA}

MEASUREMENTS CONDUCTED IN THE FIELD

Sample date: 06/23/99 $(39.56 \mathrm{~m})$ below TOC

Water elevation: $223.22 \mathrm{ft}(68.04 \mathrm{~m}) \mathrm{ms}$

\section{WELL MSB 30B}

MEASUREMENTS CONDUCTED IN THE FIELD

Sample date 06/23/99

Depth to water: $128.91 \mathrm{ft}(39.29 \mathrm{~m})$ below TOC

Water elevation: $224.59 \mathrm{ft}(68.46 \mathrm{~m}) \mathrm{ms}$

Time: 8:47
WELL MSB 30C

MEASUREMENTS CONDUCTED IN THE FIELD

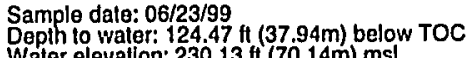

Time: 18:22

\section{WELL. MSB 30CC}

MEASUREMENTS CONDUCTED IN THE FIELD

Sample date: 06/23/99

Time: 18:19

\section{WELL MSB 31A}

MEASUREMENTS CONDUCTED IN THE FIELD

Sample date: 06/22/99

Dample date: $06 / 2299$
Deph to waler: $150.55 \mathrm{ft}(45.89 \mathrm{~m})$ below TOC
Water elevation: $197.55 \mathrm{ft}(60.21 \mathrm{~m}) \mathrm{ms}$ (

\section{WELL MSB 31B}

MEASUREMENTS CONDUCTED IN THE FIELD

Sample date: $06 / 22 / 99$
Depth to waler: $136.68 \mathrm{ft}(41.66 \mathrm{~m})$ below TOC
Water elevation: $211.62 \mathrm{ft}(64.50 \mathrm{~m}) \mathrm{msl}$

Time: 14:48

\section{WELL MSB 31C}

MEASUREMENTS CONDUCTED IN THE FIEL.D

Sample date: 06/22/99

Time: $14: 47$

\section{WELL MSB 31CC}

MEASUREMENTS CONDUCTED IN THE FIELD

Sample date: 06/22/99

Depth to water: $136.88 \mathrm{ft}(41.72 \mathrm{~m})$ below TOC

\section{WELL MSB 32}

MEASUREMENTS CONDUCTED IN THE FIELD

Sample date: 06/22/9

Deph to waler: 32.2 f $(9.81 \mathrm{~m})$ below TOC
Time: 14:57 


\section{WELL MSB 32B}

MEASUREMENTS CONDUCTED IN THE FIELD

Sample date: 06/22/99

Depth to water: 44.38 ft $(13.53 \mathrm{~m})$ below TOC

\section{WELL MSB 32C}

MEASUREMENTS CONDUCTED IN THE FIELD

Sample dale: 06/22/99

Depth to water: $39.9 \mathrm{ft}(12.16 \mathrm{~m})$ below TOC

\section{WELL MSB 33}

MEASUREMENTS CONDUCTED IN THE FIELD

Sample date: 06/22/99

Sample date: 06/22/99
Dephto water: $39.2 \mathrm{ft}(11.95 \mathrm{~m})$ below TOC
Water elevation: $216.7 \mathrm{H}(66.05 \mathrm{~m}) \mathrm{ms}$

\section{WELL MSB 33A}

MEASUREMENTS CONDUCTED IN THE FIELD

Sample date: 06/22/99
Depth to water: $50.51 \mathrm{tt}(15.40 \mathrm{~m})$ below TOC
Water elevation: $204.89 \mathrm{tt}(62.45 \mathrm{~m}) \mathrm{msl}$

\section{WELL MSB 33B}

MEASUREMENTS CONDUCTED IN THE FIELD

Sample date: 06/22/99

Depth to water: $47.6 \mathrm{ft}(14.51 \mathrm{~m})$ below TOC

\section{WELL MSB 33C}

MEASUREMENTS CONDUCTED IN THE FIELD

Sample data: 06/22/99

Time: 14:36

\section{WELLL MSB 33TA}

MEASUREMENTS CONDUCTED IN THE FIELD

Sample date: 06/22/99

Sample date: 06/22/99
Depth io waler: $59.95 \mathrm{ft}(18.27 \mathrm{~m})$ below TOC

Time: 14:34

Time: 14:35

\section{WELL MSB 34A}

MEASUREMENTS CONDUCTED IN THE FIELD

Sample date: 06/22/99

Time: 14:11

Waler elevalion: $217.4 \mathrm{ft}(66.26 \mathrm{~m}) \mathrm{msl}$

\section{WELL MSB 34B}

MEASUREMENTS CONDUCTED IN THE FIELD

Sample date: 06/22/9

Depht to waler: $150.33 \mathrm{H}(48.26 \mathrm{~m})$ below TOC
Water elevaliton: $225.67 \mathrm{H}(68.79 \mathrm{~m}) \mathrm{msl}$

Time: 14:11

\section{WELL MSB 34C}

MEASUREMENTS CONDUCTED IN THE FIELL

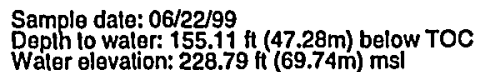

Time: 14:11

\section{WELLL MSB 34TA}

MEASUREMENTS CONDUCTED IN THE FIELD

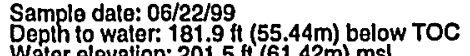

Time: 14:10

\section{WELL MSB 34TB}

MEASUREMENTS CONDUCTED IN THE FIELD

Sample dale: 06/22/99

aeph to water: $181.7 \mathrm{ht}(55.38 \mathrm{~m})$ below TOC

Time: 14:09

\section{WELL MSB 35A}

MEASUREMENTS CONDUCTED IN THE FIELD

Sample date: 06/23/99

Depth to water: $135.05 \mathrm{ft}(41.16 \mathrm{~m})$ below TOC

Time: 10:12

\section{WELL MSB 35B}

MEASUREMENTS CONDUCTED IN THE FIELD

Sample date: 06/23/99 $40.58 \mathrm{~m})$ below TOC

Depth to water: $133.15 \mathrm{ft}(40.58 \mathrm{~m})$ below T
Water elevation: $218.45 \mathrm{ft}(66.58 \mathrm{~m}) \mathrm{msl}$
Time: 10:13 

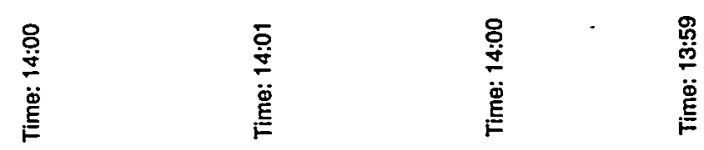

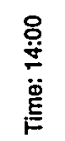

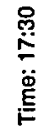
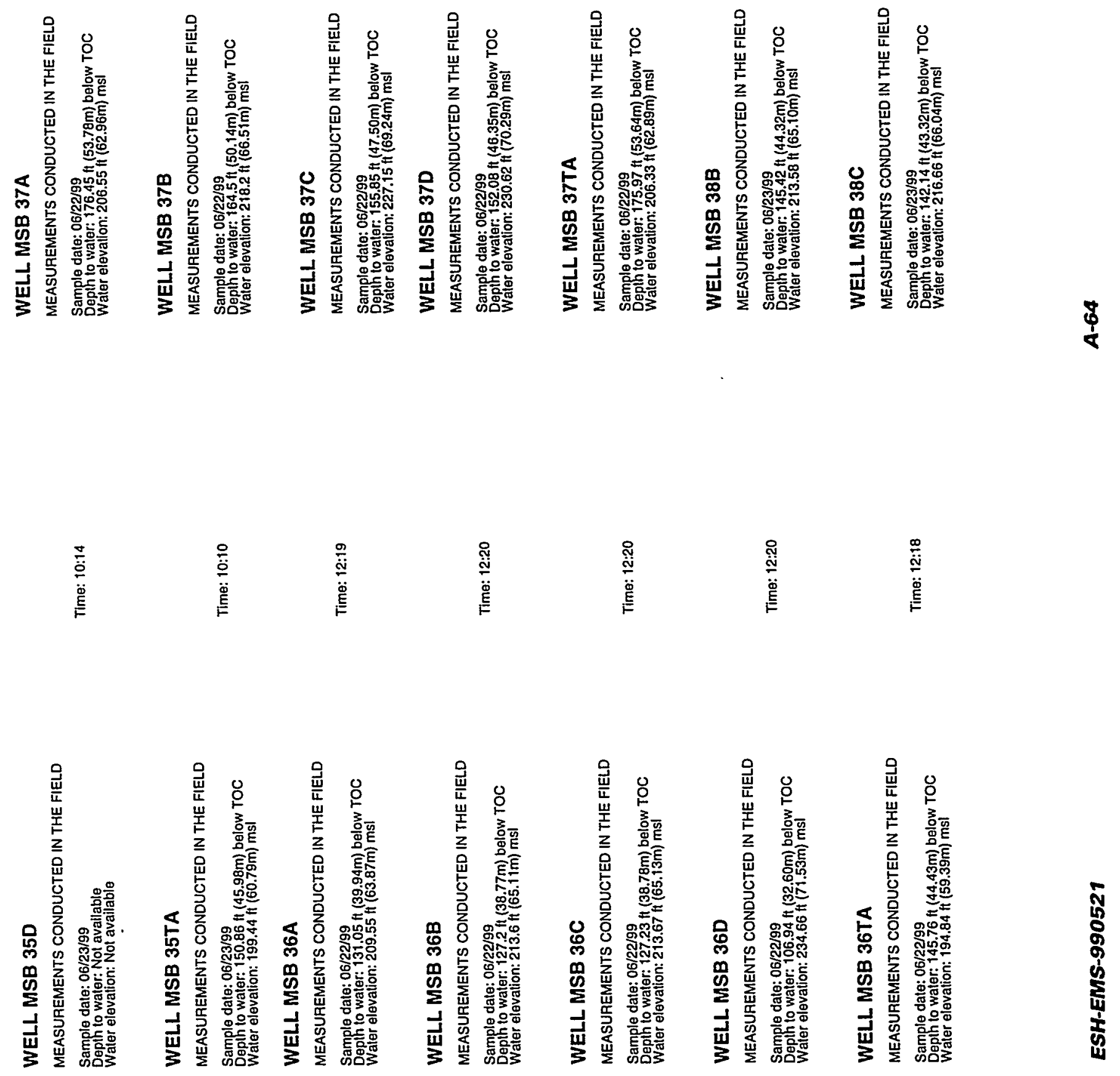


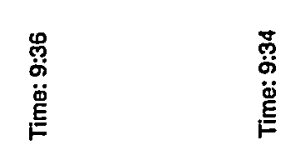

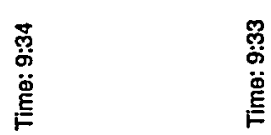

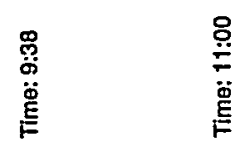

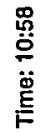

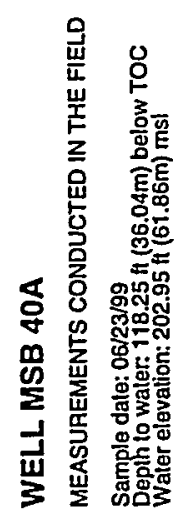

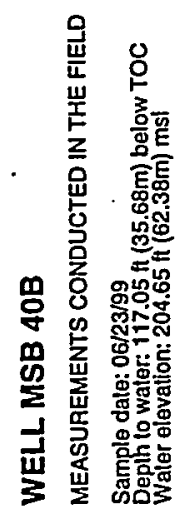
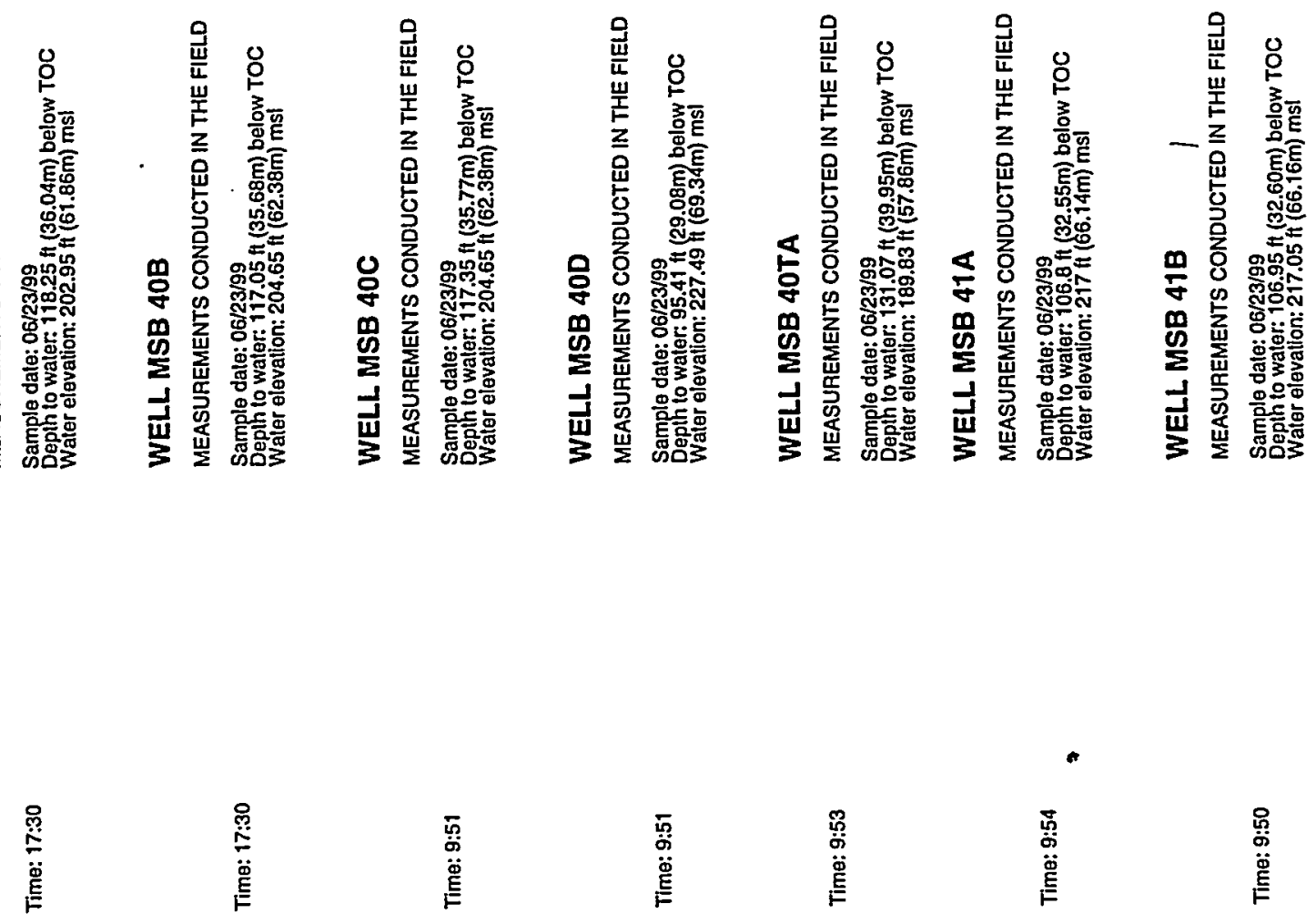

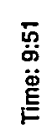

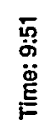



莺

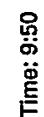
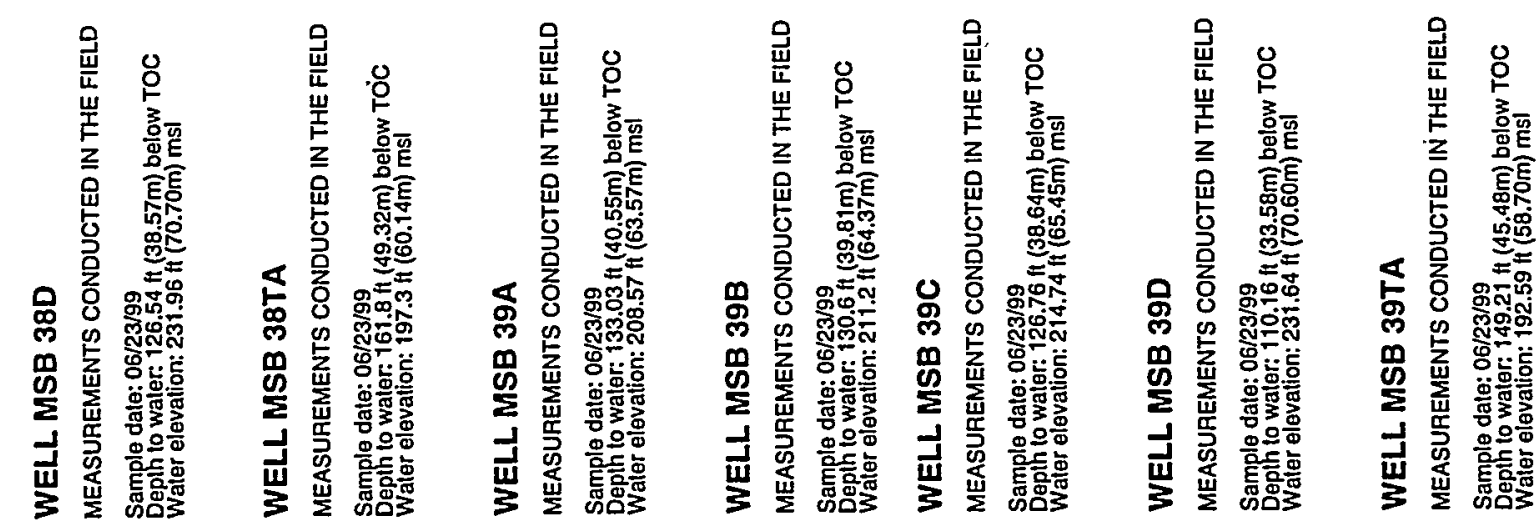

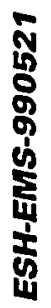




\section{WELL MSB 41C}

MEASUREMENTS CONDUCTED IN THE FIELD

Sample date: 06/23/99
Depth to water: $107.06 \mathrm{ft}(32.63 \mathrm{~m})$ below TOC
Water elevation: $217.54 \mathrm{ft}(66.31 \mathrm{~m}) \mathrm{msl}$

\section{WELLL MSB 41D}

MEASUREMENTS CONDUCTED IN THE FIELD

Sample date: $06 / 23 / 99$
Depth to water: 84 $\mathrm{ft}(25.60 \mathrm{~m})$ below TOC
Water elevation: $241 \mathrm{H}(73.46 \mathrm{~m}) \mathrm{ms}$

\section{WELL. MSB 41TA}

MEASUREMENTS CONDUCTED IN THE FIELD

Sample dale: 06/23/99
Depth to water: 117.22 it $(35.73 \mathrm{~m})$ below TOC
Water elevation: 206.48 it $(62.94 \mathrm{~m})$ msl

\section{WELL MSB 42A}

MEASUREMENTS CONDUCTED IN THE FIELD

Sample dale: 06/22/99 $(48.20 \mathrm{~m})$ below TOC

Depth to water: $158.13 \mathrm{At}(48.20 \mathrm{~m})$ below

\section{WELL MSB 42B}

MEASUREMENTS CONDUCTED IN THE FIELD

Sample date: 06/22/99

Water elevation: $224.6 \mathrm{ft}(68.46 \mathrm{~m}) \mathrm{msl}$

\section{WELL MSB 42C}

MEASUREMENTS CONDUCTED IN THE FIELD

Sample date: 06/22/99
Depth to water: $146.44 \mathrm{ft}(44.64 \mathrm{~m})$ below TOC
Waler elevation: $229.96 \mathrm{ft}(70.09 \mathrm{~m}) \mathrm{ms}$

\section{WELL MSB 42TA}

MEASUREMENTS CONDUCTED IN THE FIELD

Sample dale: $06 / 22 / 99$ ft $(52.37 \mathrm{~m})$ below TOC

Time: 13:49
WELL MSB 43A

MEASUREMENTS CONDUCTED IN THE FIELD

Sample date: 06/22/99 $1.39 .33 \mathrm{~m})$ below TOC

Time: 8:36

\section{WELL MSB 43B}

MEASUREMENTS CONDUCTED IN THE FIELD

Sample date: 06/22/99

Depth to waler: $129 \mathrm{ft}(39.32 \mathrm{~m})$ below TOC
Water elevation: $228.8 \mathrm{ft}(69.74 \mathrm{~m}) \mathrm{ms}$

Time: 8:37

WELL MSB 43D

MEASUREMENTS CONDUCTED IN THE FIELD

Sample dale: 06/22/99

Sample dale: $06 / 2299$
Depth to water: 127.07 ft $(38.73 \mathrm{~m})$ below TOC
Water

Time: 8:38

\section{WELL MSB 43DD}

MEASUREMENTS CONDUCTED IN THE FIELD

Sample date: $06 / 22 / 99$
Depth to waler: $126.9 \mathrm{ft}(38.68 \mathrm{~m})$ below TOC

Time: $8: 40$

\section{WELL MSB 43TA}

MEASUREMENTS CONDUCTED IN THE FIELD

Sample date: 06/22/99 $\mathrm{H}(47.14 \mathrm{~m})$ below TOC

Time: 8:35

\section{WELL MSB 44A}

MEASUREMENTS CONDUCTED IN THE FIELD

Sample dale: 06/22/99

epth to water: $159.93 \mathrm{ft}(48.75 \mathrm{~m})$ below TOC

Water elevation: $216.97 \mathrm{ft}(66.13 \mathrm{~m}) \mathrm{msl}$

Time: 13:26

\section{WELL MSB 44B}

MEASUREMENTS CONDUCTED IN THE FIELD

Sample date: $06 / 22 / 99$ H $(46.86 \mathrm{~m})$ below TOC

Time: 13:25 


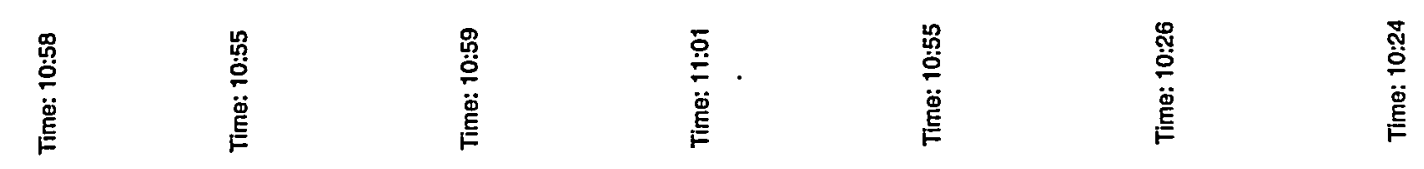
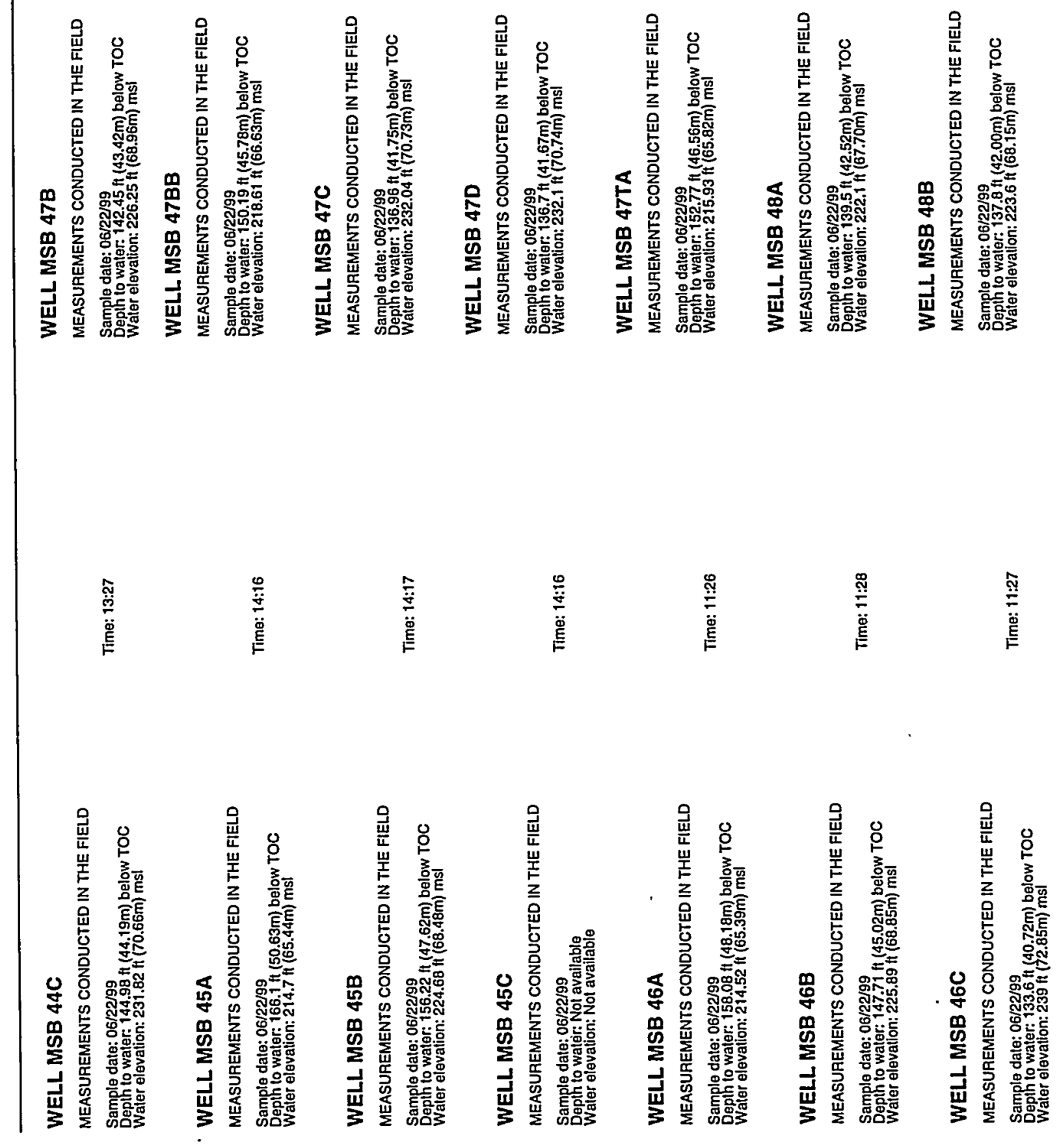


\section{WELL MSB 48C}

MEASUREMENTS CONDUCTED IN THE FIELD

Sample date: 06/22/99

Depth to waler: $138.15 \mathrm{ft}(42.11 \mathrm{~m})$ below TOC

\section{WELL MSB 48D}

MEASUREMENTS CONDUCTED IN THE FIELD

Sample date: 06/22/99

Depth to water: $130.04 \mathrm{ft}(39.64 \mathrm{~m})$ below TOC

Waler elevation: $232.56 \mathrm{ft}(70.89 \mathrm{~m}) \mathrm{msl}$

\section{WELL MSB 48TA}

MEASUREMENTS CONDUCTED IN THE FIELD

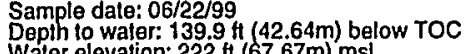

\section{WELL MSB 49A}

MEASUREMENTS CONDUCTED IN THE FIELD

Sample date: 06/24/99

Depth to waler: $137.42 \mathrm{tt}(41.89 \mathrm{~m})$ below TOC

\section{WELL MSB 49B}

MEASUREMENTS CONDUCTED IN THE FIELD

Sample date: 06/24/99

Depth to water: $131.2 \mathrm{ft}(39.99 \mathrm{~m})$ below TOC

Water elevation: $202.9 \mathrm{ft}(61.84 \mathrm{~m}) \mathrm{ms}$

\section{WELL MSB 49D}

MEASUREMENTS CONDUCTED IN THE FIELD

Sample date: 06/24/99

Deppth to water: $104.67 \mathrm{ft}(31.90 \mathrm{~m})$ below TOC
Water elevation: $229.63 \mathrm{ft}(69.99 \mathrm{~m}) \mathrm{msl}$

\section{WELL MSB 50B}

MEASUREMENTS CONDUCTED IN THE FIELD

Sample date: 06/23/99

Depth to waler: 21.48 tt $(6.55 \mathrm{~m})$ below TOC
WELL MSB 50D

MEASUREMENTS CONDUCTED IN THE FIELD

Sample date: 06/23/99

Weph

\section{WELL MSB 51B}

MEASUREMENTS CONDUCTED IN THE FIELD

Sample date: 06/23/99

Depth to water: 58.28 Ht $(17.76 \mathrm{~m})$ below TOC

Time: 14:43

\section{WELL MSB 51D}

MEASUREMENTS CONDUCTED IN THE FIELD

Sample date: 06/23/99

Depth to water: $51.63 \mathrm{ht}(15.74 \mathrm{~m})$ below TOC

Water elevation: $210.57 \mathrm{ft}(64.18 \mathrm{~m}) \mathrm{ms}$

WELL MSB 51DD

MEASUREMENTS CONDUCTED IN THE FIELD

Sample date: 06/23/99

Water elevation: Not available

Time: $14: 41$

\section{WELL MSB 52B}

MEASUREMENTS CONDUCTED IN THE FIELD

Sample date: 06/23/99

Depth to waler: $102.83 \mathrm{ft}(31.34 \mathrm{~m})$ below TOC
Waler elevation: $218.87 \mathrm{ft}(66.71 \mathrm{~m}) \mathrm{msl}$

Time: 10:45

\section{WELL MSB 52D}

MEASUREMENTS CONDUCTED IN THE FIELD

Sample date: 06/23/99 $25.79 \mathrm{~m})$ below TOC

Time: 10:47

\section{WELL MSB 538}

MEASUREMENTS CONDUCTED IN THE FIELD

Sample date: 06/23/99

Time: 11:44 

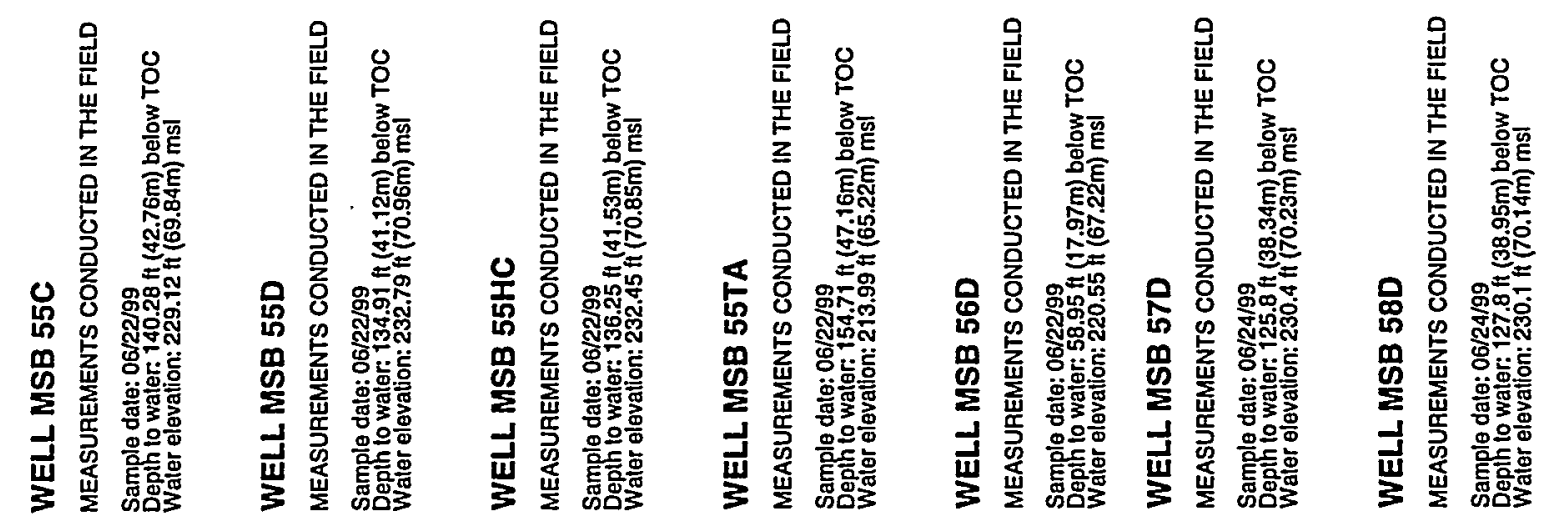

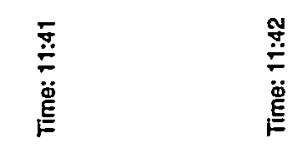
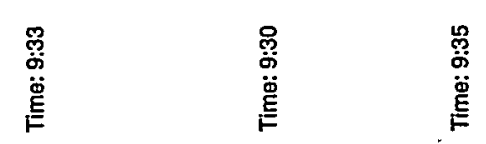

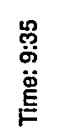

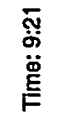
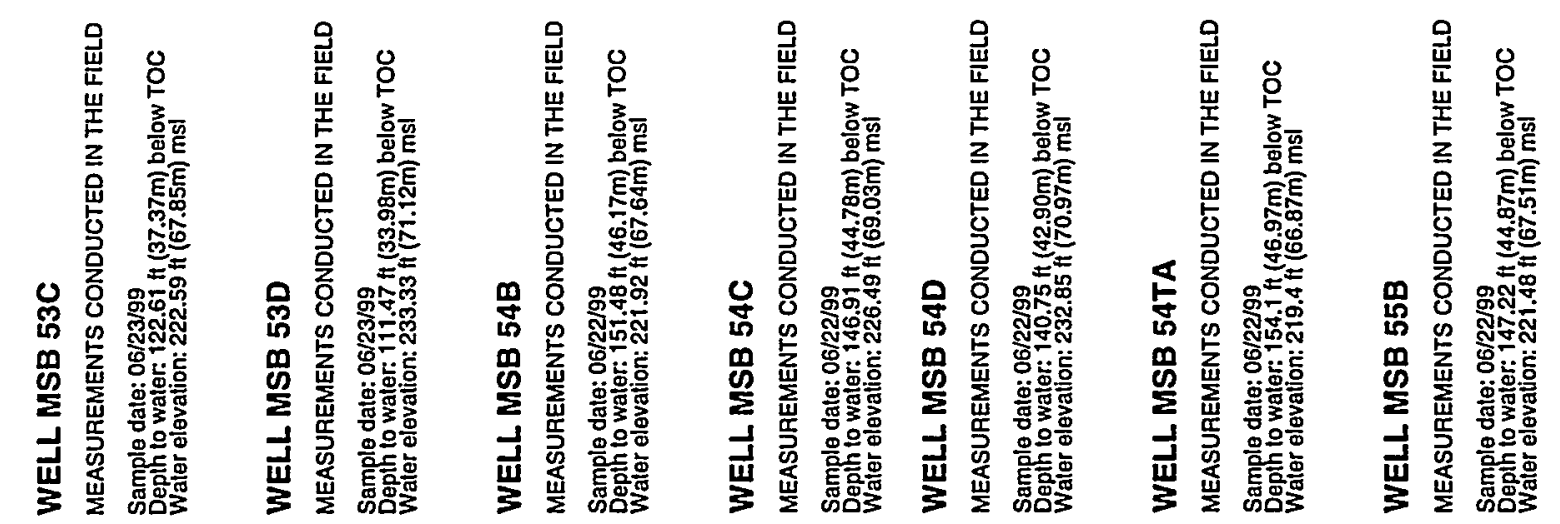


\section{WELL MSB 59D}

MEASUREMENTS CONDUCTED IN THE FIELD

Sample date: $06 / 23 / 99 \mathrm{H}(39.68 \mathrm{~m})$ below TOC

Water elevation: $229.13 \mathrm{ft}(69.84 \mathrm{~m}) \mathrm{msl}$

\section{WELL MSB 60D}

MEASUREMENTS CONDUCTED IN THE FIELD

Sample date: 06/24/99

(3)

Waler elevalion: $229.42 \mathrm{ft}(69.93 \mathrm{~m}) \mathrm{msl}$

\section{WELL MSB 61C}

MEASUREMENTS CONDUCTED IN THE FIELD

Sample date: 06/23/99

Depth to waler: $93.78 \mathrm{ft}(28.58 \mathrm{~m})$ below

\section{WELLL MSB 61D}

MEASUREMENTS CONDUCTED IN THE FIELD

Sample date: 06/23/99

(6.74m) ms

\section{WELL MSB 62B}

MEASUREMENTS CONDUCTED IN THE FIELD

Sample date: 06/24/99

Sample date: $06 / 24 / 99$
Depth to waler: $140.97 \mathrm{ft}(42.97 \mathrm{~m})$ below TOC
Water elevalion: $208.13 \mathrm{ft}(63.44 \mathrm{~m}) \mathrm{ms}$

Time: 18:04

\section{WELLL MSB 62C}

MEASUREMENTS CONDUCTED IN THE FIELD

Sample date: $06 / 24 / 99$
Depth to waler: $126.68 \mathrm{ft}(38.61 \mathrm{~m})$ below TOC
Water elevation: $222.42 \mathrm{At}(67.79 \mathrm{~m}) \mathrm{msl}$

\section{WELL MSB 62D}

MEASUREMENTS CONDUCTED IN THE FIELD

Sample date: $06 / 24 / 99 \mathrm{ft}(36.88 \mathrm{~m})$ below TOC

Time: 18:00

\section{WELL MSB 63B}

MEASUREMENTS CONDUCTED IN THE FIELD

Sample date: 06/24/99

Deph to waler: $138.61 \mathrm{ft}(42.25 \mathrm{~m})$ below TOC

Time: 18:11

\section{WELL MSB 63C}

MEASUREMENTS CONDUCTED IN THE FIELD

Sample date: 06/24/99

Depth to water: $127.2 \mathrm{ft}(38.77 \mathrm{~m})$ below TOC

Time: 18:14

WELL MSB 63D

MEASUREMENTS CONDUCTED IN THE FIELD

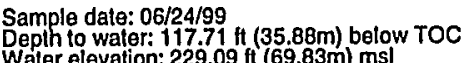

Time: 18:17

\section{WELL MSB 64B}

MEASUREMENTS CONDUCTED IN THE FIELD

Sample date: 06/23/99 $\mathrm{ft}(42.99 \mathrm{~m})$ below TOC

Time: 22:24

\section{WELL MSB $64 C$}

MEASUREMENTS CONDUCTED IN THE FIELD

Sample date: 06/23/99

Time: 22:25

\section{WELL MSB 640}

MEASUREMENTS CONDUCTED IN THE FIELD

Sample date: 06/23/99 $(37.14 \mathrm{~m})$ below TOC

Depth to water: $121.85 \mathrm{ft}(37.14 \mathrm{~m})$ below
Water elevalion: $226.75 \mathrm{ft}(69.1 \mathrm{~m}) \mathrm{msl}$

Time: 22:29

\section{WELL MSB 65D}

MEASUREMENTS CONDUCTED IN THE FIELD

Sample date: 06/24/99 $\mathrm{f}(35.71 \mathrm{~m})$ below TOC

Time: 22:29 
WELL MSB 66B

MEASUREMENTS CONDUCTED IN THE FIELD

Sample date: 06/22/99

Sample date: 06/22/99
Deph to water $165.25 \mathrm{~h}(50.37 \mathrm{~m})$ below TOC
Water elevation: $218.15 \mathrm{ft}(66.49 \mathrm{~m}) \mathrm{msl}$

\section{WELL MSB 66C}

MEASUREMENTS CONDUCTED IN THE FIELD

Sample date: 06/22/9

Depth to water: $155.81 \mathrm{ft}(47.49 \mathrm{~m})$ below TOC
Water elevation: $227.59 \mathrm{ft}(69.37 \mathrm{~m}) \mathrm{ms}$

\section{WELL MSB 66D}

MEASUREMENTS CONDUCTED IN THE FIELD

Sample date: 06/22/99

Depth to water: $117.1 \mathrm{H}(35.69 \mathrm{~m})$ below TOC
Waler elevation: $266.1 \mathrm{fH}(86.11 \mathrm{~m}) \mathrm{ms}$

\section{WELL MSB 66TA}

MEASUREMENTS CONDUCTED IN THE FIELD

Sample dale: 06/22/99
Depith to water: $176.83 \mathrm{ft}(53.90 \mathrm{~m})$ below TOC
Waler elevation: $205.87 \mathrm{tt}(62.75 \mathrm{~m}) \mathrm{ms}$

\section{WELL. MSB 67B}

MEASUREMENTS CONDUCTED IN THE FIELD

Sample date: 06/24/99

Sample dale: $06 / 24 / 99$ ( $44.89 \mathrm{~m})$ below TOC

\section{WELL MSB 67C}

MEASUAEMENTS CONDUCTED IN THE FIELD

Sample date: 06/24/99

Depth to water: $138 \mathrm{ft}(42.06 \mathrm{~m})$ below TOC
Water elevation: $226.8 \mathrm{ft}(69.13 \mathrm{~m}) \mathrm{msl}$

\section{WELL MSB 67D}

MEASUREMENTS CONDUCTED IN THE FIELD

Sample date: 06/24/99 $\mathrm{H}(40.30 \mathrm{~m})$ below TOC

Water elevation: $232.79 \mathrm{ft}(70.9 \mathrm{~m}) \mathrm{msl}$
Time: 11:16

Time: 11:14

Time: 11:19

Time: 21:28

Time: 21:30

Time: 21:31
WELL MSB 68B

MEASUREMENTS CONDUCTED IN THE FIELD

Sample dale: 06/24/99 $\mathrm{n}(37.78 \mathrm{~m})$ below TOC

Time: 21:37

\section{WELL MSB 68C}

MEASUREMENTS CONDUCTED IN THE FIELD

Sample dale: 06/24/99

Depth to water: $130.92 \mathrm{ft}(39.90 \mathrm{~m})$ below TOC

Time: 21:39

\section{WELL. MSB 68D}

MEASUREMENTS CONDUUCTED IN THE FIELD

Sample date: 06/24/99

Depth io water: $138.49 \mathrm{ft}(42.21 \mathrm{~m})$ below TOC

\section{WELL MSB 69B}

MEASUREMENTS CONDUCTED IN THE FIELD

Sample date: 06/22/99
Depth to water: $161.36 \mathrm{ft}(49.18 \mathrm{~m})$ below TOC
Water elevalion: $220.14 \mathrm{ft}(67.10 \mathrm{~m}) \mathrm{msl}$

Time: 9:50

\section{WELL MSB 69C}

MEASUREMENTS CONDUCTED IN THE FIELD

Sample date: 06/22/99

epih to waler: $154.2 \mathrm{ft}(47.00 \mathrm{~m})$ below TOC
Waler elevation: $227.4 \mathrm{ft}(69.31 \mathrm{~m}) \mathrm{msl}$

Time: 9:52

\section{WELLL MSB 69D}

MEASUREMENTS CONDUCTED IN THE FIELD

Sample date: $06 / 22 / 99$ (1) $(45.45 \mathrm{~m})$ below TOC

Time: 9:54

\section{WELL MSB 69TA}

MEASUREMENTS CONDUCTED IN THE FIELD

Sample date: 06/22/99

Time: 9:50 
WELLL MSB 70C

MEASUREMENTS CONDUCTED IN THE FIELD

Sample date: 06/24/99

\section{WELL MSB 70D}

MEASUREMENTS CONDUCTED IN THE FIELD

Sample date: 06/24/99 $\mathrm{H}(43.02 \mathrm{~m})$ below TOC

\section{WELL MSB 71B}

MEASUREMENTS CONDUCTED IN THE FIELD

Sample date: 06/23/99

Depth to water: $127.65 \mathrm{ft}(38.91 \mathrm{~m})$ below TOC

Water elevation: $217.05 \mathrm{f}(66.16 \mathrm{~m}) \mathrm{ms}$ !

\section{WELL MSB 72B}

MEASUREMENTS CONDUCTED IN THE FIELD

Sample date: 06/23/99

Sample date: 06/23/99 $\mathrm{H}(39.01 \mathrm{~m})$ below TOC

\section{WELL MSB 73B}

MEASUREMENTS CONDUCTED IN THE FIELD

Sample date: 06/24/99

Time: 19:31

\section{WELL MSB 74B}

MEASUAEMENTS CONDUCTED IN THE FIELD

Sample date: 06/23/99

Depth to water: $104.07 \mathrm{At}(31.72 \mathrm{~m})$ below TOC
Waler elevation: $210.43 \mathrm{ft}(64.14 \mathrm{~m}) \mathrm{msl}$

\section{WELL MSB 74C}

MEASUREMENTS CONDUCTED IN THE FIELD

Sample date: $06 / 23 / 99$
Depth to water: $104.6 \mathrm{ft}(31.88 \mathrm{~m})$ below TOC
WELL MSB 74D

MEASUREMENTS CONDUCTED IN THE FIELD

Sample date: 06/23/99 Depth to water: $3.3 \mathrm{H}(25.39 \mathrm{~m})$ below TOC
Water elevation: $231.8 \mathrm{H}(70.65 \mathrm{~m}) \mathrm{msl}$

Time: 9:14

\section{WELL MSB 75B}

MEASUREMENTS CONDUCTED IN THE FIELD

Sample date: 06/23/99

Depth to waler: $117.21 \mathrm{ft}(35.73 \mathrm{~m})$ below TOC

Time: 9:41

\section{WELL MSB 75C}

MEASUREMENTS CONDUCTED IN THE FIELD

Sample date: 06/23/99

Time: 9:43

Waier glevation: $209.25 \mathrm{ft}(63.78 \mathrm{~m}) \mathrm{ms}$ )

\section{WELL MSB 76C}

MEASUREMENTS CONDUCTED IN THE FIELD

Sample date: 06/23/99

Depth to waler: $131.82 \mathrm{H}(40.18 \mathrm{~m})$ below TOC

Time: 19:00

\section{WELL MSB 77B}

MEASUREMENTS CONDUCTED IN THE FIELD

Sample date: 06/23/99

Depth to water: $136.15 \mathrm{n}(\mathrm{n}) .50 \mathrm{~m})$ below TOC
Water elevation: $221.05 \mathrm{t}(67.38 \mathrm{~m}) \mathrm{msl}$

Time: 11:32

\section{WELL MSB 77C}

MEASUREMENTS CONDUCTED IN THE FIELD

Sample date: 06/23/99 $\mathrm{ft}(40.76 \mathrm{~m})$ below TOO

Time: 11:33

\section{WELL MSB 77D}

MEASUREMENTS CONDUCTED IN THE FIELD

Sample date: 06/23/99

Depth to water: 123.42 ft $(37.62 \mathrm{~m})$ below TOC

Time: 11:35 

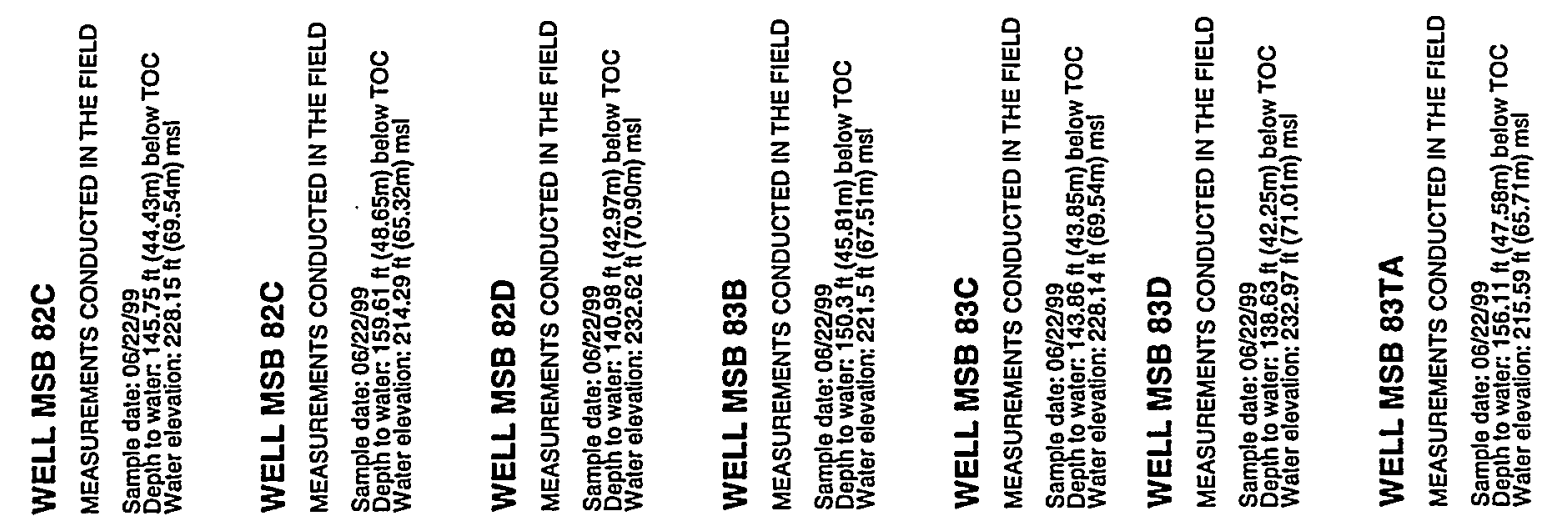

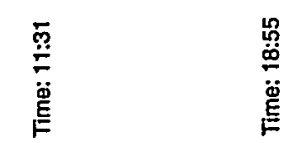
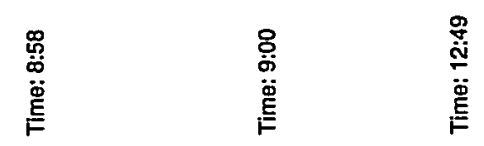

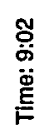

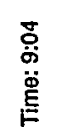
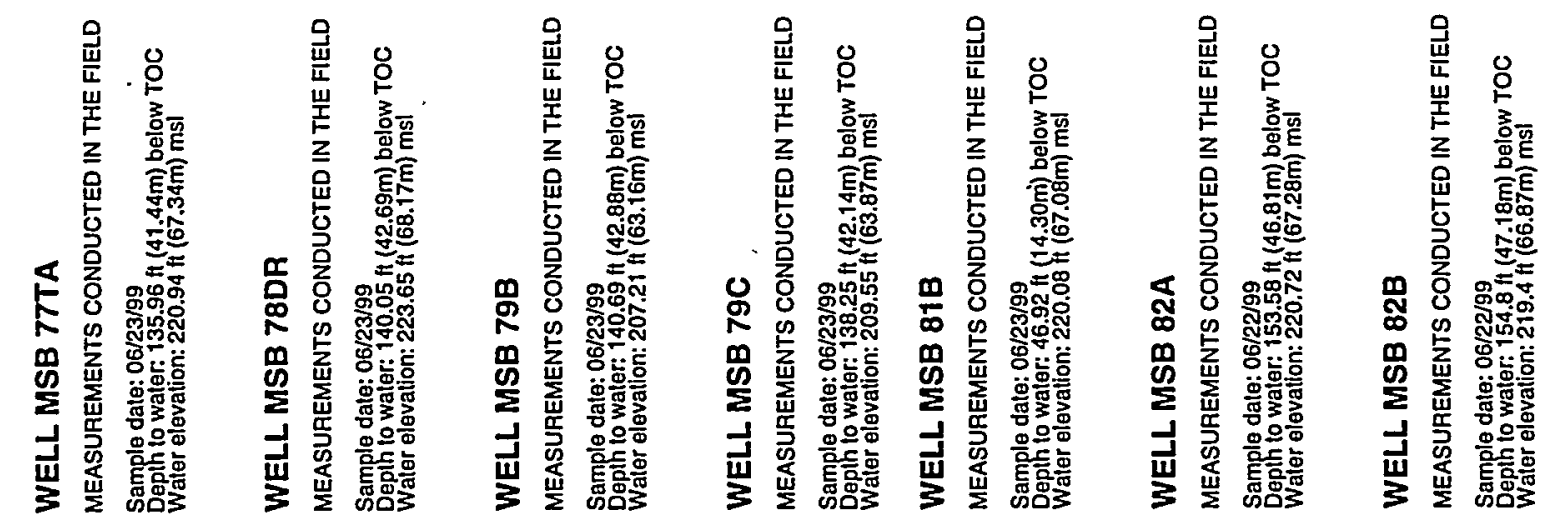

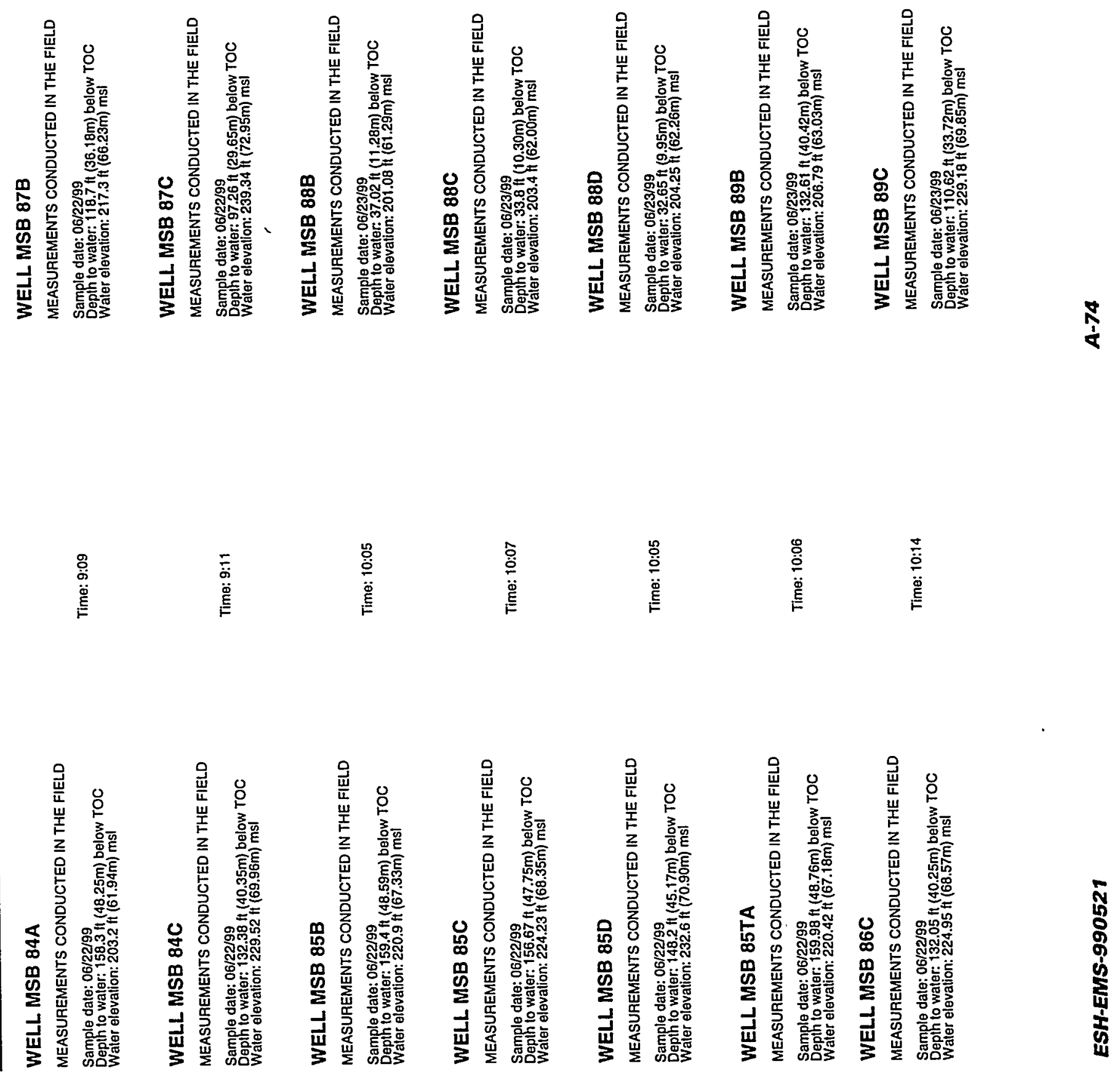
WELL SRW 1

MEASUREMENTS CONDUCTED IN THE FIELD

Sample date: 06/23/99

Water elevalion: $212.6 \mathrm{tt}(64.80 \mathrm{~m}) \mathrm{msl}$

\section{WELL SRW 1 BB}

MEASUREMENTS CONDUCTED IN THE FIELD

Sample date: 06/23/9

Dephh o waler: $108.9 \mathrm{ft}(33.19 \mathrm{~m})$ below TOC
Water elevation: $207.4 \mathrm{ft}(63.22 \mathrm{~m}) \mathrm{msl}$

\section{WELL SRW 2}

MEASUREMENTS CONDUCTED IN THE FIELD

Sample date: 06/23/99

Depth to water: $106.6 \mathrm{Ht}(32.49 \mathrm{~m})$ below TOC

\section{WELL SRW 2A}

MEASUREMENTS CONDUCTED IN THE FIELD

Sample date: 06/23/99 $(34.80 \mathrm{~m})$ below TOC

Water elevation: 206.44 ft $(6202 \mathrm{~m}) \mathrm{msl}$

\section{WELL SRW 2B}

MEASUREMENTS CONDUCTED IN THE FIELD

Sample date: 06/23/99

Sample date: 06/23/99
Depth io water: $113.11 \mathrm{Ht}(34.48 \mathrm{~m})$ below TOC
Water elovation: 207.49 (t) $(63.24 \mathrm{~m}) \mathrm{msl}$

WELL SRW 3A

MEASUREMENTS CONDUCTED IN THE FIELD

Sample date: $06 / 23 / 99$
Depth to water: $160.85 \mathrm{H}(49.03 \mathrm{~m})$ below TOC
Water elevation: $171.25 \mathrm{ft}(52.20 \mathrm{~m}) \mathrm{msl}$

\section{WELL SRW 3BB}

MEASUREMENTS CONDUCTED IN THE FIELD

Sample date: 06/23/99

Depth to water: $123.85 \mathrm{ft}(37.75 \mathrm{~m})$ below TOC

Time: 19:12
Time: 19:21

Time: 19:15

Time: 19:16

Time: 19:18

Time: 19:11

WELL SRW 4

MEASUREMENTS CONDUCTED IN THE FIELD

Sample date: $06 / 23 / 99$

Time: 19:48

\section{WELL SRW 4BB}

MEASUREMENTS CONDUCTED IN THE FIELD

Sample dale: 06/23/99

Time: 19:48

\section{WELL SRW 5}

MEASUREMENTS CONDUCTED IN THE FIELD

Sample date: 06/23/99

\section{WELL SRW 6}

MEASUREMENTS CONDUCTED IN THE FIELD

Sample dale: 06/23/99

Sample dale: $06 / 23 / 99$
Depth to waler: $95.55 \mathrm{ft}(29.12 \mathrm{~m})$ below TOC
Waler elevation: $212.15 \mathrm{Ht}(64.66 \mathrm{~m}) \mathrm{msl}$

Time: 19:24

\section{WELL SRW 7}

MEASUREMENTS CONDUCTED IN THE FIELD

Sample date: $06 / 23 / 99$

Water elevation: Not available

Time: 19:32

\section{WELL SRW 8}

MEASUREMENTS CONDUCTED IN THE FIELD

Sample dale: 06/23/99

Wepth to water: 79 it $(24.08 \mathrm{~m})$ below TOC

Time: 20:17

\section{WELL SRW 8BB}

MEASUREMENTS CONDUCTED IN THE FIELD

Sample date: 06/23/99 $26.11 \mathrm{~m}$ ) below TOC

Time: 20:17 


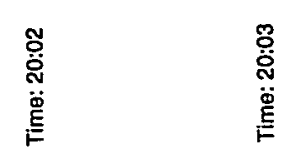

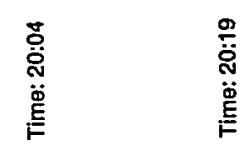

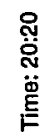

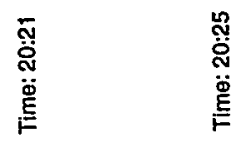

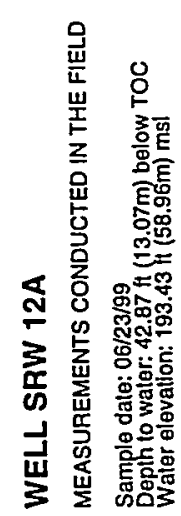

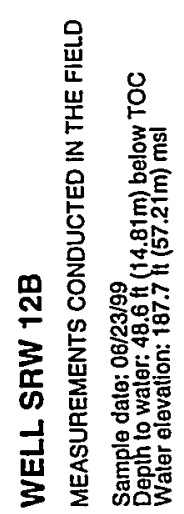

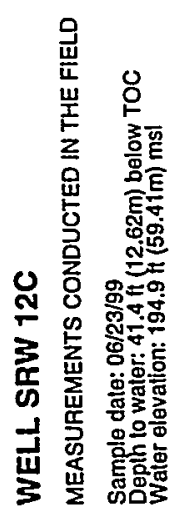
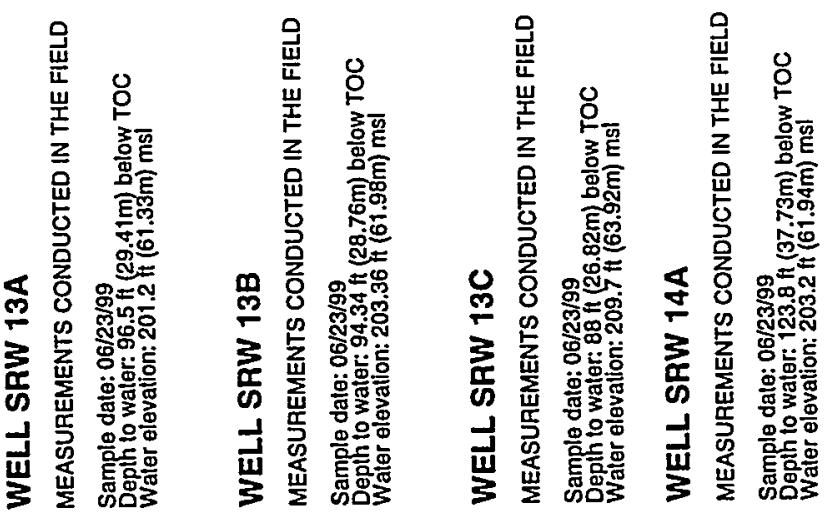

$\stackrel{0}{1}$

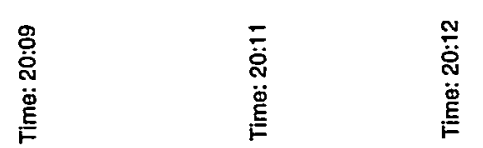

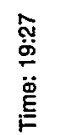

$\frac{\bar{s}}{\stackrel{\dot{0}}{0}}$

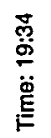

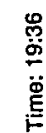

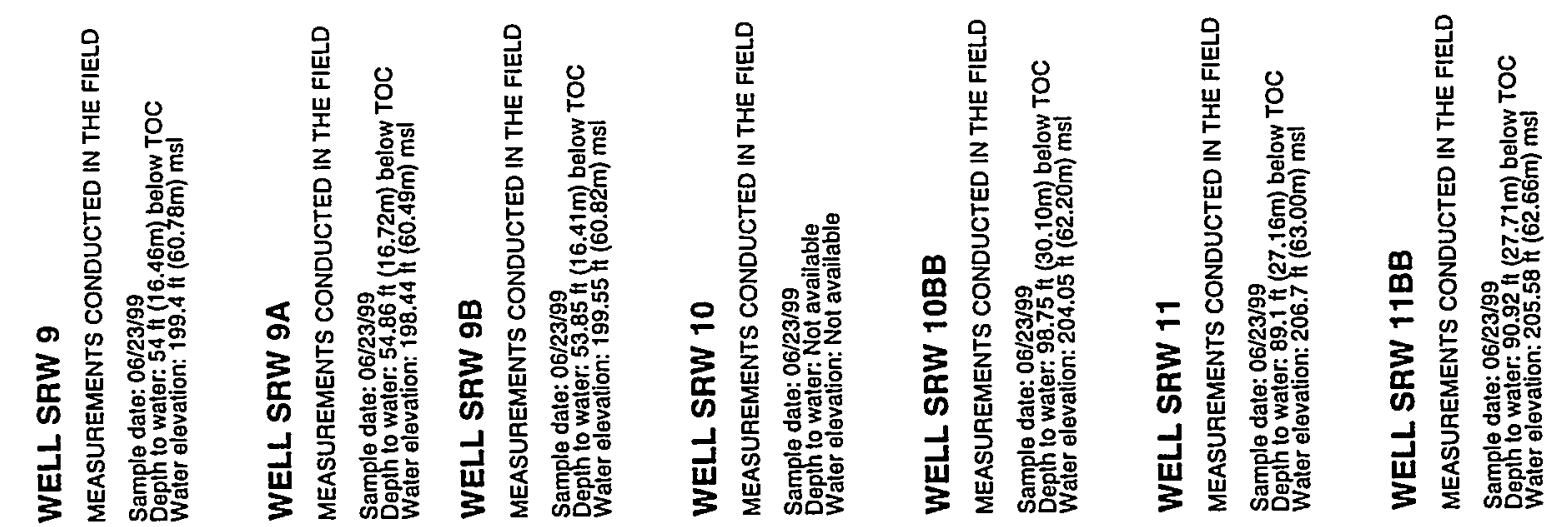


WELL SRW 14B

MEASUREMENTS CONDUCTED IN THE FIELD

Sample date: 06/23/99

Depth lo waler: $121.75 \mathrm{H}(37.11 \mathrm{~m})$ below TOC

WELL SRW 14C

MEASUREMENTS CONDUCTED IN THE FIELD

Sample date: 06/23/99

Water elevation: Not available

\section{WELL SRW 15A}

MEASUREMENTS CONDUCTED IN THE FIELL

Sample date: 06/23/99

Wath to waler: $110.08 \mathrm{ft}(33.55 \mathrm{~m})$ below TOC

\section{WELL SRW 15B}

MEASUREMENTS CONDUCTED IN THE FIELD

Sample date: 06/23/99
Depth to waier: $109.7 \mathrm{ft}(33.44 \mathrm{~m})$ below TOC
Water elevalion: $209.4 \mathrm{ft}(63.83 \mathrm{~m}) \mathrm{msl}$

\section{WELL SRW 15C}

MEASUREMENTS CONDUCTED IN THE FIELD

Sample date: 06/23/99

WELLL SRW 16A

MEASUREMENTS CONDUCTED IN THE FIELD

Sample date: 06/23/99

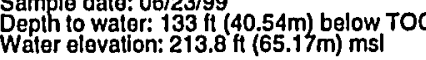

WELL SRW 16B

MEASUREMENTS CONDUCTED IN THE FIELD

Sample dale: $06 / 23 / 99$.

Depth to water: 132.28 $\mathrm{H}(40.32 \mathrm{~m})$ below
Waler elevation: $214.52 \mathrm{tt}(65.39 \mathrm{~m}) \mathrm{ms}$

\section{WELL SRW 16C}

MEASUREMENTS CONDUCTED IN THE FIELD

Sample data: 061231999 . $(40.11 \mathrm{~m})$ below TOC

Time: 20:52

\section{WELL SRW 17BB}

MEASUREMENTS CONDUCTED IN THE FIELD

Sample date: 06/23/99

epth to waler: $121.31 \mathrm{ft}(36.98 \mathrm{~m})$ below TOC

\section{WELL SRW 17C}

MEASUREMENTS CONDUCTED IN THE FIELD

Sample date: 06/23/99

Water to waler: $121.25 \mathrm{ft}(36.96 \mathrm{~m})$ below
Wation: $212.35 \mathrm{ft}(64.73 \mathrm{~m}) \mathrm{msl}$

Time: 20:45

\section{WELL SRW 17DR}

MEASUREMENTS CONDUCTED IN THE FIELD

Sample dale: 06/23/99

Time: 20:47 


\section{Appendix B. Analytical Results}

This section presents the field and analytical results for samples collected during second quarter 1999 . The results tables are presented in alphabetical order by well series and in numerical order within each series. The Site Index section of this report contains the area name(s) for each series.

The tabular data contain all field and analytical results for well samples collected during this quarter. Results of laboratory analyses on sampling blanks are in Appendix $\mathbf{C}$ of this report.

Due to space limitations, the following abbreviations are used in the analytical and sampling blanks results tables.

\begin{tabular}{ll}
\hline Method or Analyte & Abbreviation \\
\hline EICHROMTC1M & EICHROM \\
MMES16009MOD & MMES16009 \\
ASTMD888-92B & ASTMD888 \\
EICHROMSRW01M. & EICHROMS \\
5-day biochemical oxygen demand & 5 -day biochem oxygen demand \\
ESESOPM008 & ESOPM008 \\
ESESOPM017 & ESOPM017 \\
ESESOPM020 & ESOPM020 \\
ESESOPM022 & ESOPM022 \\
ESESOPM029 & ESOPM029 \\
ESESOPM030 & ESOPM030 \\
ESESOPM031 & ESOPM031 \\
ESESOPM032 & ESOPM032 \\
\hline
\end{tabular}

The Field Notes section of this report contains information about the inability to collect samples, unusual conditions during sample collection, and samplers' observations.

Properly defined and used modifiers or qualifiers can be a key component in assessing data usability. Modifiers designated by EPD/EMS and provided to the primary laboratories are defined below.

Key to the Tables

E exponential notation (e.g., $1.1 E-09=1.1 \times 10^{-9}=0.0000000011$ )

EMS EMS codes

F Flag

FG EPA functional guideline codes

Fibers $/ L \quad$ fibers per liter 


\begin{tabular}{cl}
$\mu \mathrm{Ci} / \mathrm{mL}$ & microcuries per milliliter \\
$\mu \mathrm{g} / \mathrm{L}$ & micrograms per liter \\
$\mu \mathrm{S} / \mathrm{cm}$ & Microsiemens per centimeter \\
$\mathrm{mg} / \mathrm{L}$ & milligrams per liter \\
$\mathrm{msl}$ & mean sea level \\
$\mathrm{NTU}$ & Nephelometric turbidity units \\
$\mathrm{S}$ & EPA STORET codes \\
$\mathrm{SQL}$ & sample quantitation limit \\
$\mathrm{TOC}$ & top of casing \\
\hline
\end{tabular}

EPA Functional

\section{Definition}

(Blank) Data not remarked. The analytical result is acceptable for use as reported.

$J \quad T h e$ analyte was positively identified; the associated numerical value is an estimated concentration of the analyte in the sample.

$\mathrm{N} \quad$ The analysis indicated the presence of an analyte for which there is presumptive evidence to make a tentative identification. Use for all TIC results.

$\mathrm{R} \quad$ The sample results are rejected due to serious deficiencies in the ability to analyze the sample and meet quality control criteria. The presence or absence of the analyte cannot be verified. Assignment of $R$ requires approval by the appropriate WSRC data validation coordinator.

U The analyte was analyzed for but was not detected above the reported sample quantitation limit.

NJ The analysis indicates the presence of an analyte that has been tentatively identified and the associated numerical value represents its approximate concentration.

UJ The analyte was not detected above the reported sample quantitation limit. The reported quantitation limit is approximate, and may not represent the actual limit of quantitation necessary to accurately and precisely measure the analyte in the sample.

\section{EPA STORET COdes Definition}

(Blank) Data not remarked.

A The result is the mean of two or more results.

$\mathrm{B \dagger} \quad$ The result is based on colony counts outside the acceptance range.

C The result is calculated. 
D Field measurement.

E† Extra samples were taken at composite stations.

F Indicates female of the species.

G The result reported is the maximum of two or more results.

$\mathrm{H} \quad$ The result is from a field kit determination and may not be accurate.

I The result is less than the SsEQL, but equal to or greater than the MDL.

J The result is estimated.

$\mathrm{K}$ The actual concentration is known to be less than the reported result.

$L \quad$ The actual concentration is known to be greater than the reported result.

M Indicates male of the species.

$N \downarrow \quad$ There is presumptive evidence of the presence of the analyte.

- The sample was received by the laboratory, but the analysis was lost or not fortnd.

Pf Too numerous to count.

Q The sample was held beyond the normal holding time prior to analysis.

$\mathrm{RT} \quad$ There was significant rain in the past 48 hours.

S Laboratory test.

T† The result is less than the criteria of detection.

$U \quad$ Undetermined sex of the species.

$\checkmark \quad T$ The analyte was detected in both the method blank and the sample.

W† The result is less than the lowest reportable under TSTORET code.

$\mathrm{X}+\quad$ The value is from a quasi-vertically integrated sample.

$Y \quad T h e$ result is from an unpreserved or incorrectly preserved sample; the data may not be accurate.

$\mathrm{Z \dagger} \quad$ There were too many colonies present to count (TNTC); the numeric value represents the filtration volume.

T The code is not currently used for EMS/EGG programs, but may be used in the future or in some other SRS programs.

- Indicated STORET code or secondary code definition is redundant to a Functional Guideline code and will not be used at this time.

\section{EMS Codes Definition}

(Blank) Data not remarked. The analytical result is acceptable for use as reported.

A Compound identification criteria were not met. 
B Not currently. used.

C LCS or BS criteria were not met.

D ICP serial dilution criteria were not met.

E Not currently used.

F Not currently used.

G Not currently used.

$\mathrm{H}$

Internal standard criteria were not met when the IS was used for quantitation.

1

K

L

M

$N$

0

$P$

Q

R

S

$T$

$\mathrm{U}$

V

W

$x$

Y

Z
Matrix spike recovery was not within the control limits.

A tentatively identified compound is a suspected aldol-condensation product.

Initial or continuing calibration criteria were not met.

Not currently used.

Not currently used.

Surrogate or tracer spike recovery is out of specification.

Graphite fumace atomic absorption QC

a. Duplication injection criteria were not met.

b. Post-digestion spike recovery was not within control limits and the sample absorbance is $>50 \%$ of the post-digestion spike absorbance.

Not currently used.

Not currently used.

The sample was analyzed by the method of standard additions.

Not currently used.

Not currently used.

Not currently used.

Graphite furnace atomic absorption QC: the post-digestion spike recovery is not within control limits and the sample absorbance is $<50 \%$ of the post-digestion spike absorbance.

The laboratory duplicate RPD or MS/MSD RPD was not within control limits.

Not currently used.

Not currently used.

Matrix interference is present.

The analyte was detected in both the sample and associated field blank.

The analyte was detected in both the sample and associated rinsate.

The analyte was detected in both the sample and associated trip blank.

The field duplicate RPD was not within control limits. 


\section{Field Qualifiers}

Sample interference field qualifiers were added to the field data in the analytical results tables beginning fourth quarter 1996. The qualifiers describe sampling interferences encountered during sample collection that could affect analytical results. They are used to qualify analytical data based on field conditions. Due to space limitations, the sample interference field qualifiers are referred to as field qualifiers in the following table and in the field data section of the analytical results tables.

\section{Field Qualifiers Definition}

A

B

C

G

H

N

S

U

V

$\mathrm{X}$
The pump was surging excessively. Aeration could cause oxidation reactions and loss of volatiles (low results). Analytical results may be of poor precision (high variability) due to sampling bias. The sample qualifier shall include an $A$ if the site code is an $A$.

If the method code for a sample is $B$, then the sample qualifier shall include a $B$. This indicates that an open bucket bailer was used to collect the sample, which typically agitates the sample, increasing aeration and suspended solids. All analytical results may be of poor precision, volatile organic results may be biased low, and some metal and radionuclide results may be biased high.

Analytical results may be unrepresentative of true values due to reactions with metal well casing. This value will be automatically filled in if the casing type in the well inventory table is Al, CS, Iron, SS, or Steel. Analytical results for some metals and radionuclides may be higher or lower than actual groundwater concentrations.

If the method code for a sample is $G$, then the sample qualifier shall include a $G$. This indicates that an open bucket bailer was used to collect the sample without purging the well to attain stabilized field parameters. The grab sample method collects water that has undergone chemical reactions with the atmosphere and typically agitates the sample, increasing aeration and suspended solids. All analytical results may be of poor precision, volatile organic results may be biased low, and some metal and radionuclide results may be biased high. Analytical results may differ significantly for actual groundwater concentrations.

Analytical results may be unrepresentative of actual groundwater concentrations due to an elevated $\mathrm{pH}$, possibly due to well installation materials (drilling mud, grout). Results for some inorganic constituents (i.e., sodium, metals, radionuclides) may be affected. If the $\mathrm{pH}$ for a sample is greater than eight, then the sample qualifier shall include an $H$.

Analytical results may be unrepresentative of actual groundwater concentrations due to well installation or formation interferences causing elevated turbidity. Results for particle reactive constituents (i.e., metals, radionuclides) may be elevated. If the turbidity for a sample is greater than $15 \mathrm{NTU}$, then the sample qualifier shall include an $N$.

If the sample method is an $S$, then the sample qualifier shall include an $S$. Single-speed centrifugal submersible pump flow rates vary from 1 to $15 \mathrm{gpm}$, and agitation of the sample may occur at higher flow rates, causing poor precision, low volatile organic results, or elevated metal or radionuclide results.

One or more of the field parameters (i.e., $\mathrm{pH}$, conductivity, turbidity) did not stabilize prior to sample collection. The results may be of poor precision (high variability) due to sampling bias. The sample qualifier shall be a $U$ if the stabilized field is $N$ or the method code is $G$.

If the method code is a $V$, then the sample qualifier shall include a $V$. Sample collection with variable-speed pumps indicates that flow rates were less than one liter per minute. Sample collection at low flow rates provides the best estimates of actual groundwater concentrations due to reduced sampling bias.

If the site code is an $X$, then the sample qualifier shall include an $X$. Analytical results may be of poor precision for many constituents, and volatile organic results may be biased low because the well went dry during purging. 


\section{Calculation of Alkalinity Relationships}

The results obtained from the phenolphthalein and total alkalinity determinations offer a means for stoichiometric classification of the three principal forms of alkalinity present in many waters. The classification ascribes the entire alkalinity to bicarbonate, carbonate, and hydroxide, and assumes the absence of other (weak) inorganic or organic acids, such as silicic, phosphoric, and boric acids. It further presupposes the incompatibility of hydroxide and bicarbonate alkalinities. Because the calculations are made on a stoichiometric basis, ion concentrations in the strictest sense are not represented in the results, which may differ significantly from actual concentrations, especially at $\mathrm{pH}>10$. According to this scheme:

(1) Carbonate $\left(\mathrm{CO}_{3}{ }^{2}\right)$ alkalinity is present when phenolphthalein alkalinity is not zero but is less than total alkalinity.

(2) Hydroxide $(\mathrm{OH})$ alkalinity is present if phenolphthalein alkalinity is more than half the total alkalinity.

(3) Bicarbonate $\left(\mathrm{HCO}_{3}\right)$ alkalinity is present if phenolphthalein alkalinity is less than half the total alkalinity. These relationships may be calculated by the following scheme, where $P$ is phenolphthalein alkalinity and $T$ is total alkalinity:

Select the smaller value of $P$ or $(T-P)$. Then, carbonate alkalinity equals twice the smaller value. When the smaller value is $P$, the balance $(T-2 P)$ is bicarbonate. When the smaller value is $(T-P)$, the balance $(2 P-T)$ is hydroxide. All results are expressed as $\mathrm{CaCO}_{3}$.

\begin{tabular}{llll}
\hline $\begin{array}{l}\text { If Phenolphthalein } \\
\text { Alkalinity Result }=\end{array}$ & $\begin{array}{l}\text { then Hydroxide } \\
\text { Alkalinity }=\end{array}$ & $\begin{array}{l}\text { then Carbonate } \\
\text { Alkalinity }=\end{array}$ & $\begin{array}{l}\text { then Bicarbonate } \\
\text { Alkalinity }=\end{array}$ \\
\hline 0 & 0 & 0 & Total Alk \\
$<1 / 2$ Total Alk & 0 & 2 (Phen Alk) & Total Alk - 2(Phen Alk) \\
$=1 / 2$ Total Alk & 0 & 2 (Phen Alk) & 0 \\
$>1 / 2$ Total Alk & 2(Phen Alk) - Total Alk & 2 (Total Alk - Phen Alk) & 0 \\
Phen Alk = Total Alk & Total Alk & 0 & 0 \\
\hline
\end{tabular}


WELL BGO 1D

MEASUREMENTS CONDUCTED IN THE FIELD

Sample date: $05 / 17 / 199$

Water el

gp. conduclance: $44 \mu \mathrm{S} / \mathrm{cm}$

Water evacuated from the well prior to sampling: 22 gal

ANALYSES

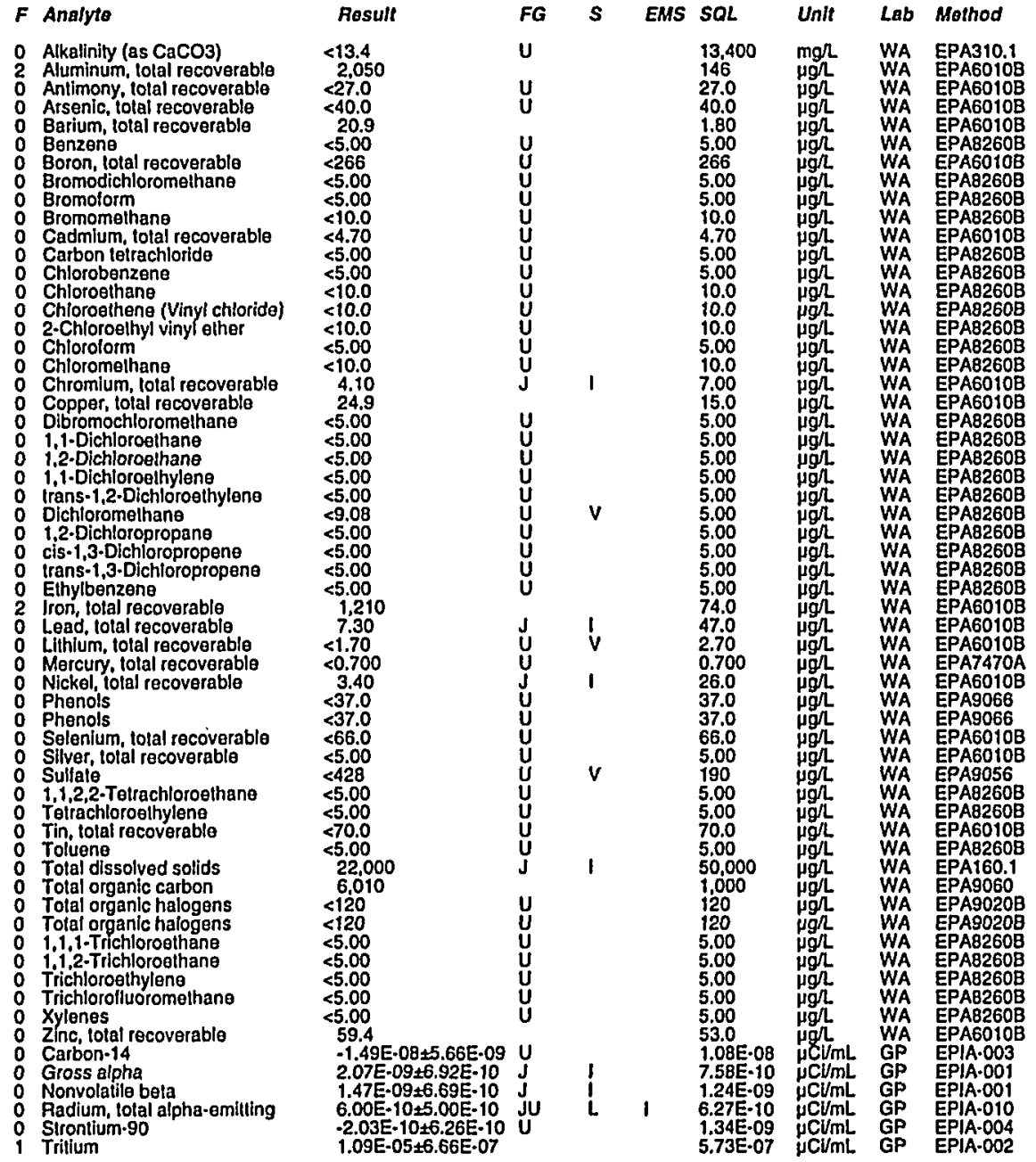

Waler temperalure: $24.4^{\circ} \mathrm{C}$

Air temperalure: $22,3{ }^{2}$
Tolal alkalinity (as CaCO3): $0 \mathrm{mg} /$
Phenolphthalein alkalinity: $0 \mathrm{mg} / \mathrm{L}$

\section{WELL BGO 2D}

MEASUREMENTS CONDUCTED IN THE FIELD

Sample date: 06/21/99

Wepler to waler: Nol available
Water el

$\mathrm{pH}: 4.4$

Water evacualed from the well prior to sampling: $\mathbf{4 6} \mathrm{gat}$

Water temperature: $22.1^{\circ} \mathrm{C}$

Total alkalinity (as Caco3): $0 \mathrm{mg} /$

ANALYSES

$F$ Analyto

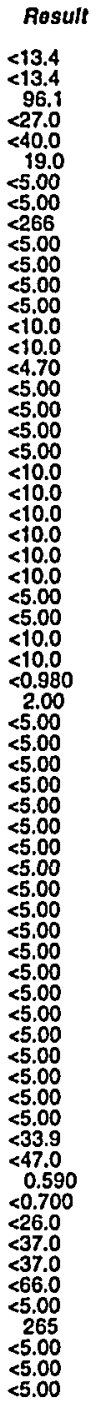

Alkalinity (as $\mathrm{CaCO}$ )

Aluminum, total recovorable
o Antimony, total recoverable
Arsenic, total recoverable

Arsenic, lotal recoverablo

Benzenti

Boron, total recoverable

Bromodichloromethan

Bromolorm

Bromomethane

iolal recoverable

Carbon teirrachlorid

Chlorobenzens

Choroethene (Vinyl chloride)

2.Chloroelhyl vinyl ether

Chloroform

Chloromethane

Chromilum, total recoverabla

Copper, loial recoverable

Dibromochloromethan

1,1 -Dichloroethan

1.2.Dichloroethane

i. Ochoroenyleno

trans-1,2-Dichloroeshylen

Dichloromethan

1.2. Dichloropropane

o ciss-1,3.Dlchroropropene

trans-1, 1 - Dichloropropene

Eithylbenzene

Iron, lotal recoverable

Lithium, total recoverablo

Mercury, lotal recoverablo

Phenols

Selenium, total recoverab

Silver, tolal rocoverablo

1,1,2,2-Tetrachloroethane

7 s

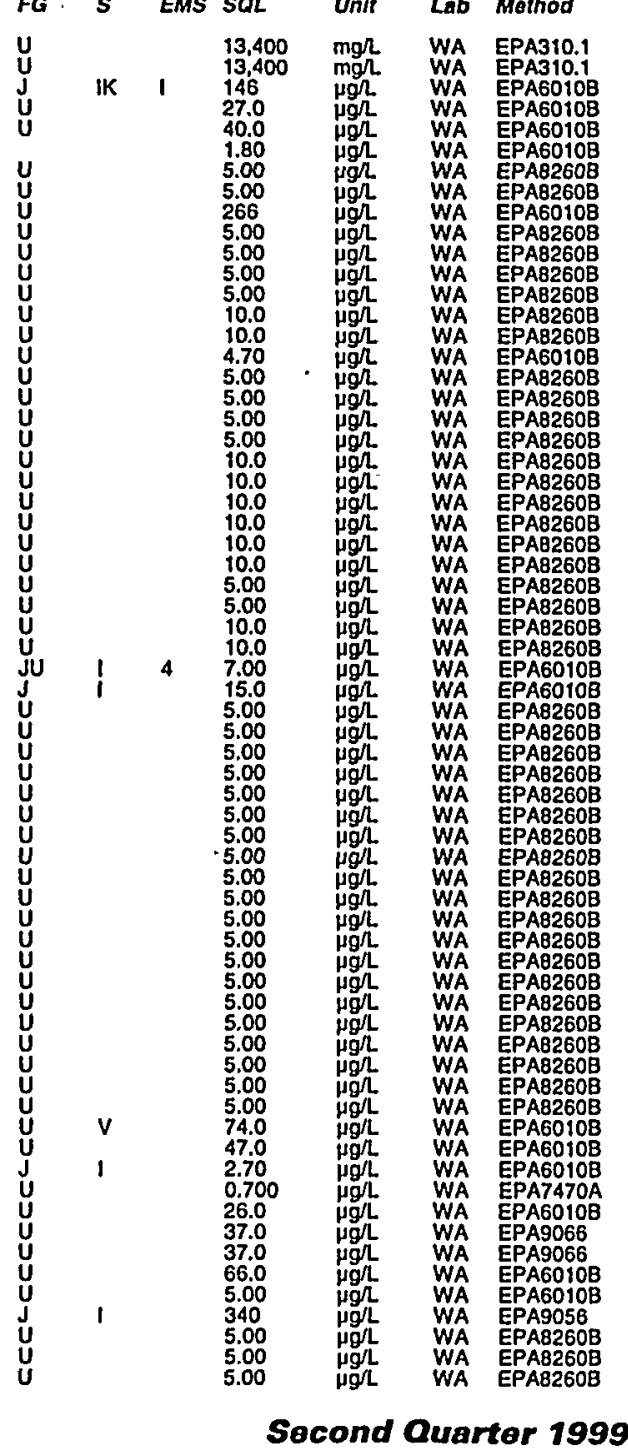


ANALYTICAL RESULTS

Well BGO 2D collected on 06/21/99 (cont.)

$F$ Analyte

o Tetrachlorosthylene Toluene

0 Tolal dissolved solids

Tolal dissolved solids

Tolal organic halogens

1,1,1-Trichloroethane

1,1,2. Trichloroethane

Trichloroethylene

Trichlorolluoromethane

xylenes

Zylenes

Carbon-14

Gross alpha

Radium, tolal alpha-emilling

Strontium-90

Tritium

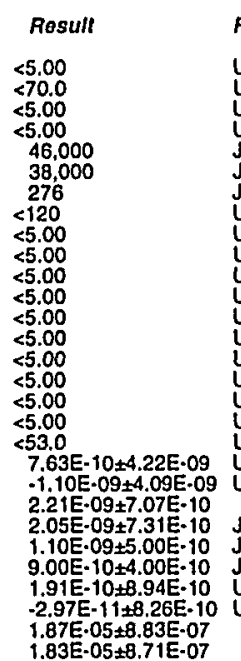

\section{WELL BGO $3 A$}

MEASUREMENTS CONDUCTED IN THE FIELD

Sample date: $05 / 18 / 99 \mathrm{ft}(39.3 \mathrm{~m})$ below TOC

Whater elevati 6.6

Sp. conductance: $120 \mu \mathrm{S} / \mathrm{cm}$

Water evacuated from the well prior to sampling: $28 \mathrm{ga}$

ANALYSES

$F$ Analyto

Result
48.9
37.7
36.5
$<27.0$
$<27.0$
$<40.0$
$<40.0$
80.1
74.1
55.00
$<266$
$<266$
$<5.00$
25.00
$<10.0$
24.70
$<4.70$
25.00
25.00
$<10.0$
210.0
$<10.0$
25.00
$<10.0$
3.00
3.00
2.40
2.30
$<5.00$
$<5.00$
25.00
$<5.00$

- Alkalinity (as $\mathrm{CaCO}$ )

Aluminum, tolal recoverable

Antimony, total recoverable

Anlimony, lotal recoverablo

Arsenic, total recoverab

Barium, lotal recoverable

Benzena

Boron, total recoverable

Bromodichloromethane

0 Bromolorm

Cadmium, total recoverable

Cadmium, tolal recoverabla

Carbon tetrachlorid

Chlorobenzene

Chloroethene (Vinyl chloride)

2.Chioroethy

Chloromethan

Chromium, total recoverable

Choper

Copper, total recoverable

1,j-Dichloroethane

1.,-Dichloroethane

ESH-EMS-990521
Well BGO $3 A$ collecled on 05/18/99 (cont.)

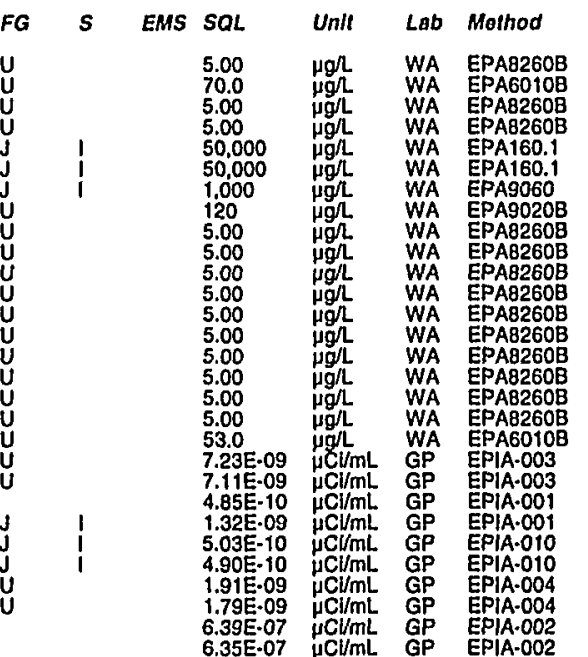

Time: 13:20

Wirter lemperalure: $21.9^{\circ} \mathrm{C}$ Total alkalinity (as CaCO3): $38 \mathrm{mg} / \mathrm{L}$ Phenolphthalein alkalinity: $0 \mathrm{mg} h$

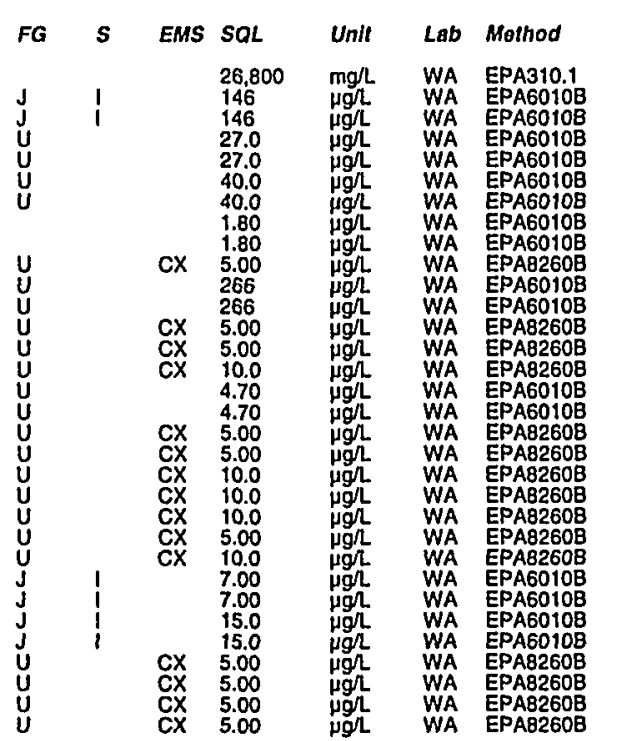

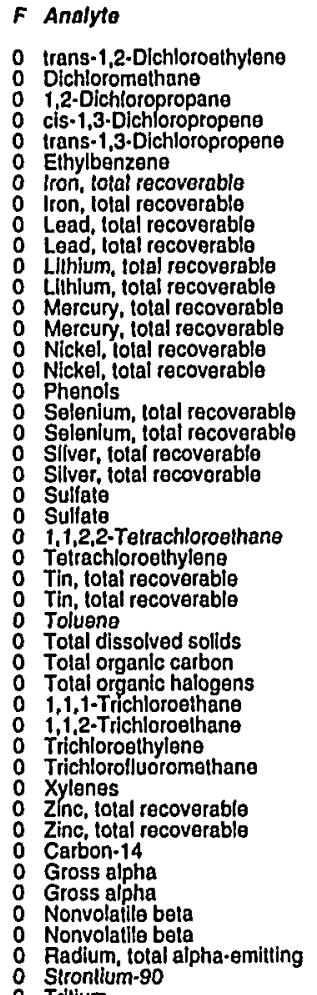

Result

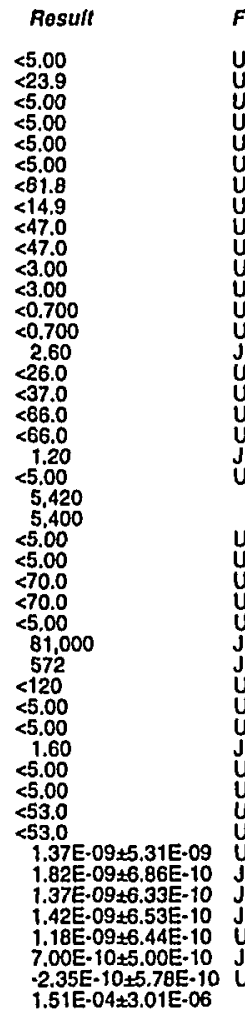

ELL BGO 3C

MEASUREMENTS CONDUCTED IN THE FIELD

Sample date: 05/19/99

Water waler: Not available

$\mathrm{gH}$ : Not avallable
$\mathrm{Sp}$. conductance: Not available

No water was evacuated from the well prior to sampling. ANALYSES

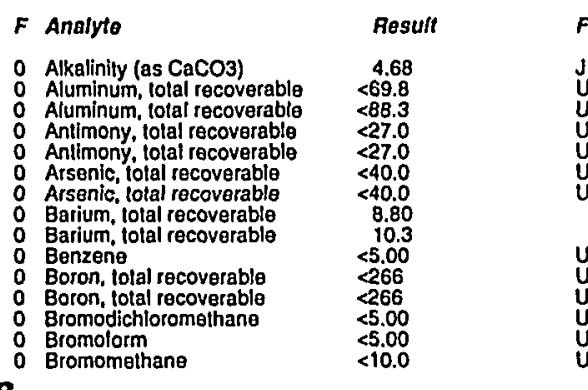

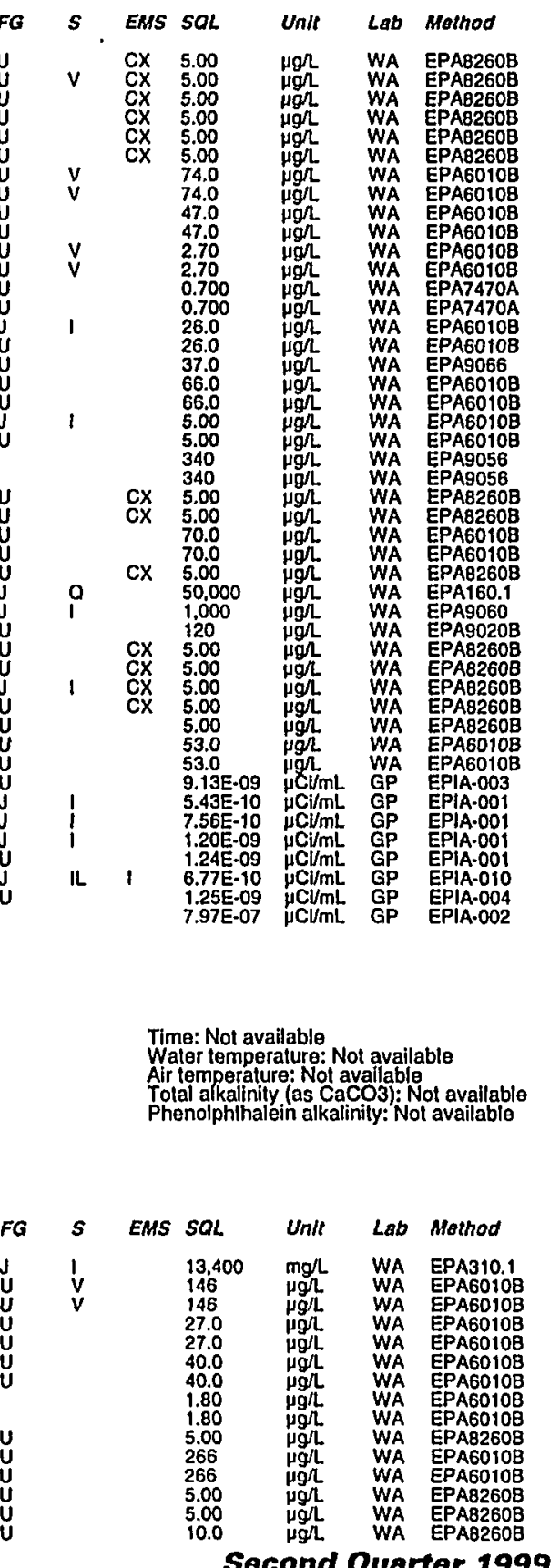


WELL BGO 4D

MEASUREMENTS CONDUCTED IN THE FIELD

Sample date: $05 / 18 / 99$
Depth to water: $67 \mathrm{tt}(20.42 \mathrm{~m})$ below TOC
Waler elevation: $230.5 \mathrm{H}(70.26 \mathrm{~m}) \mathrm{ms}$ )

$\mathrm{pH}: 5.6$

p. conductance: $24 \mu \mathrm{s} / \mathrm{cm}$

Water evacuated from the well prior to sampling: $1 \mathrm{gal}$ The well went diry during purging.

ANALYSES

F Analyto

- Alkalinity (as $\mathrm{CaCO} 3$ )

Aluminum, tolal recoverable

Arsenic, lot

Barium, total recoverable

Boron, total recoverable

Bromolorm

Bromomethane
Cadmium, tolal recoverable
Carbon tetrachloride

Chlorobenzene

Chlorosthane

2.Chloroethyl vinyl ether

Chlorolorm

CChromium, lotal recoverable

Copper, total recoverable

1.1-Dichloroelhane

i,i.Dichloroethylene

trans-1,2-Dichloroethylene

1,2-Dichloropropane

cis-1,3-Dichloropropene

Elhylbenzene

Lead, total recoverable

Lithium, total recoverable

Nickel, total recoverable

Silver, total recoverable

o $1,1,2,2$-Tetrachloroethane

Telrachloroethylene

Toluene

Total dissolved solids

Total organic carbon

Total organic halogens

1,1,1-Trichloroethan

Trichloroelhylens

Trichlorolluoromelhane

Xylenes

Zinc, tolal recoverable

Gross alpha

Nonvolatile bela
Radium, tolal alpha-emitting

Strontium.90

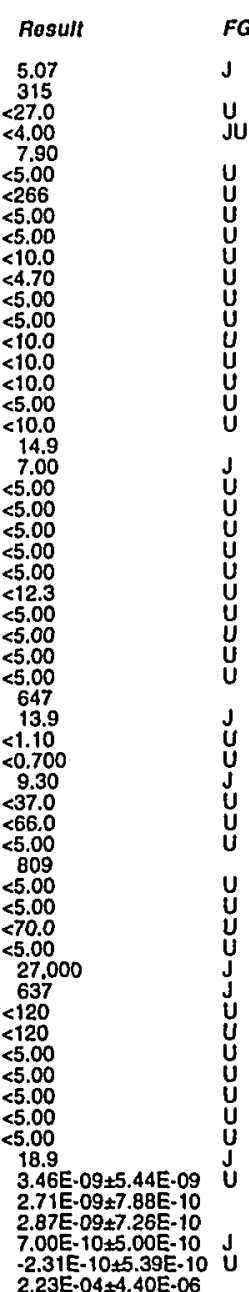

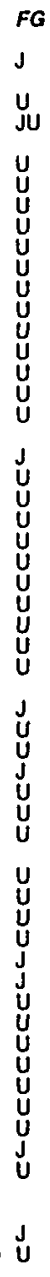

Time: 14:00

mperature: $20.4^{\circ} \mathrm{C}$

Total alkalinity (as CaCO3): $0 \mathrm{mg} / \mathrm{h}$

Field Oualifer(s): $S X$.

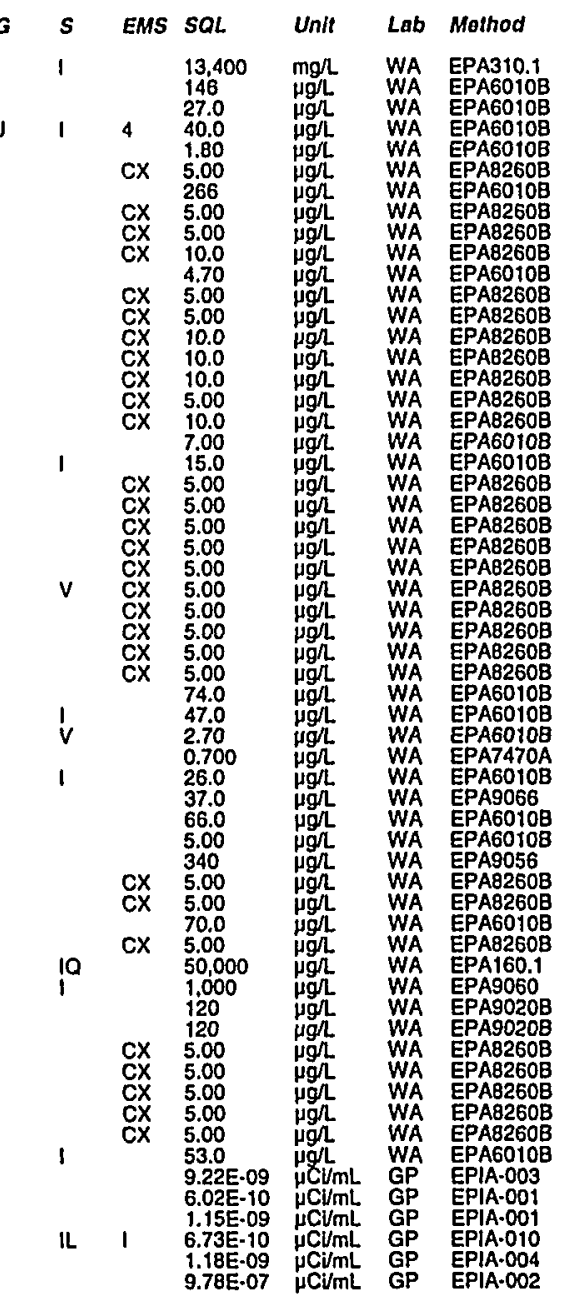

WELL BGO 5C

MEASUREMENTS CONDUCTED IN THE FIELD

Sample date: 05/18/99

Demple date: 05/18/99
Water elevation: $81.68 \mathrm{ft}(24.9 \mathrm{~m})$ below TOC
Water $214.42 \mathrm{ft}(65.36 \mathrm{~m}) \mathrm{msl}$

p. conductance: $34 \mu \mathrm{S} / \mathrm{cm}$

Water evacuated irom the well prior to sampling: 6 gar the well went dry during purging.

ANALYSES

\begin{tabular}{|c|}
\hline $\begin{array}{l}\text { ecoverable } \\
\text { ecoverable } \\
\text { coverable } \\
\text { methane } \\
\text { î recoverable } \\
\text { iloride } \\
\text { (Vinyl chloride) } \\
\text { vinyl ether } \\
\theta\end{array}$ \\
\hline
\end{tabular}

Result

6.96
386
$<27.0$
$<40.0$
17.1

$<266$

$<5.00$

$<10.0$

$<5.00$

$<10.0$

$<10.0$
$<5.00$
$<10.0$
8.50

8.50

8.60
$<5.00$

$\$ 5.00$
55.00
55.00
55.00

$<5.00$

5.00
$<.00$

$<5.00$

$<4.0$
$\leq 1.60$

$<.700$
2.60

$<66.0$

587
$<5.00$

$<5.00$
$<70.0$

54,000
877

877
$<120$

$<5.00$
$<5.00$
$<5.00$
$<5.00$

$<5.00$

18.5
$-1.03 E-09 \pm 5.23 E-09$

$.3 .65 \mathrm{E} \cdot 11 \pm 2.91 \mathrm{E} \cdot 10 \mathrm{U}$

6.62E-10.6.46E-10 U

$-1.88 E-10+6.40 E-10 U$
Time: 14:55

Air temperature: $21.9^{\circ} \mathrm{C}$

Tolal alkalinily (as CaCO3): $8 \mathrm{mg}$

列) 
ANALYTICAL MESULTS

\section{WELL BGO 5D}

MEASUREMENTS CONDUCTED IN THE FIELD

Sample date: $05 / 24 / 99$ Water elevation: $229.65 \mathrm{~h}(70 \mathrm{~m}) \mathrm{msl}$

ph: 4.7

p. conductance: $44 \mu \mathrm{S} / \mathrm{cm}$ Water evacuated from the well prior to sampling: 1 gal
The well went dry during purging.

ANALYSES

$F$ Analyte

- Alkalinity (as $\mathrm{CaCO}$ ) Aluminum, lotal recoverable Arsenic, total recoverable

Barium, total recoverable

genzena

Bromodichloromethane

Bromolorm

Cadmium, toral recoverable

Chlorobenzene

Chloroethene (Vinyl chloride)

Chloroform

Chroromium, tolal recoverable

Chromium, tolal recoverab

D Dibromochloromathan

i,2-Dichloroethane

1,1-Dichloroethylene
irans- $\$, 2-$ Dichloroelhylene Dichloromethane cis-1.3-DIchloropropene
itans $-1,3 \cdot$ Dichloropropen Eithylbenzene

Lead, tolal recoverable

Mercury, total recoverablo

Selenium, lotal recoverable

Silver, total

1.1,2,2.Tetrachloroethane

Tiefrachloroethylene
Tin, total recoverable

Toluene Tolal dissolved solids

Tolal organic carbon
Total organic halogens

1,1.1. Trichleroethane

Trichloroethylene

Zylenes Znc, total recoverable

Carbon-14

Nonvolatile beta
Radium, lotal alpha.emitting

Stronlium.90

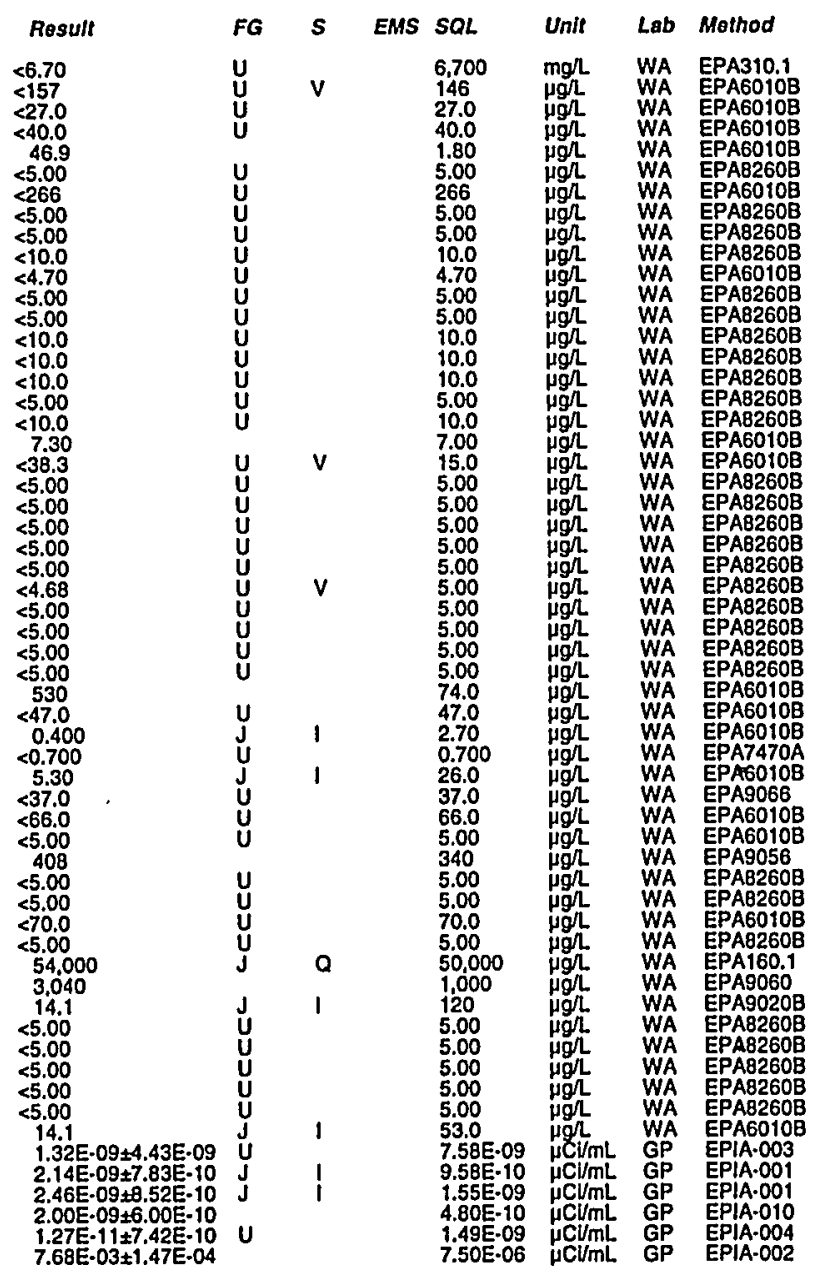

WELL BGO 6A

MEASUREMENTS CONDUCTED IN THE FIELD

Time: 12:05

$23.1{ }^{\circ} \mathrm{C}$ Tolal alkalinity (as CaCO3): $0 \mathrm{mg} / \mathrm{L}$ Phenolphthalein alkalinily: $0 \mathrm{mg} / \mathrm{L}$
Field Qualifier(s): $S X$

Sample date: 05/18/9

Wepth to water: $126.5 \mathrm{ft}(38.56 \mathrm{~m})$ below TOC

$\mathrm{gH}$. 7.4 conductance: $280 \mu \mathrm{S} / \mathrm{cm}$

Water evacuated from the well prior to sampling: 103 gal ANALYSES

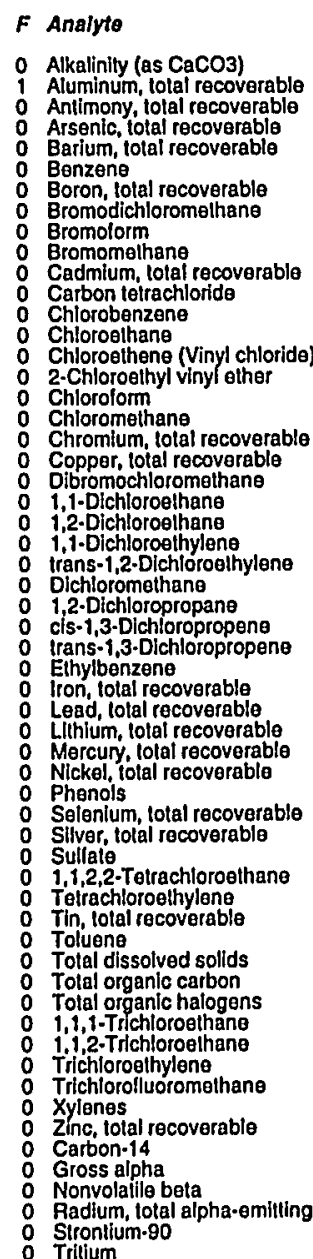

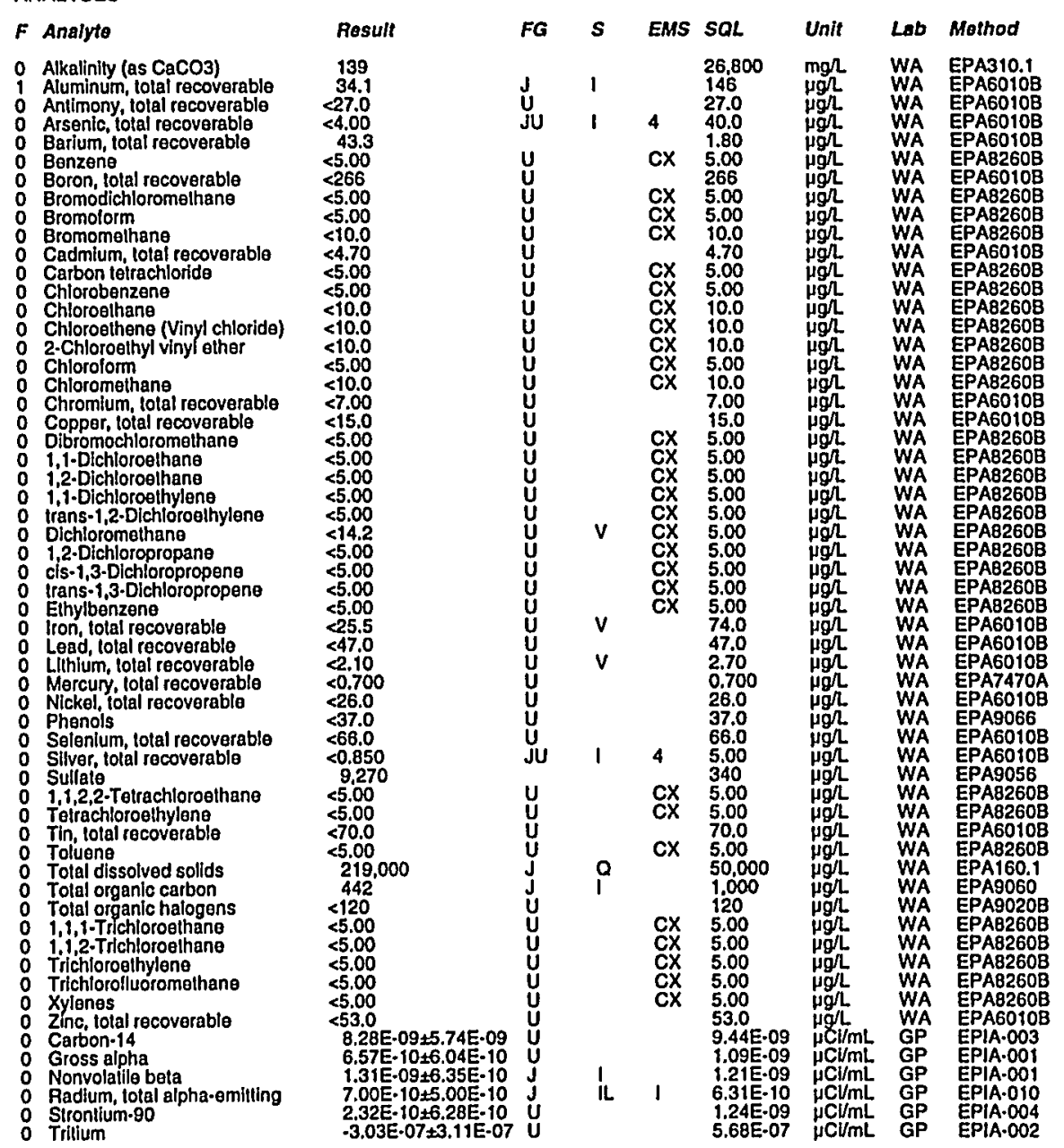

Time: 9:35

Wirer $19.9^{\circ} \mathrm{C}$ Total alkalinity (as CaCO3): $118 \mathrm{mg} /$ Phenolphthalein alkalinity: $0 \mathrm{mg} / \mathrm{L}$
Field Qualifier(s): $S$ 


\section{WELL BGO 6B}

MEASUREMENTS CONDUCTED IN THE FIELD

Sample date: 05/19/99 $21.3 \mathrm{~m}$ ) below TOC

Waler eleval
$\mathrm{pH}: 11.2$

Sp. conduclance: $420 \mu \mathrm{S} / \mathrm{cm}$

Waler evacualed from the well prior to sampling: $1 \mathrm{gal}$ The well went dry during purging

ANALYSES

$F$ Analyte

Alkalinily (as CaCO3)

Antimony, otal recoverabto

Arsenic, total recoverablo

Boron, lotal recoverable

Bromodichioromethane

Bromolorm

Cadmium, tolal recoverable

Carbon telrachloride

Chloroethene (Vinyl chloride)
2.Chloroothyl vinyl ether

Chlorolorm

Chromlum, Iotal recoverable

Dibromochloromethane

1,2-Dichloroethane

1,1-Dichloroethyleng
trans-1,2-Dichloroathylene

trans-1,2-Dichloroe日l
Dichloromethane

1,2-Dichloropropane
cis-1,3-Dichloropropene

trans-1,3-Dichloropropene

Iron, total recoverable

Lithium, total recoverable

Nickel, tolal recoverable

Phenols

Selenlum, total recoverable

Sulfate

Teirachloroothylene

Ton, total recoverable

Tolal dissolved solids

Total organic halogens

1,1,1-Trichloroethane

Trichloroethylene

Zylenes

Gross alpha

Ronvolatile beta

Strontiun
Tritium

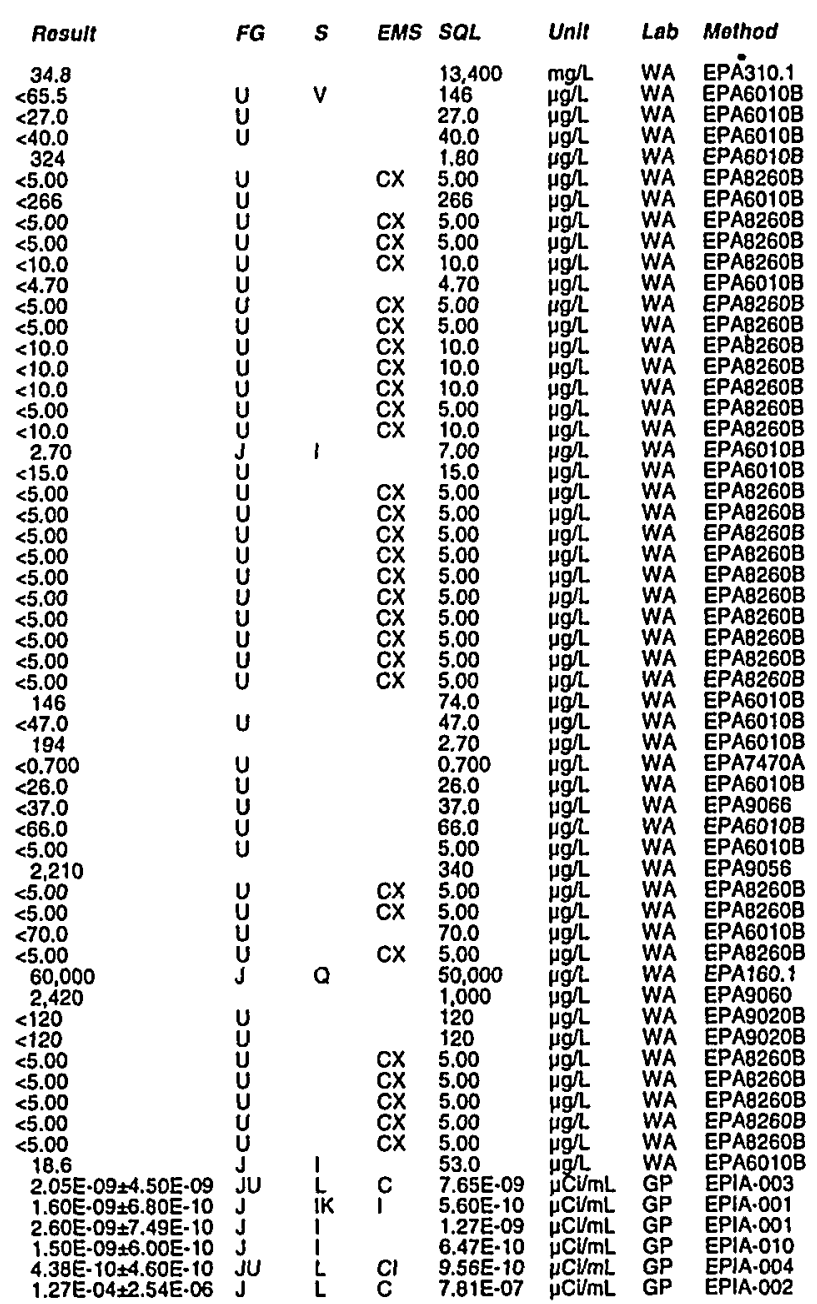

\section{WELL BGO 6C}

MEASUREMENTS CONDUCTED IN THE FIELD

Sample date: $05 / 18 / 99$ ( $20.35 \mathrm{~m})$ below TOC Waler elevalion: $218.83 \mathrm{kt}(66.7 \mathrm{~m}) \mathrm{ms}$

$\mathrm{gH}: 7.2$

Water $8: 05$ temperature: $20.5^{\circ} \mathrm{C}$ Total alkalinity (as Caco3): $85 \mathrm{mg} /$
Phenolphthalein alkalinily: $77 \mathrm{mg} /$
Field Qualifier(s): $\mathrm{SXH}$ from the well prior to sampling: $108 \mathrm{gal}$ Waler temperature: $20^{\circ} \mathrm{C}$ Total alkalinity (as Caco3): $47 \mathrm{mg} \Omega$ Phenolphinaler

\section{ANALYSES}

- Alkalinity (as $\mathrm{CaCO}$ )

- Antimony, total recoverable

- Arsenlc, total recoverable

Benzene

Boron, total recoverable
Bromodichloromelhane

Bromoform

Cadmlum, total recovarablo

Carbon tetrachlorid

O Chlorobenzen

Chloroethene (Vinyl chloride)

2.Chloroethyl vinyl ether
2.

Chlorolorm

Chromium, total recoverable

Copper, total recoverable

1.1-Dichloroelhane

1,2.Dichloroethane

trans-1,2-Dichloroethylene

12-Dichloropropa

cis-1,3-Dichloropropene
trans-1,3-Dichloropropene

Ethylbenzene

Lron, total recoverable

Lilhium, total recoverable

Phenols

Solenlum, total recoverable

Sullate Trachlorosthan

Tin, total recovererable

Toluene

Total dissolved solids

Total organic halogen

1,1, 2-Trichloroethane

Trichloroelthylene
Trichlorofluoromethane

Zylenes

Garbon-14

Nons aloilila beta
Radiumm, total alpha-emitting

Stronlium.9
Sritium

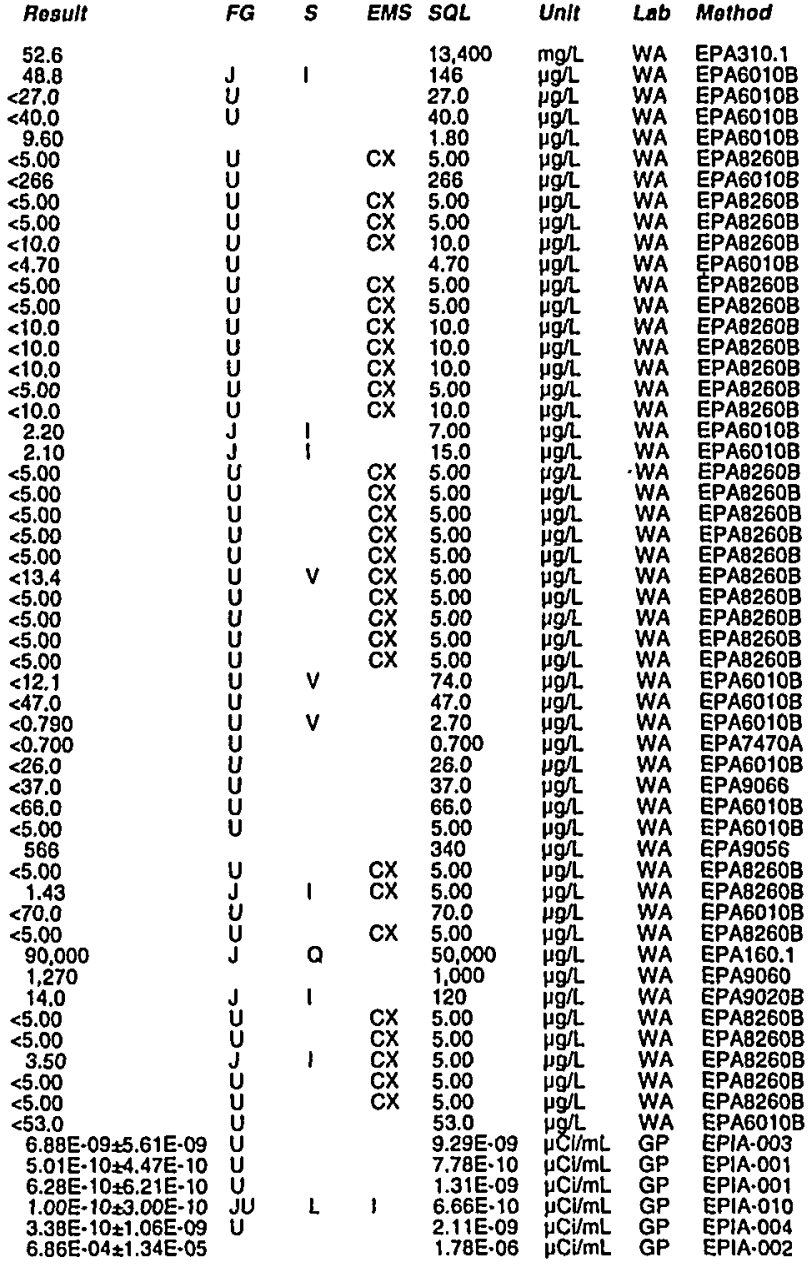


WELL BGO 6D

MEASUREMENTS CONDUCTED IN THE FIELD

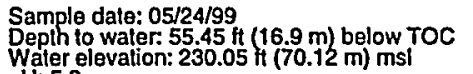

PH: 5.9 5 ductance: $160 \mu \mathrm{S} / \mathrm{cm}$

Waler evacualed from the well prior to sampling: 5 gal ANALYSES

ANALYSES

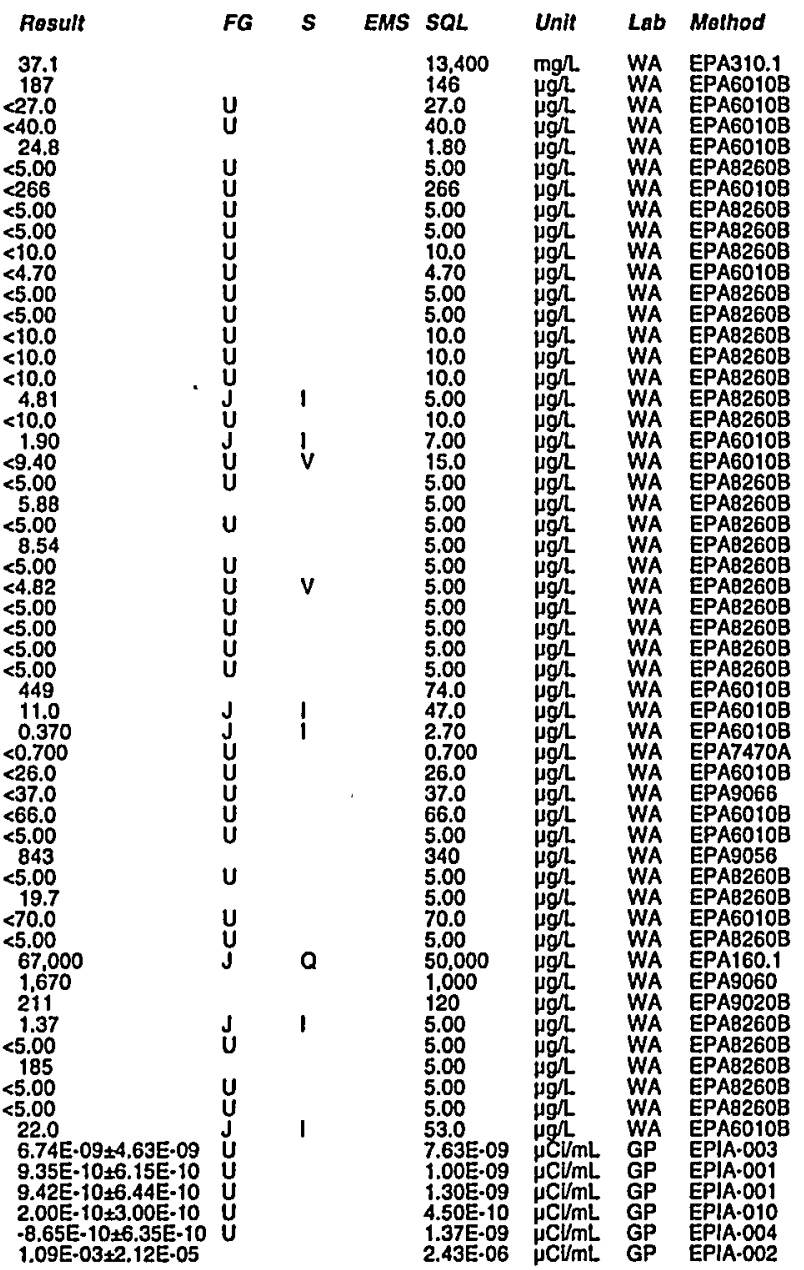

ESH-EMS-990521
WELL BGO 7D

MEASUREMENTS CONDUCTED IN THE FIELD

Sample date: $05 / 25 / 99$
Depth to water: $56.55 \mathrm{H}(17.24 \mathrm{~m})$ below TOC

$\mathrm{pH}: 4.8$

Sp. conductance: $28 \mu \mathrm{S} / \mathrm{cm}$

Turbidity: $1 \mathrm{NTU}$
Water evacuated from the well prior to sampling: $64 \mathrm{gal}$

ANALYSES

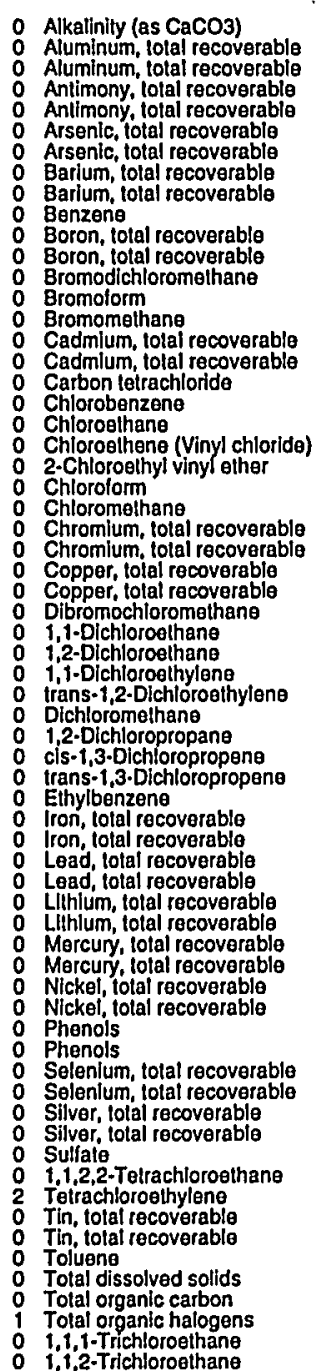

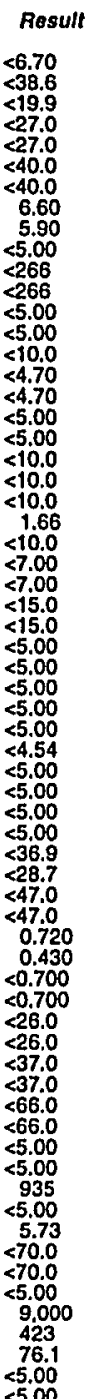

Time: 12:41

Air temperalure: $20^{\circ} \mathrm{C}$

Total alkalinity (as CaCo3): $0 \mathrm{mgh}$

Phenolphithalein alkalinity: $0 \mathrm{mg} L$
Field Qualifier(s): $\mathrm{S}$

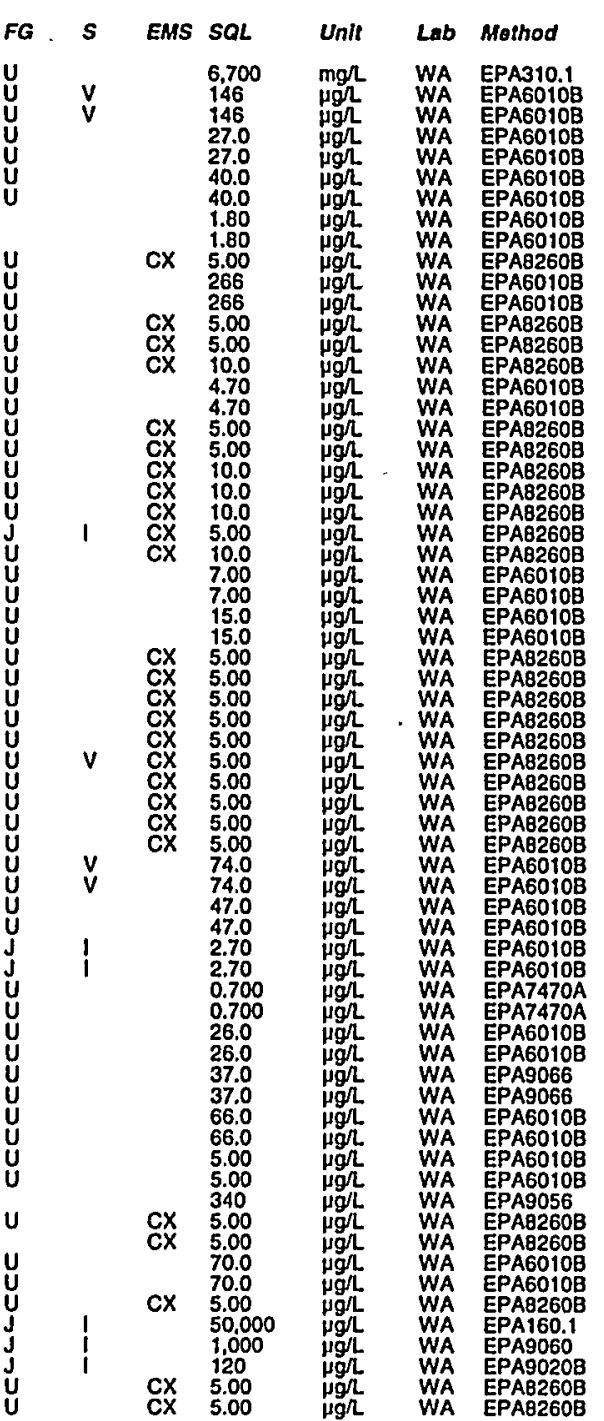

Socond Quarter 1999 
Well BGO 70 collected on 05/25/99 (cont.)

F Analyto

Rosult •

EMS SQL UnIt LOL MOTH

2 Trichloroethylene $\begin{array}{ll}0 & \text { Xylenes } \\ 0 & \text { Zinc, lolal recoverable } \\ 0 & \text { Zinc, total recoverable }\end{array}$ Gross alph

Gross alpha

Nonvolatilla beta

Radium, tolal alpha-emitting 2 Trilium

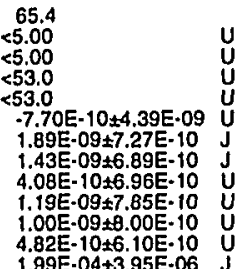

\section{WELL BGO BAR}

MEASUREMENTS CONDUCTED IN THE FIELD

$F$ Anelyto

Eithyibenzene
Sample data: 06/04/99

Water elevation: $158.74 \mathrm{ft}(48.38 \mathrm{~m}) \mathrm{ms}$

Sp. conductance: $260 \mu \mathrm{S} / \mathrm{cm}$ Turbidity: 0 NTU
The water was evacuated from the well prior to sampling.
The during purging.

ANALYSES

0 Benzene

Bromodichloromethane

Bromoform

Bromomathane

Chiorobenzene

Chloroethane

2.Chloroethyl vinyl ether

Chlorolorm

Dibromochloromethane

1.1.Dichloroethane

$1,1 \cdot$ Dichloroethylene
irans-1,2-Dichloroethylene

Dichloromethane

1,2-Dichloropropane
cis-1,3-0ichloropropene

trans-1,3.Dichloropropene

Tetrachloroethylene

Total organic carbon

Total organic halogens

1,1, - Trichloroethan

Trichloroethylene

Trichlorof
0
Xylenes

Result
$<5.00$
$<5.00$
$<5.00$
$<10.0$
$<5.00$
$<5.00$
$<10.0$
$<10.0$
$<10.0$
$<5.00$
$<10.0$
$<5.00$
$<5.00$
$<5.00$
$<5.00$
$<5.00$
$<6.45$
$<5.00$
$<5.00$
$<5.00$
$<5.00$
$<5.00$
$<5.00$
$<5.00$
625
$<120$
$<5.00$
$<5.00$
$<5.00$
$<5.00$
$<5.00$

WELL BGO 8C

MEASUREMENTS CONDUCTED IN THE FIELD

Sample dale: 05/18/99

Water

pH: 5.8 conductance: $84 \mu \mathrm{S} / \mathrm{cm}$

Water evacuated from the well prior to sampling: $94 \mathrm{gal}$

Time: 13:50

Total alkalinity (as CaCO3): $110 \mathrm{mg} / \mathrm{h}$ Phenolph halein alkalinity: $0 \mathrm{mgh}$.

\begin{tabular}{|c|c|c|c|c|c|c|}
\hline$F G$ & $s$ & EMS & SQL & Unit & $L a b$ & Molhod \\
\hline 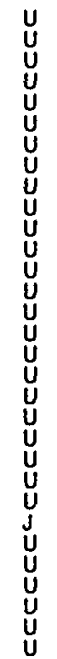 & 1 & & $\begin{array}{l}5.00 \\
5.00 \\
5.00 \\
10.0 \\
5.00 \\
5.00 \\
10.0 \\
10.0 \\
10.0 \\
5.00 \\
10.0 \\
5.00 \\
5.00 \\
5.00 \\
5.00 \\
5.00 \\
5.00 \\
5.00 \\
5.00 \\
5.00 \\
5.00 \\
5.00 \\
5.00 \\
1.000 \\
120 \\
5.00 \\
5.00 \\
5.00 \\
5.00 \\
5.00\end{array}$ & 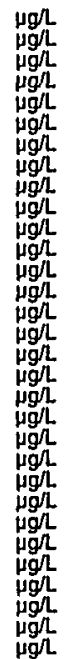 & $\begin{array}{l}\text { WA } \\
\text { WA } \\
\text { WA } \\
\text { WA } \\
\text { WA } \\
\text { WA } \\
\text { WA } \\
\text { WA } \\
\text { WA } \\
\text { WA } \\
\text { WA } \\
\text { WA } \\
\text { WA } \\
\text { WA } \\
\text { WA } \\
\text { WA } \\
\text { WA } \\
\text { WA } \\
\text { WA } \\
\text { WA } \\
\text { WA } \\
\text { WA } \\
\text { WA } \\
\text { WA } \\
\text { WA } \\
\text { WA } \\
\text { WA } \\
\text { WA } \\
\text { WA } \\
\text { WA } \\
\text { WA }\end{array}$ & 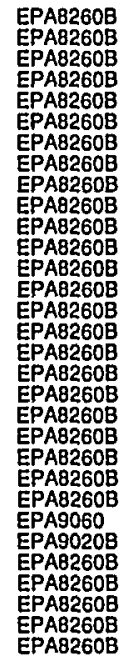 \\
\hline
\end{tabular}

ESH-EMS-990521
Water temperature: $22.7^{\circ} \mathrm{C}$

Well BGO BC collecled on 05/18/99 (cont.)

(1)

$F$ Analyto

Alkalinity (as $\mathrm{CaCO}$ )

Anlimony, lotal recoverable

Arsenic, tolal recoverable
Barlum, total recoverable

Boron, total recoverab

Bromodichloromethane

Bromolorm
Bromomethan

Cadmium, tolal recoverable

Carbon tatrachloric

o Chlorobenzen

Chloroethene (Vinyl chloride)
2.Chloroethyl vinyl ether

Chloroform

Chromium, total recoverable

O Copper, tolal recoverable

1,1-Dichloroethane

$1,1-$ Dichloroethylene
0
trans-1,2-Dichloroethylene

Dichloromethane

$\begin{array}{ll}0 & 1,2-\text {-Dichloropropane } \\ 0 & \text { cis-1,3-Dilchloropropene }\end{array}$

0 trans-1,3-0ichloropropen

o Ethylbenzene

0 Lithium, total recoverable

0 Mercury, total recoverable

O Nickel, total recoverable

Silver, total recoverable

0 Sulfate $1,1,2,2$-Tetrachloroethane

Totrachloroethylene

Tin, tolal recoverable

Total dissolved solids

o Total organic halogens

$\begin{array}{ll}0 & 1,1,1-T \text { Trichloroothane } \\ 0 & 11,1,2-\text { Trichloroethane }\end{array}$

Trichorolnylene

X Xylenes

o Groston-14

Nonvolatile beta

S Strontium-

WELL BGO 8D

MEASUREMENTS CONDUCTED IN THE FIELD

Sample date: 05/18/99

Water elevation: $230.7 \mathrm{ft}(70.32 \mathrm{~m}) \mathrm{msl}$

pH: 4.2

p. conductance: $26 \mu \mathrm{S} / \mathrm{cm}$

Waler evacuated from the well prior to sampling: 38 gal

\begin{tabular}{|c|c|c|c|c|c|c|c|}
\hline Ros & & 5 & EMS & SOL & it & Lab & \\
\hline 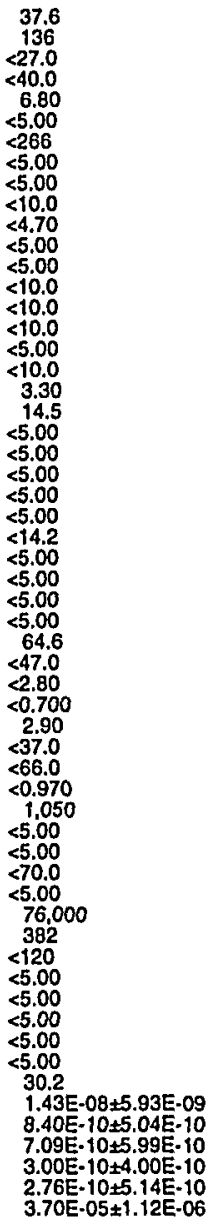 & 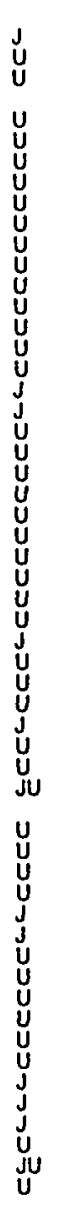 & $\begin{array}{l}1 \\
v \\
1\end{array}$ & $\begin{array}{l}c x \\
c x \\
c x \\
c x \\
c x \\
c x \\
c x \\
c x \\
c x \\
c x\end{array}$ & $\begin{array}{l}13.400 \\
146 \\
27.0 \\
40.0 \\
11.80 \\
5.00 \\
2666 \\
5.00 \\
5.00 \\
10.0 \\
4.70 \\
5.00 \\
5500 \\
10.0 \\
10.0 \\
10.0 \\
5.00 \\
10.0 \\
7.00 \\
15.0 \\
5.00 \\
5.00 \\
5.00 \\
5.00 \\
5.00 \\
5.00 \\
5.00 \\
5.00 \\
5.00 \\
5.00 \\
74.0 \\
47.0 \\
2.70 \\
0.700 \\
26.0 \\
37.0 \\
6.0 \\
5.00 \\
340 \\
5.00 \\
5.00 \\
70.0 \\
5.00 \\
50.000 \\
1.000 \\
120 \\
5.00 \\
5.00 \\
5.00 \\
5.00 \\
5.00 \\
53.0 \\
9.39 E-09 \\
6.56 E-10 \\
1.24 E-09 \\
6.34 E-10 \\
1.01 E .09 \\
5.73 E .07\end{array}$ & 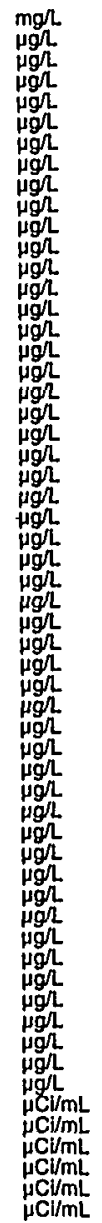 & $\begin{array}{l}\text { WA } \\
\text { WA } \\
\text { WA } \\
\text { WA } \\
\text { WA } \\
\text { WA } \\
\text { WA } \\
\text { WA } \\
\text { WA } \\
\text { WA } \\
\text { WA } \\
\text { WA } \\
\text { WA } \\
\text { WA } \\
\text { WA } \\
\text { WA } \\
\text { WA } \\
\text { WA } \\
\text { WA } \\
\text { WA } \\
\text { WA } \\
\text { WA } \\
\text { WA } \\
\text { WA } \\
\text { WA } \\
\text { WA } \\
\text { WA } \\
\text { WA } \\
\text { WA } \\
\text { WA } \\
\text { WA } \\
\text { WA } \\
\text { WA } \\
\text { WA } \\
\text { WA } \\
\text { WA } \\
\text { WA } \\
\text { WA } \\
\text { WA } \\
\text { WA } \\
\text { WA } \\
\text { WA } \\
\text { WA } \\
\text { WA } \\
\text { WA } \\
\text { WA } \\
\text { WA } \\
\text { WA } \\
\text { WA } \\
\text { GA } \\
\text { GP } \\
\text { GP } \\
\text { GP } \\
\text { GP } \\
\text { GP } \\
\text { GP }\end{array}$ & 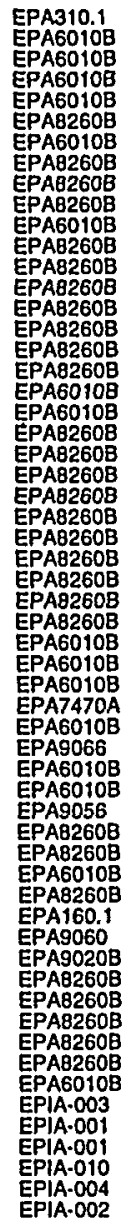 \\
\hline
\end{tabular}

Time: ::44

Water temperalure: $21^{\circ} \mathrm{C}$

Air temperature: $22.2^{\circ} \mathrm{C}$. $3 \mathrm{mg}$.

Phenolphthalein alkalinity: $0 \mathrm{mg}$ 
Well BGO BD collected on 05/18/99 (cont.) ANALYSES

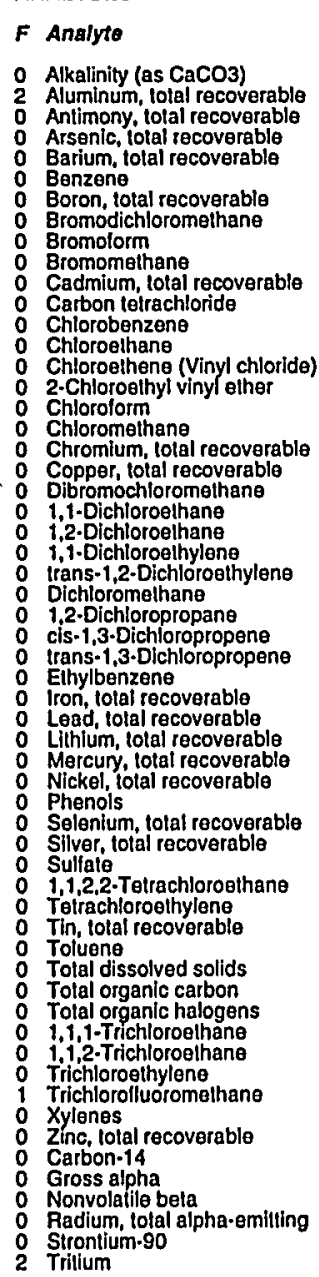

\begin{tabular}{|c|c|c|c|c|c|c|c|}
\hline$R \theta$ & & $s$ & MS & $Q L$ & ath & b & thod \\
\hline 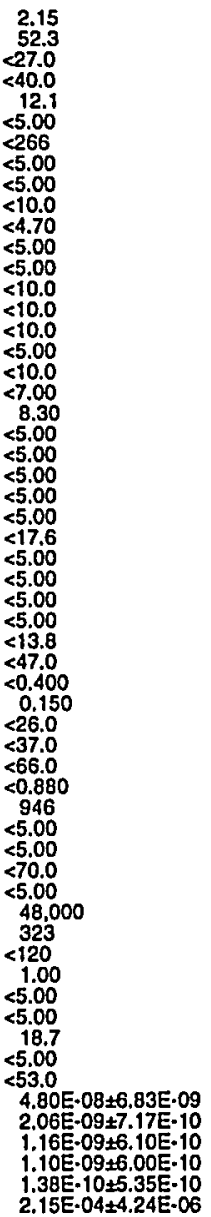 & 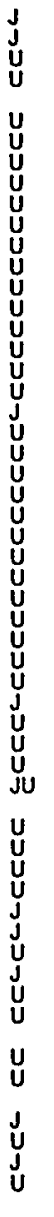 & $\begin{array}{l}v \\
v \\
i\end{array}$ & $\begin{array}{l}c x \\
c x \\
c x \\
c x \\
c x \\
c x \\
c x \\
c x \\
c x \\
c x \\
c x\end{array}$ & $\begin{array}{l}27.0 \\
40.0 \\
1.80 \\
5.00 \\
266 \\
5.00 \\
5.00 \\
10.0 \\
4.70 \\
5.00 \\
5.00 \\
10.0 \\
10.0 \\
10.0 \\
5.00 \\
10.0 \\
7.00 \\
15.0 \\
5.00 \\
5.00 \\
5.00 \\
5.00 \\
5.00 \\
5.00 \\
5.00 \\
5.00 \\
5.00 \\
74.0 \\
47.0 \\
2.70 \\
0.700 \\
26.0 \\
37.0 \\
66.0 \\
5.00 \\
340 \\
5.00 \\
5.00 \\
70.0 \\
5.00 \\
50.000 \\
1.000 \\
120 \\
5.00 \\
5.00 \\
5.00 \\
5.00 \\
53.00 \\
5.00 \\
9.09 E \cdot 09 \\
1.17 E-09 \\
7.06 E-10 \\
1.11 E .09 \\
9.63 E-07\end{array}$ & 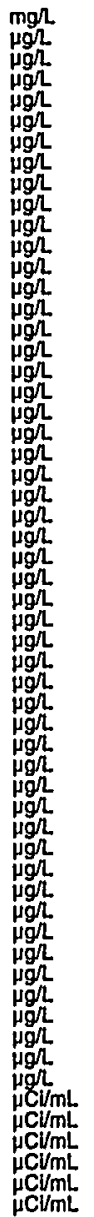 & $\begin{array}{l}\text { WA } \\
\text { WA } \\
\text { WA } \\
\text { WA } \\
\text { WA } \\
\text { WA } \\
\text { WA } \\
\text { WA } \\
\text { WA } \\
\text { WA } \\
\text { WA } \\
\text { WA } \\
\text { WA } \\
\text { WA } \\
\text { WA } \\
\text { WA } \\
\text { WA } \\
\text { WA } \\
\text { WA } \\
\text { WA } \\
\text { WA } \\
\text { WA } \\
\text { WA } \\
\text { WA } \\
\text { WA } \\
\text { WA } \\
\text { WA } \\
\text { WA } \\
\text { WA } \\
\text { WA } \\
\text { WA } \\
\text { WA } \\
\text { WA } \\
\text { WA } \\
\text { WA } \\
\text { WA } \\
\text { WA } \\
\text { WA } \\
\text { WA } \\
\text { WA } \\
\text { WA } \\
\text { WA } \\
\text { WA } \\
\text { WA } \\
\text { WA } \\
\text { WA } \\
\text { GA } \\
\text { GP } \\
\text { GP } \\
\text { GP } \\
\text { GP } \\
\text { GP }\end{array}$ & 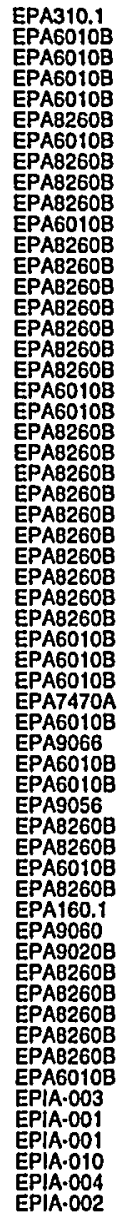 \\
\hline
\end{tabular}

WELL BGO 9D

MEASUREMENTS CONDUCTED IN THE FIELD

Sample date: $05 / 18 / 99$
Oepth to water: $56.68 \mathrm{ht}(17.28 \mathrm{~m})$ bolow TOC
Waler elevation: $228.42 \mathrm{H}(69.62 \mathrm{~m}) \mathrm{msl}$

Water elevation: $228.42 \mathrm{ft}$ (69.62

Tubidifty: $1 \mathrm{NTU}$ : $24 \mathrm{HS} / \mathrm{cm}$
Waler evacualed from the well prior to sampling: $32 \mathrm{gal}$

Air temperature: $31.7^{\circ} \mathrm{C}$ (a) $1 \mathrm{mg} / \mathrm{L}$ Total alkalinity (as Cacoly: $1 \mathrm{mg}$
Phenoiphthalein alkalinity: $\mathrm{mgh}$
Field Qualifier(s): $\mathrm{S}$
Well BGO 9D collected on 05/18/99 (cont.) ANALYSES

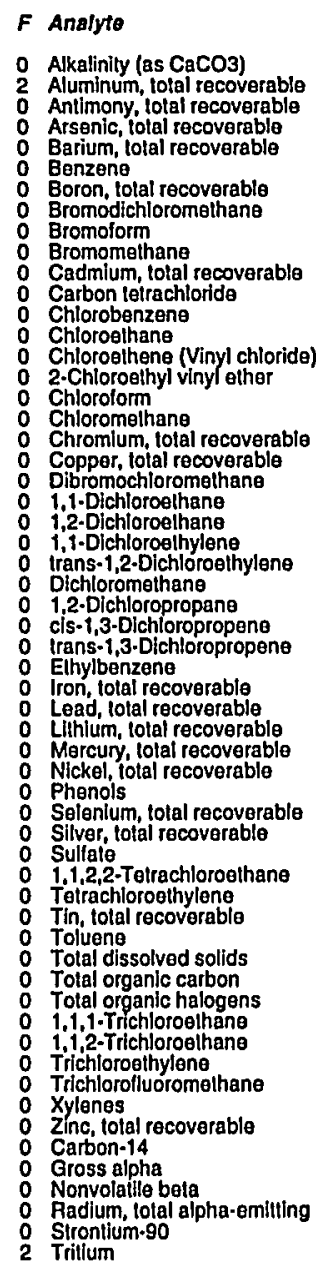

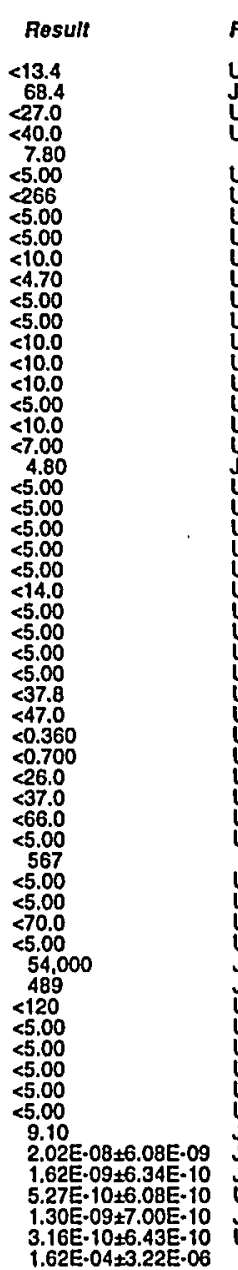

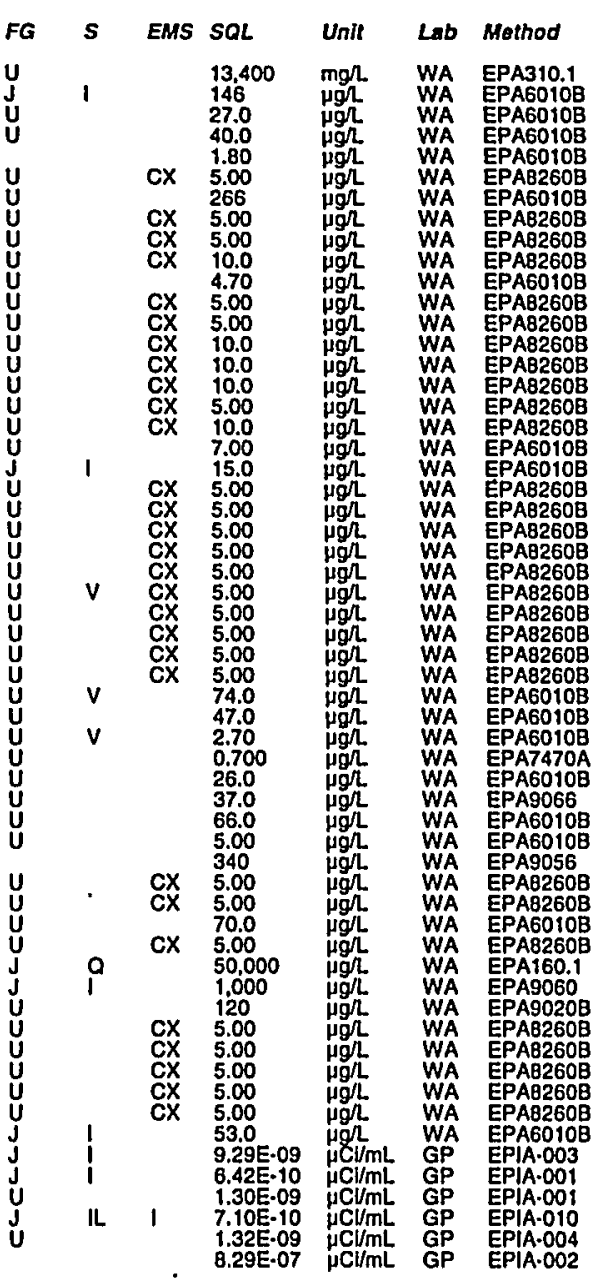

\section{WELL BGO 10AR}

MEASUREMENTS CONDUCTED IN THE FIELD

Depple date: 05/06/99 water: $142.21 \mathrm{ft}(43.35 \mathrm{~m})$ below TOC

ater elevation: $158.29 \mathrm{ft}(48.25 \mathrm{~m}) \mathrm{ms}$
Time: 9:36

Wir $20.4^{\circ} \mathrm{C}$ olal alkalinity (as CaCO3): $98 \mathrm{mg} /$ Field Qualifier(s): $\mathbf{S}$ p. conductance: $200 \mu \mathrm{S} / \mathrm{cm}$

Will prior to sampling: $150 \mathrm{gal}$ 
ANALYTICAL RESULTS

Well BGO 10AR collected on 05/06/99 (cont.) ANALYSES

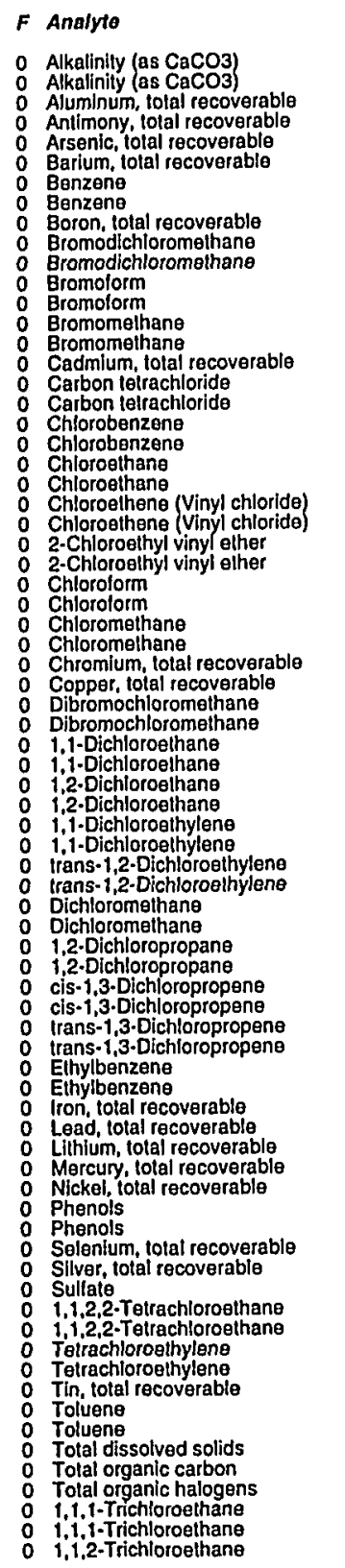

Well BGO 10AR collected on 05/06/99 (cont)
$F$ Analyte

Result

0 1,1,2-Tichloroethane

T Trichloroethylene

O Trichlorofluoromethan

X Xylenes

0 Xylenes
0 Zinc, tolal recoverable

O Gross alpha

Nonvolatile bela
0
0 Radium, tolal alpha-emilling
0

Trifium

\section{WELL BGO 10C}

MEASUREMENTS CONDUCTED IN THE FIELD

Sample date: 05/17/99 $24.98 \mathrm{~m})$ below TOC Water elevalion: $219.33 \mathrm{Ht}(66.85 \mathrm{~m}) \mathrm{ms}$

$\mathrm{gH}: 7$ conductance: $220 \mu \mathrm{S} / \mathrm{cm}$

Waler evacuated from the well prior to sampling: $6 \mathrm{gal}$

ANALYSES

$F$ Analyte

Alkalinity (as $\mathrm{CaCO} 3$ )

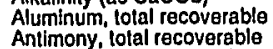

Antimony, lotal recoverable

Barium, total recoverable

Benzene

Bromodichlorom
Bromolorm

Bromomethane
Cadmium, total recoverable

Carbon teirachlo

Chloroethane

Chloroethene (Vinyl chloride)

C-Chloroelhyl

Choromethane

Copper, lotal recoverab

1.1-Dichloroethane

1,2-Dichloroethane

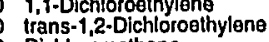

D Dichloromethane

$\begin{array}{ll}1 & \text { 1.2-Dichloropropane } \\ \text { cis-1,3.Dichloropropene } & \end{array}$

Elhylbenzene

2 Iron, total recoverable

o Lithium, total recoverable

Nickel, total recoverable

Selenium, lotal recoverablo

Silver, total recoverable

i.1,2,2-Tetrachloroethan

Tin. total recoverable

Tolvene
Total dissolved solids
Total organic carbon

16

Result
106
110
102
$<27.0$
$<40.0$
32.8
$<5.00$
$<266$
$<5.00$
$<5.00$
$<10.0$
$<4.70$
$<5.00$
$<5.00$
$<10.0$
$<10.0$
$<10.0$
55.00
$<10.0$
7.60
12.6
$<5.00$
$<5.00$
$<5.00$
$<5.00$
55.00
$<8.32$
55.00
$<5.00$
$<5.00$
$<5.00$
812
7.20
$<1.20$
$<0.700$
3.40
$<37.0$
$<66.0$
$<0.790$
5.440
55.00
25.00
570.0
$<5.00$
143.000
576
$<120$

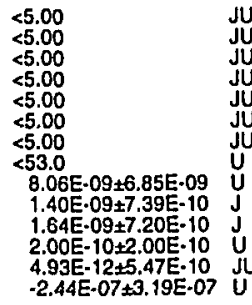

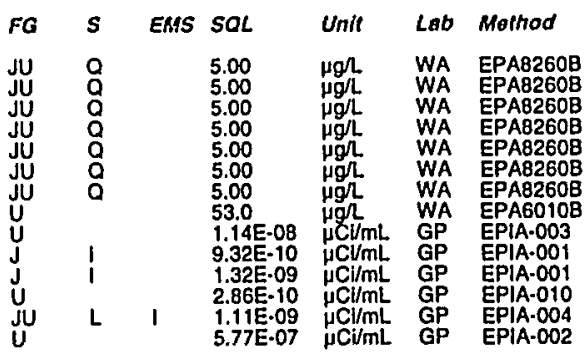

ESH-EMS-990521

Time: 15:25

Total alkalinity (as CaCO3): $107 \mathrm{mg} /$

Phenolphthalein alkalinity: $0 \mathrm{mg} /$.

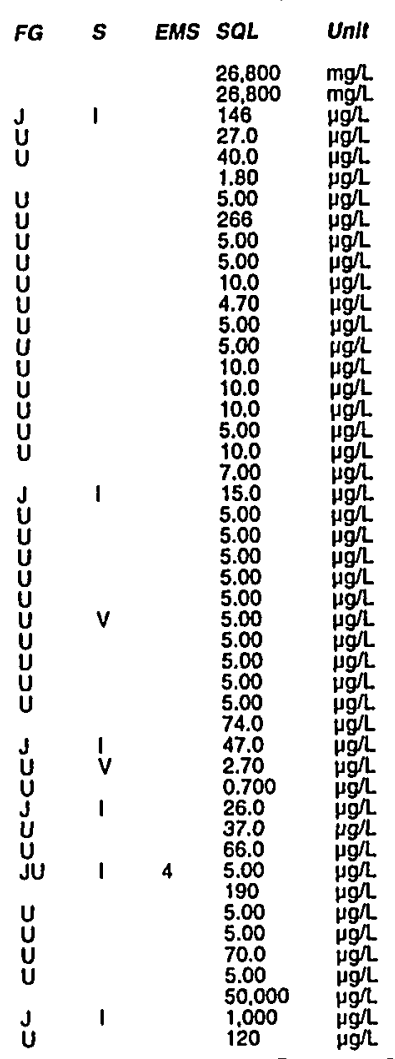

Lab Method

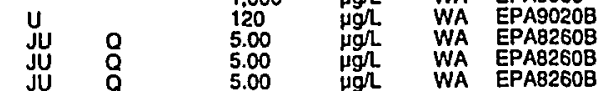

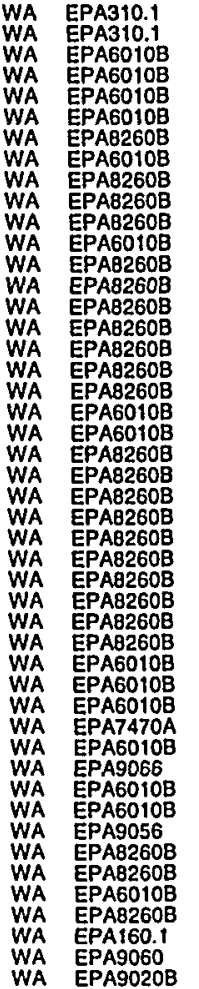

Second Quarter 1999 
Well BGO $10 \mathrm{C}$ collected on 05/17/99 (cont.)

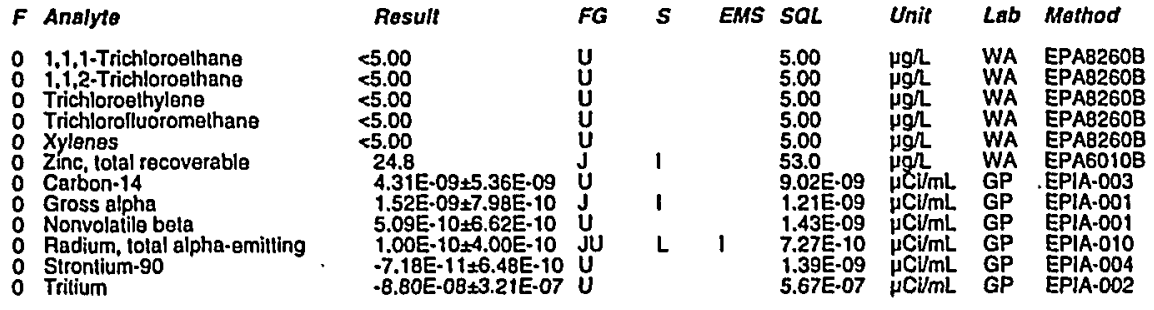

\section{WELLL BGO 10DR}

MEASUREMENTS CONDUCTED IN THE FIELD

Water elevation: $230.63 \mathrm{ht}(70.3 \mathrm{~m}) \mathrm{ms}$

PH: 6.6 . well went dry during purging

ANALYSES

F Anelyto

\begin{tabular}{|c|c|}
\hline Ialyte & Result \\
\hline 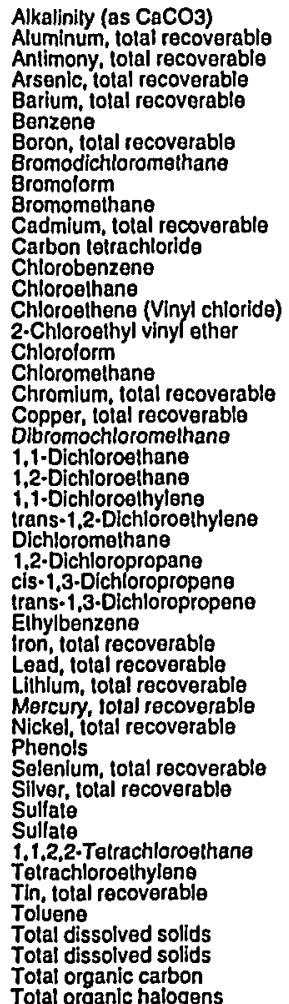 & 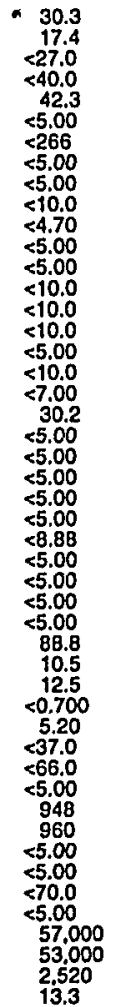 \\
\hline
\end{tabular}

ESH-EMS-99052

Total alkalinity (as Caco3): $26 \mathrm{mg} \Omega$
Phenolphthalein alkalinity: $0 \mathrm{mg} \Omega$
Field Qualifier(s): $S X$

Alkalinity (as $\mathrm{CaCO}$ )
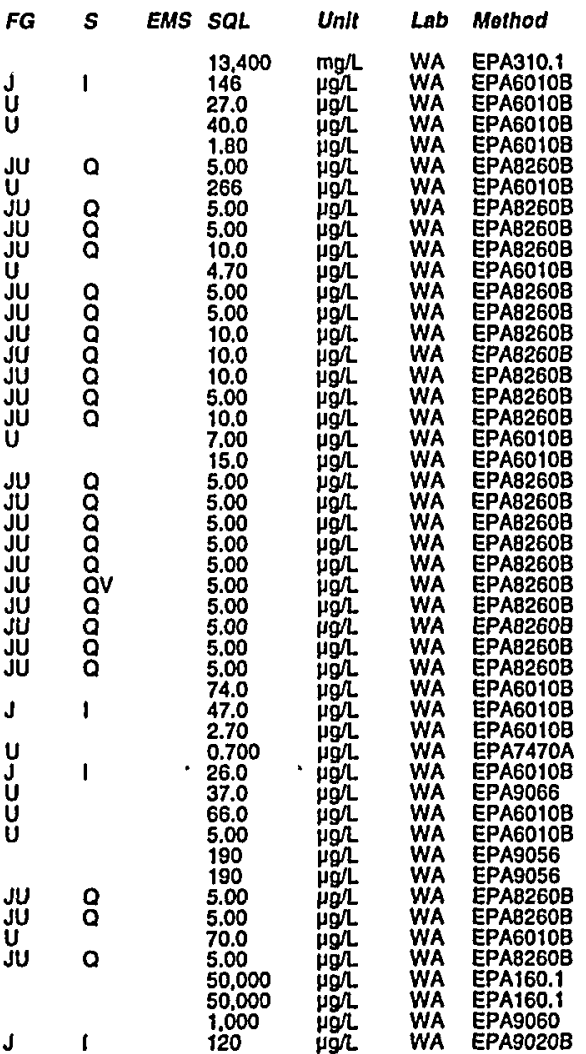

Sample date: 05/06/99

Water evacuated from the well prior to sampling: $2 \mathrm{gal}$

Well BGO 10DR collected on 05/06/99 (cont.)

\begin{tabular}{|c|c|c|c|c|c|c|c|c|}
\hline Ans & Result & $F G$ & $s$ & EMS & $O L$ & Unlt & Lab & Mothod \\
\hline 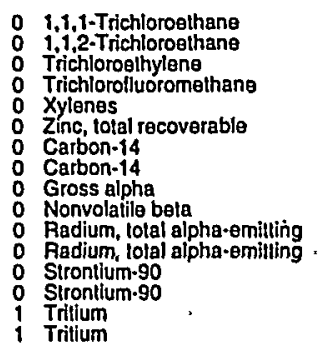 & 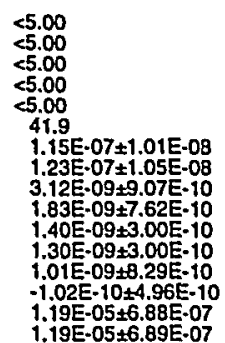 & $\begin{array}{l}\mathrm{JU} \\
\mathrm{Ju} \\
\mathrm{JU} \\
\mathrm{JU}\end{array}$ & $\begin{array}{l}a \\
a \\
a \\
a \\
0 \\
0\end{array}$ & i & $\begin{array}{l}5.00 \\
5.00 \\
5.00 \\
5.00 \\
5.00 \\
53.0 \\
1.16 E-08 \\
1.18 E-08 \\
9.01 E-10 \\
1.40 E .09 \\
3.01 E-10 \\
2.69 E-10 \\
1.57 E-09 \\
1.02 E-09 \\
5.82 E .07 \\
5.81-07\end{array}$ & 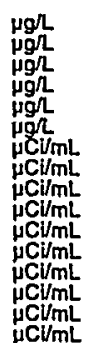 & $\begin{array}{l}\text { WA } \\
\text { WA } \\
\text { WA } \\
\text { WA } \\
\text { WA } \\
\text { WA } \\
\text { GP } \\
\text { GP } \\
\text { GP } \\
\text { GP } \\
\text { GP } \\
\text { GP } \\
\text { GP } \\
\text { GP } \\
\text { GP }\end{array}$ & $\begin{array}{l}\text { EPAB2608 } \\
\text { EPAB2608 } \\
\text { EPAB2608 } \\
\text { EPAB2608 } \\
\text { EPAB2608 } \\
\text { EPAG010B } \\
\text { EPAA-00B } \\
\text { EPIA.003 } \\
\text { EPIA.001 } \\
\text { EPIA.001 } \\
\text { EPIA.001 } \\
\text { EPIA.010 } \\
\text { EPIA.010 } \\
\text { EPIA.004 } \\
\text { EPIA.004 } \\
\text { EPIA.002 } \\
\text { EPIA.002 }\end{array}$ \\
\hline
\end{tabular}

\section{Time: 10:10 WELL BGO 110R}

MEASUREMENTS CONDUCTED IN THE FIELD

Sample data: $05 / 17 / 99$
Depth to water: $74.3 \mathrm{ft}(22.65 \mathrm{~m})$ below TOC
Water elevation: $230.9 \mathrm{tt}(70.38 \mathrm{~m}) \mathrm{ms}$

Sp. conductance: $54 \mu \mathrm{S} / \mathrm{cm}$

Turbidity: ONTU Water evacuated from the well prior to sampling: 42 gal ANALYSES

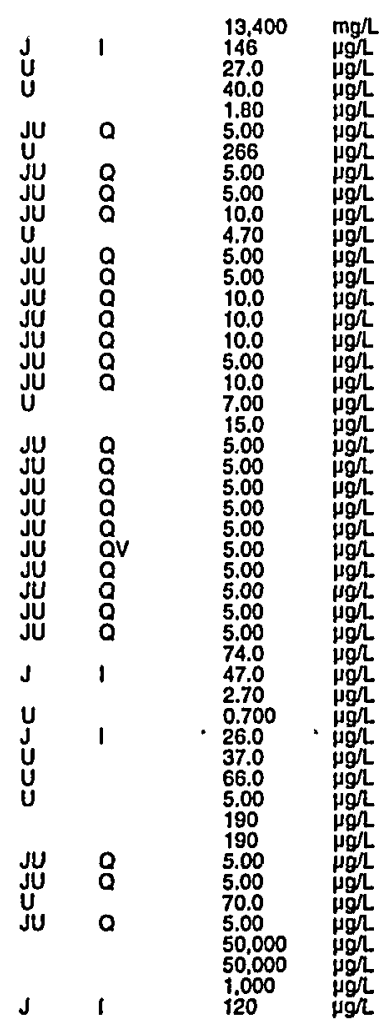

Alkallnity (as $\mathrm{CaCO}$ )

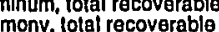

Arsenlc, total recoverablo

Boron, total recoverable

Bromodichloromelhane

Bromolorm
Bromomethan

Cadmlum, total recoverable

Chlorobanzene

Chloroelhene (Vinyt chloride)

Chrormium, total recoverable

Copper, lotal recoverable

Dibromochloromathan

1,i-Dichloroothane

$1,1 \cdot$ Dichloroethylene
irans-1,2.Dichloroethylen

Dichloromethane

cis-1,3.Dichloropropene
trans-1,3-Dichloropropene

Einybenzene

Lead, total recoverable

Mercury, total recoverable

ckel, total recoverable

Selenium, lotal recoverab

Sulfare

1,1,2.2.-Terrachloroethane

Tin, total recoverable

Tolal dissolved solids

B-17
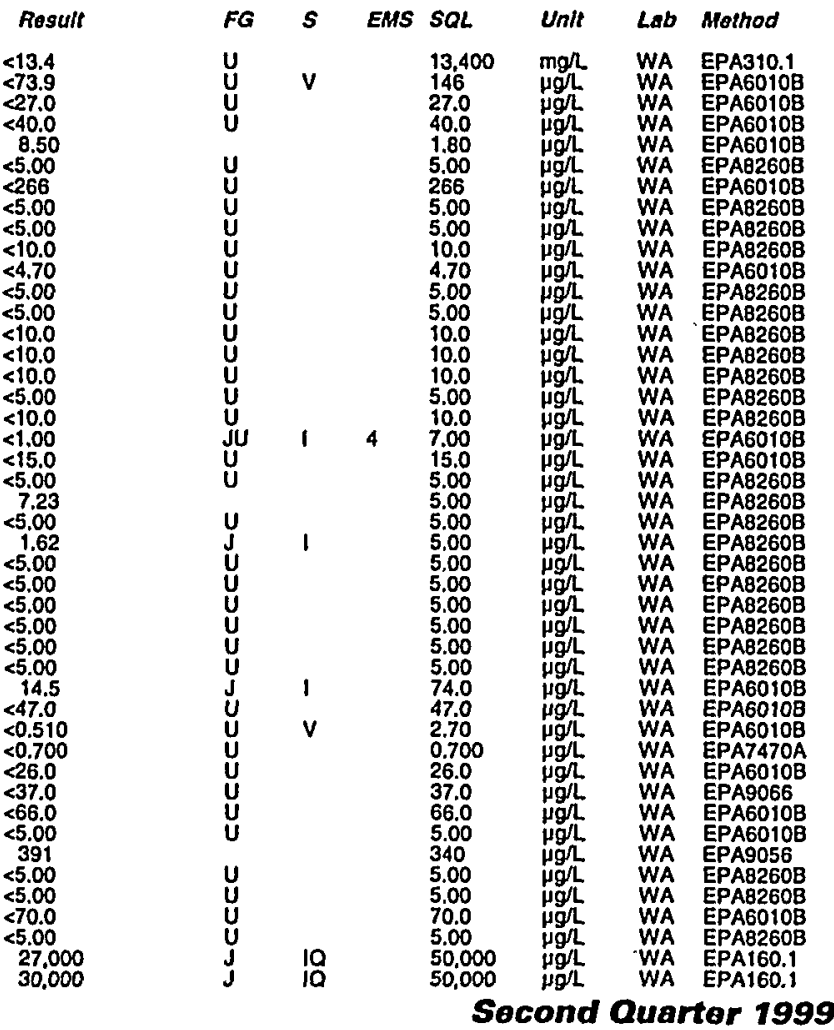
Well BGO 1 1DR collected on 05/17/99 (cont.)

$F$ Analyto

o Tolal organic carbon 1 Tolal organic halogens o $1,1,2$-Trichloroethan Trichloroelhylene
Trichlorolluoromethane Zlinc, lolal recoverable Gross alpha

Radium, lotal alpha-emilling 2 Tritium

\section{WELL BGO 12AX}

MEASUREMENTS CONDUCTED IN THE FIELD

Sample date: $05 / 17 / 99$ (1) $147.47 \mathrm{~m}$ ) below TOC

Water elevalion: $157.05 \mathrm{H}(47.87 \mathrm{~m}) \mathrm{ms}$

\begin{tabular}{|c|c|c|c|c|c|c|c|}
\hline & $\boldsymbol{G}$ & & EMS & $S Q L$. & $n i t$ & $b$ & Moth \\
\hline $\begin{array}{l}5.00 \\
5.00 \\
5.00 \\
53.0 \\
2.22 E-08 \pm 4.96 E .09 \\
4.93 E-09 \pm 1.04 E .09 \\
3.24 E-09 \pm 7.92 E-10 \\
4.209-09+1.00 .00\end{array}$ & $\begin{array}{l}J \\
J \\
J \\
U \\
U\end{array}$ & K & 4 & $\begin{array}{l}1.000 \\
120 \\
5.00 \\
5.00 \\
5.00 \\
5.00 \\
5.00 \\
53.0 \\
7.41 \mathrm{E}-09 \\
5.19 \mathrm{E} \cdot 10 \\
1.26 \mathrm{E}-09 \\
7.07 \mathrm{E}-10 \\
7.24 \mathrm{E}-10 \\
2.98 \mathrm{E}-05\end{array}$ & 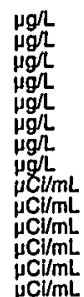 & $\begin{array}{l}\text { WA } \\
W A \\
\text { WA } \\
W A \\
W A \\
W A \\
W A \\
W A \\
W A \\
G P \\
G P \\
G P \\
G P \\
G P \\
G P\end{array}$ & $\begin{array}{l}\text { EPA } \\
\text { EPA } \\
\text { EPA } \\
\text { EPA } \\
\text { EPA } \\
\text { EPA } \\
\text { EPIA } \\
\text { EPIA } \\
\text { EPIA }\end{array}$ \\
\hline
\end{tabular}

Water evacuated from the well prior to sampling: $41 \mathrm{gal}$

ANALYSES

\begin{tabular}{|c|c|}
\hline & Analyte \\
\hline & 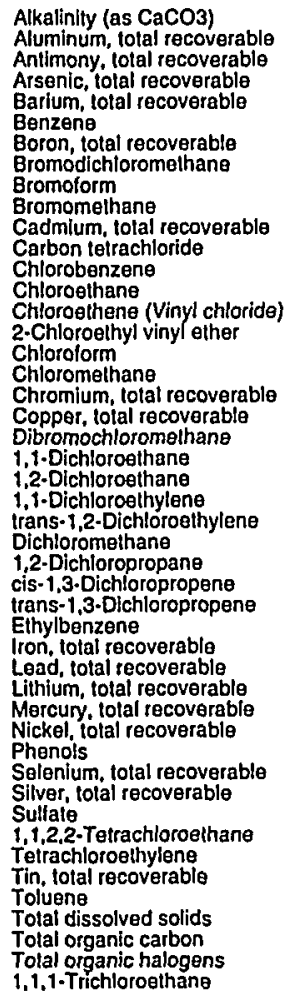 \\
\hline
\end{tabular}

ESH-EMS-990521
Time: 13:01 Air temperature: $30.6^{\circ} \mathrm{C}$ Co3): $79 \mathrm{mg} /$ Phenolphthalein alkalinity: $0 \mathrm{mg} / \mathrm{L}$

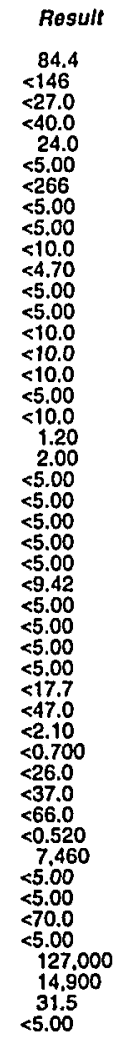
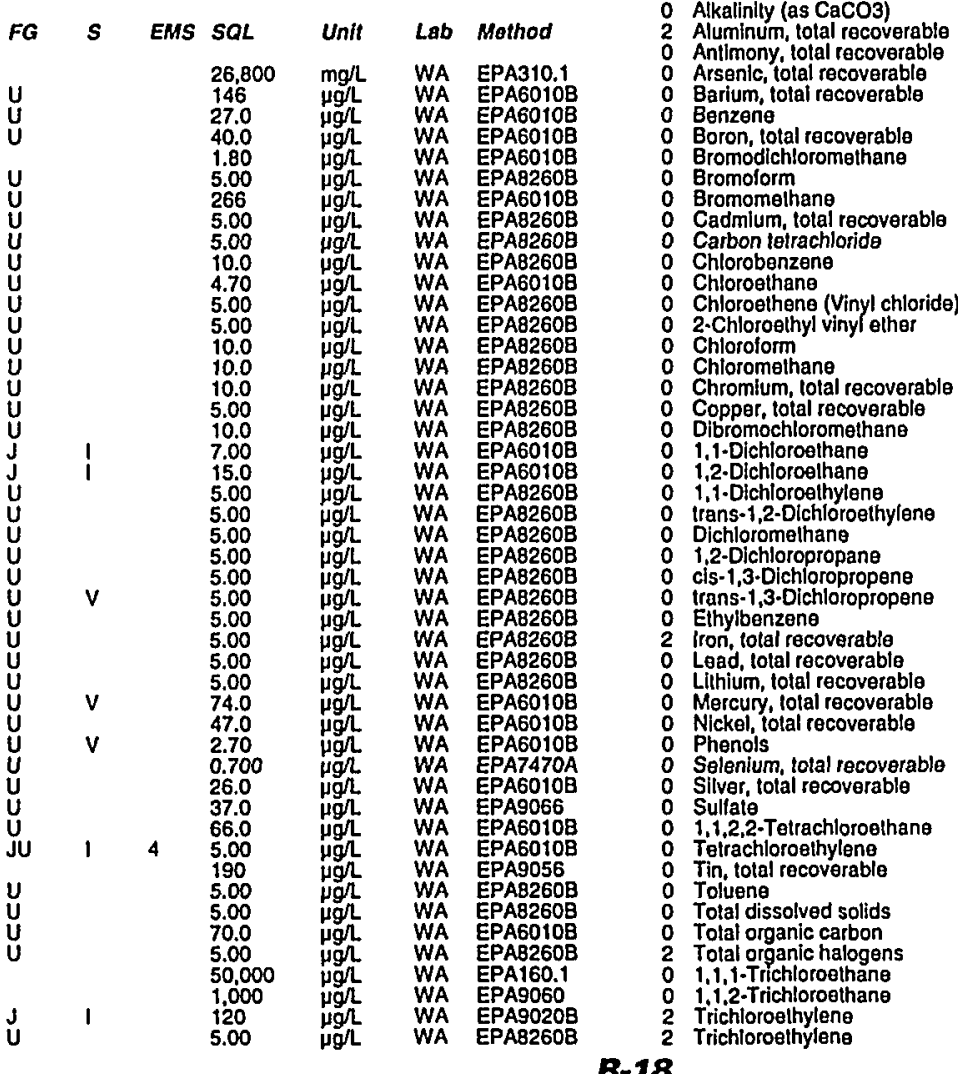

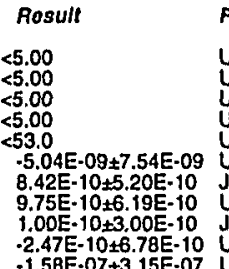

FG

$F$ Analyte

o 1,1,2-Trichloroathane

Trichlorofluoromethane

Xylenes

Carbon.14

O Padium, folal alpha-emitting

\section{WELL BGO 12CX}

MEASUREMENTS CONDUCTED IN THE FIELD

Sample date: $05 / 25 / 99$

Water elevation: $230.05 \mathrm{Ht}(70.12 \mathrm{~m}) \mathrm{ms}$

pH: 6.1

$\mathrm{Sp}$. conductance: $56 \mu \mathrm{S} / \mathrm{cm}$

Water evacuated from the well prior to sampling: $30 \mathrm{gal}$

ANALYSES Al tal recoverable

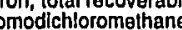

Bromolorm

ene (Vinyl chloride)

tatal recoverable

Dibromochloromethan

1,2-Dichloroethane

1. 1,2-Dichloropropan

trans-1,3-Dichloropropen

iron, total recoverab

Lithium, tolal recoverable

Nickel, total recoverable

Selenium, total recoverablo

1,1,2,2-Tetrachloroethan

ived solids

The

$8-18$

Result
7.81
722
$<27$
$<4.0$
$<4.0$
7.70
$<5.00$
$<268$
$<5.00$
$<5.00$
$<100$
$<4.0$
$<5.00$
$<5.00$
$<100$
$<10.0$
$<10.0$
$<5.00$
$<10.0$
6.40
$<15.0$
$<5.00$
$<5.00$
$<5.00$
$<5.00$
$<5.00$
$<4.32$
$<5.00$
$<5.00$
$<5.00$
$<5.00$
813
$<47.0$
1.00
$<0.700$
4.90
$<37.0$
$<66.0$
$<0.810$
974
$<5.00$
$<5.00$
$<70.0$
$<5.00$
33.000
375
174
$<5.00$
$<5.00$
228
231

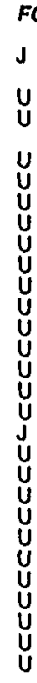

Time: 11:55

perature: $23.9^{\circ} \mathrm{C}$ Total alkalinity (as Caco3): $10 \mathrm{mg} / \mathrm{L}$ Fien
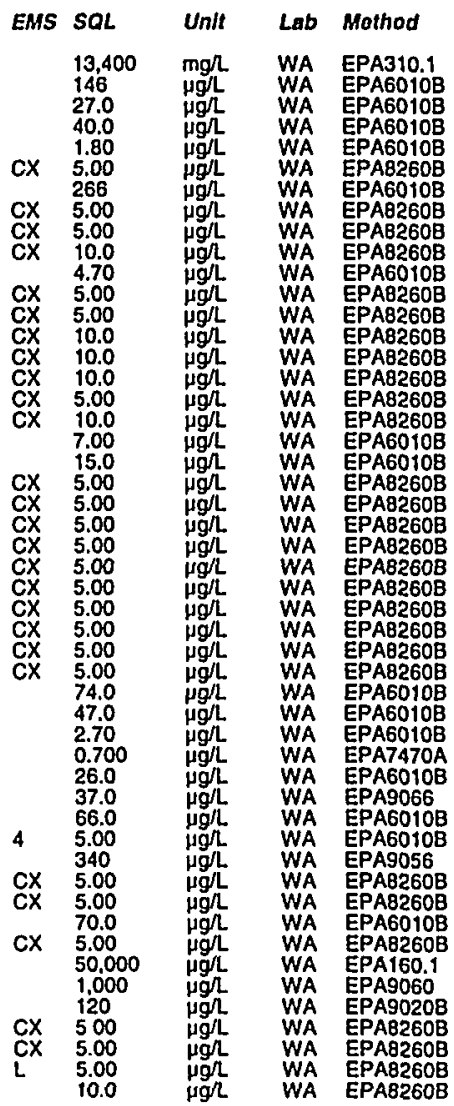

Socond Quartor 1999 
ANALYTICAL RESULTS

Well BGO 12CX collected on 05/25/99 (cont)

$F$ Analyto

o Trichlorolluoromethane Zinc, Iotal recoverable 0 Gross alpha

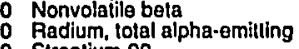
2 Strontium-9o

$\begin{array}{ll}\text { Result } & F G \\ <5.00 & U \\ <5.00 & U \\ 16.0 & J \\ -1.21 E-09 \pm 4.32 E-09 & U \\ 5.73 E-10 \pm 4.91 E-10 & U \\ 1.57 E-09 \pm 6.94 E-10 & J \\ 7.00 E-10 \pm 6.00 E-10 & U \\ -8.31 E-10 \pm 4.91 E-10 & U \\ 2.56 E-05 \pm 1.01 E-06 & J\end{array}$

FG

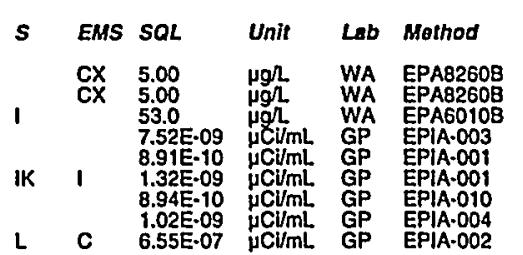

\section{WELL BGO 12DR}

MEASUREMENTS CONDUCTED IN THE FIELD

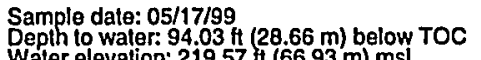
Water elevation: $219.57 \mathrm{ft}(66.93 \mathrm{~m}) \mathrm{ms}$ SH: 10.8 conductance: $800 \mu \mathrm{S} / \mathrm{cm}$

Water evacuated from the well prior to sampling: $4 \mathrm{gal}$

ANALYSES

$F$ Analyte

- Alkalinity (as $\mathrm{CaCO}$ )

Antimony, total recoverable

0 Arsenic, iotal recoverable

0 Boron, total recoverab

Bromodichloromelhane

0 Bromomelthan

Cadmium, total recoverable

Carbon tetrachiorido

Chloroethene (Vinyl chloride)
2-Chloroethyl vinyl ether

Chloromethan

Chromium, total recoverable

Copper, tolal recoverable

1.1-Dichloroethane

1.2.Dichloroelhane

trans-1,2.Dichloroethylene

1,2-Dlchloropropane

cis-1,3. Dichloropropene
trans- $-1,3 \cdot$ Dichloropropene

Ethylbenzene

Lead, lotal recoverable

Mercury, lotal recoverable

Shelenis

Silver, total recoverable

Sulfate - Tetrachloroelhane

Tin. total recoverable

- Toluene

Total organile carbon

Total organic halogens

1.i. - Trichloroethane

Trichloroethylene
Trichlorofluoromethane

ESH-EMS-990521

Result
135
363
$<27.0$
$<40.0$
58.3
$<5.00$
$<266$
$<5.00$
55.00
$<10.0$
$<4.70$
$<5.00$
$<5.00$
$<10.0$
$<10.0$
$<10.0$
$<5.00$
$<10.0$
2.10
1.70
$<5.00$
$<5.00$
$<5.00$
$<5.00$
$<5.00$
$<9.71$
55.00
$<5.00$
$<5.00$
$<5.00$
$<16.9$
$<47.0$
20.9
$<0.700$
$<26.0$
$<37.0$
$<66.0$
3.10
17.300
$<5.00$
$<5.00$
$<70.0$
$<5.00$
213.000
203.000
517
$<120$
$<5.00$
$<5.00$
1.72
$<5.00$
$<5.00$

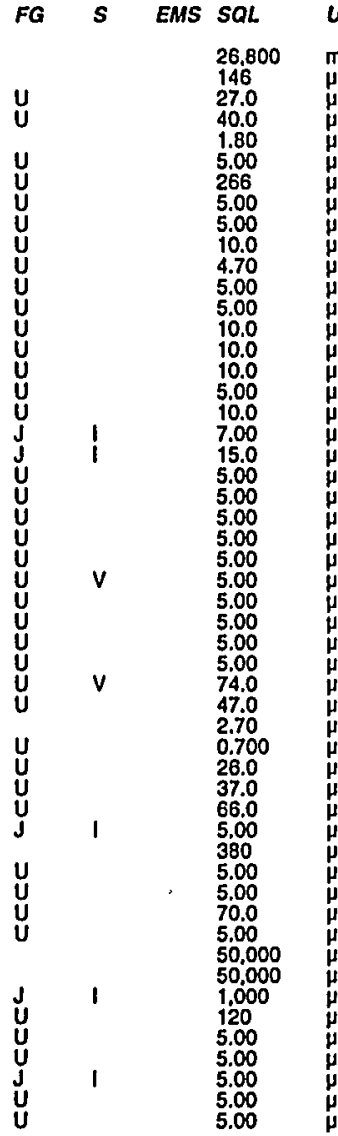

Time: $14: 26$ ater temperature: $23.3^{\circ} \mathrm{C}$ Air temperalure: $30.7^{\circ} \mathrm{C}$
Tolal alkalinity (as CaCo3): $199 \mathrm{mg} /$.
Phenolphthalein alkalinity: $199 \mathrm{mg} \mathrm{h}^{-}$ (s): VH ly: $199 \mathrm{mg}$

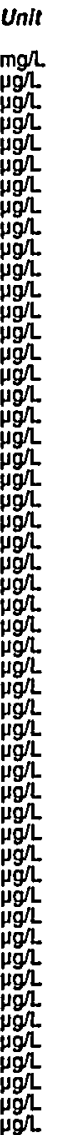

Lab Method

WA EPA310.1

WA EPAG

EPAGD10日

WA

EPA22608

WA EPAB2608

WA EPA8260B

WA EPAG010B

WA EPAB260B

WA EPAB260

WA EPAB260

WA EPA260B

WA EPA6010B

EPAG010B

WA EPA906B

WA EPA9056

WA EPA8260B

WA EPA8260B

Elhylbenzen

Iron, lotal recoverable

B-19 ANALYSES

WA EPAB260B
Well BGO 12DR collected on 05/17/99 (cont.)

-53.0
$-9.58 \mathrm{E}-11 \pm 5.39 \mathrm{E}-09$
$6.98 \mathrm{E}-11 \pm 5.26 \mathrm{E}-10$

Zinc, total recoverable

Nonvolatile bela
Radium, totalal alpha-ernitting

Strontium

9.35E-09 $\mathrm{HCJmL}$ GP EPIA.003

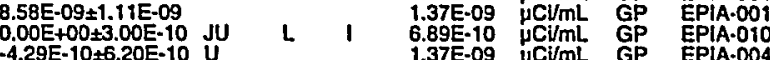

WELL BGO 13DR

MEASUREMENTS CONDUCTED IN THE FIELD

Deph to water: $89.3 \mathrm{H}(27.22 \mathrm{~m})$ below TOC

W:

Sp. conductance: $57 \mu \mathrm{S} / \mathrm{cm}$

Waler evacuated from the well pror to sampling: $1 \mathrm{gal}$

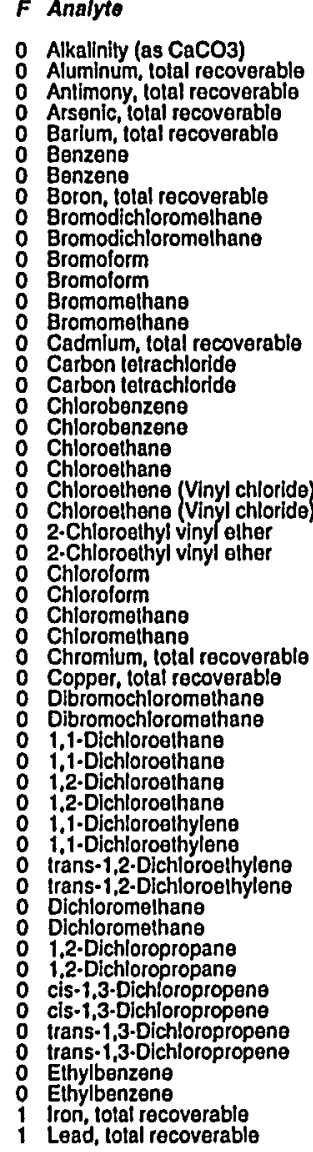

Result

FG

Time: 9:50

Water lemperature: $22.6^{\circ} \mathrm{C}$

Total alkalinily (as CaCO3): $18 \mathrm{mg} / \mathrm{L}$

Phenolphlhaloin alkalinity: $0 \mathrm{mg} /$.
Field Qualifier(s): $S X$

25.6
530.6
527.0
540.0
44.4
45.00
55.00
5266
55.00
55.00
55.00
55.00
510.0
510.0
54.70
55.00
55.00
55.00
55.00
510.0
510.0
510.0
510.0
510.0
510.0
55.00
55.00
510.0
$<10.0$
13.5
9.90
55.00
55.00
55.00
55.00
55.00
55.00
55.00
55.00
55.00
55.00
56.61
56.01
55.00
55.00
55.00
55.00
55.00
55.00
55.00
55.00
198
32.5
10

Unit Lab Method

400 mgh WA EPA3T0.1

WA EPAGO10B

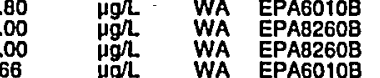

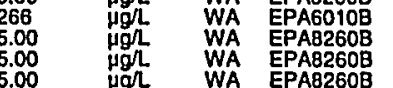

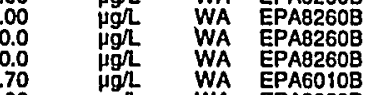

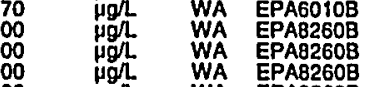

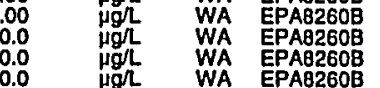

rgh WA

WA

WA

WA EPA6010B

WA EPAG260

WA

WA

WA

WA EPAB260B

WA EPA8260B

WA

WA EA EAB22608

WA EPAG010B

Socond Quarter 1999 
ANALYTICAL RESULTS

Well BGO 13DA collected on 05/20/99 (cont.)

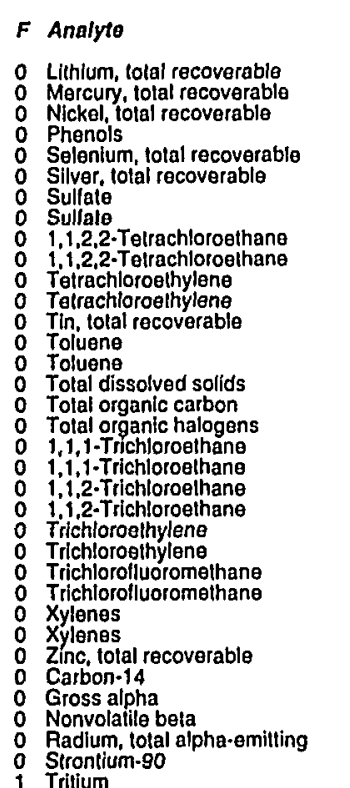

WELL BGO 14AR

MEASUREMENTS CONDUCTED IN THE FIELD

Sample date: $05 / 25 / 99$
Depth to water: $142.2 \mathrm{ft}(43.34 \mathrm{~m})$ below TOC
Water elevation: $158.5 \mathrm{ft}(48.31 \mathrm{~m}) \mathrm{msl}$

$\mathrm{pH}: 10.8$
Result

44.4
$<0.700$

9.50
$<37.0$
$<66.0$
$<5.00$

2,160
2,160
2,00

$\mathbf{5} .00$
+5.00
+5.00
$\mathbf{5} .00$
+70.0

5.00

772
32.5
$<5.00$
55.00

$<5.00$

$<5.00$
$\times 5.00$
$\times 5.00$
$\times 5.00$
$\quad 5.00$

5.00 $1.18 \mathrm{E} \cdot 09 \pm 6.78 \mathrm{E}-10 \mathrm{U}$ $7.00 \mathrm{E}-10 \pm 5.00 \mathrm{E}-10$
$5.85 \mathrm{E}-10 \pm 4.77 \mathrm{E} \cdot 10$
8.59E-10 $\pm 4.46 E-09$ U

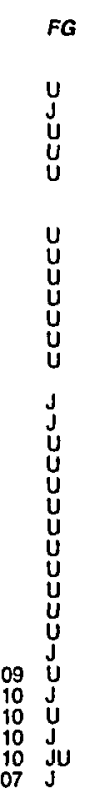

$s$
1
1
1

1

EMS SQL

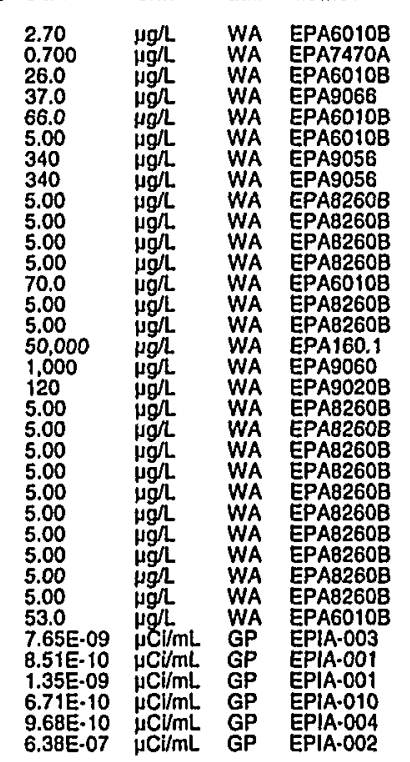

Well BGO 14AR collected on 05/25/99 (cont)

$F$ Analyto

o Chlorobenzene

Chloroothan

Chloroethene (Vinyl chloride) 2.Chloroethyl vinyl ether Chlorolorm

Chlorolorm
Chloromethane

Chromium, lotal recoverable Chromium, total recoverable Copper, tolal recoverabla

Dibromochloromethane

1.1-Dichloroethane

1,1.Dichloroethane

1,2-Dichioroethane

1,1-Dichloroethylene

trans-1,2-Dichloroethylene

Dichloromethane

Dichloromethane

1,2.Dichloropropane

cis-1,3-Dichloropropene

trans-1,3.Dichloropropene

Ethylbenzens

Iron, lotal recoverabi

- Iron, lotal recoverable

Lead, total recoverable

- Lithium, total recoverable

- Mercury, lotal recoverable

Time: 9:09

Waler temperature: $20.1^{\circ} \mathrm{C}$

$\begin{array}{ll}\text { Air temperalure: } 33.1 \% \mathrm{C} & \\ \text { Tolail akainity (as CaCo3): } 135 \mathrm{mg} / \mathrm{L} & \text { o Nickel, tolal recoverable } \\ \text { Phenolphithalein alkalinity: } 98 \mathrm{mgh} & \text { o Nickel, total recoverable }\end{array}$

0 Phenols

0 Selenium, total recoverable Selenlum, total recoverablo

Silver, tolal recoverable

ANALYSES

\begin{tabular}{|c|c|}
\hline \multirow[b]{2}{*}{ 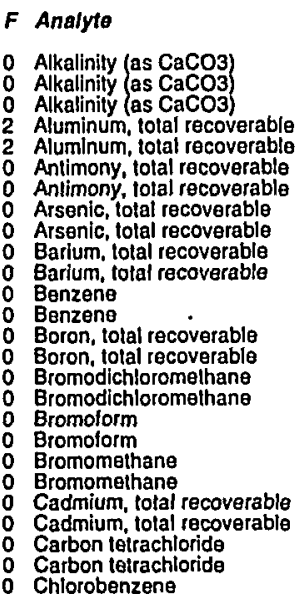 } & Result \\
\hline & $\begin{array}{r}112 \\
111 \\
121 \\
290 \\
294 \\
<10.0 \\
<27.0 \\
<5.00 \\
<40.0 \\
92.4 \\
89.9 \\
<1.00 \\
<5.00 \\
<50.0 \\
<266 \\
<1.00 \\
<5.00 \\
<1.00 \\
<5.00 \\
<1.00 \\
<100 \\
<5.00 \\
<4.70 \\
<1.00 \\
<5.00 \\
<1.00\end{array}$ \\
\hline
\end{tabular}

FG S EMS SQL Unit Lab Method

ESH-EMS-990521

\begin{tabular}{|c|c|c|c|}
\hline $\begin{array}{l}1.000 \\
1.000 \\
26.800 \\
50.00 \\
146 \\
10.0 \\
27.0 \\
5.00 \\
40.0 \\
5.00 \\
1.80 \\
1.00 \\
5.00 \\
50.0 \\
266 \\
1.00 \\
5.00 \\
1.00 \\
5.00 \\
1.00 \\
10.0 \\
5.00 \\
4.70 \\
1.00 \\
5.00 \\
1.00\end{array}$ & 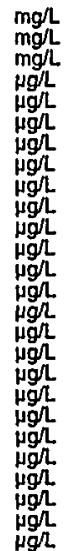 & $\begin{array}{l}G E \\
G E \\
W A \\
W A \\
G E \\
W A \\
G E \\
W A \\
G E \\
W A \\
G A \\
G E \\
W A \\
G E \\
W A \\
G E \\
W A \\
G E \\
W A \\
G E \\
W A \\
G E \\
W A \\
G E \\
W A \\
G E \\
W A \\
G E\end{array}$ & 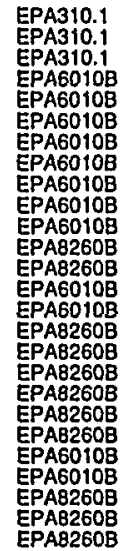 \\
\hline
\end{tabular}

0 Sulfate

$1,1,2,2-$ Telrachloroothan
Tetrachloroothylene

Tin, total recoverable

0 Toluene

Total dissolved sollds

Total dissolved sollds

Total dissolved solids

Total organíc carbon

Tolal organlic halogens

Tolal organic halogens

1,1.1. Trichloroethane

1,i,2-Trichloroothane

o 1.1.2-Trichloroothan

B-20
1,1,2,2-Tetrachloroethane

Tetrachloroethylene

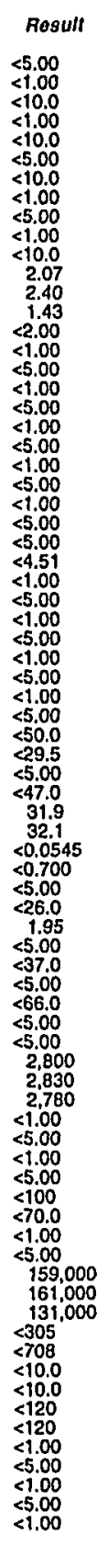

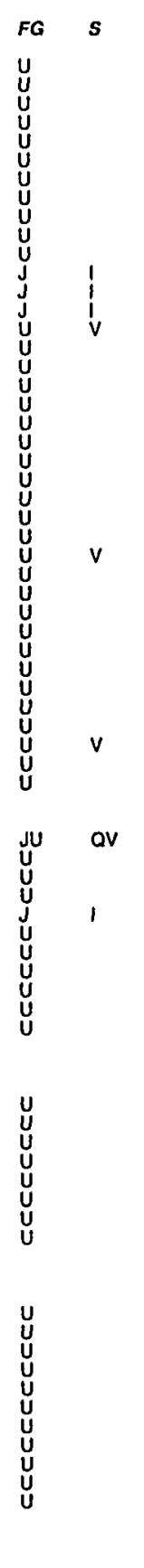

EMS SOL

CX 5.00

5.00
$\mathrm{cX} \quad 1.00$

1.00
cx 10.0

cX $\quad \begin{aligned} & 5.00 \\ & 10.0\end{aligned}$

1.00
$\mathrm{CX} \quad 5.00$

CX 10.0

5.00
7.00
5

$\mathrm{cx} 5$

cx 5.00

CX 5.00

$\mathrm{CX} \quad 5.00$

cx 5.00

5.00
$\mathrm{CX} \quad 5.00$

CX 5.00

CX $\quad 5.00$

CX $\quad 5.00$

cx $\begin{array}{r}1.00 \\ 5.00\end{array}$

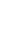

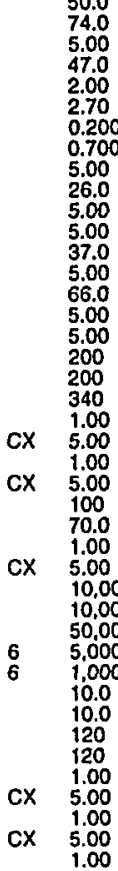

Seco

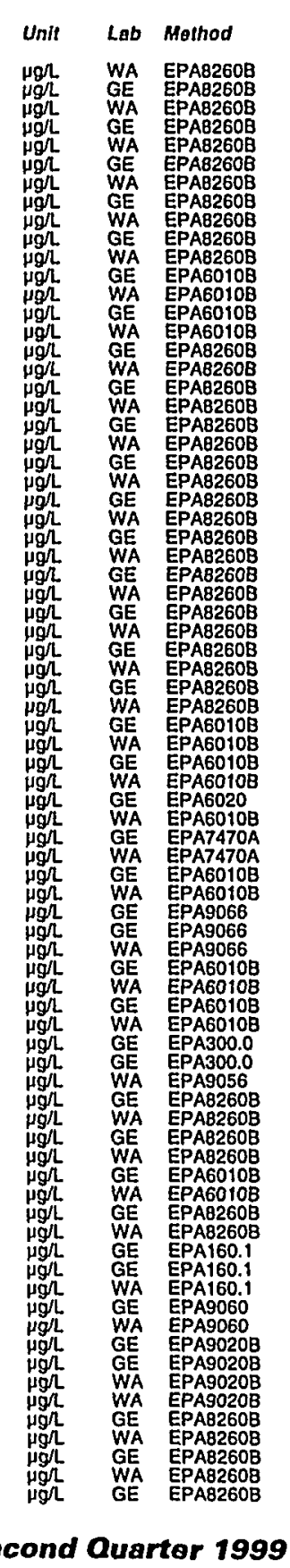




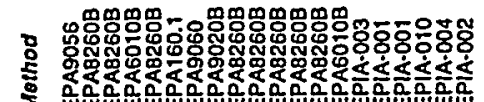

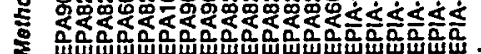

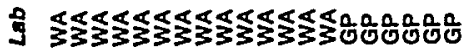

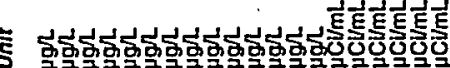

용용응우궁

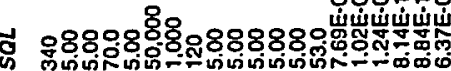

里

出

$\bullet$

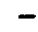

as

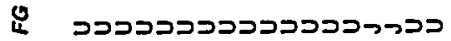

\section{융으으유소}

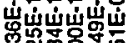

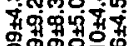

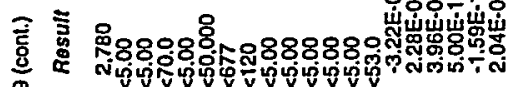
要

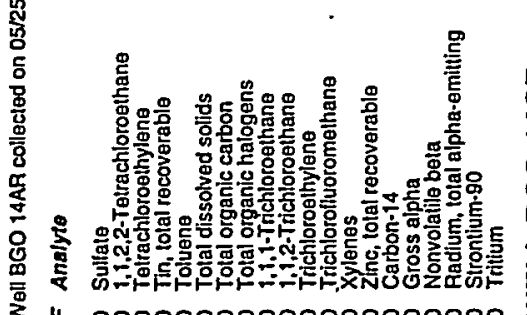

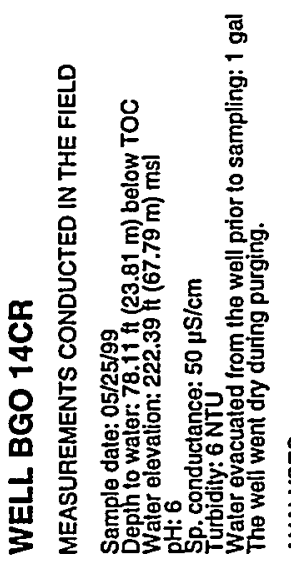

旁

1) 눙

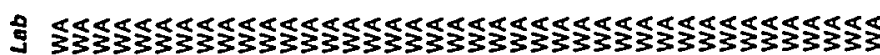

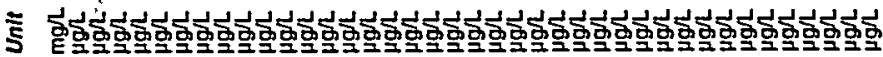

80000000000000009080880808800008000000 한

率

s - -

这

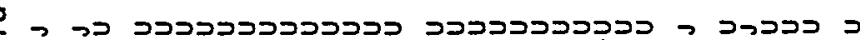
๔.

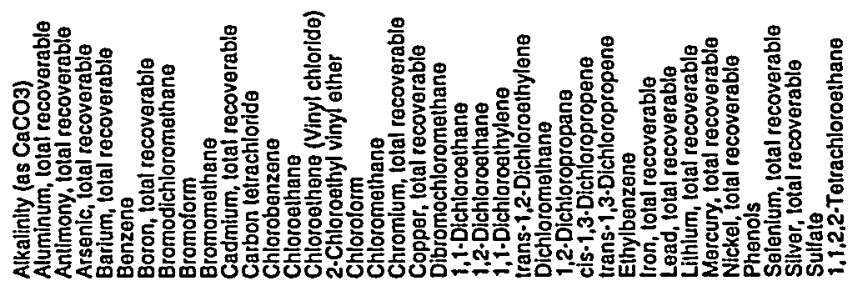

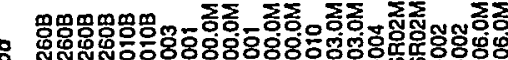

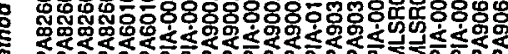
产

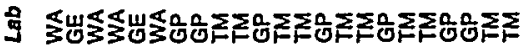

₹

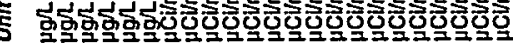

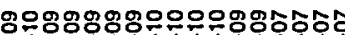

ป 88888 은

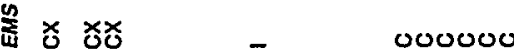

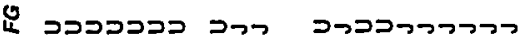

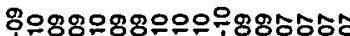

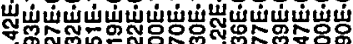
7 i

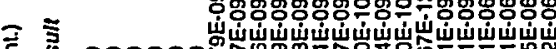

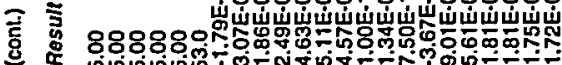

贾

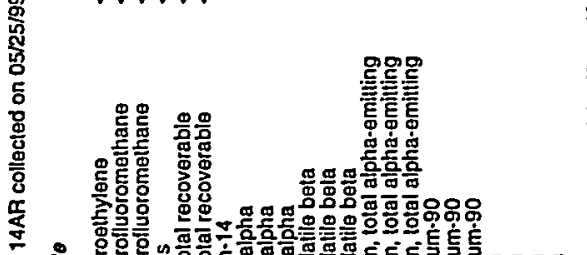

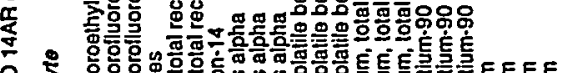

这 空

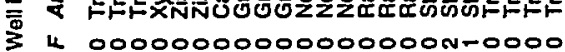

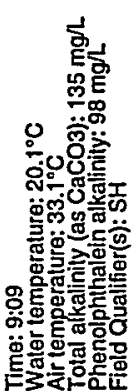

:

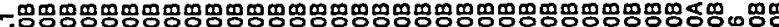
作

ป

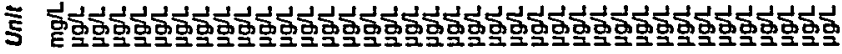

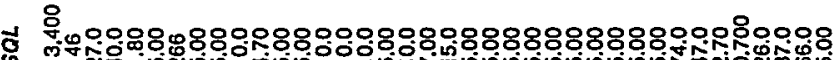
蛋

es

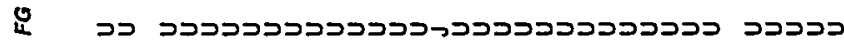

梠

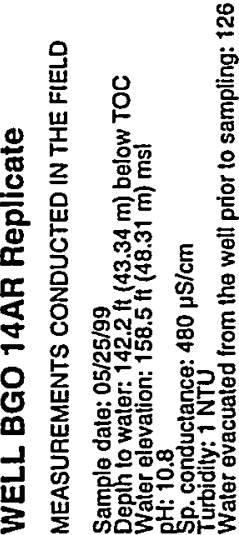

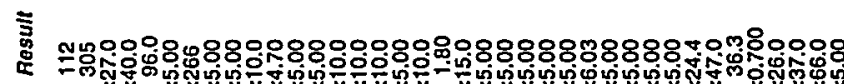

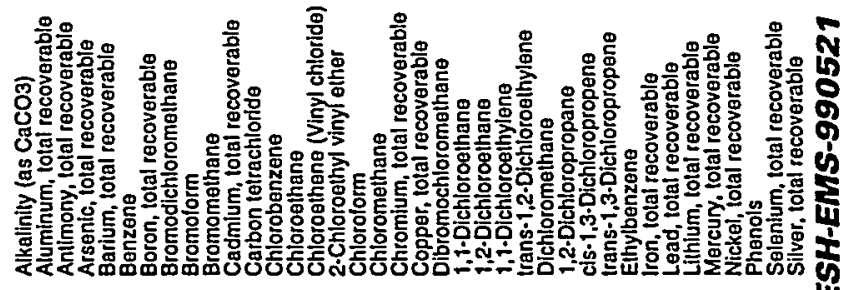




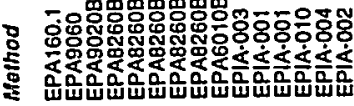

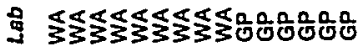

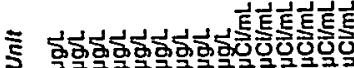

용으용우우오

1 8ิ8

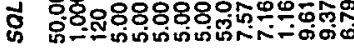

紊

n - - $\quad$ -

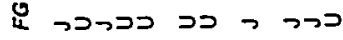

8용우유응

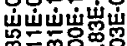

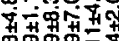

ว

空

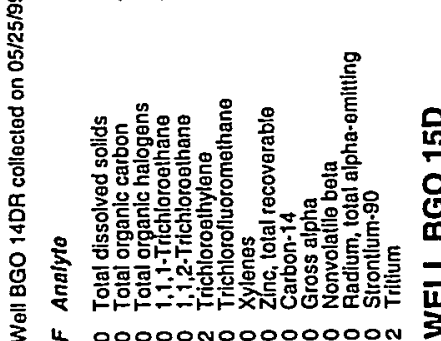

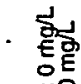

웅.

ํํํํำ

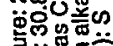

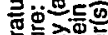
-

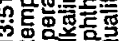
के

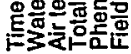

홓

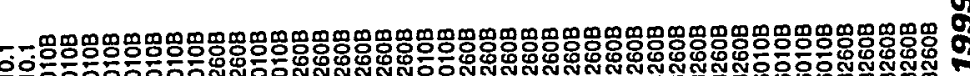

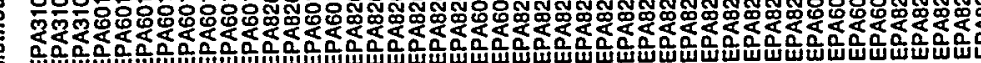
긴

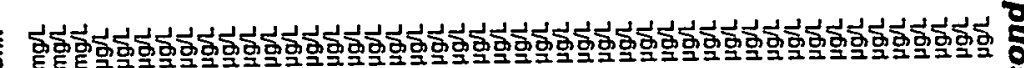

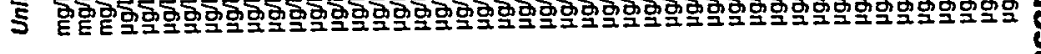

ธ 密 000

$\infty \quad>$

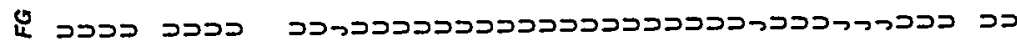
$\overline{\mathrm{g}}$

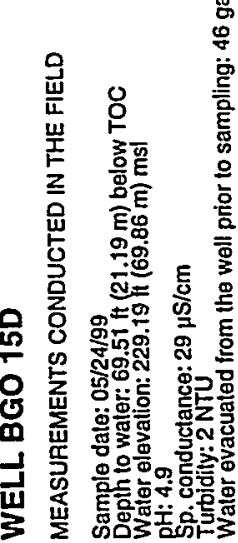

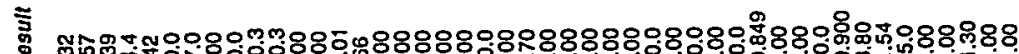

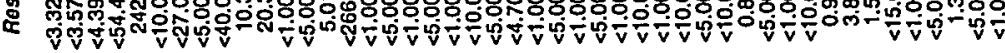

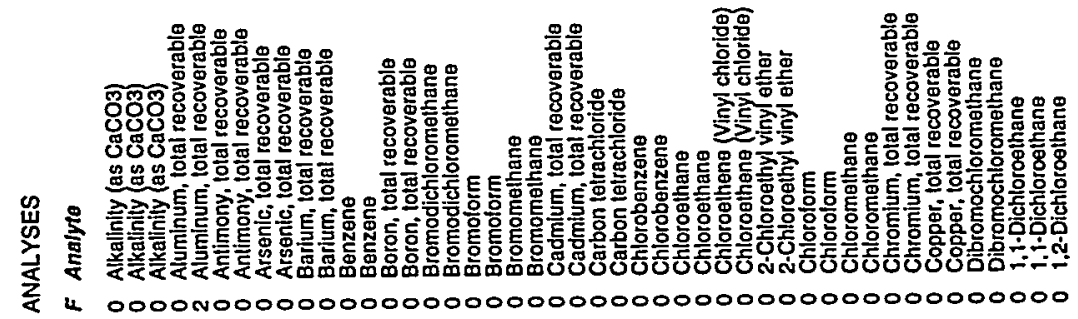

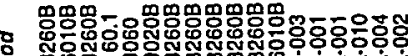

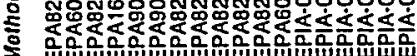

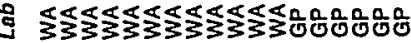

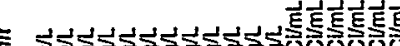

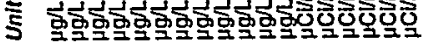

옹우용으용용

อ 80800

妾 $x$ ×

(s)

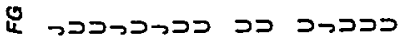

용으으으우요

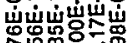

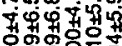

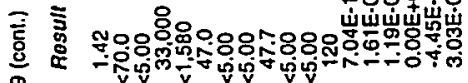

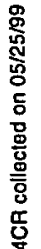

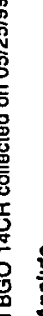

4 000000000000000000

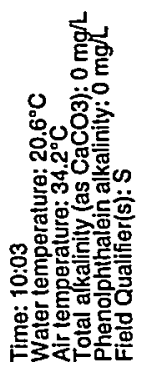

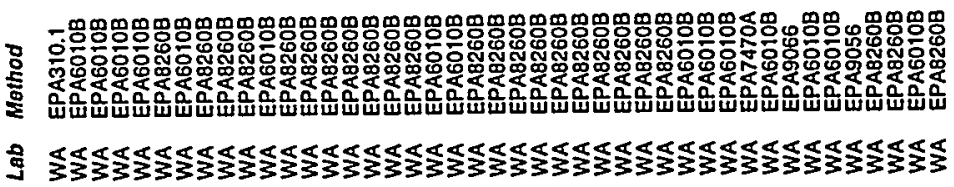

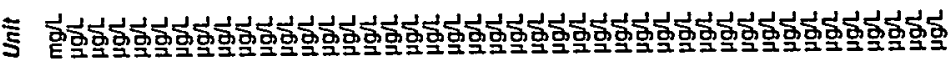

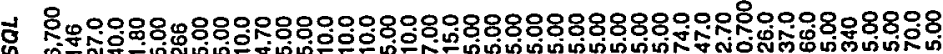

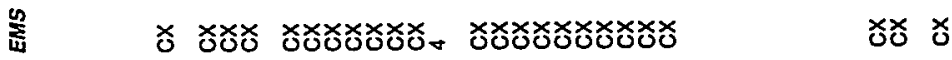

בנים

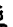

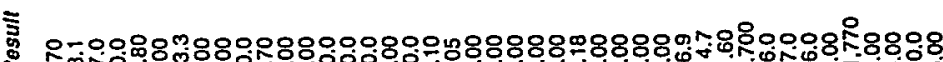

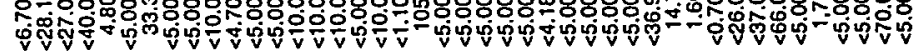

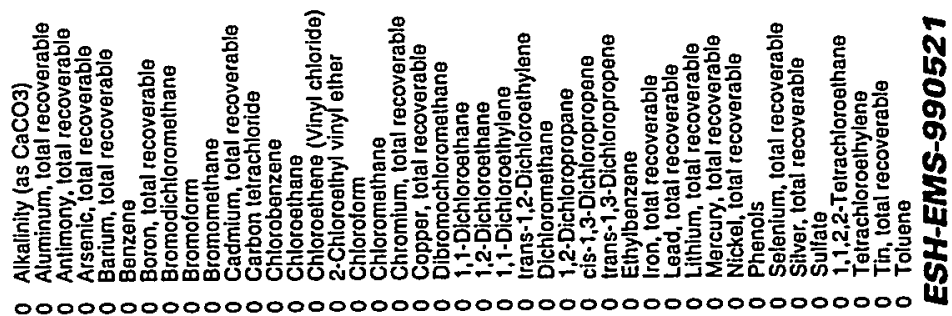



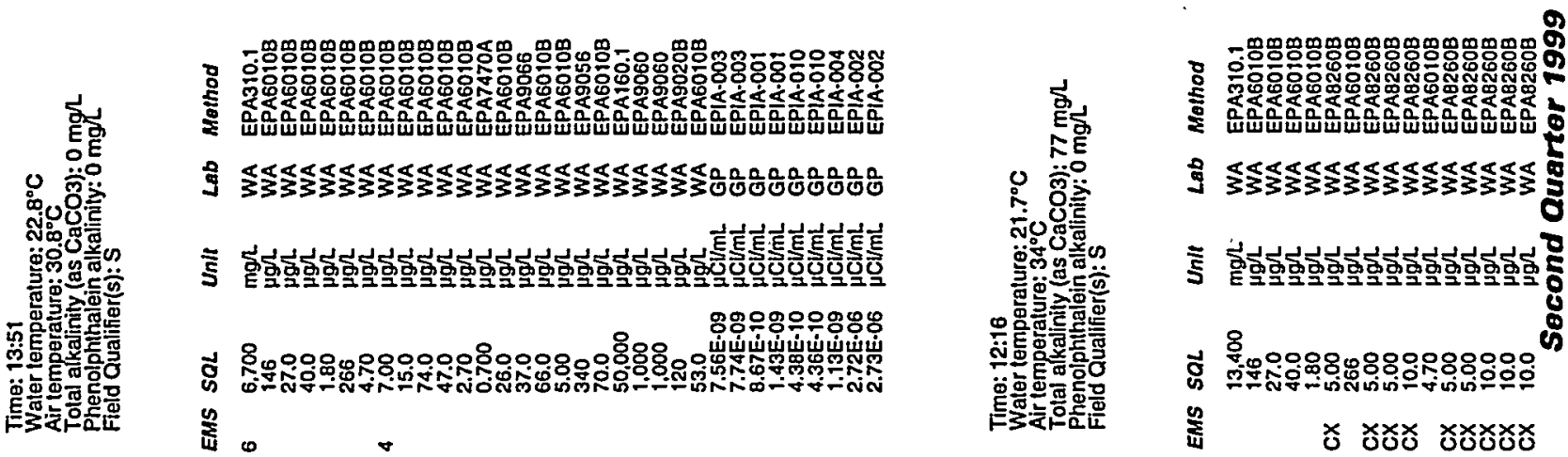

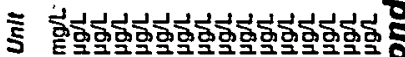

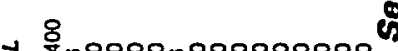

ธิ

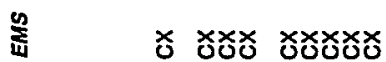

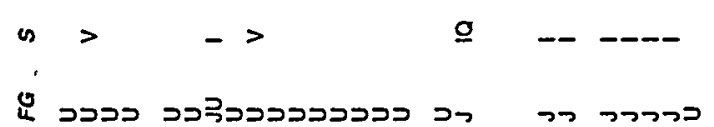

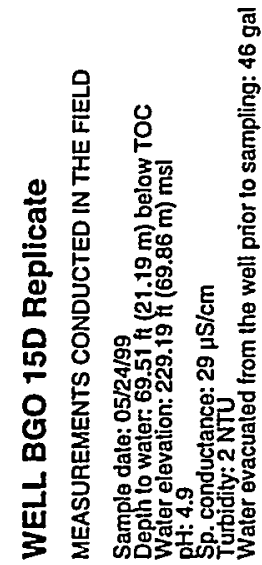

害

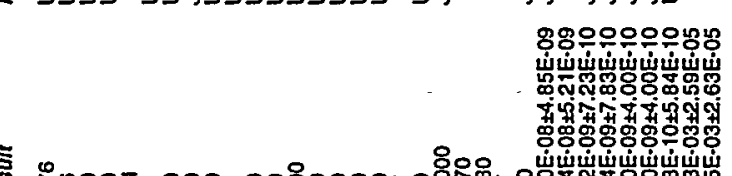

용으으응ㅇ우늉요

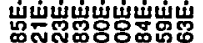

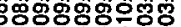

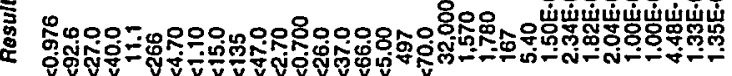

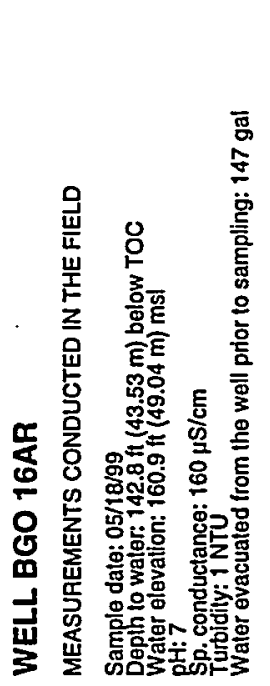

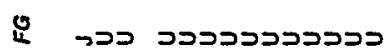

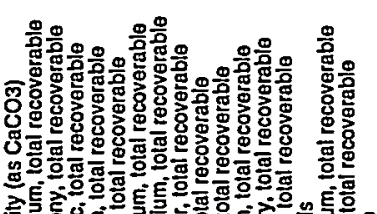

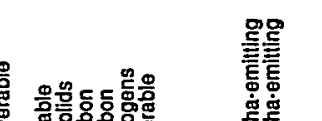

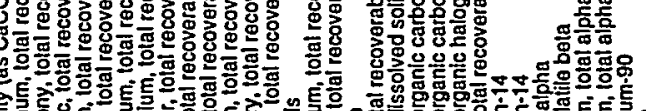

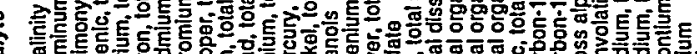

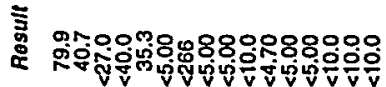

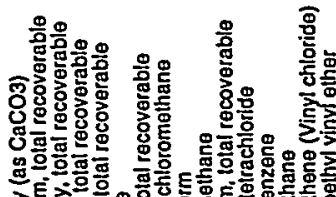

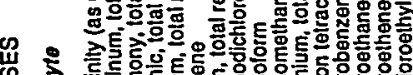

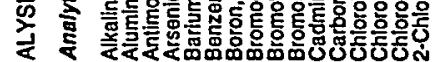

4 0-00000000000000 N

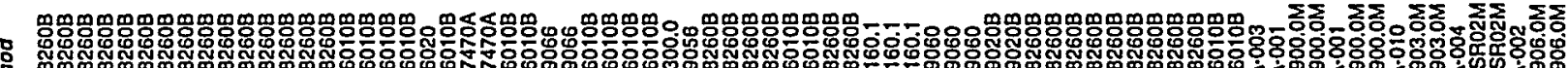

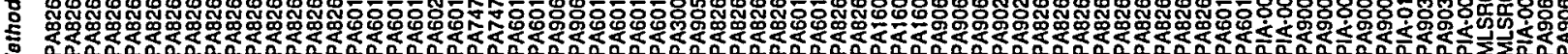

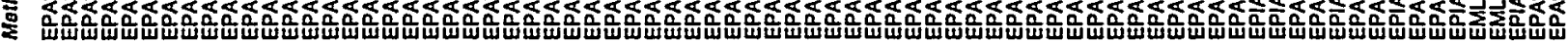

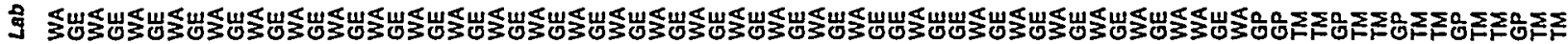

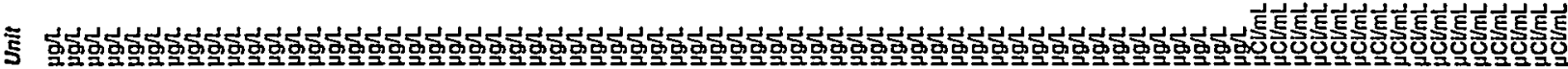

용으으으용용으우으용요용충

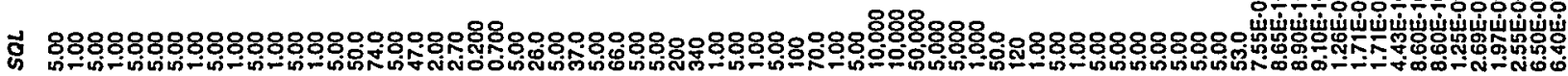
은

要

n

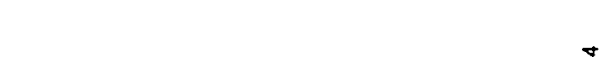

每

ơg -

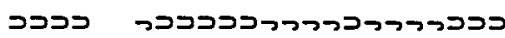

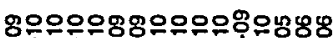

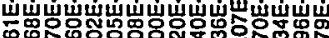

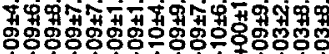

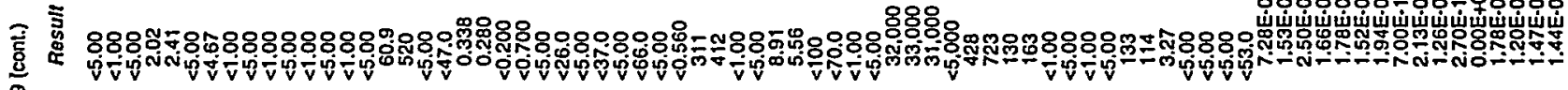

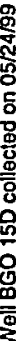

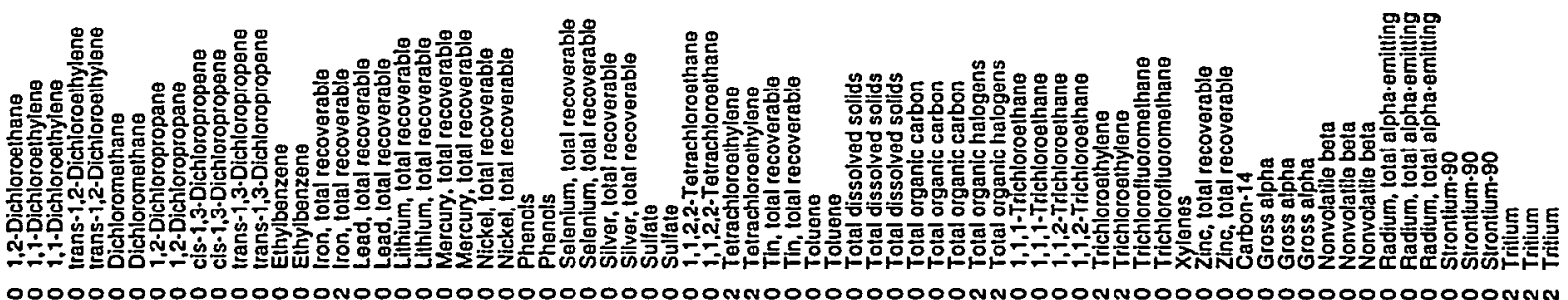


Well BGO 16AR collected on 05/18/99 (conl.)

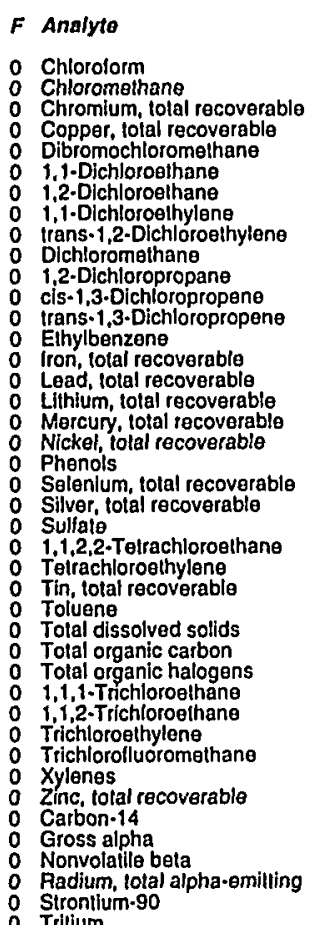

Result

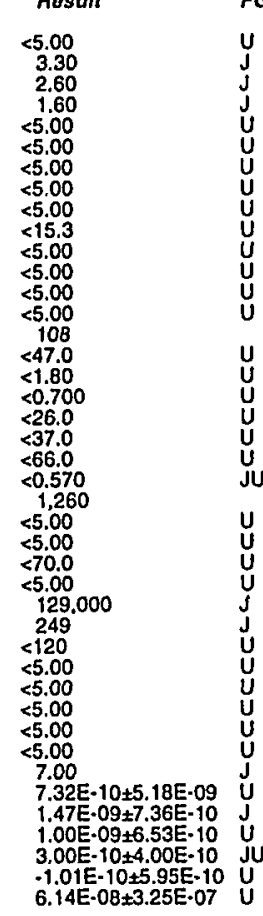

\section{WELL BGO 16B}

MEASUREMENTS CONDUCTED IN THE FIELD

Sample date: $05 / 18 / 99$
Depth to waier: $88.03 \mathrm{ft}(26.83 \mathrm{~m})$ below TOC
Water elevation: $217.07 \mathrm{tt}(66.16 \mathrm{~m}) \mathrm{ms}$

pH: 7.4

Sp. conductance: $200 \mu \mathrm{S} / \mathrm{cm}$

Water evacualed from the well prior to sampling: $2 \mathrm{gal}$ The well went dry during purging.

ANALYSES

$F$ Analyte

- Alkalinity (as CaCO3)

Antimony. Lolal recoverablo

Arsenlc, tolal recoverable

Benzenis

Boron, total recoverable

Bromolorm

Cadmium, tolal recoverable

Carbon tetrachlorid

Chlorobenzene

Chloroethene (Vinyl chloride)

ESH-EMS-990521

Result
108
120
$<27.0$
$<40.0$
43.1
$<5.00$
$<266$
$<5.00$
$<5.00$
$<10.0$
$<4.70$
$<5.00$
$<5.00$
$<10.0$
$<10.0$
$<10.0$
$<5.00$
$<10.0$

Well BGO 168 collected on 05/18/99 (cont.)

(1)

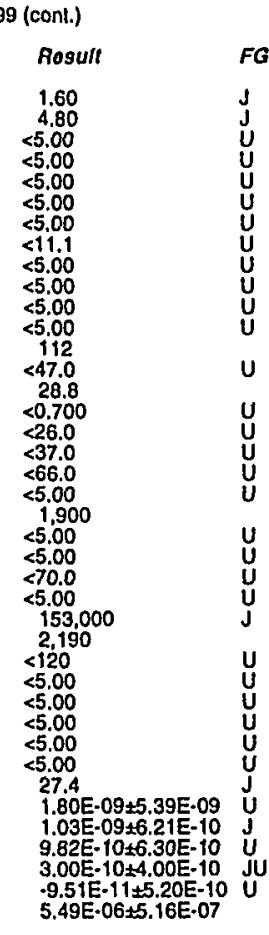

\section{WELL BGO 16D}

MEASUREMENTS CONDUCTED IN THE FIELD

Sample date: $05 / 18 / 99$ (22.8 m) below TOC

Depth to water: $74.8 \mathrm{ft}(22.8 \mathrm{~m})$ below TOC
Water elevation: $229.8 \mathrm{ft}(70.04 \mathrm{~m}) \mathrm{msl}$

pH: 7 conductance: $58 \mu \mathrm{S} / \mathrm{cm}$

Wurbidity: 5 NTU The well wenl dry during purging.

ANALYSES

F Analyte
Water temperature: $23.2^{\circ} \mathrm{C}$

Total alkalinity: (as CaCO3): $103 \mathrm{mg} / \mathrm{L}$ Phenolphthalein alkal
Field Qualifier(s): SX
- Alkalinity (as Cocos)

2 Aluminum, lotal recoverabl

Arsenic, total recoverable

- Barium, total recoverable

o Benzene

- Bromodichloromethan

B Bromolorm

Cadmium, lotal recoverable

Carbon teirachloride

Chloroethane

Chloroethene (Vinyl chloride)

2-Chloroethyl vinyl ether

: Chlorolorm

Chromium, total recoverable

24

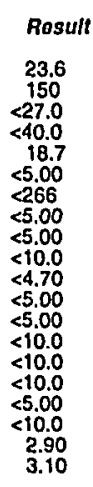

Rosuh
23.6
150
$<27.0$
$<40.0$
18.7
$<5.00$
$<266$
$<5.00$
$<5.00$
$<10.0$
$<4.70$
$<5.00$
$<5.00$
$<10.0$
$<10.0$
$<10.0$
$<5.00$
$<10.0$
2.90
3.10

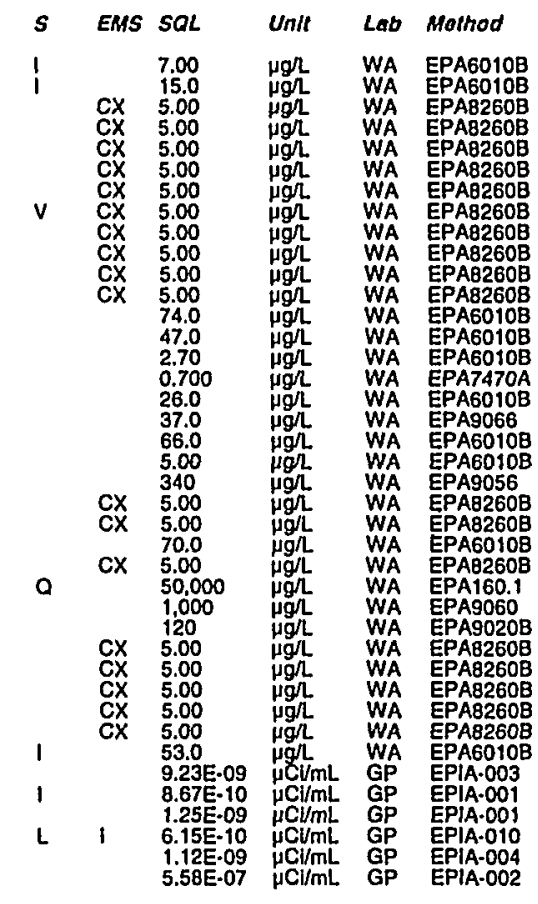

Time: 13:28

Air temperalure: $24.7^{\circ} \mathrm{C}$

Air mal akeraturity: (as Caco3): $27 \mathrm{mg} / \mathrm{L}$

Phenolphthalein alkali
Field Qualifier(s): SX

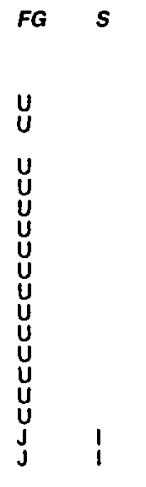

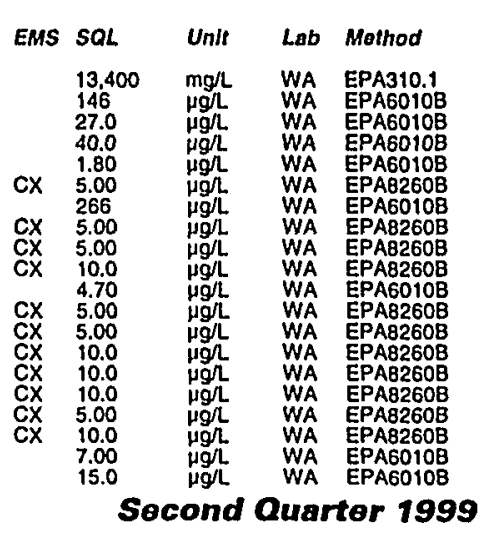


Well BGO 16D collected on 05/18/99 (cont.)

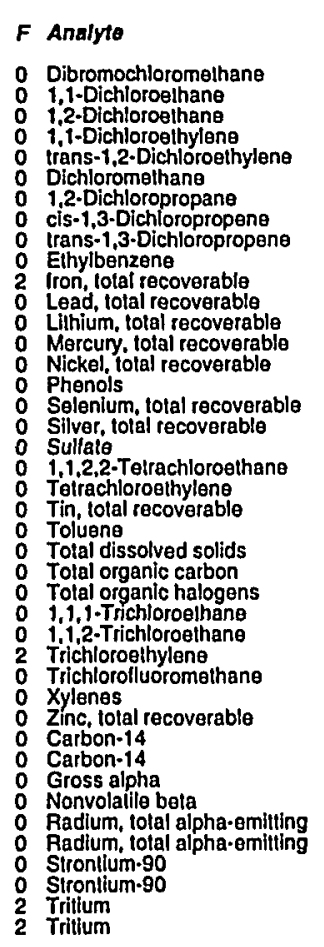

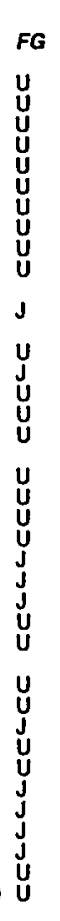

\section{WELLL BGO 17DR}

MEASUREMENTS CONDUCTED IN THE FIELD

Sample date: $05 / 20 / 99$
Depth lo water: $68.85 \mathrm{Ht}(20.99 \mathrm{~m})$ below TOC
Water elevation: $230.35 \mathrm{tt}(70.21 \mathrm{~m}) \mathrm{ms}$

Water elevation: $230.35 \mathrm{kt}(70.21$
P: 5.1
Sp. conductance: $21 \mu \mathrm{S} / \mathrm{cm}$

Sp.conductance: $21 \mu \mathrm{S} / \mathrm{cm}$

Waler ovacuated from the well prior to sampling: 4 gal

ANALYSES

F Analyto

- Alkalinity (as CaCO3)

Aluminum, total recoverable

Arsenic, tolal recoverable

Benzeng

Bromodichlorom
Bromomethan

Cadrium, tolal recoverable

Carbon teirachloride

Chloroethane

Chloroathene (Vinyl chlorida)
2.Chloroethyl vinyl ether

Chioromethane

ESH-EMS-990521

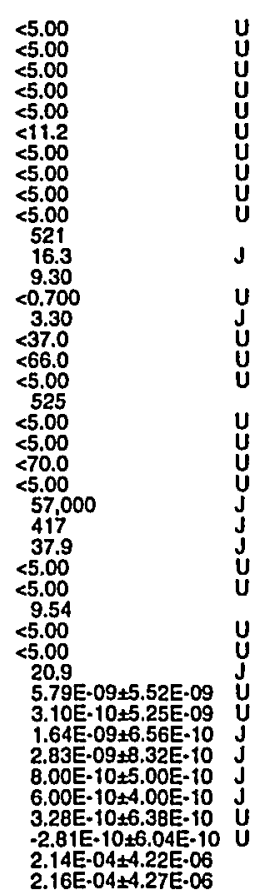

Rosult
4.29
105
$<27.0$
$<40.0$
11.1
$<5.00$
$<266$
$<5.00$
$<5.00$
$<10.0$
$<4.70$
$<5.00$
$<5.00$
$<10.0$
$<10.0$
$<10.0$
$<5.00$
$<10.0$

4.29
105
$<27.0$
$<40.0$
11.1
55.00
5266
55.00
$<5.00$
510.0
$<4.70$
$<5.00$
$<5.00$
$<10.0$
$<10.0$
$<10.0$
$<5.00$
$<10.0$

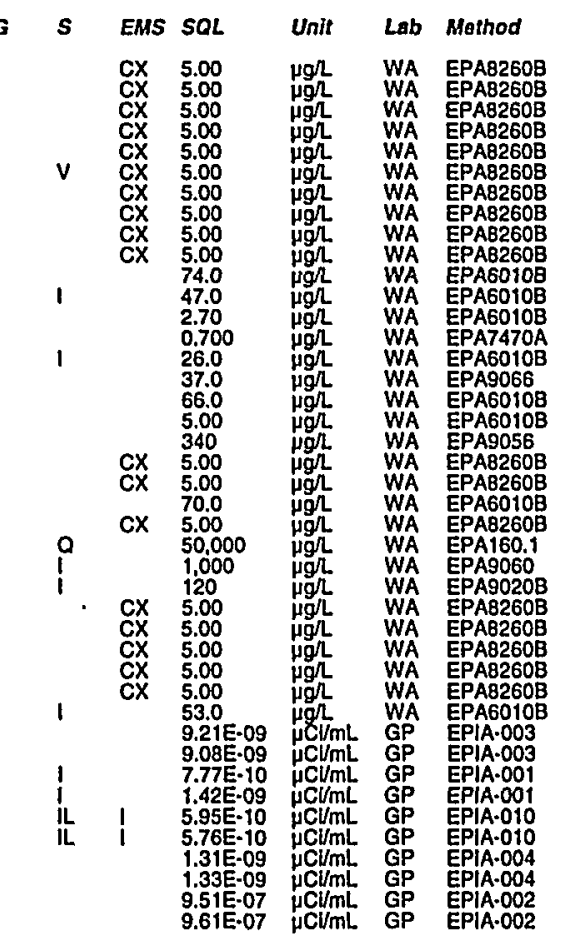

Time: 10:18

Water temperature: $22.6^{\circ} \mathrm{C}$

Air temperalure: $26^{\circ} \mathrm{C}$ C

Phenoiphithalein alkalinity: $0 \mathrm{mg} h$
Field Qualifier(s): $S X$
Well BGO 170R collected on 05/20/99 (cont.)

$F$ Analyte

Result

o Chromium, tolal recoverable

O Dibromochloromethan
0 1,1-Dichloroethane

i. -Dichloroethane

0 trans-1,2-Dichloroethylene

1.2-Dichloropropane

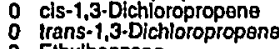

0 tron, lotal recoverable

: Lead, total recoverable

o Mercury, total recoverable

0 Selenilum, total recoverable

0 Sullate - $1,1,2,2$-Tetrachloroethan

0 Tin lolal rechyer

o Toluene

o Total organic carbon

o 1,1,1-Trichloroelthans

1 Trichloroethylene

Xylenes
Zinc, total recoverable

- Gross alpha

0
0
0 Radium, tolal alpha-emitting

$i$ Strontium 1 .

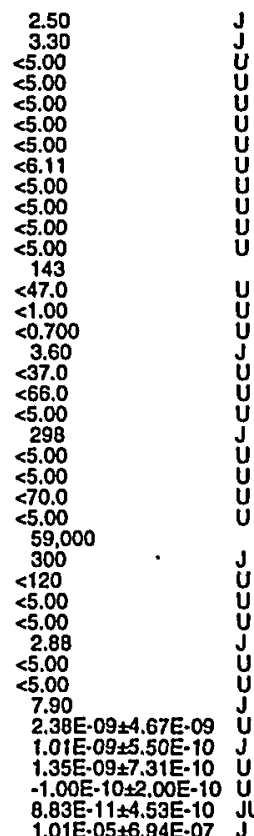

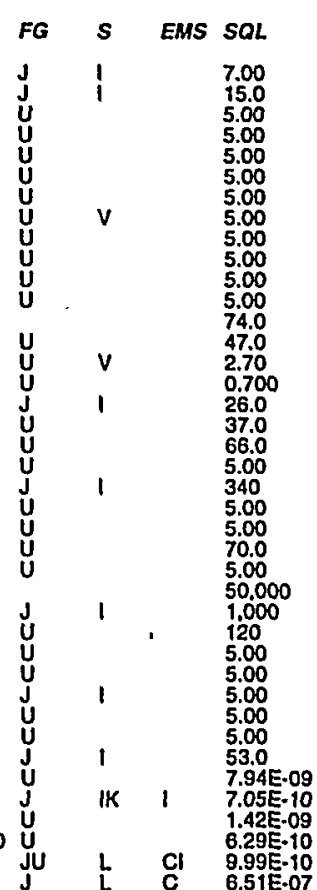

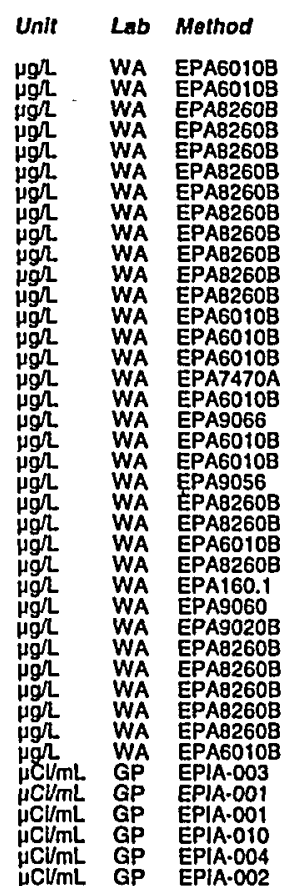

\section{WELL BGO 18A}

MEASUREMENTS CONDUCTEO IN THE FIELO

Sample date: $05 / 26 / 99$
Depth to water: $134.1 \mathrm{ht}(40.87 \mathrm{~m})$ below TOC
Water olevation: $161.1 \mathrm{ft}(49.1 \mathrm{~m}) \mathrm{ms}$ ?

Sp. conductance: $160 \mu \mathrm{S} / \mathrm{cm}$

Water evacualed from the well prior to sampling: $124 \mathrm{gal}$

ANALYSES

F Analyte

- Alkalinily (as $\mathrm{CaCO}_{0}$ )

- Aluminum, lotal recoverable

Arsenlc, total recoverable

Boron, lotal recoverablo

Bromodichlorome

Bromomelhane

Carbon telrachlorido

Chlorobenzene

Chloroethene (Vinyl chloride)

2-Chlorosthyl vinyl

O Chloromethane

Ooppor, total recoverable

B-25

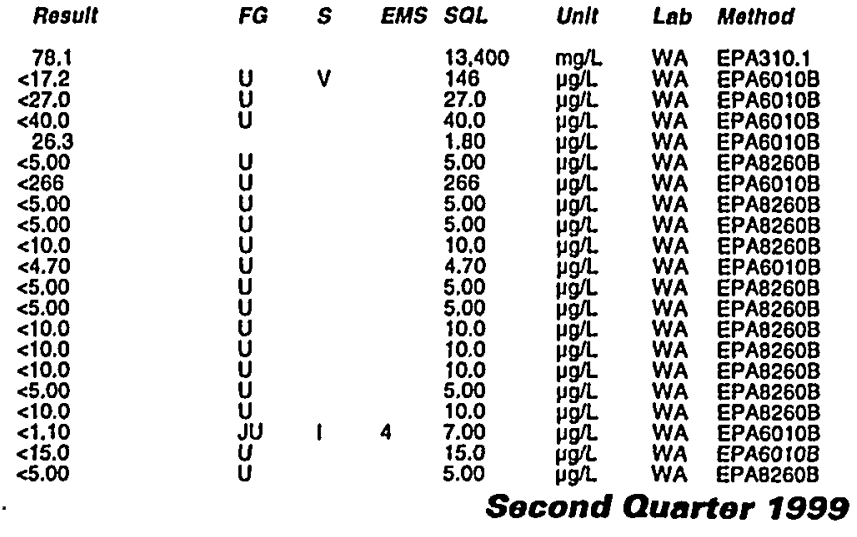

Time: 9:14 Alr temperalure: $26.4^{\circ} \mathrm{C}$ Total alkalinity (as Caco3): $72 \mathrm{mg} \Omega$ Phenolphthalein alkalinity: $0 \mathrm{mg} /$ - 


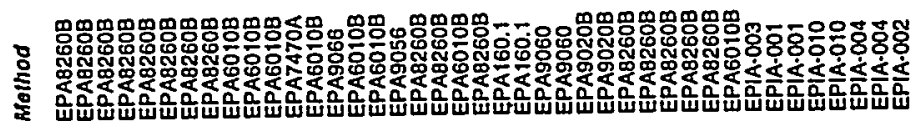

ง ำ

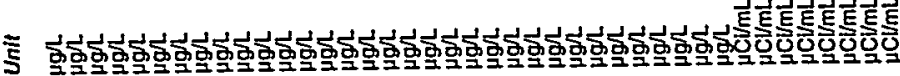

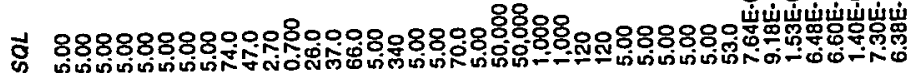

㩊

造

웅ㅇㅇㅇㅇㅇㅇㅅ

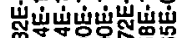

1.

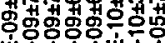

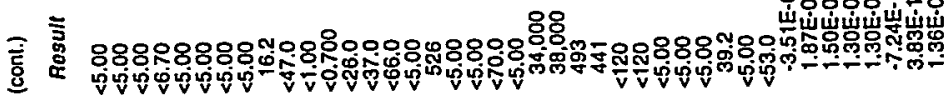

畩

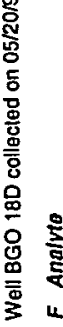

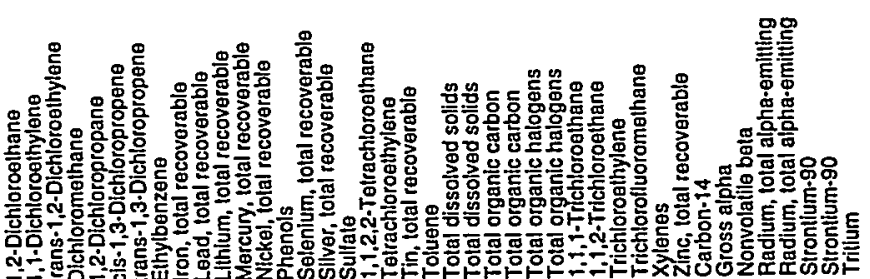

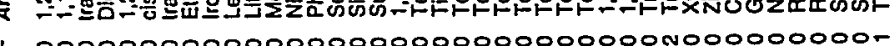

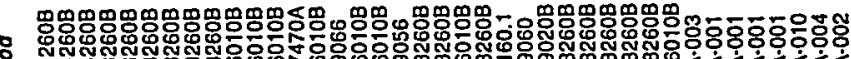
: 은

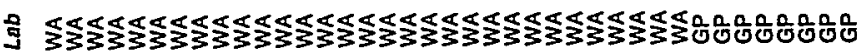

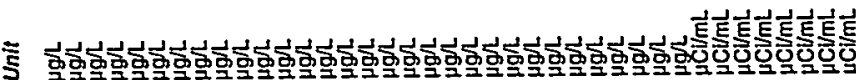
ธี 量 $-0$

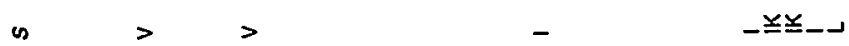

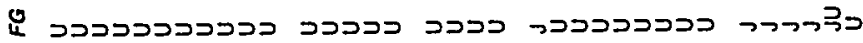
8요응ㅇㅇㅇㅇ

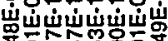
(1)

8 s

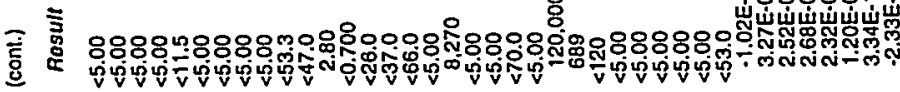
용

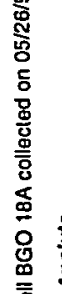

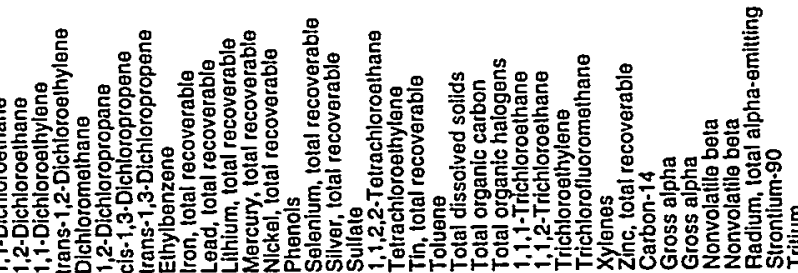

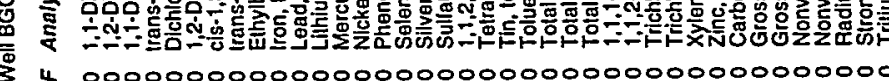

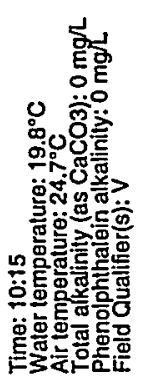

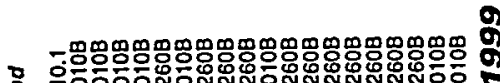

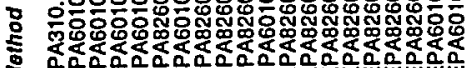

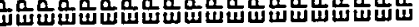

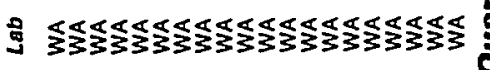

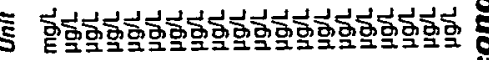

8 (3)

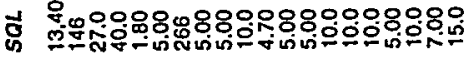

量

n >

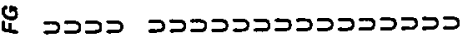

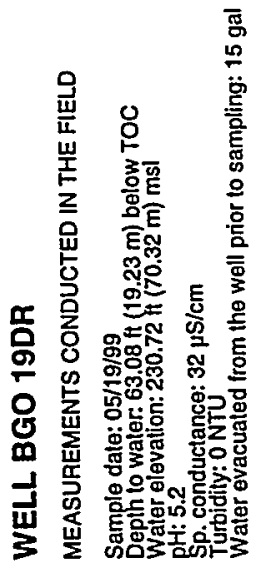



言章

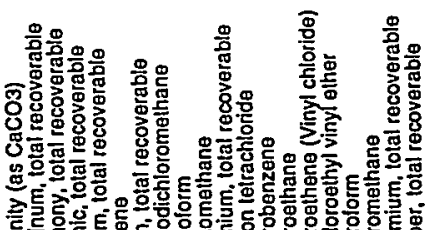

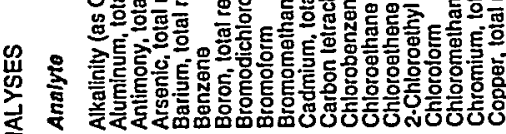

$\sum_{4} 00000000000000000000$

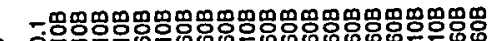

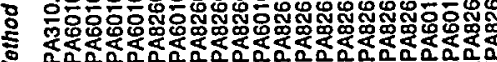

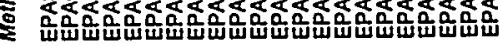

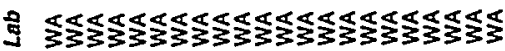

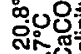

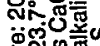

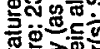

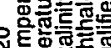

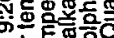

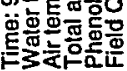

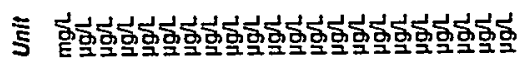

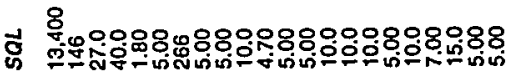

䌉

$\infty>$

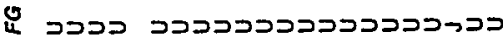

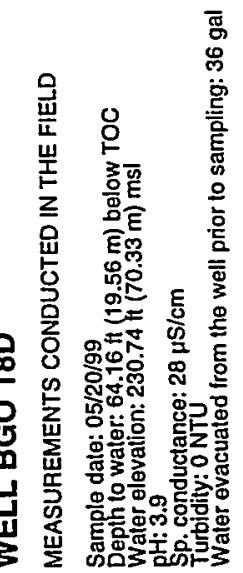

言 ตำำดัง

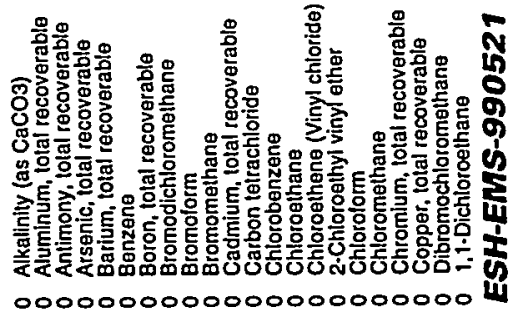


Well BGO 19DR collected on 05/19/99 (cont.)

$F$ Analyte

o Dibromochloromethane 1.2.-Dichloroothane

1,1-Dichloroethylene
trans-1,2-Dichloroethylene Dichloromethane

cis-1,3-Dichloropropene Ethyibenzene

Lead, total recoverablo

Mercury, tolal recoverable

Nickel, total recoverable

Selenlum, fotal recoverable

Sulfaie

$1,1,2,2-T e t r a c h l o r o s t h$
Titrachloroethylene

Tin, Lolat recoverable

Tolal organic carbon

1.1,1-Trichloroelhane

i, 1,2 . Trichloroelthane

Trichlorolluoromethan

Zinc, total recoverable

Gross alpha

Radium, lotal al ah

$\begin{array}{ll}0 & \text { Strontium }-90 \\ 2 & \text { Tritium }\end{array}$

\section{WELL BGO 20A}

MEASUREMENTS CONDUCTED IN THE FIELD

Sample date: 05/19/99 $(36.89 \mathrm{~m})$ below TOC

$\mathrm{gp}$. conductance: $208 \mu \mathrm{s} / \mathrm{cm}$

Trubidifity: 0 NTU
Waler evacualed from the well prior to sampling: 49 gal

ANALYSES

$F$ Analyo

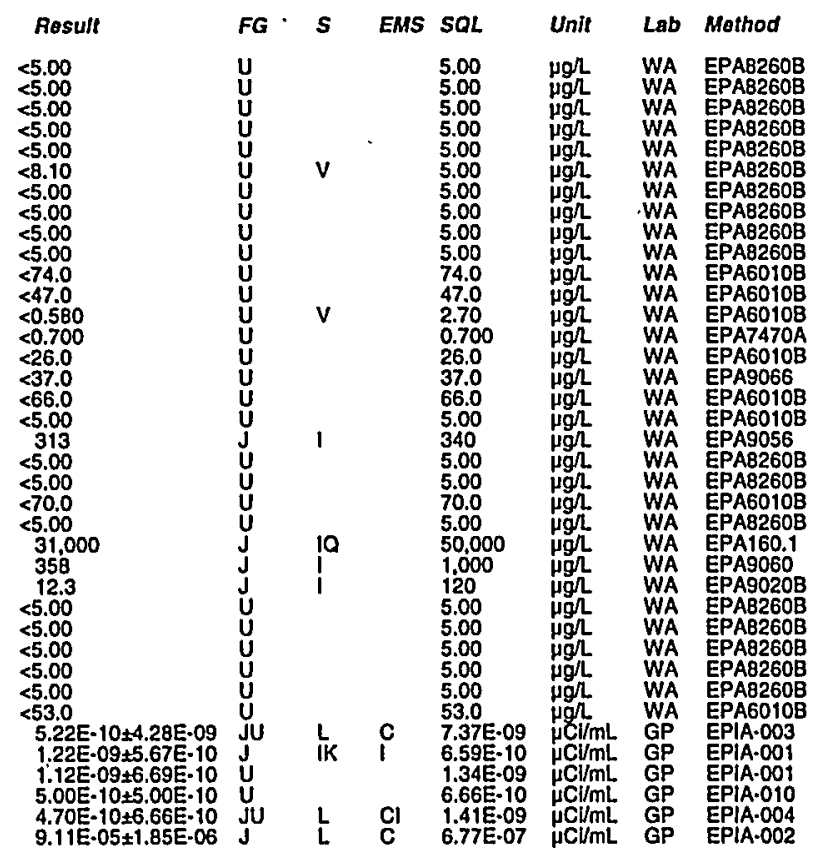

: Alkalinity (as $\mathrm{CaCO}$ )

Aluminum, lotal recoverable

: Arsenic, total recoverable

Benzenio

Bromodichloromethan

Bromolorm

Cadmlum total recoverable

C Carbon tetrachlorida

Chloroethane

Chloroethene (Vinyl chlorid
2.Chloroethyl vinyl ether

Chlorolorm

Chromlum, total recoverablo

Copper. Lotal recoverable

: 1 i. Dichochliorometh

ESH-EMS-990521

Time: 8:21

Total alkalinity (as CaCO3): $88 \mathrm{mg} / \mathrm{L}$
Phenol phithalein alkalinity: $0 \mathrm{mgh}$

Result
91.1
93.6
545.9
$<27.0$
$<40.0$
45.2
55.00
5266
55.00
$<5.00$
510.0
54.70
55.00
$<5.00$
510.0
510.0
510.0
55.00
510.0
57.00
515.0
55.00
$<5.00$

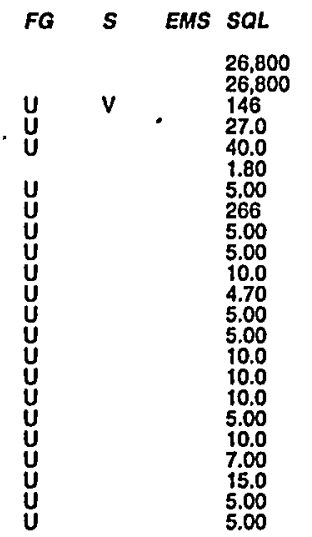

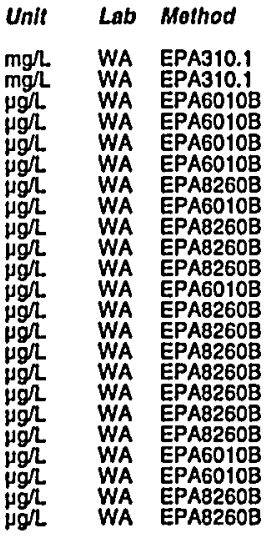

Well BGO 20A collected on 05/19/99 (cont.)
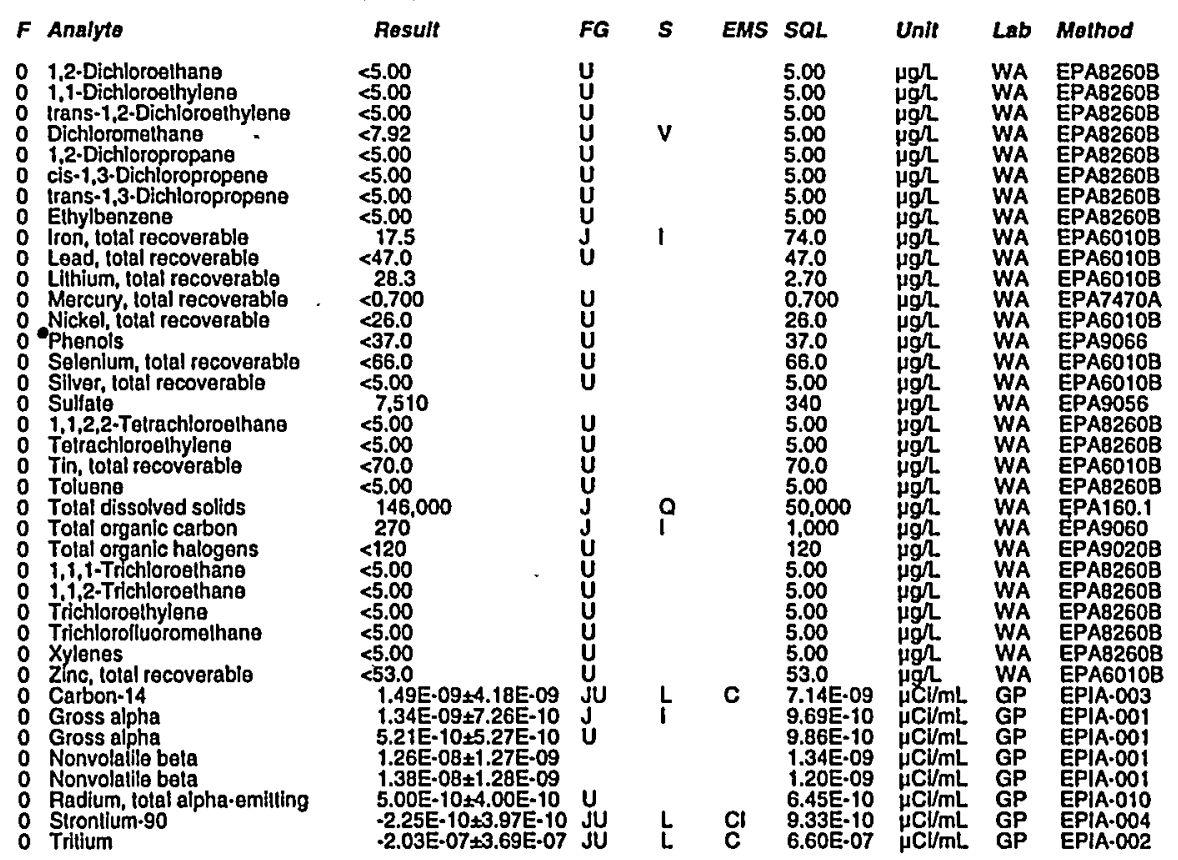

\section{WELL BGO 20AA}

MEASUREMENTS CONDUCTED IN THE FIELD

Sample date: 05/19/99
Depth to water: $122.1 \mathrm{ft}(37.22 \mathrm{~m})$ below TOC
Water

$\mathrm{pH}: 8.8$

Water evacuated from the well prior to sampling: $77 \mathrm{gat}$ ANALYSES

Time: 10:12

Air tementature: $20.4^{\circ} \mathrm{C}$

Total alkalinily (as CaCO3): $68 \mathrm{mg} / \mathrm{L}$

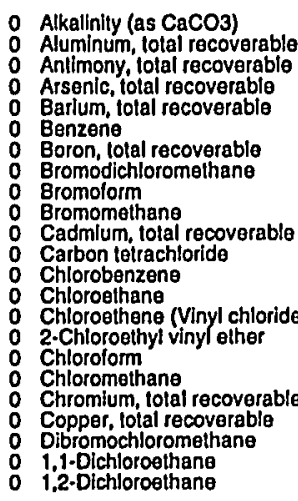

$B-27$

Rosult
72.5
$<47.9$
$<27.0$
$<40.0$
69.6
$<5.00$
$<268$
$<5.00$
$<5.00$
$<10.0$
$<4.70$
$<5.00$
$<5.00$
$<10.0$
$<10.0$
$<10.0$
$<5.00$
$<10.0$
$<7.00$
$<15.0$
$<5.00$
$<5.00$
$<5.00$

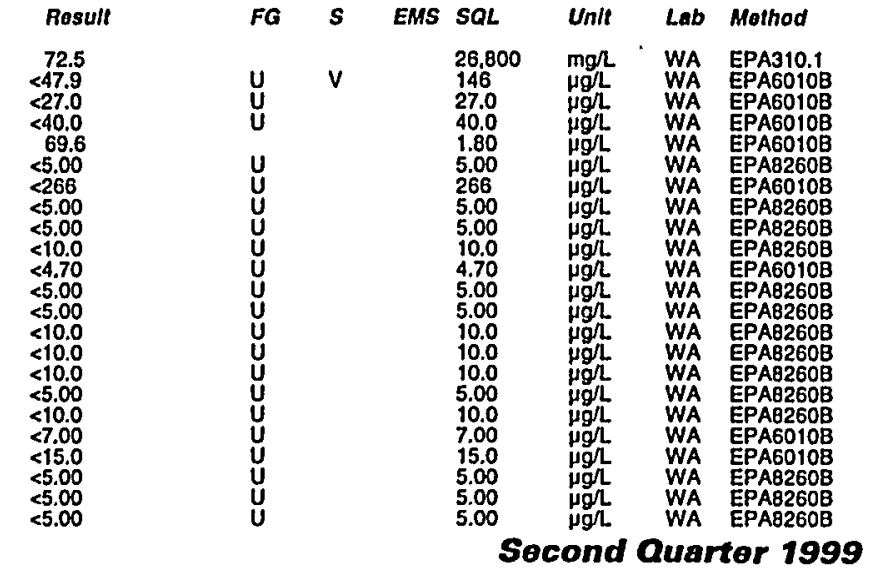




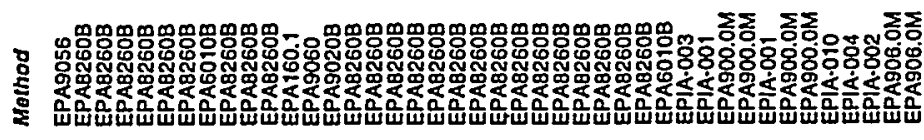

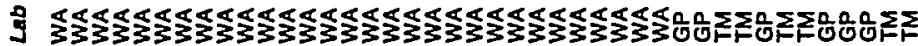

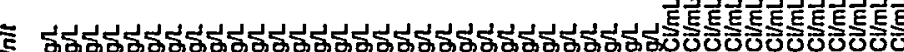

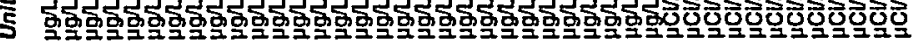

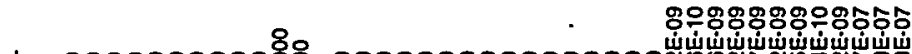

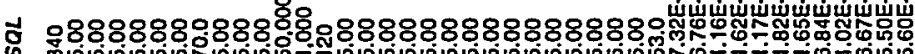

离 ‘

ōo

$\infty$

隹

o-

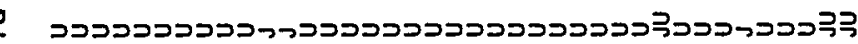

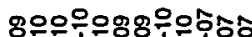
ن்

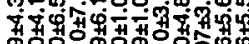

言



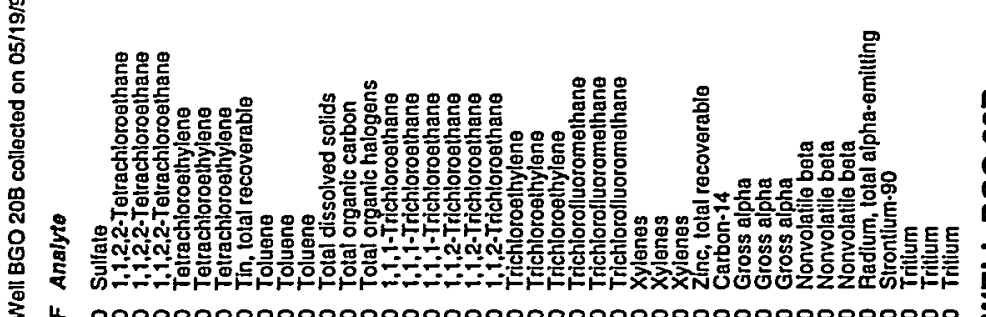

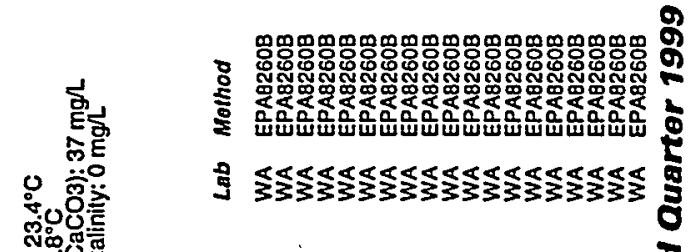

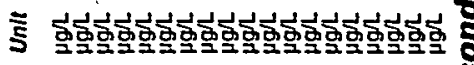

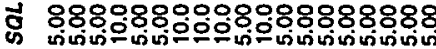

ํㅗㄴ

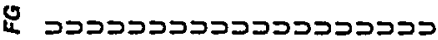

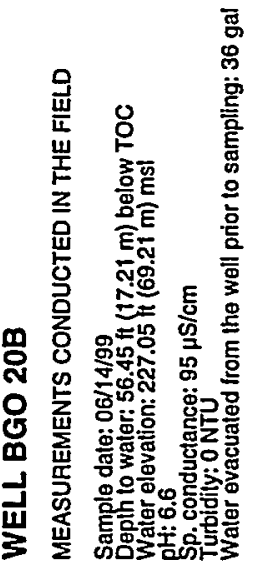

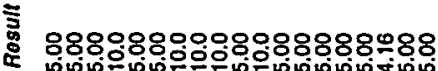

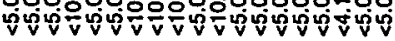

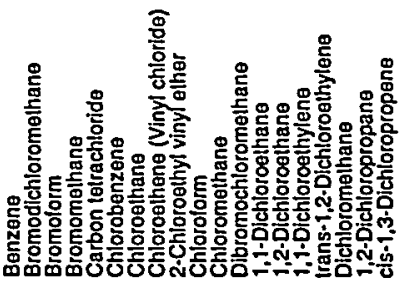

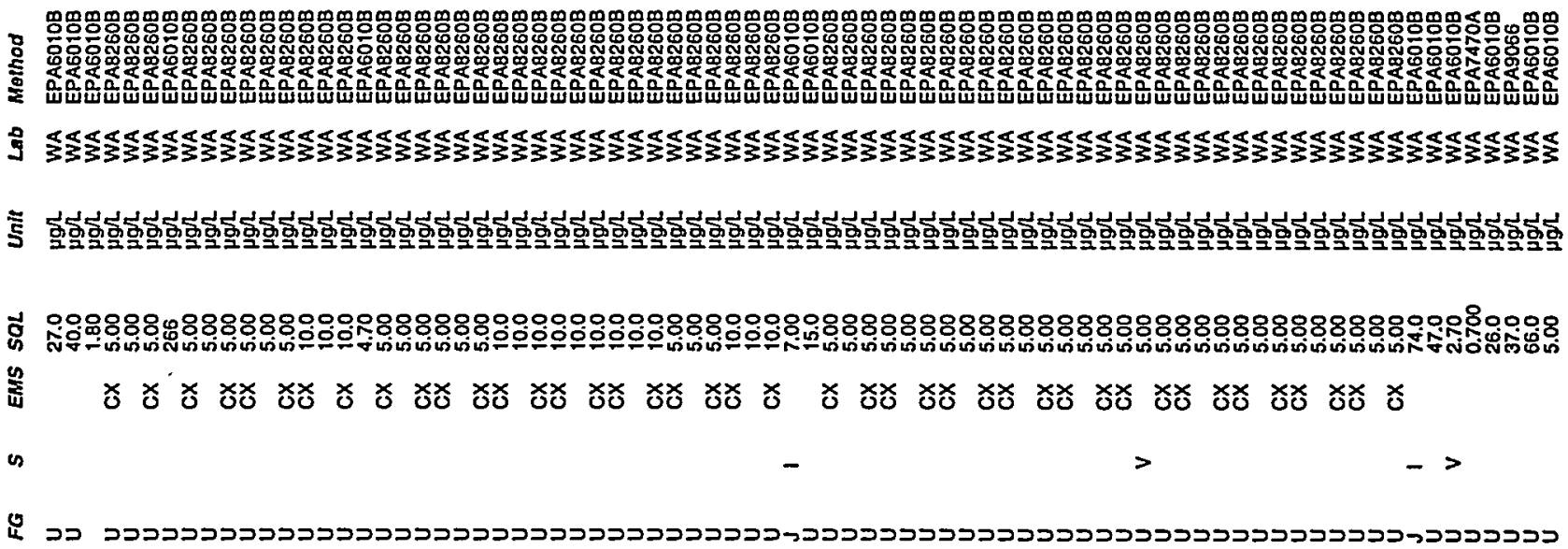

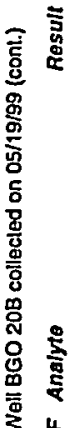

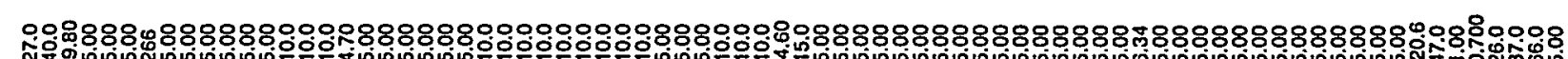

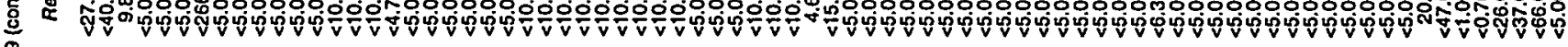

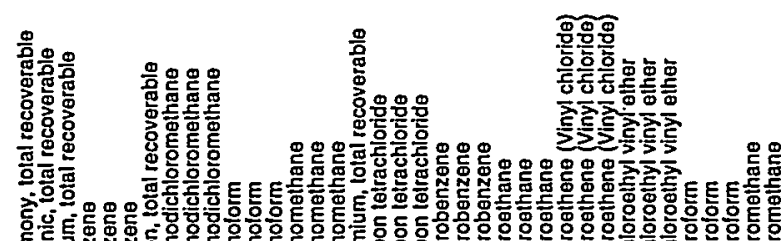

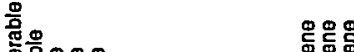

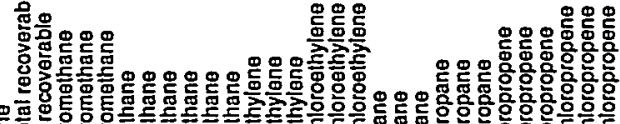

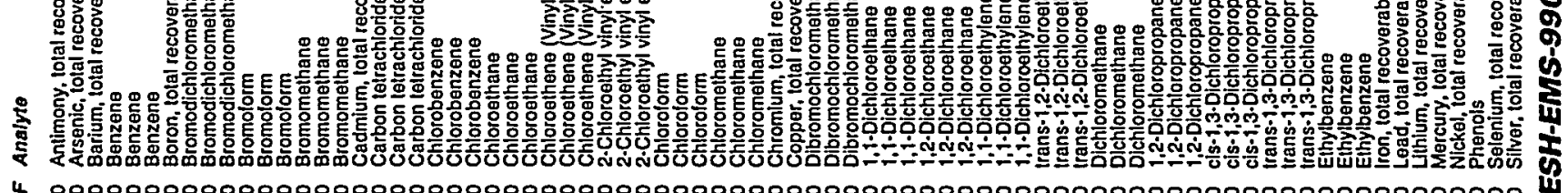


Well BGO 20C collected on 05/19/99 (cont.)
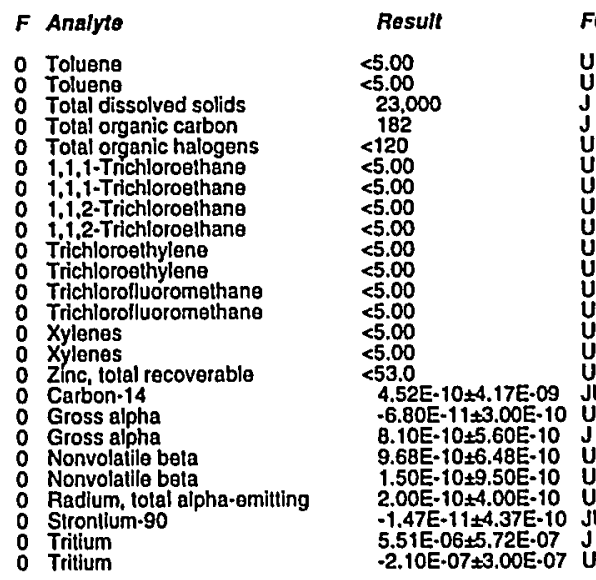

WELL BGO 20C

MEASUREMENTS CONDUCTED IN THE FIELD

Sample date: $06 / 14 / 99$
Depth to water: $55.02 \mathrm{ft}(16.77 \mathrm{~m})$ below TOC
Water elevation: $228.48(\mathrm{H}(69.64 \mathrm{~m}) \mathrm{ms}$

$\mathrm{pH}: 5.6$

Sp. conductance: $27 \mu \mathrm{S} / \mathrm{cm}$

Wurbidity: 0 NTU evacualed from the well prior to sampling: $27 \mathrm{ga}$ ANALYSES

\begin{tabular}{|c|}
\hline Analyte \\
\hline 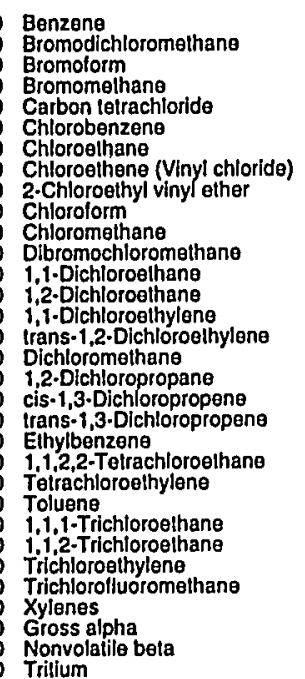 \\
\hline
\end{tabular}

\begin{tabular}{|c|c|c|c|c|c|c|c|}
\hline sulf & $F G$ & $s$ & EMS & $S Q L$ & Unit & Lab & Mathod \\
\hline $\begin{array}{l}<5.00 \\
<5.00 \\
<5.00 \\
<10.0 \\
<5.00 \\
<5.00 \\
<10.0 \\
<10.0 \\
<10.0 \\
<5.00 \\
<10.0 \\
<5.00 \\
<5.00 \\
<5.00 \\
<5.00 \\
<5.00 \\
<5.00 \\
<5.00 \\
<5.00 \\
<5.00 \\
<5.00 \\
<5.00 \\
<5.00 \\
<5.00 \\
<5.00 \\
<5.00 \\
<5.00 \\
<5.00 \\
<5.00 \\
4.00 E-10+5.30 E-10 \\
1.20 \cdot 09+0.80-10 \\
5.02 E \cdot 06 \pm 5.50 E \cdot 07\end{array}$ & $\begin{array}{l}y \\
y \\
y \\
y \\
y \\
y \\
y \\
y \\
y \\
y \\
y \\
y \\
y \\
y \\
y \\
y\end{array}$ & & & $\begin{array}{l}5.00 \\
5.00 \\
5.00 \\
10.0 \\
5.00 \\
5.00 \\
10.0 \\
10.0 \\
10.0 \\
5.00 \\
10.0 \\
5.00 \\
5.00 \\
5.00 \\
5.00 \\
5.00 \\
5.00 \\
5.00 \\
5.00 \\
5.00 \\
5.00 \\
5.00 \\
5.00 \\
5.00 \\
5.00 \\
5.00 \\
5.00 \\
5.00 \\
8.90 E-10 \\
1.61 \mathrm{E}-00 \\
4.70 \mathrm{E} \cdot 07\end{array}$ & 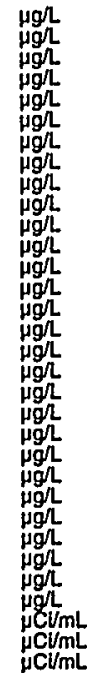 & $\begin{array}{l}\text { WA } \\
\text { WA } \\
\text { WA } \\
\text { WA } \\
\text { WA } \\
\text { WA } \\
\text { WA } \\
\text { WA } \\
\text { WA } \\
\text { WA } \\
\text { WA } \\
\text { WA } \\
\text { WA } \\
\text { WA } \\
\text { WA } \\
\text { WA } \\
\text { WA } \\
\text { WA } \\
\text { WA } \\
\text { WA } \\
\text { WA } \\
\text { WA } \\
\text { WA } \\
\text { WA } \\
\text { WA } \\
\text { WA } \\
\text { WA } \\
\text { WA } \\
\text { IM } \\
\text { TM } \\
\text { TM }\end{array}$ & 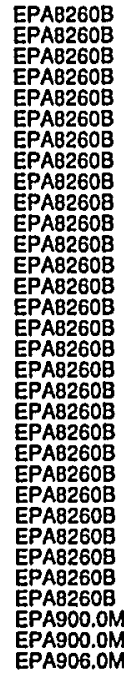 \\
\hline
\end{tabular}

ESH-EMS-990521

\section{WELL BGO 20D}

MEASUAEMENTS CONDUCTED IN THE FIELD

Sample dale: 04/14/99

Depth to water: $51.06 \mathrm{ht}(15.56 \mathrm{~m})$ below TOC

$\mathrm{pH}: 5.1$

Sp. conductance: $54 \mu \mathrm{S} / \mathrm{cm}$

Water evacuated from the well prior lo sampling: $1 \mathrm{gal}$ The well wenl dry during purging

ANALYSES

.

\begin{tabular}{|c|}
\hline 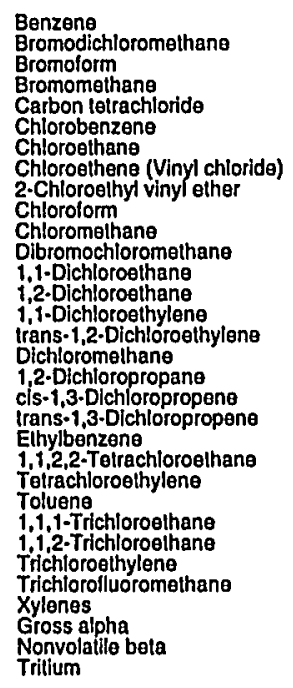 \\
\hline
\end{tabular}

Resuft
$<5.00$
$<5.00$
$<5.00$
$<10.0$
55.00
$<5.00$
$<10.0$
$<10.0$
$<10.0$
$<5.00$
$<10.0$
$<5.00$
55.00
$<5.00$
$<5.00$
$<5.00$
$<4.30$
$<5.00$
$<5.00$
$<5.00$
$<5.00$
$<5.00$
$<5.00$
$<5.00$
$<5.00$
$<5.00$
$<5.00$
$<5.00$
$<5.00$
$3.40 E-09 \pm 1.04 E .09$
$1.54 E .09 \pm 1.00 E .09$
$2.10 E .05 \pm 1.09 E .06$

Time: 13:00

erature: $21.3^{\circ} \mathrm{C}$

Total alkalinity (as CaCO3): $8 \mathrm{mgl}$

Phenolphinalein alkalinity: $0 \mathrm{mg}$

MEASUREMENTS CONDUCTED IN THE FIELD
Sample dale: $05 / 19 / 99$
Depth to water: 51.2 th $(15.61 \mathrm{~m})$ bolow TOC
Water elevation: 232.5 (1 $(70.87 \mathrm{~m}) \mathrm{ms}$

Pp. conductance: $54 \mu \mathrm{S} / \mathrm{cm}$

Water evacuated from the well prior to sampling: $1 \mathrm{gal}$

ANALYSES

$F$ Analyte

Rosult
9.75
535.6
527.0
$<40.0$
34.6
55.00
55.00
5266
55.00
55.00
55.00
55.00
510.0
510.0
$<4.70$

Alkalinity (as $\mathrm{CaCO}$ )

Aluminum, tolal recoverable

Arsenic, lotal rocoverable

Barium, to
Benzene

Boron, total recoverable

Bromodichloromethane

Bromolorm

Bromolorm
Bromomethane

Bromomethane

B-31
Time: 10:40

Air temperalure: $28.4^{\circ} \mathrm{C}$

Total alkalinity (as CaCO3): $9 \mathrm{mg} / \mathrm{L}$
Phenoiphthalein alkalinity: $0 \mathrm{mg} L$
Field Qualifier(s): $S X$
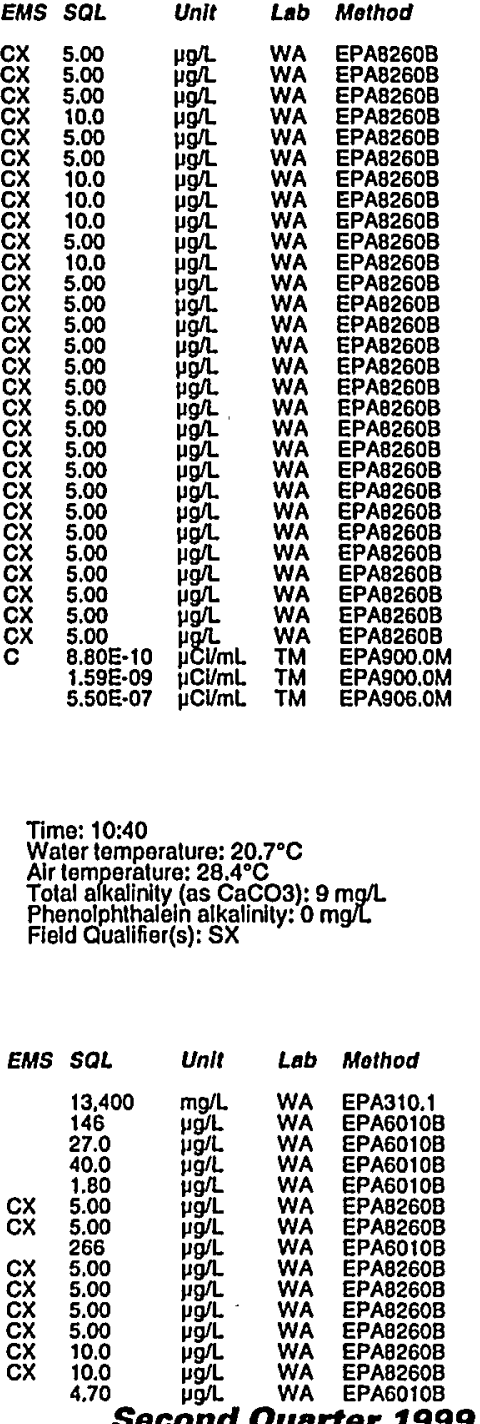
Well BGO 20D collected on 05/19/99 (cont.)

\begin{tabular}{|c|c|c|c|c|c|c|c|c|}
\hline Ana & sult & $\boldsymbol{G}$ & $\boldsymbol{s}$ & EMS & $S O L$ & Un/t & $\angle A B$ & lothod \\
\hline 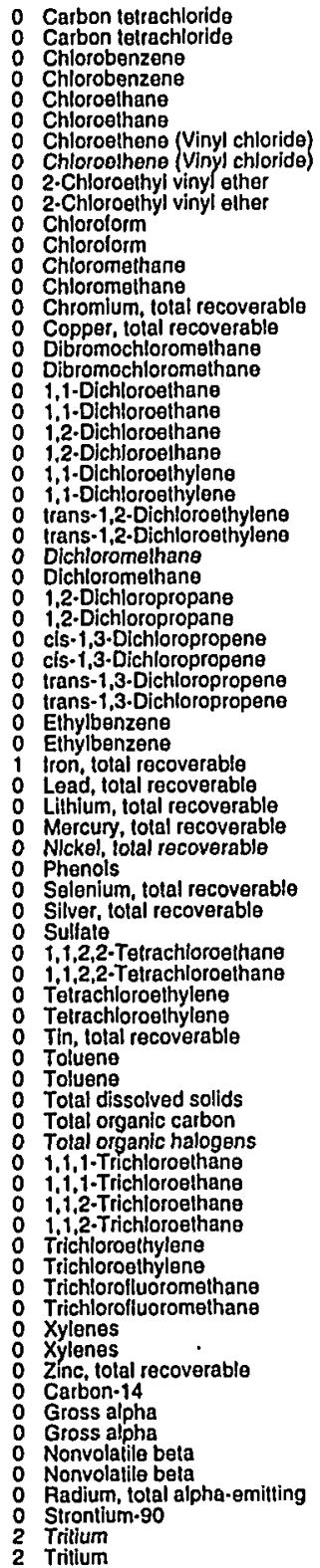 & 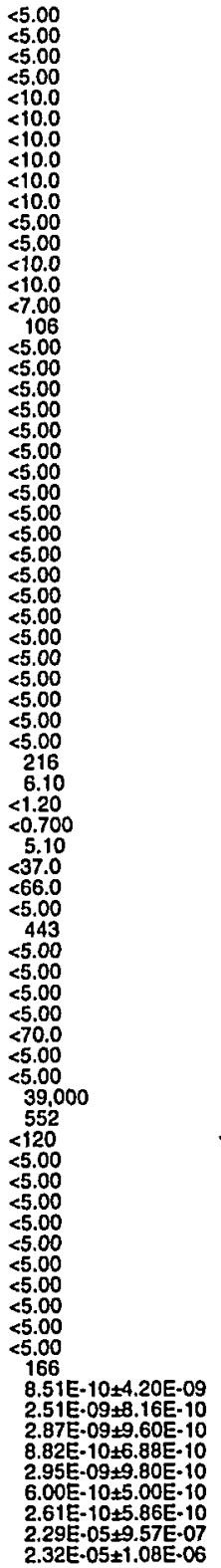 & 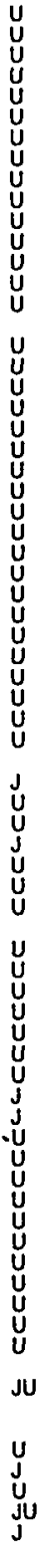 & $L$ & $\begin{array}{l}c x \\
c x \\
c x \\
c x \\
c x \\
c x \\
c x \\
c x \\
c x \\
c x \\
c x \\
c x \\
c x \\
c x \\
c x \\
c x \\
c x \\
c x \\
c x \\
c x\end{array}$ & 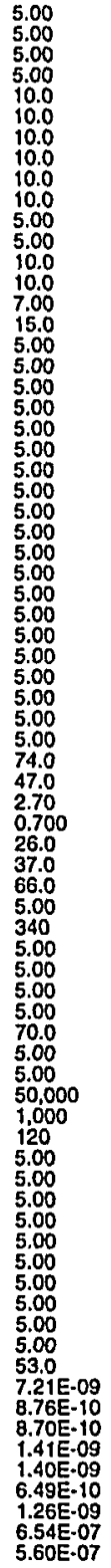 & 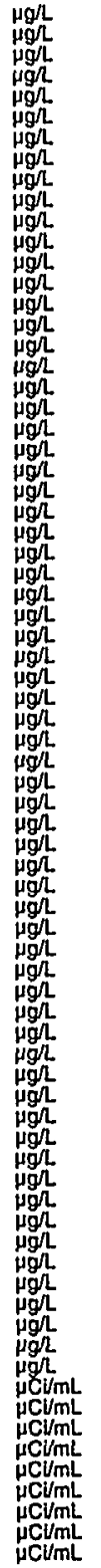 & $\begin{array}{l}\text { WA } \\
\text { WA } \\
\text { WA } \\
\text { WA } \\
\text { WA } \\
\text { WA } \\
\text { WA } \\
\text { WA } \\
\text { WA } \\
\text { WA } \\
\text { WA } \\
\text { WA } \\
\text { WA } \\
\text { WA } \\
\text { WA } \\
\text { WA } \\
\text { WA } \\
\text { WA } \\
\text { WA } \\
\text { WA } \\
\text { WA } \\
\text { WA } \\
\text { WA } \\
\text { WA } \\
\text { WA } \\
\text { WA } \\
\text { WA } \\
\text { WA } \\
\text { WA } \\
\text { WA } \\
\text { WA } \\
\text { WA } \\
\text { WA } \\
\text { WA } \\
\text { WA } \\
\text { WA } \\
\text { WA } \\
\text { WA } \\
\text { WA } \\
\text { WA } \\
\text { WA } \\
\text { WA } \\
\text { WA } \\
\text { WA } \\
\text { WA } \\
\text { WA } \\
\text { WA } \\
\text { WA } \\
\text { WA } \\
\text { WA } \\
\text { WA } \\
\text { WA } \\
\text { WA } \\
\text { WA } \\
\text { WA } \\
\text { WA } \\
\text { WA } \\
\text { WA } \\
\text { WA } \\
\text { WA } \\
\text { WA } \\
\text { WA } \\
\text { WA } \\
\text { WA } \\
\text { WA } \\
\text { GP } \\
\text { GP } \\
\text { TA } \\
\text { GP } \\
\text { TM } \\
\text { GP } \\
\text { GP } \\
\text { TM }\end{array}$ & 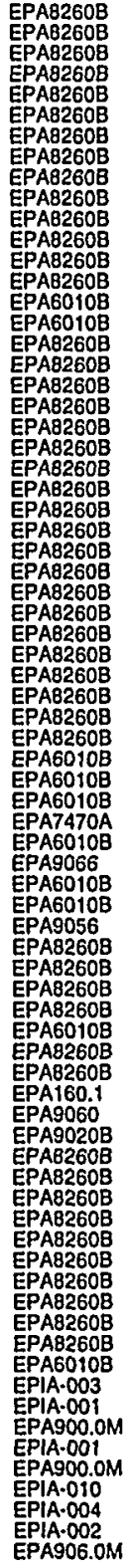 \\
\hline
\end{tabular}

ESH-EMS-990521

\section{WELL BGO 20D}

MEASUREMENTS CONDUCTED IN THE FIELD

Sample date: 06/14/99

Deplh to waler: $51.4 \mathrm{ft}(15.67 \mathrm{~m})$ below TOC

Waler ol

H: 5.5

Turbidity: 6 NTU

Waler evacualed from the well prior to sampling: $1 \mathrm{gal}$

ANALYSES

$F$ Analyto

O Benzene

Bromolorm

o Carbomethane

o Carbon tetrachlo

Chloroethene (Vinyl chlorid

2-Chloroothyl vinyl ether

o Chloromethan

o Dibromochloromethane

o trans-1,2-Dichlorosthytene

0 Dichloromethane

cis-1,3-Dichloropropene

O Ethylbenzene

$1,1,2,2-$ Tetrachloroeth
Totrachloroethylene

Toluene

o 1,1,2-Trichlorosthane

: Trichloroelhylene

0 Xylenes

Tronvolatilo beta

\section{WELL BGO 21D}

MEASUAEMENTS CONDUCTED IN THE FIELD

Sample date: 05/19/99

Wepth to water: 52.19 At (15.91 m) below TOC

pH: 5.6

Sp. conductance: $46 \mu \mathrm{S} / \mathrm{cm}$

Wurbidity: 12 NTU

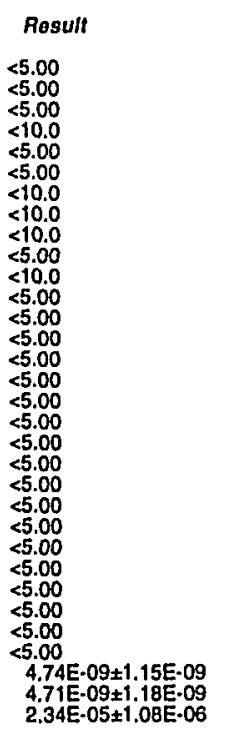

$F G$
$U$
$U$
$U$
$U$
$U$
$U$
$U$
$U$
$U$
$U$
$U$
$U$
$U$
$U$
$U$
$U$
$U$
$U$
$U$
$U$
$U$
$U$
$U$
$U$
$U$
$U$
$U$

s

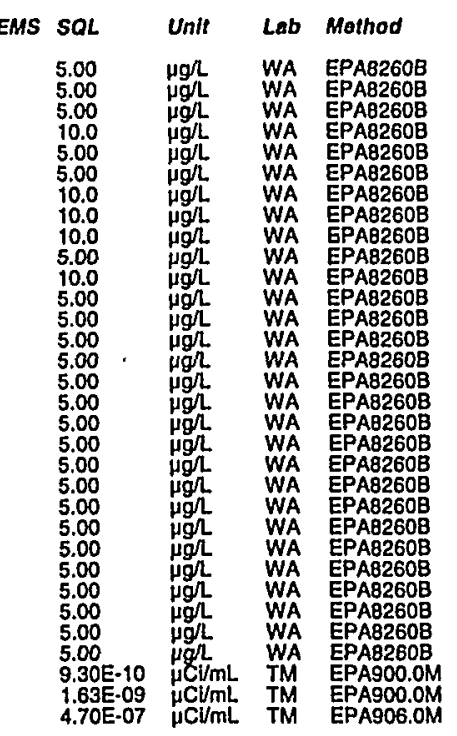

ANALYSES

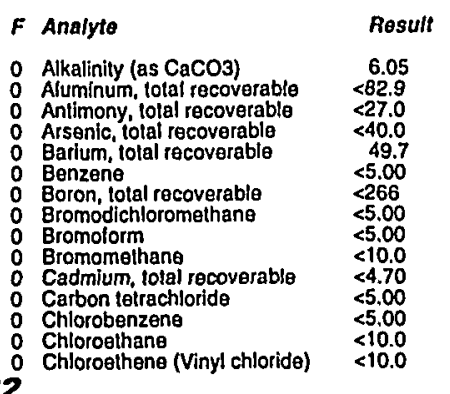

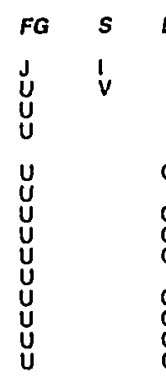

Time: 13:30

Wal temperalure: $24.9^{\circ} \mathrm{C}$

Total alkalinity (as CaCO3): $9 \mathrm{mg} /$

Field Qualifier(s): $S X$

Waler temperature: $23.9^{\circ} \mathrm{C}$ Total alkalinity (as CaCO3): $10 \mathrm{mg} /$ Phanolphilhalein alkalinity: $0 \mathrm{mg} /$ h

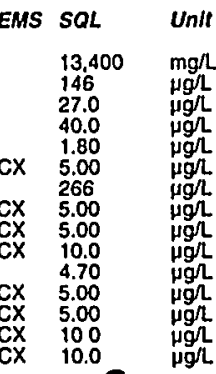

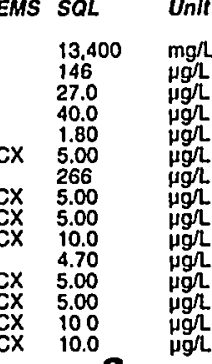

Lab Mothod

WA EPA310.1 WA EPA6010 WA EPA6010 WA EPAG010 WA EPA6010B WA EPAB260 WA EPAGO10B WA EPA82608

WA EPAB260B 
Well BGO 21D collecled on 05/19/99 (cont.)

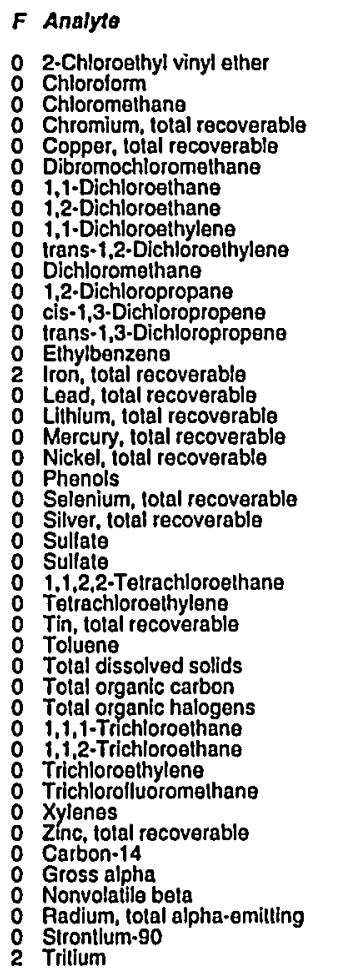

WELL BGO 22DX

MEASUREMENTS CONDUCTED IN THE FIELD

Sample date: 05/19/99

Water elevalion: $233.59 \mathrm{fi}(71.2 \mathrm{~m}) \mathrm{ms}$

$\mathrm{H}: 4.8$
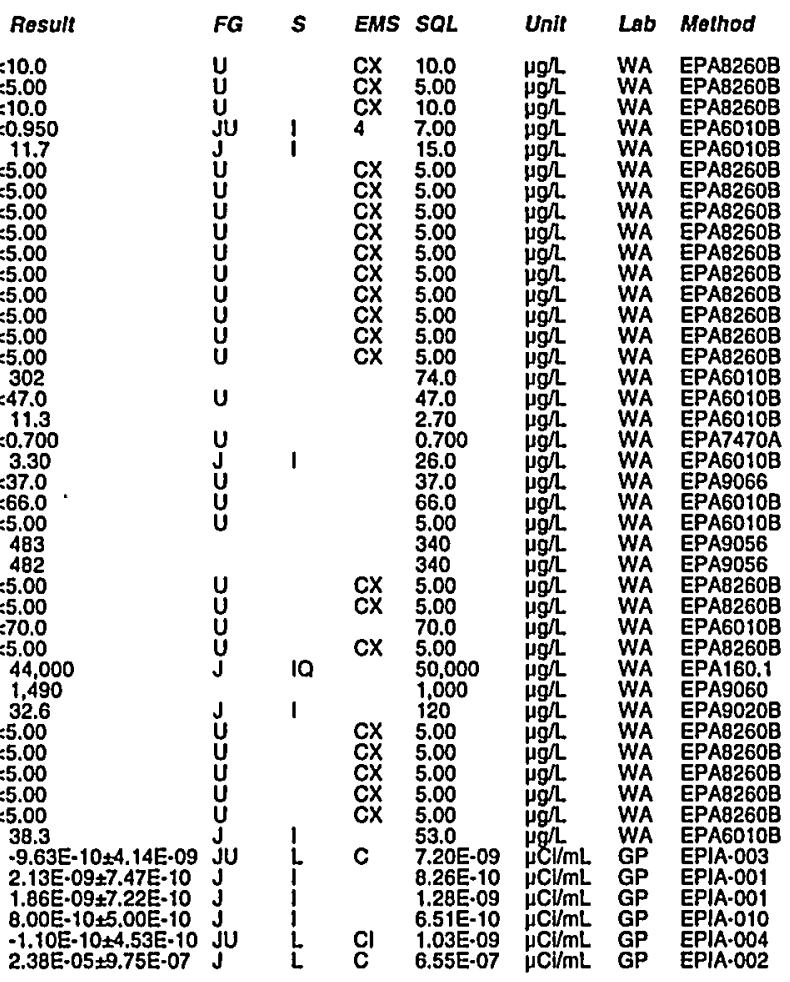

$F$ Analyte

O Chloromethane

Copper, total recoverablo

1,1-Dichloroethane
1,2.-Dichloroethane

$1,1-$ Dichloroethylene
trans-1,2-Dichloroethylen

Dichloromethane
1.2-Dichloropropan

cis-1,3-Dichloropropene
trans-1,3-Dichloropropen

Iron, total recoverable

Mercury, total recoverable

Phenols

Selenium, total recoverable

1, 1,2,2-Tetrachloroethan

Tetrachloroethylene

Total dissolved solids

Total organic carbon

$1.1,1$. Trichloroellhane

Trichloroethylene

Xrichlorolluoromelhane

Zinc, total recoverable

Carbon-14

Radium, total alpha-emitting

Strontitum-

WELL BGO 23D

MEASUREMENTS CONDUCTED IN THE FIELD

Sample dale: 05/19/99
Depth to waler: $54.4 \mathrm{ft}(16.58 \mathrm{~m})$ below TOC
Water elevation: $234.8 \mathrm{ft}(71.57 \mathrm{~m}) \mathrm{msl}$

Time: 10:58 Air temperature: $25^{\circ} \mathrm{C}$
Total alkalinify (as CaCo3): $0 \mathrm{mg} / \mathrm{l}$ Phenolphhatein alkalinily: $0 \mathrm{mg}$

Water evacuated from the well prior to sampling: 11 gal ANALYSES

F Analyte

- Alkalinity (as $\mathrm{CaCO}$ )

Antimony, total recoverable

Arsenic, total recoverable
Barlum, total recoverable

Borzen, total recoverab

Bromodichloromethan

Bromomethan

Cadmium, lotal recoverable

Chlorobenzene

Chloroethene (Vinyl chloride)

2.Chloroeth

ESH-EMS-990521

\begin{tabular}{|c|c|c|c|c|c|}
\hline Result & $F G$ & 5 & $E M S$ & $S O L$ & $U_{n n}$ \\
\hline $\begin{array}{l}<13.4 \\
<77.2 \\
<<7.0 \\
<40.0\end{array}$ & $\begin{array}{l}u \\
u \\
u \\
u\end{array}$ & v & & $\begin{array}{l}13,400 \\
146 \\
27.0 \\
40.0\end{array}$ & $\begin{array}{l}m g / 2 \\
\mu g h \\
\mu g / L \\
\mu g h \\
\mu g h\end{array}$ \\
\hline $\begin{array}{r}3.26 \\
<5.00\end{array}$ & U & & $c x$ & $\begin{array}{l}1.000 \\
.000\end{array}$ & Hg L \\
\hline $\begin{array}{l}<5.00 \\
<5.00\end{array}$ & U⿱ & & $\begin{array}{l}c x \\
c X\end{array}$ & $\begin{array}{l}5.00 \\
5.00\end{array}$ & pon \\
\hline $\begin{array}{l}<4.70 \\
<5\end{array}$ & $\underline{u}$ & & $c x$ & $\begin{array}{r}80.0 \\
4.70\end{array}$ & wgr \\
\hline $\begin{array}{l}<5.00 \\
<10.0\end{array}$ & $\stackrel{u}{u}$ & & $\begin{array}{l}\text { Cx } \\
\text { CX }\end{array}$ & $\begin{array}{l}5.00 \\
10.0\end{array}$ & por \\
\hline 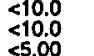 & $\stackrel{U}{U}$ & & $\begin{array}{l}c x \\
c x\end{array}$ & $\begin{array}{l}10.0 \\
10.0\end{array}$ & ig \\
\hline & & & & & \\
\hline
\end{tabular}

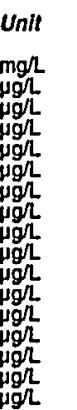

Sp. conductance: $36 \mu \mathrm{S} / \mathrm{cm}$

Water evacualed from the well prior to sampling: $24 \mathrm{ga}$ ANALYSES

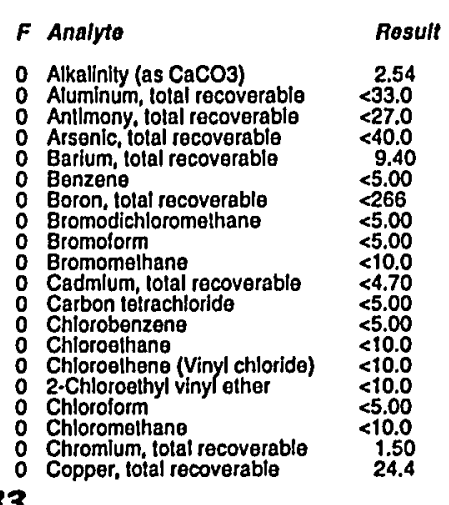

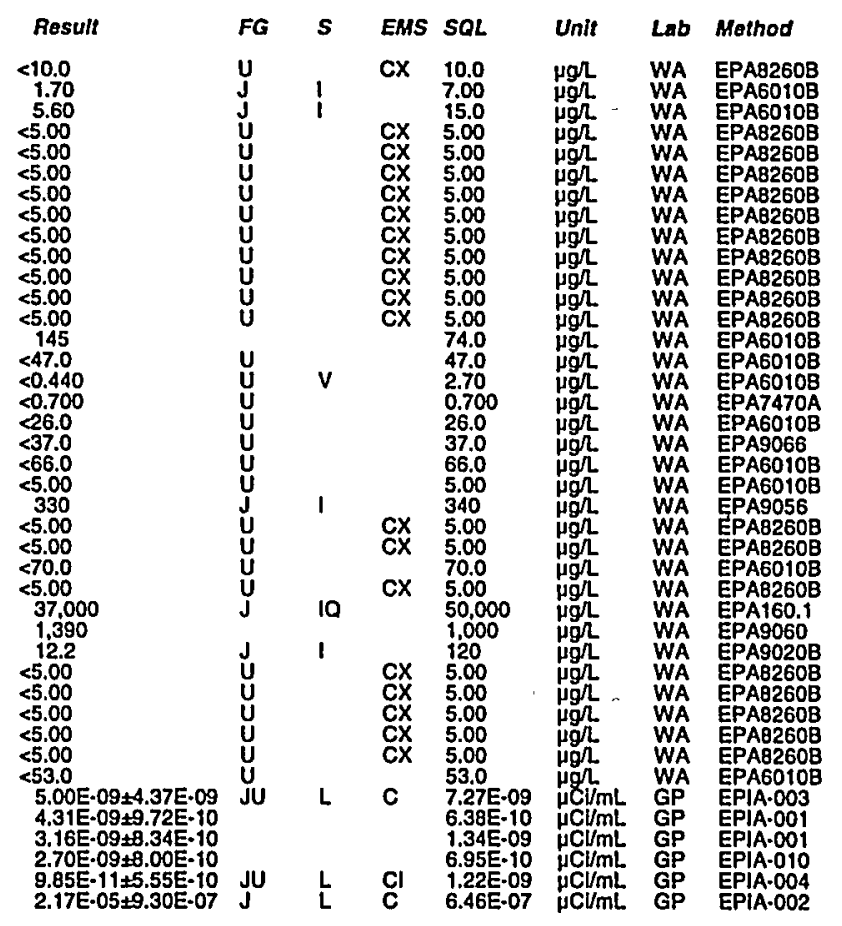

Time: 12:41

Waler $22.5^{\circ} \mathrm{C}$

Total alkalinity (as CaCO3): $5 \mathrm{mg} / \mathrm{h}$

Phenolphinalein alkalinity: $0 \mathrm{mg}$

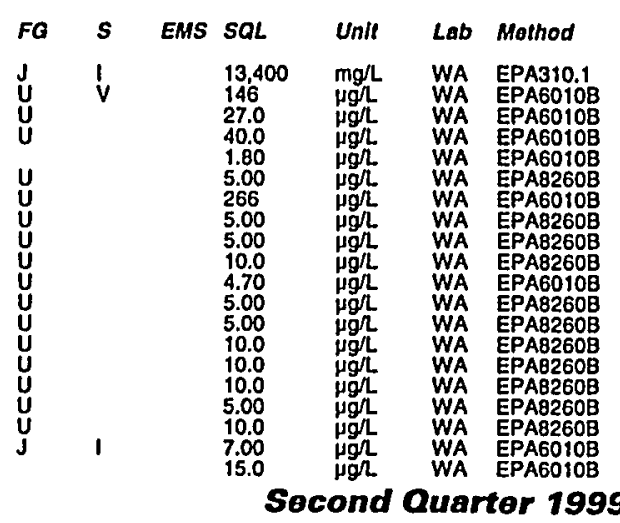


Well BGO 23D collocted on 05/19/99 (cont.)

\begin{tabular}{|c|}
\hline Analyto \\
\hline 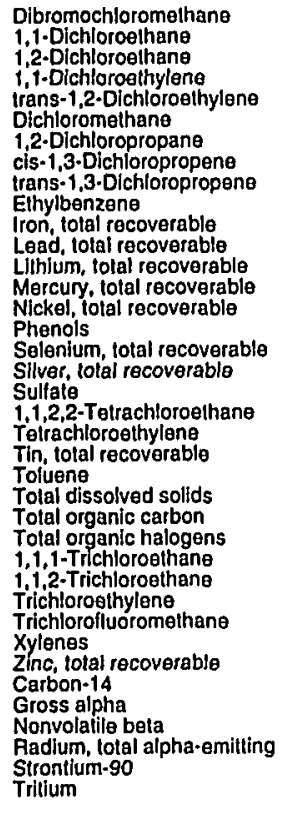 \\
\hline
\end{tabular}

$<5.00$
$<5.00$
$<5.00$

$<5.00$
$<5.00$
$<5.00$
$<6.00$

5.00
55.00
55.00
5

\begin{tabular}{c}
35.00 \\
5.00 \\
70.9 \\
\hline
\end{tabular}

$<26.0$

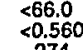

$<5.00$
$<5.00$
$<70.0$
$<5,00$

$<120$

$<5.00$$$
\text { FG }
$$

5 EMS SQL

7.80
$<1.70$
$<<.700$
$<260$

33,000
387

$<5.00$

$2.77 \mathrm{E} \cdot 09 \pm 4.25 \mathrm{E}-09$ J $7.83 \mathrm{E} \cdot 10 \pm 5.88 \mathrm{E}-10 \mathrm{U}$ $\begin{array}{ll}4.00 E-10 \pm 4.00 E-10 & \mathrm{~J} \\ 1.97 \mathrm{E}-11 \pm 7.05 \mathrm{E}-10 & \mathrm{~J} \\ 1.99 \mathrm{E}-05 \pm 8.88 \mathrm{E} \cdot 07 & \mathrm{~J}\end{array}$

\section{WELL BGO 24D}

MEASUREMENTS CONDUCTED IN THE FIELD

Sample date: 05/19/99 $17.39 \mathrm{~m})$ below TOC

Water elevation: $236.15 \mathrm{H}(71.98 \mathrm{~m}) \mathrm{msl}$

Sp: conductance: $54 \mu \mathrm{S} / \mathrm{cm}$
Turbidity: $5 \mathrm{NTU}$

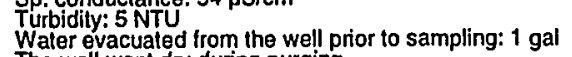
ANALYSES

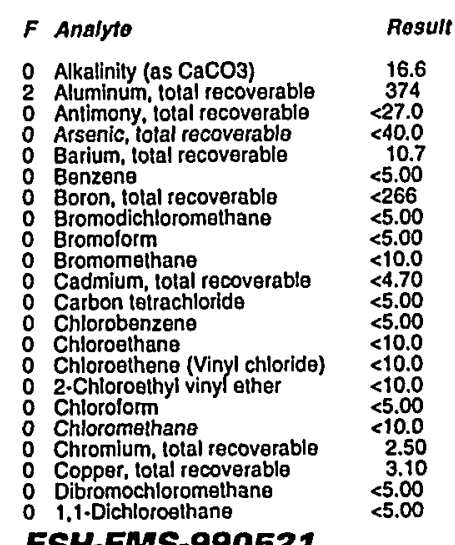

ESH-EMS-990521

Well BGO 24 D collected on 05/19/99 (cont.)

Unlt Lab Mothod

F Analyte Result

o $1,2 \cdot$ Dichloroethane

0 trans-1,2-Dlchloroethylene

1,2-Dichloropropan

trans-1,3-Dichloropropene

1 Ethylbenzene 1 ron, tolal recoverable

Lead, tolal recoverable

- Mercury, tolal recoverable

o Nickel, tolal recoverable

o Phenols Solenium, total recoverable

o Silver, tolal recover

1, 1,2,2-Tetrachloroethane

: Tetrachloroethylene

o Tolal dissolved sollds

Tolal dissolved solids

T Tolal organlc halogens

0 i.1.2. -Trichloroethane

o Trichlorosthylene

Z Xinc, total recoverable

o Carbon+14

o Radium, total alpha-emitting

O Strontium-90

\section{WELL BGO 33D}

MEASUREMENTS CONDUCTED IN THE FIELD

Sample date: 04/14/99

Weth to waier. $5.97 \mathrm{ft}(15.84 \mathrm{~m})$ below TOC

$\mathrm{pH}: 4.4$

Water temperature: $20.9^{\circ} \mathrm{C}$

Total alkalinity (as CaCO3): $18 \mathrm{mg} / \mathrm{L}$.

Phenolphinalein alkalinity: $0 \mathrm{mg} /$

$\mathrm{Sp}$. con

Turbidity: 5 NTU: $55 \mu \mathrm{S} / \mathrm{cm}$

Water evacuated from the well prior to sampling: $1 \mathrm{gal}$ ANALYSES

F Analyte

Benzene
0 Bromodichloromethane

0 Bromolorm

C Carbon tetrachloride

Chlorobenzene

O Chloroethane

2.Chloroethyl vinyl ether

Chlorolorm

0 Chloromethane

Dibromochlorometha

1,i-Dichloroethane

1,1 -Dichloroethylene
tians-1,2-Dichloroethylen

Dichloromethan

1,2-Dichloropropane

trans-1.3-Dichloropropen

1.1,2,2-Tetrachloroethane

B-34

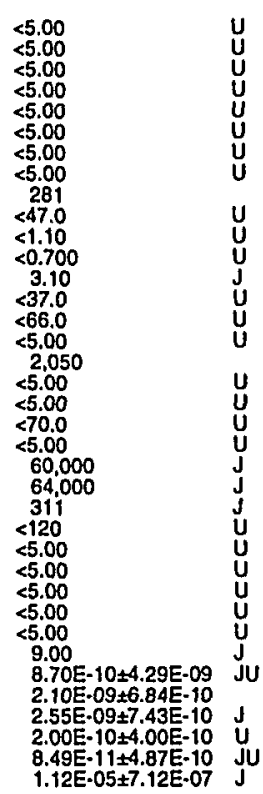

G
$u$
$u$
$u$
$u$
$u$
$u$
$u$
$J$
$u$
$u$
$u$
$u$
$u$
$J$
$J$
$u$
$u$
$u$
$J$
$J U$
$J$
$J$
$J U$
$J$

$\begin{array}{ll}\text { CX } & 5.00 \\ C X & 5.00 \\ C X & 5.00 \\ C X & 5.00 \\ C X & 5.00 \\ C X & 5.00 \\ C X & 5.00 \\ C X & 5.00 \\ & 74.0 \\ & 47.0 \\ & 2.70 \\ & 0.700 \\ & 26.0 \\ & 37.0 \\ & 66.0 \\ & 5.00 \\ C X & 540 \\ C X & 5.00 \\ C X & 70.0 \\ C X & 5.00 \\ & 50.000 \\ & 50.000 \\ & 1.000 \\ C X & 120 \\ C X & 5.00 \\ C X & 5.00 \\ C X & 5.00 \\ C X & 5.00 \\ C X & 53.0 \\ C & 7.37 E-09 \\ & 4.75 E-10 \\ & 1.19 E .09 \\ C 1 & 1.37 E-10 \\ C & 6.40 E-09 \\ & \end{array}$

Unit Lab Mothod

ugh WA EPAB260B

$\mu g \Omega$ WA

WA

WA

WA

WA

WA

WA

WA

WA

WA EPA160.1

WA

WA EPA82608

GP EPIA.001

GP EPIA-010

EPIA-004
Time: 7:55

Water temperature: $18^{\circ} \mathrm{C}$

Total alkalinity (as CaCO3): $0 \mathrm{mg} / \mathrm{L}$

Fienolphnalein alkalinity: $0 \mathrm{mgL}$ 
Well BGO 33D collected on 04/14/99 (cont.)

\begin{tabular}{|c|}
\hline alysto \\
\hline 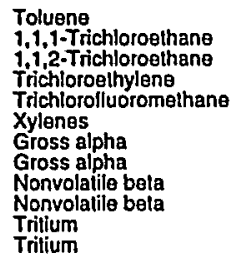 \\
\hline
\end{tabular}

Result

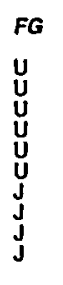

\section{WELL BGO 33D}

MEASUREMENTS CONDUCTED IN THE FIELD

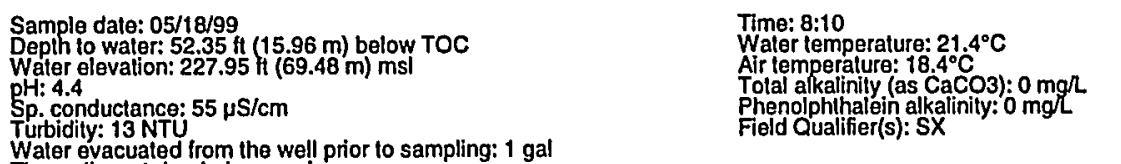

Waler evacuated from the well prior to sampling: $1 \mathrm{gal}$
The well went dry during purging. ANALYSES

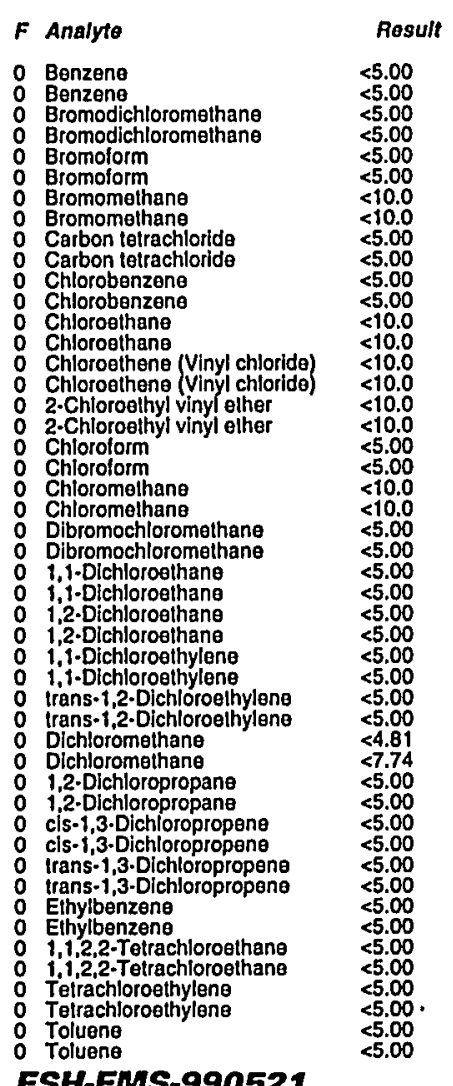

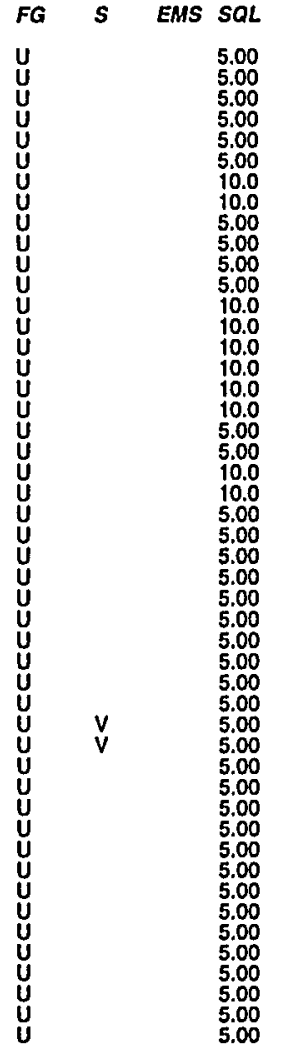

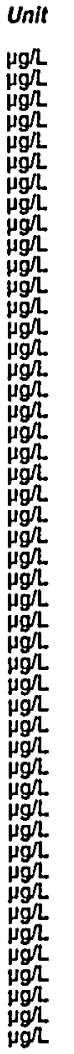

Lab Mothod
Well BGO 33D collected on 05/18/99 (cont.)

\begin{tabular}{|c|c|}
\hline Ansiyto & Result \\
\hline 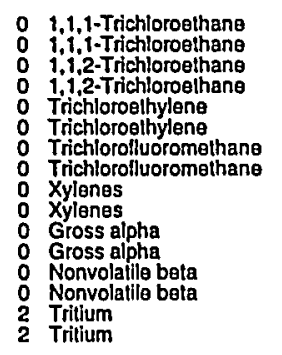 & $\begin{array}{l}<5.00 \\
<5.00 \\
<5.00 \\
<5.00 \\
<5.00 \\
<5.00 \\
<5.00 \\
<5.00 \\
<5.00 \\
<5.00 \\
4.68 E-09 \pm 1.12 E-09 \\
4.03 E .09 \pm 1.04 E .09 \\
3.34 E .09 \pm 1.19 E .09 \\
6.42 E-09 \pm 1.34 E-09 \\
2.14 E-05 \pm 1.04 E-06 \\
2.03 E-05 \pm 1.00 E-06\end{array}$ \\
\hline
\end{tabular}

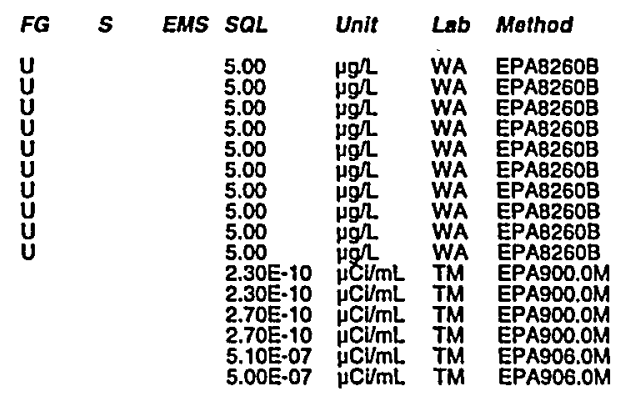

\section{WELL BGO 33D}

MEASUREMENTS CONDUCTED IN THE FIELD

Sample dale: 06/15/99

Depth to waler: $52.55 \mathrm{ft}(16.02 \mathrm{~m})$ below TOC
Water elevation: $227.75 \mathrm{ft}(69.42 \mathrm{~m}) \mathrm{ms}$

$\mathrm{PH}: 4.8$

Sp. conductance: $46 \mu \mathrm{S} / \mathrm{cm}$

Turbidily: 14 NTU

ANALYSES

$\begin{array}{ll}\text { WA EPAB260B } & \text { ANALYSES } \\ \text { WA EPAB260B } & \boldsymbol{F} \text { Analyto }\end{array}$

0 Benzene

0 Bromolorm

${ }_{0}$ Carbon tetrachiorid

Chlorobenzen

0 Chlorosthene (Vinyl chloride)

2.Chloroothyl

o Chloroform

o Dibromochioromethan

1. 1.1-Dichloroethane

1.1-Dichloroethylene
irans-1,2-Dichloroethylene

0 Dichloromethane

o cis-1,3-Dichioropropene

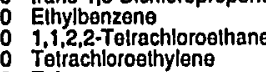

Toluene
0
0
$1,1,1-T$-Trichloroethane

o Trichloroelluyoromethane

Gross alpha

Gross alpha

Nonvolatile beta
Nonvolatile bela

Tritium
Rosult

$<5.00$

$<10.0$

$<10.0$

5.00
10.0
$<10.0$
$<10.0$

$<5$

$<5$.

$<5.00$
$<5.00$
$<7.60$

$<5.00$
$<5.00$
$<5.00$

$<5.00$
55.00
55.00
55.00

55.00
55.00
55.00
55.00
55.00

$2.64 E-09+9.60 E-10$

$2.64 E-09 \pm 9.60 E-10$
$3.23 \mathrm{E} .09 \pm 1.03 \mathrm{E}-09$
$3.02 \mathrm{E}$
$.09 \pm 1.15 \mathrm{E}$
$.43 \mathrm{E}-09 \pm 1.12 \mathrm{E}-09$

$1.99 \mathrm{E}-05 \pm 1.01 \mathrm{E} \cdot 06$
$1.93 \mathrm{E}-05 \pm 9.90 \mathrm{E}-07$
Air temperalure: $32.2^{\circ} \mathrm{C} \mathrm{C}$
Phenolphthalein alkalinity: $11 \mathrm{mg} /$

ESH-EMS-99052 


\section{WELL BGO 34D}

MEASUREMENTS CONDUCTED IN THE FIELD

Sample date: 04/14/99

Depth to waler: $44.45 \mathrm{ft}(13.55 \mathrm{~m})$ below TOC

Water elevalion: $230.45 \mathrm{Ht}$ (70.2
$\mathrm{pH}$ : 4.9

Water evacuated from the well prior to sampling: $1 \mathrm{gal}$ The well went dry during purging.

ANALYSES

$F$ Analyto

0
0
0

Bromodichlorom
Bromolorm

Carbon tefrachloride

Chlorobenzene

Chloroethene (Vinyl chloride)

2-Chloroethyl vinyl elher

Chloroform

Dibromochloromethane

i, 2 -Dichloroothan

1,1-Dichloroethylene
trans-1,2-Dlchloroethylene

cis-1,3.Dichloropropene

trans-1,3.Dichloropropene

1,1,2,2-Tetrachloroethane

1.1,1-Trichloroethane

1,1,2.Trichloroethan

Trichlorolluoromethane

Xylenes

O Nonvolatile beta

\section{WELL BGO 34D}

MEASUREMENTS CONDUCTED IN THE FIELD

Sample date: 05/18/99

Depth to water: $44.75 \mathrm{ft}(13.64 \mathrm{~m})$ below TOC

Water elevalic

Sp. conductance: $25 \mu \mathrm{S} / \mathrm{cm}$

Water evacuated from the well prior to sampling: $1 \mathrm{ga}$ The well went dry during purging

ANALYSES

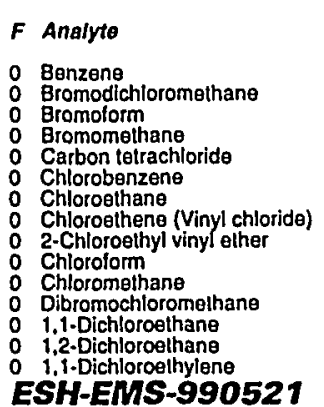

Result
$<5.00$
$<5.00$
$<5.00$
$<10.0$
55.00
$<5.00$
$<10.0$
$<10.0$
$<10.0$
$<5.00$
$<10.0$
55.00
$<5.00$
$<5.00$
$<5.00$
$<5.00$
$<5.00$
$<5.00$
$<5.00$
$<5.00$
55.00
$<5.00$
$<5.00$
$<5.00$
$<5.00$
$<5.00$
$<5.00$
$<5.00$
$<5.00$
$2.59 E-09 \pm 8.30 E-10$
$3.71 E .09 \pm 9.70 E-10$
$1.05 \cdot 05 \pm 8.00 E-07$

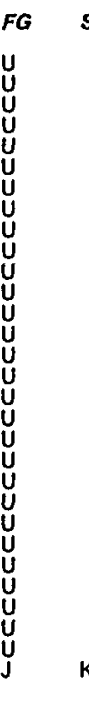

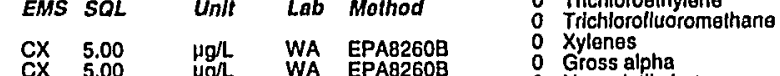

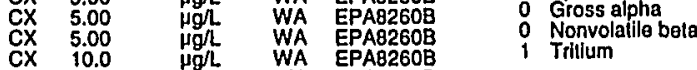 \\ WELL BGO 340}

MEASUREMENTS CONDUCTED IN THE FIELD

Sample date: 06/15/99

(1) $44.92 \mathrm{ft}(13.69 \mathrm{~m})$ below TOC

ph: 4.6

p. conductance: $54 \mu \mathrm{s} / \mathrm{cm}$

Water evacuated from the well prior to sampling: 2 gat The well went diry during purging.

ANALYSES

$F$ Analyto

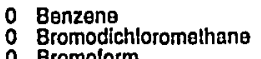

Bromolorm

Carbon tetrachiloride

Chlorobenzene

0 Chloroethane

Chlorolorm

o Dibromochloromethane

0 1,1.Dichloroethan

$1,1-D i c h l o r o e t h y l e n e$
trans-1,2-Dichloroethylen

Dichloromethano

$1,2 \cdot$ Dichloropropane
cis-1,3.0Ichloropropene

Elhylbenzene

o. 1,1,2,2-Tetrachloroe

0 Toluene

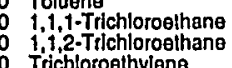

Trichlorolluoromathane

0 Xylenes

${ }_{0}$ Gross alpha

5.00
5.00
5.00
10.0
5.00
5.00
10.0
10.0
10.0
5.00
10.0
5.00
5.00
5.00
5.00



WA EPAB260B

WA

WA

WA

WA

WA

WA EPAB260

WA EPA82608
Rosult

$<5.00$
$<4.93$
$<5.00$
$<5.00$
$<5.00$
$<5.00$
$<5.00$
$<5.00$
$<5.00$
$<5.00$
$<5.00$
$<5.00$
$<5.00$
$<5.00$
$1.91 \mathrm{E}-09 \pm 7.00 \mathrm{E}-10$
$1.20 \mathrm{E}-09 \pm 1.04 \mathrm{E}-09$
$1.15 \mathrm{E} \cdot 05 \pm 7.70 \mathrm{E} \cdot 07$

FG

v

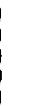

I

\begin{tabular}{|c|c|c|c|}
\hline SOL & Unit & Lab & Mothod \\
\hline $\begin{array}{l}5.00 \\
5.00 \\
5.00 \\
5.00 \\
5.00 \\
5.00 \\
5.00 \\
5.00 \\
5.00 \\
5.00 \\
5.00 \\
5.00 \\
5.00 \\
2.00 \mathrm{E}-10\end{array}$ & 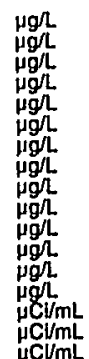 & $\begin{array}{l}\text { WA } \\
\text { WA } \\
\text { WA } \\
\text { WA } \\
\text { WA } \\
\text { WA } \\
\text { WA } \\
\text { WA } \\
\text { WA } \\
\text { WA } \\
\text { WA } \\
\text { WA } \\
\text { WA } \\
\text { WA } \\
\text { IM } \\
\text { IM } \\
\text { TM }\end{array}$ & 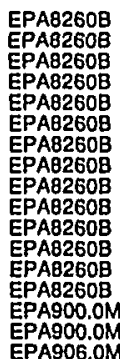 \\
\hline
\end{tabular}

Time: 8:50 Air temperalure: $25^{\circ} \mathrm{C} .1^{\circ} \mathrm{C}$ Total alkalinily (as CaCO3): $1 \mathrm{mg} / \mathrm{L}$

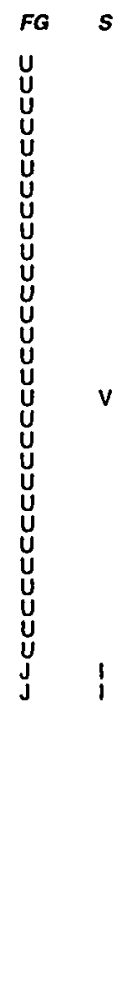


WELL BGO 35C

MEASUREMENTS CONDUCTED IN THE FIELD

Sample date: $04 / 21 / 99$
Depth to water: $45.65 \mathrm{~h}(13.91 \mathrm{~m})$ below Toc
Water elevation: $227.75 \mathrm{H}(69.42 \mathrm{~m}) \mathrm{ms}$$$
5
$$

Sp. conductance: $50 \mu \mathrm{S} / \mathrm{cm}$

Spr. conductance: $50 \mu \mathrm{S} / \mathrm{cm}$
Waler evacuated from the well prior to sampling: $123 \mathrm{gal}$ ANALYSES

0 Benzene

Bromolorm

O Carbon tetrachiorid

Chlorobenzen

Chloroethene (Vinyl chloride)
0 2-Chloroethyl vinyl ether

0 Chlorolorm

D Dibromochloromethane

$1,1-$ Dichloroethane
$1,2-$ Dichloroethane

1,i-Dichloroethyleng

$\begin{array}{ll}0 & \text { trans-1,2-Dichloroethy } \\ 0 & \text { Dichloromelthane } \\ 0 & \text { 1,2-Dichloropropan }\end{array}$

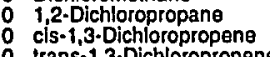

0 trans-1,3.Dichloropropene

1,1,2,2-Tetrachloroethan

0 Toluene 0 i.1-Trichloroethan

1,1,2-Trichioroethan

2 Trichloroelhylene

0
0
0
0

O Gross alpha

Nonvolatile beta

2
2 Trititum

\section{WELL BGO 35C}

MEASUREMENTS CONDUCTED IN THE FIELD

Sample dale: $05 / 24 / 99$
Depth to water: $45.32 \mathrm{ft}(13.81 \mathrm{~m})$ below TOC
Waler elevalion: $228.08 \mathrm{Ht}(69.52 \mathrm{~m}) \mathrm{ms}$

Waler el wa

Sp. conductance: $30 \mu \mathrm{S} / \mathrm{cm}$

Turbidity: $0 \mathrm{NTU}$ :
Water evacuated from the well prior to sampling: $113 \mathrm{gal}$

ANALYSES

$F$ Analyto

0 Benzene

Bromolorm

Carbon telrachlorid

Chlorobenzen

Chloroethene (Vinyl chloride)
2.Chloroethyl vinyl ether

Chloromethan

0 Dibromochloromethane

1.1.-Dichloroethane

ESH-EMS-990521
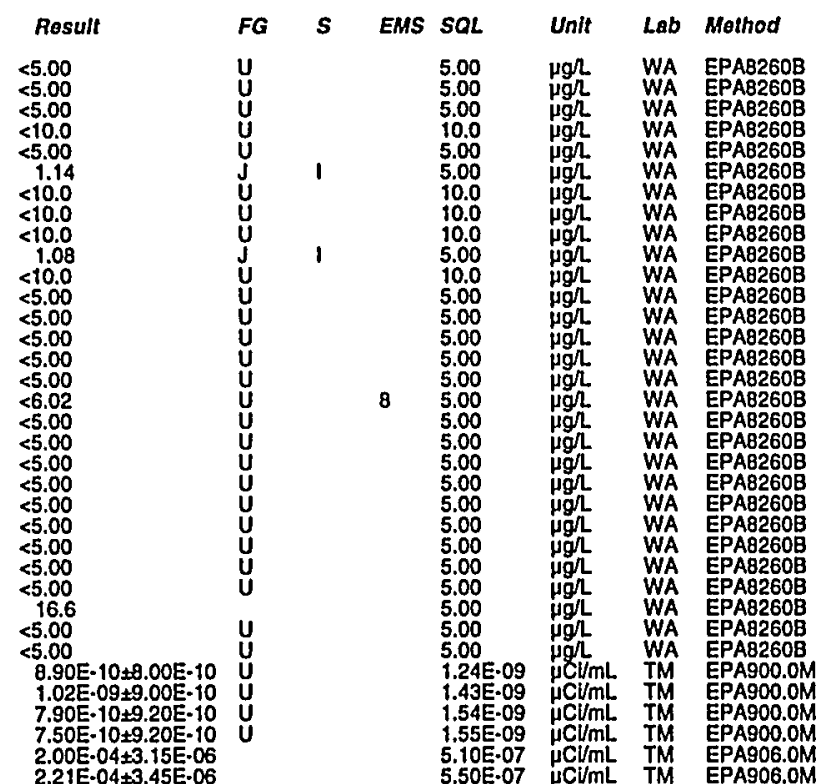

Time: 14:57

Total alkalinity (as Caco3): $3 \mathrm{mg} /$
Phenolphithalein alkalinily: $0 \mathrm{mg} /$
Field Quallifier(s): $\mathrm{s}$

Waler 1:mperature: $21.3^{\circ} \mathrm{C}$

Total alkalinity (as CaCO3): $5 \mathrm{mg} /$

Phenolphithaiein alkalinity: $0 \mathrm{mg} L$

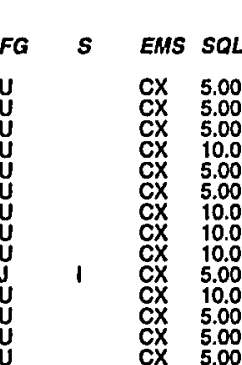

Well BGO 35C collected on 05/24/99 (cont)

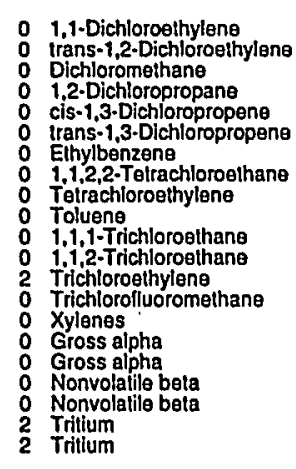

\section{WELL BGO 35C}

MEASUREMENTS CONDUCTED IN THE FIELD

Sample date: $06 / 21 / 99$
Depth to water: $44.89 \mathrm{ft}(13.68 \mathrm{~m})$ below TOC

Waler elevation: $228.51 \mathrm{ht}(69.65 \mathrm{~m}) \mathrm{ms}$

Sp. conductance: $34 \mu \mathrm{S} / \mathrm{cm}$

Waler evacualed from the well prior to sampling: $\mathbf{1 3 0} \mathrm{gal}$ ANALYSES

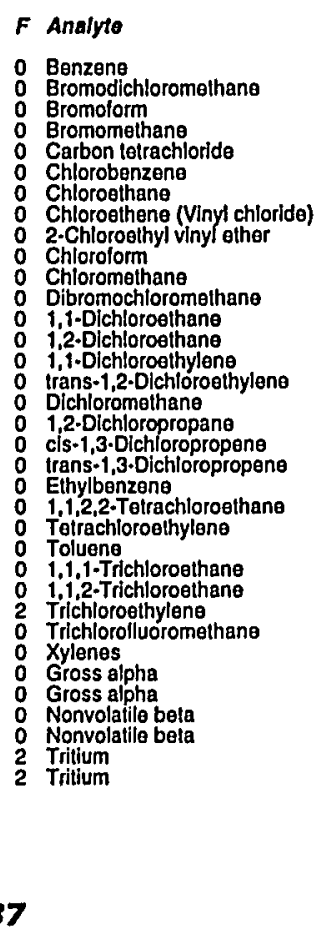

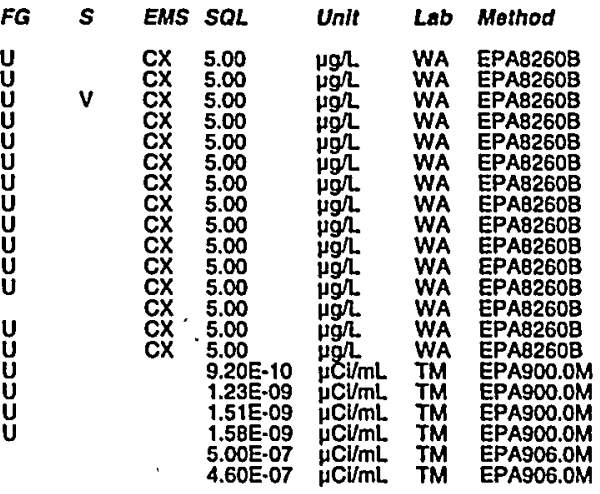

Time: 10:08

Air temperature: $20.5^{\circ} \mathrm{C}$

CaCO3): $5 \mathrm{mg} / \mathrm{L}$

Field Qualifier(s): $S$

EMS SQL Unit Lab Mathod

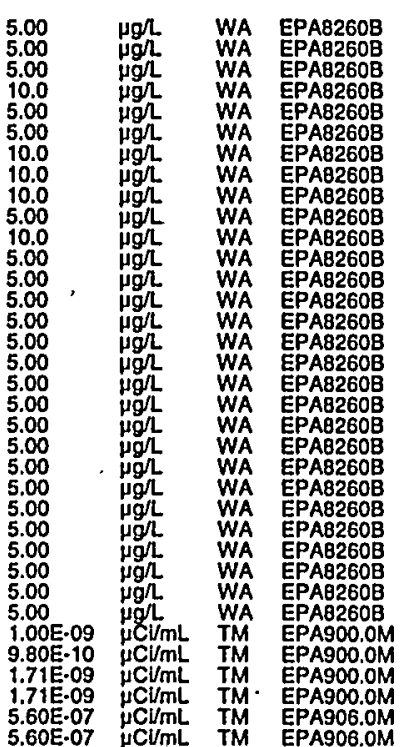




\section{WELL BGO 35D}

MEASUREMENTS CONDUCTEO IN THE FIELD

Sample date: 04/14/99 $12.51 \mathrm{~m})$ below TOC

.

Sp. conductance: $32 \mu \mathrm{S} / \mathrm{cm}$

Turbidity: 14 NTU The well went dry during purging.

ANALYSES

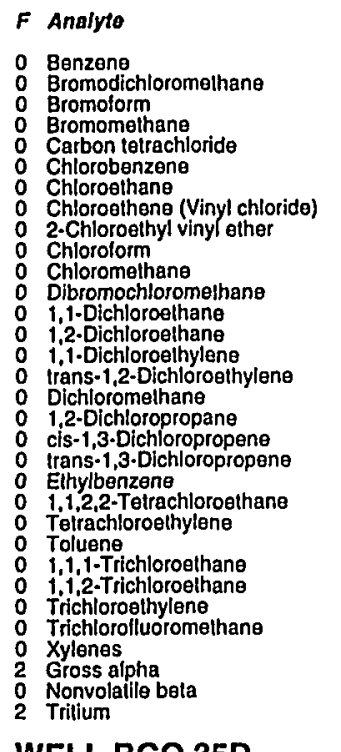

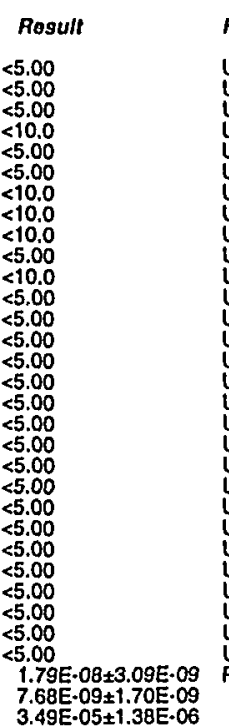

\section{WELL BGO 35D}

MEASUREMENTS CONDUCTED IN THE FIELD

Sample dale: 05/18/99

Depth to water: $41.35 \mathrm{ft}(12.6 \mathrm{~m})$ below TOC

Wh: 4.7

Sp. conductance: $39 \mu \mathrm{S} / \mathrm{cm}$

Waler ovacualed from the well prior to sampling: $1 \mathrm{gal}$

Waler evacuated rom the well pir
The well went dry during purging.

ANALYSES

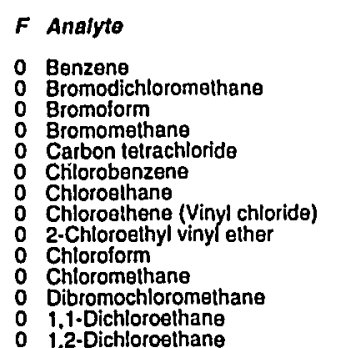

1.1-Dichloroethylen

ESH-EMS-990521

Well BGO 35D collected on 05/18/99 (conl.)

$F$ Analyte

Time: 8:15

Wir

Tolal alkalinity (as CaCo3): $0 \mathrm{mg} / \mathrm{L}$

Phenolphthalein alkalinity: $0 \mathrm{mg}$
Field Qualifier(s): SX

0 Irans-1,2-Dichloroethylene

1,2-Dichloropropan

$\begin{array}{ll}0 & \text { cis-1,3-Dichloropropene } \\ 0 & \text { irans-1,3-Dichloropropen }\end{array}$

1,1,2,2-Tetrachloroethane

- Telrachioroethylene

0 Toluene

1,1,1-Trichloroethane

Trichloroothylene

Trichloroilluoromelhane

0 Xylenes

O Nonvolatila bota

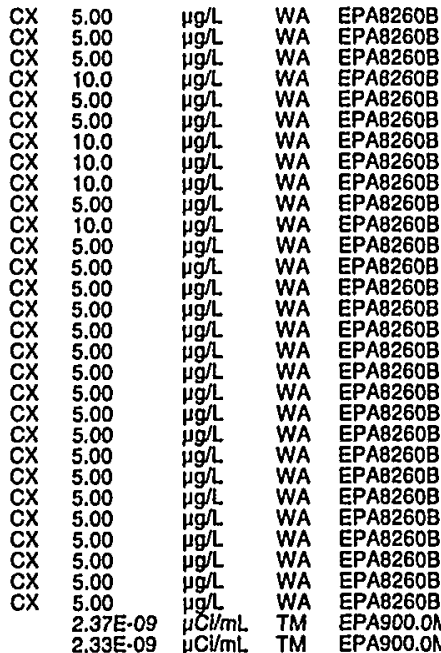

2.33E.09 $\mathrm{HC} / \mathrm{mL}$ TM EPA900.0

\section{WELL BGO 35D}

MEASUREMENTS CONDUCTED IN THE FIELD

Sample date: 06/15/99

Depth to water: 41.39 ft $(12.62 \mathrm{~m})$ below TOC

WH: 4.8

Sp. conductance: $62 \mu \mathrm{S} / \mathrm{cm}$

Water evacuated from the well prior to sampling: $2 \mathrm{ga}$ The well went dry during purging.

ANALYSES

$F$ Analyto

0
0
0

Bromolorm

Bromomethane

Carbon telrachlor

Chloroethane

Chloroethene (Vinyl chloride)

2.Chloroolhyl vinyl ether

Chlorolorm

Dibromochloromethane

$1,1-$ Dichloroethane
$1,2-$ Dichloroethan

1.1-Dichloroethylene

Dichioromethane

1,2-Dichloropropane

cis-1,3.Dichloropropene

Ethylbenzene

$1,1,2,2-$ Tetrachloroethan
Totrachloroethylene

Tetrachloroethylen

$\begin{array}{ll}0 & \text { Toluene } \\ 0 & 1,1,1-T \text { Trichloroethane } \\ 0 & 1,1,2 \text {-Trichloroethane }\end{array}$

Trichloroethylene

Xylenes

Nonvolatile beta
Rosult

$<5.00$
$<5.87$

$<5.00$

5.00
4.00

55.00

$<5.00$

$1.73 E-09+6.80 E-10$

$3.79 E \cdot 05 \pm 1.34 E \cdot 06$
Total alkalinity (as CaCO3): $0 \mathrm{mg}$

Field Qualifier(s): $S$
Result

$<5.00$

$<5.00$
$<100$
$<10.0$

5.00

$<10.0$

$<10.0$
$<10.0$

$<5.00$

$<5.00$

$<5.00$
$<5.00$
$<5.00$

$<5.00$

$<5.00$
$<5.00$

$<5.00$

$<5.00$

$<5.00$
$<5.00$

$<5.00$
$<5.00$

$5.70 E-10+6.90 E-10$

$1.46 \mathrm{E} \cdot 09 \pm 1.08 \mathrm{E} \cdot 09$
$5.73 \mathrm{E} \cdot 05 \pm 1.66 \mathrm{E} \cdot 06$
FG

r

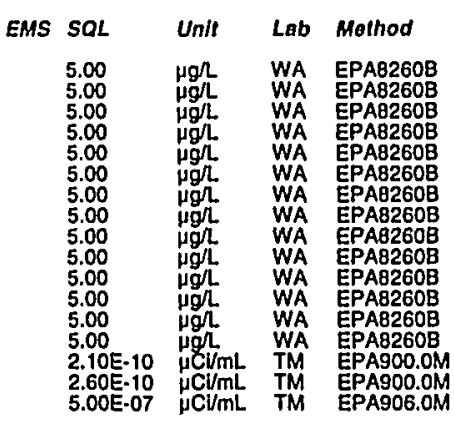

Time: 10:20

Water temperature: $32^{\circ} \mathrm{C}$

Total alkalinity (as CaCO3): $1 \mathrm{mg}$

Phenolphthalein alkalinity: $0 \mathrm{mgl}$

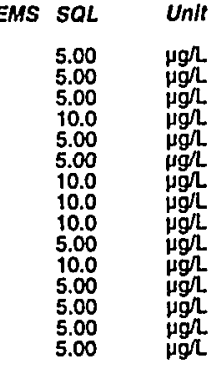

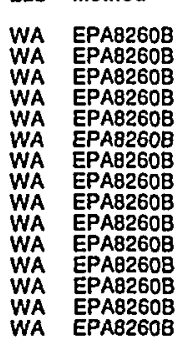

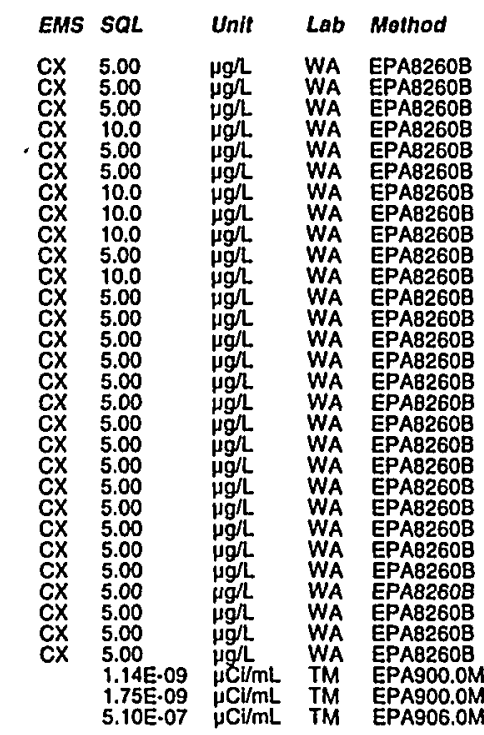




\section{WELL BGO 36D}

MEASUREMENTS CONDUCTED IN THE FIELD

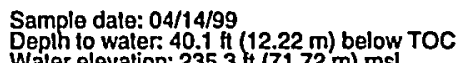

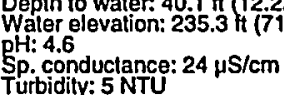
Whater evacualed from the well prior to sampling: 1 gal
The well went dry during purging.

ANALYSES

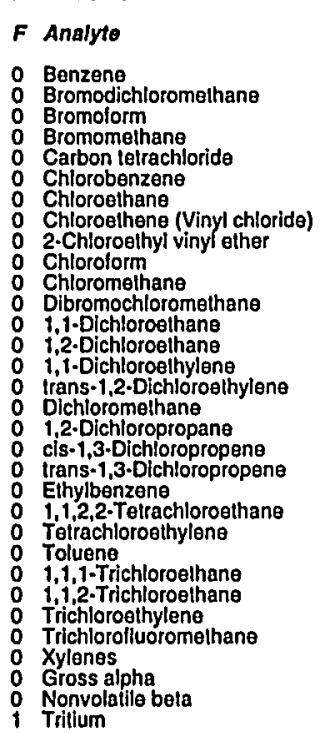

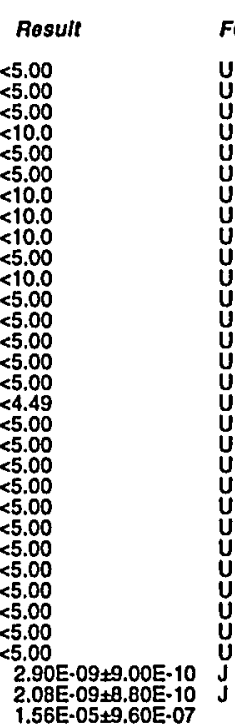

\section{WELL BGO 36D}

MEASUAEMENTS CONDUCTED IN THE FIELD

Sample dale: 05/18/99
Depth to water: $40.31 \mathrm{ft}(12.29 \mathrm{~m})$ below TOC
Water

WH: 4.5
Pponductance: $24 \mu \mathrm{S} / \mathrm{cm}$

Warbidity: 13 NTU ANALYSES

$F$ Anolyto

O Benzene

O Bromolorm

Carbon tetrachlorid

Chloroothene (Vinyl chloride)

2-Chloroethyl vinyl ether

o chloromethane

Dibromochloromethane

1.1.Dichloroethane

ESH-EMS-990521
Well BGO 360 collected on 05/18/99 (cont.)

$F$ Analyte

Time: 8:20

Air tempermperalure: $17.2^{\circ} \mathrm{C}$ Total alkalinity (as Caco3): 0 mg/
Phenolphthalein alkalinity: 0 mg

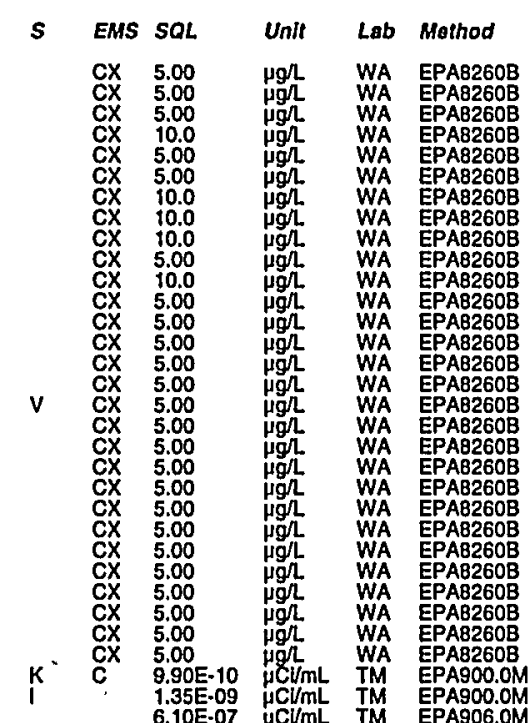

Irans-1,2-Dichloroethylene

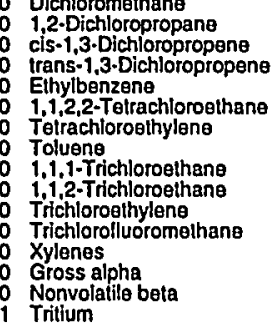

1 Nonvolatile beta

\section{WELL BGO 36D}

MEASUREMENTS CONDUCTED IN THE FIELD

Sample date: 06/15/99

$\mathrm{HH}: 4.8$.

urbidity: 14 NTU

Rosult

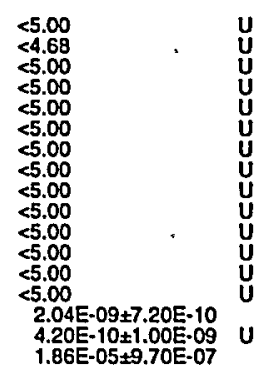

Water evacuated from the well p

ANALYSES

$F$ Analyte

0 Banzene

Bromolorm
Bromomethane

Carbon teirachiorido

Chloroethane

Chloroethene (Vinyl chloride)

Chlorolorm

Chloromelhane

Dibromochloromelh

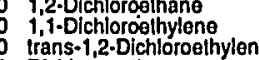

Irans-1,2-Dichloroe
Dichloromenthane

cis-1,3-Dichloropropene
irans-1,3-Dichloropropene

Elthylbenzene

T'elrachloroethylene

$\begin{array}{ll}0 & \text { Toluene } \\ 0 & 1,1,1-\text { Trichloroethane } \\ 0 & 1,1,2-T \text { richloroothane }\end{array}$

O Trichloroethylene

Gylones

1 Nonvolatile beta

\section{Total alkalinity (as Caco3): $0 \mathrm{mg}$ \\ Phenolphthalein alkain}

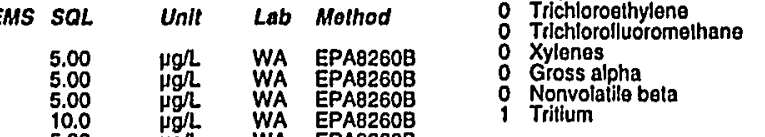

$2.78 E \cdot 0949.70 E \cdot 10$
$1.89 E .09+1.09 E \cdot 09$
$1.73 E \cdot 05 \pm 9.50 E-07$

\begin{tabular}{|c|c|c|c|c|c|c|c|}
\hline esult & $F G$ & & EMS & SQL & Unit & Lab & $\mathrm{Me}$ \\
\hline $\begin{array}{l}5.00 \\
5.00 \\
5.00 \\
10.0 \\
5.00 \\
5.00 \\
10.0 \\
10.0 \\
10.0 \\
10.00 \\
5.00 \\
10.0 \\
5.00 \\
5.00 \\
5.00 \\
5.00 \\
5.00 \\
5.00 \\
5.00 \\
5.00 \\
5.00 \\
5.00 \\
5.00 \\
5.00 \\
5.00 \\
5.00 \\
55.00 \\
5.00 \\
5.00 \\
5.00 \\
2.78 E-09+9.70 E-10\end{array}$ & 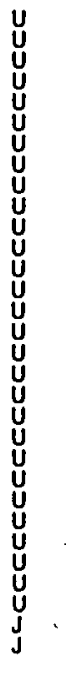 & • & & $\begin{array}{l}5.00 \\
5.00 \\
5.00 \\
10.0 \\
5.00 \\
5.00 \\
10.0 \\
10.0 \\
10.0 \\
5.00 \\
10.0 \\
5.00 \\
5.00 \\
5.00 \\
5.00 \\
5.00 \\
5.00 \\
5.00 \\
5.00 \\
5.00 \\
5.00 \\
5.00 \\
5.00 \\
5.00 \\
5.00 \\
5.00 \\
5.00 \\
5.00 \\
5.00 \\
1.10 E .09 \\
1.74 \text { E. } 09 \\
5.10 \text { E. } 07\end{array}$ & 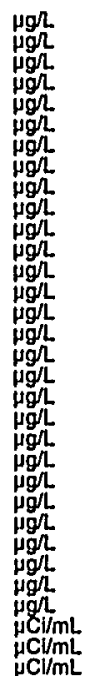 & $\begin{array}{l}\text { WA } \\
\text { WA } \\
\text { WA } \\
\text { WA } \\
\text { WA } \\
\text { WA } \\
\text { WA } \\
\text { WA } \\
\text { WA } \\
\text { WA } \\
\text { WA } \\
\text { WA } \\
\text { WA } \\
\text { WA } \\
\text { WA } \\
\text { WA } \\
\text { WA } \\
\text { WA } \\
\text { WA } \\
\text { WA } \\
\text { WA } \\
\text { WA } \\
\text { WA } \\
\text { WA } \\
\text { WA } \\
\text { WA } \\
\text { TM } \\
\text { TM } \\
\text { TM }\end{array}$ & 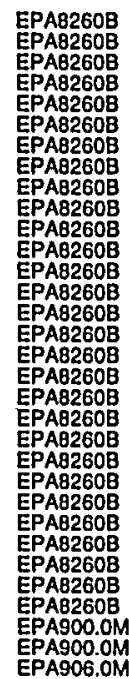 \\
\hline
\end{tabular}

Time: 10:50

Water temperature: $23{ }^{\circ} \mathrm{C}$

Total alkalinity (as CaCO3): $0 \mathrm{mg}$

Phenolphthalein alkalinity: $0 \mathrm{mgh}$
Field Qualifier(s): SX

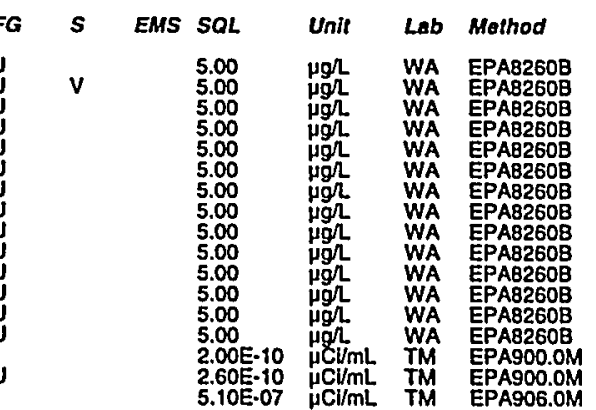




\section{ANALYTICAL RESULTS}

\section{WELL BGO $37 C$}

MEASUREMENTS CONDUCTED IN THE FIELD

Sample date: 04/21/99

Welow TOC

Wate 4

Sp. conductance: $38 \mu \mathrm{S} / \mathrm{cm}$

Water evacualed from the well prior to sampling: $120 \mathrm{gal}$

ANALYSES

$F$ Analyo

: Benzene

Bromoform

Carbon tetrachilorid

Chlorobenzeng

Chloroethene (Vinyl chloride)

2-Chloroethy

Chloromelhane

Dibromochloromethan

$1,1 \cdot$ Dichloroethane
$1,2 \cdot$ Dichloroethane

$1,1 \cdot$ Dichloroethylens
irans-1,2-Dichloroethylene

Dichloromethane

cis-1,3-Dichloropropene

trans-1,3-Dichloropropene

1,1,2,2-Tetrachloroethane

Toluene

1,1,1-Trichloroethane

Trichlorosthylethe

Trichlorofluoromethane

Xylenes

O Gross alpha

Nonvolatile bela

$\begin{array}{ll}2 & \text { Tritium } \\ 2 & \text { Trillum }\end{array}$

\section{WELL BGO $37 C$}

MEASUAEMENTS CONDUCTED IN THE FIELD

Sample date: 05/24/99
Depth lo waler: $55.3 \mathrm{tt}(16.86 \mathrm{~m})$ below TOC
Water elevation: $231 \mathrm{H}(70.41 \mathrm{~m}) \mathrm{ms}$

$$
\text { pH: } 4.5
$$

Sp. conductance: $42 \mu \mathrm{S} / \mathrm{cm}$

Wurbidity: O NTU focted from the well prior to sampling: $110 \mathrm{gal}$ ANALYSES

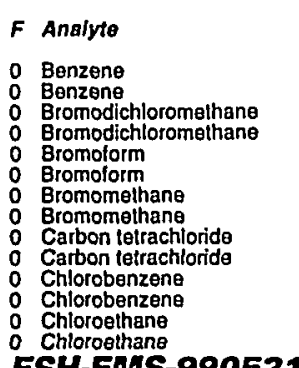

ESH-EMS-990521

\begin{tabular}{|c|c|c|c|c|c|c|c|}
\hline Rosull & $F G$ & $S$ & EMS & $S O L$ & Unit & Lab & fethod \\
\hline$<50.0$ & u & & & & & WA & 608 \\
\hline 50.0 & $\underline{U}$ & & & $\begin{array}{l}50.0 \\
50.0\end{array}$ & pah & WA & 008 \\
\hline 100 & $u$ & & & 100 & $\mu g / \mathrm{L}$ & WA & \\
\hline $\begin{array}{c}<50.0 \\
<50.0\end{array}$ & $u$ & & & $\begin{array}{l}50.0 \\
50.0\end{array}$ & $\begin{array}{l}\mu 9 \\
\mu 9\end{array}$ & WA & 2608 \\
\hline 100 & $\underline{u}$ & & & 10 & $\mu g$ & WA & 2608 \\
\hline$<100$ & $u$ & & & & $\mu g h$ & WA & 608 \\
\hline $\begin{array}{r}78.7 \\
<100\end{array}$ & $u$ & & & & 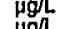 & WA & 6608 \\
\hline$<50.0$ & $u$ & & & & $\mu h$ & WA & 608 \\
\hline $\begin{array}{r}52.3 \\
<50.0\end{array}$ & $u$ & & & 50 & . & WA & EPA82608 \\
\hline $\begin{array}{r}14.8 \\
<50.0\end{array}$ & ju & 1 & & $\begin{array}{l}50.0 \\
50.0\end{array}$ & 然 & $\begin{array}{l}\text { WA } \\
\text { WA }\end{array}$ & $\begin{array}{l}\text { ЕРАВ260B } \\
\text { ЕРАВ260日 }\end{array}$ \\
\hline $\begin{array}{r}242 \\
<50.0\end{array}$ & u & & & 50.0 & L & WA & $\begin{array}{l}\text { EPAB22608 } \\
\text { EPA82608 }\end{array}$ \\
\hline$<50.0$ & $u$ & & & & 年 & WA & EPAB2608 \\
\hline $\begin{array}{l}550.0 \\
<50.0\end{array}$ & u & & & & Hgh & WA & EPA8260B \\
\hline 36.0 & $j$ & 1 & & & $7 y$ & WA & EPAB260B \\
\hline $\begin{array}{r}<50.0 \\
<50.0\end{array}$ & ư & & & & pgi & WA & EPAB260B \\
\hline $\begin{array}{r}664 \\
<50.0\end{array}$ & & & & & & WA & EPA82608 \\
\hline$<50.0$ & 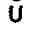 & & & 0 & pgi & WA & EPA82608 \\
\hline $1.97 \mathrm{E}-09 \pm 9.20$ & 1 & 1 & & 5 & $\mu \mathrm{ClmL}$ & $\operatorname{TM}$ & EPA900.0M \\
\hline $1.72 E^{-}$ & $\mathrm{J}$ & 1 & & & & $\operatorname{TM}$ & $.0 \mathrm{M}$ \\
\hline $\begin{array}{l}1.21 \mathrm{E}-01 \pm 1.83 \mathrm{E}-03 \\
1.20 \mathrm{E}-01 \pm 1.82 \mathrm{E}-03\end{array}$ & & & & & & $\mathrm{TM}_{\mathrm{TM}}^{\mathrm{TM}}$ & EPA906.0M \\
\hline
\end{tabular}

Time: 15:26

ater temperature: $24^{\circ} \mathrm{C}$

Total alkalinity (as CaCo3): $0 \mathrm{mg} /$

Phenolphihalein alkalinity: $0 \mathrm{mg}$ '
Field Qualifier(s): $\mathrm{S}$

\begin{tabular}{|c|c|c|c|c|}
\hline $\boldsymbol{s}$ & EMS SQL & Unit & Lab & Mothod \\
\hline • & $\begin{array}{l}50.0 \\
50.0 \\
50.0 \\
50.0 \\
50.0 \\
50.0 \\
100 \\
100 \\
500 \\
50.0 \\
50.0 \\
50.0 \\
100 \\
100\end{array}$ & $\begin{array}{l}\mu g h \\
\mu g h \\
\mu g h \\
\mu g h \\
\mu g h \\
\mu g h \\
\mu g h \\
\mu g h \\
\mu g h \\
\mu g h \\
\mu g h \\
\mu g h \\
\mu g h \\
\mu g h \\
\mu g h\end{array}$ & $\begin{array}{l}\text { WA } \\
\text { WA } \\
\text { WA } \\
\text { WA } \\
\text { WA } \\
\text { WA } \\
\text { WA } \\
\text { WA } \\
\text { WA } \\
\text { WA } \\
\text { WA } \\
\text { WA } \\
\text { WA } \\
\text { WA }\end{array}$ & 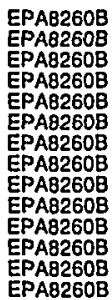 \\
\hline
\end{tabular}

Well BGO 37C collected on 05/24/99 (conl.)

F Analyto

Chloroathene (Vinyl chloride) Chloroethene (Vinyl chlorid 2-Chloroethyl vinyl ether

Chlorolorm

o Chloromethane

$\begin{array}{ll}0 & \text { Chloromelhane } \\ 0 & \text { Dibromochloromethane }\end{array}$

$1,1 \cdot$ Dichloroethen

1.1.Dichloroethane

$\begin{array}{ll}1,2 \cdot D i c h l o r o e t h a n e \\ 0 & 1,2 \cdot \text { Dichloroethane }\end{array}$

2 1,1-Dichloroethylene

trans-1,2-Dichloroethylene
trans-1,2-Dichloroethylene

Dichioromethan

o $1,2 \cdot$ Dichloropropane

o cis $1,3 \cdot$ Dichloropropene

o trans-1,3-Dichloropropene

o trans-1,3-Dichlor

1,1,2,2-Tetrachloroesthane

0 i, 1,2,2-Tolrachloroeth

2 Telrachloroelhylene

2 Telrachloro

1,1,1-Trichloroethane

1.1.1-Trichloroethane

1,i,2-Trichloroesthane

Trichloroethylene

Trichloroflluoromethan

o Xylenes

0 Gross alpha

o Gross alpha

o Nonvolatile bete

2 Tritium

\section{WELL BGO $37 C$}

MEASUREMENTS CONDUCTED IN THE FIELD

Sample date: 06/21/99

Water

Sp. conductance: $38 \mu \mathrm{S} / \mathrm{cm}$

Waler evacuated from the well prior to sampling: $123 \mathrm{gal}$

ANALYSES

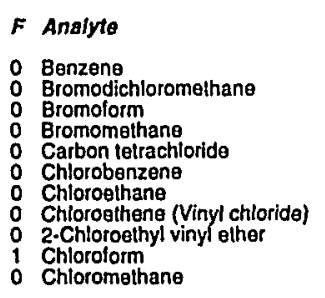

Result
$<50.0$
$<50.0$
$<50.0$
$<100$
$<50.0$
$<50.0$
$<100$
$<100$
$<100$
76.1
$<100$

76.1

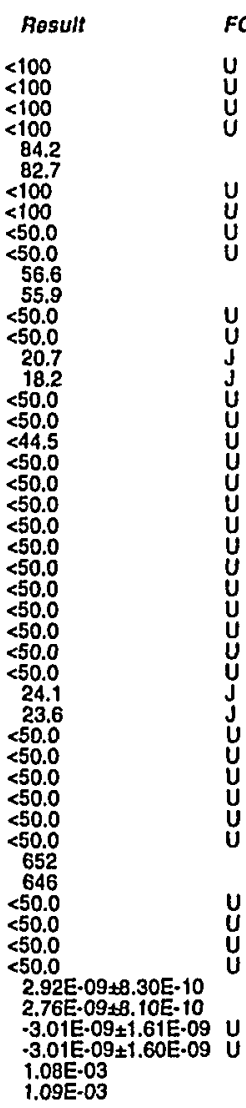

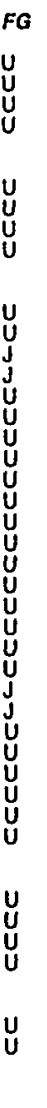

s $E$

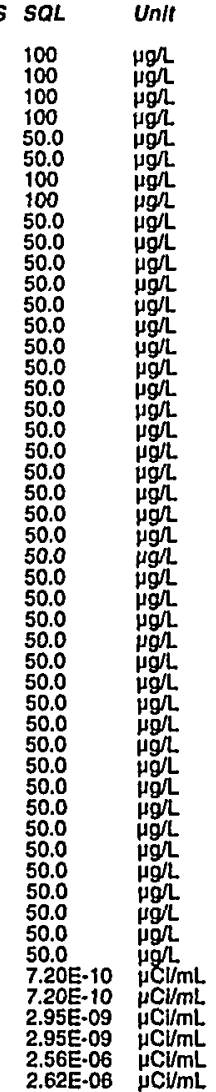

Lab Mothod

WA EPAB260B

WA

WA

WA

WA

WA

WA

WA

WA

WA

WA

WA

WA

WA

WA

A

WA

EPA900. $0 \mathrm{M}$

EPA900.0M
Time: 11:00

Wir

Total alkalinity (as CaCO3): $0 \mathrm{mg}$. Phenolphing alkalinily: $0 \mathrm{mg}$ 
Well BGO 37 D collected on 06/15/99 (cont.)

\begin{tabular}{|c|c|c|c|c|c|c|c|c|}
\hline Analyte & Result & FG & $s$ & EMS & SOL & Unlt & Lab & Mothod \\
\hline 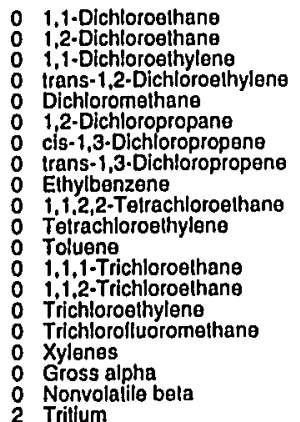 & $\begin{array}{l}<5.00 \\
<5.00 \\
<5.00 \\
<5.00 \\
<5.00 \\
<5.00 \\
<5.00 \\
<5.00 \\
<5.00 \\
<5.00 \\
55.00 \\
55.00 \\
55.00 \\
5.00 \\
<5.00 \\
5.00 \\
<5.00 \\
4.20 E \cdot 10 \pm 6.30 E-10 \\
7.40 E-10 \pm 1.03 E-09 \\
2.39 E-05 \pm 1.10 E-06\end{array}$ & $\stackrel{u}{u}$ & & - & $\begin{array}{l}5.00 \\
5.00 \\
5.00 \\
5.00 \\
5.00 \\
5.00 \\
5.00 \\
5.00 \\
5.00 \\
5.00 \\
5.00 \\
5.00 \\
5.00 \\
5.00 \\
5.00 \\
5.00 \\
5.00 \\
1.08 E \cdot 09 \\
1.73 E .09 \\
5.10 E-07\end{array}$ & 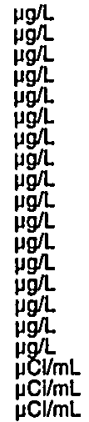 & $\begin{array}{l}\text { WA } \\
\text { WA } \\
\text { WA } \\
\text { WA } \\
\text { WA } \\
\text { WA } \\
\text { WA } \\
\text { WA } \\
\text { WA } \\
\text { WA } \\
\text { WA } \\
\text { WA } \\
\text { WA } \\
\text { WA } \\
\text { WA } \\
\text { WA } \\
\text { WA } \\
\text { IM } \\
\text { TM } \\
\text { TM }\end{array}$ & 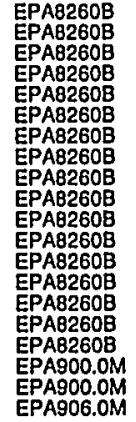 \\
\hline
\end{tabular}

\section{WELL BGO 38D}

MEASUREMENTS CONDUCTED IN THE FIELD Sample date: 04/14/99
Depth to water: $55.09 \mathrm{ft}(16.79 \mathrm{~m})$ below TOC
Water elovation: $236.51 \mathrm{tt}(72.09 \mathrm{~m}) \mathrm{msl}$

gH: 4.5
Tp. conductance: $33 \mu \mathrm{S} / \mathrm{cm}$

Water evacuated from the well prior to sampling: 1 gal The well wenl dry during purging.

ANALYSES

$F$ Analyte

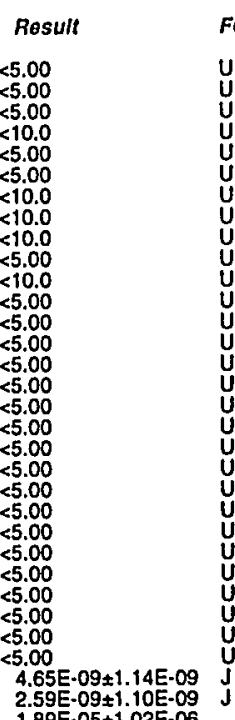

0 Benzene

Bromoform
Bromometha

Carbon tetrachlorido

Chloroform

Dibromochloromethan

1.1.Dichloroethane

$1,1-$ Dichloroethylene
irans-1,2-Dichloroethylene

Dichloromethane

cis-1,3-Dichloropropene
trans-1,3-Dichloropropene

i, , 2,2.Tetrachlorosthan

Tetrachloroethylene

1oluene

Trichloroethylene

Gross alpha

Nonvolatile bota

2.59E-09+1.10E-09

\section{WELL BGO 38D}

MEASUREMENTS CONDUCTED IN THE FIELD

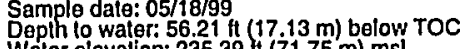

4 H. 4 .

Sp. conductance: $32 \mu \mathrm{S} / \mathrm{cm}$

Waler evacuated irom the well prior to sampling: 1 gal The well went dry during purging.

ANALYSES

$F$ Analyt

: Benzene

Bromolorm
Bromomethane

Carbon letrachlorid

Chlorosthane

Chloroelhene (Vinyl chlorid

2-Chloroloalhyl

Chloromethane
Dibromochloromelhan

1,1-Dichloroethane

1,1-Dichloroethylene
trans-1,2-Dichloroelhylene

1.2-Dichloropropan

cis-1,3-Dichloropropene
irans-1,3-Dichloropropene

1.1.2,2-Tetrachloroethane

0 Tetrachloroethylene

0 Toluene $1,1-$ Trichloroethane

Trichloroethylene

X Xylenes

Nonvolailie bet

\section{WELL BGO 38D}

MEASUREMENTS CONDUCTED IN THE FIELD

Sample date: 06/15/99

Depth to waler: $54.9 \mathrm{ft}(16.73 \mathrm{~m})$ below TOC

Water elevalion: $236.7 \mathrm{tt}(72.15 \mathrm{~m}) \mathrm{msl}$

Water evacuated from the well prior to sampling: 5 ga

Well went dry during purging.

Result
$<5.00$
$<5.00$
$<5.00$
$<10.0$
$<5.00$
$<5.00$
$<10.0$
$<10.0$
$<10.0$
$<5.00$
$<10.0$
$<5.00$
$<5.00$
$<5.00$
$<5.00$
$<5.00$
$<5.04$
$<5.00$
$<5.00$
$<5.00$
$<5.00$
$<5.00$
$<5.00$
$<5.00$
$<5.00$
$<5.00$
$<5.00$
$<5.00$
$3.34 E-09 \pm 9.00 E-10$
$2.295 .09 \pm 1.10 E .09$
$2.14 E-05 \pm 1.05 E-06$

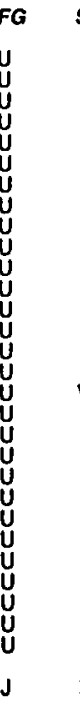

Time: 9:00

Air temporature: $22.4^{\circ} \mathrm{C}$

Total alkalinify (as CaCO3): $0 \mathrm{mg} / \mathrm{L}$

列

EMS SOL

ime: 8:45

Water temperature: $22^{\circ} \mathrm{C}$

Phenolphthalein alkalinity: $0 \mathrm{mg} \Omega$
Field Oualifier(s): $S x$
Chloroelhene (Vinyl chloride)

\section{Time: 8:40

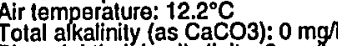 Phenolphithalein alkain}

\begin{tabular}{|c|c|c|c|c|c|}
\hline 5 & EMS & SQL & Unit & Lab & Method \\
\hline & $\begin{array}{l}c x \\
c x \\
c x \\
c x \\
c x \\
c x \\
c x \\
c x \\
c x \\
c x \\
c x \\
c x \\
c x \\
c x \\
c x \\
c x \\
c x \\
c x \\
c x \\
c x \\
c x \\
c x \\
c x \\
c x \\
c x \\
c x \\
c x \\
c x \\
c x \\
c\end{array}$ & $\begin{array}{l}5.00 \\
5.00 \\
5.00 \\
10.0 \\
5.00 \\
5.00 \\
10.0 \\
10.0 \\
10.0 \\
5.00 \\
10.0 \\
5.00 \\
5.00 \\
5.00 \\
5.00 \\
5.00 \\
5.00 \\
5.00 \\
5.00 \\
5.00 \\
5.00 \\
5.00 \\
5.00 \\
5.00 \\
5.00 \\
5.00 \\
5.00 \\
5.00 \\
5.00 \\
1.01 E .09 \\
1.70 E .09 \\
5.90 E .07\end{array}$ & 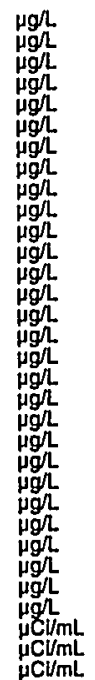 & $\begin{array}{l}\text { WA } \\
\text { WA } \\
\text { WA } \\
\text { WA } \\
\text { WA } \\
\text { WA } \\
\text { WA } \\
\text { WA } \\
\text { WA } \\
\text { WA } \\
\text { WA } \\
\text { WA } \\
\text { WA } \\
\text { WA } \\
\text { WA } \\
\text { WA } \\
\text { WA } \\
\text { WA } \\
\text { WA } \\
\text { WA } \\
\text { WA } \\
\text { WA } \\
\text { WA } \\
\text { WA } \\
\text { WA } \\
\text { WA } \\
\text { WA } \\
\text { WA } \\
\text { WA } \\
\text { TM } \\
\text { IM } \\
\text { TM }\end{array}$ & 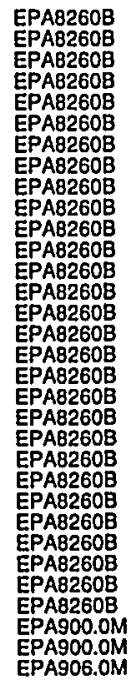 \\
\hline
\end{tabular}

Sp. conductance: $40 \mu \mathrm{S} / \mathrm{cm}$

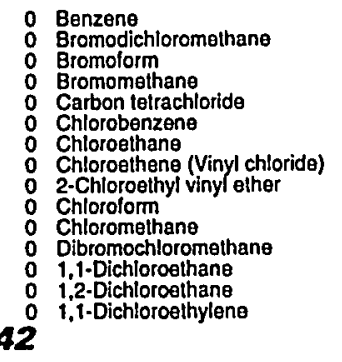

$3-42$

Result
$<5.00$
55.00
$<5.00$
510.0
$<5.00$
55.00
$<10.0$
510.0
$<10.0$
55.00
$<10.0$
55.00
$<5.00$
55.00
$<5.00$

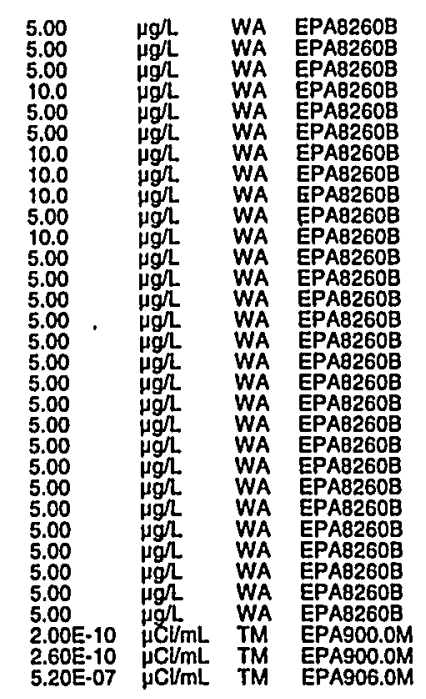

Air temperature: $24.8{ }^{\circ} \mathrm{C}$.

ESH-EMS-990521

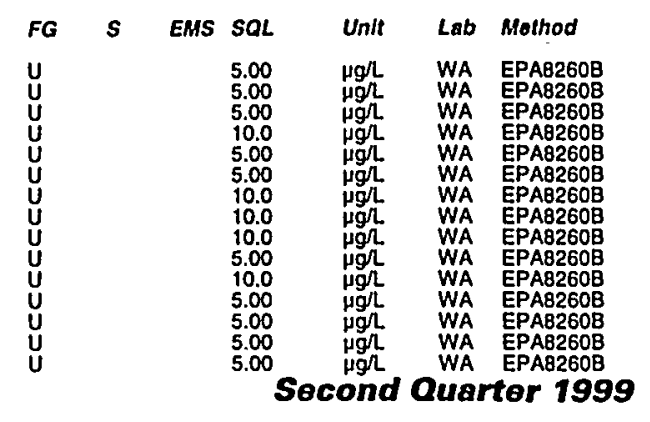


Well BGO 38D collected on 06/15/99 (cont.)

$F$ Analyte

Result

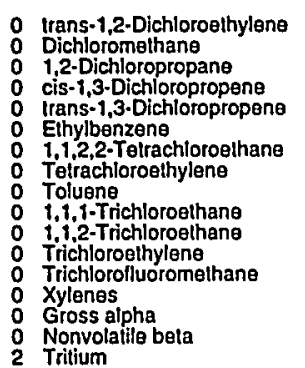

\section{WELL BGO 39C}

MEASUREMENTS CONDUCTED IN THE FIELD

Sample date: 04/14/99

Deph to waler: $65.28 \mathrm{ft}(19.9 \mathrm{~m})$ below TOC
Water elevation: $231.12 \mathrm{ft}(70.45 \mathrm{~m}) \mathrm{ms}$

$\mathrm{pH}$. 6 conductance: $45 \mu \mathrm{s} / \mathrm{cm}$

Turbidity: 1 NTU
Water evacuated from the well prior to sampling: $37 \mathrm{gal}$

ANALYSES

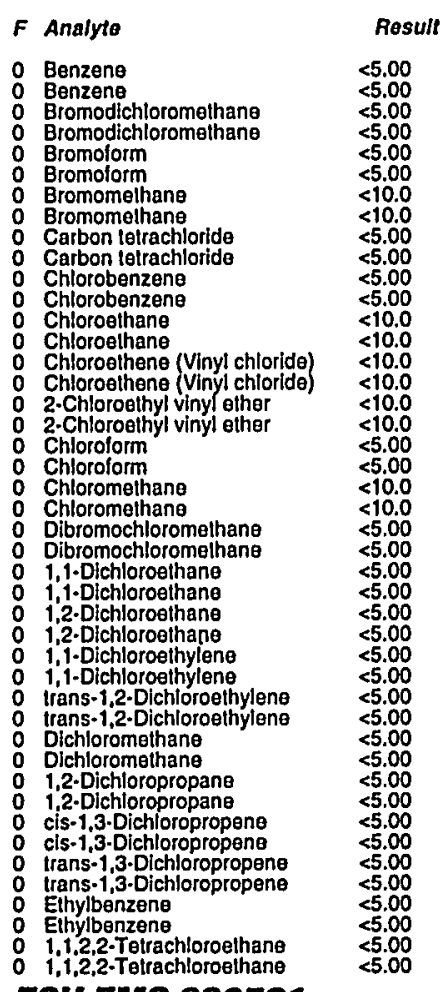

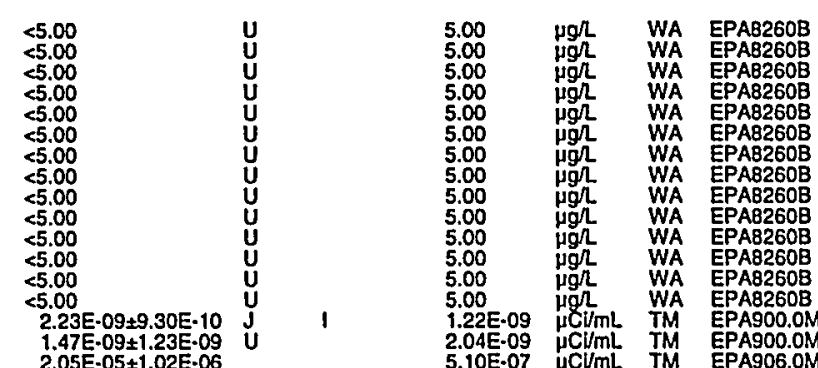

Air temperature: $17.9^{\circ} \mathrm{C}$ ) $13 \mathrm{mg} / \mathrm{L}$

Phenolphnhalein alkalinity: 0 mgl

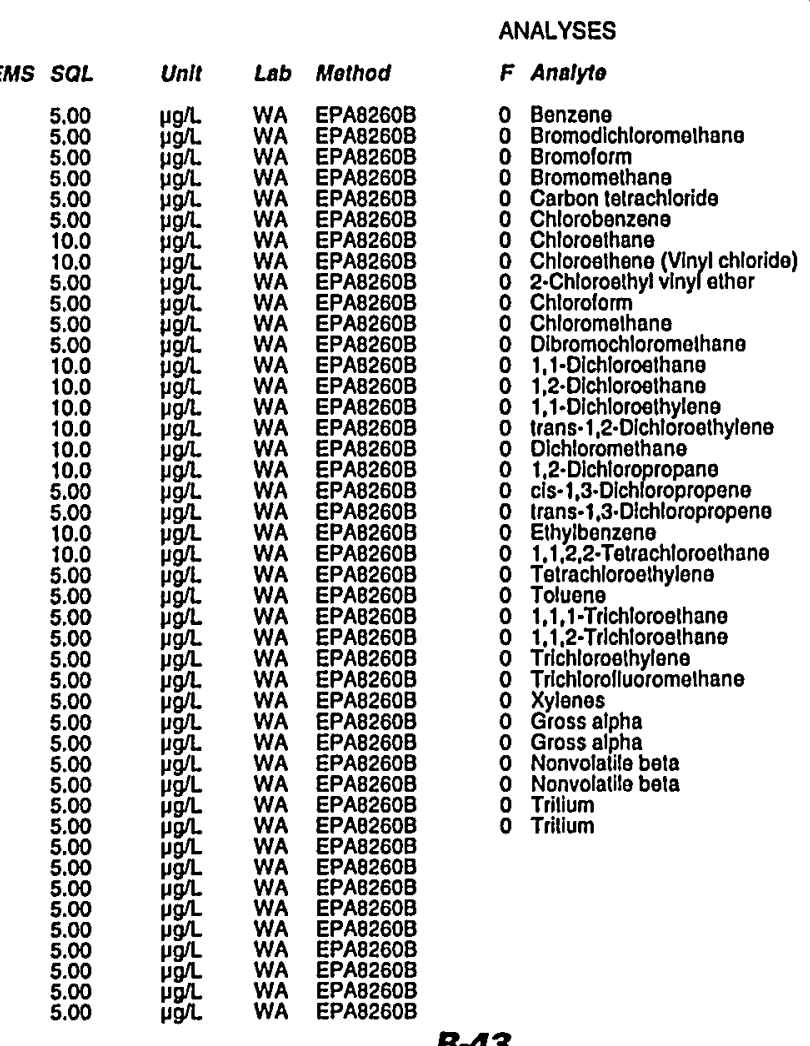

: Tetrachloroethylens

O Toluene

1,1,1-Trichloroethane

1.1.2-Trichloroethane

Trichlorosthylens

o Trichlorolluoromethane

0 Xylenes

0 Gross alpha

WELL BGO $39 C$

Sample dale: 05/17/99



p. conductance: $54 \mu \mathrm{S} / \mathrm{cm}$

\begin{tabular}{|c|c|c|}
\hline$F G$ & $\mathbf{s}$ & EMS \\
\hline 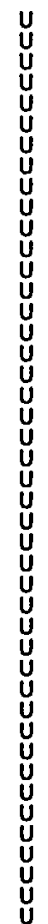 & & $\cdot$ \\
\hline
\end{tabular}

Wit

Well BGO $39 \mathrm{C}$ collected on 04/14/99 (cont.)

$F$ Analyte Resull

MEASUREMENTS CONDUCTED IN THE FIELD

Wepth to water: $66.7 \mathrm{ft}(20.33 \mathrm{~m})$ below TOC

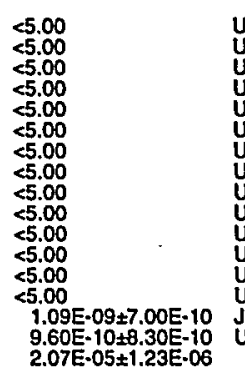

FG

EMS SQL

Unit Lab Mothod

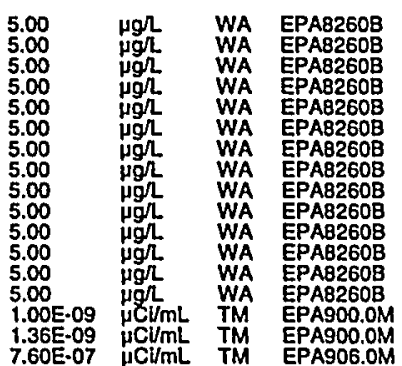

IK C

Time: 11:50

Waler temperature: $21^{\circ} \mathrm{C}$ Total alkalinity (as CaCO3): $14 \mathrm{mg} /$ Phenolphthalein alkalinity: $0 \mathrm{mg} \Omega$

Water evacuated from the well prior to sampling: $29 \mathrm{gal}$

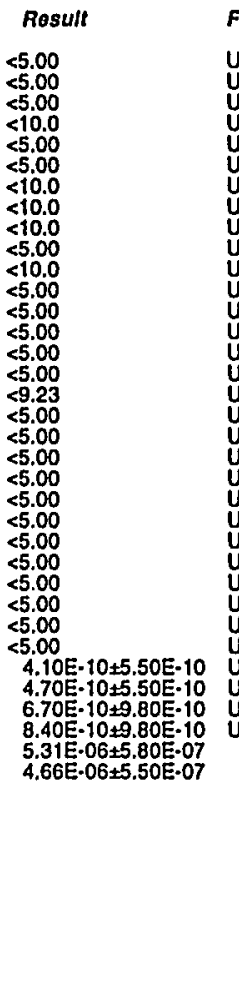




\section{WELL. BGO 39C Replicate}

MEASUREMENTS CONDUCTED IN THE FIELD

Sampla dala: 05/17/99

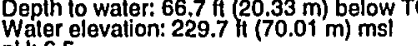

WH: 6 .

5. conductance: $54 \mathrm{\mu S} / \mathrm{cm}$

Water evacuated from the well prior to sampling: $29 \mathrm{gal}$

ANALYSES

$F$ Analyto

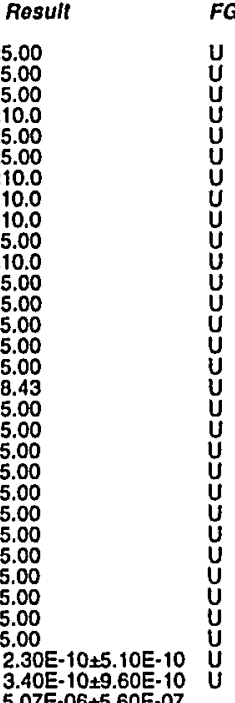

Benzene
Bromodichloromelhane

Bromolorm

Carbon telrachloride

Chloroethane

Chloroethene (Vinyl chloride)

Chlorolorm

Cibromochloromethane

1,1-Dlchloroethan

$1,1-$ Dichloroethylene
trans-1,2-Dichloroethylene

: Dichloromethane

cls-1,3.Dichloropropene
trans-1,3-Dichloropropene

$1,1,2,2$-Tetrachloroethan

Tetrachloroethylene

o $1,1,1$-Trichloroethane

Trichloroethylene

Xylenes

0 Nonvolatile beta

$3.40 \mathrm{E}-10 \pm 9.60 \mathrm{E}-10$

WELL BGO 39C

MEASUREMENTS CONDUCTED IN THE FIELD

Depth to waler: $65.2 \mathrm{ft}(19.87 \mathrm{~m})$ below TOC
Water elevation: $231.2 \mathrm{ft}(70.47 \mathrm{~m}) \mathrm{ms}$

ph: 6.5

p. conductance: $54 \mu \mathrm{S} / \mathrm{cm}$

Water evacuated from the well prior to sampling: $20 \mathrm{gal}$

ANALYSES

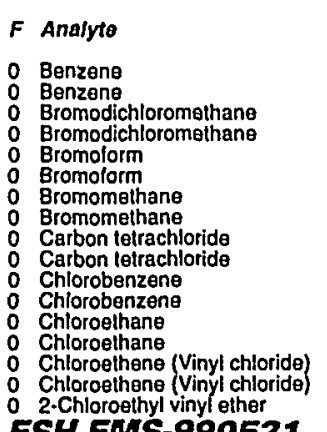

Rosult

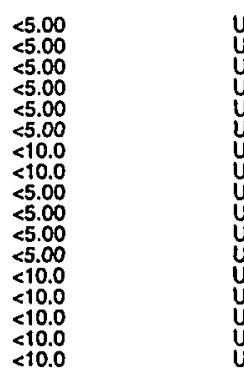

ESH-EMS-990521
Time: $11: 50$

Air temperalure: $257^{\circ} \mathrm{C}$

Total alkalinity (as CaCo3): $14 \mathrm{mg} /$

Field
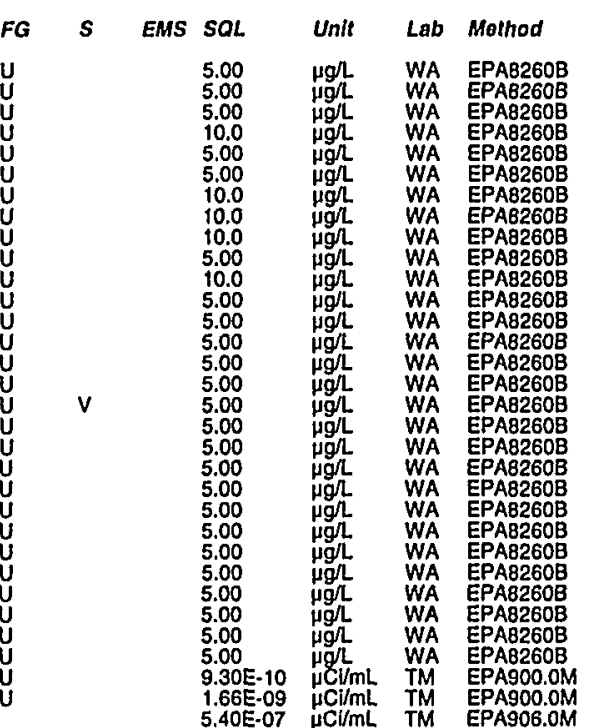

5.40.07 $\mu \mathrm{CIML}$ TM EPA900.0M

Time: 8:56

Air temperalure: $24.3^{\circ} \mathrm{C} \mathrm{C}$

otal alkalinity (as CaCO3): $18 \mathrm{mg} / \mathrm{L}$

henolphthalein alkalinity: $0 \mathrm{mgh}$
Well BGO $39 \mathrm{C}$ collocled on 06/14/99 (cont.)

Rosult

2.Chloroethyl vinyl ether

$<10.0$
$<5.00$
$<5.00$

Chloromethan

O Dibromochloromethane

1,1.Dlchloroethane

1.2.Dichloroolhane

1.i.Dichloroethylene

o lrans-1,2-Dichloroethylene

Dichloromethane

o 1,2 -Dichloropropane

cis-1,3-Dichloropropen

0
0
0
trans $-1,3 \cdot$-Dichloropropene

0

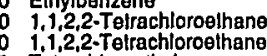

T Tetrachlorosthylene

0 Teirachloroethylene

0 Toluene

1,1,-Trichloroethan

1.1.2-Trichloroothan

Trichlorofluorometh

Trichlorofluoromelhane

Xylenes

0 Gross alpha

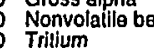

WELL BGO 39D

MEASUAEMENTS CONDUCTED IN THE FIELD

Sample date: 04/14/99
Depth to waler: $60.3 \mathrm{Ht}(18.38 \mathrm{~m})$ below TOC
Water elevation: $235.4 \mathrm{Ht}(71.75 \mathrm{~m}) \mathrm{ms}$

pH: 4.4

Sp. conductance: $33 \mu \mathrm{S} / \mathrm{cm}$

Water evacuated from the well prior to sampling: 3 gal ANALYSES

$F$ Analyto

0
0 Benzene
0

O Bromolichlor

O Carbon telrachiorid

Chlorobenzen

Chloroethene (Vinyl chlorida)

2.Chloroethyl vinylether

Coloromethane

Dibromochloromethan

1.i.-Dichloroethane

1,1-Dichloroethylene
0 trans $1,2-$ Dichloroethylene

$B-44$

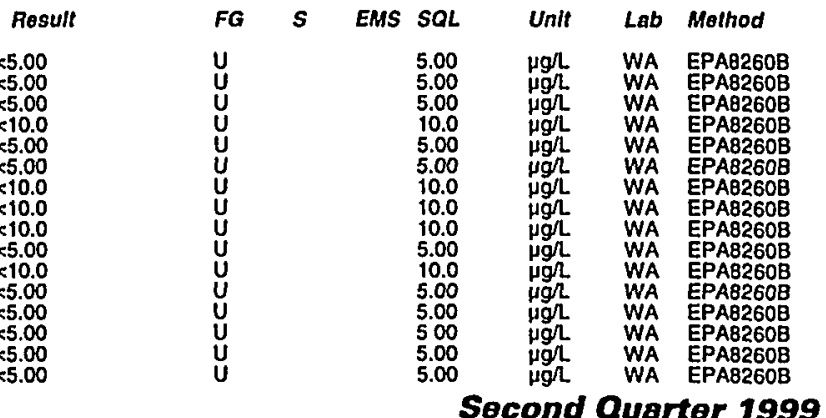

Time: 10:30

perature: $22^{\circ} \mathrm{C}$

otal alkalinity (as CaCO3): $0 \mathrm{mg} /$

Phenolphinalein alkalinity: $0 \mathrm{mg}$ L

Second Quarter 1999 
Well BGO 49D collected on 04/13/99 (conl.)

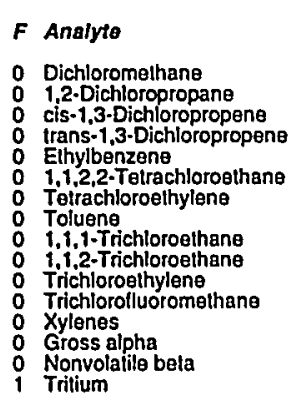

Result

55.00
5.00
55.00
5.00
55.00
55.00
5.00
55.00
5.00
55.00
55.00
5.00
55.00
$1.60 \mathrm{E}-09 \pm 6.60 \mathrm{E}-10$
$2.08 \mathrm{E}-09 \pm 1.00 \mathrm{E}-09$

\section{WELL BGO 49D}

MEASUREMENTS CONDUCTED IN THE FIELD

Sample date: 05/17/99
Deppth to wa: 0r: Not available
Water elevation: Not available
pH: 5.2

pH: 5.2 conductance: $26 \mu \mathrm{S} / \mathrm{cm}$

Turbidity: $6 \mathrm{NTU}$
Water evacuated irom the well prior to sampling: 2 gal

ANALYSES

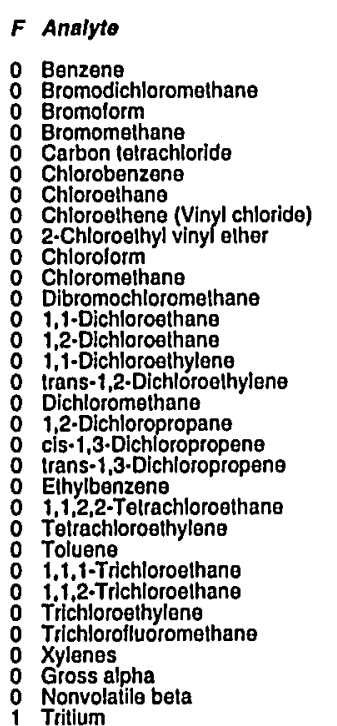

\begin{tabular}{|c|c|c|c|c|c|c|c|}
\hline Rosult & $F G$ & 5 & MS & SQL & Unit & Lab & Method \\
\hline . & 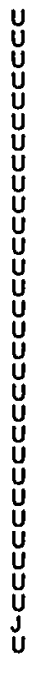 & v & & $\begin{array}{l}5.00 \\
5.00 \\
10.0 \\
5.00 \\
5.00 \\
10.0 \\
10.0 \\
10.0 \\
5.00 \\
10.0 \\
5.00 \\
5.00 \\
5.00 \\
5.00 \\
5.00 \\
5.00 \\
5.00 \\
5.00 \\
5.00 \\
5.00 \\
5.00 \\
5.00 \\
5.00 \\
5.00 \\
5.00 \\
5.00 \\
5.00 \\
5.00 \\
8.90 E-10 \\
1.64 \mathrm{E}-09 \\
5.50 \mathrm{E} \cdot 07\end{array}$ & 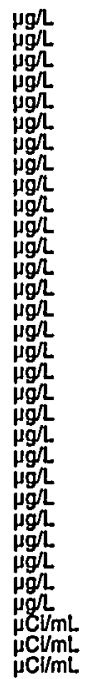 & $\begin{array}{l}\text { WA } \\
\text { WA } \\
\text { WA } \\
\text { WA } \\
\text { WA } \\
\text { WA } \\
\text { WA } \\
\text { WA } \\
\text { WA } \\
\text { WA } \\
\text { WA } \\
\text { WA } \\
\text { WA } \\
\text { WA } \\
\text { WA } \\
\text { WA } \\
\text { WA } \\
\text { WA } \\
\text { WA } \\
\text { WA } \\
\text { WA } \\
\text { WA } \\
\text { WA } \\
\text { WA } \\
\text { WA } \\
\text { WA } \\
\text { WA } \\
\text { WA } \\
\text { IM } \\
\text { TM } \\
\text { TM }\end{array}$ & 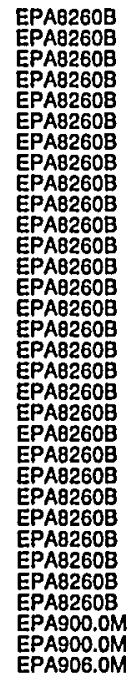 \\
\hline
\end{tabular}

ESH-EMS-990521

WELL BGO 49D

MEASUREMENTS CONDUCTED IN THE FIELD

Sample date: 06/14/99

(n) Nol available

H: 4.6 . Water evacuated from the well prior to sampling: $1 \mathrm{gal}$
The well went dry during purging. ANALYSES

$F$ Analyte

B Benzene

Bromoform

Bromomethane
Carbon letrachlorid
Chlorobenzene

Chloroothane

Chlorolithene (Vinyl chloride)

Chloroform

Chloromethane
Dibromochloromethane

1.1. Dichloroethane

1,i. Dichloroethylene
trans $-1,2 \cdot$ Dichloroethylen

Irans.1,2.0ichloroel
Dichloromethane
1. Dichloropopopan

$\begin{array}{ll}0 & 1,2 \cdot \text { Dichloropropane } \\ 0 & \mathrm{cis} \cdot 1,3 \cdot \text { Dichloropropene }\end{array}$

itrans-1,3-Dichloropropene

1,1,2,2-Tetrachloroethan

Toluene

o $1,1,1$-Trichloroethane

Trichloroofluoromethane

Gylenes

1 Tritlum

\section{WELL BGO 51B}

MEASUREMENTS CONDUCTED IN THE FIELD

Sample date: $04 / 14 / 99$ (18.01 $\mathrm{m}$ ) below TOC

$\mathrm{gH}$. 8 conductance: $200 \mu \mathrm{S} / \mathrm{cm}$

Water evacuated from the well prior to sampling: $50 \mathrm{gal}$ ANALYSES

\section{$F$ Analyto}

0 Benzene

Bromolorm

0 Carbon tetrachlorido

Chlorobenzene

Chloroelthene (Vinyl chloride)

2-Chloroethyl viny

o Chlorolorm

Dibromochloromethane

1.1.Dichloroethane

i,1.Dichloroeothylene
trans-1.2.Dichloroethylen

$B-47$
Resuit

$<5.00$

$<10.0$

$<10.0$

$<10.0$

$<5.00$
$<5.00$
$<5.00$

$\$ 5.00$
$<1.4$
5.00
55.00
5.00

$<5.00$

55.00
5.00
55.00
5.00

$<5.00$
$<5.00$
$<5.00$

1.39E-09+7.10E-10

$8.20 E-10 \pm 9.60 E-10$
$1.75 E-05+9.40 E-07$
Time: 10:08

(1) $21.8^{\circ} \mathrm{C}$

Total alkalinity (as CaCO3): $1 \mathrm{mg}$

Field Oualifier(s): $S x$ 
Well BGO 51 B collected on 04/14/99 (cont.)

\begin{tabular}{|c|c|c|c|c|c|c|c|c|}
\hline Analyto & Result & $F G$ & $s$ & EMS & $S Q L$ & Unit & Lab & Method \\
\hline 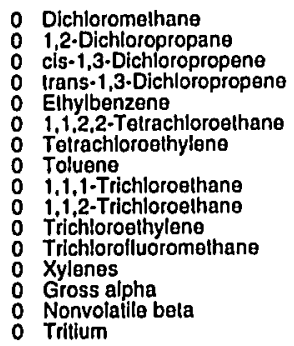 & $\begin{array}{l}<5.00 \\
<5.00 \\
<5.00 \\
<5.00 \\
<5.00 \\
<5.00 \\
<5.00 \\
<5.00 \\
<5.00 \\
<5.00 \\
<5.00 \\
<5.00 \\
<5.00 \\
9.70 E-10 \pm 8.70 E-10 \\
9.40 E-10 \pm 8.30-10 \\
3.00 E-08 \pm 3.40 E-07\end{array}$ & 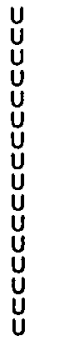 & & & $\begin{array}{l}5.00 \\
5.00 \\
5.00 \\
5.00 \\
5.00 \\
5.00 \\
5.00 \\
5.00 \\
5.00 \\
5.00 \\
5.00 \\
5.00 \\
5.00 \\
1.39 E .09 \\
1.37 E .09 \\
6.10 E \cdot 07\end{array}$ & 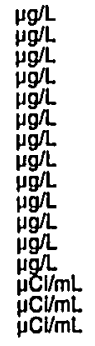 & $\begin{array}{l}\text { WA } \\
\text { WA } \\
\text { WA } \\
\text { WA } \\
\text { WA } \\
\text { WA } \\
\text { WA } \\
\text { WA } \\
\text { WA } \\
\text { WA } \\
\text { WA } \\
\text { WA } \\
\text { IM } \\
\text { TM } \\
\text { TM }\end{array}$ & 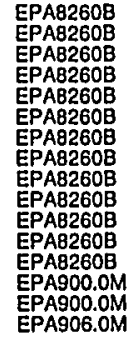 \\
\hline
\end{tabular}

\section{WELL BGO 51B}

MEASUREMENTS CONDUCTED IN THE FIELD

\section{Sample date: 05/18/99 \\ Water \\ Sp: 8.3 . conductance: $199 \mu \mathrm{S} / \mathrm{cm}$}

Water evacuated from the well prior to sampling: 41 gal ANALYSES

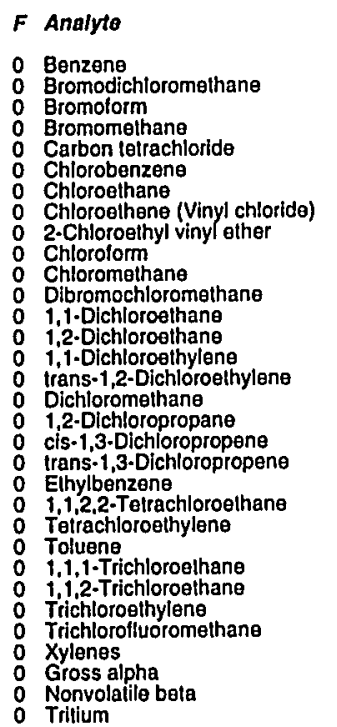

\begin{tabular}{|c|c|c|c|c|c|c|c|}
\hline sult & $F G$ & $s$ & EMS & SOL & Unit & Lab & Mothod \\
\hline $\begin{array}{l}<5.00 \\
<5.00 \\
<5.00 \\
<10.0 \\
<5.00 \\
<5.00 \\
<10.0 \\
<10.0 \\
<10.0 \\
<5.00 \\
<10.0 \\
<5.00 \\
<5.00 \\
55.00 \\
<5.00 \\
<5.00 \\
<5.45 \\
<5.00 \\
<5.00 \\
<5.00 \\
<5.00 \\
<5.00 \\
<5.00 \\
<5.00 \\
<5.00 \\
<5.00 \\
<5.00 \\
<5.00 \\
<5.00 \\
2.09 E-09+18.60 E-10 \\
3.40 E-10+1.05-09 \\
4.90-07+0.00\end{array}$ & 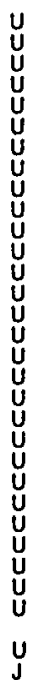 & $v$ & & $\begin{array}{l}5.00 \\
5.00 \\
5.00 \\
10.0 \\
5.00 \\
5.00 \\
10.0 \\
10.0 \\
10.0 \\
5.00 \\
10.0 \\
5.00 \\
5.00 \\
5.00 \\
5.00 \\
5.00 \\
5.00 \\
5.00 \\
5.00 \\
5.00 \\
5.00 \\
5.00 \\
5.00 \\
5.00 \\
5.00 \\
5.00 \\
5.00 \\
5.00 \\
2.70 E-10 \\
2.70 E-10 \\
.900-07\end{array}$ & 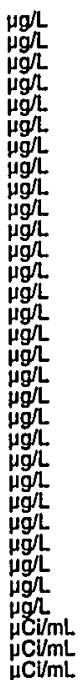 & $\begin{array}{l}\text { WA } \\
\text { WA } \\
\text { WA } \\
\text { WA } \\
\text { WA } \\
\text { WA } \\
\text { WA } \\
\text { WA } \\
\text { WA } \\
\text { WA } \\
\text { WA } \\
\text { WA } \\
\text { WA } \\
\text { WA } \\
\text { WA } \\
\text { WA } \\
\text { WA } \\
\text { WA } \\
\text { WA } \\
\text { WA } \\
\text { WA } \\
\text { WA } \\
\text { WA } \\
\text { WA } \\
\text { WA } \\
\text { WA } \\
\text { WA } \\
\text { WA } \\
\text { WA } \\
\text { WM } \\
\text { TM } \\
\text { TM }\end{array}$ & 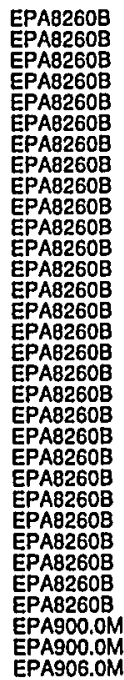 \\
\hline
\end{tabular}

Time: 12:42

Tin $213^{\circ} \mathrm{C}$ Tolal alkalinity (as CaCO3): $92 \mathrm{mg} /$ Phenolphihalein alkalinity: $0 \mathrm{mg} / \mathrm{L}$

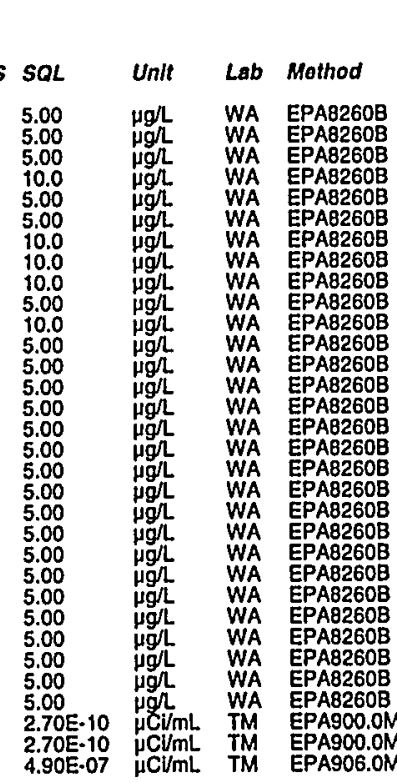

\section{WELL BGO 51B}

MEASUREMENTS CONDUCTED IN THE FIELD

Sample date: $06 / 14 / 99$
Depth lo waler: 59.1 ft $(18.01 \mathrm{~m})$ below TOC

Water

Sp. conductance: $190 \mu \mathrm{S} / \mathrm{cm}$

Thater evacuated from the well prior to sampling: 45 gal ANALYSES

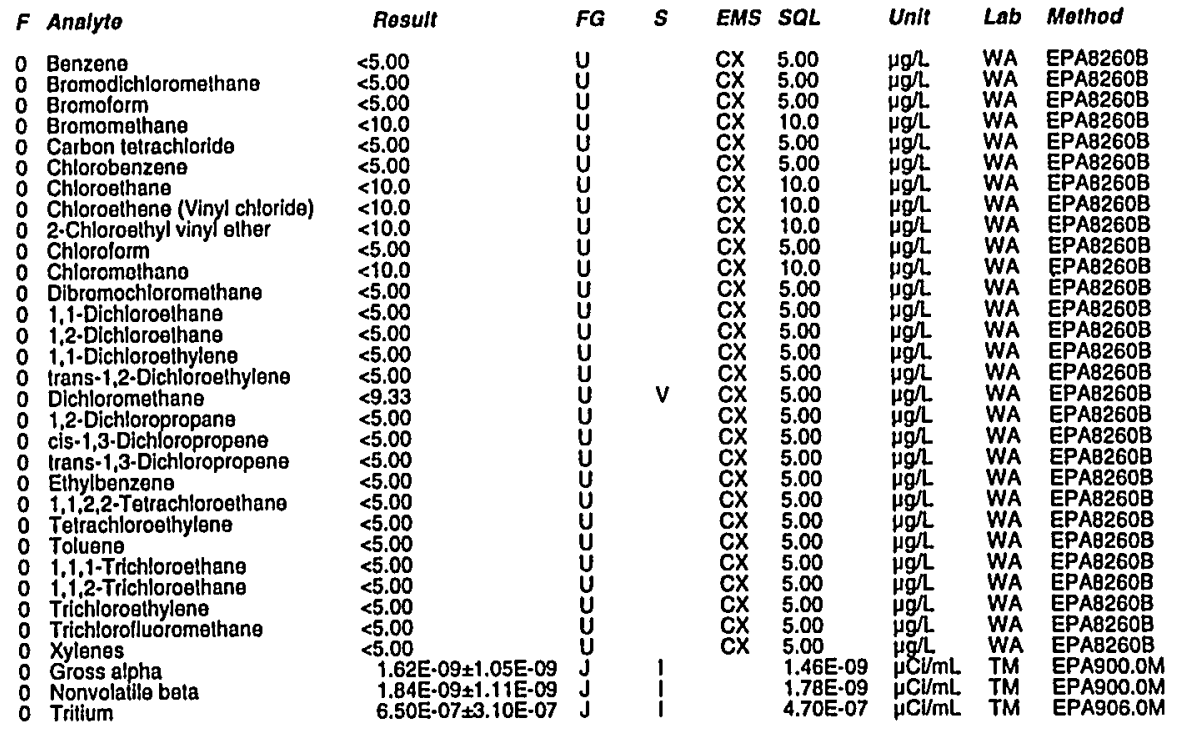

\section{WELL BGO 51C}

MEASUREMENTS CONDUCTED IN THE FIELD

Sample date: 04/14/99

Water elevation: $230.89 \mathrm{~h}(70.38 \mathrm{~m}) \mathrm{ms}$

SH: 4.9 .

Water evacualed from the well prior to sampling: $\mathbf{4 7} \mathrm{gal}$

ANALYSES

F Analyte

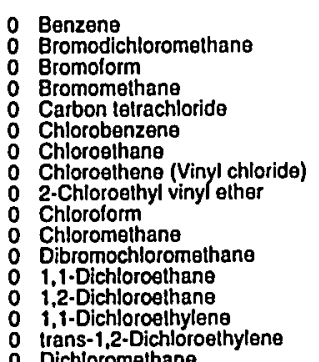

Res
$<5.00$
$<5.00$
$<5.00$
$<10.0$
$<5.00$
$<5.00$
$<10.0$
$<10.0$
$<10.0$
$<5.00$
$<10.0$
$<5.00$
$<5.00$
$<5.00$
$<5.00$
$<5.00$
$<5.00$

$<5.00$
$<5.00$
$<5.00$
$<10.0$
$<5.00$
$<5.00$
$<1.0$
$<10.0$
$<10.0$
$<5.00$
$<10.0$
$<5.00$
$<5.00$
$<5.00$
$<5.00$
$<5.00$
$<5.00$

Time: 9:33

Air temperalure: $23^{\circ} \mathrm{C}$

Total alkalinity (as CaCO3): $87 \mathrm{mg}$

Phenolphinalein alkalinity: $0 \mathrm{mg} /$

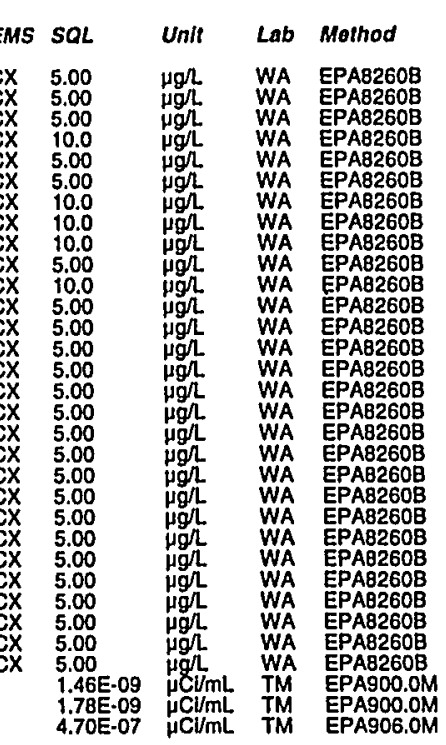

Time: 9:29

erature: $19.9^{\circ} \mathrm{C}$

Total alkalinity (as Cacos): $0 \mathrm{mg} / \mathrm{l}$

Phenolphthalein alkalinity: $0 \mathrm{mg} /$

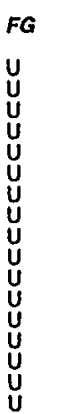

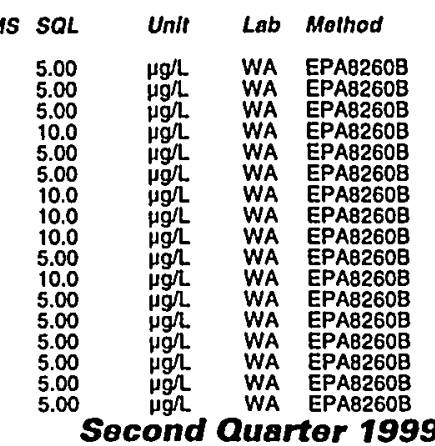


Well 8GO 51C collected on 04/14/99 (cont.)

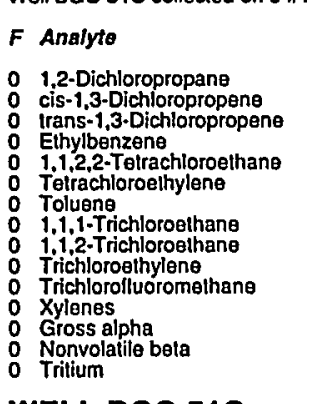

Result

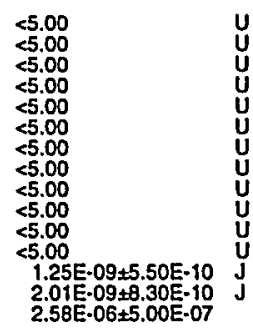

WELL BGO 51C

MEASUREMENTS CONDUCTED IN THE FIELD

Sample date: 05/18/99
Oepth to water: $59.3 \mathrm{ft}(18.07 \mathrm{~m})$ below TOC
Waler elevation: $229.8 \mathrm{ft}(70.04 \mathrm{~m}) \mathrm{ms}$

pH: 5

Sp. conductance: $20 \mu \mathrm{S} / \mathrm{cm}$

Water evacuated from the well prior to sampling: 34 gal ANALYSES

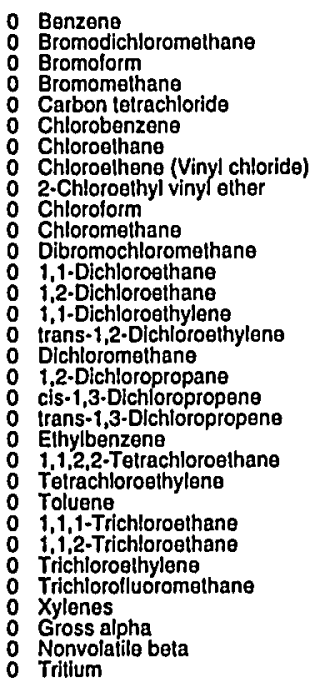

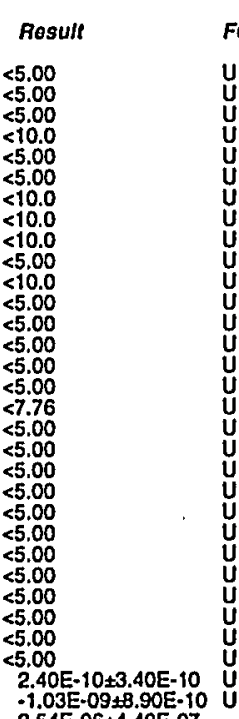

Nonvolatile beta

$2.54 \mathrm{E}-05 \pm 3.40 \mathrm{E}-10$

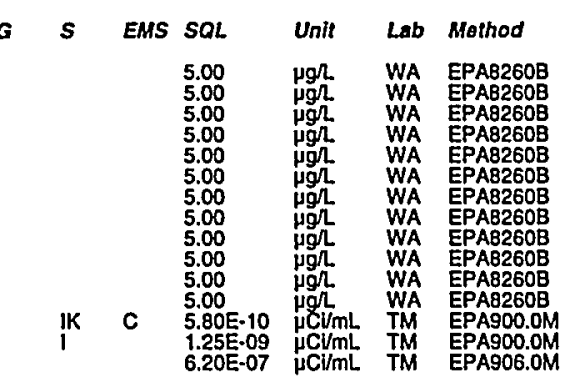

Time: 12:18

Water lemperature: $21.3^{\circ} \mathrm{C}$ Air temperalure: $30^{\circ} \mathrm{C}$. Phenoiphinalein alkalinity: $0 \mathrm{mg} \Omega$

\begin{tabular}{|c|c|c|c|c|c|}
\hline$s$ & EMS & SQL & Unit & Lab & Mothod \\
\hline v & & $\begin{array}{l}5.00 \\
5.00 \\
5.00 \\
10.0 \\
5.00 \\
5.00 \\
10.0 \\
10.0 \\
10.0 \\
5.00 \\
10.0 \\
5.00 \\
5.00 \\
5.00 \\
5.00 \\
5.00 \\
5.00 \\
5.00 \\
5.00 \\
5.00 \\
5.00 \\
5.00 \\
5.00 \\
5.00 \\
5.00 \\
5.00 \\
5.00 \\
2.00 E-10 \\
2.60 E \\
5.10 .07\end{array}$ & 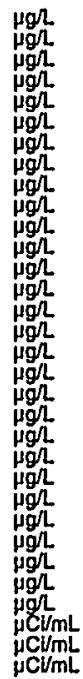 & $\begin{array}{l}\text { WA } \\
\text { WA } \\
\text { WA } \\
\text { WA } \\
\text { WA } \\
\text { WA } \\
\text { WA } \\
\text { WA } \\
\text { WA } \\
\text { WA } \\
\text { WA } \\
\text { WA } \\
\text { WA } \\
\text { WA } \\
\text { WA } \\
\text { WA } \\
\text { WA } \\
\text { WA } \\
\text { WA } \\
\text { WA } \\
\text { WA } \\
\text { WA } \\
\text { WA } \\
\text { WA } \\
\text { WA } \\
\text { WA } \\
\text { WA } \\
\text { WA } \\
\text { TM } \\
\text { TM } \\
\text { TM }\end{array}$ & 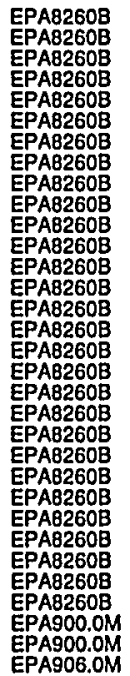 \\
\hline
\end{tabular}

ESH-EMS-990521

WELL BGO 51C

MEASUREMENTS CONDUCTED IN THE FIELD

Sample dale: 06/14/99

Water elevation: $230.89 \mathrm{ft}(70.38 \mathrm{~m}) \mathrm{msi}$

Hp. conductance: $21 \mu \mathrm{S} / \mathrm{cm}$

Water evacuated from the well prior to sampling: $26 \mathrm{gal}$ ANALYSES

$F$ Analyte

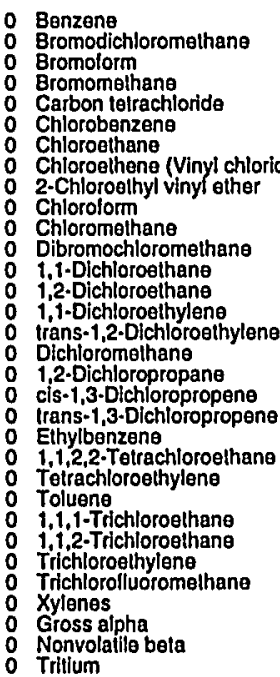

WELL BGO 51D

MEASUREMENTS CONDUCTED IN THE FIELD

Sample date: 04/14/99

Depth to waler: $54.54 \mathrm{ft}(16.62 \mathrm{~m})$ below TOC

$\mathrm{pH}: 4.8$

Sp. conductance: $32 \mu \mathrm{S} / \mathrm{cm}$

Turbidity: 2 NTU
Result

$<5.00$
$\$ 5.00$
$\$ 5.00$
$<10.0$

$<10.0$
55.00
$<5.00$
$<10.0$

$<10.0$
$<10.0$
$<10.0$

$<5.00$

$<5.00$
$<5.00$
$<5.00$
$<5.00$

$<5.00$

$<1.00$
$<5.00$
$<5.00$
$<5$

5.00
5.00
55.00

$<5.00$
$<5.00$
$<5.00$

$<5.00$
45.00

$\$ 5.00$

3.00
$3.90 E-10 \pm 5.20 E-10$
$1.75 E-09 \pm 1.01 E-09$
$2.81 E-06 \pm 4.50 E-07$

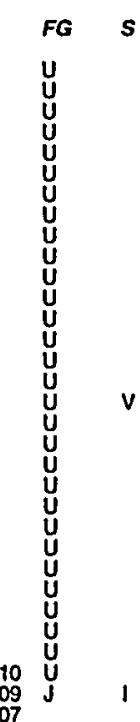

ANALYSES

$F$ Analyto

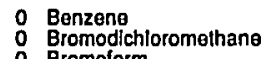

0 Bromoform

Carbon tetrachloride

Chlorobenzene

Chlorosthene (Vinyl chloride)

2.Chloroeshyl vinyl ether

Chloromethane

Dibromochloromethane

1.,. Dichloroethane

1,1-Dichloroethylene
trans-1,2-Dichloroethylo

$B-49$

Result
$<5.00$
55.00
55.00
$<10.0$
$<5.00$
5.00
510.0
$<10.0$
$<10.0$
55.00
$<10.0$
$<5.00$
5.00
55.00
55.00
$<5.00$

Time: 8:42

$22.8^{\circ} \mathrm{C}$

Total alkalinity (as CaCo3): $0 \mathrm{mgl}$

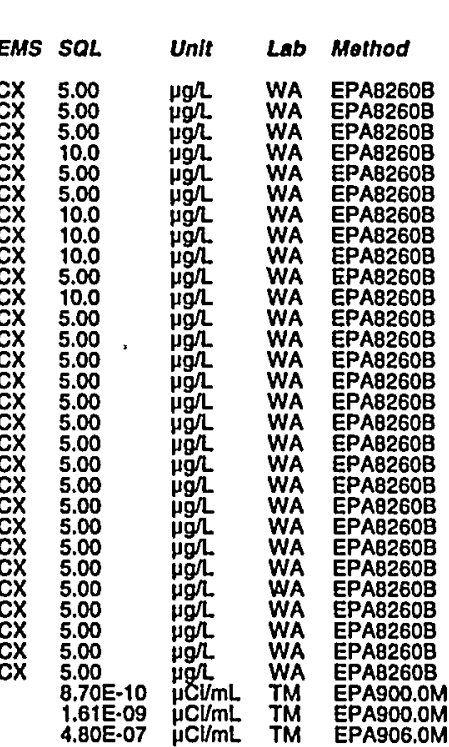

Time: 9:50

Water temperalure: $19.9^{\circ} \mathrm{C}$

Total alkalinity (as CaCO3): $0 \mathrm{mg} /$

Phenolphthalein alkalinity: $0 \mathrm{mgh}$
Field Qualifier(s): $V X$

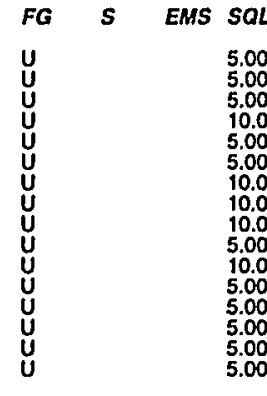

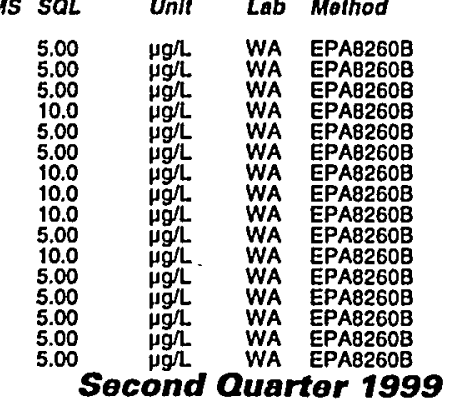


Well $8 G O 510$ collected on 04/14/99 (cont.)

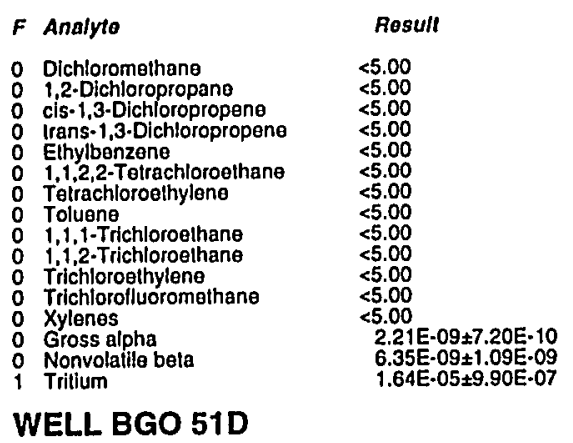

WELL BGO 51D

MEASUREMENTS CONDUCTED IN THE FIELD

Sample date: 05/18/9 Depth to water: $54.86 \mathrm{Ht}(16.72 \mathrm{~m})$ below TOC Water el

Sp. conductance: $31 \mu \mathrm{S} / \mathrm{cm}$

Water evacuated trom the well prior to sampling: 1 gal The well went dry during purging.

ANALYSES

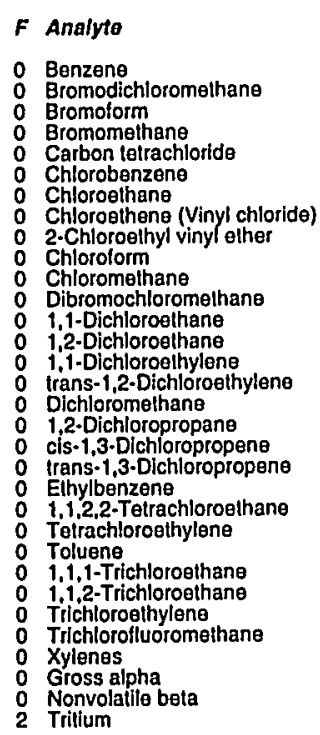

\begin{tabular}{|c|c|c|c|c|c|c|c|}
\hline tesult & $\mathbf{F G}$ & $\boldsymbol{s}$ & EMS & SQL & Unit & L.ab & Mothod \\
\hline $\begin{array}{l}<5.00 \\
<5.00 \\
<10.0 \\
<5.00 \\
<5.00 \\
<10.0 \\
<10.0 \\
<10.0 \\
55.00 \\
<10.0 \\
<5.00 \\
<5.00 \\
55.00 \\
<5.00 \\
55.00 \\
<7.27 \\
<5.00 \\
55.00 \\
<5.00 \\
55.00 \\
<5.00 \\
<5.00 \\
<5.00 \\
55.00 \\
55.00 \\
55.00 \\
<5.00 \\
<5.00 \\
8.30 E-1\end{array}$ & 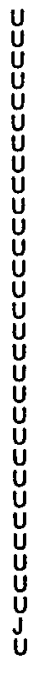 & v & & $\begin{array}{l}5.00 \\
10.0 \\
5.00 \\
5.00 \\
10.0 \\
10.0 \\
10.0 \\
5.00 \\
10.0 \\
5.00 \\
5.00 \\
5.00 \\
5.00 \\
5.00 \\
5.00 \\
5.00 \\
5.00 \\
5.00 \\
5.00 \\
5.00 \\
5.00 \\
5.00 \\
5.00 \\
5.00 \\
5.00 \\
5.00 \\
5.00 \\
2.00 E-10 \\
.60 \mathrm{~F}\end{array}$ & 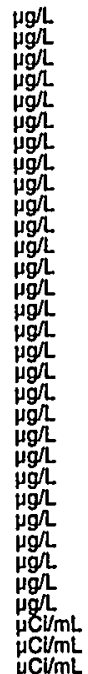 & $\begin{array}{l}\text { WA } \\
\text { WA } \\
\text { WA } \\
\text { WA } \\
\text { WA } \\
\text { WA } \\
\text { WA } \\
\text { WA } \\
\text { WA } \\
\text { WA } \\
\text { WA } \\
\text { WA } \\
\text { WA } \\
\text { WA } \\
\text { WA } \\
\text { WA } \\
\text { WA } \\
\text { WA } \\
\text { WA } \\
\text { WA } \\
\text { WA } \\
\text { WA } \\
\text { WA } \\
\text { WA } \\
\text { WA } \\
\text { WA } \\
\text { WA } \\
\text { IM } \\
\text { TM } \\
T M\end{array}$ & 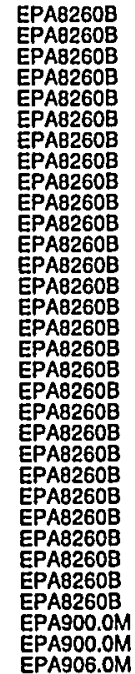 \\
\hline
\end{tabular}

ESH-EMS-990521

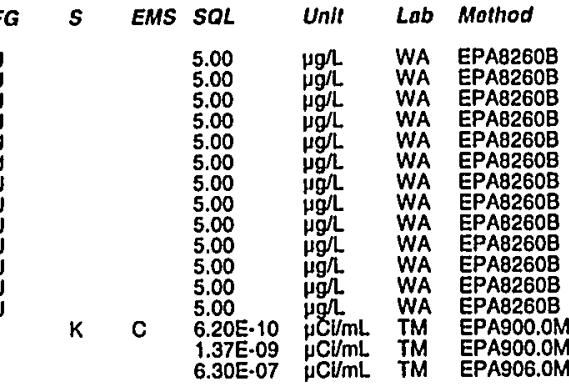

Time: $12: 55$

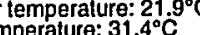

Total alkalinity (as CaCO3): $0 \mathrm{mg} /$

Phenolphthalein alkalinity: $0 \mathrm{mg} /$
Field Qualifier(s): $\mathrm{VX}$

2 Tritium

\section{WELL BGO 51D}

MEASUREMENTS CONDUCTED IN THE FIELD

Sample date: $06 / 14 / 99$ (16.75 m) below TOC

Waler elevation: 234.35 li $(71.43 \mathrm{~m}) \mathrm{ms}$

pH: 5.1

p. conductance: $29 \mu \mathrm{S} / \mathrm{cm}$

Water evacualed from the well prior to sampling: $1 \mathrm{ga}$ the well went dry during purging.

ANALYSES

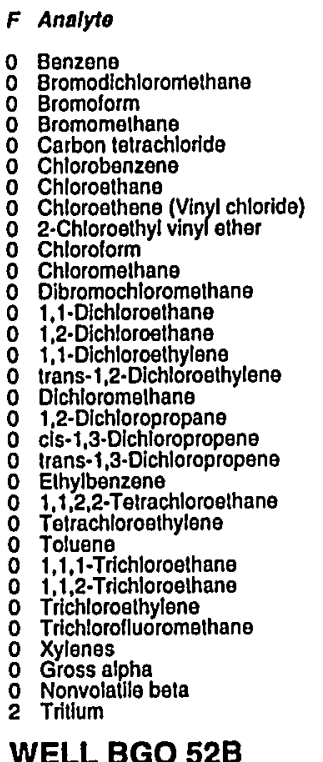

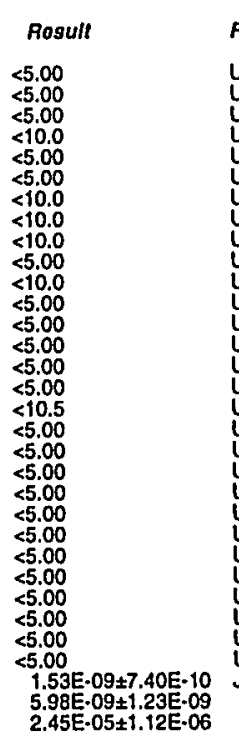

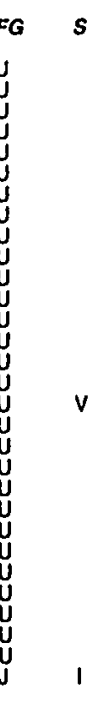

MEASUREMENTS CONDUCTED IN THE FIELD

Sample date: $04 / 14 / 99$

Water elova

p. conductance: $83 \mu \mathrm{S} / \mathrm{cm}$

Water evacuated from the well prior to sampling: $42 \mathrm{gal}$

ANALYSES

$F$ Analyto

Benzene
Bromodichloromethane

Bromoform

Carbon tetrachloride

Chlorobenzene

Chloroethane
Chloroethene (Vinyl chloride)
2.Chloroethyl vinyl ether

Chloroform

Chiloromethane
Dibromochloromethane

$1,1 \cdot$ Dichloroethane
$1,2$. Dichloroethane

1.

$B-50$
Time: 9:45 Air temperature: $26.2^{\circ} \mathrm{C}$. Phenolphthalein alkalinity: $0 \mathrm{mg} /$

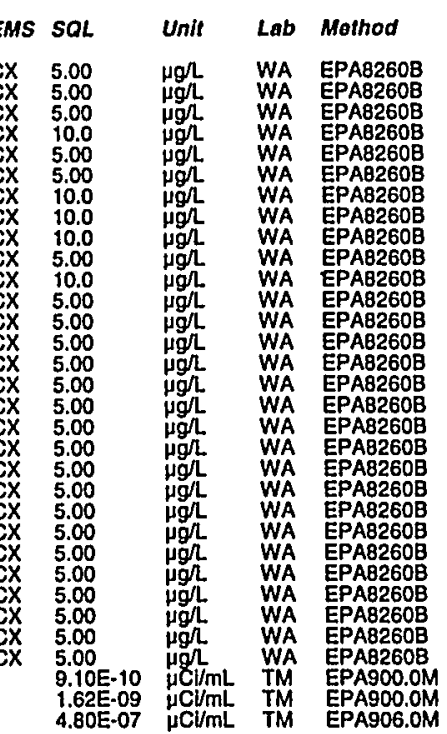

Time: 11:23

Waier temperature: $20.5^{\circ} \mathrm{C}$

Total alkalinity (as CaCO3): $38 \mathrm{mg} /$

Phenolphthalein alkalinity: $0 \mathrm{mg} / \mathrm{L}$
Field Quallier(s): $\mathrm{VH}$

Feld Qualifier(s):

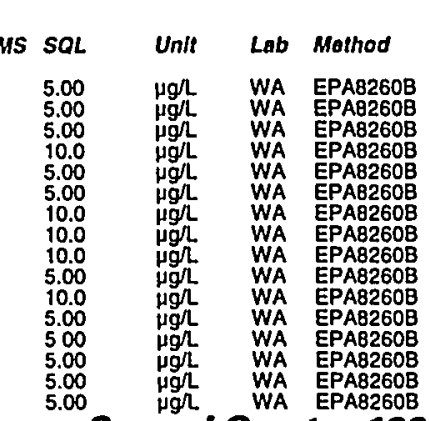


Well BGO 52B collected on 04/14/99 (cont.)

\section{F Analyte}

Result

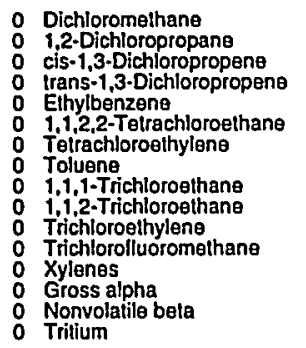

$<5.00$
$<5.00$
$<5.00$
$<5.00$
$<5.00$
$<5.00$
$<5.00$
$<5.00$
$<5.00$
$<5.00$
$<5.00$
$<5.00$
$<5.00$
$3.70 E-10 \pm 4.50 E-10$
$7.22 E .09 \pm 1.09=09$
$1.37 E .06 \pm 4.06=.07$

FG

\section{WELL BGO 52B}

MEASUREMENTS CONDUCTED IN THE FIELD

Sample date: 05/19/99
Depth to water: $57.43 \mathrm{H}(17.5 \mathrm{~m})$ below TOC
Water elevation: $226.97 \mathrm{ft}(69.18 \mathrm{~m}) \mathrm{msl}$
ph: 7.7

$\mathrm{pH}: 7.7$ conductance: $78 \mu \mathrm{S} / \mathrm{cm}$

Turbidity: ONTU
Waler evacuated from the well prior to sampling: $52 \mathrm{gat}$ ANALYSES

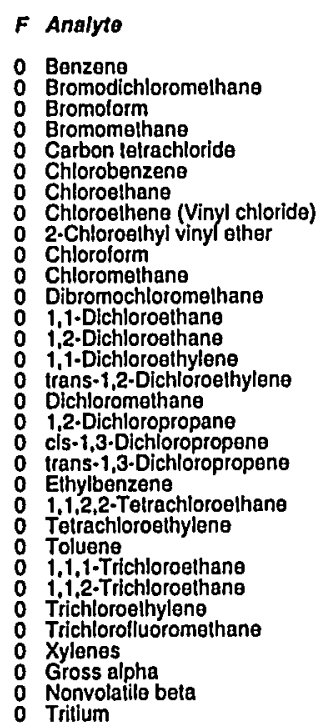

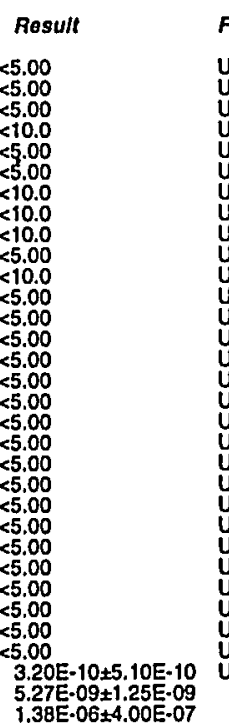

FG

Air temperature: $29.2^{\circ} \mathrm{C} \mathrm{C}$

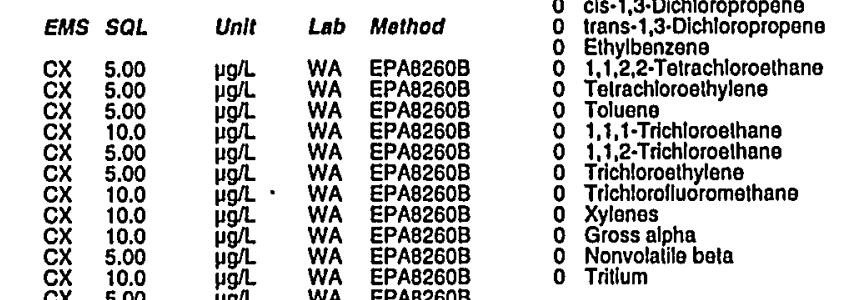

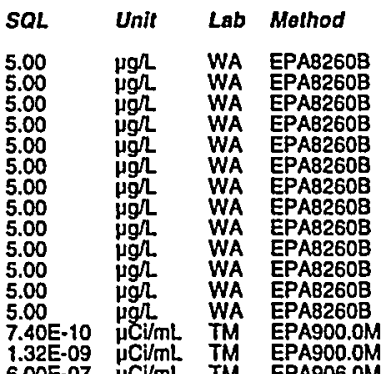

Time: 11:55

Total alkalinity (as CaCO3): $28 \mathrm{mg} /$

Field Qualifier(s): $V$

WELL BGO 52C

MEASUREMENTS CONDUCTED IN THE FIELD

Sample date: 04/14/99

Water elevation: $229.24 \mathrm{H} / 69.8$
$\mathrm{pH}: 5$
$\mathrm{Sp}$. conductance: $21 \mu \mathrm{S} / \mathrm{cm}$

Wuiblerily: 0 NTU evacuated from the well prior to sampling: $29 \mathrm{gal}$ ANALYSES

WELL BGO 52B

P. conductance: $85 \mu \mathrm{S} / \mathrm{cm}$

Water evacualed from the well prior to sampling: $\mathbf{4 2} \mathrm{gal}$

Benzene

Bromomethane

Chlorobenzene

Chloroethene (Vinyl chlorlde)

2-Chioroethy

Dibromochloromethan

1,2-Dichloroethane

,1.Dichloroethylene
rans $-1,2 \cdot$-Dichloroethyle

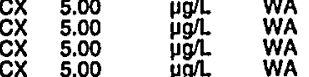

$\begin{array}{ll}C X & 5.0 \\ C X & 5.00 \\ C X & 5.00 \\ C X & 5.00 \\ C X & 5.00 \\ C X & 5.0 \\ C X & 5.00 \\ C X & 5.0 \\ C X & 5.00 \\ C X & 5.00 \\ C X & 5.00 \\ C X & 5.00\end{array}$

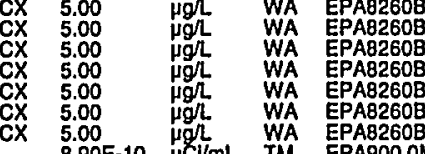

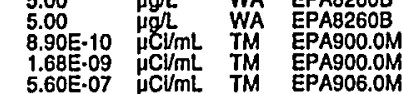

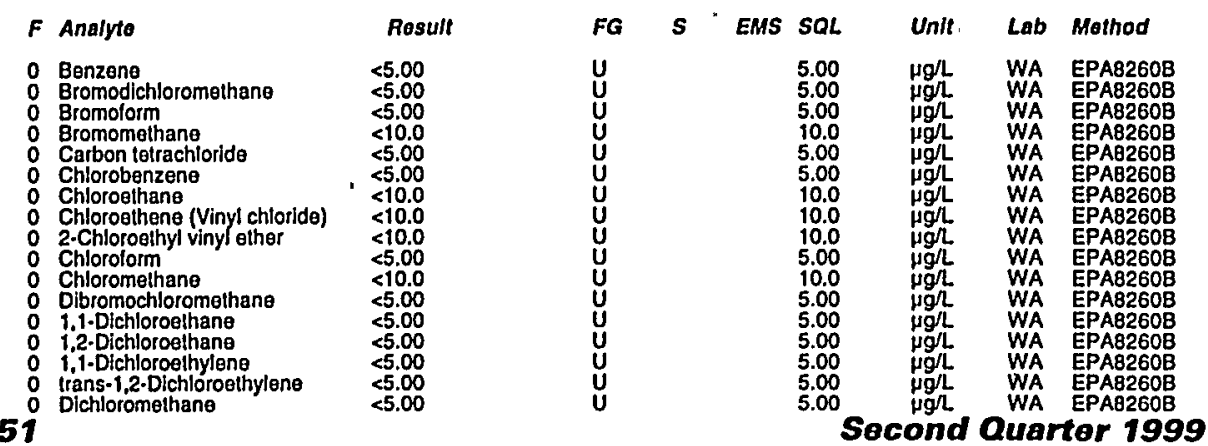

Time: $11: 36$ Air temperature: $30.10 \mathrm{C}$ ): $33 \mathrm{mg}$ Phenolphthalein alkalinity: $0 \mathrm{mg} /$

\begin{tabular}{|c|c|c|c|}
\hline & Unit & Lab & Mothod \\
\hline $\begin{array}{l}5.00 \\
5.00 \\
5.00 \\
10.0 \\
5.00 \\
5.00 \\
10.0 \\
10.0 \\
10.0 \\
5.00 \\
10.0 \\
5.00 \\
5.00 \\
5.00 \\
5.00 \\
5.00 \\
5.00 \\
5.00 \\
5.00 \\
5.00 \\
5.00 \\
5.00 \\
5.00 \\
5.00 \\
5.00 \\
5.00 \\
5.00 \\
5.00 \\
1.00 \mathrm{E}-09 \\
1.66-09 \\
4.80 \mathrm{E}-07\end{array}$ & 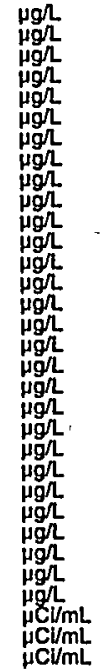 & $\begin{array}{l}\text { WA } \\
\text { WA } \\
\text { WA } \\
\text { WA } \\
\text { WA } \\
\text { WA } \\
\text { WA } \\
\text { WA } \\
\text { WA } \\
\text { WA } \\
\text { WA } \\
\text { WA } \\
\text { WA } \\
\text { WA } \\
\text { WA } \\
\text { WA } \\
\text { WA } \\
\text { WA } \\
\text { WA } \\
\text { WA } \\
\text { WA } \\
\text { WA } \\
\text { WA } \\
\text { WA } \\
\text { WA } \\
\text { WA } \\
\text { WA } \\
\text { WA } \\
\text { WA } \\
\text { WM } \\
\text { TM } \\
\text { TM }\end{array}$ & 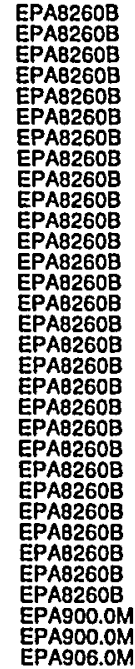 \\
\hline
\end{tabular}

Time: 11:12

Wir $20.1^{\circ} \mathrm{C}$ Tolal alkalinity (as CaCO3): $1 \mathrm{mg} /$ Field Qualfier(s):

Socond Quartor 1999 
Well BGO $52 \mathrm{C}$ collecled on 04/14/99 (cont.)

\section{$F$ Analyto}

Result
$<5.00$
$<5.00$
$<5.00$
$<5.00$
$<5.00$
$<5.00$
$<5.00$
$<5.00$
$<5.00$
$<5.00$
$<5.00$
$<5.00$
$2.01 E-09 \pm 8.60 \mathrm{E}-10$
$1.57 \mathrm{E}-09 \pm 8.50 \mathrm{E}-10$
$1.30 \mathrm{E}-07 \pm 3.50 \mathrm{E}-07$

Gross alpha
0 Nonvolatile beta
Tritivm

$F G$
$U$
$U$
$U$
$U$
$U$
$U$
$U$
$U$
$U$
$U$
$J$
$J$
$J$

WELL BGO $52 C$

MEASUREMENTS CONDUCTED IN THE FIELD

Sample date: 05/19/99

Water elevation: $228.25 \mathrm{ft}(69.57 \mathrm{~m}) \mathrm{ms}$

$\mathrm{gH}: 5.2$. conductance: $20 \mu \mathrm{S} / \mathrm{cm}$

Water evacuated from the well prior to sampling: $\mathbf{3 1} \mathrm{ga}$

ANALYSES

F Analyte

0 Benzene

Bromolorm

Bromomethane

Chlorobenzene

Chloroethene (Vinyl chlorida)

2.Chloroelhy
Chlorolorm

Chloromelhane

1,1-Dichloroethane

: 1,9-Dichloroethylene

Dichloromethane
1,2-Dichloropropa

is cis-1,3-Dichloropropene

Eithylbenzene

Tetrachloroethylene

1.1.1-Trichloroethane

o 1.1.2-Trichloroethane

: Trichloroethylene

0 Gylenes

Tritium

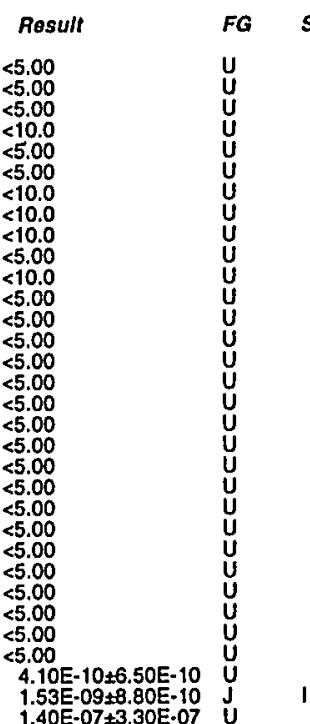

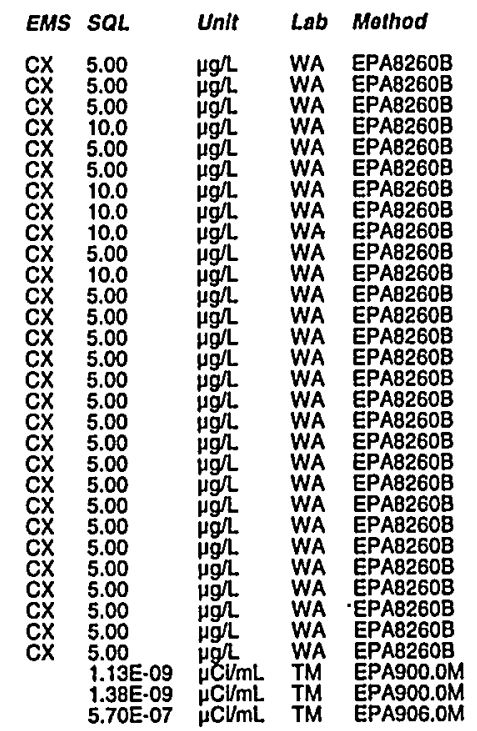

ESH-EMS-990521

Time: $11: 34$ Tater temperature: $199^{\circ} \mathrm{C}$

Air temperature: $27,7^{\circ} \mathrm{C}$

Total alkalinity (as CaCO3): $1 \mathrm{mg} /$

Field Qualifier(s): $V$.
WELL BGO 52C

MEASUREMENTS CONDUCTED IN THE FIELD

Sample dale: $06 / 14 / 99$ (16.85 m) below TOC

Water elevation: $229.22 \mathrm{ft}(69.87 \mathrm{~m}) \mathrm{ms}$

H: 5.2

Pp. conduclance: $21 \mu \mathrm{S} / \mathrm{cm}$

Water evacualed from the well prior to sampling: $31 \mathrm{gal}$

ANALYSES

$F$ Analyto

Result

Benzene
Bromodichloromethane

Bromolorm

Carbon tetrachloride

Chlorobenzen

2.Chloroeng (Vinyl chloride)

Chloroform

Chloromethane

Dibromochloremeln

i, 1 - Dichloroethylene

Irans-1,2-Dichloroet
Dichloromethane
1

cls-1,3-Dichloropropene
trans-1,3-Dichloropropene

Ethylbenzene

$1,1,2,2$-Tetrachloroethan
Telrachloroethylene

1,1,1-Trichloroethane

1,1,2.Trichloroethane

Trichlorofluoromethane

Xylenes

O Nonvolatile beta

WELL BGO 52C Replicate

MEASUREMENTS CONDUCTED IN THE FIELD

Sample dale: 06/14/99 $(16.85 \mathrm{~m})$ below TOC

Water elevation: $229.22 \mathrm{ft}(69.87 \mathrm{~m}) \mathrm{m}$

gp. conductance: $21 \mu \mathrm{S} / \mathrm{cm}$

Water evacuated from the well prior to sampling: $31 \mathrm{gal}$

ANALYSES

F Analyto

Result

Bromodichloromethane

Bromoform

Bromomelhane

Chlorobenzene

CCloroethenen (Vinyl chloride)

Chloroethene (Vinyl chlor
2-Chloroethyl vinyl ether

Chlorolorm

Dibromochloromethane

1.1.Dichloroethane

i.1.Dichloroethylene

Dichloromethane

$B-52$

$<5.00$
$<5.00$
$<5.00$
$<10.0$
$<5.00$
55.00
$<10.0$
$<10.0$
$<10.0$
55.00
$<10.0$
55.00
$<5.00$
55.00
$<5.00$
$<5.00$
$<7.21$

$\begin{array}{ll}F G & \text { S } \\ U & \\ U & \\ U & \\ U & \\ U & \\ U & \\ U & \\ U & \\ U & \\ U & \\ U & \\ U & \\ U & V\end{array}$

Time: 10:25

Tolal aḱkalinity (as CaCo3): $1 \mathrm{mgl}$

Field Qualifier(s): $: \mathrm{V}$

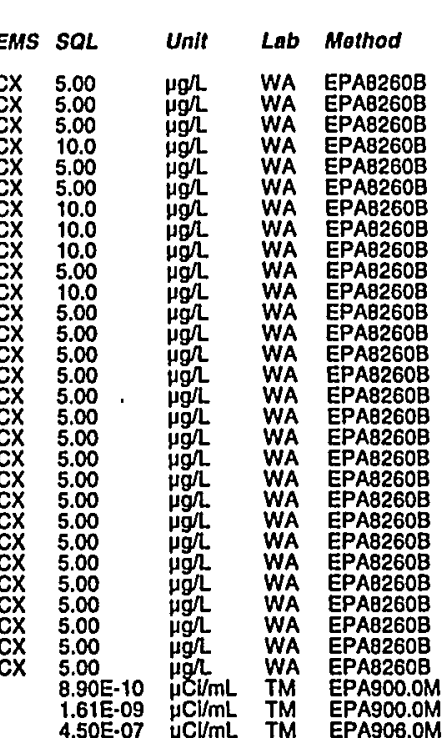

Time: 10:25

Air temperature: $22.3^{\circ} \mathrm{C}$

Tolal alkalinity (as CaCO3): $1 \mathrm{mg} / \mathrm{l}$

Field Qualifier(s): $v$

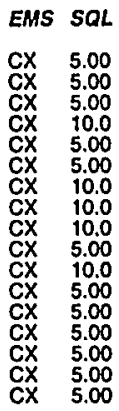

Unit Lab Mathod

$\mu g^{\prime}$ W WA EPA8260B

WA

WA

WA

WA

WA

Second auarter 1999 
Well BGO 52C collectod on 06/14/99 (cont.)

\section{$F$ Analyto}

$$
\text { Result }
$$

FG

0 1.2-Dichloropropane o trans-1,3-Dichloropropene : Ethylbenzene : Tolrachlorosthylen 1.1.1.Trichloroethane D Trichloroethylene
Trichlorolluoromethane O Xylenes O Nonvolatila bota 0 Tritium

\section{WELL BGO 52D}

MEASUREMENTS CONDUCTED IN THE FIELD

Sample date: $04 / 14 / 99$ Water elevation: $233.02 \mathrm{ft}(71.03 \mathrm{~m}) \mathrm{ms}$ pH: 4.9

Sp. conductance: $38 \mu \mathrm{S} / \mathrm{cm}$

Water evacualed from the well prior to sampling: 1 gal ANALYSES

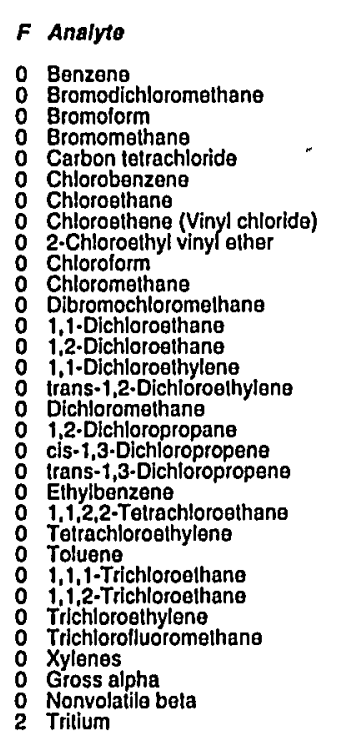

\begin{tabular}{|c|c|c|c|c|c|c|c|}
\hline ssult & $F \boldsymbol{G}$ & s & EMS & $S Q L$ & Unit & Lab & Mothod \\
\hline $\begin{array}{l}<5.00 \\
<5.00 \\
<5.00 \\
<10.0 \\
<5.00 \\
<5.00 \\
<10.0 \\
<10.0 \\
<10.0 \\
<5.00 \\
<10.0 \\
<5.00 \\
<5.00 \\
<5.00 \\
<5.00 \\
<5.00 \\
<5.00 \\
<5.00 \\
<5.00 \\
<5.00 \\
<5.00 \\
<5.00 \\
<5.00 \\
<5.00 \\
<5.00 \\
<5.00 \\
<5.00 \\
<5.00 \\
<5.00 \\
3.52 E-09+0.30 E-10 \\
3.81 \cdot 09.000 \\
2.71 E-05 \pm 1.24 E-10 \\
2.06\end{array}$ & 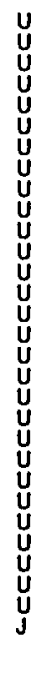 & $\mathrm{K}$ & C & $\begin{array}{l}5.00 \\
5.00 \\
5.00 \\
10.0 \\
5.00 \\
5.00 \\
10.0 \\
10.0 \\
10.0 \\
5.00 \\
10.0 \\
5.00 \\
5.00 \\
5.00 \\
5.00 \\
5.00 \\
5.00 \\
5.00 \\
5.00 \\
5.00 \\
5.00 \\
5.00 \\
5.00 \\
5.00 \\
5.00 \\
5.00 \\
5.00 \\
5.00 \\
8.60 \\
1.38-10 \\
6.30 E .09\end{array}$ & 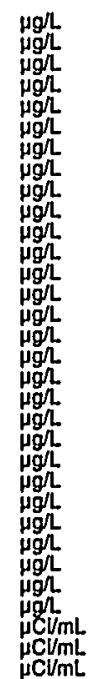 & $\begin{array}{l}\text { WA } \\
\text { WA } \\
\text { WA } \\
\text { WA } \\
\text { WA } \\
\text { WA } \\
\text { WA } \\
\text { WA } \\
\text { WA } \\
\text { WA } \\
\text { WA } \\
\text { WA } \\
\text { WA } \\
\text { WA } \\
\text { WA } \\
\text { WA } \\
\text { WA } \\
\text { WA } \\
\text { WA } \\
\text { WA } \\
\text { WA } \\
\text { WA } \\
\text { WA } \\
\text { WA } \\
\text { WA } \\
\text { WA } \\
\text { WA } \\
\text { WA } \\
\text { TM } \\
\text { TM } \\
\text { TM }\end{array}$ & 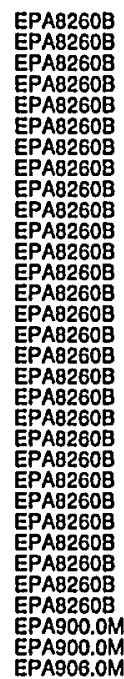 \\
\hline
\end{tabular}

ESH-EMS-990521

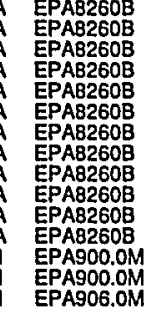

Time: 11:30

Air temperalure: $20: 203^{\circ} \mathrm{C}$

Total alkalinity (as CaCO3): 1 mgl

Phenolphthalein alkalinity: $0 \mathrm{mg} L$
Field Qualifier(s): $\mathrm{VX}$

\section{WELL BGO 52D}

MEASUREMENTS CONDUCTED IN THE FIELD

Sample date: 05/19/99

Depter elevation: $232.82 \mathrm{ft}(70.96 \mathrm{~m}) \mathrm{msl}$
WH: 4.8

列

Water evacuated trom the well prior to sampling: 1 gal went dry during purging.

ANALYSES

\section{$F$ Analyto}

: Benzene

o Bromoform

C Carbon telrachioride

0 Chlorobenzene

O Chloroethane

2.Chloroethyl

Chloromethane

Dibromochloromethane

1.2-Dichloroothane

1.1.Dichloroethylene
irans $-1,2 \cdot$ Dichloroethylene

o Dichloromethane

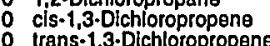

E Elhylbenzene

$1,1,2,2$-Tetrachloroethan
Teirachloroethylene

Toluene

I. $1.2-$-Trichloroesthane

- Trichloroflluoromethane

Gylenes

Trillum

\section{WELL BGO 52D}

MEASUREMENTS CONDUCTED IN THE FIELD

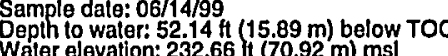

$\mathrm{H}: 5$

Sp. conductance: $39 \mu \mathrm{S} / \mathrm{cm}$

Waler evacualed from the well prior to sampling: $1 \mathrm{gal}$

well went dry during purging.

ANALYSES

$F$ Analyto

Rosult

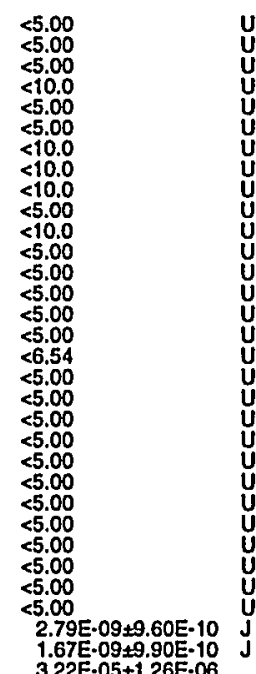

FG

s

Time: 11:40

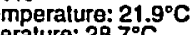

Total alkalinity (as CaCO3): $0 \mathrm{mg} /$
Phenolphthalein alkalinity: $0 \mathrm{mg}$ L

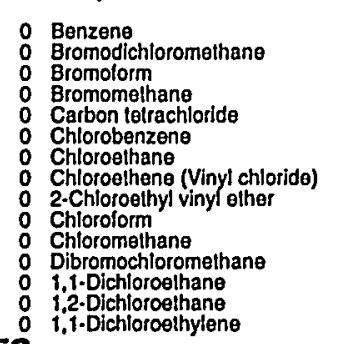

$B-53$
Result

$<5.00$
$<5.00$
$<5.00$
$<10.0$
$<5.00$
$<5.00$
$<10$.
$<10.0$
$<10.0$
$<5.00$
$<10.0$
$<5.00$
$<5.00$
$<5.00$
$<5.00$

FG.

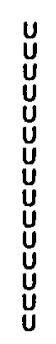

Waler temperature: $22.9^{\circ} \mathrm{C}$ Total alkalinily (as CaCO3): $0 \mathrm{mg} / \mathrm{L}$ Phenophnthalein alkalinity: $0 \mathrm{mg}$
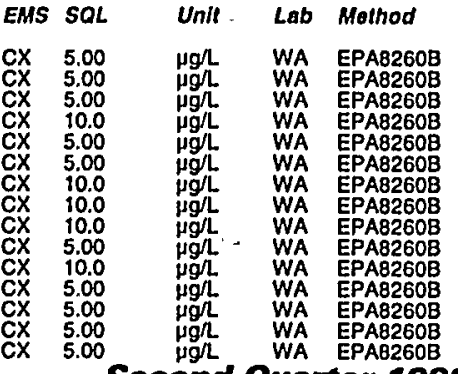
Well BRD 5D coilected on 06/08/99 (cont.)

\begin{tabular}{|c|c|}
\hline Analyto & Rosult \\
\hline $\begin{array}{ll}0 & \text { Tron, lotal recoverable } \\
0 & \text { Lithium, otal recoverable } \\
0 & \text { Mercury, lotal recoverable } \\
0 & \text { Selenium, tolal recoverable } \\
0 & \text { Telrachlorothylene } \\
0 & \text { Total organic halogens } \\
0 & 1,1,1-T \text { Trichloroetthane } \\
0 & \text { Trichloroelhylene } \\
0 & \text { Gross alpha }\end{array}$ & $\begin{array}{l}59.9 \\
2.40 \\
<0.700 \\
<66.0 \\
<1.00 \\
<120 \\
<1.00 \\
<1.00 \\
5.20 E-10 \pm 5.90 E-1\end{array}$ \\
\hline
\end{tabular}

\section{WELL BRR 3D}

MEASUREMENTS CONDUCTED IN THE FIELD

Sample dale: $06 / 07 / 99$
Depth to water: $76.38 \mathrm{Ht}(23.28 \mathrm{~m})$ below TOC
Water elevation: $215.32 \mathrm{tt}(65.63 \mathrm{~m}) \mathrm{ms}$

Water elevation: $215.32 \mathrm{ft}(65.63$
gH: 4.7
Sp. conductance: $145 \mu \mathrm{S} / \mathrm{cm}$

Tubididty: $1 \mathrm{NTU}$ (rom the well prior to sampling: $46 \mathrm{gal}$
Water evacuated from

ANALYSES

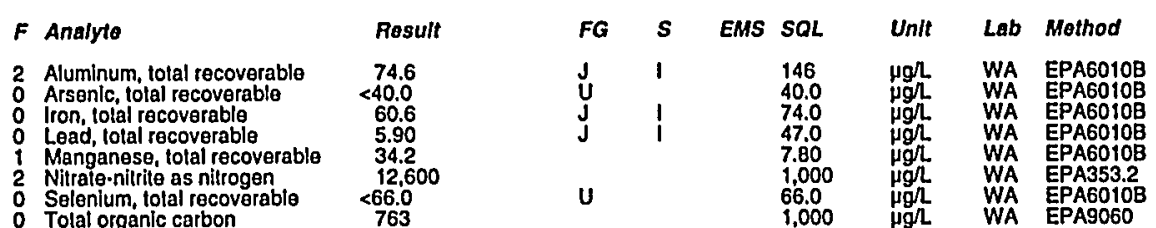

\section{WELLL BRR 5D}

MEASUREMENTS CONDUCTED IN THE FIELD

Sample date: 06/07/99

Water e

Pp. conductance: $96 \mu \mathrm{S} / \mathrm{cm}$

Wurbidity: 13 NTU

\begin{tabular}{|c|c|c|c|c|c|}
\hline$s$ & EMS & SQL & Unit & Lab & Mothod \\
\hline 1 & & $\begin{array}{l}74.0 \\
2.70 \\
0.700 \\
66.0 \\
1.00 \\
120 \\
1.00 \\
1.00 \\
9.70 E-10\end{array}$ & 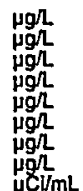 & $\begin{array}{l}\text { WA } \\
\text { WA } \\
\text { WA } \\
\text { WA } \\
\text { WA } \\
\text { WA } \\
\text { WA } \\
\text { WA } \\
\text { TM }\end{array}$ & $\begin{array}{l}\text { EPA6010B } \\
\text { EPAG010B } \\
\text { EPA7470A } \\
\text { EPAG010B } \\
\text { EPABO21B } \\
\text { EPA9020B } \\
\text { EPABO21B } \\
\text { EPABD21B } \\
\text { EPA900.0M }\end{array}$ \\
\hline
\end{tabular}

ANALYSES

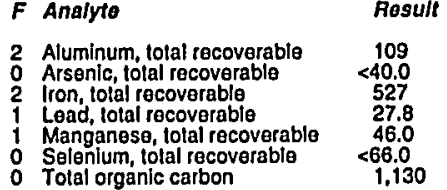

\section{WELL BRR 6D}

MEASUREMENTS CONDUCTED IN THE FIELD

Sample date: 06/07/99 $27.09 \mathrm{~m}$ ) below TOC

Deph to waler: $88.87 \mathrm{ft}(27.09 \mathrm{~m})$ below
Water elevalion: $207.03 \mathrm{H}(63.1 \mathrm{~m}) \mathrm{msl}$
t: 6

$\mathrm{Sp}$. conductance: $60 \mu \mathrm{S} / \mathrm{cm}$

Water evacuated from the well prior to sampling: $15 \mathrm{gal}$

ANALYSES

$F$ Analyte

1 Aluminum, total recoverable

Result

38.9

ESH-EMS-990521

Wat:er temperalure: $21.7^{\circ} \mathrm{C}$
Air temperature: $34.4^{\circ} \mathrm{C}$

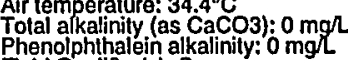

Field Qualifier(s): $S$

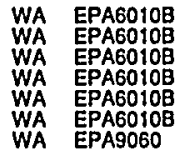

Time: $12: 50$ Waler temperature: $21.3^{\circ} \mathrm{C}$ Air lemperature: $36.2^{\circ} \mathrm{C}$
Total alkalinity (as Cacos): $41 \mathrm{mg} / \mathrm{L}$ Phenolphinalein alkalinity: $0 \mathrm{mg} /$
Well BRR 6D collected on 06/07/99 (conl.)

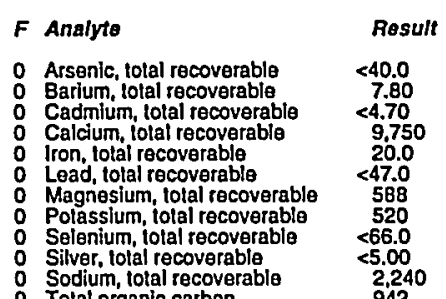

\begin{tabular}{|c|c|c|c|c|c|c|}
\hline$F G$ & $s$ & EMS & SQL & Unit & Lab & Mothod \\
\hline u & & & & & A & $P_{A 6010 B}$ \\
\hline u & & & 4.70 & jol & WA & EPA6010B \\
\hline J & 1 & & $\begin{array}{l}74.0 \\
47.0 \\
74.0\end{array}$ & 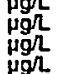 & $\begin{array}{l}\text { WA } \\
\text { WA } \\
\text { WA }\end{array}$ & $\begin{array}{l}\text { EPA6010B } \\
\text { EPA6010B } \\
\text { EPA6010B }\end{array}$ \\
\hline U & & & $\begin{array}{l}187 \\
66.0 \\
5.00 \\
285 \\
1.000\end{array}$ & $\begin{array}{l}\mu g h \\
\mu g h \\
\mu g h \\
\mu g h \\
\mu g \Omega\end{array}$ & $\begin{array}{l}\text { WA } \\
W A \\
W A \\
W A \\
W A\end{array}$ & $\begin{array}{l}\text { EPA6010B } \\
\text { EPAGO10B } \\
\text { EPAG0108 } \\
\text { EPAG010B } \\
\text { EPA9060 }\end{array}$ \\
\hline
\end{tabular}

\section{WELL CBR 1D}

MEASUREMENTS CONDUCTED IN THE FIELD

Sample date: $06 / 08 / 99$
Deplh to water: $49.36 \mathrm{ft}(15.05 \mathrm{~m})$ below TOC
Water elevation: $251.24 \mathrm{ft}(76.58 \mathrm{~m}) \mathrm{msl}$

Waler eleval
ph: 5.3

gh: 5.3 . conductance: $28 \mu \mathrm{S} / \mathrm{cm}$

Warter evacuated from the well prior to sampling: $38 \mathrm{gal}$ ANALYSES

$F$ Analyto

: Aluminum, total recoverable

Arsenic, total recoverable
0 Barlum, tolal recoverable
0 Cadmium, total recoverable
0 Calcium, total recoverable
0 Carbon letrachloride

0 Chlorido

ciss-1,2-Dichloroethylene

0
0 Lron, lotal recoverabio
0 Lad, total recoverable

0 Magneslum, total recoverable

Molasslum, total recoverable recoverable

Silenlum, iotal recoverabla

Sodfum, total recoverab

Te Sulfale

Total dissolved sollds

1,1,1-Trichloroethan
Trichloroethylene

Gross alpha

0 Nonvolatila bola

$\begin{array}{ll}0 & \text { Nonvola } \\ 0 & \text { Tritium } \\ 0 & \text { Tritium }\end{array}$

\section{WELL CBR 2D}
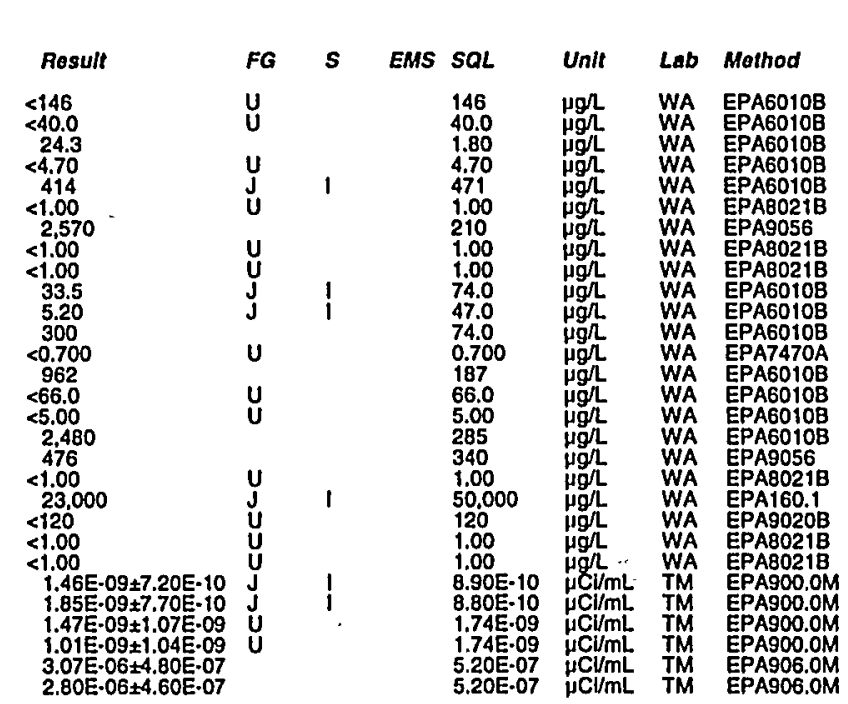

MEASUREMENTS CONDUCTEO IN THE FIELD

Sample date: 06/08/99

$\mathrm{pH}: 4$.

p. conductance: $30 \mu \mathrm{S} / \mathrm{cm}$

Water evacuated from the well prior to sampling: $56 \mathrm{gal}$ ANALYSES
$F$ Analyte
- Result
1 Aluminum, total recoverable
\begin{tabular}{rlr}
1 & Aluminum, total recoverable & 46.3 \\
0 & Arsenic, ototal recoverable & $<40.0$ \\
0 & Barium, total recoverable & 34.4 \\
\hline 5 & &
\end{tabular}

Time: 13:11

Total alkalinity (as Caco3): $3 \mathrm{mgh}$
Phenoiphinalein alkalinity: $0 \mathrm{mgl}$
Field Quallfier(s): $\mathrm{S}$

Time: 12:21

Total alkalinity (as CaCo3): $0 \mathrm{mg} / \mathrm{L}$

Phenolphthalein alkalinity: $0 \mathrm{mg} h$
Field Qualifier(s): $s$

EMS SO

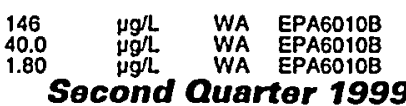

Unit

Lab Mathod

J 1 
Well CMP 10D collected on 06/08/99 (cont.)

$F$ Analyte

o Lithium, total recoverable

Manganese, total recovererable
Mercuny, total recoverable

Nitrate-nitrite as nitrogen

Sillica, total recoverable

Silver, iotal recoverable

Sullate

Totrachloroethylene

Tolal dissolved solids

Tolal organic halogens

$1,1,1$-Trichloroethane

Nonvolatilie beta

o Trilium

\section{WELL CRP 5D}

MEASUREMENTS CONDUCTED IN THE FIELD

Sample dato: $06 / 08$ (9)

Depth to waler: $66.92 \mathrm{ft}(20.4 \mathrm{~m})$ below TOC

Waler elevation: $209.58 \mathrm{H}$
pH: 5.4
Sp. conductance: $30 \mu \mathrm{S} / \mathrm{cm}$

Sp. conductance: $30 \mu \mathrm{S} / \mathrm{cm}$
Tubbifily: $6 \mathrm{NTUU}$
Water evacuated from the well

Water evacuated from the well prior to sampling: 1 ga

ANALYSES

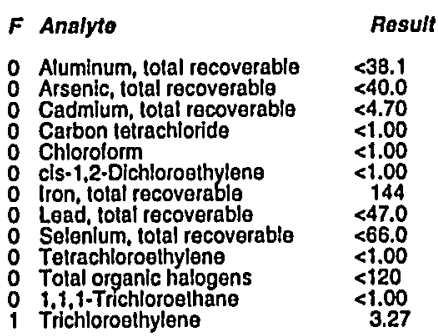

\section{WELL CRP BD}

MEASUREMENTS CONDUCTED IN THE FIELD

Sample date: 06/08/99

Wh: 4.9 evation: $205.58 \mathrm{Ht}(62.66 \mathrm{~m}) \mathrm{ms}$

Sp. conductance: $28 \mu \mathrm{S} / \mathrm{cm}$

Water evacualed from the well prior to sampling: $132 \mathrm{gal}$

ANALYSES

$F$ Analyto

Aluminum, total recoverable

Carbon tetráchloride

Chis-1,2-Dichlosoethylen

ESH-EMS-990521
Result

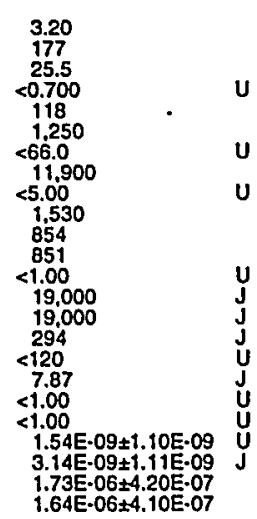

$$
\begin{aligned}
& F G \\
& u \\
& u \\
& u \\
& u \\
& u \\
& u \\
& u \\
& u \\
& u
\end{aligned}
$$

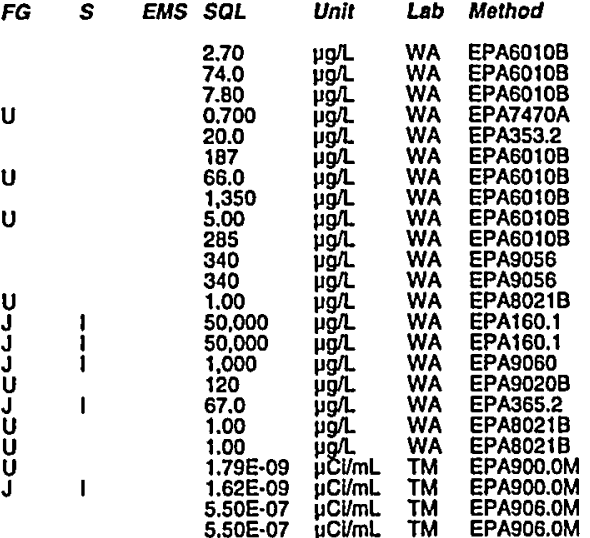

Time: 15:05

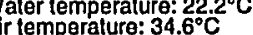
total alkalinity (as Cacos): $4 \mathrm{mgl}$ Pield Qualifier(s): VX
Fe

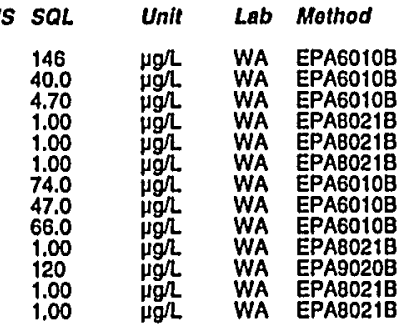

Time: 10:31

perature: $21.4^{\circ} \mathrm{C}$ Tolal alkalinity (as Caco3): $0 \mathrm{mg} /$ Fhenoiph hatein alkalinity: $0 \mathrm{mg} /$

61.6
$<40.0$
$<1.00$
$<1.00$
$<1.00$
$<47.0$

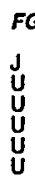

EMS SQL

Unit Lab Mathod

$\begin{array}{ll}146 & \mu g \Omega \\ 40.0 & \mu g \Omega \\ 1.00 & \mu g \Omega \\ 1.00 & \mu g \Omega \\ 1.00 & \mu g \Omega \\ 47.0 & \mu g \Omega\end{array}$

WA EPABO21B

WA EPABO21B
Well CRP 8D collected on 06/08/99 (cont.)

$<66.0$
$<1.00$
$<120$
$<120$
$<1.00$
$<1.00$

FG S EMS SOL

Unit

Lab Method

: Selenium, total recoverable

Total organic halogens

o 1,1,1-Trichloroethan

\section{WELL CSB TA}

MEASUREMENTS CONDUCTED IN THE FIELD

Sample date: 06/08/99
Depth 10 water: 80.72 h $(24.6 \mathrm{~m})$ below TOC
Water

DH:5.9

Sp. conductance: $96 \mu \mathrm{S} / \mathrm{cm}$

Waler evacuated from the well prior to sampling: 1 gal

The well went dry during purging.

ANALYSES

$F$ Analyte

Result

2 Aluminum, total recoverable

O Cadmium, tolal recoverable

Carbon tilrachlorida

cis-1,2.Dichloroelhylene

Lead, lolal recoverable

Tetrachloroethylene

Tolal organic halogens

\section{WELL CSB 2A}

476
$<40.0$
$<4.70$
$<1.00$
$<1.00$
$<1.00$
820
43.8
$<6.8$
$<1.00$
$<1.00$
$<1.00$
$<1.00$

MEASUREMENTS CONDUCTED IN THE FIELD

Sample data: 06/08/99

Water elevation: $210.31 \mathrm{ft}(64.1 \mathrm{~m}) \mathrm{ms}$

$\mathrm{pH}: 5.5$

Turbidity: $15 \mathrm{NTU}$. $47 \mu \mathrm{S} / \mathrm{cm}$

Water evacuated from the well prior to sampling: $7 \mathrm{gal}$

U⿺

66.0
1.00
120
120
1.00
1.00

$\mu g h$
$\mu g h$
$\mu g h$
$\mu g h$
$\mu g h$
$\mu g h$

WA EPAG010B

WA EPASO21B

WA EPA9020B

ANALYSES

$F$ Analyto.

Rosult

Time: $10: 15$

A $258^{\circ} \mathrm{C}$

Total alkalinity (as CaCO3): $32 \mathrm{mg} /$

Phenolphthalein alkalinity: $0 \mathrm{mg} / \mathrm{L}$.
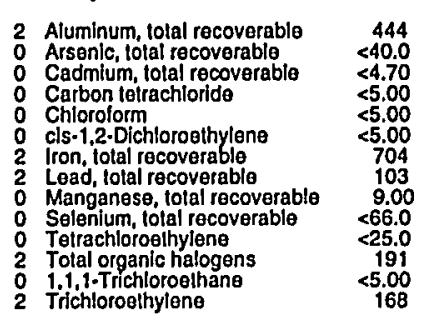

WA EPA6010B
Total alkalinity (as Caco3): $9 \mathrm{mg} /$ Phenolphthalein alkalinity: $0 \mathrm{mgh}$
Field Qualifier(s): $\mathrm{SX}$
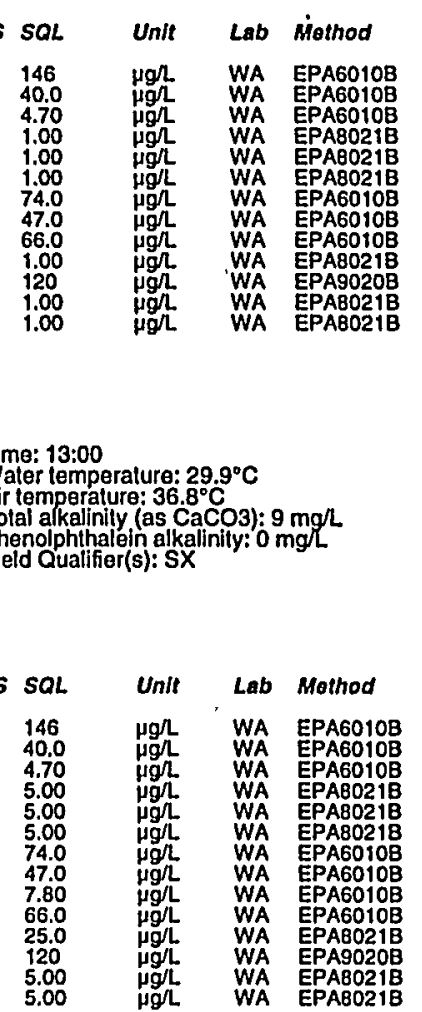
WELL CSB 3A

MEASUREMENTS CONDUCTED IN THE FIELD

Depth o water: $75.06 \mathrm{ft}(22.88 \mathrm{~m})$ below TOC
Water elevallon: $209.84 \mathrm{lt}(63.96 \mathrm{~m}) \mathrm{ms}$ l
pH: 5.8

Sp. conductance: $39 \mu \mathrm{S} / \mathrm{cm}$

Water evacuated from the well prior to sampling: $57 \mathrm{gal}$ ANALYSES

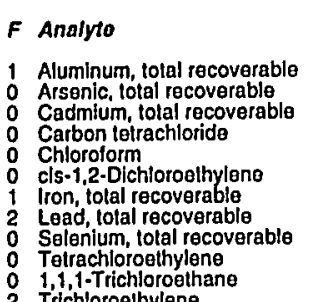

Rosult
44.5
440.0
$<4.70$
$<10.0$
$<10.0$
$<10.0$
181
104
106
$<66.0$
$<10.0$
$<10.0$
254

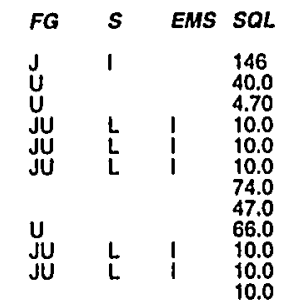

Time: 11:36

Water temperature: $24^{\circ} \mathrm{C}$

Total alkalinity (as CaCo3): $8 \mathrm{mg} /$ Phanolphinhalein alkall
Field Qualifier(s): $S$

\section{WELL CSB 4A}

MEASUREMENTS CONDUCTED IN THE FIELD

Sample date: 06/08/99
Depth to waler: 75.21 th $(22.92 \mathrm{~m})$ below TOC
Water elevation: $209.89 \mathrm{ft}(63.98 \mathrm{~m}) \mathrm{ms}$

Waler

H. conductance: $18 \mu \mathrm{S} / \mathrm{cm}$

Turbidity: $2 \mathrm{NTU}$
Waler evacualed from the well prior to sampling: $47 \mathrm{gal}$ ANALYSES

\begin{tabular}{|c|c|c|c|c|c|c|c|c|}
\hline Analyte & Result & $F G$ & $s$ & EMS & SOL & Unit & Lab & Method \\
\hline 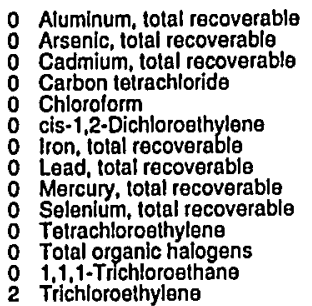 & $\begin{array}{l}<146 \\
<40.0 \\
<4.70 \\
<1.00 \\
<1.00 \\
<1.00 \\
<42.7 \\
17.4 \\
<0.700 \\
<66.0 \\
<1.00 \\
42.6 \\
<1.00 \\
48.3\end{array}$ & 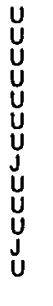 & i & & $\begin{array}{l}146 \\
40.0 \\
4.70 \\
1.00 \\
1.00 \\
1.00 \\
74.0 \\
47.0 \\
0.700 \\
66.0 \\
1.00 \\
120 \\
1.00 \\
1.00\end{array}$ & $\begin{array}{l}\mu g h \\
\mu g h \\
\mu g h \\
\mu g h \\
\mu g h \\
\mu g h \\
\mu g h \\
\mu g h \\
\mu g h \\
\mu g h . \\
\mu g h \\
\mu g h \\
\mu g h \\
\mu g h\end{array}$ & $\begin{array}{l}\text { WA } \\
\text { WA } \\
\text { WA } \\
\text { WA } \\
\text { WA } \\
\text { WA } \\
\text { WA } \\
\text { WA } \\
\text { WA } \\
\text { WA } \\
\text { WA } \\
\text { WA } \\
\text { WA } \\
\text { WA }\end{array}$ & $\begin{array}{l}\text { EPA6010B } \\
\text { EPA6010B } \\
\text { EPA6010B } \\
\text { EPABO21B } \\
\text { EPA8021B } \\
\text { EPABO21B } \\
\text { EPA6010B } \\
\text { EPA6010B } \\
\text { EPA7470A } \\
\text { EPA60108 } \\
\text { EPAB021B } \\
\text { EPA9020B } \\
\text { EPAB021B } \\
\text { EPAB021B }\end{array}$ \\
\hline
\end{tabular}

\section{WELL CSB 5A}

MEASUREMENTS CONDUCTED IN THE FIELD

Sample date: 06/08/99
Depth to wate: $72.95 \mathrm{Ht}(22.24 \mathrm{~m})$ below TOC
Water levation: $209.85 \mathrm{ft}(63.96 \mathrm{~m}) \mathrm{ms}$

Wh:er el

Sp. conductance: $67 \mu \mathrm{S} / \mathrm{cm}$

Water evacuated from the well prior to sampling: 54 gal

ANALYSES

$F$ Analyto

2 Aluminum, tolal recoverable

Cadrium, total recoverabl

0 Carbon tetrach
0 Chlorotorm

ESH-EMS-990521

Well CSB SA collected on 06/08/99 (cont.)

$F$ Analyte

Rosult

0 cis-1,2-Dichloroethylene

Laad, total recoverablo

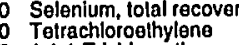

: 1,1,1-Trichloroethan

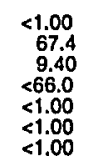

J

EMS SQL UnII

Unit Lab Mothod

\section{WELL CSB 6A}

MEASUREMENTS CONDUCTED IN THE FIELD

Sample date: 06/08/99 $23.16 \mathrm{~m}$ ) bolow TOC

Water e wa

Sp. conductance: $70 \mu \mathrm{S} / \mathrm{cm}$

Water evacuated from the well prior to sampling: 50 gal

ANALYSES

\begin{tabular}{|c|c|c|c|c|c|c|c|c|}
\hline Analyte & Result & FG & $s$ & EMS & SQL & Unit & Lab & Mothod \\
\hline 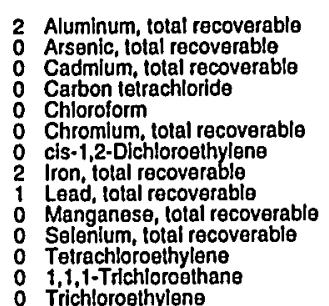 & $\begin{array}{r}225 \\
<40.0 \\
<4.70 \\
<1.00 \\
<1.00 \\
4.90 \\
<1.00 \\
544 \\
34.7 \\
12.4 \\
<66.0 \\
<1.00 \\
<1.00 \\
<1.00\end{array}$ & 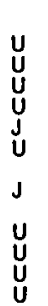 & 1 & & $\begin{array}{l}146 \\
40.0 \\
4.70 \\
1.00 \\
1.00 \\
7.00 \\
1.00 \\
74.0 \\
47.0 \\
7.80 \\
66.0 \\
1.00 \\
1.00 \\
1.00\end{array}$ & 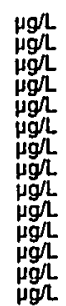 & $\begin{array}{l}\text { WA } \\
\text { WA } \\
\text { WA } \\
\text { WA } \\
\text { WA } \\
\text { WA } \\
\text { WA } \\
\text { WA } \\
\text { WA } \\
\text { WA } \\
\text { WA } \\
\text { WA } \\
\text { WA } \\
\text { WA }\end{array}$ & 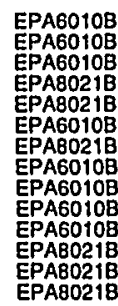 \\
\hline
\end{tabular}

\section{WELL CSB 7D}

MEASUREMENTS CONDUCTED IN THE FIELD

Sample date: 04/09/99

Depth to waler: $74.31 \mathrm{ft}(22.65 \mathrm{~m})$ below TOC

$\mathrm{P}: 5$

. conductance: $53 \mu \mathrm{S} / \mathrm{cm}$

Waler evacualed from the wall prior to sampling: $24 \mathrm{gal}$ ANALYSES

F Analyto

Acenaphthene

Acetoni

Aluminum, tolal recoverable

Anthracene

Antimony, rotal recoverable

Barium, total recoverable

alpha.:Benzena hexachlorid

delta-Benzene hexachlorido

Benzidine

Benzo(a)anthracene

Benzo ik) flluoranthene

Benzolc acid

Benzo(a)pyreng

Beryllium, total recoverable

$B-58$

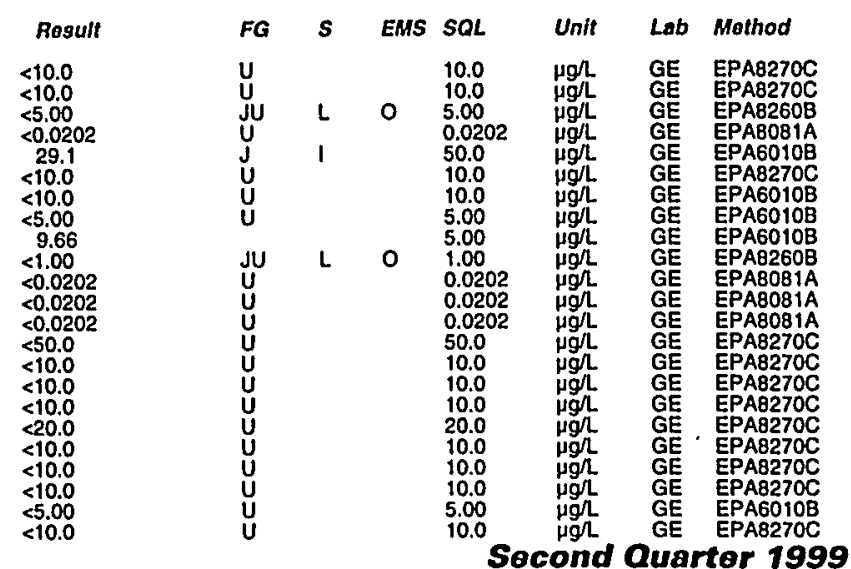

Socond Quartor 1999

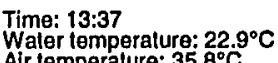
Total.alkalinity (as $\mathrm{CaCO}$ ): $16 \mathrm{mg}$ henolph halein alkalinity: $0 \mathrm{mg} / \mathrm{L}$ Air tempermeralure: $21.2^{\circ} \mathrm{C}$ Total alkalinity (as CaCo3): $0 \mathrm{mg} /$ Prenolphthalein alkalinity: $0 \mathrm{mgl}$ 
Well CSB 70 collected on 04/09/99 (cont.)

$F$ Analyte

- Bis(2-chloroethyl) ether

: Bis(2-chloroisopropyl) ether
0 Bis(2-ethylhexyl) phithalate
0 Bromodichloromelhane

o Bromoform

4. Bromophenyl phenyl ether
0 Cadmium, total recoverable

: Calcium, total recoverable

- Carbon letrachloride

o gamma.Chlordan

$\begin{array}{ll}0 & \text { Chlorobanzene } \\ \text { o } & 4 \text { Chloro-m-cresol }\end{array}$

- Chloroethene (Vinyl chloride)

Chlorolorm

: Chloromethane

4.Chlorophenyl phenyl ethe

0 Chromium, lotal recoverabl

0 Cobalt, total recoverable -

$\begin{array}{ll}0 & \mathrm{~m} / \mathrm{p} \cdot \text { Cresol } \\ 0 & 0 . \text { Cresol (2-Methylphenol) }\end{array}$

o Cyanide

$0, p^{2}-D D E$
0
0

Bibenz(a,h)anthracene

Dibenzofuran

Di.n.butyl phithalate

1.3. Dichlorobenzene
1.4. Dichlorobenzene

1,3.-Oichlorobenzldine

i, -2.Dichloroelhane

1.2-Dichloroethylen

2,4-Dichlorophenol

cls-1,3-Dichloropropene

Dieldrin

2,4-Dimethyl phenol

2,4.Dinitrophenol

2,6-Dinitrotoluene

Endosullan sullate

Endosultian il

Endrin aldehyde

Endrin aldehyde

Fluoranthene

Fluorene

Heptachlor epoxide

Hexachlorobutadiene

Hexachlorocyclopentadiene

2.Hexanone

Indeno(1,2,3-c,d)pyrene

ESH-EMS-990521

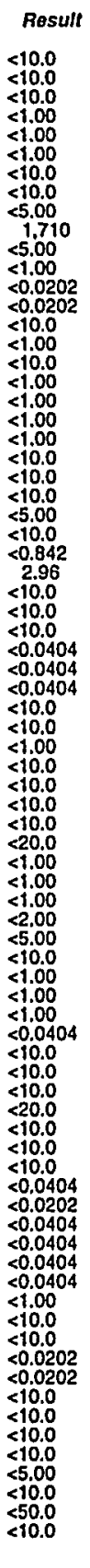

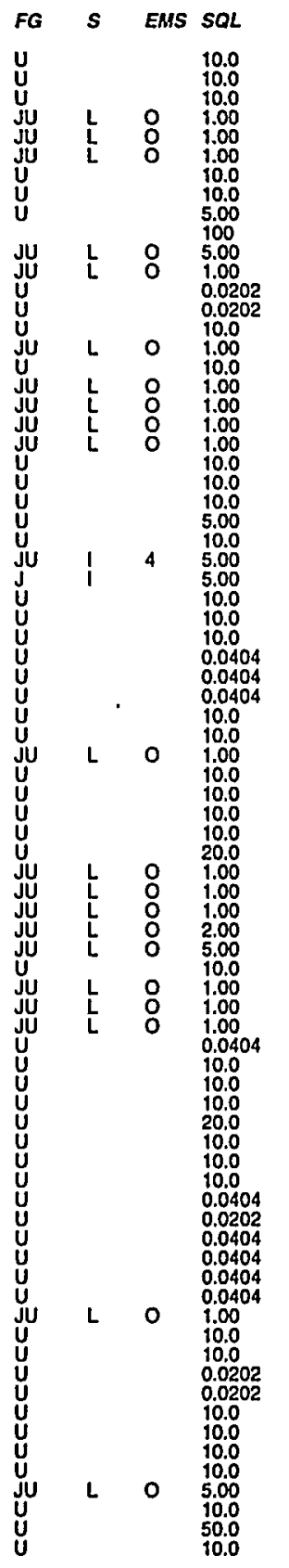

Well CSB 7D collected on 04/09/99 (cont.)

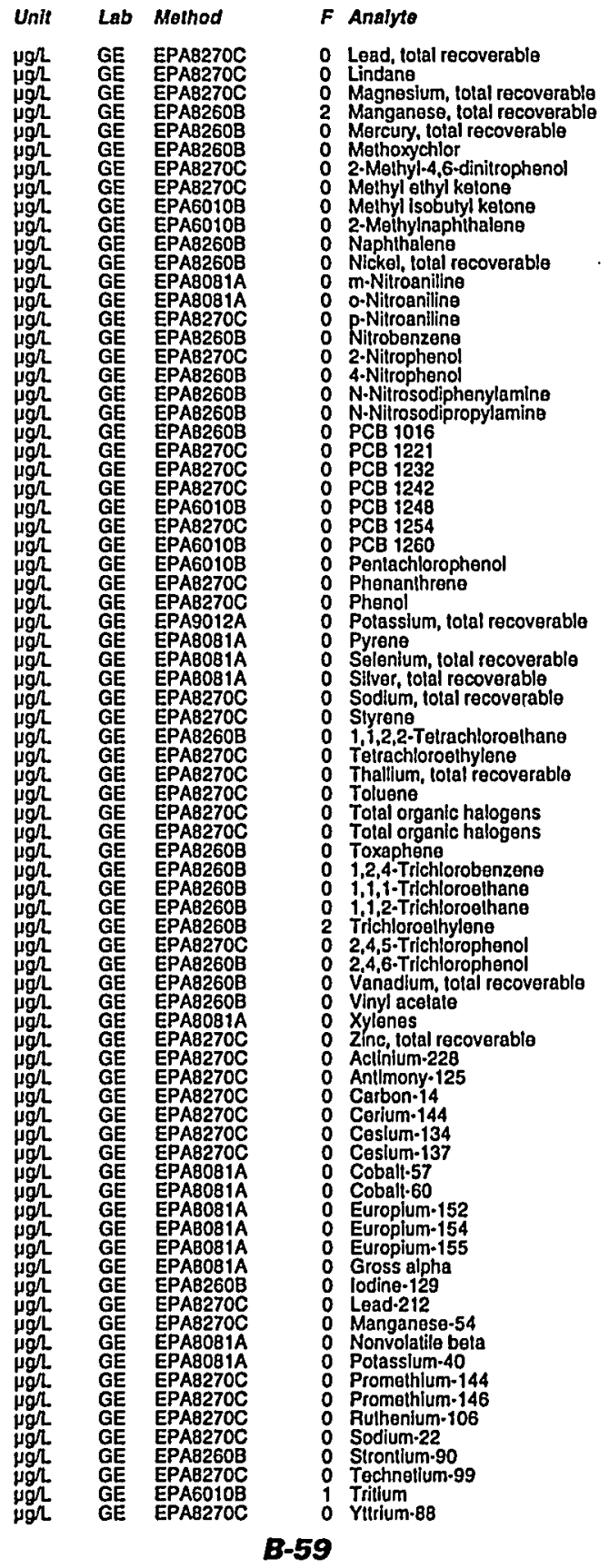

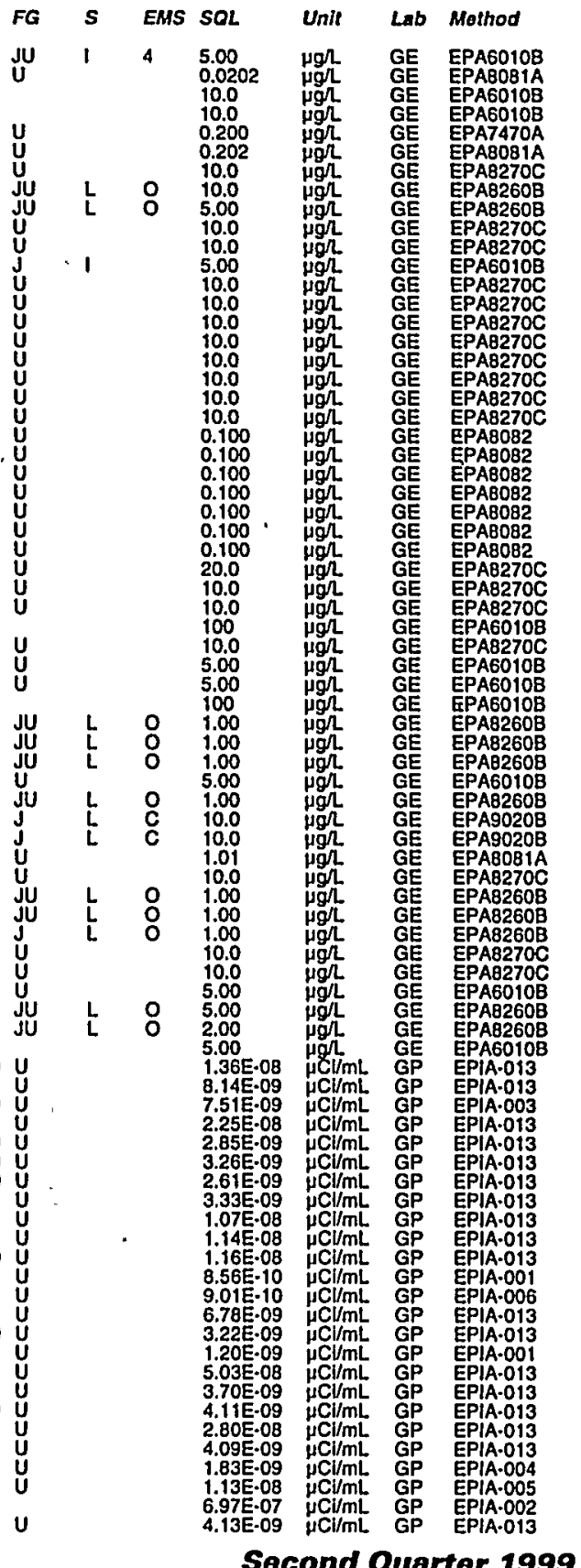


ANALYTICAL RESULTS

Well CSB 70 collecled on 04/09/99 (cont.)

W글ㄴ:65 CSB 8D

$-3.32 E \cdot 10 \pm 4.13 E \cdot 09 U$

MEASUREMENTS CONDUCTED IN THE FIELD

Sample dale: 04/09/99

eplh to water: $69.25 \mathrm{ft}(21.11 \mathrm{~m})$ below TOC $\mathrm{g} \mathrm{H}$. 5 conduclance: $45 \mu \mathrm{S} / \mathrm{cm}$

Water evacuated from the well prior to sampling: $90 \mathrm{gal}$ ANALYSES

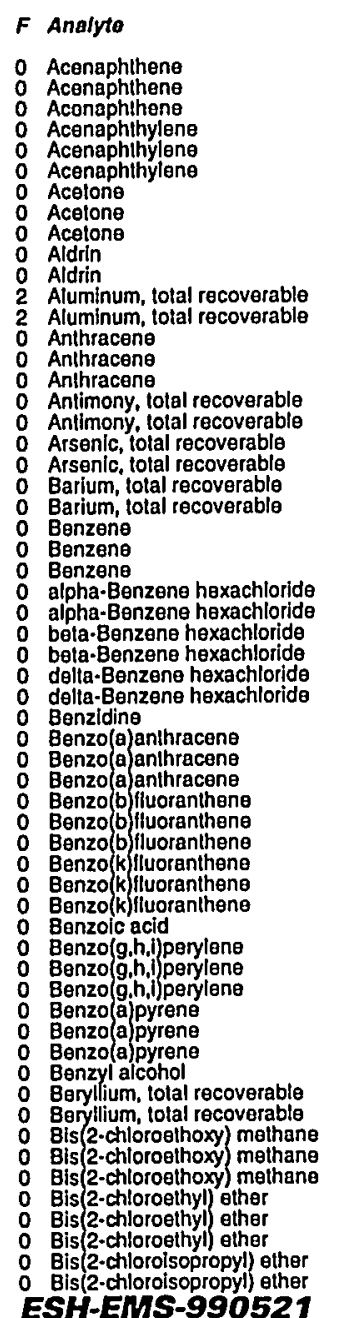

Rosult
$<10.0$
$<10.0$
$<20.0$
$<10.0$
$<10.0$
$<20.0$
$<5.00$
$<50.0$
$<50.0$
$<0.0200$
$<0.0520$
393
228
$<10.0$
$<10.0$
$<20.0$
$<10.0$
$<27.0$
$<5.00$
$<40.0$
13.8
13.0
$<1.00$
$<25.0$
$<25.0$
$<0.0200$
$<0.0520$
$<0.0200$
$<0.0520$
$<0.0200$
$<0.0520$
$<50.0$
$<10.0$
$<10.0$
$<20.0$
$<10.0$
$<10.0$
$<20.0$
$<10.0$
$<10.0$
$<20.0$
$<20.0$
$<10.0$
$<10.0$
$<20.0$
$<10.0$
$<10.0$
$<20.0$
$<10.0$
$<5.00$
$<1.60$
$<10.0$
$<10.0$
$<20.0$
$<10.0$
$<10.0$
$<20.0$
$<10.0$
$<10.0$

ESH-EMS-99052
SOL Unit Lab Mothod $7.49 E-09 \mu \mathrm{Cl} / \mathrm{mL}$ GP EPIA-013

Well CSB 8D collected on 04/09/99 (cont.)

F Analyto Rosult

0 Bis(2-chlorolsopropyl) ether $<20.0$

Bis 2-ethylhexyl) phithalate

Bis(2-ethythexyl) phthala

Bromodichloromethane

Time: 9:20

Air temperature: $21.9^{\circ} \mathrm{C}$ Co3): $4 \mathrm{~m}$
Total alkalinity (as CaCOC Phenolphthalein alkalinity: $0 \mathrm{mg}$ L
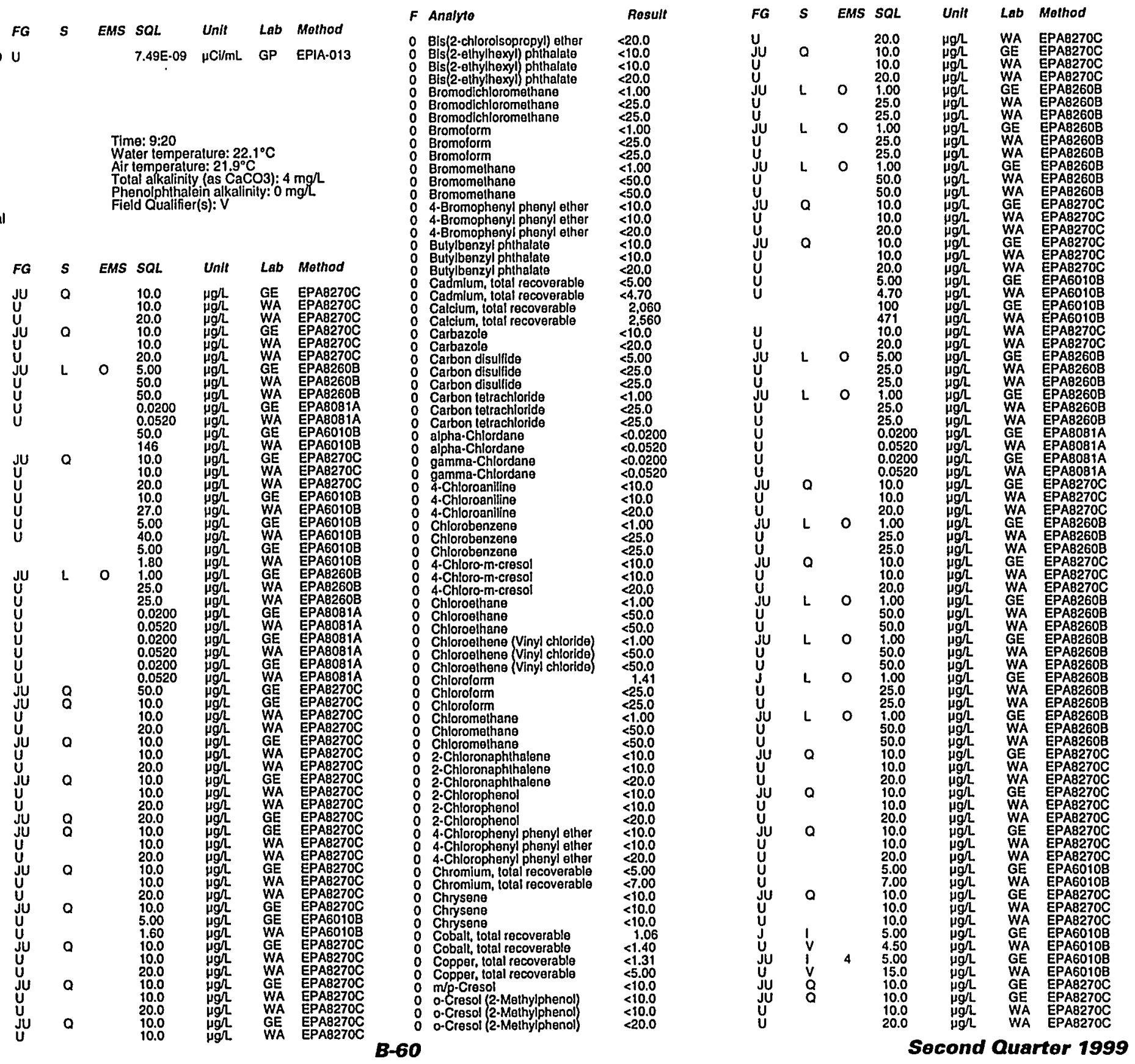
Well CSB 8D collected on 04/09/99 (cont)

: p-Cresol (4-Methylphenol)

o Cyanide

$\begin{array}{ll}0 & \text { p.p-DDD } \\ 0 & \text { P.p-DDD } \\ 0 & \text { p.p-DDE }\end{array}$

o p.p-DDE

O Bibenz(a.h)anthracene

- Dibenz a hanthracen

Dibenzofuran

Dibanzoluran

O Dibromochloromethane

D Di-n-butyl phinalale

Dil-n-butyl phihalale

1,2-Oichlorobenzeno

1,2-Dichlorobenzen

1,3.Dichlorobenzen

1,4-Dichlorobenzen

1.4-Dichlorobenzene

3,3-Dichlorobenzidine

1, pichloroothane

1.Dichloroethane

: 1,2.Dichloroesthane

: 1,i-Dichloroelhylene

i,2. Dichloroethylene

1.2.0. Dichloroethylene

Dichloromethan

2.4.Dichlorophenol

2.4. Dichlorophenol

o 1,2-Dichloropropane

c cis-1,3.Dichloropropene

cis-1.3. Dichloropropene

Irans-1,3-Dichloropropen

Dieldrin

O Dielhyl phthalate

2,4.Dimethyl pheno

2.4-Dimethyy pheno

Dimethyl phthalat

Dimethyl phithalato

2,4-Dinitrophenol

2.4.D.Dinitrotoluen

ESH-EMS-990521
Result

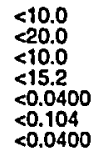

$<0.104$
$<0.0400$
$<0.104$

20.104
$<10.0$
$<10.0$
$<20.0$
$<10.0$
$<10.0$

22.0
2100
252.0
$<25.0$
$<25$

$<10.0$
$<10.0$
$<10.0$
$<10.0$
$<10.0$

$<10.0$
$<20.0$
$<10.0$
$<10.0$

$<2.0$
$<1.0$
$<10.0$

$<20.0$
$<20.0$
$<20.0$
$<20.0$

$<25.0$
$<1.00$
$<5.00$
$<5.0$

<it.

6.12
5.09
5.58
$<5.00$

$<18.0$
$<15.1$
$<10.0$
$<10.0$

$<10.0$
$<20.0$
$<1.00$

$<25.0$
41.00
255.0
$<<5.0$
$<1.00$
25.0
25.0
20.00

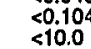

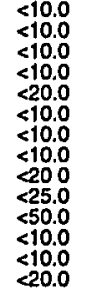

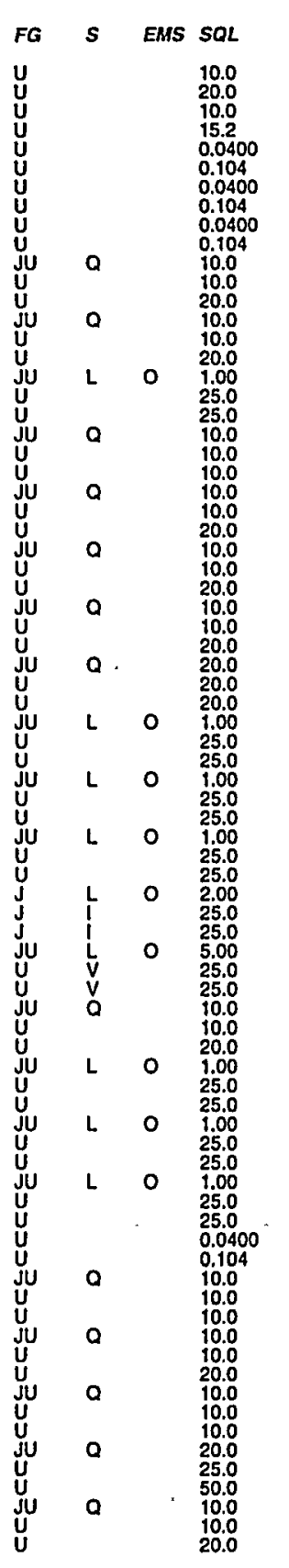

Unit

Lab Mothod

$\begin{array}{lll}\mu g h & \text { WA } & \text { EPAB270C } \\ \mu g \Omega & \text { WA EPAB270C } \\ \mu g \Omega & \text { GE } & \text { EPA9012A }\end{array}$

WA

WA EPABOBIA

WA EPABOBAA

WA EPAB270C

GE EPAB270C

GE EPA8260B

WA EPA8260B

WA EPAB270C

GE

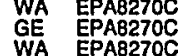

WA EPA8270C

WA

WA EPAB270C

WA EPA8270C

GE

GE EPAB260B

WA

WA

WE EPAB260B

WA EPAB260B

WA EPAB260B

GE EPAB270C

WA EPAB270C

WA

WA EPAB260B

GE EPAB260B
WA EPAB260B
WA EPAB260B

GE EPAB081A

GE EPAB270C

WA EPAB270C

WA EPAB270C
WE
EPAB270C

GE
WA EPAB270C
WA
EPAB270C
GE
WA EPA270C
WPAB270C

WA
WPAB270C
GE EPAB270C
EPAB270C

WA EPAB270C
Well CSB 8D collected on 04/09/99 (cont.)

$F$ Analyto Result

$\begin{array}{ll}0 & 2,6 \cdot \text { Dinitrotoluen } \\ 0 & 2,6-6 \text {-Dinitrololuen } \\ 0 & 2,6 \text {-Dinitrololouen } \\ 0 & \end{array}$

D Di-n-octyl phthalaite

Endosulfan sulfate

Endosullan II

Endrin

Endrin aldehydo

Endrin kelone

Ethylbenzen

Fluoranthene
Fuuoranthene
Fluoranthene

Fluorene

Fluorene

Heplachlor
Heplachlor epoxida

Heptachlor epoxida

Hexachlorobenzene
Hexachlorobenzene
Hexachlorobutadiene

Hexachlorobutaciene
Hexachlorobutadione

Hexachlorocyclopentladiene
Hexachlorocyclopentadiene
Hexachlorocyclopentadiene

Hexachloroethane
Hexachloroethane

Hexachloroethan

2.Hexanone

0 indeno $(1,2,3-$ c,d)pyreno

Indeno(f,2,3-c,c,dpyren

Iron, lolal recoverable

Isophorone

Lead, total recoverable

Lindane

Magneslum, total recoverabr

Magneslum, total recoverabt

Manganese, total recoverable

Mercury, total recoverabl

Mercury, tolarychlor

Melhoxychlor
$2-$ Methyl-4,6-dinitrophenol

2-Methyl-4,6-dinitiophenol

Methyl ethy? katone

Melhyl ethyl ketone

Mehyll sobuty ketone

2.Meihyynaphithalene

B-61

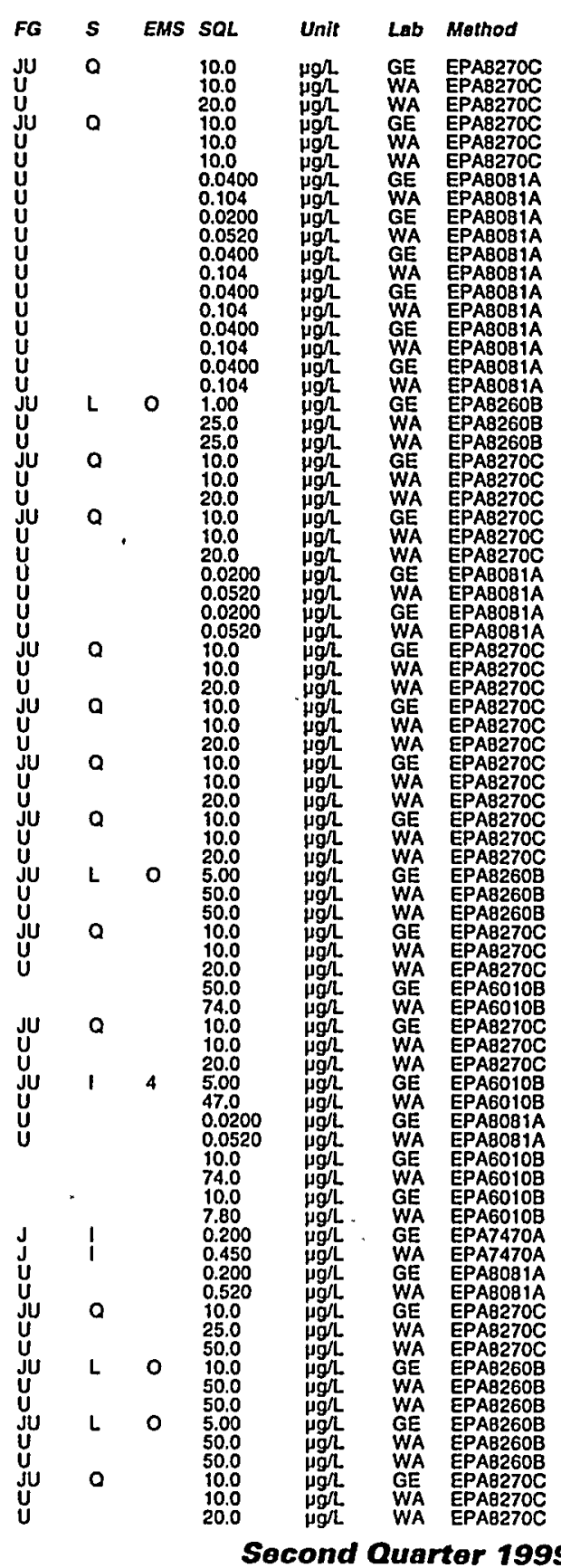




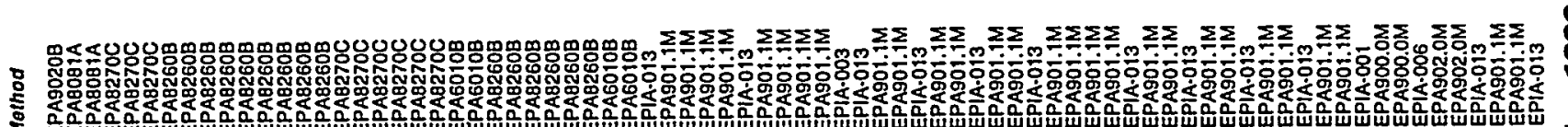

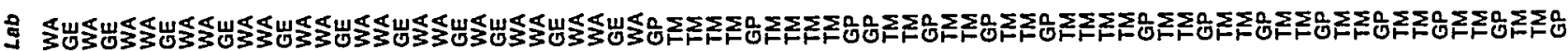

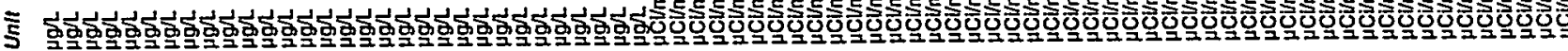

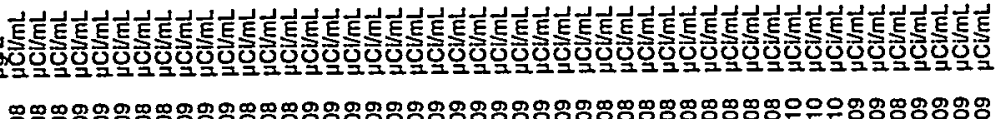

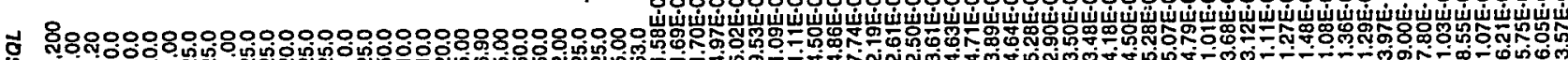

魚

窝 0 - 0 -

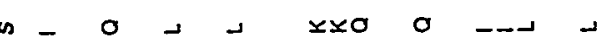

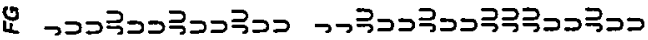

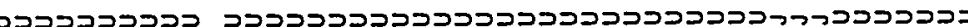

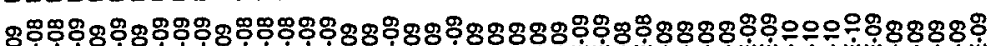

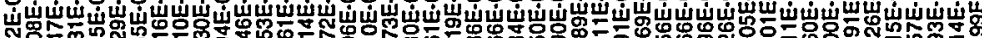

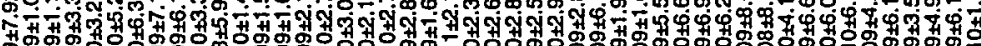

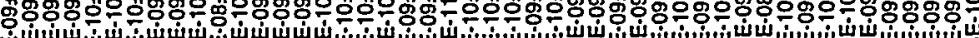
亏 응

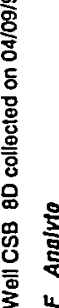

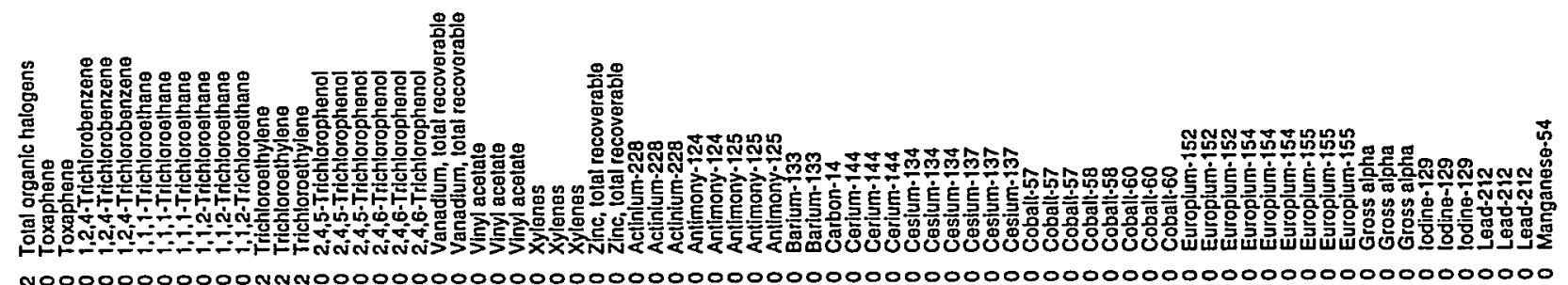

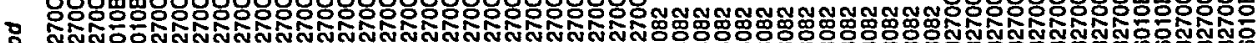

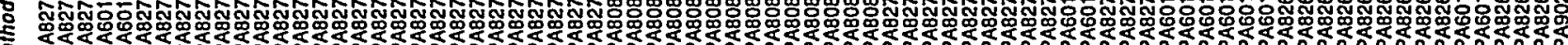

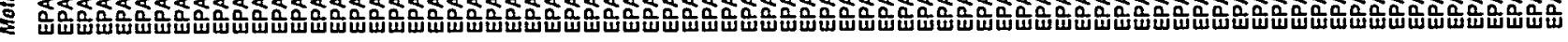

司

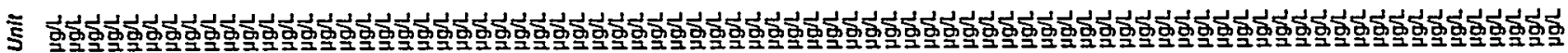

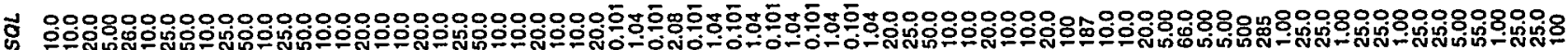
蛋

a

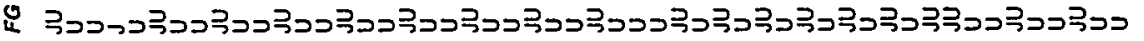

בכבכבכן

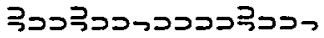

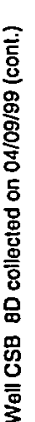

苛

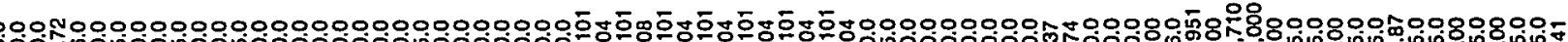

兽 $\div \mathrm{v}$ บ 
Well CSB BD collected on 04/09/99 (cont.)

$F$ Analyte

Result

FG

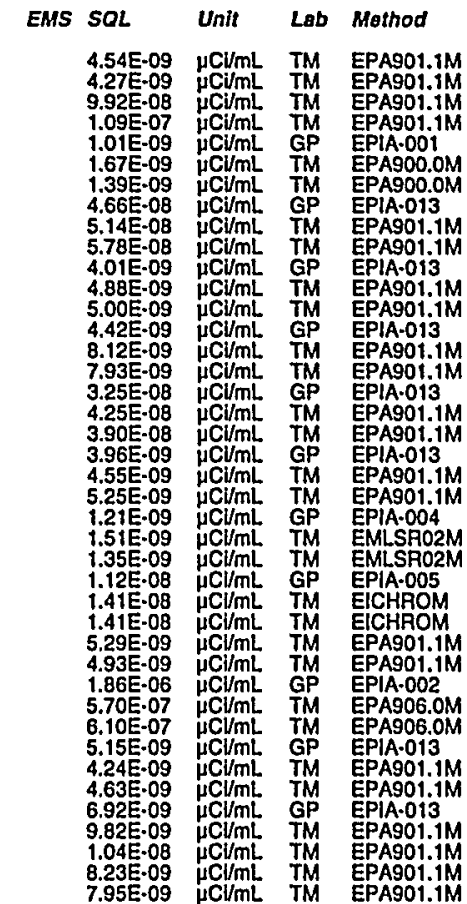

O Manganese-54

Neprunium-239

Nonvolatili beta

0 Nonvolatile beta

Polassium-40

Promethium-144
0 Promethium-144

Promathium-144

Promethium-146

Ruthenium-106

Rulhenjum-106

Sodium-22

Stronitium-90

Strontium 90

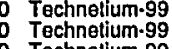

0
0 Technel
0 Tin-113
0 Tin-113

Tritium

2 Tritium

0 Yttrium-88

0 Yitrium-65

Zinc. 65

Z Zirconlum-95

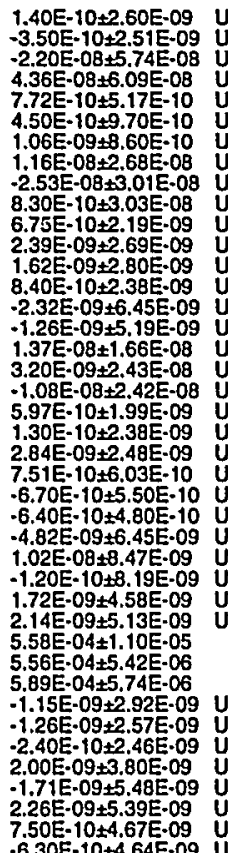

WELL CSB 8D Replicate

MEASUREMENTS CONDUCTED IN THE FIELD

Sample date: 04/09/99

Deplh to water: $69.25 \mathrm{H}(21.11 \mathrm{~m})$ below TOC

$\mathrm{gH}$. 5 conductance: $45 \mu \mathrm{S} / \mathrm{cm}$

Turbidily: $10 \mathrm{NTU}$ (rom the well prior to sampling: $90 \mathrm{gal}$

ANALYSES

$F$ Analyte

: Acenaphthene

0 Acetone

Aluminum, lotal recoverable

Anthracene

Anlimony, lotal recoverable
Barium, total recoverable
Batal recoverable

Benzene
alpha-Benzene hexachloride

alpha-Benzene hexachloride
bela. Benzene hexachloride
della.Benzene hexachloride

Benzidine
Benzo(a)anthraceno

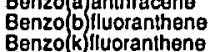

Benzolc acid

ESH-EMS-990521

Result
$<10.0$
$<10$
$<100$
$<100$
$<0.0200$
383
$<10.0$
$<10.0$
$<5.00$
14.1
$<20.0$
$<0.0200$
$<0.0200$
0.00949
$<50.0$
$<1.0$
$<10.0$
$<10.0$
$<20.0$
$<10.0$
$<10.0$

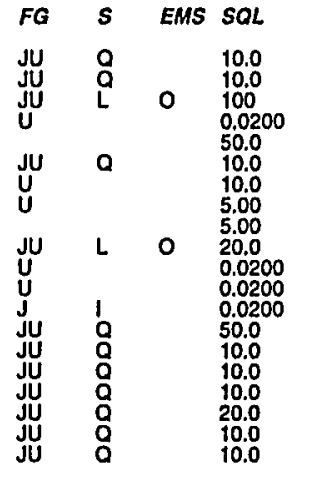

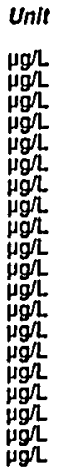

Well CSB 8D collected on 04/09/99 (cont)

$F$ Analyte

O Benzyl alcohol

O Bis (2-chloroethoxy) methane

Bis(2-chioroisopropyl) ether

Bromodichloromethan

Bromolorm

4.Bromophenyl phenyl ether

Butylbenzyl phithalate

Cadmium, total recoverable

Carbon disulfide

alpha-Chlordane

4.Chloroanllina

4-Chloro-m-cresol

Chloroothane
Chloroethene (Vinyl chloride)

Chlorolorm

o 2-Chloronaphithalene

4-Chlorophenyl phenyl ether

Chrysene

Copper, total recoverable

解

o p,p':DD

p.,

Gibenz(a,h)anthracene

Dibenzofuran

Di-n-butyl phthatate

1,2-Dichlorobenzene

1,4-Dichlorobenzone
3,33 -Dichlorobenzidine

$1,1 \cdot$ Dlchloroethane

1.1. Dichloroelthylene

Dichloromethane

2,4.Dichlorophenol

cis-1,3-DIchloropropene

Dieldrin phthalate

2,4-Dimethyl phenol

2,4.Dinitrophenol

2,4-Dinilitrololuene

Di-n-octyl phthalate

Endosultan 1

Endrin

- Endrin aldehyde

Ellyylbenzene

Fluoranthen
Fluorene

Heptachlor

Hexachlorobenzene
Hexachlorobutadien

Hexachloroethane

63

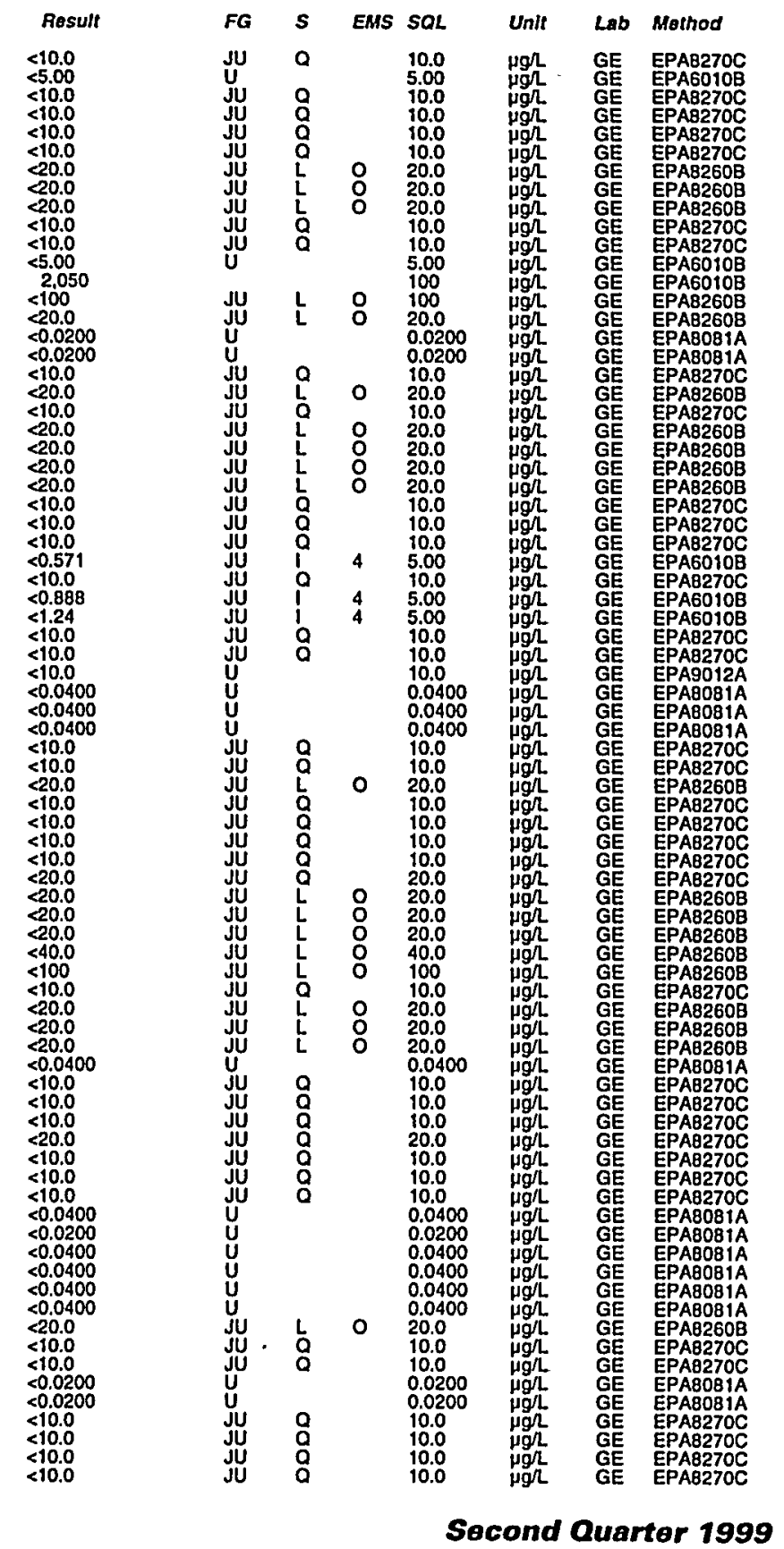


Well CSB BD collecled on 04/09/99 (cont.)

\section{F Analyte}

o 2.Hexanone Iron, tolal recoverablo

Lead, tolal recoverable

Magnesium, total recoverable Manganese, total recoverable

Mercury, tola recoverabio
Methoxychlor

Mathyl ethyl katone Methyl Isobutyl ketone
$2 \cdot$ Meithylnaphithalene Naphihalene
Nickel, total recoverablo Nickel, total reco
m-Nilroaniline

Pititrobenziline

2-Nitropheno

N-Nitrosodiphenylamine

PCB 1016

PCB 1232
PCE 1242
PCB 1248

PCB 1254
PCB 1260

Pentachlorophen

Potassium, total recoverable

Pyrene

Silver, total recoverable

Siyrene

Tetrachloroethylene
Thallium, total recoverable

Toluane
Total organic halogens

o $1,2,4$-Trichlorobenzene

$1,1,1$-Trichloroelhane
$1,1,2$-Trichloroethane

Trichloroethylene

2,4,5-Trichlorophenol

Vanadium, tolal recoverable

Vinyl acetate

Zinc, lotal recoverabte

Actinium-228

Carbon-14

Cesium-134

Cobalt.57.-

Europlum-152

Guropium-15s

loding-129

Manganese-54

Polassium-40

Promethium-144

1 Ruthenium-106

ESH-EMS-990521
Well CSB 8D collected on 04/09/99 (cont.)

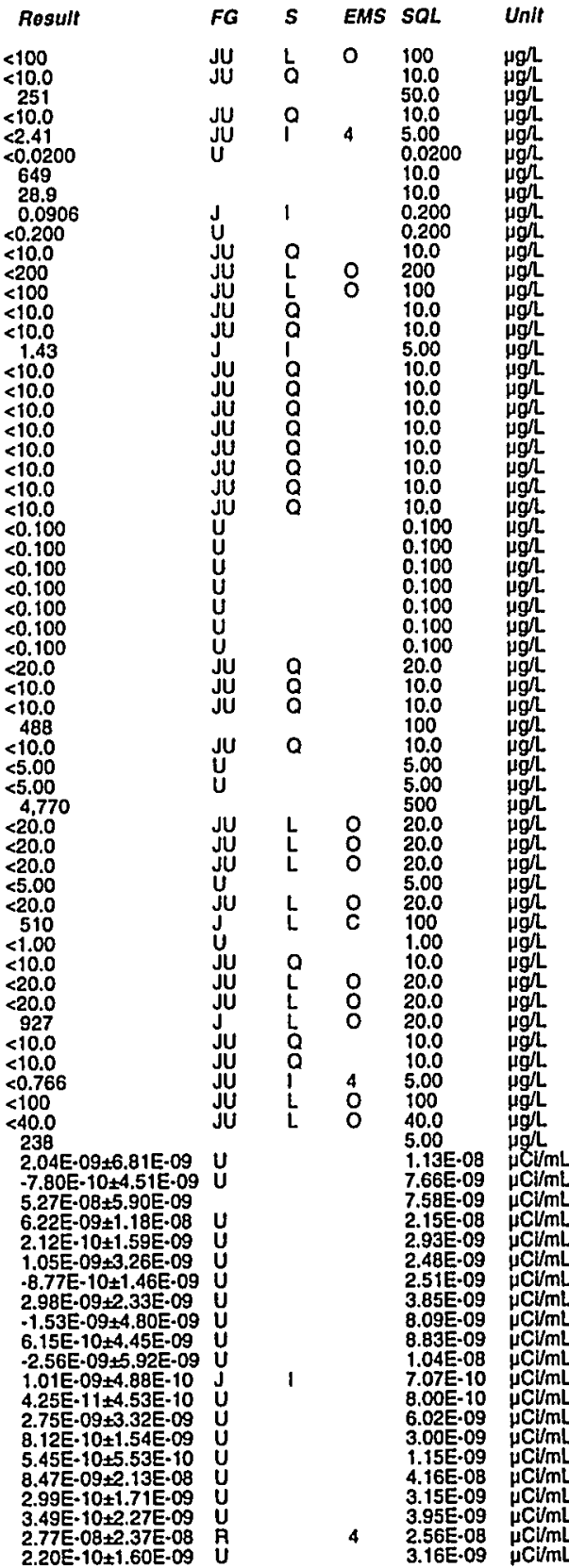

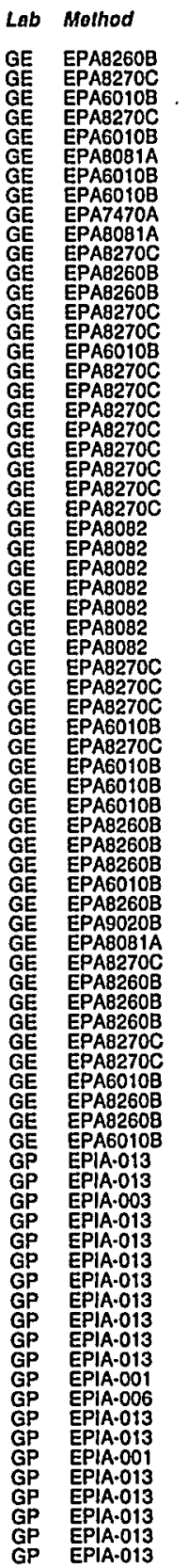

Rosult

FG

$\begin{array}{ll}0 & \text { Strontlum.90 } \\ 0 & \text { Technetlum-99 }\end{array}$

$7.54 \mathrm{E}-10 \pm 6.57 \mathrm{E}-10$
$-4.28 \mathrm{E}-09+6.78 \mathrm{E}-09$

2 Tritlum

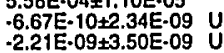

WELL CSB 9D

MEASUREMENTS CONDUCTED IN THE FIELD

Sampla data: 04/09/99

Water elevalion: $210.3 \mathrm{Ht}(64.1 \mathrm{~m}) \mathrm{ms}$

.

conductance: $45 \mu \mathrm{S} / \mathrm{cm}$

Water evacuated from the well prior to sampling: $20 \mathrm{gal}$

ANALYSES

F Analyto

0 Acenaphthene

0 Acetone

1 Aluminum, total recoverable

Anthracene
Antimony, total recoverable

Antimony, tofal recoverable
Arsenic, tolal recoverable

Barlum, lotal recoverablo

alpha-Benzene hexachloride
bela-Benzene hexachloride

dalla-Benzene hexachloride

Benzidine

Benzob bfluoranthen

Benzolc acld
Benzo(g,h,i)perylene

Benzola)pyren

Beryllium, total recoverable

ais

Bis (2-chlorolisopropyi) eth

Bis(2-ethylhexyl) phithal

Bromolorm

4-Bromophenyl phenyl elther

Cudmium, total recoverable

Calcium, fotal recoverablo

Carbon tetrachloride

gamma-Chlordane

Chlorobeaniline

4.Chloro-m-creso

Chloroethene (Vinyl chloride)

Chlorolorm

2.Chloronaphthalen

4.Chlorophennyl phenyl elhe

Chrsene,

Cobalt, tolat recoverable
Copper, total recoverable

0.Cresol (2-Methylphenol)

Pyanide
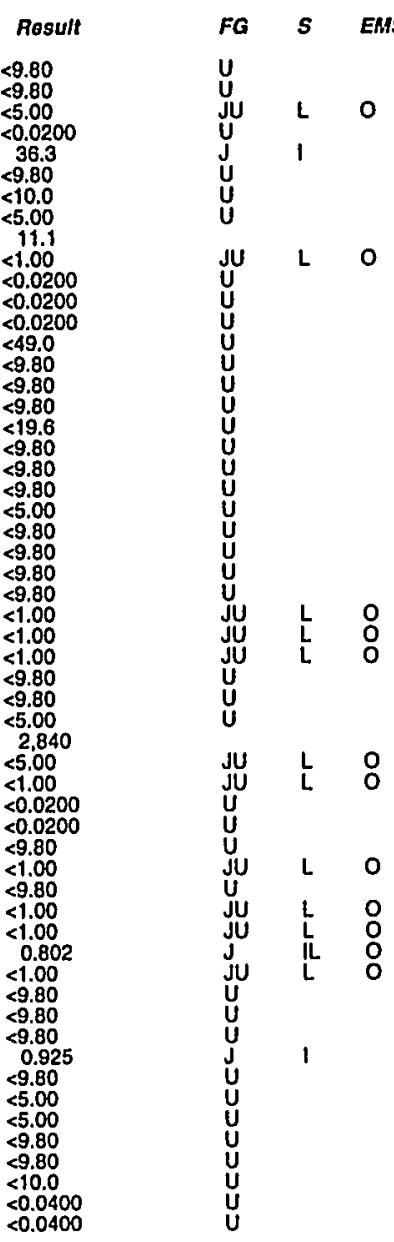

Time: 11:09

ir tementure: $21.6^{\circ} \mathrm{C}$

Total alkalinity (as CaCO3): $12 \mathrm{mgh}$

Phenolphihalein alkalinity: $0 \mathrm{mg} /$
Field Qualifier(s): $V$

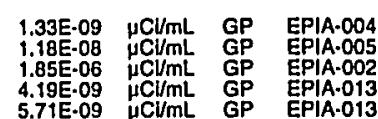

sat

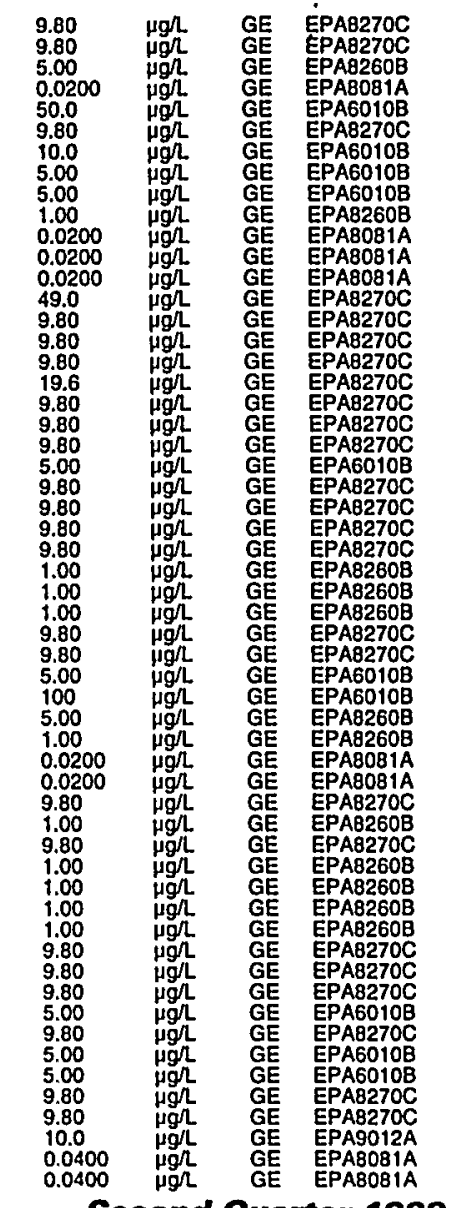

Second Quarter 1999 
ANALYTICAL RESULTS

Well CSB 9D collected on 04/09/99 (cont.)

\begin{tabular}{|c|}
\hline 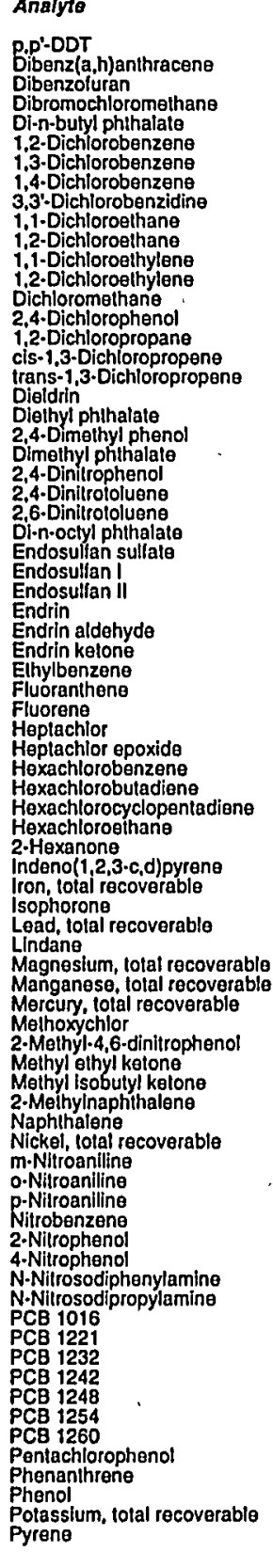 \\
\hline
\end{tabular}

ESH-EMS-990521

Well CSB SD collacted on 04/09/99 (cont.)

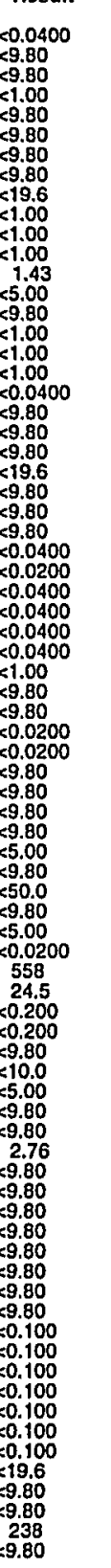

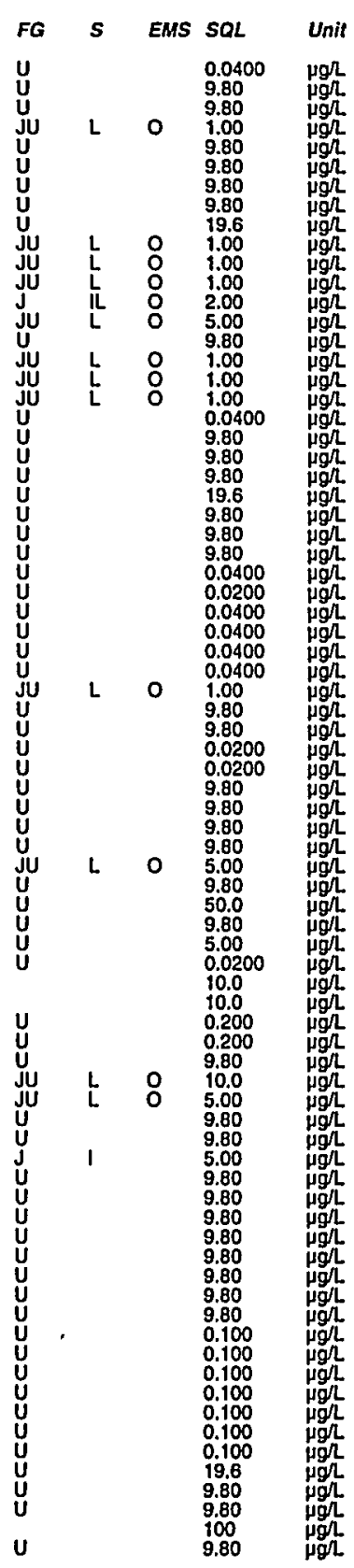

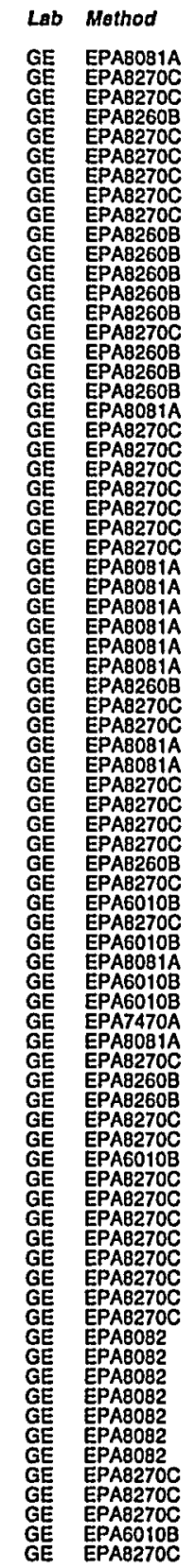

$F$ Analyte

- Solenium, tolal recoverable

Silver, tolal recoverable

1,1,2,2-Tetrachloroethane

Thatrachloroethylene

Toluene

T,2,4-Irichihorobenzene

$1,1,2$ - Trichloroethan

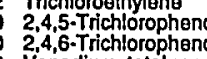

Vanadium, total recoverable

Vinyl acotate

Zinc, total recoverable

Anlimony-125

Cerium-144
Cesium-134
Cesium-137

Cobalt-57

$\begin{array}{ll} & \\ 0 & \text { Europpum-152 } \\ 0 & \text { Europium-154 } \\ 0 & \text { Europlum. } 155\end{array}$

Gross alpha

Lead-212

Manganese.54
Nonvolatile beta

Promethlum-144

Ruthenium 106

Srochnetium-90

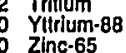

\section{WELL CSL 21D}

MEASUREMENTS CONDUCTED IN THE FIELD

Sample date: $04 / 13 / 99$

Water elevation: 245.59 tt $(74.86 \mathrm{~m}) \mathrm{ms}$

$\mathrm{pH}: 6.5$

Sp. conductance: $50 \mu \mathrm{S} / \mathrm{cm}$

Water evacuated from the well prior to sampling: $18 \mathrm{gal}$ ANALYSES

$F$ Analyto

o Acenaphthene

O Acelone

Aluminum, total recoverable

Antirimony, lotal recoverable

Arsenic, Iotal recoverable

alpha. Benzene hexachioride

beta. Benzene hexachloride

0
0 Benzidine
0 Benzo(a)anthracene
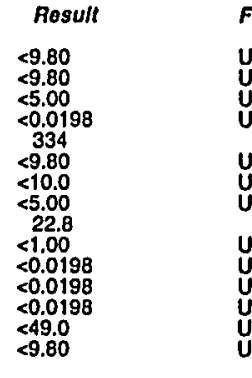

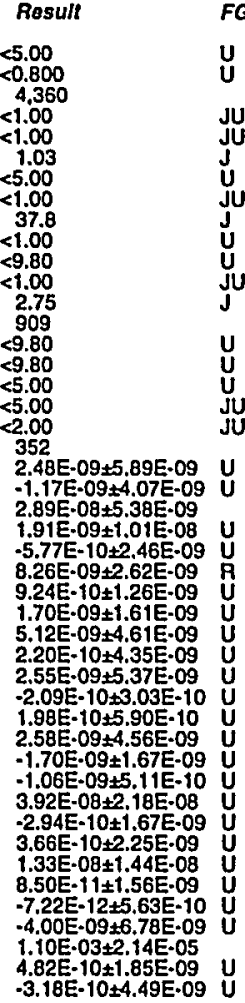

FG

EMS SO

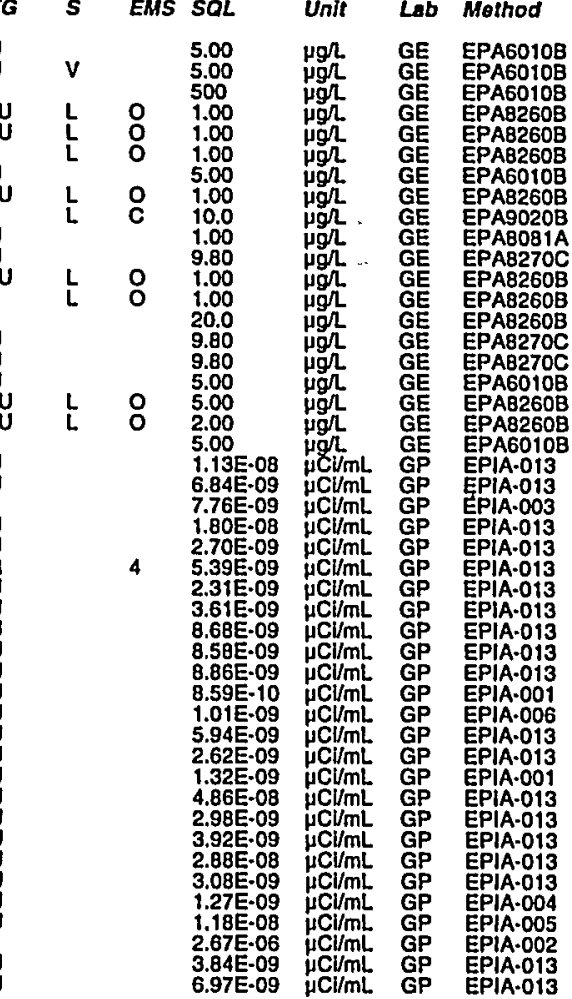

Time: 10:06

Alr temperature: $14.2^{\circ} \mathrm{C}{ }^{\circ} \mathrm{C}$

Total alkalinify (as Caco3): $15 \mathrm{mg} /$

Phenophthalein al
Field Quallfier(s): $v$

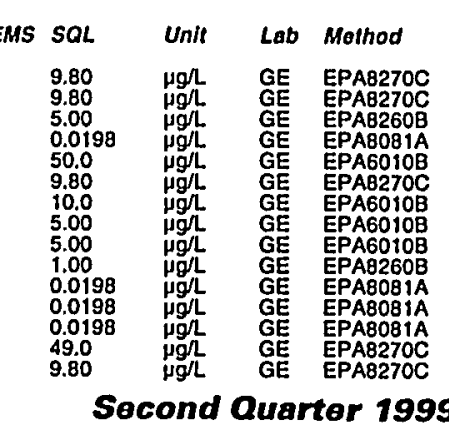


ANALYTICAL RESULTS

Well CSL 210 collected on 04/13/99 (cont.)

$F$ Analyto

o Benzo(b)fluoranthene

Benzolc acid

Benzo(g,h,l)perylene

Beryllum, tolal recoverable

Bis(2-chloroethoxy) methan

Bis 2 -chloroisopropyl) ether
Bis (2-ethythexyl) phithalate

Bromodichloromelhane

Bromolorm

4-Bromophanyl phenyl ether

Cadmium, total recoverable

Calcium, total recoverable

Carbon tetrachlorid

alpha.Chlordane
gamma.Chlordane

Chlorobenzene

4-Chloro-m-cresol

Chloroethen

Chloromethane
2.Chloronaphithalene

4-Chlorophenyl phenyl ether

Chrysene

C Copper, lotal recoverable

m/p-Cresol
0. Cresol (2-Methylphenol)

0 $\mathrm{pyanide}$

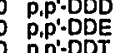

bibenz (a,n)anthracene

Dibromochloromethan

Di-n-butyl phihalate

1,3-Dichlorobenzene

1,4. Dichlorobenzene

1,1 -Dichloroethane

1,2-Dichloroethane

1,2-Dichloroethylen

2,4.Dichlorophenol

1,2-Dichloropropane

irans $-1,3$-Dichloropropen

Diel-yll phthalate

2,4-Dimethyl pheno

2,4-Dinitiophenol

$2,6-$ Dinitrotoluene
Di-n-octyl phthalate

Endosulfan sullate

Endosulfan !

Endrin aldehyde

Endrin ketone

Fluoranthene

o Heplachior

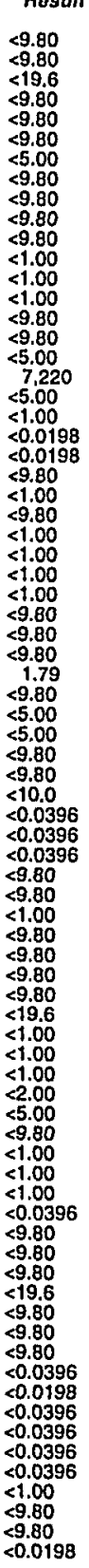

ESH-EMS-990521

Well CSL 21D collecled on 04/13/99 (conl.)

F Analyte

0 Heptachlor epoxide

o Hexachlorobutadiene

- Hexachlorocyclopen

O Indeno(1, 2,3-c,d)pyrene

0 isophorone

L Lad, tolal recoverable

L Magnesium, tolal recoverable

o Manganese, lotal recoverable

2-Methyl-4,6-dinitrophenol

Methyl ethyl kelone

0 Melhyl Isobutyl ketone
2-Methylnaphithalene

o Nickel, toral recoverable

o m-Nitroaniline

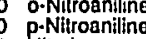

2-Nitrophenol

4-Nitropheno

N.Nitrosodiphenylamine

0
0

0
0

PCB 1248

0 PCB 1260

Pentachloropheno

0 Phenanthrene

o Potassium, tolal recoverable

o Pyrens

Solenium, total recoverablo

Sodium, total recoverable

o Styrene $1,1,2,2-$ Tetrachloroethane

Thetrachloroethylene

Toluene

$1,2,4$-Trichlorobenzene

1,i,2-Trlchloroethane

2,4,5-Trichloropheno

Vanadium, tolal recoverable

Vinyl acetate

Zinc, lotal recoverable

Antimony-125

Cosilum-134

Cobalt-60

0 Europium-152

Lead-212

o Nonvolatile beta

Promethium-146

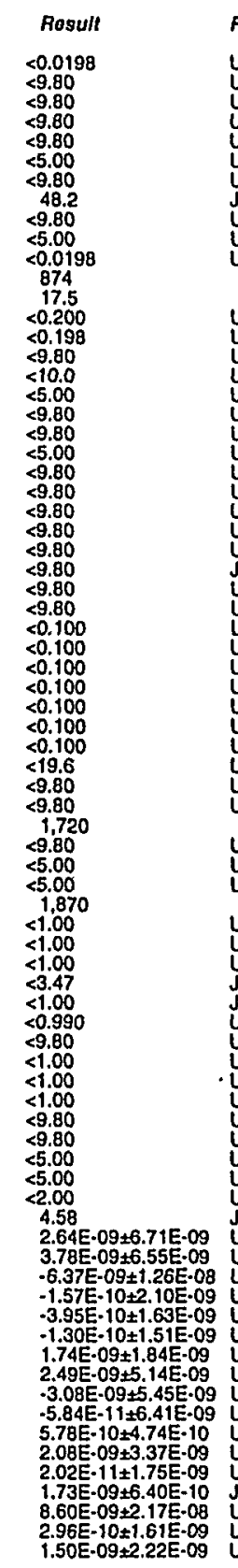

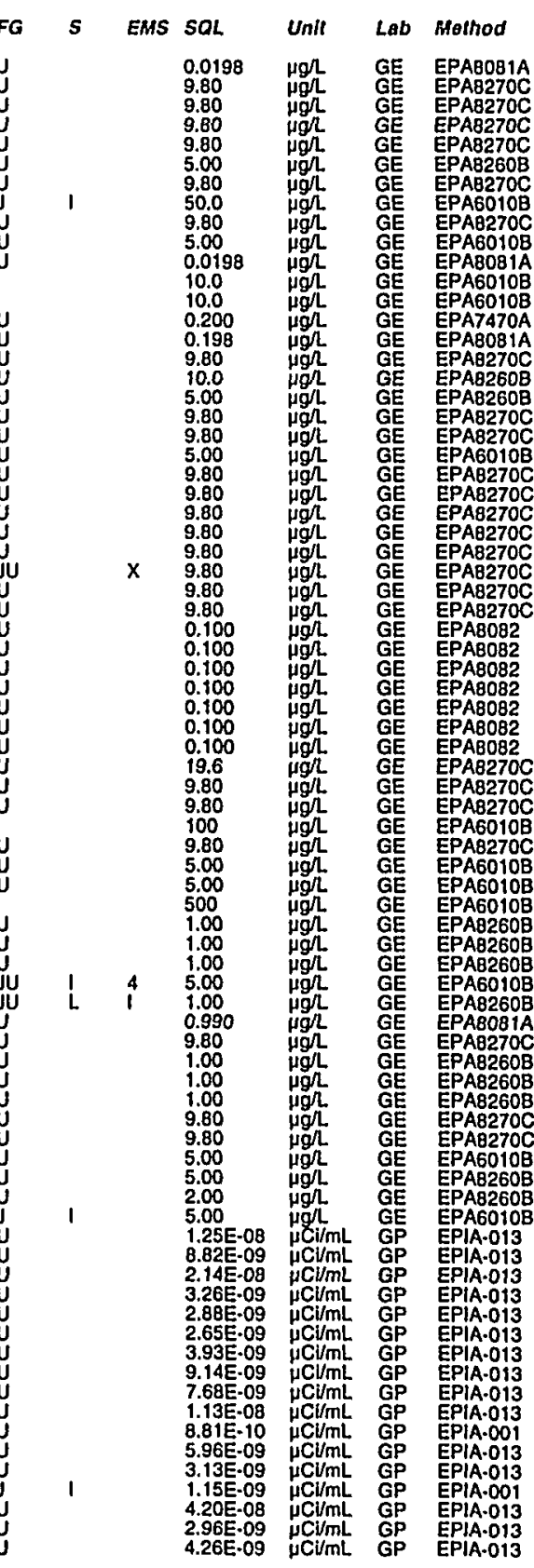


ANALYTICAL RESULTS

Well CSL 21D collected on 04/13/99 (cont.)

$F$ Analyo

Result

FG

EMS

Unit Lab Mothod

o Ruthenium-106

$4.87 E-09 \pm 1.49 E-08$
$-1.08 E-09 \pm 1.95 E-09$

$-1.08 E-09 \pm 1.95 E-09$
$1.36 E-09+1.81 E-09$
$-4.17 E-10 \pm 4$

WELL CSL 22D

MEASUREMENTS CONDUCTED IN THE FIELD

Sample date: 04/13/99

Wh: 4.2

Sp: conduclance: $22 \mu \mathrm{S} / \mathrm{cm}$

Water evacuated from the well prior to sampling: $14 \mathrm{gal}$

ANALYSES

$F$ Analyto

O Acenaphthene

Acenaphithlor
Acelone
Aldrin

Aluminum, total recoverable

Anlimony, tolal recoverable
Arsenlc, total recoverable

Arsenlc, itial recoverablo

alpha-Benzene hexachloride
bela. Benzene hexachloride
della:-Benzene hexachloride

Benzidine
Benzofa)anthracene
Benzobbifluoranthene

Benzolk)fluoranthene

Benzo(g,hi)perylen
Benzo(a)pyrene

Benzyllium, total recoverable

Bis(2-chloroethoxy) methan

Bis 2-chloroethyl) ether
Bis 2-chloroisopropyl) ether

Eis(2-ethylhexyl) phthalate

Bromolorm

4.Bromophanyl phenyl ether Butylbenzy! phithalate Calcium, total recoverable Carbon letrachlorid

alpha-Chlordane

4.Chloroanlline
Chiorobenzene

4.Chloro-meresol

Chloroethene (Vinyl chloride)

Chlorolorm

2.Chloronaphthalene

4.Chlorophenyl phenyl ether
Chromium, tolal recoverable

Chrysene

Cobalt, total recoverable

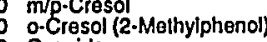

P.P'-DDD

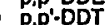

ESH-EMS-990521

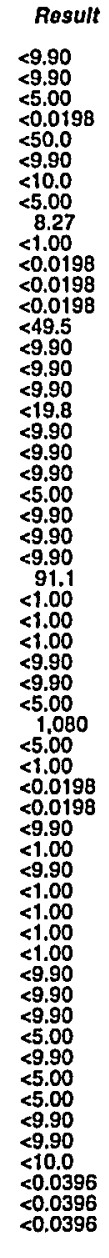

Time: 12:57

Air temperature $21.1^{\circ} \mathrm{C}$ Total aikalinity (as Caco3): $1 \mathrm{mg} /$

Field Qualifier(s): $v$

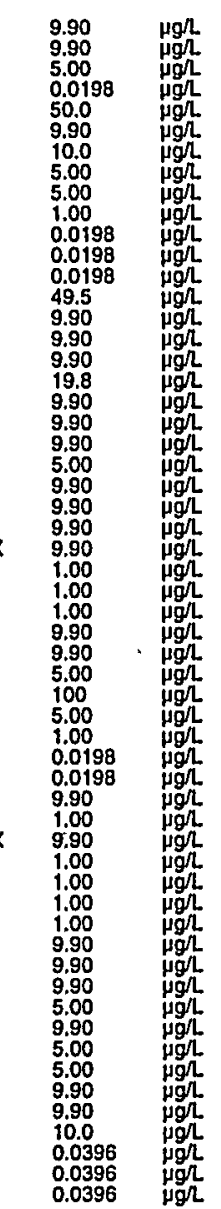

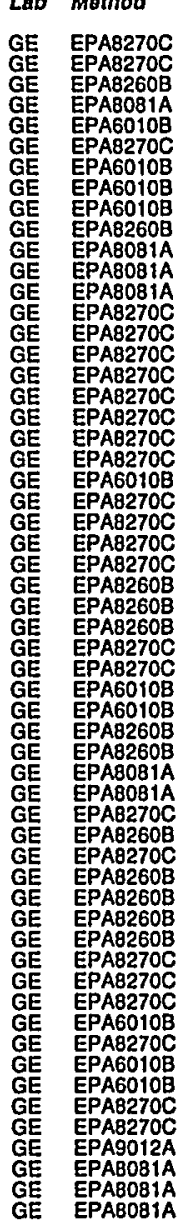

Well CSL 22D collected on 04/13/99 (cont.)
Result

O Dibenz(a,h)anthracene

Dibromochloromethane

Di-n-butyl phthalate

1,2-Dichlorobenzen

3,3'-Dichlorobenzidine

1.1.Dichloroethan

1,2-Dichloroeshylene

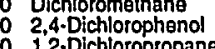

cis-1,3-Dichloropropene
0 irans-1,3-Dichloropropene

Dieldrin

o Diethy! phithalate

2,4-Dinitrophenol

$2,4-$ Dinitrotoluene
$2,6 \cdot$ Dinitrotoluenene

OI-n-octyl phthalate

Endosullan I

0 Endrin aldehyde

Endrin ketone

Heptachior

Heptachlor epoxide

Hexachlorobutadieng

Hexachlorocyclopen

2.Hexanone

Indeno(1,2,3-c,d)pyrene
Iron, tolai recoverable

Lead, total recoverable

Magneslum, total recoverable Manganese, total recoverab

Methoxychlor
2-Melhyl-4,6-dinitropheno

Methyl elhyl ketone

Methyl isobutyl katon
2.Mehthylnaphithalene

Naphihalone

作-Nitroaniline

o. Nitroaniline

Nitrobenzene

2-Nitrophenol
0. -Nitrophenol

N-Nitrosodiphenylamine

0 PCB 1016

0 PCB 1232

0 PCB 1254
0 PCB 1260

- PCB 1260

o Phenanthrene

Phenanthrene
Phenol

Polassium, total recoverable

- Pyrene, sontum, tolal recoverable

B-67

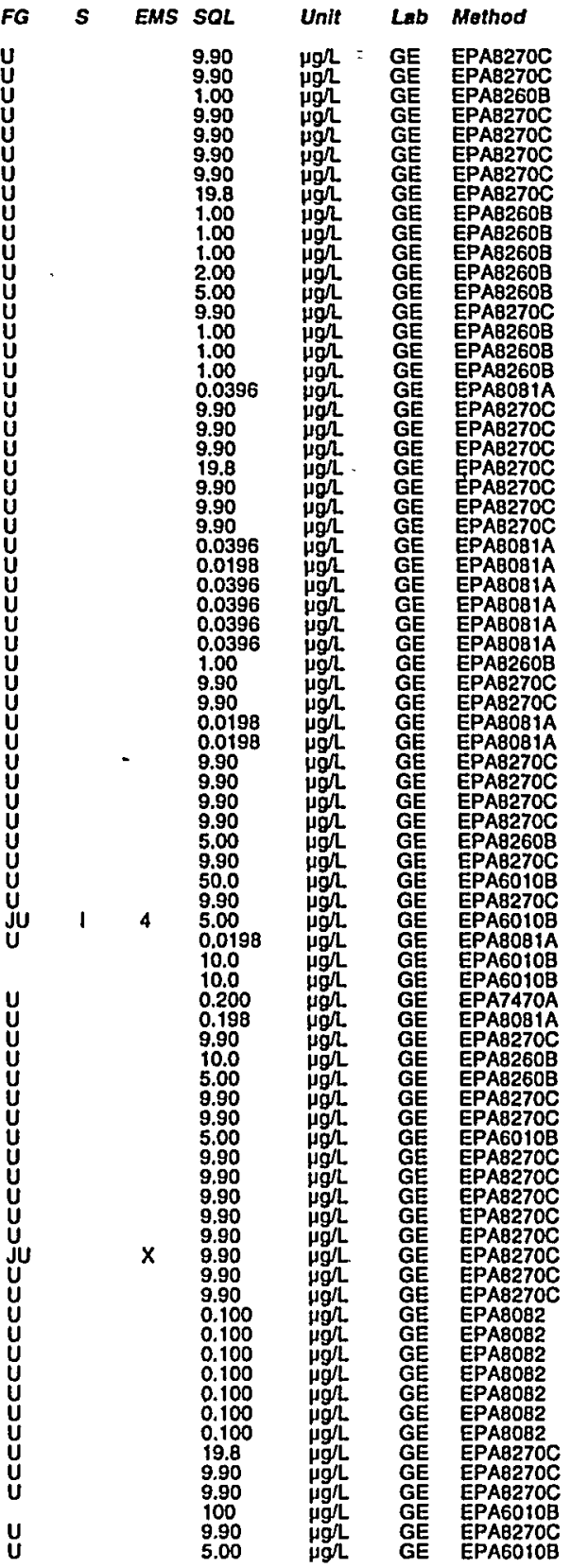

Socond Quartor 1999 
Well CSL 22D collected on 04/13/99 (cont.)

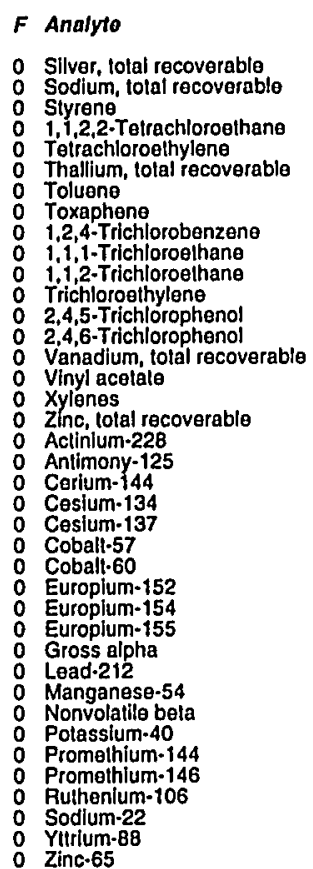

\section{WELL CSL 23D}

MEASUREMENTS CONDUCTED IN THE FIELD

Sample date: 04/13/99 23 m below TOC

Depth to waler: $38.82 \mathrm{ft}(11.83 \mathrm{~m})$ below
Water elevation: $245.98 \mathrm{ft}(74.98 \mathrm{~m}) \mathrm{ms}$

$\mathrm{pp}$. conductance: $34 \mu \mathrm{S} / \mathrm{cm}$

Waler evacualed from the well prior to sampling: $18 \mathrm{gat}$

ANALYSES

$F$ Analyto

: Acenaphthene

Acenaphth
Acetone
0 Aldrin

Aluminum, lotal recoverable

Anthracene

Arsanlc, total recoverable

alpha.-Benzene hexachloride

o bela-Benzene hexachloride

Benzidine

Benzo b)fluoranthene

Benzoic acid

Benzo(g,hi)peryl

Benylium, lotal recoverable

ESH-EMS-990521

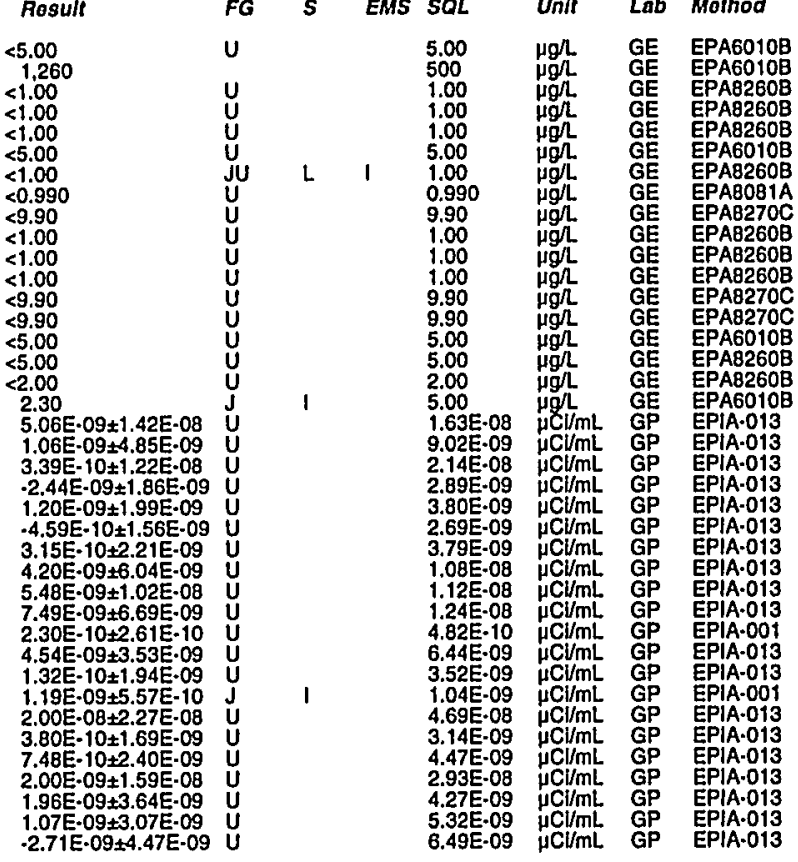

Time: 12:03

Aotal alkalinity: (as CaCO3): $2 \mathrm{mg} /$

Phenolphthalein al

$F$ Analyto

: Bis(2-chloroethoxy) methane

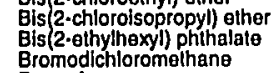

Bromolorm

$\begin{array}{ll}0 & \text { Bromomethane } \\ 0 & 4 \text {-Eromophenyl phenyl ether }\end{array}$

Bulylbenzyl phinalaie

Calcium, tolal recoverable

Carbon titruchlorido

gama-Chiordane

o $\begin{array}{ll}\text { 4-Chloroanlline } \\ 0\end{array}$

4.Chloro-m-cresol

Chloroothene (Vinyl chloride)

Chloroform

2-Chloronaphthalene

0 4.Chlorophenyl phenyi ether

Chromlum, toial recoverabla

: Chrysene

Copper, tolal recoverable

: m/g-Cresol

: Cyanide

p.p.'DDE

O Dibbenz(a,h)anthracene

Dibromochloromethan

Di-n-butyl phithalale

o 1,3.Dichlorobenzene

3,3'-Dichlorobenzidin

1,2.Dichloroeshane

i.,-Dichloroethylene

2,4-Dichlorophenol

1,2-Dichloropropane

cis-1,3-Dichloropropene

Dieldrin phichalate
Diethyl phinhala
2,4 -Dimethyl phenol

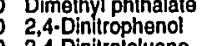

$2,4-$ Dinitrololuene
$2,6 \cdot$ Dinitrololuene

Di-n-octyl phithalate

Endosultan I

Endosullan II

Endrin aldehyde

Ethylbanzen

Fluorene

Heplachlor epoxide

Hexachlorobenzenene

Hexachlorocyclopentadien

Hexachloroethan

2.Hexanone
indeno(1,2,3-c,d)pyrene

$<9.90$

$<9.90$
$<9.90$
$<1.00$

$<1.00$
$<1.00$
$<9.90$
$<9.90$
$<5.00$

1,250
$<5.00$
$<1.00$

0.0518
0.0257
$<9.90$

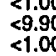

$<\begin{array}{r}<1.00 \\ <1.00\end{array}$

$<1.00$
$<1.00$
$<9.90$

$<9.90$
$<9.90$
$<9.90$

3.90
$<5.00$

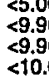

$<0.0396$
$<0.0396$
$<0.0396$

s.

$\int_{<1.00}<9.90$

$<9.90$

$\leq 19.8$

$<1.00$
$<1.00$
$<1.00$
$<2.00$

$<1.00$
$<2.00$
$<5.00$
$<9.90$

$<9.90$
$<1.00$
$<1.00$

$<0.0396$

$<9.90$

$<19.8$
$<9.90$
$<9.90$

$<9.90$
$<0.0396$
$<0.0198$
$<0.0396$
$<0.0396$
$<0.0396$
$<0.0396$
$<1.00$
$<9.90$
$<.90$
$<0.019$
$<0.019$
$<9.90$
$<9.90$
$<9.90$
9.90
55.00
$<9.90$

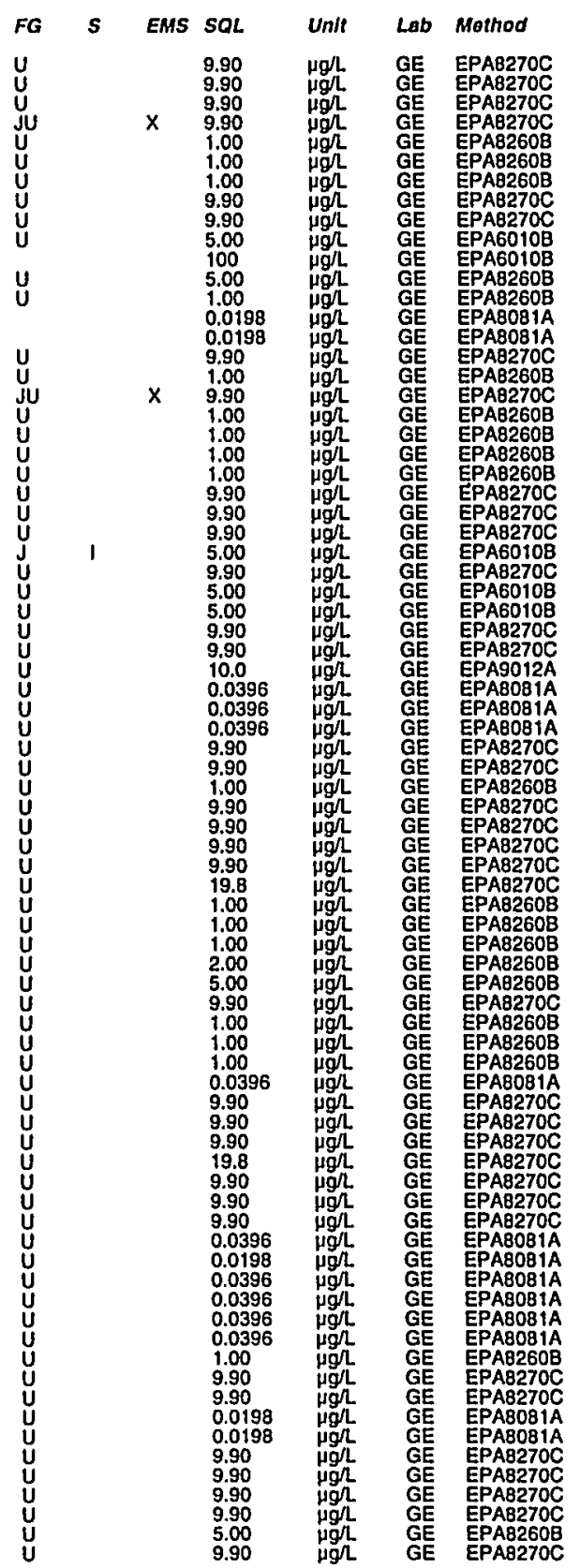

Second Quarter 1999 
Well CSL 23D collected on 04/13/99 (cont.)

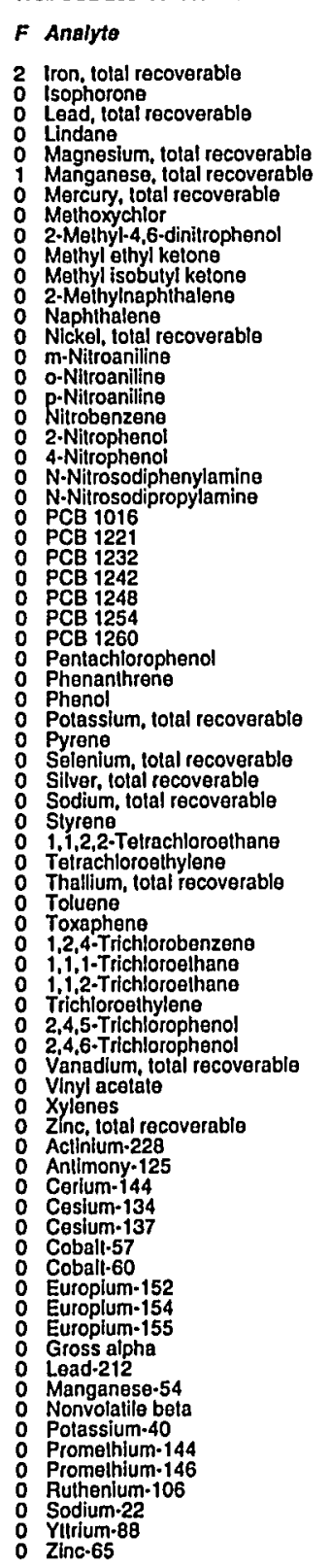

Result

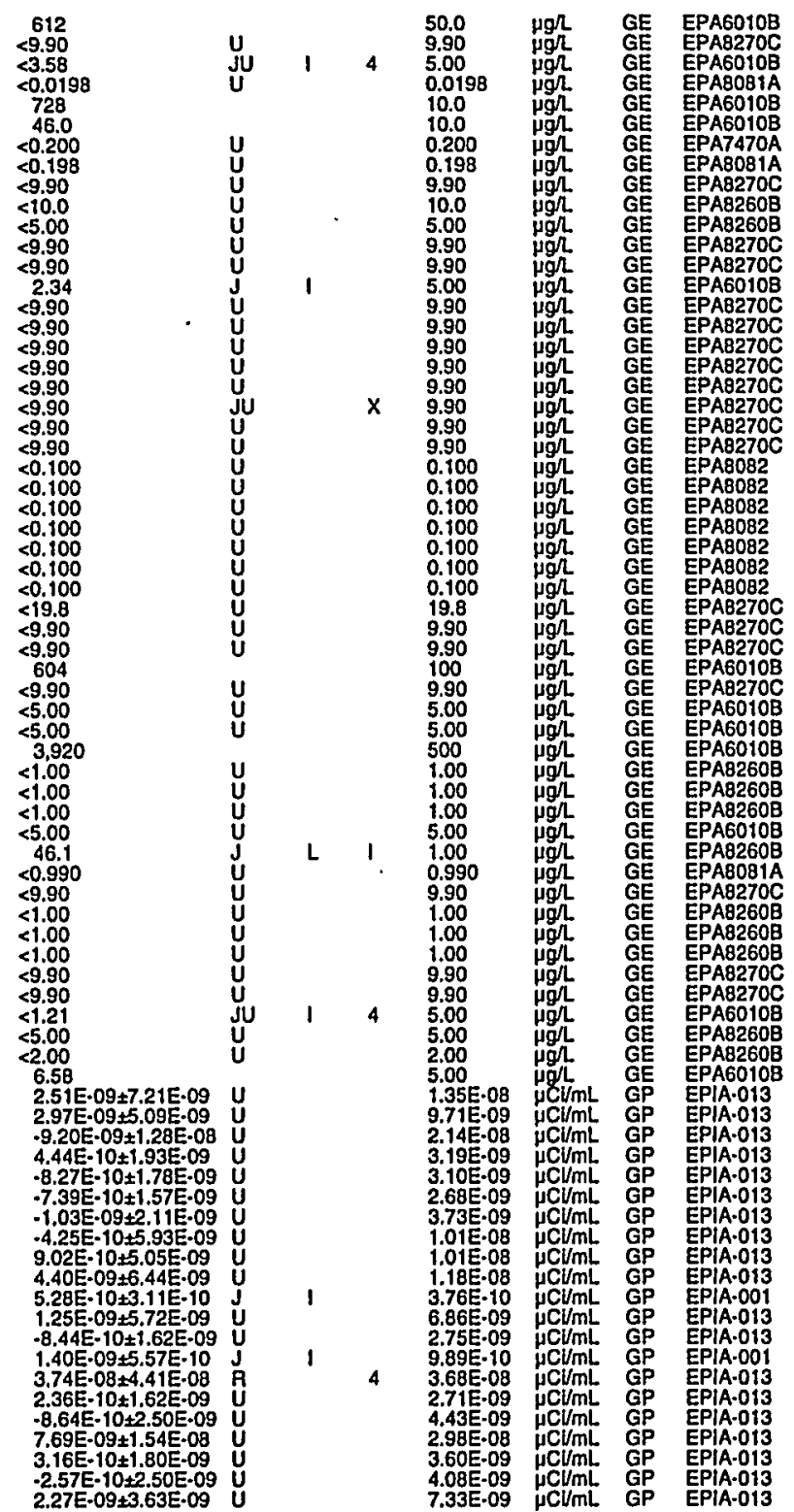

WELL CSL 23D

MEASUREMENTS CONDUCTED IN THE FIELD

Sample date: 04/28/99
Depth lo water: $39.52 \mathrm{~h}(12.05 \mathrm{~m})$ below TOC
Water elevation: $245.28 \mathrm{tt}(74.76 \mathrm{~m}) \mathrm{msl}$

Water

$\mathrm{Sp}$. conduclance: $34 \mu \mathrm{S} / \mathrm{cm}$

Wurbidity: $4 \mathrm{NTU}$ U. ANALYSES

$F$ Analyte

Resuit

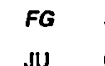

EMS SOL

- Chromium, hexavalent

$\ll 20.0$

JU $Q$

20.0

Hgl. GE EPA7196A

WELL CSL 24D

MEASUREMENTS CONDUCTED IN THE FIELD

Sample date: $04 / 13 / 99$

Waler elevalion: $246.34 \mathrm{t}(75.09 \mathrm{~m}) \mathrm{ms}$

PH: 4.6 conductance: $18 \mu \mathrm{s} / \mathrm{cm}$

Waler evacuated from the well prior to sampling: $26 \mathrm{gal}$

Air temperperature: $19^{\circ} \mathrm{C}$

Total alkalinily (as Cacos): $0 \mathrm{mg}$

ANALYSES

F Analyte

0 Acenaphthene

O Acenaphi

2 Aldrin

Antimony, Iotal recoverable

Arsenlc, total recoverable

Benzene

bela-Benzene hexachloride
della-Benzene hexachloride

Benzidina

Benzo(a)anthracene

Benzolkilluoranthene

Benzo(gh,i)perylene

O Benzo(a)pyrene

o Beryllium, total recoverable

EIs (2-chloroethoxy) methan
BIs 2.chlorogthy) ether

Bis 2.chlorolsopropyl) ether

Bromodichloromethane

Bromolorm

4. Bromophenyl phenyl ather

Cadylbenzyl phthalate

Calcium, iotal recoverablo

Carbon disullido

o gamma.Chlordane

4.Chloroanillne

$\begin{array}{ll}0 & \text { Chlorobenzene } \\ 0 & 4 \text {-Chloro-m.cresol }\end{array}$

Chloroethene (Vinyl chloride)

Chloromerm

$\begin{array}{ll}0 & \text { Chloromethane } \\ 0 & 2 \cdot C h l o r o n a p h t h a \\ 0 & \end{array}$

4.Chlorophenyl phenyl ether

$-69$

Result
$<9.90$
$<9.90$
$<5.00$
$<0.0200$
79.2
$<9.90$
$<10.0$
$<5.00$
17.7
$<1.00$
$<0.0200$
$<0.0200$
$<0.0200$
$<4.5$
$<9.90$
$<9.90$
$<9.90$
$<19.8$
$<9.90$
$<9.90$
$<9.90$
$<5.00$
$<9.90$
$<9.90$
$<9.90$
$<9.90$
$<1.00$
$<1.00$
$<1.00$
$<9.90$
$<9.90$
$<5.00$
913
$<5.00$
$<1.00$
$<0.0200$
$<0.0200$
$<9.90$
$<1.00$
$<9.90$
$<1.00$
$<1.00$
$<1.00$
$<1.00$
$<9.90$
$<9.90$
$<9.90$
1.71

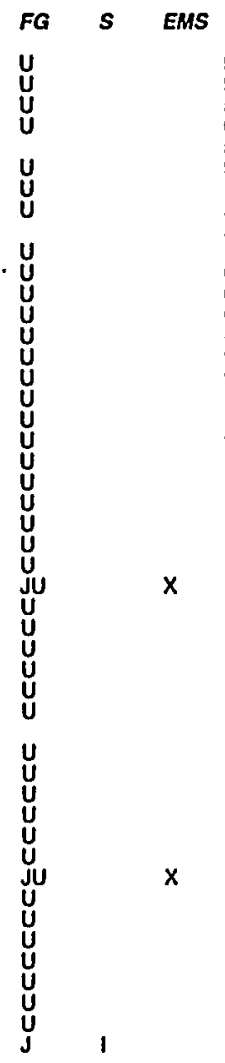

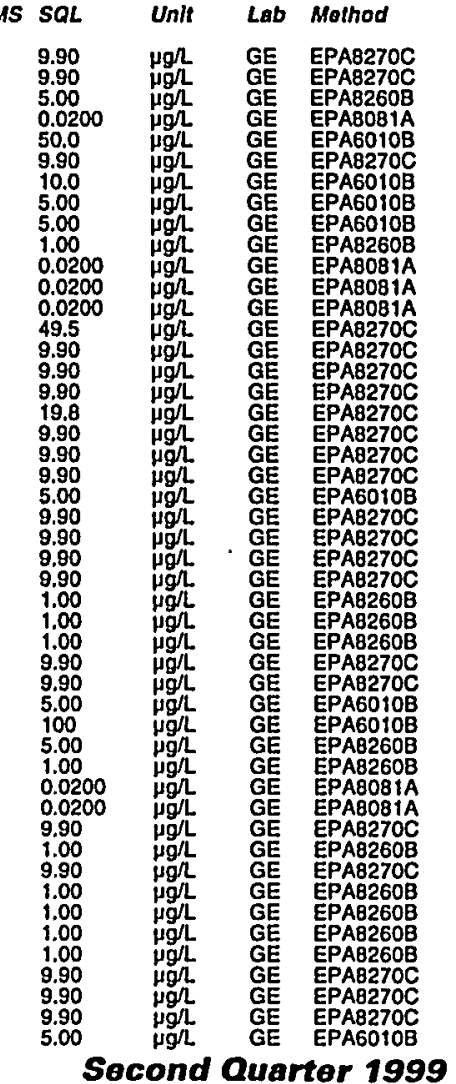


Well CSL 240 collected on 04/13/99 (cont.)

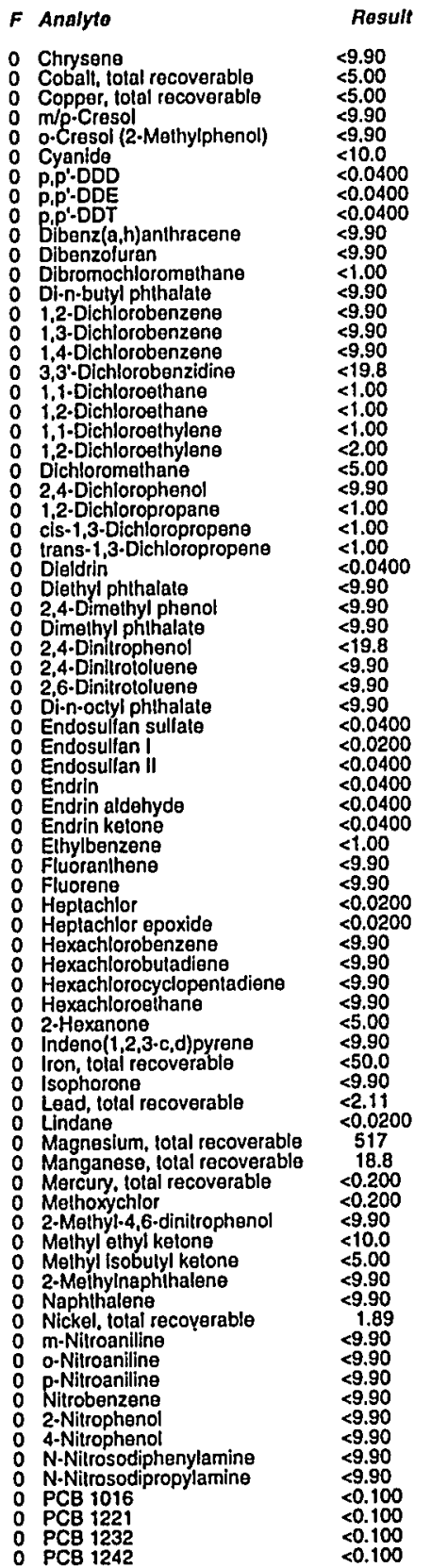

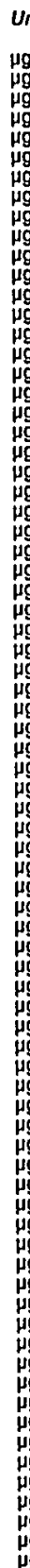

ESH-EMS-990521

Well CSL. 24D collected on 04/13/99 (conl.)

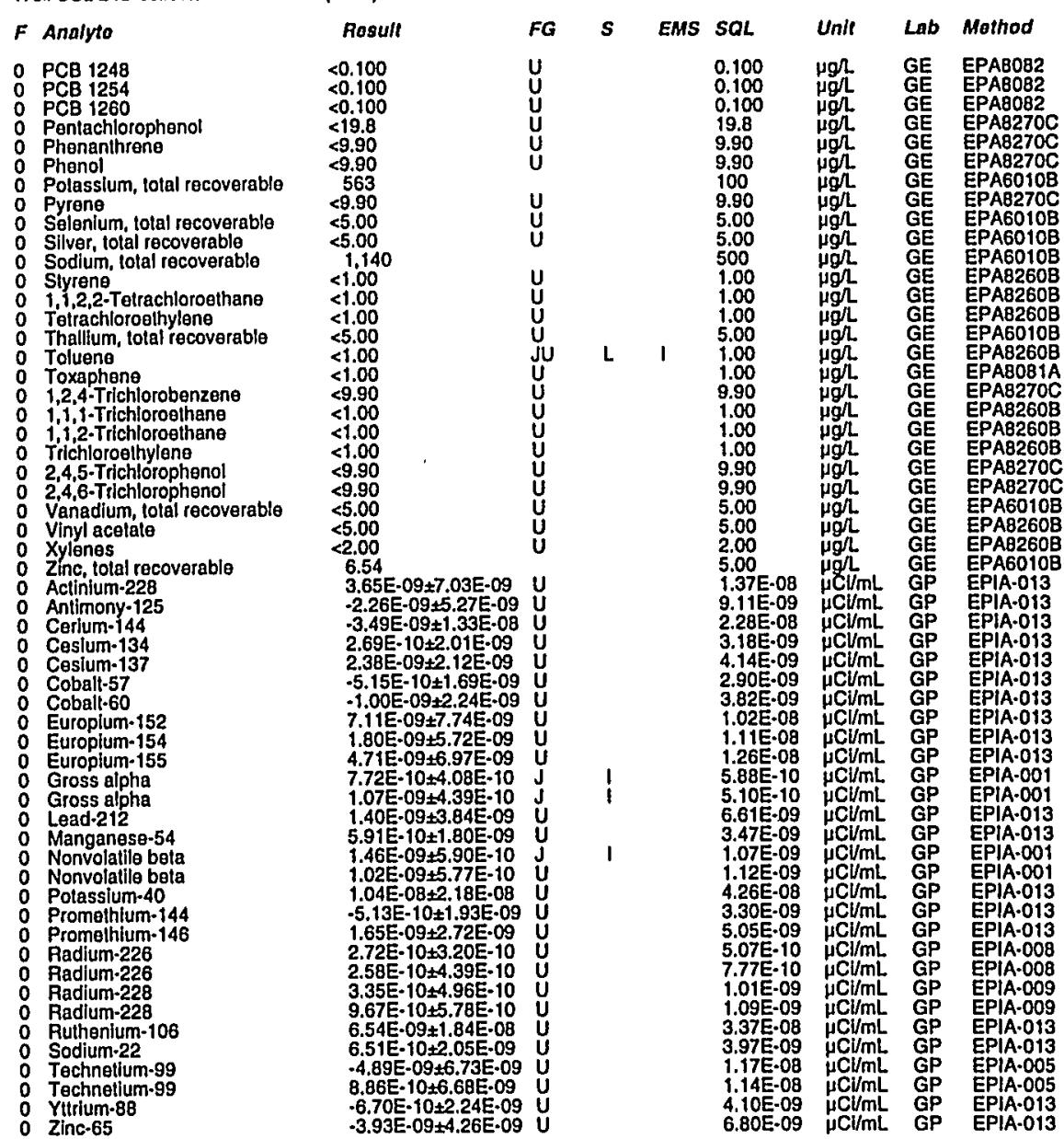

\section{WELL CSL 24D}

MEASUREMENTS CONDUCTED IN THE FIELD

Sample date: 04/28/99
pH: 4.7

conductance: $21 \mu \mathrm{S} / \mathrm{cm}$

Turbidity: 0 NTU
Water evacuated from the well prior to sampling: $15 \mathrm{gal}$

ANALYSES

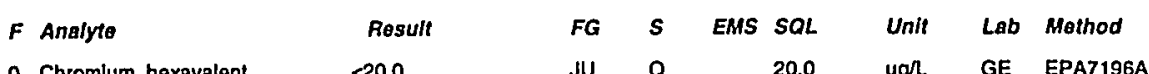

Time: 11:42

Water temperature: $19^{\circ} \mathrm{C}$

Alr

Phenolphthalein alkalinity: $0 \mathrm{mg}$.
Field Qualifier(s): $V$

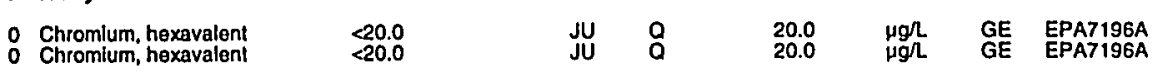


WELL CSL 25D

MEASUREMENTS CONDUCTED IN THE FIELD

Sample data: 04/14/99 $12.0 \mathrm{~m}$ ) below TOC

婓p: 5.2 .2 conductance: $32 \mu \mathrm{s} / \mathrm{cm}$

Waler evacuated from the well prior to sampling: $1 \mathrm{gal}$ The well went dry during purging

ANALYSES

$F$ Analyte

: Acenaphithene

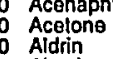

Atuminum, lotal recoverable

Antimation, lotal recoverablo

Arsentic, tolal recoverable
garium, total recoverabile

alpha-Benzene hexachloride

beta-Benzzene hexachloride
della-Benzene hexachlorido

Benzicina analhracene

Benzob) filuoranthene

0 Benzolic acid

Benzo(a)pyene

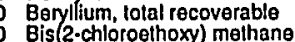

Bis 2 -chloroethoxy) melthan
Bis 2 -chloroethyl) ether

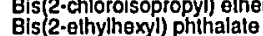

Bromodichloromelhan

4-Bromophenyl phenyl ether

Butylbenzyl hhithalate
Cadmium tolal recoverable
Calcium, iotal recoverable

Carbon disullidide
0 Carbon tetrachloride

alpha.Chlordane

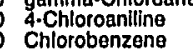

4.Chloro-m-cresol

Chloroeshane (Vinyl chloride)

Con
0 Chorolorm
0

Chloromethane
2.CChloronaphthalene

2.Chlorophenol
4.Chlorophenyl phenyl alt

0 Chromium, toral recoverable

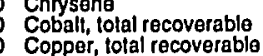

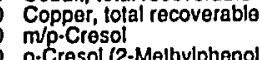

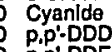

: P.p:DDE

Gibenz(a,h)anthracene

Dibromochloromethan

Di-n-butyl phihalate

$\begin{array}{ll}0 & 1.3-3 \text { Dichlorobenzene } \\ 0 & \text { i.4. Dichlorobenzene }\end{array}$

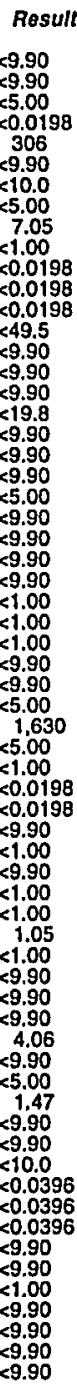

ESH-EMS-990521

Well CSL 25D collected on 04/14/99 (cont)

F Analyto

Time: 12:30

Air

Total alkalinity (as CaCO3): $5 \mathrm{mg} / \mathrm{L}$
FG $S$ EMS SQL UnI

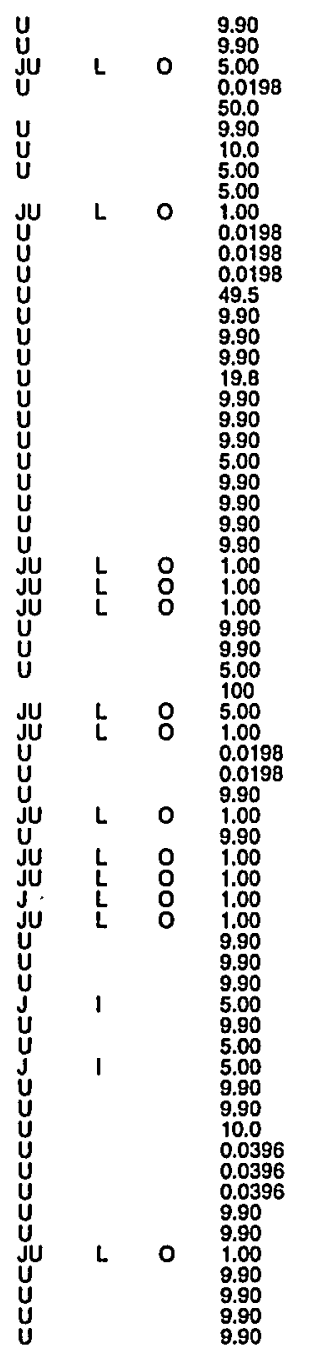

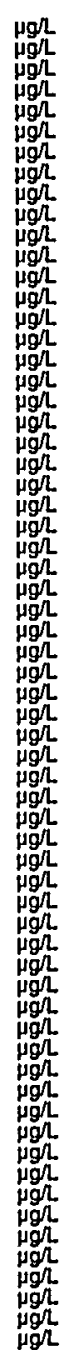

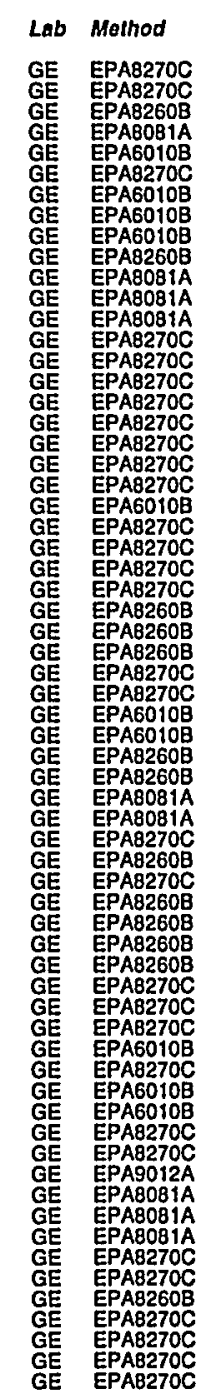

2,4-Dinitrophenol
0 3,3'-Dichlorobenzidine

1,2-Dichloroethan

1,1-Dichloroethylene

Dichloromethane
2,4-Dichloropheno

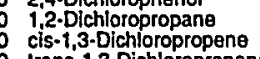

0 Dinstrin
Diethy! phichlorata

2,4-Dimethyl phen

Result

$<19.8$

$<.1 .00$
$<1.00$
2.00
$<5.00$
$<9.90$
$<1.00$
$<1.00$
$<0.00$
$<9.0$

Din-octyl phihalate
Endosulfon sulfale

Endosullan I

Endrin aldehyde

0 Endrin ketone

Fiuorene

Heptachlor

Hexachlorobenzene

Hexachlorocyclopen

2.Hexanone
Indeno(i,2,3-c,djpyrene

0 isophorona

Lead, tolal recoverable

Magnesium, lotal recoverable

Manganese, lotal recoverable

Mercury, total recoverable

2-Methyl.4,6-dinilropheno

Melhyl elhyl ketone

Naphthalene

Nickef, tolal recoverable

m-Nitroaniline
o.Nitroaniline

: Pitrobanzentilne

2-Nitropheno

: N.Nilrosodiphenylamine

0
0

PCB 124

PCB 1248

Pentachloropheno

Phenanthrene

Potassium, total recoverable

o Pyrene , Lotal recoverable

Silver, total recoverable

Styrene

Thallium, total recoverable
o Toluene

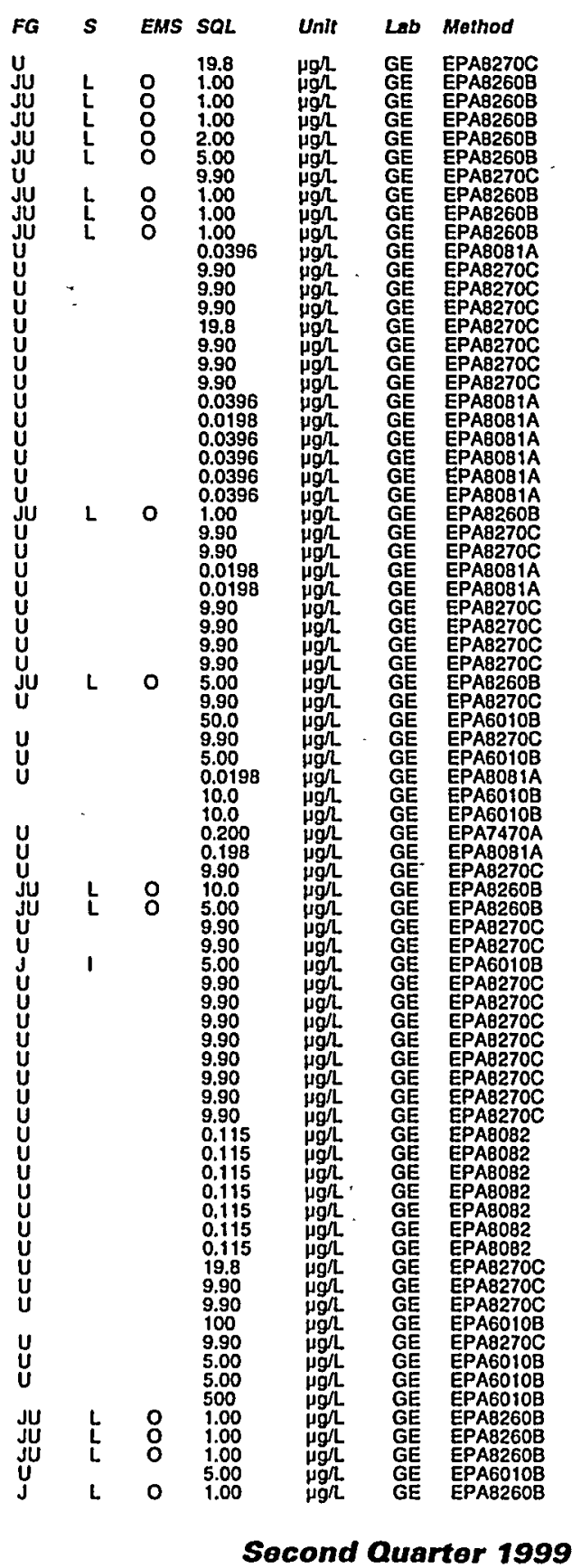


Well CSL 25D collected on 04/14/99 (cont.)

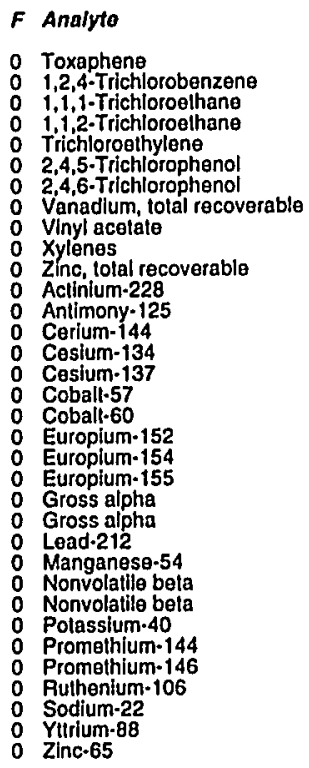

\section{WELL CSL 26D}

MEASUREMENTS CONDUCTED IN THE FIELD

Sample date: $04 / 14 / 99$
Depth to waier: $38.69 \mathrm{tt}(11.79 \mathrm{~m})$ below TOC
Water elevation: $246.11 \mathrm{ft}(75.02 \mathrm{~m}) \mathrm{ms}$
pH: 4.4 .
Sp.conductance: $30 \mu \mathrm{S} / \mathrm{cm}$

Sp.conductance: $30 \mu \mathrm{N} / \mathrm{cm}$
Walidity: $2 \mathrm{NTU}$.
Wacualed from the well prior to sampling: $18 \mathrm{gat}$ ANALYSES

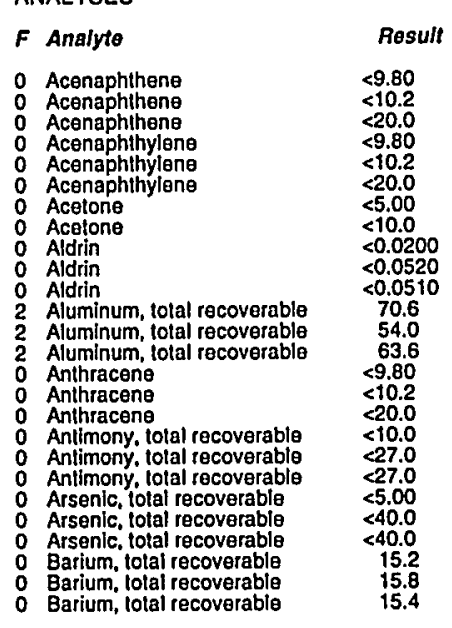

ESH-EMS-990521
Well CSL 26D collected on 04/14/99 (cont.)

\begin{tabular}{|c|c|c|c|c|c|c|c|}
\hline Rosult & $F G$ & $s$ & EMS & $S Q L$ & Untt & Lab & Mothod \\
\hline 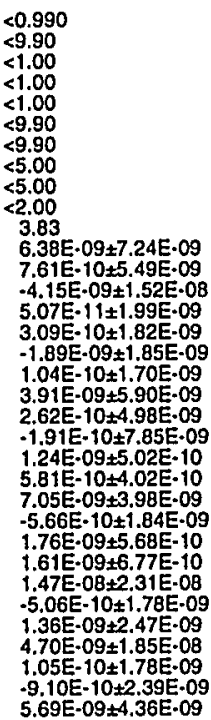 & $\begin{array}{l}\mathbf{U} \\
\mathbf{J} \\
\mathbf{J U} \\
\mathbf{J U} \\
\mathbf{U} \\
\mathbf{U} \\
\mathbf{U} \\
\mathbf{J U} \\
\mathbf{J U} \\
\mathbf{J} \\
\mathbf{U} \\
\mathbf{U} \\
\mathbf{U} \\
\mathbf{U} \\
\mathbf{U} \\
\mathbf{U} \\
\mathbf{U}\end{array}$ & $\begin{array}{l}\mathbf{L} \\
\mathbf{L}\end{array}$ & $\begin{array}{l}\circ \\
:\end{array}$ & 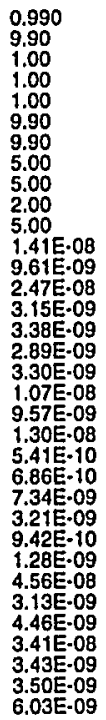 & 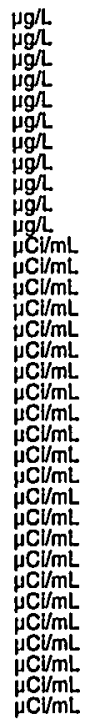 & $\begin{array}{l}G E \\
G E \\
G E \\
G E \\
G E \\
G E \\
G E \\
G E \\
G E \\
G E \\
G E \\
G P \\
G P \\
G P \\
G P \\
G P \\
G P \\
G P \\
G P \\
G P \\
G P \\
G P \\
G P \\
G P \\
G P \\
G P \\
G P \\
G P \\
G P \\
G P \\
G P \\
G P \\
G P \\
G P\end{array}$ & 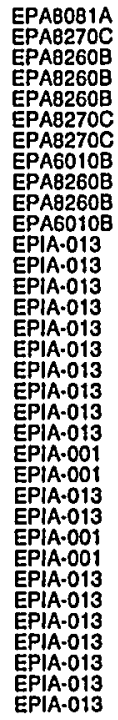 \\
\hline
\end{tabular}

Analyto

0 Benzena

o alpha-Benzene hexachlorido

alpha-Benzene hexachloride

beta. Benzene hexachloride

beta-Benzene hexachloride

della.Benzene hexachloride

o della.Benzene hexachlo

Benzo(a)anthracene
Benzogajanthracene

Benzo a anthracene

Benzolb fluoranthen

Benzo (k) fluoranthene
Eenzo (kfiluoranthene

Benzo(k)lluoran

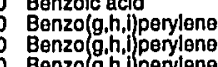

Benzog,hi,

Benzola pyrane

Benzyl alcohol

Beryllium, tolal recoverable

Bis(2-chloroethoxy) methane

Bis 2-chlorothexthy mathan

Bis
Bis 2-chloroethyly ether
Bis 2-chloroethyl ether

Bis 2-chloroethy) ether

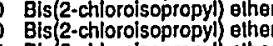

Bis 2-ethylhexyl) phthalate

Bis 2 -ethythexy) phithalate
Bis(2-ethythexyl) phithalate

Bromodichloromethane

Bromolorm
Bromoform

Bromomelthane

4-Bromophenyl phenyl ether 4.-Bromophenyl phenyl ether Butylbenzy! phthalate Butybenzyy phthalate Cadmium, total recoverable Cadmium, total recoverable recoverable Cadmium, tolal recoverable Calcium, lotal recoverable Calcium, total recoverable C Carbazolo

Carbon disullide

Carbon tetrachloride

alpha-Chiordane
alpha-Chlordane
alpha-Chlordane

gamma-Chlordane

gamma.Chlordane

4-Chloroaniline

4.Chloroanlline

B-72

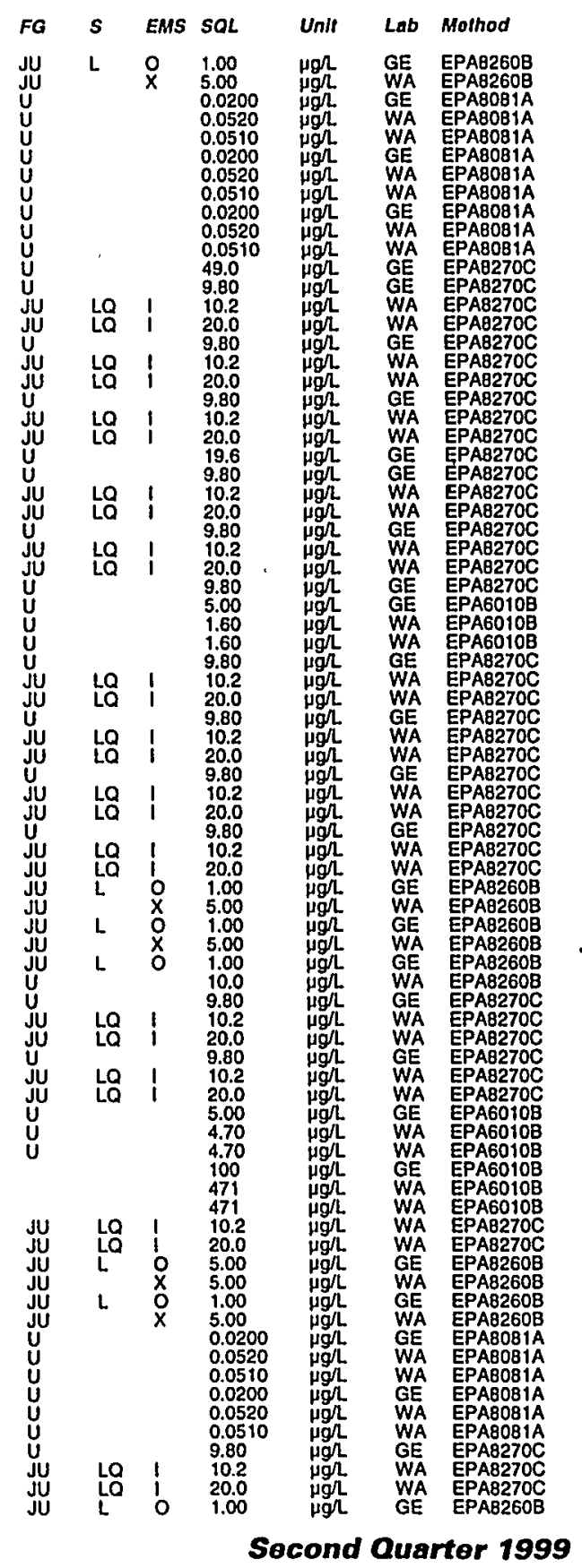


Well CSL 26D collected on 04/14/99 (conl.)

$F$ Analyte

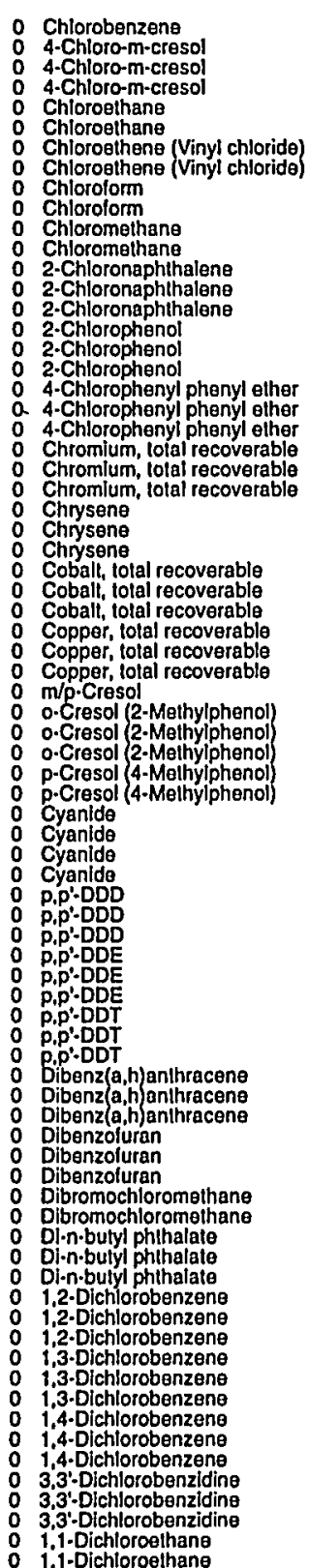

ESH-EMS-990521
Well CSL 26D collected on 04/14/99 (cont.)

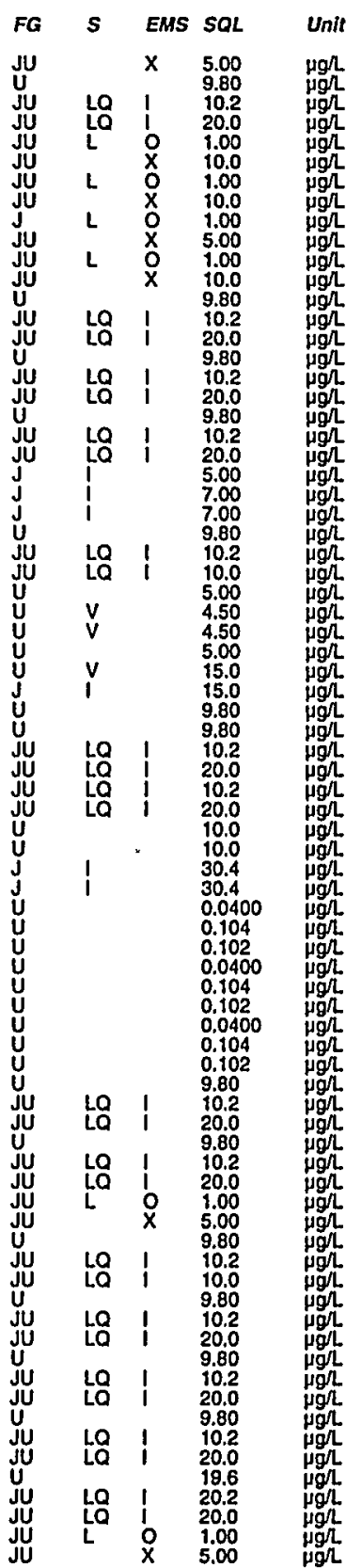
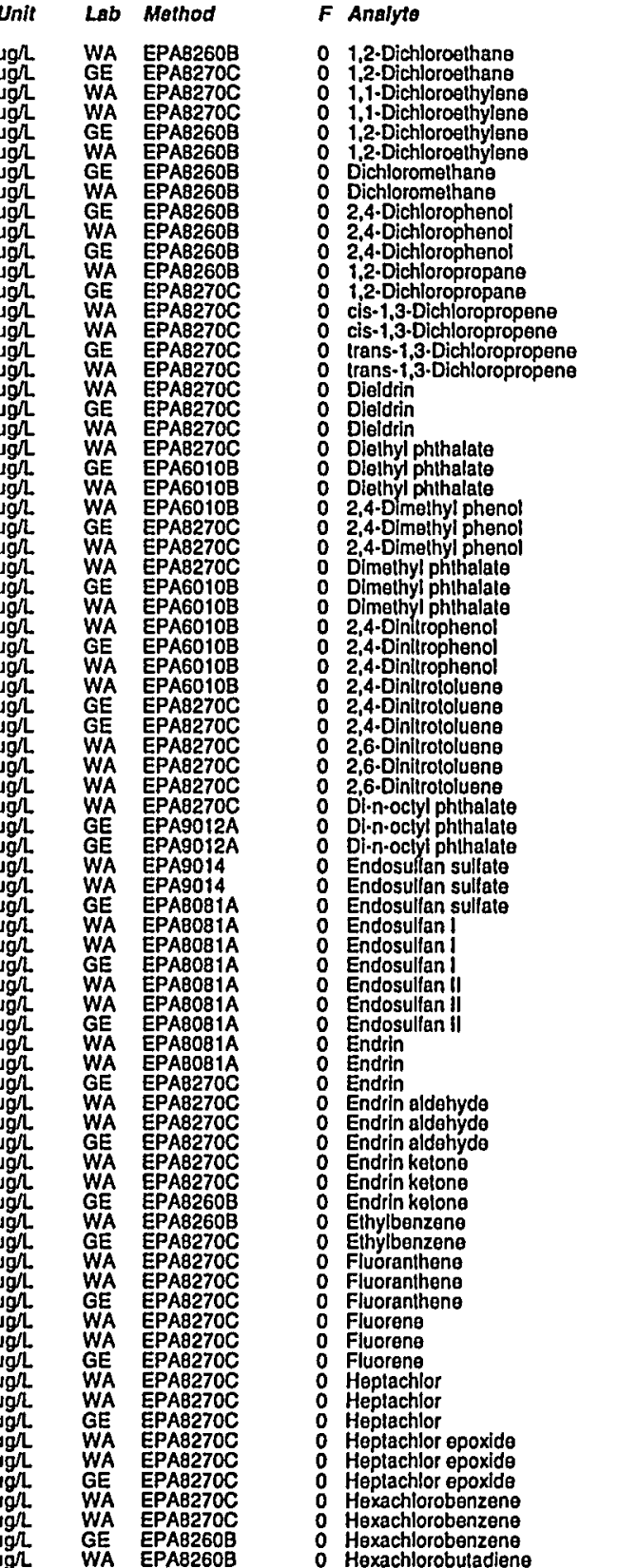

Result

\begin{tabular}{|c|}
\hline 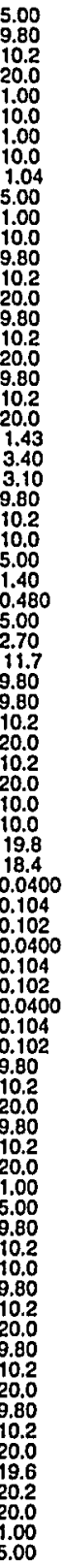 \\
\hline
\end{tabular}

$<1.00$
$<5.00$
$<1.00$

$<1.00$
$<2.00$

$<5.00$
$<5.00$

$<9.80$
$<10.2$
$<20.0$

$<\begin{array}{r}<1.00 \\ <5.00\end{array}$

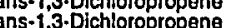

D Dieldrin

Dielhyl phthalate

Dieltyi phithalate

$2,4-D$ methyl pheno
$2,4 \cdot D$.

Dimethyl phithalate

Dimethyl phihalale

2.4-Ointitopheno

2,4-Diniliophen

$2,4 \cdot$ Dinitiotoluene
2,4 -Dinfltrotoluene

$2,6 \cdot$ Dinitrotoluene
$2,6 \cdot D$ Initrotoluene

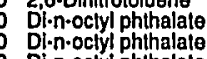

Dif-n.octyy phthalat
Endoctyithithalate
Endosulan sullate

Endosulfan sulfate

Endosulfan 1

Endosulfan

Endosulfan

Endrin

Endrin

Endrin aldehydo

Endrin aldehydo

Endrin ketone

Ethylbenzen

Fluoranthene
Fluoranthene

oranth

Fluorene

Fluorene

Heplachlor

$<0.0200$

Hexachlorobenzene $\quad<9.80$

$\begin{array}{ll}\text { Hexachlorobenzene } & <9.80 \\ \text { Hexachlorobenzenen } & <10.2 \\ \text { Hexachlorobutadiene } & <9.0 \\ & \end{array}$

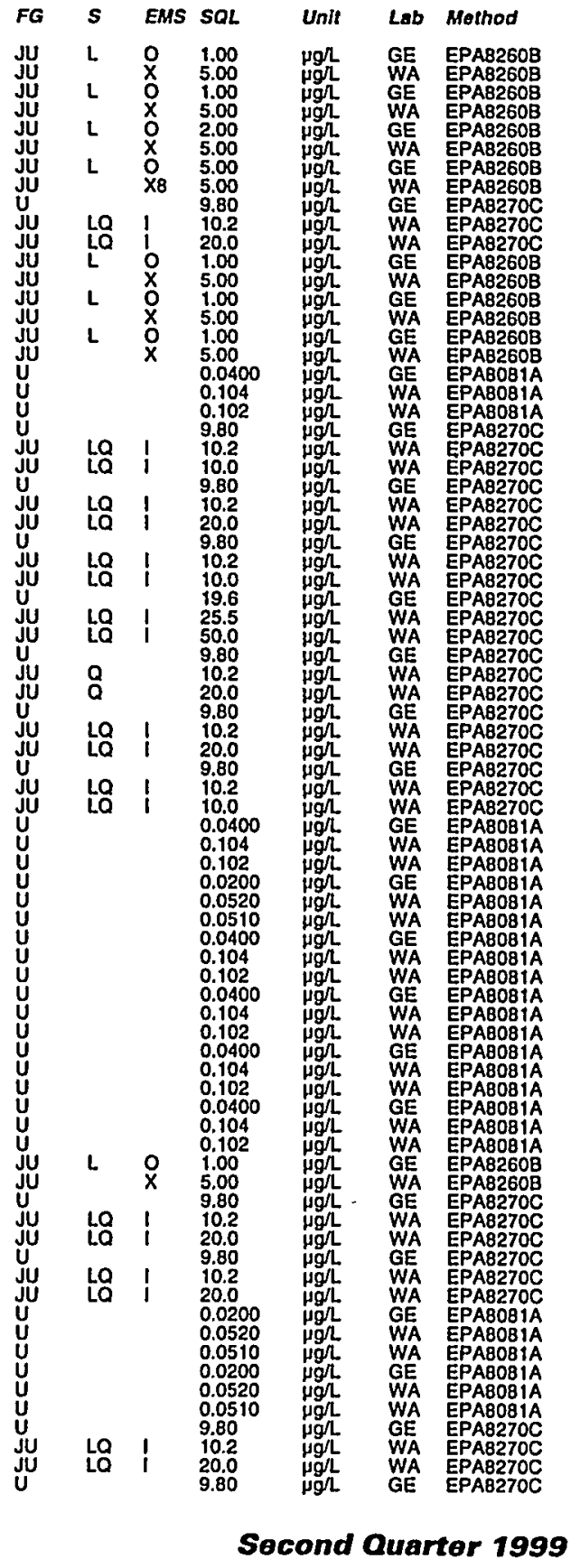


Well CSL 26D collected on 04/14/99 (cont.)

\begin{tabular}{|c|c|}
\hline \multirow[b]{2}{*}{ 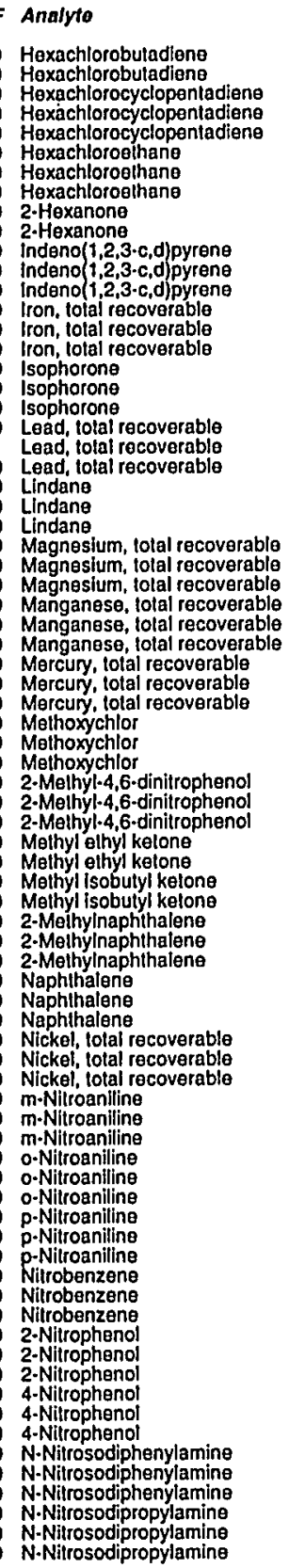 } & \\
\hline & $\begin{array}{c}<10.2 \\
<20.0 \\
<9.80 \\
<10.2 \\
<20.0 \\
<9.80 \\
<10.2 \\
<20.0 \\
<5.00 \\
<10.0 \\
<9.80 \\
<10.2 \\
<20.0 \\
63.7 \\
56.6 \\
76.0 \\
<9.80 \\
<10.2 \\
<20.0 \\
<5.00 \\
43.5 \\
19.6 \\
<0.0200 \\
<0.0520 \\
<0.0510 \\
779 \\
727 \\
728 \\
16.5 \\
18.9 \\
19.9 \\
<0.0 \\
<0.700 \\
<0.700 \\
<0.200 \\
<0.520 \\
<0.510 \\
<9.80 \\
<25.5 \\
<50.0 \\
<10.0 \\
<10.0 \\
<5.00 \\
<10.0 \\
<9.80 \\
<10.2 \\
<20.0 \\
<9.80 \\
<10.2 \\
<20.0 \\
1.48 \\
4.70 \\
2.80 \\
<9.80 \\
<25.5 \\
<50.0 \\
<9.80 \\
<25.5 \\
<50.0 \\
<9.80 \\
<25.5 \\
<50.0 \\
<9.80 \\
<10.2 \\
<20.0 \\
<9.80 \\
<10.2 \\
<20.0 \\
<9.80 \\
<25.5 \\
<50.0 \\
<9.80 \\
<10.2 \\
<20.0 \\
<9.80 \\
<10.2 \\
<20.0\end{array}$ \\
\hline
\end{tabular}

Well CSL 26D collected on 04/14/99 (cont.)

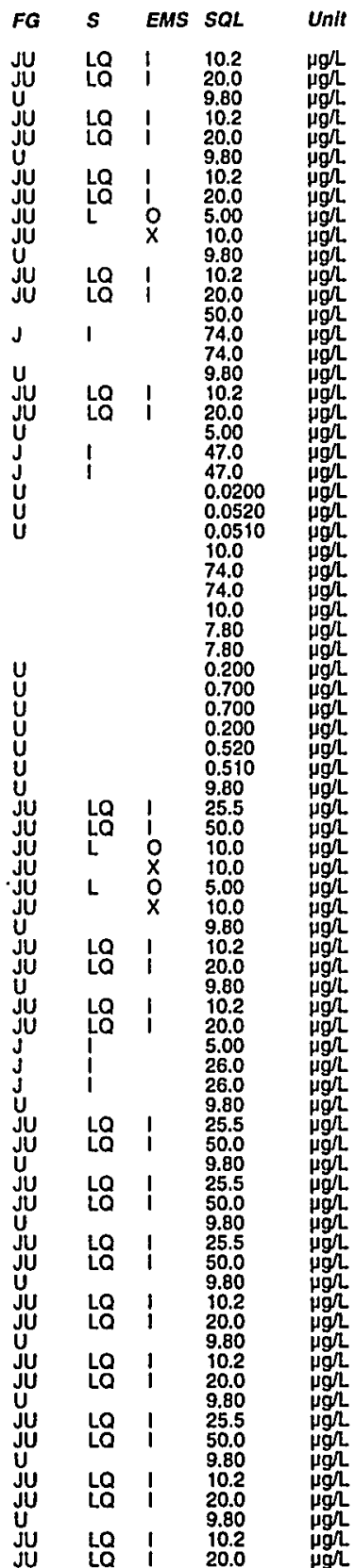

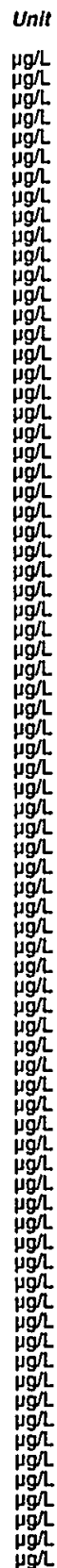

$F$ Analyto

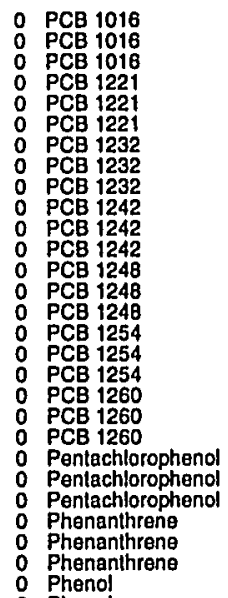

o Phenol

Polassium, lotal recoverable

: Pyrene

Pyrene

Selenium, total recoverable
Selenium, total recoverable

Silver, total recoverab

Silver, total recoverable

Sodium, total recoverable

styreng,

Styreng
$1,1,2,2$-Tetrachloroothane
0
$1,1,2,2$-Tetrachlorogthane

Tetrachloroethylene

Thallium, tolal recoverable

0 Thallium,

Toxaphene

1,2.4-Trichlorobenzene

1.2.4-Trichlorobenzene

1,2,4-Trichlorobenzen

I, i, T. Trichlorosthane

0 i,i,2-Trichloroethane

o T,1,2-Trichloroeth

$\begin{array}{ll}0 & 2,4,5-\text { Trichlorophenol } \\ 0 & 2,4,5 \text { - Trichlorophenol } \\ 0 & 2,4,5 \text { - Trichlorophenol }\end{array}$

$2,4,6$-Trichlorophenol
0

Vanadium, lotal recoverabl

o Vanadium, lotal recoverable
Potassium, total recoverab

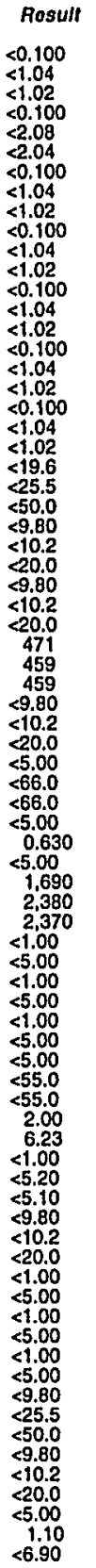
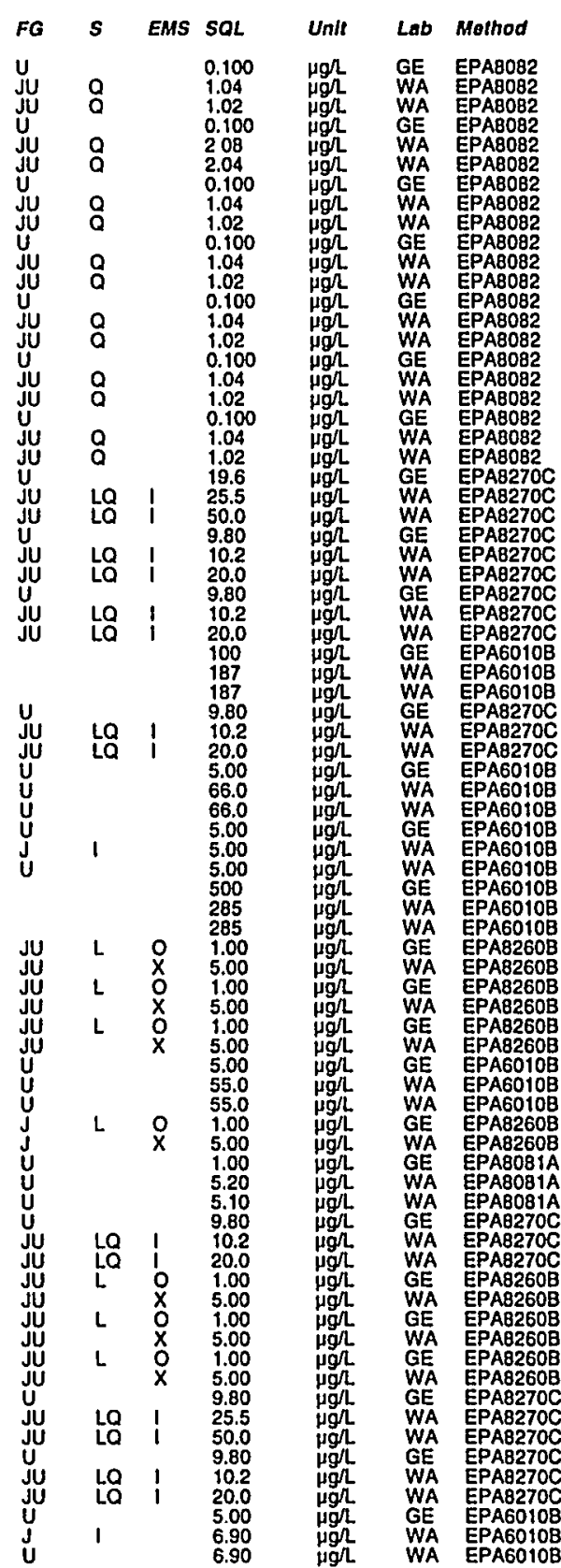
Well CSL 26D collected on 04/14/99 (cont)

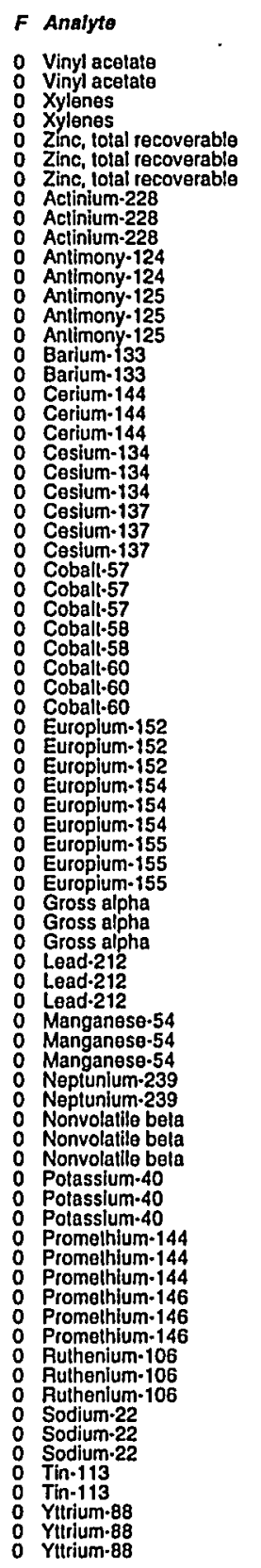

ESH-EMS-990521
Well CSL 26D collected on 04/14/99 (cont.)

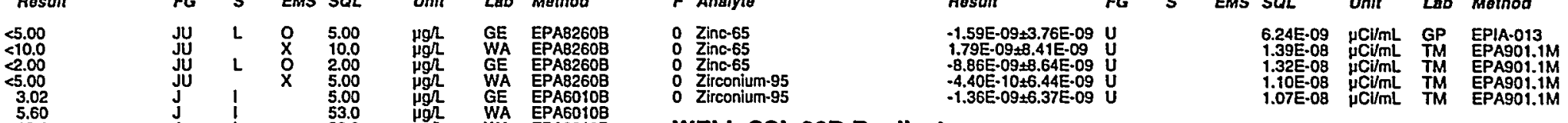

\section{WELL CSL 26D Replicate}

MEASUREMENTS CONDUCTED IN THE FIELD

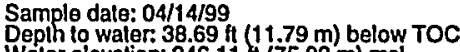

PH: 4.4 conductance: $30 \mu \mathrm{S} / \mathrm{cm}$

Water evacualed from the well prior lo sampling: $18 \mathrm{gal}$

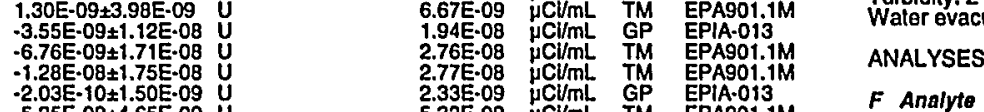

$-5.25 E-09 \pm 4.65 E-09$

1.18E-10+1.47E-09

$3.58 E-09 \pm 3.82 E .09$

$-1.09 E-09+2.14 E-09$

$-2.90 \mathrm{E} \cdot 10 \pm 2.09 \mathrm{E}-09$

$3.10 \mathrm{E}-10 \pm 4.08 \mathrm{E}-09$

$3.50 E-10 \pm 3.68 \mathrm{~B}-09$

$-1.82 \mathrm{E}-09 \pm 4.85 \mathrm{E} \cdot 09$
$-9.64 \mathrm{E} \cdot 09 \pm 2.48 \mathrm{E}-08$

$-9.85 E \cdot 09 \pm 2.51 E \cdot 08$
$-1.78 E \cdot 09 \pm 4.92 E-09$

$-4.20 E \cdot 09 \pm 1.02 E .08$
$-2.53 E-09 \pm 1.11 E \cdot 08$

$5.88 E-09 \pm 5.977-09$
$3.40-107.44 \mathrm{E}-09$

$4.60 \mathrm{E}-10 \pm 3.29 \mathrm{E}-10$
$2.70 \mathrm{E}-10 \pm 5.20 \mathrm{E}-10$

$2.92 E-09 \pm 3.19 E-09$

$-4.74 E-09 \pm 5.59 E-09$
$-5.10 E-11 \pm 1.43 E-09$

$3.73 E \cdot 09+4.99 \mathrm{E} \cdot 09$

5.67E.09+3.73E.08

$1.50 \mathrm{E}-09+6.01 \mathrm{E}-10$
$9.70 \mathrm{E}-10 \pm 1.06 \mathrm{E}-09$

$-2.90 E-10 \pm 8.90 E-10$
$1.89 E-08 \pm 2.04 E \cdot 08$

$1.89 E-08+2.04 E-08$

$-8.07 E-10 \pm 1.42 E-09$
$1.80 E-10+3.92 E .09$

1. $.86 \mathrm{E} .09 \pm 3.73 \mathrm{E} .09$

$-2.79 \mathrm{E}-09 \pm 6.77 \mathrm{E} \cdot 09$

5.50E-10+6.16E.09

9.89E- $09+3.14 \mathrm{E}-08$

$-1.57 E-09 \pm 3.63 E-09$

$-8.10 E-10 \pm 3.95 E-09$
$-2.50 E-09 \pm 4.77 \mathrm{E}-09$

$-9.15 E-10+4.77 E-09$

$4.80 E-10 \pm 2.82 E \cdot 09$
$9.50 E-10 \pm 2.84 E-09$

IK C

0 Acenaphthene

o Acenaph

1 Aluminum, total recoverable

Anthraceno

o Arsenic, lotal recoverable

o alpha.Benzene hexachloride

beta.Benzene hexachloride
0 delta.Benzene hexachloride

o Benzidine

o Benzo(b) (lucranthene

Benzo gachld perylene

0 Benzo(a)pyrene
Benzyl alcohol

o Beryllium, total recoverable

o Bis (2-chloroethoxy) methan

B Bis (2-chloroethyl) ether
Bis (2-chlorolsopropyl) elher

Bis(2-ethylhexyl) phithalal

Bromolorm

o 4. Bromophenuy phenyl ether

Cadrilum, tolal recoverable

Calcium, iotal recoverablon disulifde

Carbon tetrachloride

o gamma.Chlordane

4.Chloroaniline
0 Chlorobenzene
4.Chloro-m.cresol

Chloroethane (Vinyl chloride)

Chlorolorm

o Chloromethane

4.Chlorophenyl phenyl athe

o Coball, lotal recoverable

o m/l.Cresol (2-Methylphenol)

$\begin{array}{ll}0 & \text { Cyanide } \\ 0 & \text { p.p'-DDD } \\ 0 & \text { p.p'-DDE }\end{array}$

B-75
Time: 8:57

Waler temperalure: $18.9^{\circ} \mathrm{C}$

Total alkalinity (as CaCO3): $1 \mathrm{mg} / \mathrm{L}$

Phenolphthalein alkalinity: $0 \mathrm{mg} h$
Field Qualifier(s): $V$

Second Quarter 1999

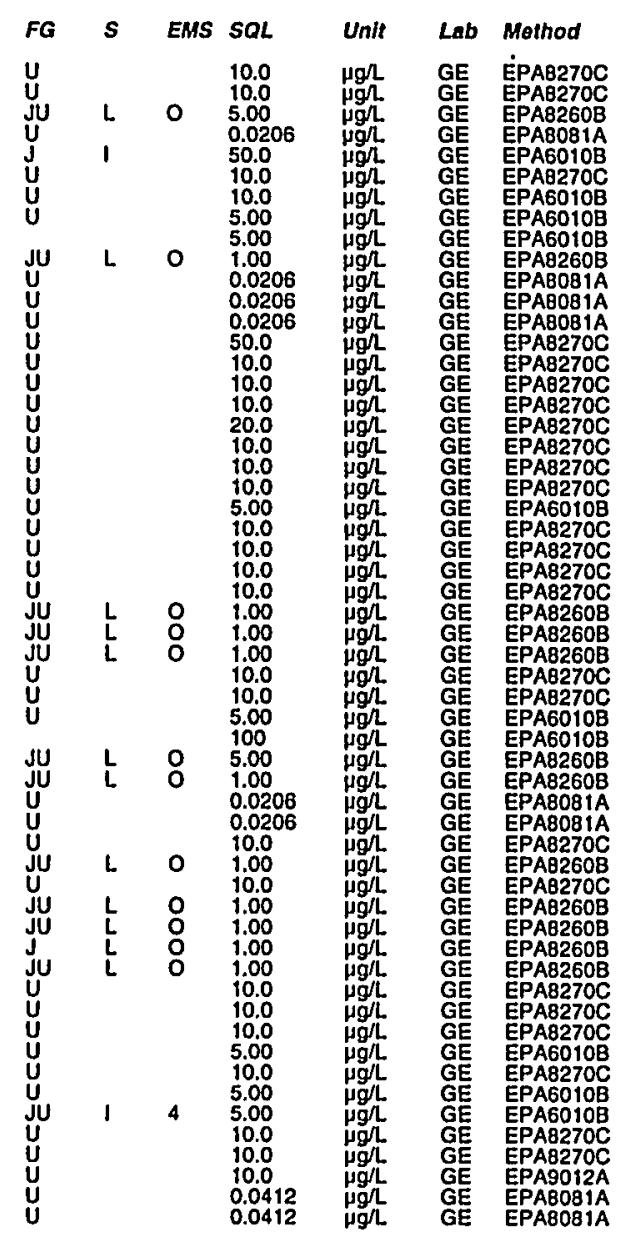




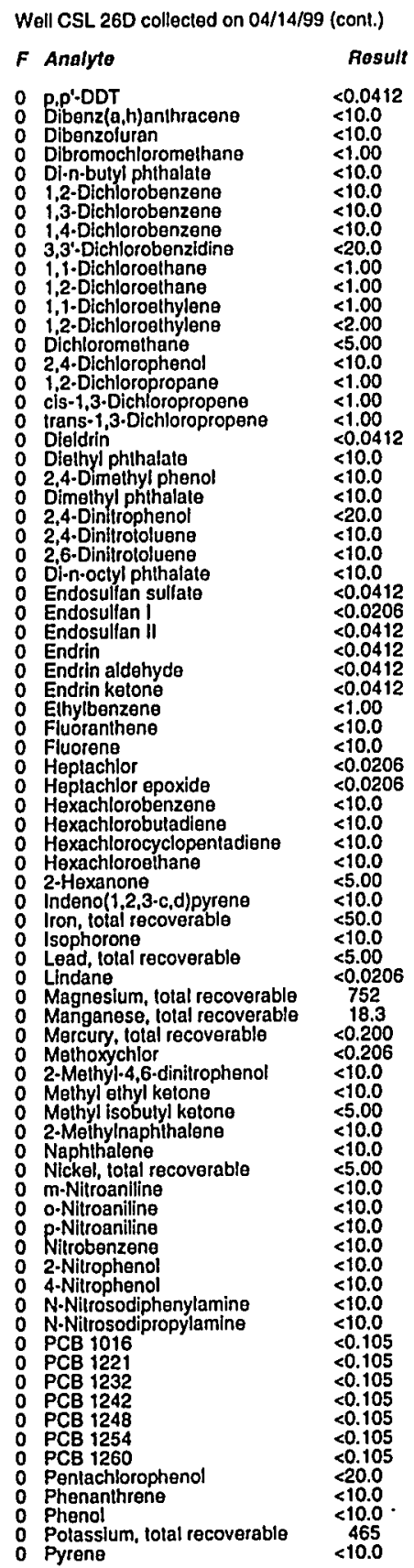

ESH-EMS-990521

Well CSL 26D collecled on 04/14/99 (cont.)

$F$ Analyio

Selenium, total recoverable Sodium, total recoverable

: Styrene Thallum, total recoverable Toluene 1,2,4-Trichlorobenzon 1.1,2-Trichioroethan $2,4,5$-Trichloropheno
$2,4,6$ - Trichloropheno Vanadium, lotal recoverable Vinyl acetate

Z Zinc, lotal recoverable Anlimony-125 Cesium -134 Coball-60 Europium-152 Gross alpha

Manganese-54 Potasslum-40 Promethium-146 Sodium-22

\section{WELL CSL 27D}

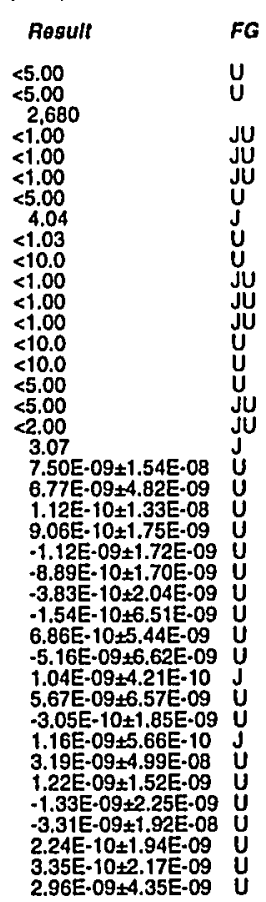

MEASUREMENTS CONDUCTED IN THE FIELD Sample date: 04/15/99 Depth to waler: 40.9 ti $(12.47 \mathrm{~m})$ below TOC$$
\text { Waler elevation: } 245.5 \text { it }(74.83 \mathrm{~m}) \mathrm{ms}
$$$$
\text { Wurbidity: } 9 \text { NTU } 22 \mu \mathrm{S} / \mathrm{cm}
$$

Water evacuated from the well prior to sampling: $4 \mathrm{gal}$ ANALYSES

$F$ Analyto

Rosult
$<10.0$
$<10.0$
$<5.00$
$<0.0200$
63.9
$<10.0$
$<10.0$
$<5.00$
10.5
$<1.00$
$<0.0200$
$<0.0200$
$<0.0200$
$<50.0$
$<10.0$
$<10.0$
$<10.0$
$<20.0$
$<10.0$
$<10.0$

0 Acenaphthene

Acetone

2 Aluminum, total recoverable

o Antimony, lotal recoverable

Barium, total recoverable

alpha-Benzene hexachloride

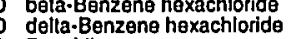

Benzo(a)anthracene

Benzo (k) flluoranthen

Benzo(g.h.j)perylen

B-76

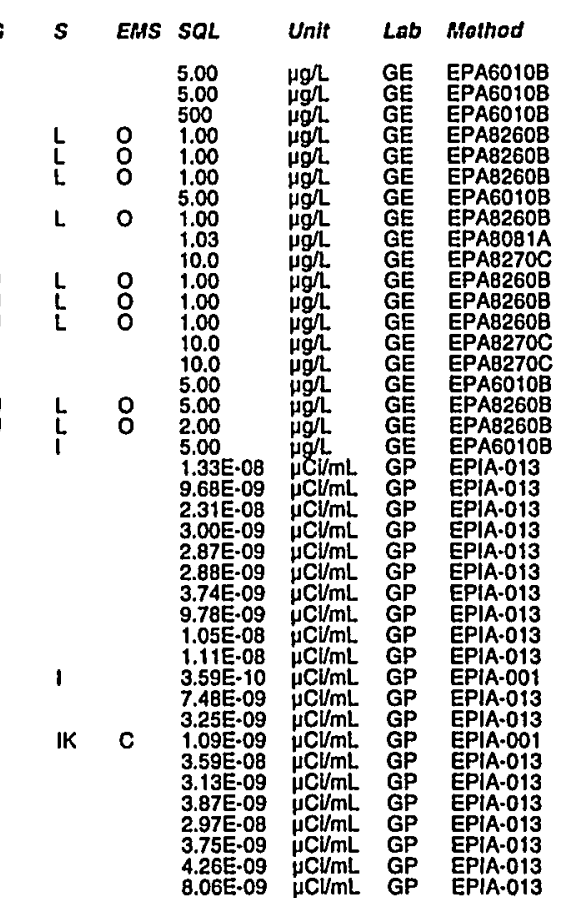

Time: $9: 15$

Total alkalinity (as CaCO3): $3 \mathrm{mg} / \mathrm{L}$ 


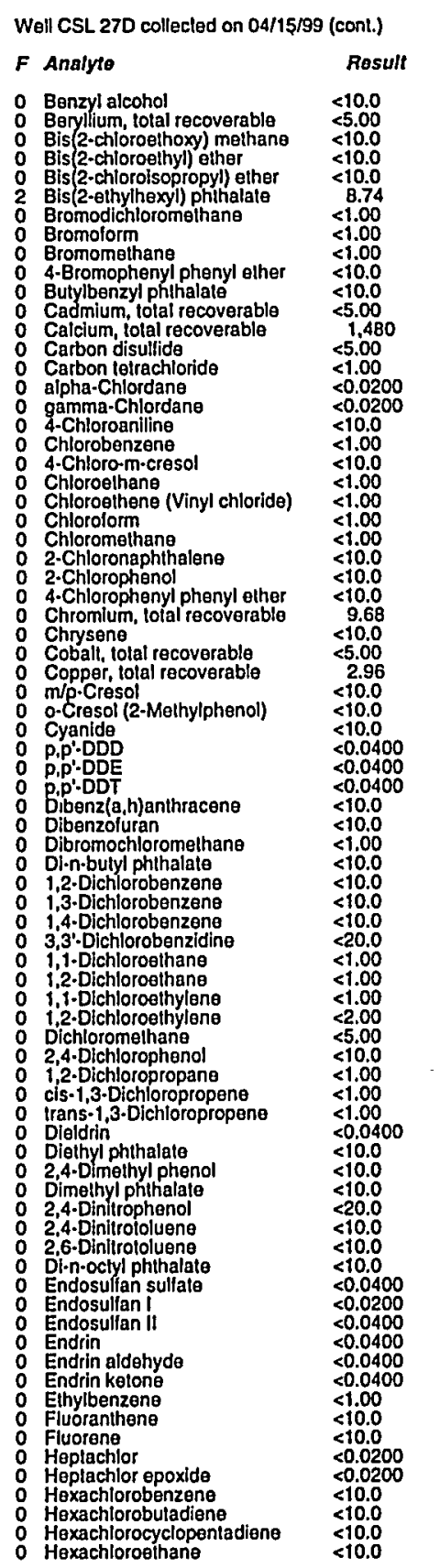

ESH-EMS-990521

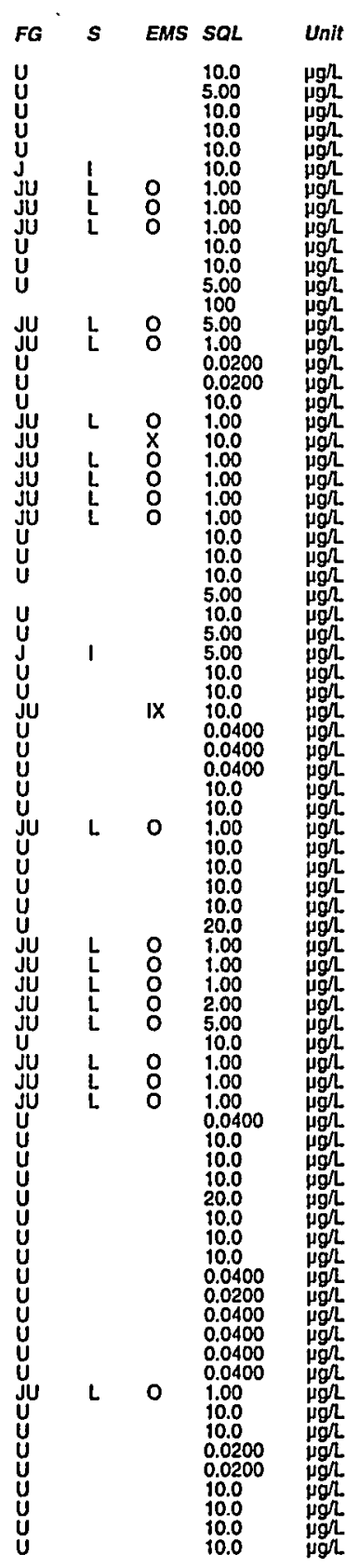

Lab Method

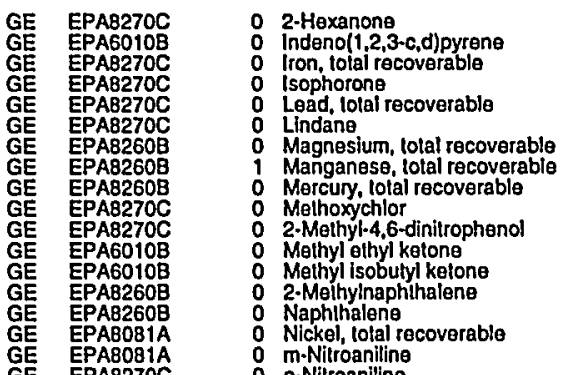

o o-Nitroaniling

o $\begin{aligned} & \text { Nitrobenzenitine } \\ & 0\end{aligned}$

4-Nitrophene

N-Nilrosodiphenylamine

0
0

0
0
0

PCB 1254

Penlachloropheno

Phenol
Phention

Polassium, total recoverable

Selenium total recoverable

Silver, total recoverable

Styreng Thetrachloroethane Tetrachloroethylene

1,2,4-Trichlorobenzen

$1,1,1-$ Trichloroothan

Trichloroelhylene

2,4,5-Trichlorophenol Vanadium, total recoverable Vinyl acetate

o Zinc, total recoverable

Actinitum-228
Actinium.228

: Antlmony-125

O Corlum. 144

Cesium.134

Cosium.137

C Cosium.137

${ }_{0}^{0}$ Coball 57

0 Cobalt. 60

o Europlum-152

Europium-154
0 Europium-154
0 Europlum-155
Europlum-155

Europlum-15
Gross aipha
Gross alpha

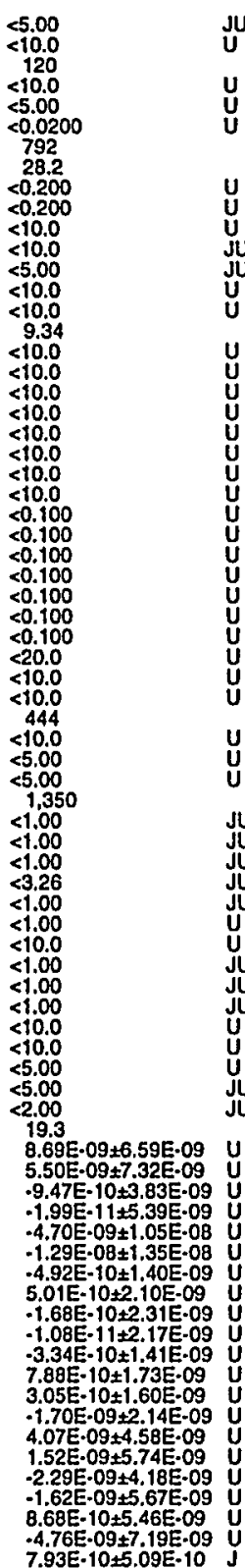

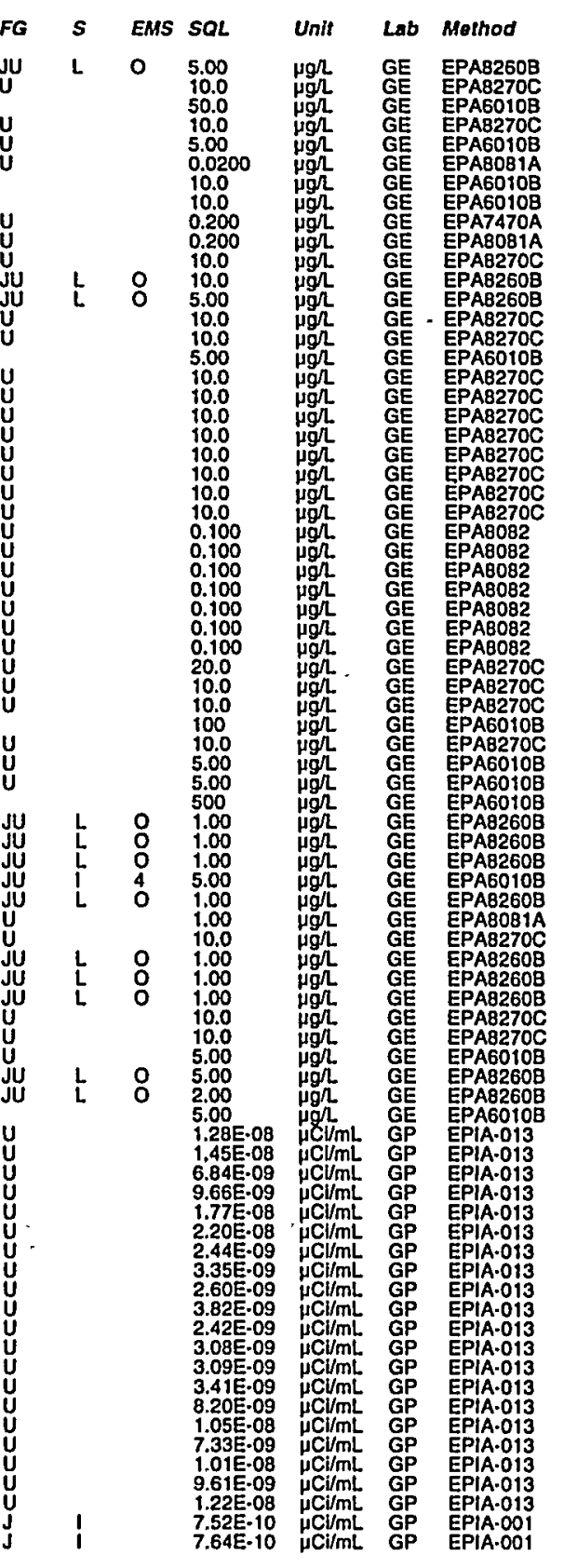

Second Quarter 1999 
Well CSL 27D collected on 04/15/99 (cont.)

\begin{tabular}{|c|c|c|c|c|c|c|c|c|}
\hline Analyto & Rosult & $F G$ & $s$ & EMS & $S Q L$ & Unit & Lab & Method \\
\hline 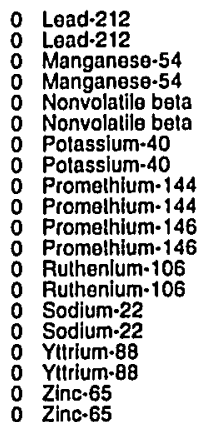 & 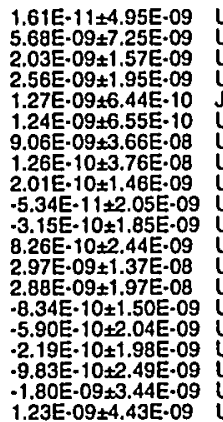 & 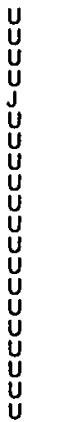 & IK & c & 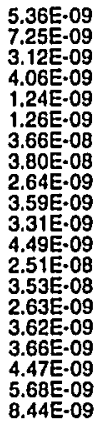 & 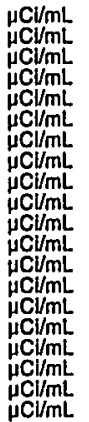 & $\begin{array}{l}\text { GP } \\
\text { GP } \\
\text { GP } \\
\text { GP } \\
\text { GP } \\
\text { GP } \\
\text { GP } \\
\text { GP } \\
\text { GP } \\
\text { GP } \\
\text { GP } \\
\text { GP } \\
\text { GP } \\
\text { GP } \\
\text { GP } \\
\text { GP } \\
\text { GP } \\
\text { GP } \\
G P\end{array}$ & 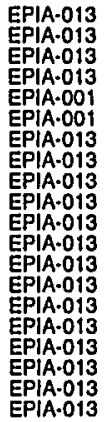 \\
\hline
\end{tabular}

\section{WELL CSR 2D}

MEASUREMENTS CONDUCTED IN THE FIELD

Sample dale: 06/04/9 Depth to water: $43.85 \mathrm{ft}(13.37 \mathrm{~m})$ below TOC pH: 6.1 Sp. conductance: $44 \mu \mathrm{S} / \mathrm{cm}$

Water evacuated from the well prior to sampling: $23 \mathrm{gal}$ ANALYSES

$F$ Analyto

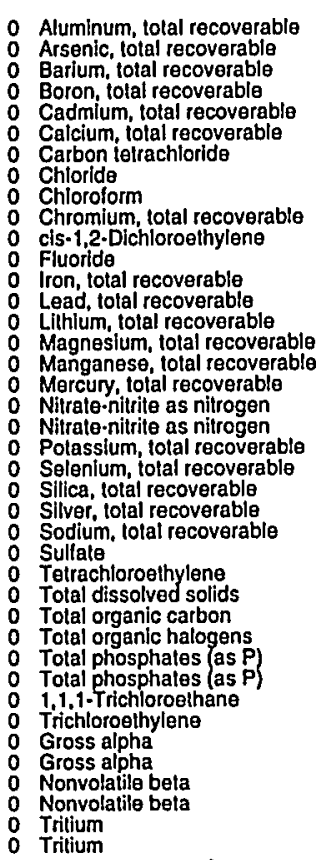

ESH-EMS-990521

\section{WELL CSR 5D}

MEASUREMENTS CONDUCTED IN THE FIELD

Sample date: 06/04/99
Depth to waler: $17.61 \mathrm{~h}(5.37 \mathrm{~m})$ below TOC
Water elevalion: $255.49 \mathrm{H}(77.87 \mathrm{~m}) \mathrm{msl}$

$\mathrm{pH}: 4.5$. conductance: $330 \mu \mathrm{S} / \mathrm{cm}$

Waler evacuated from the well prior to sampling: $13 \mathrm{gat}$

\section{ANALYSES}

FG S EMS SQL

2 Aluminum, lotal recoverable

Arsenic, lolal recoverable

Boron, lotal recoverable

Cadmium, total recoverable

Carbon tetrachlorlde

Carbon tet
Chiorido
Cheloritom

Chlorolorm

Chromium, total recoverable

cis-1,2-Dichloroethylene
cls-1,2-Dichloroethylene

Iron, lotal recoverable

Lead total recoverable

Magnesium, total recoverable

Manganese, total recoverab

Nitrate-nitrite as nitrogen

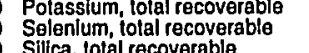

Result

Time: 8:51

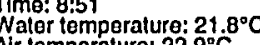

Total alkalinity (as CaCO3): $0 \mathrm{mg} / \mathrm{L}$

mperature: $21.5^{\circ} \mathrm{C}$ Total alkalinity (as CaCO3): $9 \mathrm{mg} / \mathrm{L}$ Field Oualifier(s): $v$

\begin{tabular}{|c|}
\hline 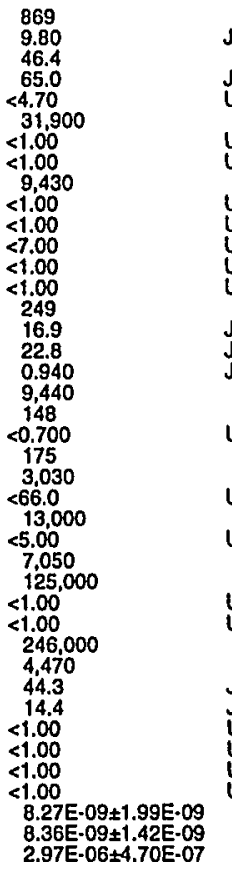 \\
\hline
\end{tabular}

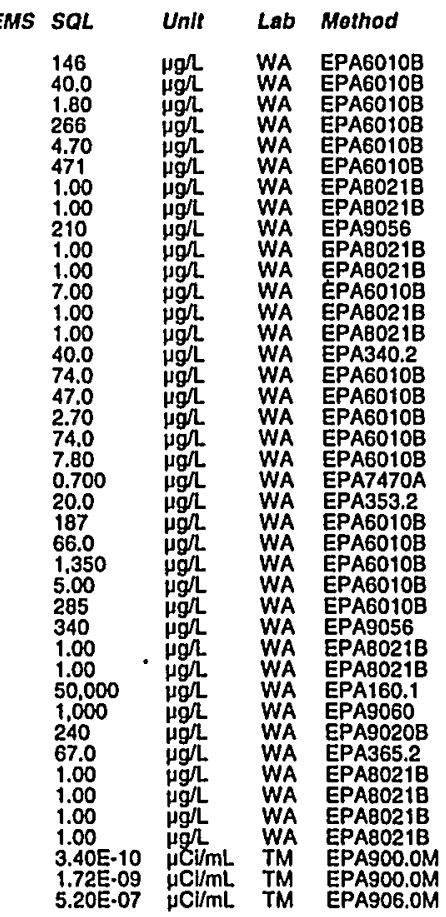

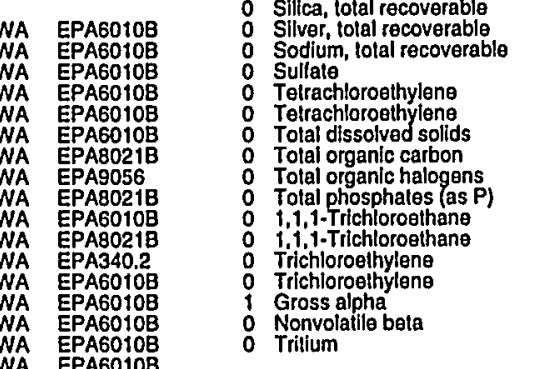

WELL CSR 6D

MEASUREMENTS CONDUCTED IN THE FIELD

Sample date: 06/04/99 2 m) below TOC

Water elevation: $255.7 \mathrm{ft}(77.94 \mathrm{~m}) \mathrm{msl}$

$\mathrm{gh}$ : 4.9

. conductance: $23 \mu \mathrm{S} / \mathrm{cm}$

Water evacuated from the well prior to sampling: $19 \mathrm{gal}$ ANALYSES

$F$ Analyte

0 Aluminum, total recoverable

- Arsenic, total recoverable

o Coron, lotal recoverable

Calcium, tolal recoverab

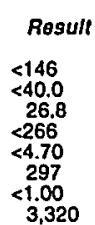

$\begin{array}{ll}F G & S \\ U & \\ U & \\ U & \\ U & \text { I }\end{array}$

Time: 9:28

Air temperature: $24.6^{\circ} \mathrm{C}$ Total allal (as $\mathrm{CaCO}$ ): $1 \mathrm{mg} /$ Field Qualifier(s): V

EMS SOL
146
40.0
1.80
266
4.70
471
1.00
210

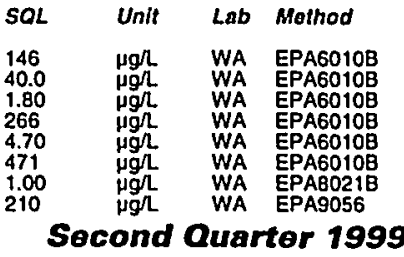


Well CSR 6D collected on 06/04/99 (cont.)

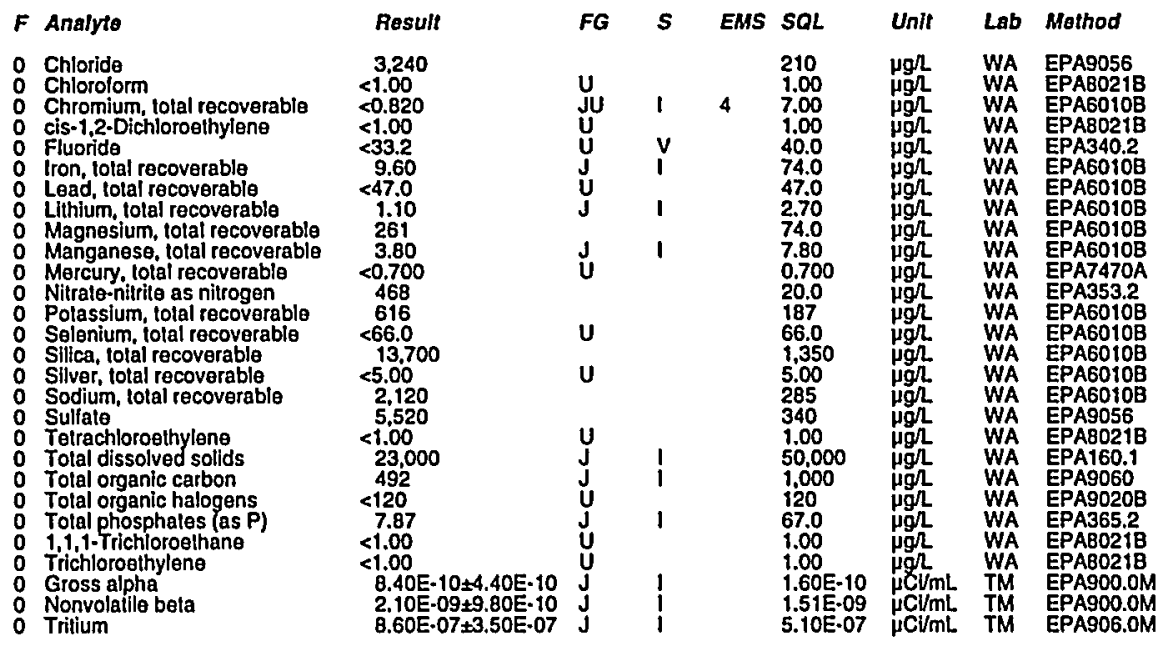

WELL DBP 1

MEASUREMENTS CONDUCTED IN THE FIELD

Sample date: 04/13/99

Sample date: 04/13/99
Depth to water: $171.1 \mathrm{f}(5.21 \mathrm{~m})$ below TOC
Water elevation: $118.1 \mathrm{f}(36 \mathrm{~m}) \mathrm{msl}$
oH: 4.5

Sp. conductance: $62 \mu \mathrm{S} / \mathrm{cm}$

Water evacuated from the well prior to sampling: 75 gal

ANALYSES

$F$ Analyte

Oclachlorodibenzo-p.dioxin

Acenaphthene
Acenaphthene

Acenaphthylene

Acelophenone

2. Acelylaminofluorene

Atuminum, tolal recoverablo

4-Aminobipheny

Anlline

Anthe
Anthracene
Anthracene

Aramile

Aramilto

Arsenlc, lotal recoverable

O Benzone (a)anthracene

Benzo(a) anthracene

Benzo (b) fluoranthene

Benzo (k) fluoranilhene

Benzo(g.h., perylene

Benzola)pyrene

0 Benzyy alcohol

ESH-EMS-990521
Well DBP 1 collected on 04/13/99 (cont.)

$F$ Analyte

o Bis(2-chloroethoxy) methane

Result

: Bis(2-chloroethoxy) meth

Bis 2-chloroisopropyl) ether

Bis 2-ethylhexyly phithalate

Bis(2-ethylhexyl) phthalate
Bromodichloromethane

Bromoform

4-Bromophenyl phenyl ether
0

Butylbenzyl phthalate

Carbon telrachloride

4-Chloroaniline

Chlorobenzena

Chlorobenziliat

Chloroethene (Vinyl chloride)

2-Chloroethyl vinyl ether

Chloromethe

2.Chloronaphihalene
2.Chloronaphthalene

2.Chloronaphthalene
4.Chlorophenyl phenyl ether

C.Cromlum, tofal recoverab

o Chrysene

0 Chrysen

Time: 11:08

The: $18.9^{\circ} \mathrm{C}$

Total alkalinity (as CaCO3): $0 \mathrm{mg}$

Phenolphthalein alkalinity: $0 \mathrm{mg} L$

Dibenz $(a, h)$ anthracene
0 Dibenz $(a, h)$ anthraceng
0

Obenzoluran

Dibenzoluran

Dibromochloromethan

1.2.-Dichlorobenzene

1.2. Dichlorobenzene

$1.3 \cdot$ Dichlorobenzene

1.4. Dichlorobenzenen

3,3: Dichlorobenzildine

1.1.Dichloroethane

o 1,1 . Dichloroesthylene

Dichloromelhane

1,2-Dichloropropane

trans-1,3.Dichloropenene

Diethyy phithalale

Dimeihyy phihalale

p.Dlmelhylaminoazobenzeno

7,12.0imethylbenz

3,3. Oimethylbenzidine

a,a.Dimethylphenethylamine

a,a.Dimethyphenethyla

o $1,3 \cdot$ Dinitrobenzene

2.4. Dintritrololuene

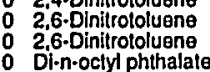

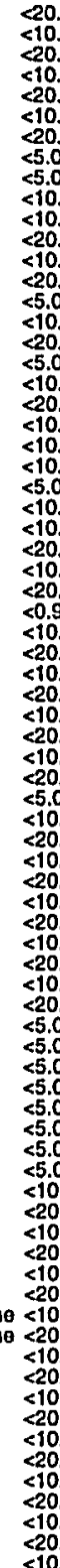

B-79

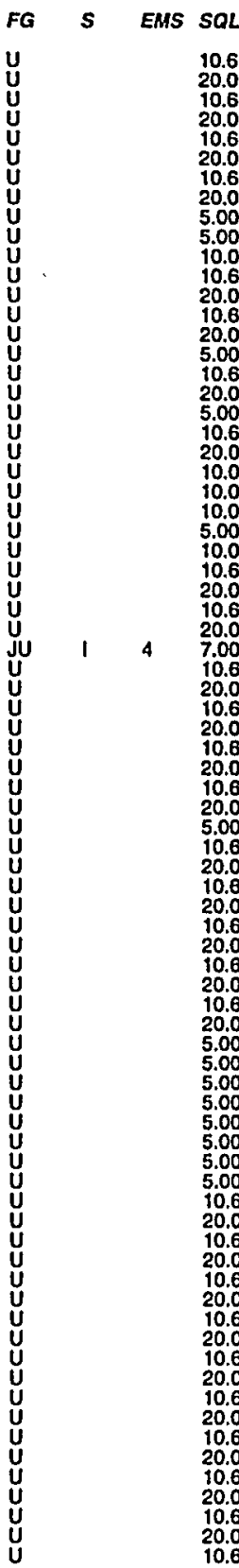

Unit Lab Method

\begin{tabular}{|c|c|c|}
\hline 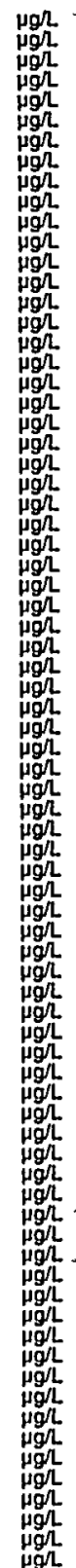 & $\begin{array}{l}\text { WA } \\
\text { WA } \\
\text { WA } \\
\text { WA } \\
\text { WA } \\
\text { WA } \\
\text { WA } \\
\text { WA } \\
\text { WA } \\
\text { WA } \\
\text { WA } \\
\text { WA } \\
\text { WA } \\
\text { WA } \\
\text { WA } \\
\text { WA } \\
\text { WA } \\
\text { WA } \\
\text { WA } \\
\text { WA } \\
\text { WA } \\
\text { WA } \\
\text { WA } \\
\text { WA } \\
\text { WA } \\
\text { WA } \\
\text { WA } \\
\text { WA } \\
\text { WA } \\
\text { WA } \\
\text { WA } \\
\text { WA } \\
\text { WA } \\
\text { WA } \\
\text { WA } \\
\text { WA } \\
\text { WA } \\
\text { WA } \\
\text { WA } \\
\text { WA } \\
\text { WA } \\
\text { WA } \\
\text { WA } \\
\text { WA } \\
\text { WA } \\
\text { WA } \\
\text { WA } \\
\text { WA } \\
\text { WA } \\
\text { WA } \\
\text { WA } \\
\text { WA } \\
\text { WA } \\
\text { WA } \\
\text { WA } \\
\text { WA } \\
\text { WA } \\
\text { WA } \\
\text { WA } \\
\text { WA } \\
\text { WA } \\
\text { WA } \\
\text { WA } \\
\text { WA } \\
\text { WA } \\
\text { WA } \\
\text { WA } \\
\text { WA }\end{array}$ & 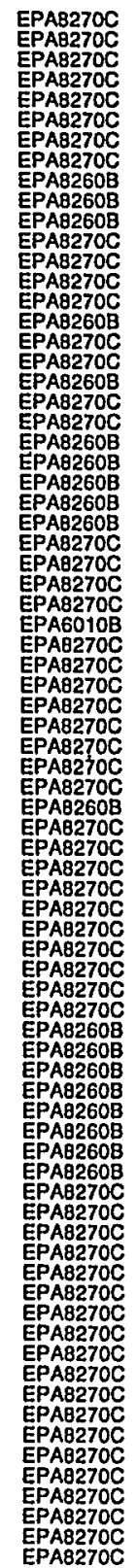 \\
\hline
\end{tabular}

Socond Quarter 1999 
Well DBP 1 collecled on 04/13/99 (cont.)

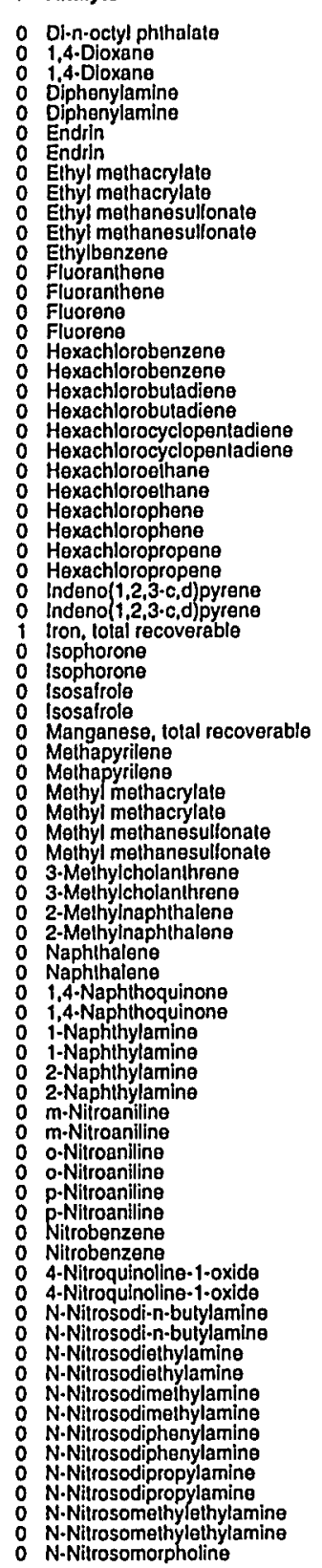

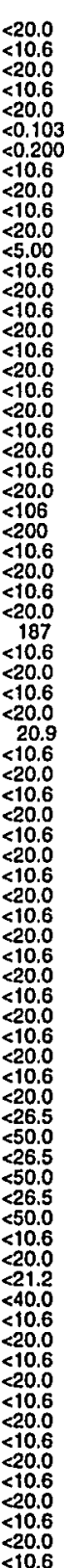

ESH-EMS-990521
Well DBP 1 collectod on 04/13/99 (cont.)

O N-Nitrosomorpholine

N-Nitrosopperildine
N-Nitrosopyrrolidine

N.Nitrosopyrrolldidi

5.Nilro-0-toluidin
PCB 1260

Pentachlorobenzene

Pentachloroethane
Pentachloroethane

Pentachloronitrobenzen

Phenacetin
Phenacetin

Phenanthrene

p.phenylenediamine

2.Plcoline

Pronamld

Pyrene

Pyrdine

Pyridine

1 $1,2,4,5$-Telrachlorobenzen

i, $1,2,2$-Telrachloroethane

Tolrachloroethylene

Toluene

1,2,4-Trlchilorobenzene

1,1,1-Trlchloroethane

i., 2 -Trichloroethan

Trichlorofluoromethane

i, 3,5-Tínilrobenzene

Radium. total alpha-emitting

Tritium

WELL DBP 2

MEASUREMENTS CONDUCTED IN THE FIELD

Sample date: 04/13/99

Waler elevation: $116.9 \mathrm{ft}(35.63 \mathrm{~m}) \mathrm{ms}$

Wh: 4.1

p. conductance: $200 \mu \mathrm{S} / \mathrm{cm}$

Water evacuated from the well prior to sampling: $103 \mathrm{ga}$

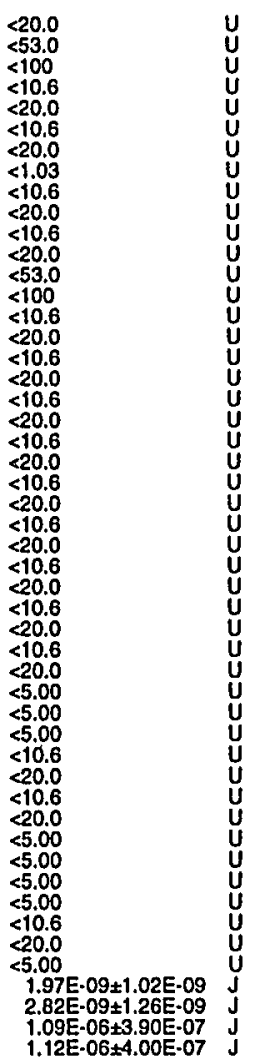

FG

EMS SO

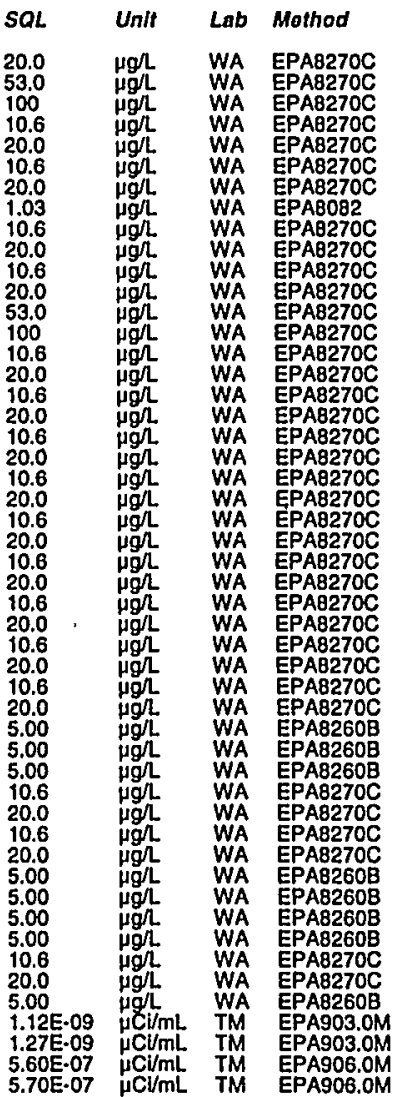

ANALYSES

Octachlorodibenzo-p-dioxin

Acenaphthene
Acenaphthylene

Acetophenone

2-Acerylaminoluorene

4-Aminobiphenyl

Anitins

Aramile

Arsenic, total recoverable

Result
$<2.00$
$<10.4$
$<10.4$
$<10.4$
$<10.4$
1.650
$<10.4$
$<10.4$
$<10.4$
$<20.8$
$<40.0$

FG

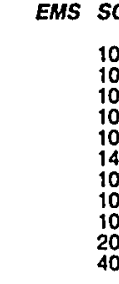

Time: 12:52

Wir temperature: $19^{\circ} \mathrm{C} 9^{\circ} \mathrm{C}$

Total alkalinily (as CaCO3): $0 \mathrm{mg} /$

Field Qualifier(s): $S$

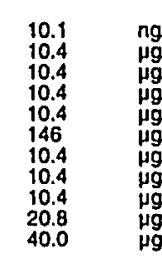

nit Lab Mothod

B-80 
Well DBP 2 collected on 04/13/99 (cont.)

: Benzene
: Benzo(a)anthracene
0
0 Benzob flluoranthen

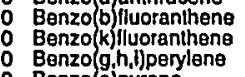

Benzo(j)pyrene

Benzyl alcohol
Bis(2-chloroethoxy) methane

Bis 2-chlorolso

Bis(2-ethylhexyl) phithalate

0 Bromoform

Bromomethane
4 -Bromophenyl phanyl ether

Butylbenzyl phthalate
Carbon terrachloride

4-Chloroansline

Chlorobenzena

Chloroesthene (Vinyl chloride)

2.Chloroethy (vinyl chlorica)

Chlorolorm

2.Chloronaphthalene

4-Chiorophenyl phenyl ether

Chrysene

O Dibenz(a,h)anthracene

Dibromochloromethan

Di-n-butyl phithalate

i, 3 -Dichlorobenzeno

1.4-Dichlorobenzene

1.1.Dichloroethane

o 1, 1 -Dichloroglhylene
trans $=1,2-$ Dichloroethylen

Dichloromethane

o cis-1.3-Dichloropropene

Irans-1,3-Dichloroprope

phithalalo

7.12.Dimelhylbenz(a)anthrac

a,a.Dimathyphazlne

1,3.Dinitrobenzene
2.4.Dinitrotoluene

2,6-Dinitrotoluene

o 1.4-Dioxans

O Endin

Ethy methanesulton

o Fluoranthene

- Hexachlorobenzene

Hexachlorobuladiene

Hexachlorestano

Hexachloropt

o indeno(1,2,3-c,d)pyrens

Isophorono

Manganese, total recoverable

Methylmethacrylate

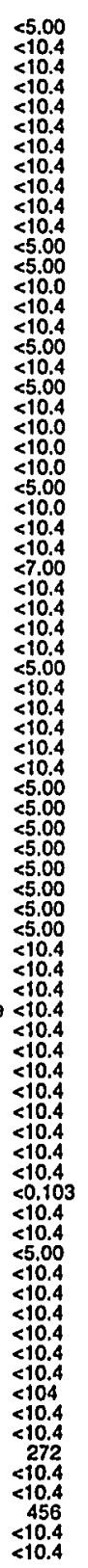

ESH-EMS-990521

Well DBP 2 collected on 04/13/99 (cont.)

$F$ Analyto

0 Methyl methanesulfonate

2-Methyynoaphthalen

1.4-Naphthoquinon

2-Naphthylaming

m-Nitroaniling

Pitrobenzen

4-Nitroquinoline-1-oxide

N-Nitrosodiethylamine

N N Nitrosodimethylamine

N.Nititossomethylethyllamine
N.Nitrosomorpholine

N-Nitrosopiperidine

PCB 1260

O PCB 1260

Pentachlorobenzene

Pentachloronitrobenze
Phenacetin
Phenanthrene
p-Phenthylenediamine
2-Picoline

O Pronamid

Pyrene

1,2.4,5-Tetrachlorobenzene

$1,1,4,2$ - Torrachloroetthan
Totrachloroethylene

Toluena

1,2,4-Trichlorobenzene

1,1,1-Trichloroothan

T Trichloroelhylene

$1,3,5$-Ttinitrobenzene

Radium, total alpha-emitting
0 Tritlum

WELL DBP 2

MEASUREMENTS CONDUCTED IN THE FIELD

Sampla dale: 06/09/99

Water

$\mathrm{Sp}$. conductance: $160 \mu \mathrm{S} / \mathrm{cm}$

Water evacualed from the well prior to sampling: 78 gal

FG

ANALYSES

$F$ Analyte

Rosult

FG

EMS SQL

2 Aluminum, tolal recoverablo

Solon totam, total recoverable
Sola

1.050
$<4.70$
287
66.0
43.400 $\begin{array}{ll}146 & \mu g h \\ 4.70 & \mu g h \\ 74.0 & \mu g / L \\ 66.0 & \mu g g h \\ 340 & \mu g / L\end{array}$

Unit Lab Mothod

Yater limperature: $19.7^{\circ} \mathrm{C}$

Total alkalinily (as Caco3): $0 \mathrm{mg} / \mathrm{L}$

WA EPAG010B 


\section{WELL DBP 3}

MEASUREMENTS CONDUCTED IN THE FIELD

Sample date: 04/13/99

Waler elevalion: $122 \mathrm{ft}(1.91 \mathrm{~m})$ below TOC

Sp. conductance: $60 \mu \mathrm{S} / \mathrm{cm}$

Wurbidily: 1 NTU

\section{ANALYSES}

$F$ Analyte

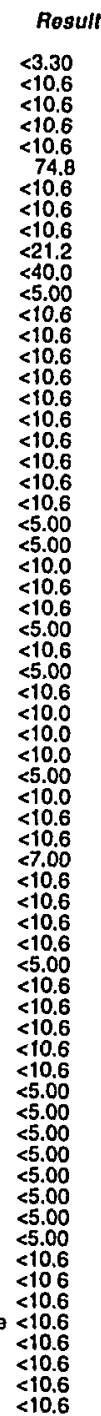

: Octachlorodibe

Acenaphithylene
: Acelophenona
2.Acolylaminolluoren

Aluminum, total recoverab 4.Aminobipheny

Anthracene

o Aramile tolat recoverable

Benzene

Benzo (b) lluoranthen

Benzyl alcohol

Bis(2-chlorothoxy) methane

Bis 2-chioroisopropyl) ethe

Bis(2-alhyihexyl) phithalat

Bromolorm

4-Bromophenyl phenyl ether

Cuybonzyl phinalate

4-Chloroaniline

Chlorobenzen

Chloroethene (Vinyl chloride)

2.Chloroethyl vinyl ether

Chlorometh

2-Chloronaphithalene

Chromium, tolal renyl eth Diailale

Dibenz(a,h)anthracene

Dibromochloromethane

Dl-n.butyl phthalate

1. Dichlorobenzene

3.3'-Dichlorobenzidin

i,2.Dichloroethane

$1,1-D i c h l o r o e t h y l e n e$
trans-1,2-Dichloroelthylene

1.2-Dichloropropan

trans-1,3-Dichloropropene Dielhyl phithalate
Dimeithyl phthalate

p.Dimelhylaminoazobenzens 3.3.-Dimethylbenzidine 1,3-Dinitrobenzen

$<10.6$

ESH-EMS-990521
Well DBP 3 collected on 04/13/99 (cont)
$F$ Analyto

Time: 10:10

Walure: $16.1^{\circ} \mathrm{C}$

Total alkalinily (as Caco3): $3 \mathrm{mg} /$

Phenolphthalein alkalinity: $0 \mathrm{mgl}$

: 2,6.Dinitrotolueno

O 1,4-Dioxane

Endrin

o Elhyl methacrylate

o Elhylbenzene

Fluorene

Hexachlorobutadiene

Hexachlorocyclopentadiene

Hexachlorophene

indeno $(1,2,3 \cdot c, 0)$ d)pron

0 Iron, total iaco

o isosalrole

1 Manganese, total recoverable

: Mellapyrliene

o Methyl methanosulitionate

3.Molhylcholanthrene

2-Melhylnaphthalen

1.4-Naphthoquinone

2.Naphihylamine

2.Naphihylamin
0 m.Nitroaniline

P-Nitroaniling

4-Nitroquinoline-1-oxide

N-Nitrosodi-n-butylamin

o N-Nitrosodimathylamine

o N-Nitrosodiphenylamine

o N-Nitrosomethylethylamin

N. Nitrosomorpholine

: N-Nitrosopiperidinin

5.Nitro-0-ololuidine

- Pentachlorobenzen

Pentachloroghane

Phenacetin

o p.Phenylenediamine

0 Pyrene

1,2,4,5-Tetrachlorobenzene

1,1,2,2-Tetrachlornethan

Toluene

1,2,4-Trichlorobenzen

1.1.2-Trichloroethan

Trichloroethylene

1.3,5.Trinitrobemenzene

OX Rylones
Telrachioroathylen
FG

EMS SOL

$10.6 \mu g /$ WA EPA8270C

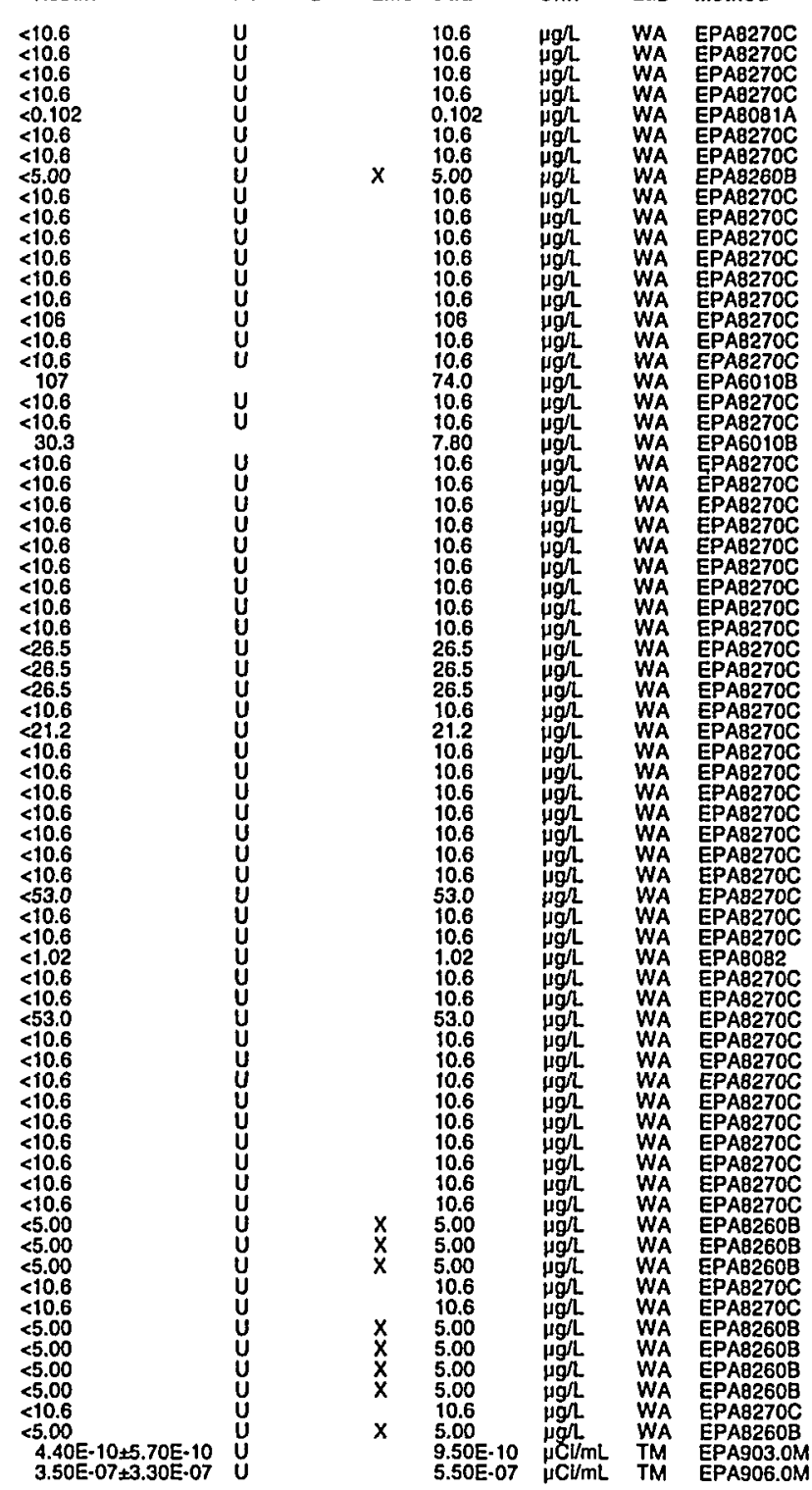

Socond Quarter 1999 
WELL DBP 3

MEASUREMENTS CONDUCTED IN THE FIELD

Sample date: 06/09/99 $(3.09 \mathrm{~m})$ below TOC

$\mathrm{PH}: 5$

Sp. conductance: $60 \mu \mathrm{S} / \mathrm{cm}$

Turblifity: 2 NTU
Waler evacualed from the well prior to sampling: 52 gal

ANALYSES

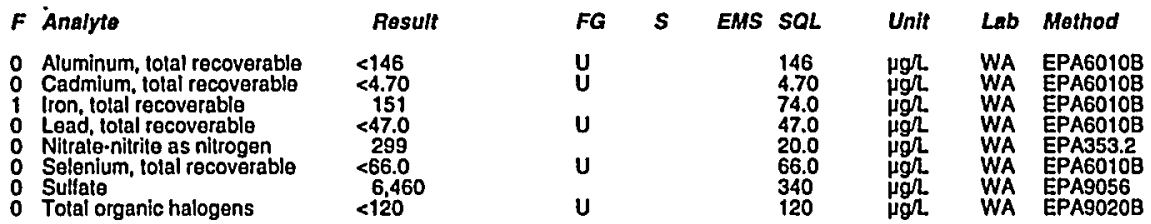

\section{WELL DBP 4}

MEASUREMENTS CONDUCTED IN THE FIELD

Sample date: 04/13/99 2 .

pH: 4.1
$\mathrm{Sp}$ conductance: $94 \mu \mathrm{S} / \mathrm{cm}$

Water evacuated from the well prior to sampling: $70 \mathrm{gal}$

ANALYSES

$F$ Analyte

Rosult

Time: 9:08

Waler temperalure: $20.6^{\circ} \mathrm{C}$

Arr temperalutale: alkalinity (as CaCO3): $4 \mathrm{~mol}$

Phenolphthalein alkalinity: $0 \mathrm{mg} L$

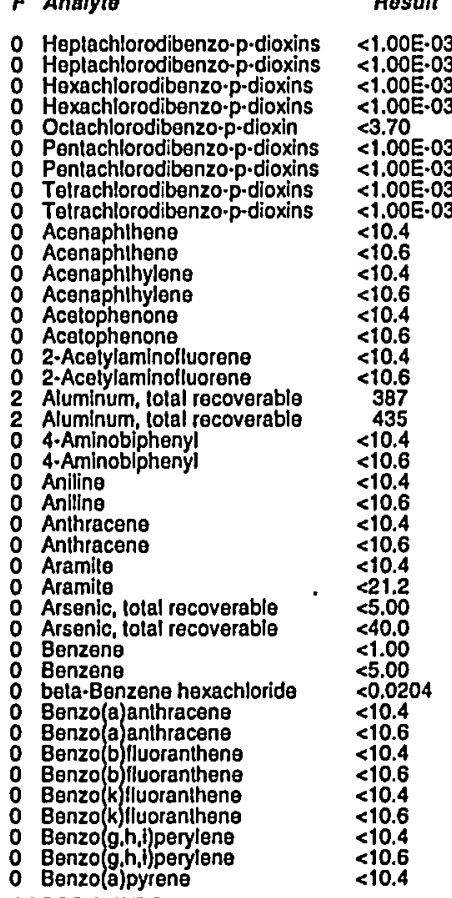

ESH-EMS-990521
Well DBP 4 collected on 04/13/99 (cont.)

$F$ Ansiyto

Result

0 Benzo(a)pyrene

o Bis(2-chloroelhoxy) methan

0
0
0

Bis (2-chlorolshyi) ether

o Bis (2-chloroisopropy) ether

Bromodichloromethane
Bromodichloromethane

o Bromolorm

Bromomethane

4-8romophenyl phenyl ether

4-8romophenyl phenyl th

Butylbenzyl phithalale

Burybonzyl phithalate
Carbonloride

Carbon telrachl
4.Chloroanlline

4-Chloroanlline

o Chlorobenzilate

Chloroesthane

Chloroethane
Chloroethene (Vinyl chloride

2-Chloroelhyl viny? ether

2-Chloroethyl vinyl eth

Chlorolorm

Chloromethane

2.Chloronaphthalene

4.Chlorophenyl phenyl ther

4.Chlorophenyl phenyi ether

o Chromlum, total recoverable

: Chrysene

Diallato

O Dibenz(a,h)anthracene

o Dibenz(a,h)anith

$\begin{array}{ll}0 & \text { Dibenzoluran } \\ 0 & \text { Dibenzofuran } \\ 0 & \text { Dibromochloromethane }\end{array}$

O Dibromochloromethan

0 Di.n-butyl phihalats

o 1.2-Dlchlorobenzene

i) T,2-Dichlorobenzene

1.3.-Dichlorobenzene

1.4-Dichlorobenzene

3,3'-Dichlorobenzidin日

o 1,i-Dichloroothane

1,2-Dichloroesthan

1,i-Dichloroesthylene

trans-1.2.Dichloroothylene

D Dichloromethane

$\begin{array}{ll}0 & 1.2-D i c h l o r o p r o p a n e \\ 0 & 1,2 \text {-Dichloropropane }\end{array}$

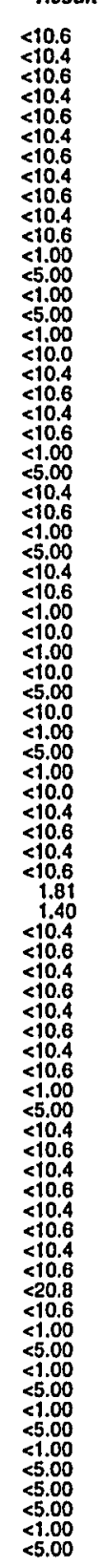

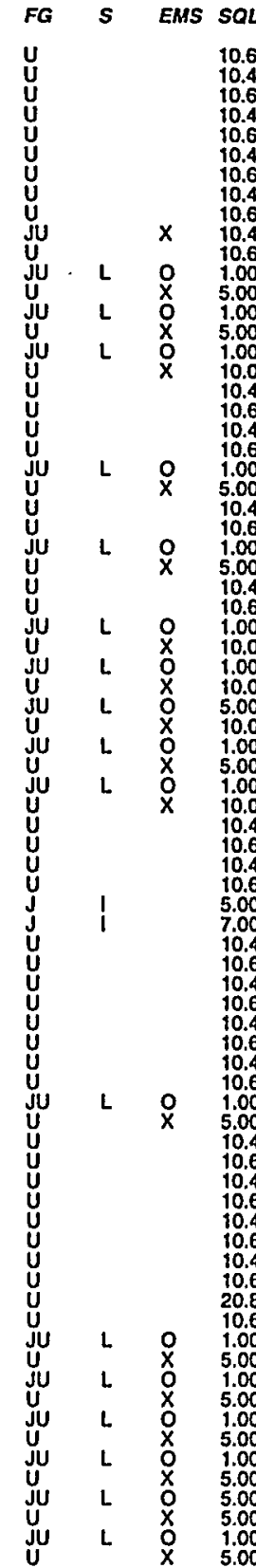

Unit Lab Mothod

10.6 Hgh WA EPAB270C

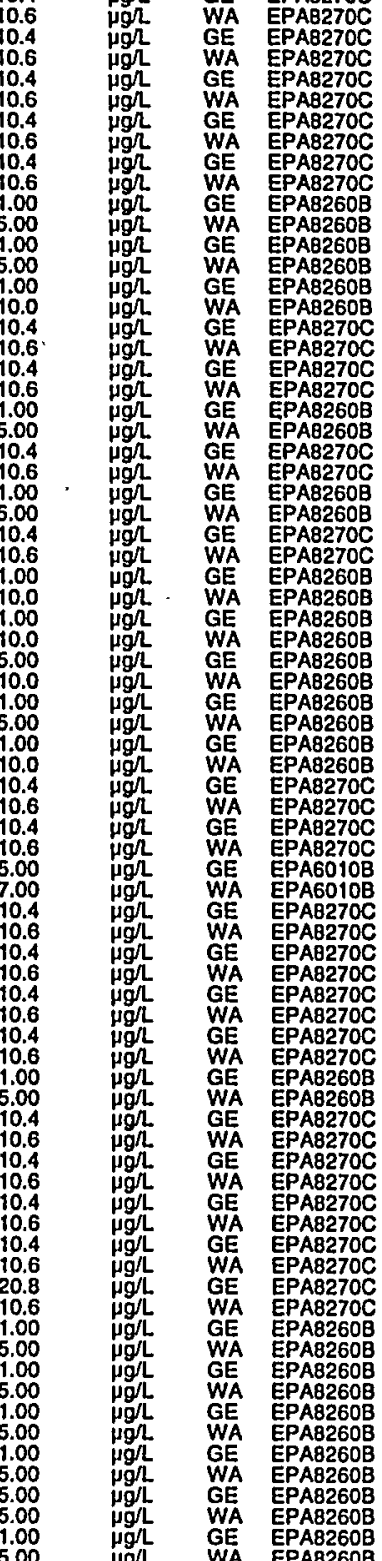

Second Quarter 1999 
ANALYTICAL RESULTS

Well DBP 4 collected on 04/13/99 (conl.)

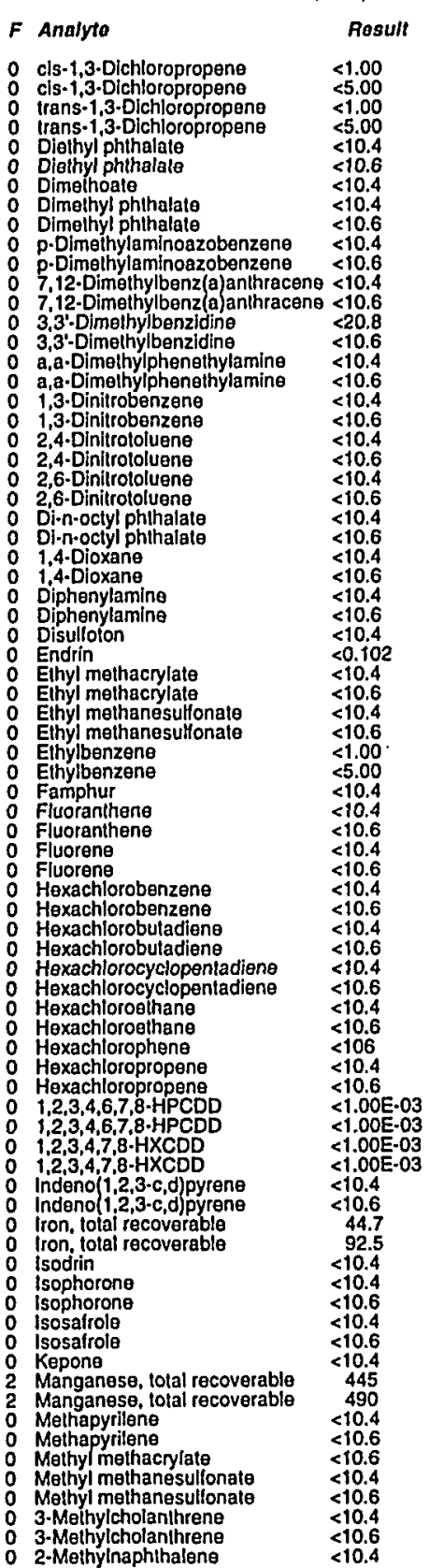

ESH-EMIS-990521
Well DBP 4 collected on 04/13/99 (cont.)

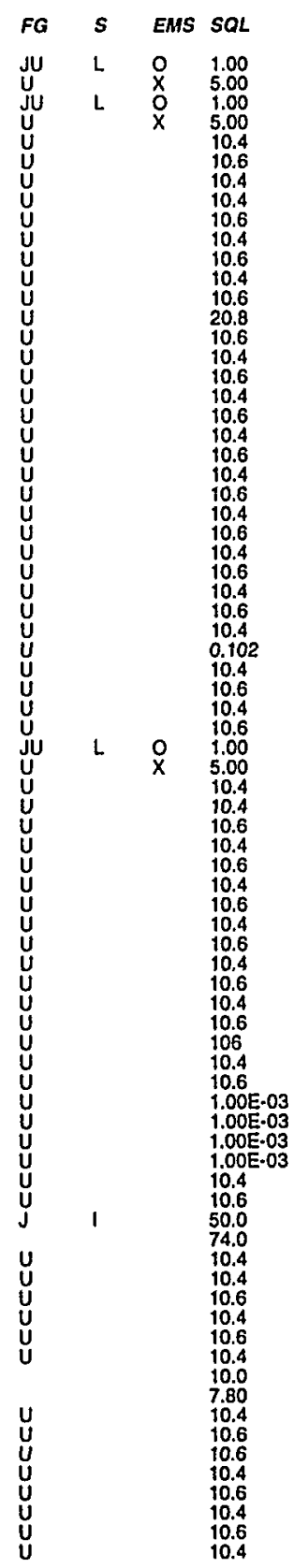

$F$ Analyte Rosult

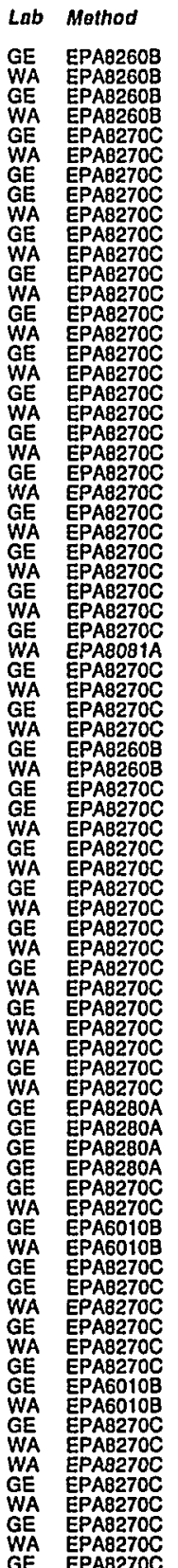

2.Methylnaphthalene

O Naphihalene

$\begin{array}{ll}1,4 \text {-Naphthoquinone } \\ 0 & 1,4 \text {-Naphthoquinone }\end{array}$

1. Naphithylamine

$\begin{array}{ll}0 & \text { 2-Naphthylamine } \\ 0 & \text { 2-Naphthylamine }\end{array}$

0 m.Niliroaniline

o M.Nitroanlline

o-Nitroaniline

o

No Nitrobenzen

4-Nitroquinoline-1-oxide

- N-Nitrosodl-n-butylamine

0 N-Nittosodl-n-butylaming

O N-Nitrosodiethylamine

o N-Nitrosodimelhylamine

N N-Nitrosodimelhylamin

o N-Nitrosodiphenylamine

- N-Nitrosodipropylamine

N N-Nitrosomethylethylamine

N.Nitrosomopholine

0 N-Nittosoplperidine

o N-Nitrosoplperiding

0 N-Nitrosopyrrolidin

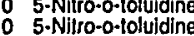

0 Oclachlorodibenzo-p-dioxin

0 PCE 1260

1,2,3,7,8.PCDD

o Pentachlorobenzene

- Pentachlorobethane

Pentachioronitrobenzen

- Phenacetin

0 Phenanthrene

o p.Phenylenediamine

2.Plcoline

o Pronamid

- Pyrene

0 Pyridine

0 Satrole

$\begin{array}{ll}0 & \text { Salrole } \\ 0 & \text { Sullotepp } \\ 0 & 2,3,7,8-1 \mathrm{CDD}\end{array}$

$\begin{array}{ll}0 & 2,3,7,8-T C D D \\ 0 & 1,2,4,5-T \text { etrachlorobenzene }\end{array}$

o $1,2,4,5$-Tetrachlorobenzen 1, , 2,2-Tetrachloroethane

O Teirachloroethylene
0 Tetrachloroethylens

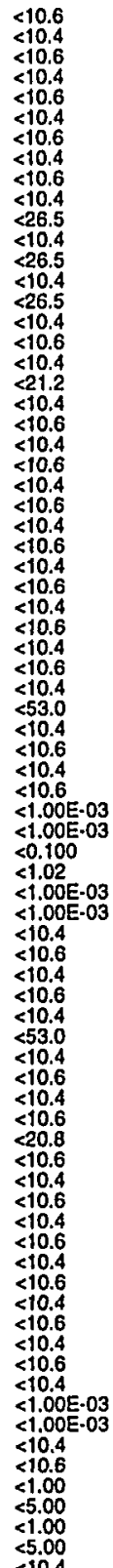

B-84

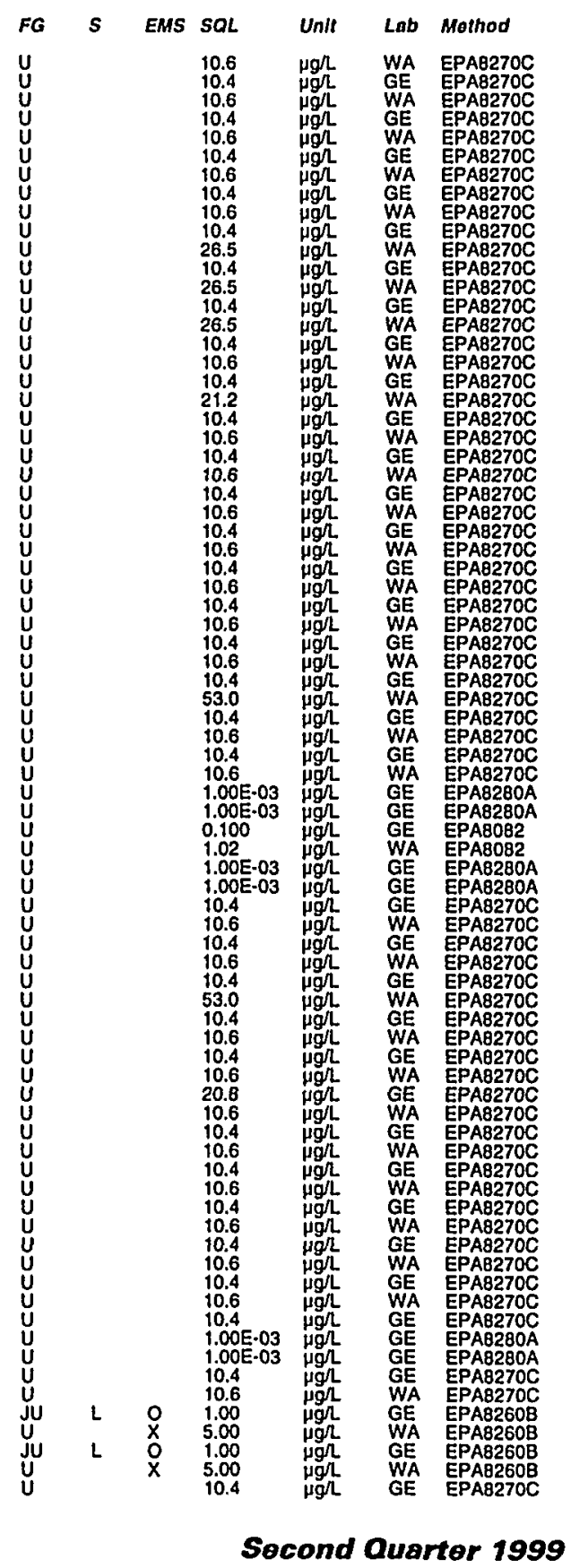


Well DBP 4 collected on 04/13/99 (cont.)

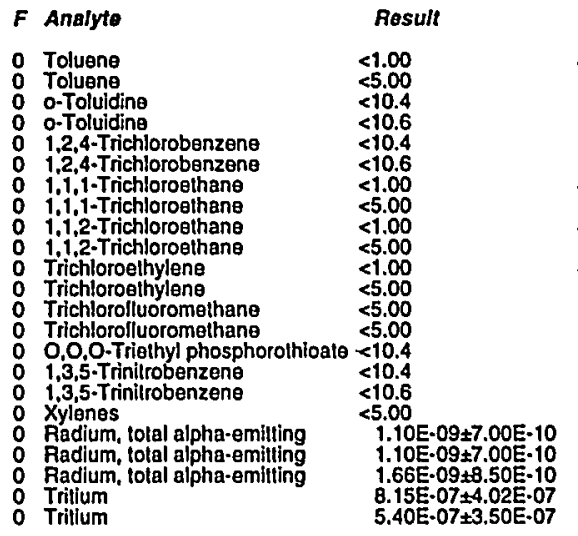

WELL DBP 4 Replicate

MEASUREMENTS CONDUCTED IN THE FIELD

Sample date: 04/13/99

Deplh to waler: $7.4 \mathrm{ft}(2.26 \mathrm{~m})$ below TOC

W: 4.1

p. conductance: $94 \mu 5 / \mathrm{cm}$

Water evacuated from the well prior to sampling: $70 \mathrm{gal}$

ANALYSES

$F$ Analyto

- Octachlorodibenzo-p.dioxin

Acenaphthylen

Acetophenone
2-Acelylaminolluorene

Aluminum, tolal recoverable

4 Aminobiphenyl

- Anthracen

Arsenic, tolal recoverable

Benzola)anthracene

Benzo(b) Iuoranthene

Benzo g., hi, peryle.

Benzyl alcohol

Bis(2-chloroethoxy) mathane

Bis 2-chlorolsopropyl) elh

Bis(2-ethythexyl) phithalate

Bromolorm

4-Bromophenyl phenyl ether

Butylbenzyl phithalate
Carbon tetrachlorido

4-Chloroaniline

o Chlorobenzillal

Chioroethene (Vinyl chloride)

2.Chloroethyl

Chloromethane

2-Chloronaphthalene
4-Chlorophenyl phenyl ether

ESH-EMS-990521

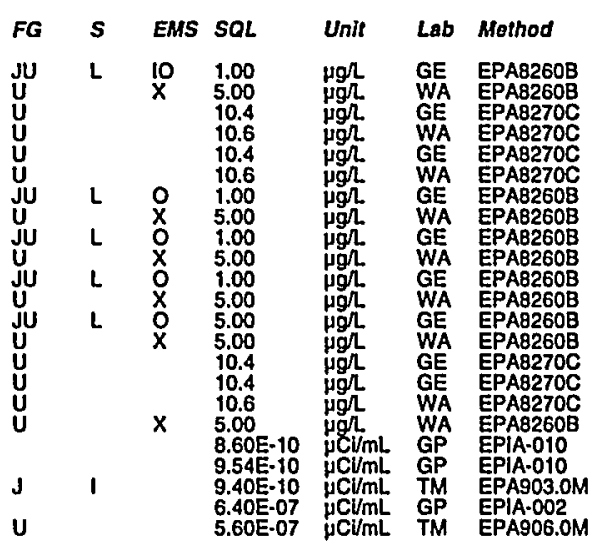

Well DBP 4 collected on 04/13/99 (cont)

$F$ Analyte Result

- Chromium, tolal recoverable $\quad 00.850$

Chrysene
Diallate

Dibenz(a,h)anthracen

Dibromochloromethan
Di-n-buty phthalate

1,2-Dichlorobenzen

1.4-Dichlorobenzene

i.j.Dichloroelhane

i, 1 -Dichloroethylene
trans-1,2-Dichloroothylene

Dichloromethane

cis-1.3-Dichloropropene
trans-1,3.-Dichlioropropene

Dienyl phinglate

9-Dimelhylaminoazobenzene 1,3.0initrobenzene 2,4.Dinitrololuene $2,6 \cdot$ - Dinitrololuene
Dil-n.octyl phthalate

Time: 9:08 Air temperature: $127^{\circ} \mathrm{C}{ }^{\circ} \mathrm{C}$ Total alkalinity (as Caco3): $0 \mathrm{mg} / \mathrm{L}$
Phenolphinalein alkalinity: $0 \mathrm{mg}$.
Field Qualififer(s): $\mathrm{S}$

\section{4-Dioxane
Diphenylamin
Endrin}

Enthy! methacrylate Eihylbenzene

Fluoranthen

O Hexachlorobenzene
0 Hexachlorobutadiene

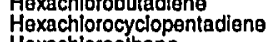

Hexachloroulhane
Hexachlorophene

Hexachloropropene
indeno(1,2,3-c,d)pyrene

\section{Isophorone}

Masarranese, total recoverable Methy melhacrylate

\section{Melhylcholanthrene}

1.4-Naphthoquinon
1-Naphthylamine

2.Naphthylamine

$\begin{array}{ll}0 & \text { m.N.Nirroaniline } \\ 0 & \text { o-Nitroaniline }\end{array}$

p.Nitroaniline

4-Nitroquinoline-1-oxide

N.Nitrosodi-n-butylamin

N.Nilrosodimeihylamino

N.Nilirosodiphenylamine

N.Nitrosomelhylethylamine

- N-Nilrosomorpholine

N-Nitrosopiperidine

PCB 1260

Penlachlorobenzene
Penlachloroethane

Penlachloronitrobenzene
Phenacetion

$<0.850$
$<10.4$
$<10.4$

$<10.4$
$<10.4$

$<5.00$
$<10.4$
$<10.4$

$<10.4$
$<10.4$

$<10.4$

$<.00$
$<5.00$

$<5.00$
$<5.00$
$<5.00$
$<5.00$

$<10.4$
$<10.4$
$<10.4$

$<10$

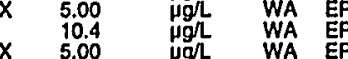

WA EPAB260B

WA

WA EPAB260B

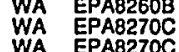

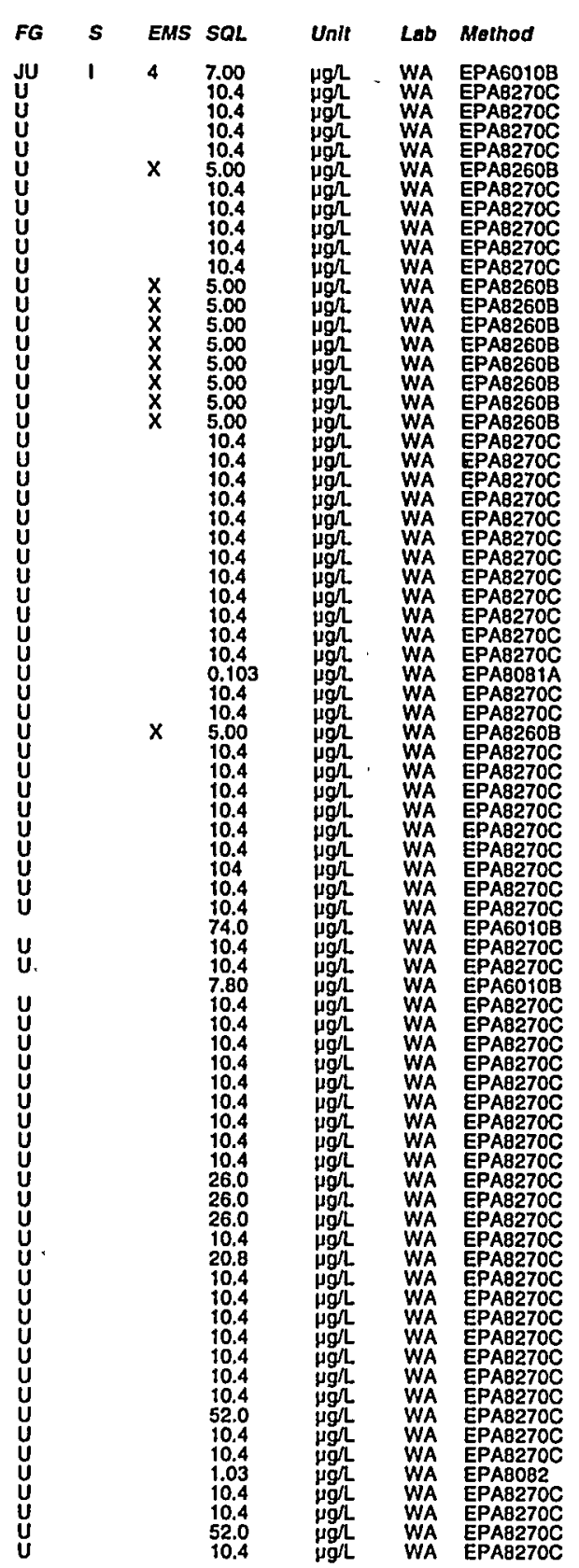

Second Quarter 1999 
Well DBP 4 collected on 04/13/99 (cont.)

F Analyto

Rosull

0
0

2.Picoling

0 Pyrano

1,2,4,5-Totrachlorobenzene

$1,1,2,2 \cdot T$ Tetrachloroeth
Tetrachloroethylene

Toluene

1,2,4-Trichilorobenzene

1,1,1-Trichlorosthane

Trichloroelhyleng

Trichlarolluoromethane

Rylenes Radium, lotal alpha-emittin

WELL DBP 5

MEASUREMENTS CONDUCTED IN THE FIELD

Sample date: 04/13/99

Water elevation: $117.23 \mathrm{Ht}(35.73 \mathrm{~m}) \mathrm{ms}$

$\mathrm{p}^{\mathrm{H}:}: 4.4$

Sp. conductance: $54 \mu \mathrm{S} / \mathrm{cm}$

Waler evacualed from the well prior to sampling: 23 gal

ANALYSES

\begin{tabular}{|c|}
\hline 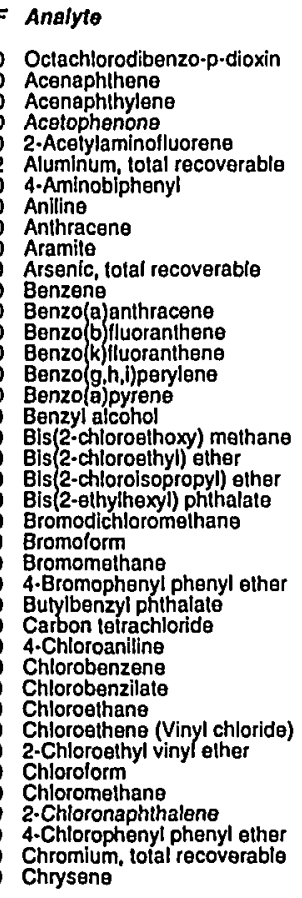 \\
\hline
\end{tabular}

ESH-EMS-990521

Result
$<3.20$
$<10.6$
$<10.6$
$<10.6$
$<10.6$
51.7
$<10.6$
$<10.6$
$<10.6$
$<21.2$
$<40.0$
$<5.00$
$<10.6$
$<10.6$
$<1.6$
$<10.6$
$<10.6$
$<10.6$
$<10.6$
$<10.6$
$<10.6$
$<10.6$
$<5.00$
$<5.00$
$<10.0$
$<10.6$
$<10.6$
$<5.00$
$<10.6$
$<5.00$
$<10.6$
$<10.0$
$<10.0$
$<10.0$
$<5.00$
$<10.0$
$<10.6$
$<10.6$
$<0.860$
$<10.6$

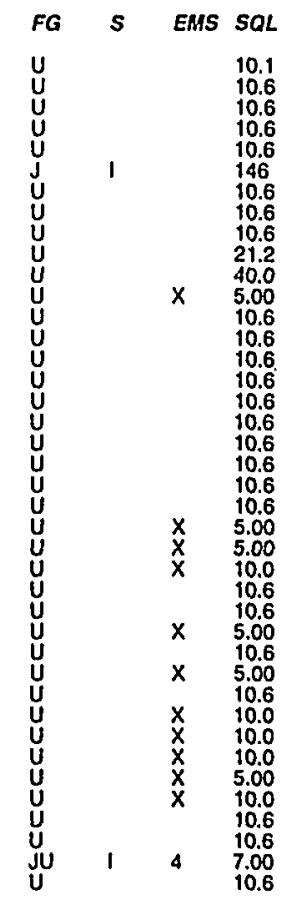

Time: 11:40

Water temperature: $19.3^{\circ} \mathrm{C}$

Total alkalinity (as CaCO3): $0 \mathrm{mg} /$

Field Qualifier(s): $v$

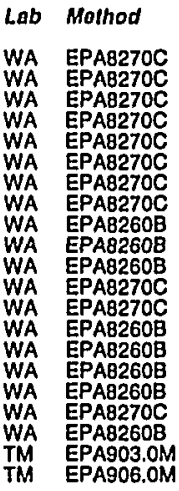

$F$ Analyte

D Dlallate

$<10.8$

Dibenzoluran

Dibromochloromethan

Di.n-butyl phthalale

1.3.Dichlorobenzen

3,3'-Dichlorobenzidine

1.2-Dichloroethane

t,1-Dichloroelhylene

Dichloromethane

cis-1,3-Dichloropropene

Dimeithyi phithalato

p-Dimelhylaminoazobenzene

7.12.Dimethylbenz(a) anthrace

a,a-Dimethyiphenethylamin

2,4-Dinitrololuene

Di-n.octyl phthalate

Endrin

Eihyl methacrylato

Elhylbenzene

Fluorantione

Hexachlorobenzene

Hexachlorocyclopentadiene

Hexachloroethane
Hexachlorophene

Hexachiloropropens

Iron, total recoverable

Isophorone

Manganese, total recoverable

Methyl melhacrylate

Melhy methanesullonat

2.Methylnaturing

Naphthalene

1,4 .Naphlhoquinon
1. Naphithylaming

2-Naphthylamino

o-Nitroaniline

P-Nitroaniliting

4-Nilroquinoline-1-oxlde

N-Nitrosodi-n.butylamine

N.Nilrosodiethylamine

N-Nitrosodimeihylamine

N.Nitrosodipropylamine

N-Nitrosomethylethylamin

N.Nitrosomorpholine

N.Nibrosopyrrolidin

5-Nitro-0.10

Pentachlorobenzene

- Pentachloroethane

Phenacelin

Phenanthrene
p-Phenylenediamine

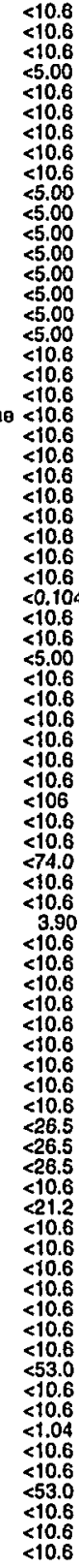

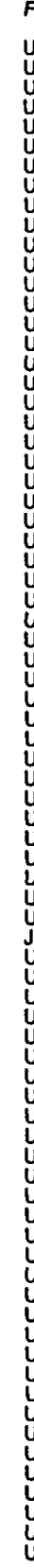

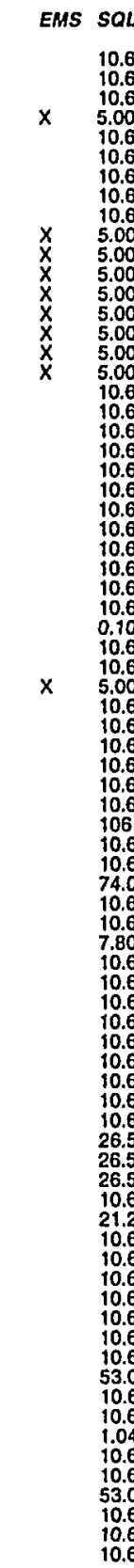

Unit Lab Mothod

Hg/ WA EPAB27OC

ugr WA EPAB270C

WA EPAB270C

WA WA EPA2270C

WA EPAB270C
Wa

Hgi WA EPAD2608

WA

WA

WA

WA

WA

WA

WA EPAB270C

WA EPAB270

WA

WA

WA

WA

WA

WA

EPAB270C

WA

WA

WA

WA

WA

WA

WA

WA

EPAB270C

WA EPA9270C

WA EPAB270C

WA EPAB270C

WA EPAA27OC

WA EPAA270C

WA EPAB270C

Socond Quartor 1999 
Well DBP 5 collected on 04/13/99 (cont)

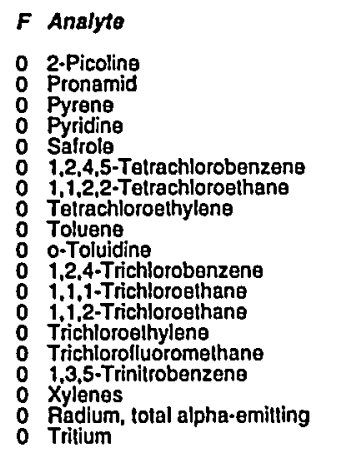

Result
$<10.6$
$<10.6$
$<1.06$
$<10.6$
$<10.6$
$<10.6$
$<5.00$
$<5.00$
$<5.00$
$<10.6$
$<10.6$
$<5.00$
$<5.00$
$<5.00$
$<5.00$
$<10.6$
$<5.00$
$2.49 \mathrm{E}-09 \pm 1.04 \mathrm{E}-09$
$1.79 \mathrm{E}-06 \pm 4.40 \mathrm{E} \cdot 07$

\section{WELL DBP 5}

MEASUREMENTS CONDUCTED IN THE FIELD

Depple dale: $06 / 09 / 99$ water: $19.55 \mathrm{ft}(5.96 \mathrm{~m})$ below TOC

Wh: 3.8

p. conductance: $58 \mu \mathrm{S} / \mathrm{cm}$

Waler evacualed from the well prior to sampling: $20 \mathrm{gal}$

ANALYSES

$F$ Analyto

\begin{tabular}{|c|c|c|c|c|c|c|c|}
\hline Result & $F G$ & $s$ & EMS & SQL & Unit & Lab & Method \\
\hline $\begin{array}{r}41.4 \\
<266 \\
<4.70 \\
<29.8 \\
<47.0 \\
<66.0 \\
341 \\
365 \\
<320 \\
3.53 \mathrm{E} \cdot 09 \pm 1.04 \mathrm{E} \cdot 09 \\
3.98 \mathrm{E} \cdot 09 \pm 1.09 \mathrm{E}-09\end{array}$ & 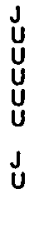 & 1 & & $\begin{array}{l}146 \\
266 \\
4.70 \\
74.0 \\
47.0 \\
66.0 \\
340 \\
1,000 \\
120 \\
1.02 E .09 \\
1.02 E .09\end{array}$ & $\begin{array}{l}\mu g / L \\
\mu g / L \\
\mu g h L \\
\mu g h L \\
\mu g h L \\
\mu g / L \\
\mu g / L \\
\mu g h L \\
\mu g / L \\
\mu C L / m L \\
\mu C l / m L\end{array}$ & $\begin{array}{l}\text { WA } \\
\text { WA } \\
\text { WA } \\
\text { WA } \\
\text { WA } \\
\text { WA } \\
\text { WA } \\
\text { WA } \\
\text { WA } \\
\text { TM } \\
\text { TM }\end{array}$ & $\begin{array}{l}\text { EPA6010B } \\
\text { EPA6010B } \\
\text { EPA6010B } \\
\text { EPA6010B } \\
\text { EPA60108 } \\
\text { EPA6010B } \\
\text { EPA9056 } \\
\text { EPA9060 } \\
\text { EPA90208 } \\
\text { EPA900.0M } \\
\text { EPA900.0M }\end{array}$ \\
\hline
\end{tabular}

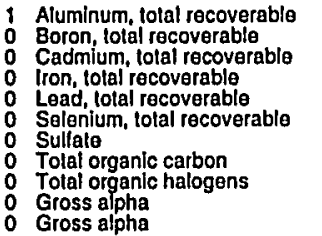

WELL DCB 4A

MEASUREMENTS CONDUCTED IN THE FIELD

Sample date: $06 / 09 / 99$
Depth to water: $12.08 \mathrm{ft}(3.68 \mathrm{~m})$ below TOC
Water elevation: $117.42 \mathrm{ft}(35.79 \mathrm{~m}) \mathrm{msl}$

H: 3.8

p. conduclance: $780 \mu \mathrm{S} / \mathrm{cm}$

Waler evacuated from the well prior to sampling: $84 \mathrm{gal}$

ANALYSES
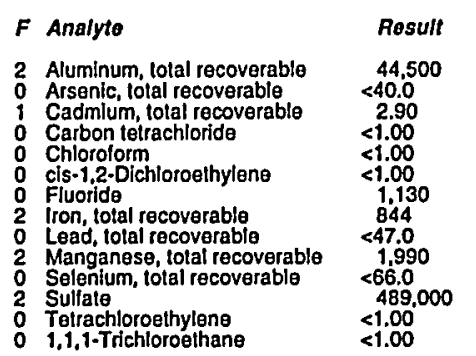

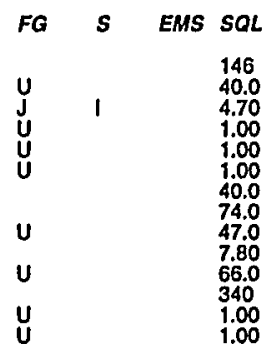

Time: 11:42

Water lemperature: $21.4^{\circ} \mathrm{C}$ Tolal alkalinity (as Caco3): $0 \mathrm{mg} /$ Phenolphthalein alkgin

Water temperature: $18.6^{\circ} \mathrm{C}$ Air temperalure: $24.6^{\circ} \mathrm{C}$ ) $0 \mathrm{mgh}$
Total alkalinity (as CaCO3): $0 \mathrm{mg}$ Tolal alkalinity (as CaCO3): $0 \mathrm{mg} /$
Phenolphinalein alkalinity: $0 \mathrm{mg} \Omega$

ESH-EMS-990521
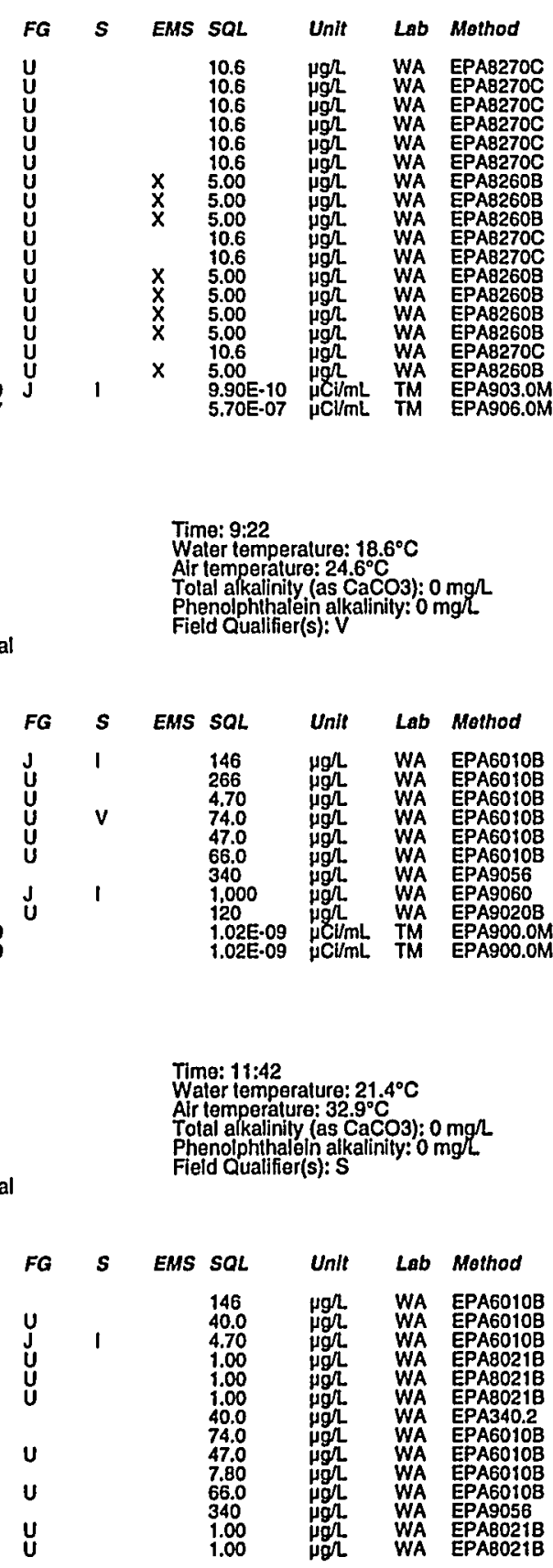

Well DCB 4 A collected on 06/09/99 (cont.)

$F$ Analyte Result

- Trichloroethylene

$<1.00$

FG

EMS SQL

Unit Lab Mothod

WELL DCB 8

MEASUREMENTS CONDUCTED IN THE FIELD

Sample date: 06/09/99

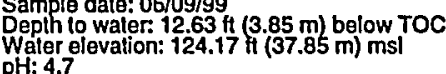

Sp. conductance: $30 \mu \mathrm{S} / \mathrm{cm}$

Water evacuated from the well prior to sampling: 66 gal ANALYSES

\begin{tabular}{|c|c|}
\hline F Analyto & Result \\
\hline 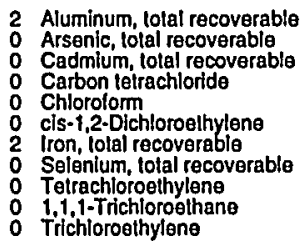 & $\begin{array}{r}131 \\
<40.0 \\
<4.70 \\
<1.00 \\
<1.00 \\
<1.00 \\
305 \\
<68.0 \\
<1.00 \\
<1.00 \\
<1.00\end{array}$ \\
\hline
\end{tabular}

FG $S$ EMS

Time: 11:05

Water lemperature: $19.8^{\circ} \mathrm{C}$

Total alkalinity (as CaCO3): $0 \mathrm{mgl}$ Phenolphthalein alkalinity: $0 \mathrm{mg}$ L
Field Qualifier(s): $S$

\section{WELL DCB 8C}

MEASUREMENTS CONDUCTED IN THE FIELD

Sample date: 05/10/99
Depth to waler: $13.11 \mathrm{ft}(4 \mathrm{~m})$ below Toc
Water elevalion: 124.09 lt $(33.82 \mathrm{~m}) \mathrm{ms}$

$\mathrm{pH}: 4.6$

Sp. conductance: $48 \mu \mathrm{S} / \mathrm{cm}$

Waler evacuated from the well prior to sampling: $30 \mathrm{gal}$ ANALYSES

$F$ Analyto

0 Chloride

o Sulfale

2 Trichloroothylene

WELL DCB 12

MEASUREMENTS CONDUCTED IN THE FIELD

Sample date: 06/09/99

Depth to waler: $9.28 \mathrm{tt}(2.83 \mathrm{~m})$ below TOC

Waler el

p. conductance: $420 \mu \mathrm{S} / \mathrm{cm}$

Waler evacualed from the well prior to sampling: 25 gal

ANALYSES

$F$ Analyto

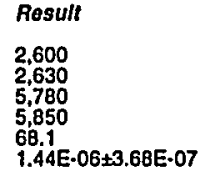

FG

EMS SQL

\begin{tabular}{|c|c|c|c|}
\hline$a L$ & nit & La & Method \\
\hline $\begin{array}{l}146 \\
40.0 \\
4.70 \\
1.00 \\
1.00 \\
1.00 \\
74.0 \\
66.0\end{array}$ & $\begin{array}{l}\mu g h \\
\mu g h \\
\mu g h \\
\mu g h \\
\mu g h \\
\mu g h \\
\mu g h \\
\mu g h \\
\mu g h \\
\mu g h \\
\mu g h\end{array}$ & $\begin{array}{l}\text { wh } \\
w \\
w \\
w \\
w \\
w\end{array}$ & $\begin{array}{l}\text { EPA6010B } \\
\text { EPA60108 } \\
\text { EPA6010B } \\
E P A B 0218 \\
\text { EPAB021B } \\
\text { EPABO21B } \\
\text { EPA6010B } \\
\text { EPA6010B } \\
\text { EPAB021B } \\
\text { EPAB021B } \\
\text { EPAB021B }\end{array}$ \\
\hline
\end{tabular}

Time: 10:19

Water temperature: $20.3^{\circ} \mathrm{C}$

Total alkalinity (as CaCo3): $2 \mathrm{mg} h$.

Phenolphithalein alkalinity: $0 \mathrm{mg} L$
Field Qualifier(s): $V$

2 Aluminum, total recoverable

0 Arsenic, total recoverable

Cadmlum, total recover

cis-1.2-Dichloroethylen

Iron, lotal recoverable

$B-87$

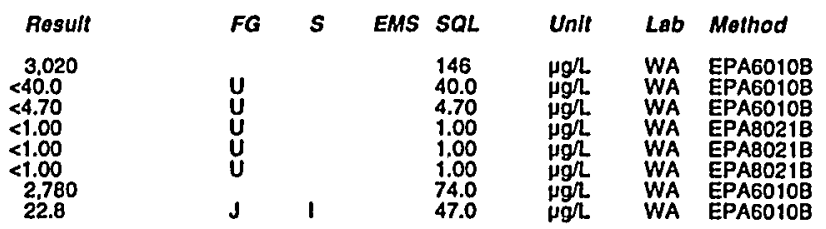

Socond Quarter 1999

Time: 12:34

Air temperature: $35,20.6^{\circ} \mathrm{C}$

Total alkalinily (as CaCO3): $0 \mathrm{mg} /$

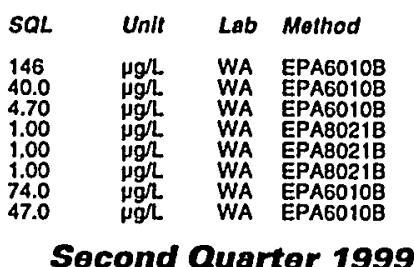

Field Oualifier(s): $s$. 
Well DCB 12 collected on 06/09/99 (cont.)

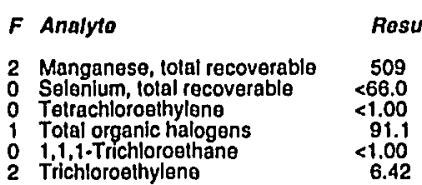
Result WELL DCB 15R

MEASUAEMENTS CONDUCTED IN THE FIELD

Sample date: 05/11/99

Depth to wa: $05.20 .24(6.16 \mathrm{~m})$ below TOC

Waler

gH: 4.5 conductance: $2,300 \mu \mathrm{S} / \mathrm{cm}$

Waler evacualed from the well prior to sampling: $46 \mathrm{gal}$ ANALYSES

\begin{tabular}{|c|c|c|c|c|c|c|c|c|}
\hline F Analyto & Result & $F G$ & $s$ & EMS & SQL & Unit & Lab & Mothod \\
\hline $\begin{array}{l}\text { Chloride } \\
\text { Sullate } \\
\text { Trichloroethylene } \\
\text { Tritium }\end{array}$ & $\begin{array}{l}1,280 \\
1,730,000 \\
4.87 \\
1.96 \mathrm{E}-06 \pm 7.75 \mathrm{E}-07\end{array}$ & & & & $\begin{array}{l}100 \\
10,000 \\
1.00 \\
1.20 \mathrm{E} .06\end{array}$ & $\begin{array}{l}\mu g / L \\
\mu g h \\
\mu g h \\
\mu C \mathrm{~L} / \mathrm{mL}\end{array}$ & $\begin{array}{l}\mathrm{GE} \\
\mathrm{GE} \\
\mathrm{GE} \\
\mathrm{GP}\end{array}$ & $\begin{array}{l}\text { EPA300.0 } \\
\text { EPA300.0 } \\
\text { EPAB2608 } \\
\text { EPIA.002 }\end{array}$ \\
\hline
\end{tabular}

\section{WELL DCB 16R}

MEASUREMENTS CONDUCTEO IN THE FIELL

Sample date: $05 / 11 / 99$

Water elevation: Not avaliable

$\mathrm{pH}: 4.4$

Sp. conductance: $980 \mu \mathrm{S} / \mathrm{cm}$

Water ovacuated from the well prior to sampling: $36 \mathrm{gal}$ ANALYSES

\begin{tabular}{|c|c|c|c|c|c|c|c|c|}
\hline F Analyto & Result & $F G$ & $s$ & EMS & $S O L$ & Unit & $L a b$ & Mothod \\
\hline $\begin{array}{ll}0 & \text { Chlorlde } \\
2 & \text { Sulfiale } \\
2 & \text { Trichloroethylene } \\
1 & \text { Tritium }\end{array}$ & $\begin{array}{l}5,720 \\
5077.000 \\
101 \\
1.02 E-05 \pm 6.68 E-07\end{array}$ & & & & $\begin{array}{l}100 \\
4.000 \\
1.00 \\
5.77 E-07\end{array}$ & $\begin{array}{l}\mu g / L \\
\mu g h \\
\mu g h \\
\mu C / m L\end{array}$ & $\begin{array}{l}\mathrm{GE} \\
\mathrm{GE} \\
\mathrm{GE} \\
\mathrm{GP}\end{array}$ & $\begin{array}{l}\text { EPA300.0 } \\
\text { EPA300.0 } \\
\text { EPAB2600 } \\
\text { EPIA.002 }\end{array}$ \\
\hline
\end{tabular}

\section{WELL DCB 27}

MEASUREMENTS CONDUCTED IN THE FIELD

Sample date: 05/12/99
Depth to water: $10.05 \mathrm{ft}(3.06 \mathrm{~m})$ below TOC
Water elevation: $106.75 \mathrm{H}(32.54 \mathrm{~m}) \mathrm{msl}$

$\mathrm{pH}: 4.6$

Sp. conductance: $46 \mu \mathrm{S} / \mathrm{cm}$

Water evacuated from the well prior to sampling: $14 \mathrm{gal}$

ANALYSES

\begin{tabular}{|c|c|c|c|c|c|c|c|c|}
\hline F Analyte & Result & $F G$ & $s$ & EMS & SQL & Untt & Lab & Mothod \\
\hline $\begin{array}{ll}0 & \text { Chloride } \\
0 & \text { Sulliate } \\
1 & \text { Trichloroethylene } \\
0 & \text { Tritium }\end{array}$ & $\begin{array}{l}5,720 \\
725 \\
4.03 \\
6.0+E-06 \pm 5.23 E-07\end{array}$ & & & & $\begin{array}{l}100 \\
200 \\
1.00 \\
5.30 E-07\end{array}$ & $\begin{array}{l}\mu g h \\
\mu g \Omega \\
\mu g / L \\
\mu \mathrm{Cl} / \mathrm{mL}\end{array}$ & $\begin{array}{l}\mathrm{GE} \\
\mathrm{GE} \\
\mathrm{GE} \\
\mathrm{GP}\end{array}$ & $\begin{array}{l}\text { EPA300.0 } \\
\text { EPA300.0 } \\
\text { EPA82608 } \\
\text { EPIA.002 }\end{array}$ \\
\hline
\end{tabular}

Time: $13: 04$ Water temperature: $23.1^{\circ} \mathrm{C}$

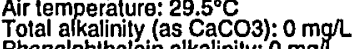

Phenolphthalein alkalinity: $0 \mathrm{mgh}$

Time: 13:05

Wair

Total alkalinity (as CaCo3): $7 \mathrm{mg} /$

Phenolphthalein alkalinity: $0 \mathrm{mg} L$
Field Qualifier(s): VN

\section{WELL DCB 28}

MEASUREMENTS CONDUCTED IN THE FIELD Sample date: 05/10/99

Water elevation: $95.52 \mathrm{ft}(29.11 \mathrm{~m}) \mathrm{ms}$

Sp: conductance: $200 \mu \mathrm{S} / \mathrm{cm}$

Water evacualed from the well prior to sampling: 12 gal ANALYSES

\begin{tabular}{|c|c|c|c|c|c|c|c|c|}
\hline Analyte & Rosult & $\boldsymbol{F G}$ & $s$ & EMS & $S Q L$ & UnIt & Lab & Mothod \\
\hline $\begin{array}{ll}0 & \text { Chloride } \\
0 & \text { Chloride } \\
0 & \text { Sullate } \\
0 & \text { Sullate } \\
2 & \text { Trichloroethylene } \\
2 & \text { Triillum }\end{array}$ & $\begin{array}{l}5.430 \\
5,350 \\
76.700 \\
76.400 \\
18.8 \\
3.50 \mathrm{E} \cdot 05 \pm 1.07 \mathrm{E} \cdot 06\end{array}$ & & & & $\begin{array}{l}100 \\
100 \\
400 \\
400 \\
1.00 \\
5.30 E-07\end{array}$ & $\begin{array}{l}\mu g \Omega \\
\mu g \Omega \\
\mu g L \\
\mu g L \\
\mu g L \\
\mu C \mathrm{C} / \mathrm{mL}\end{array}$ & $\begin{array}{l}G E \\
G E \\
G E \\
G E \\
G E \\
G E \\
G P\end{array}$ & $\begin{array}{l}\text { EPA300.0 } \\
\text { EPA300.0 } \\
\text { EPA300.0 } \\
\text { EPA300.0 } \\
\text { EPA82608 } \\
\text { EPIA.002 }\end{array}$ \\
\hline
\end{tabular}

\section{WELL DCB 29R}

MEASUREMENTS CONDUCTED IN THE FIELD

Sample date: 05/10/99

Water el water: $13.96 \mathrm{f}(4.26 \mathrm{~m})$ below TOC

pH: 3.9

Sp. conductance: $1,400 \mu \mathrm{S} / \mathrm{cm}$

Turbidity: 1 NTU
Water evacuated from the well prior to sampling: $13 \mathrm{gal}$ ANALYSES

F Analyto

C Chlorido

2 $\begin{aligned} & \text { Sullate } \\ & 0\end{aligned}$

0 Tritium

3700

\section{WELLL DCB 30}

MEASUREMENTS CONDUCTED IN THE FIELO

Sample date: 05/12/99

Depth to water: $11.98 \mathrm{ft}(3.65 \mathrm{~m})$ below TOC

$\mathrm{HH}: 4.5$
Sp. conductance: $64 \mu \mathrm{S} / \mathrm{cm}$

Water evacuated from the well prior to sampling: $1 \mathrm{gal}$ ANALYSES

$F$ Analyte

O Chlorido

1 Trichloroethylene

11,400
1.730
3.43

WELL DCB 31

MEASUREMENTS CONDUCTED IN THE FIELD

Sample date: 05/10/99

water: $10.73 \mathrm{H}(3.27 \mathrm{~m})$ below TOC

pH: 3.8

Sp. conductance: $920 \mu \mathrm{S} / \mathrm{cm}$

Water evacualed from the well prior to sampling: 7 gal
Time: 9:17

mperature: $212^{\circ} \mathrm{C}$

Total alkalinity (as CaCO3): $0 \mathrm{mg}$ henolphthalein alkalinity: $0 \mathrm{mg} /$

Time: $9: 17$

Wiremerature: $22.1^{\circ} \mathrm{C}$

Total alkalinity (as CaCO3): $0 \mathrm{mg} / \mathrm{L}$

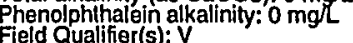

SQL Unit Lab Mothod

$\begin{array}{llll}100 & \mu g h & G E & \text { EPA300.0 } \\ 5.000 & \mu g h & G E & \text { GPA300. }\end{array}$ $\begin{array}{llll}1.00 & \mu g / & G E & \text { EPA8260B } \\ 6.46 E-07 & \mu \mathrm{GL} / \mathrm{mL} & \mathrm{GP} & \text { EPIA.002 }\end{array}$

Water temperature: $20^{\circ} \mathrm{C}$

Total alkalinity (as CaCO3): $4 \mathrm{mg} /$

Phenolphthalein alkalinily: $0 \mathrm{mgh}$
Field Qualifier(s): $\mathrm{VXN}$

FG $\quad s$

$\begin{array}{llll}\text { EMS SQL } & \text { Unit } & \text { Lab } & \text { Mothod } \\ 100 & \mu g h \text { LE } & \text { GE } & \text { EPA300.0 } \\ 200 & \mu g / L & \text { GE } & \text { EPA300.0 } \\ 1.00 & \mu g L & \text { GE } & \text { EPAB260B } \\ 5.29 E-07 & \mu \mathrm{L} / \mathrm{mL} & \text { GP } & \text { EPIA-002 }\end{array}$

Time: 8:18

Water temperature: $18.5^{\circ} \mathrm{C}$

Tolal alkalinity (as CaCo3): $0 \mathrm{mg}$

Phenolphinalein alkalinity: $0 \mathrm{mgh}$. 
Well DCB 31 collected on 05/10/99 (cont)

ANALYSES

$F$ Analyto

0 Acenaphhhene

Acetone

2 Aluminum, total recoverable

Anthracene

Arsenic, total recoverable

Benzene

beta-Benzene hexachloride

Benzidine
Benzo/a)anthracene

Benzo bluoranthen

Benzoic acid

8enzo(a),pyrene

Beryllium, total recoverable

Bis(2.chloroethoxy) melhan

Bis (2-chloroethyl) ether

Bis(2-elhylhexyl) phithalat

Bromolorm

4-Bromophenyl phenyl ether

Butylbonzyl phithalale

Calcium, iolal recoverable

Carbon disullide

alpha.Chlordane

4-Chloroaniline
Chlorobenzene

4.Chloro-m.cresol

Chloroethene (Vinyl chloride)

Chlorolorm

Chloromelhane
2.Chloronaphithalen

4.Chlorophenyl phenyl ether

Chrysene

Cobalt, lotal recoverable

: m/p.Cresol Methylphenol)

0 Cyanide

0 p,p'DDD

Obibenz(a,h)anthracene

$\begin{array}{ll}0 & \text { Dibenzofuran } \\ 0 & \text { Dibromochloromethane } \\ 0 & \text { Di-n-butyl phlhalate }\end{array}$

1.2.Dichlorobenzene

1,4-Dichlorobenzene

1.1.Dichloroethane

1,2.Dichloroelhane

Dichloromethane

1,2.Dichloropropan

is.1,3-Dichlotopropene

Dieldrin

ESH-EMS-990521

Well DCB 31 collected on 05/10/99 (cont)

$F$ Analyte

0 Diethyl phthalate

2.4-Dimethyl pheno
2.4-Dinititrophenalate

$2,6-$ Diniltrololueng
Di-n-octyl phthalate
Endosultan sulfate

Endosultan 1

Endrin aldehyda

Fluoranthen

Heplachlor
Heplachlor epoxide
Hexachlorobenzene

Hexachlorobenzen

Hexachlorocyclopentadiene

2.Hexanone

Indeno(1,2,3-c,d)pyrene

o Lead, total recoverable

Magnesium, total recoverable

2 Manganese, iotal recoverablo

Methoxychlor

2-Mellyll-4,6-dinilroph
Methyl athyl katone

2-Methylnaphthalene

2 Nickel, lotal recoverable

Nitrate-niltrile as nitrogen

o m.Nilroanilline

p-Nilroanilin

2-Nitropheno

4-Nilrophenol
0 N-Niltrosodiphenylamine

(n)

PCB 1010

PCB

0
0

Pentachlorophenol

0 Phenanthrene

Potassium, total recoverable

Pyrene

Silver, total recoverable

Styrene

1,1,2,2-Tetrachloroethane Thallium, total recoverable

- Total dissolved solids

Total organic carbon

Total organic carbon

Total organic halogens

$<1.00$
$<1.00$
$<0.040$
: Toxaphene
Result

$<><0.0$

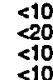

$<10.0$
$<10.0$
$<10.0$

$<0.0404$
$<0.0202$
$<0.0404$

50.0404
0.0404

$<100$

$<10.002$
0.0202
$0<.0202$
$<100$

$<10.0$
$<10.0$

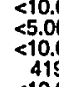

419
$<10.0$
1.37
$<0.020$

$<0.0202$

0.405
$<0.202$
$<10.0$

$<10.0$
$<10.0$
$<5.00$

$<10.0$

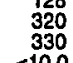

$<10.0$
$<10.0$
$<10.0$

$<<10.0$

$<10.0$
$<1.0$
$<0,100$

$<0.100$
$<0.100$
$<0.100$

$<0.100$
$<0.100$
$<0.100$
$<0.100$

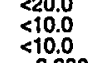

$<\begin{gathered}2.320 \\ <10.0 \\ 4\end{gathered}$

19.2
$<1.00$
8,880

$\mathbf{5 8 0}, 000$
$\mathbf{5 7 2}, 000$

$<1.00$
$<1.00$
0.500

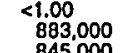

845,000
1.960
1,650
12.3
11.8
$<1.01$
$<10.0$

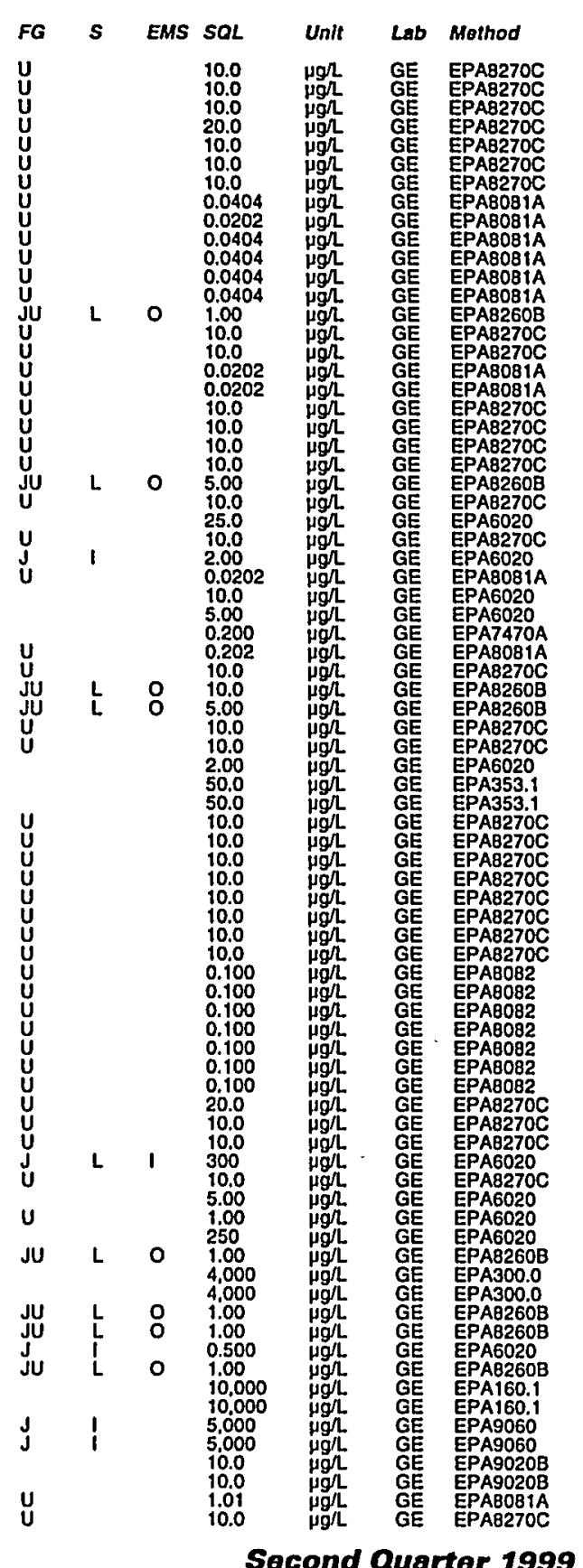


ANALYTICAL RESULTS

Well DCB 31 collected on 05/10/99 (cont.)

$F$ Analyto

Rosult

0 1.1,1-Trichlorosthane

2.4.5. Trichloropheno

2.4,6. Trichloropheno
Vanadium, total recoverable

Vinyl acetal

Zinc, total recoverable

Actinitum-228

Antimony-125

Cerium-144

Coslum-134
Cosium-134

Cosium.137

Coball:-57

Coball-60

Europium-152

Europium-154

Europlum-155

Gross alpha

Lead-212

Lead-212

Manganese.54

Nonvolatile beta

Polassium-40

Promethium-144

Promethium 146

Radium-226

Radium-226

Radium-22

Ruthenium: 106
Ruthenium-106

Sodium-22

Tritium

0 Yritrum

Zinc.65

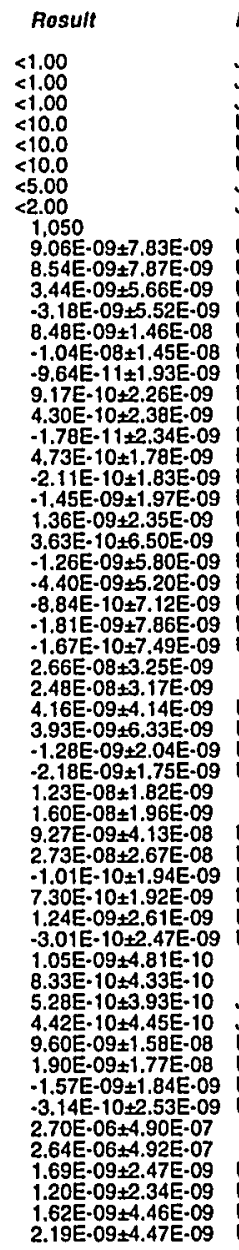

WELL DCB $32 A$

MEASUREMENTS CONDUCTED IN THE FIELD

Sample date: 05/10/99

r: $21.8 \mathrm{ft}(6.64 \mathrm{~m})$ below TOC

Water ewe

p. conductance: $230 \mu \mathrm{S} / \mathrm{cm}$

Water evacuated from the well prior to sampling: $27 \mathrm{gal}$

ANALYSES

$F$ Analyte

0 Chloride

Trichloroethylen

ESH-EMS-990521

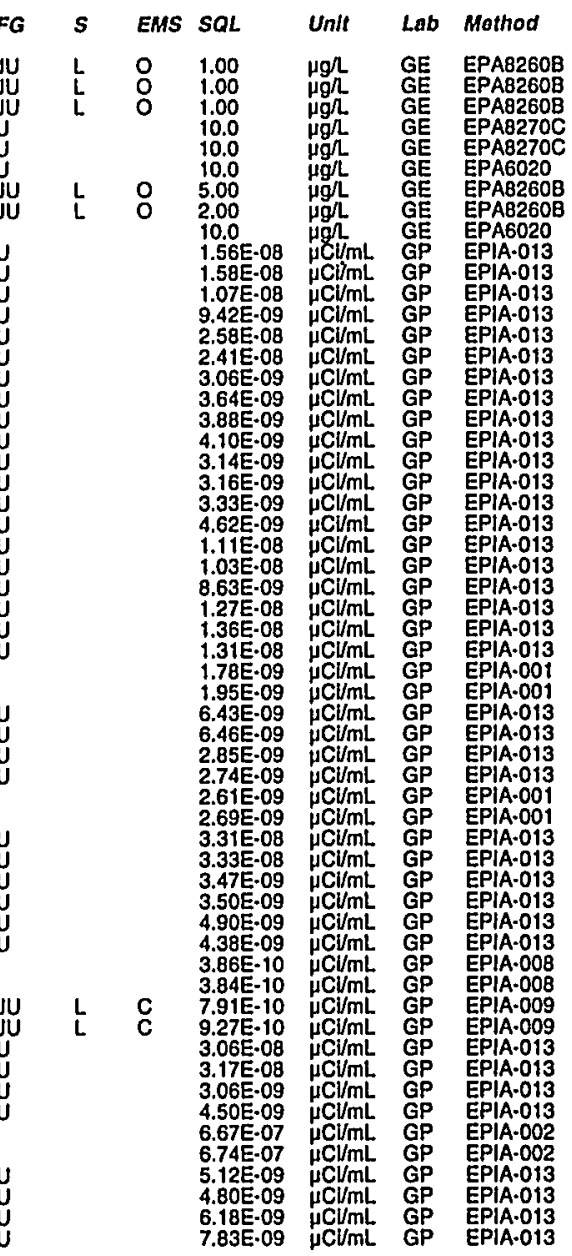

Time: 13:39

rature: $20.4^{\circ} \mathrm{C}$

Total alkalinity (as CaCO3): $0 \mathrm{mg} / \mathrm{L}$

Phenolphthalein alkalinity: $0 \mathrm{mg}$

$\begin{array}{llll}100 & \mu g l & \text { GE } & \text { EPA3000.0 } \\ 1.000 & \mu g h & \text { GE } & \text { EPA300.0 } \\ 1.00 & \mu g L & \text { GE } & \text { EPAB260B } \\ 5.17 E-07 & \mu \mathrm{UVI} / \mathrm{mL} & \text { GP } & \text { EPAA.002 }\end{array}$
WELL DCB 33B

MEASUREMENTS CONDUCTED IN THE FIELD

Sample date: $05 / 11 / 99$
Depth to waier: $10.11 \mathrm{H}(3.08 \mathrm{~m})$ below TOC
Wat

Wh: 5.3

Sp. conductance: $53 \mu \mathrm{S} / \mathrm{cm}$

Waler evacualed from the well prior to sampling: $40 \mathrm{gat}$

ANALYSES

\begin{tabular}{|c|c|c|c|c|c|c|c|c|}
\hline F Analyto & Result & $F G$ & $s$ & EMS & SOL & Unit & Lab & Method \\
\hline $\begin{array}{ll}0 & \text { Chloride } \\
0 & \text { Sulfate } \\
2 & \text { Trichloroothylene } \\
0 & \text { Tifitium }\end{array}$ & $\begin{array}{l}3,290 \\
7,420 \\
18.9 \\
1.75 E \cdot 06 \pm 3.75 E-07\end{array}$ & & & & $\begin{array}{l}100 \\
200 \\
1.00 \\
5.22 E-07\end{array}$ & $\begin{array}{l}\mu g^{\prime L} \\
\mu g^{\prime L} \\
\mu g^{\prime} \\
\mu \mathrm{CL}^{\prime} / \mathrm{mL}\end{array}$ & $\begin{array}{l}\mathrm{GE} \\
\mathrm{GE} \\
\mathrm{GE} \\
\mathrm{GP}\end{array}$ & $\begin{array}{l}\text { EPA300.0 } \\
\text { EPA300.0 } \\
\text { EPAB260日 } \\
\text { EPIA.002 }\end{array}$ \\
\hline
\end{tabular}

\section{WELL DCB 33C}

MEASUREMENTS CONDUCTED IN THE FIELD

Sample date: 05/11/99
Depth to water: $9.95 \mathrm{Ht}(3.03 \mathrm{~m})$ below TOC
Water elevation: $133.25 \mathrm{tf}(40.62 \mathrm{~m}) \mathrm{msl}$

$\mathrm{pH}: 4.8$

Sp. conductance: $46 \mu \mathrm{S} / \mathrm{cm}$

Wurbidity: 1 NTU
Waler evacualed from the well prior to sampling: $35 \mathrm{gal}$

ANALYSES

$F$ Analyte

Aosult

FG

Time: 12:25

年

Total alkalinity (as Caco3): $0 \mathrm{mgr}$

Phenolphthalein alkalinily: $0 \mathrm{mg}$

0 Chloride

$\begin{array}{ll}0 & \text { Sullate } \\ 2 & \text { Trichloroethylene } \\ 0 & \text { Tritium }\end{array}$

2,920
6,610

\section{WELL DCB 33D}

MEASUREMENTS CONDUCTED IN THE FIELD

Sample date: 05/10/99
Depth to water: $9.76 \mathrm{ft}(2.97 \mathrm{~m})$ below TOC

p. conductance: $46 \mu \mathrm{S} / \mathrm{cm}$

Well prior to sampling: 38 gat

ANALYSES

$F$ Analyto

Rosult

$F G$

Time: 12:50

Wir temperature: $19.9^{\circ}$

Total aíkalinity (as CaCO3): $0 \mathrm{mg} / \mathrm{L}$

Phenolphthalein alkalinity: $0 \mathrm{mg}$
Field Qualifier(s): $v$

0 Chloride

$\begin{array}{ll}0 & \text { Sullate } \\ 0 & \text { Trlchloroethylene } \\ 0 & \text { Tritium }\end{array}$

1,920

$\begin{array}{ll}10.600 & 0.993 \\ 1.81 E-07 \pm 3.09 E-07 & J\end{array}$

$F G \quad S$

MS SQL Unlt Lab Mathod

\section{WELL DCB 45A}

MEASUAEMENTS CONDUCTED IN THE FIELD

Sample date: 05/11/99
Depth to walor: $14.43 \mathrm{ht}(4.4 \mathrm{~m})$ below TOC
Water elevation: $123.17 \mathrm{tt}(37.54 \mathrm{~m}) \mathrm{ms}$

Water

Sp. conductance: $42 \mu \mathrm{S} / \mathrm{cm}$

Water evacuated from the well prior to sampling: $23 \mathrm{gal}$

ANALYSES

\begin{tabular}{|c|c|c|c|c|c|c|c|c|}
\hline Analyte & Result & $F G$ & $s$ & EMS & SOL & Untt & Lab & Mothod \\
\hline $\begin{array}{l}\text { Chloride } \\
\text { Sulfate }\end{array}$ & $\begin{array}{l}4,090 \\
2,530\end{array}$ & & & & $\begin{array}{l}100 \\
200\end{array}$ & $\begin{array}{l}\mu g h \\
\mu g h\end{array}$ & GE & $\begin{array}{l}\text { EPA300.0 } \\
\text { EPA300.0 }\end{array}$ \\
\hline
\end{tabular}

Water temperature: $21.2^{\circ} \mathrm{C}$

Tolal alkalinity (as CaCO3) $2 \mathrm{mg} / \mathrm{L}$
Phenolphthalein alkalinity: 0 mgh 
Well DCB 45A collected on 05/11/99 (cont)

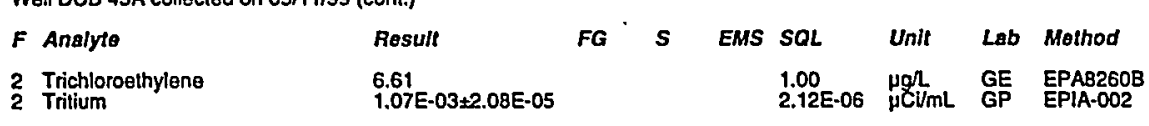

\section{WELL DCB 45C}

MEASUREMENTS CONDUCTED IN THE FIELD

Sample date: $05 / 11 / 99$
Depth to waler $14.48 \mathrm{H}(4.41 \mathrm{~m})$ below TOC
Waler elevation: $124.32 \mathrm{H}(37.89 \mathrm{~m}) \mathrm{ms}$
ph: 5

Sp. conductance: $50 \mu \mathrm{S} / \mathrm{cm}$

Water evacuated from the well prior to sampling: $23 \mathrm{gal}$

ANALYSES

$F$ Analyto

Rosult

FG

Time: 13:15

Waler temperature: $22.1^{\circ} \mathrm{C}$

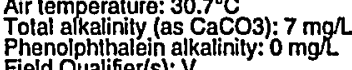

Chlorlde
00 Sulfate
2
2 Trichloroethylene
2 Trilium

3.460
2,910

WELL DCB 47C

MEASUREMENTS CONDUCTED IN THE FIELD

Sample date: 05/10/99 $05 \mathrm{~m}$ ) below TOC

Water elevation: $108.59 \mathrm{ft}(33.1 \mathrm{~m}) \mathrm{ms}$

Hi: 5.3 .

Water evacuated from the well prior to sampling: 12 gal

ANALYSES

F Analyte

0 Chlorido

2 Trichloroethylene

Trifitum

Result

FG $\quad S$

Water temperalure: $216^{\circ} \mathrm{C}$

Aotal alkalinity (as CaCO3): $2 \mathrm{mgh}$

Field Oualiber(s): $V$.

\section{WELL DCB 48D}

MEASUREMENTS CONDUCTED IN THE FIELD

Sample date: $05 / 11 / 99$ th $(4.58 \mathrm{~m})$ below TOC

Water elevalion. $94.37 \mathrm{ft}(28.76 \mathrm{~m}) \mathrm{ms}$

$\mathrm{Sp}$. conductance: $78 \mu \mathrm{S} / \mathrm{cm}$

Turbidity: 1 NTU:
Water evacualed from the well prior to sampling: $28 \mathrm{gal}$ ANALYSES

\begin{tabular}{|c|c|c|c|c|c|c|c|c|}
\hline F Analyte & Result & $F G$ & $s$ & EMS & SQL & Untt & Lab & Method \\
\hline $\begin{array}{ll}0 & \text { Chloride } \\
0 & \text { Sullate } \\
0 & \text { Trichloroethylene } \\
0 & \text { Tritium }\end{array}$ & $\begin{aligned} & 2,030 \\
& 1,3000<1,800 \\
& 1.00 \\
& 3.73 E-07 \pm 3.22 E-07\end{aligned}$ & U & & & $\begin{array}{l}100 \\
200 \\
1.00 \\
5.33 \mathrm{E}-07\end{array}$ & 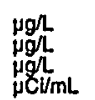 & $\begin{array}{l}\text { GE } \\
\text { GE } \\
G E \\
G P\end{array}$ & $\begin{array}{l}\text { EPA300.0 } \\
\text { EPA300.0 } \\
\text { EPAB2608 } \\
\text { EPIA-002 }\end{array}$ \\
\hline
\end{tabular}

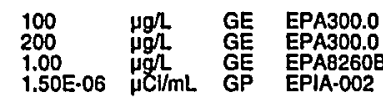

$0: 8 \cdot 0$

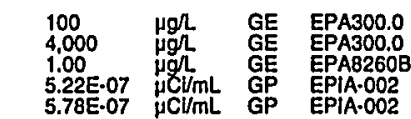

Time: 14:50

Aaler temperalure: $21.4^{\circ} \mathrm{C}$

Phenolphthalein alkalinity: $0 \mathrm{mg} h$
WELL DOB 1

MEASUREMENTS CONDUCTED IN THE FIELD

Sample date: 06/02/99

Water elevation: $141.99 \mathrm{ft}(43.28 \mathrm{~m}) \mathrm{ms}$

$\mathrm{OH}: 6.3$

p. conductance: $170 \mu \mathrm{S} / \mathrm{cm}$

Water evacuated from the well prior to sampling: $59 \mathrm{gal}$

ANALYSES

$F$ Analyto

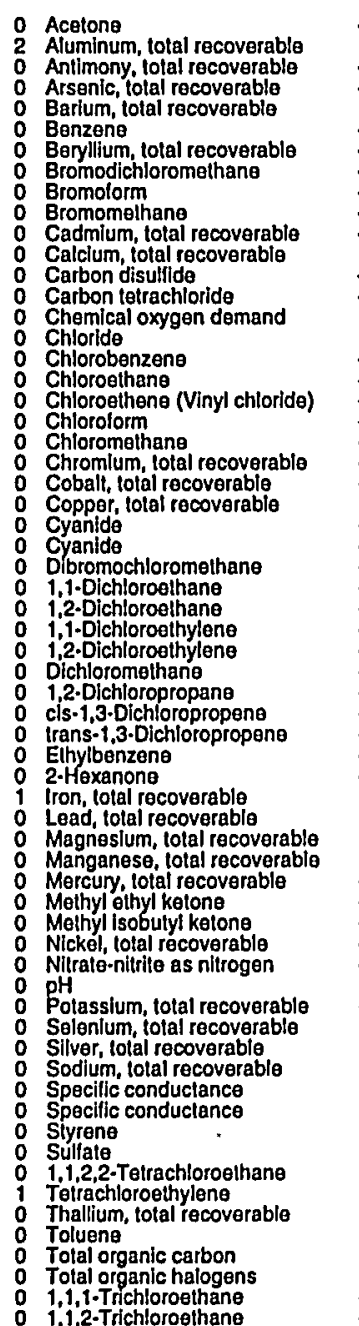

Result

Total alkalinity (as CaCO3): $19 \mathrm{mg} \Omega$
$<10.0$

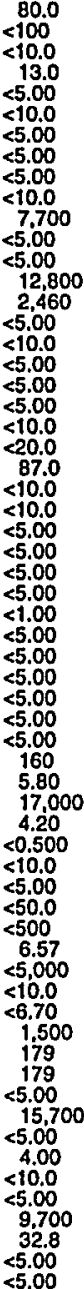

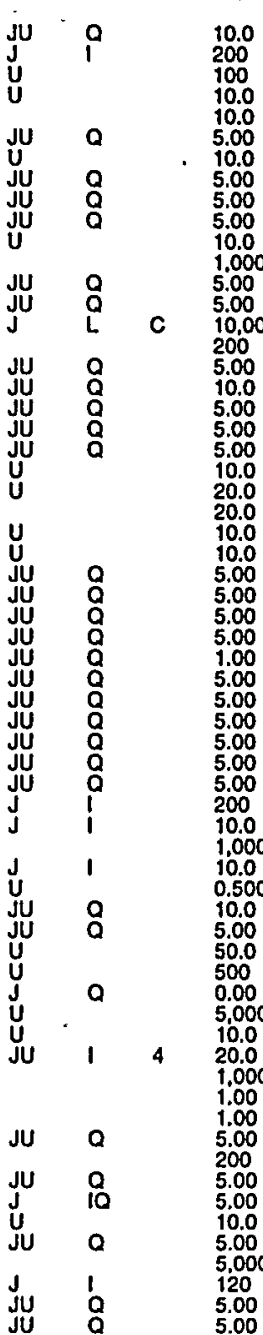

Time: 11:19 $19.6^{\circ} \mathrm{C}$ otal alkalinity (as Caco3): $63 \mathrm{mgh}$ Field
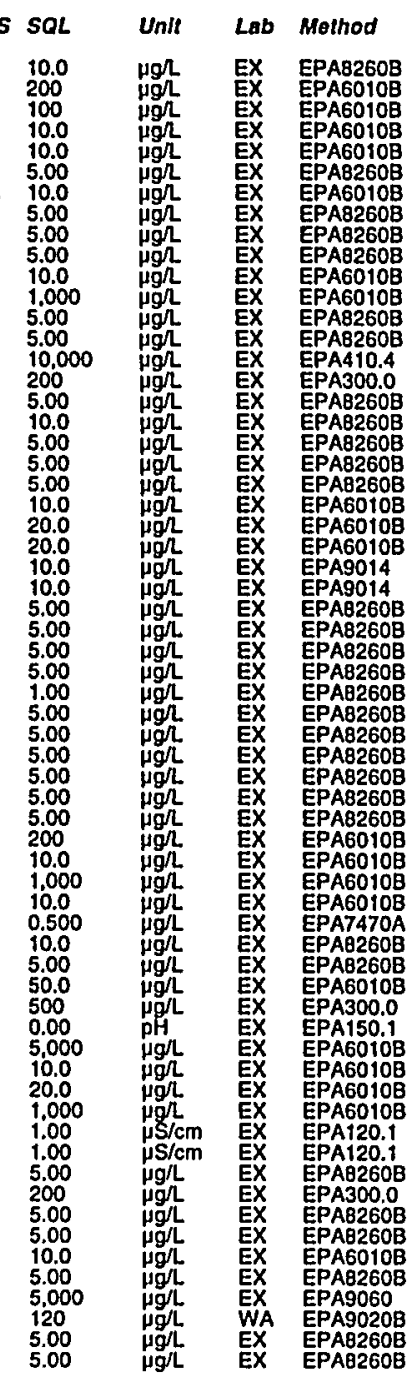

Socond Quarter 1999 


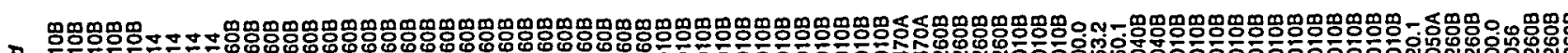

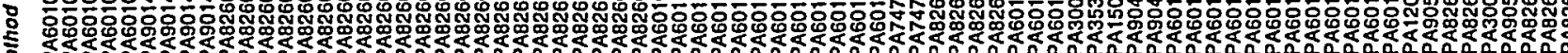

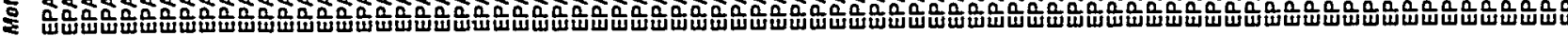

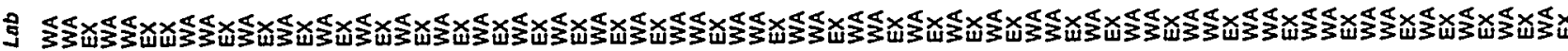

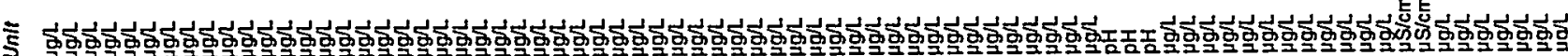

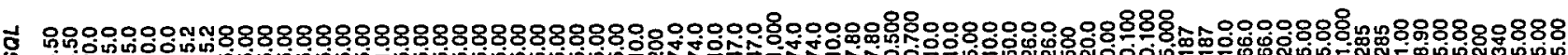

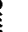

S

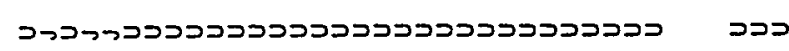

ככבכבכבכב

ooo

$\underline{\underline{ }}$

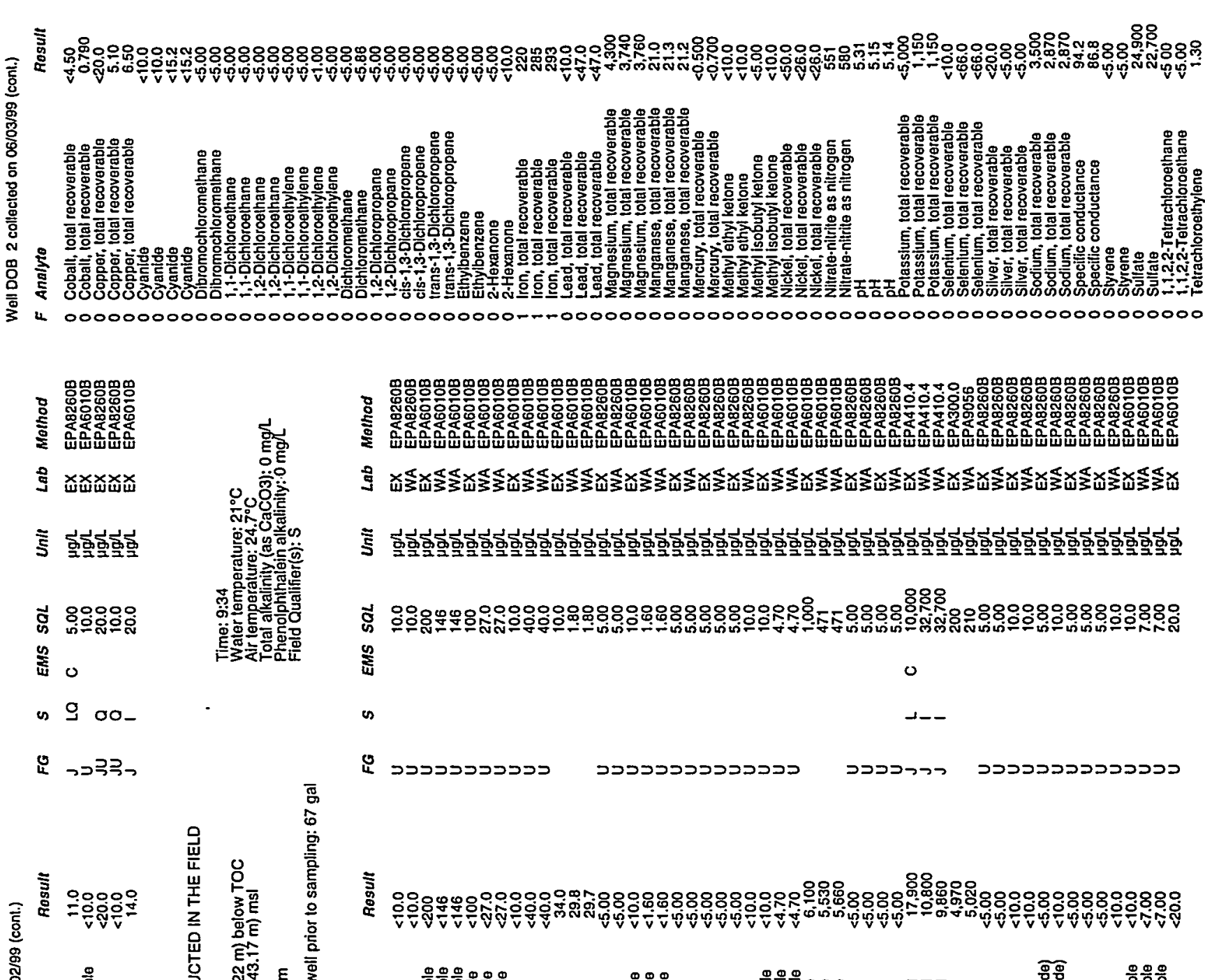

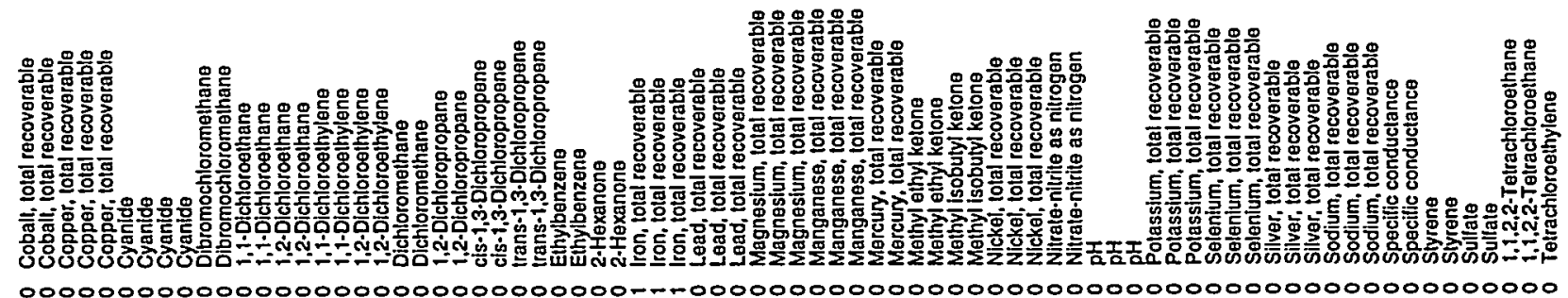

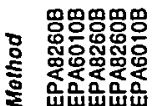

I xxxx

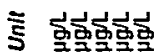

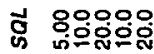

穹 0

es 9 oo-

노 >つ引ア

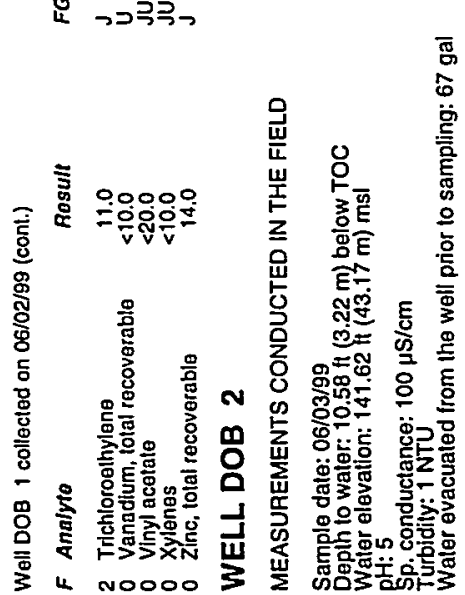

ํㅗㅇ

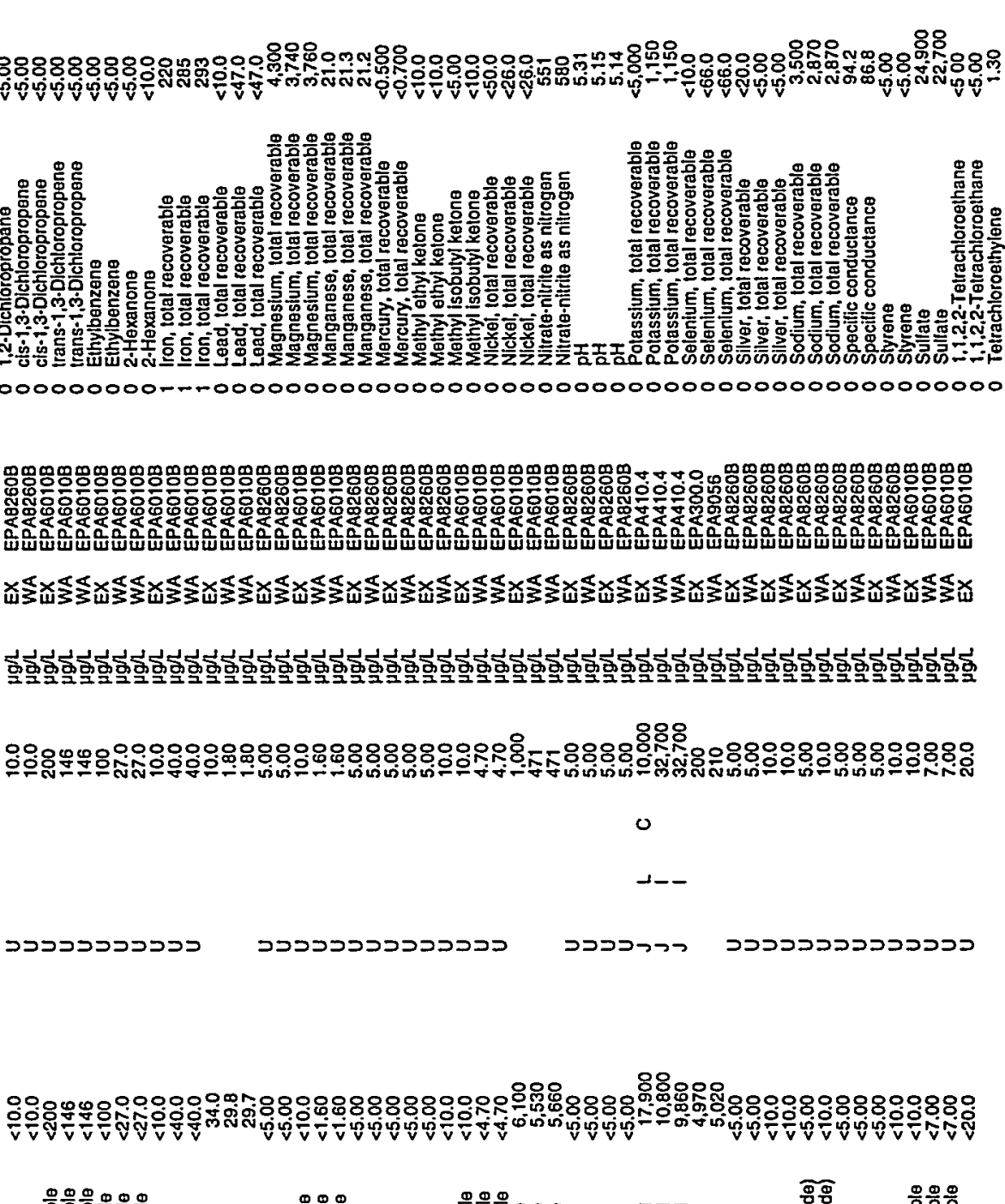

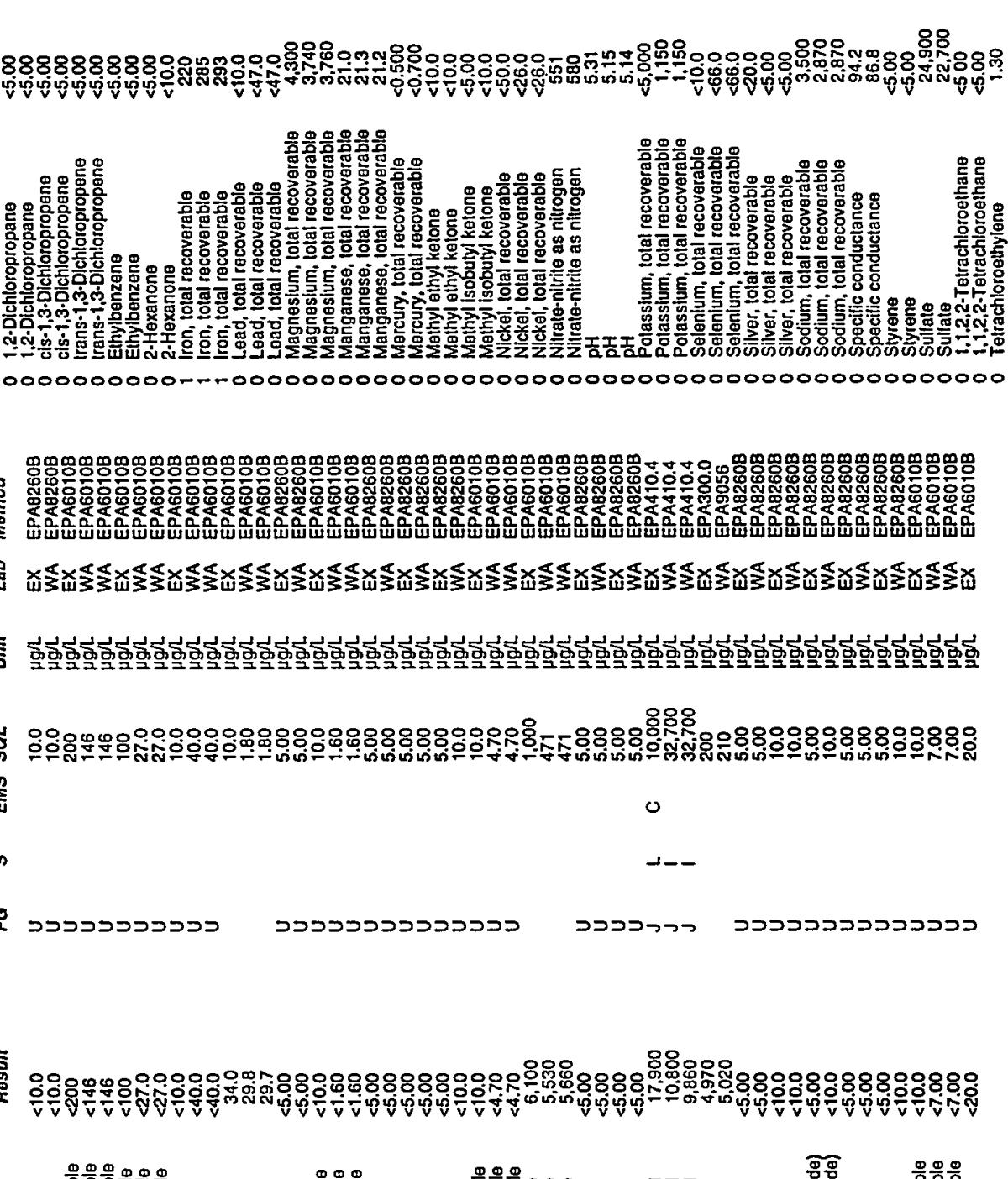

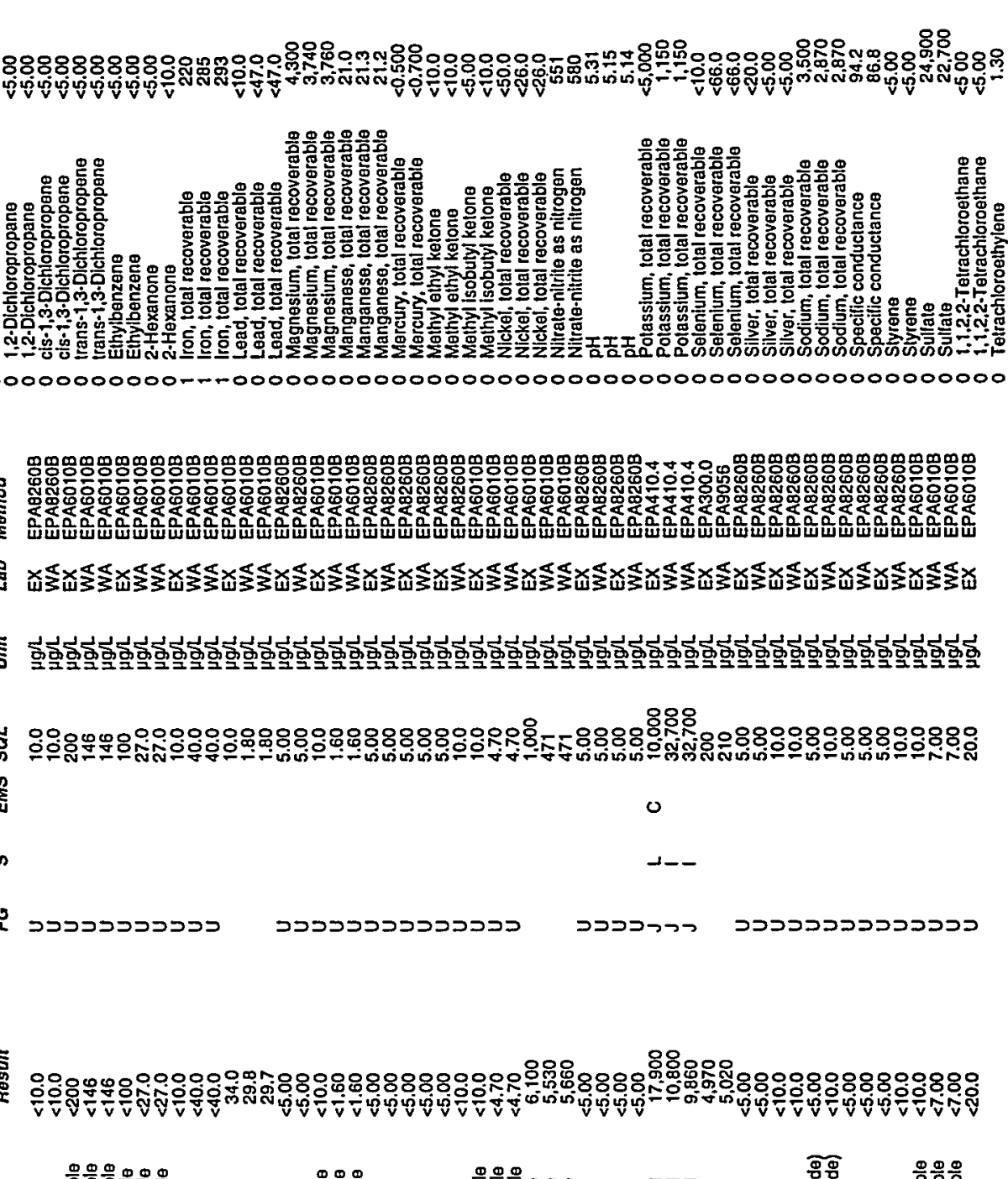

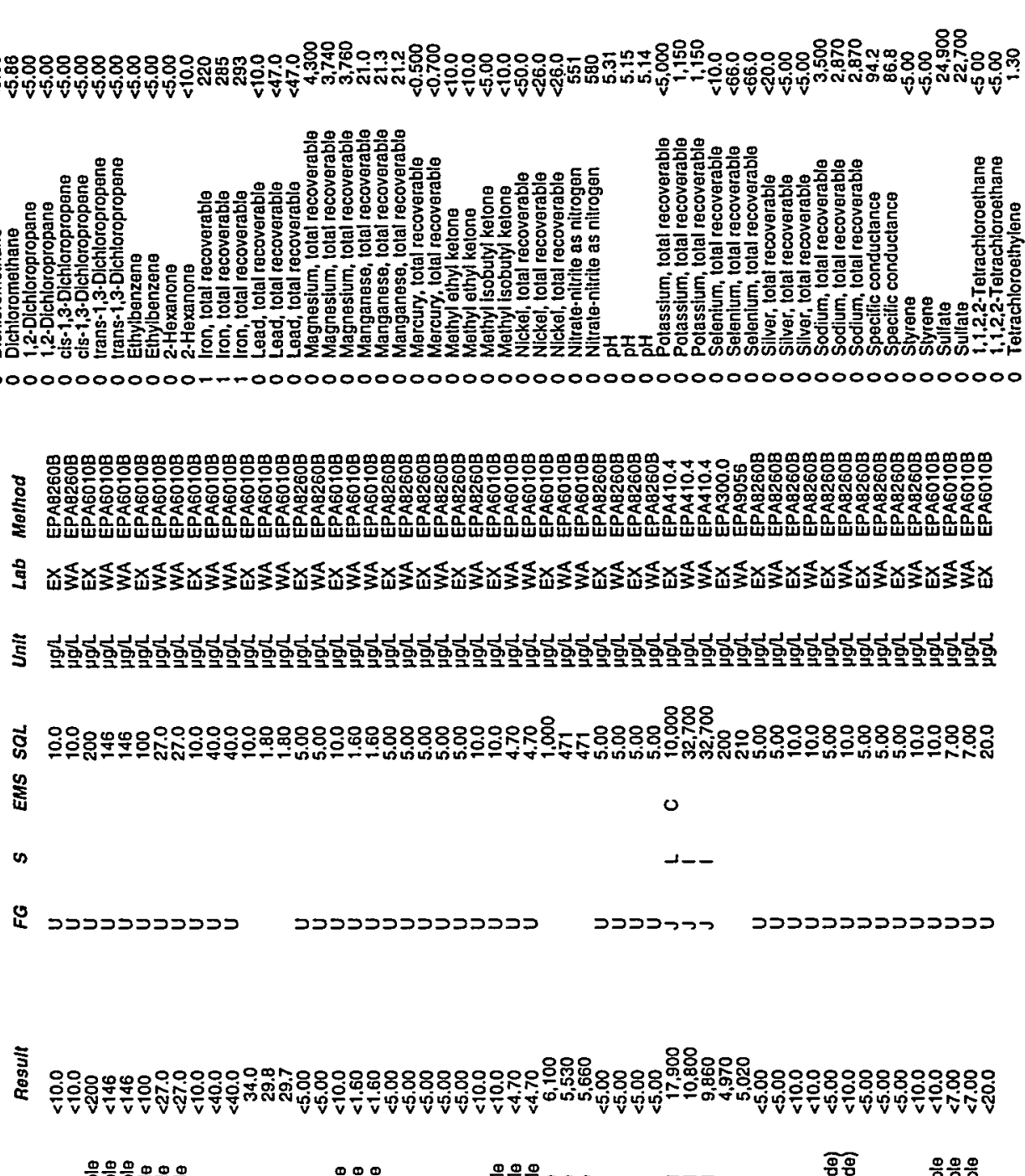

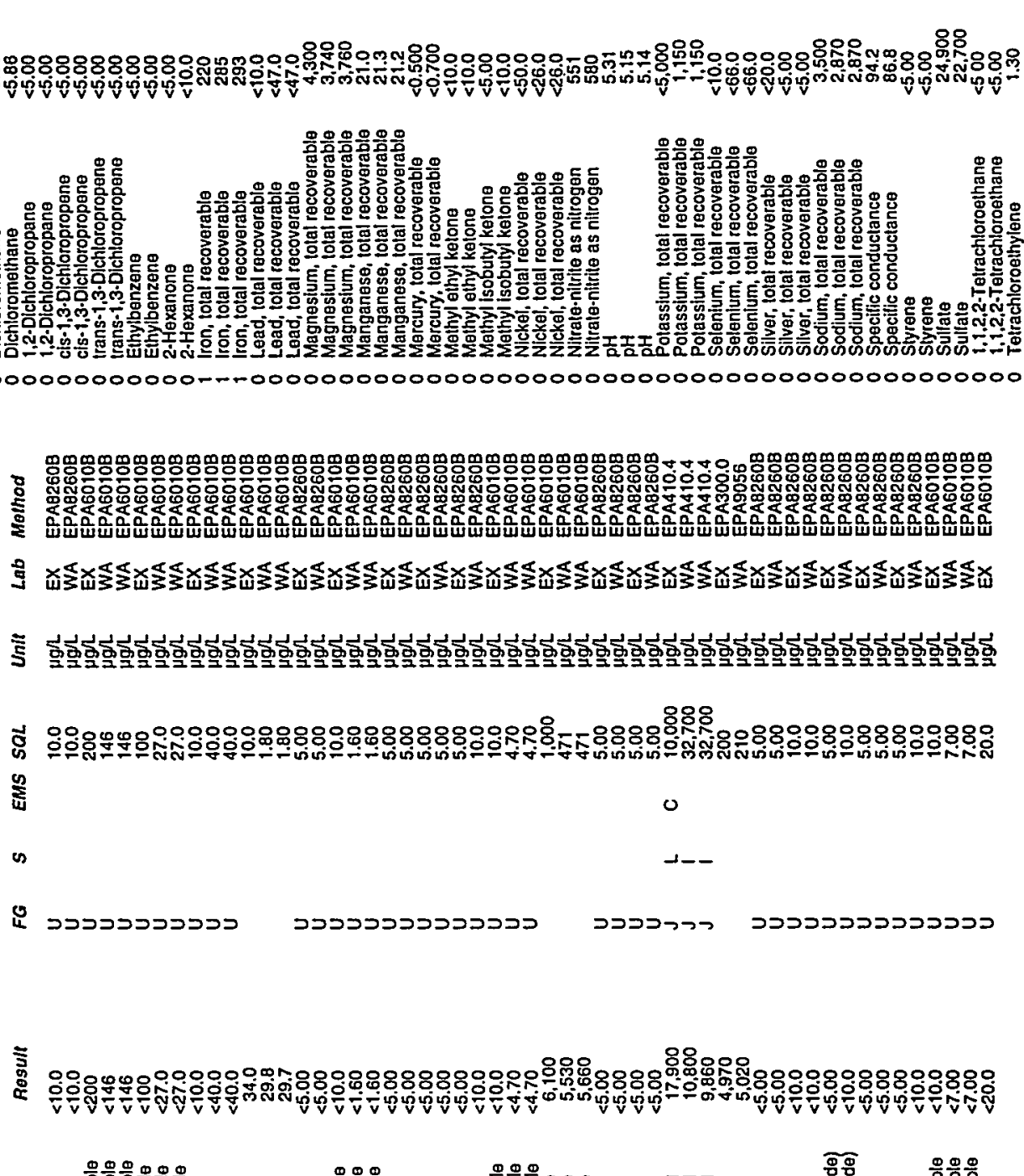

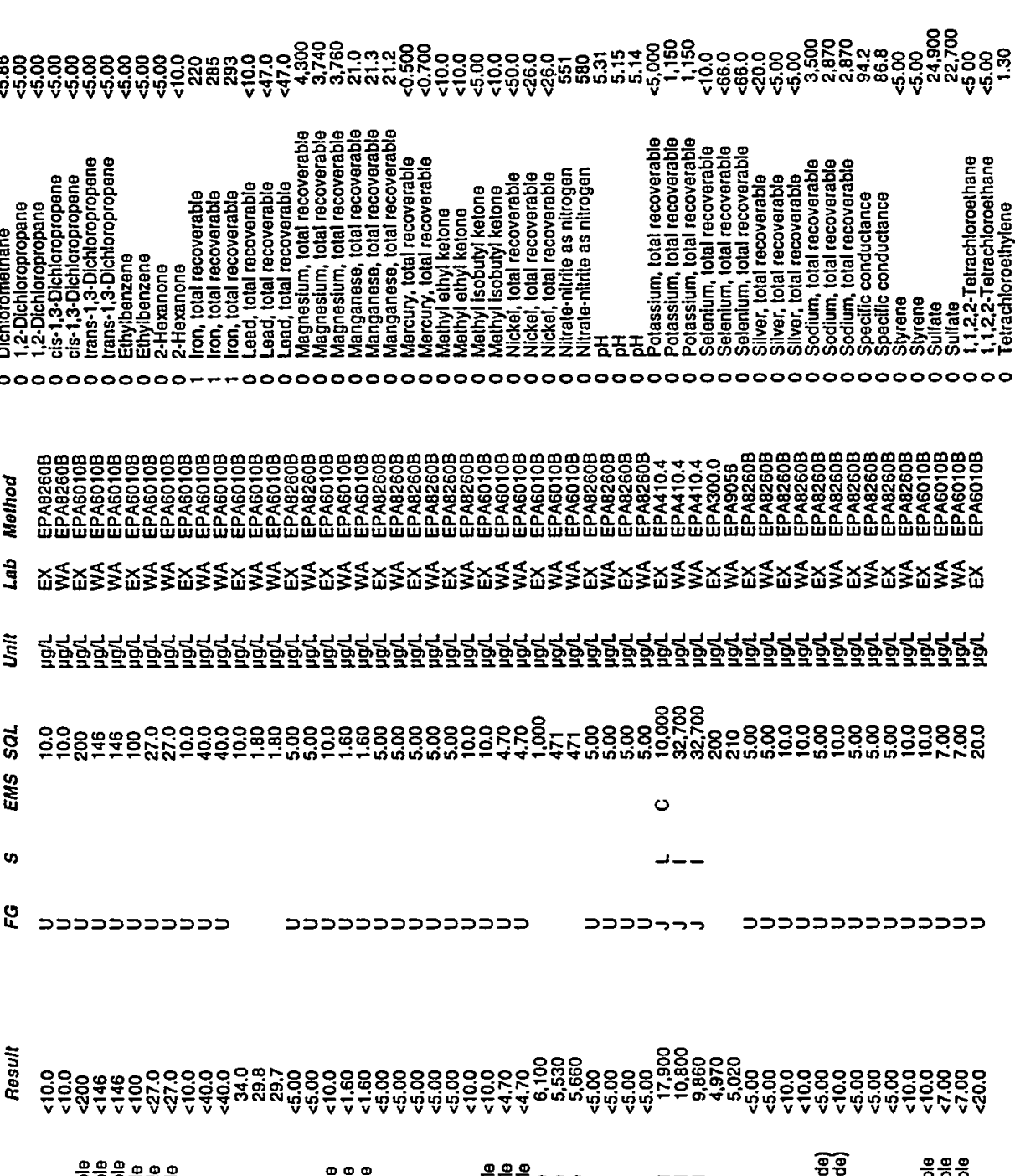
案

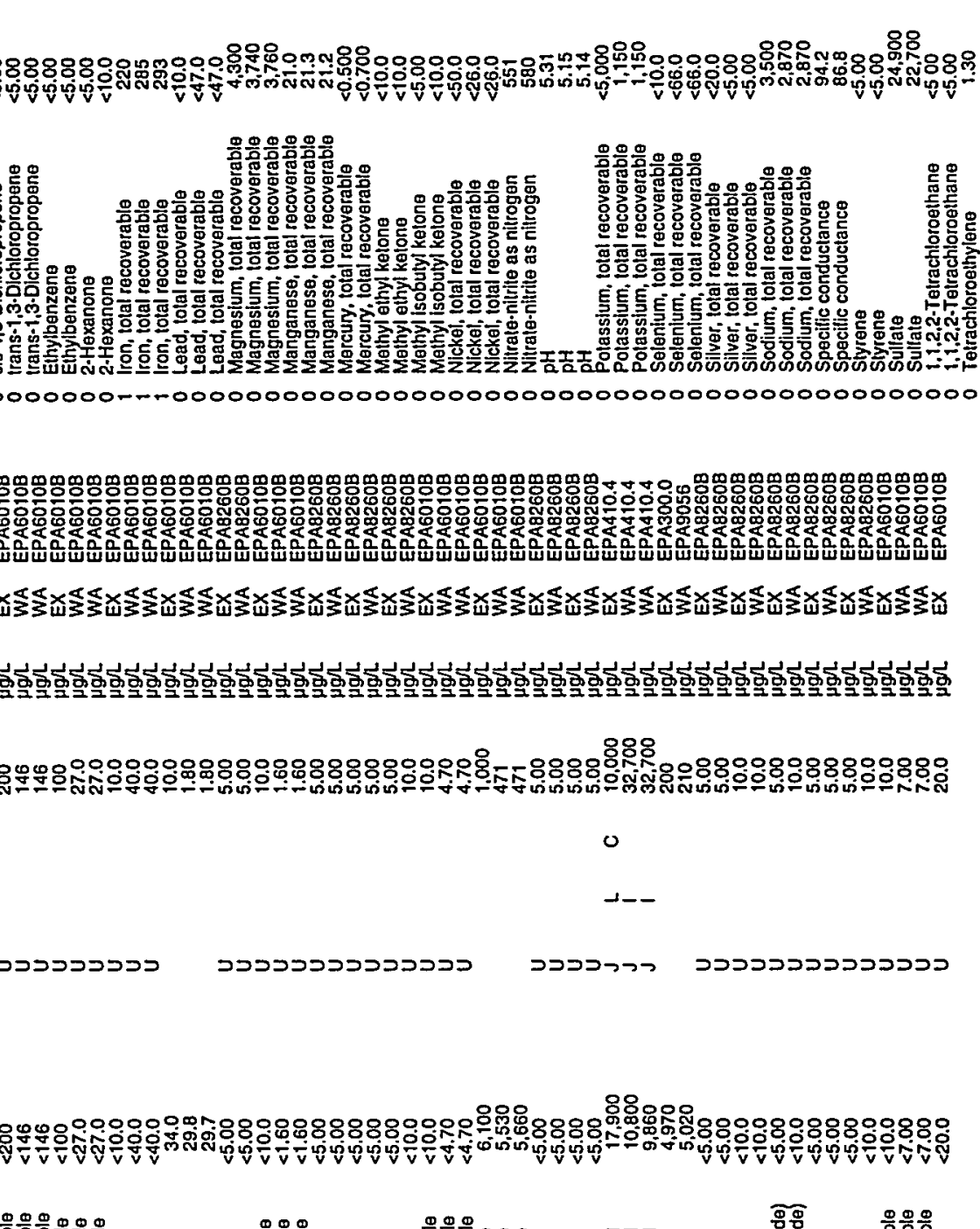

is

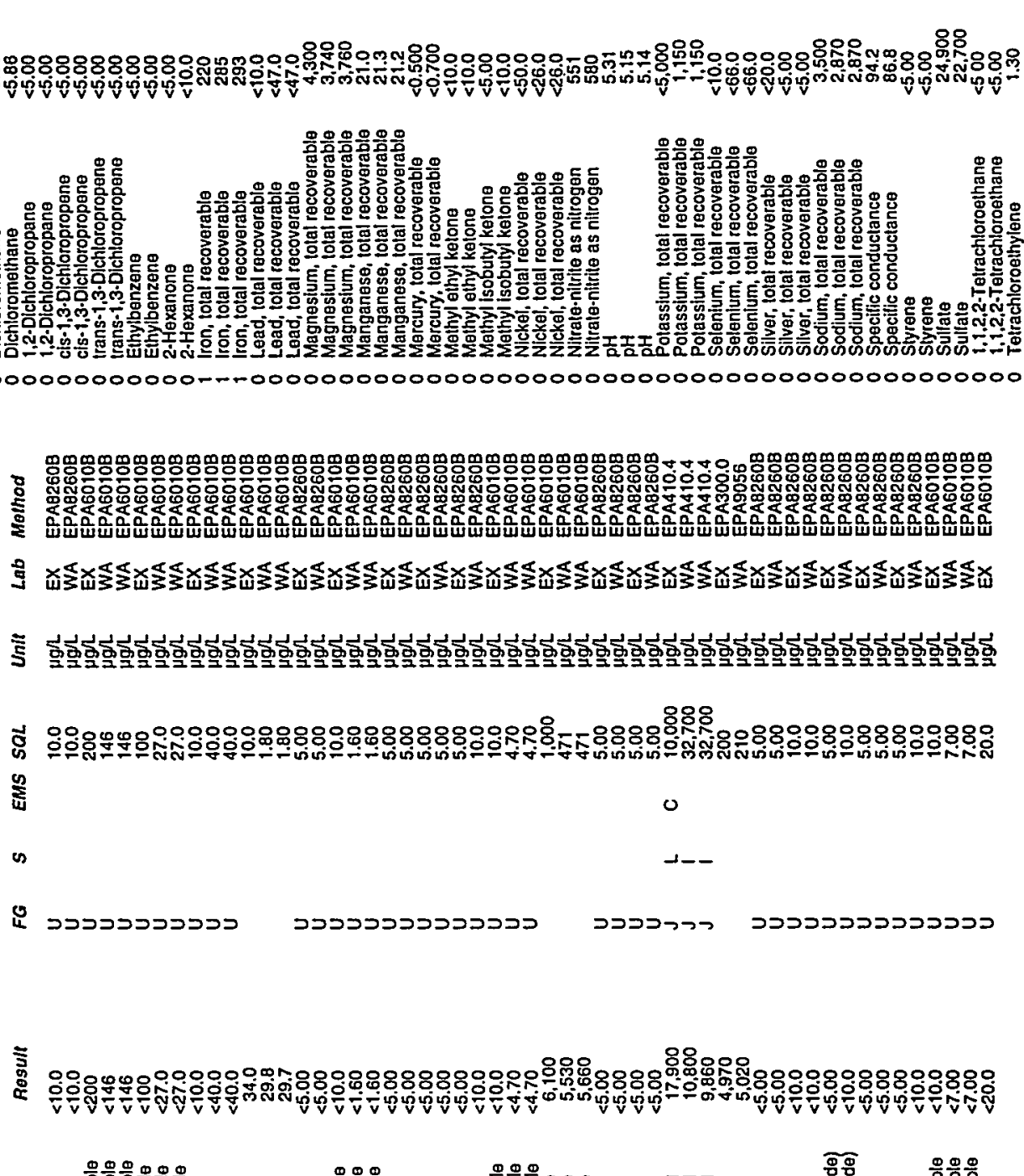

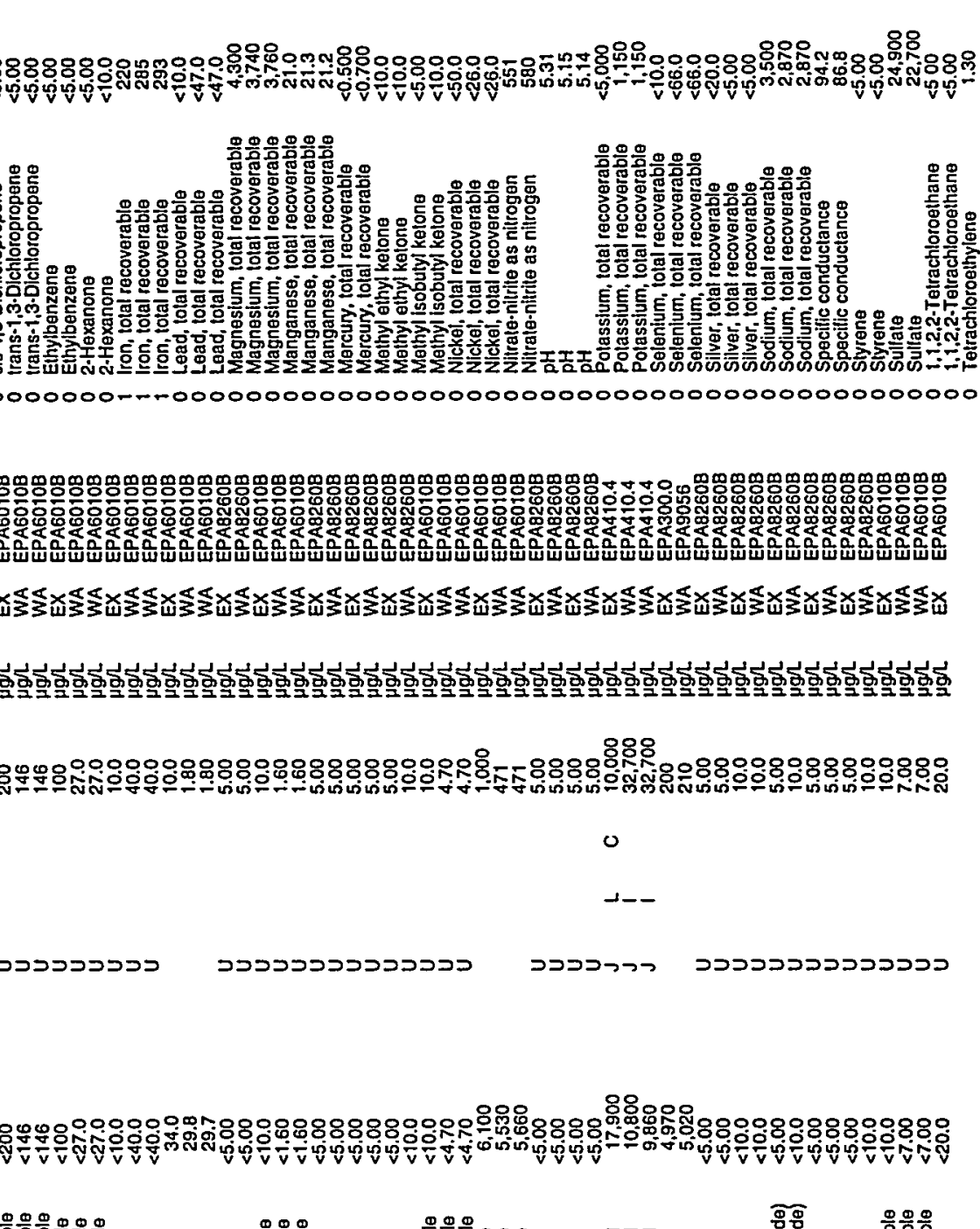

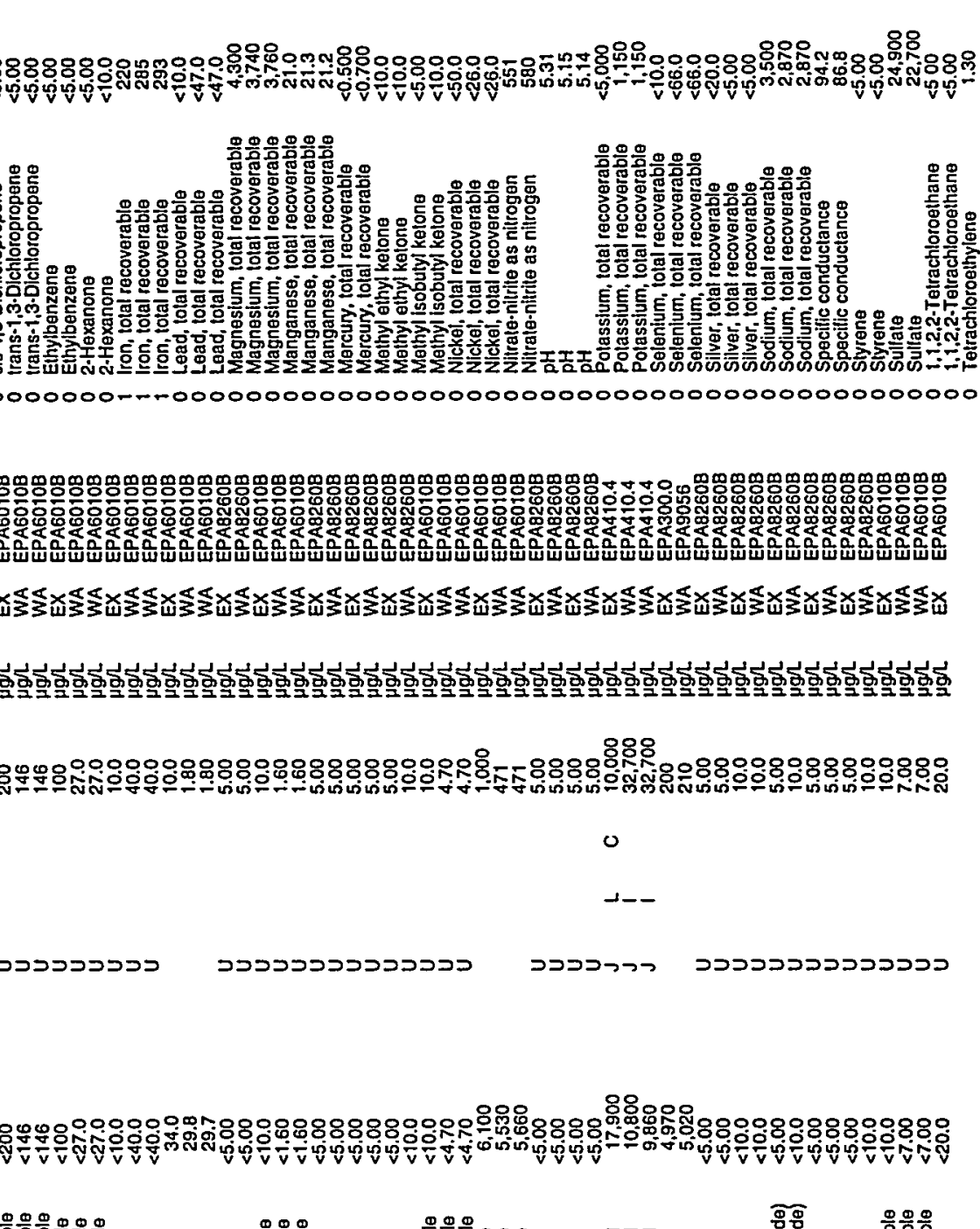

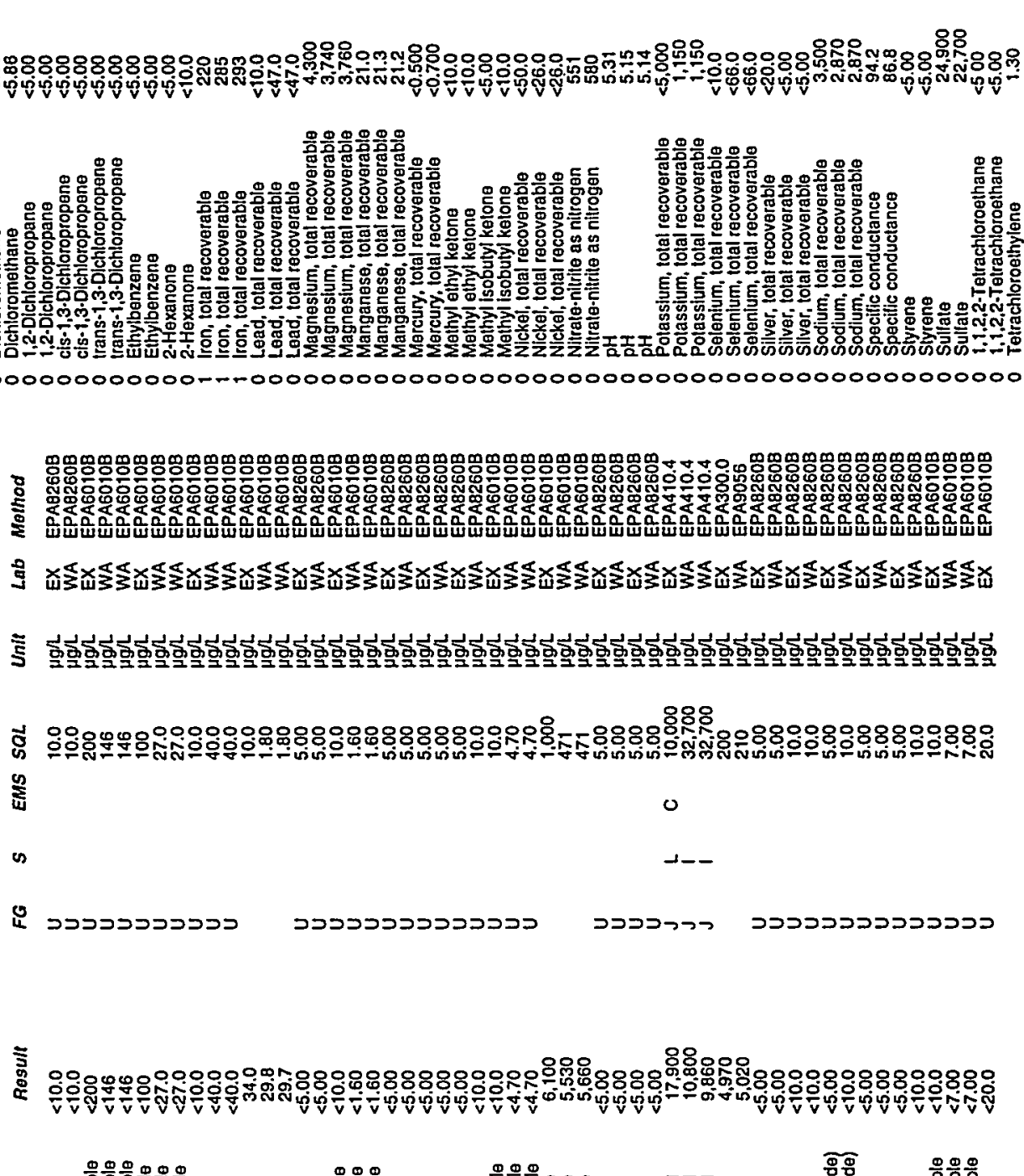

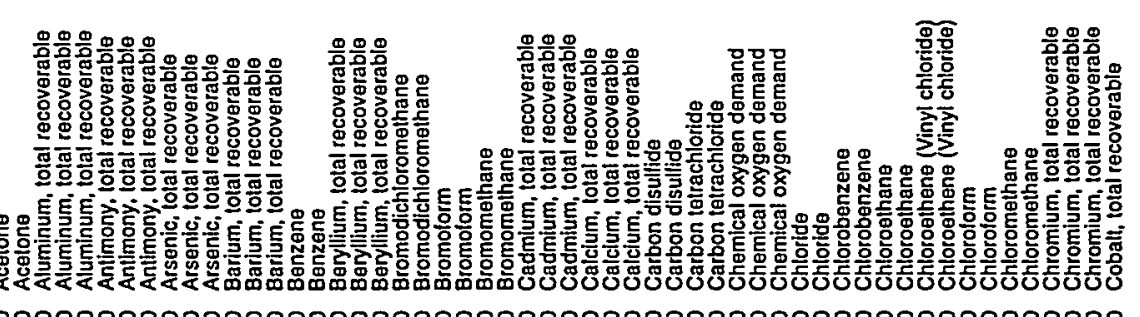


Well DOB 2 collected on 06/03/99 (cont.)

$F$ Analyte

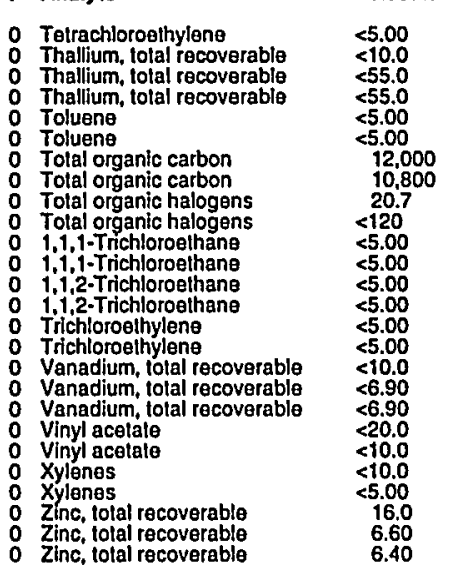

\section{WELL DOB 2 Replicate}

MEASUREMENTS CONDUCTED IN THE FIELD

\section{Sample date: 06/03/99
Depph to water: $10.58 \mathrm{Ht}(3.22 \mathrm{~m})$ below TOC
Water elevalion: $141.62 \mathrm{ft}(43.17 \mathrm{~m}) \mathrm{msl}$
pH: 5 p. conductance: $100 \mu \mathrm{S} / \mathrm{cm}$}

Waler ovacualed from the well prior to sampling: $67 \mathrm{gal}$ ANALYSES

F Analyto

\begin{tabular}{|c|c|}
\hline \multirow[b]{2}{*}{ 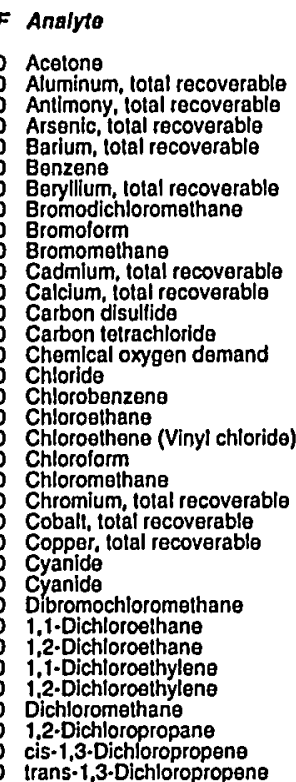 } & Rosult \\
\hline & $\begin{array}{c}<10.0 \\
<200 \\
<100 \\
<10.0 \\
33.0 \\
<5.00 \\
<10.0 \\
<5.00 \\
<5.00 \\
<5.00 \\
<10.0 \\
5,900 \\
<5.00 \\
<5.00 \\
10.000 \\
4.900 \\
<5.00 \\
<10.0 \\
<5.00 \\
<5.00 \\
<5.00 \\
<10.0 \\
<20.0 \\
<20.0 \\
<10.0 \\
<10.0 \\
<5.00 \\
<5.00 \\
<5.00 \\
<5.00 \\
<1.00 \\
<5.00 \\
<5.00 \\
<5.00 \\
<5.00\end{array}$ \\
\hline
\end{tabular}

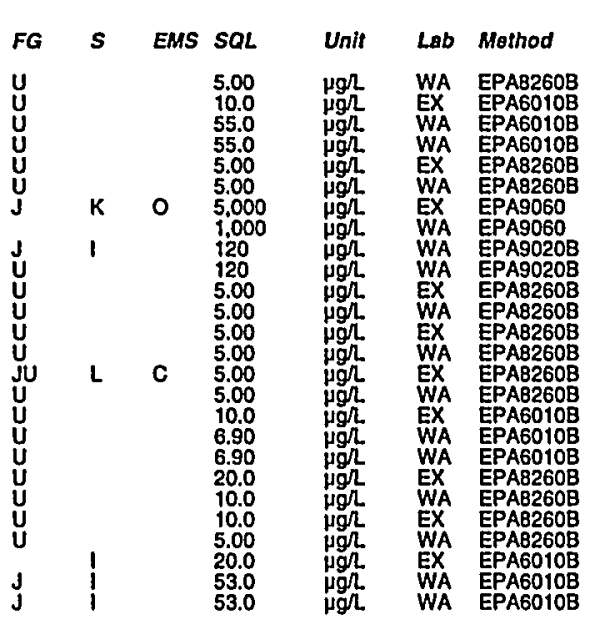

Time: 9:34

Total alkalinity (as Caco3): $0 \mathrm{mg} / \mathrm{L}$
Phenolphthalein alkalinity: $0 \mathrm{mg} /$
Field Qualifier(s): $\mathrm{S}$

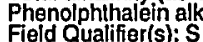

Water temperature: $21^{\circ} \mathrm{C}$

Well DOB 2 collecled on 06/03/99 (cont.)

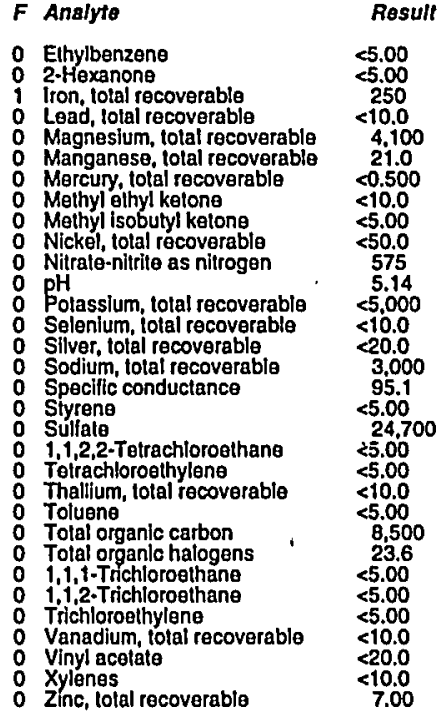

$r 5.00$
$<5.00$
$<5.00$
250
$<10.0$
4.100
21.0
$<0.500$
$<10.0$
$<5.00$
$<50.0$
575
5.14
$<5.000$
$<10.0$
$<20.0$
3.000
95.1
$<5.00$
24.700
25.00
$<5.00$
$<10.0$
$<5.00$
8.500
23.6
$<5.00$
$<5.00$
$<5.00$
$<10.0$
$<20.0$
$<10.0$
7.00
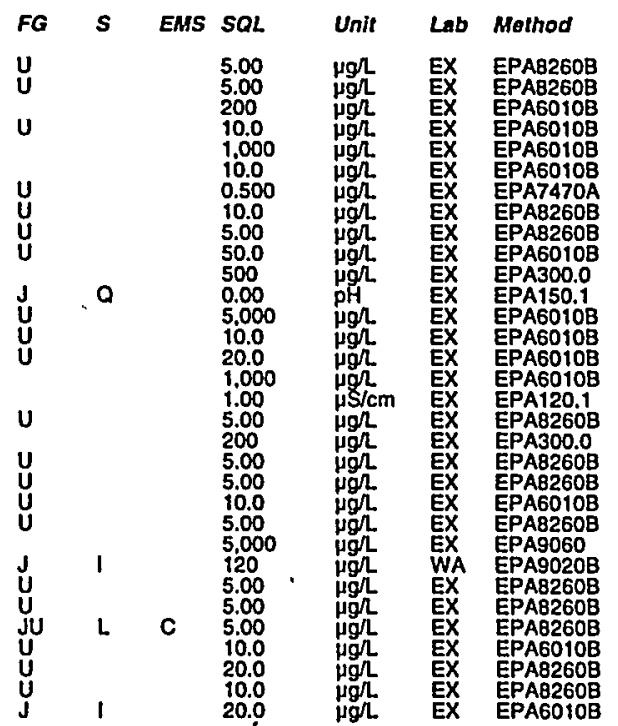

\section{WELL DOB 7}

MEASUREMENTS CONDUCTED IN THE FIELD

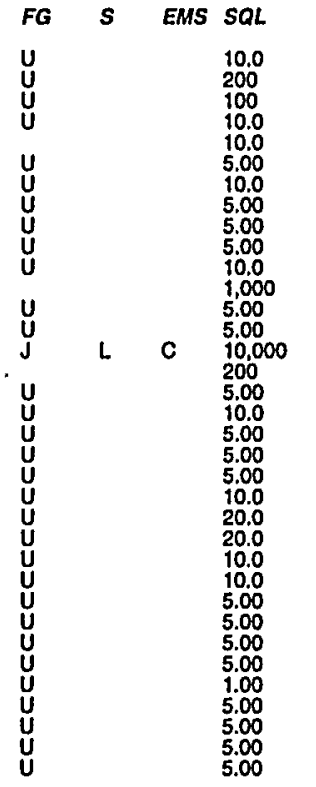

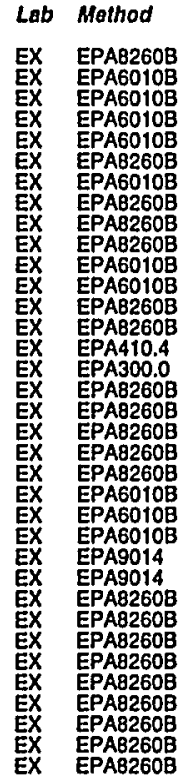

Sample date: 06/02/99
Depth to water: $9.46 \mathrm{tt}(2.88 \mathrm{~m})$ below Toc
Water olevation: $141.44 \mathrm{ti}(43.11 \mathrm{~m}) \mathrm{msl}$

Waler olevation: 141.44 it $(43.1$
pH: 4.9
Sp. conductance: $86 \mu \mathrm{S} / \mathrm{cm}$

Turbidity: ONTU Water evacuated from the well prior to sampling: $30 \mathrm{gal}$ ANALYSES

Rosult
$<10.0$
74.0
4100
$<10.0$
69.0
$<5.00$
$<10.0$
$<5.00$
55.00
$<5.00$
$<10.0$
3,900
$<5.00$
$<5.00$
17.900
4,850
$<5.00$
$<10.0$
$<5.00$
$<5.00$
$<5.00$
$<10.0$
$<20.0$
$<20.0$
$<10.0$
$<10.0$
55.00
$<5.00$
$<5.00$

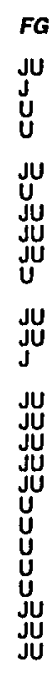

Time: 12:16

Water temperature: $18.3^{\circ} \mathrm{C}$ Total alkalinity (as Caco3): 6 mg/ Phenolphthalein alk
Field Qualifier(s): $V$

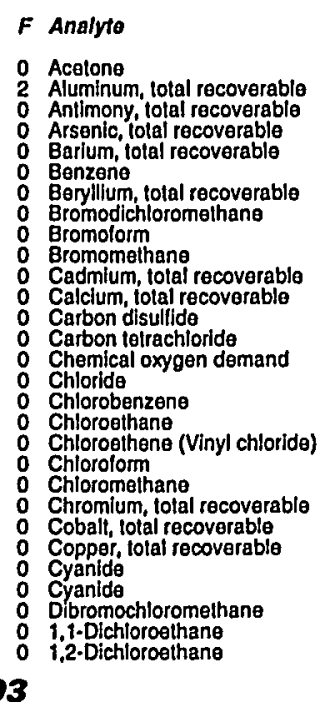

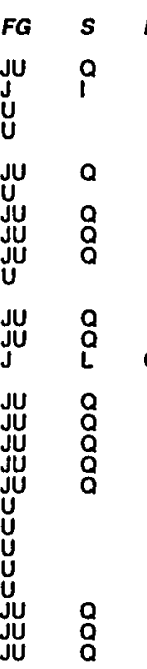

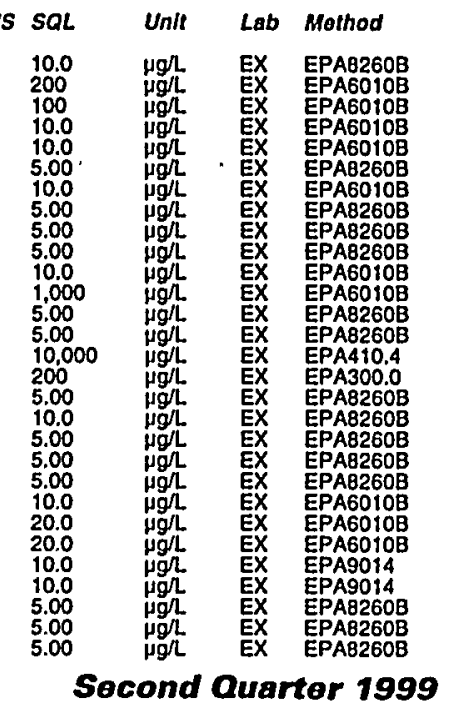


Well DOB 7 collected on 06/02/99 (cont.)

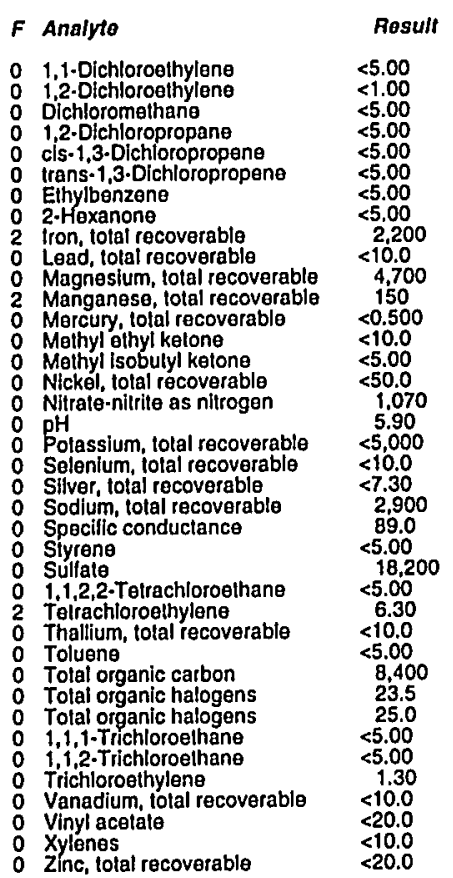

\section{WELL DOB 8}

MEASUREMENTS CONDUCTED IN THE FIELD

\section{Sample date: $06 / 02 / 99$
Depht 10 water: $11.88 \mathrm{ft}(3.62 \mathrm{~m})$ below TOC
Water elevalion: $141.62 \mathrm{ft}(43.13 \mathrm{~m}) \mathrm{msl}$ \\ Water el
pH: 4.8
Sp.cond \\ p. conductance: $73 \mu \mathrm{S} / \mathrm{cm}$}

Water evacuated from the well prior to sampling: 36 gal

ANALYSES
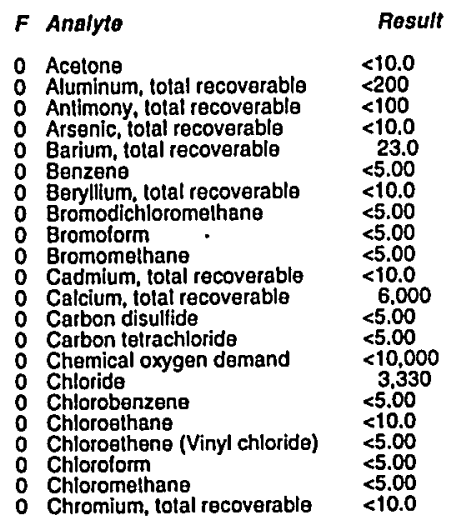

ESH-EMS-990521

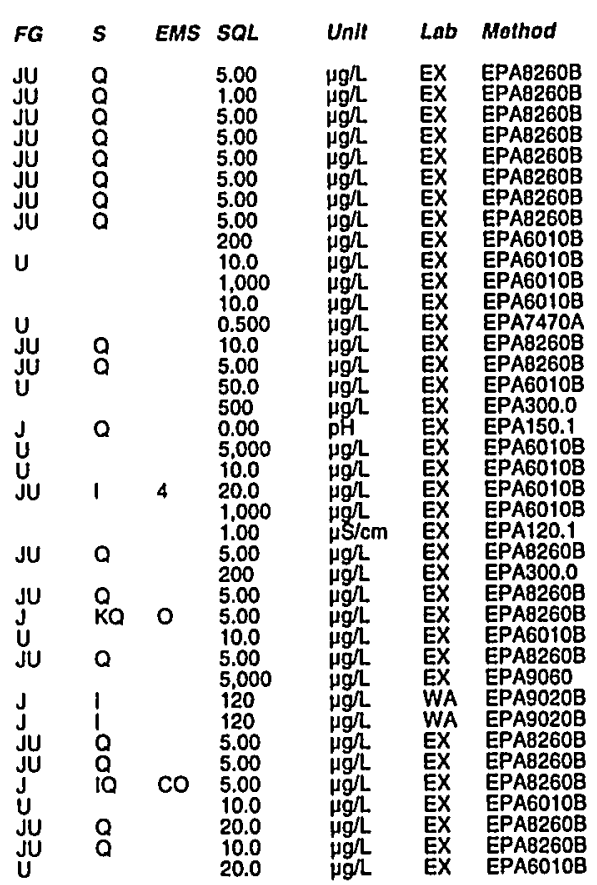

Time: 13:25 Air termperature $34^{\circ} \mathrm{C} .5^{\circ} \mathrm{C}$ Air tomperal alkalinity (as Caco3): $3 \mathrm{mg} /$
Phenolphthalein alkalinity: $\mathrm{mg} \mathrm{L}^{-}$
Field Qualifier(s): $\mathrm{V}$

\begin{tabular}{|c|c|c|c|}
\hline$F G$ & $s$ & EMS & SQL \\
\hline Ư & 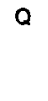 & & $\begin{array}{l}10.0 \\
200 \\
100 \\
10.0\end{array}$ \\
\hline JU & $\mathrm{a}$ & & 5.00 \\
\hline U & $\begin{array}{l}0 \\
\mathrm{Q} \\
\mathrm{Q}\end{array}$ & & $\begin{array}{l}5.00 \\
5.00 \\
5.00 \\
10.0\end{array}$ \\
\hline JU & $\begin{array}{l}\text { O } \\
\mathrm{O}\end{array}$ & C & $\begin{array}{l}5.00 \\
5.00 \\
100.000\end{array}$ \\
\hline $\begin{array}{l}J U \\
J U \\
J U \\
J U \\
J U\end{array}$ & $\begin{array}{l}Q \\
Q \\
Q \\
Q \\
Q \\
0\end{array}$ & & $\begin{array}{l}5.00 \\
10.0 \\
5.00 \\
5.00 \\
5.00 \\
10.0\end{array}$ \\
\hline
\end{tabular}

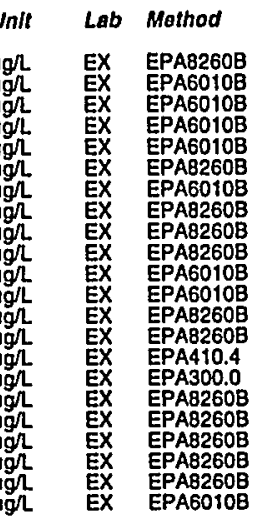

Well DOB 8 collected on 06/02/99 (cont.)

\section{$F$ Analyte}

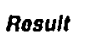

O Coball, lotal recoverable

Copper, total recoverab
0 Dibromochloromethane

1,1-Dichloroelhane

1,2-Dichloroethylen

Dichloromalhane
$1,2 \cdot$ Dichloropropane
cis-1,3-Dlchloroprope

Irans- -, 3-Dichloropropene

2.Hexanone

Iron, tolal recoverable
Lead, total recoverable

Magnesium, rotal recoverable

Mercury, lotal recoverablo

Methyl elhyl katone

Nitrale-nilfite as nitrogen

Polasslum, lotal recoverable

Silver, lotal recoverable

Sodlum, total recovera

Siyrene

Sulfale

Thallium, total recoverable

Toluene

Total organic carbon

$1,1,1-T$ Trchloroelhane
1,1,2-Trichloroethane

O Vanadium, total recoverable

vinyl acetale
Xylenes

Z Xilenes

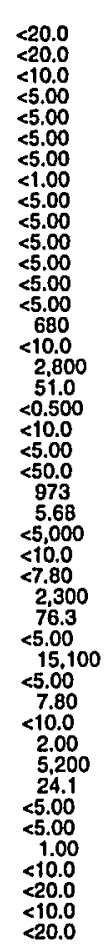

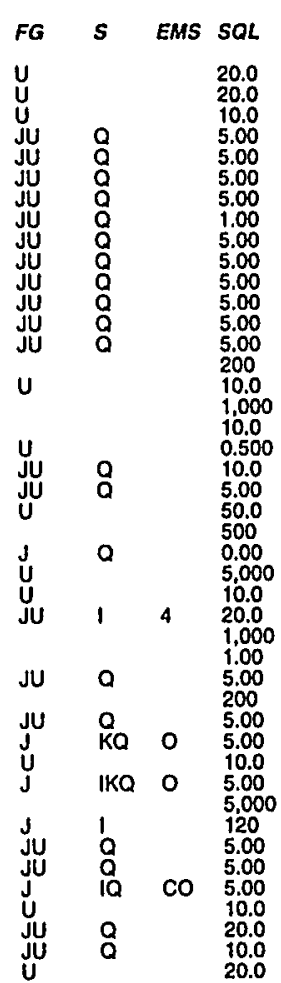

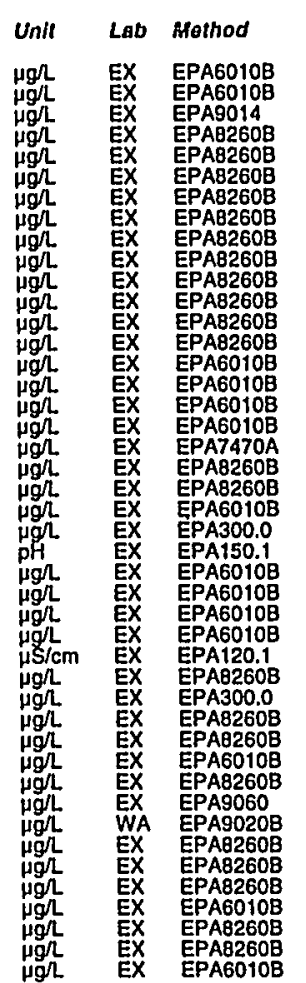

WELL DOB 10

MEASUREMENTS CONDUCTED IN THE FIELD

Sample date: 06/02/99

Depth to water: $11.96 \mathrm{ft}(3.65 \mathrm{~m})$ below TOC
Water elevation: $141.54 \mathrm{ft}(43.14 \mathrm{~m}) \mathrm{ms}$

Sp. conductance: $130 \mu \mathrm{S} / \mathrm{cm}$

Water evacuated from the well prior to sampling: $35 \mathrm{gal}$ ANALYSES

\section{$F$ Analyte}

Acetone
o Aluminum, total recoverable

A Antimony, total recoverable

Barlum, total recoverable

: Benzene

Bromodichlorm

O Bromomelhane

Cadmium, total recoverabte

- Carbon disullideco

o Chemical oxygen demand

Chemical oxygen demand

B-94

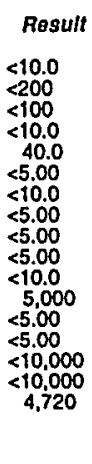

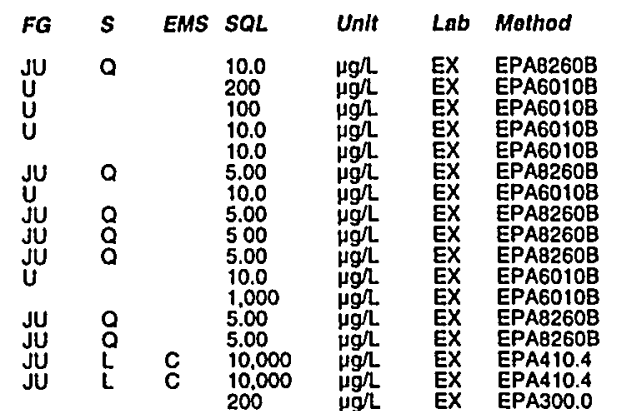

Second Quarter 1999
Water lemperature: $18.6^{\circ} \mathrm{C}$

Airt temperalure: alkalinity (as CaCo3): $5 \mathrm{mg} / \mathrm{h}$

Phenolphthalein alkalinity: $0 \mathrm{mg} / \mathrm{L}$
Field Qualifier(s): $\vee$ 


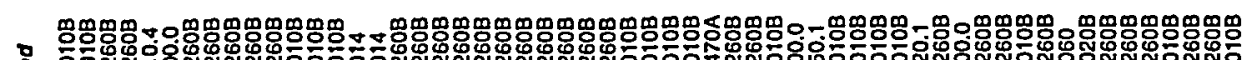

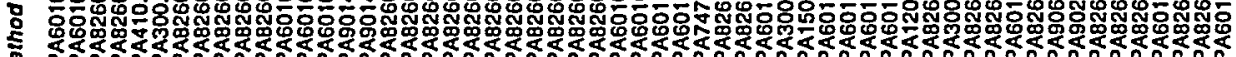

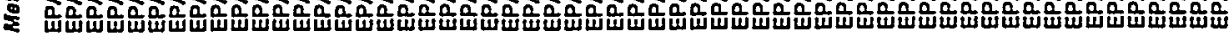

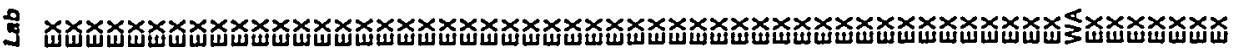

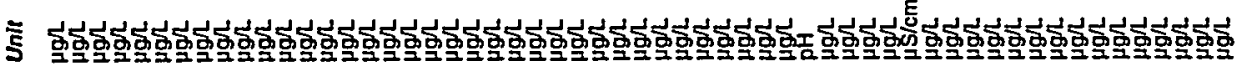

|

密

s

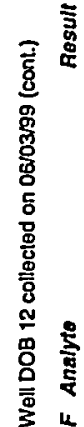

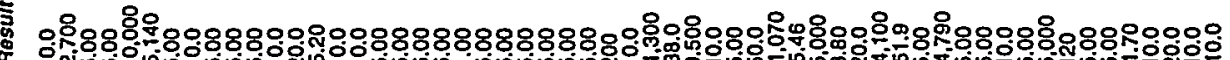

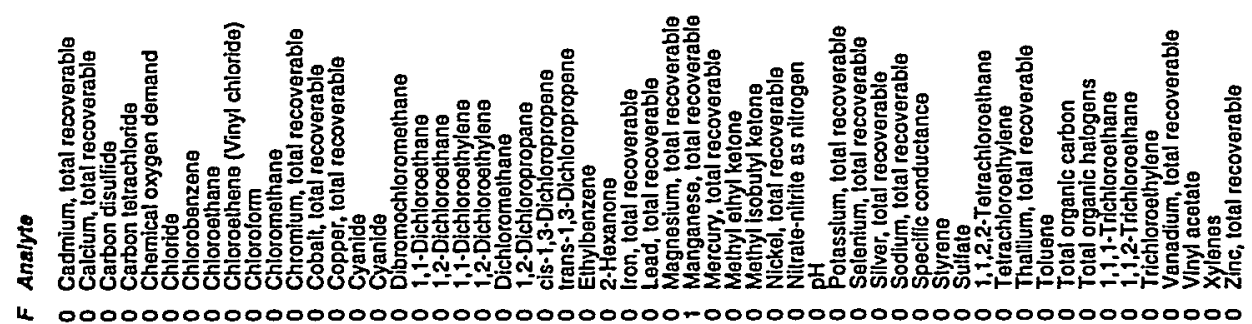

8

$0>$

מככ ככנ

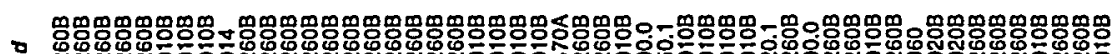

:

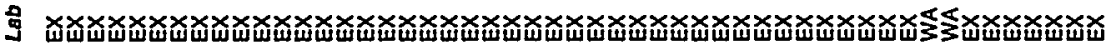

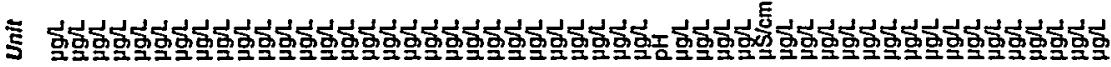

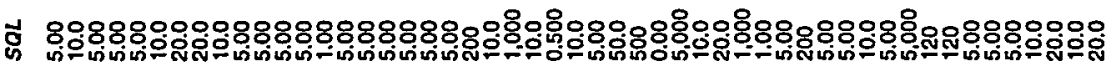
畜

$\circ \quad 0 \quad 8$

is $00000 \quad 00000000000 \quad 00 \quad 0 \quad 0$ 09 $\underline{\underline{P}}$ _- 000 00_

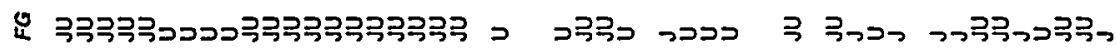

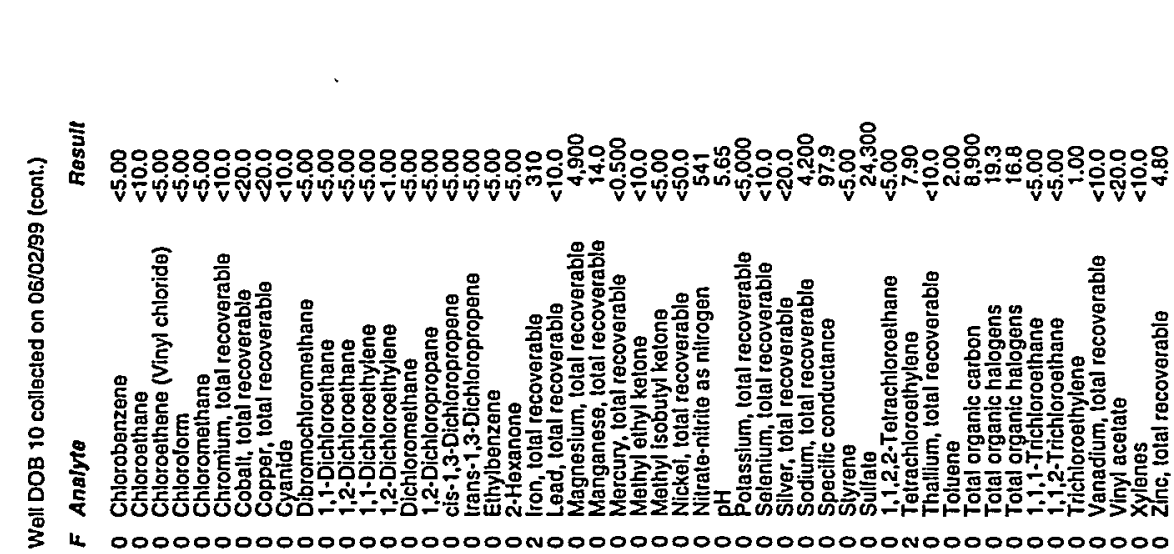

告
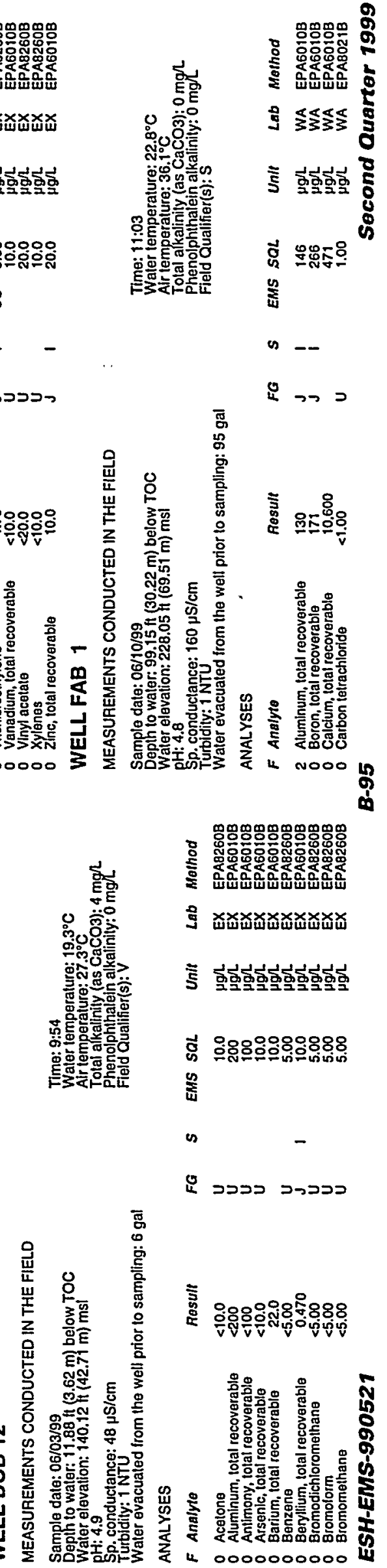
Well FAB 1 collecled on 06/10/99 (cont.)

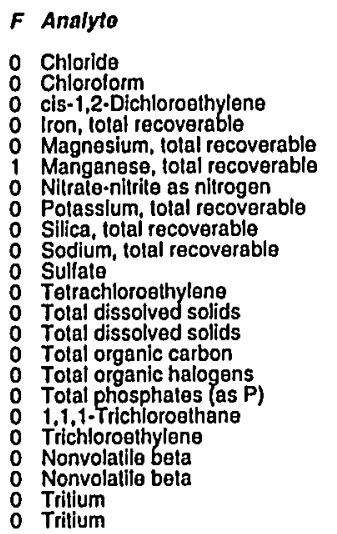

Bosult

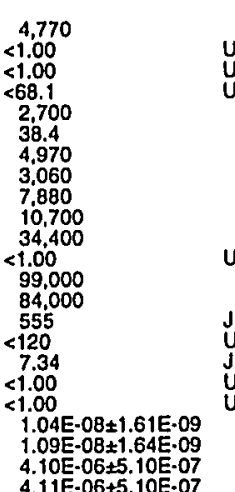

\section{WELLL. FAB 2}

MEASUREMENTS CONDUCTED IN THE FIELD

Sample date: 06/11/99

Waler

p. conductance: $120 \mu \mathrm{S} / \mathrm{cm}$

Turbidity: 13 NTU Water evacuated from the well prior

ANALYSES

\begin{tabular}{|c|c|c|c|c|c|c|c|c|}
\hline Analyto & Aesult & $F G$ & $s$ & EMS & $S Q L$ & Unit & Lab & Method \\
\hline 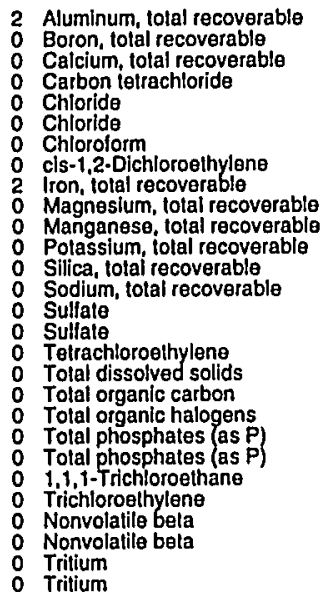 & $\begin{array}{c}201 \\
144 \\
2.290 \\
<1.00 \\
3.300 \\
3.160 \\
<1.00 \\
<1.00 \\
341 \\
660 \\
11.3 \\
1,390 \\
10.200 \\
17,500 \\
16,900 \\
16,800 \\
<1.00 \\
<50,000 \\
636 \\
<120 \\
122 \\
110 \\
<1.00 \\
<1.00 \\
4.40 \mathrm{E}-10 \pm 1.14 \mathrm{E}-09 \\
2.72 \mathrm{E}-09 \pm 1.28 \mathrm{E} .09 \\
2.85 \mathrm{E}-06 \pm 4.80 \mathrm{E}-07 \\
2.67 \mathrm{E}-06 \pm 4.70 \mathrm{E}-07\end{array}$ & $\begin{array}{l}J \\
\text { U }\end{array}$ & 1 & & $\begin{array}{l}146 \\
266 \\
471 \\
1.00 \\
210 \\
210 \\
1.00 \\
1.00 \\
74.0 \\
74.0 \\
7.80 \\
187 \\
1.350 \\
285 \\
1.700 \\
1.700 \\
1.00 \\
50.000 \\
1.000 \\
120 \\
67.0 \\
67.0 \\
1.00 \\
1.00 \\
1.97 \mathrm{E}-09 \\
2.00 \mathrm{E} \cdot 09 \\
5.50 \mathrm{E}-07 \\
5.50 \mathrm{E}-07\end{array}$ & 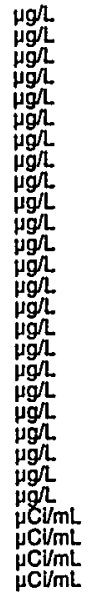 & $\begin{array}{l}\text { WA } \\
\text { WA } \\
\text { WA } \\
\text { WA } \\
\text { WA } \\
\text { WA } \\
\text { WA } \\
\text { WA } \\
\text { WA } \\
\text { WA } \\
\text { WA } \\
\text { WA } \\
\text { WA } \\
\text { WA } \\
\text { WA } \\
\text { WA } \\
\text { WA } \\
\text { WA } \\
\text { WA } \\
\text { WA } \\
\text { WA } \\
\text { WA } \\
\text { WA } \\
\text { TM } \\
\text { TM } \\
\text { TM }\end{array}$ & $\begin{array}{l}\text { EPA6010B } \\
\text { EPA6010B } \\
\text { EPA6010B } \\
\text { EPAB021B } \\
\text { EPA9056 } \\
\text { EPA9056 } \\
\text { EPABO21B } \\
\text { EPAB021B } \\
\text { EPA6010B } \\
\text { EPA6010 } \\
\text { EPAG010B } \\
\text { EPAG010B } \\
\text { EPAG010B } \\
\text { EPA6010B } \\
\text { EPA6010B } \\
\text { EPA9056 } \\
\text { EPA9056 } \\
\text { EPAB021B } \\
\text { EPA160.1 } \\
\text { EPA9060 } \\
\text { EPA9020B } \\
\text { EPA365.2 } \\
\text { EPA365.2 } \\
\text { EPAB021B } \\
\text { EPA8021B } \\
\text { EPA900.0M } \\
\text { EPA900.0M } \\
\text { EPA906.0M } \\
\text { EPA906.0M }\end{array}$ \\
\hline
\end{tabular}

\section{WELL FAB 3}

MEASUREMENTS CONDUCTED IN THE FIELD

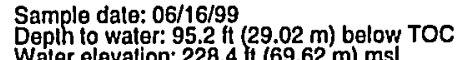

pH: 5.5

Sp. conductance: $48 \mu \mathrm{S} / \mathrm{cm}$
Turbidity: 13 NTU

Wurbidity: 13 NTU
Waler evacuated from the well prior to sampling: $8 \mathrm{gal}$ The well went dry during purging.

ANALYSES

o

\begin{tabular}{|c|}
\hline 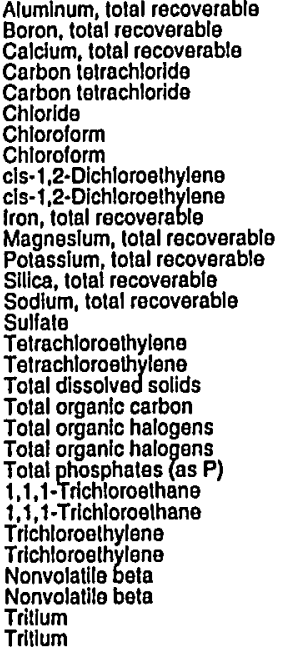 \\
\hline
\end{tabular}

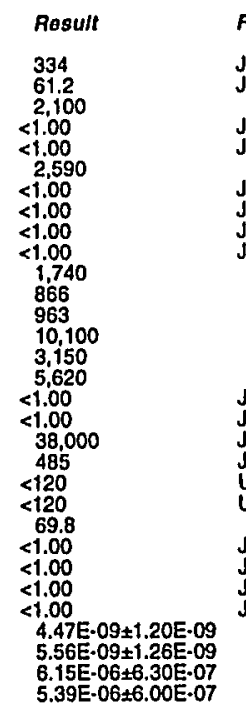

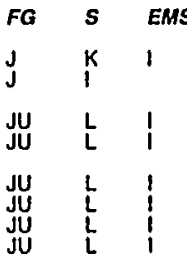

\section{WELL FAB 4}

MEASUREMENTS CONDUCTED IN THE FIELD

Sample date: $06 / 11 / 99$

Depth to water: $97.85 \mathrm{ft}(29.83 \mathrm{~m})$ below
Water elevation: $228.25 \mathrm{tt}(69.57 \mathrm{~m}) \mathrm{ms}$

$\mathrm{pH}: 5.4$

Sp.conductance: $62 \mu \mathrm{S} / \mathrm{cm}$

Water evacualed from the well prior to sampling: $9 \mathrm{gal}$ The well went dry during purging.

ANALYSES

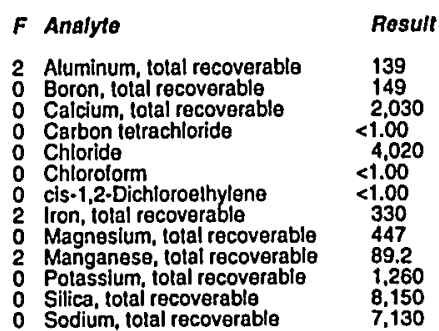

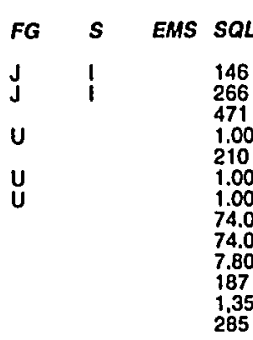

Time: 10:50

Air teme $21.4^{\circ} \mathrm{C}$

Tolal alkalinity (as CaCO3): $8 \mathrm{mg} /$.

Phenoiphthalein alkalinity: $0 \mathrm{mg} /$ 
Well FAB 4 collected on 06/11/99 (cont.)

\begin{tabular}{|c|c|c|c|c|c|c|c|c|}
\hline$A_{1}$ & Result & FG & $\boldsymbol{s}$ & EMS & SOL & Unit & La & thod \\
\hline 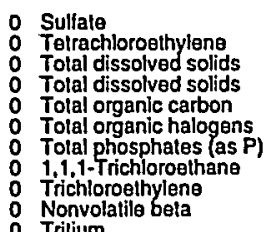 & 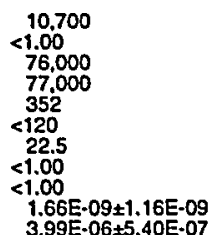 & J & $\begin{array}{l}1 \\
1\end{array}$ & & $\begin{array}{l}340 \\
1.00 \\
50,000 \\
50.000 \\
1,000 \\
120 \\
67.0 \\
1.00 \\
1.00 \\
1.88 E-09 \\
5.70 E-07\end{array}$ & 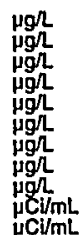 & & $\begin{array}{ll}\text { E EPA9056 } \\
\text { A } \\
\text { EPAB021B } \\
\text { EPA160.1 } \\
\text { EPA160.1 } \\
\text { A EPA9060 } \\
\text { A EPA9020B } \\
\text { EPA365.2 } \\
\text { A EPA8021. } \\
\text { EPA80218 } \\
\text { EPA900.0M } \\
\text { EPA906.0M }\end{array}$ \\
\hline
\end{tabular}

\section{WELL FBP $2 A$}

MEASUREMENTS CONDUCTED IN THE FIELD

\begin{abstract}
Sample date: 06/14/99 $29.66 \mathrm{~m})$ below TOC
Water

Sp. 4.7 conductance: $180 \mu \mathrm{S} / \mathrm{cm}$
\end{abstract}

Waler evacualed from the well prior to sampling: $88 \mathrm{gal}$ ANALYSES

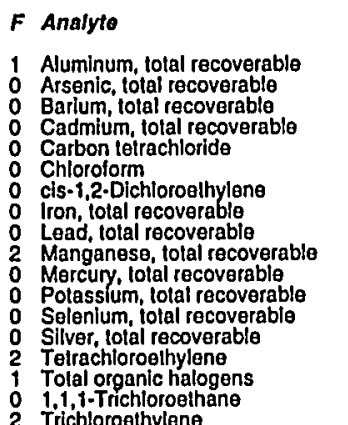

Result
49.3
$<40.0$
24.4
$<4.70$
2.35
$<1.00$
1.50
$<32.3$
$<47.0$
90.7
$<0.700$
1.640
$<6.0$
$<5.00$
18.5
76.7
$<1.00$
23.0

\section{WELL FBP 5D}

MEASUREMENTS CONDUCTED IN THE FIELLD

Sample date: 06/14/99

Sample date: $06 / 14 / 99$
Qppth to water: $87.48 \mathrm{ft}(26.66 \mathrm{~m})$ below TOC
Water elevation: $204.82 \mathrm{H}(62.43 \mathrm{~m}) \mathrm{ms}$

Sp. conductance: $48 \mu \mathrm{S} / \mathrm{cm}$

Turbiditity: $1 \mathrm{NTU}$.
Waler evacualed from the well prior to sampling: $12 \mathrm{gal}$

ANALYSES

$F$ Analyto

Rosult
64.4
$<40.0$
9.70
$<266$
0.520
$<1.00$
$<1.00$
$<1.00$
$<1.00$
$<1.00$
$<1.00$
$<53.0$

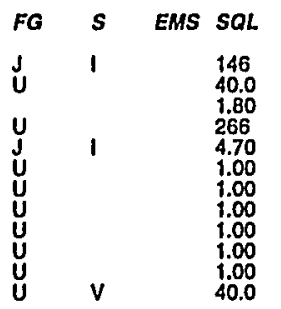

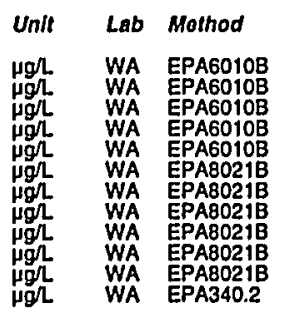

Time: 14:50

Waler temperature: $19.7^{\circ} \mathrm{C}$

Total alkalinity (as Caco3): $0 \mathrm{mg} / \mathrm{L}$

Field Qualifier(s): $\mathbf{S}$

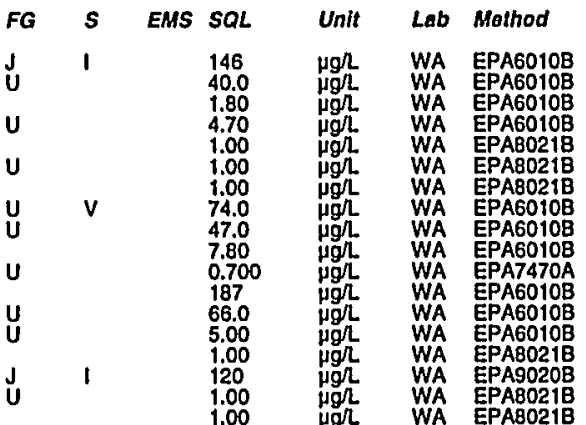

2 Aluminum, total recoverable

Barium tol recoverablo

Boron, total recoverable

Carbon letrachloride

Chlorolom

cis-1,2-Dichloroethylene

0 Fluorida

ESH-EMS-990521

Well FBP 5D collecled on 06/14/99 (cont.)

$F$ Analyte

o lron, lotal recoverable

- Lithium, total recoverable

Manganese. Tolal recoverable
Mercury, lotal recoverable

Silver, total recoverabla

Totrachloroethylen

Tital organic halogen

1,1,1-Trichloroetha

Trichloroethylen

\section{WELL FBP 6D}

MEASUREMENTS CONDUCTED IN THE FIELD

Sample date: 06/15/99

Depth 10 water: $95.37 \mathrm{ft}(29.07 \mathrm{~m})$ below TOC

Water

p. conduclance: $67 \mu \mathrm{S} / \mathrm{cm}$

Water evacuated from the well prior to sampling: 8 gal
The well went dry during purging.

112
$<47.0$
1.10
12.9
$<0.700$
452
$<66.0$
$<5.00$
$<1.00$
$<1.00$
$<120$
$<1.00$
$<1.00$
$<1.00$
$<1.00$

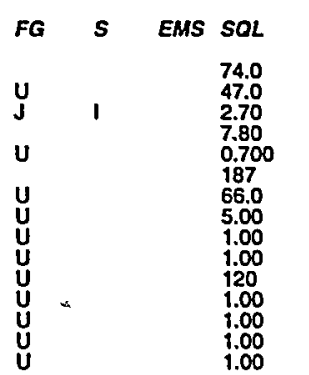

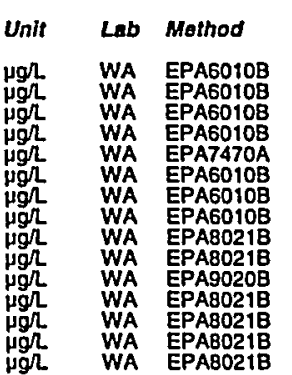

ANALYSES
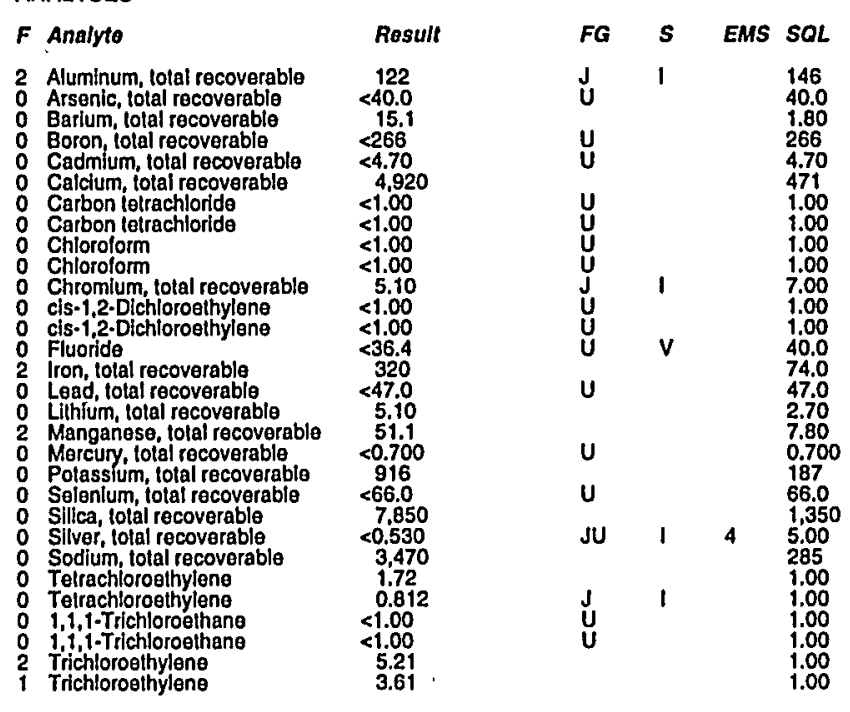

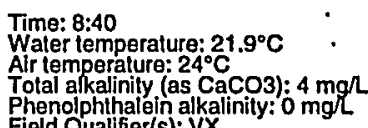

\section{WELL FBP 10D}

MEASUREMENTS CONDUCTED IN THE FIELD

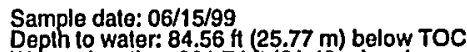

Water olevation: $201.74 \mathrm{fi}(61.49 \mathrm{~m}) \mathrm{ms}$

$\mathrm{PH}: 7.5$

conductance: $320 \mu \mathrm{S} / \mathrm{cm}$

Water evacualed from the well prior to sampling: $21 \mathrm{gal}$

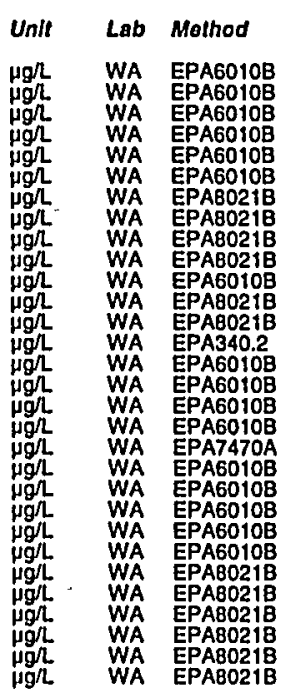

Time: 10:11

23.

Total alkalinity (as CaCO3): $92 \mathrm{mgh}$

Phenolphthalein alkalinity: $0 \mathrm{mg} / \mathrm{L}$ 
Well FBP 10D collacted on 06/15/99 (cont.)

ANALYSES

F Analyto

Resull

2 Aluminum, lotal racoverable Arsenic, total recoverable Carbon letraction Chromium, total recoverable cis-1,2-Dichloroethylen
Iron, total recoverable

Lead, total recoverable Manganesest total recoverable Selenium, total recoverab 0.1 .1 -Trichloroethane
2 Trichloroethylene

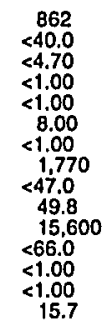

WELL. FBP 13D

MEASUREMENTS CONDUCTED IN THE FIELD

Sample dale: 06/15/99 $\mathrm{ft}(31.49 \mathrm{~m})$ below TOC Water elevation: $194.69 \mathrm{ft}(59.34 \mathrm{~m}) \mathrm{ms}$ H: 4.9 Sp. conductance: $44 \mu \mathrm{S} / \mathrm{cm}$ Waler evacualed from the well prior to sampling: $15 \mathrm{gal}$ ANALYSES

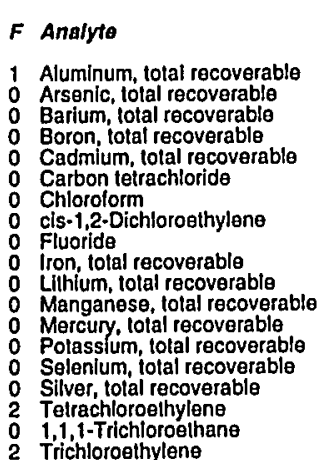

Result
34.3
$<40.0$
9.40
$<266$
$<4.70$
1.71
$<1.00$
$<1.00$
$<27.2$
117
0.900
11.0
$<0.700$
370
$<66.0$
$<5.00$
12.8
$<1.00$
21.3

WELL FCB 2

MEASUREMENTS CONDUCTED IN THE FIELD

Sample date: 06/09/99 Water elevation: $229.7 \mathrm{Ht}(70.01 \mathrm{~m}) \mathrm{ms}$

gH: 4.8 .

Water evacualed from the well prior to sampling: $\mathbf{5 7}$ gal

ANALYSES

$F$ Analyto

Result
$<146$
$<40.0$
$<4.70$
1.840
67.4
66.0
155
120

- Aluminum, total recoverable

Cadmium, total recoverab

Iron, total recoverable

Total organle carbon

ESH-EMS-990521

$\begin{array}{ll}F G & s \\ J & 1 \\ U & \\ U & \\ U & \\ U & \\ U & v \\ J & 1 \\ U & \\ U & \\ U & \\ U & \end{array}$

\begin{tabular}{|c|c|c|c|c|c|c|}
\hline$F \boldsymbol{F}$ & $s$ & $E M S$ & SQL & Unit & Lab & Mothod \\
\hline $\begin{array}{l}\mathbf{U} \\
\mathbf{U} \\
\mathbf{U}\end{array}$ & & & $\begin{array}{l}146 \\
40.0 \\
4.70 \\
1.00 \\
1.00\end{array}$ & 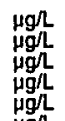 & $\begin{array}{l}\text { WA } \\
\text { WA } \\
\text { WA } \\
\text { WA } \\
\text { WA }\end{array}$ & $\begin{array}{l}\text { EPA6010B } \\
\text { EPA6010B } \\
\text { EPA6010B } \\
\text { EPAB021B } \\
\text { EPA8021B }\end{array}$ \\
\hline u & & & 1.00 & $\begin{array}{l}\mu g / 2 \\
\mu g / 2\end{array}$ & WA & EPABO21日 \\
\hline U & & & $\begin{array}{l}4.0 \\
47.0 \\
7.80\end{array}$ & 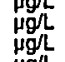 & $\begin{array}{l}\text { WA } \\
\text { WA }\end{array}$ & EPA6010B \\
\hline U⿺ & & & $\begin{array}{l}1,000 \\
66.0 \\
1.00 \\
1.00 \\
1.00\end{array}$ & $\begin{array}{l}\mu g / L \\
\mu g / L \\
\mu g / 2 \\
\mu g / d \\
\mu g / L\end{array}$ & $\begin{array}{l}\text { WA } \\
\text { WA } \\
\text { WA } \\
\text { WA } \\
\text { WA }\end{array}$ & $\begin{array}{l}\text { EPA63.2 } \\
\text { EPAO108 } \\
\text { EAA821B } \\
\text { EPAO218 } \\
\text { EPAB0218 }\end{array}$ \\
\hline
\end{tabular}

Time: 10:55

Water temperature: $20.7^{\circ} \mathrm{C}$ Toial alkalinity (as CaCO3): $0 \mathrm{mg} /$ Field Qualifier(s): $v$

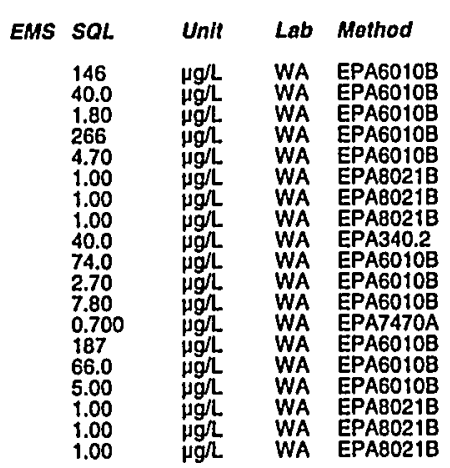

Time: 9:20 0 Air temperatura: $25.5^{\circ} \mathrm{C}$ (a) $0 \mathrm{mg} /$ Phenolphthalein alkalinity: $0 \mathrm{mg} /$

\begin{tabular}{|c|c|c|c|}
\hline SQL & Unit & Lab & Method \\
\hline $\begin{array}{l}146 \\
40.0 \\
4.70 \\
74.0 \\
47.0 \\
66.0 \\
1.000 \\
120\end{array}$ & $\begin{array}{l}\mu g \Omega \\
\mu g h \\
\mu g h \\
\mu g \Omega \\
\mu g \Omega \\
\mu g \Omega \\
\mu g \Omega \\
\mu g \Omega \\
\mu g \Omega\end{array}$ & $\begin{array}{l}\text { WA } \\
\text { WA } \\
\text { WA } \\
\text { WA } \\
\text { WA } \\
\text { WA } \\
\text { WA } \\
\text { WA }\end{array}$ & $\begin{array}{l}\text { EPA6010B } \\
\text { EPA6010B } \\
\text { EPA6010B } \\
\text { EPA6010B } \\
\text { EPA6010B } \\
\text { EPA6010B } \\
\text { EPA9060 } \\
\text { EPA9020B }\end{array}$ \\
\hline
\end{tabular}

\section{WELL FCB 5}

MEASUREMENTS CONDUCTED IN THE FIELD

Damplie do water: $75.5 \mathrm{H}(23.01 \mathrm{~m})$ bolow TOC

$\mathrm{pH}: 4.7$

Sp. conductance: $27 \mu \mathrm{S} / \mathrm{cm}$

Water evacuated from the well prior to sampling: $1 \mathrm{gal}$ The well went dry during purging.

ANALYSES

$F$ Analyte

Result
193
$<40.0$
$<266$
$<4.70$
$<1.00$
$<1.00$
$<1.00$
734
0.780
$<6.0$
$<1.00$
55.660
$<120$
$<1.00$
$<1.00$

EMS SOL

146
40.0
266
4.70
1.00
1.00
1.00
74.0
2.70
66.0
1.00
1.000
120
1.00
1.00

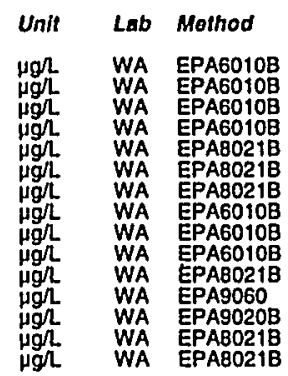

\section{WELL FEX 1TK}

MEASUREMENTS CONDUCTED IN THE FIELLD

Sample date: 06/07/99

Water elevalion: Not available

Sp. conductance: $710 \mu \mathrm{S} / \mathrm{cm}$

The well was continuously pumping.

ANALYSES

\section{$F$ Analyte}

2 Aluminum, lotal recoverable

Barlum, total recoverablo

Beryllium, total recoverable

Bis(2-ethylhexyl) phthatal

Bromodichloromelhan

Bromoform

Cadmilum, tołal recoverable

Chlorobenzene

Chloroelhane

Chloroothene (Vinyl chlorld
2.Chloroethyl vinyl elher

Chlorolorm

Chloromethane

Coball, lotal recoverable

0 Cyanide

D Dyanide

1,2-Dichloroethane

1,1-Dichloroethylens

trans-1,2-Dichlorool
O Dichloromethane
1.2.Dichloropropan

oc cis-1,3-Dichloropropene

B-98
Time: 13:05

Total alkalinily (as $\mathrm{CaCO}$ ): $0 \mathrm{mg} /$.

Phenolph halein alkalinity: $0 \mathrm{mg}$ L
Time: 12:45

Total alkalinity (as CaCO3): $0 \mathrm{mg}$

lein alkalinity: $0 \mathrm{mg} \mathrm{L}^{2}$

23,500

3.39
340
$<1.00$

2.00
$<10.4$
$<15.0$

41.00
$<1.00$
$<1.00$
5.61

$<1.00$
5.61
$<1.00$
$<1.00$

$<1.00$

<i.

$<1.00$
$<1.00$
3.09
124

$<10.0$
$<1.0$
$<1.00$
$<1.00$

$<1.00$
$<1.00$
$<1.00$
$<3.12$
$<1.00$
$<1.00$

$<1.00$
$<1.00$
$<1.00$

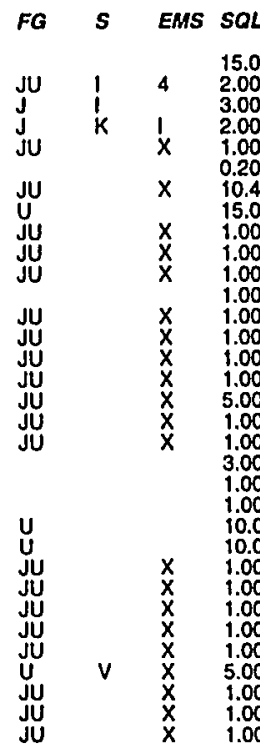

Unit Lab Mathod

15.0
2.00
3.00
2.00
1.00
0.200
10.4
15.0
1.00
1.00
1.00
1.00
1.00
1.00
1.00
1.00
5.00
1.00
1.00
3.00
1.00
1.00
10.0
10.0
1.00
1.00
1.00
1.00
1.00
5.00
1.00
1.00

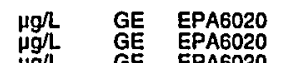

ggh

$G E$

GE EPAG020

GE EPA8260B

$\mathrm{GE}$

GE

EPA82608

EPAB2608

GE

GE EPA9012A

EPA82608

EPA8260B

PA82608
PA8260B
PAB260B

EPAB260B

Second Quartor 1999 
Well FEX 1TK collected on 06/07/99 (cont.)

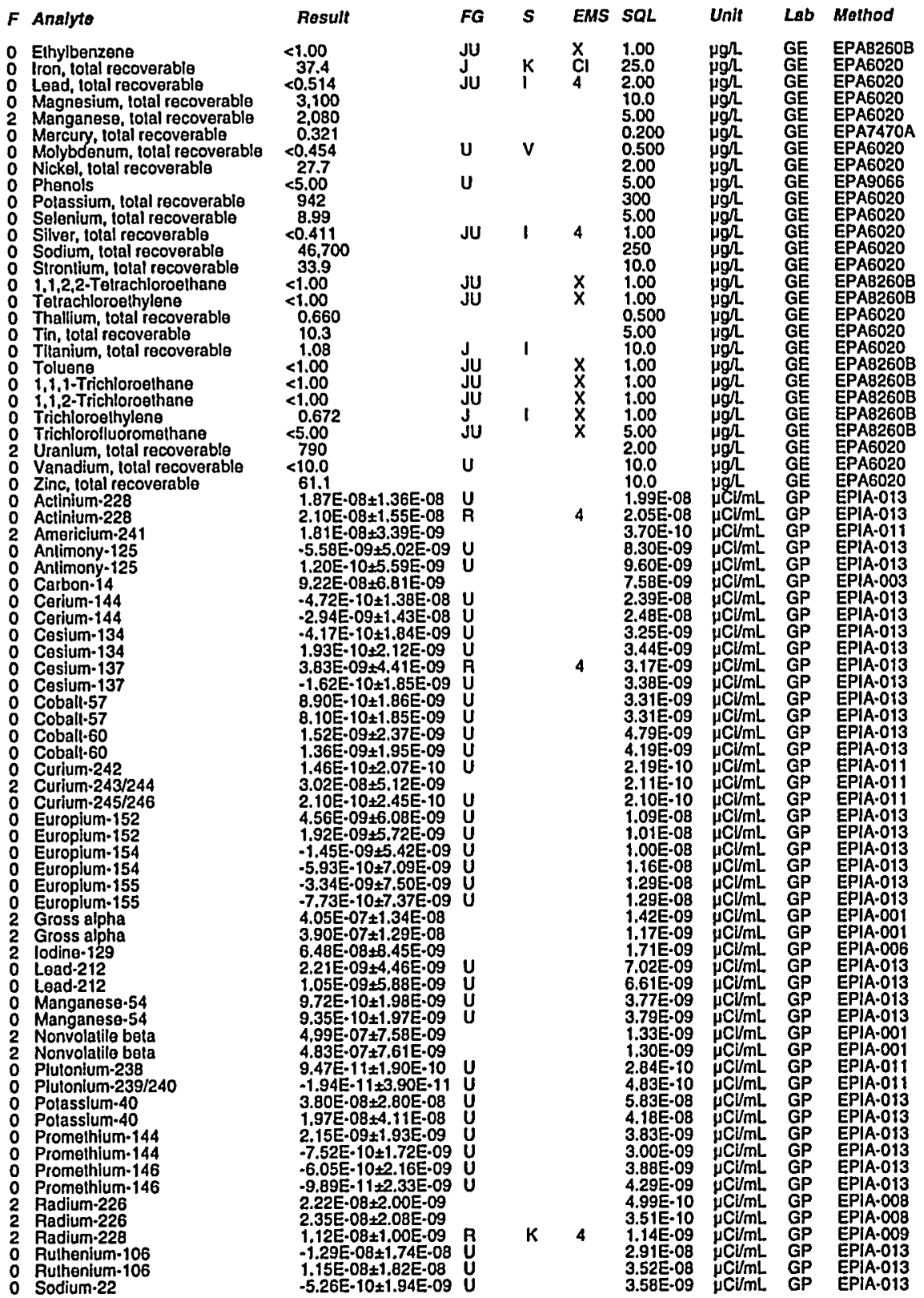

Well FEX ITK collected on 06/07/99 (cont.)

$F$ Analyto

Result

FG

o Sodium-22

2 Stronllum.90

0 Thorium-2230

0 Thorium-232

2 Uranlum.238

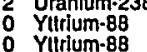

$\begin{array}{ll}0 & \text { Yllrium-68 } \\ 0 & \text { Zinc-65 } \\ 0 & \text { Zine-65 }\end{array}$

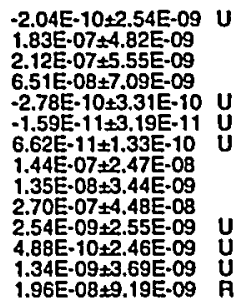

WELL FIN 2TK

MEASUREMENTS CONDUCTED IN THE FIELD

Sample date: 04/08/99

Depth to waler: Not available
Water elevation: Not available

Sp: 4.2 conductance: $850 \mu \mathrm{S} / \mathrm{cm}$

The well was continuously pumping.

ANALYSES

$F$ Analyto

2 Aluminum, total recoverable

Arsenlc, iotal recoverable

Benzeno

Beryllium lotal racoverablo

Bis(2-ethylhexyl) phthalat
Bromodichloromethang

Bromolorm

Cadmlum, tolal recoverable

Calcium, total recovera

Carbon tolrachlor

Chloroethane

Chloroethene (Vinyl chlorida)
2.Chloroolhyl vinyl ether

Chlorolorm

Chroromelhane

Cobalt, lotal recoverablo

Cyanide

D Dibromochloromethane

T.2.-Dichioroethan

$1,1-D$ lchloroethylene
trans $1,2 \cdot$ Dlchloroethylene

1,2-Dichloropropan

cls-1,3-Dichloropropene
trans-1,3-Dichloropropene

Ethylbenzene

Lead, tolal recoverable

Magnesium, total recoverable

Mercury, tofal recoverable Phenols

O Polasslum, total recoverable
Time: 10:55

ralure: $20.8^{\circ} \mathrm{C}$

Tolal akelinity (as Caco3): 0 mgr
Phenolphthalein alkalinity: 0 mgr

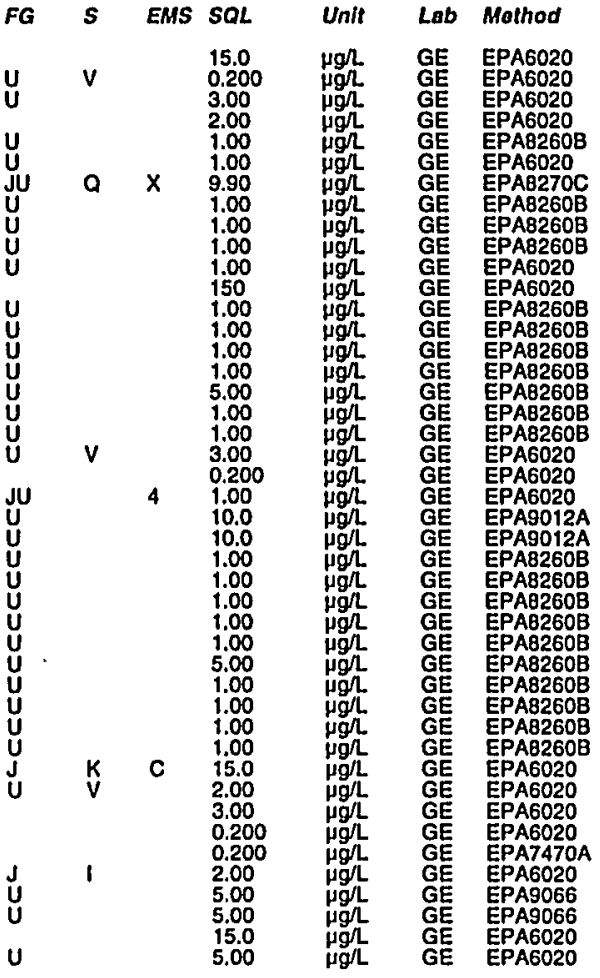


Well FIN 2TK collected on 04/08/99 (cont.)

\begin{tabular}{|c|}
\hline 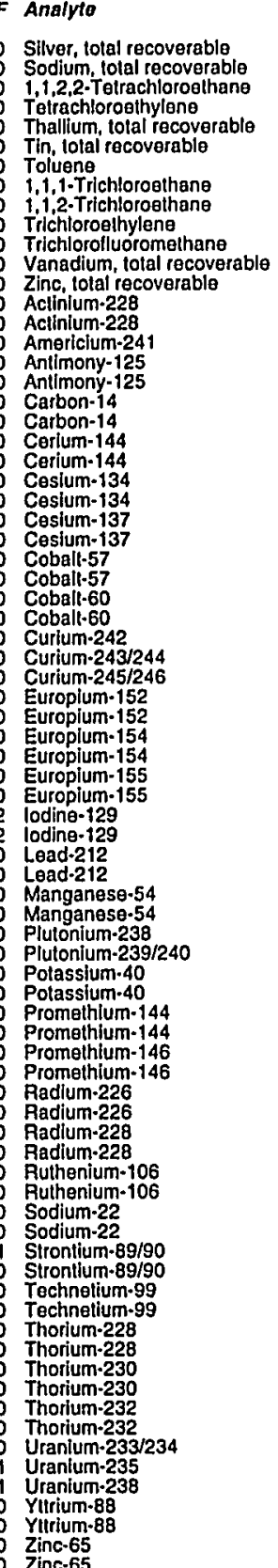 \\
\hline
\end{tabular}

ESH-EMS-990521

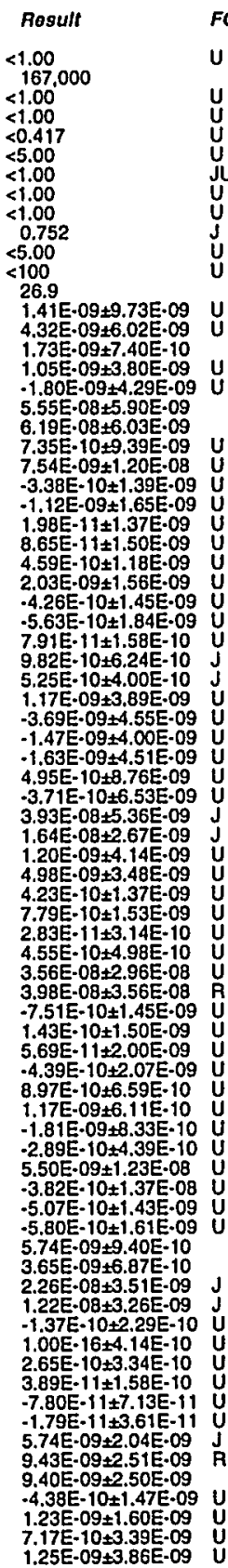

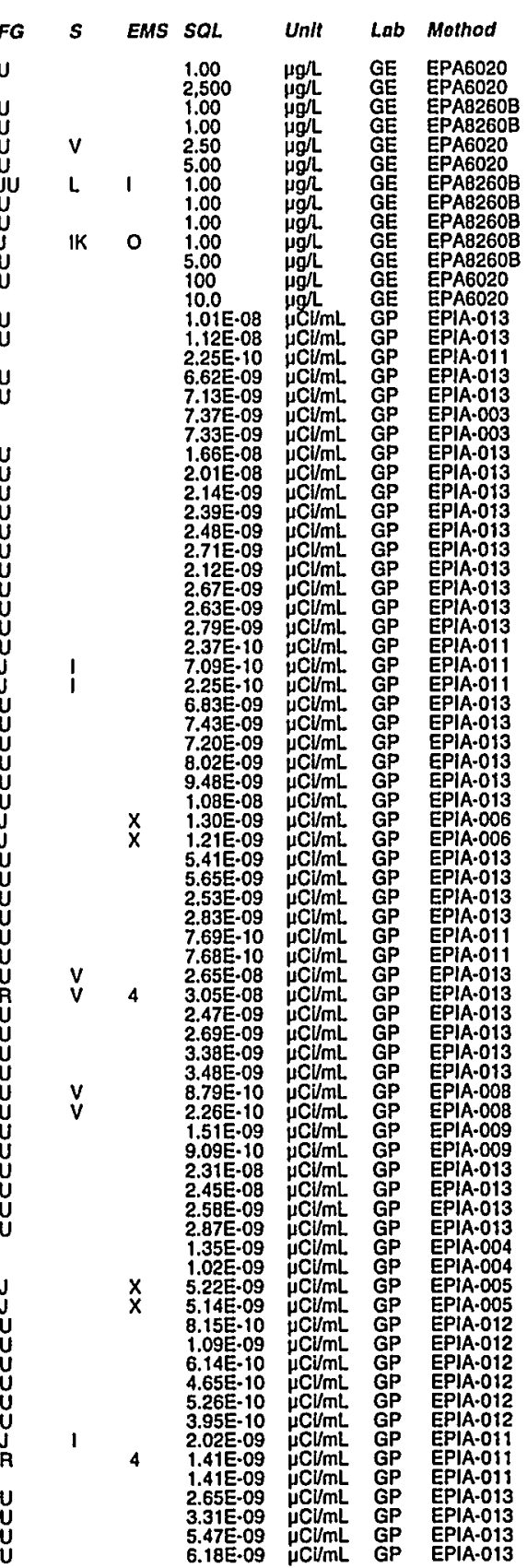

WELL. FIN 2TK

MEASUREMENTS CONDUCTED IN THE FIELD

Sample date: 05/11/99

Wath to waler: Not avalable

Sp: 3.7 conductance: $900 \mu \mathrm{S} / \mathrm{cm}$

Waler temperature: $22.2^{\circ} \mathrm{C}$

Air temperature: $15^{\circ} \mathrm{C}$
Total alkalinily (as Caco3): $0 \mathrm{mg} /$
Phenolphthalein alkalinily: $0 \mathrm{mg} /$

The well was continuously pumping.

ANALYSES

$F$ Analyte

2 Aluminum, total recoverable

Arsenlc, lotal recoverable

Benzene
Bls(2-elhythexyl) phihalate$$
\text { Bromolorm }
$$

Cadmilum, tolal recoverable
Carbon teirachloride

Chloroethane

2-Chloroethene

Chlorolorm

Chloromethane

Coball, total racoverable

Cyanide

$1,1-$ Dichloroethane
1,2 -Dichlorcethane

$1,1 \cdot$ Dichloroellhylene
trans-1,2-Dlchloroethylene Dichloromothane
1,2-Dichloropropan cis-1,3-Dichloropropene Eihylbenzene Lead, tolal recoverable Nickel, tolal recoverable Phenols

Selenium, total recoverable

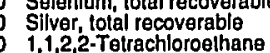
Thallium, total recoverable Tin, total recoverable
Toluen
i, $1,1-$ Trichloroeathane 1,1,-Trichloroelhan Trichlorofluoromethane Zinc, total recoverable Acllnium-228 Antimony-125 O Carbon-14 Cesium.144 Curium-242 Curium-245/246 Europlum-154

列

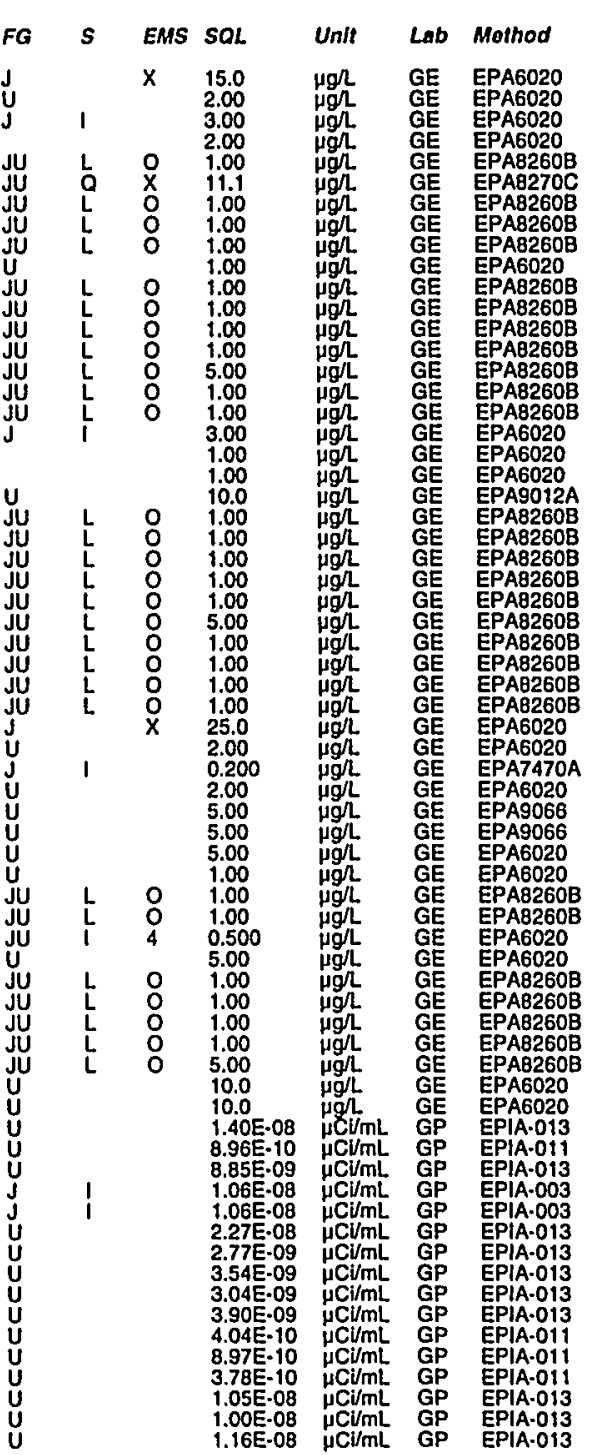


Well FIN 2TK collected on 05/11/99 (cont)

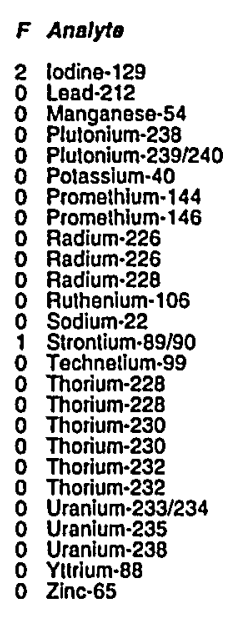

\section{WELL FIN 2TK}

MEASUREMENTS CONDUCTED IN THE FIELD

Sample date: 06/07/99

Water elevation: Not available

PH: 4.3

Sp. conductance: $410 \mu \mathrm{S} / \mathrm{cm}$

The well was continuously pumping

ANALYSES

$F$ Analyte

2 Aluminum, total recoverable Anlimony, tolal recoverablo

o Arsenlc, total recoverable

, Bonzene Bis(2-othythexyl) phthalat

Bromodichlorymethane

Bromoform

Cadmlum, total recoverable

Carbon tolrachloride

Chloroethana

Chloroethene (Vinyl chloride)

2.Chloroethyl vinyl elher

Chloromethan

Chromium, total recoverable

Copalt, total recoverable

Cyanide
Dibromochloromethane

1,1-Dichloroethane

$1,1 \cdot$ Dichloroethylene
trans-1,2-Dichloroethylene

Dichloromethane

o cis-1,3-0ichloropopopene

: Elhylbenzene

0 Lead, lotal recoverable

o Mercury, total recoverable

ESH-EMS-990521

Result

504
$<0.155$
$<3.00$

$<1.00$
$<10.0$
$<1.00$

$<1.00$
$<1.00$

$<1.00$
$<5.00$
$<1.00$

$<1.00$
$<1.00$
3.42

2.50
$<1.68$
$<10.0$

$<1.00$
$<1.00$
$<1.00$
$<1.00$
$<1.00$

$<2.46$

$<1.00$

97.3
$<2.00$
0.280
3.47

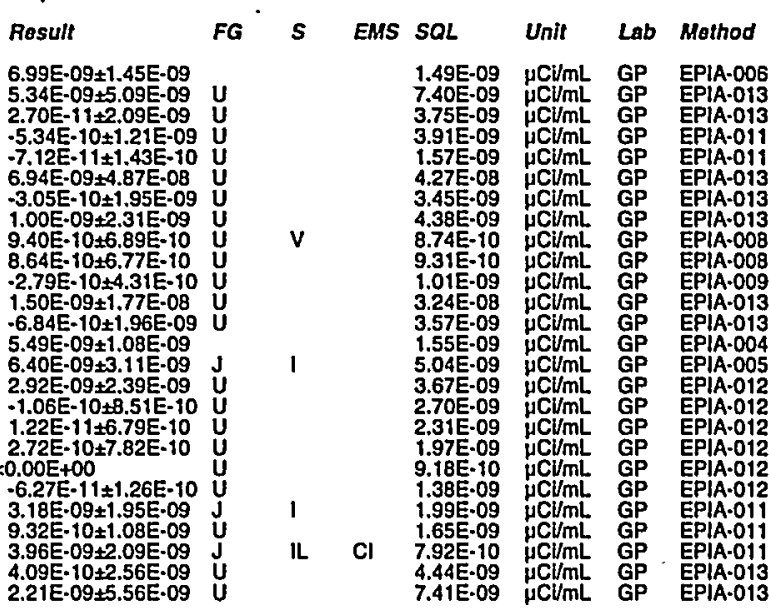

Time: 12:30

erature: $23.9^{\circ} \mathrm{C}$

Total akalinity (as CaCO3): $0 \mathrm{mg} / \mathrm{L}$
Phenolphthalein alkalinily: $0 \mathrm{mg} / \mathrm{L}$
Well FIN 2TK collected on 06/07/99 (cont)

Phenols

Selenium, lotal recoverable

$1,1,2,2-$ Tetrachloroethane

Thallium, total recoverable

Toluene

1.1,2-Trichloroethan

Trichlorofluoromathane

O Vanadium, total recovera

Actinium-228
Actinium-228

Americium-241

Ambricium:245
Antimonn:125
Antimony-125

Carbon-14

Carium-144

$\begin{array}{ll}0 & \text { Cosium-134 } \\ 0 & \text { Cosium-134 } \\ 0 & \text { Cesium-137 }\end{array}$

O Cosium-137

Coball.57

$\begin{array}{ll}0 & \text { Coball-60 } \\ 0 & \text { Curium-242 } \\ 0 & \text { Curlum-242 }\end{array}$

Curium-242

Curium-243/244
Curium-243/244
Curium-245/246

Curium-245/240

o Europium-1 12

0 Europlum-154
0
0 Europlum-154
0 Europlum-155
0

loding-129

L Load-212

M Manganese-54

Plutonium-238

Plutonlum-238
Plutonlum-239/240
Plutonlum-239/240

Plutonlum-239

Promethlum. 144

Promethium-146

Promethium.146

Radium-228

Ruthenium-106
Ruthenium-106

Sodium-22

Strontlum $\cdot 89 / 90$

Strontlum-89/90

Technellum-99

Thorium-228

Thorium-228

Thrilum-230
Thorium-232

2 Uranlum-233/234

B-101

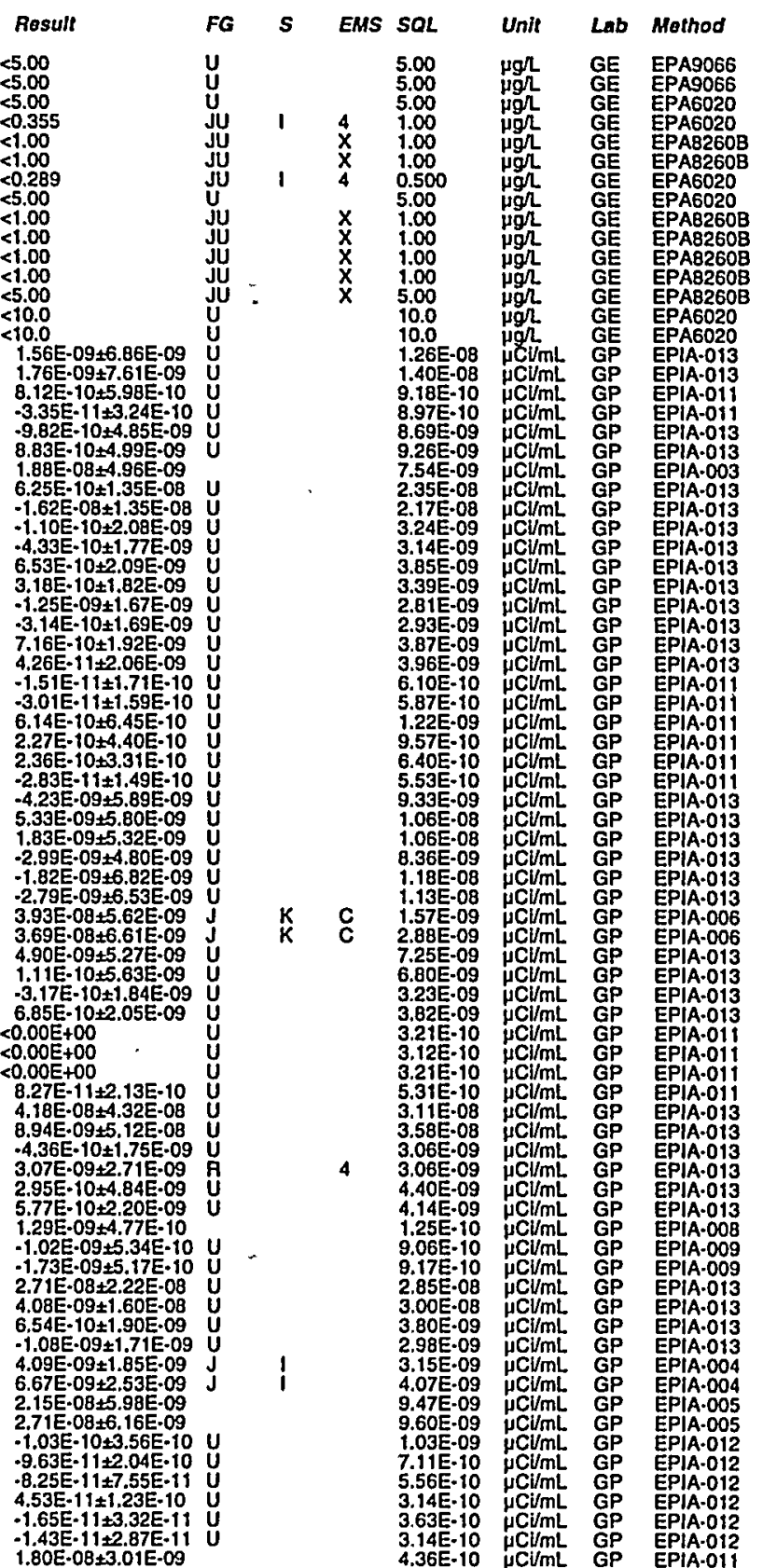

Socond Quartor 1999 
要

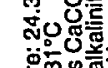

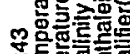

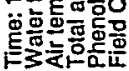

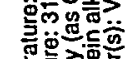

호을

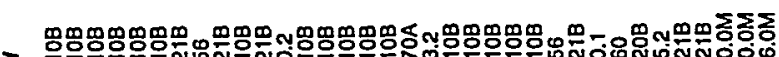

寉

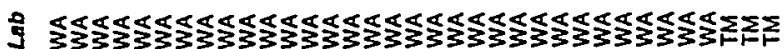

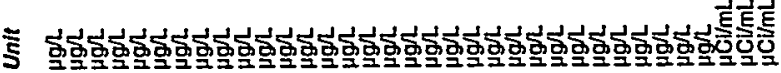

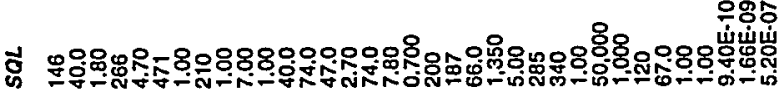
密

$\infty>$

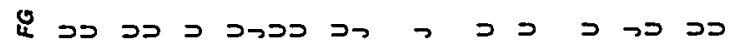

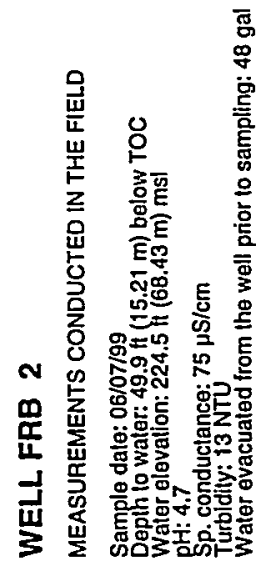

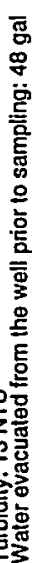

-

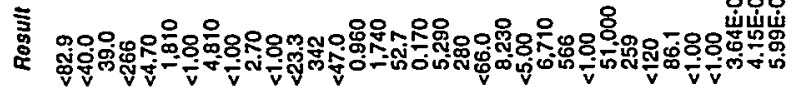

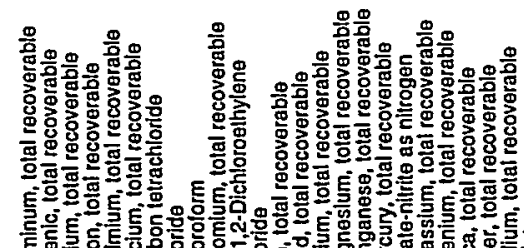

究

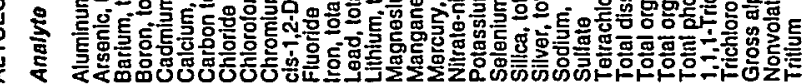

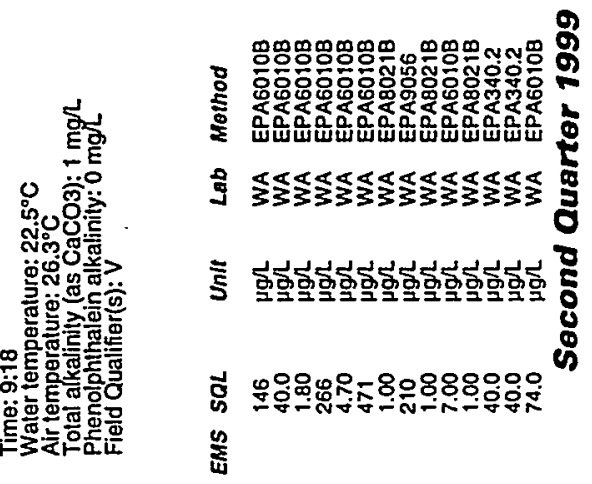

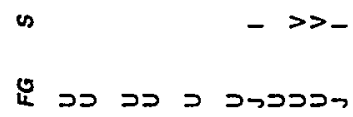
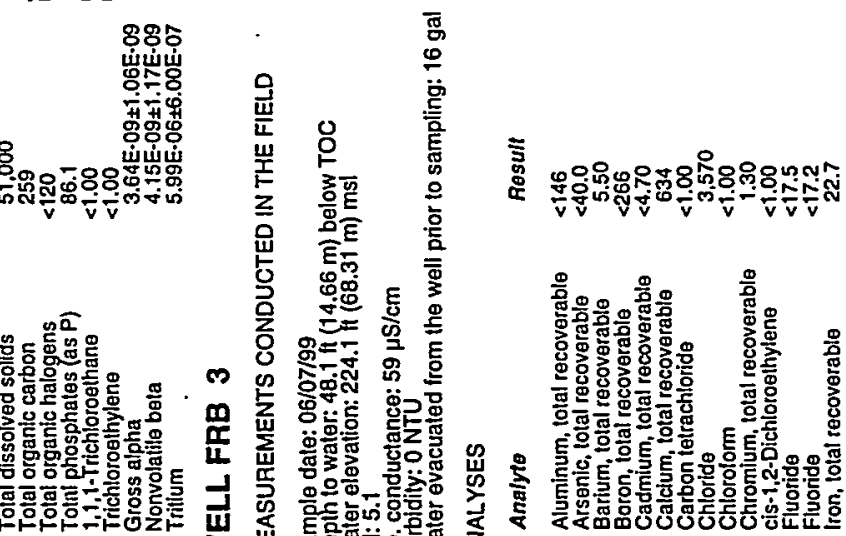
vำ

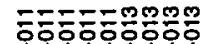

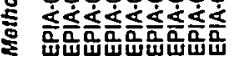

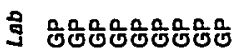

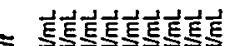

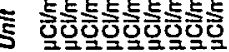

으으으으응ㅇㅇㅇㅇㅇㅇㅇㅇ

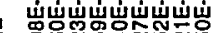

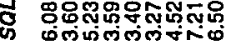

훈

$\omega$

8

בככד

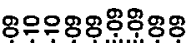

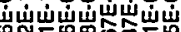
(1)

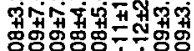

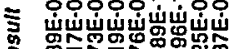

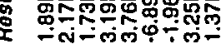
兽 产

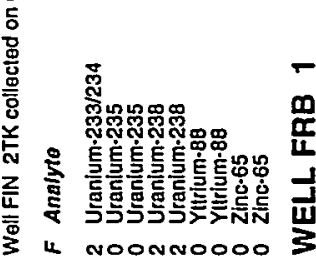

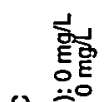

응 \%ํ.

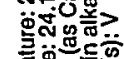

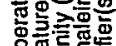

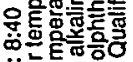

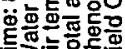

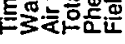

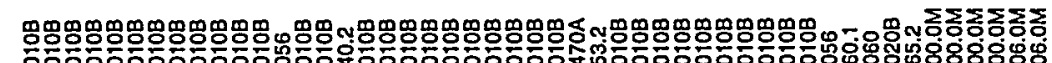

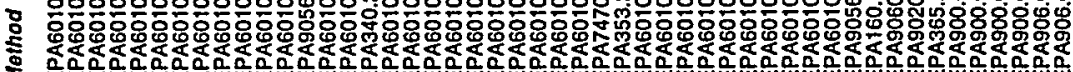

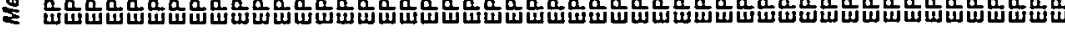

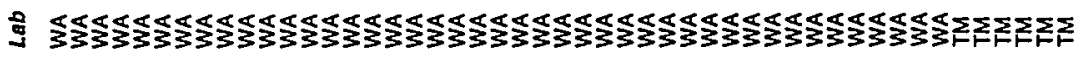

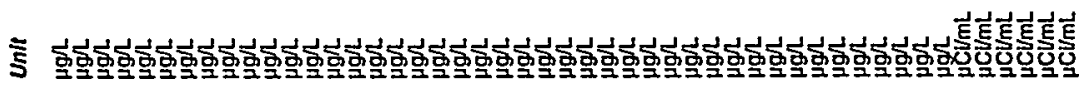
으요응

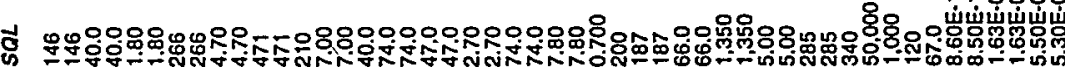
蛋

$\infty>>$

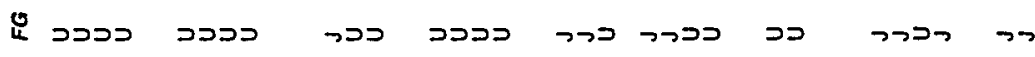

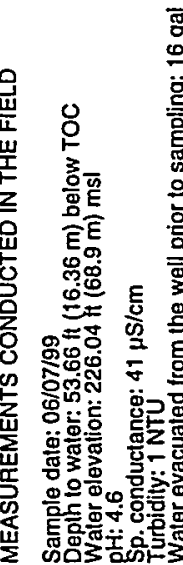

$\overline{\mathrm{\sigma}}$

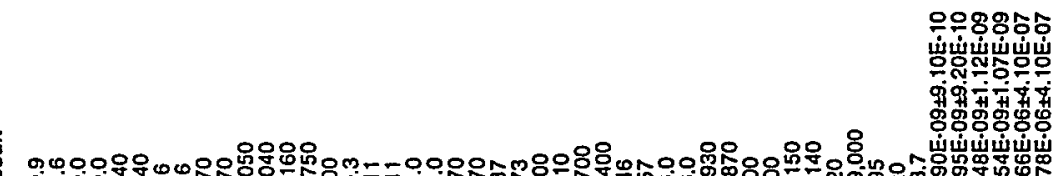

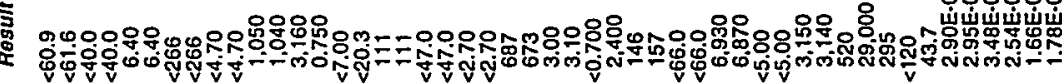

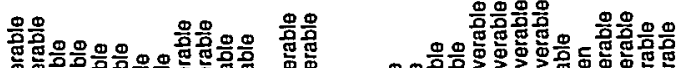

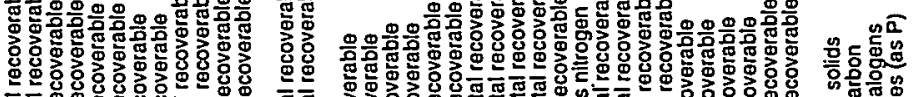

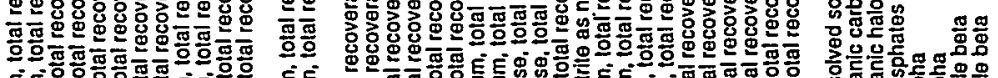




\section{WELL FSB 78A}

MEASUAEMENTS CONDUCTED IN THE FIELD

Sample date: 04/05/99 Water elava

Sp. conductance: $110 \mu \mathrm{S} / \mathrm{cm}$

Water evacuated from the well prior to sampling: $255 \mathrm{gal}$ ANALYSES

\begin{tabular}{|c|c|c|c|c|c|c|c|c|}
\hline$F$ Analyte & Rosult & $\boldsymbol{F G}$ & $s$ & EMS & $S Q L$ & Unit & Lab & Method \\
\hline $\begin{array}{ll}1 & \text { Aluminum, tolal recoverable } \\
0 & \text { Cadmium, tolal recoverable } \\
0 & \text { lron, total recoverable } \\
0 & \text { Lead, tolal recoverable } \\
0 & \text { Nitrate-nitrite as nitrogen } \\
0 & \text { pH } \\
0 & \text { Specllic conductance } \\
0 & \text { Gross alpha } \\
0 & \text { Nonvolatilie bela } \\
1 & \text { Tritium }\end{array}$ & $\begin{array}{l}30.6 \\
<1.00 \\
76.7 \\
<2.00 \\
700 \\
6.86 \\
139 \\
1.92 E-10 \pm 3.44 E-10 \\
1.23 E-09 \pm 6.69 E-10 \\
1.18 E-05 \pm 6.86 E-07\end{array}$ & $\begin{array}{l}u \\
u \\
u \\
u\end{array}$ & 0 & & $\begin{array}{l}15.0 \\
1.00 \\
25.0 \\
2.00 \\
50.0 \\
0.100 \\
1.00 \\
7.58=-10 \\
1.32 E \cdot 09 \\
5.66=.07\end{array}$ & 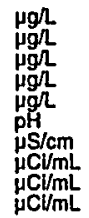 & $\begin{array}{l}\mathrm{GE} \\
\mathrm{GE} \\
\mathrm{GE} \\
\mathrm{GE} \\
\mathrm{GE} \\
\mathrm{GE} \\
\mathrm{GE} \\
\mathrm{GF} \\
\mathrm{GP} \\
\mathrm{GP}\end{array}$ & $\begin{array}{l}\text { EPA6020 } \\
\text { EPA6000 } \\
\text { EPA6020 } \\
\text { EPA6020 } \\
\text { EPA353.1 } \\
\text { EPA900B } \\
\text { EPA9050A } \\
\text { EPA.001 } \\
\text { EPAA.001 } \\
\text { EPIA.002 }\end{array}$ \\
\hline
\end{tabular}

\section{WELL FSB 78B}

MEASUREMENTS CONDUCTED IN THE FIELD

Sample date: 04/15/99

Water elevation: $154.77 \mathrm{ft}(47.17 \mathrm{~m}) \mathrm{ms}$

Sp: 6.9 conductance: $240 \mu \mathrm{S} / \mathrm{cm}$

Water evacuated from the well prior to sampling: $165 \mathrm{gal}$

ANALYSES
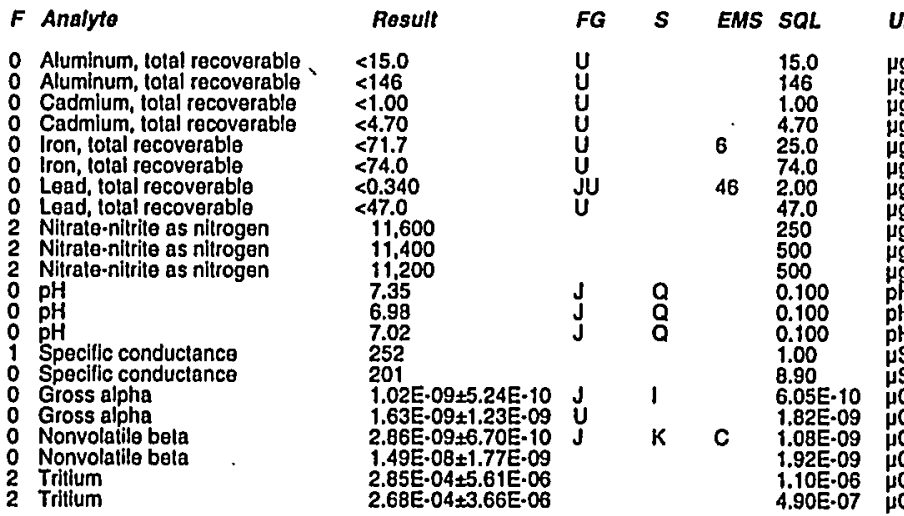

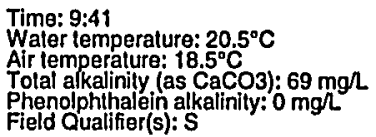

Total alkalinity (as CaCO3): $69 \mathrm{mgh}$
Phenolphthalein alkalinity: $0 \mathrm{mg}$.

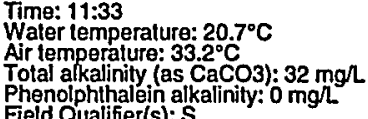

Total alkalinity (as CaCo3): $32 \mathrm{mg} /$

Phenolphthalein alk

.

MEASUREMENTS CONDUCTED IN THE FIELD

Sample date: 04/15/99

(3) $35.98 \mathrm{~m})$ below TOC

Water

Sp. conductance: $240 \mu \mathrm{S} / \mathrm{cm}$

Waler evacuated from the well prior to sampling: $165 \mathrm{gal}$

ANALYSES
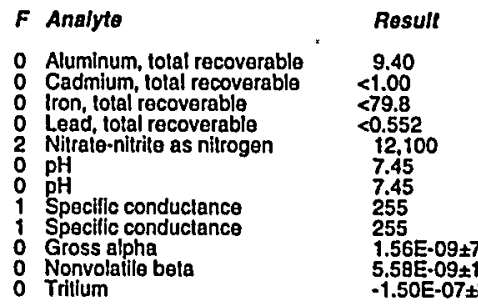

\section{WELL FSB 78C}

MEASUREMENTS CONDUCTED IN THE FIELD

Sample dale: 04/09/99
Depth to water: $67.21 \mathrm{Ht}(20.49 \mathrm{~m})$ below TOC
Water elevalion: $206.29 \mathrm{tt}(62.88 \mathrm{~m}) \mathrm{ms}$

Water elevalion: $206.29 \mathrm{ft}(62.88 \mathrm{~m})$

Th. conduclance: $2,100 \mu \mathrm{S} / \mathrm{cm}$

Water evacualed from the well prior to sampling: 1 gal ANALYSES

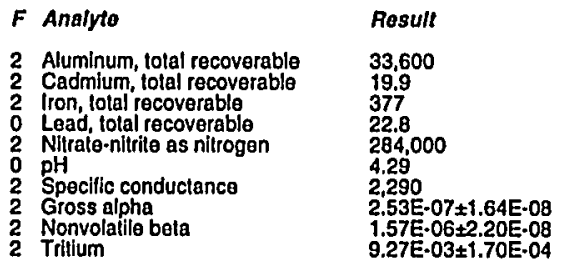

FG $s$

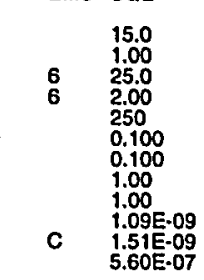

Time: 9:41

temperature: $20.5^{\circ} \mathrm{C}$

Total alkalinity (as CaCO3): $69 \mathrm{mg} / \mathrm{s}$

Phenolphithalein alkalinity: 0 mgh

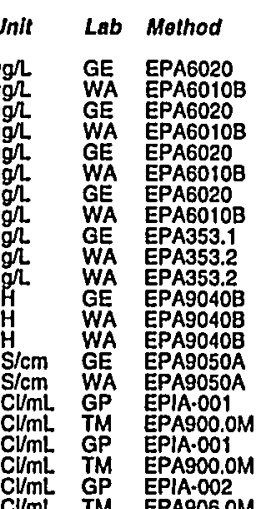

2 Tritium

\section{WELL FSB 79}

MEASUREMENTS CONDUCTED IN THE FIELD

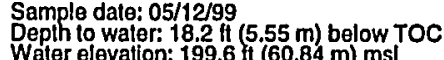

Waler elevation: $199.6 \mathrm{ft}(60.8$
pH: 3.6

Sp. conduclance: $750 \mu \mathrm{S} / \mathrm{cm}$

Waler evacuated from the well prior to sampling: $45 \mathrm{gal}$

ANALYSES

\begin{tabular}{|c|c|c|c|c|c|c|c|}
\hline F Analyte & Result & $F G$ & $s$ & EMS SOL & Unit & Lab & Mothod \\
\hline $\begin{array}{ll}2 & \text { Aluminum, lotal recoverable } \\
2 & \text { Cadmium, lotal recoverable } \\
2 & \text { Iron, lotal recoverable } \\
0 & \text { Lead, total recorerable } \\
2 & \text { Nitrate-nitrite as niltogen } \\
1 & \text { pH } \\
2 & \text { Specific conductance } \\
2 & \text { Gross alpha }\end{array}$ & $\begin{array}{l}28,200 \\
5.47 \\
3.13 \\
2.00 \\
92.500 \\
3.73 \\
862 \\
2.78 E-07 \pm 1.02 E-08\end{array}$ & $\begin{array}{l}\text { U } \\
\text { J }\end{array}$ & $a$ & $\begin{array}{l}15.0 \\
1.00 \\
25.0 \\
2.00 \\
2.500 \\
0.100 \\
1.00 \\
1.13 \mathrm{E}-09\end{array}$ & $\begin{array}{l}\mu g / \mathrm{L} \\
\mu g / \mathrm{L} \\
\mu g / \mathrm{L} \\
\mu g / \mathrm{L} \\
\mu g / \mathrm{L} \\
\mathrm{pg} \\
\mu \mathrm{H} / \mathrm{cm} \\
\mu \mathrm{Ci} / \mathrm{mL}\end{array}$ & $\begin{array}{l}G E \\
G E \\
G E \\
G E \\
G E \\
G E \\
G E \\
G E \\
G E \\
G P\end{array}$ & $\begin{array}{l}\text { EPA6020 } \\
\text { EPA6020 } \\
\text { EPA6020 } \\
\text { EPA6020 } \\
\text { EPA353.1 } \\
\text { EPA9040B } \\
\text { EPA9050A } \\
\text { EPIA.001 }\end{array}$ \\
\hline
\end{tabular}

Second Quartor 1999
Time: 13:20 Total alkalinity (as CaCO3): $0 \mathrm{mg} / \mathrm{h}$ Phenolphthalein alkalinity: $0 \mathrm{mg} /$
Field Qualifier(s): $V X$
Air temperalure: $259^{\circ} \mathrm{C}$
Time: 9:58

ter temperalura: $22.1^{\circ} \mathrm{C}$

Total alkalinity (as CaCO3): $0 \mathrm{mg} / \mathrm{L}$ Field Qualifier(s): $V$ kalinity: $0 \mathrm{mg}$ 
Well FSB 79 collected on 05/12/99 (cont.)

\begin{tabular}{|c|c|c|c|c|c|c|c|c|}
\hline Analyte & Result & $F G$ & $s$ & EMS & SQL & Unit & Lab & Mothod \\
\hline $\begin{array}{l}2 \\
2\end{array} \frac{\text { Nonvolatile beta }}{\text { Tritium }}$ & $\begin{array}{l}4.78 \mathrm{E}-07 \pm 7.14 \mathrm{E} \cdot 09 \\
4.02 \mathrm{E}-03 \pm 7.89 \mathrm{E} \cdot 05\end{array}$ & & & & $\begin{array}{l}1.23 E .09 \\
5.23 E .06\end{array}$ & $\underset{\mu \mathrm{C} / \mathrm{mL}}{\mu \mathrm{mL}}$ & $\underset{G P}{G P}$ & $\begin{array}{l}\text { EPIA.001 } \\
\text { EPIA.002 }\end{array}$ \\
\hline
\end{tabular}

WELL FSB 79A

MEASUREMENTS CONDUCTED IN THE FIELD

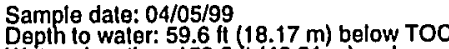

Water elevalion: $158.5 \mathrm{Ht}(48.31 \mathrm{~m}) \mathrm{ms}$

$\mathrm{H}: 6.2$

p. conductance: $78 \mu \mathrm{S} / \mathrm{cm}$

Wurbidily: O NTU

ANALYSES

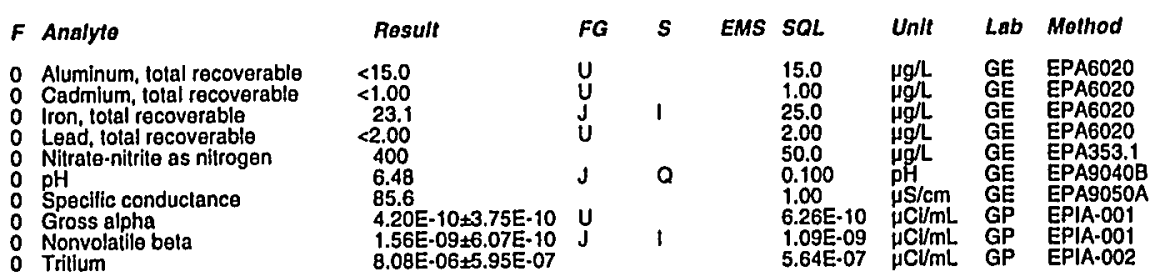

\section{WELLL FSB 79B}

MEASUREMENTS CONDUCTED IN THE FIELD

Sample date: 04/05/99

water: $59.41 \mathrm{Ht}(18.11 \mathrm{~m})$ below TOC

Waler 6

Sp. conductance: $160 \mu \mathrm{S} / \mathrm{cm}$

Waler evacuated from the well prior to sampling: $180 \mathrm{gal}$

ANALYSES

$F$ Analyto

\begin{tabular}{|c|c|c|c|c|c|c|c|}
\hline Rosult & $F G$ & $s$ & EMS & SQL & Unit & Lab & Method \\
\hline $\begin{array}{l}<15.0 \\
<1.00\end{array}$ & U & & & & $\underset{\mu g h}{\mu g}$ & $\begin{array}{l}\text { GE } \\
\text { GE }\end{array}$ & $\begin{array}{l}\text { EPA6020 } \\
\text { EPA6020 }\end{array}$ \\
\hline$<2.00$ & $u$ & & & 2.00 & $g$ & GE & EPAG020 \\
\hline $\begin{array}{l}2.880 \\
7.16\end{array}$ & $\mathrm{~J}$ & Q & & $\begin{array}{l}150 \\
0.100\end{array}$ & $\mathrm{pH}$ & GE & EPA9040B \\
\hline $\begin{array}{l}5.36 \mathrm{E}-10 \pm 4.73 \mathrm{E}-10 \\
1.74 \mathrm{E}-09 \pm 7.42 \mathrm{E}-10 \\
3.99 \mathrm{E}-05 \pm 1.16 \mathrm{E}-06\end{array}$ & J & 1 & & $\begin{array}{l}8.02 E-10 \\
1.41 \mathrm{E}-09 \\
5.62 \mathrm{E}-07\end{array}$ & $\begin{array}{l}\mu \mathrm{C} C / \mathrm{mL} \\
\mu \mathrm{C} / \mathrm{mL} \\
\mu \mathrm{C} / \mathrm{mL}\end{array}$ & $\begin{array}{l}G P \\
G P \\
G P\end{array}$ & $\begin{array}{l}\text { EPIA.001 } \\
\text { EPIA.001 } \\
\text { EPIA.002 }\end{array}$ \\
\hline
\end{tabular}

Iron, total recoverable

Nilrate-nitrite as nitrogen

Speciflc conductance

0 Gross alpha
0 Nonvolatile beta

$1.74 \mathrm{E}-09 \pm 7.42 \mathrm{E}-10$
$3.99 \mathrm{E}-05 \pm 1.16 \mathrm{E}-06$

\section{WELL FSB $79 C$}

MEASUREMENTS CONDUCTED IN THE FIELD

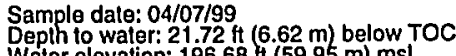

$\mathrm{H:} 3.6$

Sp. conductance: $1,200 \mu \mathrm{S} / \mathrm{cm}$

Waler evacuated from the well prior to sampling: $62 \mathrm{ga}$

ANALYSES

$F$ Anslyto

Result

FG S EMS SOL

2 Aluminum, total recoverable

49,800
15.5
54.9

$K \quad I \quad \begin{array}{r}15.0 \\ 1.00 \\ 25.0\end{array}$

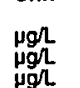

Lab Mothod

ESH-EMS-99052 Air temperature: $31.8^{\circ} \mathrm{C}$
Total alkalinity (as CaCo3): $56 \mathrm{mg} / \mathrm{h}$ Phenolphthalein alkalinity: $0 \mathrm{mg} \mathrm{L}^{\prime}$
Well FSB 79C collected on 04/07/99 (cont)

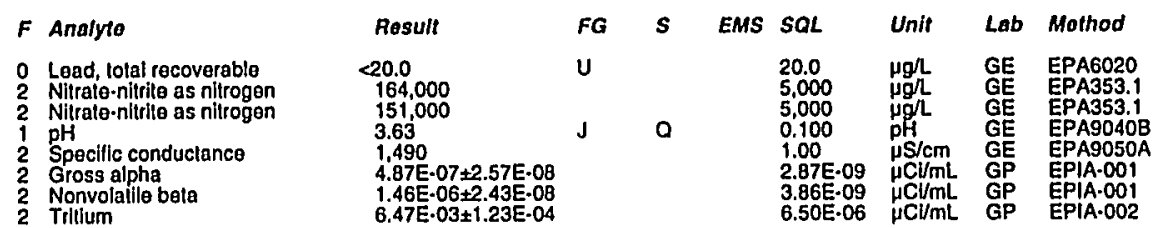

\section{WELL FSB 87A}

MEASUREMENTS CONDUCTED IN THE FIELD

Sample date: 04/06/99

Water elevalion: $154.4 \mathrm{ff}(47.06 \mathrm{~m}) \mathrm{msl}$

H: 6.1

. conductance: $92 \mu \mathrm{S} / \mathrm{cm}$

Water evacuated from the well prior to sampling: 220 gal

ANALYSES

F Analyto

Result

Aluminum, total recoverable

Cadmium, lotal recoverable

Cron, lotal recoverable

Lead, lotal recoverab

Nead, total recoverable

$0 \mathrm{pH}$

${ }_{0}^{0} \mathrm{pH}$

\section{Specilic conductance}

Specilic conduclence

Grocss alpha

Gross alphe

Nonvolatile beta

Nonvolatili beta

Tritium

0
0
0

$<15.0$

$<146$
$<1.00$
$<4.70$

$<4.70$
26.3
18.4
$<2.00$

42.00
$<47.0$
130
114

114
6.49
6.48
6.70

6.48
6.70
6.66
105

105

$\begin{array}{ll}73.2 \\ 2.09 E-10 \pm 3.85 E-10 & U \\ 1.23 E-0997.70 E-10 & J\end{array}$

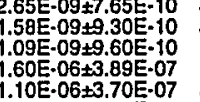

\section{WELL FSB 87A Replicate}

MEASUREMENTS CONDUCTED IN THE FIELD

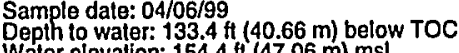

WH: 6.1

p: conduclance: $92 \mu \mathrm{S} / \mathrm{cm}$

Water evacuated from the well prior to sampling: $220 \mathrm{gal}$

ANALYSES

F Analyto

$\begin{array}{ll}\text { Result } & \\ 13.1 & J \\ <1.00 & U \\ 26.6 & \\ <2.00 & \\ 90.0 & \\ 6.57 & J \\ 95.5 & \\ 6.35 E-11 \pm 3.88 E-10 & U \\ 9.15 E-10 \pm 6.64 E-10 & U \\ 1.42 E-06 \pm 3.81 E-07 & \end{array}$

FG $S$

Aluminum, lotal recoverable

Iron, tolal recoverable

Nitrale-nitrita as nitrogen

Specific conductance

Nonvolatila bota

1. $12 E-10 \pm 6.64 E-10 \quad U$

B-106
Time: 10:01

Total alkalinity (as CaCO3): $32 \mathrm{mg} \Omega$

Phenolphthalein alkalinity: $0 \mathrm{mg} /$

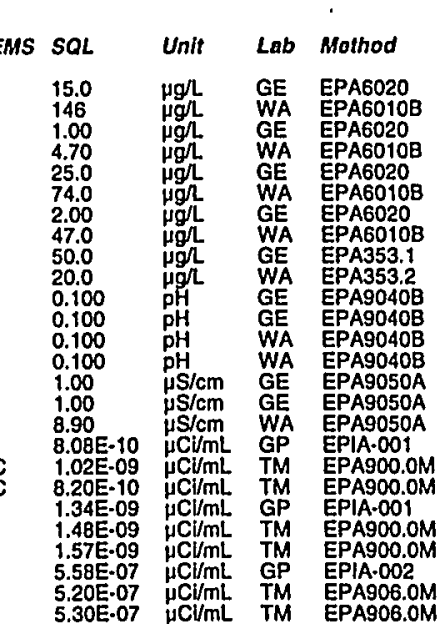

Time: 10:01

Air temperature: $152^{\circ} \mathrm{C}{ }^{\circ} \mathrm{C}$

Total alkalinily (as CaCO3): $32 \mathrm{mg} \Omega$

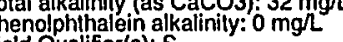

EMS SQL Unit Lab Mothod

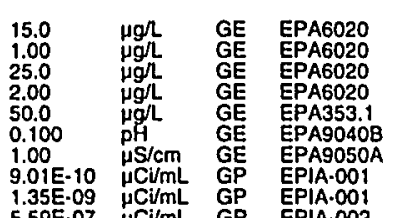

Socond auartor 
Well FSB 87A collected on 04/06/99 (cont.)

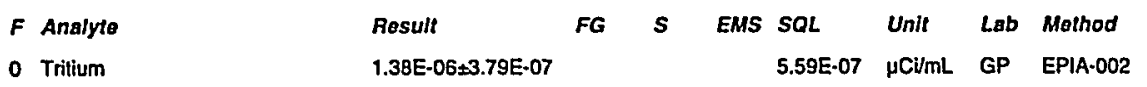

\section{WELL FSB $87 B$}

MEASUREMENTS CONDUCTED IN THE FIELD

Sample date: 04/06/99
Depth to water: $136.45 \mathrm{H}(41.59 \mathrm{~m})$ below TOC
Water elevation: $151.05 \mathrm{ft}(46.04 \mathrm{~m}) \mathrm{ms}$

Sp. 5.2 conductance: $100 \mu \mathrm{S} / \mathrm{cm}$

Tiubidity: 0 NTU
Water evacuated from the well prior to sampling: $119 \mathrm{ga}$

ANALYSES

$F$ Analyte

o Aluminum, total recoverable

Iron, total recoverable

Nitrale-nitrite as nilrogen

Specific conductance

Gross alpha

2 Tritium

\section{WELL FSB $87 C$}

MEASUREMENTS CONDUCTED IN THE FIELD

Sample date: 04/06/99

water: $78.14 \mathrm{Ht}(23.82 \mathrm{~m})$ below TOC

Water e

Sp. conductance: $100 \mu \mathrm{S} / \mathrm{cm}$

Wuater evacuated from the well prior to sampling: $104 \mathrm{gal}$

ANALYSES

F Analyto

- Aluminum, lotal recoverable

Iron, total recoverable

Nitrate-nilrite as nítrogen

$\mathrm{PH}$

Nonvolatile beta

2
2
2 Trillum
Trifum

\section{WELL FSB 87D}

MEASUREMENTS CONDUCTED IN THE FIELD

Sample date: 04/26/99

Water elevation: Not available

$\mathrm{H}: 3.8$

conductance: $80 \mu \mathrm{S} / \mathrm{cm}$

Water evacuated from the well prior to sampling: 95 gal

ANALYSES

$F$ Analyte

2 Aluminum, total recoverable

o lron, tolal recoverable

ESH-EMS-990521
Result

22.6
$<1.00$
23.0
1.71
9.900
5.79

$6.29 \mathrm{E}-10 \pm 4.61 \mathrm{E}-10$

7.77E-10.5.38E-10

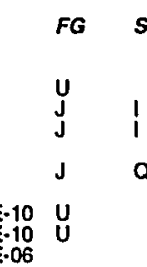

Result

$\begin{array}{llll}F G & S & \text { EMS SOL } \\ \mathrm{J} & \mathrm{K} & \mathrm{I} & 15.0 \\ \mathrm{~J} & \mathrm{I} & \mathrm{Cl} & 1.00 \\ & \mathrm{IK} & \mathrm{Cl} & 2.00\end{array}$

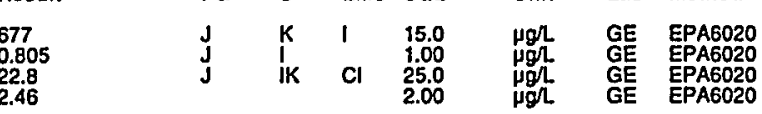

Lab Method

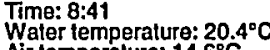

Total alkalinity (as CaCo3): $3 \mathrm{mg} \Omega$

Phenolphthalein alkalinity: $0 \mathrm{mg} /$
Field Qualifier(s):

20.7

Air temperature: $14.4^{\circ} \mathrm{C}$
Total alkalinily (as CaCo3): $3 \mathrm{mg} /$

Phenolphthalein alkalinily: $0 \mathrm{mg}$ L

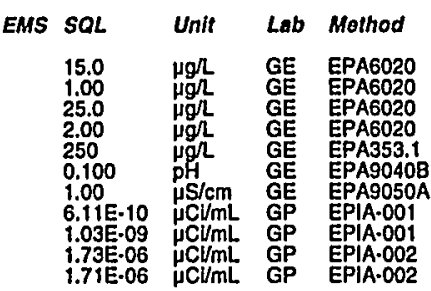

Timo: 15:02

The: $21.5^{\circ} \mathrm{C}$

Total akalinity (as CaCO3): $0 \mathrm{mg}$

Field Qualifier(s): $s$ alinity: $0 \mathrm{mgh}$

677
0.805
22.8
2.46
Well FSB 87D collected on 04/26/99 (cont)

\begin{tabular}{|c|c|c|c|c|c|c|c|c|}
\hline Anaiyte & Result & $F G$ & $s$ & EMS & $S Q L$ & Unit & Lab & Mothod \\
\hline $\begin{array}{ll}2 & \text { Nirrate-nitrite as nitrogen } \\
0 & \mathrm{pH} \\
0 & \mathrm{pH} \\
0 & \mathrm{Specilic} \text { conductance } \\
2 & \text { Gross alpha } \\
2 & \text { Nonvolatile beta } \\
2 & \text { Tritium }\end{array}$ & $\begin{array}{l}11.500 \\
4.20 \\
4.23 \\
130 \\
8.77 E-08 \pm 4.07 E-09 \\
5.63 E-08 \pm 2.30 E-09 \\
5.82 E-04 \pm 4.49 E-06\end{array}$ & $\vec{J}$ & $\mathrm{a}$ & & $\begin{array}{l}250 \\
0.100 \\
0.100 \\
1.00 \\
7.72 E-10 \\
1.22 E-09 \\
6.36 E-07\end{array}$ & $\begin{array}{l}\mu \mathrm{g} / \mathrm{L} \\
\mathrm{pH}_{\mathrm{H}} \\
\mathrm{pH} \\
\mu \mathrm{S} / \mathrm{cm} \\
\mathrm{\mu C \textrm {mL }} \\
\mu \mathrm{C} / \mathrm{mL} \\
\mu \mathrm{C} / \mathrm{mL}\end{array}$ & $\begin{array}{l}G E \\
G E \\
G E \\
G E \\
G E \\
G P \\
G P \\
G P\end{array}$ & $\begin{array}{l}\text { EPA353.1 } \\
\text { EPA9040B } \\
\text { EPAO040B } \\
\text { EPA9050A } \\
\text { EPIA-001 } \\
\text { EPIA.001 } \\
\text { EPIA.002 }\end{array}$ \\
\hline
\end{tabular}

\section{WELL FSB 88C}

MEASUREMENTS CONDUCTED IN THE FIELD

Sample date: 04/07/99

(2) $69.78 \mathrm{ft}(21.27 \mathrm{~m})$ below TOC

Water

5 : 5 evation: 213.22 it (64.9

Water evacuated from the well prior to sampling: $169 \mathrm{gal}$

ANALYSES

$F$ Analyto

Rosult

O Aluminum, total recoverable

Iron, total recoverable

Nitrate-nitrite as nitrogen

$\mathrm{Sp}$ Secilic conductance

Gross alpha

$<15.3$
$<1.00$
63.0
$<0.520$
1.580

$<0.520$
1.580
5.66
49.3
$9.16 E$

9.16E-10 $14.29 E-10 \mathrm{~J}$

\section{WELL FSB 88D}

MEASUREMENTS CONDUCTED IN THE FIELD

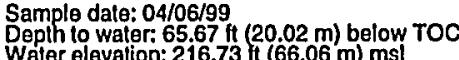

Water 4

$\mathrm{H:}: 4$ elevation:

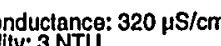

Wer evacuated from the well prior to sampling: $19 \mathrm{gal}$

ANALYSES

\begin{tabular}{|c|c|c|c|c|c|c|c|c|}
\hline Anslyte & Result & $F \boldsymbol{G}$ & $s$ & EMS & $S Q L$ & Untt & Lab & Mothod \\
\hline $\begin{array}{l}\text { Aluminum, lotal recoverable } \\
\text { Cadmilum, total recoverable } \\
\text { lron, lotal recoverable } \\
\text { Lead, total recoverable } \\
\text { Nituate-nitrite as nitiogen } \\
\text { pH } \\
\text { Specllic conductance } \\
\text { Gross alpha } \\
\text { Nonvolatilie beta } \\
\text { Trittum }\end{array}$ & $\begin{array}{l}9.880 \\
1.23 \\
34.1 \\
5.27 \\
31.000 \\
3.87 \\
326 \\
3.01 E-07 \pm 8.06 E-09 \\
2.67 \mathrm{E} \cdot 07 \pm 4.57 \mathrm{E} \cdot 09 \\
2.29 \mathrm{E}-04 \pm 4.52 \mathrm{E} \cdot 06\end{array}$ & $J$ & $a$ & & $\begin{array}{l}15.0 \\
1.00 \\
25.0 \\
2.00 \\
1,250 \\
0.100 \\
1.00 \\
6.14 E \cdot 10 \\
1.111 .09 \\
9.89 \mathrm{E} \cdot 07\end{array}$ & 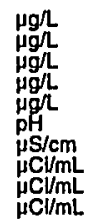 & $\begin{array}{l}\mathrm{GE} \\
\mathrm{GE} \\
\mathrm{GE} \\
\mathrm{GE} \\
\mathrm{GE} \\
\mathrm{GE} \\
\mathrm{GE} \\
\mathrm{GE} \\
\mathrm{GP} \\
\mathrm{GP}\end{array}$ & 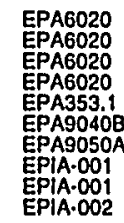 \\
\hline
\end{tabular}

\section{WELL FSB $89 \mathrm{C}$}

MEASUREMENTS CONDUCTED IN THE FIELD

Sample date: 04/06/99

Depth to water: $68.99 \mathrm{ft}(21.03 \mathrm{~m})$ below TOC

Water e

conductance: $54 \mu \mathrm{S} / \mathrm{cm}$

Water evacuated from the well prior to sampling: $125 \mathrm{gal}$
Time: 9:46

Air temperature: $207^{\circ} \mathrm{C}$

Total alkalinity (as Caco3): $5 \mathrm{mgh}$

Phenolphthalein alkalinity: $0 \mathrm{mg} L$
Field Qualifier(s): $\mathrm{S}$

EMS SQL Unit Lab Hothod

\begin{tabular}{|c|c|c|}
\hline $\begin{array}{l}15.0 \\
1.00 \\
25.0 \\
2.00 \\
50.0 \\
0.100 \\
1.00 \\
5.34 \text { E. } 10 \\
9.64 E-10\end{array}$ & $\begin{array}{l}\mu g h \\
\mu g h \\
\mu g h \\
\mu g h \\
\mu g h \\
\mu g \\
p H \\
\mu S / c m \\
\mu C / m L \\
\mu C / m L \\
\mu C / m L\end{array}$ & $\begin{array}{l}G E \\
G E \\
G E \\
G E \\
G E \\
G E \\
G E \\
G E \\
G E \\
G P \\
G P\end{array}$ \\
\hline
\end{tabular}

Time: 8:30

4alure: $19.9^{\circ} \mathrm{C}$

Total alkalinity (as CaCO3): $0 \mathrm{mg} /$
Phenolphithalein alkalinity: $0 \mathrm{mg} \mathrm{L}^{2}$

.

Time: 11:21

Air temperature: $19.2^{\circ} \mathrm{C}$

Total alkalinity (as Caco3): $8 \mathrm{mgh}$

Phenolphinalein alk
Field Qualifier(s): $S$ 
Well FSB 9iD collected on 04/06/99 (cont.)

$\begin{array}{llllrlll}F \text { Analyte } & \text { Result } & \text { FG } & S & \text { EMS SQL } & \text { Unit } & \text { Lab Molhod } \\ 2 \text { Triltum } & 2.35 E-04 \pm 4.64 E-06 & & & 9.97 E-07 & \mu C V \text { MLL } & \text { GP } & \text { EPIA-002 }\end{array}$

WELL FSB 92C

MEASUREMENTS CONDUCTED IN THE FIELD

Sample date: $04 / 06 / 99$

Waler ele
pH: 5.4

Sp. conductance: $290 \mu \mathrm{S} / \mathrm{cm}$

Water evacuated from the well prior to sampling: $79 \mathrm{gat}$

ANALYSES

$F$ Analyte

\begin{tabular}{|c|c|c|c|c|c|c|c|}
\hline & $F G$ & $\boldsymbol{s}$ & EMS & SQL & Unit & Lab & Method \\
\hline $\begin{array}{l}1.040 \\
4.43 \\
49.8 \\
<0.394 \\
32,300 \\
5.66 \\
321 \\
3.17 E-08+2.78 E-09\end{array}$ & $\begin{array}{l}\text { JU } \\
\text { J }\end{array}$ & $\begin{array}{l}1 \\
0\end{array}$ & 4 & $\begin{array}{l}15.0 \\
1.00 \\
25.0 \\
2.00 \\
1.250 \\
0.100 \\
1.00 \\
7.60 \mathrm{E} \cdot 10 \\
1.15 \mathrm{E} .09 \\
1.84 \mathrm{E} \cdot 06\end{array}$ & $\begin{array}{l}\mu g h \\
\mu g h \\
\mu g h \\
\mu g h \\
\mu g h \\
\mu g h \\
p H \\
\mu S / c m \\
\mu C / m L \\
\mu C / m L \\
\mu C / m L\end{array}$ & $\begin{array}{l}\text { GE } \\
\text { GE } \\
\text { GE } \\
\text { GE } \\
\text { GE } \\
\text { GE } \\
\text { GE } \\
\text { GP } \\
\text { GP } \\
\text { GP }\end{array}$ & $\begin{array}{l}\text { EPA60020 } \\
\text { EPA6020 } \\
\text { EPA6020 } \\
\text { EPA353.1 } \\
\text { EPA90408 } \\
\text { EPA90500A } \\
\text { EPIA.001 } \\
\text { EPIA.001 } \\
\text { EPIA.002 }\end{array}$ \\
\hline
\end{tabular}

2 Aluminum, tolal recoverable

Iron, lotal recoverable

Nitrale-nitrite as nilrogen

Spectic conductance

2 Gross alpha

\section{WELL FSB $92 D$}

MEASUREMENTS CONDUCTED IN THE FIELD

\section{Sample date: 04/08/99
Depth to water: 63.94 $\mathrm{H}(19.49 \mathrm{~m})$ below TOC \\ Water \\ p. conductance: $910 \mu \mathrm{S} / \mathrm{cm}$}

Waler evacualed from the well prior to sampling: $16 \mathrm{gal}$

ANALYSES

F Analyte

\begin{tabular}{|c|c|c|c|c|c|c|c|c|}
\hline osult & $F \boldsymbol{G}$ & 5 & $E M$ & SOL & $u_{r}$ & & & \\
\hline $\begin{array}{l}28,700 \\
19.1 \\
37.1 \\
4.94 \\
102,000 \\
3.62 \\
3.61 \\
920 \\
6.266-07+2.92 E-5\end{array}$ & $\mathbf{J}$ & K & 1 & $\begin{array}{l}15.0 \\
1.00 \\
25.0 \\
2.00 \\
2,500 \\
0.100 \\
0.100 \\
1.00 \\
3.62 E \cdot 09 \\
4.02 E \cdot 09 \\
4.79 \mathrm{E} \cdot 06\end{array}$ & $\begin{array}{l}\mu g / 2 \\
\mu g / 2 \\
\mu g h \\
\mu g \Omega \\
\mu g \Omega \\
p H \\
p H \\
p H \\
\mu S / c r\end{array}$ & & & $\begin{array}{l}\text { Method } \\
\text { EPA6020 } \\
\text { EPA6020 } \\
\text { EPA6020 } \\
\text { EPA6020 } \\
\text { EPA353.1 } \\
\text { EPA9040B } \\
\text { EPA9040B } \\
\text { EPA9050A } \\
\text { EPA.001 } \\
\text { EPAA-001 }\end{array}$ \\
\hline
\end{tabular}

Aluminum, total recoverable

Iron, lotal recoverabla

Nitrale-nitrite as nitrogen

$\mathrm{pH}$

Specilic conductance

Nonvolatile bela

$3.80 \mathrm{E} \cdot 03 \pm 7.34 \mathrm{E} \cdot 05$

\section{WELL FSB 93C}

MEASUREMENTS CONDUCTED IN THE FIELD

Sample dale: 04/06/99
Depth to water: 67.5 th $(20.57 \mathrm{~m})$ below TOC
Water elevation: $208.7 \mathrm{ht}(63.61 \mathrm{~m}) \mathrm{ms}$ (

pH: 4.4

Sp. conductance: $280 \mu \mathrm{S} / \mathrm{cm}$

Turbidily: ONTU Waler evacualed trom the well prior to sampling: $205 \mathrm{gal}$

ANALYSES

$F$ Analyto

Rosult

1 Aluminum, total recoverable

1 Aluminum, total recoverable

42.7
41.5
$<1.56$
$<1.30$

ESH-EMS-990521
Tima: 11:22

Air lemperature: $18.1^{\circ} \mathrm{C}$

Total alkalinity (as CaCO3): $9 \mathrm{mg} /$

Field Qualifier(s): $V$

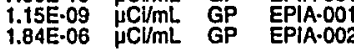

Time: 10:05

Air temperaterature: $20.1^{\circ} \mathrm{C}$

Total alkalinity (as CaCo3): $0 \mathrm{mg} /$

Time: 13:06

Water temperature: $20.4^{\circ} \mathrm{C}$

Tolal alkalinity (as Caco3): $1 \mathrm{mg} /$.

Phenolphthalein alkalinily: $0 \mathrm{mg}$

FG S EMS SOL

Lab Mothod

$\begin{array}{llll}J & 1 & & 15.0 \\ U & & 146 \\ & & 6 & 1.00 \\ & & 4.70\end{array}$

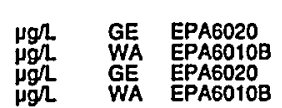

B-109
Filly: $0 \mathrm{mg}$
Well FSB 93 C collected on 04/06/99 (cont.)

\begin{tabular}{|c|c|c|c|c|c|c|c|c|}
\hline Analyte & Result & $F G$ & $s$ & EMS & SQL & Unit & Lab & Mathod \\
\hline 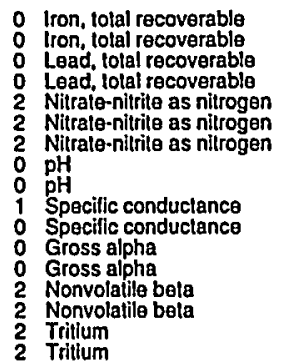 & $\begin{array}{l}40.3 \\
14.0 \\
<1.04 \\
<47.0 \\
31,300 \\
31,800 \\
32.500 \\
5.00 \\
5.04 \\
308 \\
211 \\
4.75 E-09 \pm 1.05 E-09 \\
6.02 E-09 \pm 1.60 E-09 \\
6.34 E-08 \pm 2.22 E-09 \\
7.92 E .09 \pm 3.32 E-09 \\
8.73-04 \pm 1.70 E-05 \\
7.23 E \cdot 04 \pm 6.32 E-06\end{array}$ & U⿺ & : & c & $\begin{array}{l}25.0 \\
74.0 \\
2.00 \\
47.0 \\
1.250 \\
1.250 \\
2.000 \\
0.100 \\
0.100 \\
1.00 \\
8.90 \\
7.29 E-10 \\
1.211 E-09 \\
1.02-09 \\
1.91 E-09 \\
2.02 E-06 \\
6.00 E-07\end{array}$ & 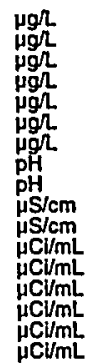 & $\begin{array}{l}G E \\
W A \\
G E \\
W A \\
G E \\
G E \\
G A \\
W A \\
G E \\
W A \\
G E \\
W A \\
G P \\
G M \\
G P \\
G M \\
G P \\
T M\end{array}$ & $\begin{array}{l}\text { EPA6020 } \\
\text { EPA6010B } \\
\text { EPA6020 } \\
\text { EPA6010B } \\
\text { EPA353.1 } \\
\text { EPA353.1 } \\
\text { EPA353.2 } \\
\text { EPA9040B } \\
\text { EPA90408 } \\
\text { EPA9040 } \\
\text { EPA9050A } \\
\text { EPA9050A } \\
\text { EPIA-001 } \\
\text { EPA900.0M } \\
\text { EPIA.001 } \\
\text { EPA900.0M } \\
\text { EPIA.002 } \\
\text { EPA906.0M }\end{array}$ \\
\hline
\end{tabular}

\section{WELL FSB 93C Replicate}

MEASUREMENTS CONDUCTED IN THE FIELLD

Sample date: 04/06/99
Depth to water: $67.5 \mathrm{th}(20.57 \mathrm{~m})$ below TOC
Water elevation: $208.7 \mathrm{~h}(63.61 \mathrm{~m}) \mathrm{ms}$

$\mathrm{pH}: 4.4$

. conductance: $280 \mu \mathrm{S} / \mathrm{cm}$

Water evacuated Irom the well prior to sampling: $205 \mathrm{gal}$ ANALYSES

\begin{tabular}{|c|}
\hline$=$ Analyte \\
\hline 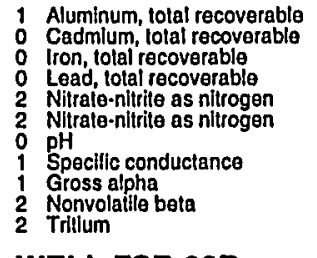 \\
\hline
\end{tabular}

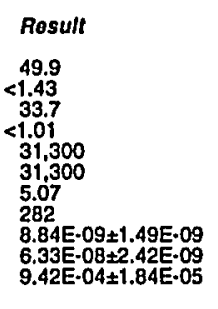

FG

Time: 13:06

Water lemperalure: $20.4^{\circ} \mathrm{C}$

Thenolphinaly (as CaCO3): $1 \mathrm{mg} /$

Field Qualifier(s): $S$

MEASUREMENTS CONDUCTED IN THE FIELD

Sample date: 04/12/99

Depth to water: $65.67 \mathrm{ft}(20.02 \mathrm{~m})$ below TOC

Waler elevalion: $210.43 \mathrm{ft}$ (6

Turbidity: 1 NTU

Waler ovacuated from the well prior to sampling: $1 \mathrm{gal}$

ANALYSES

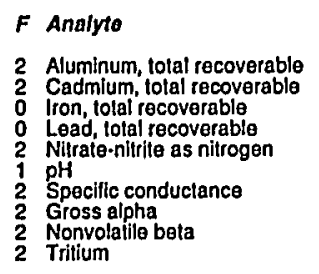

Result

23,800
12.1

12.1
55.7
5.38
71,000

71.000
3.94

$1.60 \mathrm{E}-07+6.56 \mathrm{E}-09$

$1.60 \mathrm{E} \cdot 07+6.56 \mathrm{E} \cdot 09$
$1.49 \mathrm{E} \cdot 06+1.08 \mathrm{E} \cdot .08$
$2.04 \mathrm{E} \cdot 03 \pm 3.97 \mathrm{E} \cdot 05$

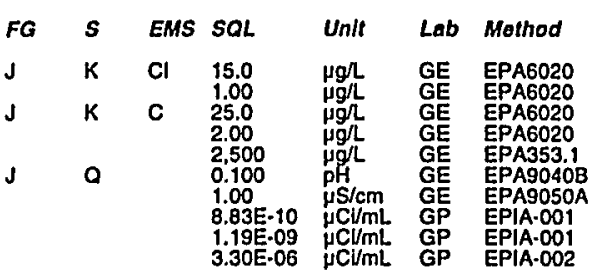

Time: 8:55

Air temperature: $18.8^{\circ} \mathrm{C}$

Total alkalinity (as CaCO3): $0 \mathrm{mg} /$

Phenolphthalern alkalinity: $0 \mathrm{mg} h$
Field Qualifier(s): $V X$

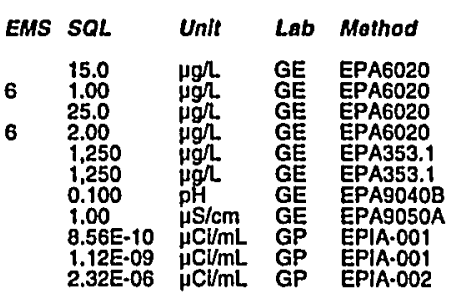


WELL FSB 94C

MEASUREMENTS CONDUCTED IN THE FIELD

Sample date: $04 / 09 / 99$ (t) $22.73 \mathrm{~m})$ below TOC

Water e eleva
gH: 4.1

$\mathrm{ft}(62.95 \mathrm{~m}) \mathrm{msl}$

Pp. conductance: $2,200 \mu \mathrm{S} / \mathrm{cm}$

Waler evacuated from the well prior to sampling: $1 \mathrm{~g}$ The well went ory during purging.

ANALYSES

F Analyto

2 Aluminum, total recoverable

lron, total recoverable

Nitraie-nitrite as nitrogen

Specilic conductance

Nonvolatila be

2 Tillium

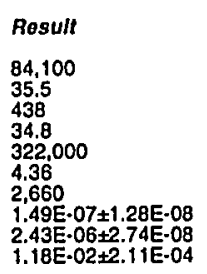

WELL FSB 94DR

MEASUREMENTS CONDUCTED IN THE FIELD

Sample date: $04 / 07 / 99$ ( $21.62 \mathrm{~m})$ below TOC

Waler elevation: $209.58 \mathrm{tt}(63.88 \mathrm{~m}) \mathrm{ms}$

$\mathrm{HH}: 3.4$

p. conductance: $440 \mu \mathrm{S} / \mathrm{cm}$

Water evacuated from the well prior to sampling: $50 \mathrm{gal}$

ANALYSES

$F$ Analyte

Result
13,300
1.82
59.7
$<1.61$
45.000
3.53
585
$5.20 \mathrm{E}-07 \pm 2.33 \mathrm{E}-00$
$5.05 \mathrm{E} .07 \pm 1.42 \mathrm{E}$
$1.92 \mathrm{E} \cdot 03 \pm 3.75 \mathrm{E} \cdot 05$

FG

2 Aluminum, toal recoverablo

Iron, total recoverable

Nitrate-nitrite as nitrogen

$\mathrm{pH}$ pecific conductance

Gross alpha

$5.05 \mathrm{E} \cdot 07+1.42 \mathrm{E} \cdot 08$
$1.92 \mathrm{E} \cdot 03 \pm 3.75 \mathrm{E} \cdot 05$

\section{WELL FSB 95CR}

MEASUREMENTS CONDUCTED IN THE FIELD

Sample date: $04 / 07 / 99$
Depph to waler: $77.65 \mathrm{Ht}(23.67 \mathrm{~m})$ below TOC
Water elevalion: $206.35 \mathrm{H}(62.9 \mathrm{~m}) \mathrm{msl}$
phH: 3.7

p. conductance: $2,000 \mu \mathrm{S} / \mathrm{cm}$

Water evacuated from the well prior to sampling: $100 \mathrm{gal}$

ANALYSES

$F$ Analyte

2 Aluminum, total recoverable

Iron, tolat recoverable

Lead toral recoverable

phecific conductance

Gross alpha

2 Nonvolatile

ESH-EMS-990521
WELL FSB 95DR

MEASUREMENTS CONDUCTED IN THE FIELD

Sample date: 04/07/99 2 (22.68 m) below TOC

Waler

Water temperature: $20.1^{\circ} \mathrm{C}$

Air temperature: $25.8^{\circ} \mathrm{C}$
Total alkalinity (as CaCO3): $0 \mathrm{mg} / \mathrm{l}$

Tolal alkalinity (as CaCO3): $0 \mathrm{mg} /$
Phenolphthalein alkalinily: $0 \mathrm{mg}$.
Field

Sp. conducta

p. conductance: $840 \mu \mathrm{S} / \mathrm{cm}$

Water evacualeo from the well prior to sampling: $42 \mathrm{gal}$

ANALYSES

$F$ Analyto

Cadminum, total recoverable

Iron, total recoverable

Nitrate-nitrite as nitrogen

Specillc conductanco

Nonolatile bel
Tritlum

WELL FSB 96AR

MEASUREMENTS CONDUCTED IN THE FIELD

Sample date: 04/07/99

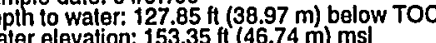

$\mathrm{HH} 6.6$

Time: $12: 30$ Water temperalure: $20.7^{\circ} \mathrm{C}$

Air lemperature: $29.5^{\circ} \mathrm{C}$ ): $0 \mathrm{mg} /$

Waler evacuated from the well prior to sampling: $140 \mathrm{gal}$

ANALYSES

$F$ Analyte

Result

Aluminum, total recoverable

Iron, total 'recoverable

Nitrate-niltrite as nitrogen

$\mathrm{pH}$ specilic conductance

Nonss alpha

\section{WELL FSB 97A}

MEASUREMENTS CONDUCTED IN THE FIELD

Sample date: 04/07/99 $\mathrm{ft}(40.75 \mathrm{~m})$ below TOC

Water

Water temperature: $20.6^{\circ} \mathrm{C}$

Total alkalinity (as CaCO3): $0 \mathrm{mg} /$

Phenolphnarein alkalinity: $0 \mathrm{mg} L$

Sp: conductance: $260 \mu \mathrm{S} / \mathrm{cm}$

Water evacuated from the well prior to sampling: $148 \mathrm{gal}$ ANALYSES

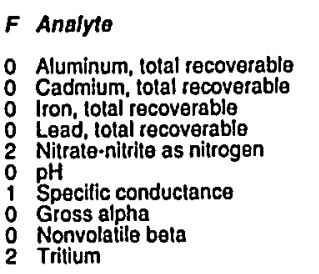

Result

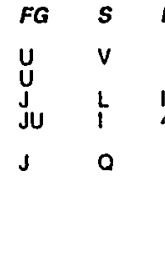

Time: 11:49

Total alkalinity (as CaCO3): $58 \mathrm{mg} /$.

Phenolphthalein alkalinity: $0 \mathrm{mg} /$

EMS SQL Unlt Lab Method

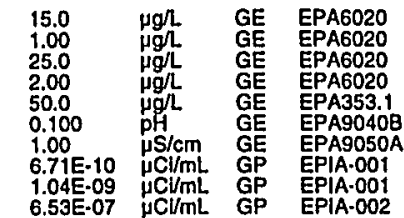

Time: 10:46 4 Tater temperature: $21^{\circ} \mathrm{C}$

Total alkalinity (as CaCO3): $67 \mathrm{mg} /$

Phenoiphthalein alkalinity: $0 \mathrm{mg} / \mathrm{L}$

EMS SQL Unit Lab Method

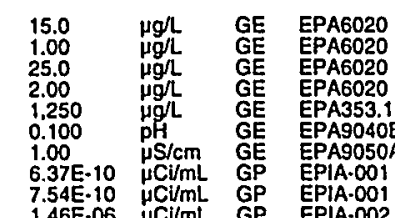

$2.88 \mathrm{E}-09+6.40 \mathrm{E}-10$

$2.74 E-09 \pm 5.01 E-10$
$3.96 E-04 \pm 7.79 E-06$

B-110

Second Quarter 1999 


\section{WELL FSB 97C}

MEASUREMENTS CONDUCTED IN THE FIELD

Sample date: 04/05/99

Depth to wa: 0 r: $77.7 \mathrm{ft}(23.68 \mathrm{~m})$ below TOC
Waler elevation: $208.4 \mathrm{ft}(63.52 \mathrm{~m}) \mathrm{ms}$

Sp: 3.8 conductance: $1,000 \mu \mathrm{S} / \mathrm{cm}$

Waler evacualed from the well prior to sampling: 82 gal

ANALYSES

$F$ Analyto

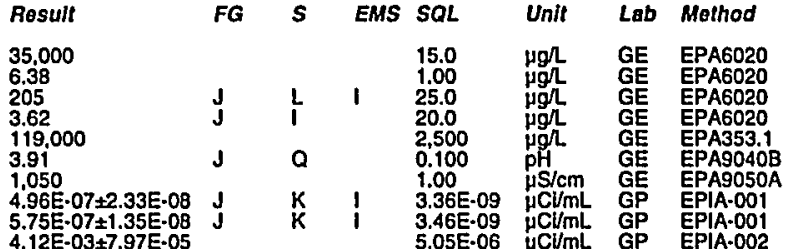

2 Aluminum, total recoverable

Iron, total recoverable

Lead, total recoverable
Nitrale-nitrite as nitrogen

$\mathrm{pH}$ Specillc conductanco

Gross alpha
Nonvolatile beta

\section{WELL FSB 97D}

MEASUREMENTS CONDUCTED IN THE FIELD

Sample date: $04 / 07 / 99$
Depth to water: 75.21 .t $(22.92 \mathrm{~m})$ below TOC
Water elevation: $210.79(\mathrm{tt}(64.25 \mathrm{~m}) \mathrm{msl}$

gH: 3.8
Sp. conductance: $510 \mu \mathrm{S} / \mathrm{cm}$

Water evacualed from the well prior to sampling: 1 gal

The well went dry during purging.

ANALYSES

F Analyto

\begin{tabular}{|c|c|c|c|c|c|c|c|c|}
\hline Analyto & Result & FG & $s$ & EMS & SQL & Unit & Lab & Mathod \\
\hline $\begin{array}{l}\text { Aluminum, lotal recoverable } \\
\text { Cadmlum, otal recoverable } \\
\text { lron, lotal recoverable } \\
\text { Lead, otal recovarbable } \\
\text { Nitrate-nitrite as nitrogen } \\
\text { pH } \\
\text { Specifilc conduclance } \\
\text { Gross alpha } \\
\text { Nonvolatile bela } \\
\text { Tritium }\end{array}$ & $\begin{array}{l}13,400 \\
3.33 \\
538 \\
60.9 \\
64,000 \\
3.99 \\
659 \\
4.84 \mathrm{E} \cdot 07+07.13 \mathrm{E} \cdot 09 \\
4.81 \mathrm{E} \cdot 07+0.47 \mathrm{E} \cdot 09 \\
1.38 \mathrm{E} \cdot 03 \pm 2.71 \mathrm{E} \cdot 05\end{array}$ & $J$ & K & 1 & $\begin{array}{l}15.0 \\
1.00 \\
25.0 \\
2.00 \\
1.250 \\
0.100 \\
1.00 \\
1.08 \mathrm{E} \cdot 09 \\
1.10 \mathrm{E} \cdot 09 \\
3.08 \mathrm{E} \cdot 06\end{array}$ & 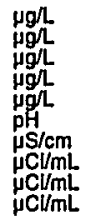 & $\begin{array}{l}\mathrm{GE} \\
\mathrm{GE} \\
\mathrm{GE} \\
\mathrm{GE} \\
\mathrm{GE} \\
\mathrm{GE} \\
\mathrm{GE} \\
\mathrm{GP} \\
\mathrm{GP} \\
\mathrm{GP}\end{array}$ & $\begin{array}{l}\text { EPA6020 } \\
\text { EPA620 } \\
\text { EPA6020 } \\
\text { EPA620 } \\
\text { EPA35.1 } \\
\text { EPA353.1 } \\
\text { EPAO40B } \\
\text { EPA9050A } \\
\text { EPA.001 } \\
\text { EPPA.001 } \\
\text { EPIA.002 }\end{array}$ \\
\hline
\end{tabular}

\section{WELL FSB 98AR}

MEASUREMENTS CONDUCTED IN THE FIELD

Sample date: $04 / 15 / 99$
Depth to water: $132.26 \mathrm{ft}(40.31 \mathrm{~m})$ below TOC
Water elevation: $151.74 \mathrm{ft}(46.25 \mathrm{~m}) \mathrm{msl}$

$\mathrm{pH}: 6.8$

Sp. conductance: $160 \mu \mathrm{S} / \mathrm{cm}$

Waler evacualed Irom the well prior to sampling: 143 gal ANALYSES

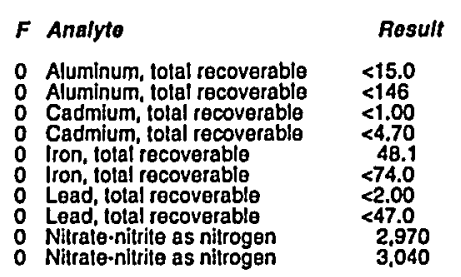

Rosult
$<15.0$
$<146$
$<1.00$
$<4.70$
48.1
$<74.0$
$<2.00$
$<47.0$
2.970
3,040

$\begin{array}{lrl}F G & S & \text { EMS SOL } \\ U & & 15.0 \\ U & 146 \\ U & & 1.00 \\ U & & 4.70 \\ U & & 75.0 \\ U & 2.00 \\ U & & 2.00 \\ & & 47.0 \\ & & 100\end{array}$

Time: 8:43

Water lemperature: $20.5^{\circ} \mathrm{C}$ Total alkalinily (as CaCO3): $61 \mathrm{mg} / \mathrm{L}$ Phenoiphinalein alkalinily: 0 mg $/$ L

ESH-EMS-990521

Well FSB 9BAR collecled on 04/15/99 (cont)

$F$ Analyte

$\therefore \mathrm{pH}$

Specilic conductance

Specilic conductance

Gross alpha

Nonvolatilia be

Nonvolatile bota

\begin{tabular}{ll}
2 & Tritium \\
2 & Tritum \\
2 & Tritium \\
\hline &
\end{tabular}

\section{WELL FSB 98AR Replicate}

MEASUREMENTS CONDUCTED IN THE FIELD

Sample date: 04/15/99

(at

$\mathrm{pH}$. 6.8 conductance: $160 \mu \mathrm{S} / \mathrm{cm}$

Waler evacuated from the well prior to sampling: $143 \mathrm{gal}$

ANALYSES

$F$ Analyto

Result

O Aluminum, lotal recoverable

- Iron, lotal recoverable

Lead, total recoverable

$0 \mathrm{pH}$-nitrite as nilrogen

O Spaciflc conductanco

O Goss alpha

\section{WELL FSB 98C}

MEASUREMENTS CONDUCTED IN THE FIELD

Sample date: 05/12/99

Water to waler: $74.71 \mathrm{ft}(22.77 \mathrm{~m})$ below TOC

$\mathrm{HH}: 3.4$

Sp. conductance: $570 \mu \mathrm{S} / \mathrm{cm}$

Waler evacuated from the well prior to sampling: 107 gal ANALYSES

\begin{tabular}{|c|c|c|c|c|c|c|c|c|}
\hline$F$ Analyte & Result & FG & s & EMS & $S Q L$ & Untt & Lab & Mothod \\
\hline $\begin{array}{ll}2 & \text { Aluminum, total recoverable } \\
2 & \text { Cadmium, tolal recoverable } \\
0 & \text { Iron, lotal recoverablo } \\
0 & \text { Lead, tolal rocoverable } \\
2 & \text { Nitrate-nitrite as nitrogen } \\
1 & \text { pH } \\
1 & \text { pH } \\
2 & \text { Specillc conduclance } \\
2 & \text { Gross alpha } \\
2 & \text { Nonvolatile beta } \\
2 & \text { Trifium }\end{array}$ & $\begin{array}{l}16.400 \\
6.23 \\
29.4 \\
<2.00 \\
58.800 \\
3.55 \\
3.56 \\
617 \\
3.81 \mathrm{E} \cdot 07 \pm 1.18 \mathrm{E}-08 \\
4.31 \mathrm{E}-07 \pm 6.75 \mathrm{E}-09 \\
2.55 \mathrm{E}-03 \pm 4.93 \mathrm{E}-05\end{array}$ & $\begin{array}{l}\mathbf{U} \\
\mathbf{J}\end{array}$ & : & & $\begin{array}{l}15.0 \\
1.00 \\
25.0 \\
2.00 \\
1.250 \\
0.100 \\
0.100 \\
1.00 \\
1.07 E \cdot 09 \\
1.35 E .09 \\
3.93 E .06\end{array}$ & 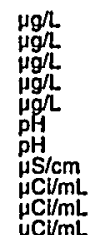 & $\begin{array}{l}\mathrm{GE} \\
\mathrm{GE} \\
\mathrm{GE} \\
\mathrm{GE} \\
\mathrm{GE} \\
\mathrm{GE} \\
\mathrm{GE} \\
\mathrm{GE} \\
\mathrm{GP} \\
\mathrm{GP} \\
\mathrm{GP}\end{array}$ & $\begin{array}{l}\text { EPA6020 } \\
\text { EPA6020 } \\
\text { EPA6020 } \\
\text { EPA6020 } \\
\text { EPA353.1 } \\
\text { EPA9040B } \\
\text { EPA9040B } \\
\text { EPA9050A } \\
\text { EPIA.001 } \\
\text { EPIA.001 }\end{array}$ \\
\hline
\end{tabular}

Time: 9:00

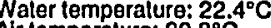

Total alkalinity (as Caco3): $0 \mathrm{mg} / \mathrm{L}$

henolphthalein alkalinity: $0 \mathrm{mg} /$

ater temperature: $20.5^{\circ} \mathrm{C}$

列
Tolal alkalinity (as CaCO3): $61 \mathrm{mg} /$ 
WELL FSB 98D

MEASUREMENTS CONDUCTED IN THE FIELD

Sample date: 05/04/99

Depth to waler: $71.85 \mathrm{ft}(21.9 \mathrm{~m})$ below TOC

Water elevation: $212.65 \mathrm{ft}(64.82 \mathrm{~m}) \mathrm{ms}$

Sp. conductance: $460 \mu \mathrm{S} / \mathrm{cm}$

Water evacuated from the well prior to sampling: 1 gal ANALYSES

$F$ Anaiyte

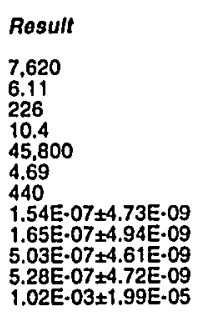

2 Aluminum, total recovarable

Cadmium, tolal recovera

Lead, total recoverabi

pH

Specilic conduclance

Gross alpha

Nonvolatile beta

\section{WELL FSB 99A}

MEASUREMENTS CONDUCTED IN THE FIELD

Sample date: $04 / 07 / 99$ ft $(41.71 \mathrm{~m})$ below TOC

Waler elevation: $150.76 \mathrm{ft}(45.95 \mathrm{~m}) \mathrm{msl}$

$\mathrm{pH}: 6.6$

Sp. conductance: $150 \mu \mathrm{S} / \mathrm{cm}$

Waler evacualed from the well prior to sampling: $151 \mathrm{gal}$

ANALYSES

\section{F Analyto}

Aluminum, total recoverable

Cadmilum, total recovere

Lead, tolal recoverable
Nitrate-nitrile as nilrogen

pH

Gross alpha

\section{WELL FSB 99C}

MEASUREMENTS CONDUCTED IN THE FIELD

Sample date: 04/06/99

Depth to water: $77.56 \mathrm{ft}(23.64 \mathrm{~m})$ below TOC

WH: 5.4
$\mathrm{Sp}$ conductance: $250 \mu \mathrm{S} / \mathrm{cm}$

Turbidity: O NTU
Water evacuated from the well prior to sampling: $91 \mathrm{gal}$

ANALYSES

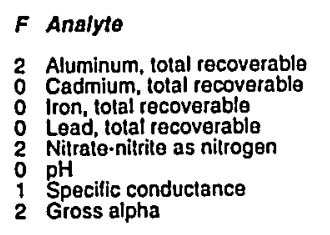

$\begin{array}{lll}\text { Result } & \text { FG } & \text { S } \\ 76.9 & & \\ 1.21 & & \\ 46.1 & & \\ 1.85 & \mathrm{~J} & \mathrm{I} \\ 39.000 & \mathrm{~J} & \mathrm{O} \\ 5.49 & \mathrm{~J} & \mathrm{O} \\ 279 & \\ 2.48 \mathrm{E}-08 \pm 2.38 \mathrm{E}-09 & & \end{array}$

ESH-EMS-990521

Well FSB 99C collected on 04/06/99 (cont.)

\begin{tabular}{|c|c|c|c|c|c|c|c|c|}
\hline $\begin{array}{l}\text { F Analyto } \\
2 \text { Nonvolatle bete } \\
2 \text { Tritfum } \\
\text { WELL FSB 99D }\end{array}$ & $\begin{array}{l}\text { Rosult } \\
6.84 \mathrm{E} \times 2.08 \pm 2.31 \mathrm{E} \cdot 09 \\
7.89 \mathrm{E} \cdot 04 \pm 1.55 \mathrm{E}-05\end{array}$ & $\boldsymbol{F G}$ & $s$ & $E M$ & IS $\begin{array}{l}\text { SQL } \\
1.13 \mathrm{E} \cdot 09 \\
1.94 \mathrm{E} \cdot 06\end{array}$ & $\begin{array}{l}\text { Unif } \\
\mu \mathrm{C} / \mathrm{mL} \\
\mu \mathrm{C} / \mathrm{mL}\end{array}$ & $\begin{array}{l}\text { Lat } \\
G P \\
G P\end{array}$ & $\begin{array}{ll}\text { Mb Mathod } \\
P \\
P \\
P \text { EPIA.001 }\end{array}$ \\
\hline
\end{tabular}

Time: 9:05

Waler temperature: $20^{\circ} \mathrm{C}$ Air temperature: $19^{\circ} \mathrm{C}$
Total alkalinity (as Caco3): $46 \mathrm{mg} /$ Phenolphthalein alkalinity): $0 \mathrm{mg} / \mathrm{L}$
Field Qualifier(s): $V X$

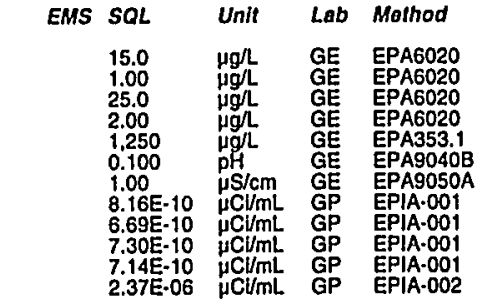

Time: 13:24 Atal alkalinity (as CaCo3): $40 \mathrm{mg} / \mathrm{L}$ Phenolphthalein alkalinity: $0 \mathrm{mg} / \mathrm{L}$

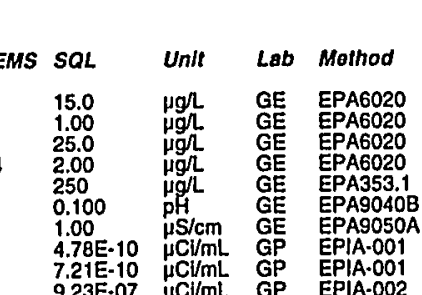

Time: 14:24

Water temperature: $19.8^{\circ} \mathrm{C}$

"Total alkalinity (as Caco3): $6 \mathrm{mg}$

Phenolphthalein alkalinity: 0 mg
Field Qualifier(s): $S$

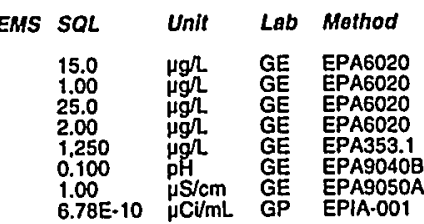

Time: 13:17 Air temperature: $29^{\circ} \mathrm{C} C 03$ ): $0 \mathrm{mor}$

Sample date: 04/07/99 Water elevation: 213.8 if $(65.17 \mathrm{~m}) \mathrm{ms}$ |

oH: 4.7

Sp. conductance: $34 \mu \mathrm{S} / \mathrm{cm}$

Waler evacuated from the well prior to sampling: $54 \mathrm{ga}$ ANALYSES

$F$ Analyto

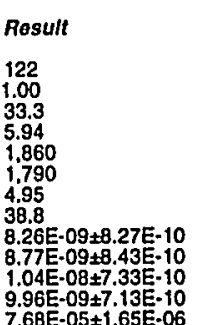

$F G$ Phenolphthalein alkalinity: $0 \mathrm{mg}$

2. Aluminum, total recoverable

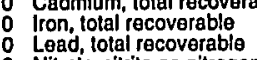

Nifrale-nilritita as nitrogen

$\mathrm{Sp} \mathrm{H}$ ecilic conductance

Gross alpha

Nonvolatilile bela

WELL FSB100A

MEASUREMENTS CONDUCTED IN THE FIELD

Sample date: 04/07/99

Depth to water: $134.2 \mathrm{~h}(40.9 \mathrm{~m})$ below TOC

Dater eve

p. conductance: $140 \mu \mathrm{S} / \mathrm{cm}$

Turbidity: $1 \mathrm{NTU}$
Water evacuated from the well prior to sampling: $185 \mathrm{gal}$ ANALYSES

$F$ Analyto

Rosult

Cadmium, total recoverable

Iron, total recoverable

Nitrale-nitrite as nitrogen

Specilic conductance

Nonvolatile beta

Tritium

$<12.6$
$<1.00$
101
$<2.00$
3,800
7.13

u

WELL FSB101A

MEASUREMENTS CONDUCTED IN THE FIELD

Sample date: 04/12/9

epth to waler: $133.2 \mathrm{ft}(40.6 \mathrm{~m})$ below TOC

Waler elevation: $152 \mathrm{Ht}(46.33 \mathrm{~m})$
$\mathrm{pH} 6.8$
Sp. conductance: $150 \mu \mathrm{S} / \mathrm{cm}$

Water evacualed from the well prior to sampling: $107 \mathrm{gal}$

ANALYSES

$F$ Analyto

Result

Aluminum, tolal recoverable

$<15.0$

tron, total recoverable

45.9

u

\section{Waler temperature: $22.1^{\circ} \mathrm{C}$ Total alkalinity (as CaCO3): $44 \mathrm{mg} /$ Phenolphthalein alkalinily: $0 \mathrm{mg} / \mathrm{L}$.}

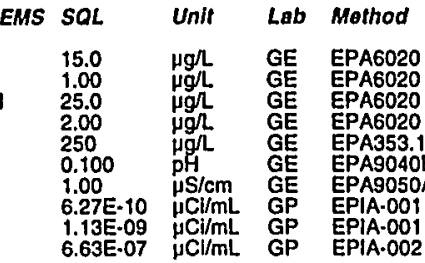

Time: 8:38

mperature: $20.9^{\circ} \mathrm{C}$

Total alkalinity (as CaCO3): $55 \mathrm{mg} /$

Phenolphthalein alkalinity: $0 \mathrm{mg} /$

$\begin{array}{llll}\text { SQL } & \text { Unil } & \text { Lab } & \text { Mathod } \\ 15.0 & \mu g / L & \text { GE } & \text { EPAG020 } \\ 1.00 & \mu g h \text { G } & \text { GE } & \text { EPA6020 } \\ 25.0 & \mu g \Omega & \text { GE } & \text { EPA6020 }\end{array}$

Second Quarter 1999 
Well FSB101A collected on 04/12/99 (cont.)

Nonvolatila beta

$5.04 \mathrm{E}-10 \pm 4.74 \mathrm{E}-10$
$F$ Analyte Result

- Lead, tolal recoverable Nitrate-nitrite as nitrogen

pH

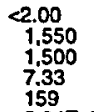
$0.046-10 \pm 4.74 E-10$
$1.96-09+6.75 E-10$
$-1.49 E-07+3.397 E-07$

FG

0

WELL FSB102C

MEASUREMENTS CONDUCTED IN THE FIELD

Sample date: 04/06/99

Depth lo water: $5.9 \mathrm{tg}(1.8 \mathrm{~m})$ below TOC
Water elevation: $195.2 \mathrm{ft}(59.5 \mathrm{~m}) \mathrm{msl}$

pH: 4.8

Wurbidily: O NTU evacuated from the well prior to sampling: 72 gal ANALYSES

\begin{tabular}{|c|c|}
\hline Analyto & Rosult \\
\hline 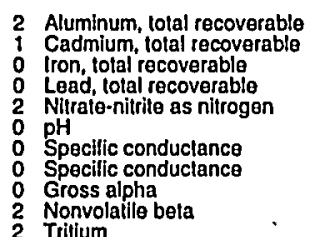 & $\begin{array}{l}336 \\
3.21 \\
20.1 \\
<2.00 \\
21.000 \\
4.72 \\
219 \\
219 \\
4.46 E-09 \pm 9.76 E-10 \\
2.18 E-07 \pm 4.04 E-09 \\
4.29 E-04 \pm 8.44 E-06\end{array}$ \\
\hline
\end{tabular}

\section{WELL FSB103C}

MEASUREMENTS CONDUCTED IN THE FIELD

Sample date: 04/12/99

Depth to water: $40.45 \mathrm{H}(12.33 \mathrm{~m})$ bolow TOC

Waler el

Water evacuated from the well prior to sampling: 96 gal ANALYSES

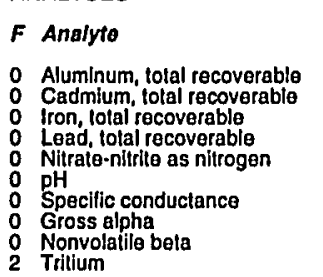

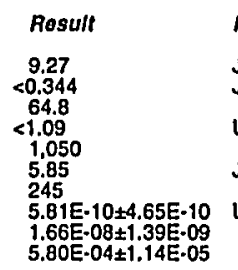

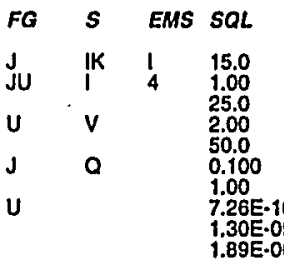

Time: 11:46
Sp. conductance: $200 \mu \mathrm{S} / \mathrm{cm}$

H: 5.6 .

WELL FSB104C

MEASUREMENTS CONDUCTED IN THE FIELD

Sample date: 04107199

Depth to water: $18.65 \mathrm{ft}(5.68 \mathrm{~m})$ below TOC

Waler

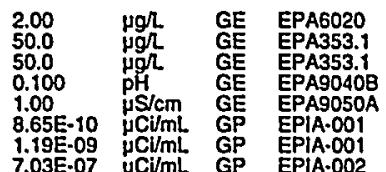

Sp. conductance: $440 \mu \mathrm{S} / \mathrm{cm}$

Water evacuated from the well prior to sampling: $117 \mathrm{gal}$

ANALYSES

$F$ Analyto

Result
$<53.1$
$<0.727$
116
0.611
49.800
5.17
462
$1.70 E-09 \pm 7.22 E-10$
$3.00 E-00 \pm 1.57 E-09$
$1.03 E-03 \pm 2.01 E-05$

J J
Ju
Ju
J

Air temperature: $19.9^{\circ} \mathrm{C}$ C

Total alkalinily (as CaCO3): $0 \mathrm{mg} / \mathrm{L}$

Field Qualifier(s): $V$

0 Aluminum, lotal recoverable

Iron, lotal recoverable

Nitrate-nitrite as nilrogon

Specific conductance

Gross alpha

\section{WELL FSB104D}

MEASUREMENTS CONDUCTED IN THE FIELD

Sample date: 05/04/99

Deplar to water: $16.98 \mathrm{ft}(5.18 \mathrm{~m})$ below TOC

$\mathrm{pH}: 3.8$ . conductance: $230 \mu \mathrm{S} / \mathrm{cm}$

Water evacuated from the well prior to sampling: 22 gal ANALYSES

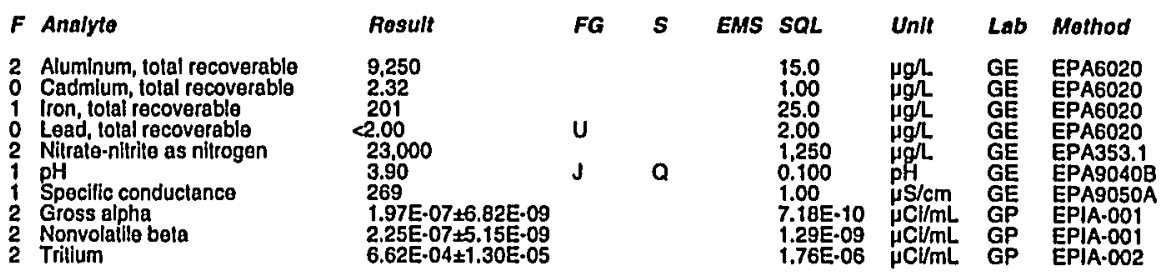

Water 10:35

Total alkalinily (as Caco3): $0 \mathrm{mg}$ Phenolphithalein alkalinity: $0 \mathrm{mg} /$
Field Qualifier(s): $V$

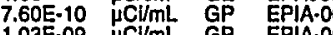

$1.03 E .09 \mu \mathrm{C} / \mathrm{mL}$ GP EPIA.00

Air temperature: $25,20.6^{\circ} \mathrm{C}$ Total alkalinity, (as Caco3): $8 \mathrm{mg} / \mathrm{L}$

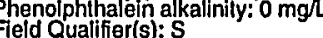

Trillum

\section{WELL FSB105C}

MEASUAEMENTS CONDUCTED IN THE FIELD

Sample date: 04/05/99
Depth to water: $77.62 \mathrm{ft}(23.72 \mathrm{~m})$ below TOC
Water elevation: $207.98 \mathrm{t}(63.39 \mathrm{~m}) \mathrm{ms}$

Sp. conductance: $1,100 \mu \mathrm{S} / \mathrm{cm}$

Walter evacuated from the well prior to sampling: 94 gal ANALYSES

$$
\begin{aligned}
& \text { ANALYSES } \\
& \begin{array}{ll}
2 & \text { Aluminum, lotal recoverable } \\
2 & \text { Cadmium, lotal recoverable } \\
0 & \text { Iron, lotal recoverable } \\
0 & \text { Lead, Lolal recoverable } \\
2 & \text { Nitrate-nitrite as nitrogen } \\
1 & \text { pH } \\
2 & \text { Specifle conductance } \\
2 & \text { Gross alpha } \\
2 & \text { Nonvolatilie beta } \\
2 & \text { Tritium }
\end{array}
\end{aligned}
$$

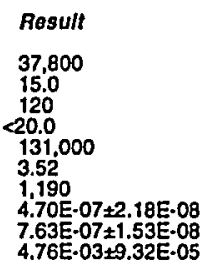

$\begin{array}{ll}\text { FG } & S \\ J & L \\ J & 0 \\ J & K \\ J & K\end{array}$

Time: 10:48

Air temperature: $25.5^{\circ} \mathrm{C} \mathrm{C}$ Tolal a Field Qualifier(s): $V$ 


\section{WELL FSB105DR}

MEASUREMENTS CONDUCTED IN THE FIELD

Sample date: $04 / 06 / 99$
Depth to water: $74.91 \mathrm{ft}(22.83 \mathrm{~m})$ below TOC
Water elevation: $210.69 \mathrm{Ht}(64.22 \mathrm{~m}) \mathrm{ms}$

Water

Tp. conductance: $68 \mu \mathrm{S} / \mathrm{cm}$

Turbidity: 1 NTU ANALYSES

\begin{tabular}{|c|c|c|c|c|c|c|c|c|}
\hline Analyte & Result & $F G$ & $s$ & EMS & $S O L$ & Unit & Lab & Mothod \\
\hline 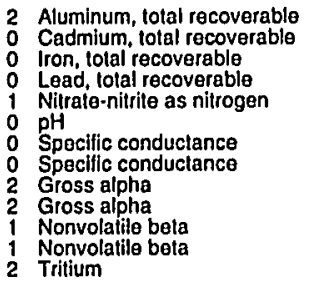 & 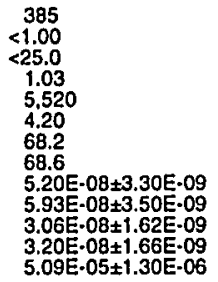 & $\begin{array}{l}\mathbf{U} \\
\mathbf{J} \\
\mathbf{J}\end{array}$ & $\begin{array}{l}1 \\
0\end{array}$ & & $\begin{array}{l}15.0 \\
1.00 \\
25.0 \\
2.00 \\
100 \\
0.100 \\
1.00 \\
1.00 \\
8.00 E-10 \\
6.777 \cdot 10 \\
1.13 E \cdot 09 \\
1.211 .09 \\
5.70 E \cdot 07\end{array}$ & 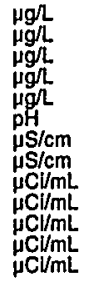 & $\begin{array}{l}G E \\
G E \\
G E \\
G E \\
G E \\
G E \\
G E \\
G E \\
G F \\
G P \\
G P \\
G P \\
G P\end{array}$ & 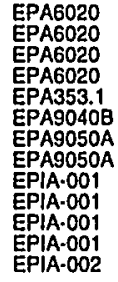 \\
\hline
\end{tabular}

\section{WELL FSB106C}

MEASUREMENTS CONDUCTED IN THE FIELD

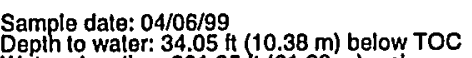

Water e

p. conductance: $470 \mu \mathrm{S} / \mathrm{cm}$

Water evacuated from the well prior to sampling: $73 \mathrm{ga}$

ANALYSES

F Analyte

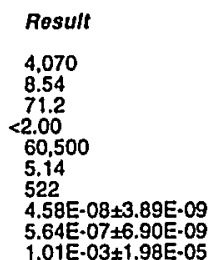

Aluminum, total recoverable

Iron, total recoverabla

Nitrate-nitrite as nitrogen

Specific conductance

Gross alpha

\section{WELL. FSB106D}

MEASUREMENTS CONDUCTED IN THE FIELD

Sample date: 04/26/99

Wepth to water: Not available

H: 6.2
$\mathrm{Sp}$. conductance: $80 \mu \mathrm{S} / \mathrm{cm}$

Turbidity: 4 NTU from the well prior to sampling: $1 \mathrm{gal}$
The ell evacuated from
the well dry during purging.

ANALYSES

$F$ Analyte

Result
206
$<0.426$
280
18.6
940
960
6.59

Iron, totat recoverable

Nitrate-nitrite as nitrog

Nitrate-nitrite as nitrogen

ESH-EMS-990521

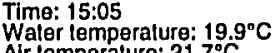

Total alkalinity (as CaCo3): 0 mg/l

Time: 12:21 Air temperature: $19.1^{\circ} \mathrm{C}$ C

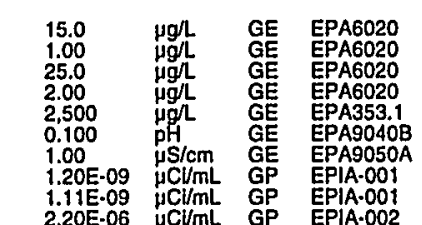

Total alkalinity (as CaCo3): $33 \mathrm{mg} / \mathrm{L}$ Phenolphithaein alkalinity: $0 \mathrm{mg} / \mathrm{L}$.

$\begin{array}{ll}\text { GE } & E P A 6020 \\ \text { GE } & \text { EPA6020 } \\ \text { GE } & \text { EPA6020 } \\ \text { GE } & \text { EPA6020 } \\ \text { GE } & \text { EPA35.1 } \\ \text { GE } & \text { EPA355.1 } \\ \text { GE } & \text { EPA9040 }\end{array}$
Well FSB 106 D collected on 04/26/99 (conl.)

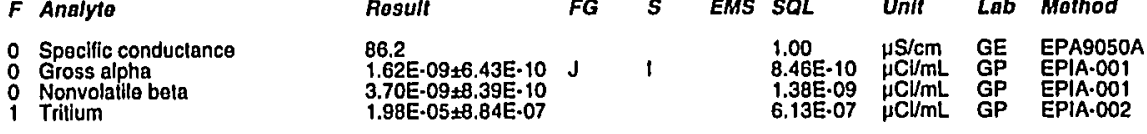

1 Tritium

WELLL FSB107C

MEASUREMENTS CONDUCTED IN THE FIELD

Sample date: 04/07/9

(1) $60 \mathrm{ft}(18.29 \mathrm{~m})$ below TOC

$\mathrm{OH}: 5.8$

Sp. conductance: $140 \mu \mathrm{S} / \mathrm{cm}$

Water evacuated from the well prior to sampling: $102 \mathrm{gal}$

ANALYSES

\section{$F$ Analyto}

Resutt
$<56.4$
$<0.286$
164
$<2.00$
7.500
6.43
163
$1.61 E-09 \pm 5.81 E-10$
$3.08-08+58 E-09$
$1.04 E-04 \pm 2.10 E .06$

FG S EMS Sa

Time: $15: 41$ Water temperature: $20.7^{\circ} \mathrm{C}$ Air temperature: $31.4^{\circ} \mathrm{C}$
Total alkalinity (as CaCo3): $31 \mathrm{mg} / \mathrm{L}$ Field Qualifier(s): $s$

- Aluminum, total recovorable Cadmitum, total rocovorab Lead, tolal recoverabio pirrate-nitrite as nitrog Gpecilic conduclan
Gross alpha Phenolphthalein alkalinity: $0 \mathrm{mg}$ m

\section{WELL FSB1070}

MEASUREMENTS CONDUCTED IN THE FIELD

Sample date: 05/04/99

Water elevation: $214.62 \mathrm{ft}(65.42 \mathrm{~m}) \mathrm{ms}$

$\mathrm{pH}: 3.7$ . conductance: $270 \mu \mathrm{S} / \mathrm{cm}$

Water evacuated from the well prior to sampling: 22 gal ANALYSES

\begin{tabular}{|c|c|}
\hline Analyte & Rosult \\
\hline 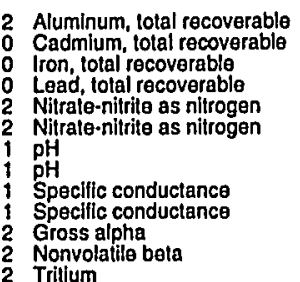 & $\begin{array}{l}6,050 \\
1.35 \\
26.0 \\
1.02 \\
24,300 \\
25,000 \\
3.86 \\
3.86 \\
282 \\
233 \\
3.12 \mathrm{E}-07 \pm 8.97 \mathrm{E} \cdot 09 \\
4.31 \mathrm{E}-07+0.97 \mathrm{E}-09 \\
7.66 \mathrm{E} \cdot 04 \pm 1.50 \mathrm{E} \cdot 05\end{array}$ \\
\hline
\end{tabular}

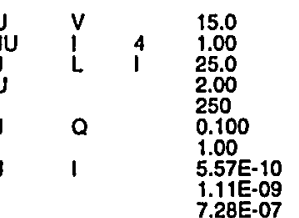

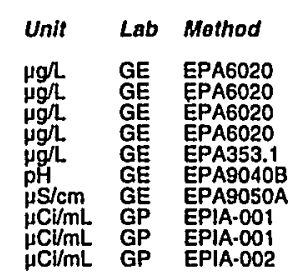

\section{WELL FSB108D}

MEASUREMENTS CONDUCTED IN THE FIELD

Sample date: $04 / 12 / 99$

Waler elevation: $218.47 \mathrm{Ht}(66.59 \mathrm{~m}) \mathrm{ms}$

PH: 5

. conductance: $31 \mu \mathrm{S} / \mathrm{cm}$

Waler evacualed from the well prior to sampling: $1 \mathrm{gal}$
Time: 9:53

Air

Total akralinity: (as CaCO3): $0 \mathrm{mg} / \mathrm{h}$ Phenolphthalein alkalinity: $0 \mathrm{mg}$ L

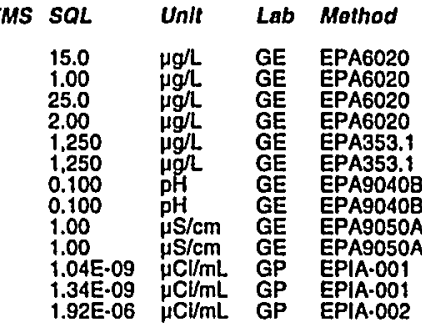

Time: 13:50

Water temperature: $20.8^{\circ} \mathrm{O}$

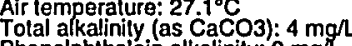
Phenolphthalein alkalinity: $0 \mathrm{mg} L$ 
Well FSB108D collected on 04/12/99 (cont.)

ANALYSES

\begin{tabular}{|c|}
\hline F Analyte \\
\hline 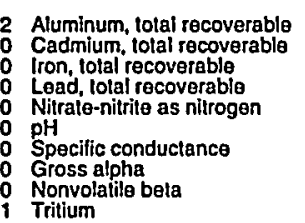 \\
\hline
\end{tabular}

\begin{tabular}{|c|c|c|c|c|c|c|c|}
\hline Result & $F G$ & $s$ & EMS & SQL & Unit & Lab & Method \\
\hline $\begin{array}{l}68.5 \\
<1.00 \\
63.2 \\
8.90 \\
1.00 \\
5.66 \\
33.0 \\
1.19 \mathrm{E}-09 \pm 5.54 \mathrm{E}-10 \\
1.15 \mathrm{E}-09+6.00 \mathrm{E} \\
1.10 \mathrm{E}-05+34-07\end{array}$ & $\vec{u}$ & $\begin{array}{l}0 \\
1\end{array}$ & 1 & $\begin{array}{l}15.0 \\
1.00 \\
25.0 \\
2.00 \\
50.0 \\
0.100 \\
1.00 \\
6.45 E-10 \\
1.16 E-09\end{array}$ & 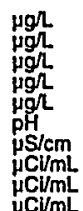 & $\begin{array}{l}\mathrm{GE} \\
\mathrm{GE} \\
\mathrm{GE} \\
\mathrm{GE} \\
\mathrm{GE} \\
\mathrm{GE} \\
\mathrm{GE} \\
\mathrm{GP} \\
\mathrm{GP} \\
\mathrm{GP}\end{array}$ & 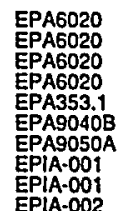 \\
\hline
\end{tabular}

\section{WELL FSB109D}

MEASUREMENTS CONDUCTED IN THE FIELD

Sample date: 04/07/99

Water elevation: $214.63 \mathrm{~h}(65.42 \mathrm{~m}) \mathrm{ms}$ !

\section{$\mathrm{pH}: 5.4$}

. conductance: $32 \mu \mathrm{S} / \mathrm{cm}$

Water evacuated from the well prior to sampling: $24 \mathrm{gal}$ ANALYSES

F Analyto

A Aluminum, tolal recoverable

0
0
0 ron. lotal recoverable

N Litrate-nitrite as nitrogen

Specllic conductance

o Grosss alpha

Nonvolatile beta
0 Trittum

\section{WELL FSB110C}

MEASUREMENTS CONDUCTED IN THE FIELD

Sample dale: 04/12/99

Water elevation: $200.61 \mathrm{ft}(61.15 \mathrm{~m}) \mathrm{ms}$

W:: 5.5

p. conductance: $730 \mu \mathrm{S} / \mathrm{cm}$

Waler evacualed from the well prior to sampling: $125 \mathrm{gal}$ ANALYSES

$F$ Analyto

2 Aluminum, total recoverable

Iron, total recoverable

Lead, lotal recoverable

Nitrate-nitrite as nilrog

Grocific conductan

2
2
2

$<34.1$

100
3.95
1.470
5.72
35.3

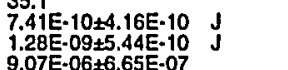

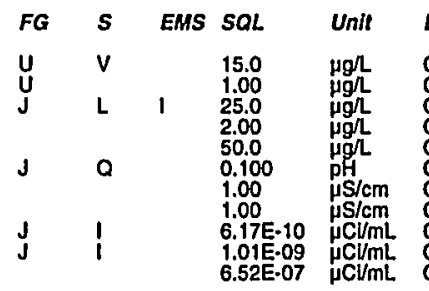

Time: $14: 16$

mperature: $22.6^{\circ} \mathrm{C}$

Tolal alkalinity (as CaCO3): $3 \mathrm{mg}$

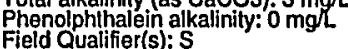

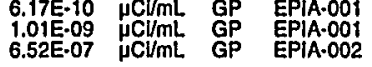

Time: 9:55

mperature: $21^{\circ} \mathrm{C}$

Total alkalinity (as Caco3): $6 \mathrm{mg} /$

Phenolphthalein alkalinity: $0 \mathrm{mg} /$
Field Qualifier(s): $\mathrm{s}$

Thun

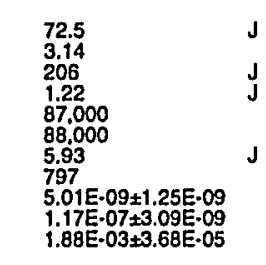

\section{WELL FSB110D}

MEASUREMENTS CONDUCTED IN THE FIELD

Sample date: 04/05/99

Water elevation $20455.01 \mathrm{~m})$ below TOC

$\mathrm{HH}: 3.6$

Sp. conductance: $390 \mu \mathrm{S} / \mathrm{cm}$

Water evacuated from the well prior to sampling: 21 gal ANALYSES

\begin{tabular}{|c|c|c|c|c|c|c|c|c|}
\hline Analyto & Result & $F G$ & $s$ & EMS & SQL & Unit & Lab & Mothod \\
\hline $\begin{array}{ll}2 & \text { Aluminum, lotal recoverable } \\
0 & \text { Cadmium, lotal recoverable } \\
0 & \text { Iron, lotal recoverable } \\
0 & \text { Lead total recoverable } \\
2 & \text { Nitraie-niltite as nitrogen } \\
1 & \text { pH } \\
2 & \text { Specific conductance } \\
2 & \text { Gross alpha } \\
2 & \text { Gross alpha } \\
2 & \text { Nonvolatile beta } \\
2 & \text { Nonvolatile beta } \\
2 & \text { Trittum }\end{array}$ & $\begin{array}{l}9.530 \\
1.70 \\
59.1 \\
00.546 \\
59.500 \\
3.48 \\
630 \\
2.70 E-07 \pm 1.57 E-08 \\
3.11 \mathrm{E}-07 \pm 1.75 \mathrm{E}-08 \\
3.00 \mathrm{E}-07 \pm 9.55 \mathrm{E}-09 \\
3.11 \mathrm{E}-07 \pm 9.98 \mathrm{E}-09 \\
2.45 \mathrm{E}-03 \pm 4.75 \mathrm{E}-05\end{array}$ & $\begin{array}{l}J \\
J\end{array}$ & $\begin{array}{l}k \\
\mathbf{k} \\
\mathbf{Q} \\
\mathbf{k} \\
\mathbf{k} \\
\mathbf{k} \\
\mathbf{k}\end{array}$ & C & $\begin{array}{l}15.0 \\
1.00 \\
25.0 \\
2.00 \\
1.250 \\
0.100 \\
1.00 \\
2.62 E-09 \\
1.85 E \cdot 09 \\
2.87 E .09 \\
3.11 E .09 \\
3.70 E .06\end{array}$ & 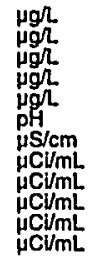 & $\begin{array}{l}\mathrm{GE} \\
\mathrm{GE} \\
\mathrm{GE} \\
\mathrm{GE} \\
\mathrm{GE} \\
\mathrm{GE} \\
\mathrm{GE} \\
\mathrm{GP} \\
\mathrm{GP} \\
\mathrm{GP} \\
\mathrm{GP} \\
\mathrm{GP}\end{array}$ & $\begin{array}{l}\text { EPA6020 } \\
\text { EPAG020 } \\
\text { EPA6020 } \\
\text { EPA6020 } \\
\text { EPA353.1 } \\
\text { EPA9040 } \\
\text { EPA9050A } \\
\text { EPAA.001 } \\
\text { EPIA.001 } \\
\text { EPA.001 } \\
\text { EPIA.001 } \\
\text { EPIA.002 }\end{array}$ \\
\hline
\end{tabular}

\section{WELL FSB111C}

MEASUREMENTS CONDUCTED IN THE FIELD

Sample date: 04/05/9

(1) 63.9 ft $(19.48 \mathrm{~m})$ below TOC

H: 5 .

conductance: $58 \mu \mathrm{S} / \mathrm{cm}$

Water evacuated from the well prior to sampling: $97 \mathrm{gal}$

ANALYSES

$F$ Analyte

Result

FG

- Aluminum, total recoverable

Iron, tolal recoverable

Lead, total recoverable

$\mathrm{Sp}$ pecifle conduclance

: Gonvolatila beta

O Nrifium

$<15.0 \quad U$

64.5
$<0.373$
1.910
5.81
59.0

$\mathrm{J} \quad \mathrm{a}$

\section{WELL FSB111D}

MEASUREMENTS CONDUCTED IN THE FIELD

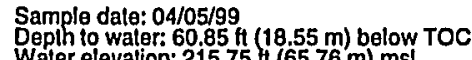

Water elevation: $215.75 \mathrm{Ht}$

urbidity: 0 NTU: $44 \mu \mathrm{S} / \mathrm{cm}$

Whe well prior to sampling: $24 \mathrm{gal}$

ANALYSES

F Analyte
0 Aluminum, total recoverable
0 Cadmium, total recoverable
0 tron, total recoverable
0 Lead total recoverable
0 Nitrate-nitrite as nitrogen
0 pH
0 Specific conductance
0 Gross alpha
0 Gross alpha

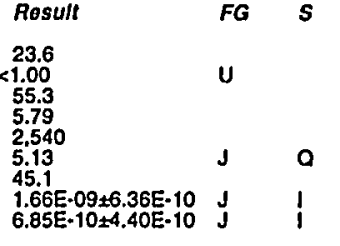

Time: 14:00

Witer temperature: $20.3^{\circ} \mathrm{C}$

Total alkalinity (as CaCO3): $0 \mathrm{mg} /$

Phenolphthalein alkalinity: $0 \mathrm{mgh}$
Field Qualifier(s): $v$

Water temperature: $20.5^{\circ} \mathrm{C}$

Total alkalinity (as CaCO3): $8 \mathrm{mg}$

Fhenolphinalein alkalinity: $0 \mathrm{mgh}$

EMS SQL Unit Lab Mathod

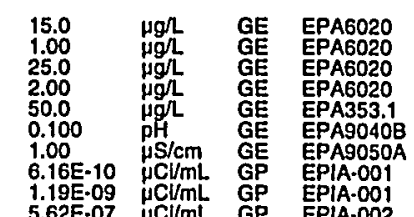

Time: 9:10

Air temperature: $20,4^{\circ} \mathrm{C}$

Tolal alkalinity (as CaCO3): $0 \mathrm{mg} /$

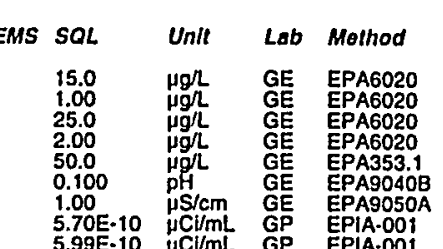

Second Quartor 1999
Phenolphthatein alkalinily: $0 \mathrm{mg}$ 
Well FSB1110 collected on 04/05/99 (cont.)

\begin{tabular}{|c|c|c|c|c|c|c|c|c|}
\hline Analyte & Rosult & $F G$ & $s$ & EMS & SQL & Unit & Lab & Method \\
\hline $\begin{array}{ll}0 & \text { Nonvolatille bola } \\
0 & \text { Nonvolatile beta } \\
2 & \text { Trifiumm }\end{array}$ & $\begin{array}{l}2.19 \mathrm{E}-09 \pm 7.19 \mathrm{E}-10 \\
1.48 \mathrm{E}-0977.04 \mathrm{E}-10 \\
2.37 \mathrm{E}-04 \pm 4.68 \mathrm{E}-06\end{array}$ & J & i & & $\begin{array}{l}1.26 \mathrm{E} .09 \\
1.33 \mathrm{E} .09 \\
9.92 \mathrm{E} \cdot 07\end{array}$ & $\begin{array}{l}\mu \mathrm{C} / \mathrm{mL} \\
\mu \mathrm{C} / / \mathrm{mL} \\
\mu \mathrm{C} / \mathrm{mL}\end{array}$ & $\begin{array}{l}G P \\
G P \\
G P\end{array}$ & $\begin{array}{l}\text { EPIA.001 } \\
\text { EPAA-001 } \\
\text { EPIA-002 }\end{array}$ \\
\hline
\end{tabular}

\section{WELL FSB112A}

MEASUREMENTS CONDUCTED IN THE FIELD

Sample date: $04 / 12 / 99$ (23.05 m) below TOC

Water alevation: $153.48 \mathrm{ft}(46.78 \mathrm{~m}) \mathrm{ms}$ )

$\mathrm{pH}: 6.5$

Sp. conductance: $150 \mu \mathrm{S} / \mathrm{cm}$

Water evacualed from the well prior to sampling: $128 \mathrm{gat}$ ANALYSES

\begin{tabular}{|c|c|c|c|c|c|c|c|c|}
\hline & & $G$ & & MS & & & & \\
\hline \multirow{4}{*}{ 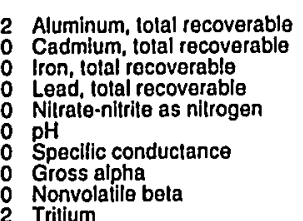 } & \multirow{4}{*}{$\begin{array}{l}53.4 \\
<1.00 \\
94.5 \\
<2.00 \\
2,710 \\
6.92 \\
170 \\
9.90 E-10 \pm 5.43 E-10 \\
1.33 E-00 \pm 1.12 E-09 \\
7.38 E .05 \pm 1.55 E-06\end{array}$} & & & & \multirow{4}{*}{$\begin{array}{l}15.0 \\
1.00 \\
25.0 \\
2.00 \\
50.0 \\
0.100 \\
1.00 \\
7.44 E-10 \\
1.07 E-09 \\
5.73 E \cdot 07\end{array}$} & \multirow{4}{*}{ 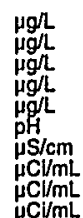 } & \multirow{4}{*}{$\begin{array}{l}G E \\
G E \\
G E \\
G E \\
G E \\
G E \\
G E \\
G E \\
G P \\
G P \\
G P\end{array}$} & \multirow{4}{*}{$\begin{array}{l}\text { EPAG020 } \\
\text { EPAG020 } \\
\text { EPA6020 } \\
\text { EPA6020 } \\
\text { EPA35.1 } \\
\text { EPA9040 } \\
\text { EPA950 } \\
\text { EPIA.001 } \\
\text { EPA.0.01 } \\
\text { EPIA.002 }\end{array}$} \\
\hline & & & & & & & & \\
\hline & & & $Q$ & & & & & \\
\hline & & & & & & & & \\
\hline
\end{tabular}

\section{WELL FSB112C}

MEASUREMENTS CONDUCTED IN THE FIELD

Sample date: 04/09/99

Depth to water: 28.33 ft $(8.64 \mathrm{~m})$ below TOC

$\mathrm{pp}$ : 4.2 conductance: $1,700 \mu \mathrm{S} / \mathrm{cm}$

Turbidity: $1 \mathrm{NTU}$.
Water evacuated from the well prior to sampling: $110 \mathrm{gal}$

ANALYSES

\begin{tabular}{|c|c|c|c|c|c|c|c|c|}
\hline F Analyto & Result & $F G$ & $s$ & EMS & SQL & Unit & Lab & Mothod \\
\hline \multirow{3}{*}{$\begin{array}{ll}2 & \text { Aluminum, total recoverable } \\
2 & \text { Cadmium, lotal recoverable } \\
2 & \text { lron, total recoverable } \\
0 & \text { Lead, total recoverable } \\
2 & \text { Nitrate-nitrite as nitrogen } \\
0 & \text { pH } \\
2 & \text { Specific conductance } \\
2 & \text { Gross alpha } \\
2 & \text { Nonvolatitie beta } \\
2 & \text { Tritium }\end{array}$} & \multirow{3}{*}{$\begin{array}{l}28.600 \\
44.00 \\
339 \\
<20.0 \\
223.000 \\
4.60 \\
1.940 \\
1.81 \mathrm{E}-07 \pm 1.34 \mathrm{E}-08 \\
1.91 \mathrm{E}-06 \pm 2.40 \mathrm{E} \\
6.69 \mathrm{E} \cdot 03 \pm 1.25 \mathrm{E}-04\end{array}$} & $J$ & $k$ & $\mathrm{Cl}$ & \multirow{3}{*}{$\begin{array}{l}150 \\
1.00 \\
25.0 \\
20.0 \\
5,000 \\
0.100 \\
1.00 \\
2.95 E-09 \\
4.57 E \cdot 09 \\
6.45 E \cdot 06\end{array}$} & \multirow{3}{*}{ 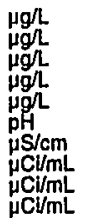 } & \multirow{3}{*}{$\begin{array}{l}\mathrm{GE} \\
\mathrm{GE} \\
\mathrm{GE} \\
\mathrm{GE} \\
\mathrm{GE} \\
\mathrm{GE} \\
\mathrm{GE} \\
\mathrm{GP} \\
\mathrm{GP} \\
\mathrm{GP}\end{array}$} & \multirow{3}{*}{$\begin{array}{l}\text { EPA6020 } \\
\text { EPA620 } \\
\text { EPA6020 } \\
\text { EPA6020 } \\
\text { EPA353.1 } \\
\text { EPA9040B } \\
\text { EPA9050A } \\
\text { EPAA.001 } \\
\text { EPA.001 } \\
\text { EPIA.002 }\end{array}$} \\
\hline & & $\vec{u}$ & $\mathrm{~K}$ & C & & & & \\
\hline & & $J$ & a & & & & & \\
\hline
\end{tabular}

\section{WELLL FSB112D}

MEASUREMENTS CONDUCTED IN THE FIELD

Sample date: $04 / 12 / 99$

Water elevation: $205.1 \mathrm{t}(62.52 \mathrm{~m}) \mathrm{msl}$

Sp. conductance: $220 \mu \mathrm{S} / \mathrm{cm}$

Water evacuated from the well prior to sampling: 32 gal

ANALYSES

$F$ Analyto

Result

2 Aluminum, total recoverable

Iron, total recoverable

7.510
3.55
64.6

FG S EMS SQL

15.0
1.00
25.0

Unit

Mathod

Time: 8:35

Air temperature: $16.8^{\circ} \mathrm{C} \mathrm{C}$

Total alkalinity (as Caco3): $0 \mathrm{mg} / \mathrm{h}$

Field Qualifier(s): $s$

ESH-EMS-990521
Well FSB 1 12D collected on 04/12/99 (cont.)

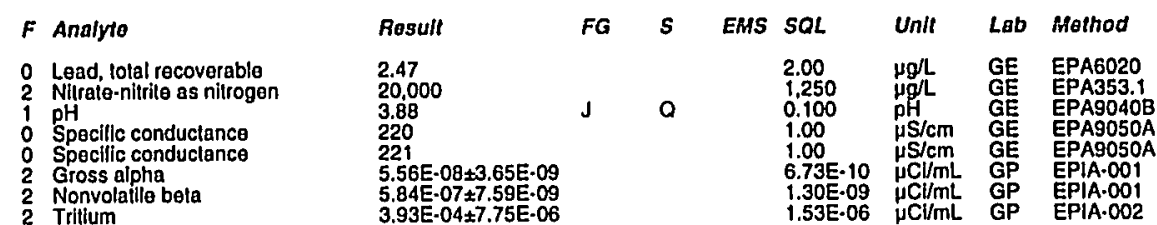

\section{WELL FSB113A}

MEASUREMENTS CONDUCTED IN THE FIELD

Sample date: 04/05/99

Depth to waler: $63.6 \mathrm{ft}(19.39 \mathrm{~m})$ below TOC

Waler elevation: $159.6 \mathrm{ft}(48.65$
gh: 11.4
Sp. conductance: $2,200 \mu \mathrm{S} / \mathrm{cm}$

Water evacuated from the well prior to sampling: $1 \mathrm{gat}$

ANALYSES

$F$ Analyto

Result

2 Aluminum, total recoverable

Iron, lotal recoverable

Nitrate-nitrite as nitrogen

Specific conductance

Gross alpha

Nonvolalilie beta

2 Tritium

\begin{tabular}{|c|}
\hline 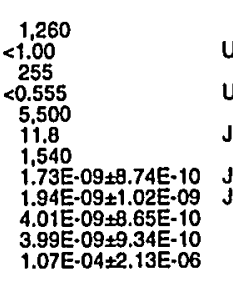 \\
\hline
\end{tabular}

FG $\quad S$

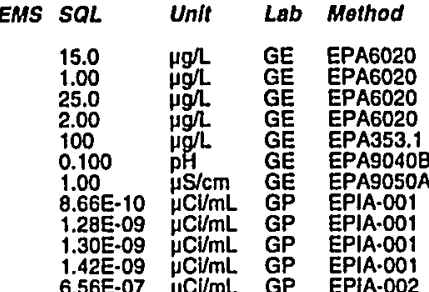

Time: 10:50

Warterate: $19.7^{\circ} \mathrm{C}$

Total alkalinity (as CaCO3): $473 \mathrm{mg} /$

Phenolphthalein alkalinity: $458 \mathrm{mg}$.
Field Qualifier(s): $S X H$

\section{WELL FSB113C}

MEASUREMENTS CONDUCTED IN THE FIELD

Sample date: 04/05/99
Depth to water: $20.54 \mathrm{ft}(6.26 \mathrm{~m})$ below TOC
Water elevation: $202.36 \mathrm{tt}(61.68 \mathrm{~m}) \mathrm{msl}$

Water e

p. conductance: $130 \mu \mathrm{S} / \mathrm{cm}$

Water evacuated from the well prior to sampling: $74 \mathrm{gal}$

ANALYSES

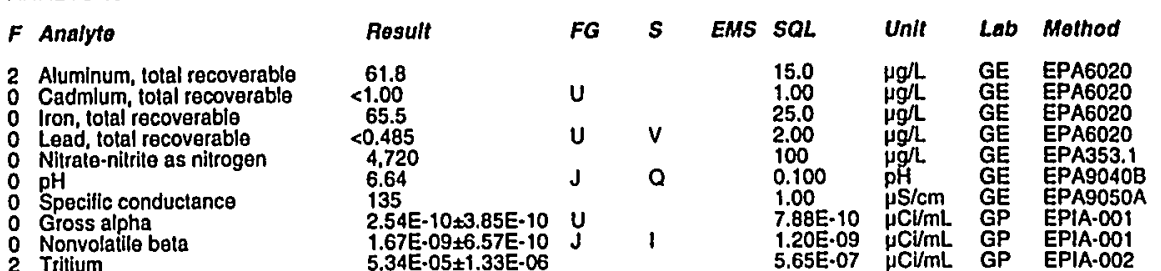

Time: 10:25

Air tamperature: $21.4^{\circ} \mathrm{C}$

Total alkalinity (as CaCO3): $27 \mathrm{mg} /$ Phenolphthalein alkalinity: $0 \mathrm{mg} / \mathrm{L}$.

Titium 
Well FSB1 15D collected on 04/06/99 (cont.)

$F$ Analyto

$F G$

0 Nonvolatilo beta

$7.79 \mathrm{E}-10 \pm 4.92 \mathrm{E}-10 \quad \mathrm{U}$
$7.29 \mathrm{E} \cdot 06 \pm 5.73 \mathrm{E} \cdot 07$

\section{WELL FSB116C}

MEASUREMENTS CONDUCTED IN THE FIELD

Sample date: 04/06/99

Depth to water: $13.05 \mathrm{~h}(3.98 \mathrm{~m})$ below TOC

Water elevation: $189.45 \mathrm{ft}(57.75 \mathrm{~m}) \mathrm{msl}$

Sp. conductance: $21 \mu \mathrm{S} / \mathrm{cm}$

Turbidily: 2 NTU
Waler ovacualed from the well prior to sampling: 72 gal ANALYSES

\section{$F$ Analyte}

$F G$

2 Aluminum, total recoverable

- Iron, iotal recoverable

Nitrate-nitrite as nitrogen

0 Specilic conductance

O

${ }_{0}^{0}$ Trifium

$\begin{array}{lll}69.8 & & \\ <1.00 & U & \\ 51.2 & & \\ 2.36 & & \\ 780 & & \\ 5.22 & J & O \\ 20.1 & & \\ 7.47 \mathrm{E}-10 \pm 3.90 \mathrm{E}-10 & \mathrm{~J} & 1 \\ 4.97 \mathrm{E}-10 \pm 4.93 \mathrm{E}-10 & \mathrm{U} & \\ 9.20 \mathrm{E}-06 \pm 6.15 \mathrm{E}-07 & & \end{array}$

\section{WELL FSB116D}

MEASUREMENTS CONDUCTED IN THE FIELD

Sample date: 04/06/99

$\mathrm{pH}: 5.2$

Water evacuated from the well prior to sampling: $5 \mathrm{gal}$ The well went dry during purging.

ANALYSES

\begin{tabular}{|c|c|c|c|c|c|c|c|c|}
\hline Analyte & Result & $F G$ & $s$ & EMS & SOL & Unit & Lab & Method \\
\hline 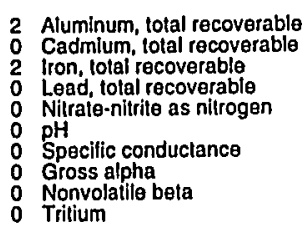 & $\begin{array}{l}520 \\
<1.00 \\
861 \\
13.4 \\
370 \\
5.52 \\
26.3 \\
6.78 E-10 \pm 4.13 E-10 \\
8.23 E-10 \pm 5.87 E-10 \\
9.45 E-06 \pm 6.27 E-07\end{array}$ & $\begin{array}{l}J \\
\text { u }\end{array}$ & $\begin{array}{l}0 \\
1\end{array}$ & & $\begin{array}{l}15.0 \\
1.00 \\
25.0 \\
2.00 \\
50.0 \\
0.100 \\
1.00 \\
6.39 E-10 \\
1.18 E-09 \\
5.65 \mathrm{E}-07\end{array}$ & 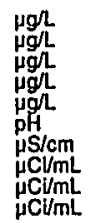 & $\begin{array}{l}G E \\
G E \\
G E \\
G E \\
G E \\
G E \\
G E \\
G E \\
G E \\
G F \\
G P \\
G P\end{array}$ & $\begin{array}{l}\text { EPA6020 } \\
\text { EPAD20 } \\
\text { EPAG020 } \\
\text { EPAG020 } \\
\text { EPAO20 } \\
\text { EPA353.1 } \\
\text { EPAO40B } \\
\text { EPA9050A } \\
\text { EPPA.001 } \\
\text { EPPA.001 } \\
\text { EPIA.002 }\end{array}$ \\
\hline
\end{tabular}

\section{WELL FSB117D}

MEASUREMENTS CONDUCTED IN THE FIELD

\section{Sample date: 04/09/99
Depth to waler: $26.54 \mathrm{Ht}(8.09 \mathrm{~m})$ below TOC
Wat \\ Water el wava}

p. conductance: $300 \mu \mathrm{S} / \mathrm{cm}$

Waler evacualed from the well prior to sampling: 35 gal

ANALYSES

\begin{tabular}{|c|c|c|c|c|c|c|c|c|}
\hline$F$ Analyte & Result & FG & $\mathbf{s}$ & EMS & SQL & Unit & Lab & Method \\
\hline $\begin{array}{l}2 \text { Aluminum, tolal recoverable } \\
\text { 1 Cadmium, total recoverable } \\
0 \text { Iron, total recoverable }\end{array}$ & $\begin{array}{l}8.860 \\
3.45 \\
62.0\end{array}$ & J & $\mathrm{k}$ & 1 & $\begin{array}{l}15.0 \\
1.00 \\
25.0\end{array}$ & $\begin{array}{l}\mu g \Omega \\
\mu g h \\
\mu g \Omega\end{array}$ & $\begin{array}{l}\mathrm{GE} \\
\mathrm{GE} \\
\mathrm{GE}\end{array}$ & $\begin{array}{l}\text { EPA6020 } \\
\text { EPA6020 } \\
\text { EPA6020 }\end{array}$ \\
\hline
\end{tabular}

Time: 10:59

er temperature: $19^{\circ} \mathrm{C}$

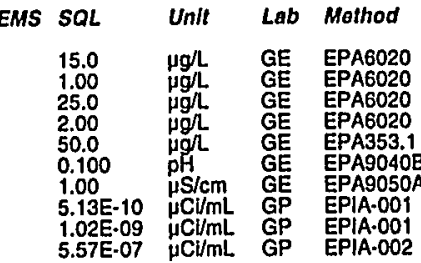

Time: 11:30

Water temperature: $25.8^{\circ} \mathrm{C}$ Phenolphthalein alkalinity: $0 \mathrm{mg}$
Field Qualifier(s): $S X$

Time: 10:15 Total alkalinity. (as CaCo3): $0 \mathrm{mg} / \mathrm{L}$

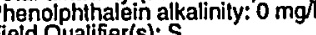

Well FSB1 17D collecled on 04/09/99 (conl.)

2 Lead, total recoverable

1 pH

Nonvolatile bela

2 Trillum

Rosult Total alkalinity (as CaCO3): $0 \mathrm{mg} /$.

WELL FSB118D

MEASUREMENTS CONDUCTED IN THE FIELD

Sample date: $04 / 07 / 99$ (11.2)

pH: 4.6

Waler evacuated from the well prior to sampling: $82 \mathrm{gal}$

ANALYSES

$F$ Analyto

Result

FG

O Aluminum, lotal recoverable

Iron, lotal recoverable

Nitrate-nilitite as niltrogen

Specilic conductanco

Gross alpha

0 Trillum Total alkalinity (as CaCO3): $2 \mathrm{mg} /$

\section{WELL FSB119D}

MEASUREMENTS CONDUCTED IN THE FIELD

Sample date: 04/09/99 $14.15 \mathrm{~m})$ below TOC$$
\text { Water }
$$
The well went dry during purging

ANALYSES

$F$ Analyto

$<50.6$

66.4
3.64
850
5.09
28.7
1.27 $1.27 E-09+4.92 E-10$
$1.25 E-09+6.15 E-10$

EMS SOL

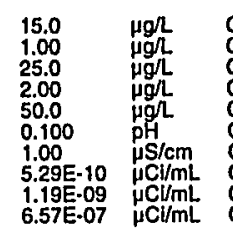

Lab Molhod

Iron, total recoverable Lead, total recoverable $\mathrm{pH}_{\mathrm{pH}}$-nitrite as nilrogen Specilic conductance Gross alpha

Tritum

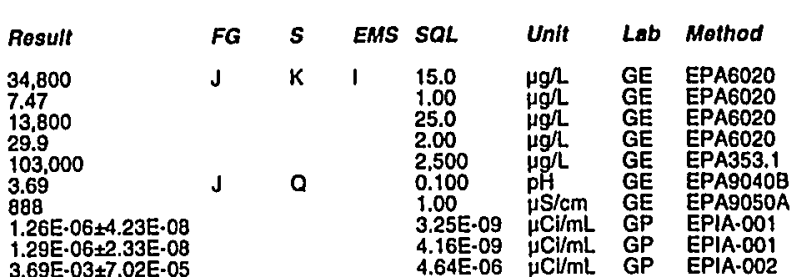

Time: 9:05 Alr temperalure: $21.9^{\circ} \mathrm{C}$
Total alkalinity (as $\mathrm{CaCO}$ ): $0 \mathrm{mo} /$ Phenolphthalein alkalinity: $0 \mathrm{mg} \mathrm{m}^{2}$
Time: 12:04 104 ater temperature: $20^{\circ} \mathrm{C}$

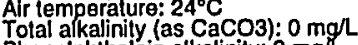
Phenolphthalein alkalinity: $0 \mathrm{mg}$
Deph to water: 11.2 ft $(3.41 \mathrm{~m})$
Water elevalion: $191.7 \mathrm{Ht}(58.43 \mathrm{~m}) \mathrm{msl}$

. conductance: $27 \mu \mathrm{S} / \mathrm{cm}$

Sp. conductance: $28 \mu \mathrm{S} / \mathrm{cm}$

$\mathrm{Sp}$. conductance: $900 \mu \mathrm{S} / \mathrm{cm}$

Water evacuated from the well prior to sampling: $1 \mathrm{gal}$

2 Aluminum, total recoverable

ESH-EMS-99052 


\section{WELL FSB120A}

MEASUREMENTS CONDUCTED IN THE FIELD

Sample date: 04/06/99
Depth to waler: $100.39 \mathrm{ht}(30.6 \mathrm{~m})$ below TOC
Waler

Turbidity: 0 NTU $2,400 \mu \mathrm{S} / \mathrm{cm}$

Water evacuated from the well prior to sampling: 1 gal

ANALYSES

\begin{tabular}{|c|c|c|c|c|c|c|c|c|}
\hline Analyto & Result & $F G$ & $\boldsymbol{s}$ & EMS & SQL & Unit & Lab & Mothod \\
\hline $\begin{array}{ll}2 & \text { Aluminum, total recoverable } \\
0 & \text { Cadmium, tolal recoverable } \\
2 & \text { Iron, tolal recoverable } \\
0 & \text { Lead, lolal recoverable } \\
2 & \text { Nitrale-niltrite as nilrogen } \\
2 & \text { pH } \\
2 & \text { pH } \\
2 & \text { Specific conductance } \\
0 & \text { Gross alpha } \\
0 & \text { Nonvolatile bela } \\
2 & \text { Tritium }\end{array}$ & $\begin{array}{l}1.200 \\
<1.00 \\
501 \\
2.48 \\
25,500 \\
12.1 \\
12.1 \\
2.960 \\
4.36 E \cdot 09 \pm 1.21 E .09 \\
2.32 E .09 \pm 1.57 E .09 \\
5.61 E \cdot 04 \pm 1.10 E .05\end{array}$ & J & Q & & $\begin{array}{l}15.0 \\
1.00 \\
25.0 \\
2.00 \\
1.250 \\
0.100 \\
0.100 \\
1.00 \\
1.13 E-09 \\
1.40 \mathrm{E} .09 \\
1.58 \mathrm{E}-06\end{array}$ & 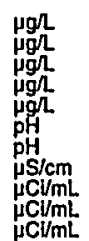 & $\begin{array}{l}\mathrm{GE} \\
\mathrm{GE} \\
\mathrm{GE} \\
\mathrm{GE} \\
\mathrm{GE} \\
\mathrm{GE} \\
\mathrm{GE} \\
\mathrm{GE} \\
\mathrm{GP} \\
\mathrm{GP} \\
\mathrm{GP}\end{array}$ & $\begin{array}{l}\text { EPAG020 } \\
\text { EPA6020 } \\
\text { EPA6020 } \\
\text { EPA6020 } \\
\text { EPA353. } \\
\text { EPA9040 } \\
\text { EPA9040 } \\
\text { EPA9050 } \\
\text { EPIA.001 } \\
\text { EPIA.001 } \\
\text { EPAA.002 }\end{array}$ \\
\hline
\end{tabular}

\section{WELL FSB120C}

MEASUREMENTS CONDUCTED IN THE FIELD

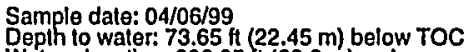

Water elevation: $206.05 \mathrm{ht}(62.8 \mathrm{~m}) \mathrm{ms}$ !

pH: 6.2 conductance: $280 \mu \mathrm{S} / \mathrm{cm}$

Water evacuated from the well prior to sampling: $105 \mathrm{gal}$

ANALYSES

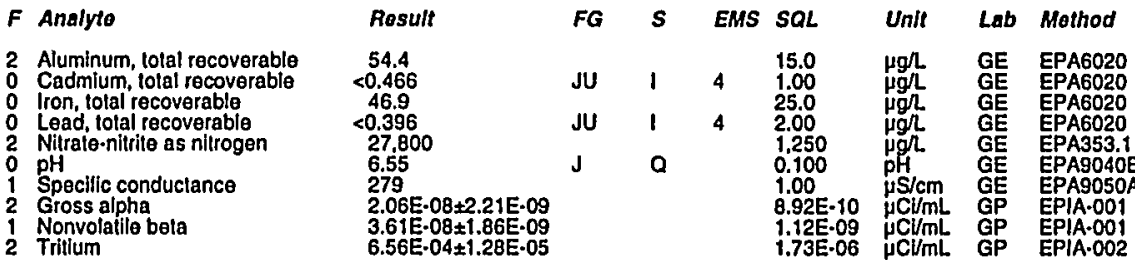

\section{WELL FSB120D}

MEASUREMENTS CONDUCTED IN THE FIELD

Sample date: 04/06/99

Wepth to water: 71 ff $21.64 \mathrm{~m}$ ) below TOC

pH: 7.9

Sp. conductance: $36 \mu \mathrm{S} / \mathrm{cm}$

Waler evacualed from the well prior to sampling: $1 \mathrm{gal}$

ANALYSES

$F$ Analyte

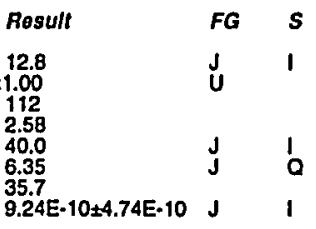

Time: 9:06

Water temperature: $18.4^{\circ} \mathrm{C}$

Total alkalinity (as CaCO3): $461 \mathrm{mg} /$ Phenolphthalein alkalinity: $448 \mathrm{mg} L$
Field Qualifier(s): $S X H$

Time: 8:15

Wir temperaturare: $19.6^{\circ} \mathrm{C}$ Total alkalinily.(as CaCO3): $11 \mathrm{mg} / \mathrm{L}$ Phenolphthalein alkalinity: $0 \mathrm{mg} / \mathrm{L}$

$173 \mathrm{E} \cdot 0$

Time: 9:17

Water temperature: $18.7^{\circ} \mathrm{C}$

Total alkalinity (as CaCo3): $8 \mathrm{mg} /$ Phenolphthaledin alkalinity: $0 \mathrm{mgl}$
Field Qualifíier(s): $\mathrm{SX}$

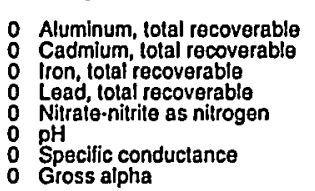

ESH-EMS-990521
Well FSB 1200 collected on 04/06/99 (cont.)

i Nonvolatile beta

Rosult

FG

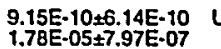

5 EMS SOL Untt Lab Mathod

WELL FSB121C

MEASUREMENTS CONDUCTED IN THE FIELD

Sample date: 04/12/99

Depth to water. $52.5 \mathrm{ft}(16 \mathrm{~m})$ below TOC
Water elevation: $204 \mathrm{ft}(62.18 \mathrm{~m}) \mathrm{msl}$

$\mathrm{HH}: 5.6$

p. conductance: $49 \mu \mathrm{S} / \mathrm{cm}$

Waler ovacualed from the well prior to sampling: $134 \mathrm{gal}$ ANALYSES

$F$ Analyto

1 Aluminum, total recoverable

Cadmium, tolal recoverable

Iron, total recoverable

0 Nilra

$\mathrm{pH}$

Gross alpha
0 Gross alpha

Nonvolatila bela

2 Tritium

WELL FSB121DR

MEASUREMENTS CONDUCTED IN THE FIELD

Sample date: 04/07/99
Depth to waler: $48.45 \mathrm{ft}(14.77 \mathrm{~m})$ below TOC

Weler elevalion: $207.05 \mathrm{ft}(63.11 \mathrm{~m}) \mathrm{ms}$

Sp. conductance: $32 \mu \mathrm{S} / \mathrm{cm}$

Waler evacuated from the well prior to sampling: 1 gal ANALYSES

ANALYSES

2 Aluminum, total recoverable

i Cadmium, total recoverablo

Nitrale-nitrite as nitrogen

Specific conduclance

Gross alpha
Nonvolatile beta

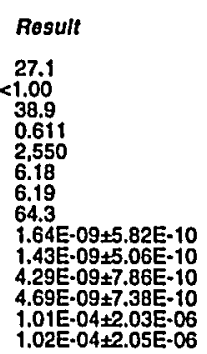

FG S EMS SOL

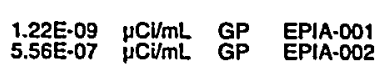

\section{WELL FSB122C}

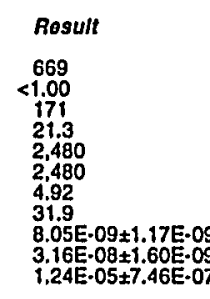

FG

Time: 13:34

Water femperature: $20.5^{\circ} \mathrm{C}$ Total alkalinity (as CaCO3): $7 \mathrm{mg}$

Phenolphthalein alkalinity: $0 \mathrm{mg} L$
Field Quatifier(s): $s$

MEASUREMENTS CONDUCTED IN THE FIELD

Sample date: 04/07/99
Depth lo water: 18.77 (11.72 $\mathrm{m})$ below TOC
Water elevation: $199.23 \mathrm{ft}(60.73 \mathrm{~m}) \mathrm{ms}$

Water e

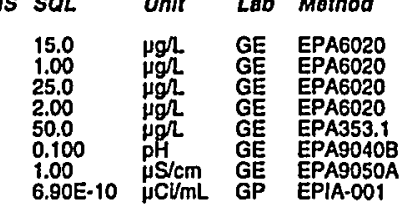

Time: 15:40

Air temperature: $30^{\circ} 0^{\circ} \mathrm{C}$

Total alkalinity (as CaCo3): $0 \mathrm{mg} / \mathrm{h}$

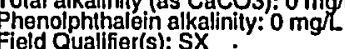

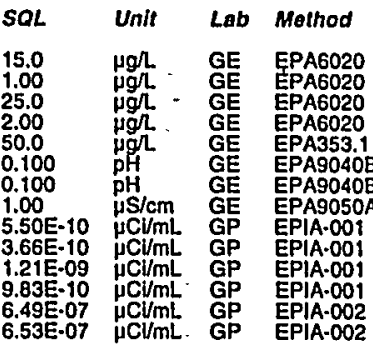

Water femperature: $19.2^{\circ} \mathrm{C}$ Total alkalinity (as Caco3): 0 mgr Phenolphthalein alkalinity: $0 \mathrm{mg} h$
Field Qualifier(s): $\mathrm{s}$. 
Well FSB122C collecled on 04/07/99 (cont.)

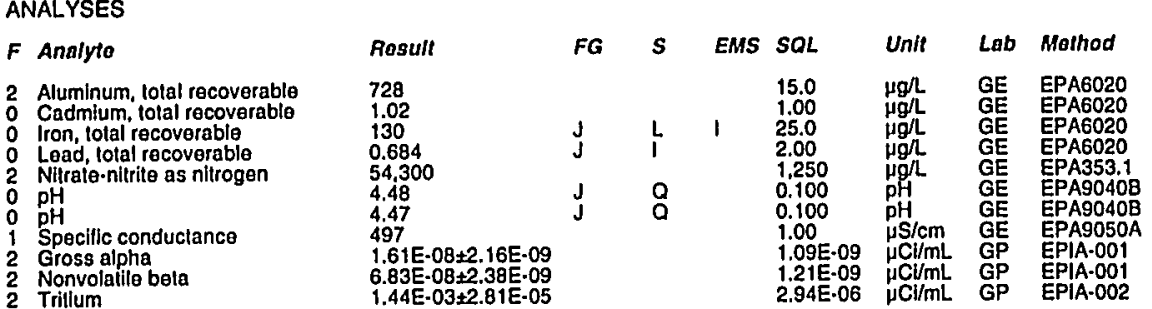

\section{WELL FSB122D}

MEASUREMENTS CONDUCTED IN THE FIELD

Sample date: 04/07/99
Depph to water: $14.9 \mathrm{Ht}(4.54 \mathrm{~m})$ below TOC
Water elevalion: $202.7 \mathrm{t}(61.78 \mathrm{~m}) \mathrm{msl}$

Water elevalion: $202.7 \mathrm{tt}(61.76 \mathrm{~m}$
$\mathrm{gH}: 4.5$
$\mathrm{Sp}$. conductance: $180 \mu \mathrm{S} / \mathrm{cm}$

Water evacuated from the well prior to sampling: $45 \mathrm{gal}$ ANALYYSES

F Analyto

Result
256
$<1.00$
95.1
3.16
18,800
4.85
191
$4.05 E-09 \pm 9.17 E-10$
$2.45 E-08 \pm 1.45 E-09$
$4.83 E-04 \pm 9.51 E-06$

2 Aluminum, total recoverable

Iron, total recoverable

Nead, tolal recoverable

$\mathrm{pH}$ Specific conductanco

Gross alpha

\section{WELL FSB123C}

MEASUREMENTS CONDUCTED IN THE FIELD

Sample date: $04 / 07 / 99$
Depth to waer: $27.95 \mathrm{~h}(8.52 \mathrm{~m})$ below TOC
Waler elevation: $210.15 \mathrm{Ht}(64.05 \mathrm{~m}) \mathrm{msl}$

pH: 5.4

p. conductance: $64 \mu \mathrm{S} / \mathrm{cm}$

Water evacualed from the well prior to sampling: $103 \mathrm{gal}$

ANALYSES

$F$ Analyte

\begin{tabular}{|c|c|c|}
\hline Result & $F G$ & 5 \\
\hline$<16.7$ & $\stackrel{U}{u}$ & v \\
\hline $\begin{array}{r}51.2 \\
<0.349\end{array}$ & Ju & i \\
\hline & $\mathrm{J}$ & a \\
\hline $\begin{array}{l}3.89 \mathrm{E}-10 \pm 3.16 \mathrm{E}-10 \\
1.23 \mathrm{E}-09 \pm 5.75 \mathrm{E}-10 \\
1.76 \mathrm{E}-06 \pm 4.40 \mathrm{E} \cdot 07 \\
2.50 \mathrm{E}-06 \pm 4.73 \mathrm{E}-07\end{array}$ & $\begin{array}{l}U \\
J\end{array}$ & 1 \\
\hline
\end{tabular}

Time: 11:05

Air temperature: $21.5^{\circ} \mathrm{C}$

Total alkalinity (as CaCO3): $0 \mathrm{mg} / \mathrm{L}$

Field Qualifier(s): $s$

\section{$\mathrm{mg} / \mathrm{L}$}

WELL FSL 1D

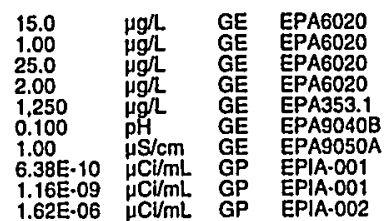

- Aluminum, lotal recoverable

: Cadmium, total recoverab

- Lead, total recoverable

o specific conductance

Gross alpha
0 Nonvolatile bela

Tritium

$2.50 \mathrm{E} \cdot 06 \pm 4.73 \mathrm{E} \cdot 07$
Time: 9:43 Total alkalinity (as CaCo3): $8 \mathrm{mg} /$ Phenolphthalein alkalinity: $0 \mathrm{mg}$

SMS SQL
15.0
1.00
25.0
2.00
100
0.100
1.00
$5.07 \mathrm{E}-10$
$1.09 \mathrm{E}-09$
$6.42 \mathrm{E}-07$
$6.53 \mathrm{E}-07$

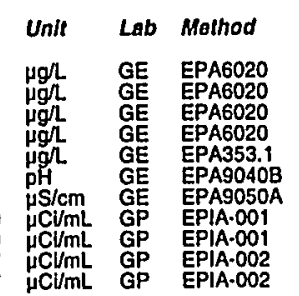

Air temperalure $193^{\circ} \mathrm{C}$

(1) waler: $26.6 \mathrm{ft}(8.11 \mathrm{~m})$ below TOC

Sp. conductance: $41 \mu \mathrm{S} / \mathrm{cm}$

Water elevation: 225.1 if $(68.61 \mathrm{~m}) \mathrm{msl}$
WELL FSL 1D

MEASUREMENTS CONDUCTED IN THE FIELD

Sample date: 04/28/99 $2636 \mathrm{~m}$ ) below TOC

Water elevalion: $224.32 \mathrm{ft}(68.37 \mathrm{~m}) \mathrm{msl}$

$\mathrm{gH}: 4$

WELL FSB123D

MEASUREMENTS CONDUCTED IN THE FIELD

Waler

ANALYSES

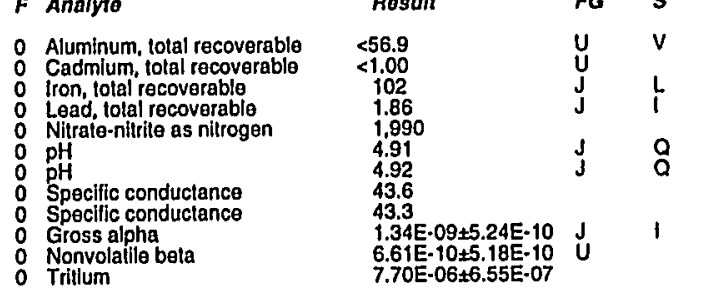

Time: 9:30

ralure: $19.1^{\circ} \mathrm{C}$

Alr temperalure: $19^{\circ} \mathrm{C}$ Total alkalinily (as CaCO3): $0 \mathrm{mg} /$ Field Qualifier(s): $s$

ctance: $60 \mu \mathrm{S} / \mathrm{cm}$

Water evacuated from the well prior to sampling: $1 \mathrm{gal}$

ANALYSES

$F$ Analyte

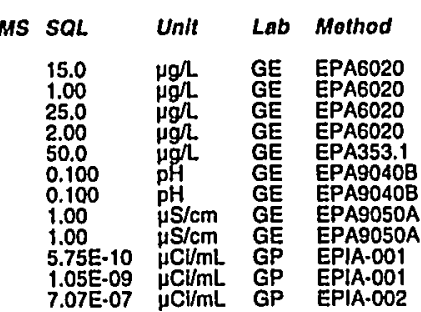

Water temperaturg: $22.2^{\circ} \mathrm{C}$

Aotal alkalinity: (as Caco3): $0 \mathrm{mgh}$

Phenoiphthalein alkalinity: $0 \mathrm{mg} L$
Field Qualifier(s): $V X$

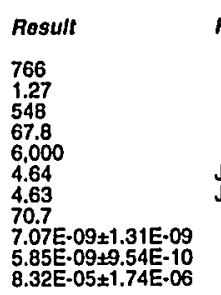

FG

EMS SOL
15.0
1.00
25.0
2.00
150
0.100
0.100
1.00
$7.16 \mathrm{E}-10$
$1.32 \mathrm{E} .09$
$6.60 \mathrm{C}-07$

Unit Lab Mathod

$\mu g$ h GE EPA6020

$\mu g$ GE EPA6020

Lead, total recoverable

Specilic conductance

Gross alpha

WELL. FSL 2D

MEASUREMENTS CONDUCTED IN THE FIELD

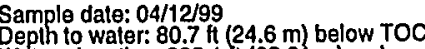

Sp: 6.4 conductance: $90 \mu \mathrm{S} / \mathrm{cm}$

Water evacuated from the well prior to sampling: $1 \mathrm{gal}$

ANALYSES

\begin{tabular}{|c|c|}
\hline Analyte & Rosult \\
\hline $\begin{array}{l}\text { Aluminum, total recoverable } \\
\text { Cadmium total recoverable } \\
\text { lron, lotal recoverable } \\
\text { Lead total receoverable } \\
\text { Nitraite-nitrite as nilrogen } \\
\text { pH } \\
\text { pH } \\
\text { Specitic conductance }\end{array}$ & $\begin{array}{c}332 \\
<0.249 \\
511 \\
6.25 \\
730 \\
6.13 \\
6.15 \\
97.2\end{array}$ \\
\hline
\end{tabular}

J

Time: 14:05

ure: $23.1^{\circ}$

Total aikalinity (as CaCO3); $29 \mathrm{mg} \Omega$

Fiold Oualifer(s): VX $\mathrm{VX}$. $0 \mathrm{mg}$

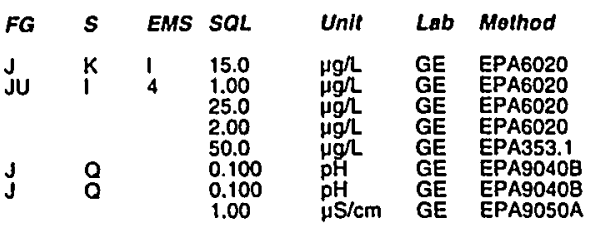

Socond Quartor 1999 
Well FSL 2D collected on 04/12/99 (cont.)

$F$ Analyte

Rosult

o Gross alpha

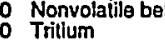

$6.38 E-09 \pm 8.34-09$
$6.67 E-06 \pm 6.18 E \cdot 07$

FG - S EMS SQL Unit Lab Mathod

WELL FSL 3D

MEASUREMENTS CONDUCTED IN THE FIELD

Sample date: 04/12/99 $24.13 \mathrm{~m})$ below TOC

Water elevation: $222.85 \mathrm{tt}(67.93 \mathrm{~m}) \mathrm{ms}$ -

H: 6.2

conductance: $80 \mu \mathrm{S} / \mathrm{cm}$

Waler evacualed from the well prior to sampling: $16 \mathrm{gal}$

ANALYSES

\begin{tabular}{|c|c|c|c|c|c|c|c|c|}
\hline \multirow[b]{5}{*}{ in } & \multirow{5}{*}{$\begin{array}{l}\text { Rosult } \\
132 \\
<1.00 \\
213 \\
<1.78 \\
2,530 \\
6.77 \\
95.7 \\
1.58 \mathrm{E} \cdot 09_{ \pm 6.04 E-10} \\
3.13 \mathrm{E} \cdot 09 \pm 7.11 \mathrm{E} \cdot 10\end{array}$} & $F G$ & $\boldsymbol{s}$ & \multirow{2}{*}{$\begin{array}{l}\text { EMS } \\
1\end{array}$} & $2 L$ & Unit & $a b$ & Mothod \\
\hline & & J & $k$ & & & & GE & \\
\hline & & u & v & & & & & \\
\hline & & $\mathbf{J}$ & 0 & & & & $G E$ & $\begin{array}{l}\text { EPA353.1 } \\
\text { EPA9040日 }\end{array}$ \\
\hline & & J & 1 & & $\begin{array}{l}1.00 \\
7.17 E-10 \\
1.16 \mathrm{E}-09 \\
6.96 \mathrm{E}-07\end{array}$ & $\begin{array}{l}\mu \mathrm{C} / \mathrm{mL} \\
\mu \mathrm{C} / \mathrm{mL} \\
\mathrm{\mu Cl} / \mathrm{mL}\end{array}$ & $\begin{array}{l}\mathrm{GP} \\
\mathrm{GP} \\
\mathrm{GP}\end{array}$ & $\begin{array}{l}\text { EPIA.001 } \\
\text { EPIA.001 } \\
\text { EPIA.002 }\end{array}$ \\
\hline
\end{tabular}

\section{WELL FSL 4D}

MEASUREMENTS CONDUCTED IN THE FIELD

Sample date: 04/12/99
Depth lo waler: $76.19 \mathrm{ft}(23.22 \mathrm{~m})$ below TOC
Water elevalion: $217.91 \mathrm{ft}(66.42 \mathrm{~m}) \mathrm{ms}$
pH: 4.5

Sp. conductance: $40 \mu \mathrm{S} / \mathrm{cm}$

Waler evacuated from the well prior to sampling: 1 gal ANALYSES

\begin{tabular}{|c|c|c|c|c|c|c|c|c|}
\hline Analyto & Result & FG & $s$ & EMS & SOL & Untt & Lab & Mothod \\
\hline 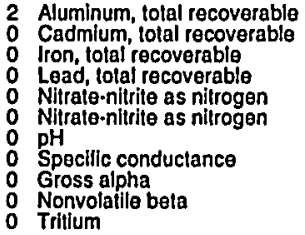 & $\begin{array}{l}159 \\
<1.00 \\
57.3 \\
13.0 \\
1.810 \\
1.780 \\
5.77 \\
55.6 \\
1.27 \mathrm{E} \cdot 09 \pm 5.13 \mathrm{E} \cdot 10 \\
2.62 \mathrm{E} \cdot 09 \pm 6.78 \mathrm{E} \cdot 10 \\
4.20 \mathrm{E} \\
4.06 \pm 5.45 \mathrm{E} \cdot 07\end{array}$ & $\begin{array}{l}\mathrm{J} \\
\mathrm{J}\end{array}$ & $\begin{array}{l}0 \\
1\end{array}$ & 1 & $\begin{array}{l}15.0 \\
1.00 \\
25.0 \\
2.00 \\
50.0 \\
50.0 \\
0.100 \\
1.00 \\
5.67 E-10 \\
1.15 E-09 \\
6.90=07\end{array}$ & 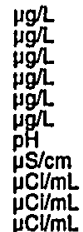 & $\begin{array}{l}\mathrm{GE} \\
\mathrm{GE} \\
\mathrm{GE} \\
\mathrm{GE} \\
\mathrm{GE} \\
\mathrm{GE} \\
\mathrm{GE} \\
\mathrm{GE} \\
\mathrm{GE} \\
\mathrm{GP} \\
\mathrm{GP} \\
\mathrm{GP}\end{array}$ & $\begin{array}{l}\text { EPAG020 } \\
\text { EPAG020 } \\
\text { EPA6020 } \\
\text { EPAG020 } \\
\text { EPA353.1 } \\
\text { EPA353.1 } \\
\text { EPA9040B } \\
\text { EPA950A } \\
\text { EPAA.001 } \\
\text { EPA.001 } \\
\text { EPIA.002 }\end{array}$ \\
\hline
\end{tabular}

\section{WELL FSL $5 D$}

MEASUREMENTS CONDUCTED IN THE FIELD

Sample date: $04 / 12 / 99$
Oepth to water: $70.81 \mathrm{H}$ (21.58 m) below TOC
Water elevation: $220.99 \mathrm{Ht}(67.36 \mathrm{~m}) \mathrm{ms}$

$\mathrm{pH:6}$

p. conductance: $190 \mu \mathrm{S} / \mathrm{cm}$

Water evacualed from the well prior to sampling: 6 gal

ANALYSES

\begin{tabular}{|c|c|c|c|c|c|c|c|c|}
\hline F Analyto & Result & $F G$ & $s$ & EMS & $S Q L$ & Unit & Lab & Method \\
\hline $\begin{array}{l}\text { Aluminum, total recoverable } \\
\text { Cadmium, total recoverable }\end{array}$ & $\begin{array}{r}261 \\
<1.00\end{array}$ & J & K & 1 & $\begin{array}{l}15.0 \\
1.00\end{array}$ & $\underset{\mu g}{\mu g}$ & $\begin{array}{l}\mathrm{GE} \\
\mathrm{GE}\end{array}$ & $\begin{array}{l}\text { EPA6020 } \\
\text { EPA6020 }\end{array}$ \\
\hline
\end{tabular}

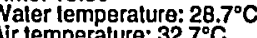
Tlomperature: 32.7
Total alkalinity (as Cacos): $26 \mathrm{mg} / \mathrm{L}$
Phenolphthalein alkalinity: $0 \mathrm{mg} / \mathrm{L}$

Time: 14:35 Waler temperalure: $23.7^{\circ} \mathrm{C}$

Total alkalinity (as CaCO) 4 mg/

Phenolphinaleern alkalinity: $0 \mathrm{mg}$
Field Qualifier(s): $\mathrm{VX}$

Total alkalinity (as CaCO3): $35 \mathrm{mg} / \mathrm{L}$ Phenolphthalein alkalinily: $0 \mathrm{mg} / \mathrm{L}$
Field Qualifier(s): $\vee$
Well FSL 5D collected on 04/12/99 (cont.)

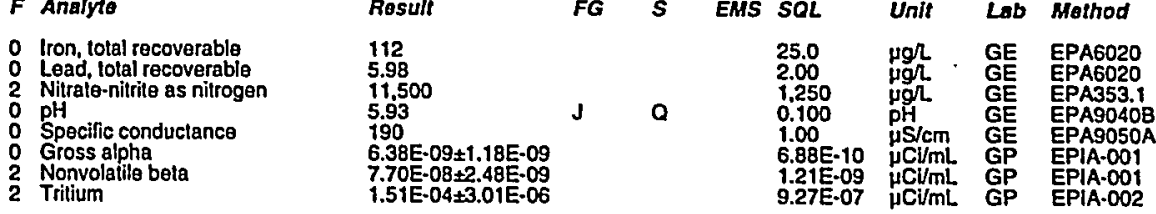

\section{Time: 13:30 \\ WELL FSL 6D}

MEASUREMENTS CONDUCTED IN THE FIELD

Sample date: 04/12/99 Depth lo water: $66 \mathrm{ft}(20.12 \mathrm{~m})$ below TOC Water elevation: $220.2 \mathrm{ft}(67$.
gi: 4.8
Sp. conduclance: $140 \mu \mathrm{S} / \mathrm{cm}$

Waler evacuated from the well prior to sampling: 21 gal ANALYSES

F Analyto

Result

1 Aluminum, total recoverable

Iron, total recoverable

1 Nitrate-nitrite as nitiogen

Specific conductance

Gross alpha

Nonvolatile bela
0 Nonvolatile bela

WELL FSL 7D

37.0
$<1.00$
$<25.0$
$<2.00$
6.150
5.13
1.44
$1.42 E-09+6.63 E-10$
$1.80=09 \pm 7.51 E-10$
$8.98-09+1.08 E-09$
$9.41 E-09 \pm 1.15 E-09$
$9.13 E \cdot 05 \pm 1.86 E-06$

FG S EMS SOL

Time: 14:51

Air emperalure: $29^{\circ} .1^{\circ} \mathrm{C}$ Total alkalinity (as CaCO3): $0 \mathrm{mg}$ Field Qualifier(s): $V$ alkalinity: $0 \mathrm{mg} /$

MEASUREMENTS CON

Dephth to water: $68.7 \mathrm{ft}(20.94 \mathrm{~m})$ below TOC
Water elevation: 2 i8.9 $\mathrm{t}(66.72 \mathrm{~m}) \mathrm{ms}$

Sp: conductance: $340 \mu \mathrm{S} / \mathrm{cm}$

Turbldity: 3 NTU Water from the well prior to sampling: 1 gal

ANALYSES

\begin{tabular}{|c|c|}
\hline Analyte & Result \\
\hline 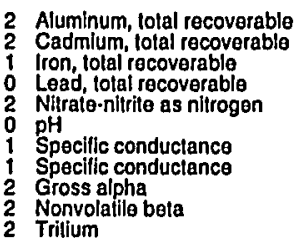 & $\begin{array}{l}3.040 \\
18.1 \\
248 . \\
6.33 \\
41.500 \\
4.24 \\
394 \\
393 \\
1.30 \mathrm{E} \cdot 07 \pm 5.77 \mathrm{E} \cdot 09 \\
1.31 \mathrm{E} \cdot 06 \pm 1.07 \mathrm{E} \cdot 08 \\
8.66 \mathrm{E} \cdot 05 \pm 1.76 \mathrm{E} \cdot 06\end{array}$ \\
\hline
\end{tabular}

$\begin{array}{ccc}S & \text { EMS } & \text { SQL } \\ & 15.0 \\ & & 1.00 \\ 1 & 1 & 25.0 \\ & 20.0 \\ a & 1.250 \\ & 0.100 \\ & 1.00 \\ & 1.00 \\ & 1.13 E \cdot 09 \\ & 1.36 E \cdot 09 \\ & 6.59 E \cdot 07\end{array}$

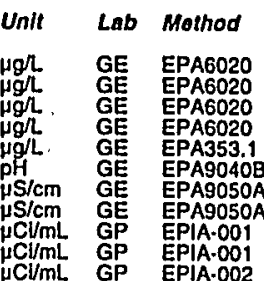

Time: 13:25

Arr temperalure: $33.1^{\circ} \mathrm{C}$ Total alkalinity (as CaCO3): $0 \mathrm{mg}$ Field Qualifier(s): VX

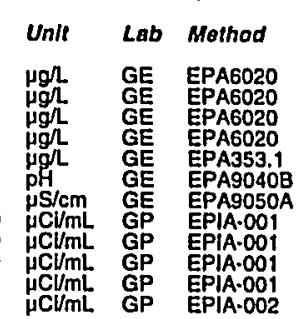




\section{WELL FSL 8D}

MEASUREMENTS CONDUCTED IN THE FIELD

Sample date: 04/07/99

Depth to waler: $72.75 \mathrm{ft}(22.17 \mathrm{~m})$ below TOC

Waler elevation: $218.05 \mathrm{ft}(66.4$
$\mathrm{H}$ : 4.2
$\mathrm{Sp}$. conductance: $100 \mu \mathrm{S} / \mathrm{cm}$

Water evacuated from the well prior to sampling: $1 \mathrm{ga}$ The well went dry during purging.

ANALYSES

\begin{tabular}{|c|c|c|c|c|c|c|c|c|}
\hline Analyto & Result & $F G$ & $s$ & EMS & SQL & Unt & Lab & Method \\
\hline $\begin{array}{l}\text { Aluminum, total recoverable } \\
\text { Cadmium, total recoverable } \\
\text { fron, lotal recoverable } \\
\text { Lead, total recoverable } \\
\text { Nitrale-nitrite as nitrogen } \\
\text { pH } \\
\text { Specilic conductance } \\
\text { Gross alpha } \\
\text { Nonvolatle beta } \\
\text { Tritium }\end{array}$ & $\begin{array}{l}197 \\
<1.00 \\
386 \\
3.87 \\
77.350 \\
4.97 \\
87.2 \\
4.74 E-09 \pm 9.36 E-10 \\
6.43 E-09 \pm 8.64 E-10 \\
3.59 E-05 \pm 1.16 E-06\end{array}$ & J & Q & 1 & $\begin{array}{l}15.0 \\
1.00 \\
25.0 \\
2.00 \\
250 \\
0.100 \\
1.00 \\
7.04 E-10 \\
1.06-09 \\
6.59 E-07\end{array}$ & 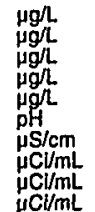 & $\begin{array}{l}G E \\
G E \\
G E \\
G E \\
G E \\
G E \\
G E \\
G P \\
G P \\
G P\end{array}$ & $\begin{array}{l}\text { EPA6020 } \\
\text { EPAG020 } \\
\text { EPAG020 } \\
\text { EPACO20 } \\
\text { EPA353.1 } \\
\text { EPA9040B } \\
\text { EPA9050A } \\
\text { EPPA.001 } \\
\text { EPIA.001 } \\
\text { EPIA.002 }\end{array}$ \\
\hline
\end{tabular}

\section{WELL FSL 9D}

MEASUREMENTS CONDUCTED IN THE FIELD

Sample date: $04 / 07 / 99$

Water elevation: $216.87 \mathrm{tt}(66.1 \mathrm{~m}) \mathrm{ms}$

pH: 3.8

sp. conductance: $340 \mu \mathrm{S} / \mathrm{cm}$

Water evacuated from the well prior to sampling: $1 \mathrm{gal}$ The well went dry during purging.

ANALYSES

\begin{tabular}{|c|c|c|c|c|c|c|c|c|}
\hline Analyte & Result & $F G$ & $\mathbf{s}$ & EMS & SOL & Unit & Lab & Method \\
\hline $\begin{array}{l}\text { Aluminum, total recoverable } \\
\text { Cadmilum, total recoverable } \\
\text { lron, total recoverable } \\
\text { Lead, total recoverable } \\
\text { Nitrale-nitrite as nilrogen } \\
\text { pH } \\
\text { Specific conductance } \\
\text { Gross alpha } \\
\text { Nonvolancotile beta } \\
\text { Tritium }\end{array}$ & $\begin{array}{l}5.840 \\
<0.488 \\
239 \\
1.30 \\
39.300 \\
4.11 \\
390 \\
2.14 \mathrm{E} \cdot 07 \pm 7.18 \mathrm{E} \cdot 09 \\
3.10 \mathrm{E} \cdot 07 \pm 5.08 \mathrm{E} .09 \\
1.35 \mathrm{E} \cdot 03 \pm 2.62 \mathrm{E}-05\end{array}$ & $\begin{array}{l}\mathrm{JU} \\
\mathbf{J} \\
\mathrm{J}\end{array}$ & 0 & $\begin{array}{l}4 \\
1\end{array}$ & $\begin{array}{l}15.0 \\
1.00 \\
25.0 \\
2.00 \\
1.250 \\
0.100 \\
1.00 \\
8.80 \mathrm{E}-10 \\
1.05 \mathrm{E}-09 \\
2.83 \mathrm{E}-06\end{array}$ & 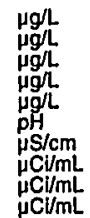 & $\begin{array}{l}G E \\
G G E \\
G E \\
G E \\
G E \\
G E \\
G E \\
G E \\
G P \\
G P \\
G P\end{array}$ & $\begin{array}{l}\text { EPAG020 } \\
\text { EPAG020 } \\
\text { EPA6020 } \\
\text { EPAG020 } \\
\text { EPA335.1 } \\
\text { EPA900B } \\
\text { EPA9050A } \\
\text { EPA.001 } \\
\text { EPAA.001 } \\
\text { EPIA.002 }\end{array}$ \\
\hline
\end{tabular}

\section{WELL HHP 10}

MEASUREMENTS CONDUCTED IN THE FIELD

Sample date: 06/09/99

Depth to water: $6.14 \mathrm{ft}(1.87 \mathrm{~m})$ below TOC

$\mathrm{pH}: 6$

. conductance: $170 \mu \mathrm{S} / \mathrm{cm}$

Water evacuated from the well prior to sampling: $13 \mathrm{gat}$

ANALYSES

F Analyte

- Aluminum, total recoverable

Arsenic, tolal recoverable

Barium, total recoverable

Result
$<146$
$<146$
$<40.0$
$<40.0$
29.4
30.4

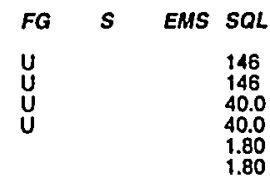

Time: 10:42

perature: $20.4^{\circ} \mathrm{C}$

Total alkalinity.(as CaCO3): $53 \mathrm{mg} \Omega$

Phenolphthalein alkalinity: $0 \mathrm{mg} h$

ter temperature: $23.9^{\circ} \mathrm{C}$ lotal alkalinity (as CaCO3): $0 \mathrm{mg} / \mathrm{l}$ Phenolphthalein alkalinity: $0 \mathrm{mg} /$ Field Qualifier(s): VX

ESH-EMS-990521
Well HHP 10 collected on 06/09/99 (cont.)

F Analyto Rosult

O Boron, lotal recoverable

Cadmium, rotal recoverable

Calclum, total recoverab

- Calclum, tolal recovo

0 Chloride

Chromium, lotal recoverable

Cis-12.Dic

o Fluoride

2 Iron, total recoverable

Lead, tolal recoverable

L Lthium, total recoverable

- Lithium, rotal recoverable

, lotal recoverable

Manganese, total recoverable

Mercury, tolal recoverablo

- Potasslum, lotal recoverable

Solassium, total recoverable

um, total recoverab

Silica, total recoverable

Silver, lotal recoverable

Sodium, tolal recoverablo

Sodium, total recoverablo

Sulfale

Tetrachloroethylene

Total organle carbon

Total organic halogens

1.1.1-Trichloroethane

Gross alpha

Nonsolatile ba

O Nonvolatile bela

O Trilium

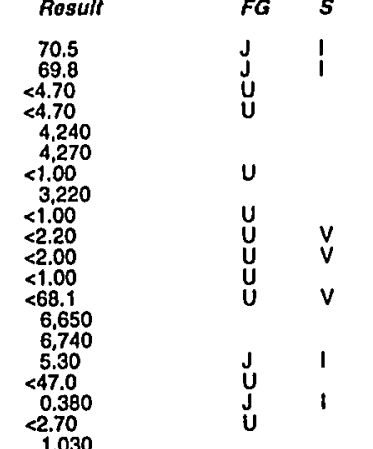

SOL UnIt LSD

WELL HHP 2D

MEASUREMENTS CONDUCTED IN THE FIELD

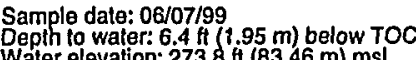

Water

$\mathrm{H}: 6$ : 6 onductance: $165 \mu \mathrm{S} / \mathrm{cm}$

Water evacuated from the well prior to sampling: $18 \mathrm{gal}$

ANALYSES

$\begin{array}{llc}\text { F } & \text { Analyto } & \text { Result } \\ 0 & \text { Aluminum, total recoverable } & <18.0 \\ 0 & \text { Arsenlc, lotal recoverable } & <40.0 \\ 0 & \text { Barium, total recoverable } & 8.00 \\ 0 & \text { Boron, total recoverable } & 66.3 \\ 0 & \text { Cadmium, otal recoverable } & <4.70 \\ 0 & \text { Calcium, folal recoverable } & 3,120 \\ 0 & \text { Carbon ietrachloride } & <1.00 \\ 0 & \text { Chloride } & 3.170 \\ 0 & \text { Chlorolorm } & <1.00 \\ 0 & \text { Chromium, tolal recoverable } & <7.00 \\ 0 & \text { cis-1,2-Dichloroethylene } & <1.00 \\ 0 & \text { Fluoride } & <43.7\end{array}$

B-122

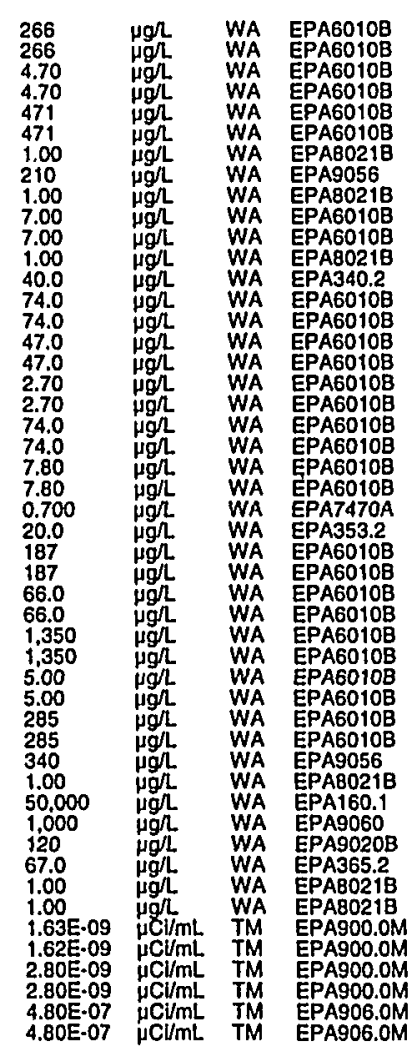

Time: 14:29

Waler temperature: $19.4^{\circ} \mathrm{C}$

Total alkalinity (as CaCO3): $59 \mathrm{mg} /$.

Phenolphthalein alkalinity: $0 \mathrm{mg} \mathrm{L}^{\prime}$

$\begin{array}{lll}\text { FG } & \text { S } & \text { EMS SO } \\ U & V & 146 \\ U & & 40.0 \\ J & 1 & 1.80 \\ U & & 4.70 \\ U & & 471 \\ U & & 1.00 \\ U & & 1.00 \\ U & & 7.00 \\ U & V & 4.00\end{array}$

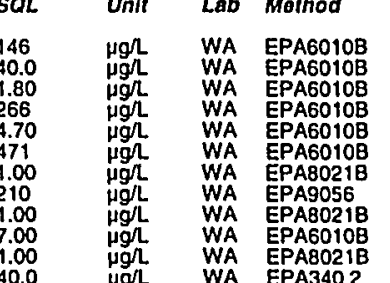

Second Quartor 1999 
Well HHP 2D collected on 06/07/99 (cont.)

$F$ Analyte Result

2 Iron, total recoverable Lithlum, lotal recoverable Mannesium, tolal recoverable Nitrate-nitrite as nitrogen Solenium, total recoverable Silver, total recoverable Sodium, total recoverable Tetrachloroethylene Tolal dissolved solids Total organic halogens 1, 1.-Trichloroethane Gross alpha

${ }_{0}$ Nonvolatile bela

\section{WELL HIN600TK}

MEASUREMENTS CONDUCTED IN THE FIELLD

Sample date: 04/08/99

Wepth to water: Not available

$\mathrm{pH}: 4$. conductance: $160 \mu \mathrm{S} / \mathrm{cm}$

The well was continuously pumping.

ANALYSES

$F$ Analyte

2 Aluminum, total recoverable Antimony, lotal recoverable Bartum, tolal recoverablo

Beryllium, total recoverable Bis(2.ethylhexyl) phthalate Bromolorm Gromomethane Carbon ietrachlorido Chlorobenzene

Chloroethene (Vinyl chloride) Chlorolorm

Chroromethane Copper, total recoverable

Dyanide 1,2-Dichloroethane

trans-1,2-Dichloroethylene Dichloromethane 1,2-Dichloropropane Elhyibenzene
Iron total recoverable Lead, lotal recoverable

Result
54.2
50.24
$<0.00$
$<1.31$
$<1.00$
$<1.00$
$<10$.
$<1.00$
$<1.00$
41.00
$<1.00$
262
$<1.00$
$<1.00$
$<1.00$
$<1.00$
$<5.00$
$<1.00$
$<1.00$
$<1.33$
$<0.779$
$<2.27$
$<10.0$
$<1.00$
$<1.00$
$<1.00$
$<1.00$
$<1.00$
5.00
$<1.00$
$<1.00$
$<1.00$
$<4.00$
46.6
$<0.423$
90.7
18.4

\begin{tabular}{|c|c|}
\hline $\begin{array}{c}10,600 \\
<47.0 \\
<2.70 \\
939 \\
519 \\
<0.700 \\
<20.0 \\
2.010 \\
<66.0 \\
3,110 \\
<5.00 \\
22.000 \\
17.000 \\
<1.00 \\
100.000 \\
109.000 \\
4.470 \\
<120 \\
20.9 \\
<1.00 \\
<1.00 \\
1.19 \mathrm{E}-0.0 \\
4.35 \mathrm{E} .0 \\
5.01 \mathrm{E} \cdot 0\end{array}$ & 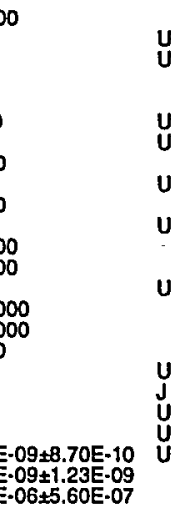 \\
\hline
\end{tabular}

Unit

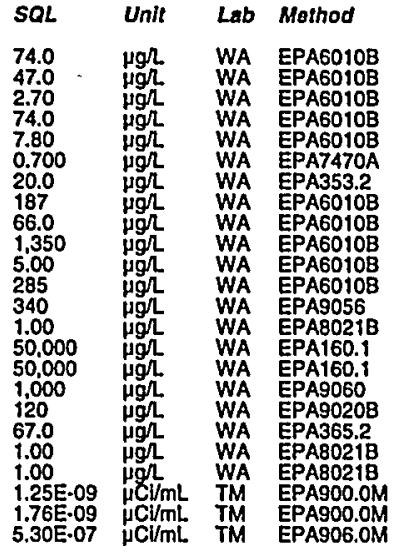

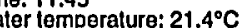
Total akalinity (as Cacos): $0 \mathrm{mgh}$
Well HINGOOTK collecled on 04/08/99 (cont.)

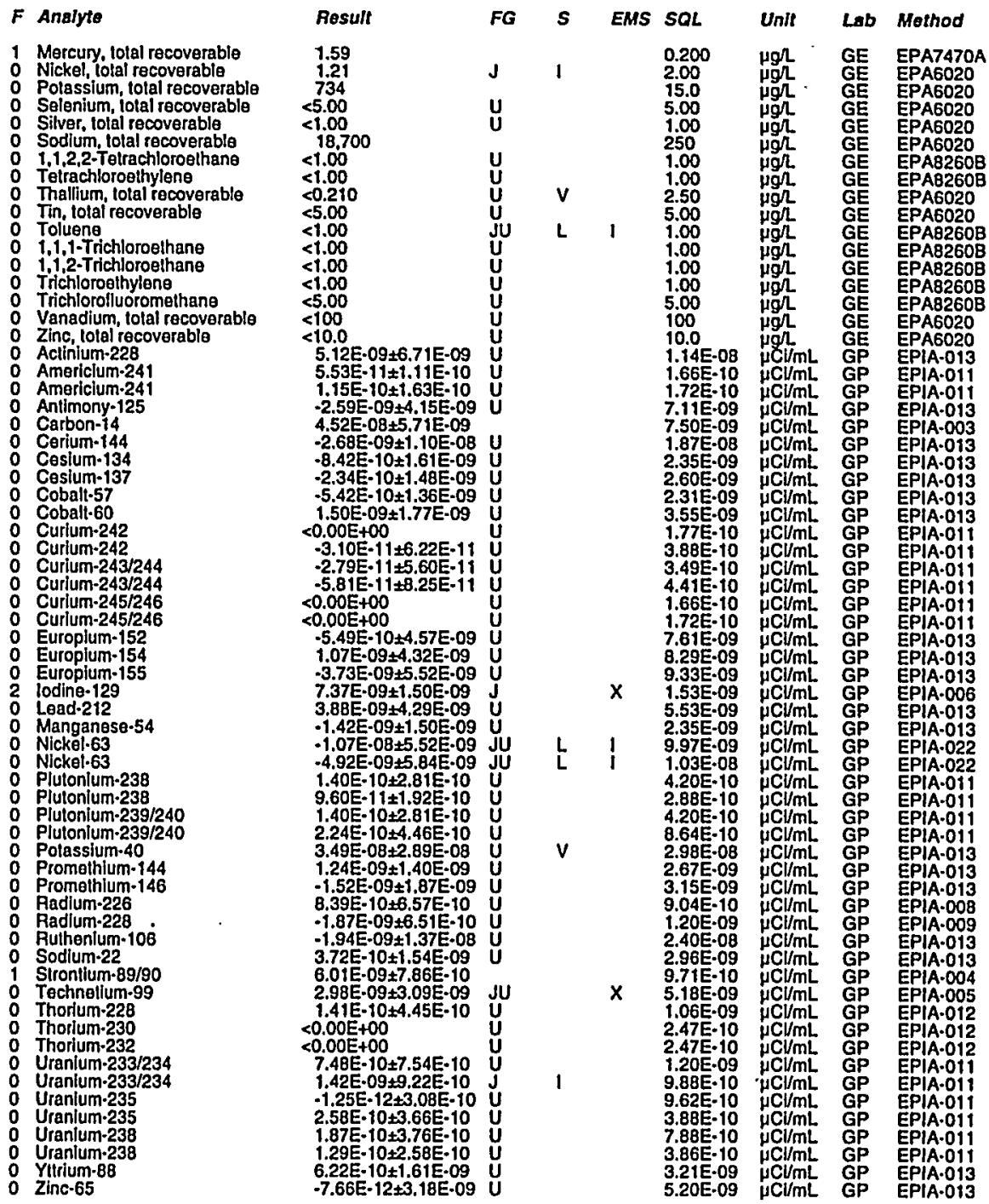


WELL HIN600TK

MEASUREMENTS CONDUCTED IN THE FIELD

Sample date: 05/11/99

Waler elevation: Not available

$\mathrm{pH}: 3.9$

Sp. conductance: $130 \mu \mathrm{S} / \mathrm{cm}$

The wefl was continuously pumping.

ANALYSES

$F$ Analyto

Rosult

- Aluminum, total recoverable

o Arsenlc, total recoverable

Barium, total recoverable

$\begin{array}{ll}0 & \text { Benzene } \\ 0 & \text { Bls(2-ethylhexyl) phthalate }\end{array}$

Gromodich

Bromomethane

Carbon tetrachlorid

Chloroethane

Chloroelthene (Vinyl chloride)
2-Chloroethyl vinyl ether

Chlorolorm

Chromium, tolal recoverable

O Cobalt, total recoverable

o Copper,

Dibromochloromethane

1,1-Dichloroethane

1, 1-Dichloroethylene

Irans-1,2-Dichioroethylene

1,2-Dichloropropan

cis-1,3-Dichloropropene
0
trans-1,3-Dichloropropene
Ethylbenzene

Iron, total recoverable

1 Mercury, lotal recoverable

Selentum lotal recoverab

S Silver, total rocoverable

o Totrachloroethylene

o Tin, total recoverable

1,1,1-Trichloroethane

Trichloroethylene

Trichlorofluoromethane
Vanadium, total recoverable

Zinc, total recoverable

Actinium-228

Americicium-241

Antimony-125

Carbon-14

Cerium-144

Cesium-134

C Cesium-137

0 Coball-60

ESH-EMS-990521
Well HINGOOTK collected on 05/1 1/99 (cont.)

$F$ Analyto

FG $S$ EMS SQL Unit Lab Method

Cobalt.60

Time: 9:30

Water temperature: $23.2^{\circ} \mathrm{C}$

Air temperature: $17.9^{\circ} \mathrm{C}$ ) $0 \mathrm{mg} /$

Curium-242

Curium-243/244

Curium-245/246
Curium.245/246

Eurium-245/246

Europium-152

0 Europlum-154

Europlum-155

2 lodini-129

0 Lead-212

0 Manganese-54

0 Nickel-63

o Nickel-63

Plutonium-239/240

Plutonlum.239/240

Potasslum-40

Promethium-144

Promethium-146

o Radium-226

Radium-228

Ruthenlum-106

0 Sodium-22

Stronllium-89/90

Stronilum-89/90

0 Technetlum-99

0 Thorlum-228

0 Thorium-230

Uranium-233/234

O Uranium-235

0 Uranium-235

0 Uranlum-238

Y Ytrium-88

0 Yitrium-8

0 .inc.65

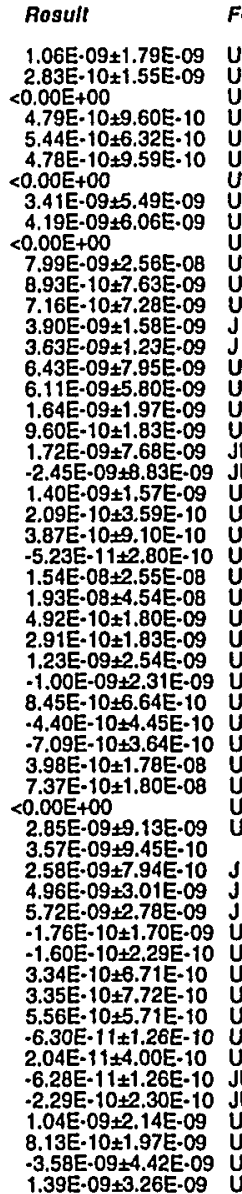

\section{WELL HIN600TK}

MEASUREMENTS CONDUCTED IN THE FIELD

Sample date: 06/16/99

Wepth to water: Nol available

$\mathrm{pH}: 4.8$

Sp. conductance: $130 \mu \mathrm{S} / \mathrm{cm}$

The woll was continuously pumping.

ANALYSES

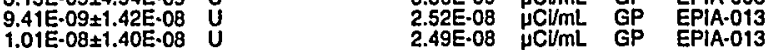

$-6.28 E-10 \pm 2.28 E-09$

$-1.51 E-09+2.04 E-09$

$3.38 \mathrm{E}-10 \pm 1.98 \mathrm{E}-09$
$5.12 \mathrm{E}-10 \pm 1.71 \mathrm{E}-09$

$7.57 \mathrm{E} \cdot 10 \pm 2.21 \mathrm{E} \cdot 09 \mathrm{U}$

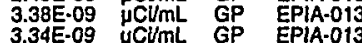

$3.01 \mathrm{E}-09$

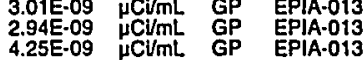

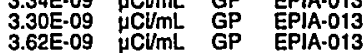

F Analyte Result

Aluminum, total recoverable

Anlimony, rotal recoverablo

Arsenic, lotal recoverable

Bis(2-ethylhexyl) phthatate
48.1
$<.00$
0.55

$\begin{aligned} & 0.700 \\ &< 1.00 \\ &<10.0\end{aligned}$

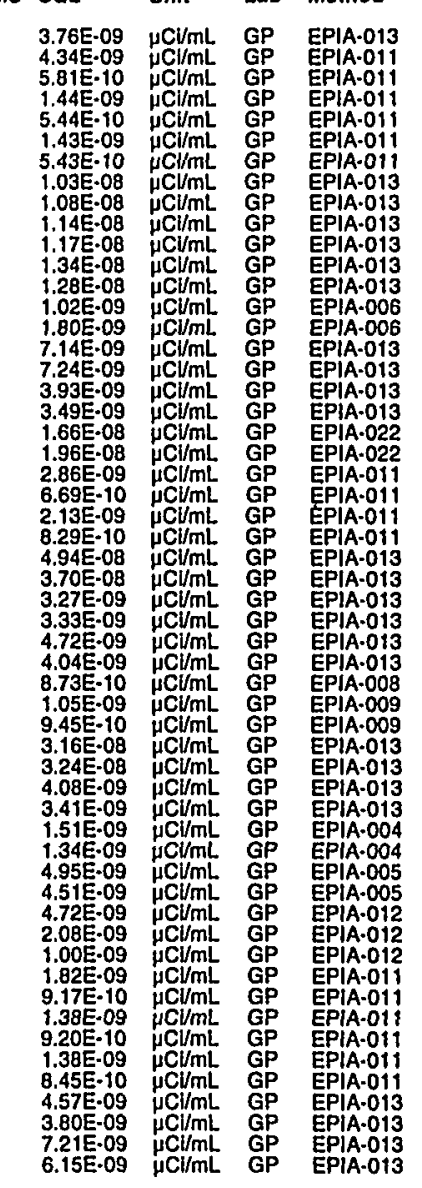

Time: 8:30

Total alkalinity (as CaCO3): $0 \mathrm{mg} / \mathrm{L}$
Phenolphthalein alkalinity: $0 \mathrm{mg} L$
Water temperature: $21.4^{\circ} \mathrm{C}$ $\begin{array}{llrr}\text { FG } & \text { S } & \text { EMS SOL } \\ & & & 15.0 \\ U & & & 2.00 \\ J & 1 & & 3.00 \\ J & 1 & & 2.00 \\ J U & L & \circ & 1.00 \\ J U & \text { LQ } & \text { OX } & 10.0\end{array}$ $\begin{array}{lll}\text { Unlt } & \text { Lab } & \text { Mothod } \\ \mu g h & \text { GE } & \text { EPAG020 } \\ \mu g h & \text { GE } & \text { EPA6020 } \\ \mu g / & \text { GE } & \text { EPAG020 } \\ \mu g h & \text { GE } & \text { EPAG020 } \\ \mu g h & \text { GE } & \text { EPAB2608 } \\ \mu g h & \text { GE } & \text { EPAB270C }\end{array}$

Second Quarter 1999 
Well HINGOOTK collected on 06/16/99 (cont.)

F Analyte

0 Bromodichloromethane

Bromomethan

Cadmium. total recoverable

Chlorobenzene

Chloroethene (Vinyl chloride)

Chiorolorm

Chroromethane

Copper, total recoverable

Cyanide

Dibromochloromethan
1.t.-Dichloroothane
i. D. Dichloroethane

1.2-Dichloroeshane

Irans-1,2-Dichloroethylene 1,2-Dichloropropan irans-1,3-Dichloropropene Elhylbenzene Lead, cotal recoverable Nickel, total recoverable Silver, total recoverable Silver, total recoverable Thallium, total recoverable Tin, tota

\$1, 2-Trichloroethane Trichloroeshylene Vanadium, tolal recoverab Zinc, lotal recoverab
Actinium-228

Actinium-228

Americium-241

Antimony-125

Carbon:14

Cerium-144

Cosium-134

Oesium-137

o Coball.57

Coball-60

O Curlum.242

C Curium-243/244

Curium-245/246

Europium.152

Europlum.15a

Europium-154

Europium.15

2 lodine-129

Manganese-54

ESH-EMS-990521

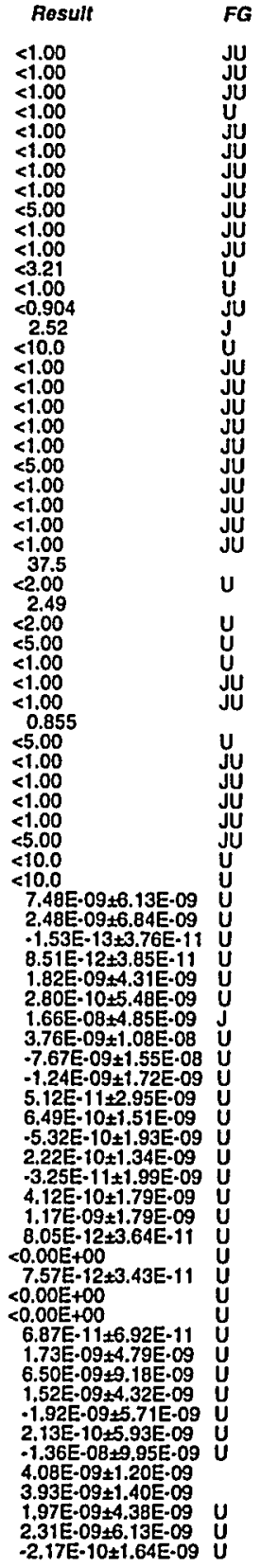

Ju

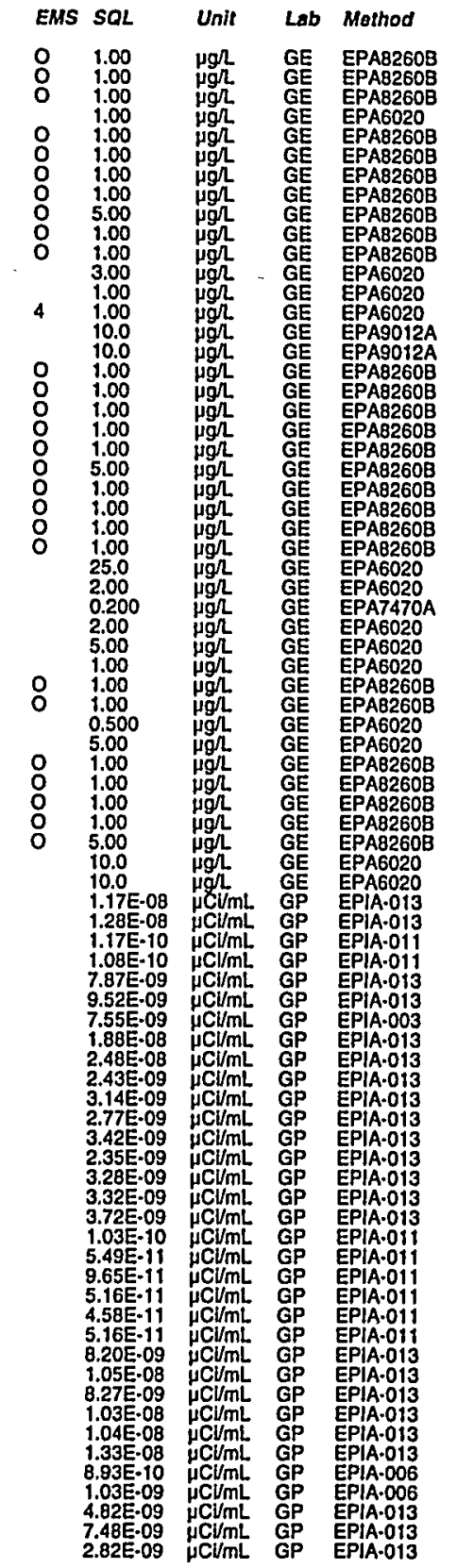

Well HINGOOTK collected on 06/16/99 (cont.)

$F$ Analyte

0 Nickel-63

0 Plutonium-238

o Plutonilum-233/240

o Polassium-40

0 Promelhlum-144

Promelhlum-14

1 Radium-22

00 Radium-228

0 Ruthenium-106

O) Sodlum-22

0 Sirontium-89/90

0 Sirontium-89/90

: Technetium-99

0 Thorium-22

Thorium-230

Thorium-232

o Uranlum.233/234

0 Uranlum-233/235

: Uranlum-235

: Uranlum-23日

0
0
0
0

WELL HR3 14DU

FG $S$ EMS SaL Unit" Lab Method

MEASUAEMENTS CONDUCTED IN THE FIELD

Sample date: 06/03/99

Wh: 4.6

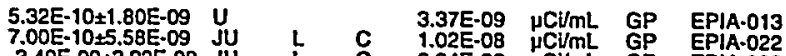

C 6.04E.09 HCi'mL GP EPIA.022

$5.03 E-11+6.99 E-11$
$-9.31 E-12+9.31 E-11$

$9.30 E-12 \pm 4.93 E-11$

$4.57 E-09+2.878-08$
$3.572 .18 E-08$

$-7.65 \mathrm{E}-10 \pm 1.78 \mathrm{E}-09 \mathrm{O}$

$5.91 E-10 \pm 1.91 E-09$

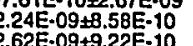

$1.95 E-10+5.63 E-10$
$3.11 E-10 \pm 5.99 E-10$

-6.46 - $09+1.70 \mathrm{E}-08$

$5.47 E \cdot 10 \pm 1.54 E-09$

$-5.05 E-10 \pm 7.84 E-10 \mathrm{U}$

$1.87 E-08 \pm 4.06 E-09$

$1.30 \mathrm{E}-10 \pm 1.61 \mathrm{E} \cdot 10$

$-7.63 E-11+1.38 E-10$

$1.25 \mathrm{E}-11+6.86 \mathrm{E}-11$

$-2.15 E-11 \pm 2.18 E-11$
$-1.23 E-11 \pm 1.76-11$

$9.66 E-1177.87 E-11$ U

$2.34 \mathrm{E}-11 \pm 4.38 \mathrm{E}-11$

$4.05 E-1144.70 E-11$
$7.38 E-11 \pm 6$

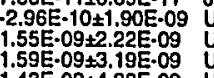

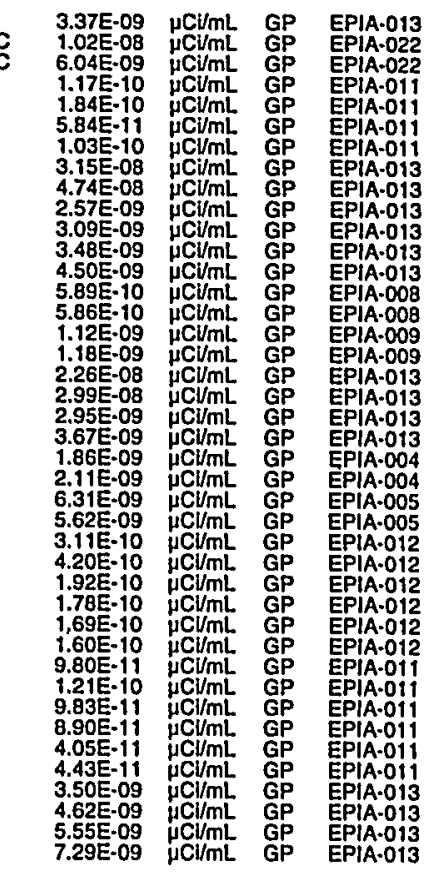

Waler temperature: $19.4^{\circ} \mathrm{C}$ Total alkalinily.(as CaCO3): $0 \mathrm{mg} /$

Surbldity: $14 \mathrm{NTO}$ ( $400 \mu \mathrm{S} / \mathrm{cm}$

Water evacuated from the well prior to sampling: 1 gal ANALYSES

Anumo

Rosult -

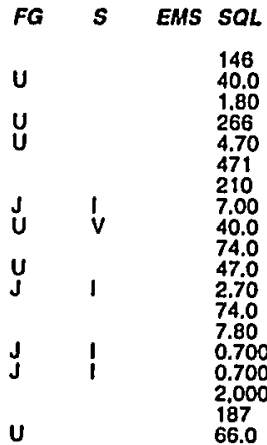
Phenolphthalein alkalinity: $0 \mathrm{mg}$

Barlum, lotal recoverablo

Coron, total recoverable

Calclum, total recoverable

Chromium, total recoverable

Iron, lotal recoverable

Lithlum, total recoverable Magnesium, total recoverable Mercury, total recoverable Nitrale-nitrite as nitrogen
Polassium, lotal recoverablo Selenlum, total recoverable

B-125

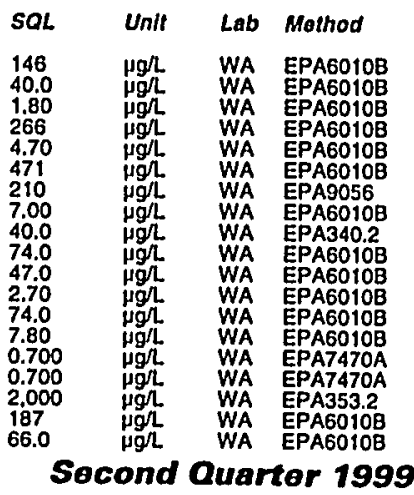




\section{WELL HSB 67}

MEASUREMENTS CONDUCTED IN THE FIELD

Sample date: 04/12/99 列 Sp. conductance: $120 \mu \mathrm{S} / \mathrm{cm}$

Water evacuated from the well prior to sampling: $23 \mathrm{ga}$ ANALYSES

F Analyto

2 Mercury, tolal recoverable

$\mathrm{pH}$-nitrite as nitrogen

0 Specilic conduct
2 Gross alpha

2 Nonnolatile bet

\section{WELL. HSB 68}

MEASUREMENTS CONDUCTED IN THE FIELD

Sample dato: $04 / 12$ (9)

Depth lo waler: $31.36 \mathrm{ft}(9.56 \mathrm{~m})$ below TOC

Water eleval

Sp. conductance: $110 \mu \mathrm{S} / \mathrm{cm}$

Water evacuated from the well prior to sampling: $9 \mathrm{gal}$

ANALYSES

F Analyto

2 Mercury, lotal recoverable

0 Specific conductance

Gross alpha

2 Tritium

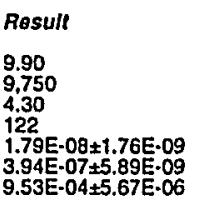

WELL HSB 68A

MEASUREMENTS CONDUCTED IN THE FIELD

Sample date: 04/15/99 $23.46 \mathrm{~m})$ below TOC Water elevalion: $172.42 \mathrm{ft}(52.55 \mathrm{~m}) \mathrm{msl}$

$\mathrm{gH}: 6.5$ conductance: $120 \mu \mathrm{S} / \mathrm{cm}$

Water evacuated Irom the well prior to sampling: $185 \mathrm{ga}$

ANALYSES

$F$ Analyto

Mercury, total recoverable

phecillc conductance

Nonvolatile beta

0 Tritium

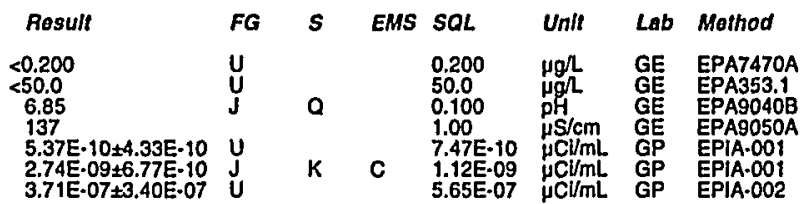

Unth Lab Mothod

0.200 Ual

WELL HSB 68B

MEASUREMENTS CONDUCTED IN THE FIELD

Sample date: 04/15/99

Depth to waler. $34.28 \mathrm{ft}(10.45 \mathrm{~m})$ below TOC

Waler el

emperalure: $19.4^{\circ} \mathrm{C}$ Air temperature: $26.7^{\circ} \mathrm{C}$ ) $0 \mathrm{mg}$ Phenolphinalein alkalinity: $0 \mathrm{mgh}$

Sp. conductance: $210 \mu \mathrm{S} / \mathrm{cm}$

Water evacuated from the well prior to sainpling: $138 \mathrm{gal}$

ANALYSES

$F$ Analyto

Norcury, total recoverable

$0 \mathrm{pH}$

Specific conductance

Nonvolatile beta $1.02 E-09 \quad \mu \mathrm{CV} / \mathrm{mL}$ GP EPIA.00

\section{WELL HSB 68C}

Time: $13: 00$

Water temperature: $21.3^{\circ} \mathrm{C}$

Total alkalinity (as CaCo3): $0 \mathrm{mg} / \mathrm{L}$

Phenolphthalein alkalinity: $0 \mathrm{mg}$ L
Field Qualifier(s): $\vee$

MEASUREMENTS COND

Sample date: 04/26/99

Weptow TOC

W: 5.4

Sp. conductance: $150 \mu \mathrm{S} / \mathrm{cm}$

Waler evacualed from the well prior to sampling: $1 \mathrm{gal}$

ANALYSES

$F$ Analyto

\begin{tabular}{|c|c|c|c|}
\hline $\begin{array}{l}0.200 \\
250 \\
0.100 \\
1.00 \\
8.98 E-10 \\
1.21 E-09 \\
6.37 E \cdot 07\end{array}$ & 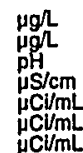 & $\begin{array}{l}\mathrm{GE} \\
\mathrm{GE} \\
\mathrm{GE} \\
\mathrm{GE} \\
\mathrm{GP} \\
\mathrm{GP} \\
\mathrm{GP}\end{array}$ & $\begin{array}{l}\text { EPA7470A } \\
\text { EPA353.1 } \\
\text { EPA9040 } \\
\text { EPA9050A } \\
\text { EPA.001 } \\
\text { EPA.01 } \\
\text { EPA.001 }\end{array}$ \\
\hline
\end{tabular}

2 Mercury, total recoverable

0 oH

Gross alpha

2 Trittum

\section{WELL HSB 69}

Time: 9:04 Arr temperature: $19.2^{\circ} \mathrm{C}$ Colal $45 \mathrm{mg} /$ Phenolphthalein alkalinity: $0 \mathrm{mg} /$

MEASUREMENTS CONDUCTED IN THE FIELD

Sample date: 04/12/99
Oepth to wal $1.01: 19.25 \mathrm{ft}(5.87 \mathrm{~m})$ below TOC
Wel

$\mathrm{HH}: 4.4$

Sp. conductance: $46 \mu \mathrm{S} / \mathrm{cm}$

Water evacualed from the well prior to sampling: $30 \mathrm{gal}$

ANALYSES

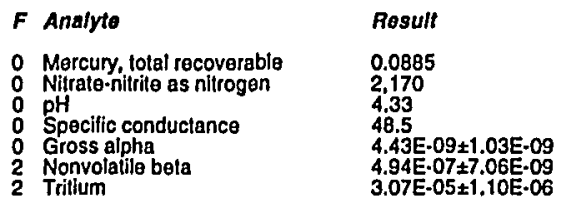

Time: 10:05 Tit $20.1^{\circ} \mathrm{C}$ Total alkainity (as CaCO3): $100 \mathrm{mg} / \mathrm{L}$ Phenolphinalein a

Waler temperalure: $20.4^{\circ} \mathrm{C}$ Total alkalinity (as CaCO3): $8 \mathrm{mg}$ / Phenolphthalein alkalinity: $0 \mathrm{mg}$.

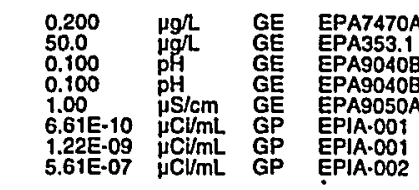




\section{WELL HSB 69A}

MEASUREMENTS CONDUCTED IN THE FIELD

Sample date: 04/15/99
Depth to waler: $63.9 \mathrm{Ht}(19.48 \mathrm{~m})$ below TOC
Waler olevation: $172.7 \mathrm{~h}(52.64 \mathrm{~m}) \mathrm{ms}$
pH: 6.2

Sp: conductance: $100 \mu \mathrm{S} / \mathrm{cm}$

ANALYSES

$F$ Analyto

Nitrate-nitrile as nitrogen

0 Specilic conductance

Gross alpha

0 Tritum

\section{WELL HSB 70}

MEASUREMENTS CONDUCTED IN THE FIELD

Depth to water: $18.88 \mathrm{ft}(5.75 \mathrm{~m})$ below
Water elevation: $223.92 \mathrm{t}(68.25 \mathrm{~m}) \mathrm{ms}$

Sp: 4.6 conductance: $56 \mu \mathrm{S} / \mathrm{cm}$

Water evacuated from the well prior to sampling: $67 \mathrm{gal}$

ANALYSES

$F$ Angivto

O Mercury, total recoverable

$\mathrm{pH}$

Specific conductance
Specilic conductance

Gross alpha

2 Tritium

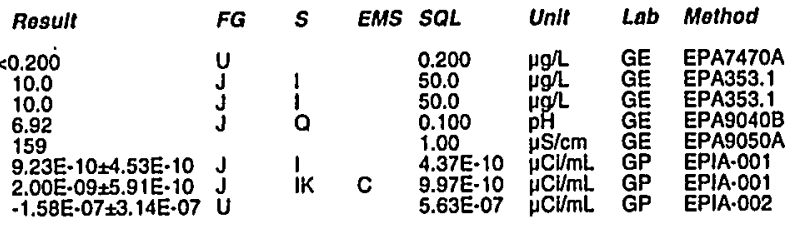

Time: 12:16

Water temperature: $20.1{ }^{\circ} \mathrm{C}$

Total alkalinity (as CaCo3): $53 \mathrm{mg} /$

Phenolphinalein alkalinily: $0 \mathrm{mg} / \mathrm{L}$

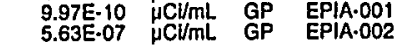

\section{WELL HSB 70C}

MEASUREMENTS CONDUCTED IN THE FIELD

Sample date: 04/26/99 0 Depth to waler: $23.55 \mathrm{f}(7.18 \mathrm{~m})$ below TOC

Deph to waler: $23.55 \mathrm{ft}(7.18 \mathrm{~m})$ below
Water elevalion: $219.55 \mathrm{ft}(66.92 \mathrm{~m}) \mathrm{ms}$

PH: 8.7 .

Sp. conductance: $400 \mu \mathrm{S} / \mathrm{cm}$

Water evacuated from the well prior to sampling: $1 \mathrm{gal}$ The well went dry during purging.

ANALYSES

$F$ Analyto

1 phecific conductance

2 Nonvolatile bela

2 Tritium

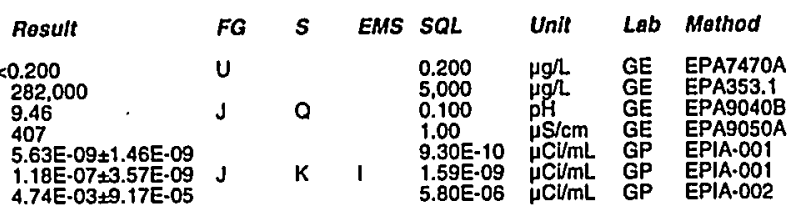

Time: $12: 16$

Total alkalinity (as Cacos): $7 \mathrm{mg} / \mathrm{L}$

Phenolphithalein alkalinity: $0 \mathrm{mg} L$
Field Qualifier(s): $\mathrm{S}$

\begin{tabular}{|c|c|c|c|c|c|c|c|}
\hline \multirow{4}{*}{$\begin{array}{l}\text { Result } \\
<0.200 \\
400 \\
5.37 \\
65.2 \\
65.6 \\
9.34 E-10 \pm 5.13 E-10 \\
9.71 E-09 \pm 1.18 E-09\end{array}$} & $F G$ & & MS & $S Q L$ & \multirow{4}{*}{$\begin{array}{l}\text { Unit } \\
\mu g / 2 \\
\mu g / \mathrm{L} \\
\mathrm{pH} \\
\mu \mathrm{S} / \mathrm{cm} \\
\mu \mathrm{S} / \mathrm{cm} \\
\mu \mathrm{Cl} / \mathrm{m} \\
\mu \mathrm{C} / \mathrm{m} \\
\mu \mathrm{C} / \mathrm{ml}\end{array}$} & \multirow{4}{*}{$\begin{array}{l}\text { Lab } \\
\mathrm{GE} \\
\mathrm{GE} \\
\mathrm{GE} \\
\mathrm{GE} \\
\mathrm{GE} \\
\mathrm{GP} \\
\mathrm{GP}\end{array}$} & \multirow{4}{*}{$\begin{array}{l}\text { Method } \\
\text { EPA7470A } \\
\text { EPA35.1 } \\
\text { EPA9040B } \\
\text { EPA950A } \\
\text { EPA9050A } \\
\text { EPAA-001 } \\
\text { EPIA-001 } \\
\text { EPIA.002 }\end{array}$} \\
\hline & $\mathbf{u}$ & & & & & & \\
\hline & J & & & & & & \\
\hline & $\mathbf{J}$ & & & & & & \\
\hline
\end{tabular}

Time: 11:10

: $18.6^{\circ} \mathrm{C}$ Total alkalinity (as CaCO3): $25 \mathrm{mg} / \mathrm{l}$ Phenolphthalein alkalinity: $0 \mathrm{mg} / \mathrm{L}$ $5.80 \mathrm{E}-06 \quad \mu \mathrm{C} / \mathrm{mL}$ GP EPIA.002
Waler ovacualed from the well prior to sampling: $167 \mathrm{gal}$

0 Mercury, total rocoverable

Sample date: 04/16/99

2 Mercury, total recoverable

\section{WELL HSB 71}

MEASUREMENTS CONDUCTED IN THE FIELD

Sample date: 04/26/99

Depth to water: $25.23 \mathrm{Ht}(7.69 \mathrm{~m})$ below TOC

Water e

p. conductance: $30 \mu \mathrm{S} / \mathrm{cm}$

Water evacuated from the well prior to sampling: $42 \mathrm{gal}$ ANALYSES

$F$ Analyte

${ }_{0}^{0}$ Mercury, lotal recoverable

$\mathrm{pH}$ Specific conductance

Gross alpha

2 Tilfium

\section{WELL HSB 71C}

MEASUREMENTS CONDUCTED IN THE FIELD

Sample date: $04 / 26 / 99$

$22.26 \mathrm{ft}(6.78 \mathrm{~m})$ below TOC

p. conductance: $270 \mu \mathrm{S} / \mathrm{cm}$

Water evacuated from the well prior to sampling: $1 \mathrm{gal}$ the well went dry during purging.

ANALYSES

$F$ Analyte

Mercury, total recoverable

pH
Specilic conductance

Nonvolatilie bela

2 Trillum

\section{WELL HSB 83A}

MEASUREMENTS CONDUCTED IN THE FIELD

Sample date: 04/19/99

列

Water eleval
pH: 7.1

p. conductance: $170 \mu \mathrm{S} / \mathrm{cm}$

Water evacualed from the well prior to sampling: $174 \mathrm{gal}$

ANALYSES

\section{F Analyte}

- Mercury, lotal recoverable

Mercury, total recoverable

Nitrate-nitrite as nitrogen

${ }_{0}^{0} \mathrm{pH}$

\section{Specilic conductance}

Specific conductance

Gross alpha

Gross alpha

0 Nonvolatilie beta

Result
0.0564
18.500
6.49
202
$5.93 \mathrm{E} \cdot 09+1.30 \mathrm{E} \cdot 09$
$3.59 \mathrm{E} \cdot 08+1.98 \mathrm{E} \cdot 09$
$1.92 \mathrm{E}-03 \pm 3.70 \mathrm{E} \cdot 05$

Time: 10:44

Water temperalure: $19.4^{\circ} \mathrm{C}$

Air temperalure: $20.5^{\circ} \mathrm{C}$ (al alkalinity (as CaCO3): $2 \mathrm{mg} /$

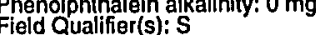

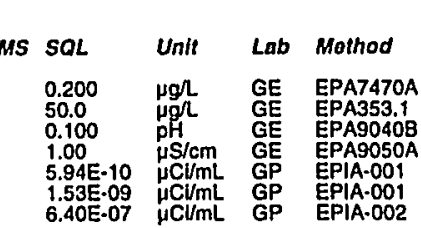

Time: 10:50

Water temperalure: $20^{\circ} \mathrm{C}$

Total alkalinity (as CaCO3): $39 \mathrm{mg} / \mathrm{L}$

Phonolphthalein alkalinity: $24 \mathrm{mg}$

\begin{tabular}{|c|c|c|c|}
\hline$s$ & EMS & SQL & Untt \\
\hline I & & 0.200 & L \\
\hline 0 & & $\begin{array}{l}0.100 \\
1.00\end{array}$ & $\mathrm{pH} / \mathrm{cm}$ \\
\hline$\kappa$ & 1 & $\begin{array}{l}1.44 \mathrm{E}-09 \\
3.42 \mathrm{E}-06\end{array}$ & $\begin{array}{l}\mu \mathrm{C} V \mathrm{ml} \\
\mu \mathrm{C} U \mathrm{ml}\end{array}$ \\
\hline
\end{tabular}

Lab Method

EPA7470A

$\begin{array}{ll}\text { GE } & \text { EPA9050 } \\ \text { GP } & \text { EPIA.001 } \\ \text { GP } & \text { EPIA.001 }\end{array}$ EPIA.002

ESH-EMS-990521

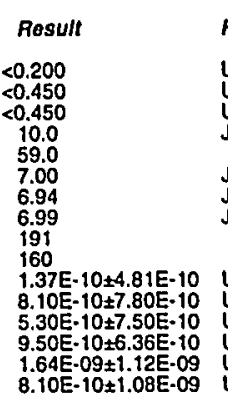

$F G$
$u$
$u$
$J$
$J$
$J$
$J$
$u$
$u$
$u$
$u$
$u$.

Time: 14:40 Air temperatura: $25^{\circ} \mathrm{C} C \mathrm{C}$ ) $70 \mathrm{mg} / \mathrm{L}$ Phenolphthalein alkalinity: $0 \mathrm{mg} /$
Field Qualifier(s): $\mathrm{S}$

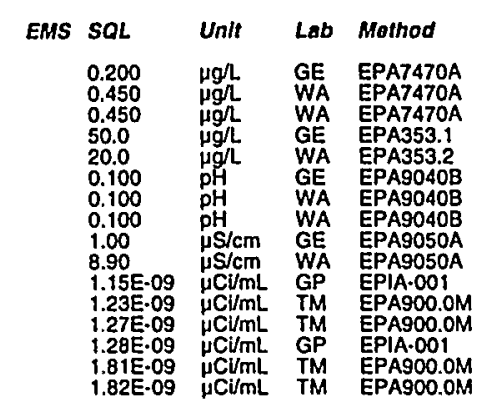

Second Quarter 1999 
Well HSB 83A collected on 04/19/99 (cont)

$F$ Analyte Result

FG $S$ EMS SOL Unit Lab Method

Tritium

$-5.51 E-07+3.58 E-07 \mathrm{U}$
$-9.00 \mathrm{E}-0.8+2.90 \mathrm{E}-07 \mathrm{U}$
$1.50 \mathrm{E} \cdot 07 \pm 3.10 \mathrm{E}-07 \mathrm{U}$

\section{WELL HSB 83A Replicate}

MEASUREMENTS CONDUCTED IN THE FIELD

Sample date: 04/19/99

Sample date: $04 / 19 / 99$
Wepht to waler. $63.65 \mathrm{H}(19.4 \mathrm{~m})$ below TOC
Water elevation: $173.65 \mathrm{~h}(52.93 \mathrm{~m}) \mathrm{msl}$
pH: 7.1

conductance: $170 \mu \mathrm{S} / \mathrm{cm}$

Water evacuated from the well prior to sampling: $174 \mathrm{gal}$

ANALYSES

$F$ Analyto

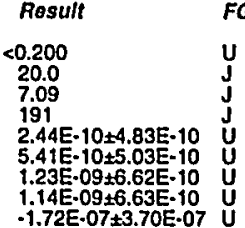

FG

Mercury, Lotal recoverable

Specific conduclance

Gross alpha

Nonvolatile beta

\section{WELL HSB 83B}

MEASUREMENTS CONDUCTED IN THE FIELD

Sample date: $04 / 19 / 99$
Depth to water: $14.58 \mathrm{H}(4.44 \mathrm{~m})$ below TOC
Waler elevation: $222.42 \mathrm{ft}(67.79 \mathrm{~m}) \mathrm{msl}$

Waler

Sp. conductance: $98 \mu \mathrm{S} / \mathrm{cm}$

Water evacuated from the well prior to sampling: $160 \mathrm{gal}$ ANALYSES

F Anaiyto

\begin{tabular}{|c|c|c|c|c|c|c|c|}
\hline Result & $F G$ & $s$ & EMS & SQL & Unit & Lab & Method \\
\hline $\begin{array}{l}<0.200 \\
30.0 \\
6.88 \\
112 \\
3.41 E-10 \pm 3.68 E-10 \\
1.36 E-09 \pm 6.42 E-10 \\
7.43 E-07 \pm 4.18 E-07\end{array}$ & $\begin{array}{l}U \\
J \\
J\end{array}$ & a & & $\begin{array}{l}0.200 \\
50.0 \\
0.100 \\
1.00 \\
6.69 \mathrm{E}-10 \\
1.20 \mathrm{E} \cdot 09 \\
6.73 \mathrm{E} \cdot 07\end{array}$ & 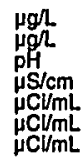 & $\begin{array}{l}G E \\
G E \\
G E \\
G G \\
G P \\
G P \\
G P\end{array}$ & $\begin{array}{l}\text { EPA7470A } \\
\text { EPA353.1 } \\
\text { EPA9000 } \\
\text { EPA9050A } \\
\text { EPAA.001 } \\
\text { EPIA.001 } \\
\text { EPIA.002 }\end{array}$ \\
\hline
\end{tabular}

: Mercury, total recoverable

${ }_{0}^{0}$ pH $\mathrm{Specific} \mathrm{conductance}$

O Gross alpha $7.43 E-07 \pm 4.18 E .07$

\section{WELL HSB $83 C$}

MEASUREMENTS CONDUCTED IN THE FIELD

Sample dalo: 04/19/99

Depth to water: $12.98 \mathrm{ft}(3.96 \mathrm{~m})$ below TOC
Water elevation: $224.12 \mathrm{ft}(68.3 \mathrm{~m}) \mathrm{ms}$

pH: 5 .9

Sp. conductance: $21 \mu \mathrm{S} / \mathrm{cm}$

Water ovacualed Irom the well prior to sampling: 98 gal

ANALYSES

$F$ Analyto

Nercury, total recoverable

Specific conductance

Gross alpha

Tritium

ESH-EMS-990521

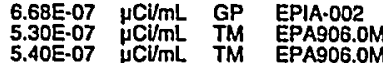

Time: 14:40

Wir $19.4^{\circ} \mathrm{C}$ Total alkalinily (as CaCO3): $70 \mathrm{mg} / \mathrm{L}$

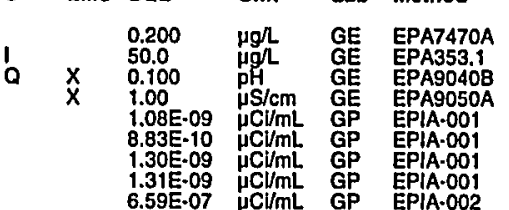

Time: 14:25

Wirat $19.6^{\circ} \mathrm{C}$ Total alkalinity (as CaCo3): $43 \mathrm{mg} / \mathrm{L}$ Phenolphthalein alkalinily: $0 \mathrm{mg} \Omega$

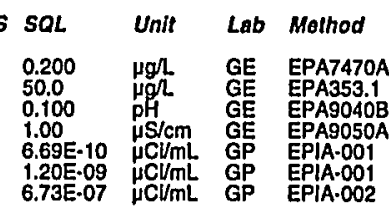

Time: 14:57 Total alkalinity (as CaCo3): $1 \mathrm{mg} /$ Phenolphthalein alkalinity: $0 \mathrm{mg} /$
Field Qualifier(s): $S$ Phenolphthalein alkalinity: $0 \mathrm{mg} /$

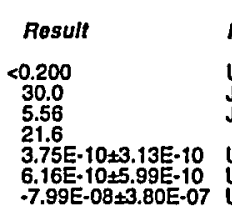

$F G$
$\mathbf{J}$
$\mathbf{J}$
$\mathbf{U}$
$\mathbf{U}$

\section{WELL HSB 83D}

MEASUREMENTS CONDUCTED IN THE FIELD

Sample dale: 04/26/99
Depth to water: $1322 \mathrm{ft}(4.03 \mathrm{~m})$ below TOC
Water elevation: 223.78 tit $(68.21 \mathrm{~m}) \mathrm{ms}$ !

$\mathrm{pH}: 4.8$

Sp. conductance: $53 \mu \mathrm{S} / \mathrm{cm}$

Water evacualed from the well prior to sampling: $60 \mathrm{gal}$ ANALYSES

$F$ Analyto
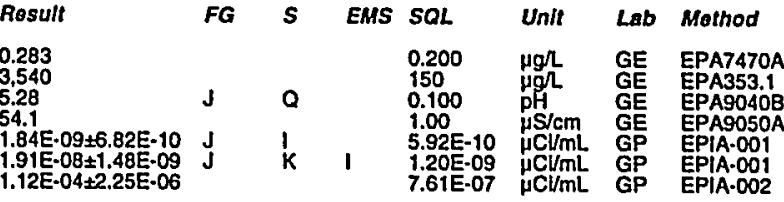

O Mercury, tolal recoverable

00 pH

Nonvolatile bele

WELL HSB 84A

MEASUREMENTS CONDUCTED IN THE FIELD

Sample date: 04/26/99

Wepter to waler: 56.25 ft $(17.15 \mathrm{~m})$ below TOC

pH: 6

p. conductance: $60 \mu \mathrm{S} / \mathrm{cm}$

Water evacuated from the well prior to sampling: $174 \mathrm{gal}$ ANALYSES

$F$ Analyte

- Mercury, Lotal recoverable

O $\mathrm{pH}$-iflc conductance

O Gross alpha

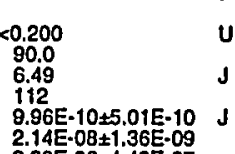

a

\section{WELL HSB 84B}

MEASUREMENTS CONDUCTED IN THE FIELD

Sample date: 04/13/99

Depth to water: $19.7 \mathrm{ft}(6 \mathrm{~m})$ below TOC

Wh: 6.5

. conductance: $140 \mu \mathrm{S} / \mathrm{cm}$

Turbidity: 0 NTU 110 pScm

ANALYSES

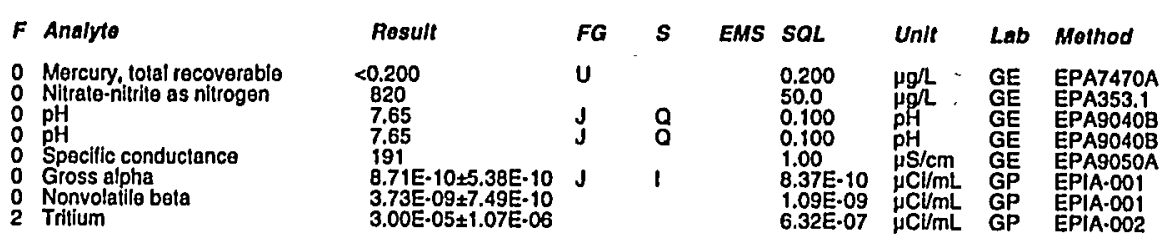

Water 11:58 Total alkalinity (as CaCO3): $37 \mathrm{mg} / \mathrm{L}$ Phenolphthalein alkalinity: $0 \mathrm{mgh}$.
Field Qualifier(s): $V$

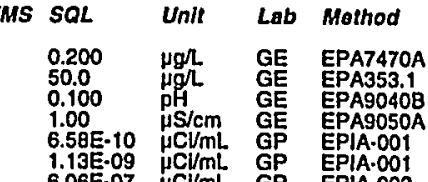

Time: 17:02

Air temperature: $20.7^{\circ} \mathrm{C}$

Total alkalinity (as CaCO3): $66 \mathrm{mg} / \mathrm{L}$ Phenolphthalein alkalinity: $0 \mathrm{mg}$

$$
\begin{aligned}
& \text { EMS SQL Unit Lab Method }
\end{aligned}
$$

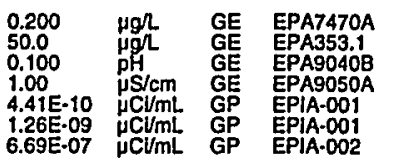




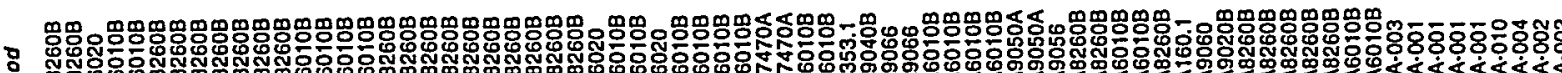

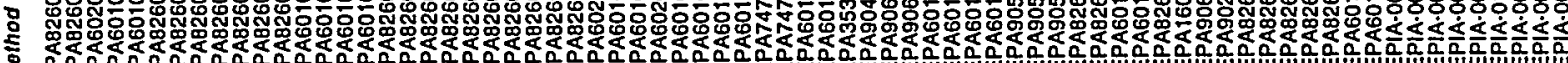

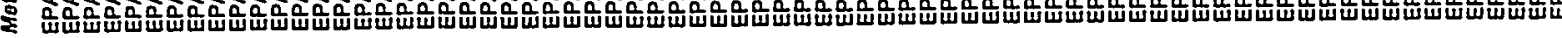

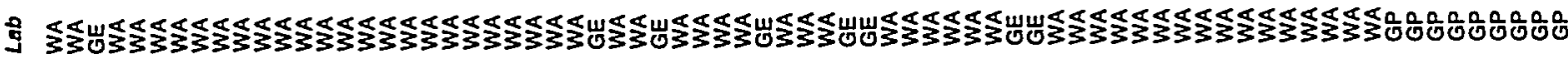

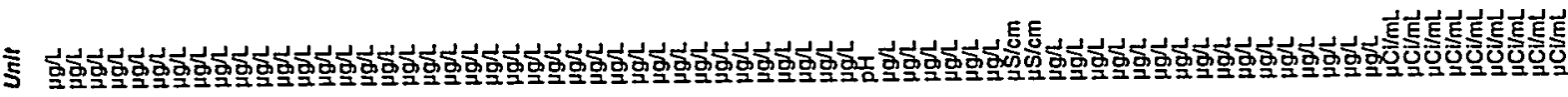

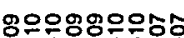

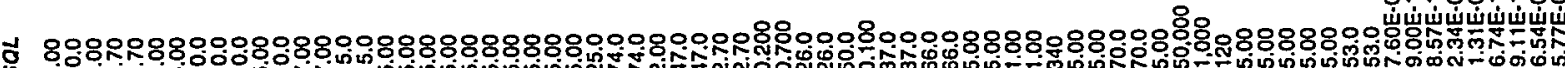
密

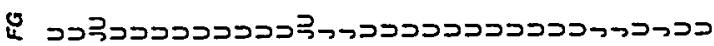

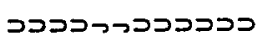

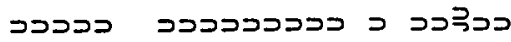
용ㅇㅇㅇㅇㅇㅇㅇㅇㅎㅇ

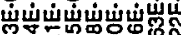

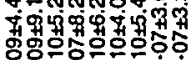
స

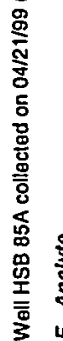
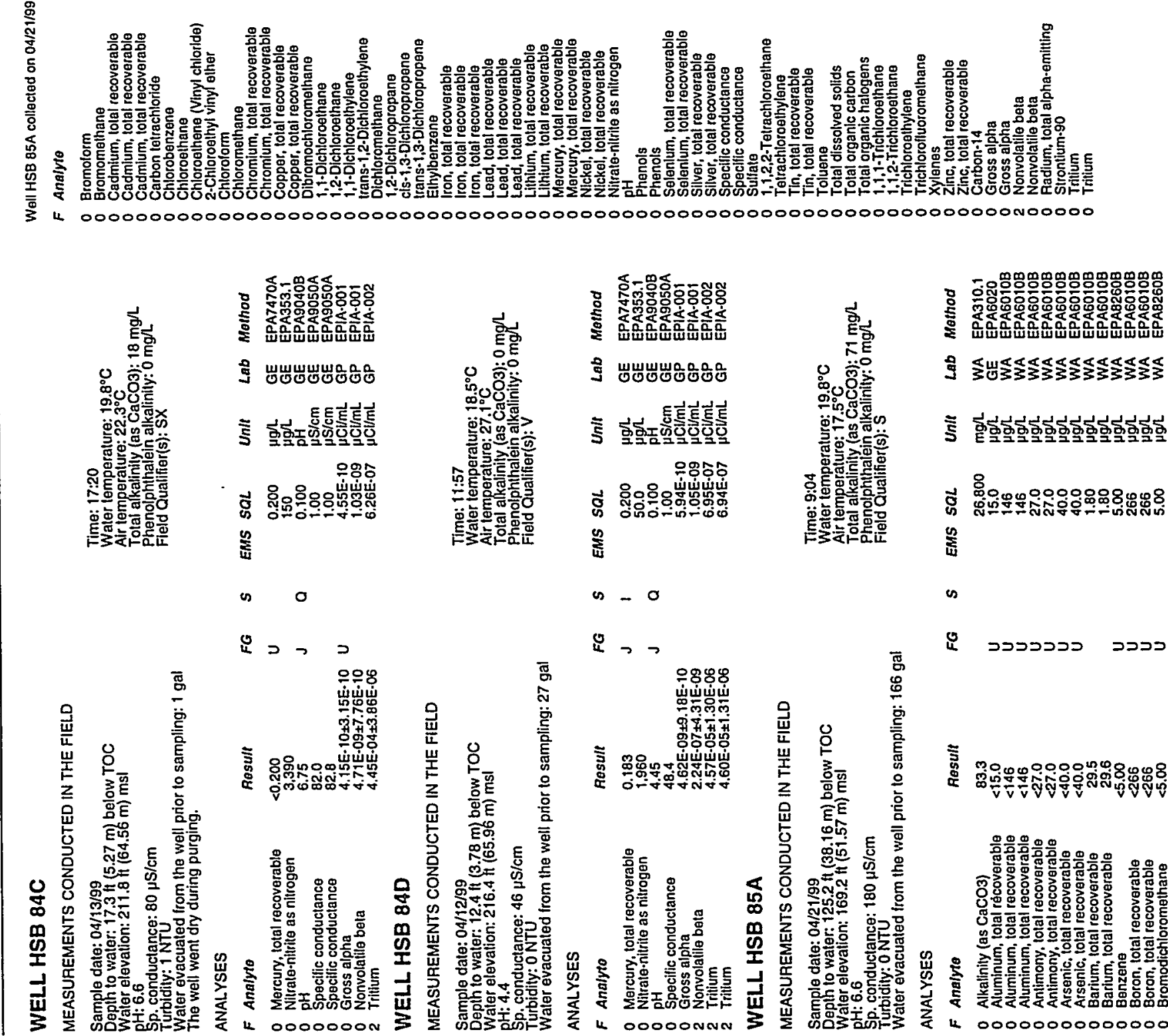

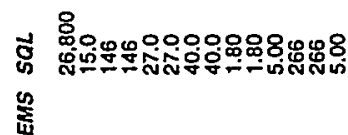

$\infty$

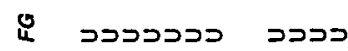

骂

$\mathscr{8}$

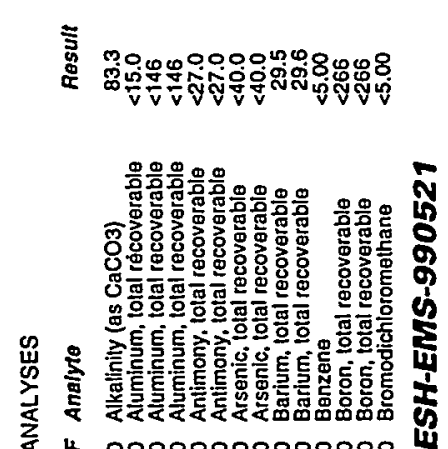




\section{WELL HSB 85B}

MEASUREMENTS CONDUCTED IN THE FIELD

Sample date: 04/21/99
Depth to waler: 61.78 $18.83 \mathrm{~m})$ below TOC
Water elevation: 232.72 (70.93 m) msl

Water elevation: 232.72 Ht $(70.93 \mathrm{~m}) \mathrm{msl}$

Sp: 11.2 conductance: $500 \mu \mathrm{S} / \mathrm{cm}$

Water evacuated from the well prior to sampling: $1 \mathrm{gal}$

ANALYSES

$F$ Analyto

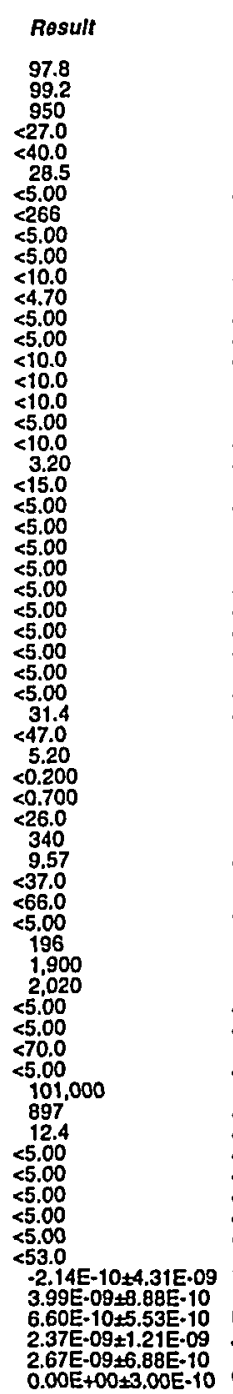

A Alkalinity (as CaCO3

2 Antimony, total recoverable

- Arsenic, tolal recoverable

- Benzene

Bromodichloromelhane

Bromomethan

Cadmlum. 1otal recoverable

- Chlorobenzene

Chloroethene (Vinyl chloride)

Chlorolorm

Chroromium, lotal recoverable

Copper, loial recoverable

1.1.Dichloroothane

1, 1.Dichloroethylene
trans $-1,2 \cdot$ Dichloroethylen

Dichioromethane

cls-1,3. Dichloropropene

Lead, lotal recoverable

Mercury, tolal recoverable

Nickel, total recoverable

I Phenols

Selenlum, total recoverable

Silver, tolal recoverable

S Sullate

1,1,2,2-Tetrachloroethane

Tin, tolal recoverable

Toluene

Tolal organic carbon

Tolal organlc halogens

1.1.2. Trichloroethane

Trichlorolluoromethane

Zinc, lotal recoverable

Gross alpha

Nonvolatile b

Radium, total alpha-emitting
Time: 9:25

Water temperature: $19.7^{\circ} \mathrm{C}$ Total alkalinity (as CaCO3): $108 \mathrm{mg}$ Phenolphthalein alkalinity: $82 \mathrm{mg} /$

Iron, tolal recoverable

ESH-EMS-990521
Well HSB 85B collected on 04/21/99 (cont.)

\begin{tabular}{|c|c|c|c|c|c|c|c|c|}
\hline F Analyto & Result & $F G$ & $s$ & EMS & SaL & Unit & LAb & Method \\
\hline $\begin{array}{ll}0 & \text { Strontium-90 } \\
0 & \text { Trifium } \\
0 & \text { Trifitum } \\
\text { Srifilum }\end{array}$ & $\begin{array}{l}2.08 \mathrm{E}-11 \pm 4.99 \mathrm{E}-10 \\
1.08 \mathrm{E}-06 \pm 4.25 \mathrm{E}-07 \\
1.01 \mathrm{E}-06 \pm 4.20 \mathrm{E}-07 \\
9.59 \mathrm{E}-07 \pm 3.73 \mathrm{E}-07\end{array}$ & $\begin{array}{l}\mathrm{JU} \\
\mathbf{J} \\
\mathrm{J}\end{array}$ & $i_{1}^{2}$ & C & $\begin{array}{l}8.43 E-10 \\
66.61 \mathrm{E}-07 \\
6.57 \mathrm{E}-07 \\
5.79 \mathrm{E}-07\end{array}$ & 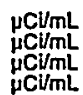 & $\begin{array}{l}\text { GP } \\
\text { GP } \\
\text { GP }\end{array}$ & $\begin{array}{l}\text { EPIA.004 } \\
\text { EPIA.002 } \\
\text { EPIA-DO2 } \\
\text { EPIA-002 }\end{array}$ \\
\hline
\end{tabular}

\section{WELL HSB 85C}

MEASUREMENTS CONDUCTED IN THE FIELD

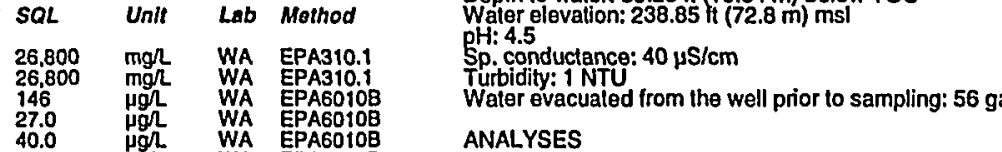

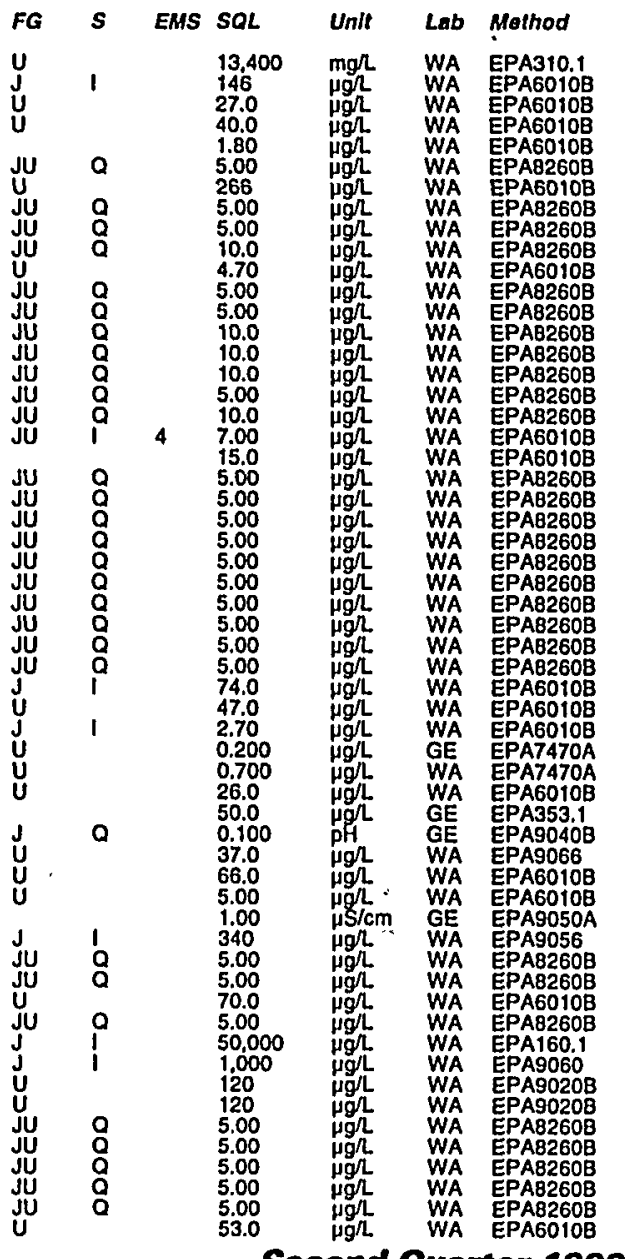

B-131
Sample date: 04/21/99
Depth to water: $55.25 \mathrm{Ht}(16.84 \mathrm{~m})$ below TOC
Water elevation: 238.85 t $(72.8 \mathrm{~m}) \mathrm{ms}$ ( ANALYSES

$F$ Analyte

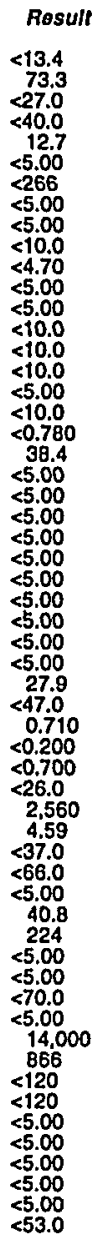

Time: $8: 40$

Total alkalinity (as CaCO3): $0 \mathrm{mg} / \mathrm{L}$

Phenolphthalein alkalinity: 0 mgl
Field Qualifier(s): $S$

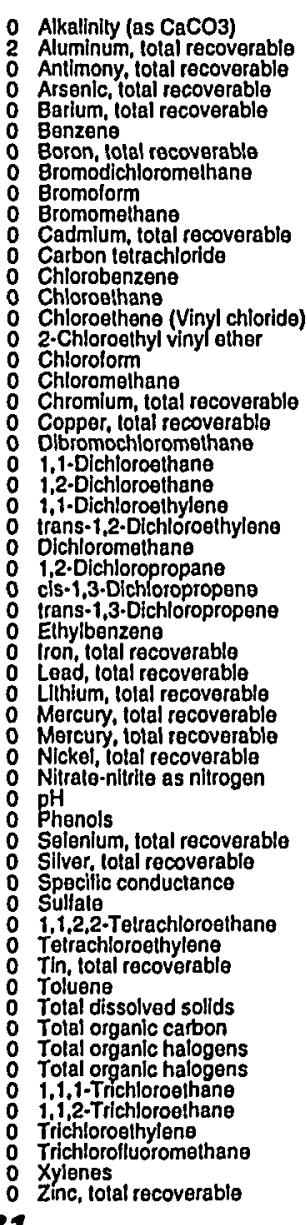

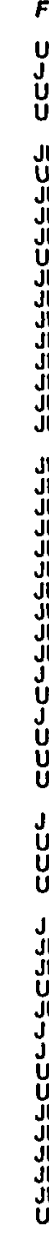




\section{WELL HSB100C}

MEASUREMENTS CONDUCTED IN THE FIELD Sample date: 04/19/99 Water elevation: $226.37 \mathrm{ft}(69 \mathrm{~m})$ ms below TOC pH: 4.9 conductance: $30 \mu \mathrm{S} / \mathrm{cm}$

Water evacualed from the well prior to sampling: $171 \mathrm{gal}$ ANALYSES

F Analyto

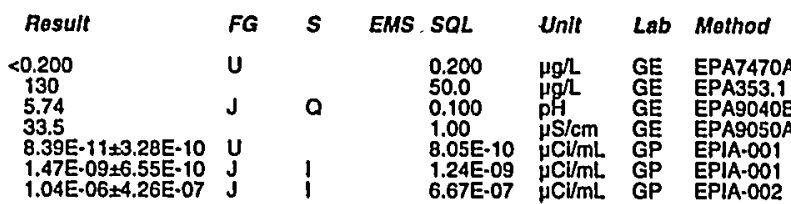

Mercury, tolal recoverable

$\mathrm{pH}$

Gross alpha

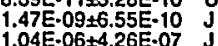

\section{WELL HSB100D}

MEASUREMENTS CONDUCTED IN THE FIELD

Sample date: $04 / 19 / 99$
Depth to water: $25.58 \mathrm{ft}(7.8 \mathrm{~m})$ below TOC
Water elovalion: $234.52 \mathrm{ft}(71.48 \mathrm{~m}) \mathrm{msl}$
pH: 4.6
Sp. conductance: $52 \mu \mathrm{S} / \mathrm{cm}$

pH. 4.6 conduclance: $52 \mu \mathrm{S} / \mathrm{cm}$

Waler ovacualed from the well prior to sampling: $38 \mathrm{gal}$ ANALYSES

\begin{tabular}{|c|c|c|c|c|c|c|c|c|}
\hline \multirow[b]{2}{*}{$\begin{array}{ll}\text { F } & \text { Analyte } \\
0 & \text { Mercury, total recoverable } \\
0 & \text { Nitrate-nitrite as nitrogen } \\
0 & \text { pH } \\
0 & \text { Specilic conductance } \\
0 & \text { Gross alpha } \\
2 & \text { Nonvolatila beta } \\
2 & \text { Tritlum }\end{array}$} & \multirow{2}{*}{$\begin{array}{l}\text { Rosult } \\
<0.200 \\
3,140 \\
5.38 \\
57.5 \\
1.81 E-09 \pm 6.60 E-10 \\
1.10 E-07 \pm 3.29 E \\
8.84 E-05 \pm 1.78 E-06\end{array}$} & & $s$ & EMS & SQL & Unit & Lab & \multirow[b]{2}{*}{$\begin{array}{l}\text { Method } \\
\text { EPA7470A } \\
\text { EPA353.1 } \\
\text { EPA9040B } \\
\text { EPA9050A } \\
\text { EPA.001 } \\
\text { EPAA.001 } \\
\text { EPIA.002 }\end{array}$} \\
\hline & & $\begin{array}{l}\text { u } \\
\text { J } \\
\text { J }\end{array}$ & $\begin{array}{l}a \\
1\end{array}$ & \multicolumn{2}{|r|}{$\begin{array}{l}0.200 \\
100 \\
0.100 \\
1.00 \\
6.58 E-10 \\
1.31 E \cdot 09 \\
6.69 E \cdot 07\end{array}$} & 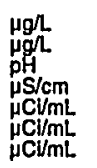 & $\begin{array}{l}G E \\
G E \\
G E \\
G E \\
G F \\
G P \\
G P\end{array}$ & \\
\hline \multicolumn{9}{|l|}{ WELL HSB101C } \\
\hline \multicolumn{9}{|c|}{ AEASUREMENTS CONDUCTED IN THE FIELD } \\
\hline \multicolumn{3}{|c|}{ 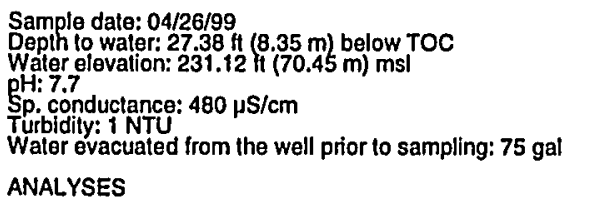 } & & \multicolumn{5}{|c|}{ 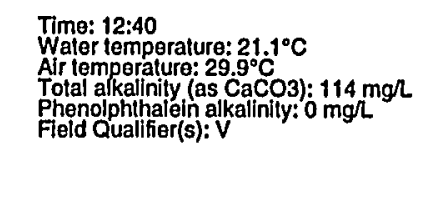 } \\
\hline Analyto & Result & $\boldsymbol{F G}$ & 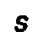 & EMS & so & $\| t$ & Lab & Mothod \\
\hline $\begin{array}{l}\text { Mercury total recoverable } \\
\text { Nilrate-nitrite as nitrogen } \\
\text { pH } \\
\text { Specific conductance } \\
\text { Gross alpha } \\
\text { Nonvolatile beta } \\
\text { Tritlum }\end{array}$ & $\begin{array}{l}7.83 \\
25.500 \\
7.85 \\
516 \\
7.91 E \cdot 09 \pm 1.88 E-09 \\
2.81 E \cdot 00 \pm 1.84 E-09 \\
3.47 E-03 \pm 6.74 E-05\end{array}$ & $\mathrm{~J}$ & 0 & 1 & $\begin{array}{l}0.200 \\
1.250 \\
0.100 \\
1.00 \\
1.71 \cdot .09 \\
1.45 \cdot .09 \\
4.83 E \cdot 06\end{array}$ & 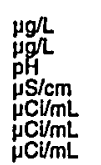 & $\begin{array}{l}\mathrm{GE} \\
\mathrm{GE} \\
\mathrm{GE} \\
\mathrm{GE} \\
\mathrm{GP} \\
\mathrm{GP} \\
\mathrm{GP}\end{array}$ & $\begin{array}{l}\text { EPA7470A } \\
\text { EPA353.1. } \\
\text { EPA9040B } \\
\text { EPA9050A } \\
\text { EPIA.001 } \\
\text { EPIA.001 } \\
\text { EPIA.002 }\end{array}$ \\
\hline
\end{tabular}

Time: 9:31
WELL HSB101D

MEASUREMENTS CONDUCTED IN THE FIELD

Sample date: $04 / 19 / 99$

Depth to water: 33.27 ft $(10.14 \mathrm{~m})$ below TOC

Water

Sp. conductance: $64 \mu 5 / \mathrm{cm}$

Water evacualed from the well prior to sampling: $56 \mathrm{gal}$ ANALYSES

\begin{tabular}{|c|c|c|c|c|c|c|c|c|}
\hline Anslyto & Result & $F G$ & $s$ & EMS & SQL & $U_{n i t}$ & Lab & Method \\
\hline 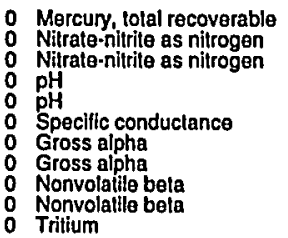 & $\begin{array}{l}<0.200 \\
530 \\
530 \\
5.94 \\
5.92 \\
42.1 \\
4.26 E-10 \pm 1.54 E-10 \\
7.255-10 \pm 4.21 E-10 \\
1.176-09 \pm 3.07 E-10 \\
1.56-09+27.270 \\
6.71 E-06 \pm 6.16 E-07\end{array}$ & $\begin{array}{l}\mathbf{J} \\
\mathbf{J}\end{array}$ & I & & $\begin{array}{l}0.200 \\
50.0 \\
50.0 \\
0.100 \\
0.100 \\
1.00 \\
1.73 E-10 \\
4.922-10 \\
4.68 E-10 \\
1.14-09 \\
6.73 E-07\end{array}$ & 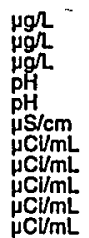 & $\begin{array}{l}G E \\
G E \\
G E \\
G E \\
G E \\
G E \\
G E \\
G E \\
G P \\
G P \\
G P \\
G P \\
G P \\
G P\end{array}$ & $\begin{array}{l}\text { EPA7470A } \\
\text { EPA353.1 } \\
\text { EPA353.1 } \\
\text { EPA9040B } \\
\text { EPA9040B } \\
\text { EPA9050A } \\
\text { EPIA-001 } \\
\text { EPIA.001 } \\
\text { EPIA.001 } \\
\text { EPIA.001 } \\
\text { EPIA.002 }\end{array}$ \\
\hline
\end{tabular}

MEASUREMENTS CONDUCTED IN THE FIELD

Sample data: 04/19/99

pH: 5.4

Sp. conductance: $140 \mu \mathrm{S} / \mathrm{cm}$

Turbidily: O NTU

ANALYSES

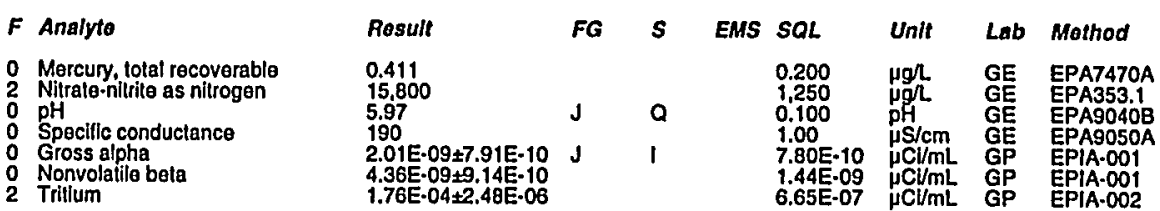

\section{WELL HSB102D}

MEASUREMENTS CONDUCTED IN THE FIELD

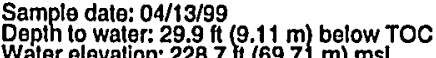

Water

Sp. conductance: $210 \mu \mathrm{S} / \mathrm{cm}$

Water evacuated from the well prior to sampling: 1 gal

Water evacuated from the well prior
The well went dry during purging.

ANALYSES

$F$ Analyto

Result

2 Mercury, Iolal recoverable

$1 \mathrm{pH}$-initic as niliogetanco

Gross alpha

\begin{tabular}{|c|}
\hline $\begin{array}{l}2.85 \\
17,800 \\
3.79 \\
223 \\
8.38 E-08 \pm 4.11 E \cdot 0 \\
1.79 E-06 \pm 1.25 E \cdot 0\end{array}$ \\
\hline
\end{tabular}

Time: 10:17

(ature: $20^{\circ} \mathrm{C}$

Total afkalinity (as CaCO3): $11 \mathrm{mg} / \mathrm{L}$

Air tempenture: $21,2^{\circ} \mathrm{C}$

Total alkalinity (as CaCO3): $12 \mathrm{mg} / \mathrm{L}$
Phenolphthalein alkalinity: 0 ing

henolphthalein alkalinity: $0 \mathrm{mgh}$
Time: 13:30

Alr temperature: $25.1^{\circ} \mathrm{C} \mathrm{C}$

Phenolphinalein alkalinity: $0 \mathrm{mg} L$
Field Qualifier(s): $\mathrm{VX}$

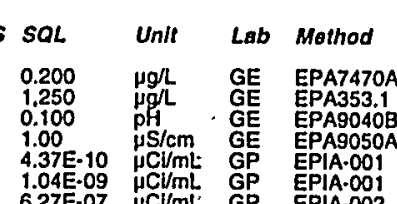

Total alkalinity (as CaCo3): 0 mgr 


\section{WELL HSB103C}

MEASUREMENTS CONDUCTED IN THE FIELD

Sample date: 04/19/99

Deph to waler: $24.4 \mathrm{ft}(7.44 \mathrm{~m})$ below TOC

Water elevation: $223 \mathrm{ft}(67.97 \mathrm{~m}) \mathrm{ms}$

p. conductance: $180 \mu \mathrm{S} / \mathrm{cm}$

Water evacualed from the well prior to sampling: $164 \mathrm{ga}$ ANALYSES

$F$ Analyto

1 Mercury, total recoverable

2 Nitral

Hocilic conductance

Gross alpha

Nonvola

\section{WELL HSB103D}

MEASUREMENTS CONDUCTED IN THE FIELD

Sample date: 04/12/99

Depth to water: 23.42 ft $(7.14 \mathrm{~m})$ below TOC

pH: 4.5

Sp. conductance: $160 \mu \mathrm{S} / \mathrm{cm}$

Water evacuated from the well prior to sampling: 15 gal

ANALYSES

$F$ Analyte

\begin{tabular}{|c|c|c|c|c|c|c|c|}
\hline sult & $F G$ & $s$ & EMS & SOL & Unit & Lab & Method \\
\hline $\begin{array}{l}3.70 \\
14.500 \\
4.57 \\
169 \\
1.61 E \cdot 08 \pm\end{array}$ & J & 0 & & $\begin{array}{l}0.200 \\
1.250 \\
0.100 \\
1.00 \\
6.91 \mathrm{E}-10 \\
1.06 \mathrm{E} \cdot 09 \\
2.48 \mathrm{~B} \cdot 06\end{array}$ & $\begin{array}{l}\mu g / L \\
\mu g / L \\
\mathrm{pH} \\
\mu \mathrm{S} / \mathrm{cm} \\
\mu \mathrm{Cl} / \mathrm{mL} \\
\mu \mathrm{C} / / \mathrm{mL} \\
\mu \mathrm{C} / \mathrm{mL}\end{array}$ & $\begin{array}{l}\mathrm{GE} \\
\mathrm{GE} \\
\mathrm{GE} \\
\mathrm{GE} \\
\mathrm{GP} \\
\mathrm{GP} \\
\mathrm{GP}\end{array}$ & $\begin{array}{l}\text { EPA7470A } \\
\text { EPA353.1 } \\
\text { EPA9040B } \\
\text { EPA9050A } \\
\text { EPIA.001 } \\
\text { EPIA.001 } \\
\text { EPIA.002 }\end{array}$ \\
\hline
\end{tabular}

Mercury, total recoverable

pH

2 Gross alpha

9.700-04+1.89E-05

\section{WELL HSB104C}

MEASUREMENTS CONDUCTED IN THE FIELD

Sample date: 04/19/99

(

Water

Sp. conductance: $80 \mu \mathrm{S} / \mathrm{cm}$

Water evacuated from the well prior to sampling: $89 \mathrm{gal}$

ANALYSES

$F$ Ansirto

0 Mercury, total recoverable 1 Nitrate-nitrite as nitrogen

Specific conductance

2 Tritium

\begin{tabular}{|c|c|c|c|c|c|c|c|}
\hline \multirow{4}{*}{$\begin{array}{l}\text { Rosult } \\
=0.200 \\
7.380 \\
7.47 \\
146 \\
1.45 \mathrm{E} \cdot 09 \pm 7.25 \mathrm{E}-10 \\
1.09 \mathrm{E} \cdot 08+1.19 \mathrm{E}-09 \\
1.99 \mathrm{E} \cdot 04+2.63 \mathrm{E}-06\end{array}$} & $F G$ & 5 & EMS & & Unit & Lab & Method \\
\hline & $U$ & & & \multirow{3}{*}{$\begin{array}{l}061 \\
0.200 \\
150 \\
0.100 \\
1.00 \\
1.01 E-09 \\
1.29 E .09 \\
6.64 E-07\end{array}$} & \multirow{3}{*}{$\begin{array}{l}\mu g / \mathrm{L} \\
\mu g \mathrm{~L} \\
\mathrm{pH} \\
\mu \mathrm{S} / \mathrm{cm} \\
\mu \mathrm{C} / \mathrm{mL} \\
\mu \mathrm{CL} / \mathrm{mL} \\
\mu \mathrm{C} / \mathrm{mL}\end{array}$} & \multirow{3}{*}{$\begin{array}{l}\mathrm{GE} \\
\mathrm{GE} \\
\mathrm{GE} \\
\mathrm{GE} \\
\mathrm{GP} \\
\mathrm{GP} \\
\mathrm{GP}\end{array}$} & \multirow{3}{*}{$\begin{array}{l}\text { EPA7470A } \\
\text { EPA353.1 } \\
\text { EPAO040B } \\
\text { EPA9050A } \\
\text { EPPA.001 } \\
\text { EPIA.001 } \\
\text { EPIA.002 }\end{array}$} \\
\hline & J & $\mathbf{Q}$ & & & & & \\
\hline & J & 1 & & & & & \\
\hline
\end{tabular}

\section{WELL HSB104D}

MEASUREMENTS CONDUCTED IN THE FIELD

Sample date: 04/12/99

Water temperature: $20.7^{\circ} \mathrm{C}$ Air temperature: $24.3^{\circ} \mathrm{C}$. 0 mg/ Phenolphithalein alkallinity: $0 \mathrm{mg} \alpha$

Depth to water: $25.41 \mathrm{H}(7.75 \mathrm{~m})$ below TOC

Water

Sp. conductance: $70 \mu \mathrm{S} / \mathrm{cm}$

Turbidity: 1 NTU
Waler evacuated from the well prior to sampling: $18 \mathrm{gal}$ ANALYSES

$F$ Analyto

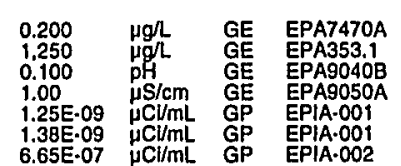

2 Mercury, total recoverable

$\mathrm{pH}$

Grostic conductance

Nonvolalile beta

\section{WELL HSB105C}

MEASUAEMENTS CONDUCTED IN THE FIELD

Sample date: 04/19/99

Depth to waler: $31.03 \mathrm{ft}(9.46 \mathrm{~m})$ below TOC
Water elevation: $218.47 \mathrm{H}(66.59 \mathrm{~m}) \mathrm{msl}$

Air temperature: $29.4^{\circ} \mathrm{C}$

Total alkalinity (as CaCO3): $0 \mathrm{mg} /$

Field Qualifíer(s): $V$

Water evacuated from the well prior to sampling: $128 \mathrm{gal}$ ANALYSES

$\begin{array}{ll}\text { F } & \text { Analyte } \\ 0 & \text { Mercury, total recoverable } \\ 0 & \text { Nitrale-nitrite as niltrogen } \\ 0 & \text { pH } \\ 0 & \text { Specilic conductance } \\ 0 & \text { Gross alpha } \\ 0 & \text { Nonvolatile beta } \\ 2 & \text { Tritium }\end{array}$

Result
$<0.200$
4.140
6.05
91.5
$1.32 E-10 \pm 3.01 E-10$
$2.02 E \cdot 09 \pm 7.18 E-10$
$9.60 E-05 \pm 1.85 E-06$

$F G$

\section{WELL HSB105D}

MEASUREMENTS CONDUCTED IN THE FIELD

Time: 12:43

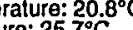

Total alkalinity (as CaCO3): $25 \mathrm{mg} /$

Phenolphthalein alkalinity: $0 \mathrm{mg} h$

Sample date: 04/13/99

Depth to water: $27.01 \mathrm{ft}(8.23 \mathrm{~m})$ below TOC

Water : 4 ductance: $100 \mu \mathrm{S} / \mathrm{cm}$

Waler evacuated from the well prior to sampling: $18 \mathrm{gal}$ ANALYSES
F Analyte
Mercury, total recoverable
Nitrate-nitrite as nitrog
Specific conduclanco
Gross alpha
2 Nonvolatio

a

Time: 15:15

Waler temperature: $19.8^{\circ} \mathrm{C}$

Total alkalinity (as CaCO3): $0 \mathrm{mg} /$ Phenolphthalein alkalinity: $0 \mathrm{mg}$

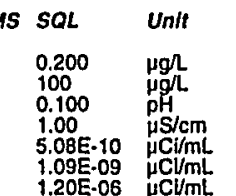

Lab Mothod

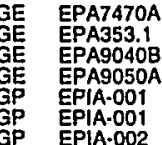

me: $13: 26$

Water temperature: $20^{\circ} \mathrm{C}$

Total akalinily as CaCOs

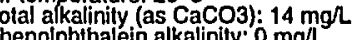
Field Qualifier(s): S

EMS SOL

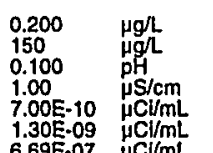

Lab Mothod

I

Time: 10:47

Waler temperalure: $19.5^{\circ} \mathrm{C}$

Total arerature: $17.9^{\circ} \mathrm{C}$

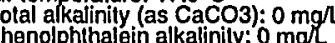
Field Qualfier(s): $V$ rily: $0 \mathrm{mg}$

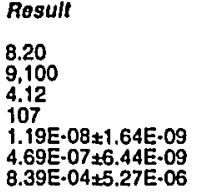

FG

EMS SQL

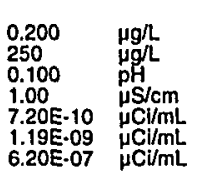

Lab Method

GE EPA7470A 


\section{WELL HSB106C}

MEASUREMENTS CONDUCTED IN THE FIELD

Sample date: 04/21/99

Depth to waler. $32.19 \mathrm{ft}(9.81 \mathrm{~m})$ below TOC

$\mathrm{gH:6.4}$

. conductance: $75 \mu \mathrm{S} / \mathrm{cm}$

Water evacuated from the well prior to sampling: $104 \mathrm{gal}$

ANALYSES

F Analyte

1 Mercury, tolal recoverable

0

Specific conductance

Gross alpha

\section{WELL HSB106D}

MEASUREMENTS CONDUCTED IN THE FIELD

Sample date: 04/13/99

Depth to waler: $28.7 \mathrm{H}(8.75 \mathrm{~m})$ below TOC
Water elevation: $224.2 \mathrm{H}(68.34 \mathrm{~m}) \mathrm{ms}$

gH: 4.4

conductance: $100 \mu \mathrm{S} / \mathrm{cm}$

Water evacualed from the well prior to sampling: $20 \mathrm{gal}$ ANALYSES

$F$ Analyto

\begin{tabular}{|c|c|c|c|c|c|c|c|}
\hline sult & $F G$ & $s$ & EMS & $S Q L$ & Unit & Lab & Mothod \\
\hline $\begin{array}{l}0.277 \\
6,330 \\
5.73 \\
80.7 \\
7.20 E-10 \pm 4.57 E-10 \\
1.88 E-09 \pm 7.03 E-10 \\
1.39 E-04 \pm 2.77 E-06\end{array}$ & $\begin{array}{l}J \\
J \\
J\end{array}$ & $i$ & & $\begin{array}{l}0.200 \\
150 \\
0.100 \\
1.00 \\
6.48 \mathrm{E}-10 \\
1.29 \mathrm{E}-09 \\
7.86 \mathrm{E}-07\end{array}$ & 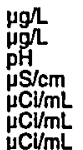 & $\begin{array}{l}G E \\
G E \\
G E \\
G E \\
G P \\
G P \\
G P\end{array}$ & $\begin{array}{l}\text { EPA7470A } \\
\text { EPA353.1 } \\
\text { EPA9040B } \\
\text { EPA9050A } \\
\text { EPIA.001 } \\
\text { EPIA.001 } \\
\text { EPIA.002 }\end{array}$ \\
\hline
\end{tabular}

1 Mercury, tolal recoverablo

1 Gross alpha

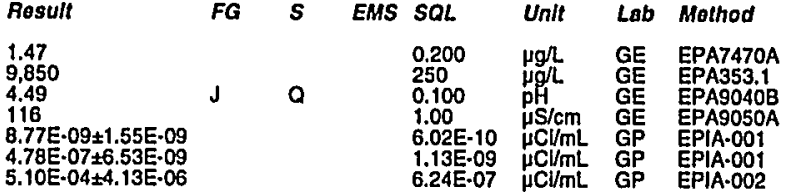

\section{WELL HSB107C}

MEASUREMENTS CONDUCTED IN THE FIELO

Water 6

p. conductance: $140 \mu \mathrm{S} / \mathrm{cm}$

Water evacuated from the well prior to sampling: $80 \mathrm{gal}$ ANALYSES

$F$ Ansiyte

$\begin{array}{ll}\text { Result } & F G \\ <0.200 & U \\ 8.340 & J \\ 6.63 & J \\ 1.49 & U \\ 1.29 \mathrm{E}-10 \pm 3.20 \mathrm{E}-10 & \mathrm{U} \\ 8.53 \mathrm{E} \cdot 09 \pm 1.06 \mathrm{E}-09 & \\ 3.84 \mathrm{E}-04 \pm 3.64 \mathrm{E}-06 & \end{array}$

u

Time: 10:38

Time: 11:37

Tir temperalure: $22^{\circ} \mathrm{C}$

Phenolphthalein alkalinity: $0 \mathrm{mg} L$
Field Qualifier(s): $V$

Waler temperature: $20.1^{\circ} \mathrm{C}$

Total alkalinily (as CaCO3): $25 \mathrm{mgh}$

Field Qualifier(s): $S$

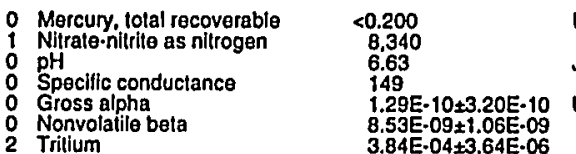

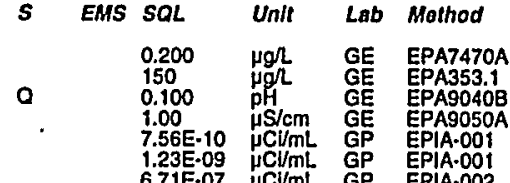

Specilic conduclance

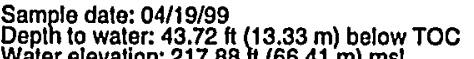

\section{WELL HSB107D}

MEASUREMENTS CONDUCTED IN THE FIELD

Sample dale: 04/13/99

Deph to water: $39.83 \mathrm{H}(12.14 \mathrm{~m})$ below TOC

$\mathrm{pH}: 4.8$

p. conductance: $115 \mu \mathrm{S} / \mathrm{cm}$

Water evacualed from the well prior to sampling: $12 \mathrm{gal}$ ANALYSES

\begin{tabular}{|c|c|c|c|c|c|c|c|c|}
\hline Analyto & Result & $F G$ & $s$ & EMS & SQL & Unit & Lab & Method \\
\hline $\begin{array}{l}\text { Mercury, total recoverable } \\
\text { Nitrale-nitrite as nitrogen } \\
\text { Nitrale-nitrite as nitrogen } \\
\text { pH } \\
\text { Specilic conductance } \\
\text { Gross alpha } \\
\text { Nonvolatile bota } \\
\text { Tritium }\end{array}$ & $\begin{array}{l}1.42 \\
11.600 \\
11,900 \\
5.02 \\
1.22 \\
1.55 E-08 \pm 1.81 E-09 \\
4.62 E-07 \pm 6.39 E-09 \\
2.89 E-04 \pm 3.14 E-06\end{array}$ & $\mathbf{J}$ & a & & $\begin{array}{l}0.200 \\
500 \\
500 \\
0.100 \\
1.00 \\
8.34 E-10 \\
1.16 E-09 \\
6.33 E-07\end{array}$ & $\begin{array}{l}\mu g / \mathrm{L} \\
\mu g / \mathrm{L} \\
\mu g h \\
\mathrm{pH} \\
\mu \mathrm{S} / \mathrm{cm} \\
\mu \mathrm{Cl} / \mathrm{mL} \\
\mu \mathrm{Cl/mL} \\
\mu \mathrm{Ci/mL}\end{array}$ & $\begin{array}{l}\mathrm{GE} \\
\mathrm{GE} \\
\mathrm{GE} \\
\mathrm{GE} \\
\mathrm{GE} \\
\mathrm{GP} \\
\mathrm{GP} \\
\mathrm{GP}\end{array}$ & $\begin{array}{l}\text { EPA7470A } \\
\text { EPA353.1 } \\
\text { EPA353.1 } \\
\text { EPA9040B } \\
\text { EPA9050A } \\
\text { EPIA.001 } \\
\text { EPIA.001 } \\
\text { EPIA.002 }\end{array}$ \\
\hline
\end{tabular}

\section{WELL HSB108C}

MEASUREMENTS CONDUCTED IN THE FIELD

Sample dale: 04/19/99

Depth to waler: $49.17 \mathrm{ft}(14.99 \mathrm{~m})$ below TOC

$\mathrm{g} \mathrm{H}$ : 6.6 conductance: $115 \mu \mathrm{S} / \mathrm{cm}$

Waler evacuated from the well prior to sampling: $60 \mathrm{gal}$

ANALYSES

F Analyto

- Mercury, total recoverable

: Nitrale-nitritio as niltrogen

$\mathrm{pH}$ Speifle conductance

Nonvolatile beta

2 Nriflum

\section{WELLL HSB108D}

MEASUREMENTS CONDUCTED IN THE FIELD

Sample dale: 04/13/99

ft $(13.79 \mathrm{~m})$ below TOC

WH: 5

Sp. conductance: $62 \mu \mathrm{S} / \mathrm{cm}$

Water evacualed from the well prior to sampling: $14 \mathrm{gal}$

ANALYSES

$F$ Analyto

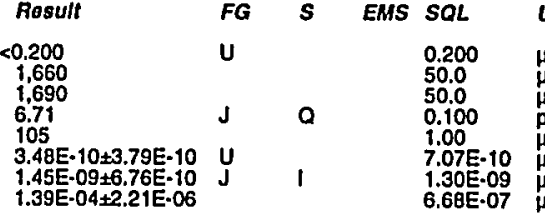

Lab Mothod

Water temperature: $19.5^{\circ} \mathrm{C}$

Total alkalinity (as CaCO3): $43 \mathrm{mg} / \mathrm{l}$ Phenolphthalein alkalinity: $0 \mathrm{mg}$.
Field Qualifier(s): $\mathrm{S}$

o Mercury, lotal recoverable

0 pH 0 Specilic conductance

2
2
2

\begin{tabular}{|c|c|c|c|c|c|c|c|}
\hline Result & $F G$ & $s$ & EMS & SQL. & Unit & Lab & Mothod \\
\hline $\begin{array}{l}0.488 \\
5,280 \\
5.14 \\
71.9 \\
1.84 E \cdot 08 \pm 2.06 E \cdot 09 \\
9.86 E \cdot 07 \pm 8.94 E \cdot 09 \\
2.10 E \cdot 04 \pm 2.67 \mathrm{E} \cdot 06\end{array}$ & $J$ & $a$ & & $\begin{array}{l}0.200 \\
150 \\
0.100 \\
1.00 \\
6.95 \mathrm{E}-10 \\
1.06 \mathrm{E} .09 \\
6.26 \mathrm{E}-07\end{array}$ & 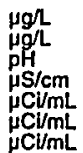 & $\begin{array}{l}G E \\
G E \\
G E \\
G E \\
G E \\
G P \\
G P \\
G P\end{array}$ & $\begin{array}{l}\text { EPA7470A } \\
\text { EPA353.1 } \\
\text { EPA9040B } \\
\text { EPA9050A } \\
\text { EPIA.001 } \\
\text { EPIA.001 } \\
\text { EPIA.002 }\end{array}$ \\
\hline
\end{tabular}




\section{WELL HSB109C}

MEASUREMENTS CONDUCTED IN THE FIELD

Sample date: 04/19/99

Depth to water: $44.35 \mathrm{ft}(13.52 \mathrm{~m})$ below TOC

Sp. conductance: $51 \mu \mathrm{S} / \mathrm{cm}$

Turbidity: 1 NTU 51 HS/cm ANALYSES

F Analyte

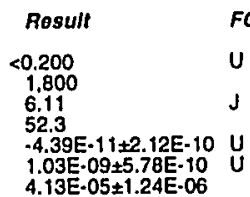

Mercury, total recoverablo

$\mathrm{pH}$

O Gross alpha

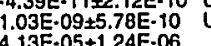

\section{WELL. HSB109D}

MEASUREMENTS CONDUCTED IN THE FIELD

Sample date: 04/13/99

Depth to water: Nol available

Waler elevation: Not availab

Tp. conductance: $46 \mu \mathrm{S} / \mathrm{cm}$

No water was evacuated from the well prior to sampling.

ring purging.

ANALYSES

$F$ Analyto

O Mercury, lotal recoverable

Specific conductance

1 Gross alpha

\section{WELLL HSB110C}

MEASUREMENTS CONDUCTED IN THE FIELD

Sample date: 04/19/99
Depth to water: $38.25 \mathrm{ft}(11.66 \mathrm{~m})$ below TOC

Water

Tp. conductance: $25 \mu \mathrm{S} / \mathrm{cm}$

Water evacuated from the well prior to sampling: $1 \mathrm{gal}$ Whell went dry during purging.

ANALYSES

F Analyto

- Mercury, tolal recoverable

$0 \mathrm{pH}$

Specific conductance

Specific conduct
Gross alpha

Nonvolatila beta

Result
0.107
2.820
5.60
47.8
$8.08 \mathrm{E}-09 \pm 1.19 \mathrm{E}-09$
$2.86 \mathrm{E}-07 \pm 4.81 \mathrm{E}-09$
$1.32 \mathrm{E}-04 \pm 2.17 \mathrm{E}-06$

EMS SQL

Unit

$\begin{array}{lll}0.200 & \mu g h & \\ 100 & \mu g h & \\ 0.100 & \mathrm{pH} & \\ 1.00 & \mu \mathrm{s} / \mathrm{cm} & \mathrm{GE} \\ 5.94 \mathrm{E}-10 & \mu \mathrm{Clm} / \mathrm{mL} & \mathrm{G}\end{array}$

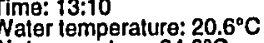

Total alkalinily (as CaCO3): $3 \mathrm{mg} / \mathrm{h}$

Phenolphthalein alkalinity: $0 \mathrm{mg} L$

Water temperature: $18.1^{\circ} \mathrm{C}$

Total akalinity (as CaCO3): $2 \mathrm{mg} / \mathrm{L}$

Field Qualifier(s): SX

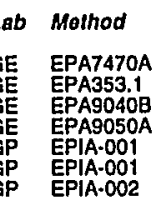

$\begin{array}{ll}\text { Result } & F G \\ <0.200 & U \\ 480 & J \\ 5.50 & J \\ 5.50 & \\ 24.1 & \\ 24.0 & \\ 4.41 E-10 \pm 4.68 E-10 & U \\ -4.31 E-10 \pm 5.87 E-10 & U \\ 8.72 E-06 \pm 0.63 E-07 & \end{array}$

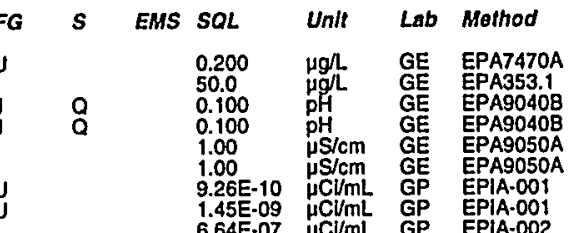

\section{WELL HSB110D}

MEASUREMENTS CONDUCTED IN THE FIELD

Samplo date: 04/19/99

Water alevation: $219.12 \mathrm{ft}(66.79 \mathrm{~m})$ below TOC

Sp: 4.6 conductance: $42 \mu \mathrm{S} / \mathrm{cm}$

Water evacuated from the well prior to sampling: $15 \mathrm{gat}$

Water temperalure: $19.7^{\circ} \mathrm{C}$

Air temperature: $10.2^{\circ} \mathrm{C}$

Total alkalinity (as CaCo3); $0 \mathrm{mgr}$

Phenolphthalesn alkalinity: $0 \mathrm{mg}$

ANALYSES

\begin{tabular}{|c|c|c|c|c|c|c|c|c|}
\hline Analyte & Rosult & $\boldsymbol{F G}$ & 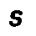 & EMS & $S Q L$ & Unit & Lab & Meinod \\
\hline $\begin{array}{l}\text { Mercury, tolal recoverable } \\
\text { Nitrale-nitrite as nitrogen } \\
\text { pH } \\
\text { Specifle conductance } \\
\text { Specllic conductance } \\
\text { Gross alpha } \\
\text { Nonvolatile bela } \\
\text { Trillum }\end{array}$ & $\begin{array}{l}<0.200 \\
1.720 \\
4.46 \\
42.3 \\
42.5 \\
2.27 E \cdot 09 \pm 7.44 E-10 \\
6.46 E .08 \pm 2.74 E-09 \\
2.41 E-05 \pm 9.78 E-07\end{array}$ & $\begin{array}{l}u \\
j \\
j \\
J\end{array}$ & a & $\begin{array}{l}x \\
x \\
x\end{array}$ & $\begin{array}{l}0.200 \\
50.0 \\
0.100 \\
1.00 \\
1.00 \\
5.30 E-10 \\
1.31 E-09 \\
6.61 \mathrm{E}-07\end{array}$ & $\begin{array}{l}\mu g / L \\
\mu g h / \\
\mu H \\
\mu \mathrm{p} / \mathrm{cm} \\
\mu \mathrm{S} / \mathrm{cm} \\
\mu \mathrm{S} / \mathrm{cm} \\
\mu \mathrm{Cl} / \mathrm{mL} \\
\mu \mathrm{Cl} / \mathrm{mL} \\
\mu \mathrm{Cl} / \mathrm{mL}\end{array}$ & $\begin{array}{l}G E \\
G E \\
G E \\
G E \\
G E \\
G E \\
G P \\
G P \\
G P\end{array}$ & $\begin{array}{l}\text { EPA33.1 } \\
\text { EPAS040B } \\
\text { EPA9050A } \\
\text { EPA9050A } \\
\text { EPAA.001 } \\
\text { EPPA.01 } \\
\text { EPA.001 } \\
\text { EPIA.002 }\end{array}$ \\
\hline
\end{tabular}

\section{WELL HSB111C}

MEASUREMENTS CONDUCTED IN THE FIELD

Sample date: 04/19/99

Water: $37.91 \mathrm{ft}(11.56 \mathrm{~m})$ below TOC

Whater êve

p. conductance: $91 \mu \mathrm{S} / \mathrm{cm}$

Water evacuated from the well prior to sampling: $132 \mathrm{gal}$

ANALYSES

$F$ Analyto

1 Mercury, Lotal recoverable

$\mathrm{pH}$

Gross alpha

2 Tritum

\section{WELLL HSB111D}

MEASUREMENTS CONDUCTED IN THE FIELD

ample date: 04/26/99

th to waler: $38.38 \mathrm{ft}(11.7 \mathrm{~m})$ below TOC

Water elevation: $217.62 \mathrm{ft}(66.33 \mathrm{~m}) \mathrm{msl}$

$\mathrm{H}: 5.2$

. conductance: $180 \mu \mathrm{S} / \mathrm{cm}$

Water evacuated from the well prior to sampling: 51 gal

ANALYSES

$F$ Analyto

- Mercury, lotal recoverable

Nitrate-nitrite as nitrogen

$\mathrm{pH}$ Specilic conductance

$\begin{array}{ll}0 & \text { Gross alpha } \\ 0 & \text { Nonvolatile beta } \\ 2 & \text { Tritium }\end{array}$
Time: 9:14 Total alkalinity. (as CaCO3): $0 \mathrm{mg} / \mathrm{L}$ Phenolphthalein alkalinity: $0 \mathrm{mg} L$

\begin{tabular}{|c|c|c|c|c|c|c|c|}
\hline Result & $F G$ & $s$ & EMS & SQL & Unit & Lab & Method \\
\hline $\begin{array}{l}<0.200 \\
18,800 \\
19,300 \\
5.43 \\
197 \\
2.25 \mathrm{E} \cdot 09 \pm 9.04 \mathrm{E}-10 \\
2.33 \mathrm{E} .08 \pm 1.64 \mathrm{E}-09 \\
2.46 \mathrm{E} \cdot 03 \pm 4.73 \mathrm{E} \cdot 05\end{array}$ & $\begin{array}{l}J \\
J \\
J\end{array}$ & $\mathrm{k}$ & I & $\begin{array}{l}0.200 \\
1.250 \\
1.250 \\
0.100 \\
1.00 \\
1.10 \mathrm{E}-09 \\
1.30 \mathrm{E} .09 \\
3.93 \mathrm{E}-06\end{array}$ & 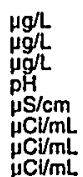 & $\begin{array}{l}\mathrm{GE} \\
\mathrm{GE} \\
\mathrm{GE} \\
\mathrm{GE} \\
\mathrm{GE} \\
\mathrm{GP} \\
\mathrm{GP} \\
\mathrm{GP}\end{array}$ & $\begin{array}{l}\text { EPA7470A } \\
\text { EPA353.1 } \\
\text { EPA353.1 } \\
\text { EPA9040B } \\
\text { EPA9050A } \\
\text { EPIA-001 } \\
\text { EPIA-001 } \\
\text { EPIA.002 }\end{array}$ \\
\hline
\end{tabular}




\section{WELL HSB111E}

MEASUREMENTS CONDUCTED IN THE FIELD Sample date: 04/12/99
Depth to water. 37.42 tt $(11.41 \mathrm{~m}$ ) below TOC pH: 4.6 Sp. conductance: $44 \mu \mathrm{S} / \mathrm{cm}$

Turbidity: 3 NTU Water evacuated from the well prior to sampling: 12 gal ANALYSES

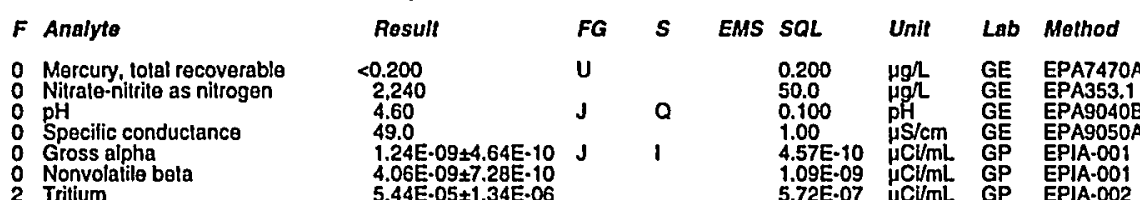

\section{WELL HSB112C}

MEASUREMENTS CONDUCTED IN THE FIELD

Sample date: 04/26/99
Dephth io waier: $36.08 \mathrm{Ht}(11 \mathrm{~m})$ below TOC
Water elevalion: $218.82 \mathrm{Ht}(66.7 \mathrm{~m}) \mathrm{ms}$

Water

Sp. conductance: $56 \mu \mathrm{S} / \mathrm{cm}$

Turbidity: 0 NTU ANALYSES

F Analyto

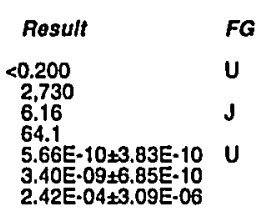

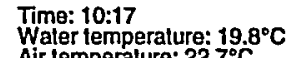
Air temperature: $22.7^{\circ} \mathrm{C}$ Phenolphthalein alkalinity: $0 \mathrm{mg} L$
Field Qualifier(s): $\mathrm{V}$ 5.72E-07 $\mu \mathrm{C} / \mathrm{mL}$ GP EPA.-001

Time: 10:06

arer temperature: $20.9^{\circ} \mathrm{C}$ Total alkalinity.(as CaCO3): $10 \mathrm{mg} /$ Phenolphthalein alkalinity: $0 \mathrm{mg} /$
Field Qualifier(s): $\mathrm{S}$ 3. $40.09 \pm 6.85 E-10$

\section{WELL HSB112D}

MEASUREMENTS CONDUCTED IN THE FIELD Sample date: 04/26/99 Depht to water: $36.03 \mathrm{ft}(10.98 \mathrm{~m})$ below TOC pH: 5.2

p. cond conductance: $62 \mu \mathrm{S} / \mathrm{cm}$

Water evacuated from the well prior to sampling: 81 gal ANALYSES

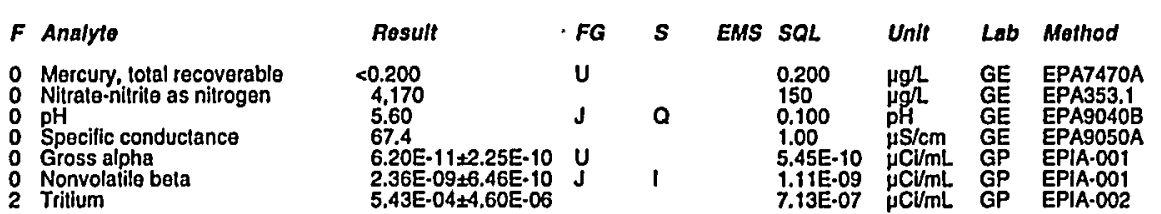

\section{WELL HSB112E}

MEASUREMENTS CONDUCTED IN THE FIELD

Sample date: 04/26/99

Depth to water: Not available

Wh: 4 2

Sp. conductance: $44 \mu \mathrm{S} / \mathrm{cm}$

\section{Waler evacualed from the well}

the well went dry during purging.

ANALYSES

$F$ Analyto

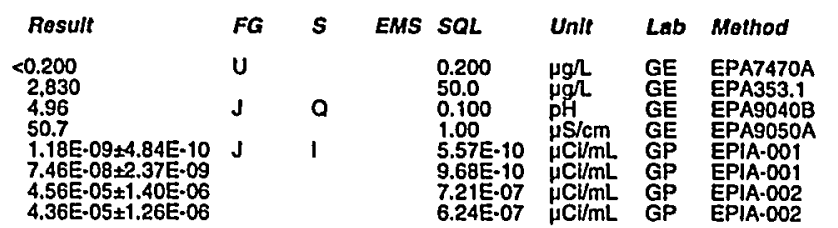

- Mercury, total recoverable

0 Specilic conductance

2 Gross alpha

$\begin{array}{ll}2 & \text { Nonvol } \\ 2 & \text { Tritium } \\ 2 & \text { Tritlum }\end{array}$

WELL HSB113C

MEASUREMENTS CONDUCTED IN THE FIELD

Sample date: 04/22/99

Water elevation: $218.85 \mathrm{H}(66.71 \mathrm{~m}) \mathrm{ms}$ |

$\mathrm{pH}: 4.2$

conductance: $90 \mu \mathrm{S} / \mathrm{cm}$

Water evacualed from the well prior to sampling: $\mathbf{1 1 6} \mathrm{ga}$

ANALYSES

$F$ Analyto

\begin{tabular}{|c|c|c|c|}
\hline $\begin{array}{l}0.200 \\
50.0 \\
0.100 \\
1.00 \\
5.98 E-10\end{array}$ & 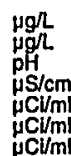 & GP & $\begin{array}{l}\text { EPA7470A } \\
\text { EPA353.1 } \\
\text { EPA9040B } \\
\text { EPA9050A } \\
\text { EPIA.001 } \\
\text { EPIA.001 } \\
\text { EPIA.002 }\end{array}$ \\
\hline
\end{tabular}

0
2
2

$00 \mathrm{pH}$

Specific conductance

Gross alpha
0 Nonvolatio bota

WELL HSB113D

MEASUREMENTS CONDUCTED IN THE FIELD

Sample date: 04/20/99
Depth to waler: $40.81 \mathrm{ft}(12.44 \mathrm{~m})$ below TOC
Waler elevation: $220.09 \mathrm{tt}(67.08 \mathrm{~m}) \mathrm{ms}$ !

PH: 3.6
Sp. conductance: $220 \mu \mathrm{S} / \mathrm{cm}$

Waler evacuated from the well prior to sampling: 1 gat

ANALYSES

$F$ Analyto

Result
0.284
27.000
3.79
3.80
2290
2290
$2.78 E-08+2.58 E-09$
$2.11 \mathrm{E}-06 \pm 1.43 \cdot 08$
$1.41 \mathrm{E}-03 \pm 2.73 \mathrm{E} \cdot 05$

FG

EMS SQL

0
2 Mercury, lotal recoverable

$\mathrm{PH}$

Spectific conductance

Gross alpha

2 Tritum
Unit Lab Mothod

Time: 12:51

ilure: $20.8^{\circ} \mathrm{C}$

Total alkalinity (as Caco3): $0 \mathrm{mg} /$

Time: 11:4

$21.4^{\circ} \mathrm{C}$

Tolal alkalinity (as Caco3): $0 \mathrm{mgh}$

Phenolphihalein alkalinity: $0 \mathrm{mgh}$

Waler temperature: $22.1^{\circ} \mathrm{C}$

Total alkalinity (as Cacos): $0 \mathrm{mg} / \mathrm{h}$

Phenolphithalein alkalinity: $0 \mathrm{mg}$.

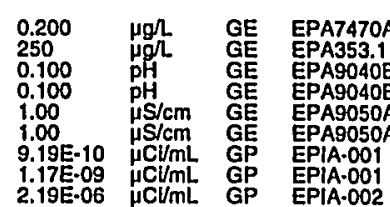

\section{me: $14: 20$}

Qualifer(s):

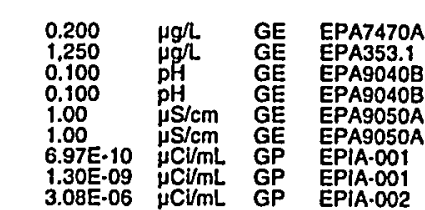




\section{WELL HSB114C}

MEASUREMENTS CONDUCTED IN THE FIELD

Sample date: 04/26/99

Water elevall

H: 4.7 conductance: $190 \mu \mathrm{S} / \mathrm{cm}$

Water evacuated from the well prior to sampling: 53 gal ANALYSES

$F$ Analyto

Rosult
$<0.200$
19.500
4.80
201
$7.58 \mathrm{E} \cdot 09 \pm 1.45 \mathrm{E} \cdot 09$
$3.92 \mathrm{E} \cdot 0.092 .09 \mathrm{E} .09$
$2.46 \mathrm{E} \cdot 03 \pm 4.81 \mathrm{E} .05$

- Mercury, total recoverablo

Nilrate-nitrite as nitrogen
0
0

1 Nonvolatilie bet

2 Tritium

WELL HSB114D

MEASUREMENTS CONDUCTED IN THE FIELD

Sample data: 05/13/99 $\mathrm{Deplh}$ to waler: $45.6 \mathrm{ft}$ (13.9 $\mathrm{m}$ ) below TOC

Deplh to waler: $45.6 \mathrm{th}(13.9 \mathrm{~m})$ below TOC
Water elevation: $2 i 8.4 \mathrm{Ht}(66.57 \mathrm{~m}) \mathrm{msl}$

pH: 3.9

p. conductance: $400 \mu \mathrm{S} / \mathrm{cm}$

Water evacuated from the well prior to sampling: $13 \mathrm{gal}$

ANALYSES

$F$ Analyto

Result
0.0807
40.500
40.800
3.98
3.97
409
410
$1.97 E-08 \pm 2.50 E-09$
$1.87 \mathrm{E}-08 \pm 2.56 \mathrm{E}-09$
$1.02 \mathrm{E}-06 \pm 1.01 \mathrm{E}-08$
$9.94 \mathrm{E}-07 \pm 1.02 \mathrm{E}$
5.98
$.99 \mathrm{E}-03 \pm 1.17 \mathrm{E}-04$

Mercury, total recoverable

Nitrate-nitrite as nitrogen

pH

Specillc conductance

Gross alpha

Nonvolatilia bel

$5.99 \mathrm{E} \cdot 03 \pm 1.17 \mathrm{E} \cdot 04$

\section{WELL HSB115C}

MEASUREMENTS CONDUCTED IN THE FIELD

Sample date: 04/26/99

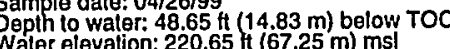

$\mathrm{Waler}$

5.5
conductance: $160 \mu \mathrm{S} / \mathrm{cm}$

Water evacuated from the well prior to sampling: 95 gal

ANALYSES

F Analyto

Mercury, total recoverable

Nitrate-nitrite as nitrogen

$0_{0}^{\mathrm{pH}}$ Specific conductance

Nonvolatile bet

2 Tritium
Timo: 9:13

Waler (emperature: $19.4^{\circ} \mathrm{C}$

Air temperature: $19.4^{\circ} \mathrm{C}$

Total alkalinily (as CaCO3): $0 \mathrm{mg} /$
Phenolphithalerin alkalinity: $0 \mathrm{mg} \mathrm{L}^{-}$
Field Qualifier(s): $V$

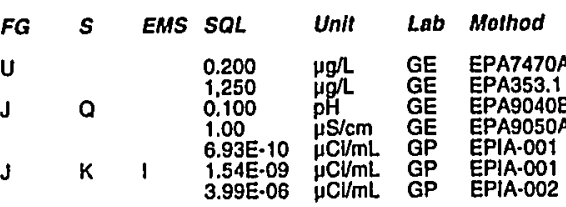

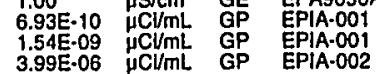

Time: 9:16

Water temperature: $22.4^{\circ} \mathrm{C}$

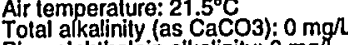

Total alkalinily, (as CaCO3): $0 \mathrm{mg} /$
Phenolphthalein alkalinity: $0 \mathrm{mg} /$
Field Qualifier(s): $V$

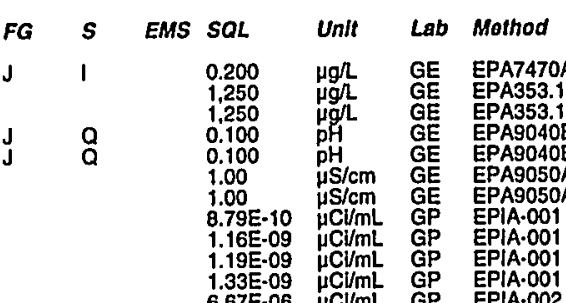

Time: 8:42

Waler temperature: $20.4^{\circ} \mathrm{C}$

Air temperalure: $17 .{ }^{2}$ Cos $): 6 \mathrm{mg} / \mathrm{L}$
Total akalinity (as Caco3
Phenolphthalein alkalinity: $0 \mathrm{mg} /$

Phenolphthalein alk
Field Qualififer(s): $S$

MS SQL Unil Lab Mothod

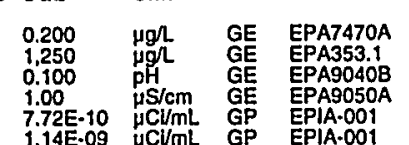

WELLL HSB115D

MEASUREMENTS CONDUCTED IN THE FIELD

Sample date: $04 / 21 / 99$
Depth 1o waler: $48.41 \mathrm{Ht}(14.76 \mathrm{~m})$ below TOC

Waler

Surbidity

Waler evacuated from the well prior to sampling: $10 \mathrm{gal}$

dry during purging.

ANALYSES

$F$ Analyto

Result

O Mercury, lotal recoverable

0 pH

2 Gross alpha

2 Tritium

\section{WELL HSB116C}

MEASUREMENTS CONDUCTED IN THE FIELD

Sample date: 04/22/99

Water e

$\mathrm{Pp}: 4.4$. conductance: $50 \mu \mathrm{S} / \mathrm{cm}$

Water evacuated from the well prior to sampling: $70 \mathrm{gal}$

ANALYSES

$F$ Analyto

O Marcury, total recoverable

1 Nitrale-niltrite as nitrogen

O Gross alpha

\section{WELL HSB116D}

MEASUREMENTS CONDUCTED IN THE FIELD

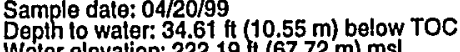

Water elo

Sp. conductance: $90 \mu \mathrm{S} / \mathrm{cm}$

Water evacualed from the well prior to sampling: $17 \mathrm{gal}$

ANALYSES

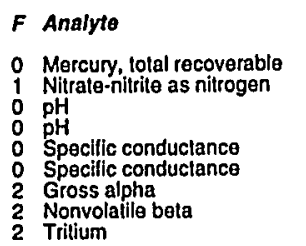

Result
$<0.200$
8,220
4.36
4.39
94.4
94.4
$2.04 \mathrm{E}-08 \pm 2.38 \mathrm{E}-09$
$9.00 \mathrm{E}-07 \pm 1.00 \mathrm{E}-08$
$4.71 \mathrm{E}-05 \pm 1.33 \mathrm{E}-06$

Time: 9:00

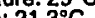

Total alkalinity. (as CaCO3): $0 \mathrm{mg} /$

Phenolphthalein alkalinity: $0 \mathrm{mg}$ 


\section{WELL HSB117A}

MEASUREMENTS CONDUCTED IN THE FIELD

Sample date: 04/16/99

Depth to water: 70.48 H $(21.48 \mathrm{~m})$ below TOC$$
\text { Water }
$$

Sp. conductance: $80 \mu \mathrm{S} / \mathrm{cm}$

Tubbidity: 1 NTU
Water evacuated from the well prior to sampling: $168 \mathrm{gal}$

ANALYSES

$F$ Analyte

\begin{tabular}{|c|c|c|c|c|c|c|c|}
\hline osult & $F G$ & $s$ & EMS & $S Q L$ & Unit & Lab & Method \\
\hline $\begin{array}{l}<0.200 \\
<10.0 \\
7.05\end{array}$ & $\underset{J}{u}$ & v & & $\begin{array}{l}0.200 \\
50.0 \\
0.100\end{array}$ & 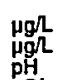 & $\begin{array}{l}\mathrm{GE} \\
\mathrm{GE} \\
\mathrm{GE}\end{array}$ & $\begin{array}{l}\text { EPA7470A } \\
\text { EPA353.1 } \\
\text { EPA9040B }\end{array}$ \\
\hline $\begin{array}{l}158 \\
9.84 E-10 \pm 5.69 E-10 \\
1.16 \mathrm{E}-096.24 \mathrm{E}-10 \\
8.97 \mathrm{E}-08 \pm 3.29 \mathrm{E}-07\end{array}$ & Ju & 1 & & $\begin{array}{l}7.00 \\
7.60 E-10 \\
1.19 E-09 \\
5.69=-07\end{array}$ & $\begin{array}{l}\mu \mathrm{cm} \\
\mathrm{HC} / \mathrm{mL} \\
\mu \mathrm{C} / \mathrm{mL}\end{array}$ & $\begin{array}{l}\mathrm{GP} \\
\text { GP } \\
\mathrm{GP}\end{array}$ & $\begin{array}{l}\text { EPPA-001 } \\
\text { EPPIA-001 } \\
\text { EPIA.002 }\end{array}$ \\
\hline
\end{tabular}

Nitrate-nitrite as niltrogen

$0 \mathrm{pH}$.

Gross alpha

\section{WELL HSB117C}

MEASUREMENTS CONDUCTED IN THE FIELD

Sample date: $04 / 26 / 99$
Depth lo water: $19.51 \mathrm{ft}(5.95 \mathrm{~m})$ below TOC
Water elovation: $217.89 \mathrm{tt}(66.41 \mathrm{~m}) \mathrm{msl}$

Water elovat

p. conductance: $360 \mu \mathrm{S} / \mathrm{cm}$

Water evacuated from the well prior to sampling: $93 \mathrm{gal}$ ANALYSES

F Analyto

Rosult
0.192
39.000
4.58
367
$1.92 E-08 \pm 2.44 E-09$
$8.81 \mathrm{E} .08 \pm 3.04 \mathrm{E}$
$5.60 \mathrm{E}-03 \pm 1.09 \mathrm{E}-04$

EMS SOL

Time: 10:06

Total alkalinity (as Cacos): $0 \mathrm{mg} / \mathrm{L}$
Phenolphthalein alkalinity: $0 \mathrm{mg}$.

0 Mercury, lotal recoverablo

$\mathrm{pH}$ inhlo as nilrogen

Gross alpha
Nonvolatile bela

\section{WELL HSB117D}

MEASUREMENTS CONDUCTED IN THE FIELD

Sample date: $04 / 23 / 99$
Depth to water: $18.23 \mathrm{ft}(5.56 \mathrm{~m})$ below TOC
Wator elovation: $219.37 \mathrm{ht}(66.86 \mathrm{~m}) \mathrm{msl}$

$\mathrm{pH}: 4.7$

p. conductance: $24 \mu \mathrm{S} / \mathrm{cm}$

Wurbidity: 1 NTU

ANALYSES

$F$ Analyte

o Mercury, total recoverable

Nitrate.

Specilic conductance

O Gross alpha

1 Trilium

ESH-EMS-990521

Time: 8:05

Total alkalinity (as CaCO3): $0 \mathrm{mg} / \mathrm{L}$

Phenolphthalein alkalinity: $0 \mathrm{mg} /$
Field Qualifier(s): $\mathrm{S}$
Water temperature: $18.7^{\circ} \mathrm{C}$

\section{WELL HSB118A}

MEASUREMENTS CONDUCTED IN THE FIELD

Depth to water: $79.25 \mathrm{Ht}(24.16 \mathrm{~m})$ below TOC

pH: 6.5

Sp. conductance: $160 \mu 5 / \mathrm{cm}$

Waler evacuated from the well prior to sampling: $135 \mathrm{gal}$ ANALYSES

\begin{tabular}{|c|c|c|c|c|c|c|c|c|}
\hline Analyte & Result & $F G$ & $s$ & EMS & $S O L$ & Unit & Lab & Mothod \\
\hline 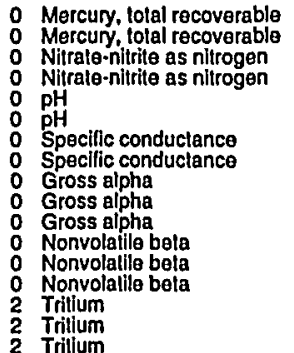 & 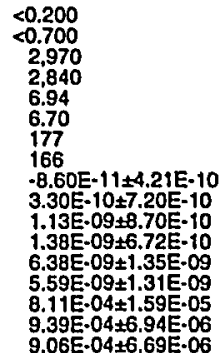 & U & : & & 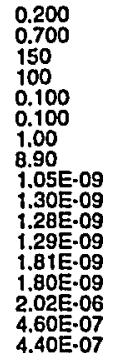 & 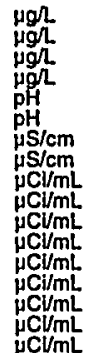 & $\begin{array}{l}G E \\
W A \\
\text { GE } \\
W A \\
\text { GE } \\
W A \\
G E \\
W A \\
G P \\
\text { GM } \\
\text { IM } \\
\text { GP } \\
\text { IM } \\
\text { IMP } \\
\text { GP } \\
\text { IM }\end{array}$ & $\begin{array}{l}\text { EPA7470A } \\
\text { EPA7470A } \\
\text { EPA353.1 } \\
\text { EPA353.2 } \\
\text { EPA9040B } \\
\text { EPA90408 } \\
\text { EPA9050A } \\
\text { EPA9050A } \\
\text { EPIA-001 } \\
\text { EPA900.0M } \\
\text { EPA900.0M } \\
\text { EPIA.001 } \\
\text { EPA900.0M } \\
\text { EPA900.0M } \\
\text { EPIA.002 } \\
\text { EPA906.0M } \\
\text { EPA906.0M }\end{array}$ \\
\hline
\end{tabular}

\section{WELL HSB118A Replicate}

MEASUAEMENTS CONDUCTED IN THE FIELD

Sample date: 04/22/99

Depth lo water: $89.79 \mathrm{ft}(27.37 \mathrm{~m})$ below TOC
Water elevation: $167.31 \mathrm{ft}(51 \mathrm{~m}) \mathrm{msl}$
Depth to waler: $79.25 \mathrm{ft}(24.16 \mathrm{~m})$ below TOC

Waler el wa

$\mathrm{Sp}$. conductance: $160 \mu \mathrm{S} / \mathrm{cm}$

Water evacualed from the well prior to sampling: $135 \mathrm{gal}$ ANALYSES

F Analyte

o Mercury, Iotal recoverable

$\mathrm{pH}$ Specilic conductance

O Gross alpha

\section{WELL HSB119A}

MEASUREMENTS CONDUCTED IN THE FIELD

Sample date: 04/21/99

Sp. 6.1 conduclanco: $140 \mu \mathrm{S} / \mathrm{cm}$

Turbidity: 0 NTU Water evacualed from the well prior to sampling: $125 \mathrm{gal}$ ANALYSES

\section{$F$ Analyto}

- Mercury, lotal recoverable

$\mathrm{pH}$ Specific conductance

Gross alpha
Nonvolatile beta

Nonvolatil

\begin{tabular}{|c|c|}
\hline Result & $F G$ \\
\hline$<0.200$ & $\mathbf{u}$ \\
\hline & $J$ \\
\hline $\begin{array}{l}\text { 1. } 43 \mathrm{EE}-09 \pm 6.60 \mathrm{E}-10 \\
3.53 \mathrm{E}-09 \pm 7.14 \mathrm{E}-10\end{array}$ & $J$ \\
\hline
\end{tabular}

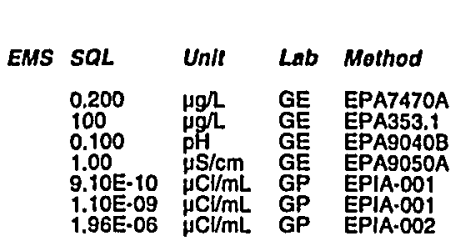

Warer emperature: $20.8^{\circ} \mathrm{C}$

Total alkalinity (as CaCO3): $31 \mathrm{mg} / \mathrm{L}$

Fhenolphthalein alkalinity: 0 mo

Water temperature: $19.5^{\circ} \mathrm{C}$

Total alkalinity (as CaCO3): $48 \mathrm{mg}$.

Phenolphthalein alkalinity: $0 \mathrm{mgh}$

\begin{tabular}{|c|c|}
\hline Result & $F G$ \\
\hline$<0.200$ & U \\
\hline & $\mathrm{J}$ \\
\hline $\begin{array}{l}1.11 \mathrm{E}-09 \pm 6.09 \mathrm{E}-10 \\
1.34 \mathrm{E} \cdot 08 \pm 1.25 \mathrm{E}-09 \\
3.84 \mathrm{E}-04 \pm 7.56 \mathrm{E}-06\end{array}$ & $J$ \\
\hline
\end{tabular}

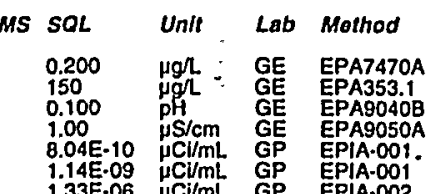

Socond Quarter 1999 


\section{WELL HSB120A}

MEASUREMENTS CONDUCTED IN THE FIELD

Sample date: 04/23/99
Depth to water: $101.6 \mathrm{ft}(30.97 \mathrm{~m})$ below TOC
Whater elevation: $166.6 \mathrm{ft}(50.78 \mathrm{~m}) \mathrm{msl}$$$
\text { Waler }
$$

Sp. conductance: $200 \mu \mathrm{S} / \mathrm{cm}$

Water evacuated from the well prior to sampling: $111 \mathrm{gal}$

ANALYSES

$F$ Analyto

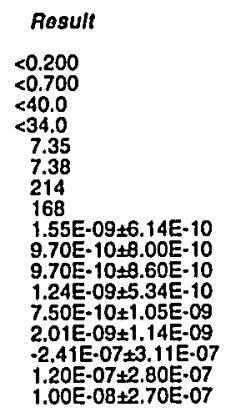

- Mercury, total recoverable

0 Nitrate-nitritit as nitrogen

$\mathrm{pH}$

Specitic conductance

Gross alpha

G Gross alpha

Nonvolatile beta

Trifium

0 Trilium

$1.00 \mathrm{E} \cdot 08+2.70 \mathrm{E} \cdot 07 \mathrm{U}$

\section{WELL HSB120A Replicate}

MEASUREMENTS CONDUCTED IN THE FIELD

Sample date: 04/23/99

Water elevation: $166.6 \mathrm{ft}(50.78 \mathrm{~m}) \mathrm{msl}$

pH: 6.9

p. conductance: $200 \mu \mathrm{S} / \mathrm{cm}$

Water evacuated from the well prior to sampling: 111 gal

ANALYSES

$F$ Analyto

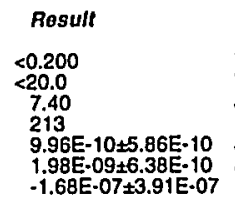

$F G$
$U$
$J$
$J$
$J$

\begin{tabular}{|c|c|c|c|c|c|}
\hline$S$ & EMS & SOL & Unit & Lab & Mothod \\
\hline & 6 & $\begin{array}{l}0.200 \\
0.700 \\
50.0\end{array}$ & $\begin{array}{l}\mu g / \mathrm{h} \\
\mu g \mathrm{~L} \\
\mu g \mathrm{~g}\end{array}$ & $\begin{array}{l}G E \\
W A \\
G E\end{array}$ & $\begin{array}{l}\text { EPA7470A } \\
\text { EPA7470A } \\
\text { EPA353.1. }\end{array}$ \\
\hline a & & $\begin{array}{l}20.0 \\
0.100 \\
0.100 \\
1.00 \\
8.90\end{array}$ & $\begin{array}{l}\mu g h- \\
\text { ph } \\
\text { pH } \\
\mu \mathrm{SS} / \mathrm{cm} \\
\mathrm{wS} / \mathrm{cm}\end{array}$ & $\begin{array}{l}\text { WA } \\
\text { GE } \\
\text { WE } \\
\text { WA }\end{array}$ & $\begin{array}{l}\text { EPA9040B } \\
\text { EPA9040B } \\
\text { EPA9050A } \\
\text { EPA9050A }\end{array}$ \\
\hline 1 & & $\begin{array}{l}6.51 \mathrm{E} \cdot 10 \\
1.20 \mathrm{E} .09 \\
1.31 \mathrm{E} .09\end{array}$ & $\begin{array}{l}\mu \mathrm{C} / \mathrm{mL} \\
\mu \mathrm{C} / \mathrm{mL} \\
\mu \mathrm{C} / \mathrm{mL}\end{array}$ & $\begin{array}{l}\text { GP } \\
\text { TM }\end{array}$ & $\begin{array}{l}\text { EPIA.001 } \\
\text { EPA900.0M } \\
\text { EPA900.0M }\end{array}$ \\
\hline I & & $\begin{array}{l}9.91 \mathrm{E} \cdot 10 \\
1.78 \mathrm{E} \cdot 09\end{array}$ & $\begin{array}{l}\mu \mathrm{C} / \mathrm{mL} \\
\mu \mathrm{C} / \mathrm{mL}\end{array}$ & GP & $\begin{array}{l}\text { EPIA.001 } \\
\text { EPA900.0M }\end{array}$ \\
\hline 1 & & $\begin{array}{l}\text { 1. } .11 \mathrm{E} .09 \\
5.63 \mathrm{E} \\
4.90 \mathrm{0}-07 \\
.000 .07\end{array}$ & $\begin{array}{l}\mu \mathrm{C} / \mathrm{mL} \\
\mu \mathrm{C} / \mathrm{mL} \\
\mu \mathrm{C} / \mathrm{mL}\end{array}$ & $\begin{array}{l}\mathrm{TM} \\
\mathrm{GP} \\
\mathrm{TM}\end{array}$ & $\begin{array}{l}\text { EPA900.0M } \\
\text { EPIA.002 } \\
\text { EPA906.0M } \\
\text { EPA906.0M }\end{array}$ \\
\hline
\end{tabular}

Time: 7:10

ature: $19.4^{\circ} \mathrm{C}$ Total alkalinity (as CaCO3): $83 \mathrm{mg}$ Phenolphthalein alkalinity: $0 \mathrm{mg} / \mathrm{L}$

$4.90 \mathrm{E}-07 \mathrm{\mu C \textrm {mL }}$ IM EPA906.0M

Time: $7: 10$ Air temperature: $14.5^{\circ} \mathrm{C}$ ) $83 \mathrm{mg} / \mathrm{l}$ Total alkalinity (as Cacios): $83 \mathrm{mg} /$
Phenolphthalein alkalinity: $0 \mathrm{mg} /$
Field Qualifier(s): $\mathrm{S}$

- Mercury, total recoverable

0 Specitic conductance

G Gross alpha

WELL HSB121A

MEASUREMENTS CONDUCTED IN THE FIELD

Sample date: 04/16/9

Depth water: $102.43 \mathrm{ft}(31.22 \mathrm{~m}$ ) below TOC

Water ol wat

7.2 elevation: $172.17 \mathrm{ft}(52.48 \mathrm{~m}) \mathrm{msl}$

Sp. conductance: $160 \mu \mathrm{S} / \mathrm{cm}$

Waler evacualed from the well prior to sampling: $184 \mathrm{gal}$

ANALYSES

$F$ Analyto

0 Mercury, lotal recoverable

PH

Gross alpha

0 Tritium

ESH-EMS-990521

\begin{tabular}{|c|c|c|c|c|c|c|c|}
\hline Result & $F G$ & $\boldsymbol{s}$ & EMS & SQL & Unit & Lab & lathod \\
\hline $\begin{array}{l}<0.200 \\
<10.0 \\
7.87 \\
244 \\
4.03 E-10 \pm 5.39 E-10 \\
8.32 E-10+46.47-10 \\
-3.30 E-07 \pm 3.00 E-07\end{array}$ & $\underset{J}{U}$ & $\begin{array}{l}v \\
\text { Q }\end{array}$ & & $\begin{array}{l}0.200 \\
50.0 \\
0.100 \\
1.00 \\
1.08 E-09 \\
1.32 E .09 \\
5.53 E-07\end{array}$ & 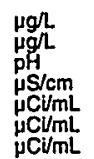 & $\begin{array}{l}\mathrm{GE} \\
\mathrm{GE} \\
\mathrm{GE} \\
\mathrm{GE} \\
\mathrm{GP} \\
\mathrm{GP} \\
\mathrm{GP}\end{array}$ & $\begin{array}{l}\text { EPA7470A } \\
\text { EPA353.1 } \\
\text { EPA9040B } \\
\text { EPA9050A } \\
\text { EPIA.001 } \\
\text { EPIA.001 } \\
\text { EPIA.002 }\end{array}$ \\
\hline
\end{tabular}

Time: $10: 00$ Air lemperature: $19.7^{\circ} \mathrm{C}$ Total alkalinity (as CaCO3): $93 \mathrm{mg} /$

\begin{tabular}{|c|c|c|c|}
\hline $\begin{array}{l}0.200 \\
50.0 \\
0.100 \\
1.00 \\
8.97 E-10 \\
1.10 \mathrm{E}-09\end{array}$ & $\begin{array}{l}\mu g h \\
\mu g h \\
\mu H \\
\mu \mathrm{H} / \mathrm{cm} \\
\mu \mathrm{C} / \mathrm{mL} \\
\mu \mathrm{C} / \mathrm{mL} \\
\mu \mathrm{Cl} / \mathrm{mL}\end{array}$ & $\begin{array}{l}G E \\
G E \\
G E \\
G E \\
G P \\
G P\end{array}$ & $\begin{array}{l}\text { EPA7470A } \\
\text { EPA353.1 } \\
\text { EPA9040B } \\
\text { EPA9050A } \\
\text { EPIA.001 } \\
\text { EPIA.001 } \\
\text { EPIA.002 }\end{array}$ \\
\hline
\end{tabular}
Phenolphthalein alkalinity: $0 \mathrm{mg} /$

\section{WELL HSB122A}

MEASUREMENTS CONDUCTED IN THE FIELD

Sample date: 04/21/99

99.73 t $(30.4 \mathrm{~m})$ below TOC

列

p. conductance: $200 \mu \mathrm{S} / \mathrm{cm}$

Waler evacualed from the well prior to sampling: $150 \mathrm{gal}$

ANALYSES

$\begin{array}{ll}0 & \text { Mercury, lotal recoverable } \\ 0 & \text { Nitrate-nitrite as niltrogen } \\ 0 & \text { pH } \\ 0 & \text { Specific conductance } \\ 0 & \text { Gross alpha } \\ 0 & \text { Nonvolattle bela } \\ 0 & \text { Trllium }\end{array}$

Result
$<0.200$
20.0
7.13
212
$3.83 E-10 \pm 4.45 E-10$
$8.87=10 \pm 6.98 E-10$
$-2.27 \mathrm{E}-07 \pm 3.20 \mathrm{E} \cdot 07$

\begin{tabular}{|c|c|c|c|c|}
\hline EMS & $S Q L$ & Untt & Lab & Mothod \\
\hline & $\begin{array}{l}0.200 \\
50.0 \\
0.100 \\
1.00 \\
8.43 E-10 \\
1.45 \cdot .09 \\
5.77 E-07\end{array}$ & 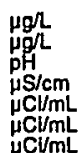 & $\begin{array}{l}G E \\
G E \\
G E \\
G E \\
G E \\
G P \\
G P \\
G P\end{array}$ & $\begin{array}{l}\text { EPA7470A } \\
\text { EPA353.1 } \\
\text { EPA9040B } \\
\text { EPA9050A } \\
\text { EPIA-001 } \\
\text { EPIA.001 } \\
\text { EPIA-002 }\end{array}$ \\
\hline
\end{tabular}

\section{WELL HSB123A}

MEASUAEMENTS CONDUCTED IN THE FIELD

Sample date: 04/21/99

Water elevation: $172.61 \mathrm{H}(52.61 \mathrm{~m}) \mathrm{ms}$

$\mathrm{pH}: 10.8$

conductance: $880 \mu \mathrm{S} / \mathrm{cm}$

Waler evacuated from the well prior to sampling: $1 \mathrm{gal}$

ANALYSES

\begin{tabular}{|c|c|c|c|c|c|c|c|c|}
\hline Analyte & Rosult & $\boldsymbol{F G}$ & $\boldsymbol{s}$ & EMS & SQL & Unt & Lab & Method \\
\hline 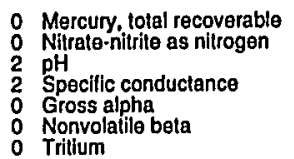 & $\begin{array}{l}<0.200 \\
40.0 \\
11.7 \\
987 \\
7.40 \mathrm{E}-10 \pm 9.05 \mathrm{E}-10 \\
6.51 \mathrm{E}-09 \pm 1.03 \mathrm{E}-09 \\
-4.96 \mathrm{E}-07 \pm 3.07 \mathrm{E}-07\end{array}$ & $\begin{array}{l}\mathbf{J} \\
\mathbf{J}\end{array}$ & $a$ & & $\begin{array}{l}0.200 \\
50.0 \\
0.100 \\
.00 \\
1.60 \mathrm{E} \cdot 09 \\
1.42 \mathrm{E}-09 \\
5.77 \mathrm{E} \cdot 07\end{array}$ & 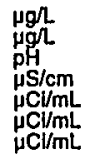 & $\begin{array}{l}G E \\
G E \\
G G \\
G E \\
G E \\
G P \\
G P \\
G P\end{array}$ & $\begin{array}{l}\text { EPA7470A } \\
\text { EPA353.1 } \\
\text { EPA9040B } \\
\text { EPA9050A } \\
\text { EPIA.001 } \\
\text { EPIA.001 } \\
\text { EPIA.002 }\end{array}$ \\
\hline
\end{tabular}

Time: 10:05

Air temperature: $22.2^{\circ} \mathrm{C}$

Total alkalinity (as CaCo3): $178 \mathrm{mg}$

Phenolphthalein alkalinity: $171 \mathrm{mg} L$

\section{WELL HSB124AR}

MEASUREMENTS CONDUCTED IN THE FIELD

Sample date: 04/21/99

$\mathrm{pH}: 6.7$

p. conductance: $210 \mu \mathrm{S} / \mathrm{cm}$

Water evacuated from the well prior to sampling: $115 \mathrm{gal}$ ANALYSES

\begin{tabular}{|c|c|}
\hline & Analyto \\
\hline & $\begin{array}{l}\text { Mercury, lotal recoverable } \\
\text { Nitrate-nithite as nitrogen } \\
\text { Nitrate-nitrite as nitrogen } \\
\text { pH } \\
\text { Specific conductance } \\
\text { Gross alpha } \\
\text { Gross alpha } \\
\text { Nonvolatile beta } \\
\text { Nonvolatile beta } \\
\text { Trifium }\end{array}$ \\
\hline
\end{tabular}

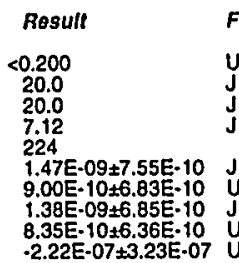

FG
$\mathbf{J}$
$\mathbf{J}$
$\mathrm{J}$
$\mathbf{J}$
$\mathbf{J}$
$\mathbf{U}$
$\mathbf{U}$

\section{Time: 9:59 \\ Air temperature: $21.5^{\circ} \mathrm{C}$ \\ Total alkalinity (as CaCO3): $81 \mathrm{mg} / \mathrm{L}$ \\ Phenolphthalein alkalinity: $0 \mathrm{mg} /$.}

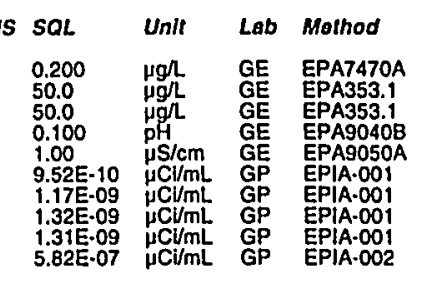




\section{WELL HSB125C}

MEASUREMENTS CONDUCTED IN THE FIELD

Sample date: 04/19/99
Depth to water: 9.19 th $(2.8 \mathrm{~m})$ below TOC
Water elevation: 222.71 it $(67.88 \mathrm{~m}) \mathrm{msl}$

Water

Sp. conductance: $26 \mu \mathrm{S} / \mathrm{cm}$

Waler evacualed from the well prior to sampling: 192 gal ANALYSES

$F$ Analyre

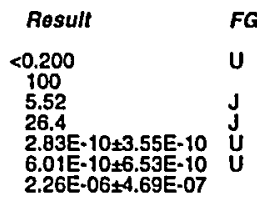

FG

- Mercury, total recoverable

Specilic conductance

$\begin{array}{ll}0 & \text { Gross alpha } \\ 0 & \text { Nonvolatile bet } \\ 0 & \text { Tritium }\end{array}$

\section{WELL HSB125D}

MEASUREMENTS CONDUCTED IN THE FIELD

Sample date: 04/19/99

Depth to water: $11.55 \mathrm{ft}(3.52 \mathrm{~m})$ below TOC
Water elevation: $220.15 \mathrm{ft}(67.1 \mathrm{~m}) \mathrm{ms}$

ph: 5.2

. conductance: $140 \mu \mathrm{S} / \mathrm{cm}$

Water evacualed from the well prior to sampling: $93 \mathrm{gal}$

ANALYSES

$F$ Analyto

\begin{tabular}{|c|c|c|c|c|c|c|c|}
\hline suft & FG & $s$ & EMS & SQL & Unlt & Lab & Mothod \\
\hline $\begin{array}{l}1.06 \\
10,100 \\
5.57 \\
141 \\
1.55 E \cdot 09+7.08 E \cdot 10 \\
6.37 \mathrm{E} \cdot 09+1.07 \mathrm{E} \cdot 09 \\
6.61 \mathrm{E}-04 \pm 4.74 \mathrm{E} \cdot 06\end{array}$ & J & $\begin{array}{l}0 \\
1\end{array}$ & $\begin{array}{l}x \\
x\end{array}$ & $\begin{array}{l}0.200 \\
300 \\
0.100 \\
1.00 \\
9.28 \mathrm{E}-10 \\
1.51 \mathrm{E} \cdot 09 \\
6.62 \mathrm{E} \cdot 07\end{array}$ & 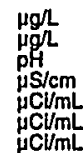 & $\begin{array}{l}\mathrm{GE} \\
\mathrm{GE} \\
\mathrm{GE} \\
\mathrm{GE} \\
\mathrm{GP} \\
\mathrm{GP} \\
\mathrm{GP}\end{array}$ & $\begin{array}{l}\text { EPA7470A } \\
\text { EPA353.1 } \\
\text { EPA9040B } \\
\text { EPA9050A } \\
\text { EPIA.001 } \\
\text { EPIA.001 } \\
\text { EPIA-002 }\end{array}$ \\
\hline
\end{tabular}

$\mathrm{SH}$ Speific conductance

Nonvolatile beta

\section{WELL HSB126C}

MEASUREMENTS CONDUCTED IN THE FIELD

Sample dale: $04 / 19 / 99$
Deph to water: $8.61 \mathrm{ft}(2.62 \mathrm{~m})$ below TOC
Wather elevallon: $203.99 \mathrm{ft}(62.18 \mathrm{~m}) \mathrm{msl}$
pH: 7

$\mathrm{H}: 7$. 7 onduclance: $270 \mu \mathrm{S} / \mathrm{cm}$

Water evacuated from the well prior to sampling: $60 \mathrm{gal}$ ANALYSES

$F$ Anslyte

$\begin{array}{ll}\text { Result } & \\ <0.200 & \\ 12,600 & \mathrm{U} \\ 7.74 & \mathrm{~J} \\ 279 & \mathrm{~J} \\ 2.27 \mathrm{E}-10 \pm 5.25 \mathrm{E}-10 & \mathrm{U} \\ 4.49 \mathrm{E}-09 \pm 9.26 \mathrm{E}-10 \\ 4.76 \mathrm{E}-04 \pm 4.03 \mathrm{E}-06\end{array}$

\begin{tabular}{|c|c|c|c|c|c|}
\hline $\mathbf{S}$ & EMS & SQL & Unit & Lab & Mothod \\
\hline$Q$ & $\begin{array}{l}x \\
x\end{array}$ & $\begin{array}{l}0.200 \\
250 \\
0.100 \\
1.00 \\
1.18 E-09 \\
1.38 E-09 \\
6.63 E-07\end{array}$ & $\begin{array}{l}\mu g / L \\
\mu g / L \\
p H \\
\mu S / c m \\
\mu C / m L \\
\mu C / m L \\
\mu C / / m L\end{array}$ & $\begin{array}{l}G E \\
G E \\
G E \\
G E \\
G E \\
G P \\
G P \\
G P\end{array}$ & $\begin{array}{l}\text { EPA7470A } \\
\text { EPA353.1 } \\
\text { EPA9000 } \\
\text { EPA9050A } \\
\text { EPAA.001 } \\
\text { EPIA.001 } \\
\text { EPIA.002 }\end{array}$ \\
\hline
\end{tabular}

Time: 14:59

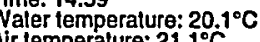
Total alkalinity (as CaCO3): $4 \mathrm{mg} /$ Fhenolphihalein alkalinity: $0 \mathrm{mg}$

\begin{tabular}{|c|c|c|c|c|}
\hline EMS & SOL & Unit & Lab & Mathod \\
\hline $\begin{array}{l}x \\
x\end{array}$ & $\begin{array}{l}0.200 \\
50.0 \\
0.100 \\
1.00 \\
6.87 E-10 \\
1.39 E-09 \\
6.62 E-07\end{array}$ & $\begin{array}{l}\mu g h \\
\mu g h \\
p H \\
\mu S / c m \\
\mu C / m L \\
\mu C / m L \\
\mu C / m L \\
\mu C / m L\end{array}$ & $\begin{array}{l}\text { GE } \\
G E \\
G E \\
G E \\
G E \\
G P \\
G P \\
G P\end{array}$ & $\begin{array}{l}\text { EPA353.1 } \\
\text { EPA9040 } \\
\text { EPA9050 } \\
\text { EPIA-001 } \\
\text { EPIA-001 } \\
\text { EPIA.002 }\end{array}$ \\
\hline
\end{tabular}

Time: 15:04

Werature $18.8^{\circ} \mathrm{C}$

Total alkalinity (as CaCO3): $5 \mathrm{mgh}$

Phenolphthalein alkalinity: $0 \mathrm{mgh}$

$\begin{array}{lll}0 & \text { Mercury, total recoverable } & <0.200 \\ 2 & \text { Nitrate-nitrile as nitrogen } & 12.600 \\ 0 & 7.74 \\ \text { 1 } & \text { Specilic conductance } & 279 \\ 0 & \text { Gross alpha } & 2.27 \mathrm{E}-10 \pm 5.25 \mathrm{E}-10 \\ 0 & \text { Nonvolatle bela } & 4.49 \mathrm{E}-09 \pm 9.26 \mathrm{E}-10 \\ 2 & \text { Tritium } & 4.76 \mathrm{E}-04 \pm 4.03 \mathrm{E}-06\end{array}$

Time: 11:22

Wiler temperature: $18.9^{\circ} \mathrm{C}$

Total alkalinity (as CaCO3): $76 \mathrm{mg} / \mathrm{L}$ Phenoiphnhaken alkalinity: $0 \mathrm{mg} / \mathrm{L}$

$6.63 E-07$ HClmL GP EPIA.001

\section{WELL HSB126D}

MEASUREMENTS CONDUCTED IN THE FIELD

Sample date: 04/19/99
Depth to water: $8.15 \mathrm{ft}(2.48 \mathrm{~m})$ below TOC
Water elevation: $204.55 \mathrm{ft}(62.35 \mathrm{~m}) \mathrm{msl}$

$\mathrm{pH}: 4.4$

Sp. conductance: $270 \mu \mathrm{S} / \mathrm{cm}$

Water evacualed from the well prior to sampling: 2 gal

ANALYSES

F Analyte

1 Mercury, lotal recoverable

2 Nitrate-nitrite as nitrogen

pH

Sonvolatile beta

2 Tritium

\section{WELLL HSB127C}

MEASUREMENTS CONDUGTED IN THE FIELD

Sample dale: 04/21/99

Water elevation: $209.35(4.98 \mathrm{~m})$ below TOC

ph: 7.4

S. conductance: $250 \mu \mathrm{S} / \mathrm{cm}$

Water evacualed from the well prior to sampling: $88 \mathrm{gal}$

ANALYSES

$F$ Analyte

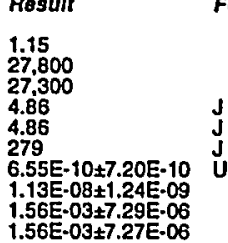

FG

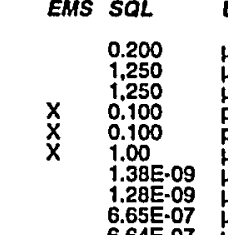

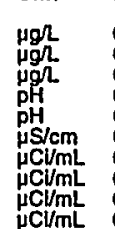

Lab Method

o Mercury, tolal recoverable

Nitrate-nitritite as niltrogen

1 Nitrator

Specille conductance

Specilic conductance

Gross alpha

Gross alpha

Nonvolatile bola

Nonvolatilis beta

WELL HSB127C Replicate

MEASUREMENTS CONDUCTED IN THE FIELD

Sample date: 04/21/99

Deph to waler: $: 6.35 \mathrm{ft}(4.98 \mathrm{~m})$ below TOC
Waler elevalion: $209.35 \mathrm{H}(63.81 \mathrm{~m}) \mathrm{msl}$

$\mathrm{BH}: 7.4$ conduclance: $250 \mu \mathrm{S} / \mathrm{cm}$

Water evacuated from the well prior to sampling: 88 ga ANALYSES

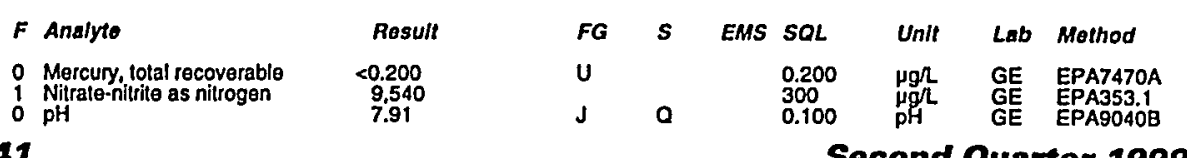

Time: 11:30 $18.8^{\circ} \mathrm{C}$ Total alkalinity (as CaCO3): $0 \mathrm{mg} /$ Phenolphthalein alkalinity: $0 \mathrm{mg} \Omega$

\section{Time: 11:06 \\ Tolal alkalinity (as CaCO3): $75 \mathrm{mg} / \mathrm{L}$}

Phenolphthalein alkaln
Field Qualifier(s): S

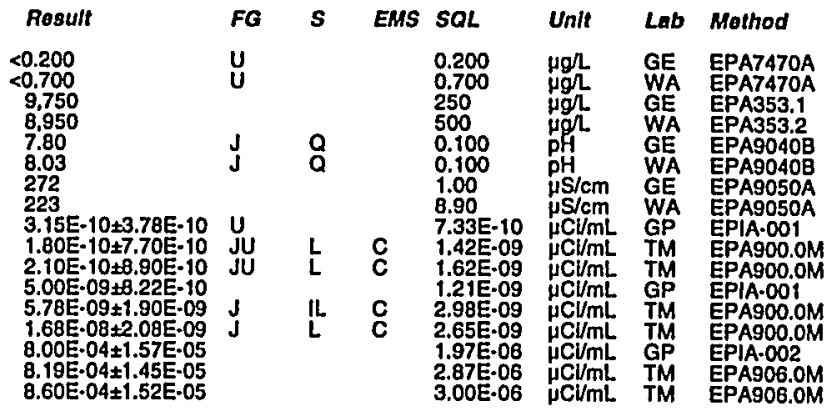

Time: 11:06

Weter temperalure: $20.5^{\circ} \mathrm{C}$ Total alkalinity (as CaCo3): $75 \mathrm{mg} / \mathrm{L}$ Phenolphthayein alkalinity: $0 \mathrm{mg} / \mathrm{L}$

Socond Quarter 1999 
Well HSB127C collecled on 04/21/99 (cont.)

\begin{tabular}{|c|c|c|c|c|c|c|c|c|}
\hline Analyto & Rosult & $F \boldsymbol{G}$ & $s$ & EMS & SQL & Unit & Lab & Mothod \\
\hline $\begin{array}{l}1 \text { Specilic conductance } \\
0 \text { Gross alpha } \\
0 \text { Nonvolatila bela } \\
2 \text { Triftum }\end{array}$ & $\begin{array}{l}273 \\
5.90 \mathrm{E}-10 \pm 4.26 \mathrm{E}-10 \\
4.04 \mathrm{E}-0947.64 \mathrm{E}-10 \\
8.20 \mathrm{E} \cdot 04 \pm 1.61 \mathrm{E}-05\end{array}$ & $\mathbf{u}$ & & & $\begin{array}{l}1.00 \\
6.46 E-10 \\
1.09 E-09 \\
2.01 E-06\end{array}$ & $\begin{array}{l}\mu \mathrm{S} / \mathrm{cm} \\
\mu \mathrm{Cl} / \mathrm{mL} \\
\mu \mathrm{CC/mL} \\
\mu \mathrm{C} / \mathrm{mL}\end{array}$ & $\begin{array}{l}\text { GE } \\
G P \\
G P \\
G P\end{array}$ & $\begin{array}{l}\text { EPA9050A } \\
\text { EPIA.001 } \\
\text { EPIA.001 } \\
\text { EPIA.002 }\end{array}$ \\
\hline
\end{tabular}

\section{WELL HSB127D}

MEASUREMENTS CONDUCTED IN THE FIELD

Sample date: 04/21/99
Depth to water: $12.7 \mathrm{ft}(3.87 \mathrm{~m})$ below TOC
Water elevation: $213.4 \mathrm{tt}(65.05 \mathrm{~m}) \mathrm{msl}$

Water

Sp. conductance: $94 \mu \mathrm{S} / \mathrm{cm}$

Turbidiliy: $1 \mathrm{NTU}$
Waler evacualed from the well prior to sampling: $53 \mathrm{gal}$

ANALYSES

$F$ Anolyto

\begin{tabular}{|c|c|c|c|c|c|c|c|}
\hline sult & $F G$ & $s$ & EMS & SQL & Unit & Lab & Mothod \\
\hline $\begin{array}{l}1.09 \\
8,600 \\
4.93 \\
97.0 \\
7.70 \mathrm{E}-09 \pm 1.21 \mathrm{E} \cdot 09 \\
2.89 \mathrm{E} \cdot 00 \pm 1.55 \mathrm{E} \cdot 09 \\
2.17 \mathrm{E} \cdot 04 \pm 4.28 \mathrm{E} \cdot 06\end{array}$ & $\mathbf{J}$ & 0 & & $\begin{array}{l}0.200 \\
250 \\
0.100 \\
1.00 \\
7.51 E \cdot 10 \\
1.08 \cdot .09 \\
9.86 E \cdot 07\end{array}$ & 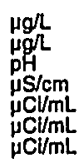 & $\begin{array}{l}\text { GE } \\
G E \\
G E \\
G E \\
G E \\
G P \\
G P \\
G P\end{array}$ & $\begin{array}{l}\text { EPA7470A } \\
\text { EPA353.1 } \\
\text { EPAO40B } \\
\text { EPA9050A } \\
\text { EPPA-001 } \\
\text { EPIA.001 } \\
\text { EPIA.002 }\end{array}$ \\
\hline
\end{tabular}

1 Mercury, 10 tal recoverable

$\mathrm{pH}$ Hinte as nilrogen

1 Gross alpha

$2.17 \mathrm{E} \cdot 04 \pm 4.28 \mathrm{E} \cdot 06$

\section{WELL HSB129C}

MEASUREMENTS CONDUCTED IN THE FIELD

Sample date: $04 / 26 / 99$
Depth to water: $00.83 \mathrm{H}(3.3 \mathrm{~m})$ below Toc
Water elevalion: $204.27 \mathrm{hi}(62.26 \mathrm{~m}) \mathrm{msl}$

Water elevalion: $204.27 \mathrm{hi}(62$.
pH: 6
Sp. conductance: $230 \mu \mathrm{S} / \mathrm{cm}$

Tp. conductance: $230 \mu \mathrm{S} / \mathrm{cm}$ Water evacuated from the well prior
The well went dry during purging.

ANALYSES

F Analyte

2 Mercury, tolal recoverable

2
0
0

2 Nonvolatila beta

\section{WELL HSB129D}

MEASUREMENTS CONDUCTED IN THE FIELDD

Sample date: 04/22/99
Dephth to water: $7.77 \mathrm{ft}(2.37 \mathrm{~m})$ below TOC
Water elevation: $206.93 \mathrm{ft}(63.07 \mathrm{~m}) \mathrm{msl}$

Waler e

Sp. conductance: $160 \mu \mathrm{S} / \mathrm{cm}$

Turbidity: 1 NTU:
Water evacualed from the well prior to sampling: $47 \mathrm{gal}$

ANALYSES

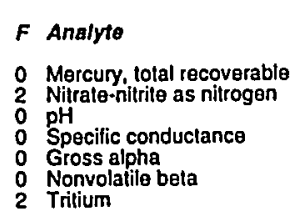

$\begin{array}{lll}\text { Result } & F G & S \\ <0.0550 & U & V \\ 16.000 & J & Q \\ 4.88 & J \\ 147 & 0 \\ 1.08 E-09 \pm 5.09 E-10 & J & 1 \\ 1.52 E-08 \pm 1.17 E-09 & \\ 1.42 E-03 \pm 2.75 E-05 & \end{array}$

ESH-EMS-990521

Time: 10:44

Total alkalinity (as CaCO3): $0 \mathrm{mg} / \mathrm{L}$

Phenolphthalein alkalinity: $0 \mathrm{mg}$

Time: 13:10

Total alkalinity (as CaCO3): $27 \mathrm{mg}$

Phenolphthalein alkalinity: $0 \mathrm{mg} / \mathrm{L}$

EMS SQL Unth Lab Mothod

Time: 9:13

Water temperature: $17.7^{\circ} \mathrm{C}$

Total alkalinity (as Caco3): $0 \mathrm{mg} / \mathrm{L}$
Phenolphinalein alkalinity: 0 mg

Phenolphihalein alkalinity: $0 \mathrm{mg} L$
Field Qualifier(s): $S$

EMS SQL Unit Lab Mathoo

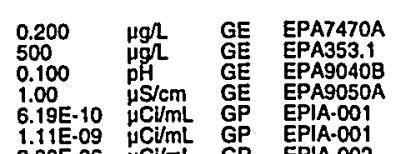

\section{WELL HSB130C}

MEASUREMENTS CONDUCTED IN THE FIELD

Sample dale: 04/22/99
Depth to water: $18.55 \mathrm{ft}(5.65 \mathrm{~m})$ below TOC
Water elevation: $199.75 \mathrm{Ht}(60.88 \mathrm{~m}) \mathrm{ms}$

pH: 7.6

Sp. conduclance: $160 \mu \mathrm{S} / \mathrm{cm}$

Water evacuated from the well prior to sampling: $75 \mathrm{gal}$

ANALYSES

$F$ Analyto

o Mercury, total recoverable

1 ppecilic conductance

Gross alpha

\section{WELL HSB130D}

MEASUREMENTS CONDUCTED IN THE FIELD

Sample date: 04/22/99

Depth to waler: $18.68 \mathrm{ft}(5.69 \mathrm{~m})$ bolow TOC

$\mathrm{pH}: 5.8$ Sp. conductance: $49 \mu \mathrm{S} / \mathrm{cm}$

Turbidity: ONTU
Water evacuated from the well prior to sampling: $33 \mathrm{gal}$

ANALYSES

F Anolyto

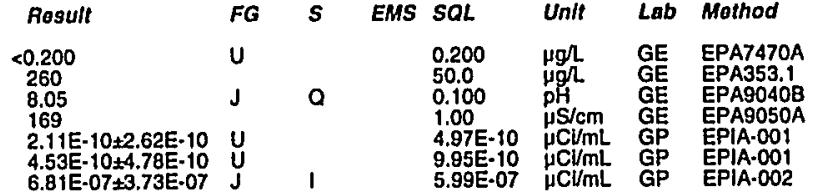

o Mercury, total recoverable

${ }_{0}^{0} \mathrm{pH}$ - Mitratrite as nilrog

Specific conductance

Gross alpha

Nonvolaille beta
o Nonvolatie beta
Tritium

$0.200 \quad \mu g / L$ GE EPA7470A WELL HSB131C

MEASUAEMENTS CONDUCTED IN THE FIELD

Sample date: $04 / 23 / 99$. $2.44 \mathrm{~m}$ ) below TOC

Water elevalion: 203.68 it $(62.08 \mathrm{~m}) \mathrm{ms}$

Sp: 7.2 conductance: $210 \mu \mathrm{S} / \mathrm{cm}$

Water evacuated from the well prior to sampling: $104 \mathrm{gal}$

ANALYSES
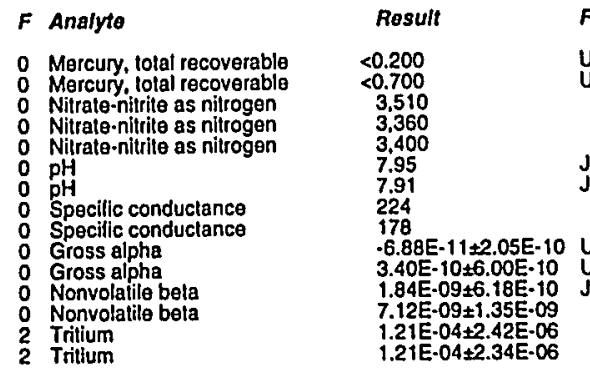

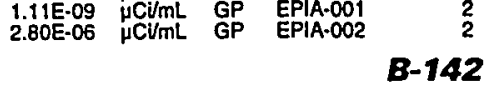

Time: 9:22

Wirtemperalure: $19.1^{\circ} \mathrm{C}$

Total alkalinily (as CaCO3): $69 \mathrm{mg}$

Phenolphinalein alkalinity: $0 \mathrm{mg} / \mathrm{L}$

Water (emperature: $18.9^{\circ} \mathrm{C}$

Total alkalinity (as CaCO3): $9 \mathrm{mg} /$

Field Qualifier(s):

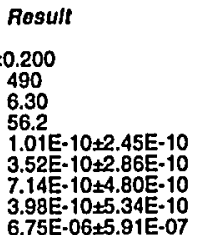

FG

\begin{tabular}{|c|c|c|c|c|}
\hline EMS & $S Q L$ & Unit & Lab & Method \\
\hline & $\begin{array}{l}0.200 \\
50.0 \\
0.100 \\
1.00 \\
5.59 E-10 \\
4.59 E-10 \\
9.53=-10 \\
1.13 E-09 \\
6.21 E-07\end{array}$ & 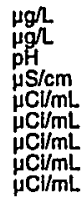 & $\begin{array}{l}G E \\
G E \\
G E \\
G E \\
G E \\
G P \\
G P \\
G P \\
G P \\
G P\end{array}$ & $\begin{array}{l}\text { EPA7470A } \\
\text { EPA353.1 } \\
\text { EPA9000 } \\
\text { EPA9050A } \\
\text { EPA.001 } \\
\text { EPAA.001 } \\
\text { EPIA.001 } \\
\text { EPA.001 } \\
\text { EPIA.002 }\end{array}$ \\
\hline
\end{tabular}

Time: 7:14

列 $18.8^{\circ} \mathrm{C}$

Air temperature: $15.8^{\circ} \mathrm{C}$ ) $75 \mathrm{mg} / \mathrm{L}$

Phenolphthalein alkalinity: $0 \mathrm{mg} / \mathrm{L}$

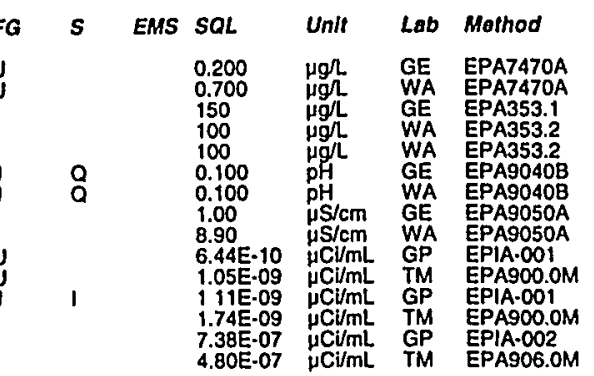

Second Quarter 1999 
WELL HSB131C Replicate

MEASUREMENTS CONDUCTED IN THE FIELD

Sample date: 04/23/99

Sample date: 04/23/99
Deph to waler: $8.02 \mathrm{Ht}(2.44 \mathrm{~m})$ below Toc
Water elevation: $203.68 \mathrm{fi}(62.08 \mathrm{~m}) \mathrm{msl}$

Sp. conductance: $210 \mu \mathrm{S} / \mathrm{cm}$

Water evacuated from the well prior to sampling: $104 \mathrm{gal}$ ANALYSES

F Analyto

\begin{tabular}{|c|c|c|c|c|c|c|c|}
\hline \multirow{3}{*}{$\begin{array}{l}\text { Result } \\
<0.200 \\
3.30 \\
8.00 \\
224 \\
3.52 E-10+3.67 E-10\end{array}$} & $F G$ & $s$ & EMS & SQL & Unh & Lab & Method \\
\hline & $u$ & & & & & & \\
\hline & $\mathrm{J}$ & a & & $\begin{array}{l}150 \\
0.100\end{array}$ & $\mathrm{PH}$ & $\overline{G E}$ & EPAO050 \\
\hline $\begin{array}{l}3.52 E-10 \pm 3.67 E-10 \\
1.43-095.95 E-10 \\
1.36 E-04 \pm 2.14 E-06\end{array}$ & J & 1 & & $\begin{array}{l}6.20 E-10 \\
1.08 E-09\end{array}$ & 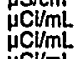 & $\mathrm{GP}$ & $\begin{array}{l}\text { EFAA.001 } \\
\text { EPIAA.001 } \\
\text { EPIA-002 }\end{array}$ \\
\hline
\end{tabular}

- Mercury, total recoverable

$\mathrm{pH}$.

O Gross alpha

\section{WELL HSB131D}

MEASUREMENTS CONDUCTED IN THE FIELD

Sample dale: 04/22/99

Water

Sp. conductance: $25 \mu \mathrm{S} / \mathrm{cm}$

Turbidity: ONTU

ANALYSES

F Anelyto

\begin{tabular}{|c|c|c|c|c|c|c|c|}
\hline iult & $F G$ & $s$ & EMS & $S Q L$ & Unit & Lab & Mothod \\
\hline & $\mathbf{u}$ & & & & ـ & GE & EPA747 \\
\hline & $J$ & a & & & ifo & GE & $\begin{array}{l}\text { EPAOAOB } \\
\text { PPA9050 }\end{array}$ \\
\hline $\begin{array}{l}19 E-09+4.83 E-10 \\
3 E-0945.56 E-10\end{array}$ & $\mathbf{J}$ & 1 & & $\begin{array}{l}5.44 E-10 \\
1.08 E-09 \\
5.20\end{array}$ & $\begin{array}{l}\mu \mathrm{cl} / \mathrm{mL} \\
\mu \mathrm{Cl} / \mathrm{mL}\end{array}$ & GP & $\begin{array}{l}\text { EPA.001 } \\
\text { EPA-001 }\end{array}$ \\
\hline
\end{tabular}

Nitrale-nitrite as nitrogen

Specilfic conductance

Gross alpha

\section{WELL HSB132C}

MEASUREMENTS CONDUCTED IN THE FIELD

Sample date: 04/20/99
Depph 10 waier: $19.93 \mathrm{ft}(6.07 \mathrm{~m})$ below TOC

Whe

Sp. conductance: $23 \mu \mathrm{S} / \mathrm{cm}$

Water evacuated from the well prior to sampling: $1 \mathrm{gal}$ ANALYSES

$F$ Ansiyto

o Mercury, total recoverable

pH

Gross alpha

Tritum
Time: 7:14

Waler temperature: $18.8^{\circ} \mathrm{C}$

Total alkalinity (as CaCO3): $75 \mathrm{mgr}$ Phenolphthalein alkalinity: $0 \mathrm{mg} \Omega$

Time: 10:20

Water temperature: $17.9^{\circ} \mathrm{C}$

Total alkalinity. (as CaCo3): $0 \mathrm{mg}$

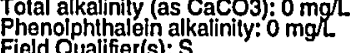

$5.62 E-07$ COML GP

Time: 11:00

Waler temperalure: $19.4^{\circ} \mathrm{C}$

Total alkalinity (as CaCO3): $1 \mathrm{mg} n$

Total alkalinity (as Caco3): $1 \mathrm{mg} /$
Phenolphthalein alkalinity: $0 \mathrm{mg}{ }^{-}$
Field Quallier(s): $\mathrm{SX}$

EMS SaL UnIt Lab Mothod

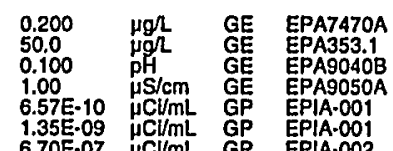

WELL HSB132D

MEASUREMENTS CONDUCTED IN THE FIELD

Sample date: 04/20/99

(a)

D.

Sp. conductance: $21 \mu \mathrm{S} / \mathrm{cm}$

Waler evacuated from the well prior to sampling: $23 \mathrm{gal}$

ANALYSES

$F$ Analyte

- Mercury, tolal recoverable

Nitrale-niltrite as nitrogen

Specific conductance

Gross alpha
Nonvolatila bet

1 Nritium

\section{WELL HSB133C}

MEASUREMENTS CONDUCTED IN THE FIELD

Sample date: 04/19/99

Waler elevalion: $230.127 .77 \mathrm{~m})$ below TOC

$\mathrm{pH}: 5.6$

p. conductance: $32 \mu \mathrm{S} / \mathrm{cm}$

Waler evacuated from the well prior to sampling: $106 \mathrm{gal}$ ANALYSES

F Analyte
: Mercury, total recoverable
0 Nitrate-nilvite as nitrogen
0 pH
0 Specifle conductance
0 Gross alpha
0 Nonvolatile beta
0 Tritimm

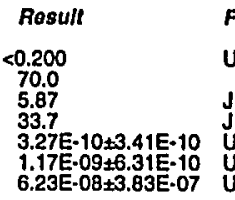

$U$
$J$
$u$
$u$

\section{WELL HSB133D}

MEASUREMENTS CONDUCTED IN THE FIELD

Sampla dalo: 04/19/99

Deph o water: $19.99 \mathrm{t}(6.07 \mathrm{~m})$ below TOC

留: 5.2 conductance: $74 \mu \mathrm{S} / \mathrm{cm}$

Turbidity: 2 NTU
Water evacualed from the well prior to sampling: $97 \mathrm{gal}$

ANALYSES

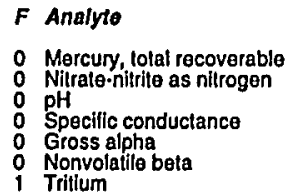

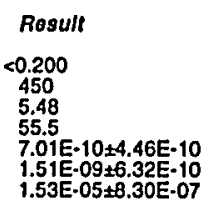

Time: 10:34

Air termper terature: $19.5^{\circ} \mathrm{C}$

Total alkalinity (as Caco3): $0 \mathrm{mg} /$

Field Qualtier(s): $s$

\begin{tabular}{|c|c|c|c|}
\hline so & Unit & Lab & Mothod \\
\hline $\begin{array}{l}0.200 \\
50.0 \\
50.0 \\
0.100 \\
1.00 \\
6.82 E-10 \\
1.39 \cdot 09\end{array}$ & $\begin{array}{l}\mu g / 2 \\
\mu g h \\
\mu g / L \\
\mu H \\
\mu S / c m \\
\mu \mathrm{s} / \mathrm{mL} \\
\mu \mathrm{CU/mL}\end{array}$ & $\begin{array}{l}\text { GE } \\
G E \\
G E \\
G E \\
G E \\
G E \\
G P \\
G P\end{array}$ & $\begin{array}{l}\text { EPA7470A } \\
\text { EPA353.1 } \\
\text { EPA353.1 } \\
\text { EPA9040B } \\
\text { EPA9050A } \\
\text { EPAA.001 } \\
\text { EPIA.001 }\end{array}$ \\
\hline
\end{tabular}

Time: 13:04

Water temperature: $19.7^{\circ}$

Total alkalinily (as Caco3): $6 \mathrm{mg}$

Phenolphthalein alkalinity: $0 \mathrm{mg} \mathrm{m}^{-}$
Field Qualifier(s): $\mathrm{S}$

\begin{tabular}{|c|c|c|c|c|c|}
\hline 5 & $E M S$ & SQL & Unit & Lab & Method \\
\hline Q & $\begin{array}{l}x \\
x\end{array}$ & $\begin{array}{l}0.200 \\
50.0 \\
0.100 \\
1.00 \\
6.26 \mathrm{E}-10 \\
1.22 \mathrm{E} \cdot 09 \\
6.63 \mathrm{E} \cdot 07\end{array}$ & 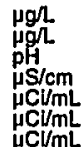 & $\begin{array}{l}\text { GE } \\
G E \\
G E \\
G E \\
G E \\
G P \\
G P \\
G P\end{array}$ & $\begin{array}{l}\text { EPA7470A } \\
\text { EPA353.1 } \\
\text { EPA9040B } \\
\text { EPA9050A } \\
\text { EPIA.001 } \\
\text { EPIA.001 } \\
\text { EPIA-002 }\end{array}$ \\
\hline
\end{tabular}

Air temperature: $17.2^{\circ} \mathrm{C}$

Total alkalinity (as Caco3): $6 \mathrm{mg}$

Field Qualifier(s): $s$

\begin{tabular}{|c|c|c|c|c|c|}
\hline$s$ & EMS & SQL & Untt & Lab & Mothod \\
\hline a & $\begin{array}{l}x \\
x\end{array}$ & $\begin{array}{l}0.200 \\
50.0 \\
0.100 \\
1.00 \\
6.32 \mathrm{E}-10 \\
1.14 \mathrm{E} \cdot 09\end{array}$ & 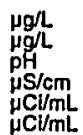 & $\begin{array}{l}\mathrm{GE} \\
\mathrm{GE} \\
\mathrm{GE} \\
\mathrm{GE} \\
\mathrm{GP} \\
\mathrm{GP}\end{array}$ & $\begin{array}{l}\text { EPA7470A } \\
\text { EPA353.1 } \\
\text { EPA9040B } \\
\text { EPA9050A } \\
\text { EPIA.001 } \\
\text { EPIA.001 }\end{array}$ \\
\hline
\end{tabular}




\section{WELL HSB134C}

MEASUREMENTS CONDUCTED IN THE FIELD

Sample dale: $04 / 15 / 99$
Depth to water: 18.18 H $(5.54 \mathrm{~m})$ bolow TOC
Water elevation: $220.22 \mathrm{ft}(67.12 \mathrm{~m}) \mathrm{msl}$

pH: 6 conductance: $40 \mu \mathrm{S} / \mathrm{cm}$

Sp. conductance: $40 \mu \mathrm{S} / \mathrm{cm}$
Turbidity: $1 \mathrm{NTU}$
Waler evacuated from the well prior to sampling: $126 \mathrm{gal}$ ANALYSES

$F$ Analyto

Mercury, tolal recoverable

0 pH

Nonvolatile beta

\section{WELL HSB134D}

MEASUREMENTS CONDUCTED IN THE FIELD

Sample date: 04/13/99
Depth 10 water: $18.47 \mathrm{ft}(5.63 \mathrm{~m})$ below TOC
Water

pH: 4.3

Sp. conductance: $140 \mu \mathrm{S} / \mathrm{cm}$

Water evacuated from the well prior to sampling: $33 \mathrm{gal}$ ANALYSES

\begin{tabular}{|c|c|c|c|c|c|c|c|c|}
\hline Analyte & Result & $F G$ & $s$ & EMS & SQL & Unit & Lab & Melhod \\
\hline $\begin{array}{l}\text { Mercury, total recoverable } \\
\text { Nilrate-nitrite as nitrogen } \\
\text { pH } \\
\text { Specillic conductance } \\
\text { Gross alpha } \\
\text { Gross alpha } \\
\text { Nonvolatilie beta } \\
\text { Nonvolatile beta } \\
\text { Tritium }\end{array}$ & $\begin{array}{l}0.373 \\
13.000 \\
4.26 \\
143 \\
1.29 \mathrm{E}-08+1.56 \mathrm{E} \cdot 09 \\
1.30 \mathrm{E} \cdot 08 \pm 1.51 \mathrm{E} \cdot 09 \\
9.88 \mathrm{E} \cdot 07 \pm 8.90 \mathrm{E} \cdot 09 \\
9.86 \mathrm{E} \cdot 07 \pm 8.89 \mathrm{E} \cdot 09 \\
5.70 \mathrm{E}-04 \pm 4.38 \mathrm{E}-06\end{array}$ & $J$ & 0 & & $\begin{array}{l}0.200 \\
500 \\
0.100 \\
1.00 \\
5.94 \mathrm{E}-10 \\
5.71 \mathrm{E} \cdot 10 \\
1.03 \mathrm{~B} \cdot 09 \\
9.6 \mathrm{EE}-10 \\
6.31 \mathrm{E}-07\end{array}$ & 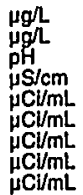 & $\begin{array}{l}G E \\
G E \\
G E \\
G E \\
G E \\
G P \\
G P \\
G P \\
G P \\
G P\end{array}$ & $\begin{array}{l}\text { EPA7470A } \\
\text { EPA353.1 } \\
\text { EPA9040B } \\
\text { EPA9050A } \\
\text { EPIA-001 } \\
\text { EPIA-001 } \\
\text { EPIA-001 } \\
\text { EPIA-001 } \\
\text { EPIA-002 }\end{array}$ \\
\hline
\end{tabular}

\section{WELL HSB135C}

MEASUREMENTS CONDUCTED IN THE FIELD

Sample date: 04/20/99

WH: 7.6 . 6 luction: $206.22 \mathrm{H} / 62.80$

Turbidity: $5 \mathrm{NTU}$ :
Waler evacualed from the well prior to sampling: $120 \mathrm{gal}$

ANALYSES -

$F$ Analyto

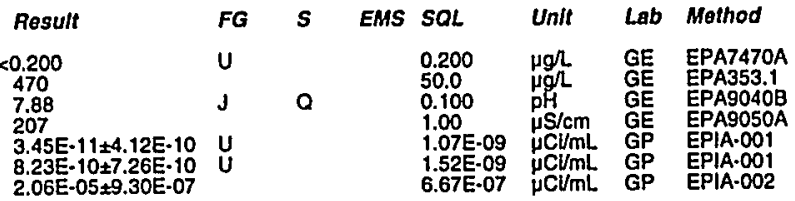

Air temperature: $19.6^{\circ} \mathrm{C}$
Total alkalinity (as CaCo3): $8 \mathrm{mg} /$

Total alkalinity (as Caco3): $8 \mathrm{mg}$
Phenoiphthalein alkalinily: $0 \mathrm{mg} /$
Field Cualifier(s): $\mathrm{S}$

Water temperature: $19.3^{\circ} \mathrm{C}$ Total alkalinity (as CaCO3): $86 \mathrm{mg} /$ Phenolphinalein alkalinity: $0 \mathrm{mg}$.

Oo Mercury, lotal recoverable

0 Specific conduclance

0 Gross alpha
Nonvolatile beta

$8.23 E-10 \pm 7.26 \cdot 10$
$2.06 E-05 \pm 9.30 E-07$
Speclic conductance

Depth to waler: 25.78 H $(7.86 \mathrm{~m})$ below TOC

WELLL HSB135D

MEASUREMENTS CONDUCTED IN THE FIELD

Sample date: 04/20/99

pH: 4.8

Sp. conductance: $35 \mu \mathrm{S} / \mathrm{cm}$

Wurbidily: 1 NTU

ANALYSES

$\begin{array}{ll}\text { Rosult } & F G \\ <0.200 & U \\ 2.280 & J \\ 5.10 & \text { J } \\ 37.3 & 5.09 E-10 \pm 4.65 E-10 \\ 1.08 E-00 \pm 1.24 E-09 & U \\ 2.11 E-05 \pm 9.39 E-07 & \end{array}$

\begin{tabular}{|c|c|c|c|c|c|}
\hline$s$ & EMS & $S Q L$ & Unit & Lab & Mothod \\
\hline$a$ & & $\begin{array}{l}0.200 \\
50.0 \\
0.100 \\
1.00 \\
8.51 E-10 \\
1.366-09 \\
6.67 E-07\end{array}$ & 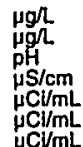 & $\begin{array}{l}G E \\
G E \\
G E \\
G E \\
G E \\
G P \\
G P \\
G P\end{array}$ & $\begin{array}{l}\text { EPA7470A } \\
\text { EPA353.1 } \\
\text { EPA90000 } \\
\text { EPA9050A } \\
\text { EPIA.001 } \\
\text { EPIA-001 } \\
\text { EPIA.002 }\end{array}$ \\
\hline
\end{tabular}

0 Nonvolatile beta

\section{WELL HSB136C}

MEASUREMENTS CONDUCTED IN THE FIELD

Sample dala: 04/26/99

Water

$\mathrm{Sp}$. conductance: $360 \mu \mathrm{S} / \mathrm{cm}$ Turbidity: 1 NTU
Waler evacuated from the well prior to sampling: $1 \mathrm{gal}$
The well went dry during purging.

ANALYSES

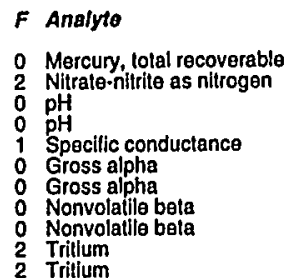

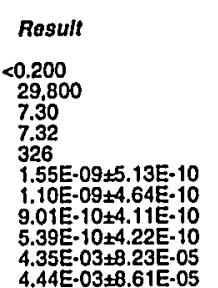

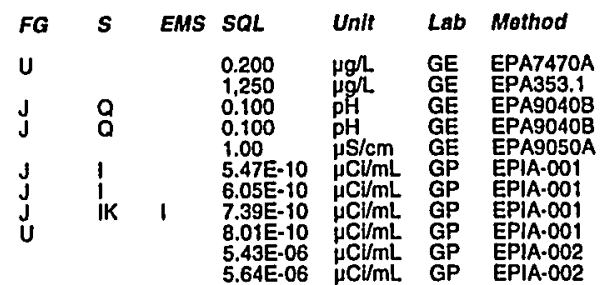

\section{WELL HSB136D}

MEASUREMENTS CONDUCTED IN THE FIELD

Sample date: $04 / 21 / 99$ ( $3.28 \mathrm{~m}$ ) below TOC

Water

$\mathrm{gh}: 3.6$

Water evacuated from the well prior to sampling: $27 \mathrm{gal}$ ANALYSES
Time: 8:12

Wir $18.5^{\circ} \mathrm{C}$

Total alkalinity (as Caco3): $0 \mathrm{mg} /$

Phenolphthalein alkalinity: $0 \mathrm{mgl}$
Time: 14:00

Wirer $20.4^{\circ} \mathrm{C}$ Total alkalinity (as CacCo3): $44 \mathrm{mg} / \mathrm{L}$
Phenolphthalein alkalinity: $30 \mathrm{mg} \mathrm{L}^{-}$

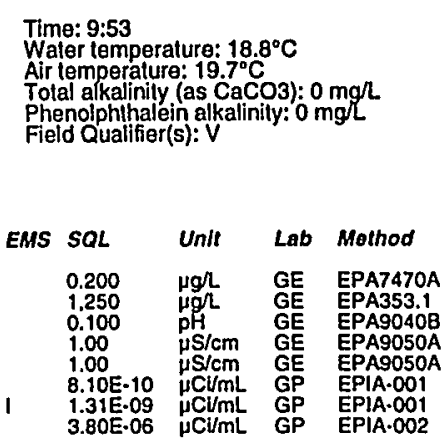

\section{$F$ Analye \\ 0 Mercury, tolal recoverable \\ o $\mathrm{pH}$ Specilic conductance \\ Specilic conductance
Sprosic conductance \\ $\begin{array}{ll}2 & \text { Gross alpha } \\ 2 & \text { Nonvolatile beta } \\ 2 & \text { Trilium }\end{array}$}




\section{WELL HSB140A}

MEASUAEMENTS CONDUCTED IN THE FIELD Sample dale: 04/23/99 Depth to water: $60.03 \mathrm{H}$ (18.3 $\mathrm{m}$ ) below TOC W 6.5 Sp. conductance: $140 \mu \mathrm{S} / \mathrm{cm}$

Turbidity: $1 \mathrm{NTU}$ : ANALYSES

\begin{tabular}{|c|c|c|c|c|c|c|c|c|}
\hline alyte & Rosult & $F G$ & $s$ & EMS & $S Q L$ & Unit & Lab & Mathod \\
\hline 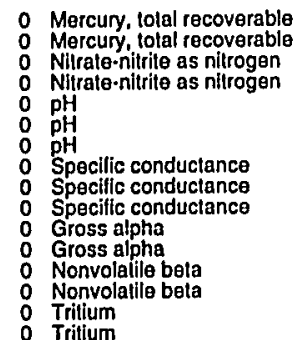 & 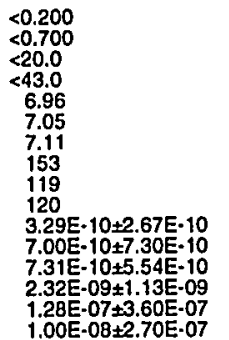 & 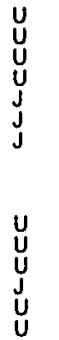 & $\begin{array}{l}0 \\
0 \\
0\end{array}$ & $\begin{array}{l}6 \\
6\end{array}$ & $\begin{array}{l}0.200 \\
0.700 \\
50.0 \\
20.0 \\
0.100 \\
0.100 \\
0.100 \\
1.00 \\
8.90 \\
8.90 \\
4.29 E-10 \\
1.16 E-09 \\
1.13 E-09 \\
1.77 \mathrm{E}-09 \\
6.19 \mathrm{E}-07 \\
4.90 \mathrm{E}-07\end{array}$ & 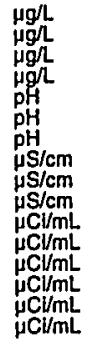 & $\begin{array}{l}\text { GE } \\
W A \\
G E \\
W A \\
G E \\
W A \\
W A \\
G E \\
\text { GA } \\
W A \\
\text { GP } \\
\text { GP } \\
G P \\
G M \\
G P \\
T M\end{array}$ & 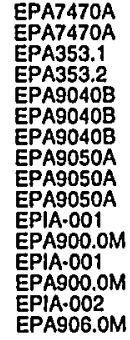 \\
\hline
\end{tabular}

\section{WELL HSB140A Replicate}

MEASUREMENTS CONDUCTED IN THE FIELD

Sample date: 04/23/99

Depth to water: $60.03 \mathrm{H}(18.3 \mathrm{~m})$ below TOC

$\mathrm{gH}: 6.5$

Sp. conductance: $140 \mu \mathrm{S} / \mathrm{cm}$

Waler evacualed trom the well prior to sampling: $145 \mathrm{gal}$ ANALYSES

\begin{tabular}{|c|c|c|c|c|c|c|c|c|}
\hline F Analyto & Result & $F G$ & $s$ & EMS & $S Q L$ & Unit & Lab & Method \\
\hline $\begin{array}{l}\text { Mercury, lotal recoverable } \\
0 \text { Nitrale-nitrite as nitrogen } \\
0 \text { pH } \\
0 \text { Specilic conductance } \\
0 \text { Gross alpha } \\
0 \text { Nonvolatila beta } \\
0 \text { Tritium }\end{array}$ & $\begin{array}{l}<0.200 \\
<20.0 \\
7.08 \\
154 \\
3.45 E-10 \pm 5.08 E-10 \\
5.82 E-10 \pm 5.73 E-10 \\
-8.88 E-08 \pm 3.50 E-07\end{array}$ & $\begin{array}{l}u \\
u \\
u \\
u\end{array}$ & $Q$ & 6 & $\begin{array}{l}0.200 \\
50.0 \\
0.100 \\
1.00 \\
1.05 E \cdot 09 \\
1.18 E .09 \\
6.19 E-07\end{array}$ & 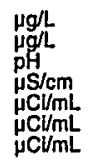 & $\begin{array}{l}\mathrm{GE} \\
\mathrm{GE} \\
\mathrm{GE} \\
\mathrm{GE} \\
\mathrm{GP} \\
\mathrm{GP} \\
\mathrm{GP}\end{array}$ & $\begin{array}{l}\text { EPA7470A } \\
\text { EPA353.1 } \\
\text { EPA90408 } \\
\text { EPA9050A } \\
\text { EPIA-001 } \\
\text { EPIA-001 } \\
\text { EPIA.002 }\end{array}$ \\
\hline
\end{tabular}

\section{WELL HSB140C}

MEASUREMENTS CONDUCTED IN THE FIELD

Sample date: 04/20/99

Depth to water: $30.06 \mathrm{Ht}(9.16 \mathrm{~m})$ below TOC

pH: 5.3 conductance: $23 \mu \mathrm{S} / \mathrm{cm}$

Wuitidity: 0 NTU

ANALYSES

$\begin{array}{ll}\text { F } & \text { Analyte } \\ 0 & \text { Mercury, tolal recoverable } \\ 0 & \text { Nilrate-nitrite as nitrogen } \\ 0 & \text { pH } \\ 0 & \text { Speitic conductance } \\ 0 & \text { Gross alpha } \\ 0 & \text { Nonnolatile beta } \\ 0 & \text { Tritium }\end{array}$

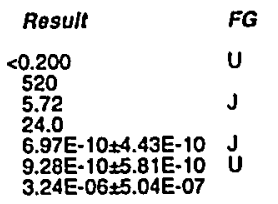

\section{ESH-EMS-990521}

Water temperature: $19.6^{\circ}$

Total alkalinity (as CaCO3): $49 \mathrm{mg} / \mathrm{L}$ Phenolph halein alkalinity: $0 \mathrm{mg} /$

Time: 9:35

Total alkalinily (as CaCO3): $49 \mathrm{mg}$

Time: 12:24

Total alkalinity (as CaCO3): $4 \mathrm{mg} /$.

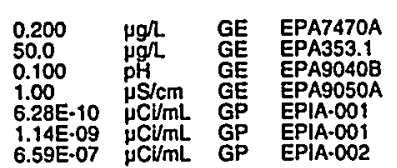

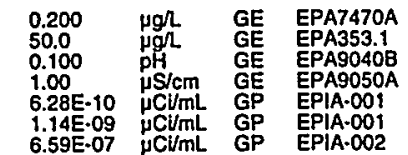

\section{WELL HSB140D}

MEASUREMENTS CONDUCTED IN THE FIELD

Sample date: 04/20/99

Depth to waler: $23.03 \mathrm{Ht}(7.02 \mathrm{~m})$ below TOC

Water elevalion: $213.17 \mathrm{ft}(64.98 \mathrm{~m}) \mathrm{ms}$

$\mathrm{H}: 4.6$

Sp. conductance: $19 \mu \mathrm{S} / \mathrm{cm}$

Waler evacuated from the well prior to sampling: $61 \mathrm{gal}$

ANALYSES

$F$ Analyte

o Mercury, total recoverable

Nitrate-nitrite as niltrogen

${ }_{0}^{0} \mathrm{pH}$ Specilic conductance

Nonvolaille beta

1 Tritium

WELL HSB141A

MEASUREMENTS CONDUCTED IN THE FIELD

Sample date: 04/15/99 $2(24.16 \mathrm{~m})$ below TOC

Water elevation: $175.33 \mathrm{ft}(53.44 \mathrm{~m}) \mathrm{ms}$

pH: 11

conductance: 1,200 $\mu \mathrm{S} / \mathrm{cm}$

Water evacuated from the well prior to sampling: $1 \mathrm{~g}$

The well went dry during purging.

ANALYSES

Air temperature: $21.6^{\circ} \circ^{\circ} \mathrm{C}$

0 Mercury, total recoverable

$\mathrm{pH}$ Specilic conductance

Specilic conductanc
Gross alpha
Nonvolatile bela

$\stackrel{\text { Nonvola }}{0}$ Tritium

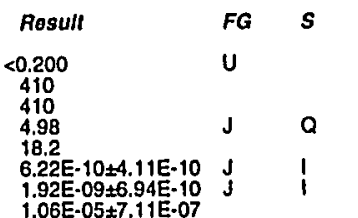

Time: 12:12

ure: $20.6^{\circ} \mathrm{C}$

Total alkalinity (as CaCo3): $0 \mathrm{mg}$

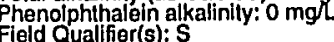

\section{WELL HSB141CR}

MEASUREMENTS CONDUCTED IN THE FIELD

Sample date: $04 / 15 / 99$
Depth to waler: $26.7 \mathrm{ft}(8.14 \mathrm{~m})$ below TOC
Waler elevation: $227.6 \mathrm{Ht}(69.3 \mathrm{~m}) \mathrm{msl}$

$\mathrm{gH}: 5.3$

Sp. conductance: $23 \mu \mathrm{S} / \mathrm{cm}$

Water evacualed from the well prior to sampling: $125 \mathrm{gal}$

Water temperature: $20.2^{\circ} \mathrm{C}$

ANALYSES

$F$ Analyto

O Mercury, total recoverable

0 : $\mathrm{pH}$ Spcilic conductance

Kross alpha
0
Nonvolatile beta
Tritium

: Tritium

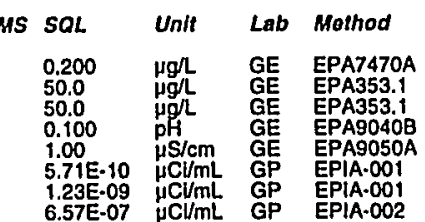

Time: 11:00

Air termperature: $194^{\circ} \mathrm{C}$

Total alkalinity (as CaCO3): $239 \mathrm{mg} /$

Phenolphthalein alkalinity: $231 \mathrm{mg} L$
Fild Qualifier(s): SXH

Air temperalure: $19.3^{\circ} \mathrm{C}$

Total alkalinity (as CaCO3): $5 \mathrm{mg}$

Field Qualifier(s): $\mathbf{S}$

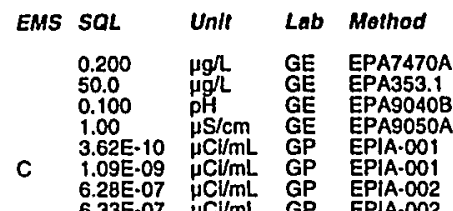

EMS SQL

140

$\begin{array}{lll}23.5 \\ 6.33 E-10 \pm 3.38 E-10 & \mathrm{~J} & \mathrm{I} \\ 1.87 \mathrm{E}-09 \pm 6.09 \mathrm{E}-10 & \mathrm{~J} & \mathrm{IK}\end{array}$

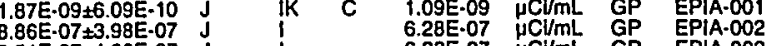




\section{WELL HSB141D}

MEASUREMENTS CONDUCTED IN THE FIELD

Sample date: 04/15/99 Depth o water: $15.9 \mathrm{ft}(5.15 \mathrm{~m})$ below TOC Sp. conductance: $21 \mu \mathrm{S} / \mathrm{cm}$

Water evacuated from the well prior to sampling: $8 \mathrm{gal}$ The well went dry during purging.

ANALYSES

F Analyto

: Mercury, total recoverable

$\mathrm{pH}$

O Gross alpha

1 Trilium

Result
$<0.200$
140
5.36
19.7
$1.82 \mathrm{E}-09 \pm 6.21 \mathrm{E}-10$
$1.69 \mathrm{E}-09+6.12 \mathrm{E}-10$
$1.45 \mathrm{E}-05 \pm 7.83 \mathrm{E}-07$

WELL. HSB142C

MEASUREMENTS CONDUCTED IN THE FIELD

Sample date: $04 / 15 / 99$
Depth to water: $7.98 \mathrm{ft}(2.43 \mathrm{~m})$ below Toc
Water elevation: $196.02 \mathrm{ft}(59.75 \mathrm{~m}) \mathrm{msl}$

Water elevation: $196.02 \mathrm{ft}$ (59.

Spurbonductance: $22 \mu \mathrm{S} / \mathrm{cm}$
Water evacuated from the well prior to sampling: 53 gal

ANALYSES

$F$ Analyto

- Mercury, lotal recoverable

Nirrale-nitrite as nitrogen

Specific conductance

Nonvolatila beta

\section{WELL HSB142D}

MEASUREMENTS CONDUCTED IN THE FIELD

Sample date: 04/15/99

Depht to water: $7.28 \mathrm{ft}(2.22 \mathrm{~m})$ below ToC
Water elevation: $196.92 \mathrm{if}(60.02 \mathrm{~m}) \mathrm{msl}$

Water

Sp. conductance: $40 \mu \mathrm{S} / \mathrm{cm}$

Water evacuated from the well prior to sampling: $1 \mathrm{~g}$

ANALYSES

\begin{tabular}{|c|c|c|c|c|c|c|c|c|}
\hline Analyta & Result & $\boldsymbol{F G}$ & $\mathbf{s}$ & EMS & $S Q L$ & Unt & Lab & Mothod \\
\hline $\begin{array}{l}\text { Mercury, lotal recoverable } \\
\text { Nilrate-nitrite as niltrogen } \\
\text { pH } \\
\text { Specilic conduclance } \\
\text { Specific conduclance } \\
\text { Gross alpha } \\
\text { Nonvolatilie beta } \\
\text { Trillum }\end{array}$ & $\begin{array}{l}<0.200 \\
460 \\
5.04 \\
43.3 \\
43.3 \\
6.66 \mathrm{E}-10 \pm 3.78 \mathrm{E} \\
3.00 \mathrm{E} \cdot 09 \pm 7.17 \mathrm{E} \\
4.13 \mathrm{E}-04 \pm 3.72 \mathrm{E}\end{array}$ & $\begin{array}{l}u \\
J\end{array}$ & $Q$ & C & $\begin{array}{l}0.200 \\
50.0 \\
0.100 \\
1.00 \\
1.00 \\
4.99 \mathrm{E}-10 \\
1.20 \mathrm{E} .09 \\
6.26 \mathrm{E} \cdot 07\end{array}$ & 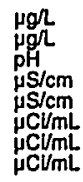 & $\begin{array}{l}\mathrm{GE} \\
\mathrm{GE} \\
\mathrm{GE} \\
\mathrm{GE} \\
\mathrm{GE} \\
\mathrm{GP} \\
\mathrm{GP} \\
\mathrm{GP}\end{array}$ & $\begin{array}{l}\text { EPA7470A } \\
\text { EPA353.1 } \\
\text { EPA9040B } \\
\text { EPA9050A } \\
\text { EPA9050A } \\
\text { EPIA.001 } \\
\text { EPIA.001 } \\
\text { EPIA.002 }\end{array}$ \\
\hline
\end{tabular}

WELL HSB143C

MEASUREMENTS CONDUCTED IN THE FIELD

Sample dale: 04/20/99

Time: $12: 45$ Water temperalure: $29.4^{\circ} \mathrm{C}$ Water elevation: $208.2 \mathrm{ft}(63.46 \mathrm{~m}) \mathrm{msl}$ Total alkalinity (as CaCO3): $3 \mathrm{mgl}$

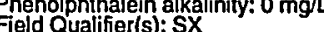

p. conductanca: $49 \mu \mathrm{S} / \mathrm{cm}$

Water evacuated from the well prior to sampling: $79 \mathrm{gal}$

ANALYSES

F Analyte

Mercury, total recoverable

Speclic conductance

Nonvolatile bota
Tritium

\section{WELL HSB143D}

MEASUREMENTS CONDUCTED IN THE FIELD

Sample date: 04/20/99

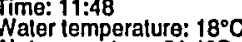

Water olevation: $211.82 \mathrm{Ht}(64.56 \mathrm{~m}) \mathrm{msl}$ Total alkalinity (as CaCo3): $1 \mathrm{mg} /$ Field Qualifier(s): $S$ conductance: $21 \mu \mathrm{S} / \mathrm{cm}$

Water evacuated from the well prior to sampling: $\mathbf{4 3} \mathrm{gal}$ ANALYSES

\section{F Analyto \\ : Mercury, total recoverable \\ $0_{0} \mathrm{pH}$ \\ Specilfic conductance \\ Gross alpha}

c $\begin{array}{r}3.61 E-10 \\ 9 \mathrm{MC} / \mathrm{mL}\end{array}$

Time: 12:05

Air

Tolal alkalinity (as Caco3): $0 \mathrm{mg} /$

Phenolphthalein alkalinity: $0 \mathrm{mgL}$
Field Qualifier(s): SX

L HSB144A

MEASUAEMENTS CONDUCTED IN THE FIELD

Sample dale: 04/22/99
Depth to water: 64.64 ft $(19.7 \mathrm{~m})$ below TOC
Watior olevation: $170.96 \mathrm{ft}(52.11 \mathrm{~m}) \mathrm{msl}$

$\mathrm{pH}: 6.4$

Sp. conductance: $140 \mu \mathrm{S} / \mathrm{cm}$

Water evacualed from the well prior to sampling: $156 \mathrm{gal}$

ANALYSES

$F$ Analyto

$\therefore$ Mercury, total recoverable

0 Specific conductance

0 Gross alpha
0 Nonvolatilo bota

$\begin{array}{lll}\text { Result } & F G & S \\ 0.200 & \text { U } & \\ 200 & \text { J } & a \\ 6.80 & 148 \\ 7.48 E-10 \pm 4.59 E-10 & J & 1 \\ 1.78 E-09 \pm 6.29 E-10 & \text { J } & \text { I } \\ 2.84 E-05 \pm 1.02 E-06 & & \end{array}$

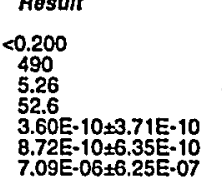

FG

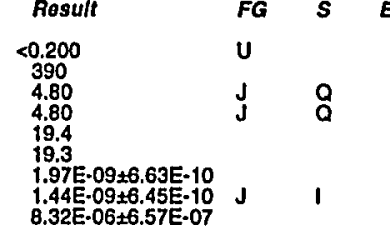

Time: 14:17

ure: $19.9^{\circ} \mathrm{C}$

Total alkalinity (as CaCO3): $0 \mathrm{mg}$

Phenolphthalein alkalinity: $0 \mathrm{mg}$

\begin{tabular}{|c|c|c|c|}
\hline $\begin{array}{l}0.200 \\
50.0 \\
0.100 \\
1.00 \\
6.82 E-10 \\
1.30 \mathrm{E}-09 \\
6.63 \mathrm{E}-07\end{array}$ & $\begin{array}{l}\mu g / \\
\mu g / L \\
. \mu h \\
\mu \mathrm{H} / \mathrm{cm} \\
\mu \mathrm{C} / \mathrm{mL} \\
\mu \mathrm{CC/mL} \\
\mu \mathrm{C} / \mathrm{mL}\end{array}$ & $\begin{array}{l}\mathrm{GE} \\
\mathrm{GE} \\
\mathrm{GE} \\
\mathrm{GE} \\
\mathrm{GP}\end{array}$ & $\begin{array}{l}\text { EPA7470A } \\
\text { EPA353.1 } \\
\text { EPA9040B } \\
\text { EPA9050A } \\
\text { EPIA.001 } \\
\text { EPIA.001 } \\
\text { EPIA.002 }\end{array}$ \\
\hline
\end{tabular}

Time: 14:08

mperature: $19.4^{\circ} \mathrm{C}$

Total alkalinity (as CaCO3): $0 \mathrm{mg} / \mathrm{L}$

Phenolphthalein alkalinity: $0 \mathrm{mg}$.

\begin{tabular}{|c|c|c|c|}
\hline SQL & Unit & Lab & Molhod \\
\hline $\begin{array}{l}0.200 \\
50.0 \\
0.100 \\
0.100 \\
1.00 \\
1.00 \\
6.20 E-10 \\
1.222 \cdot 09 \\
6.61 E-07\end{array}$ & 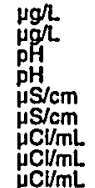 & $\begin{array}{l}\mathrm{GE} \\
\mathrm{GE} \\
\mathrm{GE} \\
\mathrm{GE} \\
\mathrm{GE} \\
\mathrm{GE} \\
\mathrm{GP} \\
\mathrm{GP} \\
\mathrm{GP}\end{array}$ & $\begin{array}{l}\text { EPA7470A } \\
\text { EPA353.1 } \\
\text { EPA9040B } \\
\text { EPA9040B } \\
\text { EPA9050A } \\
\text { EPA9050A } \\
\text { EPIA.001 } \\
\text { EPIA.001 } \\
\text { EPIA.002 }\end{array}$ \\
\hline
\end{tabular}

Warer $20.7^{\circ} \mathrm{C}$

Total akkalinity (as Caco3): $48 \mathrm{mg} /$

Thtal akainily (as Cacos): $48 \mathrm{mg} /$
Phenolphthalein alkalinity: $0 \mathrm{mg} / \mathrm{L}^{-}$
Field Qualifier(s): $\mathrm{S}$

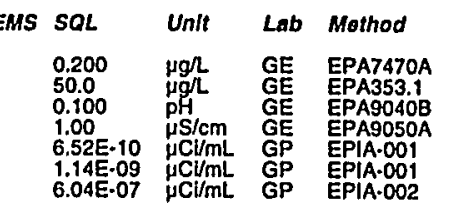




\section{WELL HSB145C}

MEASUREMENTS CONDUCTED IN THE FIELD

Sample dale: $04 / 21 / 99$
Depth to water: $23.15 \mathrm{Ht}(7.06 \mathrm{~m}$ below TOC
Sol

Waler el
$\mathrm{pH}: 5.6$

Sp. conductance: $320 \mu \mathrm{S} / \mathrm{cm}$

Water evacuated from the well prior to sampling: 81 gal ANALYSES

$F$ Analyto

Mercury, total recoverable
2 Nitrate-nitrite as nitrogen

1 ppecific conductance

1 Nonvolatile beta

WELL HSB145D

MEASUREMENTS CONDUCTED IN THE FIELD

Sample date: 04/13/99

Deph o water: $19.28 \mathrm{ft}(5.88 \mathrm{~m})$ below TOC

SH: 5 conductance: $220 \mu \mathrm{S} / \mathrm{cm}$

Waler evacuated from the well prior to sampling: $49 \mathrm{gal}$

ANALYSES

F Anaiyto

Result

1 Mercury, total recoverable

2 Nitrate-nitrite as nitrogen

Specilic conductanc

$\begin{array}{ll}2 & \text { Gross alpha } \\ 2 & \text { Tritium } \\ 2 & \text { Tritio beta }\end{array}$

\section{WELL HSB146A}

MEASUAEMENTS CONDUCTED IN THE FIELD

Sample dale: 04/19/99

Wepth to water: $75.33 \mathrm{Ht}(22.96 \mathrm{~m})$ below

pH: 6.7

Sp. conductance: $175 \mu \mathrm{S} / \mathrm{cm}$

Water evacuated from the well prior to sampling: 151 gal

ANALYSES

$F$ Analyto

O Mercury, total recoverable

0 Specific conductance

G Gross alpha

o Tritium

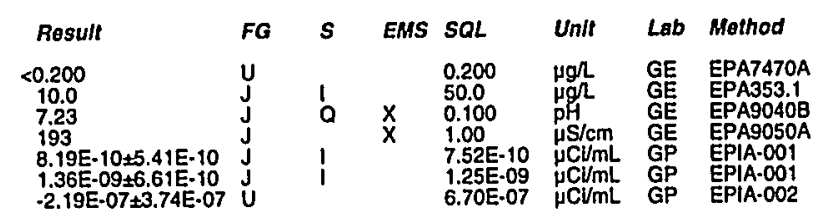

WELL HSB146C

MEASUREMENTS CONDUCTED IN THE FIELD

Sample date: 04/19/99

Depth 10 waler: 42.94 it $(13.09 \mathrm{~m})$ below TOC

$\mathrm{pH}: 8.7$

p. conductance: $59 \mu \mathrm{S} / \mathrm{cm}$

Turbidily: O NTU

ANALYSES

$F$ Anglyto

N Mercury, lotal recoverable

$1 \mathrm{pH}$ perlitic conductance

Gross alpha
Nonvolatile beta

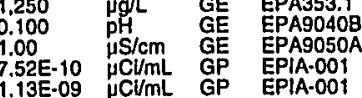

$7.52 E-10$
$2.73 E-09$
$\mu \mathrm{CUML}$

\section{WELL HSB146D}

MEASUREMENTS CONDUCTED IN THE FIELD

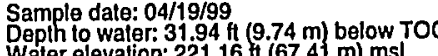

Time: 9:33 Water temperalure: $19.5^{\circ} \mathrm{C}$

Air temperature: $12.4^{\circ} \mathrm{C}$ ) $0 \mathrm{mg} /$

Phenolphthalain alkalinity: $0 \mathrm{mg} /$
Field Qualifier(s): $\mathrm{s}$

Water elave

p. conductance: $18 \mu \mathrm{S} / \mathrm{cm}$

Waler evacuated from the well prior to sampling: $28 \mathrm{gat}$

ANALYSES

\begin{tabular}{|c|c|}
\hline F Analyte & Result \\
\hline $\begin{array}{l}\text { Mercury, Lotal recoverable } \\
\text { Nitrate-nititite as nitrogen } \\
\text { pH } \\
\text { Specilic conductance } \\
\text { Gross alpha } \\
\text { Nonvolatile bota } \\
\text { Trillum }\end{array}$ & $\begin{array}{l}<0.200 \\
480 \\
5.13 \\
16.8 \\
-1.19 E-10 \pm 3.11 E-10 \\
8.39 E-10 \pm 3.51 E-10 \\
1.19 E-05 \pm 7.44 E-07\end{array}$ \\
\hline
\end{tabular}

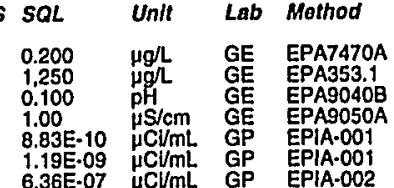

\section{WELL HSB147D}

MEASUREMENTS CONDUCTED IN THE FIELD

Sample date: $04 / 22 / 99$

Time: $12: 59$ Water temperature: $19.4^{\circ} \mathrm{C}$

Air temperature: $21.5^{\circ} \mathrm{C}$.

Total alka nity (as CaCO3): $78 \mathrm{mg} /$

Whater eleval

Sp. conductance: $26 \mu \mathrm{S} / \mathrm{cm}$

Turbldity: $14 \mathrm{NTU}$. Water evacuated from the well prior

ANALYSES

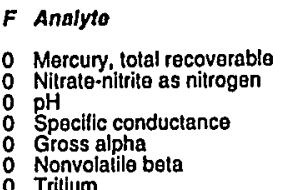

Rosult
$<0.200$
320
5.47
28.4
$9.37 \mathrm{E}-10 \pm 4.46 \mathrm{E}-10$
$1.45 \mathrm{E}-09 \pm 6.25 \mathrm{E} \cdot 10$
$8.80 \mathrm{E}-06 \pm 6.54 \mathrm{E} \cdot 07$

Time: 13:27

Wir $19.8^{\circ} \mathrm{C}$ Total alkalinity (as CaCO3): $22 \mathrm{mg} /$ Phenolphthalein alkalinily: $0 \mathrm{mg} /$
EMS SOL Unlt Lab Method

5 EMS SQL Unit Lab Mothod

$0 \quad x$

\begin{tabular}{|c|c|c|c|}
\hline $\begin{array}{l}.200 \\
0.0 \\
0.100 \\
1.00 \\
.45 E-10 \\
.42 E \cdot 09\end{array}$ & 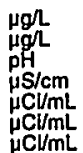 & $\begin{array}{l}\mathrm{GE} \\
\mathrm{GE} \\
\mathrm{GE} \\
\mathrm{GE} \\
\mathrm{GP} \\
\mathrm{GP}\end{array}$ & $\begin{array}{l}\text { EPA7470A } \\
\text { EPA353.1 } \\
\text { EPA9040B } \\
\text { EPA9050A } \\
\text { EPIA.001 } \\
\text { EPIA.001 } \\
\text { EPIA.002 }\end{array}$ \\
\hline
\end{tabular}

Time: 12:42

What $20.1^{\circ} \mathrm{C}$

Total akalinity (as Caco3): $0 \mathrm{mg} /$ Phenolphthalein alkalinity: $0 \mathrm{mg} L$

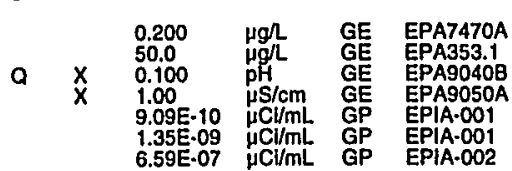

Time: 10:10

Waler temperature: $17.8^{\circ} \mathrm{C}$

Total alkalinity (as CaCO3): $1 \mathrm{mg} /$ Phenolphthalein alkalinity: $0 \mathrm{mg} h$

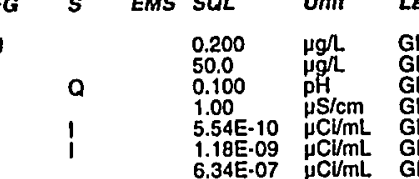

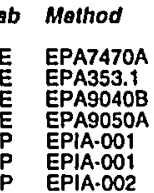




\section{WELL HSB148C}

MEASUREMENTS CONDUCTED IN THE FIELD

Sample dale: 04/21/99

. conductance: $66 \mu \mathrm{S} / \mathrm{cm}$

Water evacuated from the well prior to sampling: 1 gal ANALYSES

$F$ Anolyte

\begin{tabular}{|c|c|c|c|c|c|c|c|}
\hline \multirow{5}{*}{$\begin{array}{l}\text { Rosult } \\
<0.200 \\
500 \\
9.46 \\
69.9 \\
8.56-10 \\
2.63 \mathrm{E}-09\end{array}$} & $F G$ & 5 & EMS & \multirow{5}{*}{$\begin{array}{l}\text { S SQL } \\
0.200 \\
50.0 \\
0.100 \\
1.00 \\
4.56 \mathrm{E}-10 \\
9.88 \mathrm{E}-10 \\
5.80 \mathrm{E}-07\end{array}$} & \multirow{5}{*}{$\begin{array}{l}\text { Unit } \\
\mu \mathrm{g} / \mathrm{h} \\
\mu \mathrm{gh} \\
\mathrm{pH} \\
\mathrm{pH} / \mathrm{cm} \\
\mu \mathrm{Cl} / \mathrm{mL} \\
\mu \mathrm{Cl} / \mathrm{mL} \\
\mu \mathrm{Cl} / \mathrm{mL}\end{array}$} & \multirow{5}{*}{$\begin{array}{l}\angle a b \\
\mathrm{GE} \\
\mathrm{GE} \\
\mathrm{GE} \\
\mathrm{GE} \\
\mathrm{GP} \\
\mathrm{GP} \\
\mathrm{GP}\end{array}$} & Method \\
\hline & u & & & & & & \multirow{4}{*}{ 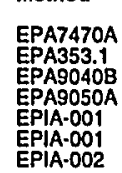 } \\
\hline & $\mathrm{J}$ & 0 & & & & & \\
\hline & J & 1 & & & & & \\
\hline & J & 1 & & & & & \\
\hline
\end{tabular}

$\begin{array}{ll}0 & \text { Nitrate-nitrite as nitrogen } \\ 1 & \text { pH } \\ 0 & \text { Specilic conduclance } \\ 0 & \text { Gross alpha } \\ 0 & \text { Nonvolatila beta } \\ 0 & \text { Tritlum }\end{array}$

$2.63 \mathrm{E}-09 \pm 6.20 \mathrm{E}-10$
$1.18 \mathrm{E}-06 \pm 3.82 \mathrm{E}-07 \mathrm{~J}$

\section{WELL HSB148D}

MEASUREMENTS CONDUCTED IN THE FIELD

Sample date: 04/21/99
Depth to water: $38.62 \mathrm{ft}(11.77 \mathrm{~m})$ below TOC
Water olevation: $212.48 \mathrm{Ht}(64.76 \mathrm{~m}) \mathrm{ms}$
pH: 6.1

p. conductance: $110 \mu \mathrm{S} / \mathrm{cm}$

Waler ovacuated from the well prior to sampling: $1 \mathrm{gal}$

ANALYSES

\begin{tabular}{|c|c|c|c|c|c|c|c|c|}
\hline Analyte & Rosult & $F G$ & $s$ & EMS & $S Q L$ & Unit & Lab & Method \\
\hline $\begin{array}{l}\text { Mercury, lotal recoverable } \\
\text { Nitrate-nitrite as nitrogen } \\
\text { pH } \\
\text { Specific conductance } \\
\text { Gross alpha } \\
\text { Nonovolatlle bela } \\
\text { Tritlum }\end{array}$ & $\begin{array}{l}<0.200 \\
<50.0 \\
7.03 \\
113 \\
2.00 \mathrm{E} \cdot 09+6.22 \mathrm{E}-10 \\
1.65 \mathrm{E} .09 \pm 6.19 \mathrm{E}-10 \\
8.84 \mathrm{E} \cdot 06 \pm 6.14 \mathrm{E} \cdot 07\end{array}$ & 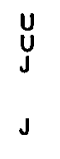 & 0 & & $\begin{array}{l}0.200 \\
5000 \\
0.100 \\
1.00 \\
5.17 E-10 \\
1.14 E-09 \\
5.77 E-07\end{array}$ & 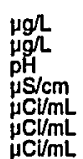 & $\begin{array}{l}\mathrm{GE} \\
\mathrm{GE} \\
\mathrm{GE} \\
\mathrm{GE} \\
\mathrm{GP} \\
\mathrm{GP} \\
\mathrm{GP}\end{array}$ & $\begin{array}{l}\text { EPA7470A } \\
\text { EPA353.1 } \\
\text { EPA9040B } \\
\text { EPA9050A } \\
\text { EPIA.001 } \\
\text { EPIA.001 } \\
\text { EPIA.002 }\end{array}$ \\
\hline
\end{tabular}

\section{WELL HSB149D}

MEASUREMENTS CONDUCTED IN THE FIELL

Sample date: 04/21/99

Deph to water: 20.04 ff $(6.11 \mathrm{~m}$ ) below TOC

$\mathrm{HH}: 5.4$

p. conductance: $19 \mu \mathrm{S} / \mathrm{cm}$

Water evacuated from the well prior to sampling: $24 \mathrm{gal}$

ANALYSES

$\begin{array}{ll}\text { F } & \text { Analyte } \\ 0 & \text { Mercury, tolal recoverable } \\ 0 & \text { Nirrate-nititite as nilrogen } \\ 0 & \text { Nilrate-nitrite as nifrogen } \\ 0 & \text { pH } \\ 0 & \text { Specific conductance } \\ 0 & \text { Gross alpha } \\ 0 & \text { Nonvolatile beta } \\ \text { i Trittum } & \end{array}$

$\begin{array}{lll}\text { Result } & \text { FG } & s \\ <0.200 & U & \\ 220 & & \\ 220 & J & Q \\ 4.97 & 1.3 & \\ 7.66 \mathrm{E}-10 \pm 3.95 E-10 & \mathrm{~J} & 1 \\ 1.18 \mathrm{E} \cdot 09 \pm 5.13 \mathrm{E}-10 & \mathrm{~J} & \mathrm{I} \\ 1.61 \mathrm{E}-05 \pm 7.73 \mathrm{E}-07 & & \end{array}$

Water lemperature: $19.3^{\circ} \mathrm{C}$

Total alkalinity (as CaCO3): $17 \mathrm{mg}$ Phenoiph halein alkalinity: $0 \mathrm{mgl}$

Time: 12:40 19.0

Total alkalinity (as CaCO3): $39 \mathrm{mg} / \mathrm{L}$ henolphthatein alkalinity: $0 \mathrm{mg} \Omega$.

\section{WELL HSB150D}

MEASUREMENTS CONDUCTED IN THE FIELD

Sample date: $04 / 21 / 99$

Water elevation: $225.52 \mathrm{ft}(68.74 \mathrm{~m}) \mathrm{ms}$ )

$\mathrm{pH}: 5.8$

$\mathrm{p}$. conductance: $32 \mu \mathrm{S} / \mathrm{cm}$

Water evacuated from the well prior to sampling: 1 gal The well wenl dry during purging.

ANALYSES

$F$ Analyto

: Mercury, total recoverable

0 Speelife conduclance

Gross alpha

1 Trifium

WELL HSB151C

MEASUREMENTS CONDL

Sample dato: 04/21/99

Water elevation: 206.33 ft $(62.69 \mathrm{~m}) \mathrm{ms}$

$\mathrm{H}: 5.1$

conductance: $76 \mu \mathrm{S} / \mathrm{cm}$

Water evacuated Irom the well prior to sampling: $60 \mathrm{gal}$

ANALYSES

$F$ Analyte

if Mercury, tolal recoverable

0 Specille conductance

Nonvolatile beta

2 Tritium

Aesult
$<0.200$
30.0
5.22
29.3
$1.35 \mathrm{E}-09 \pm 5.91 \mathrm{E}-10$
$8.00 \mathrm{E}-10 \pm 5.64 \mathrm{E}-10$
$1.59 \mathrm{E} \cdot 05 \pm 7.64 \mathrm{E}-07$

\section{WELL HSB151D}

MEASUAEMENTS CONDUCTED IN THE FIELD

Sample dala: 04/21/99
Depih to water $8.16 \mathrm{ft}$ (2.49 m) below TOC

Walter elevation: $205.44 \mathrm{ft}$

Sp. conductance: $28 \mu \mathrm{S} / \mathrm{cm}$

Water evacuated from the well prior lo sampling: $26 \mathrm{gal}$

ANALYSES

$F$ Analyte

Result
0.125
8.010
4.95
81.9
$3.99 \mathrm{E}-10 \pm 4.16 \mathrm{E}-10$
$6.44 \mathrm{E}-10 \pm 6.02 \mathrm{10}-10$
$9.02 \mathrm{E}-04 \pm 1.76 \mathrm{E} \cdot 05$

FG

EMS

\begin{tabular}{|c|c|c|c|}
\hline $\begin{array}{l}.200 \\
.00 \\
.00 \\
.04 E-10\end{array}$ & 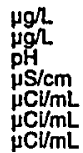 & $\begin{array}{l}\text { GE } \\
\mathrm{GE} \\
\mathrm{GE} \\
\mathrm{GE} \\
\mathrm{GF} \\
\mathrm{GF}\end{array}$ & $\begin{array}{l}\text { EP } \\
\text { EP } \\
\text { EP } \\
\text { EP } \\
\text { EP } \\
\text { EP }\end{array}$ \\
\hline
\end{tabular}

Water femperature: $19.4^{\circ} \mathrm{C}$

Total alkalinity (as CaCO3): $0 \mathrm{mg} /$

henolphthalein alkalinity: $0 \mathrm{mg}$

5.72 $-07 \mu C / m L$ GP EPIA.002

me: 11:50

年 $18.6^{\circ} \mathrm{C}$

Total alkalinity (as CaCo3): 0 mg $/$

Field Qualifier(s): $s$

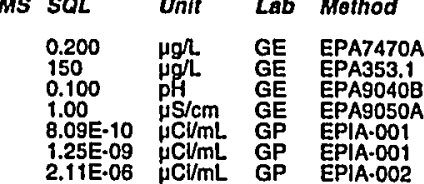

Time: $11: 40$

作 $171^{\circ} \mathrm{C}$

Total a(kalinily (as CaCO3): $0 \mathrm{mg} /$

.

\begin{tabular}{|c|c|}
\hline 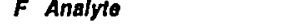 & \\
\hline $\begin{array}{ll}0 & \text { Mercury, lotal recoverable } \\
0 & \text { Nitrate-nitrite as nitrogen } \\
0 & \text { pH } \\
0 & \text { Specific conductance } \\
0 & \text { Gross alpha } \\
0 & \text { Nonvolathle beta } \\
2 & \text { Tritium }\end{array}$ & $\begin{array}{l}<0.200 \\
1.790 \\
5.17 \\
29.5 \\
1.44 \mathrm{E} \cdot 09 \pm 4.93 \mathrm{E}-10 \\
6.99 \mathrm{E} \cdot 09 \pm 8.94 \mathrm{E}-10 \\
3.83 \mathrm{E} \cdot 05 \pm 1.13 \mathrm{E} \cdot 06\end{array}$ \\
\hline
\end{tabular}

\begin{tabular}{|c|c|c|c|c|c|}
\hline $\boldsymbol{s}$ & EMS & SQL & Unit & Lab & Mothod \\
\hline 0 & & $\begin{array}{l}0.200 \\
50.0 \\
0.100 \\
1.00 \\
3.77 \mathrm{E}-10 \\
9.96 \mathrm{E}-10 \\
5.78 \mathrm{E}-07\end{array}$ & 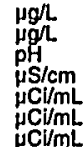 & $\begin{array}{l}\mathrm{GE} \\
\mathrm{GE} \\
\mathrm{GE} \\
\mathrm{GE} \\
\mathrm{GP} \\
\mathrm{GP} \\
\mathrm{GP}\end{array}$ & $\begin{array}{l}\text { EPA7470A } \\
\text { EPA353.1 } \\
\text { EPA9040B } \\
\text { EPA9050A } \\
\text { EPIA.001 } \\
\text { EPIA.01 } \\
\text { EPIA.002 }\end{array}$ \\
\hline
\end{tabular}




\section{WELL HSB152C}

MEASUREMENTS CONDUCTED IN THE FIELD

Sample date: $04 / 23 / 99$
Depth to water: $15.75 \mathrm{hi}(4.8 \mathrm{~m})$ below TOC
Water elevation: $198.35 \mathrm{tt}(60.46 \mathrm{~m}) \mathrm{msl}$

Dit: 48

Sp. conductance: $120 \mu \mathrm{S} / \mathrm{cm}$

Wuler evacualed from the well prior to sampling: 44 gal ANALYSES

A Analyto

0
2
2

$\mathrm{pH}$ Hific conductance

Gross alpha

\section{WELL HSB152D}

MEASUREMENTS CONDUCTED IN THE FIELD

Sample date: 04/23/99

Depth to water: Not available
Water elevation: Not avallable

WH: 5.2 . 2 vation: Not availa

Sp. conductance: $41 \mu \mathrm{S} / \mathrm{cm}$

Water evacuated from the well prior to sampling: 2 gal ANALYSES

\begin{tabular}{|c|c|}
\hline Analyte & Result \\
\hline $\begin{array}{l}\text { Mercury, total recoverable } \\
\text { Nitrate-nitrite as nilrogen } \\
\text { pH } \\
\text { Specific conductance } \\
\text { Gross alpha } \\
\text { Nonvolatile beta } \\
\text { Trittum }\end{array}$ & $\begin{array}{l}<0.200 \\
2.240 \\
5.28 \\
42.4 \\
3.54 E-09 \pm 9.14 \\
7.77 E .09 \pm 9.14 \\
.1 .69 E-04 \pm 3.35\end{array}$ \\
\hline
\end{tabular}

\section{WELL HSL 1D}

MEASUREMENTS CONDUCTED IN THE FIELD

Sample date: 04/23/99
Depth to water: 28.61 (t) $(8.72 \mathrm{~m})$ below TOC
Water elevation: $235.39 \mathrm{Ht}(71.75 \mathrm{~m}) \mathrm{ms}$ !

$\mathrm{WH}: 4.4$

p. conductance: $57 \mu \mathrm{S} / \mathrm{cm}$

Wurbidity: 1 NTU Wavacuated from the well prior to sampling: 7 gat ANALYSES

\begin{tabular}{|c|c|c|c|c|c|c|c|c|}
\hline Analyte & Result & $F G$ & $\boldsymbol{s}$ & EMS & SQL & Unit & Lab & Mothod \\
\hline $\begin{array}{l}\text { Mercury, tolal recoverable } \\
\text { Nilrale-nitrite as nitrogen } \\
\text { Nilrale-nitrite as nitrogen } \\
\text { pH } \\
\text { Specific conductance } \\
\text { Gross aloha } \\
\text { Nonvolatile beta } \\
\text { Tritium }\end{array}$ & $\begin{array}{l}<0.200 \\
3.630 \\
3.660 \\
4.60 \\
58.9 \\
4.96 \mathrm{E}-09 \pm 9.27 \mathrm{E}-10 \\
1.46 \mathrm{E}-08+1.17 \mathrm{E} .09 \\
1.36 \mathrm{E}-04 \pm 2.70 \mathrm{E}-06\end{array}$ & $u$ & a & & $\begin{array}{l}0.200 \\
150 \\
150 \\
0.100 \\
1.00 \\
5.23 E \cdot 10 \\
1.13 E-09 \\
7.54 E \cdot 07\end{array}$ & 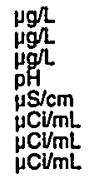 & $\begin{array}{l}G E \\
G E \\
G E \\
G E \\
G E \\
G E \\
G P \\
G P \\
G P\end{array}$ & $\begin{array}{l}\text { EPA7470A } \\
\text { EPA353.1 } \\
\text { EPA353.1 } \\
\text { EPA9040B } \\
\text { EPA9050A } \\
\text { PPA.-001 } \\
\text { EPIA.001 } \\
\text { EPIA.002 }\end{array}$ \\
\hline
\end{tabular}

Water temperature: $17.7^{\circ} \mathrm{C}$

(as CaCO3): $0 \mathrm{mg}$

Warer temperature: $18.9^{\circ} \mathrm{C}$

Total alkalinity (as Caco3): $1 \mathrm{mg} / \mathrm{L}$

Field Qualifier(s): SXN

Water temperature: $20.6^{\circ}$

Total alkalinity (as CaCO3): $0 \mathrm{mg}$

Field Qualifier(s): $y$

\section{WELL HSL 2D}

MEASUREMENTS CONDUCTED IN THE FIELD

Depth to water: $24.78 \mathrm{Ht}(7.55 \mathrm{~m})$ below TOC

$\mathrm{Sp}$. conductance: $42 \mu \mathrm{S} / \mathrm{cm}$

Water ovacuated from the well prior to sampling: $20 \mathrm{gal}$

ANALYSES

$F$ Analyto

\begin{tabular}{|c|c|c|c|}
\hline$S O L$ & Unit & Lad & 100 \\
\hline $\begin{array}{l}0.200 \\
250 \\
0.100 \\
1.00 \\
6.10 E-10 \\
9.59 E-10 \\
2.48 E-06\end{array}$ & 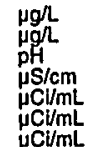 & $\begin{array}{l}G E \\
G E \\
G G \\
G E \\
G F \\
G P \\
G P \\
G P\end{array}$ & $\begin{array}{l}\text { EPA7470A } \\
\text { EPA353.1 } \\
\text { EPA9040B } \\
\text { EPA9050A } \\
\text { EPIA.001 } \\
\text { EPIA.001 } \\
\text { EPIA-002 }\end{array}$ \\
\hline
\end{tabular}

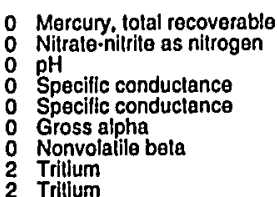

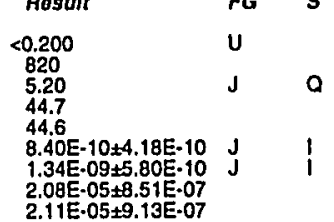

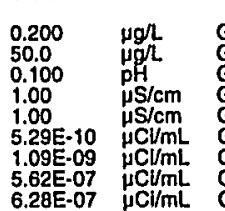

Unit Lab Mothod

\section{WELL HSL 30}

MEASUREMENTS CONDUCTED IN THE FIELD

Sample dalo: 04/23/99

Deph to water: $19.61 \mathrm{ft}(5.98 \mathrm{~m})$ below TOC

pH: 4.5 .

Turbldity: 13 NTU
Water evacuated Irom the well prior to sampling: 9 gal

ANALYSES

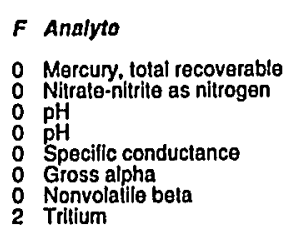

\begin{tabular}{|c|c|c|}
\hline Result & $F G$ & 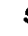 \\
\hline & u & \\
\hline $\begin{array}{l}4.70 \\
4.71 \\
31.1\end{array}$ & $\mathbf{J}$ & \\
\hline $\begin{array}{l}1.62 E-09 \pm 5.27 E-10 \\
2.15 E-095.90 E-10 \\
6.99 E-05 \pm 1.69 E-06\end{array}$ & $\mathbf{J}$ & 1 \\
\hline
\end{tabular}

Time: 8:19

ire: $20.5^{\circ} \mathrm{C}$ otal alkalinity (as CaCO3): $0 \mathrm{mgr}$ Pons

\section{WELL HSL 4D}

MEASUREMENTS CONDUCTED IN THE FIELD

Sample date: 04/23/99
Depth 10 water: $14.29 \mathrm{ft}(4.36 \mathrm{~m})$ below TOC
Water olevation: $258.91 \mathrm{Ht}(78.92 \mathrm{~m}) \mathrm{msl}$

$\mathrm{pH}: 4.9$

Sp. conductance: $62 \mu \mathrm{S} / \mathrm{cm}$

Waler evacuated from the well prior to sampling: $11 \mathrm{gal}$

ANALYSES

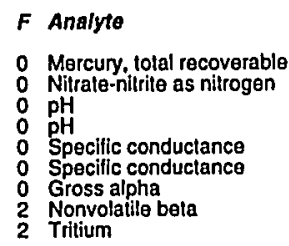

$\begin{array}{lll}\text { Result } & \text { FG } & S \\ <0.200 & \mathrm{U} & \\ 580 & \\ 5.64 & \mathrm{~J} & \mathrm{Q} \\ 5.64 & \mathrm{~J} & \mathrm{Q} \\ 66.9 & & \\ 66.7 & \\ 1.07 \mathrm{E}-09 \pm 4.49 \mathrm{E}-10 & \mathrm{~J} & \mathrm{I} \\ 6.24 \mathrm{E}-08 \pm 2.18 \mathrm{E} \cdot 09 & & \\ 2.12 \mathrm{E}-05 \pm 1.01 \mathrm{E}-06 & & \end{array}$

Timo: 8:41

temperature: $22.1^{\circ} \mathrm{C}$

Total alkalinity (as CaCO3): $0 \mathrm{mg} /$.

Phenolphihalein al
Field Qualifier(s):

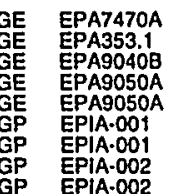

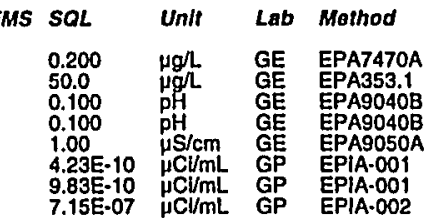


WELL HSL 5D

MEASUREMENTS CONDUCTED IN THE FIELD

Sample date: 04/23/99

Wepth to water: $16.4 \mathrm{H}(5 \mathrm{~m})$ below TOC

$\mathrm{pH}: 4.4$

Sp. conduclance: $27 \mu \mathrm{S} / \mathrm{cm}$

Water evacuated from the well prior to sampling: 9 gal

ANALYSES

F Analyto

\begin{tabular}{|c|c|c|c|c|c|c|c|}
\hline Result & $F G$ & $s$ & EMS & SOL & Unit & Lab & Mothod \\
\hline $\begin{array}{l}<0.200 \\
810 \\
5.34 \\
26.0 \\
3.34 \mathrm{E}-09 \pm 8.18 \mathrm{E}-10 \\
1.59 \mathrm{E} \cdot 08 \pm 1.17 \mathrm{E}-09 \\
6.76 \mathrm{E} \cdot 06 \pm 6.59 \mathrm{E} \cdot 07\end{array}$ & $\begin{array}{l}\text { U } \\
\mathrm{J}\end{array}$ & Q & & $\begin{array}{l}0.200 \\
50.0 \\
0.100 \\
1.00 \\
6.48 E-10 \\
9.64-10 \\
7.21 \mathrm{E} \cdot 07\end{array}$ & 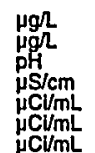 & $\begin{array}{l}\mathrm{GE} \\
\mathrm{GE} \\
\mathrm{GE} \\
\mathrm{GE} \\
\mathrm{GP} \\
\mathrm{GP} \\
\mathrm{GP}\end{array}$ & $\begin{array}{l}\text { EPA7470A } \\
\text { EPA353.1 } \\
\text { EPA9040B } \\
\text { PA9050A } \\
\text { EAPA.001 } \\
\text { EPIA.001 } \\
\text { EPIA.002 }\end{array}$ \\
\hline
\end{tabular}

o Mercury, total recoverable

0 pH 0

O Gonvolatile beta

Tritium

WELL HSL 6D

MEASUREMENTS CONDUCTED IN THE FIELD

Sample date: $04 / 23 / 99$
Depht to water: $23.07 \mathrm{ft}(7.03 \mathrm{~m})$ below TOC
Waler elevation: $256.93 \mathrm{ft}(78.3 \mathrm{~m}) \mathrm{msl}$

$\mathrm{gH}: 4$

Sp. conductance: $63 \mu \mathrm{S} / \mathrm{cm}$

Waler evacuated from the well prior to sampling: 8 gal ANALYSES

$F$ Analyto$$
\text { Result }
$$

Mercury, total recoverable

: pHecific conductance

1 Nonvolatila beta

2 Tritium

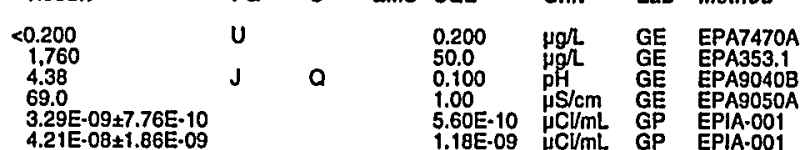

WELL HSL 7D

MEASUREMENTS CONDUCTED IN THE FIELD

Sample date: 04/23/99

(

H: 3.9

Sp. conductance: $63 \mu \mathrm{S} / \mathrm{cm}$

Water evacuated from the well prior to sampling: 3 gal

ANALYSES

$F$ Analyto

- Mercury, Lotal recoverablo

N Nilrate-nitritite as nitrogen

0 Nitrate-nitrite as nitrogen

Nonvolatile bela

\begin{tabular}{|c|c|c|c|c|c|c|c|}
\hline Result & $F G$ & $s$ & EMS & $S Q L$ & Untt & Lab & Mothod \\
\hline $\begin{array}{l}0.0547 \\
2.130 \\
2,100 \\
4.69 \\
44.6 \\
2.17 E \cdot 09+6.66 E-10 \\
2.12 E \cdot 09+6.24 E=10 \\
3.24 E \cdot 05 \pm 1.21 E=06\end{array}$ & J & 1 & & $\begin{array}{l}0.200 \\
150 \\
150 \\
0.100 \\
1.00 \\
7.11 \mathrm{E}-10 \\
7.07 \mathrm{E} \cdot 09 \\
7.32 \mathrm{E} \cdot 07\end{array}$ & 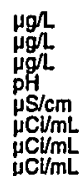 & $\begin{array}{l}G E \\
G E \\
G E \\
G E \\
G E \\
G E \\
G P \\
G P \\
G P\end{array}$ & $\begin{array}{l}\text { EPA7470A } \\
\text { EPA353.1 } \\
\text { EPA353.1 } \\
\text { EPA9040B } \\
\text { EPA9050A } \\
\text { EPIA.001 } \\
\text { EPIA.001 } \\
\text { EPIA.002 }\end{array}$ \\
\hline
\end{tabular}

ESH-EMS-990521
Time: 10:00

Air temperature: $23.4^{\circ} \mathrm{C}$

Tolal alkalinity (as CaCO3): $1 \mathrm{mg} /$

Field Oualifier(s): $v$

Time: 10:46

作 temperature: $20.9^{\circ} \mathrm{C}$

Total alkalinity (as CaCo3): $0 \mathrm{mg} /$

Field Qualifier(s): $V$ alinity: $0 \mathrm{mg}$

$7.21 \mathrm{E}-07 \mathrm{\mu CU/mL}$ GP $\mathrm{GP}$ EPIA.001

Time: 11:55

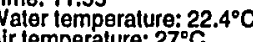

Total alkalinity (as CaCO3): $0 \mathrm{mg} / \mathrm{L}$

Phonolphthalein alkalinity: $0 \mathrm{mg}$

$.07 E .09 \mu \mathrm{Cl} / \mathrm{mL}$ GP EPIA.00
WELL HSL 8D

MEASUREMENTS CONDUCTED IN THE FIELD

Sample date: 04/23/99

Water elevation: $258.46 \mathrm{tt}(78.78 \mathrm{~m}) \mathrm{ms}$

Sp: 4.4 conductance: $59 \mu \mathrm{S} / \mathrm{cm}$

Waler evacuated from the well prior to sampling: 5 gal

ANALYSES

$F$ Analyte

1 Mercury, total recoverable

0 pH

Gross alpha

Nonvolatilia beta
0

\section{WELL HWP 2D}

MEASUREMENTS CONDUCTED IN THE FIELD

Sample dale: $06 / 10 / 99$
Depth to water: 9.23 tit $(2.81 \mathrm{~m})$ below TOC
Water elevation: $260.77 \mathrm{ft}(79.48 \mathrm{~m}) \mathrm{msl}$

Water elevan

sp. conductance: $150 \mu \mathrm{S} / \mathrm{cm}$

Waler evacuated from the well prior to sampling: 11 gal

ANALYSES

F Anolyto

- Aluminum, tolal recoverable

Arsenlc, lotal recoverable
Barlum, lotal recoverable

Boron, total recoverable

Cadclum, lotal recoverabla

Carbon telrachlorid

Chloride

Chromium, total recoverable

cls-1,2-Dichioroethylens
cls-1,2-Dichioroelhylena

Fluoride

Lead, total recoverab!
Lente

Magnitum, lotal recoverable

Manganese, tolal recoverablo

Nitrate-nitrite as niltrogen

Selenium, iotal recoverable

Sillica, total recoverable

Sodium, total recoverab

Tetrachloroethylene

Tetrachloroelhylene

Total dissolved solids

Tolal organic halogens

1.1.1- phrosphatesh (as

i.j. -Tichloroethan

Trichloroothylen

Gross alpha
Gross alpha

B-151
Time: 11:28

Air

Total alkalinity (as CaCO3): $0 \mathrm{mg} r$

Phenolphinalein alkalinity: $0 \mathrm{mg}$

EMS SOL Unit Lab Mathod

\begin{tabular}{|c|c|c|}
\hline $\begin{array}{l}0.200 \\
150 \\
0.100 \\
1.00 \\
5.09 E-10 \\
4.810-10 \\
9.699-10 \\
1.111-09 \\
6.05 E-07\end{array}$ & 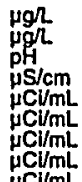 & $\begin{array}{l}\mathrm{GE} \\
\mathrm{GE} \\
\mathrm{GE} \\
\mathrm{GE} \\
\mathrm{GP} \\
\mathrm{GP} \\
\mathrm{GP} \\
\mathrm{GP} \\
\mathrm{GP}\end{array}$ \\
\hline
\end{tabular}

Time: 8:37

Air temperature: $30.9^{\circ} \mathrm{C}$

Thal

Field Qualifier(s): $V$

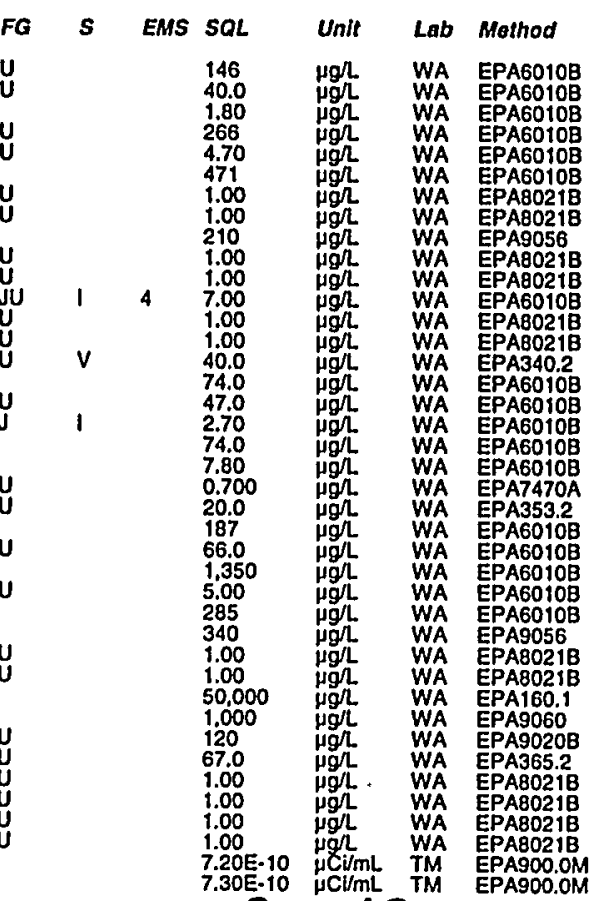


Well HWP 20 collecled on 06/10/99 (cont.)

$F$ Analyto

2 Nonvolatila bela

2 Tritium

Result

$F G$

$3.33 E-07+6.63 E-09$
$3.33 E-07 \pm 6.64 E-09$

$2.14 \mathrm{E} \cdot 05 \pm 1.03 \mathrm{E} .06$
$2.13 \mathrm{E} \cdot 05+1.02 \mathrm{E} \cdot 06$

\section{WELL KBP 1D}

MEASUREMENTS CONDUCTED IN THE FIELD

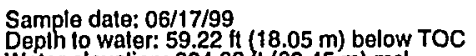

Water elevalion: $204.88 \mathrm{ft}(62.45 \mathrm{~m}) \mathrm{ms}$

pH: 4.9

P. conductance: $100 \mu \mathrm{S} / \mathrm{cm}$

Waler evacuated from the well prior to sampling: $1 \mathrm{gal}$ The well went dry during purging.

ANALYSES

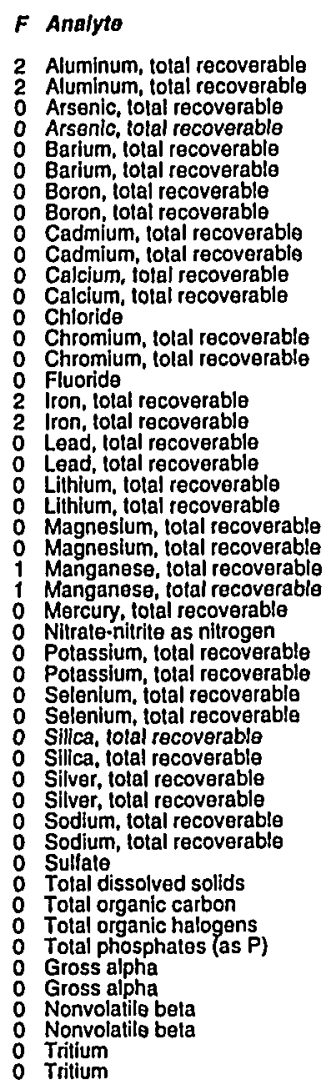

\begin{tabular}{|c|c|c|c|c|c|c|c|}
\hline Result & $F G$ & $s$ & EMS & SQL & Unit & Lab & Mothod \\
\hline $\begin{array}{l}360 \\
424 \\
440.0 \\
<40.0 \\
11.2 \\
11.1 \\
<266 \\
<266 \\
<4.70 \\
<4.70 \\
477 \\
483 \\
13.100 \\
6.70 \\
6.90 \\
<40.1 \\
1.040 \\
1.110 \\
<47.0 \\
<47.0 \\
6.20 \\
66.20 \\
416 \\
419 \\
32.2 \\
32.5 \\
0.0800 \\
1.460 \\
1.140 \\
1.150 \\
<66.0 \\
<66.0 \\
8.840 \\
9.010 \\
<5.00 \\
<5.00 \\
12,300 \\
12,300 \\
2,200 \\
51,000 \\
667 \\
13.3 \\
77.3 \\
2.50 E-09 \pm 1.05 E-09 \\
2.43 E-09 \pm 1.02 E-09 \\
4.04 E-09 \pm 1.15 E-09 \\
3.30 E-09+1.11 E-09 \\
4.70 E-06 \pm 5.60 E-07 \\
3.99 E-06 \pm 5.10 E-07\end{array}$ & $\begin{array}{l}\mathbf{U} \\
\mathbf{U} \\
\mathbf{U}\end{array}$ & 1 & & $\begin{array}{l}146 \\
146 \\
40.0 \\
40.0 \\
1.80 \\
1.80 \\
266 \\
266 \\
4.70 \\
4.70 \\
471 \\
471 \\
420 \\
7.00 \\
7.00 \\
40.0 \\
74.0 \\
74.0 \\
47.0 \\
47.0 \\
2.70 \\
2.70 \\
74.0 \\
74.0 \\
7.80 \\
7.80 \\
0.700 \\
100 \\
187 \\
187 \\
66.0 \\
66.0 \\
1.350 \\
1,350 \\
5.00 \\
5.00 \\
285 \\
285 \\
340 \\
50.000 \\
1.000 \\
120 \\
67.0 \\
1.20 \mathrm{E}-09 \\
1.16 \mathrm{E}-09 \\
1.63 \mathrm{E}-09 \\
1.63 \mathrm{E}-09 \\
5.30 \mathrm{E}-07 \\
5.10 \mathrm{E}-07\end{array}$ & 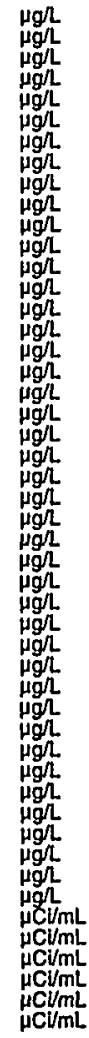 & $\begin{array}{l}\text { WA } \\
\text { WA } \\
\text { WA } \\
\text { WA } \\
\text { WA } \\
\text { WA } \\
\text { WA } \\
\text { WA } \\
\text { WA } \\
\text { WA } \\
\text { WA } \\
\text { WA } \\
\text { WA } \\
\text { WA } \\
\text { WA } \\
\text { WA } \\
\text { WA } \\
\text { WA } \\
\text { WA } \\
\text { WA } \\
\text { WA } \\
\text { WA } \\
\text { WA } \\
\text { WA } \\
\text { WA } \\
\text { WA } \\
\text { WA } \\
\text { WA } \\
\text { WA } \\
\text { WA } \\
\text { WA } \\
\text { WA } \\
\text { WA } \\
\text { WA } \\
\text { WA } \\
\text { WA } \\
\text { AA } \\
\text { WA } \\
\text { WA } \\
\text { WA } \\
\text { WA } \\
\text { TM } \\
\text { TM } \\
\text { TM } \\
\text { TM } \\
\text { TM } \\
\text { TM }\end{array}$ & 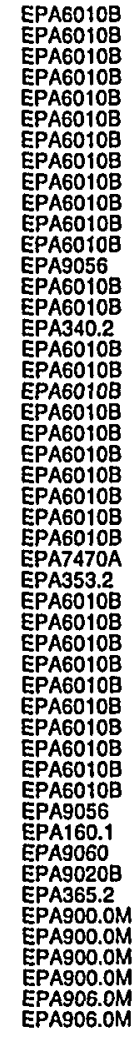 \\
\hline
\end{tabular}

WELL KBP $2 D$

MEASUREMENTS CONDUCTED IN THE FIELD

Sample date: 06/17/99

$\mathrm{pH}: 4.5$

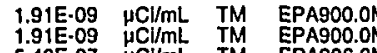

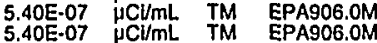

Sp.cond

Wridity: 12 NTU:

\section{$190 \mu \mathrm{S} / \mathrm{cm}$}

The well wealed from the well prior to sampling: $1 \mathrm{gal}$

ANALYSES

Time: 11:05

Air temperature: $22.3^{\circ} \mathrm{C}$
Total alkalinity.(as CaCO3): $4 \mathrm{mg} / \mathrm{L}$

Phenolphthalein alkalinity: $0 \mathrm{mg}$

$F$ Anaiyto

2 Aluminum, total rocoverable

Arsenic, tolal recoverable

o Boron, iotal recoverable

Calcium, total recoverable

Chromium, total recoverable

2 fron, lotal recoverable

Lithium lotal recoverable

Magnesium, total recoverable

Mercury, tolal recoverable

Potasslum, tolal recoverabl

o Selenium, total recoverablo

Sodium, tolal recoverable

Sullale

Tolal organic carbon

Total phosphates (as P)

1 Gross alpha

WELLL KCB 1

MEASUREMENTS CONDUCTED IN THE FIELD

Sample date: 05/12/99

Water elevation: $199.63 \mathrm{ft}(60.85 \mathrm{~m}) \mathrm{ms}$

Sp. conductance: $32 \mu \mathrm{S} / \mathrm{cm}$

Waler evacualed from the well prior to sampling: $49 \mathrm{gal}$

ANALYSES

$\begin{array}{ll}\text { F } & \text { Analyte } \\ 0 & \text { Aluminum, total recoverable } \\ 0 & \text { Beryllium, total recoverable } \\ 0 & \text { gis(2-ethylhexyl) phthalate } \\ 0 & \text { Chromlum, hexavalent } \\ 0 & \text { Chromium, total recoverable } \\ 1 & \text { Iron, total recoverable } \\ 0 & \text { pH, } \\ 0 & \text { Gross alpha } \\ 2 & \text { Radium-226 } \\ 0 & \text { Radium-228 } \\ 0 & \text { Uranium-233/234 } \\ 0 & \text { Uranium-235 } \\ 0 & \text { Uranium-238 }\end{array}$

Time: 10:50

Water temperature: $22^{\circ} \mathrm{C}$

Total alkalinity (as CaCD3): $0 \mathrm{mg} /$ Phenolphthalein alkalinity: $0 \mathrm{mgh}$

ESH-EMS-990521

Time: 14:34

Air temperature $255^{\circ} \mathrm{C}$

Total alkalinity (as CaCO3): $0 \mathrm{mg} /$ Field Oualifier(s): $S$

\begin{tabular}{|c|c|c|c|c|c|c|c|}
\hline Result & $F G$ & $s$ & EMS & $S Q L$ & Unit & Lab & Mothod \\
\hline $\begin{array}{l}<55.7 \\
<5.00 \\
<10.0 \\
<20.0 \\
6.21 \\
231 \\
5.11 \\
1.03 \mathrm{E}-09 \pm 4.74 \mathrm{E}-10 \\
6.75 \mathrm{E} \cdot 09 \pm 1.25 \mathrm{E} \cdot 09 \\
3.70 \mathrm{E}-10 \pm 5.29 \mathrm{E}-10 \\
1.07 \mathrm{E}-1 \pm 4.33 \mathrm{E}-11 \\
1.56 \mathrm{E}-11 \pm 4.23 \mathrm{E}-11 \\
1.56 \mathrm{E}-11 \pm 4.22 \mathrm{E}-11\end{array}$ & 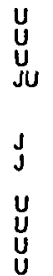 & i & $x$ & $\begin{array}{l}50.0 \\
5.00 \\
10.0 \\
20.0 \\
5.00 \\
50.0 \\
0.100 \\
4.49 \mathrm{E}-10 \\
4.37 \mathrm{E}-10 \\
1.12 \mathrm{E}-09 \\
1.28 \mathrm{E}-10 \\
1.09 \mathrm{E}-10 \\
1.08 \mathrm{E}-10\end{array}$ & 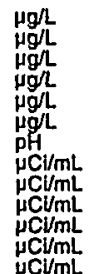 & $\begin{array}{l}\mathrm{GE} \\
\mathrm{GE} \\
\mathrm{GE} \\
\mathrm{GE} \\
\mathrm{GE} \\
\mathrm{GE} \\
\mathrm{GE} \\
\mathrm{GP} \\
\mathrm{GP} \\
\mathrm{GP} \\
\mathrm{GP} \\
\mathrm{GP} \\
\mathrm{GP}\end{array}$ & $\begin{array}{l}\text { EPA6010B } \\
\text { EPA6010B } \\
\text { EPAB270C } \\
\text { EPA7196A } \\
\text { EPA6010B } \\
\text { EPA6010B } \\
\text { EPA9040B } \\
\text { EPIA.001 } \\
\text { EPIA-008 } \\
\text { EPIA.009 } \\
\text { EPIA-011 } \\
\text { EPIA.011 } \\
\text { EPIA.011 }\end{array}$ \\
\hline
\end{tabular}




\section{WELL KCB 3}

MEASUREMENTS CONDUCTED IN THE FIELD

Sample date: 05/12/99 Water elevation: 197.1 ft $(15.48 \mathrm{~m})$ below TOC

pH: 4 . 1 conductance: $210 \mu \mathrm{S} / \mathrm{cm}$

Water evacuated from the well prior to sampling: 36 gal

ANALYSES

$F$ Analyte

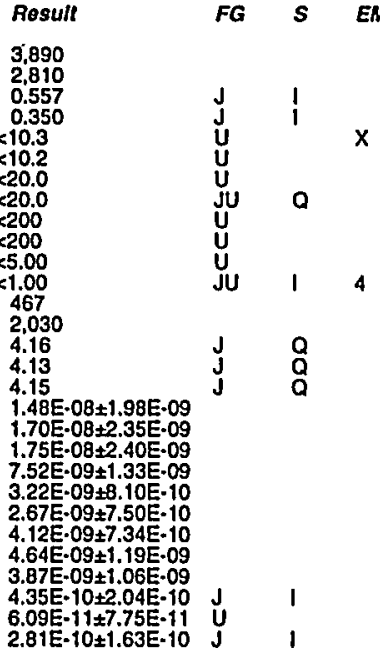

Time: 13:35

Water $21.4^{\circ} \mathrm{C}$

Total alkalinity (as CaCO3): $0 \mathrm{mgh}$

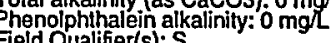
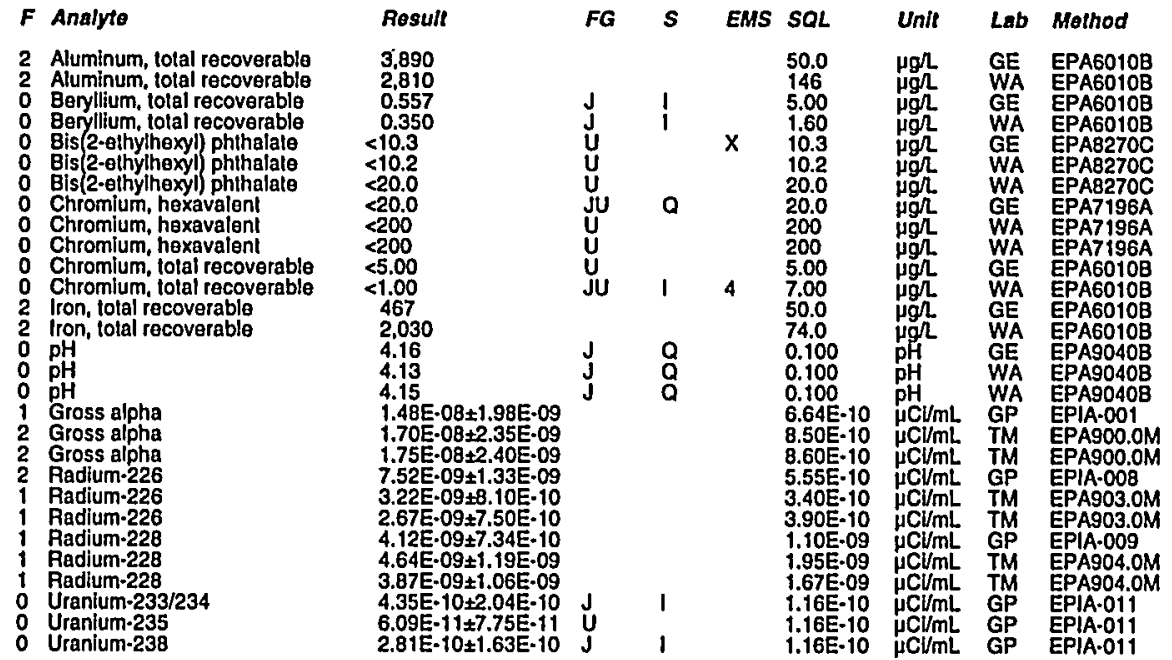

WELL KCB 3 Peplicate

MEASUREMENTS CONDUCTED IN THE FIELD

Sample date: 05/12/99

$\mathrm{pH}: 4.1$

Sp. conductance: $210 \mu \mathrm{S} / \mathrm{cm}$

Water evacuated from the well prior to sampling: $36 \mathrm{gal}$

ANALYSES

\begin{tabular}{|c|c|c|c|c|c|c|c|c|}
\hline Analyte & Result & $F G$ & $s$ & EMS & $S O L$ & Untt & Lab & Mothod \\
\hline 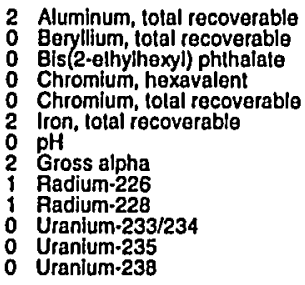 & $\begin{array}{l}3,950 \\
0.535 \\
<10.2 \\
<20.0 \\
<5.00 \\
423 \\
4.18 \\
1.67 E-08 \pm 2.14 E-09 \\
3.84 E-09 \pm 9.47 E-10 \\
2.94 \mathrm{E}-09 \pm 6.67 \mathrm{E}-10 \\
3 . .58 \mathrm{E}-10 \pm 1.79 \mathrm{E}-10 \\
2.11 \mathrm{E}-11 \pm 4.23 \mathrm{E}-11 \\
1.63 \mathrm{E}-10 \pm 1.21 \mathrm{E}-10\end{array}$ & $\begin{array}{l}J \\
J U \\
J \\
J\end{array}$ & $\begin{array}{l}1 \\
0\end{array}$ & $x$ & $\begin{array}{l}50.0 \\
5.00 \\
10.2 \\
20.0 \\
5.00 \\
50.0 \\
0.100 \\
9.63 \mathrm{E}-10 \\
4.35-10 \\
1.05-10 \\
6.32 \cdot 09-11 \\
6.34 \mathrm{E}-11 \\
1.11 \mathrm{E} \cdot 10\end{array}$ & 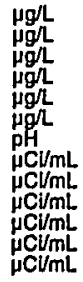 & $\begin{array}{l}\mathrm{GE} \\
\mathrm{GE} \\
\mathrm{GE} \\
\mathrm{GE} \\
\mathrm{GE} \\
\mathrm{GE} \\
\mathrm{GE} \\
\mathrm{GE} \\
\mathrm{GP} \\
\mathrm{GP} \\
\mathrm{GP} \\
\mathrm{GP} \\
\mathrm{GP} \\
\mathrm{GP}\end{array}$ & 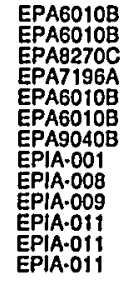 \\
\hline
\end{tabular}

ESH-EMS-990521
WELL KCB 5

MEASUREMENTS CONDUCTED IN THE FIELD

Sample date: $05 / 13 / 99$.

Water elevation: $196.8 \mathrm{t}(59.99 \mathrm{~m}) \mathrm{ms}$

PH: 3.9 conductance: $400 \mu \mathrm{S} / \mathrm{cm}$

Water evacualed from the well prior to sampling: $1 \mathrm{gal}$

The well went dry during purging.

ANALYSES

$F$ Analyto

Result

2 Aluminum, total recoverable

Beryllium, total recoverable

Chromilum, toxal recoverab

Iron, total recoverable

pH

Gross alpha

U Pranlum-228

0 Uranium-233/234

WELL KCB 6

MEASUREMENTS CONDUCTED IN THE FIELD

Sample data: 05/13/99
Dephh to wa:er:51.41 5 (15.67 m) below TOC
Waler elevation: 197.09 tt $(60.07 \mathrm{~m}) \mathrm{ms}$

pp. conductance: $47 \mu \mathrm{S} / \mathrm{cm}$

Water evacuated from the well prior to sampling: $12 \mathrm{gal}$

ANALYSES

F Analyte

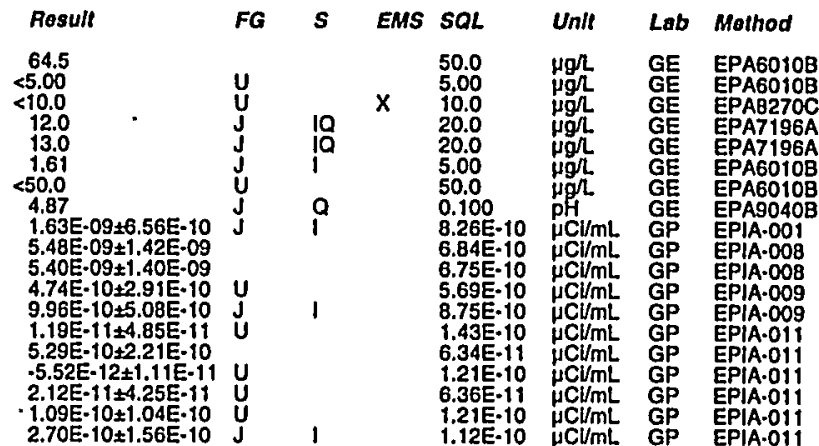

o Uranium-238

\section{WELL KDB}

MEASUREMENTS CONDUCTED IN THE FIELD

Sample date: $04 / 27 / 99$

Water to wavation: $66.15 \mathrm{ft}(20.16 \mathrm{Ht}(63.08 \mathrm{~m}) \mathrm{ms}$

$\mathrm{pH}: 5$

. conductance: $80 \mu \mathrm{S} / \mathrm{cm}$

Waler evacuated from the well prior to sampling: 1 gal

the well went dry during purging.
Time: 10:50

Wirter $24.5^{\circ} \mathrm{C}$

Tolal alkalinity (as Caco3): $0 \mathrm{mg} /$

Phenolphthalein alkalinity: $0 \mathrm{mg} L$ 
Well KDB 1 collected on 04/27/99 (cont.)

ANALYYSES

\begin{tabular}{|c|c|c|c|c|c|c|c|c|}
\hline$F$ Analyto & Result & $F G$ & $s$ & EMS & SOL & Unit & Lab & Mothod \\
\hline $\begin{array}{ll}2 & \text { Tritium } \\
2 & \text { Trílum }\end{array}$ & $\begin{array}{l}5.19 \mathrm{E} \cdot 05+1.68 \mathrm{E}-06 \\
5.10 \mathrm{E} \cdot 05 \pm 1.65 \mathrm{E}-06\end{array}$ & & & & $\begin{array}{l}\text { 5.80E.-07 } \\
\text { 5.80E.07 }\end{array}$ & $\underset{\mu \mathrm{C} U / \mathrm{mL}}{\mu \mathrm{LL}}$ & $T_{T M}^{T M}$ & $\begin{array}{l}\text { EPA906.0M } \\
\text { EPA906.0M }\end{array}$ \\
\hline
\end{tabular}

\section{WELL KDB 1}

MEASUREMENTS CONDUCTED IN THE FIELD

Sample date: 05/21/99

Depth to water: 66.64 it $(20.31 \mathrm{~m})$ below TOC

H: 4.7

Sp. conductance: $98 \mu \mathrm{S} / \mathrm{cm}$

Turbidity: 9 NTU
Waler evacualed from the well prior to sampling: 2 gal
The well went dry during purging.

ANALYSES

$F$ Analyte

2 Tritlum

Result

$F G$

\section{WELL KDB 1}

MEASUREMENTS CONDUCTED IN THE FIELD

Sample date: 06/21/99

Depth to water: $67.11 \mathrm{ft}(20.46 \mathrm{~m})$ below TOC

Water elevation: $205.99 \mathrm{ft}(62.79 \mathrm{~m}) \mathrm{m}$

PH. conductance: $120 \mu \mathrm{S} / \mathrm{cm}$
Tutididy: $14 \mathrm{NTU}$

Water evacuated from the well prior to sampling: $1 \mathrm{gal}$

ANALYSES

$\begin{array}{ll}F \text { Analyte } & \text { Rosult } \\ 2 \text { Trilium } & 8.26 \mathrm{E}-05 \pm 1.98 \mathrm{E}-06 \\ 2 \text { Tritum } & 7.26 \mathrm{E}-05 \pm 1.79 \mathrm{E}-06\end{array}$

WELL KDB 2

MEASUREMENTS CONDUCTED IN THE FIELLD

Wepth to waler: $67.98 \mathrm{ft}(20.72 \mathrm{~m})$ below TOC

Sp. conductance: $36 \mu \mathrm{S} / \mathrm{cm}$

Turbidity: 1 NTU favaler from the well prior to sampling: 47 gal

ANALYSES

F Analyte Result FG $S$ EMS SQL Unit Lab Mothod

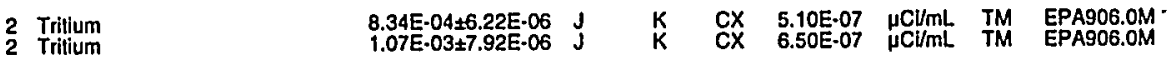

WELL KDB 2

MEASUREMENTS CONDUCTED IN THE FIELD

Sample date: $04 / 27 / 99$
Depth to waler: $68.25 \mathrm{H}(20.8 \mathrm{~m})$ below TOC
Waler elevation: $205.25 \mathrm{Ht}(62.56 \mathrm{~m}) \mathrm{msl}$

Waler elevat

Sp. conductance: $34 \mu \mathrm{S} / \mathrm{cm}$

Water evacuated from the well prior to sampling: $60 \mathrm{gal}$

Time: 10:09

Ware $24^{\circ} \mathrm{C}$

Total alkalinity (as CaCo3): $0 \mathrm{mg} /$

Phenolphthalein alkalinity: $0 \mathrm{mg} h$

ESH-EMS-990521
Well KDB 2 collected on 04/27/99 (cont.)

ANALYSES

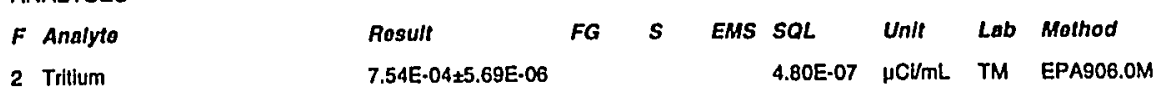

\section{WELL KDB 2}

MEASUREMENTS CONDUCTED IN THE FIELD

Sample date: 05/21/99

Deph to water: $69.7 \mathrm{ft}(21.24 \mathrm{~m})$ below TOC
Water elevalion: 203.8 ft $62.12 \mathrm{~m}) \mathrm{ms}$

$\mathrm{pH}: 4.4$

Sp. conductance: $37 \mu \mathrm{S} / \mathrm{cm}$

Turbidity: ONTU evacuated from the well prior to sampling: 53 gat

ANALYSES

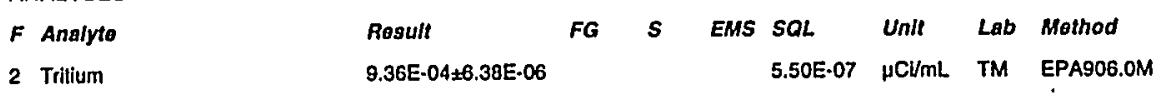

WELL KDB 2

MEASUREMENTS CONDUCTED IN THE FIELD

Sample date: 06/21/99

Water elevation: $204.41 \mathrm{fi}(62.3 \mathrm{~m}) \mathrm{msl}$

$\mathrm{pH}: 4.9$

Sp. conductance: $39 \mu \mathrm{S} / \mathrm{cm}$

Waler evacualed from the well prior to sampling: $\mathbf{4 6} \mathrm{ga}$

ANALYSES

$F$ Analyt

2 Tritlum

\section{WELL KDB 3}

MEASUREMENTS CONDUCTED IN THE FIELD

Sample date: 04/27/99

Demple date: $04 / 27.99$
Water fo water: $67.1 \mathrm{Ht}(20.45 \mathrm{~m})$ below $\mathrm{TOC}$
Wation: $206.3 \mathrm{H}(62.88 \mathrm{~m}) \mathrm{msl}$

Sp. conductance: $120 \mu \mathrm{S} / \mathrm{cm}$

Water evacuated from the well prior to sampling: $5 \mathrm{gal}$

The well went dry during purging.

ANALYSES

F Analyte Rosult $\quad$ FG $S$ EMS SQL Unit Lab Mothod

2 Tritium

Time: 8:40

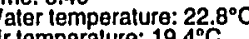

Total alkalinity (as CaCO3): $1 \mathrm{mgh}$

Phenolphnalein alkalinity: $0 \mathrm{mg}$

WELL KDB 3

MEASUREMENTS CONDUCTED IN THE FIELD

Sample date: 05/21/99

Water elevation: Not available

H.: Not available Not available

Sp. conductance: Not avallable

No water was evacuated from the well prior to sampling.

ANALYSES

$F$ Analyto

$-154$
Rosult

1.04E-03.6.93E-06

3.02E-05+1.29E-06

Result

$F$

FG

$2.21 E-05 \pm 1.06 E-06$

Time: 9:28

Water temperature: $24.9^{\circ} \mathrm{C}$

Total alkalinily (as CaCO3): $0 \mathrm{mg} /$

Field Qualifier(s): $\mathbf{S}$

EMS SaL Untt Lab Method

5.00E.07 $\mu \mathrm{Cl} / \mathrm{mL}$ TM EPA906.0M

Time: 10:23

Wirer

Total alkalinity (as CaCO3): $44 \mathrm{mg} /$

Phenolphthalein alkalinity: $0 \mathrm{mg} /$.

Field Qualifier(s): $S X$

5.80E-07 $\mu \mathrm{Cl} / \mathrm{mL}$ TM EPA906.0M

Time: Not available

ot available

Air temperature: Not available
Total alkalinity (as CaCO3): Not available
Phenolphthalein alkalinity: Not available

Tritium

Second Quarter 1999 


\section{WELL KDB 3}

MEASUREMENTS CONDUCTED IN THE FIELD

Sample date: $06 / 21 / 99$
Deph to water: $68 \mathrm{ft}(20.73 \mathrm{~m})$ below TOC
Water relevation: $205.4 \mathrm{ft}(62.61 \mathrm{~m}) \mathrm{msl}$
pH: 5.9

Sp. conductance: $170 \mu \mathrm{S} / \mathrm{cm}$

Water evacuated Irom the well prior to sampling: 2 gal The well went dry during purging.

ANALYSES
$F$ Analyto
2 Tritium
Result
FG
EMS SQL Unit Lab Method

$2.47 E \cdot 05 \pm 1.13 E \cdot 06$

WELL KDB 4

MEASUREMENTS CONDUCTED IN THE FIELD

Sample date: $04 / 27 / 99$
Depth to water: Not available
Waler elevation: Not available
pH: 5.2

Sp. 5.2 duclance: $38 \mu \mathrm{S} / \mathrm{cm}$

Waler evacualed from the well prior to sampling: 1 gal ANALYSES

$\begin{array}{ll}F \text { Analyte } & \text { Result } \\ 2 \text { Tritum } & 7.37 E-04 \pm 6.69 E-06 \\ \text { WELL KDB } 4 & \end{array}$

WELL KDB 4

MEASUREMENTS CONDUCTED IN THE FIELD

Sample date: 05/21/99

Water elevalion: Not available

$\mathrm{pH}: 5.3$

Sp. conductance: $35 \mu \mathrm{S} / \mathrm{cm}$ Water evacuated from the well prior to sampling: $1 \mathrm{gal}$
The well went dry during purging.

ANALYSES

F Analyte

2 Tritum

\section{WELL KDB 4}

MEASUREMENTS CONDUCTED IN THE FIELD

Sample date: 06/21/99

Depth to water: Not available
Water elevalion: Not available

pH: 5.6

p. conductance: $44 \mu \mathrm{S} / \mathrm{cm}$

Water evacuated from the well prior to sampling: 1 gal The well went dry during purging.

ANALYSES

$F$ Analyte

Result

2 Trilium

8.31E-04 $046.88 E-06$

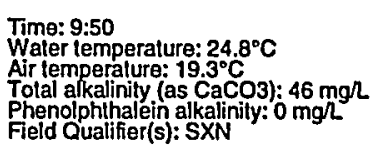

Total alkalinity (as CaCO3): $46 \mathrm{mg} /$

Field Qualifier(s): SXN

5.20E.07 $\mu \mathrm{C} / \mathrm{mL}$ TM EPA906.0M

Time: 10:42

Water temperalure: $22.9^{\circ} \mathrm{C}$

Total alkalinity (as Caco3): $6 \mathrm{mg}$

Phenolphthalein alkalinity: $0 \mathrm{mg} L$
Field Qualifier(s): $\mathrm{SX}$

FG $S$ EMS SQL Unit Lab Mothod 6.80E.07 $\mu \mathrm{CU} / \mathrm{mL}$ TM EPA9O6.0M

Time: 9:33

Air lemperature: $27^{\circ} 2^{\circ} \mathrm{C}{ }^{\circ} \mathrm{C}$

Total alkalinity (as CaCo3): $0 \mathrm{mg}$

Phenolphinalein alkalinity: $5 \mathrm{mg} / \mathrm{L}$
Field Qualifier(s): $S \mathrm{X}$

$F G$

$\begin{array}{lllll}5 & \text { EMS SQL } & \text { Unlt } & \text { Lab } & \text { Mothod } \\ 6.20 E-07 & \mu \mathrm{C} / \mathrm{mL} & \text { TM } & \text { EPA906.0M }\end{array}$

Time: 10:05

Air temperature: $19.4^{\circ} \mathrm{C}$ ) $10 \mathrm{mgh}$

Phenolphthalein alkalinity: $0 \mathrm{mg} /$
Field Qualifier(s): $\mathrm{SX}$

$F G$

$S$ EMS Sal Unth Lab Mothod 6.20E-07 $\mu \mathrm{CVML}$ TM EPA906.0M
Water temperature: $24.7^{\circ} \mathrm{C}$
WELL KDB 5

MEASUREMENTS CONDUCTED IN THE FIELD

Sample date: 04/27/99

Deph to waler: $66.05 \mathrm{ft}(20.13 \mathrm{~m})$ below TOC

$\mathrm{pH}: 5.3$

Sp. conductance: $22 \mu \mathrm{S} / \mathrm{cm}$ Waler evacuated from the well prior to sampling: 1 gal
The well went dry during purging.

ANALYSES

$F$ Analyte

Result

$1.59 E-04 \pm 2.90 E-06$

$F G$

\section{WELL KDB 5}

MEASUREMENTS CONDUCTED IN THE FIELD

Sample date: 05/21/99
Depth to water: $66.47 \mathrm{Ht}(20.26 \mathrm{~m})$ below TOC
Water elevation: $203.63 \mathrm{tt}(62.07 \mathrm{~m}) \mathrm{ms}$

$\mathrm{Sp}$. conductance: $20 \mu \mathrm{S} / \mathrm{cm}$

Turbidity: 52 NTU $20 \mu \mathrm{S} / \mathrm{cm}$

Water evacuated from the well prior to sampling: 1 ga ANALYSES

$F$ Analyte

Rosult

2 Tritum

$7.25 \mathrm{E} \cdot 05 \pm 1.88 \mathrm{E}-06$

$F G$

$F G \cdot S$

WELL KDB 5

MEASUREMENTS CONDUCTED IN THE FIELD

Sample dale: 06/21/99

Depth lo water: $66.91 \mathrm{Ht}(20.39 \mathrm{~m})$ below TOC

Water elevation: $203.19 \mathrm{ft}(61.93 \mathrm{~m}) \mathrm{ms}$

$\mathrm{pH}$. 4.9 conductance: $21 \mu \mathrm{S} / \mathrm{cm}$

Water evacuated irom the well prior to sampling: 3 gat The well went dry during purging.

ANALYSES

$\begin{array}{llrrrrr}\text { F Analyto } & \text { Result } & \text { FG } & S & \text { EMS SQL } & \text { Unit } & \text { Lab Mathod } \\ 2 \text { Tritlum } & 1.57 E-04 \pm 2.75 E-06 & & & 5.20 E-07 & \mu \mathrm{Cl} / \mathrm{mL} & \text { TM EPA906.0M }\end{array}$

\section{WELL LAW 2C}

MEASUREMENTS CONDUCTED IN THE FIELD

Sample dale: 04/27/99

Depth to water: 17.41 t $(5.31 \mathrm{~m})$ below TOC

Water elova

Sp. conductance: $43 \mu \mathrm{S} / \mathrm{cm}$

Wuter evacuated from the well prior to sampling: $68 \mathrm{gal}$

ANALYSES

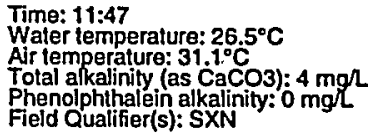

Total alkalinity (as CaCO3): $4 \mathrm{mg} /$

Field Quatififer(s): $S X N$

EMS SQL Unlt Lab Mathod 5.90E-07 $\mu \mathrm{CUML}$ TM EPA906.0M

Time: 10:18

Wer temperature: $24.3^{\circ} \mathrm{C}$

Total alkalinility.(as CaCO3): $2 \mathrm{mg} / \mathrm{h}$

Phenolphthalein alkalinity: $0 \mathrm{mgh}$
Field Qualtier(s): SXN

$F$ Analyte

2 Trillum
Rosult

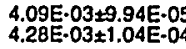

Time: 14:45

Air temperalure: $288^{\circ} .^{\circ} \mathrm{C}$

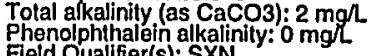

Alr temperature: $23.6^{\circ} \mathrm{C}$

Total alkalinity (as Caco3): $0 \mathrm{mg} /$

FG $S$ EMS SQL Unit Lab Mothod

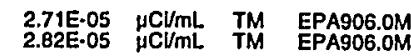

Field Qualifier(s): $s$ 


\section{WELL LAW 2C}

MEASUREMENTS CONDUCTED IN THE FIELD

Sample date: 05/24/99

Depth lo waler: $17.92 \mathrm{ft}(5.46 \mathrm{~m})$ below TOC

Water e

p. conductance: $42 \mu \mathrm{S} / \mathrm{cm}$

Wurbidity: ONTU evaled from the well prior to sampling: $70 \mathrm{ga}$

ANALYSES

\begin{tabular}{|c|c|c|c|c|c|c|c|c|}
\hline F Analyto & Result & $F G$ & $s$ & EMS & SQL & Unit & Lab & Mothod \\
\hline $\begin{array}{l}2 \\
2\end{array}$ & $\begin{array}{l}4.57 \mathrm{E}-03 \pm 1.06 \mathrm{EE} \cdot 04 \\
4.48 \mathrm{BE}-03 \pm 1.04 \mathrm{E}-04\end{array}$ & & & & $\begin{array}{l}2.76 \mathrm{E}-05 \\
2.71 \mathrm{E}-05\end{array}$ & ${ }_{\mu \mathrm{CU} / \mathrm{mL}}^{\mu \mathrm{CL}}$ & TM & $\begin{array}{l}\text { EPA906.0M } \\
\text { EPA906.0M }\end{array}$ \\
\hline
\end{tabular}

WELL LAW 2C

MEASUREMENTS CONDUCTED IN THE FIELD

Sample date: $06 / 21 / 99$ ( $15.32 \mathrm{~m})$ below TOC

pH: 4.4

p. conductance: $\mathbf{4 1} \mu \mathrm{S} / \mathrm{cm}$

Waler evacuated from the well prior to sampling: $64 \mathrm{gal}$

ANALYSES

\begin{tabular}{|c|c|c|c|c|c|c|c|}
\hline Analyto & Rosult & $F G$ & EMS & $S Q L$ & Unlt & Lab & Mothod \\
\hline 夜ritium & $\begin{array}{l}3.54 \mathrm{E}-03 \pm 9.40 \mathrm{E} \cdot 05 \\
3.92 \mathrm{E} \cdot 03 \pm 1.01 \mathrm{E} \cdot 04\end{array}$ & & & $\begin{array}{l}2.54 E-05 \\
2.65 E \cdot 05\end{array}$ & $\underset{\mu \mathrm{C} / / \mathrm{mL}}{\mu \mathrm{Cl}}$ & $\underset{T M}{T M}$ & $\begin{array}{l}\text { EPA906.0M } \\
\text { EPA906.0M }\end{array}$ \\
\hline
\end{tabular}

\section{WELL LBP 10}

MEASUREMENTS CONDUCTED IN THE FIELD

Sample date: 06/16/99

. 47.88 \# $(14.59 \mathrm{~m})$ below TOC

Water eleval

Sp. conductance: $260 \mu \mathrm{S} / \mathrm{cm}$

No water was evacuated from the well prior to sampling.

The well went dry during purging.

ANALYSES

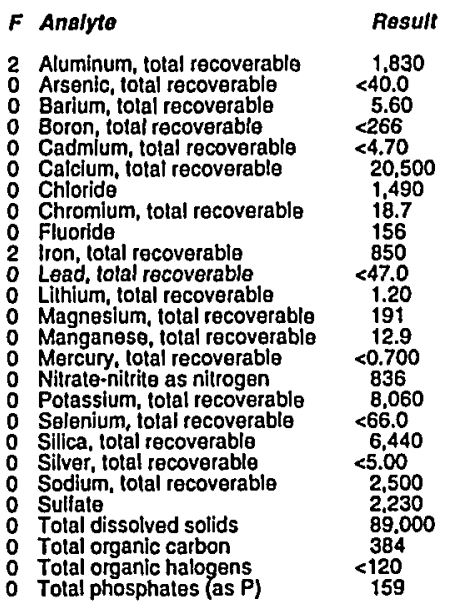

ESH-EMS-990527
Time: 12:14

Tile: $22.4^{\circ} \mathrm{C}$

Total alkalinity (as CaCO3): $0 \mathrm{mg} / \mathrm{L}$

Phenolphthalein alkalínity: $0 \mathrm{mg} / \mathrm{h}$

2.76E-05 $\mu \mathrm{CU} / \mathrm{mL}$ TM EPA906.0M

Time: 14:50

Water temperature: $22.1^{\circ} \mathrm{C}$

Total alkalinity (as CaCO3): $0 \mathrm{mg} /$

Field Qualifier(s): $s$.ility: $0 \mathrm{mg}$

SQL Unit Lab Mathod

Time: 12:40

rature: $19.6^{\circ} \mathrm{C}$

O Chromlum, rotal recoverable

Total alkalinity (as CaCO3): $59 \mathrm{mgh} \quad 0$ Fluoride

Phenolphthalein alkalinity: $47 \mathrm{mg}{ }^{2}$

Iron, total recoverable

Iron, total recoverable

Lead, total recoverable

Lithium, tolal recoverable

Magnesium, total recoverab.

Magnesium, tolai recoverab

Manganese, lotal recoverabl

Mercury, tolal recoverable

Nitrate-nitrite as niftrogen

Potassium, totai recoverable

Selenium, colal secoverab

Silica, total recoverable

Silver, total recoverabl

gr, tolal recoverable

Sodium, tolal recoverablo

Tetrachloroethylene

Total dissolved solids

Total organic carbon

Total organic halogens

Tolal phosphales (as

Titchloroethylene

Gross alpha

Tritium

B-156
$1.20 E-09 \pm 8.80 E-10$
$7.80 E-10 \pm 8.90 E-10$

$8.17 \mathrm{E}-09 \pm 1.62 \mathrm{E} \cdot 09$

$1.72 \mathrm{E}-06 \pm 4.30 \mathrm{E}-07$
$1.80 \mathrm{E} \cdot 06 \pm 4.20 \mathrm{E}-07$

$1.26 \mathrm{E} .09 \mu \mathrm{CU} / \mathrm{mL}$ TM EPA900.0M

$2.09 \mathrm{E} .09 \mathrm{\mu C} / \mathrm{mL}$ TM EPA900.0M

2.14E.09 $\mu \mathrm{Cl} / \mathrm{mL}$ TM EPA900.0M

5.70E.07 $\mu \mathrm{C} / \mathrm{mL}$ TM EPA906.0M

Time: 13:57

(emperature: $22.6^{\circ} \mathrm{C}$

Total alkalinity (as Caco3): $0 \mathrm{mg} / \mathrm{L}$

$<40$

29.0
28.9
$<266$

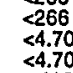

1.00

3.600
$<1.00$
$<3.80$

4.00
$<1.00$
$<30.1$
61.4

84.0
$<47.0$
$<47.0$
0.380

$0.400 \quad$ J

$\begin{array}{ll}859 & \\ 7.00 & J \\ 7.00 & \text { U }\end{array}$

636

860
$<66.0$
$<66.0$

6.580
6.560
$<5.00$

728
727
330
$<1.00$
12000

236
19.9
19.3
19.2

1.00

$1.52 E-09 \pm 7.20 E-10 J$

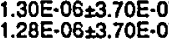

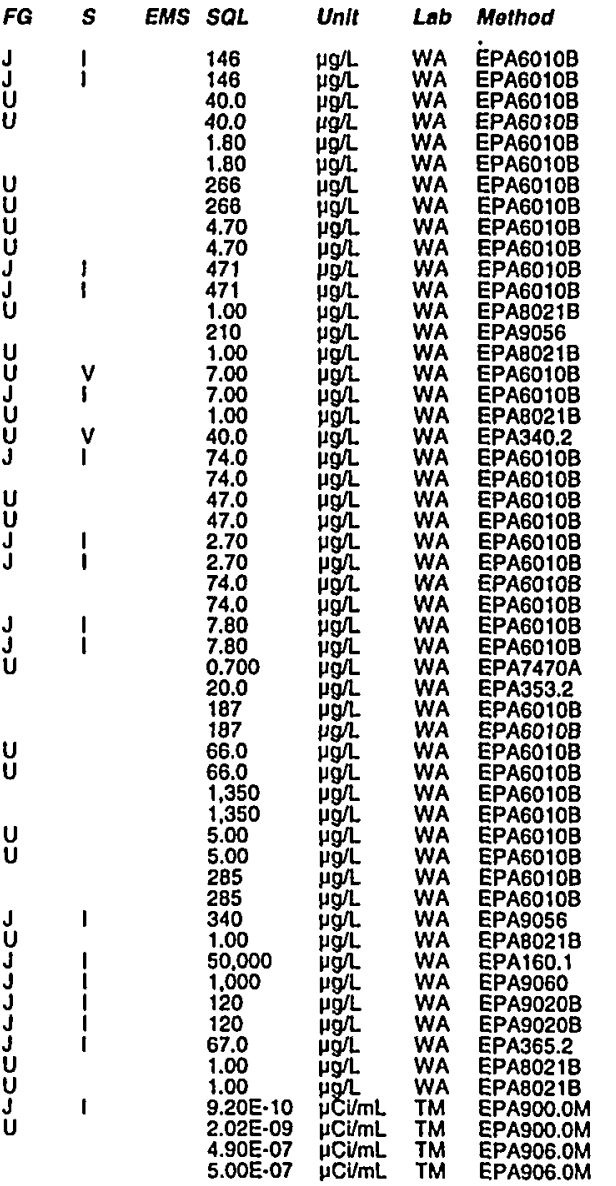

Lab Mathod

Sacond Quartor 1999 


\section{WELL LBP 3D}

MEASUREMENTS CONDUCTED IN THE FIELD

Sample date: 06/16/99

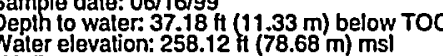

H: 5

Sp. conductance: $20 \mu \mathrm{s} / \mathrm{cm}$

Water evacuated from the well prior to sampling: $13 \mathrm{gal}$ ANALYSES
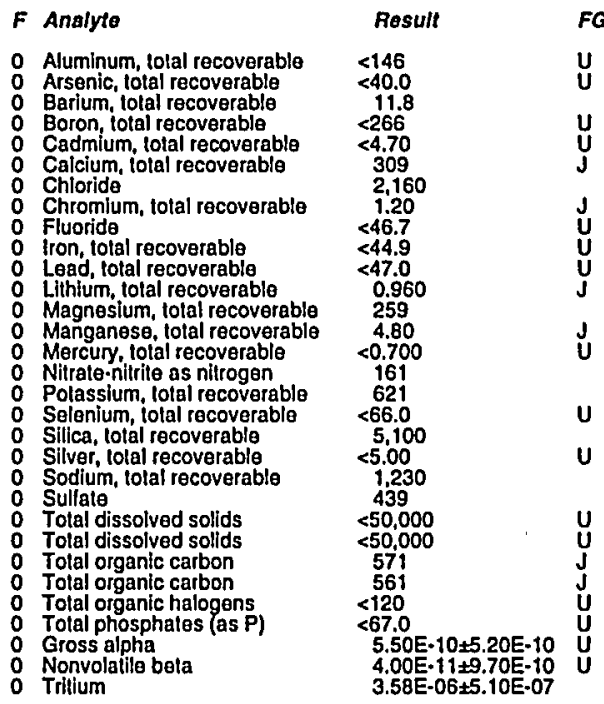

\section{WELL LDB 1}

MEASUREMENTS CONDUCTED IN THE FIELD

Sample date: 04/27/99

Water elevation: $215.65 \mathrm{Ht}(65.73 \mathrm{~m}) \mathrm{msl}$

$\mathrm{H}: 4.8$

Sp. conductance: $50 \mu \mathrm{S} / \mathrm{cm}$

Waler evacualed trom the well prior to sampling: 1 gal The well went dry during purging.

ANALYSES

\begin{tabular}{|c|c|c|c|c|c|c|c|c|}
\hline F Analyte & Result & $F G$ & $s$ & EMS & $S Q L$ & Unit & Lab & Method \\
\hline$: \begin{array}{l}\text { Triflum } \\
0\end{array}$ & $\begin{array}{l}\text { 7.34E-06+6.80E-07 } \\
8.57 E \cdot 06 \pm 7.30 E=07\end{array}$ & & & & $\begin{array}{l}5.40 E \cdot 07 \\
5.50 E \cdot 07\end{array}$ & ${ }_{\mu \mathrm{C} V \mathrm{~mL}}^{\mu \mathrm{mL}}$ & TM & $\begin{array}{l}\text { EPA906.0N } \\
\text { EPA906.0N }\end{array}$ \\
\hline
\end{tabular}

\section{WELL LDB 1}

MEASUREMENTS CONDUCTED IN THE FIELD

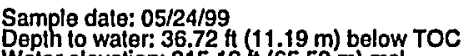

Water el

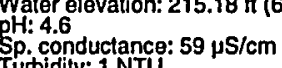

Water evacuated from the well prior to sampling: 43 gal

Time: 11:55

rature: $20.3^{\circ} \mathrm{C}$

Total alkalinity (as Caco3): $0 \mathrm{mg} /$

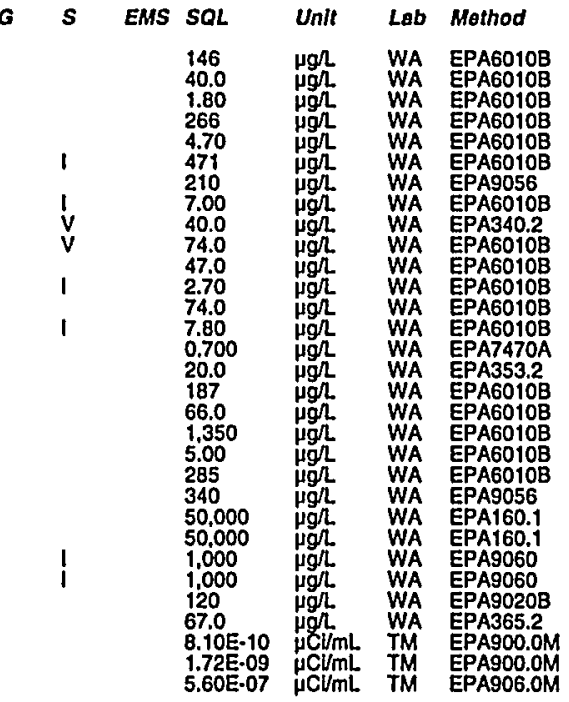

\section{ESH-EMS-99052}

Time: $14: 36$ Water temperature: $24.8^{\circ} \mathrm{C}$

Total alkainity (as CaCO3): $7 \mathrm{mg} / \mathrm{L}$

Field Qualifier(s): $S \times N$ ity: $0 \mathrm{mg}$ Total alkadinity (as Cacos): $0 \mathrm{mgh}$
Phenolphthalein alkalinity: 0 mgl
Field Qualifier(s): $\mathrm{s}$
Well LDB i collected on 05/24/99 (cont.)

ANALYSES

F Analyte Result FG $S$ EMS SQL Unit Lab Mothod

\begin{tabular}{|c|c|}
\hline $\begin{array}{l}\text { Trillum } \\
\text { Trilium }\end{array}$ & $\begin{array}{l}8.18 \mathrm{E}-06 \pm 6.80 \mathrm{E}-07 \\
8.27 \mathrm{E}-06 \pm 6.80 \mathrm{E}-07\end{array}$ \\
\hline
\end{tabular}

WELL LDB 1

MEASUREMENTS CONDUCTED IN THE FIELD

Sample date: 06/21/99 Time: 13:13

Sample date: 06/21/99
Depth to water: $37.21 \mathrm{ft}(11.34 \mathrm{~m})$ below TOC
Water levalion: $214.69 \mathrm{lt}(65.44 \mathrm{~m}) \mathrm{ms}$

pH: 4.9 evation: 214.69 ti $(65.4$

Turbidity: $5 \mathrm{NTU}$ ( $55 \mathrm{HS} / \mathrm{cm}$

ANALYSES

F Analyte Rasult FG $S$ EMS SQL Unit Lab Mothod

\begin{tabular}{|c|c|}
\hline $\begin{array}{l}0 \text { Tritium } \\
0 \text { Tritlum }\end{array}$ & $\begin{array}{l}8.89 \mathrm{E} \cdot 06 \pm 6.80 \mathrm{E}-07 \\
9.30 \mathrm{E} \cdot 06 \pm 7.10 \mathrm{E}-07\end{array}$ \\
\hline
\end{tabular}

WELL LDB 2

MEASUREMENTS CONDUCTED IN THE FIELD

Sample date: 04/27/99

Depth to water: $35.44 \mathrm{ft}(10.8 \mathrm{~m})$ below TOC

Waler

4.6 evation: $217.46 \mathrm{Ht}(66.28 \mathrm{~m}) \mathrm{ms}$

Sp. conductance; $84 \mu \mathrm{S} / \mathrm{cm}$

Water evacuated from the well prior to sampling: $1 \mathrm{gal}$

The well went dry during purging.

ANALYSES

F Analyte

Result

Air temperalure: $25.2 \mathrm{C}$ (ala alkalinity $0 \mathrm{mg} / \mathrm{Ls}$

Field Qualifier(s): $\mathbf{S}$

0 Tritlum

3.47E-06.5.20E-07

Time: 13:56

政 $25.2^{\circ} \mathrm{C}$

Total alkalinity.(as CaCO3): $6 \mathrm{mg}$

Phenolph halein alkalinity: $0 \mathrm{mgl}$

WELL LDB 2

MEASUREMENTS CONDUCTED IN THE FIELD

Sample date: 05/21/99

Wathe elevalion: 217.02 (10.94 $\mathrm{m}$ ) below TOC

pH: 4.8

Sp. conductance: $92 \mu \mathrm{S} / \mathrm{cm}$

Turbidity: 32 NTU

Waler evacuated from the well prior to sampling: 3 gal

ANALYSES

$F$ Analyte

Result

o Trillum

$3.07 E-06 \pm 4.70 E-07$

WELL LDB 2

MEASUREMENTS CONDUCTED IN THE FIELD

Sample date: 06/21/99
Depht lo water: 36.4 th $(11.09 \mathrm{~m})$ bolow TOC
Water elevation: $216.5 \mathrm{H}(65.99 \mathrm{~m}) \mathrm{ms}$

pH: 4.7 .

Turbidity: 16 NTU from the well prior to sampling: $1 \mathrm{gal}$
Water evacuated from
The well went dry during purging.
Time: 12:43

Air temperature: $22.8^{\circ} \mathrm{C}$

Total alkalinity (as CaCO3): $9 \mathrm{mg}$

Phenoiphthalein alkalinily: $0 \mathrm{mgh}$
Field Qualifier(s): SXN

Time: 13:20

Air temperature: $25.2^{\circ} \mathrm{C}$

Tolal alkalinity (as Caco3): $0 \mathrm{mg} /$

Phenolphthalein alkalinity: $0 \mathrm{mg} /$
Field Qualifier(s): $\mathrm{SX}$

Second Quarter 1999 


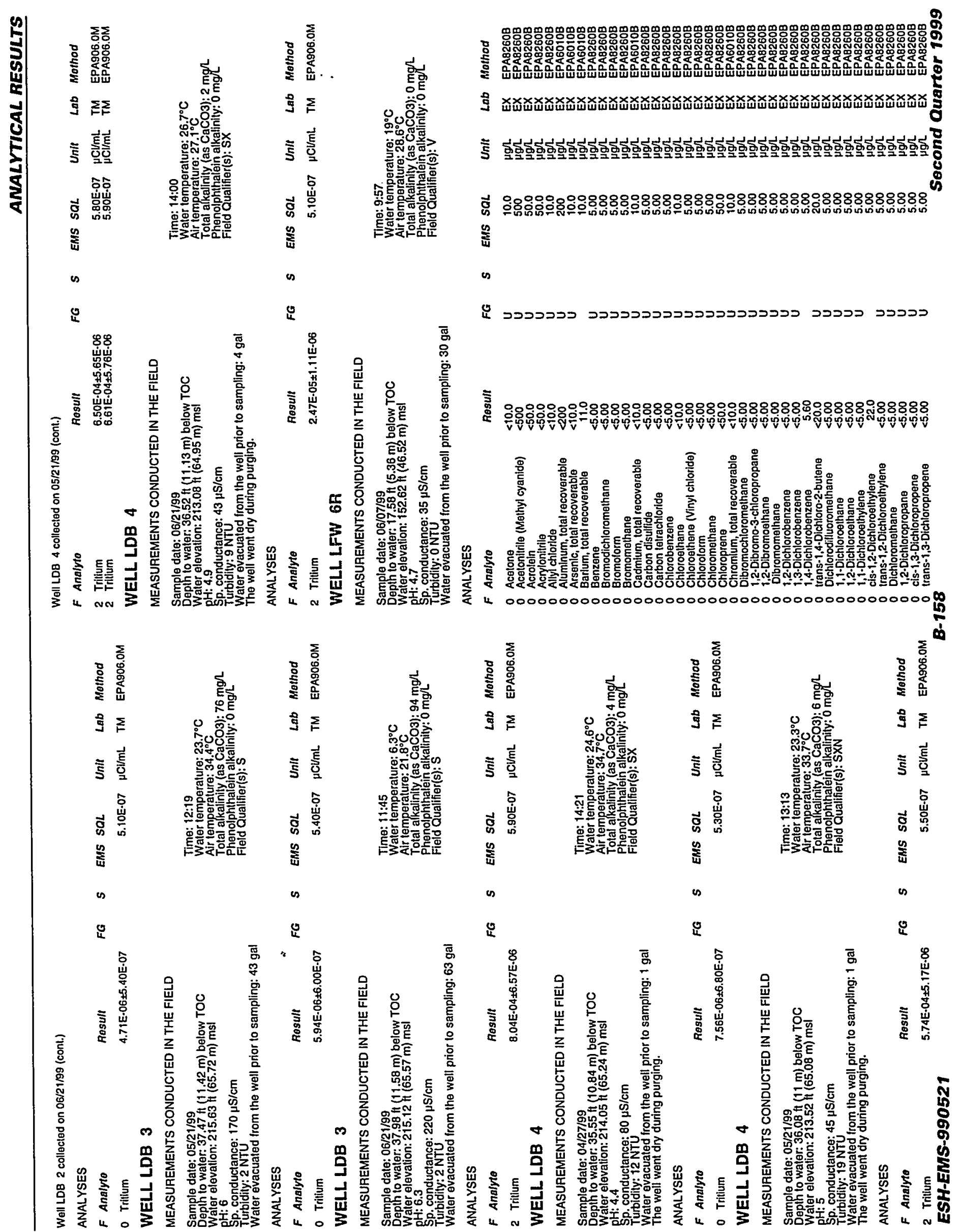


Well LFW 6R collected on 06/07/99 (cont.)

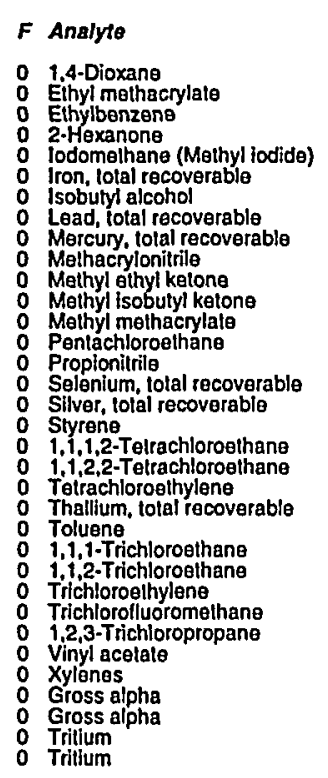

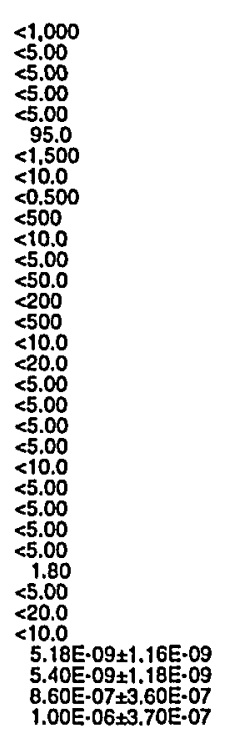

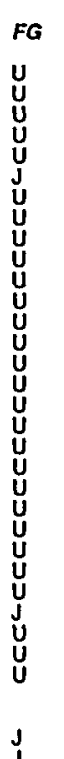

\section{WELLLFW $8 R$}

MEASUREMENTS CONDUGTED IN THE FIELD

Sample date: 06/02/99
Dephh to water: $21.91 \mathrm{ft}(6.68 \mathrm{~m})$ below TOC
Water elevation: $148.69 \mathrm{lt}(45.32 \mathrm{~m}) \mathrm{ms}$

Waler elevation: $148.69 \mathrm{lt}$ (45.
$\mathrm{pH}$. 6.5 . conductance: $200 \mu \mathrm{S} / \mathrm{cm}$

Sp. conductance: $200 \mu \mathrm{S} / \mathrm{cm}$
Tubility: $1 \mathrm{NTU}$.
Waler $\theta$ vacualed from the well prior to sampling: $26 \mathrm{gal}$

ANALYSES

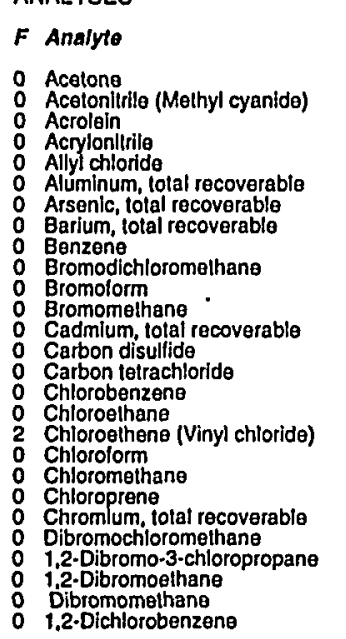

ESH-EMS-990521

\begin{tabular}{|c|c|c|c|}
\hline Result & $F G$ & $s$ & EMS \\
\hline $\begin{array}{l}<10.0 \\
<500 \\
<50.0 \\
<50.0 \\
<10.0 \\
<200 \\
<20.0 \\
<10.0 \\
<5.00 \\
<5.00 \\
<5.00 \\
<5.00 \\
<10.0 \\
<5.00 \\
<5.00 \\
3.30 \\
<10.0 \\
8.40 \\
<5.40 \\
<5.00 \\
<50.0 \\
<10.0 \\
<5.00 \\
55.00 \\
<5.00 \\
<5.00 \\
<5.00\end{array}$ & 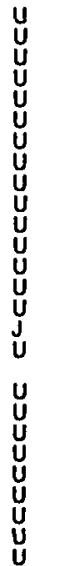 & $v$ & \\
\hline
\end{tabular}

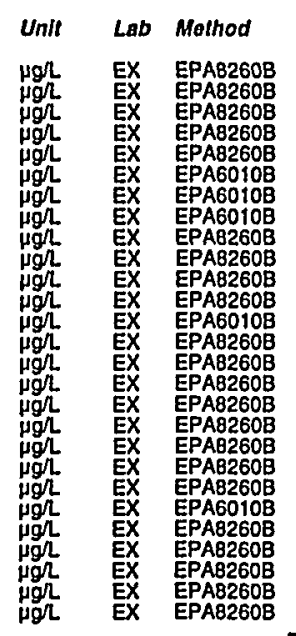

Well LFW 8R collected on 06/02/99 (cont.)

$F$ Analyte Result

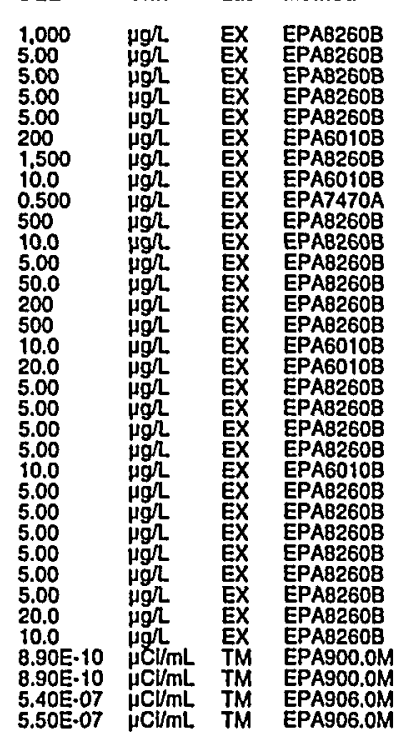

o 1,3-Dichlorobenzene

1.4-Dichlorobenzene
0 trans-1,4-Dichloro-2-bulene
0 Dichlorodilluoromethane

: 1,1.0ichloroethane

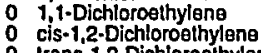

: Dichloromethane

o cis-1,3-Dichloropropene

$\begin{array}{ll}0 & 1.4 \cdot-D i o x a n \theta \\ 0 & \text { Elhyl methacrylate }\end{array}$

0
0
0

0 lodomelhane (Methyl lodide)

2 Iron, total recoverable

Mercury, lolal recoverabable

0 Methacrylonitrile

O Meihyl methacrylate

o Proplonitrita

0 Selenium, lotal recoverable
0 Silver, total recoverable

Styrene Tetrachloroethane

o i, i, 2, Tetrachloroethan

$\begin{array}{ll}0 & \text { Toluene } \\ 0 & 1,1,1-\text { richloroethane } \\ 0 & 1,1,2 \text {-Trichloroethane }\end{array}$

0 Trichloroethylene

$1,2,3$ - Trichloropropane
0 Viny acetale

Xylenes

0 Gross alpha
Tritlum

0 Tritlum

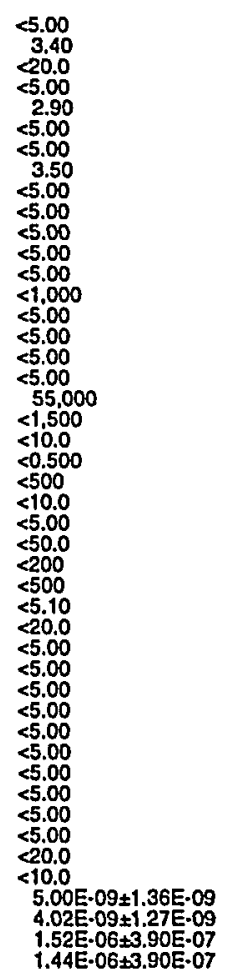

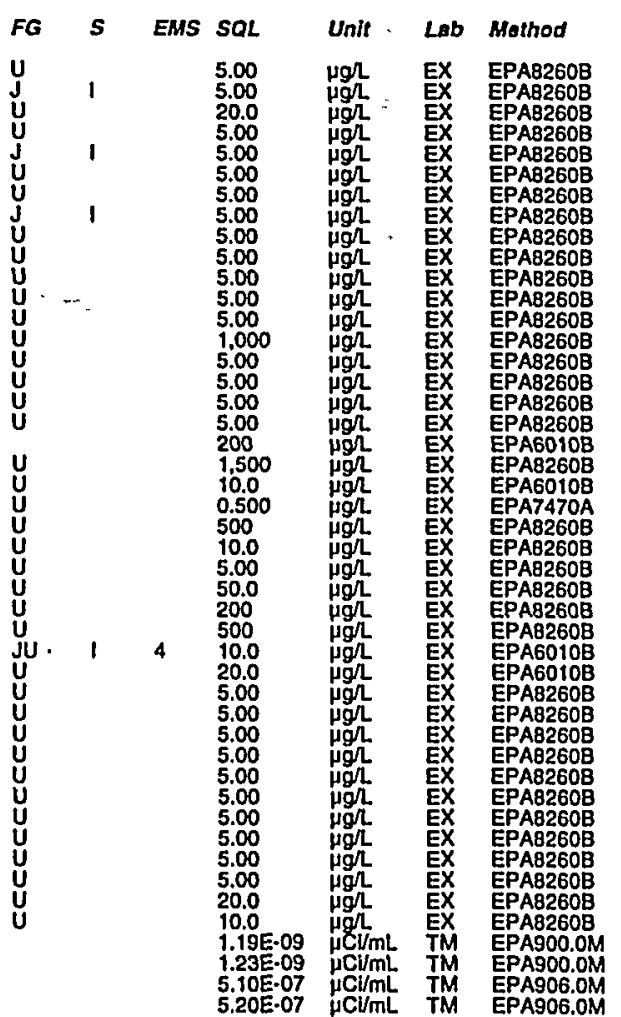

\section{WELL LFW 10A}

MEASUREMENTS CONDUCTED IN THE FIELO

Sample date: $06 / 03 / 99$
Dephto to waiter: 30.31 fif $(9.24 \mathrm{~m})$ below TOC
Waler elevation: $151.29 \mathrm{~h}(46.11 \mathrm{~m}) \mathrm{ms}$

pp. 6.6 conductance: $290 \mu \mathrm{S} / \mathrm{cm}$

Turbidity: 2 NTU
Waler evacualed from the well prior to sampling: $72 \mathrm{gal}$ ANALYSES

$F$ Analyto

0 Acetone

Acetonitrile (Methyl cyanide)
0 Acetonitrile (Methyl cyanide)

Acrolein

0 Acrylonitrile

- Allyl chloride

Aluminum, lotal recoverable

A Arsenic, tolal recoverable
0 Arsentc, total recoverable
0

B-159

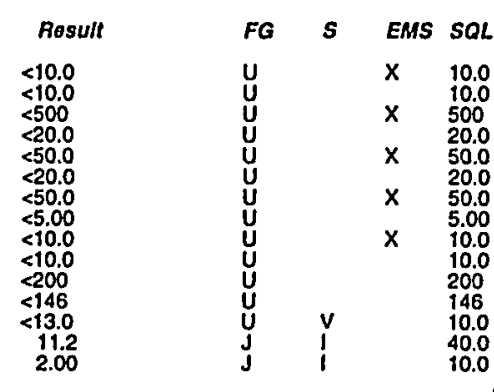

Time: 9:49

Air emperature: $28.7^{\circ} \mathrm{C} \mathrm{C}$

Total alkalinity (as CaCo3): $92 \mathrm{mg} / \mathrm{L}$

Phenolphthalein alkalinily: $0 \mathrm{mg} \Omega$
Field Qualifier(s): $V$

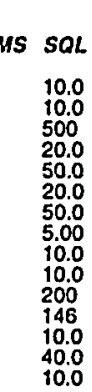

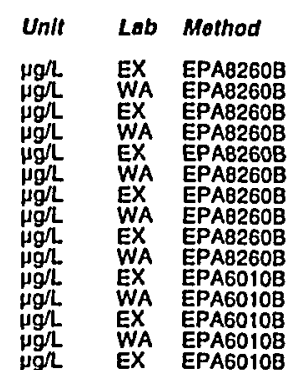

Second Quartor 1999 
ANALYTICAL RESULTS

Woll LFW 10A collected on 06/03/99 (cont.)

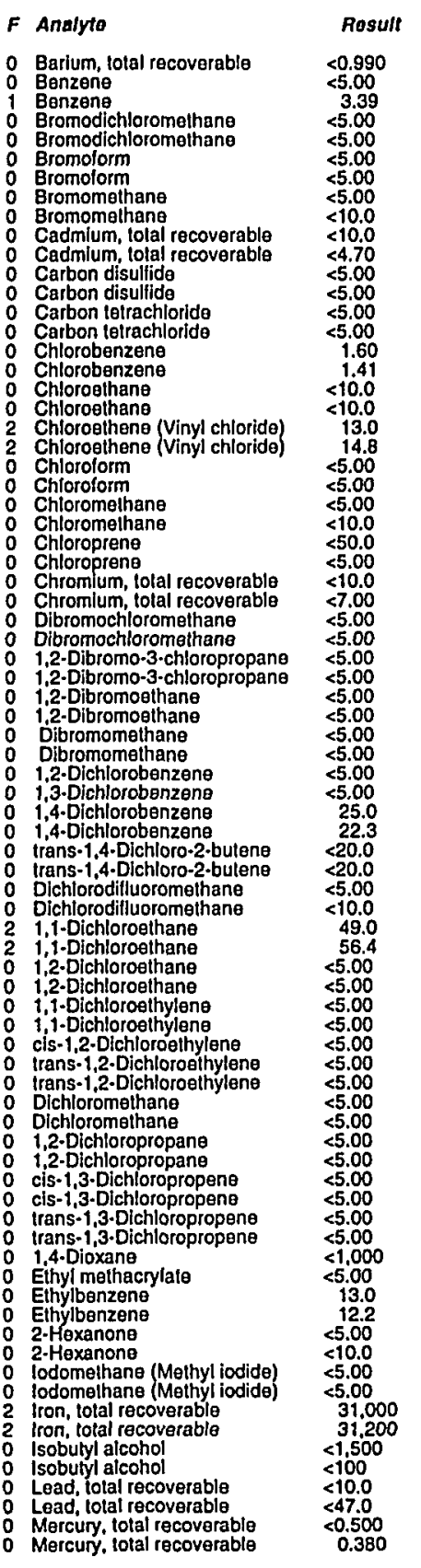

Well LFW 10A colloctod on 08/03/99 (cont.)

F Analyte

o Methacrylonllitile

0
0 Melhyl elhyl kelone
0

Methyl isobutyl kelone

Methyl mothacrylate

O Proplachloroe

Selenium, total recoverable

S Silver, total recoverable

Silver, total recoverablo

Styrenen

1,1,1,2-Tetrachloroethane

1.

$1,1,2,2$-Tetrachloroethan

Tolrachloroethylene

Toluene

$1,1,1-$ Trichloroethane

1,1,1-Trichlorosthane

1.1,2-Trichloroethane

Trichloroethylene

Trichlorofluoromelhane

1,2,3-Trichloropropane

12,3-Trichloropropan

Vinyl acetate

Xylenes

Gross alpha

Gross alpha

2 Tritium

\section{WELL LFW 10A Replicate}

MEASUREMENTS CONDUCTED IN THE FIELD

Sample date: 06/03/99

Depth to water: 30.31 ft $(9.24 \mathrm{~m})$ below TOC
Water elevation: $151.29 \mathrm{Ht}(46.11 \mathrm{~m}) \mathrm{msl}$

pH: 6.6

sp. conduct

conductance: $290 \mu \mathrm{S} / \mathrm{cm}$

Water evacualed from the well prior to sampling: 72 gal

ANALYSES

F Analyte

: Acetone

Acrolétin

0 Acrylonitrile

Aluminum, tolal recoverable

Barium, lotal recoverable

Benzene

Bromolorm

Cadmium total recoverable Carbon disullide.

Carbon tetrachlo
0 Chlorobenzene
0 Chloroethane

B-160

Result
$<10.0$
$<500$
$<50.0$
$<50.0$
$<10.0$
$<200$
$<17.0$
2.00
3.70
$<500$
$<5.00$
$<5.00$
$<10.0$
$<5.00$
$<5.00$
1.70
$<10.0$

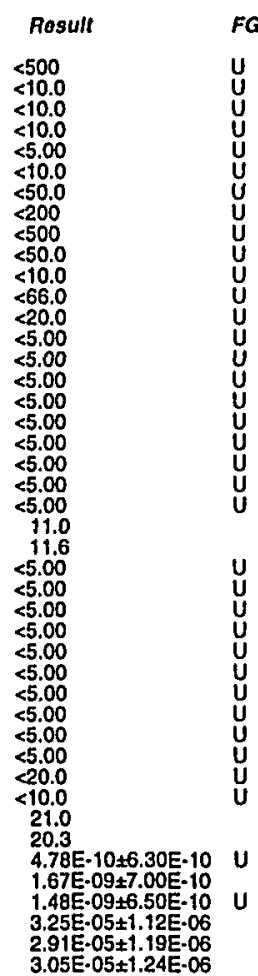

ro

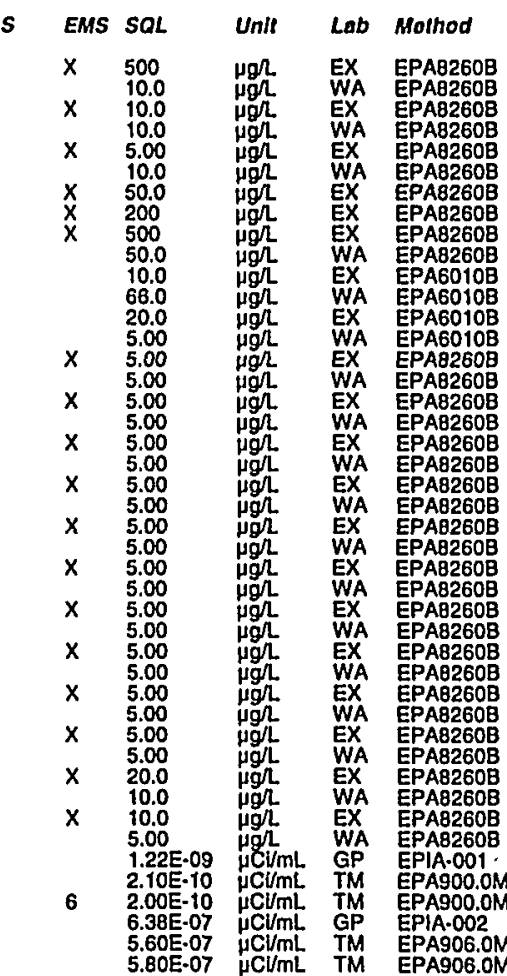

Time: 9:49

Waler temperature: $20.2^{\circ} \mathrm{C}$

Total alkalinity (as CaCO3): $92 \mathrm{mgl}$ Phenolphthalein alkalinity: $0 \mathrm{mg}$ L

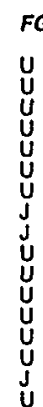

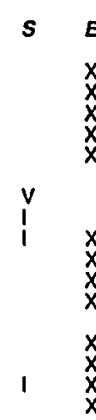

$\begin{array}{ll}\text { EMS } & \text { SQL } \\ X & 10.0 \\ X & 500 \\ X & 50.0 \\ X & 50.0 \\ X & 10.0 \\ X & 200 \\ & 10.0 \\ & 10.0 \\ X & 5.00 \\ X & 5.00 \\ X & 5.00 \\ X & 5.00 \\ X & 10.0 \\ X & 5.00 \\ X & 5.00 \\ X & 5.00 \\ X & 10.0 \\ \end{array}$
Unit Lab Mothod

$\mu g / L$ EX EPA8260B

ugh EX EPA82608

Hgh

pgic

$\mu g h$
$\mu g h$
$\mu g h$

EPAB260B

EPA6010B

EPAGO10B

EPA82608

EX EPAB2608

EX EPA6010B

EX EPA8260B

EX EPA82608

Socond Quarter 1999 
Well LFW 10A collected on 06/03/99 (cont.)

$F$ Analyto

Result

2 Chloroethene (Vinyl chloride) Chloromethane Chromum, fotal recoverable 1.2-Dibromo-3.chloropropane 1,2-Dibromoethane 1,2-Dichlorobenzene
i.3-Dichlorobenzene 1.4-Dichlorobenzene
trans-1,4-Dichloro-2-buten 1.1.-Dichloroethane $1,1 \cdot$ Dichloroethylene cis-1,2-Dichlorosthylene
trans-1,2-Dichloroethylen 1.2-Dichloropropane cis-1,3-Dichloropropene
trans-1,3-Dichloropropene Eihyl methacrylate Eihylbenzene
$2 . H e x a n o n \theta$ lodomethane (Melhyl lodide) Isobutyl alcohol Lead, rotal recoverable
Mercury, total recoverable Methacrylonitrile Methyl ethyl kelone
Methyl Isobutyl ketone Methyl methacylate Propionilrite Solenium, total recoverable 1.1,1,2-Totrachloroethano 1,1,2,2-Totrachloroethan 0
0 Toluene
1.1.1-Trichloroethane 1.1.2. Trichloroothan Trichlorolluoromethane Vinyl acelate Gross alpha
Tritium

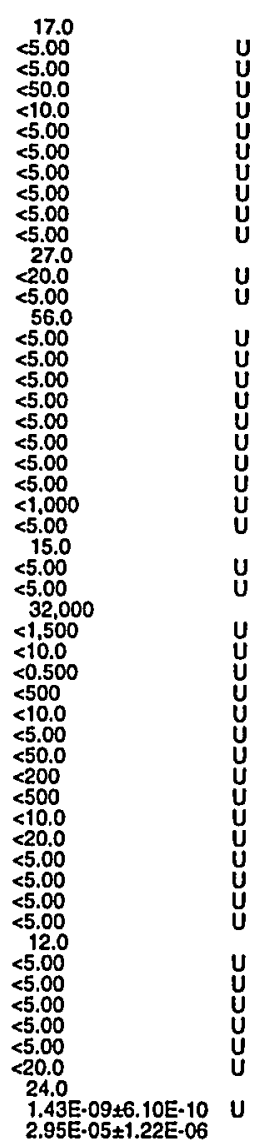
$F G$.

\begin{tabular}{|c|c|c|c|c|}
\hline EMS & $S Q L$ & Unit & Lab & Method \\
\hline $\begin{array}{l}x \\
x \\
x \\
x \\
x \\
x \\
x \\
x \\
x \\
x \\
x \\
x \\
x \\
x \\
x \\
x \\
x \\
x \\
x \\
x \\
x \\
x \\
x \\
x\end{array}$ & $\begin{array}{l}5.00 \\
5.00 \\
5.00 \\
50.0 \\
10.0 \\
5.00 \\
5.00 \\
5.00 \\
5.00 \\
5.00 \\
5.00 \\
5.00 \\
20.0 \\
5.00 \\
5.00 \\
5.00 \\
5.00 \\
5.00 \\
5.00 \\
5.00 \\
5.00 \\
5.00 \\
5.00 \\
1.000 \\
5.00 \\
5.00 \\
5.00 \\
500 \\
200 \\
1.500 \\
10.0 \\
5.500 \\
100 \\
5.00 \\
50.0 \\
200 \\
500 \\
10.0 \\
20.0 \\
5.00 \\
5.00 \\
5.00 \\
5.00 \\
5.00 \\
5.00 \\
5.00 \\
5.00 \\
5.00 \\
20.0 \\
10.00 \\
1.80 E-10 \\
5.70 E .07\end{array}$ & 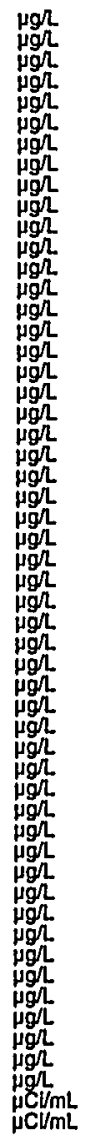 & $\begin{array}{c}\text { EX } \\
\text { EX } \\
\text { EX } \\
\text { EX } \\
\text { EX } \\
\text { EX } \\
\text { EX } \\
\text { EX } \\
\text { EX } \\
\text { EX } \\
\text { EX } \\
\text { EX } \\
\text { EX } \\
\text { EX } \\
\text { EX } \\
\text { EX } \\
\text { EX } \\
\text { EX } \\
\text { EX } \\
\text { EX } \\
\text { EX } \\
\text { EX } \\
\text { EX } \\
\text { EX } \\
\text { EX } \\
\text { EX } \\
\text { EX } \\
\text { EX } \\
\text { EX } \\
\text { EX } \\
\text { EX } \\
\text { EX } \\
\text { EX } \\
\text { EX } \\
\text { XX } \\
\text { EX } \\
\text { EX } \\
\text { EX } \\
\text { EX } \\
\text { EX } \\
\text { EX } \\
\text { EX } \\
\text { EX } \\
\text { TM } \\
\text { T }\end{array}$ & 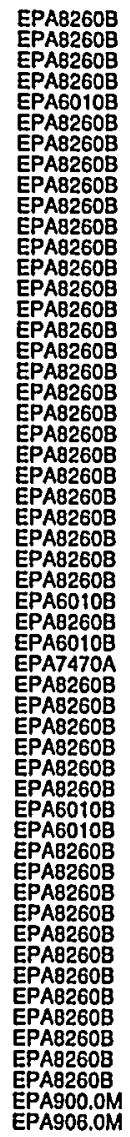 \\
\hline
\end{tabular}

WELL LFW 18

MEASUREMENTS CONDUCTED IN THE FIELD

Sample date: $06 / 03 / 99$ Water elevation: $153.85 \mathrm{ft}(46.89 \mathrm{~m}) \mathrm{msl}$

pH: 6.2

Waler temperafure: $20^{\circ} \mathrm{C}$

Total alkalinity. (as CaCo3): $40 \mathrm{mg} / \mathrm{L}$ Phenolphthalein al

Water evacuated from the well prior to sampling: $41 \mathrm{gal}$

ANALYSES

F Analyto Result

O Acetone O Acrolein

Aluminum, total recoverablo ESH-EMIS-990521
Well LFW 18 collected on 06/03/99 (cont.)

$F$ Analyte

- Barium, total recoverable

Bromodichloromethan

Oromolorm

- Cadmium, lotal recoverable

- Carbon disulfidide

: Chlorobenzene

Chloroethene (Vinyl chloride)

Chloromethan

Chromium, total recoverable

1,2-Dibromo-3-chloropropan

D. Dibromomelhane

o 1,2-Dichlorobenzene

trans-1,4-Dichloro-2-butene

o Dlchiorodicuoromethan

o i,2-Dichloroethane

$\begin{array}{ll}0 & 1,- \text { Dichloroethylene } \\ 0 & \text { cis-1,2-Dichloroelhylene }\end{array}$

0 Dichloromelhane

$\begin{array}{ll}0 & 1,2 \cdot \text { Dichloropropane } \\ 0 & \text { iss-1,3-Dichloropropene }\end{array}$

0 irans-1,3.Dichloropropen

Ethyl methacrylato

0: Ethylbenzene

0 lodomelhane (Melhyl lodide)

2 lron, lotal recovera

o Lead, fotal recoverable

Mercury, lotal recovera

0 Methyl elinyl katone

O Melhyl methacrylate

Silver, lotal recoverable

1,1,1,2-Telrachloroethane

i., i, 2, -Telrachloroethan

Tetrachloroethylene

1,1,1-Trichloroethane

Trichloroethylens

Tilchlorolluoromethane

O Vinyl acetate

Gross alpha

o Gross alpha

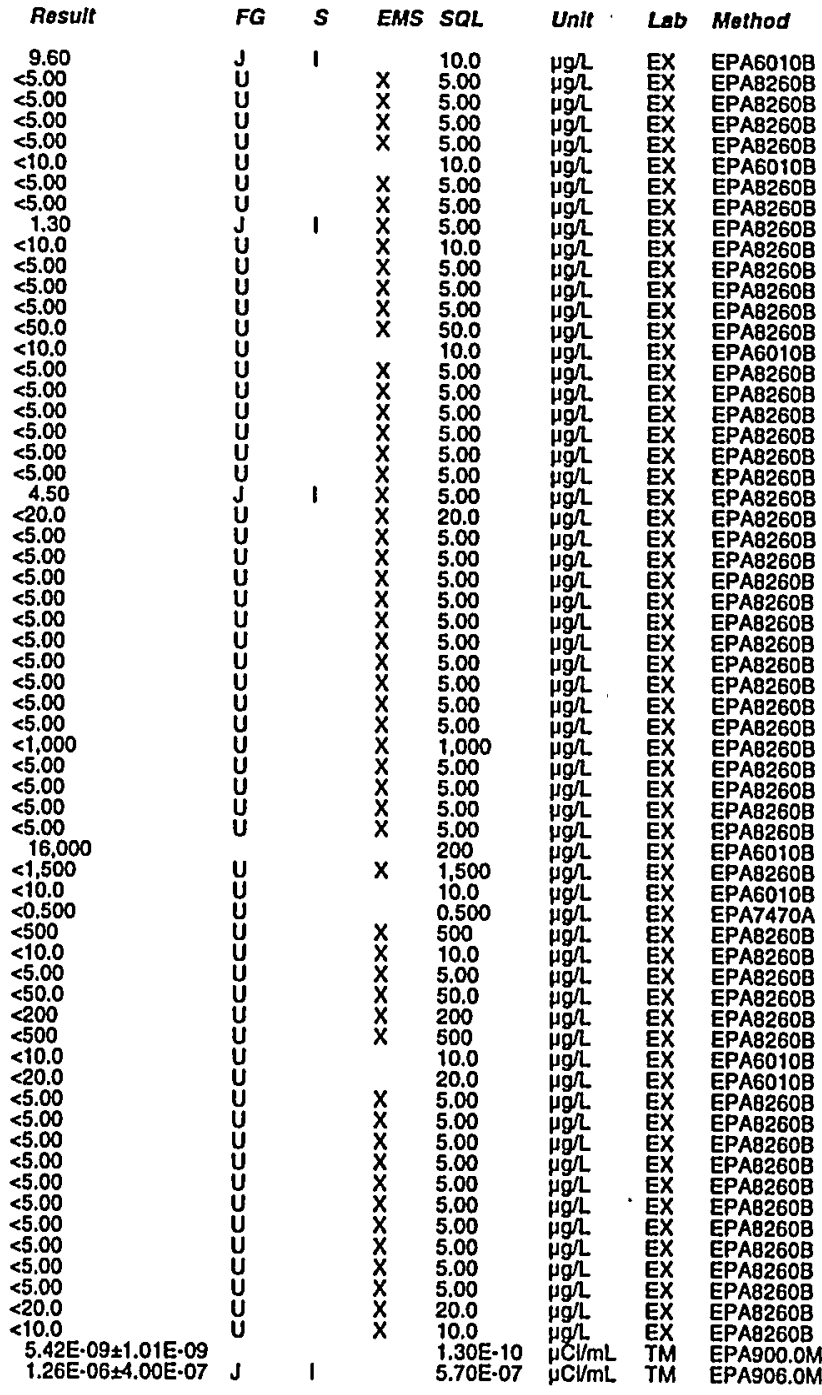




\section{WELL LFW 21}

MEASUREMENTS CONDUCTED IN THE FIELD

Sample date: 06/03/99

Welow TOC

$\mathrm{HH}: 6.5$

Sp. conductance: $220 \mu \mathrm{S} / \mathrm{cm}$

Water evacualed from the well prior to sampling: $38 \mathrm{gal}$

ANALYSES

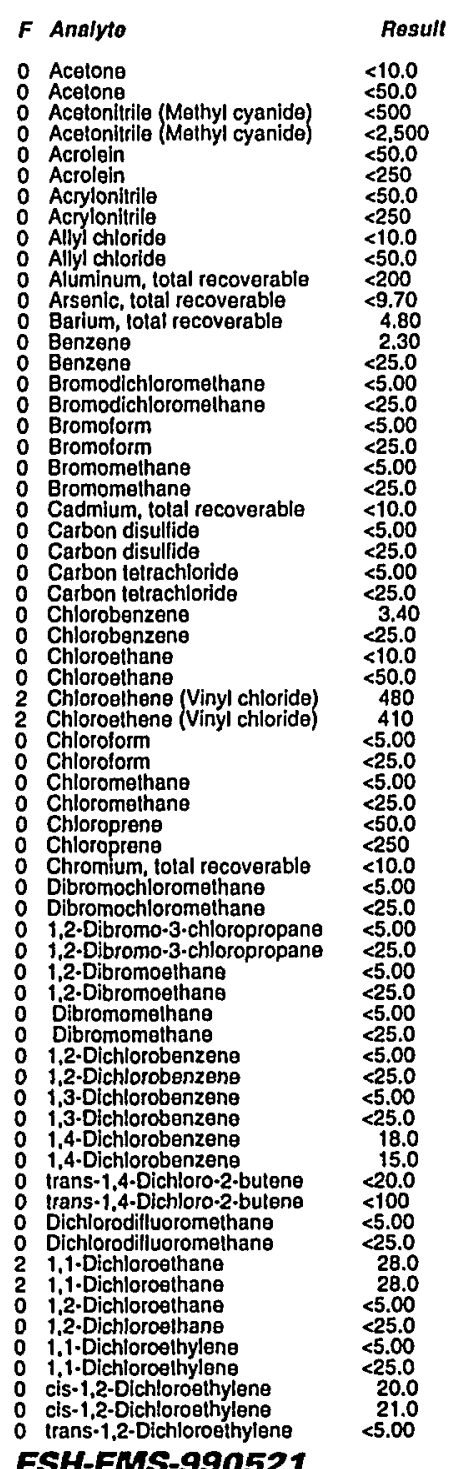

Well LFW 21 collected on 06/03/99 (cont.)
F Analyte

Time: 9:21

Air memperature: $20.3^{\circ} \mathrm{C}$ Total alkalinity (as CaCO3): $73 \mathrm{mg} /$ Field Qualifier(s): $V$
O trans-1,2-Dichloroethyleno

Dichloromethane

1,2.Dichloropropano

cis.1,3.Dichloropropen

trans-1,3-Dichjoropropene

Irans-1.3.Dichloropropen

1.4-Dioxane

E Ehyl methacrylale

0 Efhylbenzene

2. Hexanone

2-Hexanone

lodomethane (Mathyl iodide)
lodomethane (Mathyl iodide)

Iron, tofal recoverab

isobutyl alcoho
Isobulyl alcohol

o Lead, total recoverable

0 Mercury, total recar

Methacrylonilirila

Methyl ethyl ketone

Melhyl Isobutyl ketone

o Methyl methacrylalo

- Methyl methacrylale

o Pentachlorosthane

Proplonitrile

Selenlum, total recoverable

Silver, tolal recoverable

o Slyrene

o 1,1,1,2-Tetrachloroethane

1.1,1,2-Tetrachloroethane

1, 1,2,2-Tetrachloroethan日

Telrachloroethylene

o Toluene

$\begin{array}{ll}0 & \text { Toluene } \\ 0 & 1,1,1-\text { Trichloroethane } \\ 0 & 1,1,1-\text { Trichloroethane }\end{array}$

1,1,2-Trichloroethane

Trichioroethylene

o Trichlorofluoromethane

Trichlorolluoromethane

Vinyl acetato

0 Xylenes

Gylenes
1,2,3-Trichloropropane
Rosult

$<25.0$

25.00
$<5.00$
$<5.00$
5

55.00
5250
5500
5

$<25.0$
$<1,000$
$<5.000$

$<5.000$
$<5.00$
$<5.0$

15.0

$<5.00$
25.0
55.00
850

25.0
21,000
2.000

$<><1,500$

$<10.0$
$<0.500$
$<500$

2.500
$<10.0$
$<.00$

$<5$

55.00
55.0
550.0

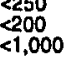

$<1,000$
5500
5

$<10.00$

20.0

$\underset{<5.00}{<2.0}$

25.0
5500
250

$<5.00$
255.0
100

1.0
13.0
13.0

$<5.00$
$<5.0$
$<5.00$

25.0
$<5.00$
$<5.0$

25.0
$<5.00$

$<25.0$
$<5.00$
$<5.0$

42.0

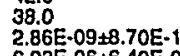

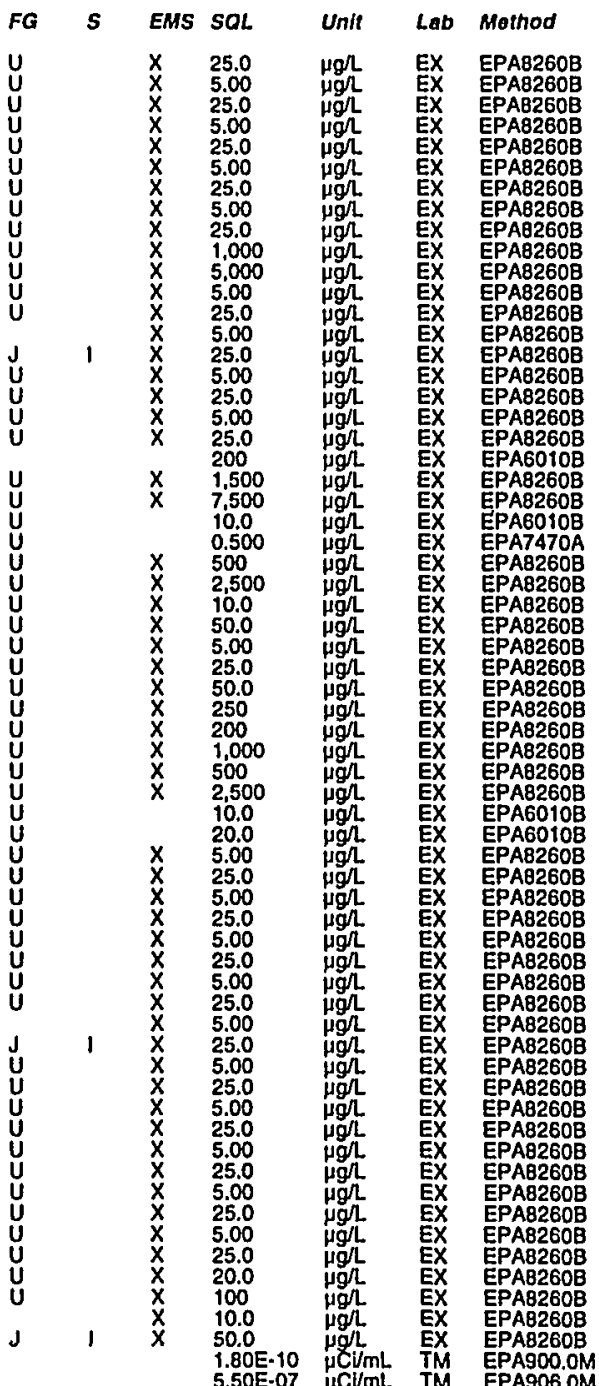




\section{WELL LFW 23R}

MEASUREMENTS CONDUCTED IN THE FIELD

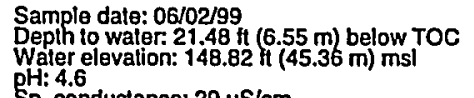

Sp. conductance: $29 \mu \mathrm{S} / \mathrm{cm}$

Water evacuated from the well prior to sampling: $25 \mathrm{gal}$ ANALYSES

$F$ Analyte

: Acclong

0
0
0

0 Ally chloride

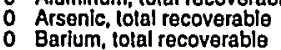

Benzena
Eromodichloromethane

Bromodichlor

o Bromomethane

$0_{0}$ Carbon disulilide

0 Chlorobenzene

- Chloroethene (Vinyl chloride)

Chloromethan

C Chromium, lotal recoverable

: Dibromochiloromethane

Ditromomothane

1,2. Dichlorobenzene

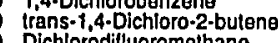

Dichloroditiluoromathane

1,1.Dichloroethane

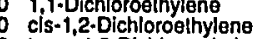

Irans-1,2-Dlechloroothylen

1,2-Dichloropropano

: cis-1,3.Dichloropropene
0
irans-1,3-Dichloropropene

Ethyl melhacylate

Oelnybenzene

lodomethane (Methyl iodide)

Iron, total recoverable

O Isobutyly alcohol

Mercury, otal recoverablo

Methacrylonltrile

Methyl sobutyl ketone

Pentachloroethane

Solenium, olal recoverable

S syrrene

I Tetrachloroesthylene

T.1,1-Trichloroethane

Trichiorothotheothan

ESH-EMS-99052

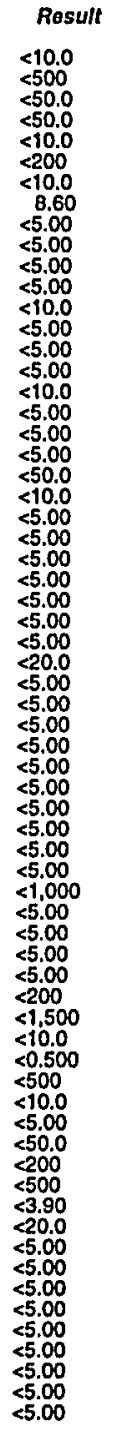

Tima: 9:15

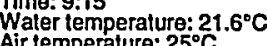

Total alkalinitiv. (as Cacos): $0 \mathrm{mgh}$

Phenolphinhalin alkalinity: $0 \mathrm{mgh}$
Field Cualifír(s):

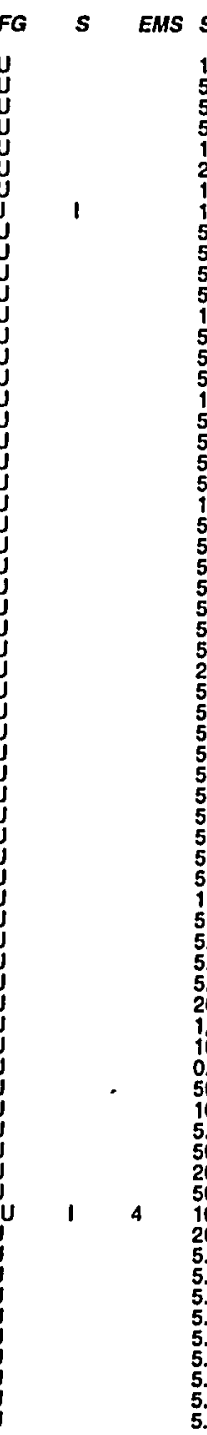

Well LFW $23 R$ collected on 06/02/99 (conl.)

\begin{tabular}{|c|c|c|c|c|c|c|c|c|}
\hline F Analyto & Result & $F G$ & $s$ & $E M S$ & SQL & Unit & Lab & Method \\
\hline 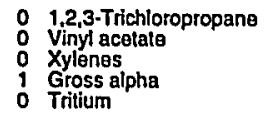 & $\begin{array}{l}<5.00 \\
<20.0 \\
<10.0 \\
8.79 E-09 \pm 1.46 E-09 \\
1.30 \mathrm{E}-06 \pm 3.70 \mathrm{E}-07\end{array}$ & $\underset{U}{U}$ & & & $\begin{array}{l}5.00 \\
20.0 \\
10.0 \\
8.80 \mathrm{E}-10 \\
5.00 \mathrm{E}-07\end{array}$ & 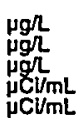 & $\begin{array}{l}\text { EX } \\
\text { EX } \\
\text { EX } \\
M \\
T M\end{array}$ & $\begin{array}{l}\text { EPAB260B } \\
\text { EPAB260B } \\
\text { EPAB260B } \\
\text { EPA900.0M } \\
\text { EPA906.0M }\end{array}$ \\
\hline
\end{tabular}

\section{WELLL LFW 28}

MEASUREMENTS CONDUCTED IN THE FIELD

Sample date: $05 / 05 / 99$
Depth to waler: $29.82 \mathrm{ft}(9.09 \mathrm{~m})$ below TOC
Water elevation: $162.58 \mathrm{Ht}(49.55 \mathrm{~m}) \mathrm{ms}$

Sp. conductance: $38 \mu \mathrm{S} / \mathrm{cm}$

Tuler evacuated from the well prior to sampling: $38 \mathrm{gat}$

ANALYSES

$F$ Analyto

Result

\begin{tabular}{ll} 
Mercury, total recoverable & $<0.450$ \\
\hline & $<0.450$
\end{tabular}

0.450
0.450

FG
$U$

G S EMS SO

Time: 10:09

erature: $29.8^{\circ} \mathrm{C}$

Tolal alkalinily (as CaCO3): $2 \mathrm{mgh}$

Field Qualifier(s): $S$

\section{WELL LFW 30}

MEASUREMENTS CONDUCTED IN THE FIELD

Sample date: 05/05/99

Water elevation: $165.04 \mathrm{ft}(50.3 \mathrm{~m}) \mathrm{mst}$

pH: 4.7

Sp. conductance: $29 \mu \mathrm{S} / \mathrm{cm}$

Water evacuated from the well prior to sampling: $\mathbf{4 6} \mathrm{gat}$

ANALYSES

$F$ Analyte

- Mercury, lotal recoverable

WELL LFW 31

MEASUREMENTS CONDUCTED IN THE FIELD

Sample date: 06/07/99

Water elovation: $164.49 \mathrm{H}(50.14 \mathrm{~m}) \mathrm{ms}$

S. conductance: $30 \mu \mathrm{S} / \mathrm{cm}$

Water evacuated from the well prior to sampling: $58 \mathrm{ga}$

ANALYSES

$F$ Analyto

0 Acelone

Acrolein

Aluminum, total recoverable

Arsenic, total recoverable

Benzeno

Bromodichloromethan

Bromolorm

Cadmlum lotal recoverable

Carbon disullide

Chiorobenzene

Chloroothene (Vinyl chloride)

$-163$
Result

$<0.450$

s

EMS SOL

$0.450 \quad \mu g$

Lab Mathod

Time: 10:42

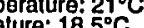

otal alkajinity (as $\mathrm{CaCO}$ ): $0 \mathrm{mg} /$

( henolphthalein alkalinity: $0 \mathrm{mg} L$

Time: 11:42

erature: $19.1^{\circ} \mathrm{C}$

Aotal akgalinity: (as Caco3): $0 \mathrm{mg}$ /

Field Qualifier(s): $s$.

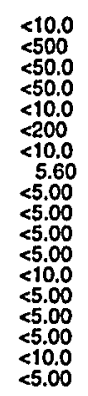

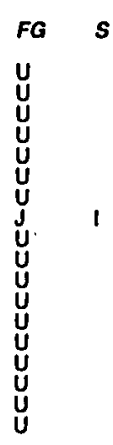

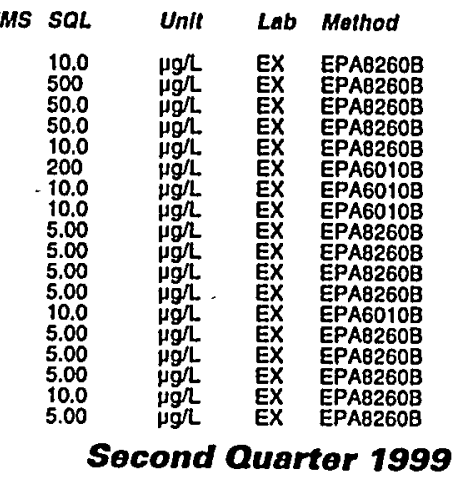


Well LFW 31 collecled on 06/07/99 (cont.)

F Analyte

Result

o Chloroform

O Choomlum, total recoverable

1,2-Dibromo-3-chloropropane

o 1.2.0ibromoeshane

1,2-Dichlorobenzene

i,4-Dichlorobenzene

Irans-1,4-Dichloro-2.butene
Dichlorodifluoromethane

1.1-Dichloroethane

1,1-Dichtoroethylene

0
0
0
trans-1,2-Dichloroelhylene

1,2-Dichloropropan

0
0
0

1.4-Dioxane

Eithylbenzene

lodomethane (Melhyl iodide)

tron, total recoverable

Lead total recoverable

Methacrylonilrile

Methyl isobulyl katon

Pentachloroethane

Solenium, tolal recoverablo

Silver, tolal recoverable

$\begin{array}{ll}0 & 1,1,1,2-T e t r a c h l o r o e t h a n e \\ 0 & 1,1,2,2-T e t r a c h l o r o e t h a n e\end{array}$

Tetrachloroethylene

Thallium, total recoverable

1,1,1-Trichlorosthane

Trichloroethylene

2 Trichlorolluoromethane

Vinyl acetal

Gross alpha

WELLL LFW 36R

MEASUREMENTS CONDUCTED IN THE FIELD

Sample date: 06/02/99
Depth to water: $22.98 \mathrm{Ht}$ (7 m) below TOC
Water elevation: 143.22 \& $(43.65 \mathrm{~m}$ ) msl

$\mathrm{pH}$ : 6.6

conductance: $140 \mu \mathrm{S} / \mathrm{cm}$

Waler evacualed from the well prior to sampling: $28 \mathrm{gal}$

ANALYSES

$F$ Analyto

Result

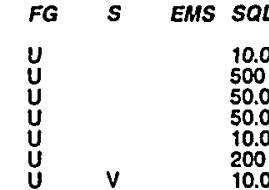

Time: 9:20

emperature: $20^{\circ} \mathrm{C}$

Total alkalinity (as Caco3): $62 \mathrm{mg} /$

Phenolphthalein alkat

Lab Mothod

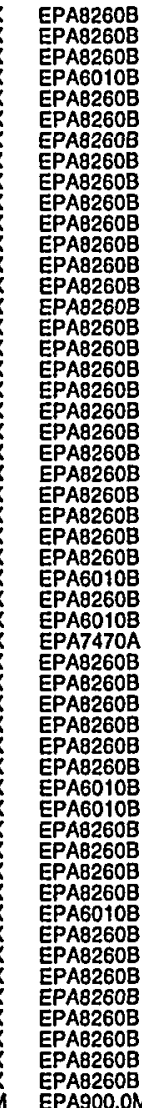

EPA900.0M

$\begin{array}{lll}\text { 0 Acetone } & <10.0 \\ 0 & \text { Acelonitrile (Methyl cyanide) } & <500 \\ 0 & \text { Acrolein } & <50.0 \\ 0 & \text { Acrilonitrile } & <50.0 \\ 0 & \text { Allyl chloride } & <10.0 \\ 0 & \text { Aluminum, tolal recoverable } & <200 \\ 0 \text { Arsenlc, total recoverable } & <5.70\end{array}$

ESH-EMS-990521
Well LFW 36R collected on 06/02/99 (conl)

\begin{tabular}{|c|c|c|c|c|c|c|c|c|}
\hline Analyto & osuft & $F G$ & 5 & EMS & $S O L$ & ant & Lab & hod \\
\hline 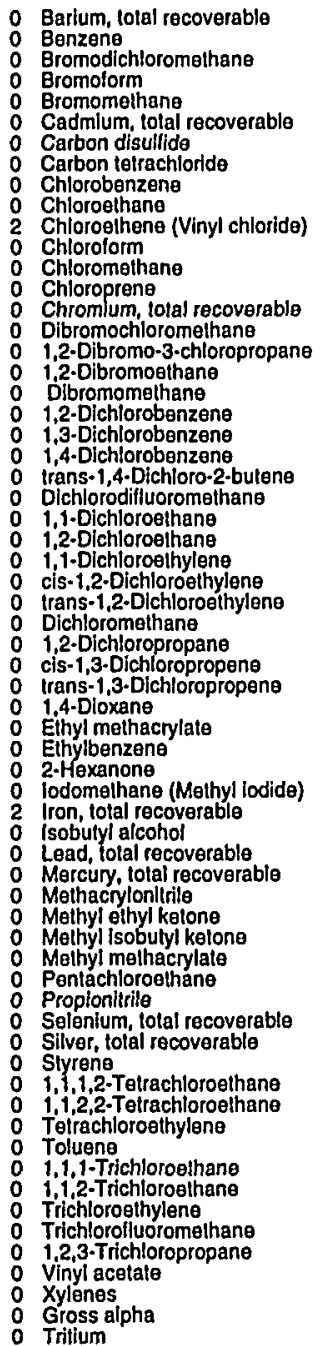 & 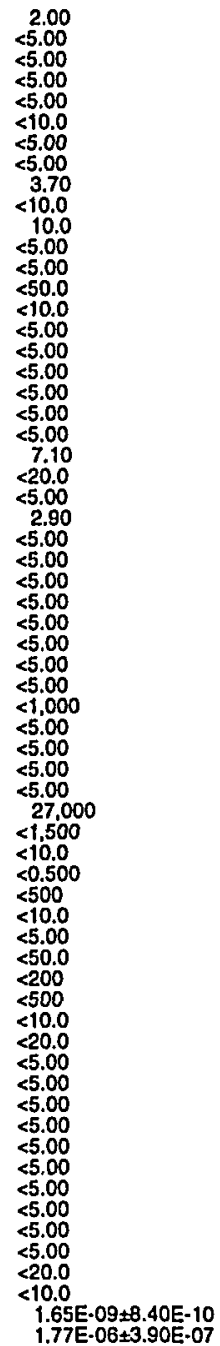 & 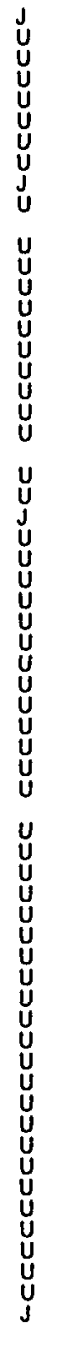 & 1 & & $\begin{array}{l}10.0 \\
5.00 \\
5.00 \\
5.00 \\
5.00 \\
10.0 \\
5.00 \\
5.00 \\
5.00 \\
10.0 \\
5.00 \\
55.00 \\
5.00 \\
50.0 \\
10.0 \\
55.00 \\
5.00 \\
5.00 \\
5.00 \\
5.00 \\
5.00 \\
20.0 \\
5.00 \\
5.00 \\
5.00 \\
5.00 \\
5.00 \\
5.00 \\
5.00 \\
5.00 \\
5.00 \\
1.000 \\
5.00 \\
55.00 \\
5.00 \\
200 \\
1.500 \\
10.0 \\
0.500 \\
500 \\
10.0 \\
5.00 \\
50.0 \\
200 \\
500 \\
100 \\
20.0 \\
5.00 \\
5.00 \\
5.00 \\
5.00 \\
5.00 \\
5.00 \\
5.00 \\
5.00 \\
5.00 \\
200 \\
10.0 \\
1.05 E-09 \\
5.00 E .07 \\
\end{array}$ & 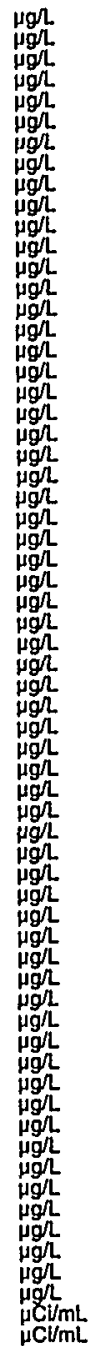 & $\begin{array}{c}\text { EX } \\
\text { EX } \\
\text { EX } \\
\text { EX } \\
\text { EX } \\
\text { EX } \\
\text { EX } \\
\text { EX } \\
\text { EX } \\
\text { EX } \\
\text { EX } \\
\text { EX } \\
\text { EX } \\
\text { EX } \\
\text { EX } \\
\text { XX } \\
\text { EX } \\
\text { EX } \\
\text { EX } \\
\text { EX } \\
\text { EX } \\
\text { EX } \\
\text { EX } \\
\text { EX } \\
\text { EX } \\
\text { EX } \\
\text { EX } \\
\text { EX } \\
\text { EX } \\
\text { EX } \\
\text { EX } \\
\text { EX } \\
\text { EX } \\
\text { EX } \\
\text { EX } \\
\text { XX } \\
\text { EX } \\
\text { XX } \\
\text { XX } \\
\text { EX } \\
\text { EX } \\
\text { EX } \\
\text { EX } \\
\text { XX } \\
\text { EX } \\
\text { XX }\end{array}$ & 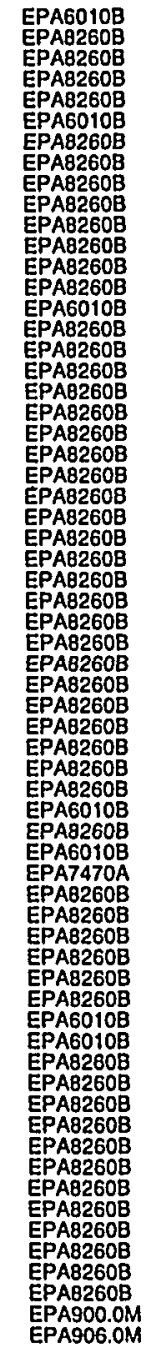 \\
\hline
\end{tabular}

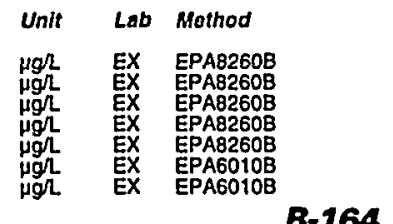


WELL LFW 41R

MEASUREMENTS CONDUCTED IN THE FIELD

Sample date: $06 / 01 / 99$
Depth 10 waier: $27.8 \mathrm{ft}(8.47 \mathrm{~m})$ below TOC
Water

Water elevation: $141.9 \mathrm{ft}(43.25 \mathrm{H}$
$\mathrm{gp}: 4.7$
Wp. conductance: $21 \mu \mathrm{S} / \mathrm{cm}$

Sp. conductance: $21 \mu \mathrm{S} / \mathrm{cm}$
Wurblity $0 \mathrm{ONTU}$.
Water evacuated from the well prior to sampling: $34 \mathrm{gal}$ ANALYSES

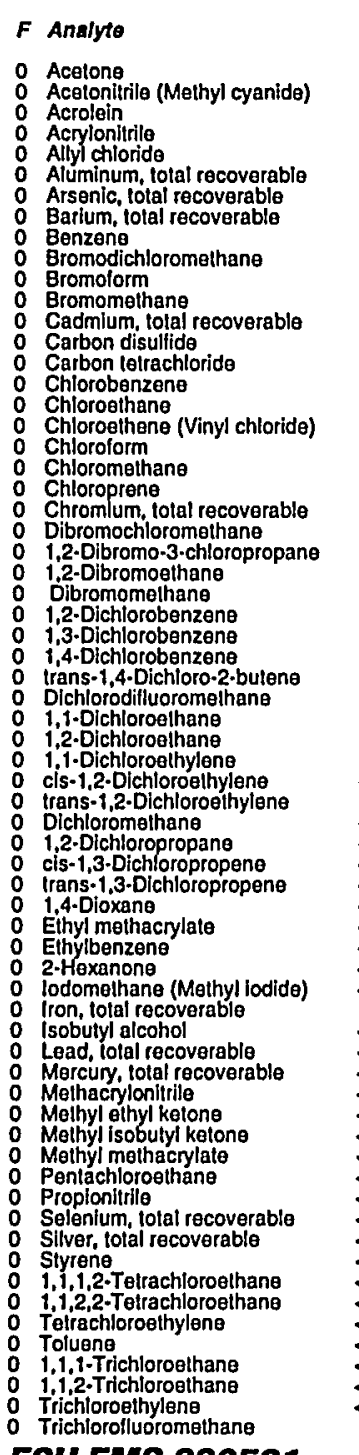

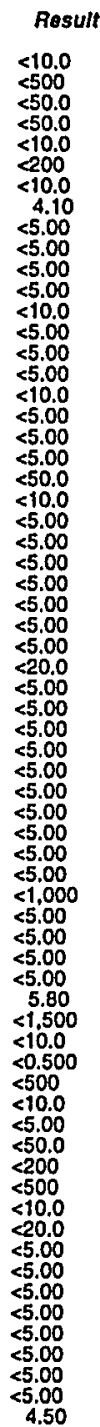

ESH-EMS-990521

Well LFW 41 R collected on 06/01/99 (cont)

F Analyte Result $\quad$ FG $S$ EMS SOL Unit LAb Method

Time: 9:24 Air temperature: $29.6^{\circ} \mathrm{C}$. Tolal alkalinity (as CaCO3): $0 \mathrm{mg} /$

\section{WELL LFW 43B}

MEASUREMENTS CONDUCTED IN THE FIELD

Sample date: 06/01/99 Water elevation: $165.17 \mathrm{ft}(50.34 \mathrm{~m}) \mathrm{ms}$

$\mathrm{Sp}$. conductance: $12 \mu \mathrm{S} / \mathrm{cm}$

Water evacuated irom the well prior to sampling: $114 \mathrm{gal}$

ANALYSES

$F$ Analyte

A Acelone

- Acrolein

o Aly chloride

Arsenic, lotal recoverable
Barlum, lotal recoverable

Bromolorm

O Bromomethan

O Cadmium, olal recoverable

Carbon tetrachiorido

C Chlorobenzene

o Chloroethene (Vinyl chloride)

o Chlorolorm

Chloroprone

Dibromochloromelhane

1,2.D.bibromo-3.chlorop

Dibromomethane

1,3.Dichlorobenzen

o trans-1,4-Dichloro-2.butene

: Dichlorodilluoromelhan

i,.-Dichloroeshane

cis-1.1. Dichloroethylene

trans-1,2-Dichloroethylen

1,2-Dichloropropan

0
0
itrans-1, $1,3 \cdot$ Dichlichloropropene

1.4.0ioxane

: Eihyl melhacry

Elhylbenzene

lodomethane (Methyl iodide)

0 iron, tolal recoverable

- Load, lotal recoverable

- Mercury, total recovoverable

: Mothacrylonilirile

Methyl methacrylate

Proptachloroethane

B-165

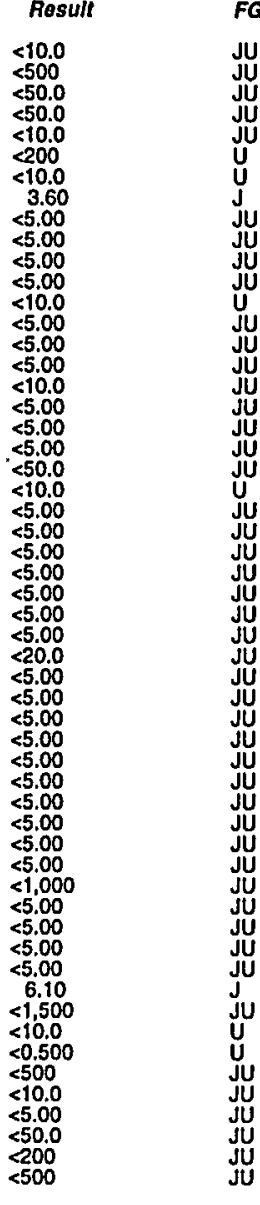

Time: $15: 47$

Air temperature: $20.8^{\circ} \mathrm{C}$ Total alkalinity (as CaCO3): $0 \mathrm{mg} /$

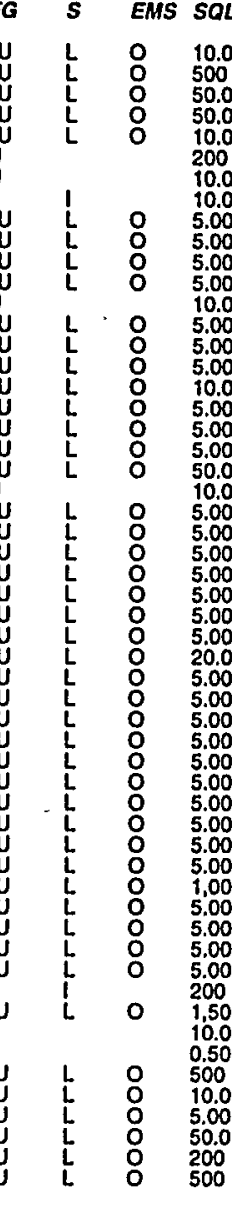

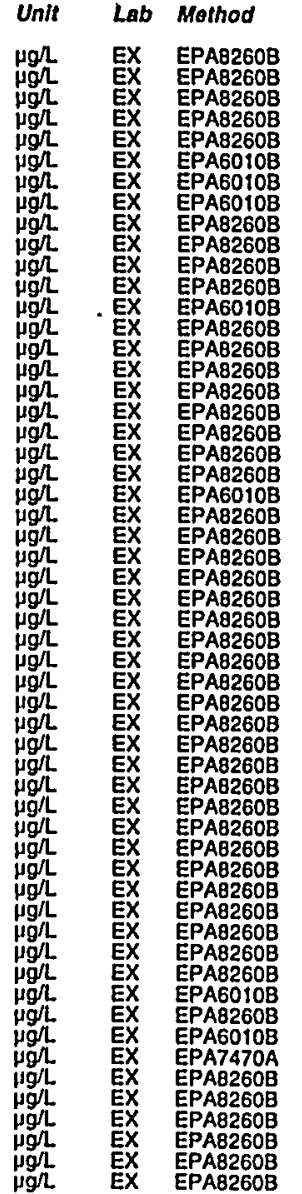

Second Quarter 1999 
Well LFW 438 collected on 06/01/99 (conl.)

$F$ Analyto

Rosult

- Selenium, total recoverable

1,1,1.2-Tetrachloroethane

T $1,1,2,2$-Tetrachloroetha

0 $1,1,1$-Trichloroethane

Trrchlorosthylene

1,2,3-Trichlaropropane

Vinyl acetale

$\begin{array}{ll}0 & \text { Gross alpha } \\ 0 & \text { Trillum }\end{array}$

\section{WELL LFW $43 C$}

MEASUREMENTS CONDUCTED IN THE FIELD

Sample dale:

Depth to waler: 37.42 11 $(11.41 \mathrm{~m})$ below TOC

Water

Sp. conductance: $9 \mu \mathrm{S} / \mathrm{cm}$

Water evacuated from the well prior to sampling: $68 \mathrm{gal}$

ANALYSES

$F$ Analyto

Acelone
0 Acelonitrile (Methyl cyanide)

Acrolein
Acrylonitrile
Allyy chloride

Alluminum, total recoverablo

Arsenic, lotal recoverable
Barium, total recoverable

Benzene
Bromodichloromethane

Bromolorm

Cadmium, total recoverable

Carbon tetrachloride

Chlorobenzene

Chloroethene (Vinyl chtoride)

Chloroform

Chromum total recoverable

1,2-Dibromo-3-chloropropan

1,2-Dibromoethan

1.2.-Dichlorobenzene

1,4-Dichlorobenzene
trans-1,4-Dichloro-2-buten

Dichlorodilluoromethane

1.1-Dichloroethane

cis- 1,2 -Dichloroethylene

trans-1,2-Dichloroethyle

1.2-Dichloropropan

cis-1,3-Dichloropropene
trans-1,3-Dichloropropene

Eithyl methacrylate

Ethylbenzene

lodomethane (Mothytiodidel

ESH-EMS-990521

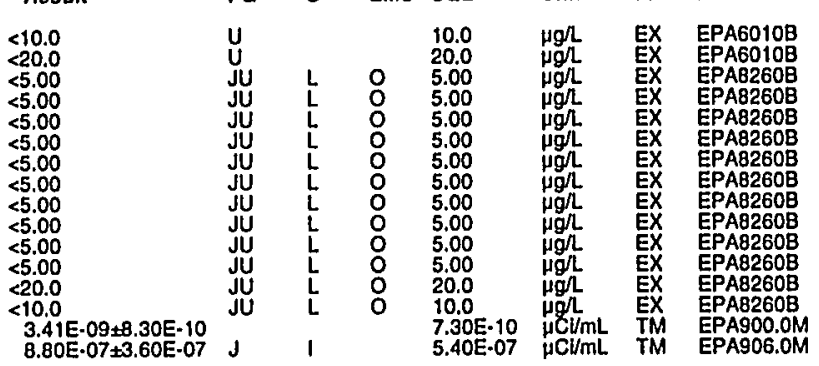

Time: 14:18

mperature: $20.2^{\circ} \mathrm{C}$ Air temperature: $38.9^{\circ} \mathrm{C}$ ) $1 \mathrm{mg}$ Phenolphihalein alkalinity: $0 \mathrm{mg}$

\begin{tabular}{|c|c|c|c|}
\hline$S Q L$ & Init & Lab & Method \\
\hline $\begin{array}{l}10.0 \\
500 \\
50.0 \\
50.0 \\
10.0 \\
100 \\
10.0 \\
5.00 \\
5.00 \\
5.00 \\
5.00 \\
10.0 \\
5.00 \\
5.00 \\
5.00 \\
5.00 \\
5.00 \\
5.00 \\
50.0 \\
10.0 \\
5.00 \\
5.00 \\
5.00 \\
5.00 \\
5.00 \\
5.00 \\
20.0 \\
5.00 \\
5.00 \\
5.00 \\
5.00 \\
5.00 \\
5.00 \\
5.00 \\
5.00 \\
5.00 \\
5.000 \\
5.00 \\
5.00\end{array}$ & 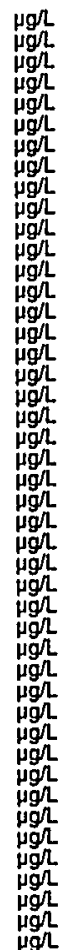 & $\begin{array}{l}\text { EX } \\
\text { EX } \\
\text { EX } \\
\text { EX } \\
\text { EX } \\
\text { EX } \\
\text { EX } \\
\text { EX } \\
\text { EX } \\
\text { EX } \\
\text { EX } \\
\text { EX } \\
\text { EX } \\
\text { EX } \\
\text { EX } \\
\text { EX } \\
\text { EX } \\
\text { EX } \\
\text { EX } \\
\text { EX } \\
\text { EX } \\
\text { EX } \\
\text { EX } \\
\text { EX } \\
\text { EX } \\
\text { EX } \\
\text { EX } \\
\text { EX } \\
\text { EX } \\
\text { EX } \\
\text { EX } \\
\text { EX } \\
\text { EX } \\
\text { EX } \\
\text { EX } \\
\text { EX } \\
E X\end{array}$ & 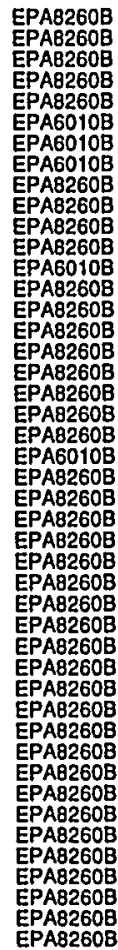 \\
\hline
\end{tabular}

Well LFW 43C collected on 06/01/99 (conl.)

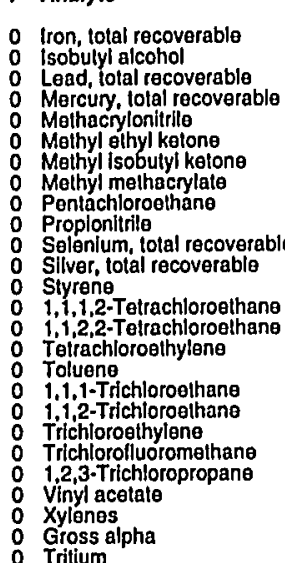

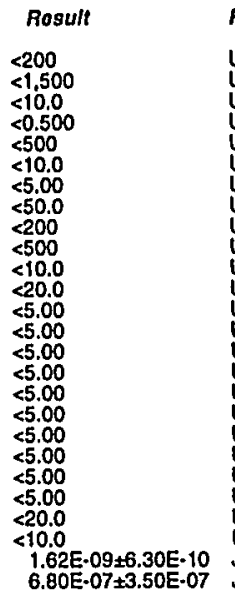

FG

\begin{tabular}{|c|c|c|c|c|}
\hline & SOL & Unit & Lab & Method \\
\hline & $\begin{array}{l}200 \\
1.500 \\
10.0 \\
0.500 \\
500 \\
10.0 \\
5.00 \\
50.0 \\
200 \\
500 \\
10.0 \\
20.0 \\
5.00 \\
5.00 \\
5.00 \\
5.00 \\
5.00 \\
5.00 \\
5.00 \\
5.00 \\
5.00 \\
5.00 \\
20.0 \\
10.0 \\
7.30 E-10 \\
5.40=-07\end{array}$ & 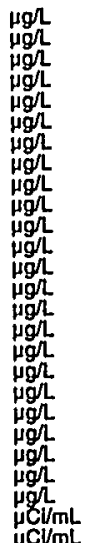 & $\begin{array}{l}\text { EX } \\
\text { EX } \\
\text { EX } \\
\text { EX } \\
\text { EX } \\
\text { EX } \\
\text { EX } \\
\text { EX } \\
\text { EX } \\
\text { EX } \\
\text { EX } \\
\text { EX } \\
\text { EX } \\
\text { EX } \\
\text { EX } \\
\text { EX } \\
\text { EX } \\
\text { EX } \\
\text { EX } \\
\text { EX } \\
\text { EX } \\
\text { EX } \\
\text { EX }\end{array}$ & 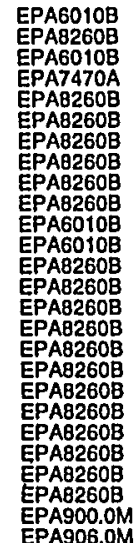 \\
\hline
\end{tabular}

\section{WELL LFW 43D}

MEASUREMENTS CONDUCTED IN THE FIELD

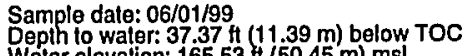

$$
\text { Water } 4.9
$$

Sp. conduclance: $8 \mu \mathrm{S} / \mathrm{cm}$

Water evacuated from the well prior to sampling: 53 gal

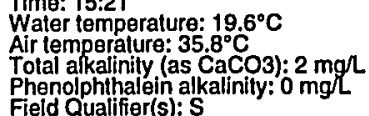

ANALYSES

$F$ Analyto

o Acetone Acelonitrile (Methyl cyanide)

Acrolein

Ally chloride
Aluminum, totat recoverable

Arsenic, total recoverable

Barium, total recoverab

Bromodichloro
Bromolorm

Cadmilum, total recoverable

Carbon disulfide

Chlorobenzens

Chloroethene (Vinyl chloride)

Chioromethan

Chloroprene
Chromium, total recoverable

Dibromochloromethane

1,2-Dibromo-3-chlo

Dibromomethane

1,2-Dichlorobenzen

1,4-Dichlorobenzene
trans: $1,4-$ Dichloro-2-butene

Dichlorodilluoromethane

1.1-Dichloroethane

i,1-Dichloroethane
cis-1,2-Dichloroene

$-166$

\begin{tabular}{|c|c|c|c|c|c|c|c|}
\hline Result & $F G$ & $s$ & EMS & SQL & Unit & Lab & Mothod \\
\hline $\begin{array}{l}<10.0 \\
<500 \\
<50.0 \\
<50.0 \\
<10.0 \\
<200 \\
<3.60 \\
7.50 \\
<5.00 \\
<5.00 \\
<5.00 \\
<5.00 \\
<10.0 \\
<5.00 \\
<5.00 \\
55.00 \\
<10.0 \\
55.00 \\
5.00 \\
55.00 \\
50.0 \\
510.0 \\
5.00 \\
55.00 \\
5.00 \\
55.00 \\
5.00 \\
<5.00 \\
5.00 \\
<20.0 \\
55.00 \\
5.00 \\
55.00 \\
5.00 \\
<5.00\end{array}$ & 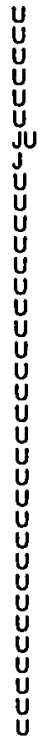 & 1 & 4 & $\begin{array}{l}10.0 \\
500 \\
50.0 \\
50.0 \\
10.0 \\
200 \\
10.0 \\
10.0 \\
5.00 \\
5.00 \\
5.00 \\
5.00 \\
10.0 \\
5.00 \\
5.00 \\
5.00 \\
10.0 \\
5.00 \\
5.00 \\
5.00 \\
50.0 \\
10.0 \\
5.00 \\
5.00 \\
5.00 \\
5.00 \\
5.00 \\
5.00 \\
5.00 \\
20.0 \\
5.00 \\
5.00 \\
5.00 \\
5.00 \\
5.00\end{array}$ & 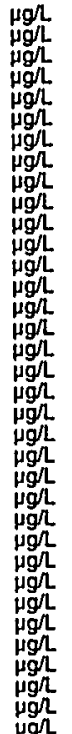 & $\begin{array}{l}\text { EX } \\
\text { EX } \\
\text { EX } \\
\text { EX } \\
\text { EX } \\
\text { EX } \\
\text { EX } \\
\text { EX } \\
\text { EX } \\
\text { EX } \\
\text { EX } \\
\text { EX } \\
\text { EX } \\
\text { EX } \\
\text { EX } \\
\text { EX } \\
\text { EX } \\
\text { EX } \\
\text { EX } \\
\text { EX } \\
\text { EX } \\
\text { EX } \\
\text { EX } \\
\text { EX } \\
\text { EX } \\
\text { EX } \\
\text { EX } \\
\text { EX } \\
\text { EX } \\
\text { EX } \\
\text { EX } \\
\text { EX }\end{array}$ & 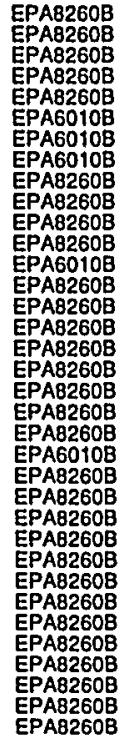 \\
\hline
\end{tabular}


Well LFW 43D collected on 06/01/99 (cont.)

\begin{tabular}{|c|c|c|c|c|c|c|}
\hline$=$ Analyte & Result & $F G^{\circ}$ & EMS SOL & Unit & Lab & Mathod \\
\hline 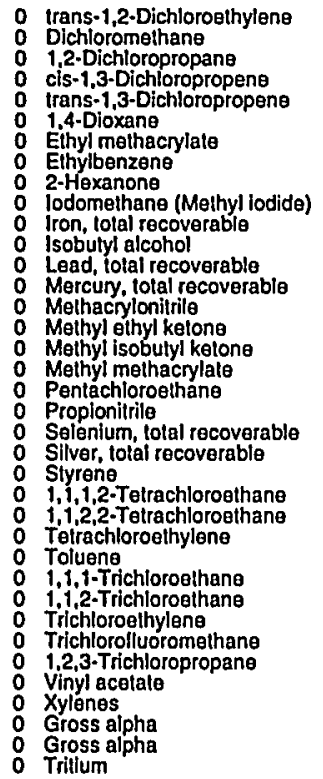 & 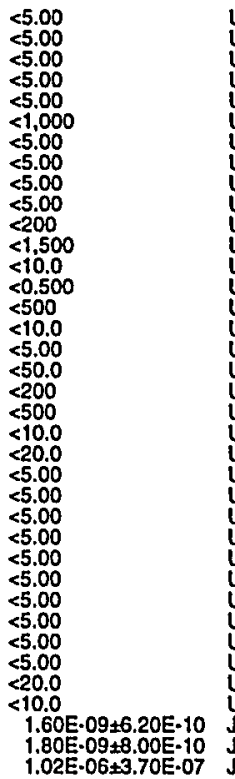 & 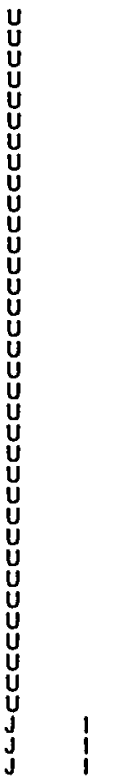 & $\begin{array}{l}5.00 \\
5.00 \\
5.00 \\
5.00 \\
5.00 \\
1.000 \\
5.00 \\
5.00 \\
5.00 \\
5.00 \\
200 \\
1.500 \\
10.0 \\
0.500 \\
500 \\
10.0 \\
5.00 \\
50.0 \\
200 \\
500 \\
10.0 \\
20.0 \\
5.00 \\
5.00 \\
5.00 \\
5.00 \\
5.00 \\
5.00 \\
5.00 \\
5.00 \\
5.00 \\
5.00 \\
20.0 \\
10.0 \\
7.10 E-10 \\
9.80-10 \\
5.30 E-07\end{array}$ & 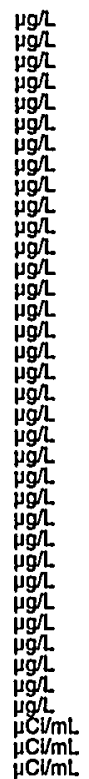 & $\begin{array}{l}\text { EX } \\
\text { EX } \\
\text { EX } \\
\text { EX } \\
\text { EX } \\
\text { EX } \\
\text { EX } \\
\text { EX } \\
\text { EX } \\
\text { EX } \\
\text { EX } \\
\text { EX } \\
\text { EX } \\
\text { EX } \\
\text { EX } \\
\text { EX } \\
\text { EX } \\
\text { EX } \\
\text { EX } \\
\text { EX } \\
\text { EX } \\
\text { EX } \\
\text { EX } \\
\text { EX } \\
\text { EX } \\
\text { EX } \\
\text { EX } \\
\text { EX } \\
\text { EX } \\
\text { TM } \\
\text { TM }\end{array}$ & 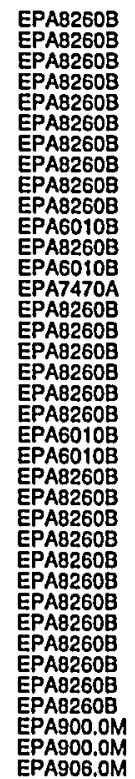 \\
\hline
\end{tabular}

\section{WELLL LFW 45D}

MEASUREMENTS CONDUCTED IN THE FIELD

Sample date: 06/02/99

Depth to water: $14.78 \mathrm{H}(4.5 \mathrm{~m})$ below TOC
Waler elevation: $151.52 \mathrm{Ht}(46.18 \mathrm{~m}) \mathrm{ms}$

pH: 4.7

Sp. conductance: $39 \mu \mathrm{S} / \mathrm{cm}$

Waler evacualed from the well prior to sampling: 53 gal

ANALYSES

$F$ Analyte

0 Acetone

Acrylonititite

Ally chloride

Arsentc, total recoverable
Barium, total recoverable

Bromodichloromethane

Bromolorm

Cadmium, total recoverable

Carbon telrachlorido

Chlorobenzene

Chloroethene (Vinyl chloride)

Chloroform

Chromlum, totat recoverable

1,2-Dibromo-3-chloropropan

ESH-EMS-990521

Time: 8:47 Total alkalinity (as Cacos): $0 \mathrm{mg} / \mathrm{L}$
Phenolphthalein alkalinity: $0 \mathrm{mg} /$.
Well LFW 45D collected on 06/02/99 (cont.)

$F$ Analyte Result

$\begin{array}{ll}0 & 1,2 \cdot D i b r o m o e t h a n e \\ 0 & \text { Dibromomethane }\end{array}$

$\begin{array}{ll}0 & \text { 1,2 Dimomethane } \\ 0 & 1,3-\text { Dichlorobenzene } \\ 0 & 1,4-\text { Dichlorobenzene } \\ 0 & \end{array}$

Irans-1,4-Dlchloro-2-butene
Olchlorodifluoromethane

1.1.Dichloroelhane

i.1-Dichloroothylene

cis-1,2-Dichloroethylene
trans-1,2-Dichloroethylene

1,2-Dichloropropan

o cis-1,3-Dichloropropene

Eihyl methacrylate

Ethyibenzene

lodomethane (Methyl iodide)

isobutyl alcohol

1 Mercury, total recoverable

Methacrylonitrile

Methy

Pentachloroethane

Propioniltile
Solenilum, total recoverable

Styrene Tetrachloroethane

Telrachloroethylene

Yoluene

Trichlorothylene

2 Trichlorofluoromethane Gylenes

0 Gross alpha
0 Tritum

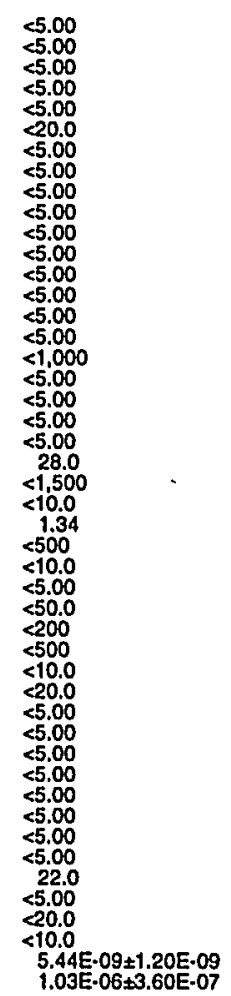

FG

EMS SOL

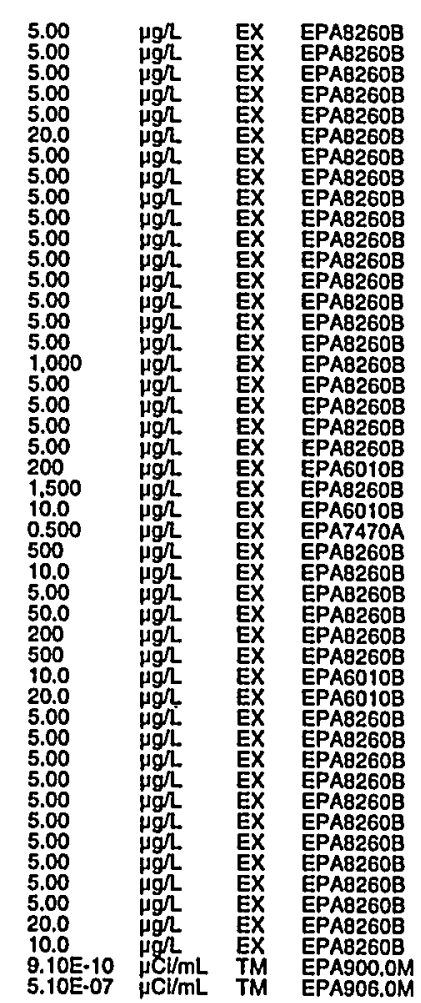

WELL LFW 47D

MEASUREMENTS CONDUCTED IN THE FIELD

Sample date: 06/02/99
Depph lo water: $13.17 \mathrm{H}(4.01 \mathrm{~m})$ below TOC
Water elevalion: $148.53 \mathrm{ti}(45.27 \mathrm{~m}) \mathrm{msl}$

p. conductance: $61 \mu \mathrm{S} / \mathrm{cm}$

Wutber evacuated from the well prior to sampling: 41 gal

ANALYSES

$F$ Analyte

Acolone
Acelonitrile (Methyl cyanide)

Acroleln

Aluminum, total recoverable

Arsonic, lotal recoverable
Barium, total rocoverable

Benzene
Bromodichloromethane

Bromoform

Cadmlum, tolal recoverable
Carbon disulfide

B-167

Rosult
$<1.0$
$<5.0$
5500
55.0
550.0
$<1.0$
$<200$
$<10.0$
27.0
55.00
55.00
55.00
5.00
$<10.0$
55.00

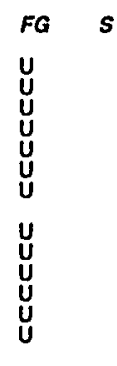

Time: 10:08

Air tempermperature: $21.1^{\circ} \mathrm{C}$

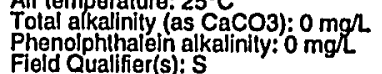

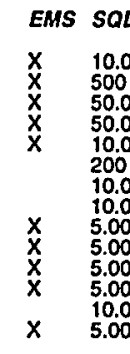

Unit Lab Mothod

\begin{tabular}{ll}
10.0 \\
$\times$ & 500 \\
$\times$ & 50.0 \\
$\times$ & 50.0 \\
10.0 \\
& 200 \\
& 10.0 \\
$\times$ & 10.0 \\
$\times$ & 5.00 \\
$\times$ & 5.00 \\
$\times$ & 5.00 \\
$\times$ & 10.0 \\
\hline
\end{tabular}

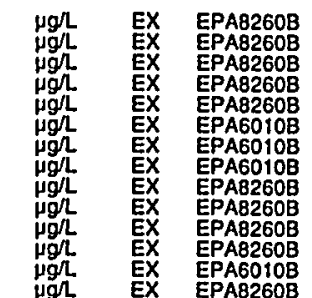

Second Quarter 1999 


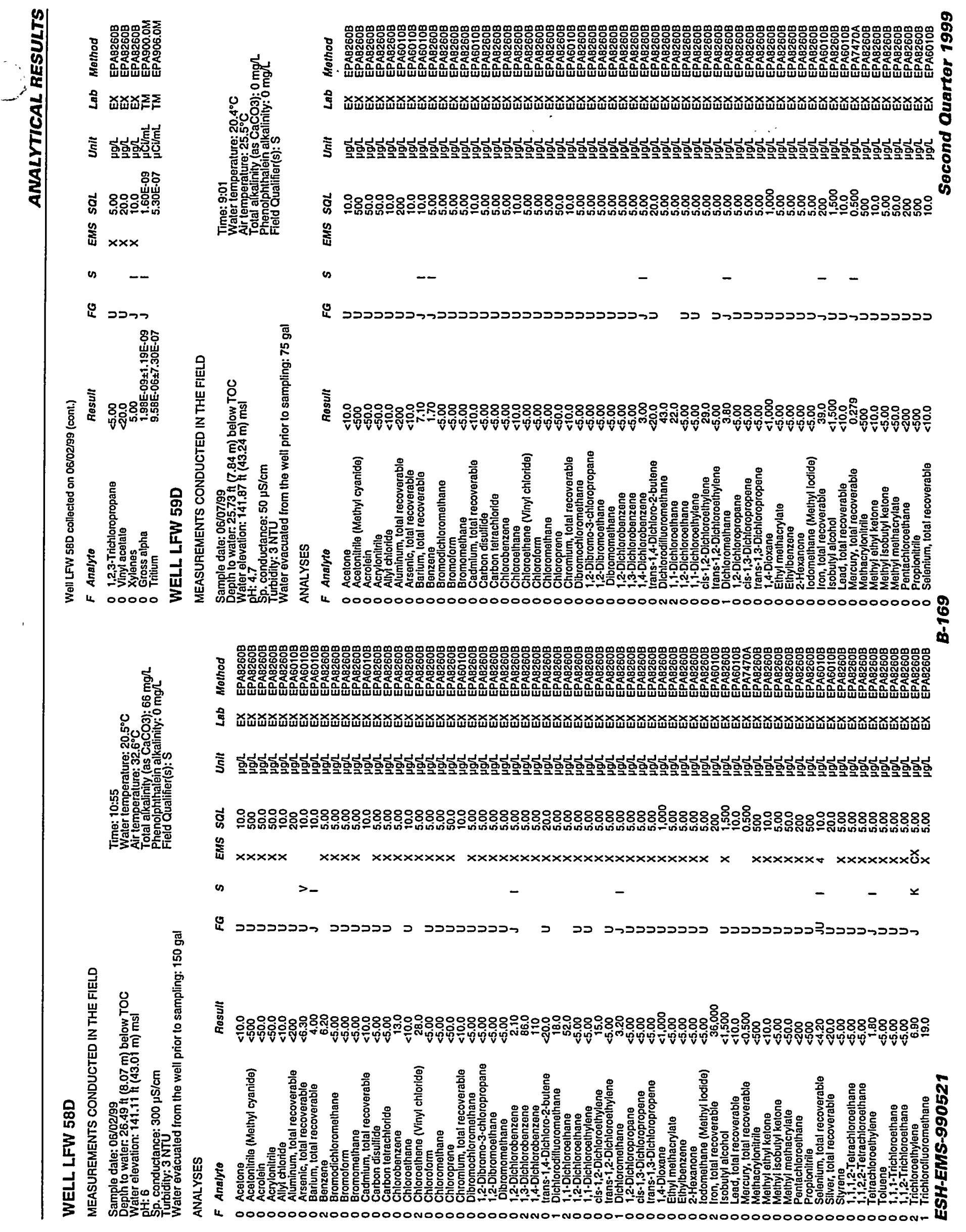


Well LFW 59D collected on 06/07/99 (cont.)

$F$ Analyto Rosult

O Silver, total recoverable $\begin{array}{ll}0 & \text { Styrene } \\ 0 & 1,1,1,2-T e t r a c h l o r o s t h a n e \\ 0 & 1,1,2,2 \text {-Telrachloroethane }\end{array}$ Telirachloroathylene Toluene I.1, 2 .Trichloroethan
Trichioroethylene Trichlorofluoromethane vinyl acelate Gross alph

\section{WELLL LFW $60 C$}

MEASUREMENTS CONDUCTED IN THE FIELD

Sample date: 06/01/99

Water elevation: $137.23 \mathrm{Ht}(41.83 \mathrm{~m}) \mathrm{ms}$

$\mathrm{pH}$ : 6.4 conductance: $420 \mu \mathrm{S} / \mathrm{cm}$

Water evacuated from the well prior to sampling: $27 \mathrm{gal}$

ANALYSES

\begin{tabular}{|c|c|}
\hline Analyto & sul \\
\hline 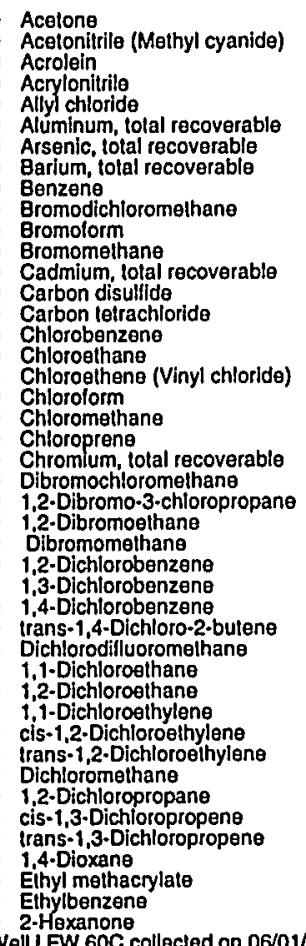 & 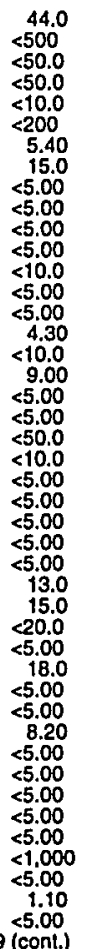 \\
\hline
\end{tabular}

Well LFW 60C collecled on 06/0
ESH-EMS-990521
F Analyio

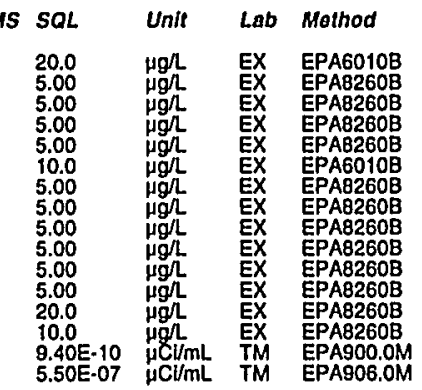

Water temperaturs: $21.9^{\circ} \mathrm{C}$ Tolal alkalinity. (as CaCo3): $170 \mathrm{mg} /$ Phenolphthalein alkalinity: $0 \mathrm{mgl}$ '

\begin{tabular}{|c|}
\hline$S Q L$ \\
\hline $\begin{array}{l}10.0 \\
500 \\
50.0 \\
50.0 \\
10.0 \\
200 \\
10.0 \\
10.0 \\
5.00 \\
5.00 \\
5.00 \\
5.00 \\
10.0 \\
5.00 \\
5.00 \\
10.0 \\
5.00 \\
5.00 \\
5.00 \\
50.0 \\
5.00 \\
5.00 \\
5.00 \\
5.00 \\
5.00 \\
5.00 \\
5.00 \\
20.0 \\
5.00 \\
5.00 \\
5.00 \\
5.00 \\
5.00 \\
5.00 \\
5.00 \\
5.00 \\
5.00 \\
5.000 \\
5.00 \\
5.00\end{array}$ \\
\hline
\end{tabular}

ANALYSES

EX EPAB2608

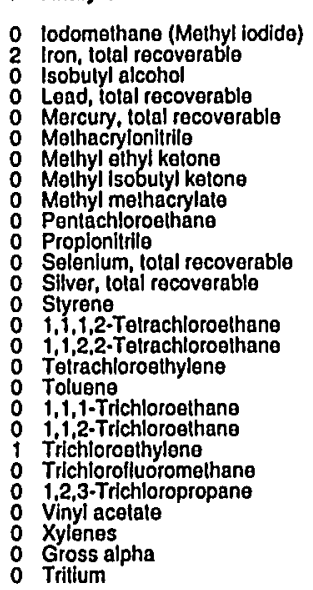

Rosult

$<5.00$

81,000
$<1,500$
$<10.0$

$<0.500$

$<500$
$<10.0$
5.00
$<50.0$

$<500$
$<10.0$

$<$

$<5.00$
$<5.00$
$<5.00$
2.00
$<5.00$

$<5.00$
2.00
$<5.00$
$<5.00$
5.20

3.20
55.00
5.00
520.0
4.10
1.80
6.27

4.10
$1.80 \mathrm{E}-09 \pm 1.18 \mathrm{E} \cdot 09$
$6.27 \mathrm{E}-09.020 \mathrm{~J}$

WELLL LFW 60D

MEASUREMENTS CONDUCTED IN THE FIELD

Sample date: $06 / 07 / 99$

pp: 4.8 conductance: $36 \mu \mathrm{S} / \mathrm{cm}$
Water elevation: $137.56 \mathrm{tt}(41.93 \mathrm{~m}) \mathrm{ms}$ l

Water evacuated from the well prior to sampling: 1 gal The well wenl dry during purging.

F Analyte

: Acclone

0 Acroleln

o Acrylonitrile

- Aluminum, total recoverable

: Arsenic, tolal recoverable

o Benzene

O Bromzone

Bromoform

o Cadmium, total recoverable

Carbon disutfide

: Carbon tetrachloride

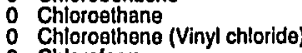

C Chloroform

o Chloroprena

o Chromium, total recoverable

: Dibromochloromethane

o 1,2 -Dibromo-3-chlo

1,2-0ichlorobenzen

1.3.Dichlorobenzene

Irans-1,4-Dichloro-2-butene

i 1,1-Dichloroethane

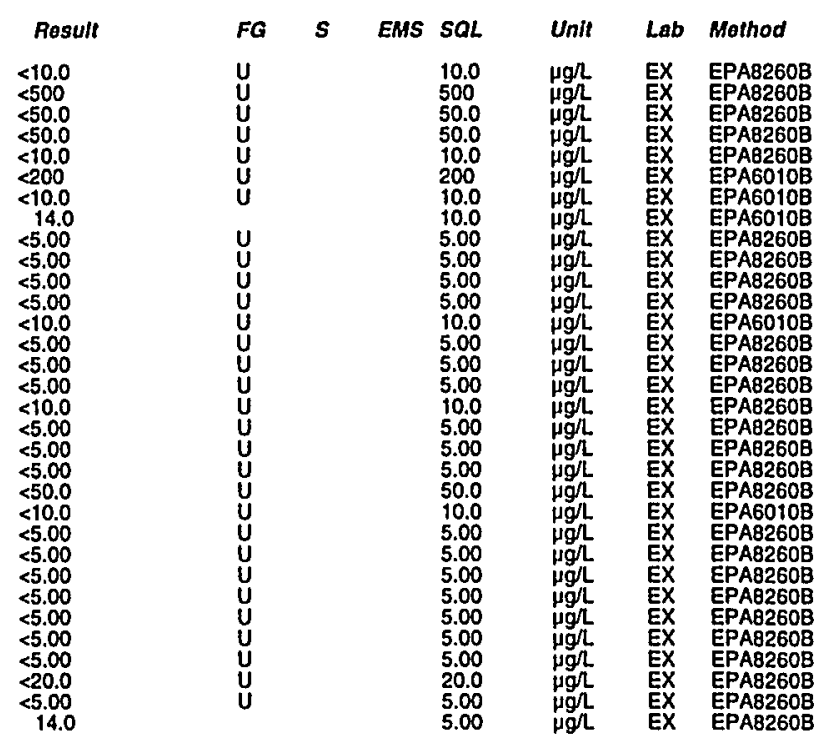

Second Quarter 1999
Time: 12:28

Total alkalinity (as CaCo3): $0 \mathrm{mg} /$

Phenolphthalein alkalinity: $0 \mathrm{mg}$ L

B-170

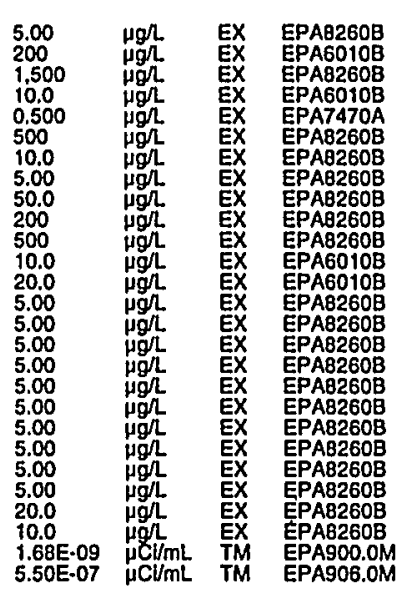


Well LFW 60D collected on 06/07/99 (cont.)

\begin{tabular}{|c|c|}
\hline 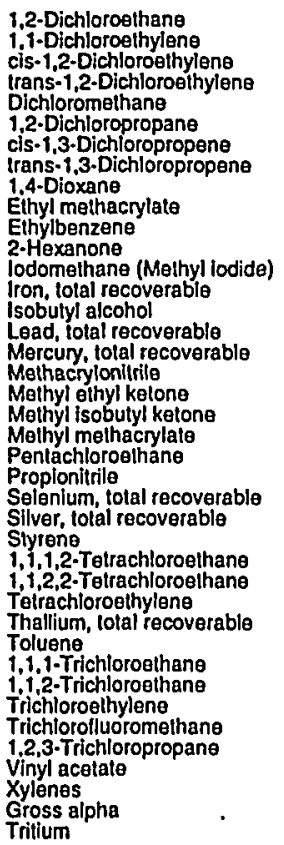 & $\begin{array}{l}<5.00 \\
<5.00 \\
6.50 \\
<5.00 \\
5500 \\
55.00 \\
5.00 \\
55.00 \\
<1.000 \\
<5.00 \\
<5.00 \\
5.00 \\
<5.00 \\
160 \\
<1.500 \\
4.00 \\
3.24 \\
<500 \\
<10.0 \\
5.00 \\
550.0 \\
<00 \\
<500 \\
<10.0 \\
<20.0\end{array}$ \\
\hline
\end{tabular}

o Gross alp

WELL LFW 61D

MEASUREMENTS CONDUCTED IN THE FIELD

Sample date: 06/07/99
Depth to water: $26.03 \mathrm{ft}(7.93 \mathrm{~m})$ below TOC
Water elevation: $142.27(4 \mathrm{t}(43.36 \mathrm{~m}) \mathrm{msl}$ Water elevat

Sp. conductance: $290 \mu \mathrm{S} / \mathrm{cm}$

Turbidity: 2 NTU
Water evacuated from the well prior to sampling: 85 gal

ANALYSES

$F$ Analyto

0 Acetone

Acctonitrile (Methyl cyanide)
Acelonitrilo (Methyl cyanide)

Acrolei

$\begin{array}{ll} & \\ 0 & \text { Accolen } \\ 0 & \text { Acryonitrill } \\ 0 & \text { Acryonitili } \\ 0 & \text { Ally }\end{array}$

Ally chloride

Aluminum, total recoverable

Arsenic, tótal recoverable

Arsenlc, tolal recoverable

Barlum, total recoverable

Benzena

Bromodichloromethane

ESH-EMS-99052

Result
150
176
$<500$
$<20.0$
$<50.0$
$<20.0$
$<50.0$
$<5.00$
$<10.0$
$<10.0$
$<200$
272
11.0
12.6
5.00
$<3.90$
2.40
1.96
$<5.00$
55.00
$<5.00$

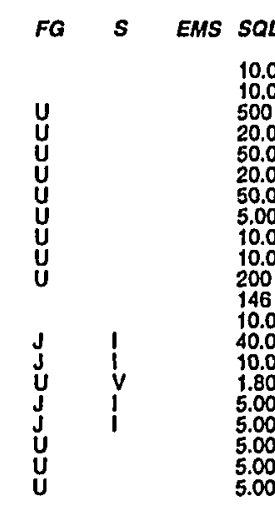

Well LFW 61D collected on 06/07/99 (cont.)

$F$ Analyte

OD Bromolorm

Cadmium total recoverable

Carbon disulfide

Carbon telrachloride

Chlorobenzene

Chloroethane

Chorethene (Vinyl chlorlde)

Chloroform

Chioromethane

Chioroprene

Chromlum, total recoverable

Chromium, tolal recoverablo

Dibromochloromethane

1.2-Dibromo-3-chloropropan

1.2-Dibromo-3-chloropropan

1,2 -Dibromosthane

Dibromomethane

1,2-Dichlorobenzen

1.4-Dlchlorobenzene

1.4-DIchlorobenzene
frans-1.4-Dichloro-2-butene

Dichlorodifluoromethane

Dichlorodifluoromethan
$1,1-$ Oichloroethane

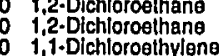

1, 1-Dichloroethylene

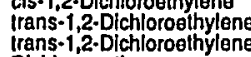

rrans-1,2.Dichloro
Dichloromethane

Dichlorommothane

i, -Dichloropropane

cis-1,3.Dichlorpopropene

trans-1,3.Dichloropropene

Eihyl melhacrylato

Elhylbanzene

2.Hexanone

lodomethane (Methyl lodide)

Iron, tolal recoverable

isobutyl alcohol

Lead, total recovoverable

Mercury, fotal recoverablo

Methacrylonitrile

O Methacrylonitrila

Methyl ethyl kelone

o Methyl e!hyl kelone

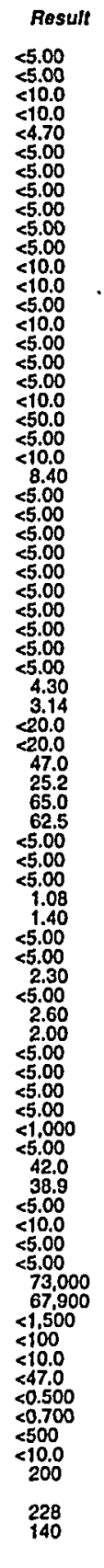

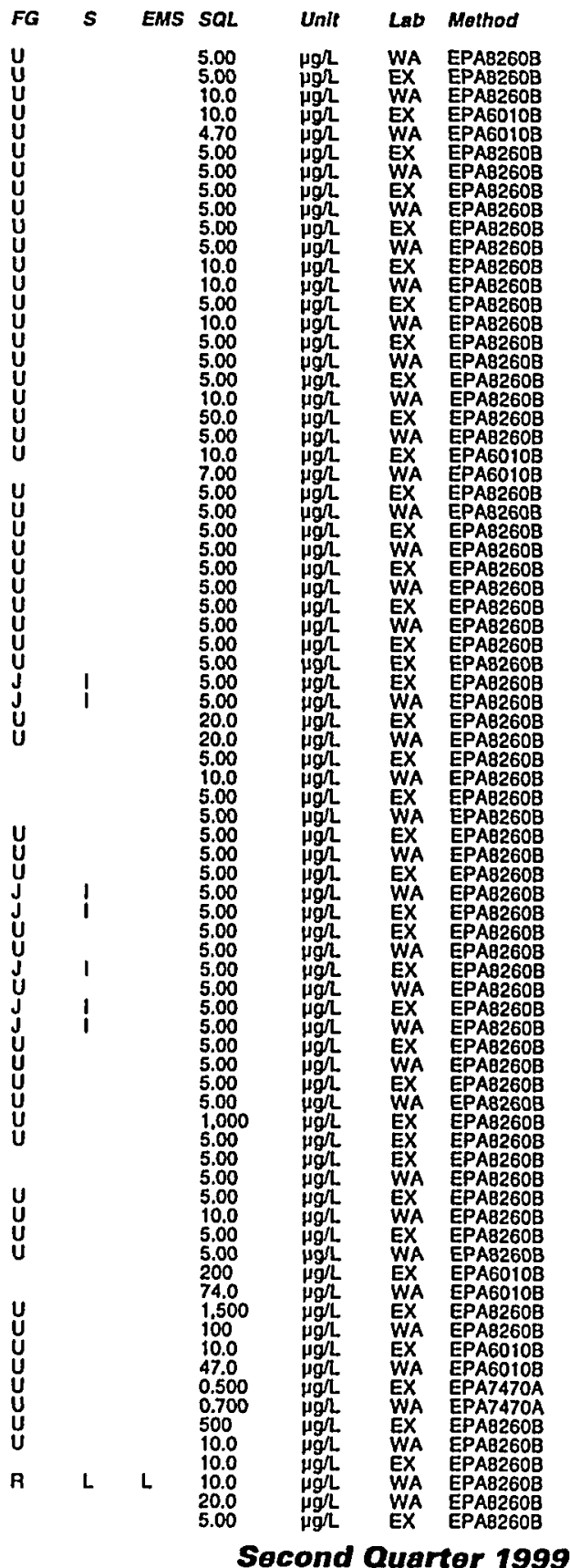


Well LFW 610 collected on 06/07/99 (cont.)

$F$ Analyte

o Mathyl isobutyl ketone

Pentachioroethan

Proplonitrile

Solenlum, tolal recoverable

Silver, tolal recoverable

0 Styrene

o Styrene

o 1,1,2-2-Terfachloroethane

i.i,2,2-Tetrachloroethan

Telrachloroelhylene

Thallium, total recoverable

Toluene

$1,1,1 \cdot$ Trichloroethane

1,1,1-Trichloroethane

Trichloroethylene

Trichlorofluoromethane

1,2,3.Trichloropropane

$1,2,3 \cdot$ Trichioropo

0 Vinyl acelale

0 Gross alpha

Tritium

\section{WELL LFW 61D Replicate}

MEASUREMENTS CONDUCTED IN THE FIELD

Sample date: $06 / 07 / 99$
Depth to water: $26.03 \mathrm{ft}(7.93 \mathrm{~m})$ below roc
Water elevation: $142.27 \mathrm{ft}(43.36 \mathrm{~m}) \mathrm{ms}$

$\mathrm{H} \mathrm{H}: 6.2$ conductance: $290 \mu \mathrm{S} / \mathrm{cm}$

Waler evacuated from the well prior to sampling: $85 \mathrm{gal}$

ANALYSES

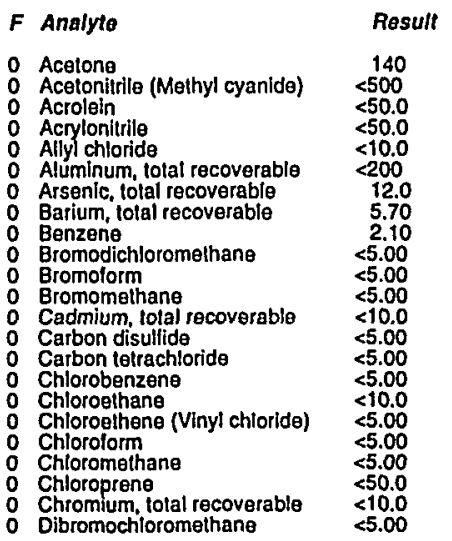

ESH-EMS-990521

Well LFW 61D collected on 06/07/99 (conl.)

F Analyte

o 1.2-Dibromo-3.chloropropent

Rosu

\begin{tabular}{|c|c|c|c|}
\hline & 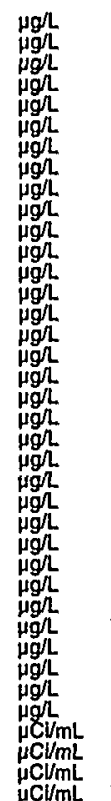 & 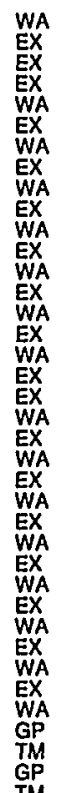 & 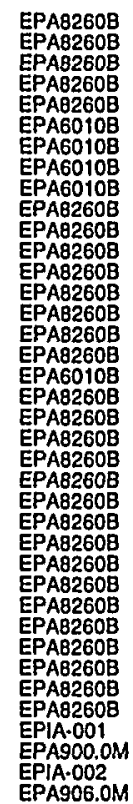 \\
\hline
\end{tabular}

: 1 1.2.:-Dibromo-3.chloribromoethan

1,2-Dichlorobenzene

o 1,4-Dichlorobanzen

trans-1,4-Dichloro-2.butene

2 1.1-Oichloroothane

1.1-Dichloroethylene

0
0
0
trans-1,2-Dlchloroethylene

o Dichloromethane

o cis-1,3-Dichloropropen

trans-1,3-Dichloropropene

Elhyl methacrylate

2-Hylbenzene

lodomethane (Melnyl lodide)

Iron, tolal recoverabilo

Mead, tolal recoverable

Methacrylonititile

Methyl isobutyl ketone

o Methyl mothacrylate

o Propionitrile Solenlum, lotal recoverable

Silver, total recoverable

$1,1,1,2$-Tolrachloroethane

1,1,2,2-Tetrach

Thallium, lotal recoverable

1,1,1-Trichloroethane

1,1,2-Trichloroeth

Trichlorofluoromethane
$1,2,3$-Trichloropropane

Vinyl acelato

Gross alpha
0 Triflum

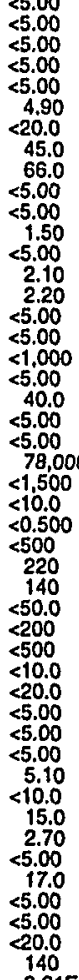

emperature: $20.9^{\circ}$

Total alkalinity (as CaCO3): $108 \mathrm{mg} /$

Fhenolphthalein all

\section{WELL LFW 62D}

MEASUREMENTS CONDUCTED IN THE FIELD

Sample date: $06 / 07 / 99$
Depth to water: $22.76 \mathrm{ft}(6.94 \mathrm{~m})$ below TOC
Water elevation: $142.04 \mathrm{ft}(43.29 \mathrm{~m}) \mathrm{msl}$

p. conductance: $190 \mu \mathrm{S} / \mathrm{cm}$

Water evacuated from the well prior to sampling: $5 \mathrm{gal}$

The well went dry during purging.

ANALYSES

$F$ Analyte

: Acelone

0 Acrolein

Achlonllio

minum, total recoverable

Arsenic, lotal recoverable

2
0
0

-172

Result
$<10.0$
$<500$
$<50.0$
$<50.0$
$<10.0$
110
$<10.0$
6.10
16.0
$<5.00$
$<5.00$

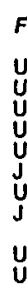

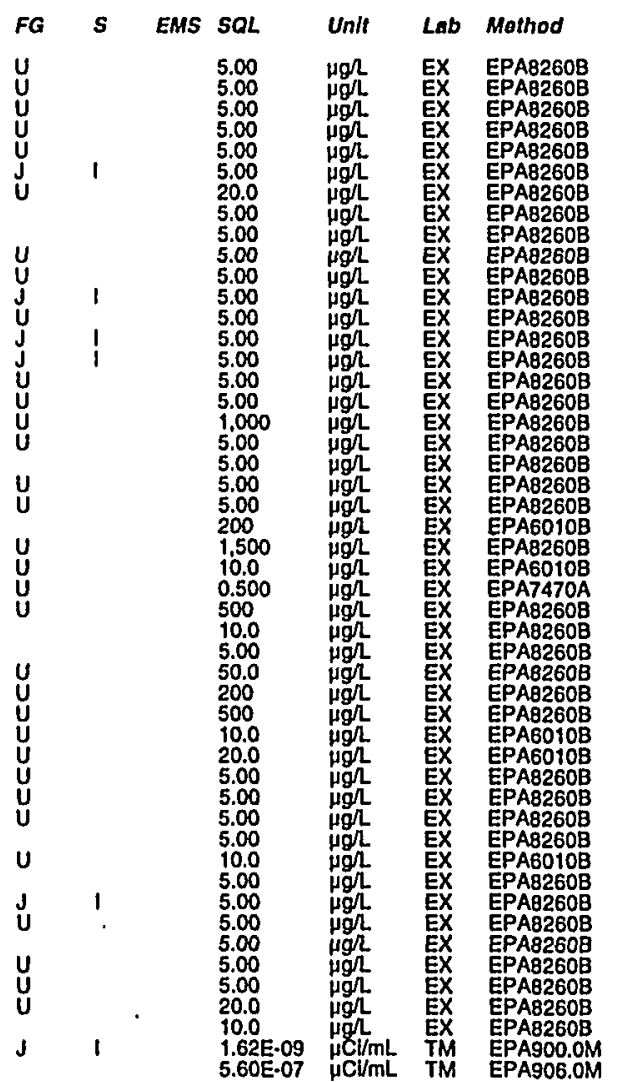

Time: 12:10

Total alkalinity (as CaCO3): $20 \mathrm{mg} \Omega$ henolphthalein alkalinity: $0 \mathrm{mg} /$

Field Qualifier(s): $S X$

10.0
500
50.0
50.0
10.0
200
10.0
10.0
5.00
5.00
5.00

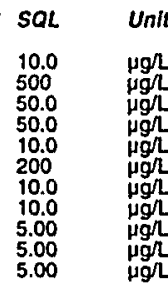

Unit
$\mu g h$
$\mu g h$
$\mu g h$
$\mu g h$
$\mu g h$
$\mu g h$
$\mu g h$
$\mu g h$
$\mu g h$
$\mu g h$

Lab Method

Second Quartor 1999 
Well LFW G2D collected on 06/07/99 (cont.)

F Analyte

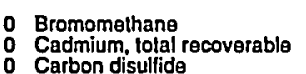

Carbon tetrachlorid

Chlorobenzene

2 Chloroethene (Vinyl chloride)

Chioromelhan

Chromium, total recoverable

1.2-Dibromo-3.chloropropan

Dibromomethane

o 1,2-Dichlorobenzene

trans-1,4-Dichloro-2-buten

Dichorodilluoromelhane

1,1-Dichloroethane

1,1-Dichloroethylene
cis-1,2-Dichloroethylene

Dichloromethane

cis- $1,3 \cdot$-Dichloropropene

Irans-1,3-Dichloropropene

Ethyl methacrylate

2.Hexanone

lodomethane (Methyl lodide)

ron, total recoverable
Isobutyl alcohol

Lead, tolal recoverable

Methacrylonitrile

Methyl Isobutyl ketone

Pentachloroethane

SSlenium total recoverable

1,1,1,2-Telrachloroethane
$1,1,2,2$-Tetrachloroethane

Thallium, total recoverable

1,1,1-Trichloroothane

Trichioroelthylens

Trichlorofluoromethan

Xylenes

1 Gross alph

\section{WELL LFW 63B}

MEASUREMENTS CONDUCTED IN THE FIELD

Sample date: 06/01/99

Deph to water: 28.42 ff $(8.66 \mathrm{~m}$ ) bolow TOC

$\mathrm{pH}: 4$

p. conductance: $58 \mu \mathrm{S} / \mathrm{cm}$

Water evacuated from the well prior to sampling: $39 \mathrm{gal}$

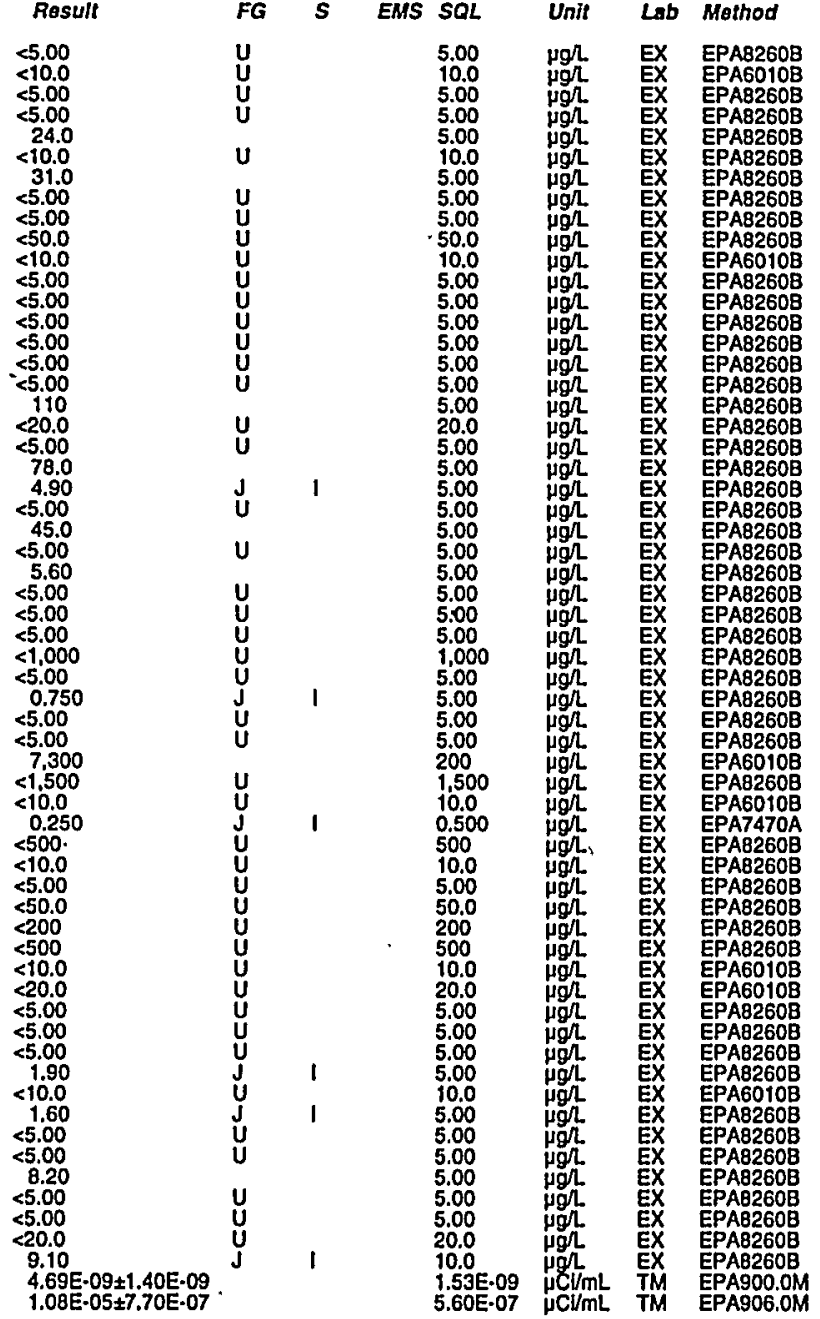

Time: 11:32 Total alkalinity (as CaCO3): $0 \mathrm{mgl}$ Field Qualitier(s): $V$
Well LFW 638 collected on 05/01/99 (cont.)

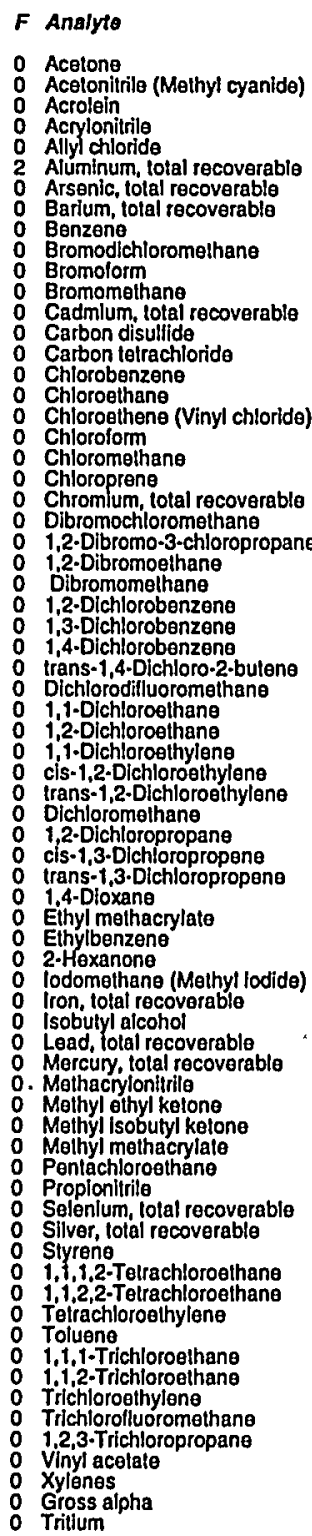

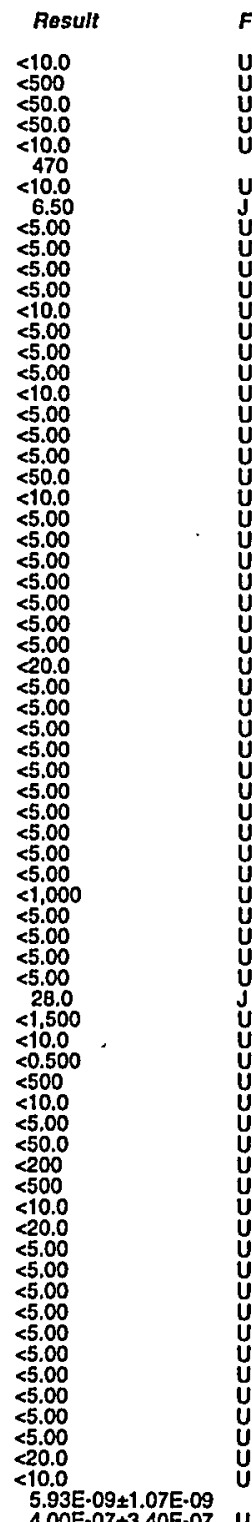

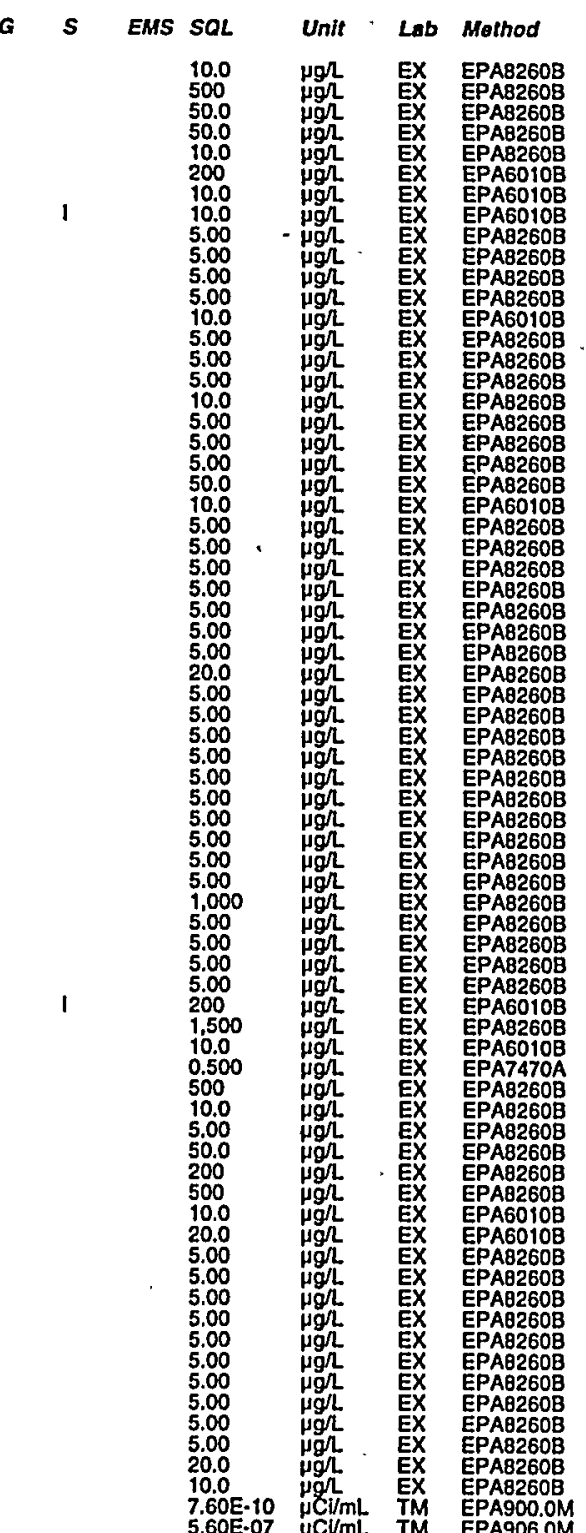

Second Quarter 1999 


\section{WELL LFW 63C}

MEASUREMENTS CONDUCTED IN THE FIELD

Sample date: 06/01/99 Waler e

pH: 4.2 conductance: $30 \mu \mathrm{S} / \mathrm{cm}$

Water evacuated from the well prior to sampling: $\mathbf{4 0} \mathbf{g a l}$ ANALYSES

\begin{tabular}{|c|c|}
\hline Analyte & Rosult \\
\hline 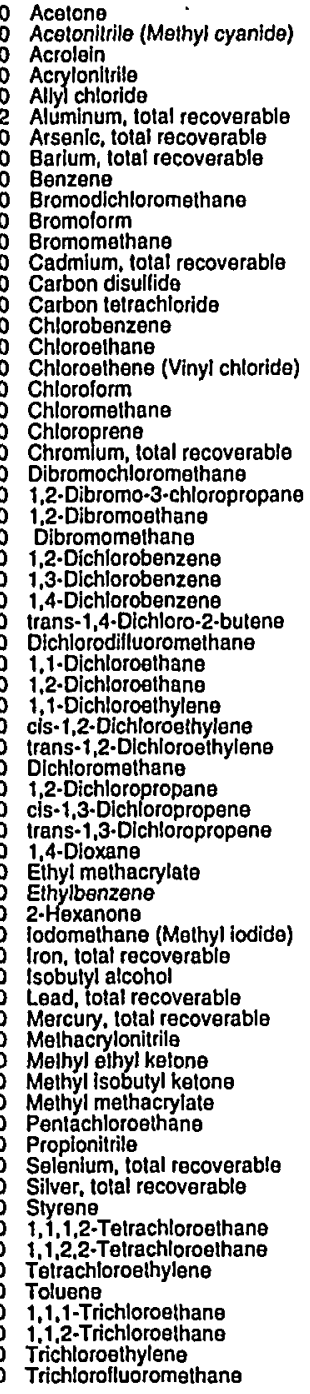 & 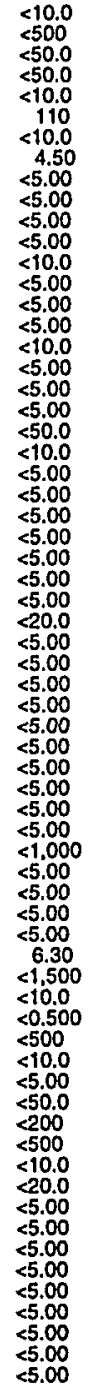 \\
\hline
\end{tabular}

ESH-EMS-990529
Well LFW 63C collected on 06/01/99 (conl.)

Time: 10:31 Waler temperature: $20^{\circ} \mathrm{C}$ Air temperature: $27.5^{\circ} \mathrm{C}$
Total afkalinity (as CaCo3): $0 \mathrm{mg} \Omega$ Phenolphthalein alkalinity: $0 \mathrm{mgl}$

1,2,3-Trlchloropropane Xinyl acolate

Gross alph
Tritium

Rosult

$<5.00$
$<20.0$

84E-09+8.80E-10 WELL LFW 63D

MEASUREMENTS CONDUCTED IN THE FIELD

Sample date: 06/07/99

Depth to water: $28.67 \mathrm{Ht}(8.74 \mathrm{~m})$ below TOC
Water elevation: $139.63 \mathrm{ft}(42.56 \mathrm{~m}) \mathrm{msl}$

H: 4.9

p. conductance: $44 \mu \mathrm{S} / \mathrm{cm}$

Water evacuated from the well prior to sampling: $12 \mathrm{gal}$ ANALYSES

\section{$F$ Analyte}

Acetone

o Acroleín

Ally chloride

Arstictiol recoverable

Garium, total recovarablo

Benzene
Bromodichloromethane

Bromoform

- Cadmium, total recoverable

Carbon disulfide

C Carbon tetrachlo

- Chloroothane

Chloroethene

Chloromethan

Chromium, total recoverable

Dibromochloromethane

1,2-Dibromo-3-chloropropan 1,2.Dibromoelhan

1,2-Dichlorobenzen

1.3.Dichlorobenzene

o 1.4-Dichlorobenzene

1 Dichiorodifluorometh

o 1,2-Dichloroethane

$1,1-D$ chhloroethylene
0 cis- $1,2 \cdot D$ Dichloroethylene

1 Dichloromethane

o $1,2 \cdot$-Dichloropropano

irans-1,3-Dichloropropene

1.4-Dioxane

Ethyl melhacry

lodomethane (Methyl lodide)

2 iron, total recoverabto

Isobulyl alcohol

Mercury, total recoverable

Melhacrylonitritle

Methyl ethyl ketone

Methyl isobutyl keton

o Pentachloroethane

Selenium, tolal recoverable

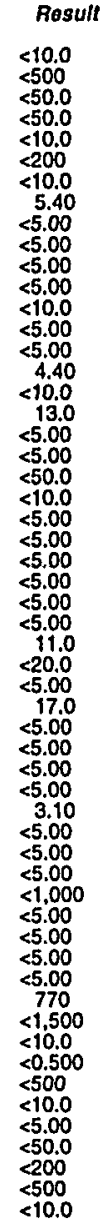

Time: 9:30

Air temper temperalure: $19^{\circ} \mathrm{C}$ Air temperature: $26.5^{\circ} \mathrm{C}$. 0 mg/ Phenolphithalein alkalinity: $0 \mathrm{mg} L$

EMS

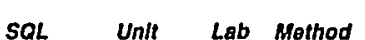

10.0
5500
50.0
50.0
10.0
200
10.0
10.0
5500
5.00
5.00
5.00
10.0
5.00
5.00
5.00
10.0
5.00
5.00
5500
50.0
10.0
5.00
5.00
5.00
5.00
5.00
5.00
5.00
20.0
5.00
5.00
5500
5.00
5500
5.00
5500
5.00
5.00
5.00
1.00
5.00
5.00
5.00
5.00
200
1.500
10.0
0.500
5500
10.0
5500
50.0
200
500
10.0

ugh EX ÉPA8260B 
Well LFW 63D collected on 06/07/99 (cont.)

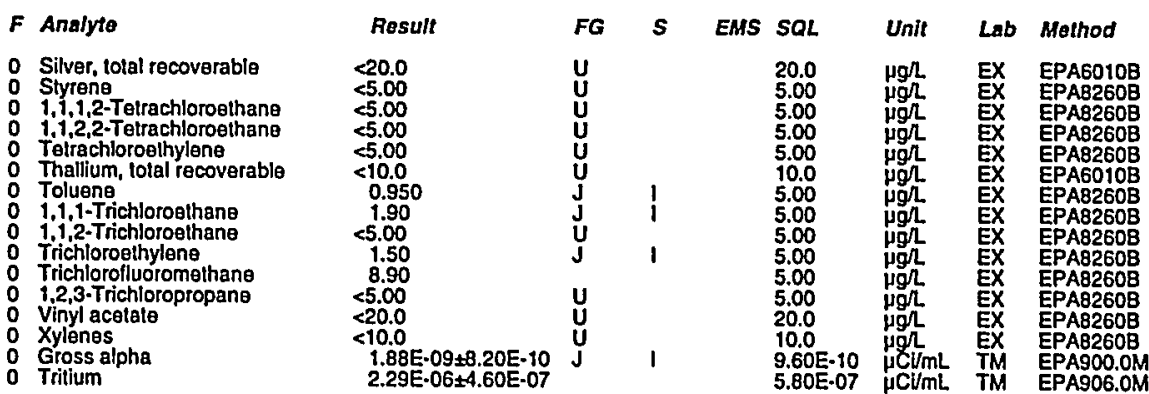

\section{WELL LFW 64C}

MEASUREMENTS CONDUGTED IN THE FIELD

Sample date: 06/01/99
Depth lo water: $12.78 \mathrm{ft}(3.9 \mathrm{~m})$ below TOC

Water elevation: $139.42 \mathrm{ft} / 42$.
$\mathrm{pH}: 3.7$

Sp. conductance: $69 \mu \mathrm{S} / \mathrm{cm}$

Water evacuated from the well prior to sampling: $\mathbf{3 4} \mathrm{gal}$

ANALYSES

$F$ Analyte

Acelong

Acrylonitrile

Aluminum, total recoverable

Arsenle, lotal recoverable

Bromodichloromethan

Bromoform

Cadmium, tolal recoverable

Carbon tetrachlorido

Chlorobenzene

Chioroethene (Vinyl chloride)

Chloromerm

Chromlum toral recoverablo

Dibromochloromethane

1,2-Dibromo-3.chlor

13-Dichlorobenzene

trans-1,4-Dichloro-2-butene

Oichlorodifluoromethan
1,1.Dichloroethane

1,2-Dichloroethane

cis-1,2-Dichloroethylen

trans-1,2-Dichloroethylen

1,2.Dichloropropane

Irans-1, - Dichichopropene
iropropene

Eithyl methacrylate

Elhylbenzene

lodomethane (Methyl lodide)

ESH-EMS-990521
Well LFW 64C collected on 06/01/99 (cont)

\begin{tabular}{|c|c|c|c|c|c|c|c|}
\hline$=$ Analyte & Result & $\boldsymbol{F G}$ & EMS & SQL & Unit & Lab & Method \\
\hline 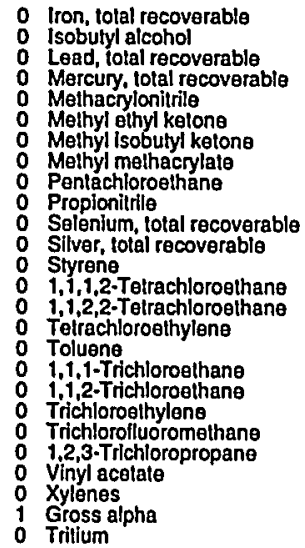 & $\begin{array}{l}9.40 \\
<1.500 \\
<10.0 \\
<0.500 \\
<500 \\
<10.0 \\
<5.00 \\
<50.0 \\
<200 \\
<500 \\
<10.0 \\
<20.0 \\
<5.00 \\
<5.00 \\
<5.00 \\
<5.00 \\
<5.00 \\
<5.00 \\
<5.00 \\
<5.00 \\
<5.00 \\
<5.00 \\
<00 \\
<10.0 \\
1.35 E-08 \pm 1.57 E-09 \\
1.10 E-06 \pm 3.80 E-07\end{array}$ & 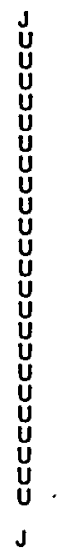 & 1 & $\begin{array}{l}200 \\
1.500 \\
10.0 \\
0.500 \\
500 \\
10.0 \\
5.00 \\
50.0 \\
200 \\
500 \\
10.0 \\
20.0 \\
5.00 \\
5.00 \\
5.00 \\
5.00 \\
5.00 \\
5.00 \\
5.00 \\
5.00 \\
5.00 \\
200 \\
10.0 \\
7.70 \mathrm{E}-10 \\
5.40 \mathrm{E}-07\end{array}$ & 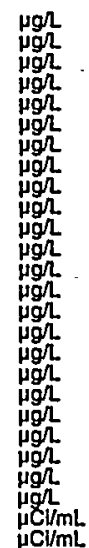 & $\begin{array}{l}\text { EX } \\
\text { EX } \\
\text { EX } \\
\text { EX } \\
\text { EX } \\
\text { EX } \\
\text { EX } \\
\text { EX } \\
\text { EX } \\
\text { EX } \\
\text { EX } \\
\text { EX } \\
\text { EX } \\
\text { EX } \\
\text { EX } \\
\text { EX } \\
\text { EX } \\
\text { XX } \\
\text { EX } \\
\text { EX } \\
\text { EX } \\
\text { TM } \\
\text { TM }\end{array}$ & 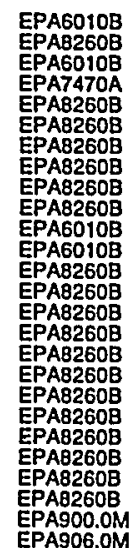 \\
\hline
\end{tabular}

\section{WELLL LFW 64D}

MEASUREMENTS CONDUCTED IN THE FIELD

Sample date: 06/02/99

Weter elevation: $139.47 \mathrm{ht}(42.51 \mathrm{~m}) \mathrm{msl}$

Sp. conductance: $44 \mu \mathrm{S} / \mathrm{cm}$

Water evacuated from the well prior to sampling: $31 \mathrm{gat}$

ANALYSES

$F$ Analyte

: Acetong

Acroleln

Aluminum total recoverable

Arsenic, tolal recoverable

o Bonzeno

0 Bromodichlo

Bromomethane
Cadmium, total recoverable

Carbon disullide

Chlorobenzene

Chloroelhene (Vinyl chlorlde)

Chloromethane

Chloroprene

1,2. Dibromo-3.chloropropan

1.2. Dibromoethane

Dibromomethane

1,3-Dchlorobenzenzene

Irans-1,4-Dichloro-2-butene

1.1.-Dichloroethane

1,1-Dichioroethylen

B-175

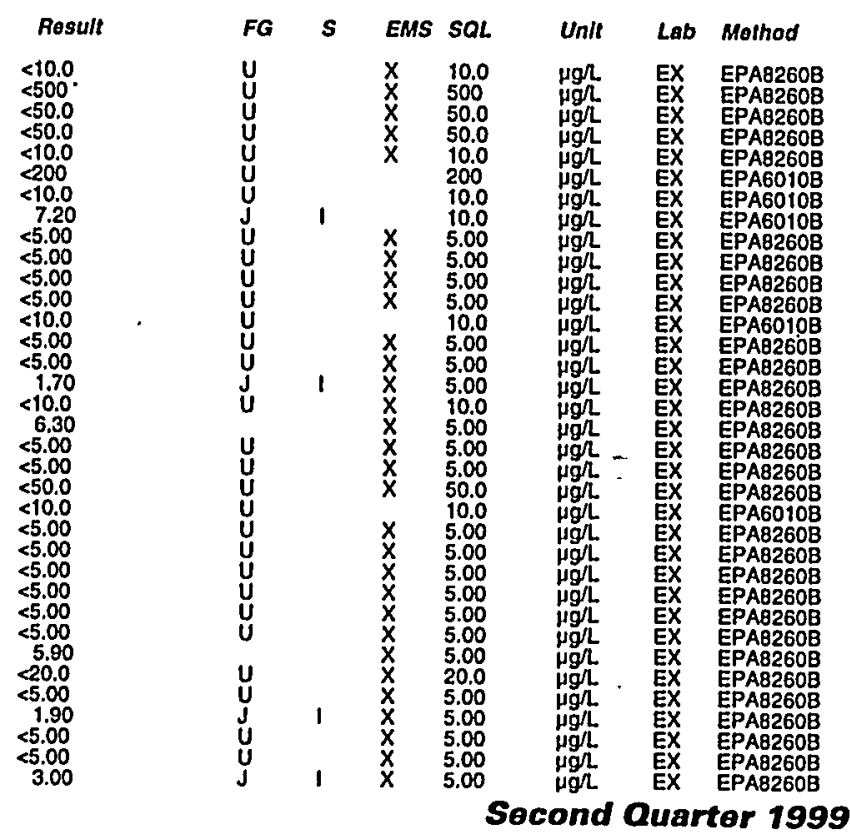

Time: 11:37

perature: $18.1^{\circ} \mathrm{C}$

Total alkalinily (as CaCo3): $10 \mathrm{mg}$.

Phenolphinalein alkalinity: $0 \mathrm{mg} / \mathrm{h}$

Socond Quarter 1999 
Well LFW 64D collected on 06/02/99 (cont.)

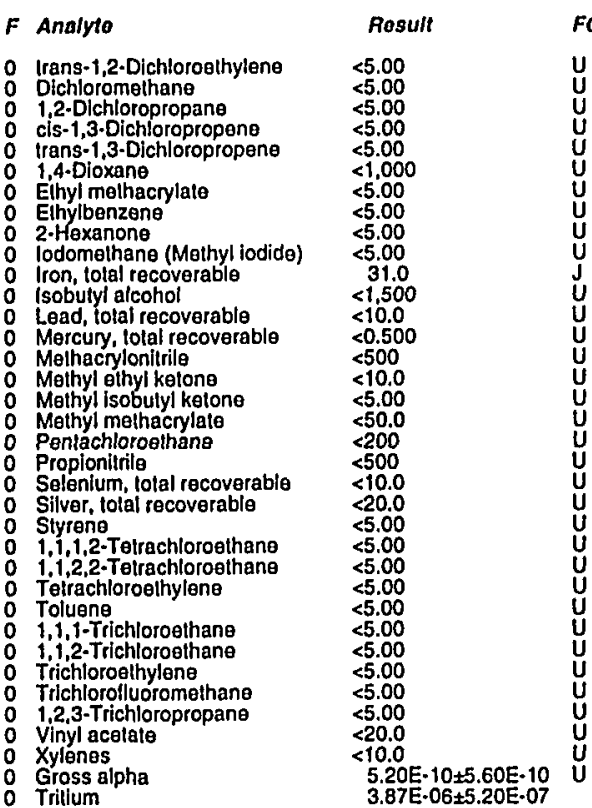

\section{WELLL LFW 65B}

MEASUREMENTS CONDUCTED IN THE FIELD

Sample date: $06 / 01 / 99$
Deph to waler: $11.05 \mathrm{ft}(3.37 \mathrm{~m})$ below TOC
Waler elevation: $137.15 \mathrm{ft}(41.8 \mathrm{~m}) \mathrm{msl}$

pH: 4.5

. conductance: $49 \mu \mathrm{S} / \mathrm{cm}$

Water evacuated from the well prior to sampling: $36 \mathrm{gal}$

ANALYSES

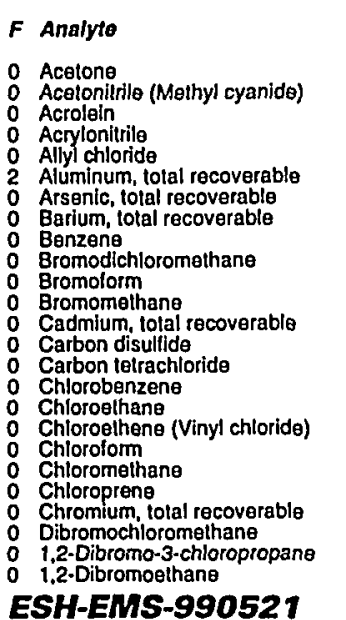

Resuht
$<10.0$
$<5.0$
$<50$.
$<50.0$
$<50$.
$<10.0$
280
$<10.0$
8.0
$<5.00$
$<5.00$
$<5.00$
$<5.00$
$<10.0$
$<5.00$
$<5.00$
$<5.00$
$<10.0$
$<5.00$
$<5.00$
$<5.00$
$<50.0$
$<10.0$
$<5.00$
$<5.00$
$<5.00$

ESH-EMS-990521

$\begin{array}{ll}F_{G} & s \\ y & \\ y & \\ y & \\ y & \\ y & \\ y & \\ y & \\ y & \\ y & \\ y & \\ y & \\ y & \\ y & \\ y & \\ y & \\ y & \\ y & \end{array}$

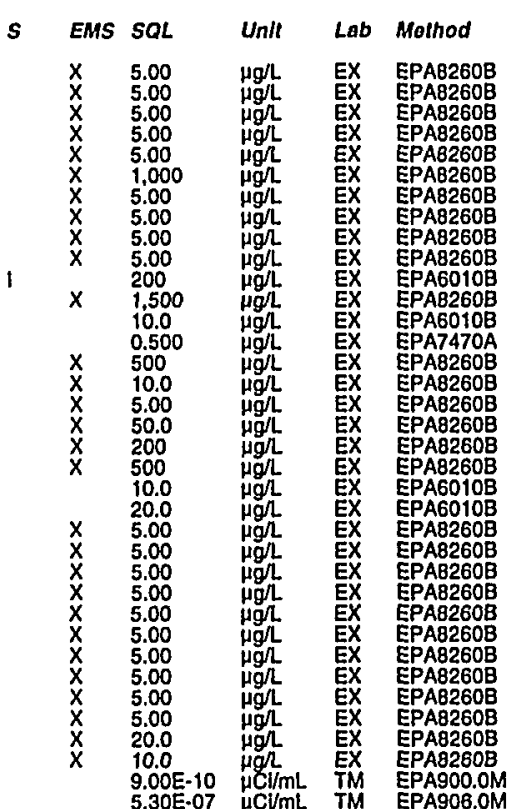

Time: $13: 16$ Water lemperature: $21.9^{\circ} \mathrm{C}$ Air tompal alkalinity (as Cacolo3): $0 \mathrm{mg} / \mathrm{L}$
Phenolphthalein alkalinity: $0 \mathrm{mg} /$

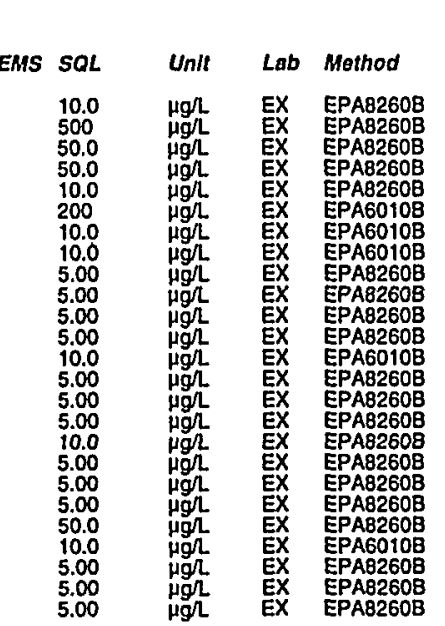

Well LFW 65B collected on 06/01/99 (cont.)

F Analyto Rosu

: Dibromomethane

$\begin{array}{ll}0 & 1,3 \cdot D \text { Dchlorobenzene } \\ 0 & 1,4 \cdot \text { Dichlorobenzene }\end{array}$

trans-1,4-0ichloro-2-butene

1,1.Dichloroethane

o 1,2-Dichloroelhane

o cis-1,2-Dichloroethylene

o 1,2-Dichloropropane

o ciss.1,3-Dichloropropene

: 1 ihyl methacrylate

0 Ethylbenzene

0 lodomelhane (Methyl iodide)

0 Iron, lotal recoverable

o Lead, lotal recoverable

Mercury, lotal recoverable

o Methyl ethyl kelone

Methyl methacrylale

- Pentachloroethane

o Selenlum, total recoverable

Silver, total recoverable

0 $1,1,1,2$-Tetrachlorogthane

0 Tetrachloroethylene

$\begin{array}{ll}0 & \text { Toluene } \\ 0 & 1,1,1-\text { Irichlorogthane } \\ 0 & 1,1,2 \text {-Trichloroethane }\end{array}$

0 Trichloroesthylene

1,2,3.Trichloropropane

0 Xylenes

0 Grons alpha
0 Tribium

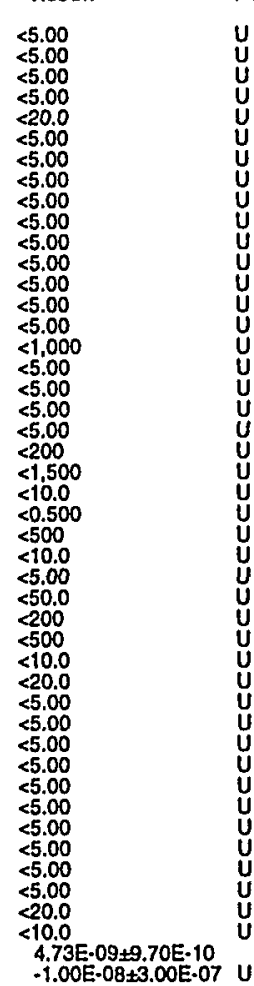

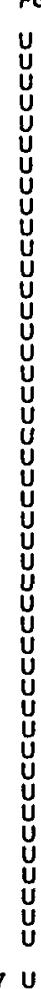

WELL LFW 65C

MEASUREMENTS CONDUCTED IN THE FIELD

Sample date: 06/01/99

Water

Sp: 4.8 conductance: $31 \mu \mathrm{S} / \mathrm{cm}$

Turbidity: 1 NTU:

ANALYSES

$F$ Analyte

0 Acelone

0 Acrolein

O Acrylonitrite

Aluminum, total recoverable

o Barium, total recoverable

Benzene

Bromolorm

Cadmium, total recoverable

Carbon disulfide

B-176

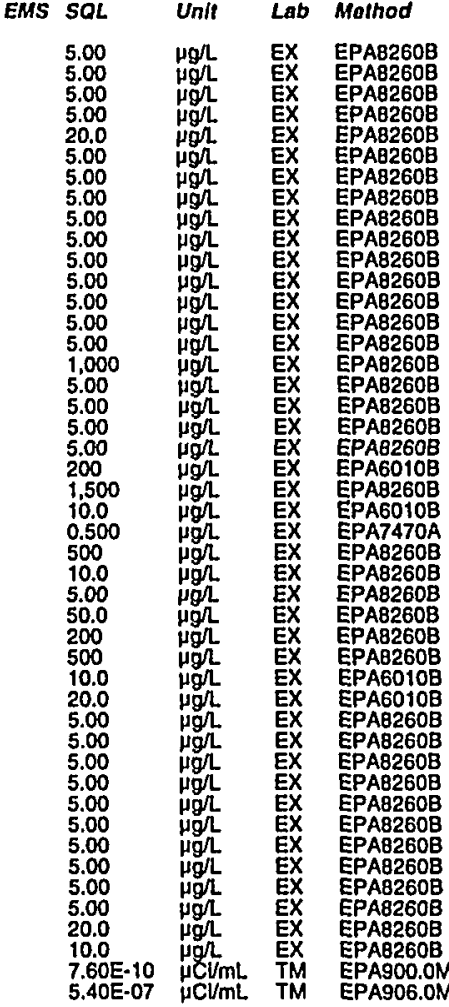

Time: 12:45

Waler temperalure: $21.9^{\circ} \mathrm{C}$

Total alkalinity (as CaCO3): $0 \mathrm{mgh}$

Phenoiphinalein al
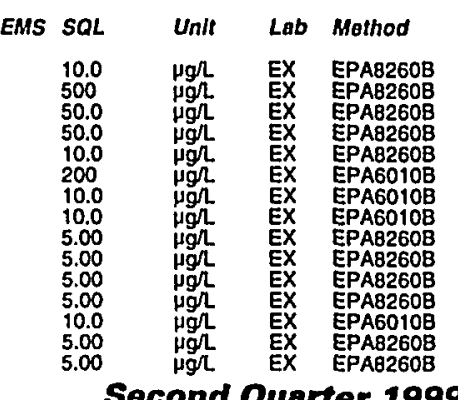
Well LFW 65C collecled on 06/01/99 (cont.)

$F$ Analyte

- Chlorobenzens

Chloroethene (Vinyl chloride)

C Chlorolorm

Chromum, total recoverable 1,2-Dibromo-3-chloropropan 1,2-Dibromo-3-chlo

1,2.Domomethane

1,3-Dichlorobenzene

Irans-1,4-Dichloro-2-butene

Dichlorodifluoromethane

1.1.Dichloroethane

cis-1,2-Dichloryelhylene

Trans-1,2-Dichloroothy

1,2.Dichloropropane

Eityl methacrylale

Ethylbenzene

lodomethane (Methyl fodide)

Iron, lotal recoverab
I Isobutyl alcohol

Lead, tolal recoverable

Melhacylonitrile

Methy! Isobutyl ketone

Pentachloroethane

Solenium, total recoverable

1.1.1.2- Totrachloroethane

loroethylene

1,1,1-Trichloroethane

Trichloroethylene

1,2,3.Trichloropropane

Gross alpha

WELL LFW 65D

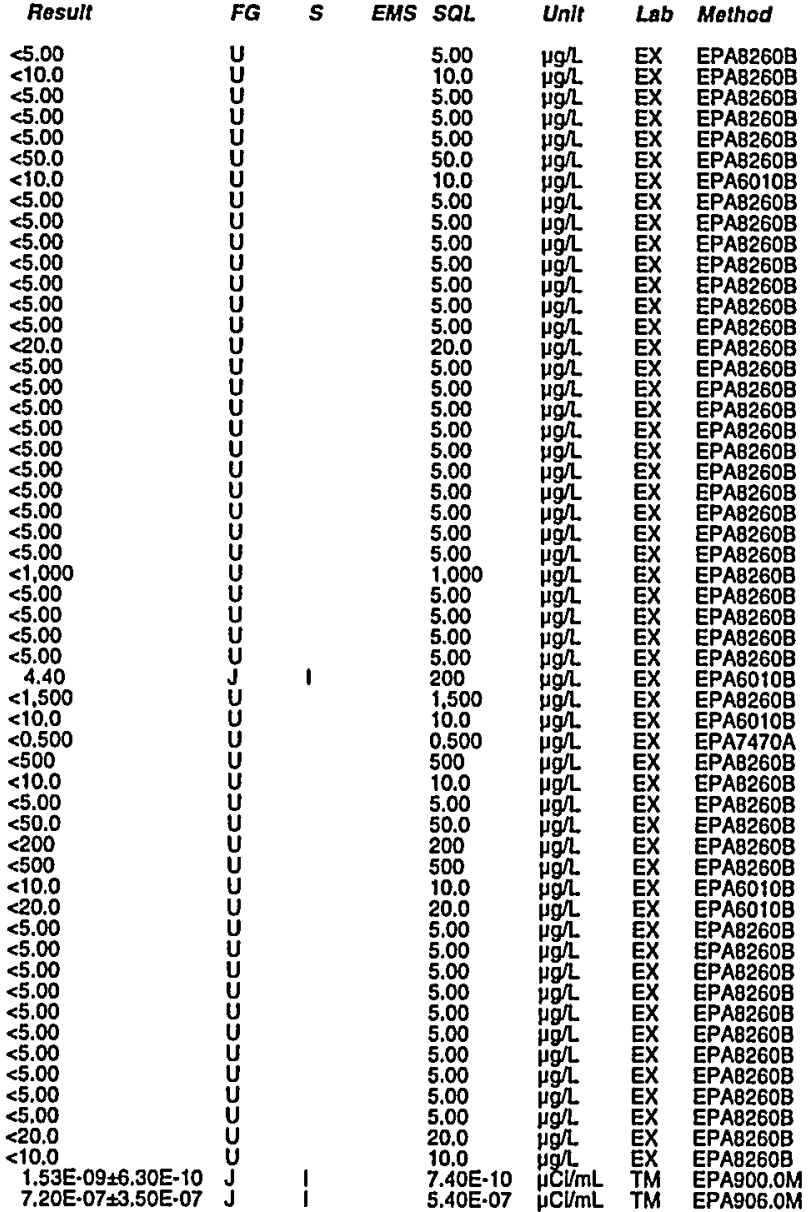

MEASUREMENTS CONDUCTED IN THE FIELD

Sample date: $06 / 02 / 99$
Depht to water: 11.3 ft $(3.44 \mathrm{~m})$ below Toc
Waler elevation: $137.1 \mathrm{Ht}(41.75 \mathrm{~m}) \mathrm{msl}$

Waler el wa

p. conductance: $28 \mu \mathrm{S} / \mathrm{cm}$

Turbidity: ONTU
Water evacuated from the well prior to sampling: $10 \mathrm{gal}$

ANALYSES

$F$ Anglyto

Result

- Acotone

$<10.0$
5500
50.0
$<50.0$
$<10.0$

$\begin{array}{llll}\text { FG } & S & \text { EMS } & \text { SOL } \\ U & & X & 10.0 \\ U & & X & 500 \\ U & & X & 50.0 \\ U & & X & 50.0 \\ U & & X & 10.0\end{array}$

$\begin{array}{ll}\text { Unit } & \text { Lab } \\ \mu g h & \text { EX } \\ \mu g g & \text { EX } \\ \mu g h . & \text { EX } \\ \mu g g & \text { EX } \\ \mu g h . & \text { EX }\end{array}$

b Method

Acrelonitrile
Allyl chlorid

ESH-EMS-99052
Well LFW 65D collecled on 06/02/99 (cont.)

$F$ Analyte Result

o Aluminum, total recoverable

Barium, otal racoverable
Benzena
Bromodichloromethane

Bromolorm

Cadmium, fotal recoverable

Carbon disulfide

Chlorobenzene

CCloroethene (Vinyl chloride)
Chlorolom

Chloroomethane

Chromlum, lotal recoverable

1,2-Dibromo-3-chloropropane

Dibromomethane

o i, -Dichliorobenzenzena

1.4-Dichlorobenzene
irans-1,4-Dichlore-2-butene

1.1-Dichloroethane

$\begin{array}{ll}0 & 1,2 \cdot D \text { chloroethane } \\ 0 & 1,1-D i c h l o r o t h y l e n\end{array}$

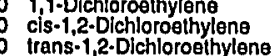

Dichloromethane

is-Dichloropropane
0 cis-1,3-Dichloropropene
tians-1,3-Dichloropropen

1,4-Dioxane

Ehyl methacry

lodomethane (Melhyl lodide)

Iron, lotal recoverab

Mercury, total recoverable

Methacrylonitrile

Methyl isobutyl ketone Pentachloroethana

Propionilitile Silver, total recoverable

1,1,1,2-Tetrachloroethane $1,1,2,2-T o t r a c h l o r o e ! h a n$
Tolrachloroethylene

1oluene 1 1. Trlechlorosthane

$1,1,2$-Trichloroethane
Trichloroethylene.

1, 2,3-Trichloropropane Vinyl acetalo

o Gross alpha Alr temperature: $31.2^{\circ} \mathrm{C}$
Total alkalinity (as CaCo3): $0 \mathrm{mg} /$ Phenolphthalein alkalinity: $0 \mathrm{mg}$.

0 Tritium
$<200$

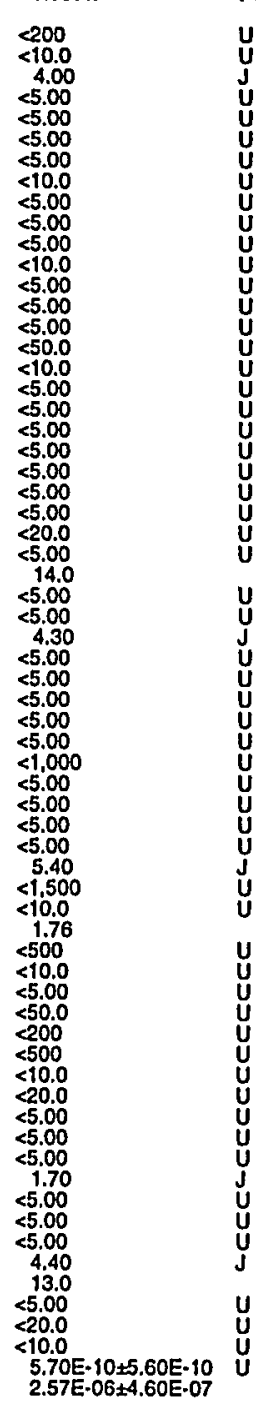

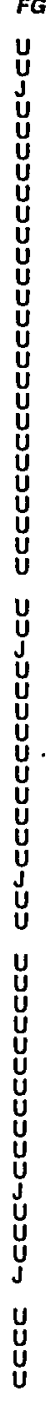


ANALYTICAL RESULTS

\section{WELL. LFW 678}

MEASUREMENTS CONDUCTED IN THE FIELD

Sample date: 06/01/99

Water olevation: $138.08 \mathrm{ft}$ (
gH: 3.7

Waler evacuated from the well prior to sampling: $45 \mathrm{gal}$

ANALYSES

\begin{tabular}{|c|c|c|}
\hline & Analyte & Rosult \\
\hline & 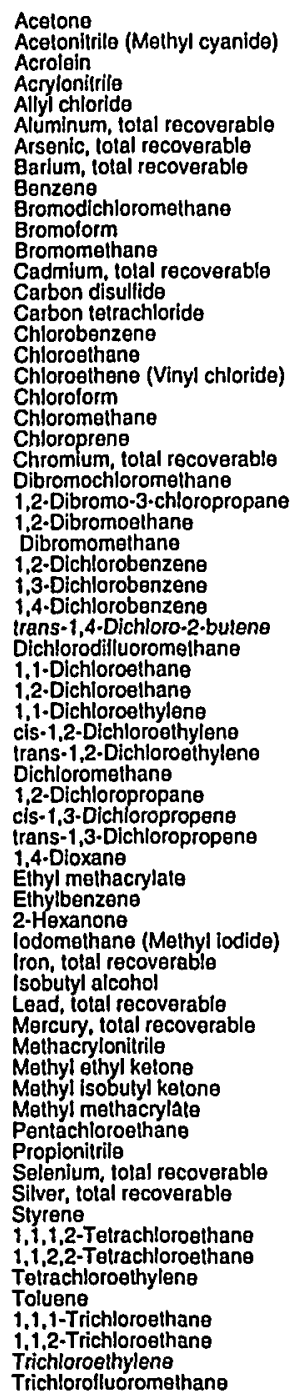 & 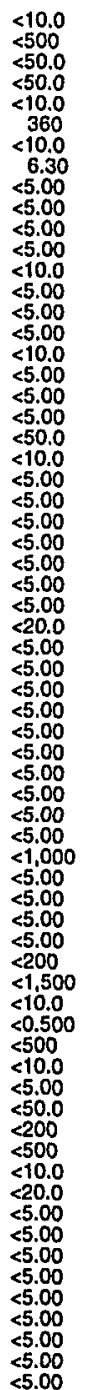 \\
\hline
\end{tabular}

ESH-EMS-990521
Well LFW 678 collocted on 06/01/99 (cont.)

F Analyto Time: $13: 15$ Air temperalure: $29.9^{\circ} \mathrm{C}$ ) $0 \mathrm{mg}$ Phenolphthalein alkalinity: $0 \mathrm{mgl}$

1,2,3-Trichloropropan

Xylenes

Gross alpha
Tritium

$<5.00$
$<200$
$<10.0$

WELL LFW 670

MEASUREMENTS CONDUCTED IN THE FIELD

Sample date: 06/02/99

Depth to waler: $19.5 \mathrm{ft}(5.94 \mathrm{~m})$ below TOC
Water elevation: $137.6 \mathrm{ft}(41.94 \mathrm{~m}) \mathrm{msl}$

$\mathrm{H}: 6.4$

p. conductance: $400 \mu \mathrm{S} / \mathrm{cm}$

Water evacualed from the well prior to sampling: $42 \mathrm{gal}$

ANALYSES

\section{$F$ Analyto}

- Acetono

Acrolein
Acrylonitrile

Ally chloride

Arsenic, total recoverable

- Barium, total recoverable

Bromodichloromelhane

Bromodichlor
Bromolorm

Cadmium, lotal recoverable

Carbon disullide

o Chlorobenzene

O Chlorothane

Chlorolorm

C Chloromethan

Chromium total recoverable

Dibromochloromathane

1,2-Dibromo-3-chlor

o Dibromomethane

1.3.Dichlorobenzenen

1,4.Dichlorobenzene

Irans-1,4-Dichloro-2-buten

2 1, 9 -Oichloroethane

o 1,2-Dichloroethane

cis-1,2 Dichloroethylene

o Dichloromethane

1 1,2-Dichloropropane

trans-1,3-Dichloropropen

1.4-Dioxane

O Elhyl melhacryla

o Elhylbenzene

lodomethane (Meshyl lodide)

2 lon, total recoverab

o isobutyl alcohol

Mercury, total recoverablo

- Methyl ethyl kelone

M Methyt isobutyl ketone

O Melhyl methacrylate

: Pentachlorosthan

Selenium, total recoverablo

Result
410.0
$<500$
$<50.0$
$<50.0$
$<10.0$
$<200$
33.0
8.90
5.60
$<5.00$
$<5.00$
$<5.00$
$<10.0$
$<5.00$
$<5.00$
1.10
$<10.0$
200
$<5.00$
$<5.00$
$<50.0$
$<10.0$
$<5.00$
$<5.00$
$<5.00$
$<5.00$
0.960
$<5.00$
40.0
$<20.0$
$<5.00$
77.0
$<5.00$
$<5.00$
34.0
$<5.00$
$<5.00$
2.60
$<5.00$
$<5.00$
$<1.000$
$<5.00$
28.0
$<5.00$
$<5.00$
46.000
$<1.500$
$<10.0$
$<0.500$
$<500$
$<10.0$
$<5.00$
$<50.0$
$<200$
$<500$
$<4.90$

Time: 13:33

Wir Total alkalinity (as CaCO3): $145 \mathrm{mg} /$ Field Qualifier(s): $v$ alinity: $0 \mathrm{mg} / \mathrm{L}$

$50 L$
10.0
500
50.0
50.0
10.0
200
10.0
10.0
55.00
5.00
5.00
5.00
10.0
5.00
55.00
5.00
10.0
5.00
5.00
5.00
50.0
10.0
5.00
5500
5.00
5.00
5.00
5.00
5.00
5.0
5.00
55.00
5.00
5.00
5.00
5.00
5.00
5.00
5.00
1.00
5.00
5.00
5.00
5.00
200
1.500
10.0
0.500
500
10.0
5.00
50.0
200
500
10.0

$\mu g$ EX EPAB260B

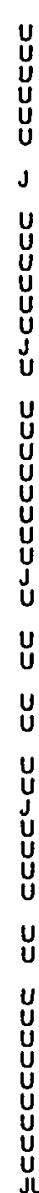

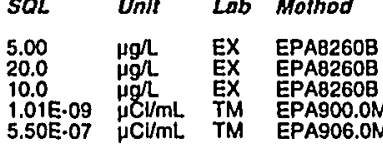

M


Well LFW 67C collected on 06/02/99 (cont)
F Analyto Result

- Silver, tolal recoverable $<20.0$
$<5.00$
$<5.00$

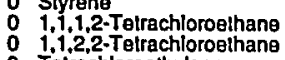

0 Tetrachloroethylene

$\begin{array}{ll}0 & 1.1 .1-\text { Trichloroethane } \\ 0 & 1.1 .2 \text { Trichloroethane }\end{array}$

1 Trichloroethylente

1,2,3-Trichlooropropane

: Vinyl acetale

1 Gross alph

WELL LFW 67D

MEASUREMENTS CONDUCTED IN THE FIELD

Sample date:0 0 (02/99

Depth to water: $17.9 \mathrm{ft}(5.46 \mathrm{~m})$ below TOC
Water elevation: $139.8 \mathrm{ft}(42.61 \mathrm{~m}) \mathrm{msl}$

$\mathrm{pH}: 4.9$

conductance: $77 \mu \mathrm{S} / \mathrm{cm}$

Water evacualed from the well prior to sampling: $18 \mathrm{gal}$

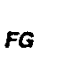

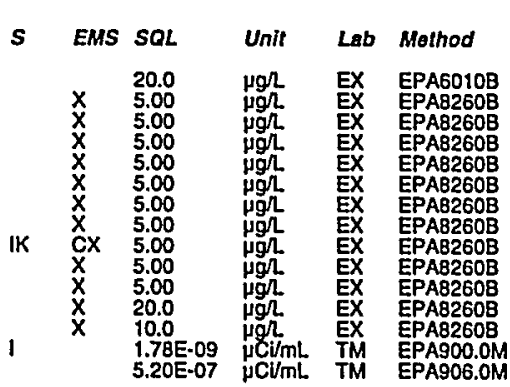

ANALYSES

F Analyto

o Acelone

Aluminum, total recoverable

Arsenlc. blal recoverablo

Eenzene

O Eromodichlorome

Bromolorm

Carbon disulfide

0 Chlorabenzene

CChoroethene (Vinyl chloride)

o Chlorolorm

Chloroprene

Dibrmm,

Dibromomethane

1,3-Dichlorobobenzenen

trans-1,4-Dichloro-2.buten

i.j.Dichloroothylone

cis-1,2.Dichloroethylens
trans-1,2.Dichloroethylen

Dichloromelhane
1.2-Dichloropropane

cis-1,3-Dichloropropene

$1.4 \cdot$ Dioxane
Ethyl mothacrylate

Ethylbenzene

lodomethane (Methyl iodide)

ESH-EMS-99052
O Acroloin

Cadmium, total recoverable

1,2-2.Dibromo-3-chloropropane

1,1-Dichiorooromatha

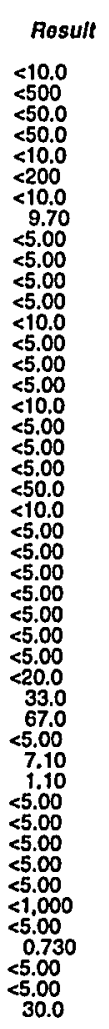

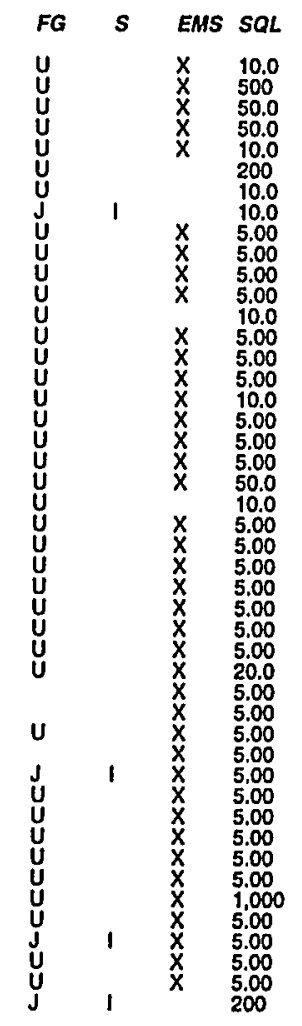

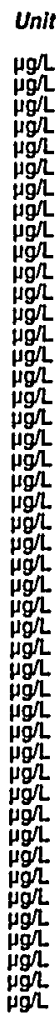

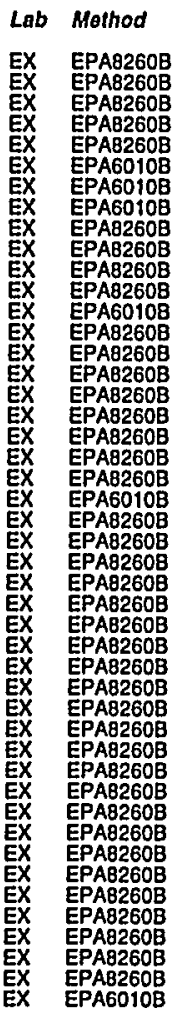

Time: 14:03

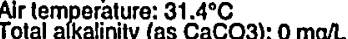
Phenolphithalein alkalinity: $0 \mathrm{mg} \mathrm{m}^{\circ}$

\section{MEASUREMENTS CONDUCTED IN THE FIELD}

Sample date: 06/02/99

Depth to waler: $20.47 \mathrm{ft}(6.24 \mathrm{~m})$ below TOC

Sp: conductance: $30 \mu \mathrm{S} / \mathrm{cm}$

Water evacualed from the well prior to sampling: $18 \mathrm{gal}$

ANALYSES

$F$ Analyte

Acetone
0 Acetonlitile (Methyl cyanide)
0 Acrolein

Acrolein
0 Acrylonitrile
$0.4 y$ chloride

: Ally chloride

Arsenlc, total recoverablo

Benzene

Bromolorm

Cromomelhane

Carbon telrachlorido

Chlorobenzene

Chloroethene (Vinyl chloride)

Chloromethan

Chromlum, total recoverable

1,2-Dibromo-3-chloropropane

o 1,2.Dibromoethane

0 1.2 . Dichlorobenzene

0 1,4-Dichlorobenzene

o

0 1,1-Dichloroethane

0 1. Dichloroelthylene

0
0 is-1,2-Dichloroethylene
0 B-179

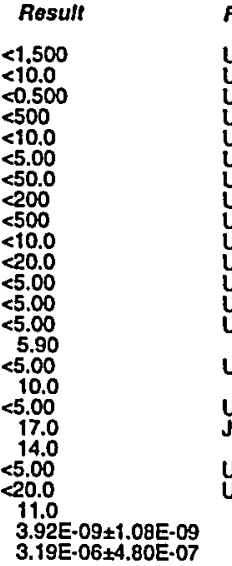

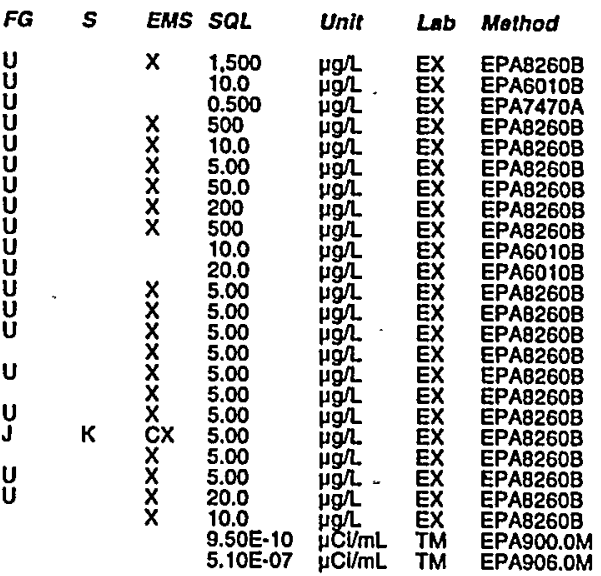

Time: 9:41

Air temperature: $22.1^{\circ} \mathrm{C}$

Total alkalinity (as CaCO3): $0 \mathrm{mg}$

Field Qualifier(s): $V$

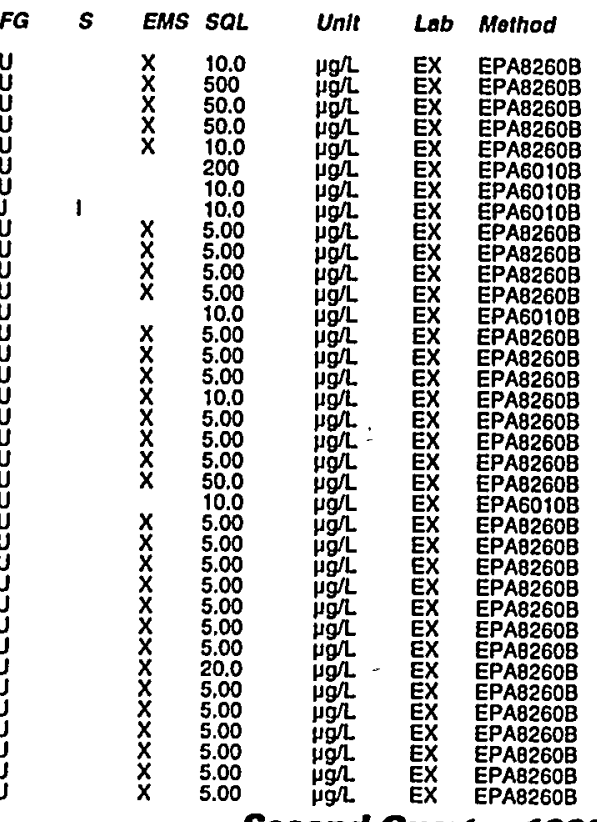


ANALYTICAL RESULTS

Well LFW 68D collected on 06/02/99 (cont.)

$F$ Analyzo

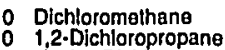
cls-1,3-Dichloropropene
irans-1,3.Dichloropropene 1.4-Dloxane Elhylbenzene

lodomelhane (Melhyl lodide) Iron, total recoverablo

Isobutyl alcohol

Lead, lotal recoverable

Methacrylonitritle

Melhyl isobutyl ketone Methyl methacrylate
Pentachloroethane

Sropionitrite Silver, total recoverable

Styrene 1,1,2,2-Tetrachloroethan

Toluene

1,i,2-Trichloroelha

Trichlorolluoromethane

Vinyl acetalo

Gross alpha

Trillium

\section{WELL LFW 69C}

MEASUREMENTS CONDUCTED IN THE FIELD

Sample date: 06/02/99

Wepth to water: 8.9 tt $(2.71 \mathrm{~m})$ below TOC

Water e

Sp. conductance: $58 \mu \mathrm{S} / \mathrm{cm}$

Water evacuated from the well prior to sampling: $32 \mathrm{gal}$

ANALYSES

$F$ Analyto

Acetone
Acelonitrile (Methyl cyanide)

Acrolein

Aluminum, total recoverable

Arsenic, total recoverable

Barium, total recoverable

Benzene
Bromodichloromethan

Bromoform

Cadmium, total recoverable

Carbon disullide

Chlorobenzzene

Chlorosthane

Chlotolorm

Chloromethane

Chromium. total recoverable

Dibromochioromelhane

1,2-Dibromoethane

ESH-EMS-990521

Result
$<10.0$
$<500$
$<50.0$
$<50.0$
$<10.0$
570
$<10.0$
7.00
$<5.00$
$<5.00$
$<5.00$
$<5.00$
$<10.0$
$<5.00$
$<5.00$
$<5.00$
$<10.0$
$<5.00$
$<5.00$
$<5.00$
$<50.0$
$<10.0$
$<5.00$
$<5.00$
$<5.00$
$<5.00$

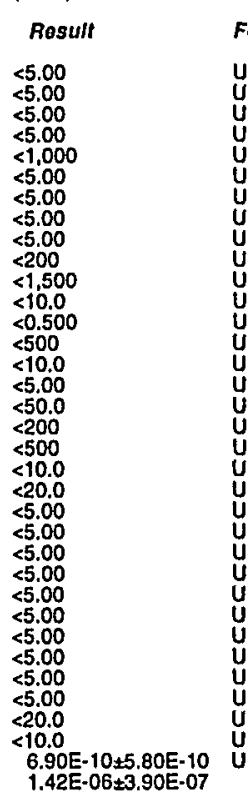

$F G$
$u$
$u$
$u$
$u$
$u$
$u$
$u$
$u$
$u$
$u$
$u$
$u$
$u$
$u$
$u$
$u$
$u$
$u$
$u$
$u$
$u$
$u$
$u$
$u$
$u$
$u$
$u$
$u$

\begin{tabular}{|c|c|c|c|c|}
\hline IS & $Q Q L$ & Init & Lab & othod \\
\hline $\begin{array}{l}x \\
x \\
x\end{array}$ & $\begin{array}{l}5.00 \\
5.00 \\
5.00 \\
5.00 \\
1.000 \\
5.00 \\
5.00 \\
5.00 \\
5.00 \\
200 \\
1,500 \\
10.0 \\
0.000 \\
500 \\
10.0 \\
5.00 \\
50.0 \\
200 \\
500 \\
10.0 \\
20.0 \\
5.00 \\
5.00 \\
5.00 \\
5.00 \\
5.00 \\
5.00 \\
5.00 \\
5.00 \\
5.00 \\
5.00 \\
20.0 \\
10.0\end{array}$ & 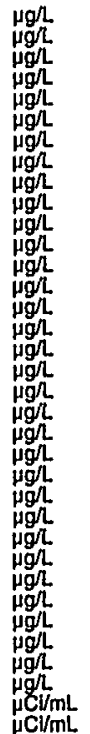 & $\begin{array}{c}\text { EX } \\
\text { EX } \\
\text { EX } \\
\text { EX } \\
\text { EX } \\
\text { EX } \\
\text { EX } \\
\text { EX } \\
\text { EX } \\
\text { EX } \\
\text { EX } \\
\text { EX } \\
\text { EX } \\
\text { EX } \\
\text { EX } \\
\text { EX } \\
\text { EX } \\
\text { EX } \\
\text { EX } \\
\text { EX } \\
\text { EX } \\
\text { EX } \\
\text { EX } \\
\text { EX } \\
\text { EX } \\
\text { XX } \\
\text { EX } \\
\text { EX } \\
\text { EX } \\
\text { EX } \\
\text { EX } \\
\text { EX } \\
\text { EX }\end{array}$ & 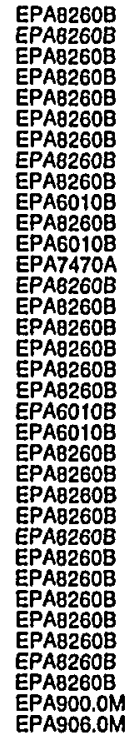 \\
\hline
\end{tabular}

Time: 10:41

Waler temperature: $21.3^{\circ} \mathrm{C}$

Air temperature: $24.7^{\circ} \mathrm{C}$ (alkalinily:(as CaCo3): $0 \mathrm{mg}$.

Phenolphthalein alkalinity: $0 \mathrm{mgh}$

Well LFW 69C collected on 06/02/99 (cont.)

$F$ Analyte

: 1,2-Dichlorobenzene

$\begin{array}{ll}0 & 1,4 \cdot \text { Dichlorobenzene } \\ 0 & \text { trans-1,4-Dichloro-2.butene } \\ 0 & \text { Dichiorodifluoromethane }\end{array}$

1,1-Dichloroothane

i.1. Dichlorosthylene

trans-1,2-Dichloroethylene

1,2-Dichloropropane

cis-1,3.Dichloropropene

1.4-Dioxane

Ethyibenzene

lodomethane (Mathyl iodide)

Iron, total recoverablo

Lead, lotal recoverable

Methacrylonilirile

\% Methyl othyl ketone

Methyl melhacrylate

- Propionitrile

Selenium, total recoverable

Silver, total recoverable

1, 1,1,2-Tetrachloroethane

i,i,2,2-Telrachloroethan

Toluene

1, 1,1-Trichloroelhane

Trichloroethylene

1:2,3-Trichloropropane

Vinyl acetalo

0 Gross alpha

Tritium

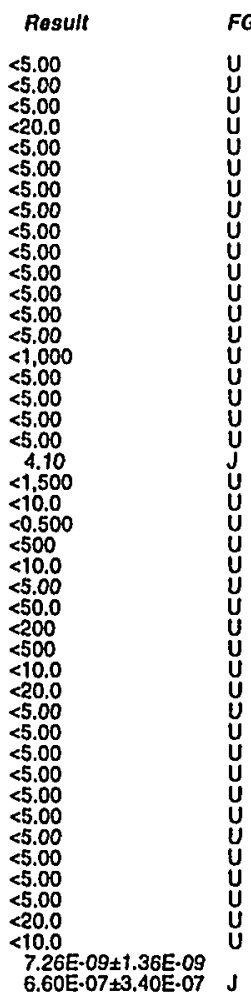

s

WELL LFW 69D

MEASUREMENTS CONDUCTED IN THE FIELD

Sample date: 06/07/99

Depth to water: $9 \mathrm{ft}(2.74 \mathrm{~m})$ below TOC
Water elevation: $137.1 \mathrm{ft}(41.79 \mathrm{~m}) \mathrm{ms}$

pH: 5.2

Sp. conductance: $53 \mu \mathrm{S} / \mathrm{cm}$

Water evacuated from the well prior to sampling: $16 \mathrm{gal}$

ANALYSES

F Analyte

: Acetone

Acrolein

Allyl chloride

B Arsenic, total recoverable

Bromodichloromethane

Cadmium, total recoverable

Carbon disulfide

Chiorobenzene

Result
$<10.0$
$<500$
$<50.0$
$<50.0$
$<10.0$
$<200$
$<10.0$
6.10
$<5.00$
$<5.00$
$<5.00$
$<5.00$
$<10.0$
$<5.00$
$<5.00$
4.60

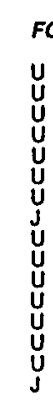

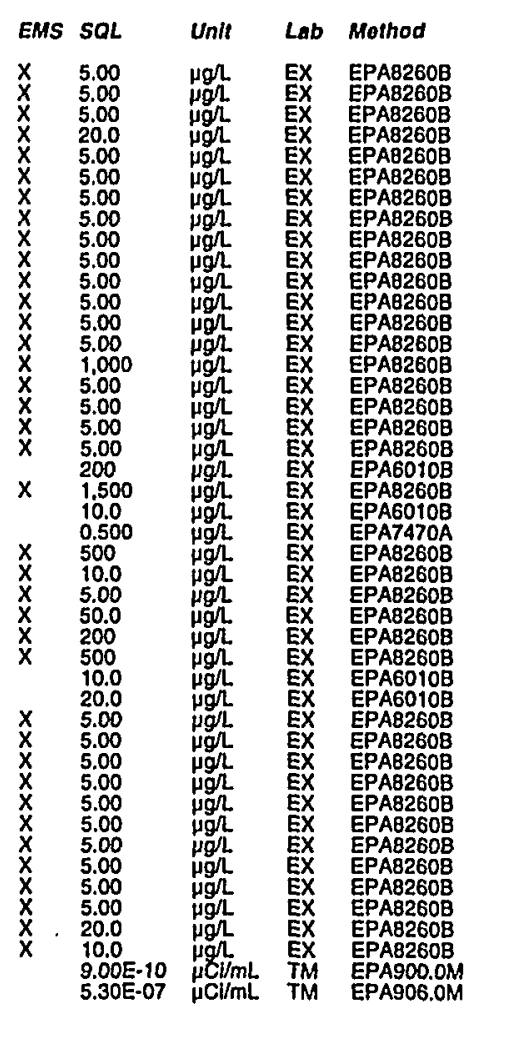

Time: 13:05

Water temperature: $18.6^{\circ} \mathrm{C}$

Total alkalinity (as CaCO3): $2 \mathrm{mgl}$

Phenolphthalein alkalinity: $0 \mathrm{mgh}$
Field Qualifier(s): $\mathrm{V}$

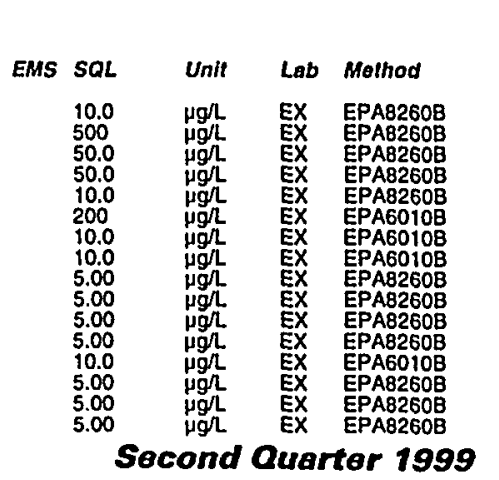


Well LFW 69D collecied on 06/07/99 (cont.)

$F$ Analyto

Result

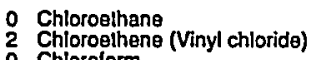

Chloromethane

Chromium, total recoverable

0 Oibromochloromethane

1,2-Dibromo-3.chlorop

Dibromomethane

1,3-Dichlorobenzene

Irans-1,4-Dichloro-2-butene

Dichlorodilluoromethane

1.2-Dichloroesthane

cis-1,2-Dichloroelhylene

Irans-1,2-Dichloroelhylene

1,2-Dichloropropan

trans-1,3-Dichloropropene

Eihyl methacrylal

lodomethane (Mathyl iodide)

Isobulyl alcohol

Lead, colal recoverable

Melhacrylonitrite

Methyy isobulyl kelone

Pentachloroethane

Sropionitrila

Silver, total recoverable

1.1,1,2-Terrachloroethane

Thallium, total recoverabi

1,1,1-Trichloroethan

Trichloroethylene

1,2,3-Trichloropropane

Krlenes

WELL LFW 71B

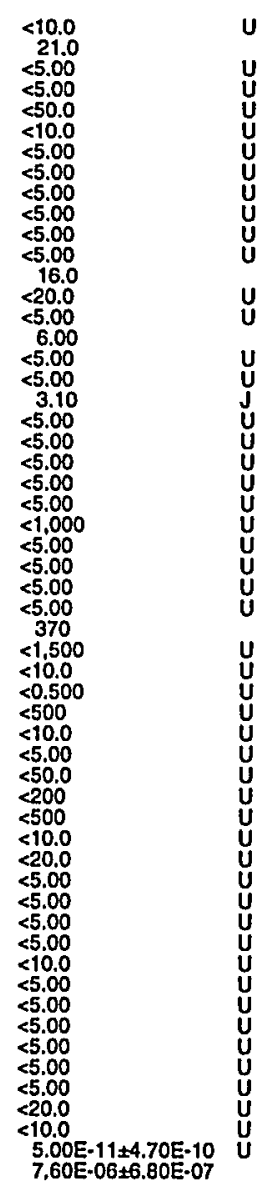

MEASUREMENTS CONDUCTED IN THE FIELL

Sample date: 06/01/99

Depth to water: $10.1 \mathrm{ft}(3.08 \mathrm{~m})$ below TOC
Water elevalion: $136.9 \mathrm{tt}(41.73 \mathrm{~m}) \mathrm{ms}$

p. conductance: $49 \mu \mathrm{S} / \mathrm{cm}$

Water evacuated from the well prior to sampling: $34 \mathrm{gal}$

ANALYSES

F Analyte
0 Acetone
0
0 Acetonitrile (Methyl cyanide)
0 Acroleln
0 Acrionitile
0 Allyl chitoride

ESH-EMS-990521
Well LFW 718 collected on 06/01/99 (cont.)

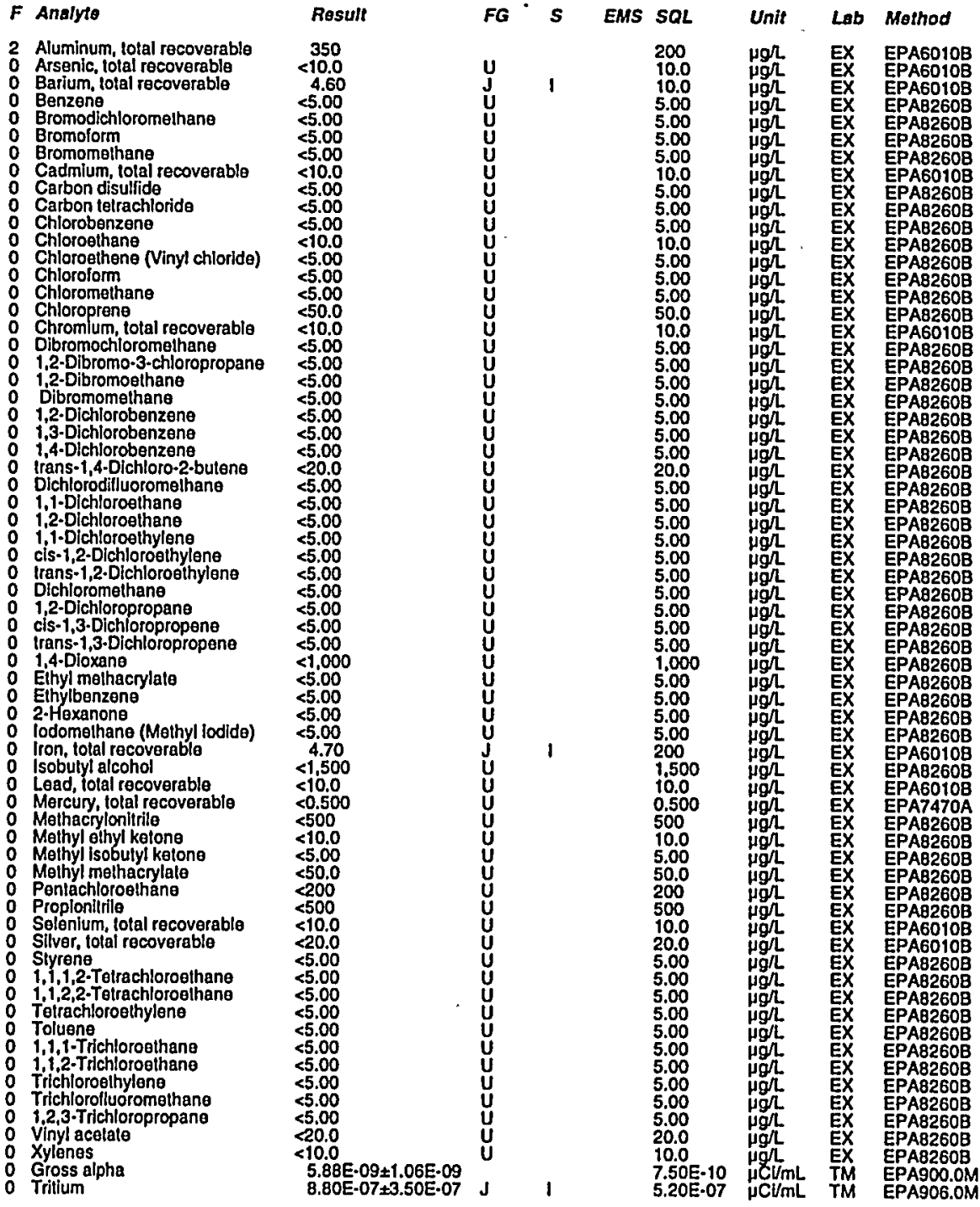

Waler te:05 Total alkalinity (as CaCO3): $0 \mathrm{mg} \Omega$ Phenolphthalein alkalinity: $0 \mathrm{mg} L$
Field Qualfier(s): $V$
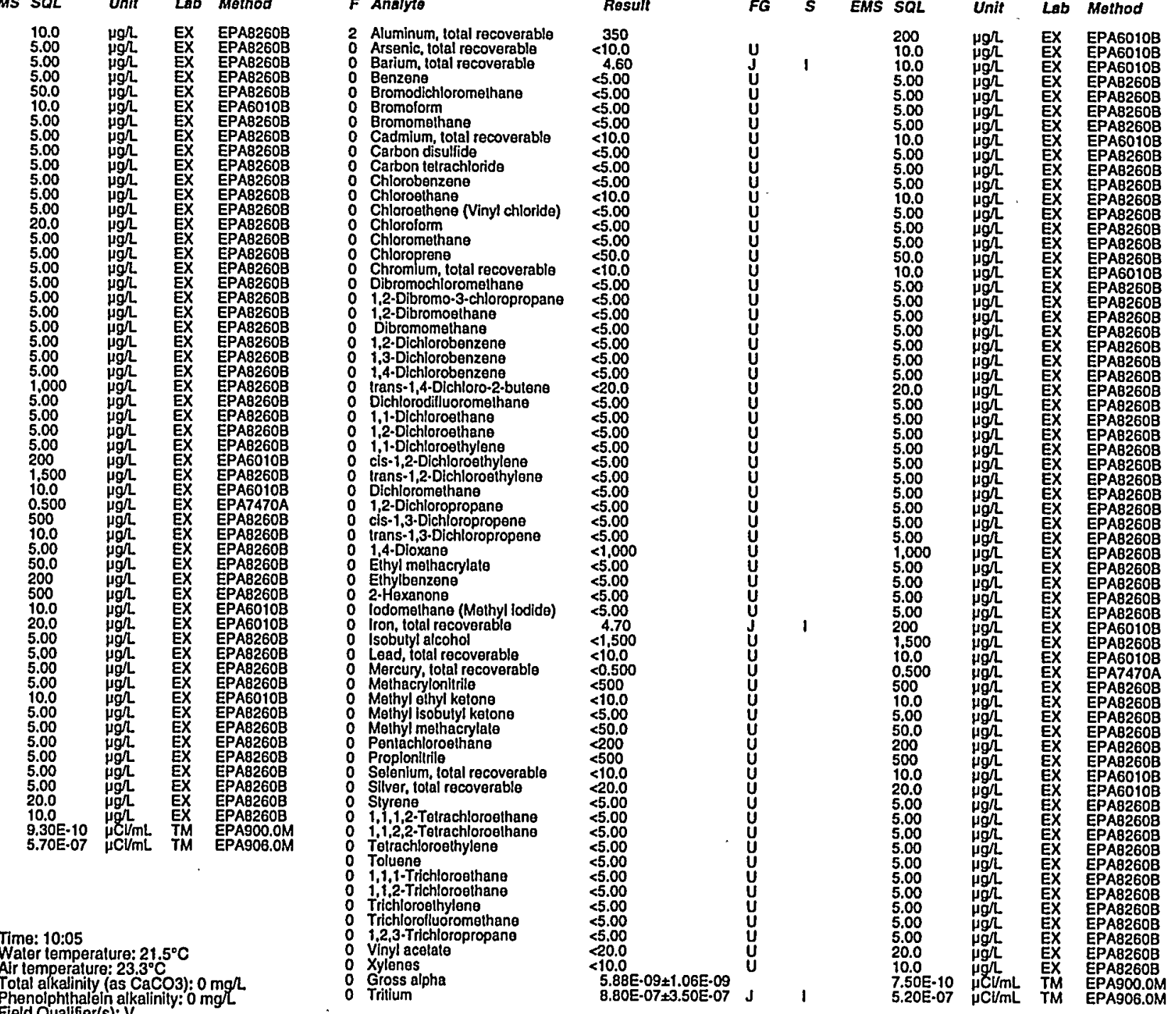

Second Quartor 1999 
WELL LFW 71C

MEASUREMENTS CONDUCTED IN THE FIELD

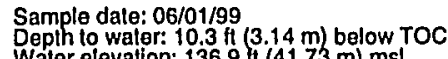

Water elevat

Sp. conductance: $40 \mu \mathrm{S} / \mathrm{cm}$

Waler evacualed from the well prior to sampling: $30 \mathrm{gal}$

ANALYSES

\begin{tabular}{|c|c|}
\hline Analyte & Rosult \\
\hline 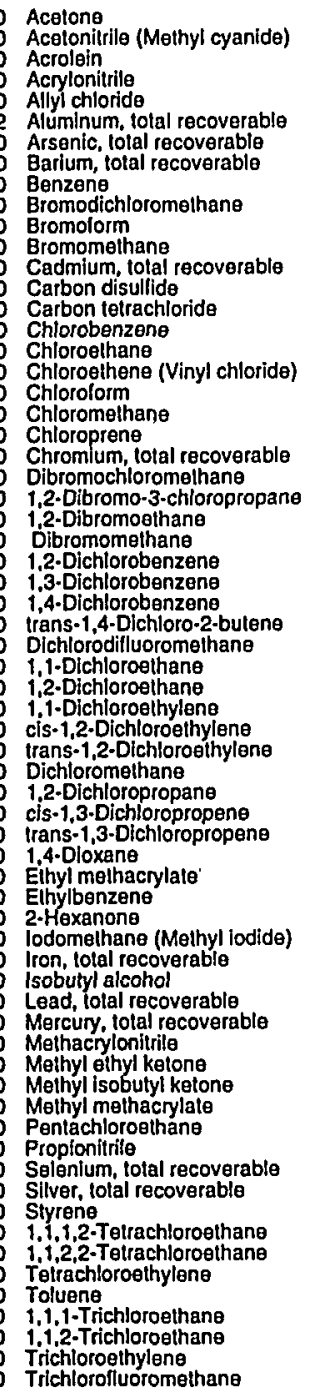 & 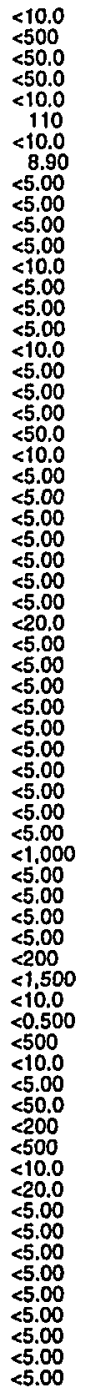 \\
\hline
\end{tabular}

ESH-EMS-990521
Well LFW 71C collocted on 06/01/99 (cont.)

$F$ Analyto

0
0
0
0

Time: 9:29

Water temperature: $22.2^{\circ} \mathrm{C}$ Air temperature: $22.6^{\circ} \mathrm{C}$ ) $0 \mathrm{mg} / \mathrm{L}$ Tolal alkalinily (as CaCO3): $0 \mathrm{mg}$ Field Qualifier(s): $v$

Gross alpha

Rosul

FG

$<20.0$

$5.79 E \cdot 09+1.04 E \cdot 09$

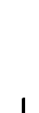

EMS SQL Unlt Lab Mathod

\section{WELLL LFW 71D}

MEASUREMENTS CONDUCTED IN THE FIELD

Sample date: 06/01/99

Sample date: $06 / 01 / 99$
Dephto water: $11.3 \mathrm{ft}(3.44 \mathrm{~m})$ below TOC
Water elovalion: $136.1 \mathrm{H}(41.46 \mathrm{~m}) \mathrm{ms}$

Sp. conductance: $23 \mu \mathrm{S} / \mathrm{cm}$

Wurbidity: 1 NTU ANALYSES

\section{$F$ Analyte}

: Acetono

$\begin{array}{ll}0 & \text { Acrolein } \\ 0 & \text { Acrylonitrile } \\ 0 & \text { Allyl chloride }\end{array}$

A Aluminum, lolal recoverable

Barlum, total recoverable

Bromodichloromethane

Bromolorm

Cadmilum, tolal recoverable

Carbon disullide

Chlorobenzene

O Chloroethane

: Chloroform

- Chromum rotal recoverable

1.2. Dibromo-3.chloropropan

1,2-Dibromo-3.chloro

1,2-Dichlorobenzene

1,3-Dichlorobenzene

trans-1,4-Dlchioro-2-buten

1.1-Olchloroothane

1,1-Dichloroethylene

cis-1,2-Dichloroethylene

Dichloromethane

1,2.Dichloropropane

trans-1,3-Dichloropropene

Ethyl melhacrylat

Ehylbenzene

lodomethane (Methyl iodide)

Iron, tolal recoverab

L Load. total recoverable

Mercury, tolal recoverable

O Methacryloniltrile

: Methyl eilhyl ketone

Pentherinacrylate

$\begin{array}{ll}0 & \text { Propionitrile } \\ 0 \text { Selenium, total recoverable } & <500 \\ & <10.0\end{array}$

Result
$<10.0$
$<500$
$<50.0$
$<50.0$
$<10.0$
$<200$
$<10.0$
4.10
$<5.00$
55.00
$<5.00$
$<5.00$
$<10.0$
$<5.00$
$<5.00$
$<5.00$
$<10.0$
$<5.00$
$<5.00$
$<5.00$
$<50.0$
$<10.0$
$<5.00$
$<5.00$
$<5.00$
$<5.00$
$<5.00$
$<5.00$
$<5.00$
$<20.0$
$<5.00$
$<5.00$
$<5.00$
$<5.00$
$<5.00$
$<5.00$
55.00
$<5.00$
$<5.00$
$<5.00$
$<1.000$
$<5.00$
$<5.00$
$<5.00$
$<5.00$
$<200$
$<1.500$
$<10.0$
0.341
$<500$
$<10.0$
$<5.00$
$<50.0$
$<200$
$<500$
$<10.0$

Time: 9:00

Water temperalure: $20.2^{\circ} \mathrm{C}$

Total alkalinily (as CaCO3): $0 \mathrm{mg} /$

Phenolphthalein alkalinity: $0 \mathrm{mg} /$
EMS SOL

10.0
500
50.0
50.0
10.0
200
10.0
10.0
5.00
5.00
5.00
5.00
10.0
5.00
5.00
5.00
10.0
5.00
5.00
5.00
50.0
10.0
5.00
5.00
5.00
5.00
5.00
5.00
5.00
20.0
5.00
5.00
5.00
5.00
5.00
5.00
5.00
5.00
5.00
5.00
1.00
5.00
5.00
5.00
5.00
200
1.50
10.0
0.500
500
10.0
5.00
50.0
200
500
10.0

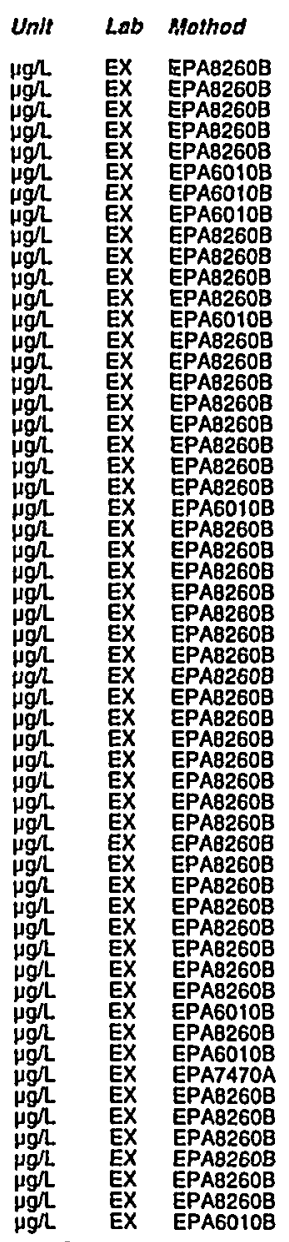

Socond Quarter 1999 
Well LFW 71D collecled on 06/01/99 (cont.)

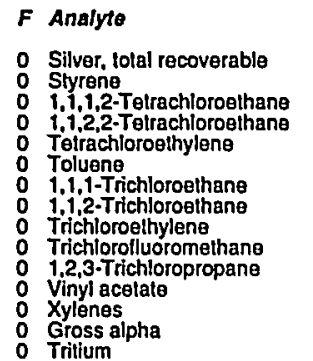

Result

FG

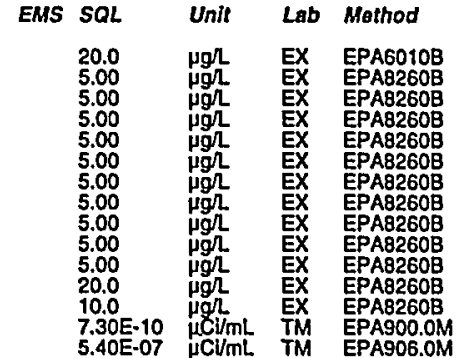

\section{WELL P 26A}

MEASUREMENTS CONDUCTED IN THE FIELD

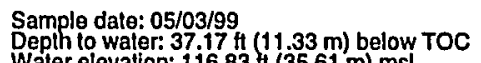

Depht lo water: $37.17 \mathrm{Ht}(11.33 \mathrm{~m})$ below
Water elevalion: $716.83 \mathrm{H}(35.61 \mathrm{~m}) \mathrm{ms}$

ph: 4.9 conductance: $34 \mu \mathrm{S} / \mathrm{cm}$

Water evacuated from the well prior to sampling: $56 \mathrm{gal}$

ANALYSES

$F$ Analyto

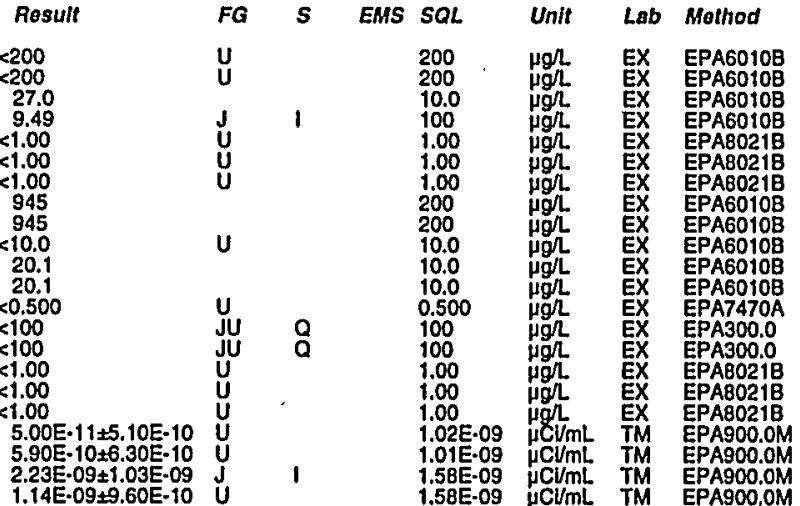

0 Aluminum, total recoverable

0 Aarium, total recoverable

${ }_{0}$ Corbon, total recoverablo

cis-1,2.Dichloroethylene

2 fron, total recoverable

O Manganese, tolal recoverable

Decoverab

0 Nitrate as nitrogen

Tetrachloroethylene

Trichloroelthylen

Gross alpha

atilo beta

\section{WELLP 26B}

MEASUREMENTS CONDUCTED IN THE FIELD

Sample date: $05 / 04 / 99$
Depth to water: $46.75 \mathrm{ft}(14.25 \mathrm{~m})$ below TOC
Water olevalion: $107.35 \mathrm{tt}(32.72 \mathrm{~m}) \mathrm{msl}$

pH: 5.8

Sp. conductance: $66 \mu \mathrm{s} / \mathrm{cm}$

Water evacualed from the well prior to sampling: $60 \mathrm{gal}$

ANALYSES

\begin{tabular}{|c|c|}
\hline Analyto & Result \\
\hline $\begin{array}{ll}\text { O } & \text { Aluminum, total recoverable } \\
2 & \text { Aluminum, total recoverabble } \\
0 & \text { Barium, toial recoverable } \\
0 & \text { Boron, tolal recoverable } \\
0 & \text { Boron, total recooverable } \\
0 & \text { Carbon tetrachloride } \\
0 & \text { Carbon telrachloride }\end{array}$ & $\begin{aligned}<200 \\
183 \\
15.0 \\
8.90 \\
<66 \\
<1.00 \\
<1.00\end{aligned}$ \\
\hline
\end{tabular}

Total alkalinity (as Caco3): $20 \mathrm{mgh}$
Phenolphthalein alkalinity: $0 \mathrm{mgh}$
Field Qualififer(s): $\mathrm{S}$

EMS SOL

200
146
10.0
100
266
1.00
1.00

Lab Mothod

EX EPAG010B

EX EPA6010B

WA EPAG010B
Well P $26 \mathrm{~B}$ collected on 05/04/99 (cont.)

\begin{tabular}{|c|c|c|c|c|c|c|c|c|}
\hline Analyto & Result & $F G$ & $s$ & EMS & $S O L$ & Unit & Lab & Method \\
\hline 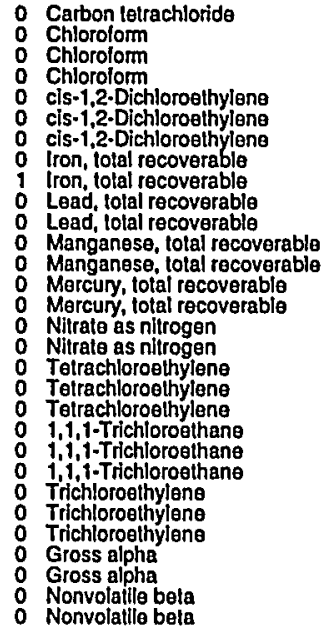 & $\begin{array}{l}<1.00 \\
<1.00 \\
<1.00 \\
<1.00 \\
<1.00 \\
<1.00 \\
<1.00 \\
82.0 \\
299 \\
<10.0 \\
<4.0 \\
<8.00 \\
20.7 \\
<0.500 \\
<0.710 \\
479 \\
441 \\
<1.00 \\
<1.00 \\
<1.00 \\
<1.00 \\
<1.00 \\
<1.00 \\
<1.00 \\
<1.00 \\
<1.00 \\
7.64 E-10 \pm 4.78 E-10 \\
6.40 E-10 \pm 5.00-10 \\
1.06=-09 \pm 6.876-10 \\
9.00 E-10 \pm 8.50 E-10\end{array}$ & $\begin{array}{l}u \\
u \\
u \\
u\end{array}$ & a & 6 & $\begin{array}{l}1.00 \\
1.00 \\
1.00 \\
1.00 \\
1.00 \\
1.00 \\
1.00 \\
200 \\
74.0 \\
10.0 \\
47.0 \\
10.0 \\
7.80 \\
0.500 \\
0.710 \\
100 \\
20.0 \\
1.00 \\
1.00 \\
1.00 \\
1.00 \\
1.00 \\
1.00 \\
1.00 \\
1.00 \\
1.00 \\
6.65 E-10 \\
6.90 E-10 \\
1.396 .09 \\
1.40=09\end{array}$ & 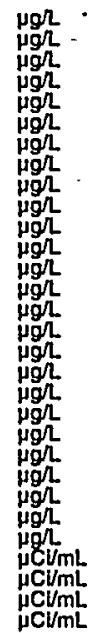 & $\begin{array}{l}\text { WA } \\
\text { EX } \\
\text { EX } \\
\text { WA } \\
\text { EX } \\
\text { EX } \\
\text { WA } \\
\text { EX } \\
\text { WA } \\
\text { EX } \\
\text { WA } \\
\text { WA } \\
\text { EX } \\
\text { WA } \\
\text { WX } \\
\text { WA } \\
\text { EX } \\
\text { WA } \\
\text { WX } \\
\text { EX } \\
\text { WA } \\
\text { EX } \\
\text { EX } \\
\text { WA } \\
\text { GP } \\
T M \\
\text { GP } \\
\text { TM }\end{array}$ & 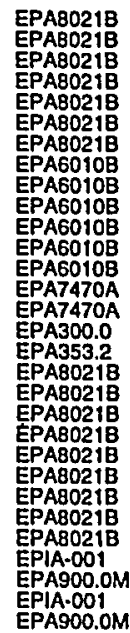 \\
\hline
\end{tabular}

\section{WELL P 26B Replicate}

MEASUREMENTS CONOUCTED IN THE FIELD

Sample date: 05/04/99

$\mathrm{pH}: 5.8$

Sp. conductance: $66 \mu \mathrm{S} / \mathrm{cm}$

Water evacuated from the well prior to sampling: $60 \mathrm{gal}$ ANALYSES

Result

: Aluminum, total recoverable

Bartum, tolal recoverable

Carbon fetrachloride

Chioroform

\section{: cis-1,2.Dichloroethylene}

Iron, tolal recoverable

Manganese, total racoverable

Marcury, tolal recoverable

Nitrate as nitrogen

Tetrachloroethylen

i,1,1-Trichloroethane

Trichloroethylens

Gross alpha 
WELLL 26D

MEASUREMENTS CONDUCTED IN THE FIELD

Sample date: $05 / 04 / 99$
Depth to water: $37.45 \mathrm{ft}(11.41 \mathrm{~m})$ below TOC
Water elevation: $116.45 \mathrm{H}(35.49 \mathrm{~m}) \mathrm{ms}$

$\mathrm{pH}: 5.7$

p. conductance: $33 \mu \mathrm{S} / \mathrm{cm}$

Water evacuated from the well prior to sampling: $30 \mathrm{gal}$

ANALYSES

$F$ Analyto

- Aluminum, lotal recoverable

B Barium, lotal recoverable

Carbon telrachlorida

Chiorolorm

cis: $1,2 \cdot$ Dichloroethylene

Manganese, total recoverable

Mercury, total recoverable

Nitrate as nitrogen

1,1,1-Trichloryleolhane

Trichloroethylene

Trichloroethylen

Gross alpha

Nonvolailie beta
0 Nonvolatle bela

WELLL PBP 1D

MEASUREMENTS CONDUCTED IN THE FIELD

Sample date: 06/15/99

Wepth to water: $38.89 \mathrm{ft}(11.85 \mathrm{~m})$ below TOC

oH: 5.3 .

p. conductance: $43 \mu \mathrm{S} / \mathrm{cm}$

Tubidity: $1 \mathrm{NTU}$.
Water evacuated from the well prior to sampling: $8 \mathrm{gal}$

ANALYSES

ESH-EMS-990521

Result
$<146$
$<40.0$
12.3
$<266$
$<4.70$
692
3.330
$<1.60$
$<26.6$
$<30.0$
$<47.0$
1.20
445
15.0
$<0.700$
1.400
2,850
$<66.0$
6.640
$<5.00$
3.160
935
14,000
375
$<120$

cis-1,2.Dichloroethylene
Iron, total recoverable
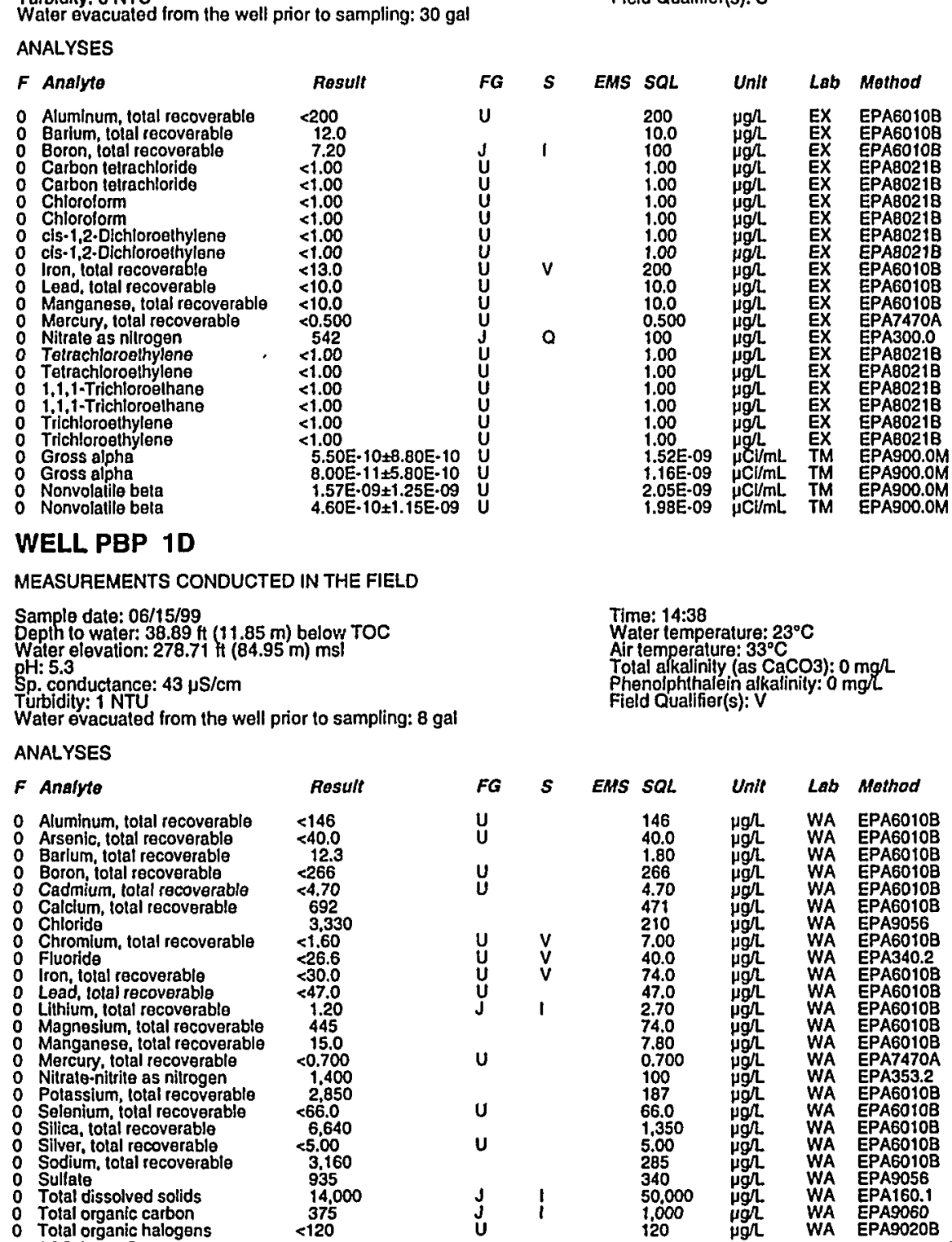

\section{Time: 11:11 \\ Water lemperature: $20.4^{\circ} \mathrm{C}$ Total alkalinity: (as CaCO3): $15 \mathrm{mg} / \mathrm{L}$ Phenolphinalein alkain}

\section{ime: 14:38}

Water temperature: $23^{\circ} \mathrm{C}$

Total alkalinity (as CaCO3): $0 \mathrm{mg} /$ Phenojphthalein alkalinity: $0 \mathrm{mg}$.
Field Qualifier(s): $v$

U日

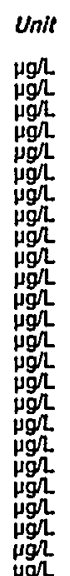

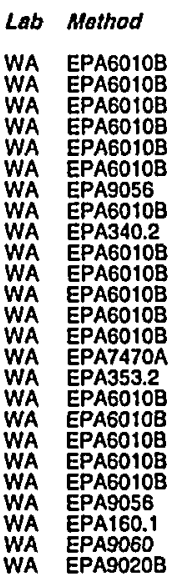

Well PBP 10 collacted on 08/15/99 (cont.)

F Analyto

0 Total phosphates (as P)

o Gross alpha

Nonvolatlla beta

0 Tritium

$\begin{array}{ll}\text { Rosult } & F C \\ <67.0 & U \\ 9.20 E-10 \pm 5.50 E-10 & J \\ 3.70 E-10 \pm 4.60 E-10 & U \\ 1.67 E-09 \pm 1.01 E-09 & J \\ 2.11 E-091.03 E \cdot 09 & J \\ 2.53 E-00 \pm 4.50 E \cdot 07 & \end{array}$

FG

S

MS SQL Unit Lab Mothod

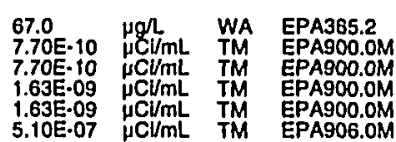

\section{WELLL PBP 2D}

MEASUREMENTS CONDUCTED IN THE FIELD

Sample date: 06/15/99

Depth to waler: 38.5 H $(11.73 \mathrm{~m}$ ) below TOC

pH: 4.8

$\mathrm{Sp}$. conductance: $30 \mu \mathrm{S} / \mathrm{cm}$

Water evacuated from the well prior to sampling: $7 \mathrm{gal}$

ANALYSES

$F$ Analyto

- Aluminum, total recoverablo

Arsenic, total recoverable
Barium, total recoverable

Boron, total recoverable

Calclum, total recoverable

Chiorldo

Chromlum, total recoverable

Fluoride

Lead, total recoverable

Lithium, lotal recoverablo

Magnesium, total recoverable

Mercury, total recoverable

Nitrale.nilirite as nilrogen
Potassium, total recoverable

Silica, tolal recoverable

Silver, total recoverable

Sodium,

Tulialo

Total organic carbon

Tolal organic halogens
Total phosphates (as P)

Gross alpha

0 Trilium

WELL PBP 3D

MEASUREMENTS CONDUCTED IN THE FIELD

Sample date: 06/15/99

Depth to water: $41.08 \mathrm{ft}(12.52 \mathrm{~m})$ below TOC

Water 1

n: $278.32 \mathrm{ft}(84.83 \mathrm{~m}) \mathrm{ms}$

p. conductance: $32 \mu \mathrm{S} / \mathrm{cm}$

Water evacuated from the well prior to sampling: $15 \mathrm{gal}$

ANALYSES

$F$ Analyte

2 Aluminum, total recoverable

Arsenic, Lolai recoverable

Boron, tolal recoverable

Calcium, tolal recoverable

8-184

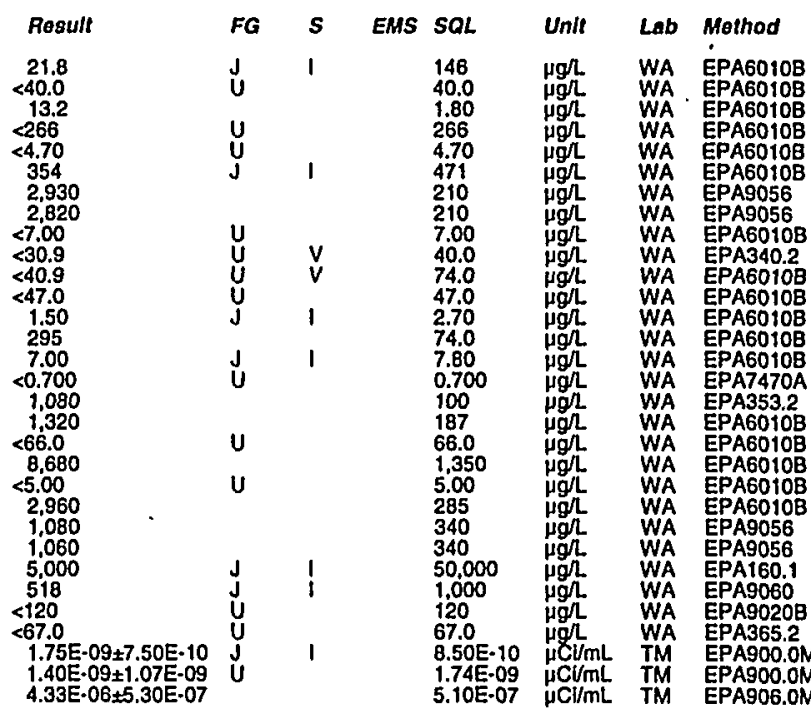

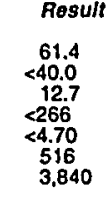

Time: 15:03

Aater temperature: $20.7^{\circ} \mathrm{C}$

Tolal alkalinity (as CaCO3): $0 \mathrm{mg} / \mathrm{L}$

Field Qualiffirer(s): $V$ alinity: $0 \mathrm{mg}$.

Time: 14:01

The $21.7^{\circ} \mathrm{C}$

Field Qualifier(s):

146
40.0
1.80
266
4.70
471
210

$\begin{array}{lr}146 & \mu g h \\ 40.0 & \mu g h \\ 1.80 & \mu g h \\ 266 & \mu g h \\ 4.70 & \mu g h \\ 471 & \mu g h \\ 210 & \mu g h \\ & \text { Sacond }\end{array}$

Lab Mathod

WA EPAG0100

WA EPAGO1OB

WA EPAGO10B

WA EPA9056

Second Quarter 1999
Tolal alkalinity (as CaCo3): $0 \mathrm{mg} / 2$ 
Well PBP 3D collected on 06/15/99 (cont.)

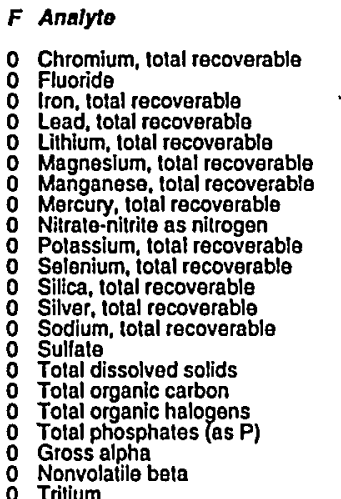

Result

$\begin{array}{ll}<1.40 & \\ <38.8 & U \\ 135 & \\ <47.0 & \\ 0.590 & \\ 765 & \\ 10.8 & \\ <0.700 & \\ 1.040 & \\ 570 & \\ <66.0 & \\ 4.400 & \\ <5.00 & \\ 2.960 & \\ 815 & \\ 12,000 & J \\ 238 & J \\ <120 & \\ <67.0 & U \\ 1.40 E-09+6.80 E-10 & J \\ 9.30 E-10+1.03 E-09 & U \\ 2.29 E-06 \pm 4.20 E .07 & \end{array}$

\section{WELL PSB 1A}

MEASUREMENTS CONDUCTED IN THE FIELD

\section{Sample date: $05 / 21 / 99$
Depth to waler: $52.35 \mathrm{ft}(15.96 \mathrm{~m})$ below TOC

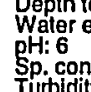 \\ Sp. conductance: $47 \mu \mathrm{S} / \mathrm{cm}$}

Water evacuated from the well prior to sampling: $30 \mathrm{gal}$ ANALYSES

\begin{tabular}{|c|c|c|c|c|c|c|c|}
\hline F Analyte & Result & $F G$ & EMS & SOL & Untt & Lab & Method \\
\hline $\begin{array}{ll}0 & \text { lodine.129 } \\
0 & \text { Strontium.90 }\end{array}$ & $\begin{array}{c}5.36 E-11 \pm 5.33 E-10 \\
-1.83 E-10+6.98 E-10\end{array}$ & & & $\begin{array}{l}1.01 \mathrm{E}-09 \\
1.42 \mathrm{E}-09\end{array}$ & ${ }_{\mu \mathrm{C} / \mathrm{mL}}^{\mu \mathrm{C} / \mathrm{mL}}$ & $\underset{G P}{G P}$ & $\begin{array}{l}\text { EPIA.006 } \\
\text { EPIA.004 }\end{array}$ \\
\hline
\end{tabular}

MEASUREMENTS CONDUCTED IN THE FIELD

Sample dale: 05/21/99

Depth to water: 47.19 ft $(14.38 \mathrm{~m})$ below TOC
Water elevation: $276.51 \mathrm{ft}(84.28 \mathrm{~m}) \mathrm{msl}$

Sp. conductance: $62 \mu \mathrm{S} / \mathrm{cm}$

Turbidity: $1 \mathrm{NTU}$
Water evacuated from the well prior to sampling: $52 \mathrm{gal}$

ANALYSES

$F$ Analyio

Rosult

FG

$\begin{array}{lll}0 & \text { lodina } 129 \\ 0 & \text { Strontlum-90 }\end{array}$

$1.64 E-10 \pm 4.58 E-10$
$8.67 \mathrm{E}-10 \pm 5.31 \mathrm{E}-10$

\section{WELL PSB 2A Replicate}

MEASUREMENTS CONDUCTED IN THE FIELD

Sample dale: 05/21/99

Water elevation: 276.51 f $(14.38 \mathrm{~m})$ below TOC

$\mathrm{pH}: 5$

conductance: $62 \mu \mathrm{S} / \mathrm{cm}$

Water evacuated from the well prior to sampling: 52 gal Phenolphthalein alkalinity: $0 \mathrm{mg}$
Well PSB 2A collected on 05/21/99 (cont.)

ANALYSES

\begin{tabular}{|c|c|c|c|c|c|c|c|c|}
\hline F Analyto & Result & FG & $s$ & EMS & SQL & Unit & Lab & Method \\
\hline $\begin{array}{ll}0 & \text { lodine-129 } \\
0 & \text { lodine-129 } \\
0 & \text { Strontium-90 } \\
0 & \text { Strontium-90 }\end{array}$ & $\begin{array}{l}9.50 E-10 \pm 8.64 E-10 \\
2.34 E-10 \pm 7.27 E-10 \\
-1.34=-10 \pm 1.3 E-09 \\
-5.79 E-10 \pm 0.23 E-10\end{array}$ & & & & $\begin{array}{l}1.42 E-09 \\
6.92 E-10 \\
2.49 E-09 \\
1.58 E-09\end{array}$ & $\begin{array}{l}\mu \mathrm{Ci} / \mathrm{mL} \\
\mu \mathrm{Ci} / \mathrm{mL} \\
\mu \mathrm{Cu} / \mathrm{mL} \\
\mu \mathrm{CI} / \mathrm{mL}\end{array}$ & $\begin{array}{l}\mathrm{GP} \\
\mathrm{GP} \\
\mathrm{GP} \\
\mathrm{GP}\end{array}$ & $\begin{array}{l}\text { EPIA-006 } \\
\text { EPIA.006 } \\
\text { EPIA-004 } \\
\text { EPIA-004 }\end{array}$ \\
\hline
\end{tabular}

\section{WELL PSB 3A}

MEASUREMENTS CONDUCTED IN THE FIELD

Sample date: 05/21/99

Deph to water: $43 \mathrm{ft}(13.11 \mathrm{~m})$ below TOC

pH: 4.7

Sp. conductance: $41 \mu \mathrm{S} / \mathrm{cm}$

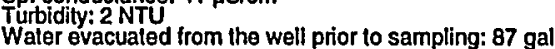

ANALYSES

F Analyte Result $F G \quad S$ EMS SQL Unit Lab Method

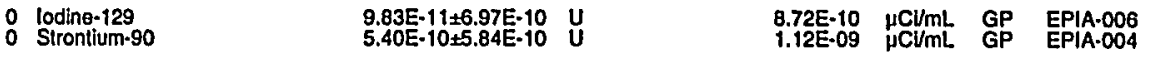

\section{WELL PSB 4A}

MEASUREMENTS CONDUCTED IN THE FIELD

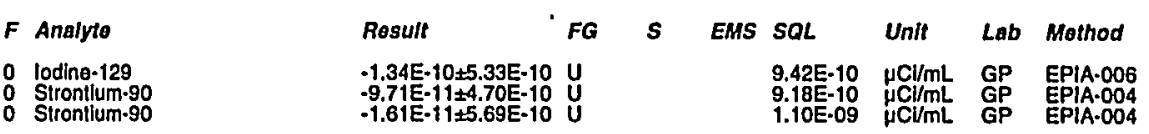

Sample date: 05/24/99 $(11.39 \mathrm{~m})$ below TOC

Water elevation: $275.12 \mathrm{H}(33.86 \mathrm{~m}) \mathrm{ms}$

Sp: 4.7 conductance: $45 \mu \mathrm{S} / \mathrm{cm}$.

Wuater evacualed from the well prior to sampling: $76 \mathrm{ga}$

ANALYSES

\section{WELL PSB 5 A}

MEASUREMENTS CONDUCTED IN THE FIELD

Total akalinity (as Caco3): $0 \mathrm{mgh}$

Phenolphthalein alkalinity: $0 \mathrm{mg} / \mathrm{L}$
Field Qualifier(s): $\mathrm{S}$

Time: 11:30

rature: $20.4^{\circ} \mathrm{C}$

Air temperature: $28.5^{\circ} \mathrm{C}$

Total alkalinity (as CaCO3): $0 \mathrm{mg}$

Field Qualifier(s): $s$

Time: 8:54 Air temperalure: $20.3^{\circ} \mathrm{C}$ C
Sample date: $05 / 24 / 99$ Water elevation: $276.47 \mathrm{ft}(84.27 \mathrm{~m}) \mathrm{ms}$

pH: 4.7 conductance: $48 \mu \mathrm{S} / \mathrm{cm}$

Water evacualed from the well prior to sampling: $24 \mathrm{gal}$

ANALYSES

$F$ Analyto

$\begin{array}{lll}2 & \text { lodine }-129 \\ 0 & \text { lodine-129 } \\ 0 & \text { Stronlium.90 }\end{array}$

Result

FG $s$

$1.06 E-09 \pm 5.48 E-10$
$4.23 E-10 \pm 2.12 E-09$
$-3.58 E-10 \pm 5.66 E-10$
$U$

Time: 10:47

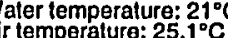
Tolal alkainily (as CaCo3): $0 \mathrm{mg} /$ Field Qualifier(s): $s$ alinity: $0 \mathrm{mg}$ $\begin{array}{llll}1.43 E-09 & \mu C V / m L & G P & E P I A-006 \\ 9.75 E-10 & \mu C V / m L & G P & \text { EPIA.004 }\end{array}$

Sronlum.
Unit Lab Mothod
8.64E-10 $\mu \mathrm{CVmL}$ GP EPIA.006

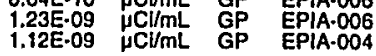


WELL PSB 6A

MEASUREMENTS CONDUCTED IN THE FIELD

Sample date: 05/24/99
Depth to water: $46.61 \mathrm{H}(14.21 \mathrm{~m})$ below TOC
Water elevation: $277.59 \mathrm{ft}(84.61 \mathrm{~m}) \mathrm{ms}$

Water e

Sp. conductance: $58 \mu \mathrm{S} / \mathrm{cm}$

Turbidity: 1 NTU
Water evacualed Irom the well prior to sampling: $60 \mathrm{gal}$

ANALYSES

$F$ Analyto

Rosult

$F G$

$s$

$\begin{array}{ll}0 & \text { lodine-129 } \\ 0 & \text { Strontium-90 }\end{array}$

$\begin{array}{ll}1.77 \mathrm{E} \cdot 09 \pm 1.91 \mathrm{E}-09 & U \\ 5.12 \mathrm{E}-10 \pm 1.22 \mathrm{E}-09 & \mathrm{U}\end{array}$

WELL PSB 7A

MEASUREMENTS CONDUCTED IN THE FIELD

Sample dato: $05 / 21 / 99$

Sample dale: 05/21/99
Depth to water: 53.51 it $(16.31 \mathrm{~m})$ below TOC
Waler elevation: $277.19 \mathrm{ft}(84.49 \mathrm{~m}) \mathrm{ms}$

Dephth to
Water
pH: 5.2

SH: 5.2 conductance: $37 \mu \mathrm{S} / \mathrm{cm}$

Waler evacualed from the well prior to sampling: $35 \mathrm{ga}$

ANALYSES

F Analyte Result FG $S$ EMS SQL Unlt Lab Mothod

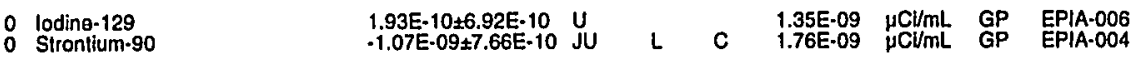

WELL RBP 10

MEASUREMENTS CONDUCTED IN THE FIELD

Sample date: 06/15/99
Depth to water: 49.58 ft (15.11 m) below TOC
Waler elevation: 256.12 ft $(78.07 \mathrm{~m}) \mathrm{msl}$
pH: 4.8

S.

Water evacualed from the well prior to sampling: $9 \mathrm{gal}$

ANALYSES

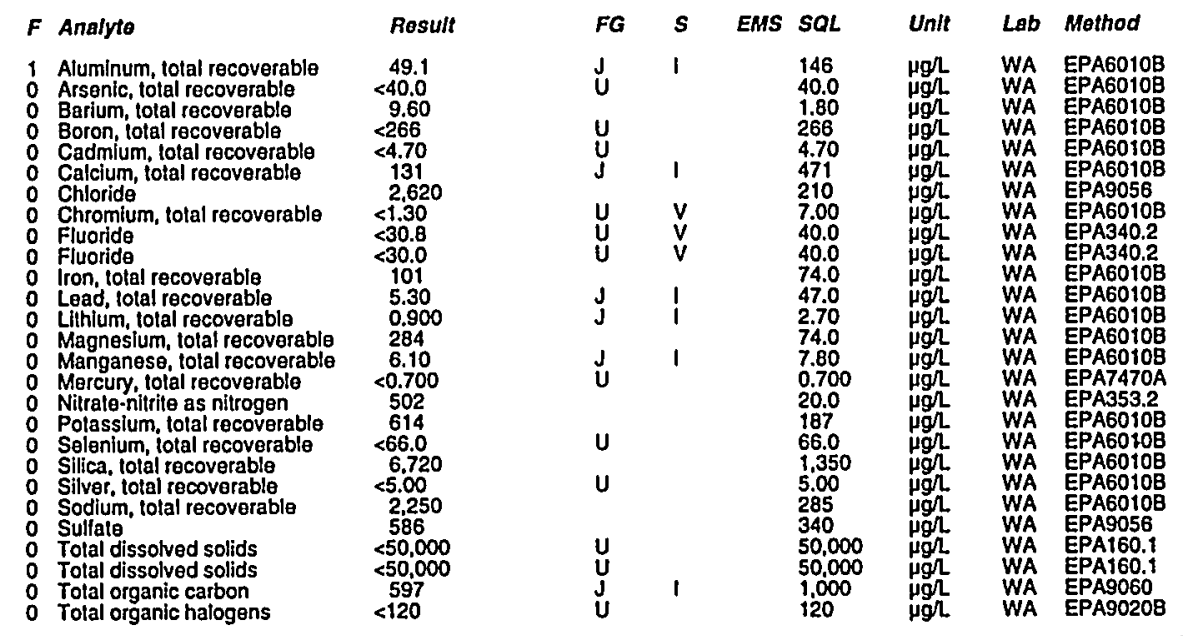

ESH-EMS-990521

Time: 10:10

Total alkalinify (as CaCo3); 0 mor

Phenolphithalein alkalinity: $0 \mathrm{mg} L$
Field Qualifier(s): $\mathrm{S}$

EMS SOL Unt Lab Mothod $\begin{array}{llll}1.13 E-09 & \mu \mathrm{C} V / m L & \text { GP } & \text { EPIA.006 } \\ 2.23 E \cdot 09 & \mu \mathrm{Cl} / \mathrm{mL} & \text { GP } & \text { EPIA.004 }\end{array}$

Tims: 10:10

Air ter temperature: $22.3^{\circ} \mathrm{C}$ Total alkalinity (as CaCO3): $0 \mathrm{mg} /$. Pienolphihalein alkalinity: $0 \mathrm{mgl}$

Time: 13:20

Waler temperalure: $19.7^{\circ} \mathrm{C}$ Aotal alkalinity (as CaCO3): $0 \mathrm{mgh}$
Phenolphthalein alkalinity: $0 \mathrm{mg}$ L

Well RBP 10 collected on 06/15/99 (cont.)

$F$ Analyto

0 Tolal phosphates (as P)

o Nonvolatile bela

T Tritum

Result

WELL RBP 2D

MEASUREMENTS CONDUCTED IN THE FIELD

Sample date: 06/10/99

Depth to waler: 47.54 HI $(14.49 \mathrm{~m})$ below TOC

Water e wa

Sp. conductance: $70 \mu \mathrm{S} / \mathrm{cm}$

Waler evacuated from the well prior to sampling: $10 \mathrm{ga}$

ANALYSES

$F$ Analyte

1 Aluminum, total recoverable

Barium, total recoverabla

Boron, total recoverable

Calcium, iolat recoverab

Chromlum, tolai recoverable
cis-1,2-Dichloroethylene

Fluoride

o Lead, total recoverabable

Magnesium, rotal recoverablo

Manganess, lotal recoverde

Nitrale-nilicite as nitrogen
Nitrale-nitrite as nitrogen

Selenlum, iotal recoverable

Silver, lotal recoverab

0 Sodium, total recover

Totrachloroethylene

Tolal organic carbon
Total organic halogens
Total hosphates (as P)

1,1,1-Trichloroethane

Gross alpha

$0 \begin{aligned} & \text { Nonvolatili } \\ & 0 \text { Tritium }\end{aligned}$

17.5
$6.70 E-10 \pm 5.50 E-10 \mathrm{U}$ $1.27 \mathrm{E} \cdot 06 \pm 3.60 \mathrm{E}-07$

(1)

EMS SOL Unth Lab Method

67.0 ${ }_{8.20 E-10} \mu \mathrm{h}$ WA EPA365.2

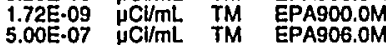

\section{WELL RBP 3D}

MEASUREMENTS CONDUCTED IN THE FIELD

Sample date: 06/10/99

Water elevation: 261.43 it $(79.68 \mathrm{~m}) \mathrm{ms}$

SH: 5.2 conductance: $39 \mu \mathrm{S} / \mathrm{cm}$

Wubier evacualed from the well prior to sampling: 12 ga

ANALYSES

$F$ Analyto

Result

Aluminum, total recoverable

Barium, total recoverable

430
$<40.0$
6.40
$<66$

$F$
$U$

Time: 11:0

Air temperature: $31.8^{\circ} \mathrm{C}$

Total alkalinity (as CaCo3): 0 mgr

Field Qualfier(s): $V$

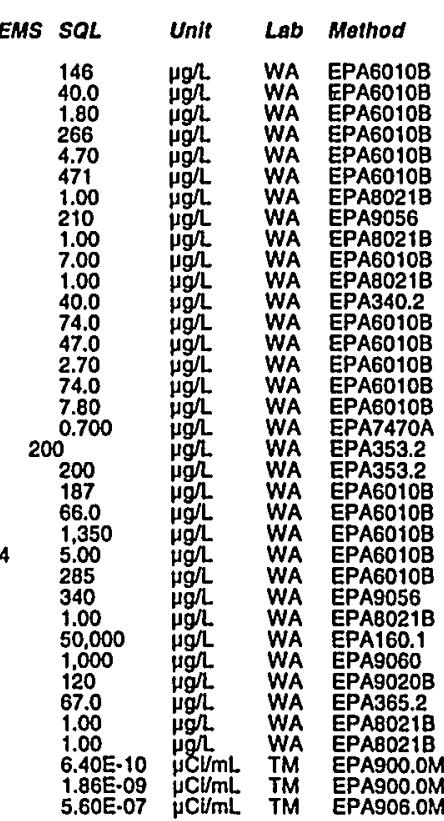

Time: 10:37

Waler temperature: $19.5^{\circ} \mathrm{C}$

Total alkalinity (as CaCO3): $0 \mathrm{mg}$

EMS SQ
146
40.
1.80
266

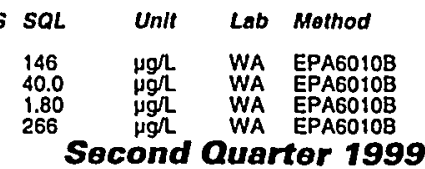

Phenolphthalein alkalinity: $0 \mathrm{mg}$ L 
Well ABP 3D collected on 08/10/99 (cont.)

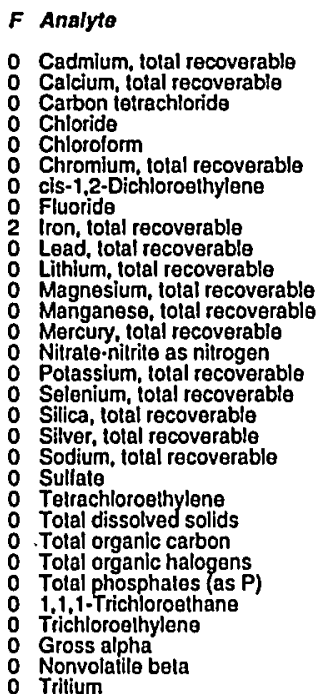

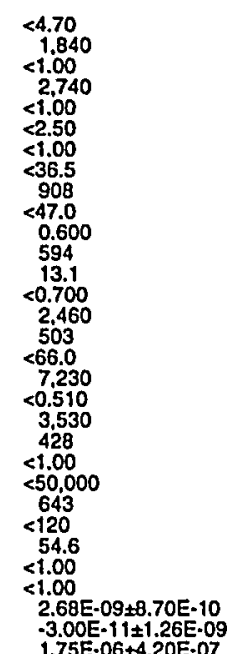

WELL RSA 7

MEASUREMENTS CONDUCTED IN THE FIELD

Sample date: 05/27/99

Water to waler: Not availiable

PH: 5.1 conductance: $28 \mu \mathrm{S} / \mathrm{cm}$

Water evacuated from the well prior to sampling: 6 gal

The well went dry during purging.

ANALYSES

$F$ Analyto

O Carbon-14

Result

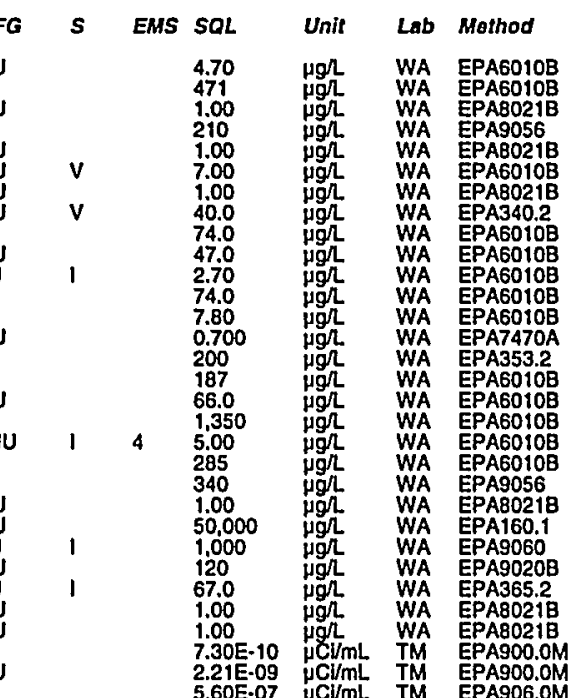

\section{WELLL RSA 7}

MEASUREMENTS CONDUCTED IN THE FIELD

Sample date: 06/17/99

Depth to water: Not available

Sp. conductance: $30 \mu \mathrm{S} / \mathrm{cm}$

Turbidity: 11 NTU
Water evacuated from the well prior to sampling: $1 \mathrm{gal}$
The well wenl dry during purging.

ANALYSES

$F$ Analyto

0 Carbon-14
Result $3.38 E-09 \pm 4.46 E-09$
Time: 10:09

Wat $30.6^{\circ} \mathrm{C}$

Total alkalinity (as CaCO3): $7 \mathrm{mg} /$
Phenolphithalein alkalinity: $0 \mathrm{mg} /$

Water timperature: $26.4^{\circ} \mathrm{C}$

Total alkalinity (as Caco3): $0 \mathrm{mg} / \mathrm{L}$

Phenolphthalein alkal
Field Qualifier(s): $S X$

7.51E.09 HCUML GP EPIA.003
WELL RSA 8

MEASUREMENTS CONDUCTED IN THE FIELD

ANALYSES
Sample date: $05 / 14 / 99$

Water elevation: Not available

H: 4.6

Sp.conductance: $21 \mu \mathrm{S} / \mathrm{cm}$

Water evacualed from the well prior to sampling: $1 \mathrm{gal}$

ANALYSES

$F$ Analyto

Result

$-2.62 E-09 \pm 4.66 E-09 U$

G

Carbon-14

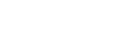

WELL RSA 8

MEASUREMENTS CONDUCTED IN THE FIELD

Sample date: 06/16/99

Water elevation: Nol availabl

H: 4.7

conductance: $23 \mu \mathrm{S} / \mathrm{cm}$

Water evacuated from the well prior to sampling: $1 \mathrm{gal}$

The well went dry during purging.

ANALYSES

$\begin{array}{llllrlll}\text { F Analyto } & \text { Result } & \text { FG } & S & \text { EMS SQL } & \text { Unit } & \text { Lab Melthod } \\ 0 \text { Carbon-14 } & -2.40 E-09 \pm 4.07 E-09 & U & & 7.13 E-09 & \mu \mathrm{CU} / \mathrm{mL} & \text { GP } & \text { EPIA.003 }\end{array}$

MEASUREMENTS CONDUCTEO IN THE FIELD

Sample date: 05/14/99
Depth to water: 13.1 tt $(3.99 \mathrm{~m})$ bolow TOC
Whis

pH: 4.6

. conductance: $26 \mu \mathrm{S} / \mathrm{cm}$

Water evacualed from the well prior to sampling: $1 \mathrm{gal}$

The well went dry during purging.

ANALYSES

F Analyto Result FG $S$ EMS SaL Unit Lab Mathod

$-3.81 E \cdot 09 \pm 4.68 E-09 U$

8.30E.09 $\mu \mathrm{Cl} / \mathrm{mL}$ GP EPIA.003

MEASUREMENTS CONDUCTED IN THE FIELD

Depth to waler: $13.1 \mathrm{ft}(3.99 \mathrm{~m})$ below TOC

Waler ele

Sp. conductance: $32 \mu \mathrm{S} / \mathrm{cm}$

Waler evacuated from the well prior to sampling: 2 gal

well went dry during purging.

F Analyte
Begult

7.89E-10ะ4.36E-09
Time: 10:17

Air temperature: $21.4^{\circ} \mathrm{C}$

Phenolphthalein (as Caco3): $0 \mathrm{mg} \Omega$

ES SQL Unit Lab Mathod

Time: 10:35

政: $24.8^{\circ} \mathrm{C}$

(as CaCO3): $0 \mathrm{mg}$

Field Qualifier(s): $S X$

eralure: $21.2^{\circ} \mathrm{C}$

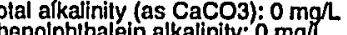
Phenolphihalein alkallinity: $0 \mathrm{mg}$.

o Carbon-14

U

Time: 8:00

Water temperalure: $21.3^{\circ} \mathrm{C}$ Total alkalinity (as CaCo3): $2 \mathrm{mg} \Omega$ Phenolphthalein alkalility: $0 \mathrm{mg}$
Field Qualifier(s): $S$ XN 7.47E.09 $\mu \mathrm{Cl} / \mathrm{mL}$ GP EPIA.003 8.20E-09 $\mu \mathrm{C} / \mathrm{mL}$ GP EPIA.003 


\section{WELL RSD 3}

MEASUREMENTS CONDUCTED IN THE FIELD

Sample date: 05/14/99

Depth to water: $14.45 \mathrm{ft}(4.4 \mathrm{~m})$ below TOC

WH: 4.6

Sp. conductance: $32 \mu \mathrm{S} / \mathrm{cm}$ Waler evacuated from the well prior to sampling: 3 gal
The well went dry during purging.

ANALYSES

$F$ Analyto

Rosult

FG

$-1.06 E-09 \pm 5.14 E-09 U$

- Carbon-14

WELL RSD 3 Replicate

MEASUREMENTS CONDUCTED IN THE FIELD

Sample date: 05/14/99

Deph to water: $14.45 \mathrm{ft}(4.4 \mathrm{~m})$ below TOC

Water eleval 4.6

Sp. conductance: $32 \mu \mathrm{S} / \mathrm{cm}$

Water evacuated from the well prior to sampling: 3 gal

ANALYSES

F Analyte

Result FG

o Carbon-14 $-3.15 \mathrm{E} \cdot 09 \pm 4.58 \mathrm{E}-09 \mathrm{U}$

\section{WELL RSD 3}

MEASUREMENTS CONDUCTED IN THE FIELD

Sample date: $06 / 17 / 99$
Depth to water: $14.45 \mathrm{ft}(4.4 \mathrm{~m})$ below TOC
Water elevation: $286.35 \mathrm{ft}(87.28 \mathrm{~m}) \mathrm{msl}$

Water elevation: $286.35 \mathrm{ft}(87.28 \mathrm{~m}) \mathrm{msl}$

Sp. conductance: $44 \mu \mathrm{S} / \mathrm{cm}$

Water evacuated from the well prior to sampling: 1 gal

The well went dry during purging.

ANALYSES

F Analyto

Result

9.19E-10ะ4.26E-09 U

$G$

0 Carbon-14

\section{WELL RSE $1 \mathrm{~A}$}

MEASUREMENTS CONDUCTED IN THE FIELD

Sample dalo: 05/4/99

Depth to water: $21.86 \mathrm{ft}(6.66 \mathrm{~m})$ below TOC

Water e .2 ductance: $20 \mu \mathrm{s} / \mathrm{cm}$

Water evacuated from the well prior to sampling: $1 \mathrm{gal}$ The well went dry during purging.

ANALYSES

$F$ Analyto

0 Carbon-14

Result

FG

$-5.81 E-09 \pm 4.64 E-09$ U
Time: $11: 14$

$303^{\circ} \mathrm{C}$ Total alkalinity (as Caco3): $5 \mathrm{mg} /$
Phenolphthalein alkalinily: 0 mg

EMS SQL Unlt Lab Method 8.95E-09 $\mu \mathrm{Cl} / \mathrm{mL}$ GP EPIA.003

Time: 11:14

Water temperature: $20.3^{\circ} \mathrm{C}$ Total alkalinity (as CaCO3): $5 \mathrm{mg} / \mathrm{h}$ Phenolphithalein alkalinity: $0 \mathrm{mg}$ L

Field Quatifier(s): 8.09E.09 $\mu \mathrm{Cl} / \mathrm{mL}$ GP EPIA.003

Time: 8:20

Waler temperature: $20.1^{\circ} \mathrm{C}$

Total alkalinity (as CaCo3): $5 \mathrm{mg}$

Total alkalinity (as Caco3): $5 \mathrm{mg} / \mathrm{h}$
Phenolphthalein alkalinity: $0 \mathrm{mgh}$
Field Qualifier(s): $\mathrm{SX}$

EMS SQL Unit Lab Method

7.30E.09 $\mu \mathrm{C} / \mathrm{mL}$ GP EPIA.003

Time: 11:17

mperalure: $23.4^{\circ} \mathrm{C}$

Total afkalinity (as CaCO3): $0 \mathrm{mg} / \mathrm{L}$

Phenolphthalein alkalinity: $0 \mathrm{mg} L$

EMS SOL Unit Lab Mothod

8.36E.09 $\mu \mathrm{CI} / \mathrm{mL}$ GP EPIA.003
WELL RSE 1A

MEASUREMENTS CONDUCTED IN THE FIELD

Sample date: 06/16/99

Wepth to water: 25.91 if $(7.9 \mathrm{~m})$ below TOC

Water elevation: 278.29 \&t $(84.82 \mathrm{~m}) \mathrm{msl}$

Sp. conductance: $29 \mu \mathrm{S} / \mathrm{cm}$

Water evecuated from the well prior to sampling: $1 \mathrm{gal}$ The well went dry during purging.

ANALYSES

$F$ Analyte

Result

$1.34 \mathrm{E} \cdot 09 \pm 4.20 \mathrm{E}-09$

G

- Carbon-14

1.34E.09.4.20

MEASUREMENTS CONDUCTED IN THE FIELD

Sample date: 05/14/99

Depth to waler: $20.96 \mathrm{ft}(6.39 \mathrm{~m})$ below TOC

$\mathrm{pH}: 4.5$

Sp. conductance: $26 \mu \mathrm{S} / \mathrm{cm}$

Water evacuated from the well prior to sampling: 3 gal

The well went dry during purging.

ANALYSES

F Analyte

Rosult

$F G$

- Carbon-14

$-4.91 E-10 \pm 4.79 E-09$ U

s

Time: $12: 40$

erature: $25.9^{\circ} \mathrm{C}$

Total alkalinily (as $\mathrm{CaCO}$ ): $0 \mathrm{mg}$

Phenolphthalein alkalinity: $0 \mathrm{mg} h$

WELLRSE 2

MEASUREMENTS CONDUCTED IN THE FIELD

Sample date: 06/16/99
Depth to water: $25.91 \mathrm{ft}(7.9 \mathrm{~m})$ below TOC

Water el wa

PH: 4.5 conductance: $49 \mu \mathrm{S} / \mathrm{cm}$

Waler evacuated from the well prior to sampling: $1 \mathrm{gal}$

The well went dry during purging.

ANALYSES

$F$ Analyte

Bosult

0 Carbon-14

2.26E-09 $4.38 \mathrm{E}-09$ U

$s$

\section{WELL RSE 7}

MEASUREMENTS CONDUCTED IN THE FIELD

Sample date: $05 / 14 / 99$

Waler elevation: $275.85 \mathrm{H}(84.08 \mathrm{~m}) \mathrm{ms}$

$\mathrm{gH}: 4.4$ conductance: $120 \mu \mathrm{S} / \mathrm{cm}$

Waler evacuated from the well prior to sampling: 1 gal the well went dry during purging.

ANALYSES

$F$ Analyto

- Carbon-14

$-3.33 E-09 \pm 4.75 E-09 U$ me: 10:45

Wire: $26^{\circ} \mathrm{C}$

Total a kalinity (as CaCO3): 0 mign

Phenolphthalein alkalinity: $0 \mathrm{mg} h$

EMS SaL. Unit Lab Mothod

8.31E.09 $\mu \mathrm{CU} / \mathrm{mL}$ GP EPIA.003

Time: 10:55

Water temperature: $28.8^{\circ} \mathrm{C}$

Tolal alkalinity.(as Caco3): $0 \mathrm{mg}$

Phenolphthalein alkalinity: $0 \mathrm{mg}$

Field Qualifier(s): SX

EMS SOL Unit Lab Mothod

7.42E.09 $\mu \mathrm{Cl} / \mathrm{mL}$ GP EPIA.003

Time: 10:25

Air temperature: $21.2^{\circ} \mathrm{C}$

Total alkalinity.(as CaCO3): $3 \mathrm{mg} /$

Fhend 
WELL RSE 7

MEASUREMENTS CONDUCTED IN THE FIELD

Sample date: 06:17.99
Pepth to waler: $27.15 \mathrm{ft}(8.28 \mathrm{~m})$ below TOC
Waler elevation: $275.25 \mathrm{ht}(83.9 \mathrm{~m})$ msl

Sp. conductance: $38 \mu \mathrm{S} / \mathrm{cm}$

Wurbidily: 34 NTU

Water evacuated from the well pior

ANALYSES

Result

FG

s

O Carbon-14

6.37E-10ะ4.16E.09 U

WELL RSE 7 Replicate

MEASUREMENTS CONDUCTED IN THE FIELD

Sample date: 06/17/99

列

pH: 5.4

Sp. conductance: $38 \mu \mathrm{S} / \mathrm{cm}$

Water evacuated from the well prior to sampling: $1 \mathrm{gal}$
The well went dry during purging. ANALYSES

F Analyte Result FG $S$ EMS SQL Unit Lab Mothod

O Carbon-14

$-1.02 E-09 \pm 4.25 E-09 U$

\section{WELL RSE 8}

MEASUREMENTS CONDUCTED IN THE FIELD

Sample date: 05/14/99

Wepter to water: 17.57 f $(5.36 \mathrm{~m})$ below TOC

H: 4.4

Pp. conductance: $50 \mu \mathrm{S} / \mathrm{cm}$

Water evacuated from the well prior to sampling: 4 gal

The well went dry during purging.

ANALYSES

$F$ Analyto

Result

$F G$

$-5.83 E-10 \pm 4.84 E-09$
$-2.37 E-09 \pm 4.68 E-09$

$\begin{array}{lll}0 & \text { Carbon-14 } \\ 0 & \text { Carbon-14 }\end{array}$

\section{WELLL RSE 8}

MEASUREMENTS CONDUCTED IN THE FIELD

Sample date: 06/16/99

Depth to water: 17.57 H $(5.36 \mathrm{~m})$ below TOC

$\mathrm{gH}: 4.8$

Sp. conductance: $48 \mu \mathrm{S} / \mathrm{cm}$

Water evacuated from the well prior lo sampling: $1 \mathrm{gal}$

ANALYSES

$F$ Analyte

Resul!
$-3.56 E-10 \pm 4.23 E-09 U$
Time: 9:50

Air temperature: $21.6^{\circ} \mathrm{C}$

Total alkalinity (as CaCO3): $7 \mathrm{mg} / \mathrm{h}$
Phenolphthalein alkalinity: $0 \mathrm{mg} /$

EMS SOL

Unit Lab Method

$7.13 E-09 \mu \mathrm{C} / \mathrm{mL}$ GP EPIA.003

Time: 9:50

Air temperature $24.4^{\circ} \mathrm{C}$ Total alkalinity (as CaCo3): $7 \mathrm{mg} /$

WELL RWM 1

MEASUREMENTS CONDUCTED IN THE FIELD

Sample dale: 04/14/99 Water elevation: Nol available

Sp. conductance: $61 \mu \mathrm{S} / \mathrm{cm}$

The wefl was continuously pumping.

ANALYSES

$F$ Analyte

O Benzene

0 Bromolorm

Carbon leltrachloride

Chloroethane

Chloroothene (Vinyl chloride)

Chlorolorm

Dibromochloromethane

1.1.-Dichloroethane

1,1-Dichloroethylene
trans-1,2-Dichloroethylen

Dichloromethane

cis-1,3-Dichloropropene
trans-1,3.Dichloropropene

Eihylbenzene

1,1,2,2-Tetrachloroethan
Totrachloroethylene

1,i,1-Trichloroothane

2 Trichloroelhylene

Time: 10:50

Waler temperature: $25.4^{\circ} \mathrm{C}$

Total alkalinity (as CaCO3): $0 \mathrm{mg} / \mathrm{l}$

Phenolphinalein alkalinity: $0 \mathrm{mgl}$
Fleld Qualifier(s): $s x$

WELL RWM 1

MEASUREMENTS CONDUCTED IN THE FIELD Sample dale: 05/17/99 Wepth to water: Nol available p. conductance: $62 \mu \mathrm{S} / \mathrm{cm}$

EMS SQL Unth Lab Mothod

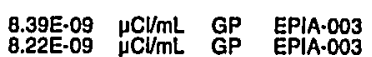

The wel was continuously pumping

ANALYSES

$F$ Analyto

Time: 10:30

Water temperature: $26.7^{\circ} \mathrm{C}$ Total alkalinity (as Caco3): $0 \mathrm{mg}$ Phenoiphinatein alkalinity: $0 \mathrm{mgh}$

o Benzene

Bromoform

Carbon telrachlorid

Chlorobenzene

Chloroethene (Vinyl chloride)

2.Chloroethyl vinyl other

Chlorolorm

Dibromochloromethan

1,1.Dichloroethane

1,1.Dichloroethylene

Dichloromethane

1,2-Dichloroppopane
cis-1,3-Dichloropropene trans-1,3-Dichloropropene 7.31E-09 $\mu \mathrm{CU} / \mathrm{mL}$ GP EPIA.003

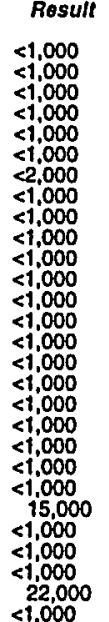

U

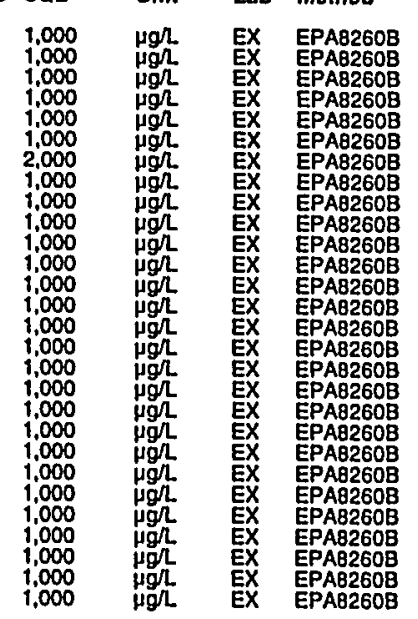

Time: 12:29

Air lemperature: $29.6^{\circ} \mathrm{C} 4^{\circ} \mathrm{C}$

Total alkallinity (as CaCO3): $0 \mathrm{mg} / \mathrm{L}$
Phenolphthalein alkalinity: $0 \mathrm{mg} \mathrm{L}^{2}$

enperature: $19.7^{\circ} \mathrm{C}$

Total alkainity (as CaCo3): $0 \mathrm{mgh}$
Phenolphthalein alkalinity: $0 \mathrm{mg}$

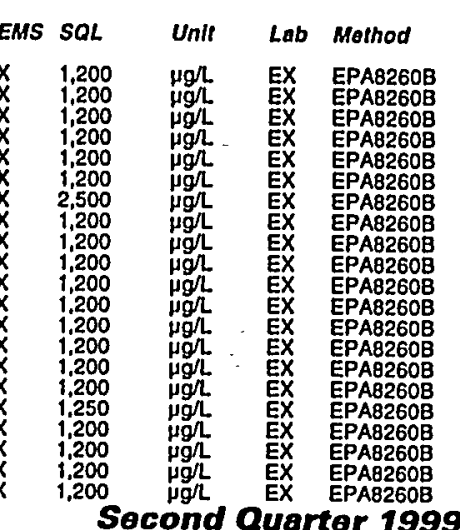




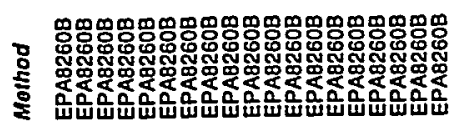

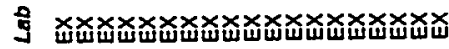

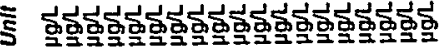

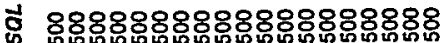
塞

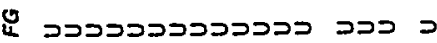

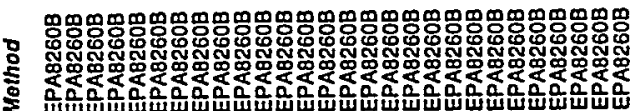

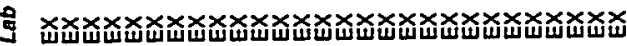

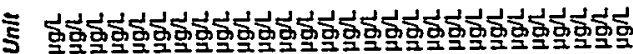

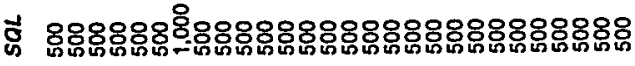

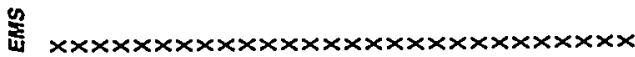

w

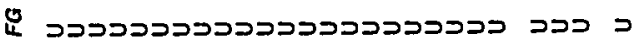
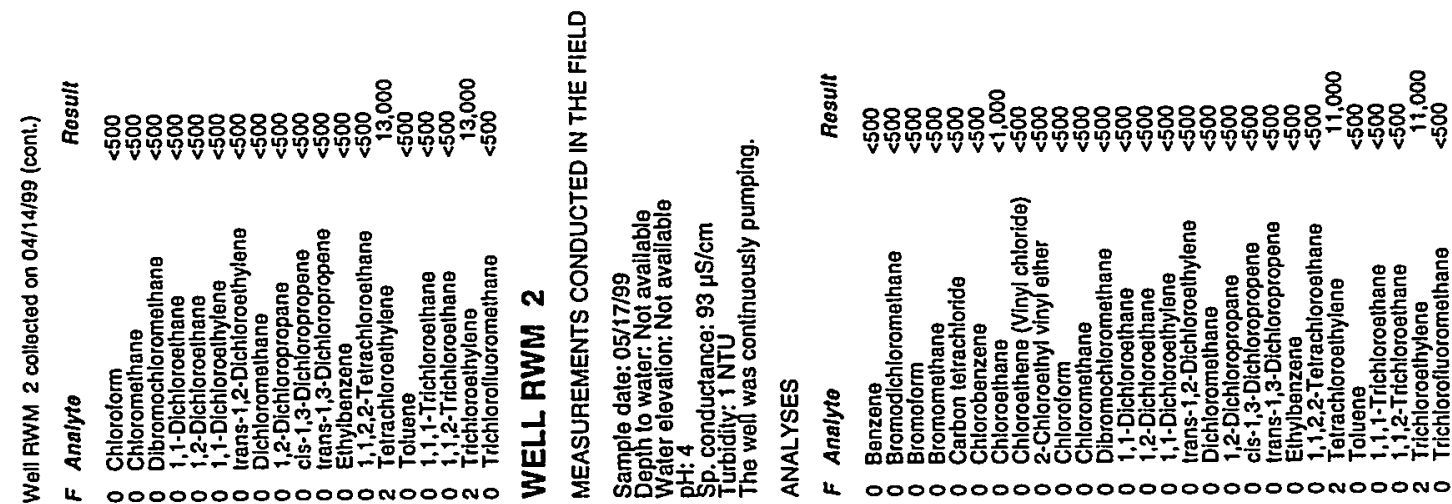

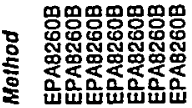

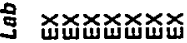

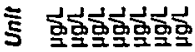

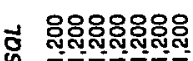

墨

a)

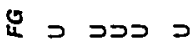

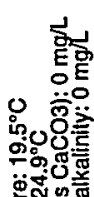

过边产

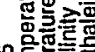

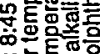

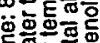

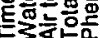

悹

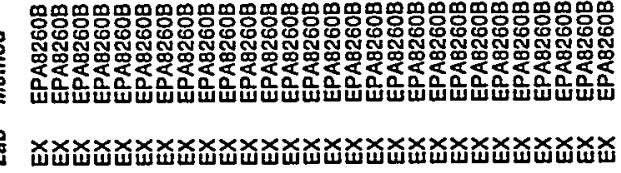

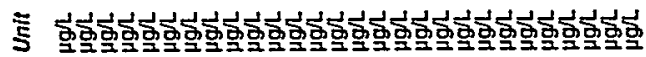

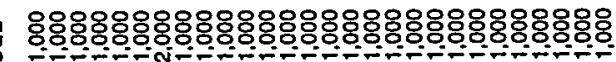

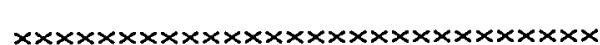

$\infty$

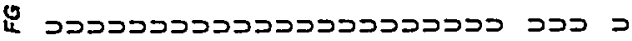

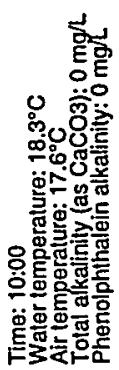

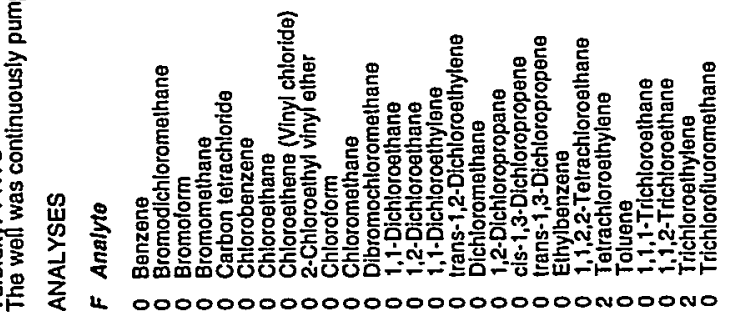

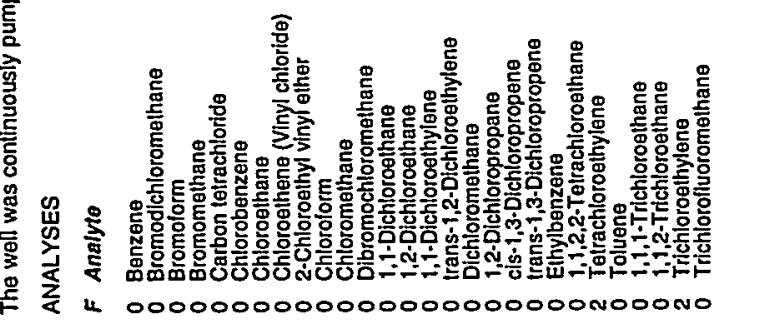

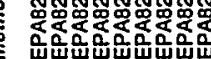

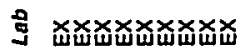

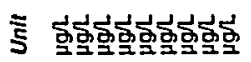

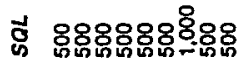

竎

is

\&

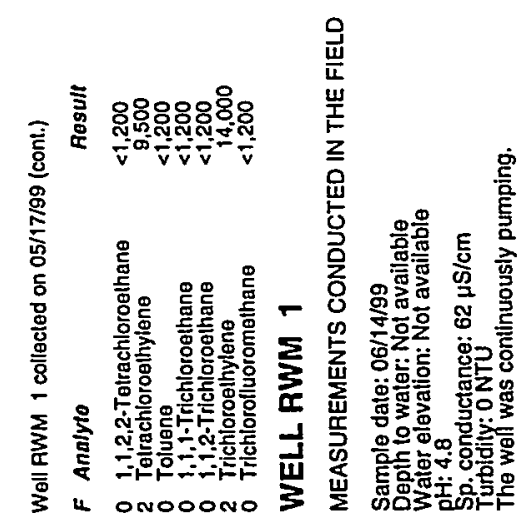

言

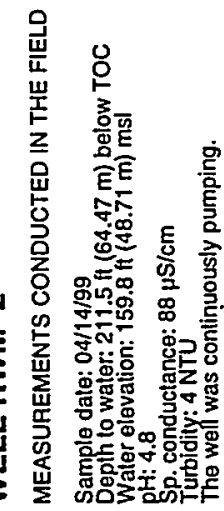

衰
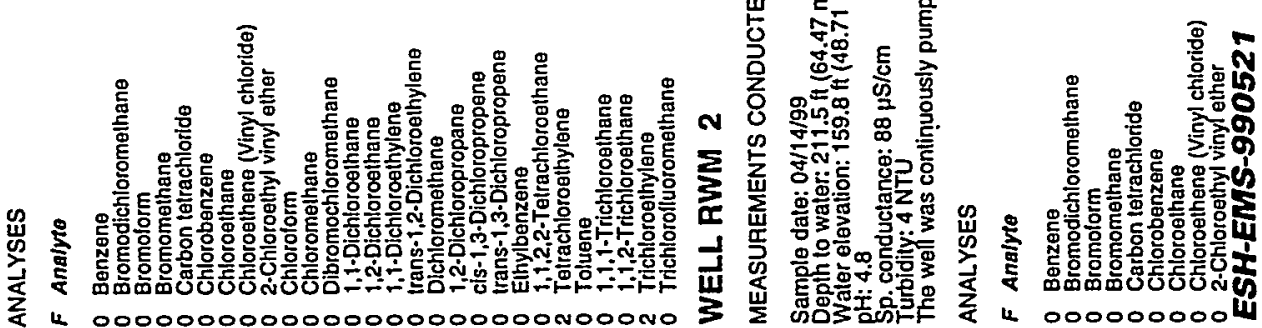


\section{WELL RWM 2}

MEASUREMENTS CONDUCTED IN THE FIELD

Samplo date: 06/14/99 hor water: Not available Sp: 4.6 conductance: $86 \mu \mathrm{S} / \mathrm{cm}$

The wefl was continuously pumping

ANALYSES

$F$ Analyte

0
0
0

$\begin{array}{ll}0 & \text { Bromodichlorom } \\ 0 & \text { Bromotorm } \\ 0 & \text { Bromomethane }\end{array}$

Carbon tetrachioric

Chloroethane

2.Chloroethyl (Vinyl chloride)

Chloroform

O Chloromethane

1,2-Dichloroethane

1,1-Dichloroethylene

1,2-Dichloropropane

0 cis-1,3-Dichloropropene

: Elhylbenzene

1,1,2,2-Tetrachloroethan

o Toluene

o 1,1,1-Trichloroethane

2
2
0 Trichloroethylene
Trichiorofluoromethane

\section{WELL RWM 3}

MEASUREMENTS CONDUCTED IN THE FIELD

Sample date: 04/14/99

Depth o waler: Not available
Water elevalion: Not avaliable

$\mathrm{pH}$ : 4.8 conductance: $48 \mu \mathrm{S} / \mathrm{cm}$

The werl was continuously pumping

ANALYSES

$F$ Analyto

0 Benzene

O Bromodichloromethane

Bromodichloromethane

Bromodlchloromethan

Bromolorm

Bromomethan

Bromomethane

Carbon tetrachloride

Carbon letrachloride

o Chlorobenzen

Chlorobenzene

Chloroethane

ESH-EMS-990521

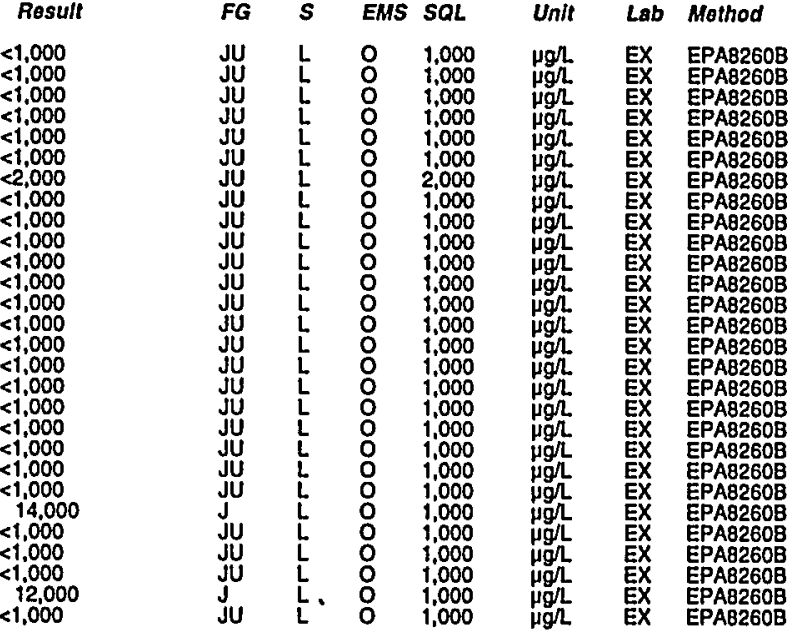

Time: 9:30 Air temperature: $27.9^{\circ} \mathrm{C}$

Phenolphthalein alkalinity: $0 \mathrm{mg} L$

$\boldsymbol{F}$ Analyto

O Chloroethene Vinyl chlorid

2-Chloroethy! vinyl ether

o 2-Chloroethyl vinyl ether

o Chlorolorm

Chlorolorm

0 Chloromethane

o Dibromochloromethane

D Dibromochloromethan

1.1-Dlchloroethan

i,2-Dichloroethan

1.2-Dichloroethane

o 1,1-Dichloroelhylene

$\begin{array}{ll}0 & 1,1-D i c h l o r o a l h y l e n \\ 0 & \text { trans }-1,2-D \text { Dichloroethylene }\end{array}$

trans-1, 2 .Dichlorosthylene
trans-1,2.Dichloroethyleng

trans-1,2-Dichloroe
Oichloromethane

Dichloromethane

0 $1,2-$ Olchloropropane

c cis-1,3.DIchloropropene

cis-1,3.Dichloropropene

Irans-1,3.Dichloropropene

rans-1,3.Dichloropropen

O Ethylbenzeno

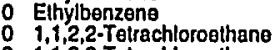

1.1.2.2-Tetrachloroethan

Totrachloroethylene
Telrachloroelhylene

Totrachloroethylene

Toluene

o Tolueno

i, 1,1 - Trichloroothane

o $1,1,1-$ Trichloroeshane

o 1,i,2-Trichloroothane

i.j. Trichioroesthane

Trichloroothylene

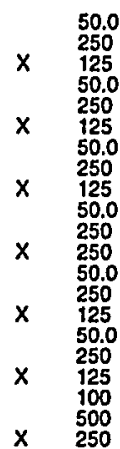

Irlchloroesthylene

Trichlorolluoromemethane

Trichlorolluoromethan

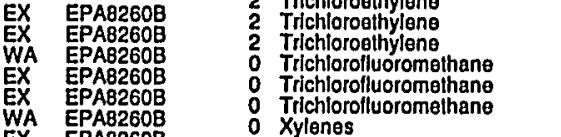

EX EPAB260B

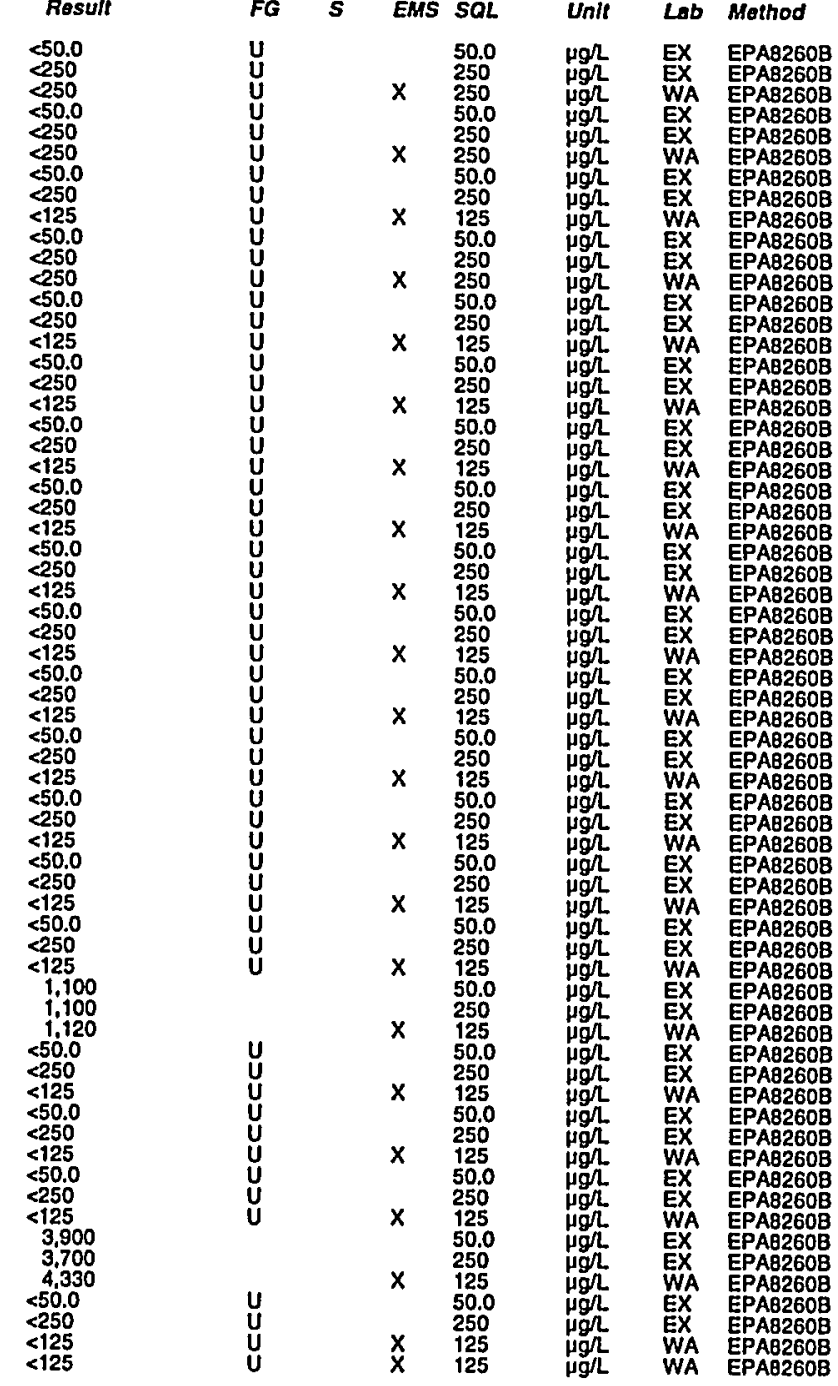




\section{WELL RWM 3 Replicate}

\section{MEASUREMENTS CONDUCTED IN THE FIELD}

Sample dale: 04/14/99

Wepth to water: Nol available

$$
\mathrm{H}: 4.8
$$

The well was continuously pumping.

ANALYSES

F Analyto

0 Benzene

Bromodichloromethan

Bromolorm
Bromolorm

Bromomethane

Carbon tetrachloride

Chlorobenzenene

Chloroethane

Chloroethene (Vinyl chlorlde)

2.Chloroethyl vinyl ether
2.Chloroethyl vinyl ether

Chloroform

Chloromelhane

Dibromochloromethan

1.1-Dichloroethane

1.2.Dichloroethan

1,i-Ochloroethylen

1,i-Dichloroelhylene
trans $-1,2$-Dichloroothylene
trans-1,2-Dichlorothylen

Dichloromelhane

1.2-Dichloropropan

cis-1,3-Dichloropropene

trans-1,3-Dichloropropene

Ethylbenzene

o $1,1,2,2$ - Tertrachloroathane

Tetrachloroothylene

Toluen

0 Toluene

1,1,1-Trichloroethane

i,i,2-Trichloroethane

Trichloroethylene

Trichlorofluoromethane

Rosull
$<50.0$
$<250$
$<50.0$
$<250$
$<50.0$
$<250$
$<50.0$
$<250$
$<50.0$
$<250$
$<50.0$
$<250$
$<100$
$<500$
$<50.0$
$<250$
$<50.0$
$<250$
$<50.0$
$<250$
$<50.0$
$<250$
$<50.0$
$<250$
$<50.0$
$<250$
$<50.0$
$<250$
$<50.0$
$<250$
$<50.0$
$<250$
$<50.0$
$<250$
$<50.0$
$<250$
$<50.0$
$<250$
$<50.0$
$<250$
$<50.0$
$<250$
$<50.0$
$<250$
1.100
1,100
$<50.0$
250
$<50.0$
$<250$
$<50.0$
$<250$
3.900
3.800
$<50.0$
$<250$

$<50.0$
$<250$
$<50.0$
$<250$
$<50.0$
$<250$
$<50.0$
$<250$
$<50.0$
$<250$
$<50.0$
$<250$
$<100$
$<500$
$<50.0$
$<250$
$<50.0$
$<250$
$<50.0$
$<250$
$<50.0$
$<250$
$<50.0$
$<250$
$<50.0$
$<250$
$<50.0$
$<250$
$<50.0$
$<250$
$<50.0$
$<250$
$<50.0$
$<250$
$<50.0$
$<250$
$<50.0$
$<250$
$<50.0$
$<250$
$<50.0$
$<250$
$<50.0$
$<250$
1.100
1,100
$<50.0$
$<250$
$<50.0$
$<250$
$<50.0$
$<250$
3.900
3.800
$<50.0$
$<250$

Time: 10:15

Waler lemperature: $19.4^{\circ} \mathrm{C}$

Total alkalinity (as CaCo3): $0 \mathrm{mg} / \mathrm{L}$
Phenolphthalein alkalinity: $0 \mathrm{mg} / \mathrm{L}$

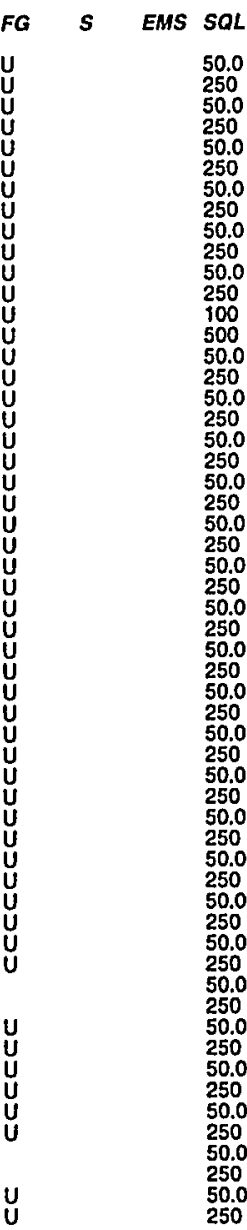

\section{WELL RWM 3}

MEASUREMENTS CONDUCTED IN THE FIELD

Sample date: 05/17/99 $(100.6 \mathrm{~m})$ below TOC

Water elevation: $210.81 \mathrm{ft}(64.26$

Sp. conductance: $45 \mu \mathrm{S} / \mathrm{cm}$

The well was continuously pumping

\section{ANALYSES}

F Ansiyto

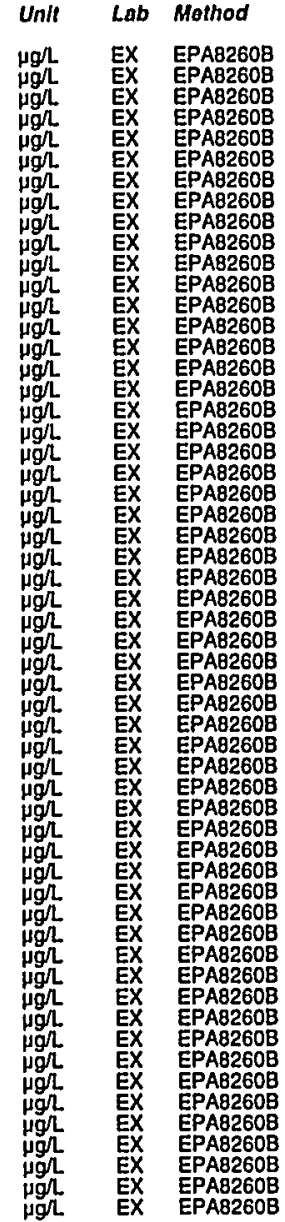

Bromodichloromethane

0 Bromolorm

Carbon tetrachlorido

Chloroesthane

Chloroethene (Vinyl chloride

2-Chloroethy'

Chloromethane

1,1-Dichloroelhane

Dichloromethane

cis-1,3-Dichloropropene

Eihylbenzene
$1,1,2,2$-Terfachloroethan

Toluene

1.1. 2-Tíchloroethane

Trichlorolluoromethane

WELL RWM 3

MEASUREMENTS CONDUCTED IN THE FIELD

Sample date: 06/14/99

Depth to water: Not available

Water

$$
\text { H: } 4.7
$$

p. conductance: $48 \mu \mathrm{S} / \mathrm{cm}$

The well was continuously pumping.

ANALYSES

$F$ Analyte

0 Benzene

Bromodichio

Bromomethane

C Chlorobenzene

Chloroethane

Chloroethenes (Vinyl chlorlde)

Chlorolorm

Chloromethane

Dibromochlorometha

1,2 -Dichloroethane

1,1-Dichloroethylene
trans-1,2-Dichloroethylene

Dichloromethane

cis-1.3-Dichloropropene

Rosult

$<100$
$<100$
$<100$
$<100$
$<100$
$<100$
$<200$
$<100$
$<100$
$<100$
$<100$
$<100$
$<100$
$<100$
$<100$
$<100$
$<100$
$<100$
$<100$
$<100$
$<100$
$<100$
900
$<100$
$<100$
$<100$
3,000
$<100$

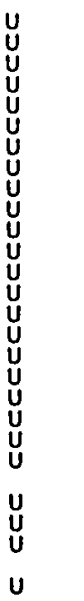

1,1-Dichloroethylena
trans-1,2-Dichloroelhylen

Tetrachloroethylen

Time: 13:04

Therature: $21.70^{\circ} \mathrm{C}$

Total alkalinity (as CaCO3): $0 \mathrm{mg} / \mathrm{L}$

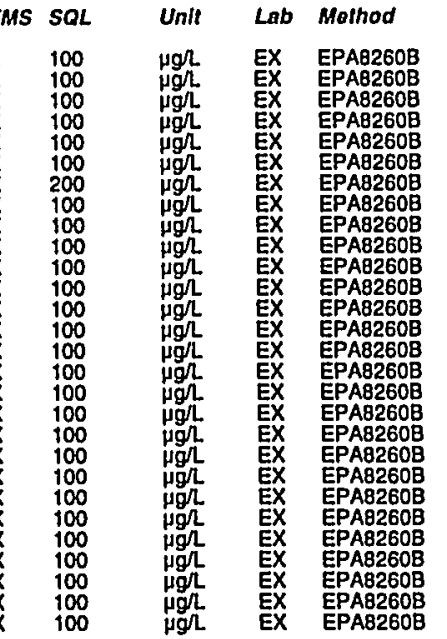

Time: 9:45

mperalure: $20.6^{\circ} \mathrm{C}$

Tolal alkalinity (as Cacos): $0 \mathrm{mg}$

B-192

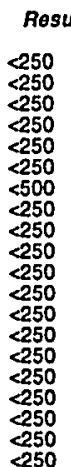

Result
250
$<250$
$<250$
$<50$
$<250$
$<250$
$<500$
$<250$
$<250$
$<250$
$<250$
$<250$
$<250$
$<250$
$<250$
$<250$
$<250$
$<250$
$<250$

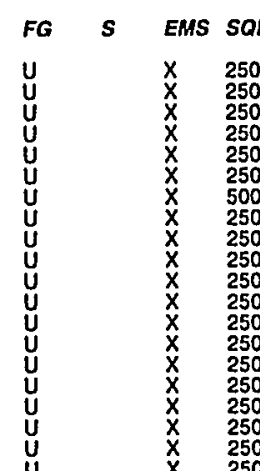

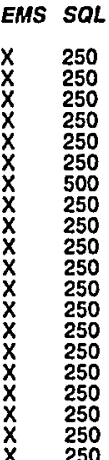

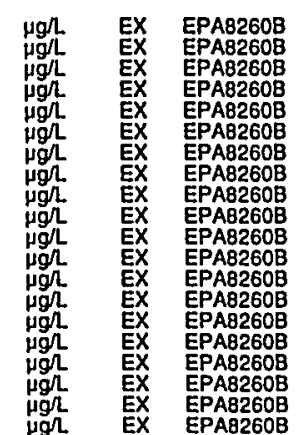

Second Quarter 1999 
Well RWM 3 collected on 06/14/99 (cont.)

$F$ Anslyte

Result

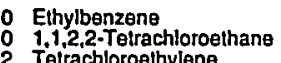

Toluene

o 1,1,1-Trichloroethane

Trichloroethylene
T Tichlorofluoromethane

WELL RWM 4

MEASUAEMENTS CONDUCTED IN THE FIELD

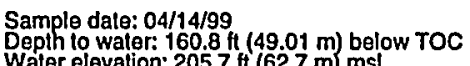

Wh: 5.1

pp. conductance: $23 \mu \mathrm{S} / \mathrm{cm}$

The well was continuously pumping.

ANALYSES

F Analyte

Result

: Benzene

Bromolorm

Carbon tetrachloride

Chloroethane

Chloroothene (Vinyl chloride)

Chloroform

Dibromochloromethane

1.1.Dichloroethane

1,1-Dichloroeshylene
trans-1,2-Dichloroethylene

Dichloromethane

cis-1,3-Dichloropropene
trans-1,3-Dichloropropene

i.1,2,2-Tetrachloroethane

Totrachloroethylene

Toluene

Trichloroethylene

Trichlorofluoromolhan

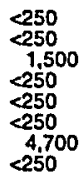

EMS SQL

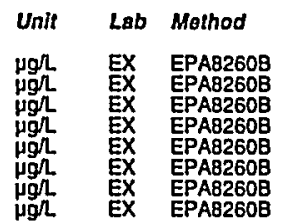

$\begin{array}{ll}X & 250 \\ X & 250 \\ X & 250 \\ X & 250 \\ X & 250 \\ X & 250 \\ X & 250 \\ X & 250\end{array}$

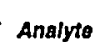

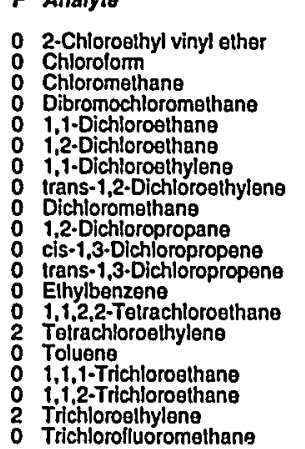

Result
$<500$
$<500$
$<500$
$<500$
$<500$
$<500$
$<500$
$<500$
$<500$
$<500$
$<500$
$<500$
$<500$
$<500$
850
$<500$
$<500$
$<500$
6.100
$<500$

\section{WELL RWM 4}

MEASUREMENTS CONDUCTED IN THE FIELD

Sample date: 06/14/99 $\mathrm{H}(49.15 \mathrm{~m})$ below TOC Waler elevation: $205.25 \mathrm{ft}(62.56 \mathrm{~m}) \mathrm{ms}$

pH: 5.1 conductance: $23 \mu \mathrm{S} / \mathrm{cm}$

The well was continuously pumping

ANALYSES

$F$ Analyto

0 Benzene
0
0 Bromodichloromelhane

$\begin{array}{ll}0 & \text { Bromodichlorome } \\ 0 & \text { Bromolorm } \\ 0 & \text { Bromomethane }\end{array}$

Carbon letrachlorid

Chloroethane
Chloroethene (Vinyl chloride)
2.Chloroethyl vinyl elher

2.Chloroethy

Dhloromathano

1,i.Dichloroethane

$1, Y-D i c h l o r o e t h y l e n$
trans-1,2-Dichloroethylen

Dichloromethane

: cis-1,3-Dichloropropene

1122.Totrachloroethen

Terrachloroethylens

o 1,1.1. Trichloroethane

Trichloroesthylene
Trichlorolluoromethan
Waler temperature: $20.7^{\circ} \mathrm{C}$ Total alkalinity (as Caco3): $0 \mathrm{mg} / \mathrm{L}$

$\mathrm{pH}: 4.3$
$\mathrm{Sp}$. conductance: $20 \mu \mathrm{S} / \mathrm{cm}$

The well was continuously pumping ANALYSES

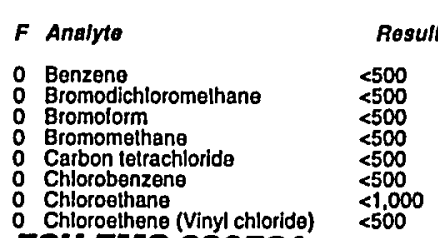

ESH-EMS-990521
$<1,000$

$F G$
$u$
$u$
$u$
$u$
$u$
$u$
$U$

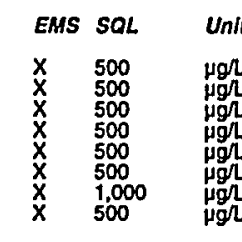

Unit Lab Method

$\begin{array}{ll}\text { EX } & \text { EPAB260B } \\ \text { EX } & \text { EPAB260B } \\ \text { EX } & \text { EPAB260B } \\ \text { EX } & \text { EPAB260B } \\ \text { EX } & \text { EPA8260B } \\ \text { EX } & \text { EPA8260B } \\ \text { EX } & \text { EPA8260B } \\ \text { EX } & \text { EPAB260日 }\end{array}$

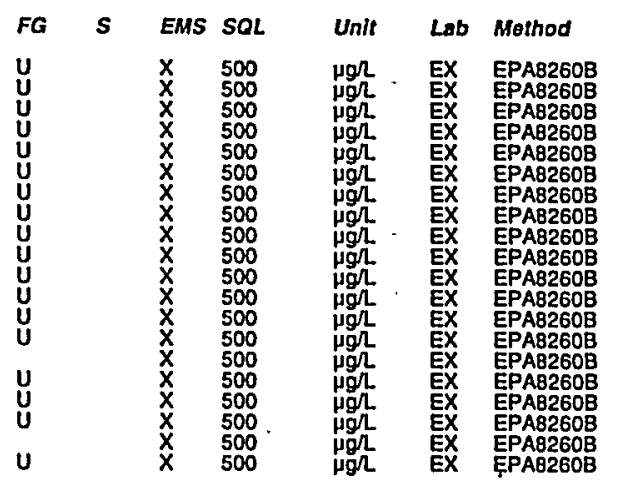

Time: 9:00

Air temperalure: $25: 20.4^{\circ} \mathrm{C}$

Total alkalinity (as Cacos): $0 \mathrm{mg} /$
Phenolphthalein alkalinity: $0 \mathrm{mg} /$

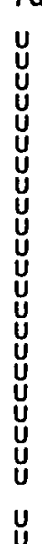

,
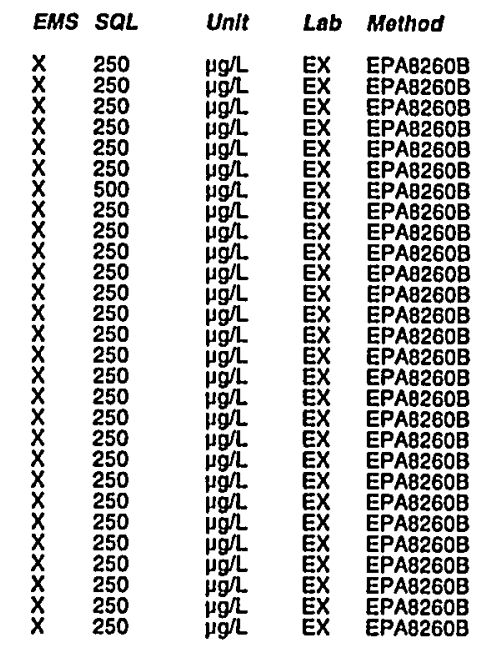

Socond Quartor 1999 


\section{WELL RWM 5}

MEASUREMENTS CONDUCTED IN THE FIELD Sample date: 04/14/99
Depth to water: $156.6 \mathrm{ft}(47.73 \mathrm{~m})$ below TOC
Water elevation: $210.3 \mathrm{ft}(64.1 \mathrm{~m}) \mathrm{msl}$ Sp. conduclance: $29 \mu \mathrm{S} / \mathrm{cm}$ Turbidity: $1 \mathrm{NTU}$ :
The well was continuously pumping. ANALYSES

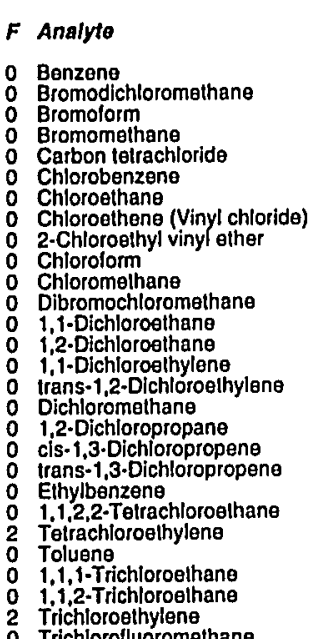

$$
\begin{aligned}
& <50.0 \\
& <50.0 \\
& <50.0 \\
& <50.0 \\
& <50.0 \\
& <50.0 \\
& <100 \\
& <50.0 \\
& <50.0 \\
& <50.0 \\
& <50.0 \\
& <50.0 \\
& <50.0 \\
& <50.0 \\
& <50.0 \\
& <50.0 \\
& <50.0 \\
& <50.0 \\
& <50.0 \\
& <50.0 \\
& <50.0 \\
& <50.0 \\
& 720 \\
& <50.0 \\
& <50.0 \\
& <50.0 \\
& 550 \\
& <50.0
\end{aligned}
$$$$
\text { Rosult }
$$

\section{WELL RWM 5}

MEASUREMENTS CONDUCTED IN THE FIELD Sample date: $05 / 18 / 99$
Depth to water: $157.1 \mathrm{ht}(47.88 \mathrm{~m})$ below TOC Water elevation: 209 tuibidity: : NTU: $25 \mu \mathrm{S} / \mathrm{cm}$

wel was continuously pumping. ANALYSES

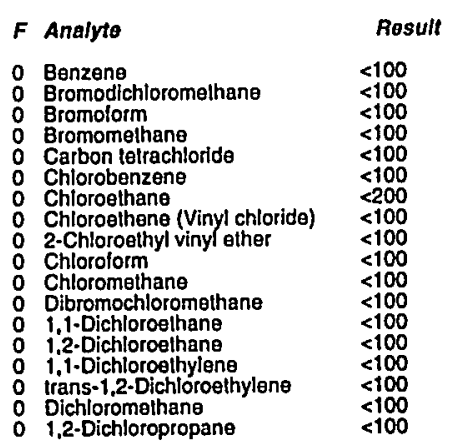

Well RWM 5 collected on 05/18/99 (cont.)

F Analyto

Time: 9:50

Waler temperalure: $19^{\circ} \mathrm{C}$ Total alkalinity (as CaCO3): $0 \mathrm{mg} / \mathrm{h}$

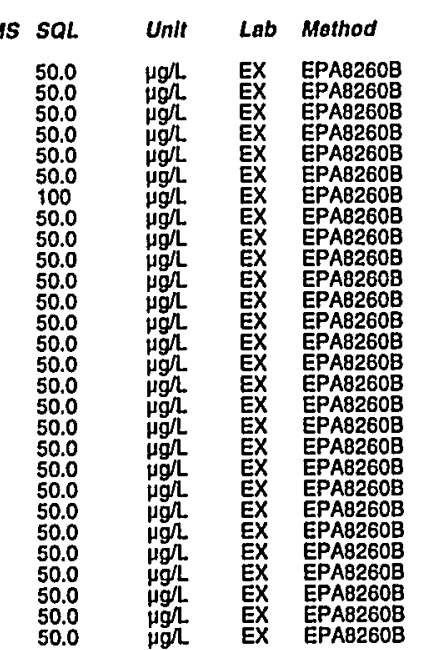

Time: 9:30 War $22.3^{\circ} \mathrm{C}$ Total alkalinity (as CaCO3): $0 \mathrm{mg} / \mathrm{L}$
Phenolphthalein alkalinity: $0 \mathrm{mg}$ L

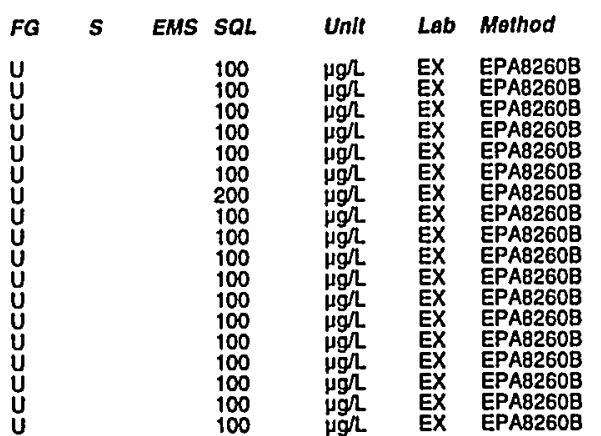

Wh: 4.9

$F$ Analyto

Wat
0 cis-1,3. Dichloropropene

1,1,2,2-Tetrachloroethan

2 Torrachloroothylene

$\begin{array}{ll}0 & 1,1,1-T \text {-Trichloroethane } \\ 0 & 1,1,2-\text { Trichloroethane }\end{array}$

2
2 Trichloroethylene
0 Trichlorofluoromethane

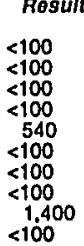

FG

EMS SOL

$\begin{array}{ll}100 & \mu 9 \\ 100 & \mu 9 \\ 100 & \mu 9 \\ 100 & \mu 9 \\ 100 & \mu 9 \\ 100 & \mu 9 \\ 100 & \mu 9 \\ 100 & \mu 9 \\ 100 & \mu g \\ 100 & \mu 9\end{array}$

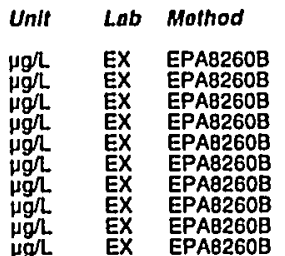

WELL RWM 5

MEASUREMENTS CONDUCTED IN THE FIELD

Sample dale: 06/14/99

Sp. conductance: $28 \mu \mathrm{S} / \mathrm{cm}$

The well was continuously pumping

ANALYSES

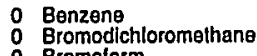

Bromolorm

Carbon teitrachlorido

Chlorobenzene

Chlloroethene (Vinyl chloride)

2-Chloroethyl

Chloromethane

1.1. Dichloroothane
1.2 .0 chloroethane

1,i-Dichloroothane

1,2-0ichloropropan

cis-1,3-Dichloropropene

Eithylbenzene

Tetrachloroethylen

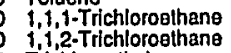

Trichloroethylene
Trichlorofluoromethane

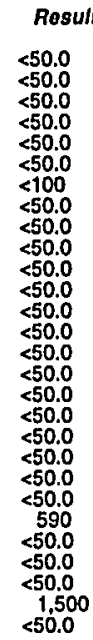

\section{WELL RWM 6}

MEASUREMENTS CONDUCTED IN THE FIELD

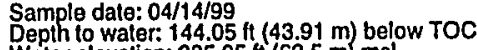

p. conductance: $32 \mu \mathrm{S} / \mathrm{cm}$

.

\section{ANALYSES}

$\begin{array}{lll}\text { F Analyte } & \text { Result } \\ 0 & \text { Benzene } & <250 \\ 0 & \text { Bromodichloromethane } & <250 \\ 0 & \text { Bromolorm } & <250\end{array}$

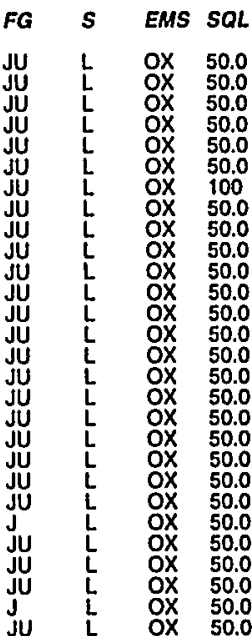

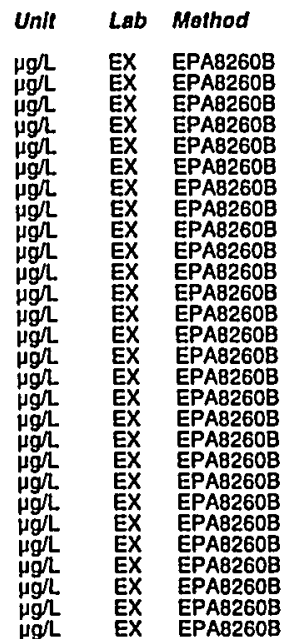

Time: 10:00

War $20.8^{\circ} \mathrm{C}$

Tolal alkalinily (as Caco3): $0 \mathrm{mg} /$
Phenolphthalein alkalinity: $0 \mathrm{mg} / \mathrm{L}$

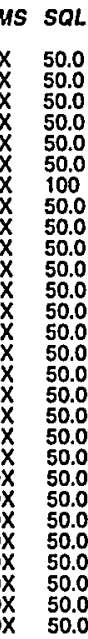

Time: 12:35

Ar temperature: $20.2^{\circ} \mathrm{C}$

Total alkalinity (as CaCO3): $0 \mathrm{mg} /$
Phenolphthalein alkalinity: $0 \mathrm{mgh}$

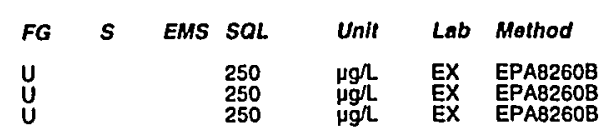




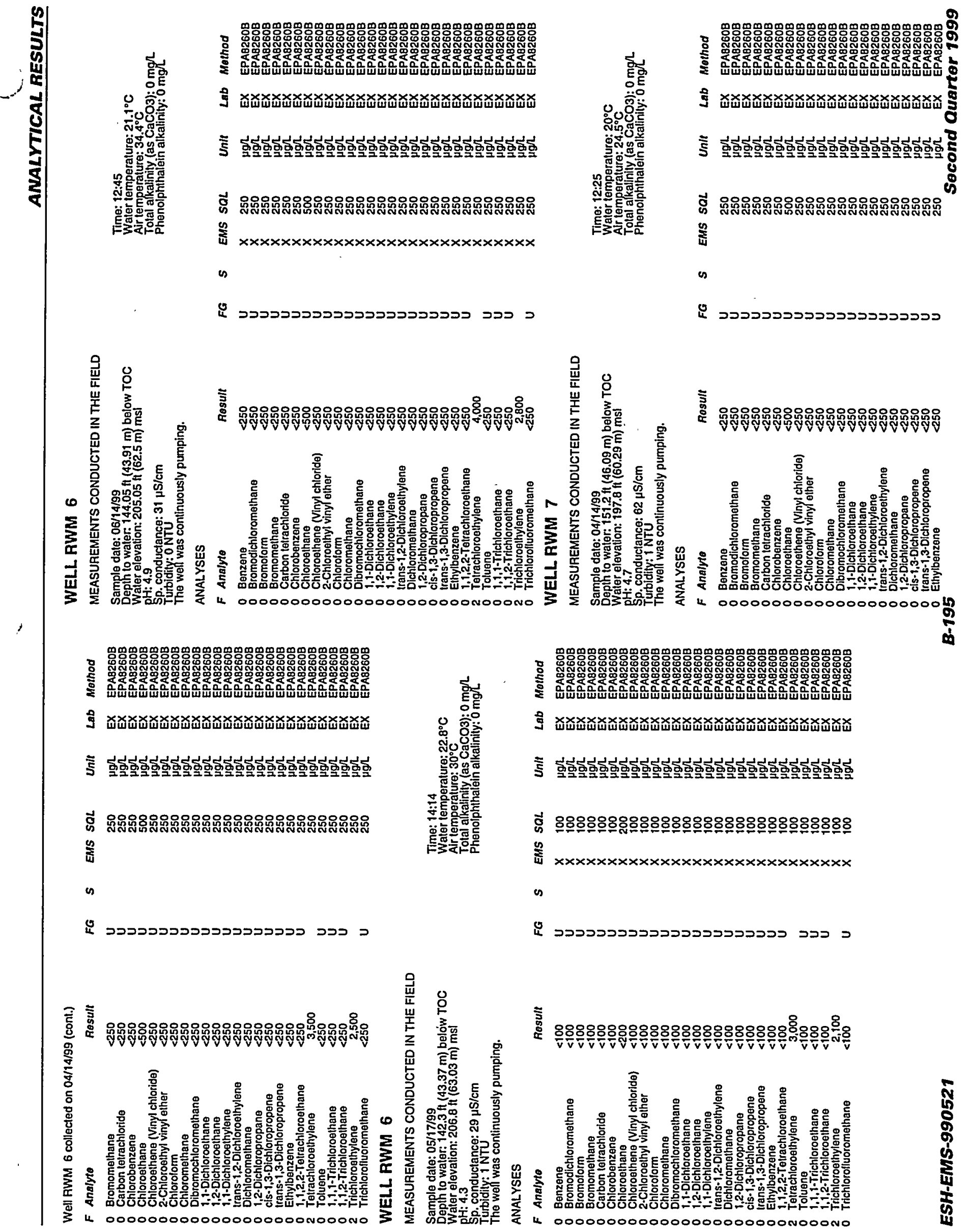


Well RWM 7 collected on 04/14/99 (cont.)

$F$ Analyto

Result
$<250$
8,300
$<250$
$<250$
$<250$
7,000
$<250$

0 Trichlorothylene

WELL RWM 7

MEASUREMENTS CONDUCTED IN THE FIELD

Sample date: 05/17/99

Depth to water: $152.45 \mathrm{ft}(46.47 \mathrm{~m}$ ) below TOC

Waler Sp. conductance: $62 \mu \mathrm{S} / \mathrm{cm}$

The well Was continuously pumping

ANALYSES

F Analyto
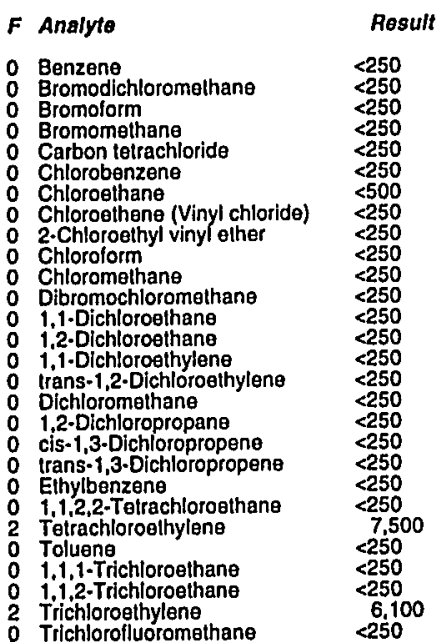

\section{WELL RWM 7}

MEASUREMENTS CONDUCTED IN THE FIELD Sample date: 06/14/99 $\mathrm{Ht}(46.04 \mathrm{~m})$ below TOC Water elevalion: $197.95 \mathrm{ft}(60.34$
pH: 4.6
Sp. conductance: $62 \mu \mathrm{S} / \mathrm{cm}$ ANALYSES

\begin{tabular}{|c|c|}
\hline Analyte & Result \\
\hline $\begin{array}{l}\text { Benzene } \\
0 \text { Bromodichloromethane } \\
0 \text { Bromoform } \\
0 \text { Bromomenthane } \\
0 \text { Carbon letrachloride } \\
0 \text { Chlorobenzene } \\
0 \text { Chloroethane } \\
0 \text { Chloroethene (Vinyl chloride) } \\
0 \text { 2-Chloroethyl vinyl ether } \\
0 \text { Chlorolorm }\end{array}$ & $\begin{array}{l}<500 \\
<500 \\
<500 \\
<500 \\
<500 \\
<500 \\
<1,000 \\
<500 \\
<500 \\
<500\end{array}$ \\
\hline
\end{tabular}

ESH-EMS-990521
FG

\begin{tabular}{|c|c|c|c|c|}
\hline MMS & SQL & Unit & Lab & Mothod \\
\hline & $\begin{array}{l}250 \\
250 \\
250 \\
250 \\
250 \\
250 \\
250\end{array}$ & 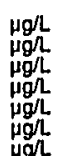 & $\begin{array}{l}\text { EX } \\
\text { EX } \\
\text { EX } \\
\text { EX } \\
\text { EX } \\
\text { EX } \\
\text { EX }\end{array}$ & $\begin{array}{l}\text { EPA8260B } \\
\text { EPAB2608 } \\
\text { EPAB260日 } \\
\text { EPA82608 } \\
\text { EPA8260B } \\
\text { EPAB260B } \\
\text { EPA8260B }\end{array}$ \\
\hline
\end{tabular}

Well RWM 7 collected on 06/14/99 (cont.)
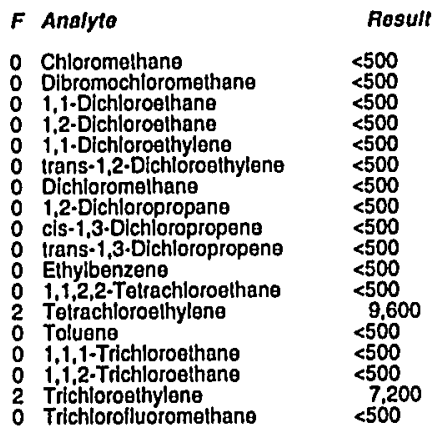

Time: 13:45 Water temperature: $21.3^{\circ} \mathrm{C}$ Total akkalinity: (as Caco3): $0 \mathrm{mg} / \mathrm{L}$
Phenolphinalein alkalinity: $0 \mathrm{mg} / \mathrm{L}$

lorofluoromethan

\section{WELL RWM 8}

MEASUREMENTS CONDUCTED IN THE FIELD

Sample date: $04 / 14 / 99$
Depth to waler: $145.1 \mathrm{ft}(44,23 \mathrm{~m})$ below TOC
Water elevation: $203.2 \mathrm{ft}(61.94 \mathrm{~m}) \mathrm{msl}$

$\mathrm{pH}: 5$
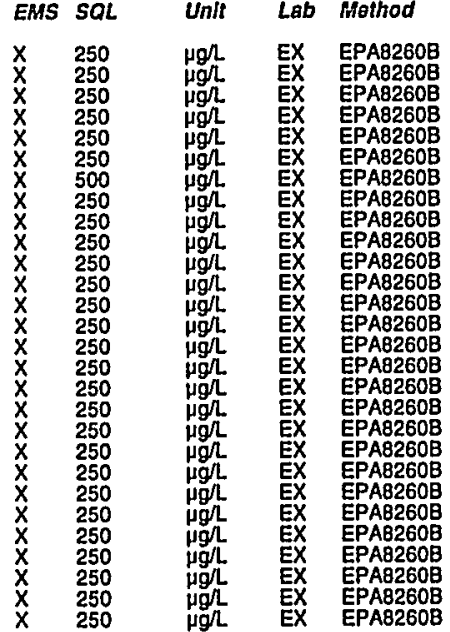

Time: 13:00

Wair temperature: $349^{\circ} \mathrm{C}$

Total alkalinity (as CaCO3): $0 \mathrm{mg} / \mathrm{L}$
Phenol phthalein alkalinity: $0 \mathrm{mg} / \mathrm{L}$

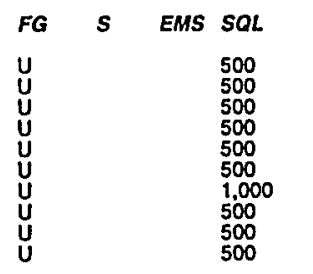

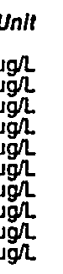

ab Mothod

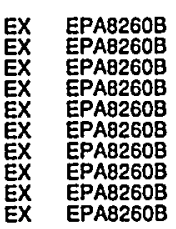

p. conductance: $100 \mu \mathrm{S} / \mathrm{cm}$

The well was continuously pumping.

ANALYSES

\begin{tabular}{|c|c|}
\hline Inalyte & Result \\
\hline 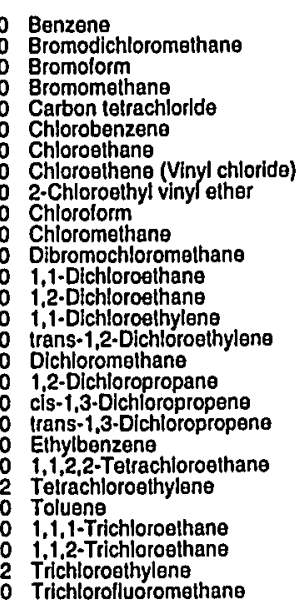 & $\begin{array}{l}<50.0 \\
<50.0 \\
<50.0 \\
<50.0 \\
<50.0 \\
<50.0 \\
<100 \\
<50.0 \\
<50.0 \\
<50.0 \\
<50.0 \\
<50.0 \\
<50.0 \\
<50.0 \\
<50.0 \\
<50.0 \\
<50.0 \\
<50.0 \\
<50.0 \\
<50.0 \\
<50.0 \\
<50.0 \\
470 \\
<50.0 \\
<50.0 \\
<50.0 \\
860 \\
<50.0\end{array}$ \\
\hline
\end{tabular}

\section{WELL RWM 8}

MEASUREMENTS CONDUCTED IN THE FIELD

Sample date: 06/14/99 $\mathrm{ft}(44.39 \mathrm{~m})$ below TOC Wather elevation: $202.65 \mathrm{ft}(61.77 \mathrm{~m}) \mathrm{msl}$

Sp: 5.1 conductance: $210 \mu \mathrm{S} / \mathrm{cm}$
The well was continuously pumping.

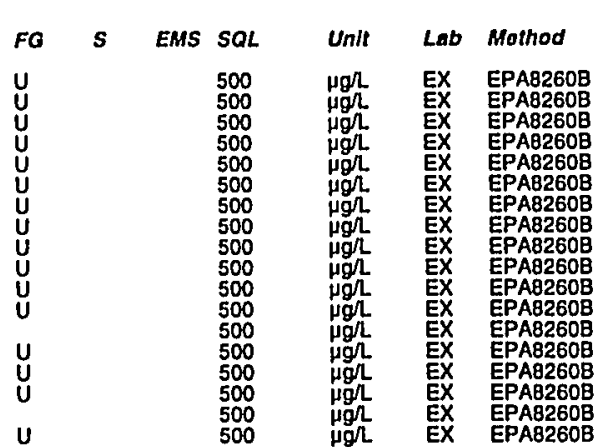

Time: 12:00

Water temperalure: $19.8^{\circ} \mathrm{C}$

Total alkalinity (as CaCO3): $0 \mathrm{mg} / \mathrm{L}^{-}$
Phenolphthalein alkalinity: $0 \mathrm{mg} \mathrm{L}^{-}$

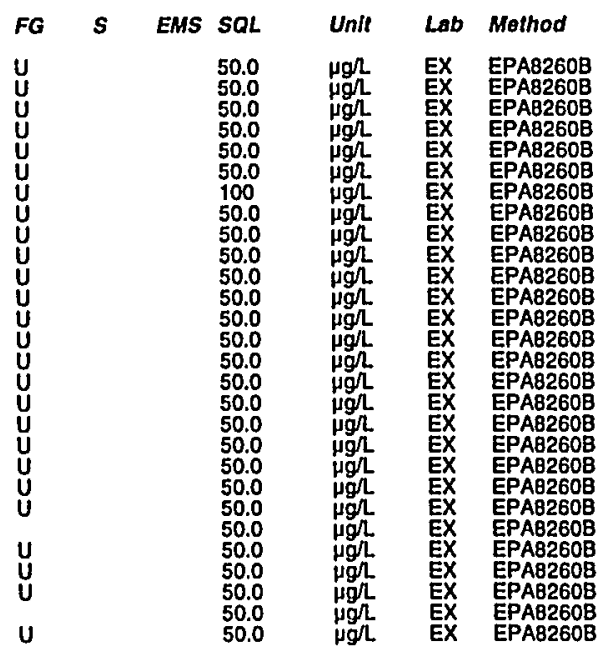

Time: $8: 30$

ture: $19.4^{\circ} \mathrm{C}$

Total alkalinity (as CaCO3): $0 \mathrm{mg} /$ 
Well RWM 8 collectod on 06/14/99 (cont.) ANALYSES

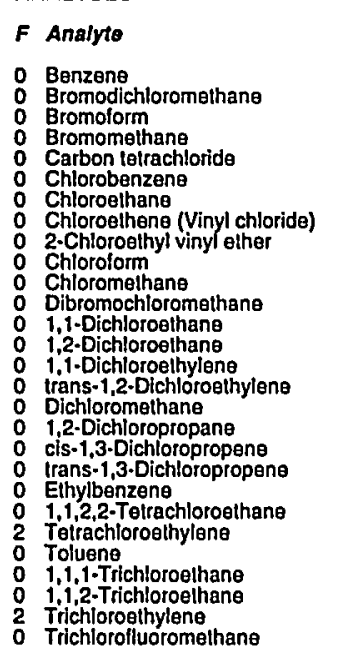

Rosult
$<50.0$
$<50.0$
$<50.0$
$<50.0$
$<50.0$
$<50.0$
$<100$
$<50.0$
$<50.0$
$<50.0$
$<50.0$
$<50.0$
$<50.0$
$<50.0$
$<50.0$
$<50.0$
$<50.0$
$<50.0$
$<50.0$
$<50.0$
$<50.0$
$<50.0$
980
$<50.0$
$<50.0$
$<50.0$
1,400
$<50.0$
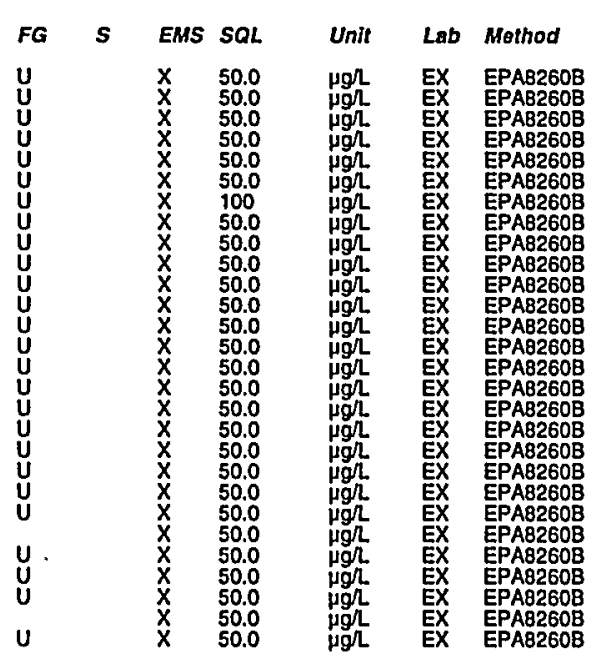

\section{WELL RWM 9}

MEASUREMENTS CONDUCTED IN THE FIELD

Sample date: $04 / 14 / 99$
Depth to water: $158.4 \mathrm{ft}(48.28 \mathrm{~m})$ below TOC
Water elevation: $222.2 \mathrm{ft}(67.73 \mathrm{~m}) \mathrm{msl}$

pH:5.4

$\mathrm{Sp}$. conductance: $51 \mu \mathrm{S} / \mathrm{cm}$

The well was continuously pumping

ANALYSES

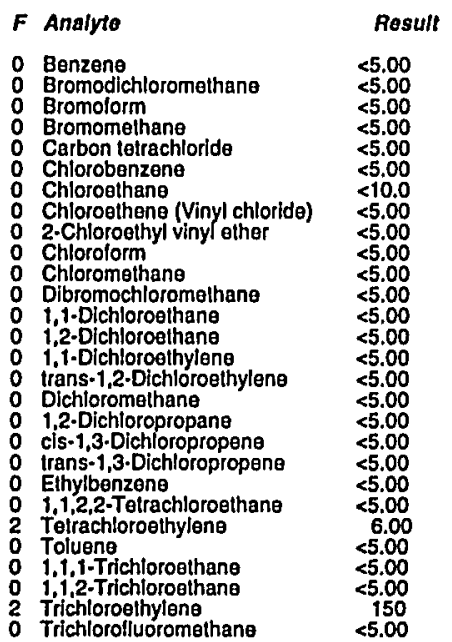

ESH-EMS-990521

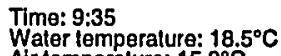

Total alkalinity (as CaCO3): $0 \mathrm{mg} / \mathrm{L}$
Phenolphthalein alkalinity: $0 \mathrm{mg} /$
WELL RWM 9

MEASUREMENTS CONDUCTED IN THE FIELD

Sample date: 05/17/99
Depth to water: $159.4 \mathrm{Ht}(48.59 \mathrm{~m})$ below TOC
Water elevation: $221.2 \mathrm{Ht}(67.42 \mathrm{~m}) \mathrm{ms}$

W $4: 9$.

Sp. conductance: $45 \mu \mathrm{S} / \mathrm{cm}$

The well was continuously pumping.

ANALYSES

$F$ Analyte

ODenzene
0
0

Bromolorm

Carbon telrachiorid

Chlorobenzen

Chloroethene (Vinyl chloride)
2-Chloroethyl vinyl ether

Chloromethan

Dibromochloromethane

1,1.Dichloroethane

$1,1-D i c h l o r e c t h y l e n$
trans- $1,2 \cdot$ Dichloroethylen

Dichloromethane

cis-1,3-Dichloropropene
trans-1,3-Dichloropropene

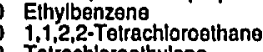

0 Tolueng

1,

Trichioroelthylene

\section{WELLL RWM 10}

MEASUREMENTS CONDUCTED IN THE FIELD

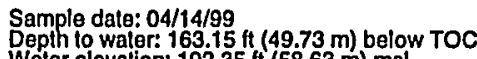

Water elevation: $192.35 \mathrm{ft}(58.63 \mathrm{~m}) \mathrm{msl}$

Sp. conductance: $84 \mu \mathrm{S} / \mathrm{cm}$

The well was continuously pumping.

Rosult
225.0
25.0
25.0
25.0
25.0
25.0
25.0
250.0
25.0
25.0
25.0
25.0
25.0
25.0
25.0
25.0
25.0
25.0
25.0
25.0
25.0
25.0
25.0
25.0
25.0
25.0
25.0
25.0
160
$<25.0$

ANALYSES

$F$ Analyte

Rंosult

0
0 genzene
0

Gromolorm
gromomelhane

Carbon telrachlorida

Chlorosthane

Chloroothene (Vinyl chlorid

: 2-Chloroothyl

O Chloromethane

1.1.-Dichloroothane

$1,1 \cdot$ Dichloroethylene
trans-1,2-Dichloroethylen

Dichloromethane

cis-1,3-Dichloropropene
trans-1,3-Dichloropropene

B-197

$<500$
$<500$
5500
5500
5500
$<500$
$<1,000$
5500
5500
5500
$<500$
5500
5500
5500
5500
5500
5500
5500
5500
5500
$<500$

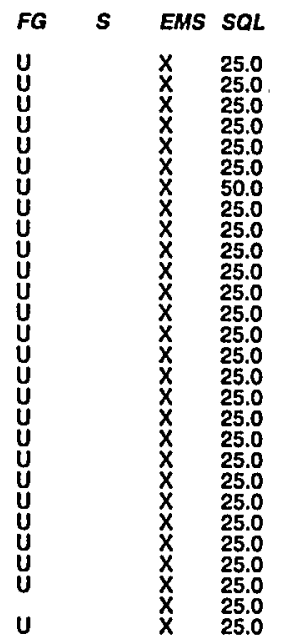

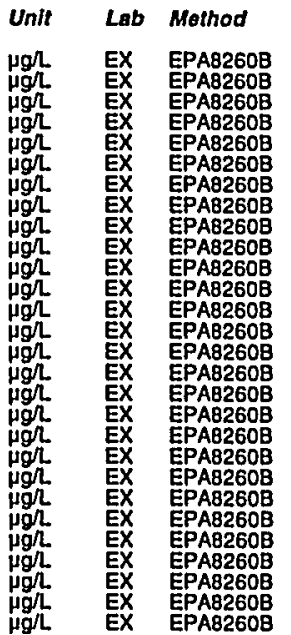

Time: 14:45

mperalura: $21.6^{\circ} \mathrm{C}$

Total akealinity (as Cacos): $3 \mathrm{mgr}$
Phenolphithalein alkalinity:

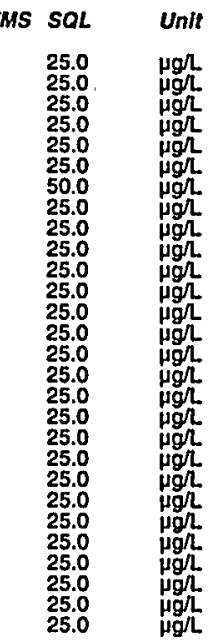

EPA8260B

Time: 12:15

Air temperture: $19.8^{\circ} \mathrm{C}$

Total alkalinity. (as CaCO3): $0 \mathrm{mg} /$
Phenolphthalein alkalinity: $0 \mathrm{mg} /$

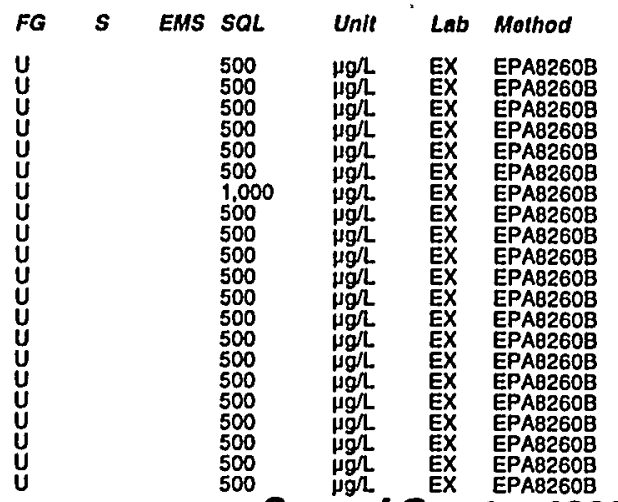

Socond Quarter 1999 
ANALYTICAL RESULTS

Well RWM to collected on 04/14/99 (conl.)

F Analyto

o 1,1,2,2-Tetrachloroothane

2 Telrachloroethylene

0 Toluene

2 Trichloroethylene

Rosult
$<500$
5,100
$<500$
$<500$
$<500$
5,700
$<500$

WELL RWM 10

MEASUREMENTS CONDUCTED IN THE FIELD

Sample date: 05/17/99 $(50.85 \mathrm{~m})$ below TOC

Water elevalion: $188.67 \mathrm{ft}(57.51 \mathrm{~m}) \mathrm{msl}$

pH: 4.4

Sp. conductance: $84 \mu \mathrm{S} / \mathrm{cm}$

The well was continuously pumping

ANALYSES

\begin{tabular}{|c|c|c|}
\hline$F$ & Analyto & Resul \\
\hline & 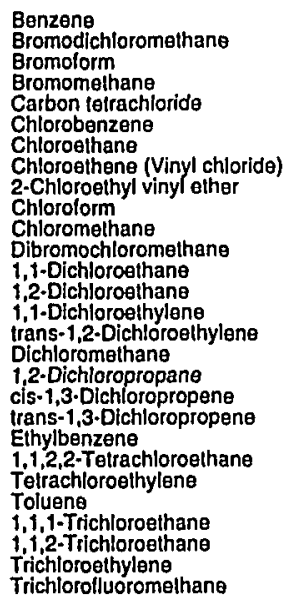 & $\begin{array}{l}<250 \\
<250 \\
<250 \\
<250 \\
<250 \\
<250 \\
<500 \\
<250 \\
<250 \\
<250 \\
<250 \\
<250 \\
<250 \\
<250 \\
<250 \\
<250 \\
<250 \\
<250 \\
<250 \\
<250 \\
<250 \\
<250 \\
7,200 \\
<250 \\
<250 \\
<250 \\
4,600 \\
<250\end{array}$ \\
\hline
\end{tabular}

WELL RWM 10

MEASUREMENTS CONDUCTED IN THE FIELD

Sample date: 06/14/99

列

H: 5.1

Sp. conductance: $78 \mu \mathrm{S} / \mathrm{cm}$

The well was continuously pumping

ANALYSES

F Analyto

Result

: Benzene

Bromolorm

Carbon tetrachioride

o Chlorobenzene

Chloroethane

2.Chlorone (Vinyl chloride)

ESH-EMS-990521

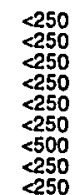

$<250$
$<250$
250
$<250$
$<250$
$<250$
$<500$
$<250$
$<250$

Time: 9:21

Wir temperature: $20.2^{\circ} \mathrm{C}$ Total alkalinity (as CaCO3): $0 \mathrm{mg} / \mathrm{L}$
Phenol phthalein alkalinily: $0 \mathrm{mgh}$

$\begin{array}{llll}\text { SQL } & \text { Unit } & \text { Lab } & \text { Mothod } \\ 500 & \mu g / & \text { EX } & \text { EPAB260B } \\ 500 & \mu g / & \text { EX } & \text { PAB2608 } \\ 500 & \mu g / & \text { EX } & \text { EAB260B } \\ 500 & \mu g \Omega & \text { EX } & \text { EAB260B } \\ 500 & \mu g L & \text { EX } & \text { EAB260B } \\ 500 & \mu g \Omega & \text { EX } & \text { EPAB2608 } \\ 500 & \mu g L & \text { EX } & \text { EPAB260B }\end{array}$
Polk

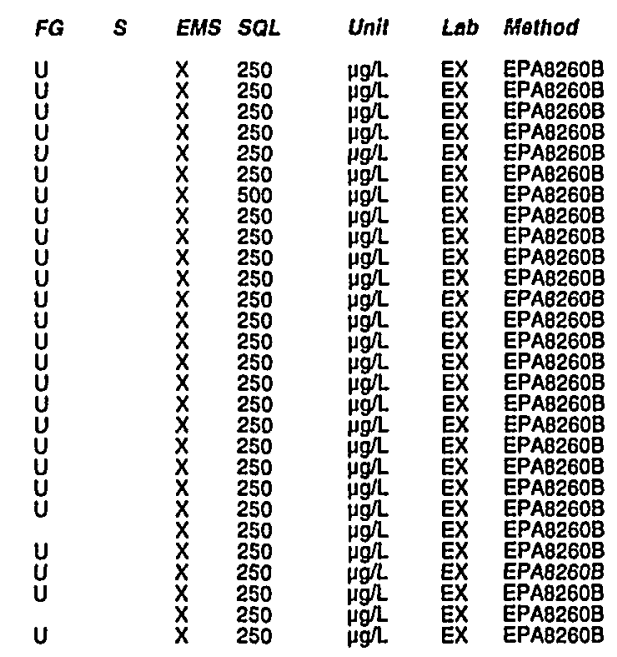

Time: 8:15 Water temperature: $19.5^{\circ} \mathrm{C}$ Total alkalinity (as CaCO3): $0 \mathrm{mg} / \mathrm{L}$
Phenolphthalein alkalinity: $0 \mathrm{mgL}$

$\begin{array}{llll}F G & S & E A S & S Q L \\ U & & X & 250 \\ U & X & 250 \\ U & & X & 250 \\ U & & X & 250 \\ U & & X & 250 \\ U & & X & 250 \\ U & & X & 500 \\ U & & X & 250 \\ U & & X & 250\end{array}$

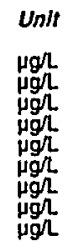

$\begin{array}{ll}\text { Lab } & \text { Mathod } \\ \text { EX } & \text { EPAB260B } \\ \text { EX } & \text { EPAB260B } \\ \text { EX } & \text { EAA260B } \\ \text { EX } & \text { EPA2608 } \\ \text { EX } & \text { EPA2608 } \\ \text { EX } & \text { EAB2608 } \\ \text { EX } & \text { EPAB260日 } \\ \text { EX } & \text { EAA260B } \\ \text { EX } & \text { EPA8260B }\end{array}$
Well RWM 10 collected on 06/14/99 (cont.)

$F$ Analyte

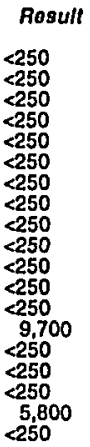

\section{WELL RWM 11}

MEASUREMENTS CONDUCTED IN THE FIELD

Sample date: 04/14/99

epth to water: $172.05 \mathrm{ft}(52.44 \mathrm{~m})$ below TOC

Water elevation: $211.25 \mathrm{ft}(64.39 \mathrm{~m}) \mathrm{ms}$

conductance: $29 \mu \mathrm{S} / \mathrm{cm}$

The well was continuously pumping.

ANALYYSES

$F$ Analyte

O Benzene

Bromolorm

Bromomethane

Chiorobenzene

Chloroethane

Chloroethene (Vinyl chloride)

2.Chloroethyl vinyl ether

Chlorolorm

Chloromethane

1.1-Dichloroethans

1.2-Dichloroelhane

trans $-1,2$-Dichloroethylene

trans-1,2-Dichloroe
Dichloromethane

1,2-Dichlioropropane
cis-1,3-Dichloropropen

trans:1,3-Dichloropropen

$1,1,2,2$-Tetrachloroelhane

Telrachloroethylene

1.1.1-Ifichloroethane

Trichloroethylene

o Trichlorolluoromethane

$<50.0$
$<50.0$
$<50.0$
$<50.0$
550.0
550.0
5100
550.0
$<50.0$
$<50.0$
$<50.0$
550.0
550.0
550.0
$<50.0$
$<50.0$
550.0
$<50.0$
$<50.0$
$<50.0$
550.0
$<50.0$
44.0
$<50.0$
$<50.0$
$<50.0$
270
$<50.0$

\section{WELL RWM 11}

MEASUREMENTS CONDUCTED IN THE FIELD

Sample date: $05 / 18 / 99$ (52.64 m) below TOC

Water elevalion: $210.6 \mathrm{H}(64.19 \mathrm{~m}) \mathrm{ms}$

Sp. conductance: $26 \mu \mathrm{S} / \mathrm{cm}$

The well was continuously pumping
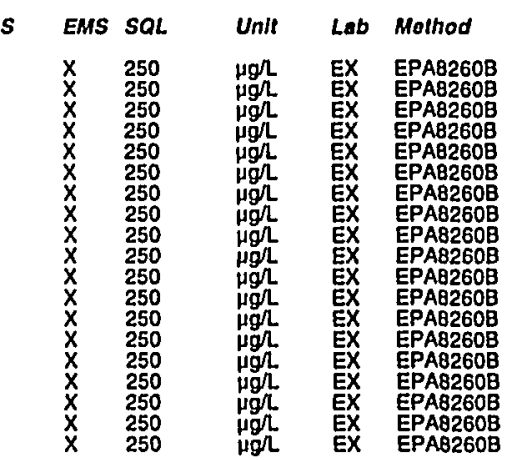

Time: 9:25

Waler temperature: $19.1^{\circ} \mathrm{C}$ Total alkalinity (as CaCO3): $0 \mathrm{mg} /$
Phenolphthalein alkalinity: $0 \mathrm{mg} \mathcal{L}^{2}$ 
Well RWM 11 collected on 05/18/99 (cont.)

ANALYSES

$F$ Analyte

: Benzene

Bromolorm

Carbon tetrachlorido

Chlorosenzane

Chloroethene (Vinyl chloride)

Chlorolorm

Dibromechloromethane

1.1.Dichloroethane

1,1-Dichloroethylene
irans-1,2-Dichloreellhylene

Dichloromethane

-cis-1,3-Dichloropropene

Ethylbenzene

1,1,2,2-Tetrachloroeth
Tetrachloroethylene

i, 1,1 -Trichloroethane

2 Trichloroeshylene

\section{WELL RWM 11}

MEASUREMENTS CONDUCTED IN THE FIELD

Sample date: 06/14/99 $(52.67 \mathrm{~m})$ below TOC

Waler

pp. conductance: $28 \mu \mathrm{S} / \mathrm{cm}$

Turbidity: 1 NTU
The well was continuously pumping

ANALYSES

$F$ Analyto

0 Benzene

0 Bromodichloromethane

0 Bromolorm

Bromomethane

Carbon tetrachioride

Carbon tetrachlo

Chlorobenzen

Chloroethane

2.Chloroelhyl viny?

2.Chloroalhyl vinyl ether

Chlorolorm

Chloromethane

Dibromochloromethane

1.1.-Dichloroethane

o 1,1-Dichloroethane

1. - Dichloroothane

o trans-1,2-Dichloroethylen

ESH-EMS-990521

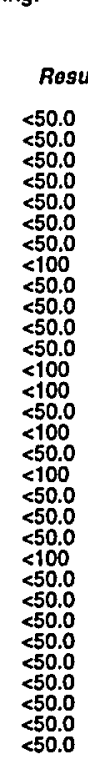

\begin{tabular}{|c|c|c|c|c|c|c|c|}
\hline Result & $F G$ & $s$ & EMS & $S Q L$ & Unit & Lab & Mothod \\
\hline $\begin{array}{l}<100 \\
<100 \\
<100 \\
<100 \\
<100 \\
<100 \\
<200 \\
<100 \\
<100 \\
<100 \\
<100 \\
<100 \\
<100 \\
<100 \\
<100 \\
<100 \\
<100 \\
<100 \\
<100 \\
<100 \\
<100 \\
<100 \\
48.0 \\
<180 \\
<100 \\
<100 \\
590 \\
<100\end{array}$ & 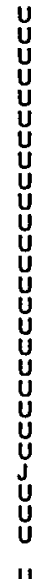 & 1 & & $\begin{array}{l}100 \\
100 \\
100 \\
100 \\
100 \\
100 \\
200 \\
100 \\
100 \\
100 \\
100 \\
100 \\
100 \\
100 \\
100 \\
100 \\
100 \\
100 \\
100 \\
100 \\
100 \\
100 \\
100 \\
100 \\
100 \\
100 \\
100 \\
100\end{array}$ & 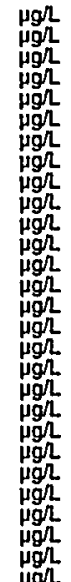 & $\begin{array}{l}\text { EX } \\
\text { EX } \\
\text { EX } \\
\text { EX } \\
\text { EX } \\
\text { EX } \\
\text { EX } \\
\text { EX } \\
\text { EX } \\
\text { EX } \\
\text { EX } \\
\text { EX } \\
\text { EX } \\
\text { EX } \\
\text { EX } \\
\text { EX } \\
\text { EX } \\
\text { EX } \\
\text { EX } \\
\text { EX } \\
\text { EX } \\
\text { EX } \\
\text { EX } \\
\text { EX } \\
\text { EX } \\
\text { EX } \\
\text { EX }\end{array}$ & 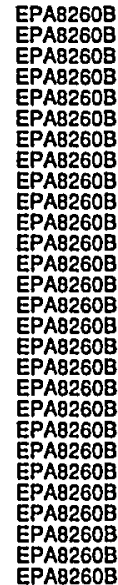 \\
\hline
\end{tabular}

Time: 10:25

Air

Aotal akalinity (as Caco3): $0 \mathrm{mg} /$
Well RWM 11 collected on 08/14/99 (cont.)

$F$ Analyte

Result

Irans-1,2-Dichlorosthylene

$<0.0$
$<50.0$

Dichloromethane

1.2-Dichloropropane

cis-1,3-Dichloropropene

rans-1.3.Dichloropropene
trans-1,3-Dichloropropene

Elhylbenzen

1,1,2,2-Tetrachloroethane

Tetrachloroethylene

Toluene

1.1.1-Trichloroethane

1.1,2-Trichlorosthane

Trichloroothylena

Trichloroethylene

Tifchlorollluoromelhane

$<52.2$
$<50.0$

$<50.0$

$<50.0$

$<50$

WELL RWM 11 Replicat

MEASUREMENTS CONDUCTED IN THE FIELD

Sample date: 06/14/99

Depth to waler: $172.8 \mathrm{ft}(52.67 \mathrm{~m})$ below TOC

$\mathrm{pH}: 4.8$

Sp. conductance: $28 \mu \mathrm{S} / \mathrm{cm}$

The well was continuously pumping.

ANALYSES

$F$ Analyto

0 Benzene

Bromoform

Carbon tetrachloric

Chlorobenzene
Chloroelhane

Chloroelthene (Vinyl chloride)
2-Chloroethyl vinyl olher

Chlorolorm

Dibromochloromathan

1., -Dichloroothane

1,i.Dichloroethylene

o trans-1,2-Dichloroeth

1,2-Dichloropropane

o trans-1,3-Dichlopropepene

Eihylbenzene
$1,1,2,2$-Tetrachloroethan

$\begin{array}{ll}0 & 1,1,2,2-\text { Tetrachloroet } \\ 2 & \text { Teirachloroethylene }\end{array}$

T,1,1-Trichloroethane

1.,1,2.Trichloroethane
2 Trichloroellhylene
O Trichlorofluoromethane

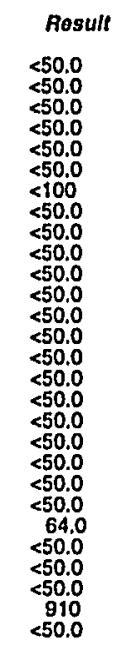

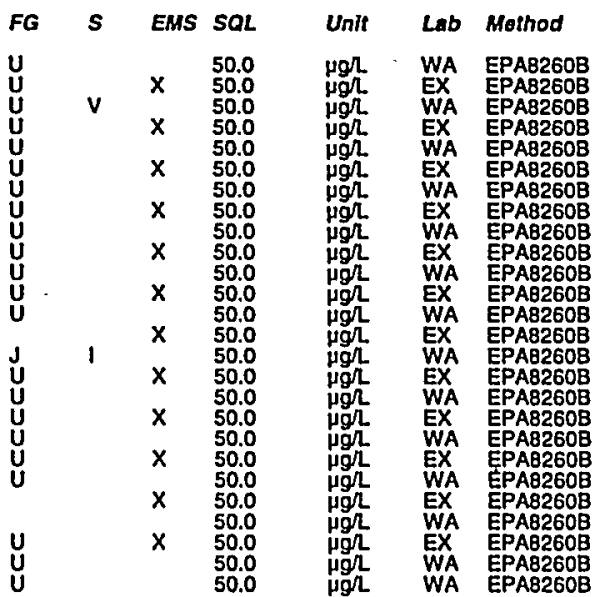

Time: 10:25

Warer lemperature: $21.3^{\circ} \mathrm{C}$ Total alkalinity. (as CaCO3): $0 \mathrm{mg} / \mathrm{L}$
Phenolphthalein alkalinity: $0 \mathrm{mgL}$

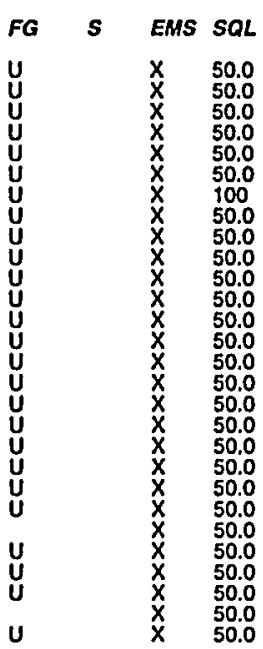


ANALYTICAL RESULTS

\section{WELL RWM 12}

MEASUREMENTS CONOUCTED IN THE FIELD

Sample dale: 04/14/99

Depth to water: $146.9 \mathrm{ft}(44.78 \mathrm{~m})$ below TOC

Water elevalion: $212.5 \mathrm{ft}(64.77 \mathrm{~m}) \mathrm{ms}$

$\mathrm{Sp}$. conductance: $42 \mu \mathrm{S} / \mathrm{cm}$

The well was continuously pumping.

ANALYSES

\section{F Analyto}

0 Benzene

Bromodichloromethane

Bromolorm
Bromolorm

Bromomothane

Carbon telrachloride
Carbon telrachloride

Chlorobenzene

Chloroethane

Chloroethane
Chloroethene (Vinyl chloride)
Chloroethene (Vinyl chloride)

2.Chloraethyl vinyl ether
2.Chloroethyl vinyl ether

Chlorolorm

Chloromethane
Chloromethane

Dibromochloromethane

1.1-Dichloroethane

o $1,1,-$ Dichloroethane

1.i. Dichloroelhylene

1.1.Dichloroethylene
trans-1,2-Dichloroethylen

Dichloromethane

1.2.Dichloropropane

cis-1,3.Dichloropropene
cis $-1,3 \cdot$ Dichloropropene

trans-1,3-Dichloropropene

Elhylbenzene

$1,1,2,2-$ Telrachloroethane

Telrachloroethylena
Tetrachloroethylena

Toluene

Toluene

1.1, 1. Trichloroethane

1.1,2-Trichloroethane

Trichloroelhylene

Trichlorolluoromethane

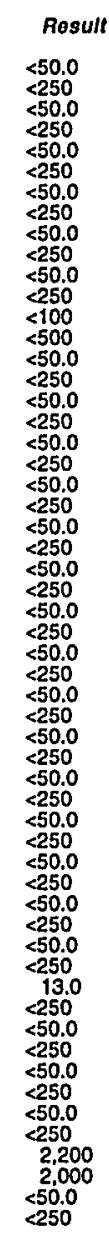

Time: 8:30

Alr temperature: $11.4^{\circ} \overrightarrow{\mathrm{C}}$

Total afkalinity (as CaCO3): $0 \mathrm{mg} / \mathrm{L}$
Phenolphthalein alkalinity: $0 \mathrm{mg} /$

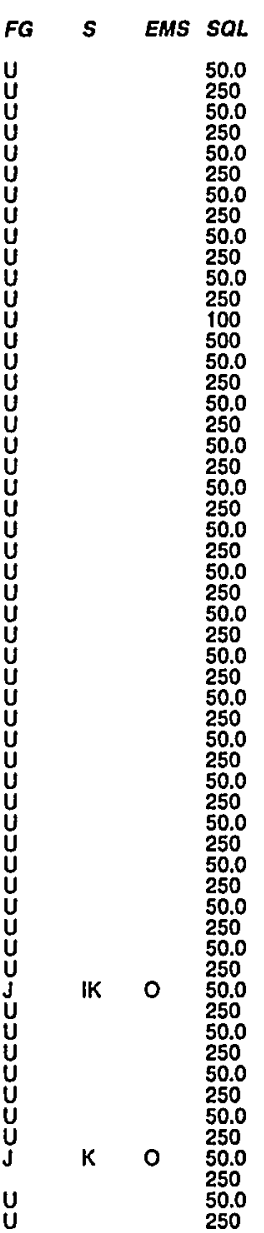

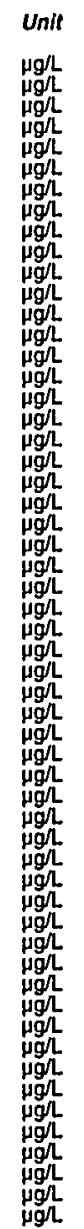

Lab Method

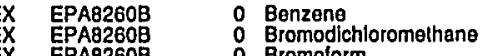

Bromoform

Carbon tetrachlorido

Chlorobenzen

Chloroethane (Vinyl chloride)

2-Chloroethyl viny

Chloromethane

$1,1 \cdot$ Dichloroethane
1,2 -Dichloroethan

1,i-Dichloroelhylene

trans-1,2-Dlchloroe日lhy
Dichloromethane

1,2-Dichloropropane
cis-1,3-Dichhoropropene

trans-1,3-Dichloropropene

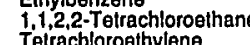

Toluene

$1,1,1$ - Trichloroethane

2 Trichloroethylene

\section{WELL RWM 12}

MEASUREMENTS CONDUCTED IN THE FIELD

Sample date: $06 / 14 / 99$

Water elevation: $224.6 \mathrm{ft}(68.46 \mathrm{~m}) \mathrm{msl}$

$\mathrm{PH}: 5.8$

H: 5.8 conductance: $41 \mu \mathrm{S} / \mathrm{cm}$

The well was continuously pumping

ANALYSES

F Analyto

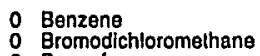

Bromolorm

Bromomethane

Carbon tetrachloride

Chloroethana

Chloroethene (Vinyl chloride)

2.Chlorosthyl viny

Chloroform

Dibromochloromethan

1,1-Dichloroethan

1.1.-Oichloroeethylene
irans-1,2-Dichloroethylene

Dichloromethane

cis-1,3-Dichloropropene

Itans-1,3.Dichloropropen

B-200
Rosull

$<50.0$
$<50.0$
550.0
550.0
550.0
550.0
$<100$
550.0
550.0
550.0
550.0
550.0
550.0
550.0
550.0
550.0
550.0
550.0
55.0
550.0
550.0
Time: 10:42

mperature: $20.2^{\circ} \mathrm{C}$

Total alkalinity (as Caco3): $0 \mathrm{mg}$

\begin{tabular}{|c|c|c|c|}
\hline ;OL & Unit & Lab & Method \\
\hline $\begin{array}{l}100 \\
100 \\
100 \\
100 \\
100 \\
100 \\
200 \\
100 \\
100 \\
100 \\
100 \\
100 \\
100 \\
100 \\
100 \\
100 \\
100 \\
100 \\
100 \\
100 \\
100 \\
100 \\
100 \\
100 \\
100 \\
100 \\
100 \\
100\end{array}$ & $\begin{array}{l}\mu g / L \\
\mu g h \\
\mu g h \\
\mu g h \\
\mu g h \\
\mu g h \\
\mu g h \\
\mu g h \\
\mu g h \\
\mu g h \\
\mu g h \\
\mu g h \\
\mu g h \\
\mu g h \\
\mu g h \\
\mu g h \\
\mu g h \\
\mu g h \\
\mu g h \\
\mu g h \\
\mu g h \\
\mu g h \\
\mu g h \\
\mu g h \\
\mu g h \\
\mu g h \\
\mu g h \\
\mu g h \\
\mu g h\end{array}$ & $\begin{array}{l}\text { EX } \\
\text { EX } \\
\text { EX } \\
\text { EX } \\
\text { EX } \\
\text { EX } \\
\text { EX } \\
\text { EX } \\
\text { EX } \\
\text { EX } \\
\text { EX } \\
\text { EX } \\
\text { EX } \\
\text { EX } \\
\text { EX } \\
\text { EX } \\
\text { EX } \\
\text { EX } \\
\text { EX } \\
\text { EX } \\
\text { EX } \\
\text { EX } \\
\text { EX } \\
\text { EX } \\
\text { EX } \\
\text { EX }\end{array}$ & 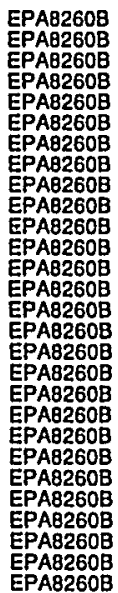 \\
\hline
\end{tabular}

Time: 11:00

Air temperature: $31.26 .7^{\circ} \mathrm{C}$

Total alkalinity (as CaCO3): $10 \mathrm{mg}$

Phenolphthalein alkalinily: $0 \mathrm{mgh}$.

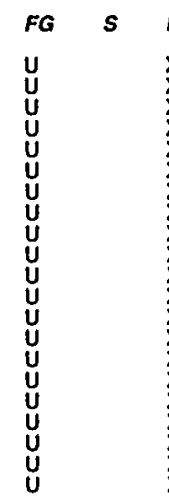

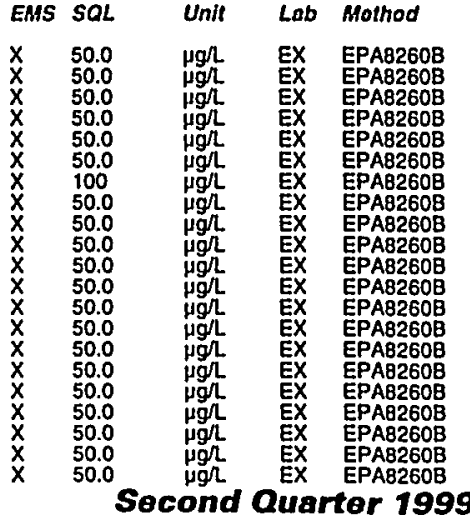




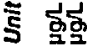

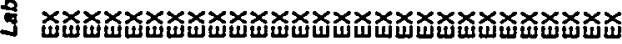

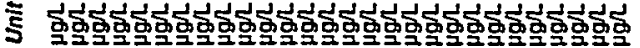

n

כ2

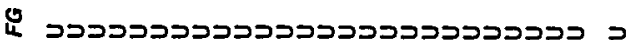
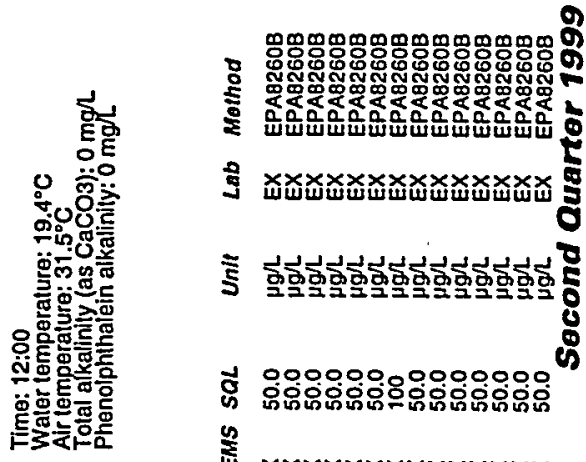

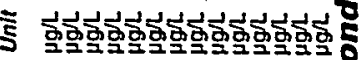

If 0000000000000

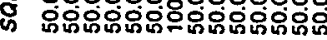

福

בכבכככככבכבכב
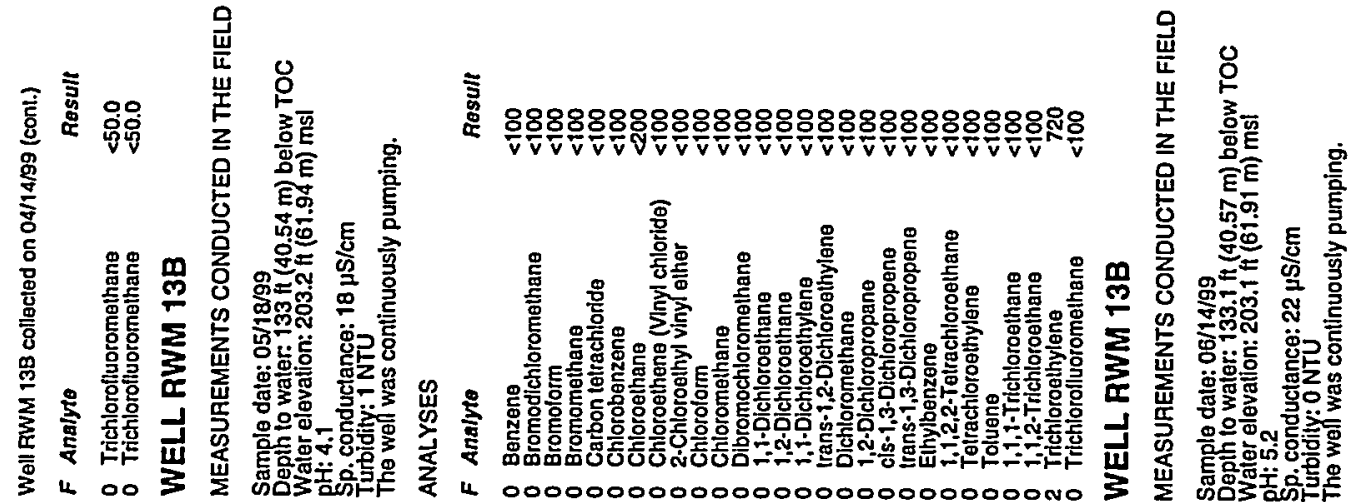

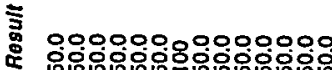

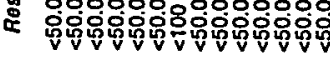

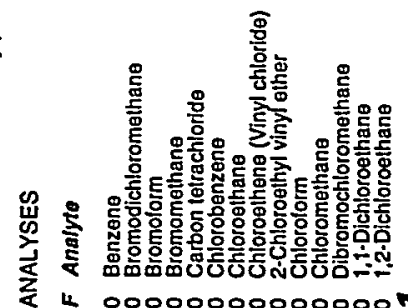

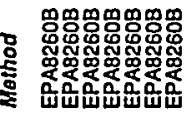

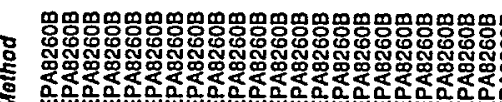

L 00000000000000

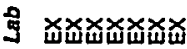

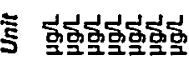

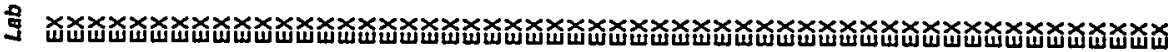

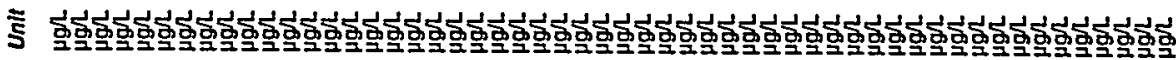

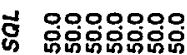

悉 $x \times x \times x \times x$

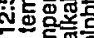

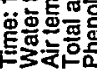

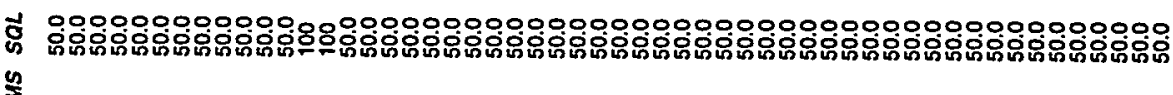

i -

ב בסכיר

a

i

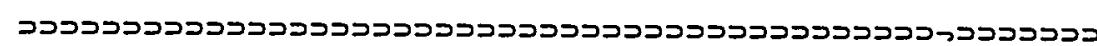

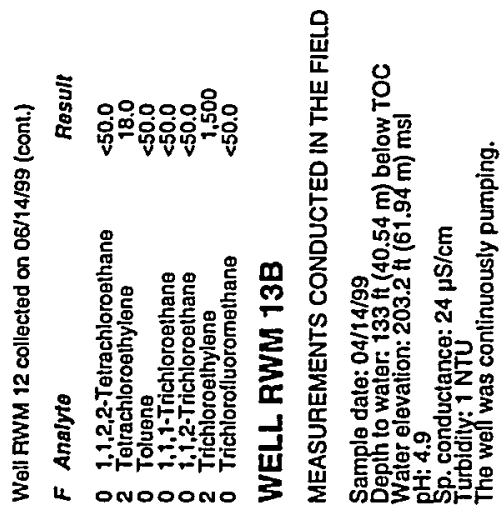

害

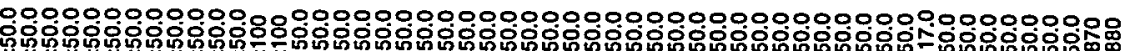

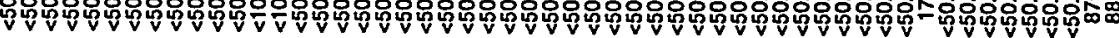

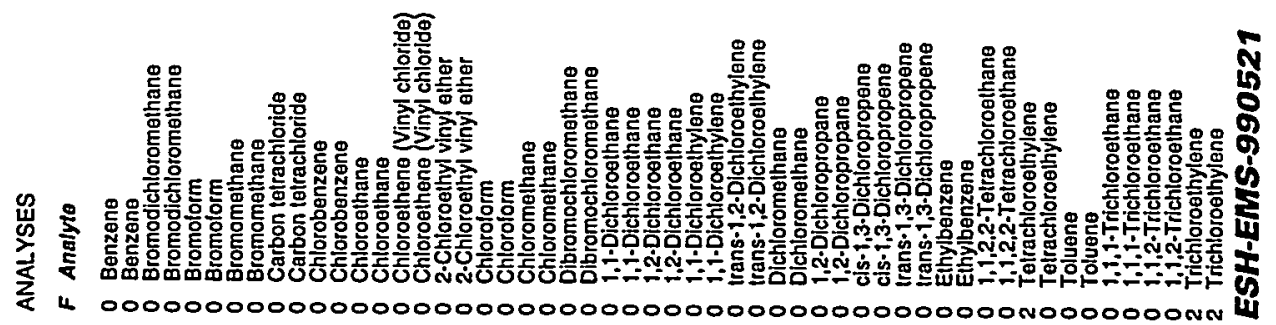


Well RWM 13B collected on 06/14/99 (cont.)

$F$ Analyto

Rosult

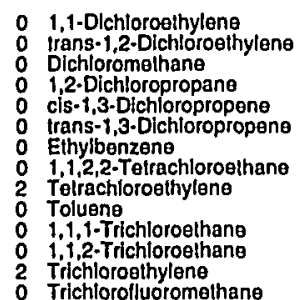

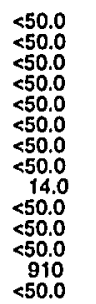

\section{WELL RWM 13C}

MEASUREMENTS CONDUCTED IN THE FIELD Sample date: 04/14/99 $\mathrm{ft}(39.12 \mathrm{~m})$ below TOC Wapth

$\mathrm{pH}:$

p. conductance: $30 \mu \mathrm{S} / \mathrm{cm}$

The well was continuously pumping.

ANALYSES

\section{$F$ Analyito}

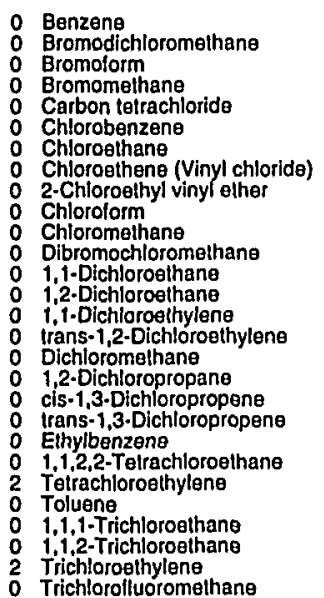

Result

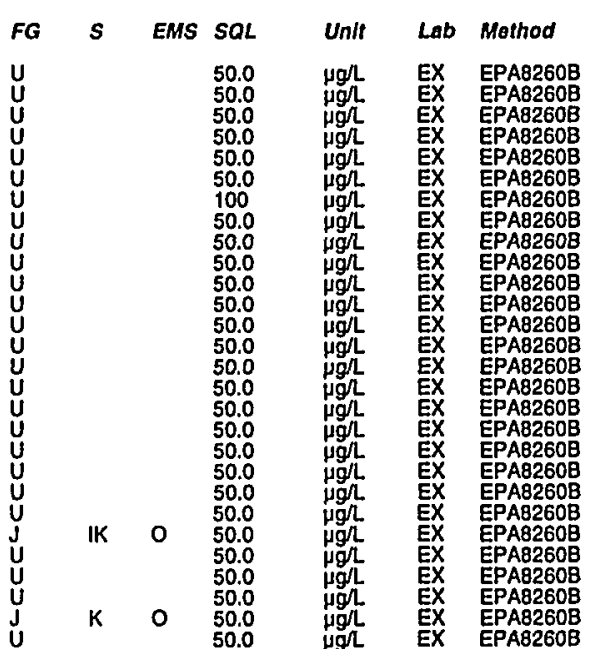

\section{WELL RWM 13C}

MEASUREMENTS CONDUCTED IN THE FIELD

Sample date: 05/18/99 $128.12 \mathrm{~m}$ ) below TOC

Water elevation: $208.06 \mathrm{ft}$ (63.4
$\mathrm{gH}: 4.4$. conductance: $27 \mu \mathrm{S} / \mathrm{cm}$

The well was continuously pumping.

ANALYSES

$F$ Analyre

Result

: Benzene

ESH-EMS-990521
FG S EMS SQL Unit Lab Mothod

$\begin{array}{ll}x & 50.0 \\ x & 50.0 \\ x & 50.0 \\ x & 50.0 \\ X & 50.0 \\ X & 50.0 \\ x & 50.0 \\ x & 50.0 \\ x & 50.0 \\ x & 50.0 \\ x & 50.0 \\ x & 50.0 \\ x & 50.0 \\ x & 50.0\end{array}$
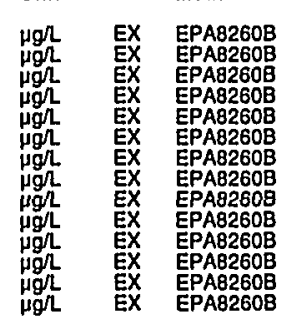

Time: 13:00

Waler temperalure: $19.1^{\circ} \mathrm{C}$ Total atkalinity (as CaCO3): $0 \mathrm{mg} /$
Time: 12:55

Total alkalinity (as Caco3): $0 \mathrm{mgh}$
Phenolphthalein alkalinity: $0 \mathrm{mgh}$
Airorienesture: $20.8^{\circ} \mathrm{C}$

$<100$
$<100$

$F G$
$U$

EMS SOL

Unit

Lab Mothod

$\begin{array}{llll}100 & \mu g h & \text { EX } & \text { EPAB260B } \\ 100 & \mu g h & \text { EX } & \text { EPA8260B }\end{array}$
Well RWM 13 C collected on 05/18/99 (cont.)

$F$ Analyto

0 Bromolorm

Carbon teirachloride

Chlorosthane

Chlorothene (Vinyl chloride)

C Chlorolorm

Dibromochloromethane

1.1.Dichloroethan

$1,1 \cdot$ Dichloroethylene
0
trans-1,2-Dichloroethylene

0 Dichloromethane

$\begin{array}{ll}0 & 1,2 \cdot \text { Dichloropropane } \\ 0 & \text { cis-1,3-DJchloropropen }\end{array}$

trans-1,3.Dichloropropen

1,1,2,2-Telrachloroethan
0 Tetrachloroethylene

Thener

o 1,1,2-Tichloroethane

2 Trichloroesthylene

WELL RWM 13C

MEASUREMENTS CONDUCTED IN THE FIEL.D

Sample date: $06 / 14 / 99$

Water elevation: 208 it $(63.4 \mathrm{~m}) \mathrm{ms}$

H.: 4.9 conductance: $30 \mu \mathrm{S} / \mathrm{cm}$

The well was continuously pumping

ANALYSES

$F$ Analyto

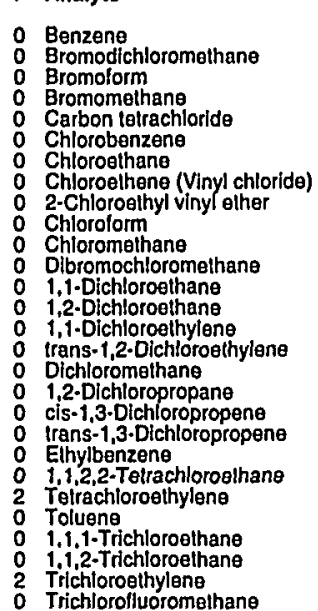

$\quad$ Result
$<50.0$
$<50.0$
$<50.0$
$<50.0$
$<50.0$
$<50.0$
$<100$
$<50.0$
$<50.0$
$<50.0$
$<50.0$
$<50.0$
$<50.0$
$<50.0$
$<50.0$
$<50.0$
$<50.0$
$<50.0$
$<50.0$
$<50.0$
$<50.0$
$<50.0$
28.0
$<50.0$
$<50.0$
$<50.0$
1.200
$<50.0$

J

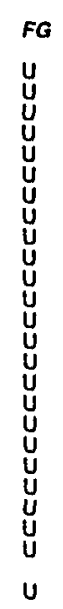

$\begin{array}{cc}\text { EMS } & \text { SO } \\ 100 \\ 100 \\ 100 \\ 100 \\ 200 \\ 100 \\ 100 \\ 100 \\ 100 \\ 100 \\ 100 \\ 100 \\ 100 \\ 100 \\ 100 \\ 100 \\ 100 \\ 100 \\ 100 \\ 100 \\ 100 \\ 100 \\ 100 \\ 100 \\ \end{array}$

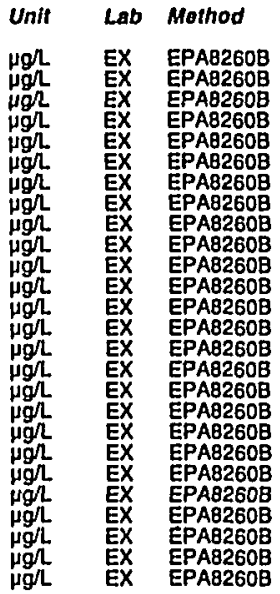

Time: 12:10

Wat $19.5^{\circ} \mathrm{C}$

Total alkalinily (as CaCO3): $0 \mathrm{mg} /$

B-202 


\section{WELL RWM 14B}

MEASUREMENTS CONDUCTED IN THE FIELD

Sample date: $04 / 14 / 99$ Water elevation: $210.5 \mathrm{ft}(64.16 \mathrm{~m}) \mathrm{ms}) \mathrm{ms}$ ?

pH: 5.3

Sp. conductance: $25 \mu \mathrm{S} / \mathrm{cm}$

The wefl was continuously pumping.

ANALYSES

\begin{tabular}{|c|c|}
\hline Analyte & Resu/h \\
\hline 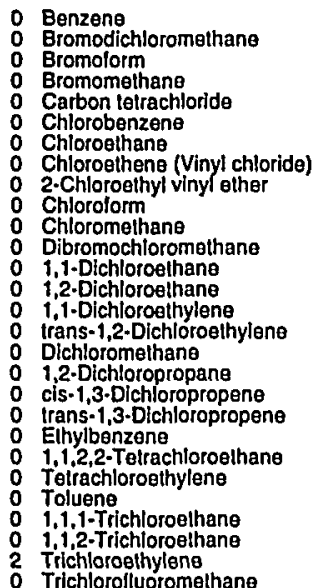 & $\begin{array}{l}<50.0 \\
<50.0 \\
<50.0 \\
<50.0 \\
<50.0 \\
<50.0 \\
<100 \\
<50.0 \\
<50.0 \\
<50.0 \\
<50.0 \\
<50.0 \\
<50.0 \\
<50.0 \\
<50.0 \\
<50.0 \\
<50.0 \\
<50.0 \\
<50.0 \\
<50.0 \\
<50.0 \\
<50.0 \\
<50.0 \\
<50.0 \\
<50.0 \\
<50.0 \\
570 \\
<50.0\end{array}$ \\
\hline
\end{tabular}

\section{WELL RWM 14B}

MEASUREMENTS CONDUCTED IN THE FIELD

Sample date: 05/18/99

Depth to water: $140.74 \mathrm{ft}(42.9 \mathrm{~m})$ below TOC

$\mathrm{pH}: 4.1$

sp. conductance: $20 \mu \mathrm{S} / \mathrm{cm}$

Turbidity: ONTU
The well was continuously pumping.

ANALYSES

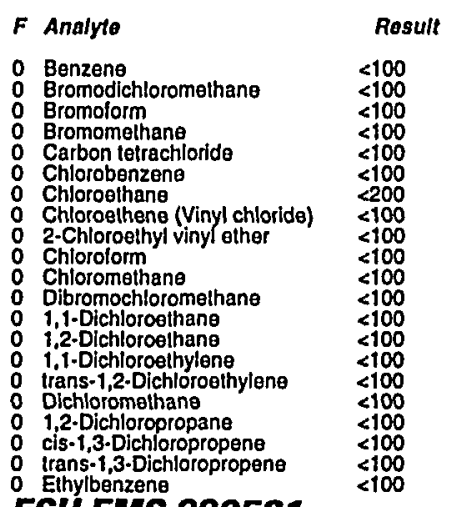

Time: 8:55
Waler temperature: $17.4^{\circ} \mathrm{C}$

Air temperature: $13.2^{\circ} \mathrm{C}$

Total akaininy (as CaCO3): $0 \mathrm{mgn}$

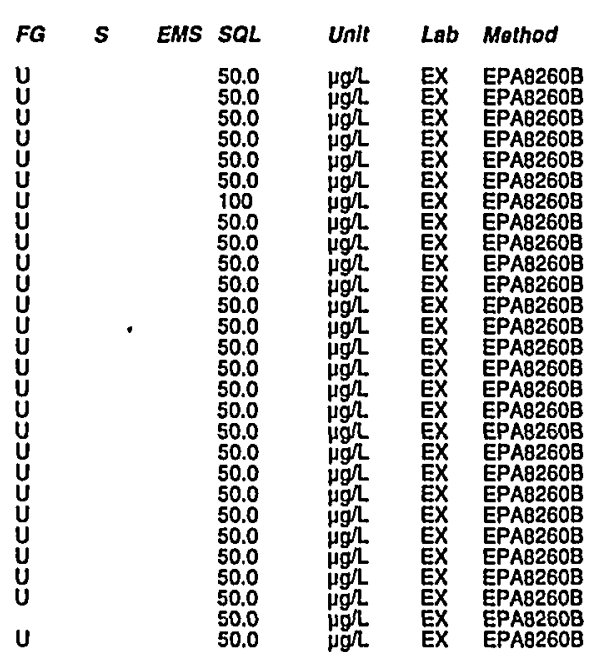

Well RWM 148 collected on 05/18/99 (cont)

$F$ Analyte Result

0 1,1,2,2-Tetrachlorosthane

o $1,1,1$-Trichloroethane

2 Trichloroethylene

WELLL RWM 14B

MEASUREMENTS CONDUCTED IN THE FIELD

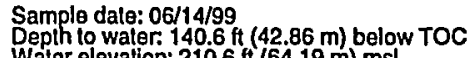

Water elevation: $210.6 \mathrm{ft}(64.19 \mathrm{~m}) \mathrm{msl}$

Sp. conductance: $24 \mu \mathrm{S} / \mathrm{cm}$

The well was continuously pumping.

ANALYSES

\section{$F$ Analyto}

$\begin{array}{ll}0 & \text { Benzene } \\ 0 & \text { Bromodichloromethane } \\ 0 & \text { Bromolorm }\end{array}$

Bromolorm

Chlorobenzene

Chloroethene (Vinyl chloride)

Chlororometh

Chloromelhane

$1,1 \cdot$ Dichloroethane
$1,2 \cdot$ Dichloroethane

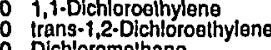

trans-1,2-Dichloroe
Dichloromethane
1 .

$1,2-D \mid c h l o r o p r o p a n e$
0
cis-1,3-Dichloropropene

Elhylbenzene $1,1,2,2-$ Tetrachloroethan

Tetrachloroethylen

1,1,1-Trichloroethane

Trichlorofluoromethane

\section{WELL RWM 14C}

MEASUREMENTS CONDUGTED IN THE FIELD

Sample date: 04/14/99

Waler elevalion: $27.9 \mathrm{ft}(45.08 \mathrm{~m})$ below TOC

$\mathrm{H}: 5.2$

Sp. conductance: $38 \mu \mathrm{S} / \mathrm{cm}$

The well was continuously pumping.

ANALYSES

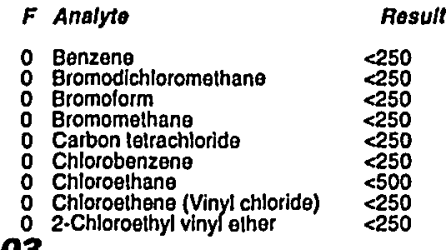

FG

u

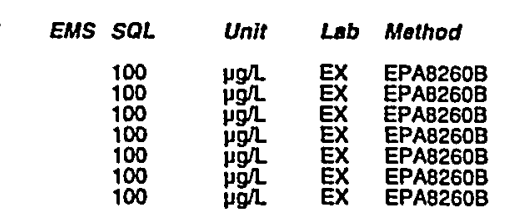

Time: 11:25

Ar temperature: $314^{\circ} \mathrm{C}$

Total alkalinity (as CaCO3): $0 \mathrm{mg} /$

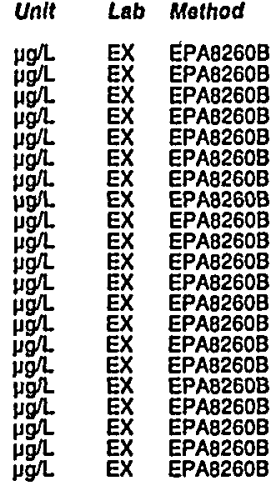

\begin{tabular}{|c|c|c|c|c|c|c|c|c|}
\hline Result & & $F G$ & $s$ & EMS & $S Q L$ & Unit & Lab & Mothod \\
\hline $\begin{array}{l}<50.0 \\
<50.0 \\
<50.0 \\
<50.0 \\
<50.0 \\
<50.0 \\
<100 \\
<50.0 \\
<50.0 \\
<50.0 \\
<50.0 \\
<50.0 \\
<50.0 \\
<50.0 \\
<50.0 \\
<50.0 \\
<50.0 \\
<50.0 \\
<50.0 \\
<50.0 \\
<50.0 \\
<50.0 \\
12.0 \\
<50.0 \\
<50.0 \\
<50.0 \\
1,000 \\
<50 .\end{array}$ & , & 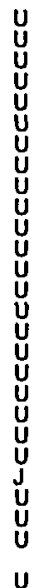 & 1 & $\begin{array}{l}x \\
x \\
x \\
x \\
x \\
x \\
x \\
x \\
x \\
x \\
x \\
x \\
x \\
x \\
x \\
x \\
x \\
x \\
x \\
x \\
x \\
x \\
x \\
x \\
x \\
x \\
x \\
x \\
x \\
x\end{array}$ & $\begin{array}{l}50.0 \\
50.0 \\
50.0 \\
50.0 \\
50.0 \\
50.0 \\
100 \\
50.0 \\
50.0 \\
50.0 \\
50.0 \\
50.0 \\
50.0 \\
50.0 \\
50.0 \\
50.0 \\
50.0 \\
50.0 \\
50.0 \\
50.0 \\
50.0 \\
50.0 \\
50.0 \\
50.0 \\
50.0 \\
50.0\end{array}$ & 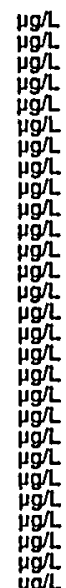 & $\begin{array}{c}\text { EX } \\
\text { EX } \\
\text { EX } \\
\text { EX } \\
\text { EX } \\
\text { EX } \\
\text { EX } \\
\text { EX } \\
\text { EX } \\
\text { EX } \\
\text { EX } \\
\text { EX } \\
\text { EX } \\
\text { EX } \\
\text { EX } \\
\text { EX } \\
\text { EX } \\
\text { EX } \\
\text { EX } \\
\text { EX } \\
\text { EX } \\
\text { EX } \\
\text { EX } \\
\text { EX } \\
\text { EX } \\
\text { EX }\end{array}$ & 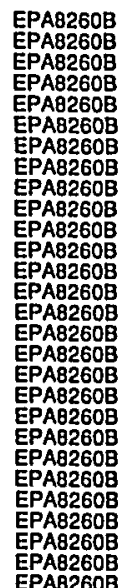 \\
\hline
\end{tabular}

Time: 9:00

Waler temperature: $171^{\circ} \mathrm{C}$

Phenal alkalinily (as Caco3): $0 \mathrm{mg} /$

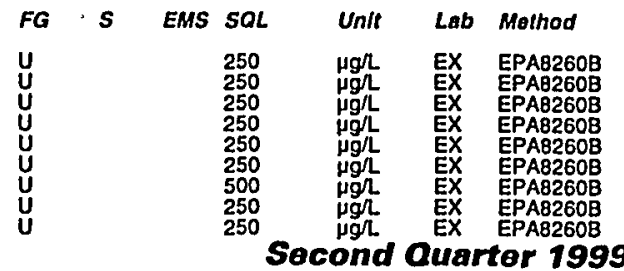


Well RWM 14 C collected on 04/14/99 (cont.)

$F$ Analyto

o Chlorolorm

Dibromochloromethane

1,2.Dichloroethane

$\begin{array}{ll}0 & 1,1-D i c h l o r o e t h y l e n \theta \\ 0 & \text { trans-1,2-Dichloroethylene }\end{array}$

Olchloromethane

o cis-1,3-Dichloropropene

Eihylbenzene

$1,1,2,2$-Tetrachloroothan
Tetrachloroethylene

$\begin{array}{ll}0 & \text { Toluene } \\ 0 & 1,1,1 \text { - Trichloroothane } \\ 0 & 1,1,2 \text {-Trichloroothane }\end{array}$

2
2
0

WELL RWM 14C

MEASUREMENTS CONDUCTED IN THE FIELD

Sample date: $05 / 18 / 99 \mathrm{H}(45.1 \mathrm{~m})$ below TOC

Water

Sp. conductance: $35 \mu \mathrm{S} / \mathrm{cm}$

Turbidity: 1 NTU: 35 S $/ \mathrm{cm}$
The wefl was continuously pumping

ANALYSES

$F$ Analyto

0 Benzene

Boromolorm

Carbon tetrachiorldo

Chlorobenzene

Chloroethene (Vinyl chloride)

Chloromethan

Chibromochlore

1,1-Dichloroethane

$1,1 \cdot$ Dichloroethylene
trans-1,2-Dichloroethylene

Dichloromethane

cis-1,3-Dichloropropene

Ethylbenzene

Telrachloroethylen

1.1, T- Trichloroethane

2 Trichlorosthylene

Rosult

FG

\begin{tabular}{|c|c|c|c|c|}
\hline EMS & $S Q L$ & Unit & Lab & Method \\
\hline & $\begin{array}{l}250 \\
250 \\
250 \\
250 \\
250 \\
250 \\
250 \\
250 \\
250 \\
250 \\
250 \\
250 \\
250 \\
250 \\
250 \\
250 \\
250 \\
250 \\
250\end{array}$ & 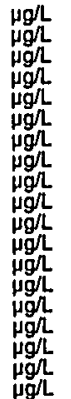 & $\begin{array}{l}\text { EX } \\
\text { EX } \\
\text { EX } \\
\text { EX } \\
\text { EX } \\
\text { EX } \\
\text { EX } \\
\text { EX } \\
\text { EX } \\
\text { EX } \\
\text { EX } \\
\text { EX } \\
\text { EX } \\
\text { EX } \\
\text { EX } \\
\text { EX } \\
\text { EX } \\
\text { EX } \\
\text { EX }\end{array}$ & 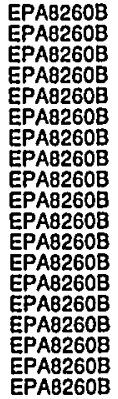 \\
\hline
\end{tabular}

\section{WELL RWM 14C}

MEASUREMENTS CONDUCTED IN THE FIELD

Sample date: 06/14/99

Sp. conductance: $36 \mu \mathrm{s} / \mathrm{cm}$

Thurbidity: 1 NTU

ESH-EMS-990521

Whater 11:30

Total alkalinity (as CaCO3): $0 \mathrm{mg} /$
Phenolphthalein alkalinity: 0 mgl
Well RWM 14C collected on 08/14/99 (cont.)

ANALYSES

$F$ Analyto

: Benzene

Bromolorm

Carbon tetrachioride

Chlorobenzene
Chloroethane

Chloroethene (Vinyl chloride)

Chlorolorm

Dibromochloromethane

1.2.Dichloroethane

1, Dichhoroeshylane
trans-1,2-Dichloroethylene

O Dichloromethane

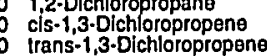

1, Elhylbenzene

Tetrachloroethylene

$\begin{array}{ll}0 & 1,1,1-\text { Trichloroethane } \\ 0 & 1,1,2-\text { Trichloroethane }\end{array}$

2 1,1,2-Trichloroethane

\section{WELL RWM 15B}

Resuft
$<250$
$<250$
$<250$
$<250$
$<250$
$<250$
$<500$
$<250$
$<250$
$<250$
$<250$
$<250$
$<250$
$<250$
$<250$
$<250$
$<250$
$<250$
$<250$
$<250$
$<250$
$<250$
97.0
$<250$
$<250$
$<250$
5,600
$<250$
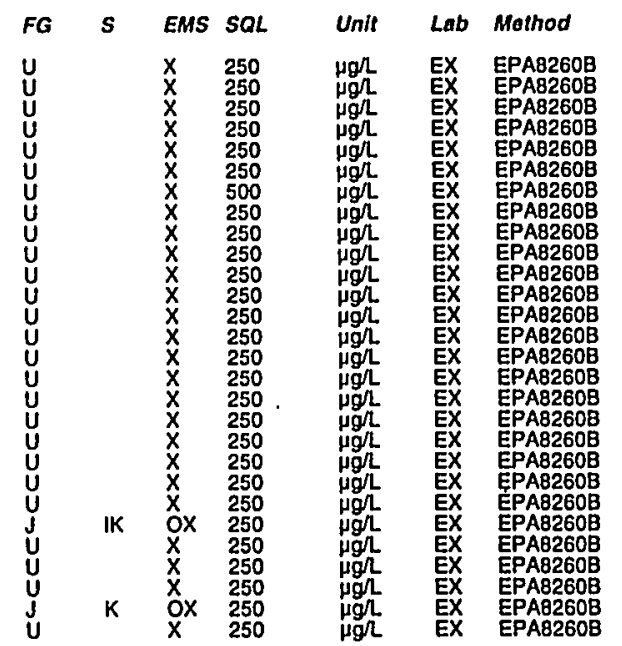

MEASUREMENTS CONDUCTED IN THE FIELD

Sample date: 04/14/99

Depth to water: $160.7 \mathrm{H}(48.98 \mathrm{~m})$ below TOC

pH: 5.1

Sp. conductance: $22 \mu \mathrm{S} / \mathrm{cm}$

The wefliti was continuously pumping.

ANALYSES

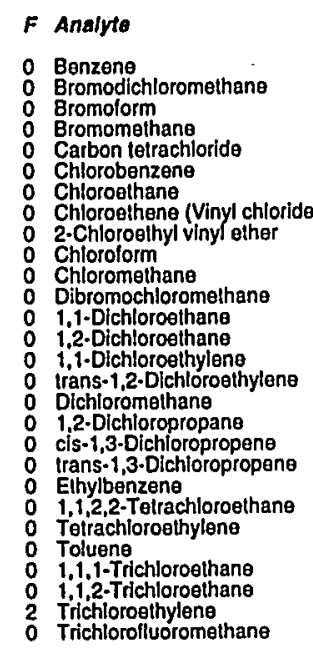

Resu
5.00
55.00
55.00
55.00
55.00
55.00
510.0
55.00
55.00
55.00
55.00
55.00
55.00
55.00
55.00
55.00
55.00
55.00
55.00
55.00
5.00
55.00
5.00
55.00
5.00
55.00
31.0
$<5.00$
Time: 13:20

Waler temperature: $19^{\circ} \mathrm{C}$

Total afkalinity (as CaCO3): $0 \mathrm{mg} /$
Phenolphthalein alkalinity: $0 \mathrm{mg} \mathrm{L}^{2}$ 


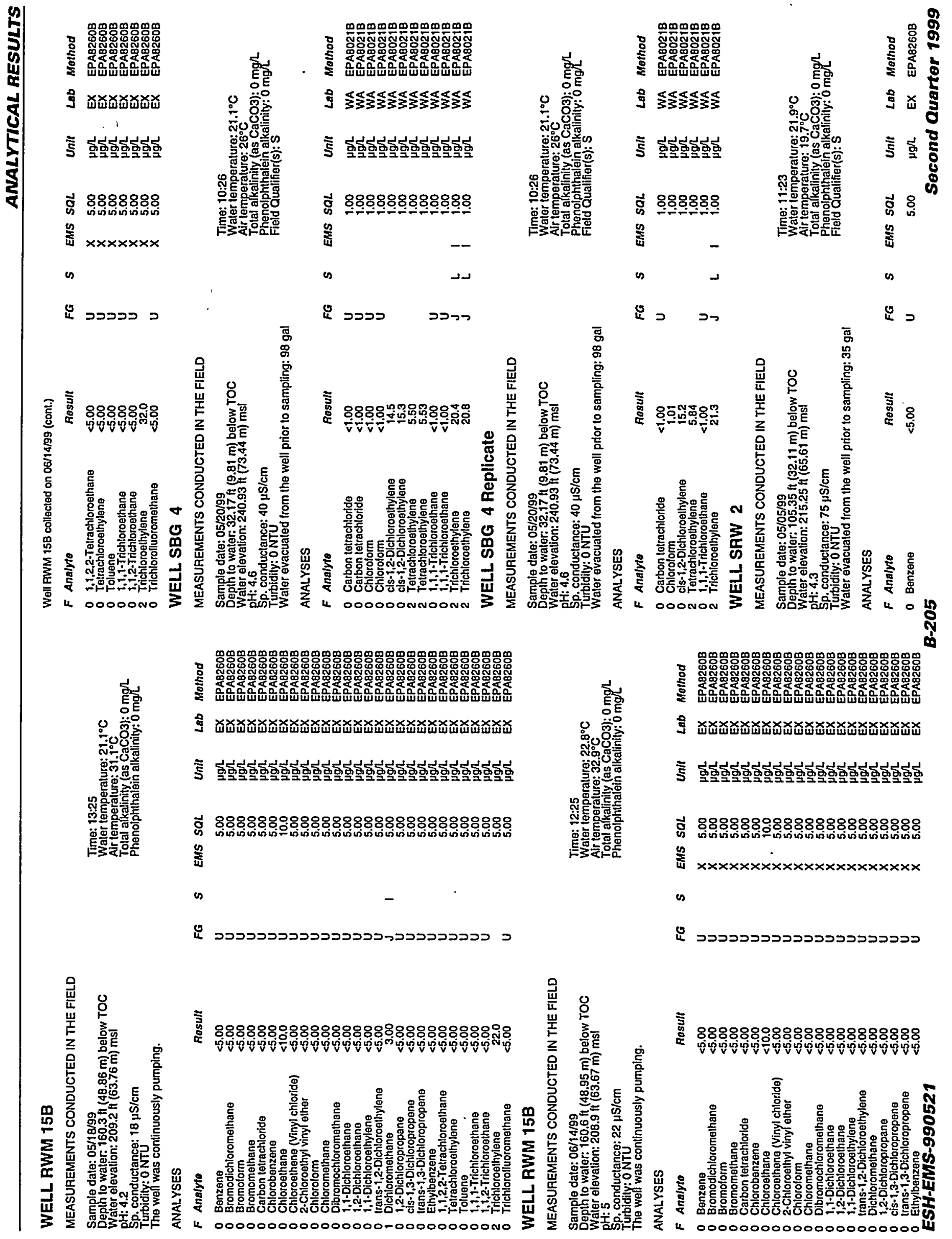


Well SRW 2 collected on 05/05/99 (cont.)

$F$ Analyto

Result

0 Bromodlchloromethane

Bromoform

Carbon tetracthloride

Chloroethane

Chloroethene (Vinyl chloride)

Chlorolorm

Dibromechloremethane

1,1.Dichloroethane

$1,1-$ Dichloroethylene
trans $=1,2-$ Dichloroethylene

Dichloromenthane

cis-1,3.Dichloropropene

Eihylbenzene

Tetrachloroethylene

1,1,1-Trichloroethane

Trichloroothylene

\section{WELL SRW 4}

MEASUREMENTS CONDUCTED IN THE FIELD

Sample date: $05 / 05 / 99$ (1) $(32.51 \mathrm{~m})$ below TOC

.06 m) $\mathrm{msl}$

pH: 4.6

p. conductance: $120 \mu \mathrm{S} / \mathrm{cm}$

Waler evacuated from the well prior to sampling: $33 \mathrm{gal}$

ANALYSES

$F$ Anglyte

Result
55.00
55.00
55.00
55.00
$<5.00$
55.00
510.0
55.00
$<5.00$
5.80
55.00
55.00
55.00
55.00
55.00
55.00
55.00
55.00
55.00
55.00
55.00
55.00
55.00
55.00
55.00
55.00
55.00
$<5.00$

ESH-EMS-990521

\section{WELL SRW 7}

MEASUREMENTS CONDUCTED IN THE FIELD

Sample date: 05/05/99
Depth to waler: $88.86 \mathrm{ht}(27.08 \mathrm{~m})$ below TOC
Water elevalion: 210.24 t $(64.08 \mathrm{~m}) \mathrm{msl}$

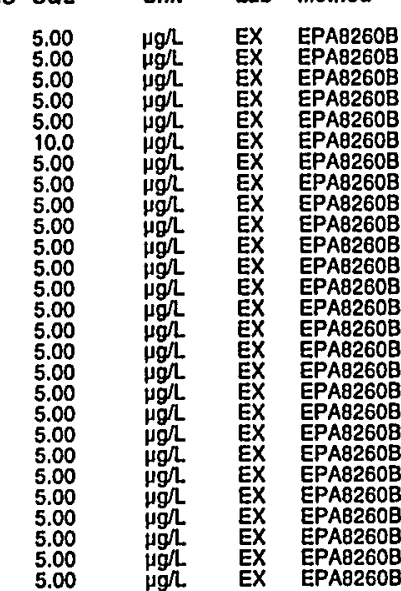

Water e

Sp. conductance: $29 \mu \mathrm{S} / \mathrm{cm}$

Wurbidity: 2 NTU Water evacualed from the well prior 10 sampling: 34 gal ANALYSES

F Analyte$$
\begin{aligned}
& F C \\
& u \\
& u \\
& u \\
& u \\
& u \\
& u \\
& u \\
& u \\
& J \\
& u \\
& u \\
& u \\
& u \\
& u \\
& u \\
& u \\
& u \\
& u \\
& J \\
& u \\
& u \\
& u \\
& u \\
& u
\end{aligned}
$$

0 Benzene

Bromolorm

1 Carbon telrachlorid

Chlorobenzene

2.Chloroethyi vinyl ether

o Chloromothan

Dibromochloromethan

o T.2-Dichloroethane

1,1-Dichloroelhylene
trans-1,2-Dichloroethylen

Dichloromethane

cis-1,3-Dichloropropene

Elhylbenzene

Tetrachloroethylene

1,i, -Trichloroethane

O Trichloroolhylene

WELL SRW 8

MEASUREMENTS CONDUCTED IN THE FIELD

Sample date: 05/06/99

Water elevalion: Not available

$\mathrm{gH}$. 4.8 conductance: $22 \mu \mathrm{s} / \mathrm{cm}$

Sp. conductance: $22 \mu \mathrm{S} / \mathrm{cm}$

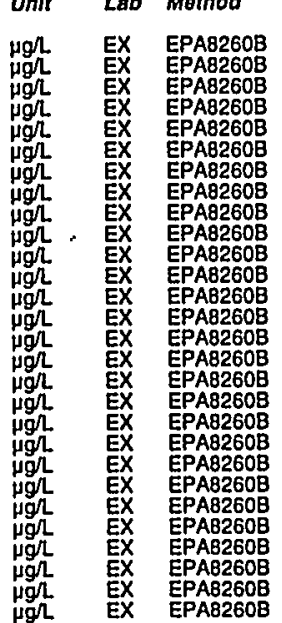

ANALYSES

$F$ Analyte

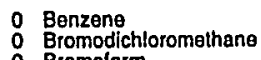

Bromolorm
Bromomethane

Carbon teltrachiorid

Chloroethane

Chloroethene (Vinyl chloride)

Chloroform

Chloromethane

1.1.Dichloroethan

i, 1 -Dichloroethylene
trans-1,2-Dichloroethylene

Dichloromethane

cis-1,3-Dichloropropene

B-206

Result
5.00
55.00
55.00
55.00
2.80
55.00
510.0
55.00
55.00
3.30
55.00
55.00
55.00
55.00
55.00
55.00
55.00
5.00
55.00
5.00
55.00
55.00
1.40
55.00
55.00
$<5.00$
55.00
$<5.00$

FG S EMS

$u$
$u$
$u$
$u$
$u$
$u$
$u$
$u$
$u$
$u$
$u$
$u$
$u$
$u$
$u$
$u$
$u$
$J$
$u$
$u$
$u$
$u$
$u$

(1)

Result
$<5.00$
$<5.00$
55.00
$<5.00$
$<5.00$
$<5.00$
$<10.0$
$<5.00$
$<5.00$
$<5.00$
$<5.00$
$<5.00$
$<5.00$
$<5.00$
$<5.00$
55.00
1.90
$<5.00$
$<5.00$
$<5.00$
$<5.00$

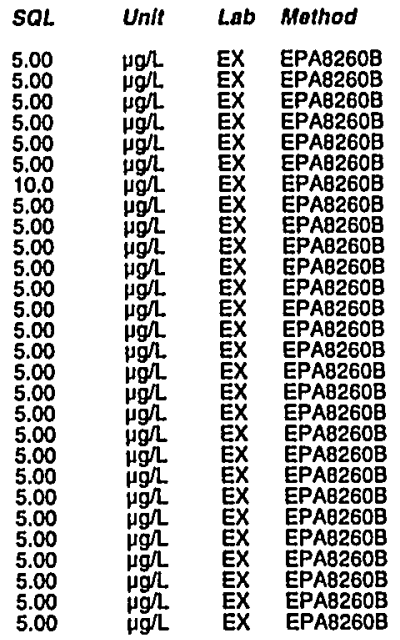

Time: 10:48

Werature: $20.6^{\circ} \mathrm{C}$

Total alkalinity (as CaCo3): $3 \mathrm{mg} /$

Field Qualifier(s):

Total alkalinity (as CaCO3): $0 \mathrm{mg}$

列

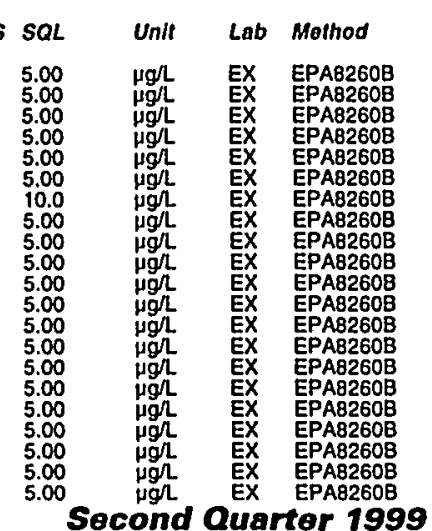




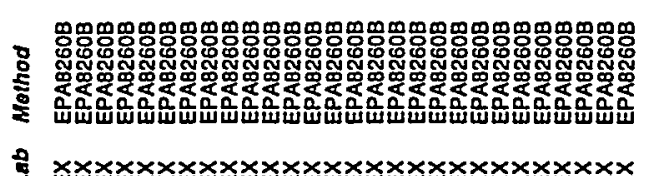

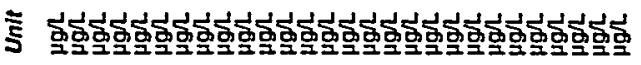

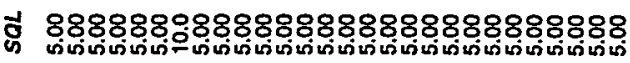
紊

s

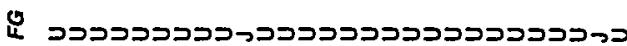

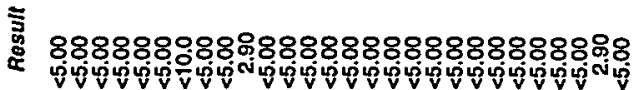

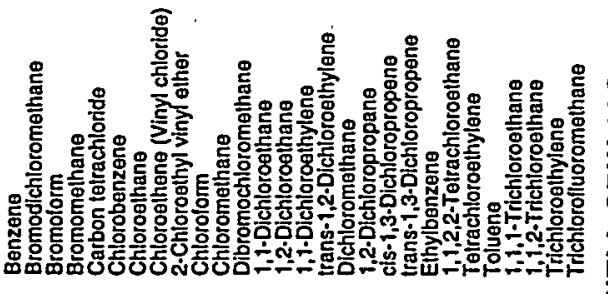

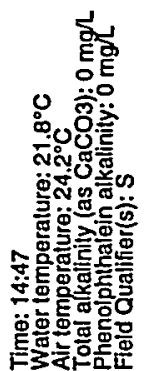

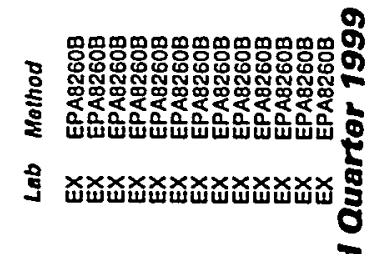

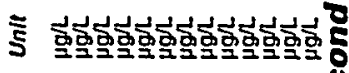

480000000

ఫ

a

a

בכבכבכבכבכבי

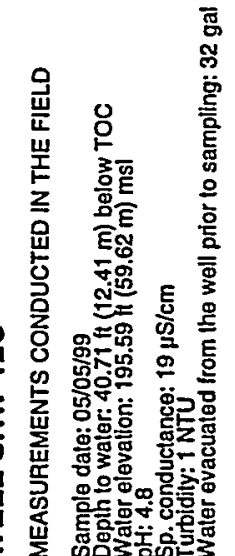

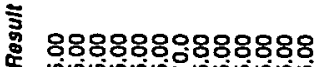

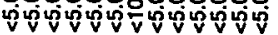

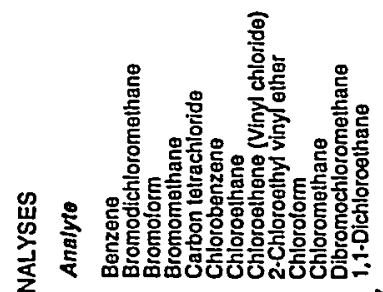

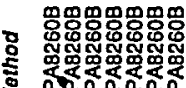

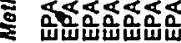

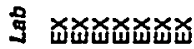

हू.

范

응

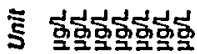

앵ํำ

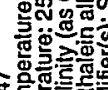

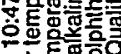

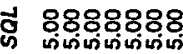

翣

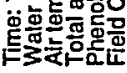

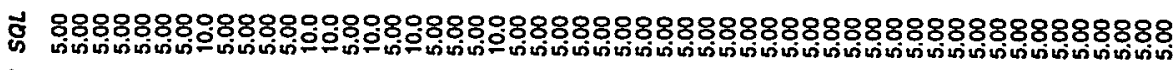

紊

ต

במיכבכב

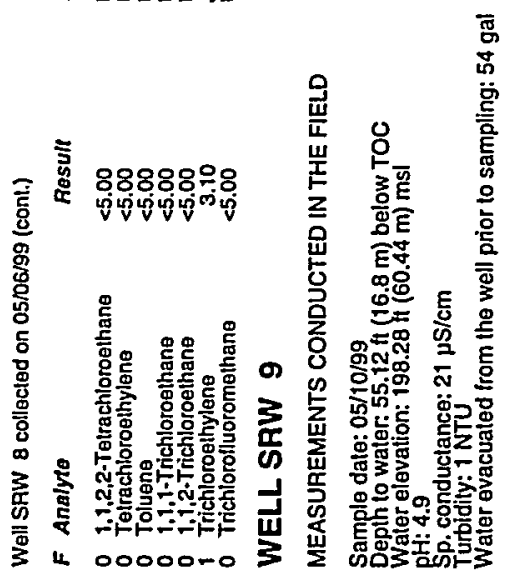

i

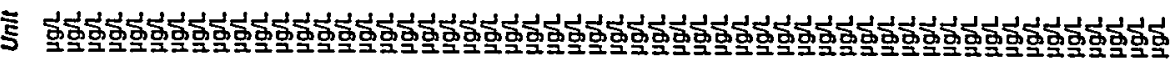

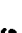

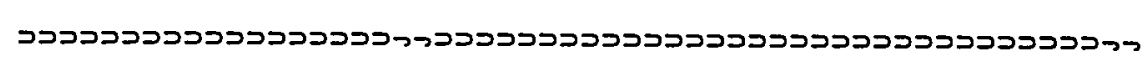

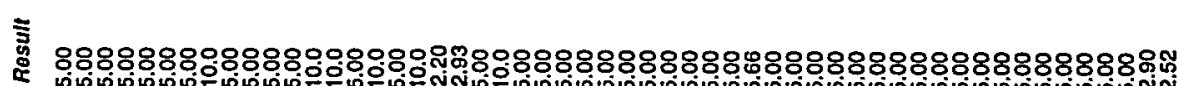

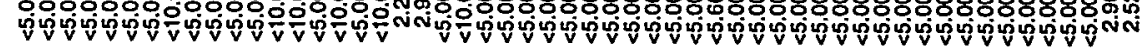

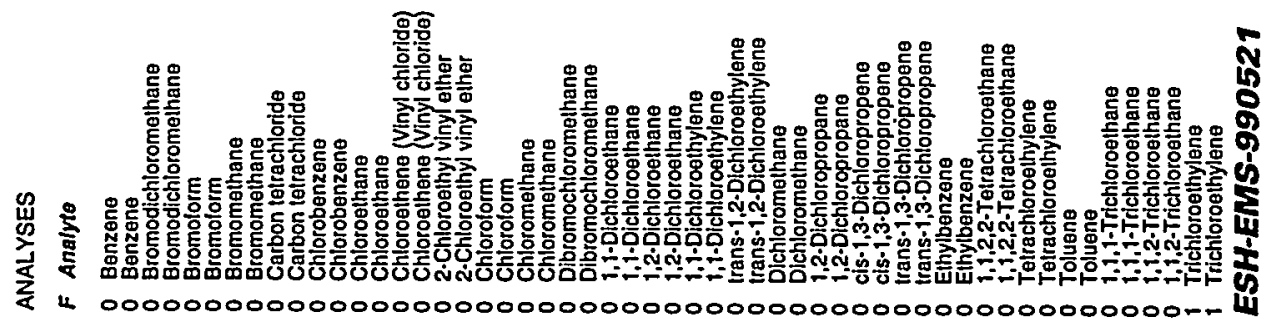


Well SRW 12C collected on 05/05/99 (cont.)

$F$ Analyte

1,2-Oichloroethane

trans:1,2-0ichloroethylene

0 Dichloromethane

cis-1,3.Dichloropropene

Elhylbenzena

1,1,2,2-Tetrachloroethan

Toluene

1.1,2-Trichloroelhane

O Trichloroelhylene

WELL SRW $16 \mathrm{C}$

MEASUREMENTS CONDUCTED IN THE FIELD

Sample date: $05 / 10 / 99 \mathrm{fl}(40.06 \mathrm{~m})$ below TOC

Waler elevation: $215.17 \mathrm{ft}(65.58 \mathrm{~m}) \mathrm{msl}$

$\mathrm{pH}: 4.6$

Sp. conductance: $11 \mu \mathrm{S} / \mathrm{cm}$

Waler evacualed from the well prior to sampling: $26 \mathrm{gal}$

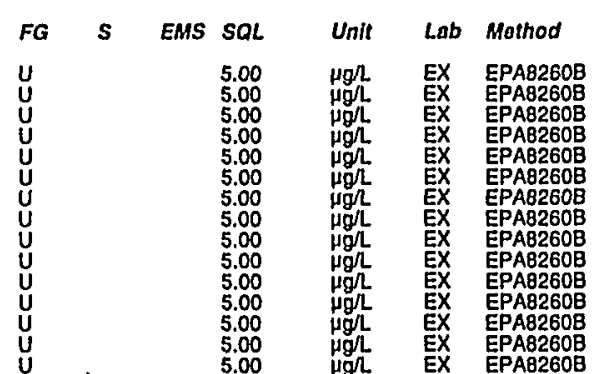

ANALYSES

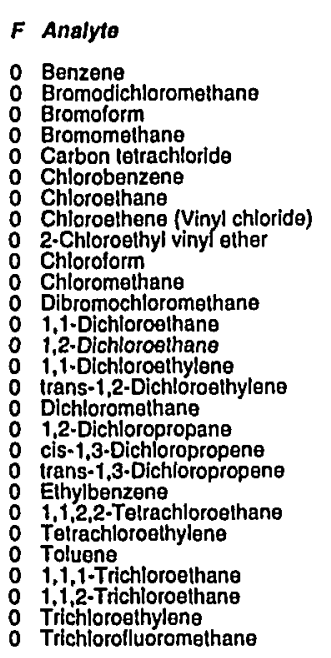

Result
$<5.00$
5.00
55.00
5.00
55.00
5.00
510.0
5.00
55.00
5.00
55.00
5.00
5.00
5.00
55.00
55.00
5.00
55.00
5.00
55.00
55.00
55.00
5.00
55.00
5.00
55.00
5.00
$<5.00$

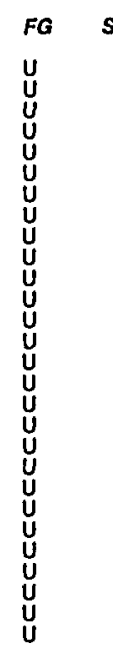

WELL SRW 17DR

MEASUREMENTS CONDUCTED IN THE FIELD

Sample date: 05/05/99 $\mathrm{f}(36.32 \mathrm{~m})$ below TOC

Waler revation: Not available

p. conductance: $260 \mu \mathrm{S} / \mathrm{cm}$

Water evacuated from the well prior to sampling: $50 \mathrm{gal}$

ANALYSES

$F$ Analyto

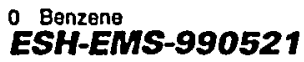

Water temperature: $20.2^{\circ} \mathrm{C}$ Air temperature: $36.8^{\circ} \mathrm{C}$. Phenolphthalein alkain
Field Qualifier(s): $S$

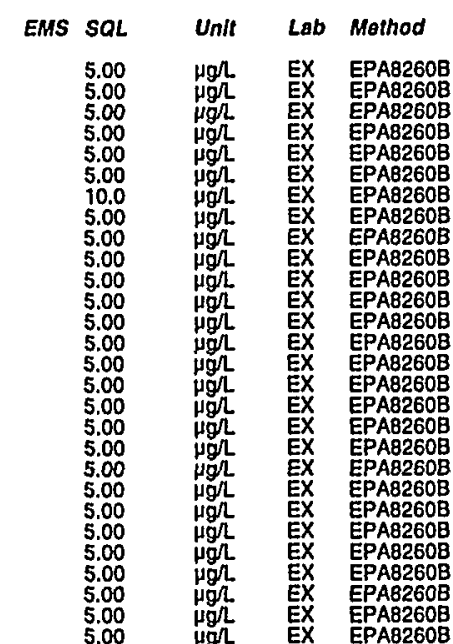

Time: 14:13

Water temperature: $23.9^{\circ} \mathrm{C}$ Air temperature: $24.1^{\circ} \mathrm{C}$
Total alkalinity (as CaCo3): $48 \mathrm{mg} /$ Phenolphthalein alkalinity: $17 \mathrm{mgh}$

Mothod

$\begin{array}{llll}5.00 & U & 5.00 & \mu g h \text { EX EPAB2608 }\end{array}$
Well SRW 17DR collected on 05/05/99 (cont.)

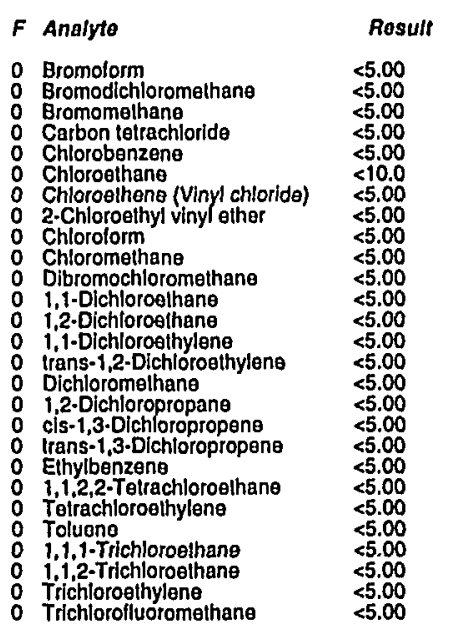
Water elevation: Nol available

\section{WELL SRW 18}

MEASUREMENTS CONDUCTED IN THE FIELD

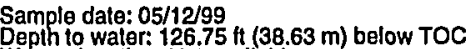

pH: 5.2

Sp. conductance: $25 \mu \mathrm{S} / \mathrm{cm}$

Water evacuated from the well prior to sampling: 84 gat

ANALYSES

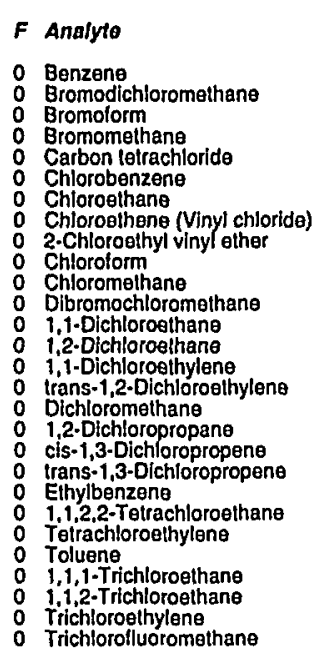

Result
55.00
55.00
55.00
5.00
55.00
5.00
510.0
5.00
55.00
5.00
55.00
5.00
55.00
5.00
55.00
55.00
5.00
55.00
5.00
55.00
55.00
55.00
5.00
55.00
5.00
55.00
5.00
55.00

\begin{tabular}{|c|c|c|}
\hline FG & $\boldsymbol{s} \quad$ EMS & SQL \\
\hline 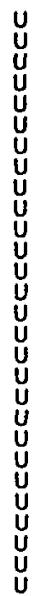 & & $\begin{array}{l}5.00 \\
5.00 \\
5.00 \\
5.00 \\
5.00 \\
5.00 \\
10.0 \\
5.00 \\
5.00 \\
5.00 \\
5.00 \\
5.00 \\
5.00 \\
5.00 \\
5.00 \\
5.00 \\
5.00 \\
5.00 \\
5.00 \\
5.00 \\
5.00 \\
5.00 \\
5.00 \\
5.00 \\
5.00 \\
5.00\end{array}$ \\
\hline
\end{tabular}

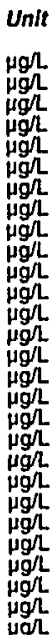

Lab Mothod

Waler temperature: $22.2^{\circ} \mathrm{C}$

Total alkalinity (as CaCO3): $2 \mathrm{mg} /$

Phenolphinalein alkalinity: $0 \mathrm{mg} h$.

$\mathbf{s} Q \mathbf{L}$
5.00
5.00
5.00
5.00
5.00
5.00
10.0
5.00
5.00
5.00
5.00
5.00
5.00
5.00
5.00
5.00
5.00
5.00
5.00
5.00
5.00
5.00
5.00
5.00
5.00
5.00
5.00
5.00

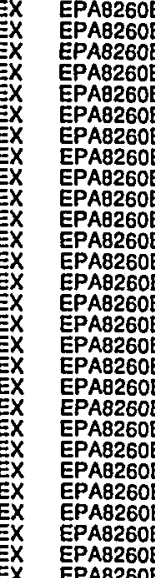

Second Quarter 1999 


\section{WELL SRW 19}

MEASUREMENTS CONDUCTED IN THE FIELD

Sample date: 05/10/99

Water elevation: Not available
p: 6.8 .
Sp. conductance: $130 \mu \mathrm{S} / \mathrm{cm}$
Turbidity: 14 NTTU

Water evacuated from the well prior to sampling: 13 gal ANALYSES

$F$ Analyte

o Benzene

0 Bromolorm

C Cromomethane

Chloroethane

Chloroethene (Vinyl chloride)

Chlorolorm

Dibromochloromethan

1.1.Dichloroethane

1,1-Dichloroethylene
trans. $1,2-$-Dichloroethylene

Dichloromethane

cis-1,3.Dichloropropene

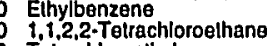

Telrachloroelhylene

1.1.1-Trichlorosthane

0 Trichloroethylene

WELL TBG 1

MEASUREMENTS CONDUCTED IN THE FIELD

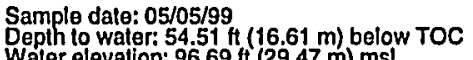

Wepth

: 4.8 evation: $96.69 \mathrm{Ht}(29.47 \mathrm{~m}) \mathrm{ms}$

p. conduclance: $94 \mu \mathrm{S} / \mathrm{cm}$

Water evacuated from the well prior to sampling: $20 \mathrm{gal}$

ANALYSES

$F$ Analyto

Aluminum, total recoverable

Boron, Iotal recoverable
Carbon tetrachloride

cis-1,2-Dichlorosthylene

Iron, lotal recoverable

Manganese, lotal recoverable

Nitrate as nitrogen
Tetrachloroethylene

1.1-Trichloroethan

Gross alpha

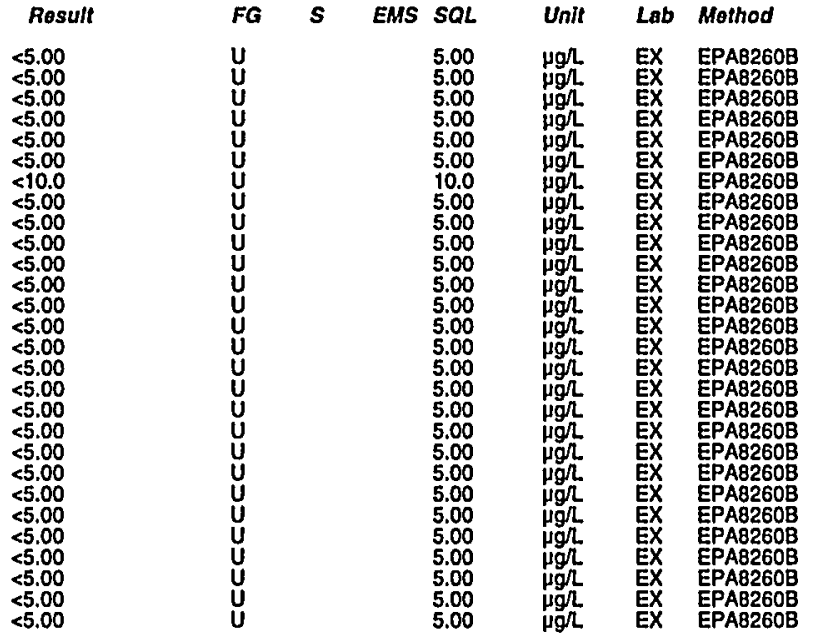

Time: 8:50

Air temperature: $18.8^{\circ} \mathrm{C} \mathrm{C}$ Total alkalinity (as CaCo3): $0 \mathrm{mg} /$ Phenolphthalein alkalinity: $0 \mathrm{mg} /$
Field Qualifier(s): $\mathrm{S}$

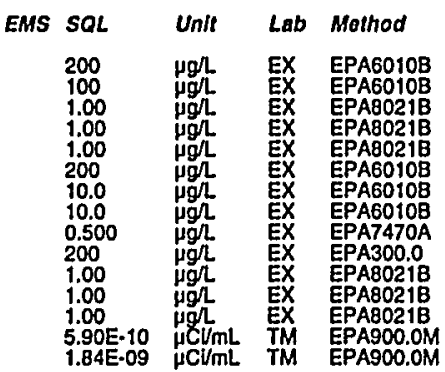

WELL TBG 3

MEASUREMENTS CONDUCTED IN THE FIELD

Sample data: 05/07/99
Depth to waler: $52.02 \mathrm{ht}(15.86 \mathrm{~m})$ below TOC
Water elevation: $99.18 \mathrm{ft}(30.23 \mathrm{~m}) \mathrm{msl}$

$\mathrm{pH}$ : 4.2 conductance: $170 \mu \mathrm{S} / \mathrm{cm}$

列 The well went dry during purging.

ANALYSES

$F$ Analyto

2 Aluminum, total recoverable

2 Carbon tetrachloride

0 Chloroform

cis-1.2-Dichloroethylene
cis-1,2-Dichloroethylene

2 Iron, tolal recoverable

Manganese, total recoverable

Mercury, total recover

Terrachloroethylene
Telrachloroethylene

1, 1. 1. Trichloroethane

Trichloroethylene

Gross alphy

: Nonvolatilie beta

WELL TBG 4

MEASUREMENTS CONDUCTED IN THE FIELD

Sample date: 05/07/99

Waler elevation: $100.35 \mathrm{ft}(30.59 \mathrm{~m}) \mathrm{ms}$

$\mathrm{pH}: 4$

. conductance: $230 \mu \mathrm{S} / \mathrm{cm}$

Water evacuated from the well prior to sampling: $\mathbf{3 2} \mathrm{ga}$

ANALYSES

$F$ Analyto

2 Aluminum, total recoverable

2 Carbon Ietrachlorida

2 Carbon lelrach

chs $-1,2 \cdot D$ Dichloroethylene

fron, total recoverable

Lead, total recoverable

Mercury, lotal recoverable

Tetrachloroethylene

T.trachloroethylene
1.1.1-Trichloroethane

Trichloroethylen

Trichloroethylen

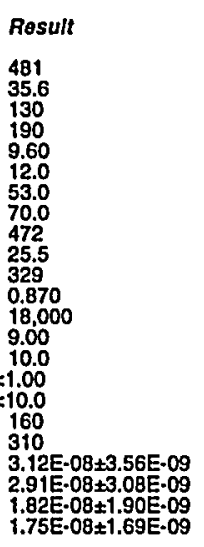

FG

200
100
1.00
10.0
1.00
100
1.00
10.0
200
10.0
10.0
0.500
500
1.00
10.0
1.00
10.0
1.00
10.0
$1.77 \mathrm{E}-09$
$9.00 \mathrm{E}-10$
$1.07 \mathrm{E}-09$
$1.54 \mathrm{E}-09$

Unit Lab Mothod

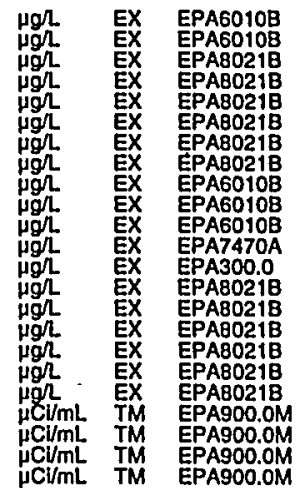

Time: 9:55

Total alkallnity (as CaCo3): $0 \mathrm{mg} /$

Phenolphthalein alkalinily: $0 \mathrm{mg} L$
Field Qualtfier(s): $V$

\begin{tabular}{|c|c|c|c|c|c|c|c|}
\hline Rosu & G & & MS & SQL & Init & $a b$ & lathod \\
\hline $\begin{array}{l}563 \\
20.0 \\
140 \\
200 \\
88.80 \\
13.0 \\
140 \\
210 \\
21.1 \\
<10.0 \\
330 \\
2.33 \\
24.200 \\
31.0 \\
41.0 \\
<1.00 \\
<10.0 \\
190 \\
500 \\
3.73 E-08 \pm 3.73 E-09 \\
2.77 E-08+2.10 E-09\end{array}$ & u & K & $\begin{array}{l}0 \\
0\end{array}$ & $\begin{array}{l}200 \\
100 \\
1.00 \\
10.0 \\
1.00 \\
10.0 \\
1.00 \\
10.0 \\
200 \\
10.0 \\
10.0 \\
0.500 \\
500 \\
1.00 \\
10.0 \\
1.00 \\
10.0 \\
1.00 \\
10.0 \\
1.20 E \cdot 09 \\
1.61-09\end{array}$ & 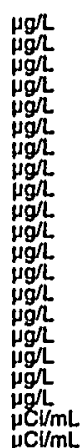 & $\begin{array}{c}\text { EX } \\
\text { EX } \\
\text { EX } \\
\text { EX } \\
\text { EX } \\
\text { EX } \\
\text { EX } \\
\text { EX } \\
\text { EX } \\
\text { EX } \\
\text { EX } \\
\text { EX } \\
\text { EX } \\
\text { EX } \\
\text { EX } \\
\text { EX } \\
\text { EX } \\
\text { EX } \\
\text { EX }\end{array}$ & 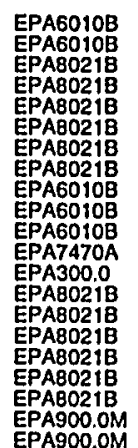 \\
\hline
\end{tabular}


ANALYTICAL RESULTS

\section{WELL TBG 5}

MEASUREMENTS CONDUCTED IN THE FIELD

Sample date: $05 / 07 / 99$
Depth to waler: $49.2 \mathrm{ft}(15 \mathrm{~m})$ below TOC
Waler elevation: $100.2 \mathrm{t}(30.54 \mathrm{~m}) \mathrm{msl}$

$$
\begin{aligned}
& \text { Waler elevation: } 100.2 \mathrm{H} / 30.54 \\
& \text { gp. conduclance: } 61 \mu \mathrm{S} / \mathrm{cm}
\end{aligned}
$$

Turbidiliy: $3 \mathrm{NTU}$
Waler evacualed from the well prior to sampling: $10 \mathrm{gal}$ ANALYSES

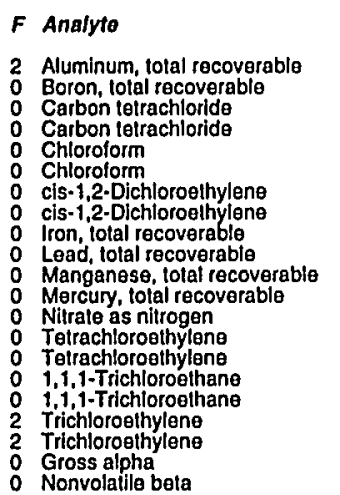

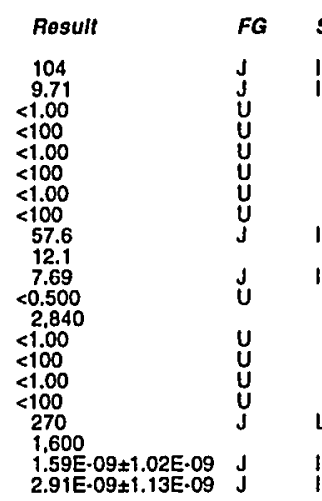

\section{WELL TBG 5A}

MEASUREMENTS CONDUCTED IN THE FIELD

Sample date: $05 / 05 / 99$ (15.21 m) below TOC Water elevation: $100.09 \mathrm{H}(30.51 \mathrm{~m}) \mathrm{ms}$

$\mathrm{H}: 4.8$

p. .onductance: $26 \mu \mathrm{S} / \mathrm{cm}$

Water evacuated from the well prior to sampling: $71 \mathrm{ga}$

ANALYSES

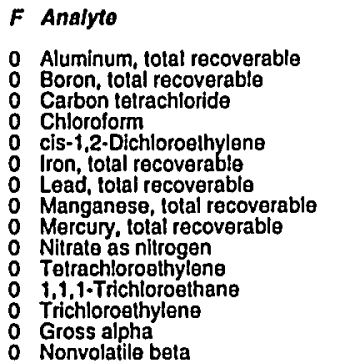

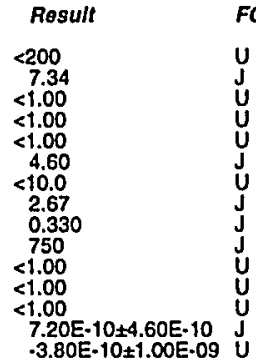

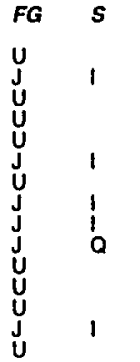

Time: 8:57

Waler temperature: $24.5^{\circ} \mathrm{C}$

Total alkalinity (as $\mathrm{CaCO}$ ): $0 \mathrm{mg}$

Phenolph halein alkalinity: $0 \mathrm{mg}$

Field Qualifier(s): $v$

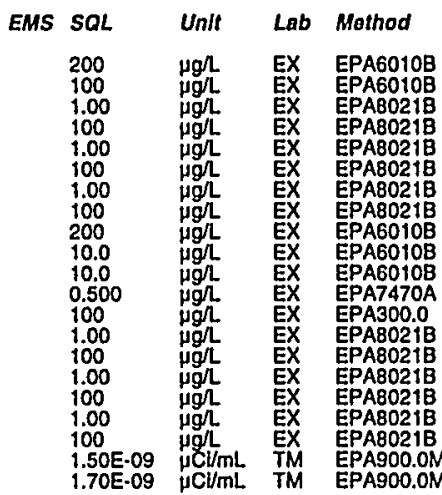

Time: 11:19

: $21.8^{\circ} \mathrm{C}$

Air temperature: $21.2^{\circ} \mathrm{C}$. 3 mgl

Fhenolphthalein alkalinity: $0 \mathrm{mg} L$

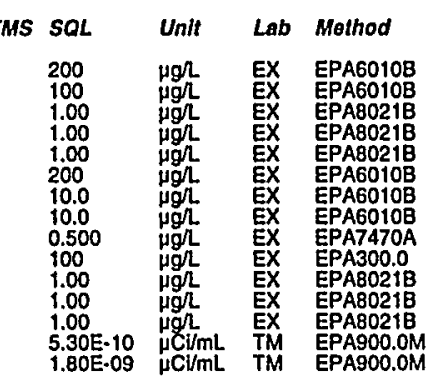

\section{WELL TBG 5B}

MEASUREMENTS CONDUCTED IN THE FIELD

Sample date: 05/05/99

H: 4.8

Sp. conductance: $30 \mu \mathrm{S} / \mathrm{cm}$

Water evacuated from the well prior to sampling: $112 \mathrm{gal}$

\begin{tabular}{|c|c|c|c|c|c|c|c|}
\hline Analyte & Result & $F G$ & EMS & $S Q L$ & Unit & Lab & Mothod \\
\hline 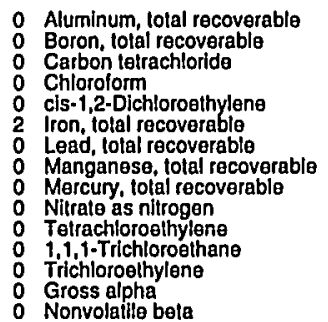 & $\begin{array}{l}<200 \\
9.80 \\
<1.00 \\
<1.00 \\
<1.00 \\
817 \\
<10.0 \\
16.1 \\
<0.500 \\
<100 \\
<1.00 \\
<1.00 \\
<1.00 \\
1.21 E \cdot 09 \pm 5.90 E-10 \\
1.10 E-10 \pm 1.04 E-09\end{array}$ & 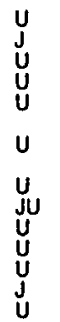 & (1) & $\begin{array}{l}200 \\
100 \\
1.00 \\
1.00 \\
1.00 \\
200 \\
100 \\
10.0 \\
0.500 \\
100 \\
1.00 \\
1.00 \\
1.00 \\
5.60 E-10 \\
1.03 E-09\end{array}$ & 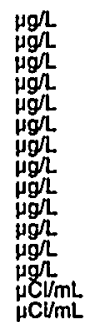 & $\begin{array}{l}\text { EX } \\
\text { EX } \\
\text { EX } \\
\text { EX } \\
\text { EX } \\
\text { EX } \\
\text { EX } \\
\text { EX } \\
\text { EX } \\
\text { EX } \\
\text { EX } \\
\text { EX } \\
\text { TX } \\
T M\end{array}$ & 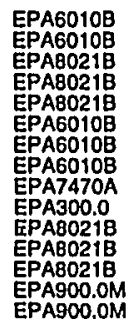 \\
\hline
\end{tabular}
ANALYSES

\section{WELL TBG 6}

MEASUREMENTS CONDUCTED IN THE FIELD

Sample date: 05/07/99
Depph to water: $49.28 \mathrm{ft}(15.02 \mathrm{~m})$ below TOC

$\mathrm{H}: 4.5$

Sp. conductance: $100 \mu \mathrm{S} / \mathrm{cm}$

Water evacuated from the well prior to sampling: $5 \mathrm{gal}$

dry during purging.

ANALYSES

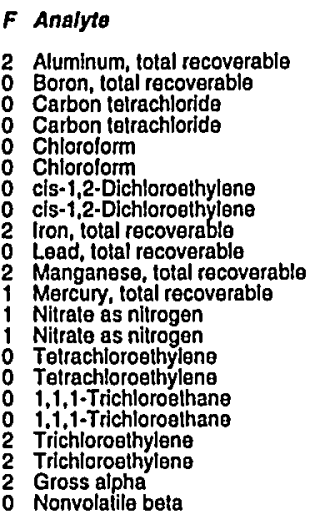

Result
471
15.0
$<1.00$
$<100$
$<1.00$
$<100$
14.0
$<100$
767
$<10.0$
98.6
1.80
88.650
88.530
$<1.00$
$<100$
$<1.00$
$<100$
360
3.000
$1.61 E \cdot 08 \pm 2.46 E-09$
$9.82 E-09 \pm 1.49 \mathrm{E} \cdot 09$

Time: 10:29 Tolal alkalinily (as CaCO3): $2 \mathrm{mg} /$ Phenolphthalein alkalinity: $0 \mathrm{mg} L$.

Total alkalinity (as CaCO3): $0 \mathrm{mg} /$

Phenolphthalein alkalinity: $0 \mathrm{mg} L$
Field Qualifier(s): VXN 


\section{WELL TBG 7}

MEASUREMENTS CONDUCTED IN THE FIELD

Sample date: $05 / 05 / 99$
Depth lo water: $44.25 \mathrm{ft}(13.49 \mathrm{~m})$ below TOC
Water elevation: $102.55 \mathrm{ft}(31.26 \mathrm{~m}) \mathrm{ms}$

$\mathrm{pH}: 5.7$ conductance: $46 \mu \mathrm{S} / \mathrm{cm}$

Water evacuated from the well prior to sampling: $49 \mathrm{gat}$

ANALYSES

$F$ Analyto

Result

0 Aluminum, total recoverable

Iron, total recoverable

$\begin{array}{ll}0 \text { Manganes, lolal recoverablo } & <10.0 \\ 1.72\end{array}$

\section{WELL TCM 1}

MEASUREMENTS CONDUCTED IN THE FIELD

Sample dalo: 05/04/99
Depth to water: 7.02 ft $(2.14 \mathrm{~m}$ ) below TOC
Water elevation: Not available

Water

p. conductance: $64 \mu \mathrm{S} / \mathrm{cm}$

Waler evacualed from the well prior to sampling: $13 \mathrm{gal}$

ANALYSES

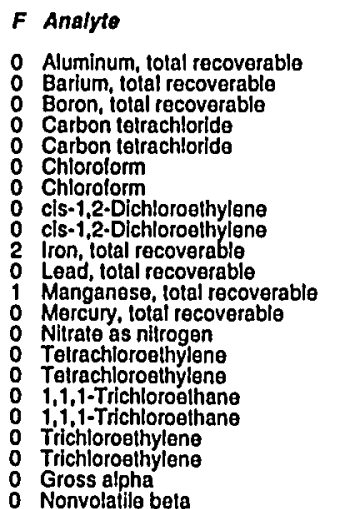

Result
$<200$
31.0
130
$<1.00$
$<1.00$
$<1.00$
$<1.00$
$<1.00$
$<1.00$
860
$<10.0$
27.0
$<0.500$
$<100$
$<1.00$
$<1.00$
$<1.00$
$<1.00$
$<1.00$
$<1.00$
$5.306-10 \pm 6.50 E-10$
$2.36 E-09 \pm 9.70 E-10$

WELL TCM 2

MEASUREMENTS CONDUCTED IN THE FIELD

Sample date: $05 / 06 / 99$
Depth to water: $6.18 \mathrm{th}(1.88 \mathrm{~m})$ below TOC
Water

Water el

Sp. conductance: $150 \mu \mathrm{S} / \mathrm{cm}$

Water evacuated from the well prior to sampling: $25 \mathrm{gal}$

ANALYSES

$F$ Analyto

$$
\text { Rosult }
$$

2 Aluminum, total recoverablo

o Boron, total recoverabl

170
324
$<1.00$

ESH-EMS-990521
Time: 9:17

Air temperature: $224^{\circ} \mathrm{C}$

Tolal alkalinity (as Caco3): $7 \mathrm{mg} / \mathrm{L}$

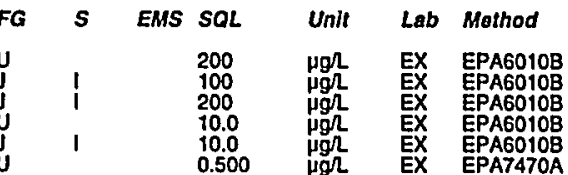

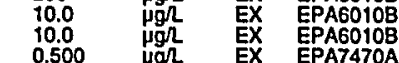

Time: 10:02

Water lemperature: $20.3^{\circ} \mathrm{C}$

Artemperature: $14.1 \mathrm{C}^{\circ}$ ): $1 \mathrm{mgh}$
Total alkalinity (as Caco3)
Phenolphthalein alkalinily: $0 \mathrm{mg} / \mathrm{L}$

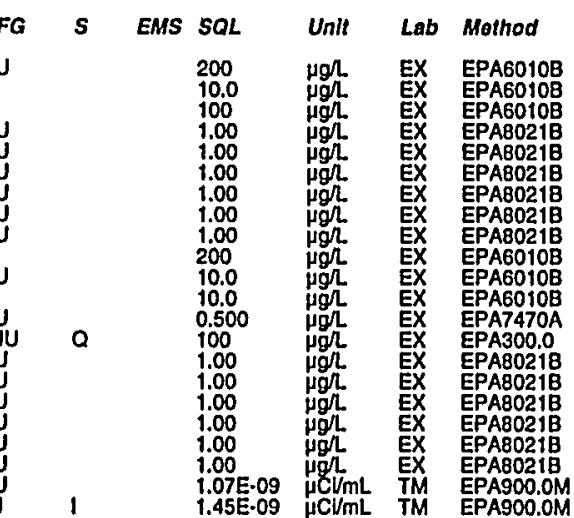

Time: 10:38

Waler temperature: $20{ }^{\circ} \mathrm{C}$ Artal alkalinity (as CaCO3): $5 \mathrm{mg} /$

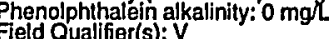

$\begin{array}{cccc}\text { EMS SOL } & \text { UnIt } & \text { Lab Method } \\ 200 & \mu g h \text { EX } & \text { EPAGO10B } \\ 100 & \text { Egh } & \text { EX } & \text { EPAG018 } \\ 1.00 & \text { pgr } & \text { EX } & \text { EPAB0218 }\end{array}$

Well TCM 2 collected on 05/06/99 (cont.)

$F$ Analyte

Rosult

: Chlorolorm

0
0 lon, total recoverable
0

Manganese, fotal recoverable

1 Nitrale as nitrogen

Telrachloroethylene

Gross alpha

Nonvolatilia beta

WELL TCM 3

MEASUREMENTS CONDUCTED IN THE FIELD

Sample date: 05/06/99

Waler elevalion: Not available

$\mathrm{H}$ : 5.5

p. conductance: $200 \mu \mathrm{S} / \mathrm{cm}$

Waler evacuated from the well prior to sampling: 20 gal ANALYSES

$F$ Analyte

Rosult

2 Aluminum, total recoverable

: Corbon, total recoverable

chloroform

1 Iron, lotal recoverable

Manganese, lotal recoverable

Nilrate as nitrogen
Tetrachloroethylene

Telrachloroethylene

Grichloroethylene

Nonvolatilia beta

WELL TIR 1L

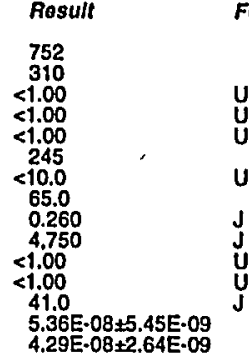

FG $S$ EMS SOL Unit LAB Mathod

MEASUREMENTS CONDUCTED IN THE FIELD

Depth to water: $9.52 \mathrm{ft}(2.9 \mathrm{~m})$ bolow TOC

Wh: 4.8

ance: $120 \mu \mathrm{s} / \mathrm{cm}$

Water evacualed from the well prior to sampling: 11 gal ANALYSES

F Analyto

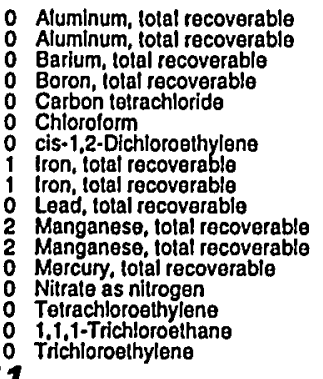

Rosult
$<200$
$<200$
27.9
818
$<1.00$
$<1.00$
$<1.00$
165
165
$<10.0$
74.6
74.6
$<0.500$
167
$<1.00$
$<1.00$
2.46

Time: 11:11

Air temperature: $20: 20.2^{\circ} \mathrm{C}$ Total alkalinty (as CaCO3): $29 \mathrm{mg} \Omega$

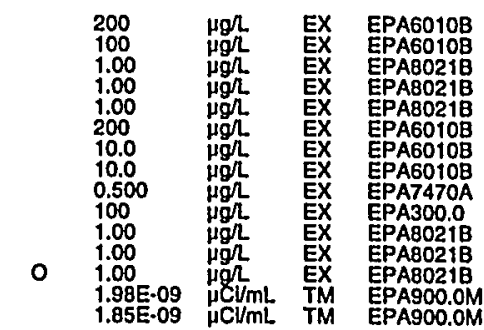

Time: 15:32

re: $19.1^{\circ} \mathrm{C}$

Total alkalinity (as CaCO3): $0 \mathrm{mg} /$
Phenol phthalein alkalinity: $0 \mathrm{mg} L$ Field Qualifier(s): VN

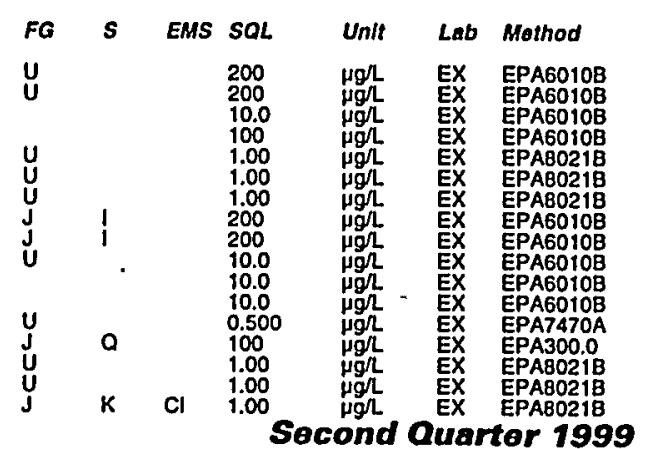


Well TIR 1 L collected on 05/03/99 (cont.)

$F$ Analyte

Rosult

$\begin{array}{ll}0 & \text { Gross alpha } \\ 0 & \text { Nonvolatile beta }\end{array}$

$7.30 \mathrm{E}-10 \pm 7.20 \mathrm{E}-10 \quad U$
1.50E-09+1.00E-09 $U$

EMS SQL

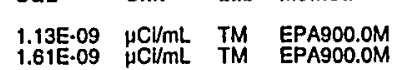

WELL TIR $1 \mathrm{M}$

MEASUREMENTS CONDUCTED IN THE FIELD

Sample dato: 05/03/99

Depth to water: $9.19 \mathrm{Hi}(2.8 \mathrm{~m})$ below TOC
Water elevalion: $92.51 \mathrm{kt}(28.2 \mathrm{~m}) \mathrm{msl}$

Wh: 4.8

p. conductance: $80 \mu \mathrm{S} / \mathrm{cm}$

Wurbidity: ONTU Navacuated from the well prior to sampling: 4 gal

ANALYSES

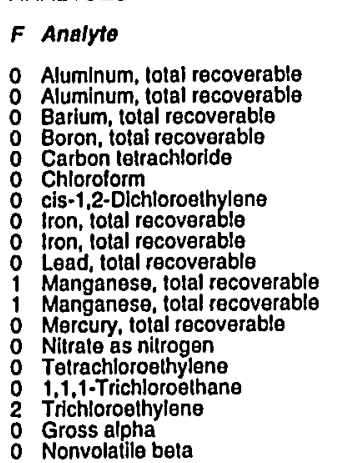

Resuh
$<200$
$<200$
13.8
662
$<1.00$
$<1.00$
$<1.00$
10.8
10.8
$<10.0$
47.1
47.1
$<0.500$
3.080
$<1.00$
$<1.00$
7.67
$8.20 E-10 \pm 6.50 E-10$
$1.85-09 \pm 1.00 E-09$

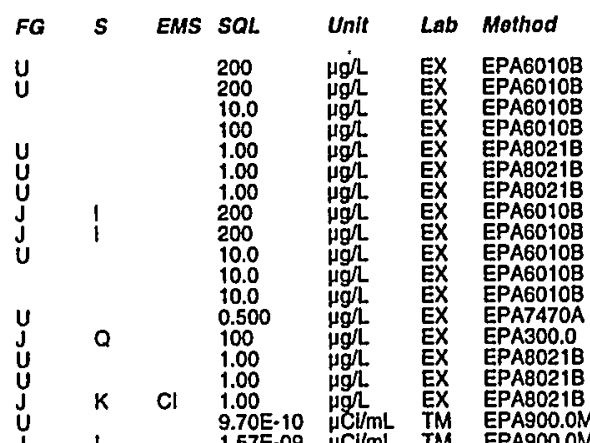

WELL TIR 1U

MEASUREMENTS CONDUCTED IN THE FIELD

Sample date: $05 / 07 / 99$
Depth to water: $9.04 \mathrm{ft}(2.76 \mathrm{~m})$ below TOC
Water elevation: $92.56 \mathrm{H}(28.21 \mathrm{~m}) \mathrm{msl}$

$\mathrm{H}: 4.1$ conductance: $150 \mu \mathrm{S} / \mathrm{cm}$

Wurbidity: 1 NTU ANALYSES

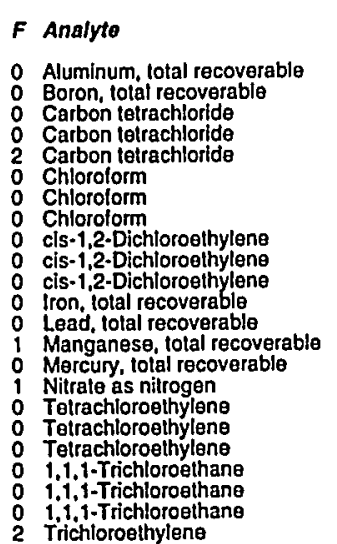

Rosult
$<200$
669
61.00
$<1.00$
21.0
$<1.00$
$<1.00$
$<100$
$<1.00$
$<1.00$
34.0
73.7
$<10.0$
39.6
$<0.500$
6.440
$<1.00$
$<1.00$
$<100$
$<1.00$
$<1.00$
$<10.0$
24.0

ESH-EMS-990521
Time: 14:48

Water $19.6^{\circ} \mathrm{C}$

Air temperature: $23.6^{\circ} \mathrm{C}$ ) $0 \mathrm{mg}$
Time: $8: 56$ Water temperature: $18.8^{\circ} \mathrm{C}$

Air temperature: $18.3^{\circ} \mathrm{C}$ ) $0 \mathrm{mgh}$

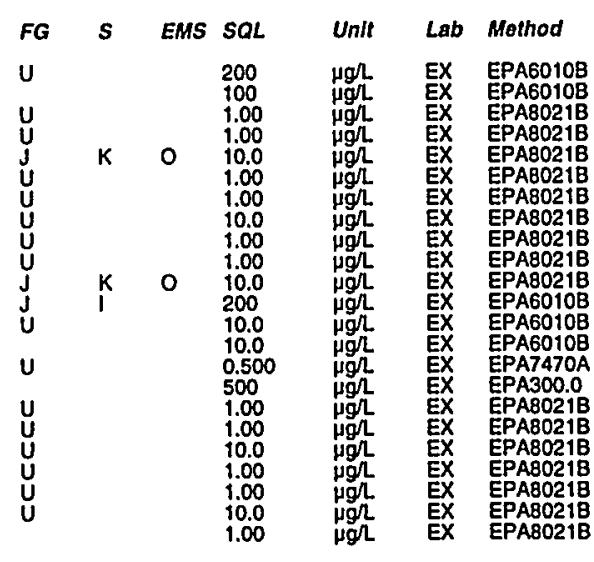

Well TIR IU collected on 05/07/99 (cont.)

\begin{tabular}{|c|c|c|c|c|c|c|c|c|}
\hline F Analyto & Rosulf & $\boldsymbol{F G}$ & $s$ & EMS & SQL & Unit & Lab & Mothod \\
\hline $\begin{array}{ll}2 & \text { Trichloroethylene } \\
2 & \text { Trichloroeshyllene } \\
1 & \text { Gross alpha } \\
0 & \text { Nonvolatile beta }\end{array}$ & $\begin{array}{l}23.0 \\
160 \\
9.77 \mathrm{E} \cdot 09 \pm 1.89 \mathrm{E} \cdot 09 \\
8.15 \mathrm{E} \cdot 09 \pm 1.42 \mathrm{E} \cdot 09\end{array}$ & J & $\begin{array}{l}\mathbf{k} \\
\mathbf{k}\end{array}$ & $\stackrel{\circ}{\circ}$ & $\begin{array}{l}1.00 \\
10.0 \\
1.31 E-09 \\
1.74 E-09\end{array}$ & 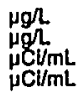 & $\begin{array}{l}\text { EX } \\
\text { EX } \\
\text { TM } \\
\text { TM }\end{array}$ & $\begin{array}{l}\text { EPA8021B } \\
\text { EPA8021B } \\
\text { EPA900.0M } \\
\text { EPA900.0M }\end{array}$ \\
\hline
\end{tabular}

\section{WELL TIR 2}

MEASUREMENTS CONDUCTED IN THE FIELD

ample date: 05/07/99

(2) $9.33 \mathrm{ft}(2.84 \mathrm{~m})$ below TOC

Water enc

Sp. conductance: $88 \mu \mathrm{S} / \mathrm{cm}$

Water evacuated from the well prior to sampling: $5 \mathrm{ga}$

ANALYSES

$F$ Analyto

O Aluminum, total recoverable

Boron, total recoverable
Carbon telrachloride

chloroform 1 -Dichloroathylen

Iron, tolal recoverable

Lead, total recoverable

Mercury, total recoverable

Tetrachloroethylene

1.1, 1. Trichitoroetha
Trichioroethylene

0 Gross alpha

WELL TIR 3B

MEASUREMENTS CONDUCTED IN THE FIELD

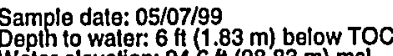

Water elevation: $94.6 \mathrm{Ht}(28.83 \mathrm{~m}) \mathrm{msl}$

$\mathrm{gH}: 4.4$ conductance: $170 \mu \mathrm{S} / \mathrm{cm}$

Water evacualed from the well prior to sampling: $5 \mathrm{gal}$

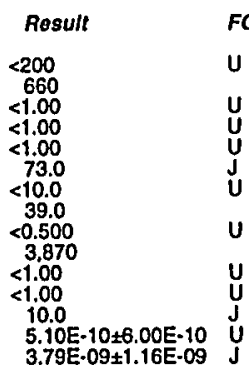

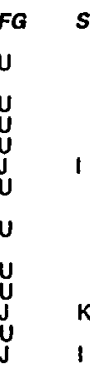

EMS

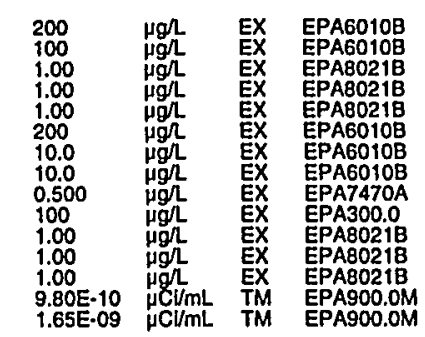

ANALYSES

$F$ Analyto

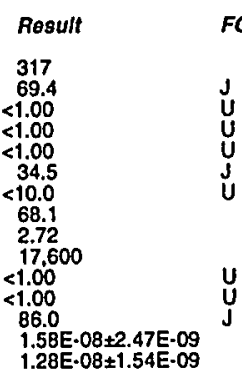

FG S EMS SOL

Tima: 9:40

Wir temperature: $195^{\circ} \mathrm{C}$

Total alkalinity (as CaCO3): $0 \mathrm{mg}$

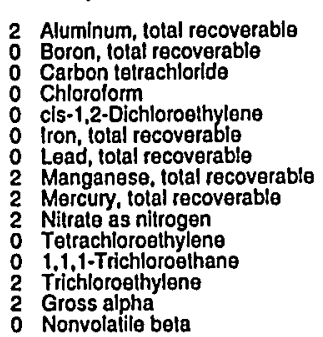

$1.28 \mathrm{E} \cdot 08 \pm 1.54 \mathrm{E} \cdot 09$
Time: 8:40

Tolal akalnity (as CaCO3): $0 \mathrm{mg} /$ 


\section{WELL TNX 1D}

MEASUREMENTS CONDUCTED IN THE FIELD Sample date: $05 / 04 / 99$
Depth to water: $60 \mathrm{tt}(18.29 \mathrm{~m})$ below TOC
Water olevation: $96.5 \mathrm{tt}(29.41 \mathrm{~m}) \mathrm{mst}$

gh: 5.4 conductance: $46 \mu \mathrm{S} / \mathrm{cm}$

Waler evacualed from the well prior lo sampling: $1 \mathrm{gal}$ The well went dry during purging.

ANALYSES

\begin{tabular}{|c|c|c|}
\hline & Analyte & Result \\
\hline & 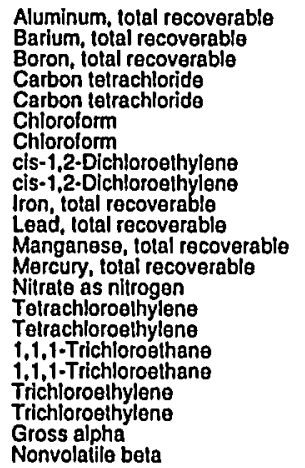 & $\begin{array}{l}<200 \\
18.0 \\
11.0 \\
<1.00 \\
<1.00 \\
<1.00 \\
<1.00 \\
<1.00 \\
<1.00 \\
120 \\
5.00 \\
58.0 \\
<0.500 \\
<100 \\
<1.00 \\
<1.00 \\
<1.00 \\
<1.00 \\
4.50 \\
4.50 \\
3.80 \mathrm{E}-10 \pm 6.20 \\
1.45 \mathrm{E}-09 \pm 9.30\end{array}$ \\
\hline
\end{tabular}

WELL TNX 20

MEASUREMENTS CONDUCTED IN THE FIELD

Sample date: 05/04/99 Water elevation: $95.91 \mathrm{ft}(29.23 \mathrm{~m}) \mathrm{ms}$

gH: 5.6
Sp. conductance: $48 \mu \mathrm{S} / \mathrm{cm}$

Water evacuated from the well prior to sampling: $1 \mathrm{gal}$ The well went dry during purging.

ANALYSES

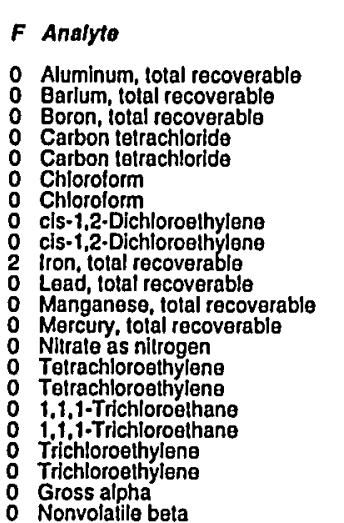

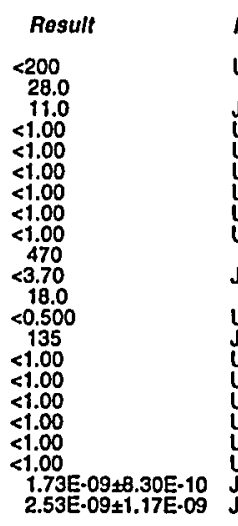

Time: 14:15

Air temperarature: $21^{\circ} \mathrm{C}$ Total alkalinity (as CaCO3): $9 \mathrm{mg} /$ Field Qualifier(s): SX

\section{WELL. TNX 3D}

MEASUREMENTS CONDUCTED IN THE FIELD

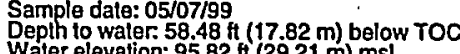

$\mathrm{pH}: 4.9$

Sp. conductance: $71 \mu \mathrm{S} / \mathrm{cm}$ Turbidity: 9 NTU
Whater evacualed from the well prior to sampling: 1 gal
The well went dry during purging.

ANALYSES

$F$ Analyto

Result

2 Aluminum, lotal recoverable

Boron, total recoverab
Carbon tetrachlorida

O Chlorolorm

Iron, total recoverable

Manganese, tolal recoverabl

Nitrate as nitrogen
Tetrachloroethylan

1,1,1.Trichloroethane

Gross alpha
Nonvolatile beta

\section{WELL TNX 4D}

MEASUREMENTS CONDUCTED IN THE FIELD

Sample date: $05 / 04 / 99$ Waler elevation: $99.65 \mathrm{ft}(30.37 \mathrm{~m}) \mathrm{msl}$ $\mathrm{SH}$. 5 . conductance: $73 \mu \mathrm{S} / \mathrm{cm}$

Water evacuated from the well prior to sampling: $1 \mathrm{gal}$

Time: 13:08

Water temperature: $21.9^{\circ} \mathrm{C}$ Tolal alkalinity (as CaCo3): $14 \mathrm{mg} /$ Phenolphthalein alkalinity: 0 mgh

ANALYSES

$F$ Analyte

2 Aluminum, total recoverable

Earium, lotal recoverable
0 Boron, tolal recoverable

Carbon teirachlorid

O Chloroform

cis-1,2.DIchloroethylene

Lron, total recoverable

Manganese, lotal recoverabl

Marcury, total recover

Tolrachloroothyleno

1.1.1-Trichloroethane
1, 1. T-Trichloroethane

Trichloroethylene

Gross alpha

$\begin{array}{ll}\text { Result } & \\ 330 & \\ 20.0 & \\ 18.0 & \\ <1.00 & \\ <1.00 & \\ <1.00 & \\ <1.00 & \\ <1.00 & \\ <1.00 & \\ 460 & \\ 6.10 & \\ 25.0 & \\ <0.500 & \\ 5.070 & \\ <1.00 & \\ <1.00 & \\ <1.00 & \\ <1.00 & \\ <1.00 & \\ <1.00 & \\ 1.08 \mathrm{E}-08 \pm 1.85 \mathrm{E}-09 \\ 8.92 \mathrm{E}-09 \pm 1.61 \mathrm{E}-09\end{array}$

Time: 10:50

Air termperature: $24.6^{\circ} \mathrm{C}$

的 Phenolphthalein alkalinity: $0 \mathrm{mg} h$
Field Qualifier(s): SX

\section{ESH-EMS-990521}




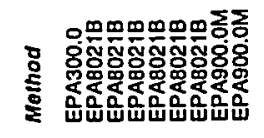

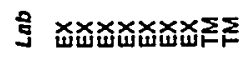

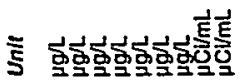

응

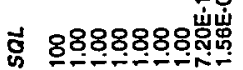

突

is 0 xx--

《ט

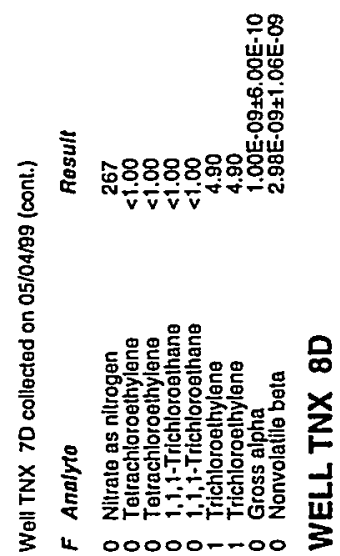

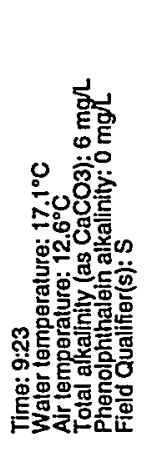

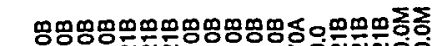

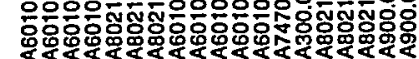

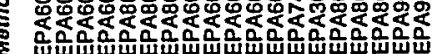

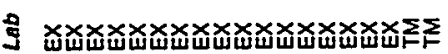

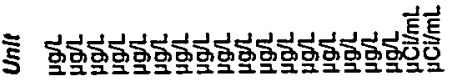

1

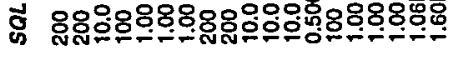

密

$\bar{v}$

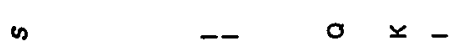

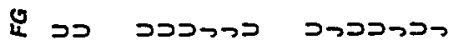

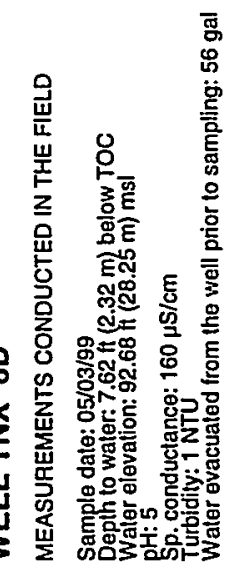

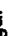

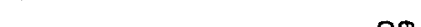

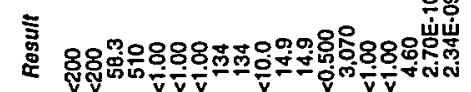

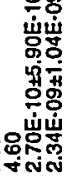

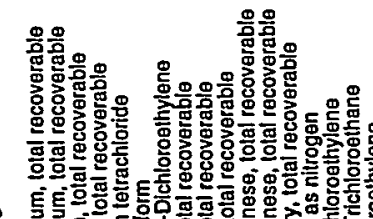

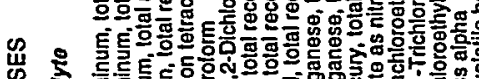

旁

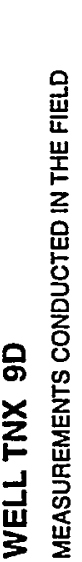

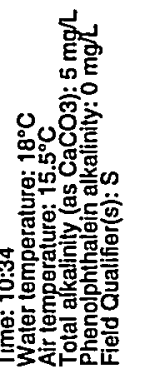

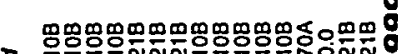

政

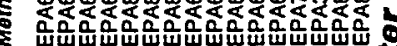

I 준 준

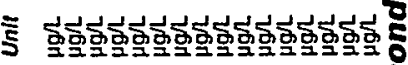

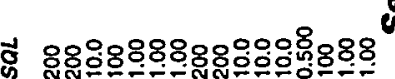

量

$\infty$

כבדכ כ בכב כבי

$\overline{\mathrm{g}}$

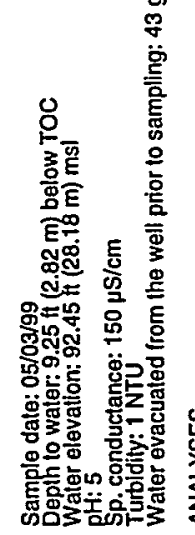

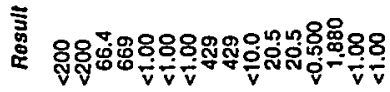

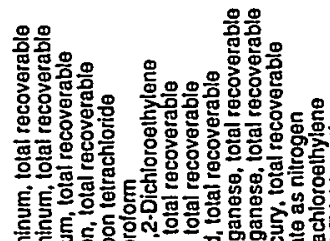

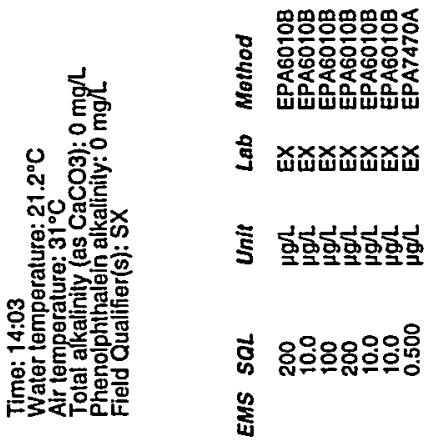

s

$8=0$

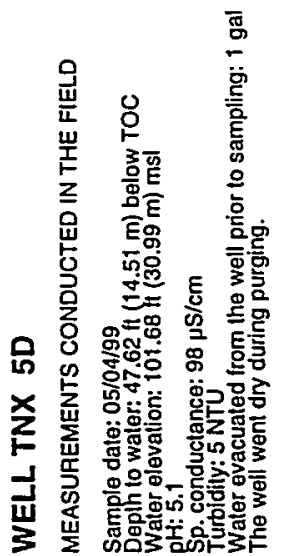

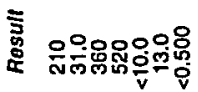
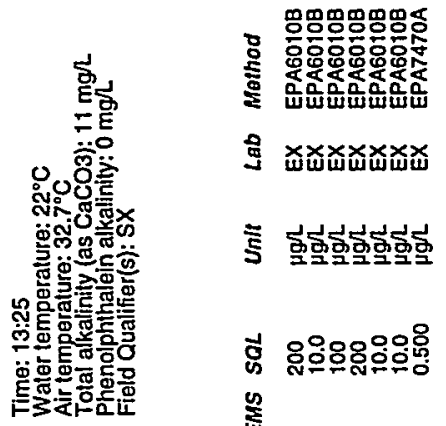

홍 웅ㅇㅇㅇㅇㅇㅇํㅇ융

帚

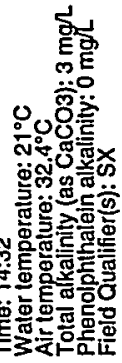

as

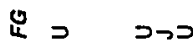

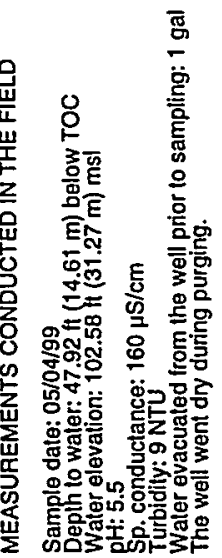

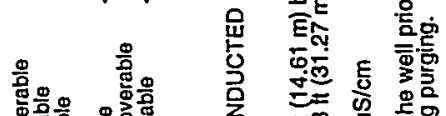

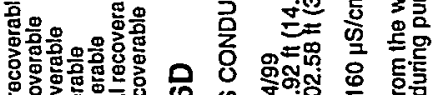

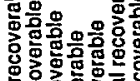

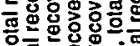

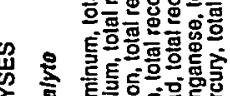

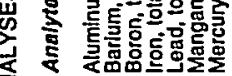

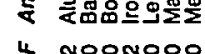


Well TNX 9D collected on 05/03/99 (cont)

\begin{tabular}{|c|c|c|c|c|c|c|c|c|}
\hline F Analyto & Result & $F G$ & $s$ & EMS & SOL & Unit & Lab & Method \\
\hline $\begin{array}{l}\text { Trichloroethylene } \\
\text { o Gross alpha } \\
\text { o Nonvolatile beta }\end{array}$ & $\begin{array}{l}0.00 \\
2.85 \mathrm{E}-09 \pm 1.15 \mathrm{E}-09 \\
3.85 \mathrm{E}-09 \pm 1.16 \mathrm{E}-09\end{array}$ & $\begin{array}{l}R \\
j \\
J\end{array}$ & i & & $\begin{array}{l}1.00 \\
1.29 E-09 \\
1.65 E-09\end{array}$ & $\begin{array}{l}\mu \mathrm{L} \\
\mu \mathrm{L} / \mathrm{mL} \\
\mu \mathrm{Ci} / \mathrm{mL}\end{array}$ & $\begin{array}{l}\underset{\mathrm{EX}}{\mathrm{TM}} \\
\mathrm{TM}\end{array}$ & $\begin{array}{l}\text { EPAB021B } \\
\text { EPA900.0M } \\
\text { EPA900.0M }\end{array}$ \\
\hline
\end{tabular}

WELL TNX 100

MEASUREMENTS CONDUCTED IN THE FIELD

Sample date: $05 / 03 / 99$

Waler elevation: $92.25 \mathrm{ft}(28.12 \mathrm{~m}) \mathrm{ms}$ |

SH: 4.6 conductance: $125 \mu \mathrm{S} / \mathrm{cm}$

Waler evacualed from the well prior to sampling: $63 \mathrm{ga}$

ANALYSES

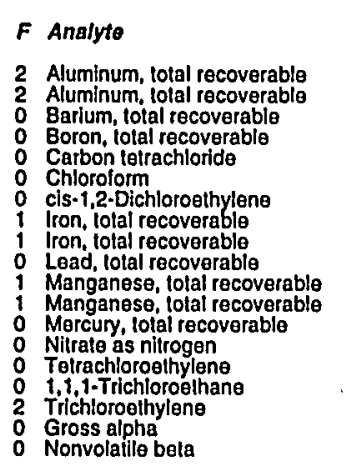

Rosult
179
179
36.8
839
$<1.00$
$<1.00$
$<1.00$
248
248
$<10.0$
47.3
47.3
$<0.500$
3.600
$<1.00$
$<1.00$
20.1
$3.35 E-09 \pm 1.08 E-09$

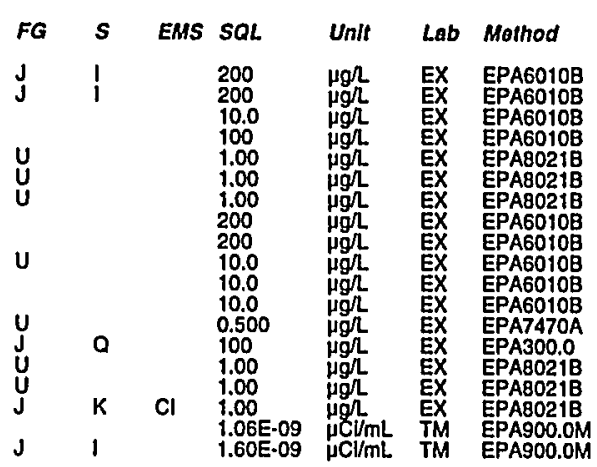

WELL TNX 11D

MEASUREMENTS CONDUCTED IN THE FIELD

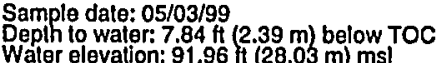

Waler elevath 4.8

$\mathrm{H}$ : 4.8 .8

Turbidity: $1 \mathrm{NTU}$
Waler evacualed from the well prior to sampling: $104 \mathrm{gal}$

ANALYSES

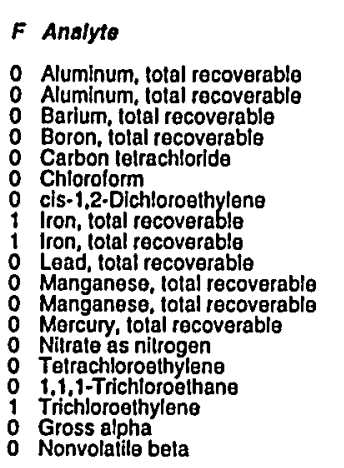

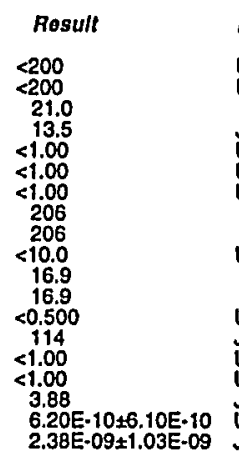

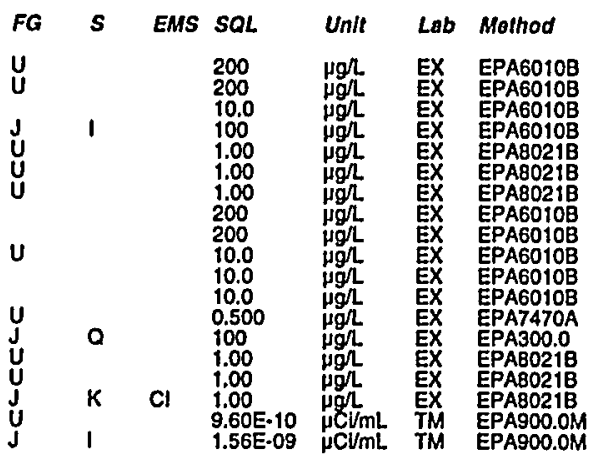

Air temperalure: $20.4^{\circ} \mathrm{C}$

Total alkalinity (as CaCo3): $2 \mathrm{mgh}$

Phenolphihalein alkalinity: 0 mgt
Field Qualifier(s): $S$

Water temperature: $20.2^{\circ} \mathrm{C}$

Air temperalure: $21.2^{\circ} \mathrm{C}$. $2 \mathrm{mg}$

Phenolphithalein alkalinily: $0 \mathrm{mgh}$
Field Oualfier(s): $\mathrm{S}$
WELL TNX 12D

MEASUREMENTS CONDUCTED IN THE FIELD

Sample date: 05/03/99

Water 5.5 p. conductance: $58 \mu \mathrm{S} / \mathrm{cm}$

Water evacuated Irom the well prior to sampling: $50 \mathrm{gal}$

Time: 11:29 $18.8^{\circ} \mathrm{C}$ ANALYSES

$F$ Analyto

o Aluminum, total recoverable

Barium, total recoverable

Boron, total recoverab
Carbon telrachloride

cis-1,2-Dichloroethylene
Iron, total recoverable

Iron, total recoverable

Manganese, tolal recoverabl

Mercury, total recoverable

Nitrate as nitrogen
Tetrachlorosthylen

$1,1,1$-Trichloroethane

Nonvolatila beta

\section{WELL TNX 13D}

MEASUREMENTS CONDUCTED IN THE FIELD

Sample date: 05/03/99

epth to water: $5.64 \mathrm{Ht}(1.72 \mathrm{~m})$ below TOC

gh: 5.3

conductance: $140 \mu \mathrm{S} / \mathrm{cm}$

Waler evacualed from the well prior to sampling: $2 \mathrm{gal}$

Result
$<200$
$<200$
21.7
13.1
$<1.00$
$<1.00$
$<1.00$
32.9
32.9
$<10.0$
1,010
1,010
$<0.500$
$<100$
$<1.00$
$<1.00$
$<1.00$
$4.80 E-10 \pm 5.60 E-10$
$3.23 E \cdot 09 \pm 1.07 E-09$

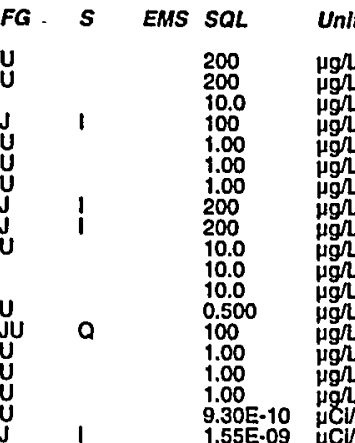

Time: 13:37

Wirermperature: $18.5^{\circ} \mathrm{C}$

Total akralinity (as CaCO3): $16 \mathrm{mg} \Omega$

Phenolphthalein alkalinity: $0 \mathrm{mgh}$.

ANALYSES

F Analyte

A Aluminum, lotal recoverable

Barium, total recoverable

Boron, total recoverab
Carbon letrachloride

cis-1,2.201chloroethylene

Iron, tolal recoverable

Lead, lotal recoverable

Manganese, total recoverab

Nitrate as nilitogen

Teirachloroethylene
1.1,1-Trichloroethene

Gross alpha
Time: 12:12

Air temperature: $17.8^{\circ} \mathrm{C}$

Total alkalinity (as CaCO3): $5 \mathrm{mg} / \mathrm{L}$
Phenolphthalein alkalinity: $0 \mathrm{mg}$. 


\section{WELL TNX 14D}

MEASUREMENTS CONDUCTED IN THE FIELD

Sample dale: $05 / 03 / 99$
Dopth to water: $3.35 \mathrm{ft}(1.02 \mathrm{~m})$ below TOC
Waler elevation: $89.45 \mathrm{Ht}(27.26 \mathrm{~m}) \mathrm{msl}$

Waler oleval

Pp. conductance: $100 \mu \mathrm{S} / \mathrm{cm}$

Waler evacuated trom the well prior to sampling: $2 \mathrm{gal}$ ANALYSES

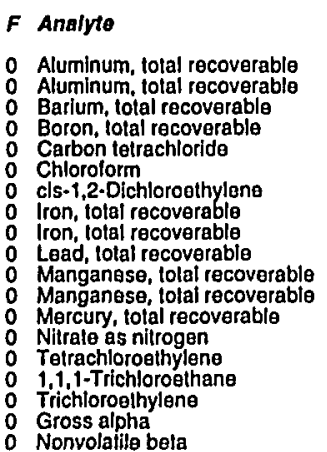

\begin{tabular}{|c|c|c|c|c|c|c|c|}
\hline Result & $F G$ & $s$ & EMS & SOL & Unft & Lab & Mothod \\
\hline $\begin{array}{r}<200 \\
<200 \\
13.1 \\
716 \\
<1.00 \\
0.00 \\
<1.00 \\
56.2 \\
56.2 \\
<10.0 \\
21.5 \\
21.5 \\
<0.500 \\
3.270 \\
<1.00 \\
<1.00 \\
<1.00 \\
3.30 E-10 \pm 6.00 E-10 \\
2,46 E-09 \pm 1.05 E-09\end{array}$ & $\begin{array}{l}U \\
\text { U } \\
\text { J } \\
J \\
U\end{array}$ & 0 & & $\begin{array}{l}200 \\
200 \\
10.0 \\
100 \\
1.00 \\
1.00 \\
1.00 \\
200 \\
200 \\
10.0 \\
10.0 \\
10.0 \\
0.500 \\
100 \\
1.00 \\
1.00 \\
1.00 \\
1.06 \mathrm{E} \cdot 09 \\
1.59 \mathrm{E} \cdot 09\end{array}$ & $\begin{array}{l}\mu g h \\
\mu g h \\
\mu g h \\
\mu g h \\
\mu g h \\
\mu g h \\
\mu g h \\
\mu g h \\
\mu g h \\
\mu g h \\
\mu g h \\
\mu g h \\
\mu g h \\
\mu g h \\
\mu g h \\
\mu g h \\
\mu g h \\
\mu C l / m L \\
\mu C l / m L\end{array}$ & $\begin{array}{l}\text { EX } \\
\text { EX } \\
\text { EX } \\
\text { EX } \\
\text { EX } \\
\text { EX } \\
\text { EX } \\
\text { EX } \\
\text { EX } \\
\text { EX } \\
\text { EX } \\
\text { EX } \\
\text { EX } \\
\text { EX } \\
\text { EX } \\
\text { EX } \\
\text { EX } \\
\text { TM } \\
\text { TM }\end{array}$ & $\begin{array}{l}\text { EPA60108 } \\
\text { EPA6010B } \\
\text { EPA6010B } \\
\text { EPA6010B } \\
\text { EPAB0218 } \\
\text { EPAB0218 } \\
\text { EPAB021日 } \\
\text { EPAG0108 } \\
\text { EPA60108 } \\
\text { EPA6010B } \\
\text { EPA6010B } \\
\text { EPA6010B } \\
\text { EPA7470A } \\
\text { EPA300.0 } \\
\text { EPAB0218 } \\
\text { EPAB021B } \\
\text { EPAB021B } \\
\text { EPA900.0M } \\
\text { EPA900.0M }\end{array}$ \\
\hline
\end{tabular}

\section{WELL TNX 15D}

MEASUREMENTS CONDUCTED IN THE FIELD

Sample date: 05/03/99

Depth to water: $5.87 \mathrm{ft}(1.79 \mathrm{~m})$ below TOC

W: 4.8

p. conductance: $130 \mu \mathrm{S} / \mathrm{cm}$

Wurbidity: 1 NTU Wacuated from the well prior to sampling: $5 \mathrm{gal}$ ANALYSES

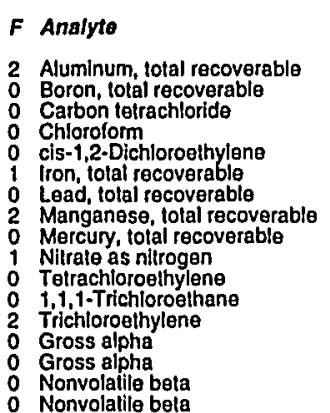

$\begin{array}{ll}\text { Result } & F G \\ 376 & \\ 799 & \\ <1.00 & U \\ 0.00 & R \\ <1.00 & U \\ 207 & U \\ <10.0 & \\ 52.2 & U \\ <0.500 & J \\ 6.820 & U \\ <1.00 & U \\ <1.00 & J \\ 18.6 & J .00 \\ 1.03 E-09 \pm 1.00 E-09 & U \\ -1.00 E-10 \pm 7.80 E-10 & U \\ 3.90 E-09 \pm 1.13 E-09 & U \\ 5.20 E-10 \pm 1.08 E-09 & U\end{array}$

Time: 12:05

Total a akalinily:(as CaCO3): $3 \mathrm{mgn}$

Phenolphthalein alkalinity: $0 \mathrm{mg}$
Wir temperature: $17.6^{\circ} \mathrm{C}$

Time: $13: 07$
Tolal alkalinity (as CaCO3): $0 \mathrm{mg} /$
Phenolphthalein alkalinity: $0 \mathrm{mg}$

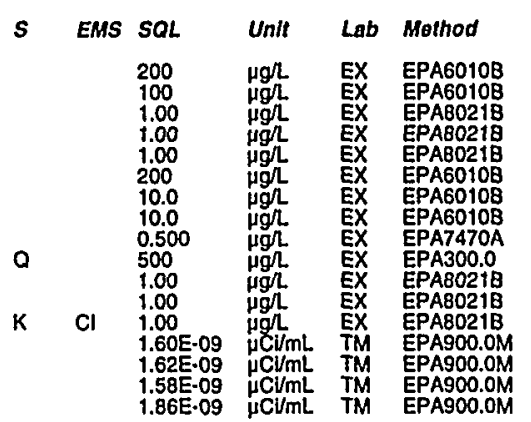

\section{WELL TNX 16D}

MEASUREMENTS CONDUCTED IN THE FIELD

Sample dale: $05 / 03 / 99$
Depth to water: $5.9 \mathrm{ft}(1.8 \mathrm{~m})$ below TOC

Water el wa

Sp. conduct

conductance: $150 \mu \mathrm{S} / \mathrm{cm}$

Water evacualed from the well prior to sampling: 2 gal

ANALYSES

\begin{tabular}{|c|c|c|c|c|c|c|c|c|}
\hline Analyto & Rasult & $\boldsymbol{F G}$ & $s$ & EMS & $S Q L$ & Unit & Lab & Mothod \\
\hline 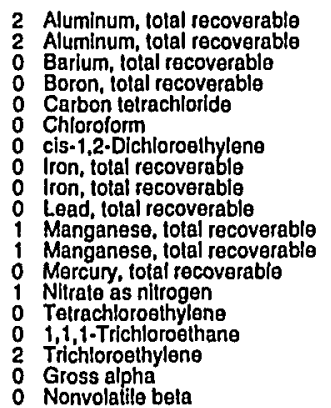 & $\begin{array}{l}80.6 \\
80.6 \\
3.3 \\
784 \\
<1.00 \\
0.00 \\
0.00 \\
6.40 \\
6.40 \\
<10.0 \\
42.3 \\
42.3 \\
<0.500 \\
8.510 \\
<1.00 \\
<.00 \\
54.3 \\
5.20 \mathrm{E}-10 \pm 6.80 \mathrm{E}-10 \\
1.49 \mathrm{E}-09 \pm 1.16 \mathrm{E}-09\end{array}$ & $\begin{array}{l}U \\
J \\
U \\
U \\
J \\
U\end{array}$ & i & $\mathrm{Cl}$ & $\begin{array}{l}200 \\
200 \\
10.0 \\
100 \\
1.00 \\
1.00 \\
1.00 \\
200 \\
200 \\
10.0 \\
10.0 \\
100 \\
0.500 \\
500 \\
1.00 \\
1.00 \\
1.00 \\
1.12 E-09 \\
1.88 E-09\end{array}$ & $\begin{array}{l}\mu g h \\
\mu g h \\
\mu g h \\
\mu g h \\
\mu g h \\
\mu g h \\
\mu g h \\
\mu g h \\
\mu g h \\
\mu g h \\
\mu g h \\
\mu g h \\
\mu g h \\
\mu g h \\
\mu g h \\
\mu g h \\
\mu g h \\
\mu C L / m L \\
\mu C l / m L\end{array}$ & $\begin{array}{l}\text { EX } \\
\text { EX } \\
\text { EX } \\
\text { EX } \\
\text { EX } \\
\text { EX } \\
\text { EX } \\
\text { EX } \\
\text { EX } \\
\text { EX } \\
\text { EX } \\
\text { EX } \\
\text { EX } \\
\text { EX } \\
\text { EX } \\
\text { EX } \\
\text { EX } \\
\text { TM }\end{array}$ & 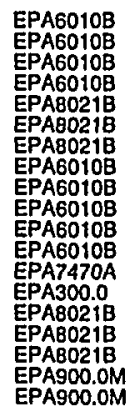 \\
\hline
\end{tabular}

\section{WELL TNX 170}

MEASUREMENTS CONDUCTED IN THE FIELD

Depth to water: $6.8 \mathrm{ft}(2.07 \mathrm{~m})$ below TOC

$\mathrm{OH}: 5.9$

Sp. conductance: $89 \mu \mathrm{S} / \mathrm{cm}$

Wutibidity: 2 NTU ANALYSES

\begin{tabular}{|c|c|}
\hline & Analyte \\
\hline & 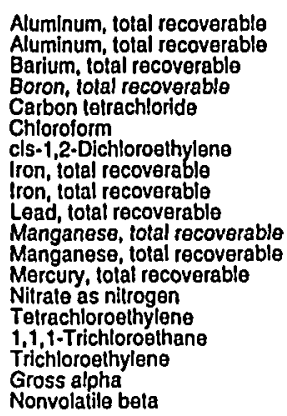 \\
\hline
\end{tabular}

Rosult
$<200$
$<200$
26.6
7.90
$<1.00$
$<1.00$
$<1.00$
3.020
3,020
$<10.0$
1,700
1,700
$<0.500$
$<100$
$<1.00$
$<1.00$
$<1.00$
$-4.00 E \cdot 11 \pm 5.50 \mathrm{E}-10$
$2.35 \mathrm{E} \cdot 09 \pm 1.04 \mathrm{E} \cdot 09$

Time: 12:38

Water temperature: $18^{\circ} \mathrm{C}$

Total alkalinily (as Caco3): $0 \mathrm{mg} /$ 
WELL TNX 22D

MEASUREMENTS CONDUCTED IN THE FIELD
Sample date: 05/03/99
Depth to water: $4.2 \mathrm{Ht}(1.28 \mathrm{~m})$ below TOC
Water elevation: $88.8 \mathrm{Ht}(27.07 \mathrm{~m}) \mathrm{msl}$

$\mathrm{pH}$ : 5.6 conductance: $50 \mu \mathrm{S} / \mathrm{cm}$

Turbidity: $6 \mathrm{NTU}$ NU $50 \mathrm{~S} / \mathrm{cm}$
Water evacuated from the well prior to sampling: 3 gal

ANALYSES

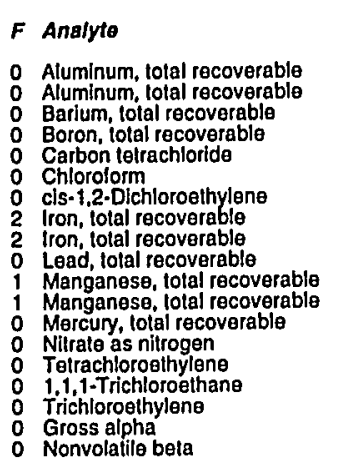

Result
$<200$
$<200$
47.0
56.3
$<1.00$
$<1.00$
$<1.00$
866
866
$<10.0$
47.3
47.3
$<0.500$
$<100$
$<1.00$
$<1.00$
$<1.00$
$2.00 E \cdot 10 \pm 6.10 E-10$
$2.46 E-09 \pm 1.03 E-09$

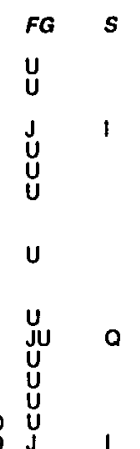

Time: 9:35

Water temperature: $16.5^{\circ} \mathrm{C}$

Aotal akalinity (as CaCO3): $10 \mathrm{mg} /$
Phenolphthalein alkalinity: $0 \mathrm{mg} / \mathrm{L}$

\section{WELL TNX 23D}

MEASUREMENTS CONDUCTED IN THE FIELD

Sample date: 05/05/99

Water owa

Sp. conductance: $38 \mu \mathrm{S} / \mathrm{cm}$

Tubidity: 0 NTU
Water evacuated from the well prior to sampling: $40 \mathrm{gal}$

ANALYSES

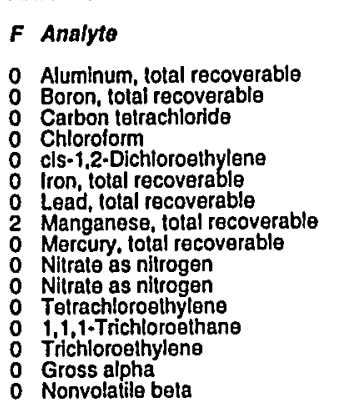

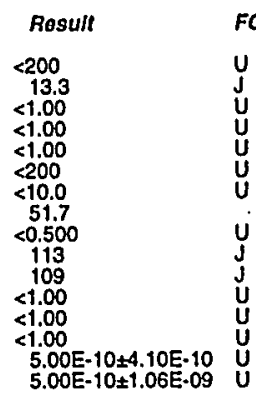

\section{WELL TNX 24D}

MEASUREMENTS CONDUCTED IN THE FIELD

Sample date: 05/05/99

Depth to waler: 34.57 ft $(10.54 \mathrm{~m})$ below TOC

$\mathrm{PH}: 5.1$ conductance: $130 \mu \mathrm{S} / \mathrm{cm}$

Water evacuated from the well prior to sampling: 7 gal ANALYSES

$\begin{array}{llc}\text { F Analyto } & \text { Result } \\ 0 & \text { Aluminum, total recoverable } & <200 \\ 0 & \text { Boron tolal recoverable } & 10.7 \\ 0 & \text { ron, total recoverable } & 45.8 \\ 0 & \text { Lead, total recoverable } & <10.0 \\ 0 & \text { Manganese, lotal recoverable } & 3.74 \\ 0 & \text { Mercury, total recoverable } & <0.500\end{array}$

$<0.500$

\section{WELL TNX 26D}

MEASUREMENTS CONDUCTED IN THE FIELD

Sample date: 05/03/99
Depht lo water: $7.8 \mathrm{H}(2.38 \mathrm{~m})$ below TOC
Water elevation: $93 \mathrm{ft}(28.35 \mathrm{~m})$ msl

Sp: conductance: $86 \mu \mathrm{S} / \mathrm{cm}$

Water evacuated from the well prior to sampling: $4 \mathrm{gal}$ ANALYSES

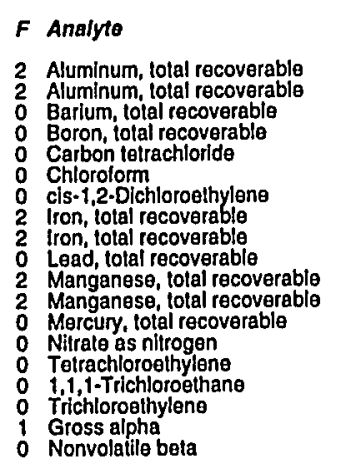

Result
382
382
-36.6
169
$<1.00$
$<1.00$
$<1.00$
637
637
$<10.0$
90.0
90.0
0.381
53.9
$<1.00$
$<1.00$
$<1.00$
$8.78 \mathrm{.0}-09 \pm 1.60 E-09$
$5.00 \mathrm{E} \cdot 09 \pm 1.17 \mathrm{E} \cdot 09$

FG S EMS SQL

200
100
200
10.0
10.0
0.500

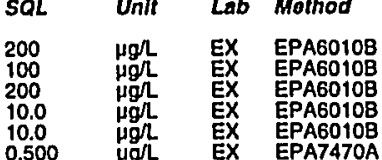

We: 13.16 (1)

Total alkadinity (as CaCO3): $14 \mathrm{mg}$

Thelphthalein alkalinily: $0 \mathrm{mg} /$.

\section{WELL TNX 26D}

MEASUREMENTS CONDUCTED IN THE FIELD

Sample date: 06/17/199
Depth to water: $8.28 \mathrm{ft}(2.52 \mathrm{~m})$ below TOC
Water elevation: $92.52 \mathrm{tt}(28.2 \mathrm{~m}) \mathrm{ms}$ l

Water elevation: $92.52 \mathrm{ht}(28.2 \mathrm{~m}) \mathrm{ms}$

Sp. conductance: $80 \mu \mathrm{S} / \mathrm{cm}$

Turbidity: 10 NTU evacuated from the well prior to sampling: $4 \mathrm{gal}$ ANALYSES

$\begin{array}{llc}F \text { Analyte } & \text { Result } \\ 2 \text { Aluminum, total recoverable } & 408 \\ 0 \text { Arsonic, lotal recoverable } & <40.0 \\ 0 \text { Barium, total recoverable } & 30.1 \\ 0 \text { Boron, total recoverable } & 139 \\ 0 \text { Cadmilum, total recoverable } & <4.70 \\ 0 \text { Calcium, total recoverable } & 3,030\end{array}$

Time: 13:47

Water temperature: $179^{\circ} \mathrm{C}$

Tirtal alkalinity (as CaCo3): $19 \mathrm{mg} \Omega$
Time: 10:10

Water temperature: $19.4^{\circ} \mathrm{C}$ Air temperature: $21.5^{\circ} \mathrm{C}$
Total alkalinity (as CaCO3): $18 \mathrm{mg} \Omega$
Phenolphthalein alkalilinity: $0 \mathrm{mg} / \mathrm{m}$

ran


Well TNX 26D collected on 06/17/99 (cont.)

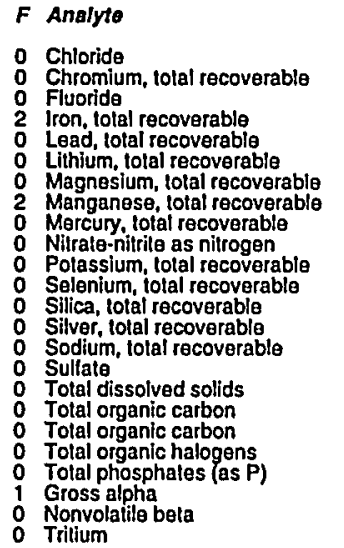

Result

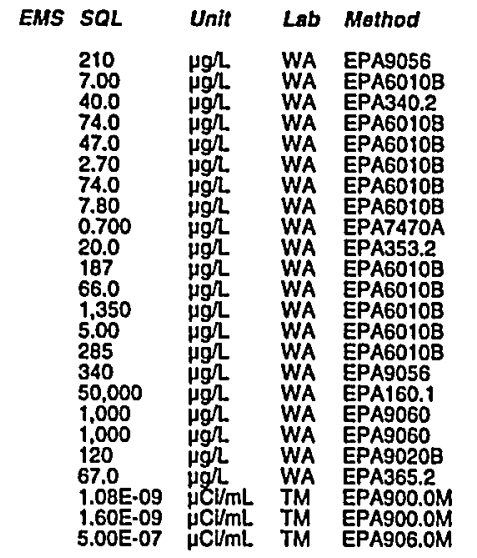

\section{WELL TNX 27D}

MEASUREMENTS CONDUCTED IN THE FIELD

Sample date: $05 / 07 / 99$
Depth to waier: $15.7 \mathrm{tt}(4.79 \mathrm{~m})$ below TOC
Water elevalion: $94.9 \mathrm{tt}(28.93 \mathrm{~m}) \mathrm{ms}$

pp. conductance: $58 \mu \mathrm{S} / \mathrm{cm}$

Turbidity: 1 NTU
Water evacuated from the well prior to sampling: $19 \mathrm{gal}$

ANALYSES

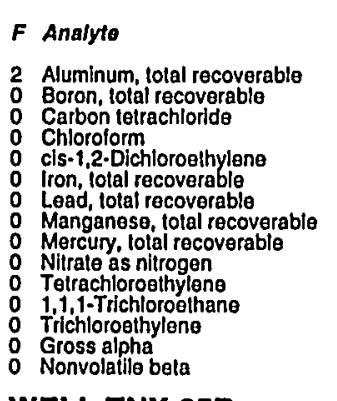

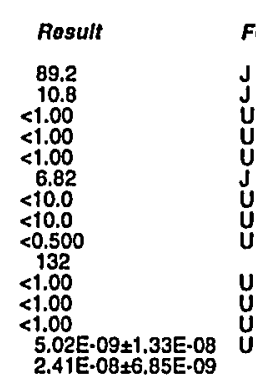

\section{WELL TNX 65D}

MEASUREMENTS CONDUCTEO IN THE FIELD

Sample date: 06/29/99

Depth to water: Not available

Water elevation: Not available
pH: Nol available

Sp. conductance: Not available

No water was evacuated from the well prior to sampling

ANALYSES

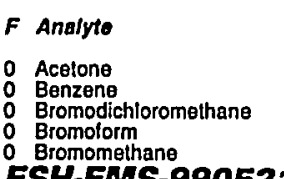

$$
\begin{aligned}
& \text { Rosulh } \\
& 55.87 \\
& <1.00 \\
& <1.00 \\
& <1.00 \\
& <1.00
\end{aligned}
$$

ESH-EMS-990521

Time: 9:39

Water temperalure: $18.6^{\circ} \mathrm{C}$ Total alkalinity (as CaCo3): $10 \mathrm{mg} /$ Phenolphthalein alkallinity: $0 \mathrm{mg} / \mathrm{L}$
Field Qualifier(s): $\mathrm{V}$

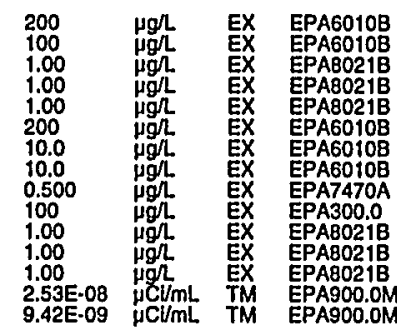

Time: Not available Wr temperature: Not availablable

\begin{tabular}{|c|c|}
\hline & \\
\hline 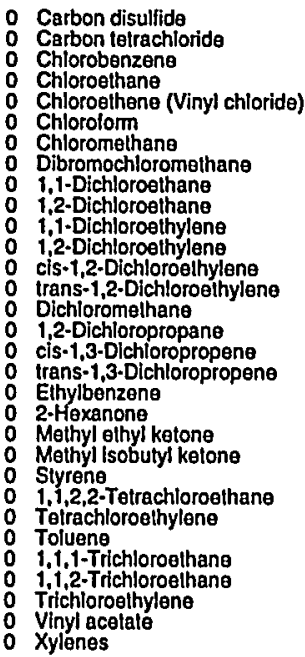 & $\begin{array}{l}<5.00 \\
<1.00 \\
<1.00 \\
<1.00 \\
<1.00 \\
<1.00 \\
<1.00 \\
<1.00 \\
<1.00 \\
<1.00 \\
<1.00 \\
<1.00 \\
<1.00 \\
<1.00 \\
<4.38 \\
<1.00 \\
<1.00 \\
<1.00 \\
<1.00 \\
<5.00 \\
<5.00 \\
<5.00 \\
<1.00 \\
<1.00 \\
<1.00 \\
0.330 \\
<1.00 \\
<1.00 \\
<1.00 \\
<5.00 \\
<1.00\end{array}$ \\
\hline
\end{tabular}
Total alkalinity (as CaCO3): Not available
Phenolphthalein alkalinity: Not available
Well TNX 65D collected on 06/29/99 (cont.)

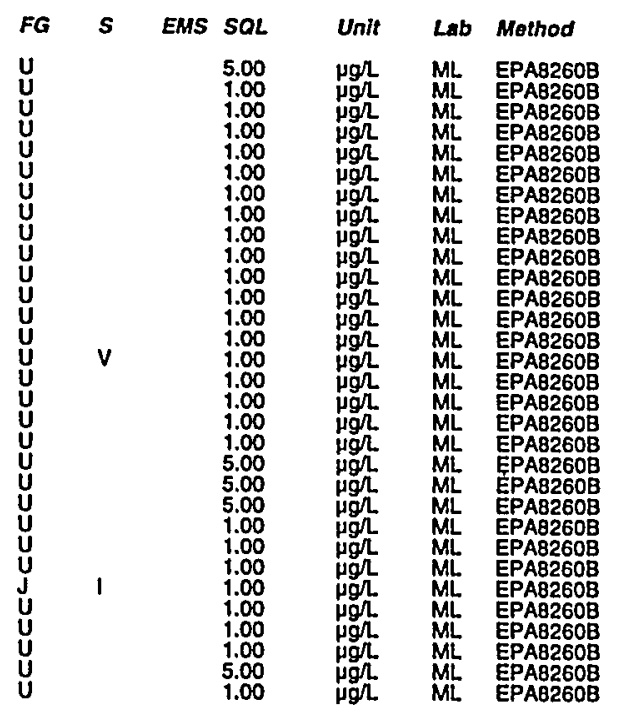

\section{WELL TRW 1}

MEASUREMENTS CONDUCTED IN THE FIELD

Sample date: 04/22/99 $20.67 \mathrm{~m})$ below TOC

Water olevation: $88.47 \mathrm{tt}(26.97 \mathrm{~m}) \mathrm{ms}$

Sp. 4.6 conductance: $60 \mu \mathrm{S} / \mathrm{cm}$

Waler evacuated from the well prior to sampling: $1 \mathrm{gal}$

\begin{tabular}{|c|}
\hline 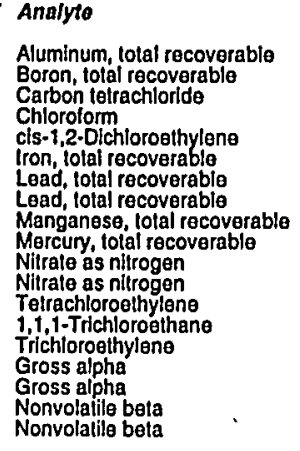 \\
\hline
\end{tabular}

ANALYSES
Time: 8:55

Air temperature $20^{\circ} 4^{\circ} \mathrm{C}{ }^{\circ} \mathrm{C}$

Total alkalinity (as CaCO3): $1 \mathrm{mg} / \mathrm{L}$
Phenolphthalein alkalinity: $0 \mathrm{mg} / \mathrm{L}$

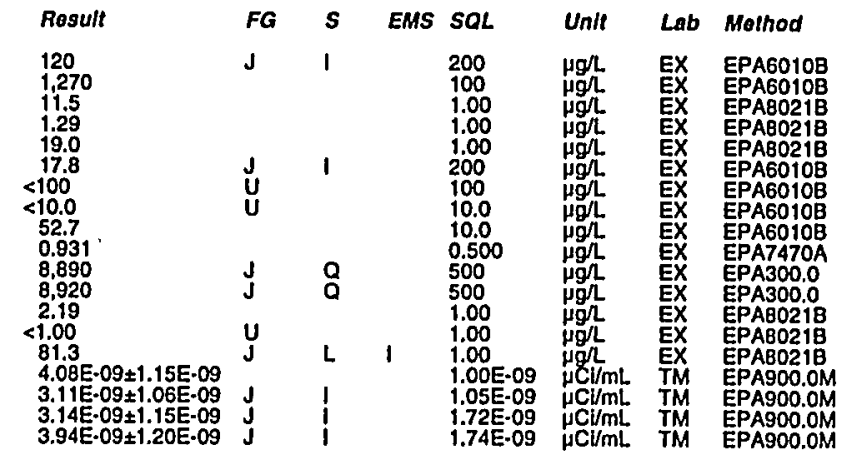




\section{WELL TRW 1}

MEASUREMENTS CONDUCTED IN THE FIELD

Sample dale: 05/17/99

Sample date: 05/17/99
Depht lo water: $68.6 \mathrm{tt}(20.91 \mathrm{~m})$ below TOC
Water elevation: $87.7 \mathrm{ft}(26.73 \mathrm{~m}) \mathrm{msl}$ Sp. conduclance: $101 \mu \mathrm{S} / \mathrm{cm}$

The well was continuously pumping.

ANALYSES

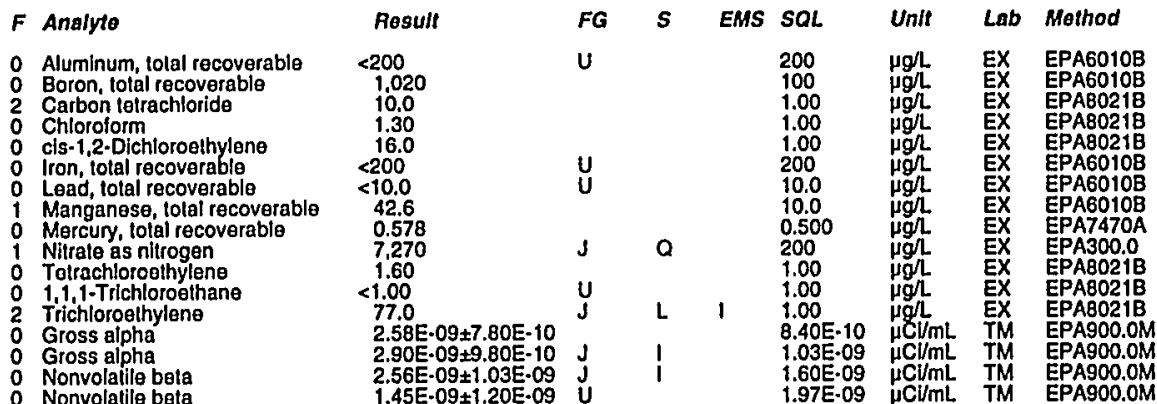

\section{WELL TRW 1}

MEASUREMENTS CONDUCTED IN THE FIELD

Sample date: 06/01/99

Depth to water: $69.28 \mathrm{ft}(21.12 \mathrm{~m})$ below $\mathrm{T}$
Water elevalion: $87.02 \mathrm{ft}(26.52 \mathrm{~m}) \mathrm{msl}$

pH: 5.3

Sp. conductance: $97 \mu \mathrm{S} / \mathrm{cm}$

The well was continuously pumping.

ANALYSES

$F$ Analyto

- Aluminum, total recoverable

Boron, total recoverable
Carbon tetrachlorida

chloroform

Lad, total recoverable

Manganese, total recoverablo

Nitrate as nitrogen

1.1,1-Trichloroethane

Gross alpha

Gross a!pha

\section{WELL TRW 2}

MEASUREMENTS CONDUCTED IN THE FIELD

Sample date: 04/22/99

Water

p. conductance: $82 \mu \mathrm{S} / \mathrm{cm}$

Wurbidity: 1 NTU from the well prior to sampling: 1 gal

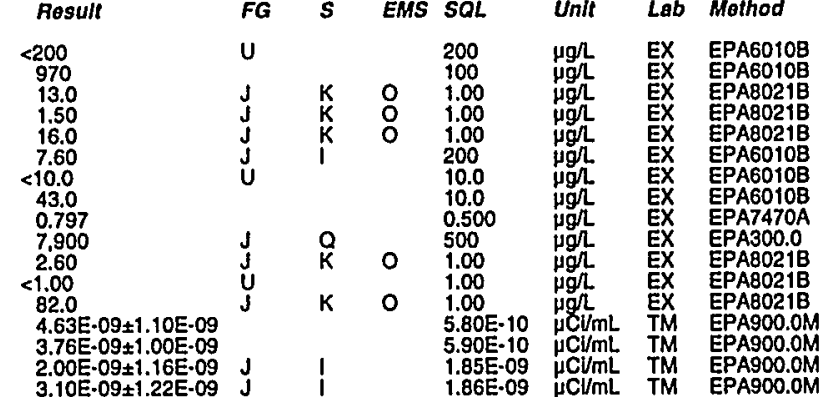

Time: 9:35

Atal alkalinity (as CaCo3): $5 \mathrm{mgh}$

Water temperature: $21^{\circ} \mathrm{C}$ Total alkalinity (as CaCO3): $1 \mathrm{mg} / \mathrm{L}$
Phenolphithalein alkalinity: $0 \mathrm{mg}$

ESH-EMS-990521
Time: 8:30

What $20.8^{\circ} \mathrm{C}$ Total alkalinity (as CaCO3): $1 \mathrm{mg} \Omega$
Phenolphthalein alkalinity: $0 \mathrm{mg}{ }^{2}$
Well TRW 2 collected on 04/22/99 (cont.)

ANALYSES

\begin{tabular}{|c|c|c|c|c|c|c|c|c|}
\hline Analyto & Result & $F G$ & $s$ & EMS & $S Q L$ & Untt & Lab & Mothod \\
\hline 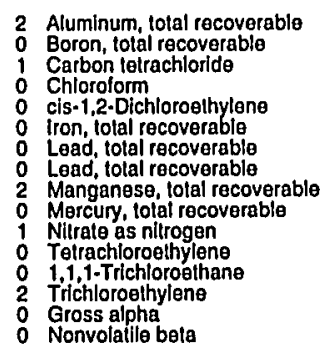 & $\begin{array}{l}200 \\
55.7 \\
3.43 \\
0.764 \\
3.47 \\
<200 \\
<100 \\
<10.0 \\
81.5 \\
0.538 \\
5,710 \\
<1.00 \\
<1.00 \\
24.6 \\
5.50 \mathrm{E} \cdot 09 \pm 1.29 \mathrm{E}-09 \\
4.59 \mathrm{E}-09 \pm 1.22 \mathrm{E}-09\end{array}$ & $\begin{array}{l}\mathbf{J} \\
\mathbf{J} \\
\mathbf{J} \\
\mathbf{J} \\
\mathbf{J} \\
\mathbf{U} \\
\mathbf{U}\end{array}$ & $\begin{array}{l}1 \\
k \\
k \\
k \\
k \\
k\end{array}$ & $\begin{array}{l}\circ \\
\circ \\
0\end{array}$ & $\begin{array}{l}200 \\
100 \\
1.00 \\
1.00 \\
1.00 \\
200 \\
100 \\
10.0 \\
10.0 \\
0.500 \\
100 \\
1.00 \\
1.00 \\
1.00 \\
9.80 \text { E. } 10 \\
1.71 \text { E. } 09\end{array}$ & 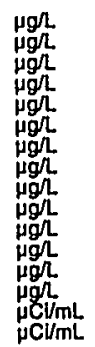 & 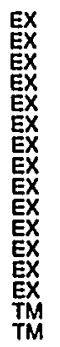 & 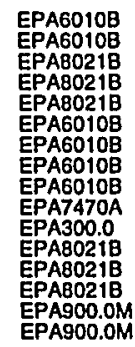 \\
\hline
\end{tabular}

\section{WELL TRW 2}

MEASUREMENTS CONDUCTED IN THE FIELD

Sample date: 05/17/99

$65.34 \mathrm{ft}(19.92 \mathrm{~m})$ below TOC

Water elevation: $88.96 \mathrm{ft}$ (27.
pH: 5.2
Sp. conductance: $82 \mu \mathrm{S} / \mathrm{cm}$

The well was continuously pumping.

ANALYSES

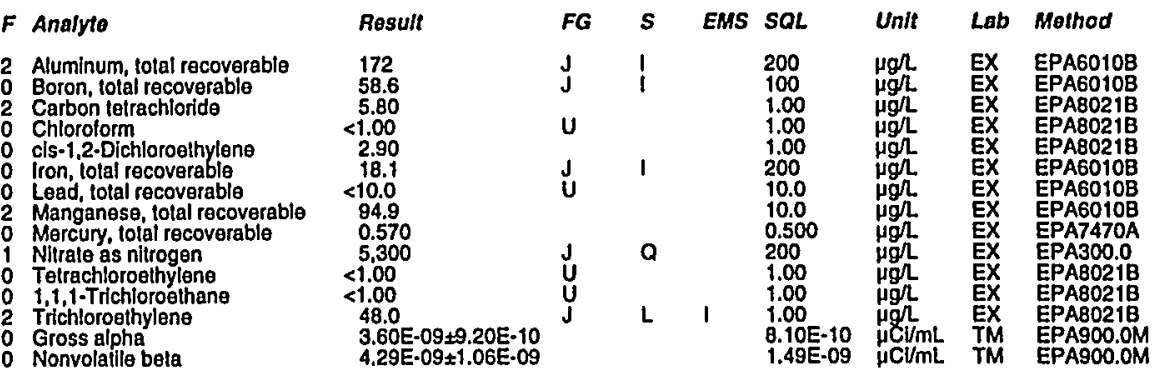

\section{WELL TAW 2}

MEASUREMENTS CONDUCTED IN THE FIELD

Sample date: 06/01/99

Water elever: 06 (20.12 m) below TOC

$\mathrm{pH}: 5.4$

p. conductance: $78 \mu \mathrm{S} / \mathrm{cm}$

The well was continuously pumping.

ANALYSES

F Analinto

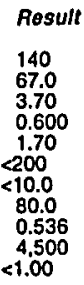

$B-220$
Time: 9:30

Air temperature: $20^{3} 0^{\circ} 6^{\circ} \mathrm{C}$

Total alkalinity (as CaCO3): $1 \mathrm{mg} /$
2 Aluminum, total recoverablo

Boron, lotal recoverab

: Chloroform

Iron, total recoverable

Manganese, total recoverable

Mercury, lotal recove
Nitrate as nitrogen
Tetrachloroethylene
Time: 9:55

Air temperaturere: $20.7^{\circ} \mathrm{C}$

Total alkalinity (as CaCO3): $3 \mathrm{mg} / \mathrm{L}$
Phenolphthalein alkalinity: $0 \mathrm{mg} /$

$F G$
$J$
$J$
$J$
$u$
$J$
$U$

EMS SOL Unit Lab Mothod

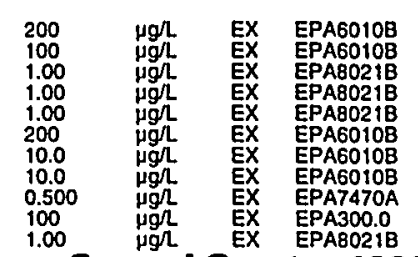


Well TRW 2 collected on 06/01/99 (cont.)

$F$ Analyte Result

\section{FG' $S$ EMS SQL}

Unit

Lab Mothod

1,1,1-Trichloroethane

2 Trichloroalhylen

$<1.00$

$6.23 \mathrm{E}-09 \pm 1.27 \mathrm{E}-09$
$3.75 \mathrm{E}-09 \pm 1.30 \mathrm{E}-09$

1.00 pgh EX EPABO21日

WEL TRW

MEASUREMENTS CONDUCTED IN THE FIELD

Sample date: 04/22/99

Depth to water. Not available
Water elevation: Not available

Hp. conductance: $52 \mu \mathrm{S} / \mathrm{cm}$

Water evacuated from the well prior to sampling: 1 gal

ANALYSES

\begin{tabular}{|c|c|c|c|c|c|c|c|c|}
\hline Analy & esult & $F G$ & & EMS & $\lambda L$ & $n / t$ & Lab & thod \\
\hline 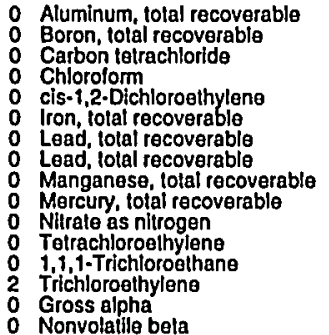 & $\begin{array}{l}<200 \\
<100 \\
<1.00 \\
<1.00 \\
2.05 \\
25.1 \\
<100 \\
<10.0 \\
6.09 \\
<0.500 \\
1.420 \\
<1.00 \\
<1.00 \\
49.6 \\
2.66 \mathrm{E} \cdot 09 \pm 9.20 \mathrm{E}- \\
3.06 \mathrm{E} \cdot 09 \pm 1.13 \mathrm{E}-\end{array}$ & 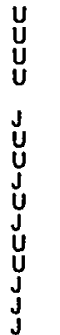 & $\mathrm{a}$ & 1 & $\begin{array}{l}100 \\
1.00 \\
1.00 \\
1.00 \\
200 \\
100 \\
10.0 \\
10.0 \\
0.500 \\
100 \\
1.00 \\
-1.00 \\
1.00\end{array}$ & $\begin{array}{l}\mu g \Omega \\
\mu g h \\
\mu g h \\
\mu g h \\
\mu g h \\
\mu g h \\
\mu g \Omega \\
\mu g \Omega \\
\mu g \Omega \\
\mu g h \\
\mu g h \\
\mu g h \\
\mu g h\end{array}$ & 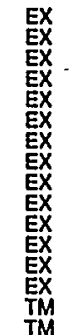 & $\begin{array}{l}1021 \mathrm{~B} \\
021 \mathrm{~B} \\
021 \mathrm{~B} \\
0.10 \mathrm{~B} \\
01010 \mathrm{~B} \\
010 \mathrm{~B} \\
01010 \mathrm{~B} \\
470 \mathrm{~A} \\
000.0 \\
0.1 \mathrm{~B} \\
021 \mathrm{~B} \\
021 \mathrm{~B} \\
0.00 \mathrm{M}\end{array}$ \\
\hline
\end{tabular}

\section{WELL TRW 3}

MEASUREMENTS CONDUCTED IN THE FIELD

Sample date: 05/17/99

Wepth to water: Nol available

$\mathrm{pH}$ : 5.6 conductance: $54 \mu \mathrm{S} / \mathrm{cm}$

Turbidity: ONTU

ANALYSES

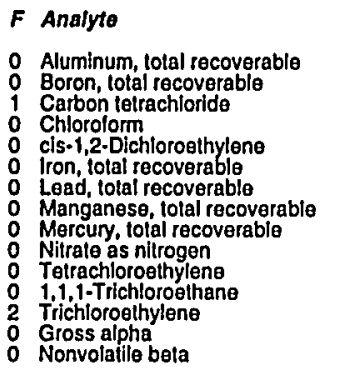

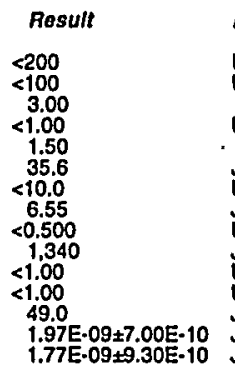

נj

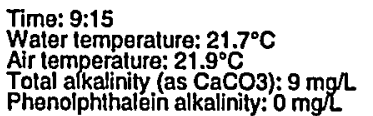

Total alkainitity (as CaCO3): $9 \mathrm{mg} / \mathrm{L}$
Phenolphthalein alkalinity: $0 \mathrm{mg}$.

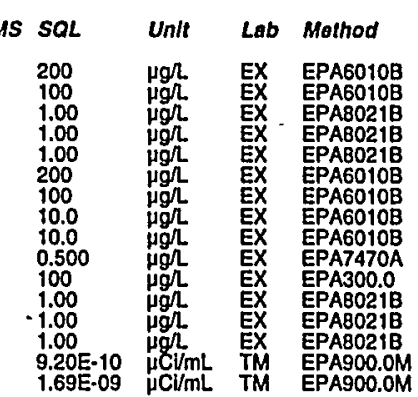

Time: 9:00

Total afkalinity (as CaCO3): $8 \mathrm{mg} / \mathrm{L}$
Phenolphthalein alkalinity: $0 \mathrm{mg} L$

0 Nonvolatile bela

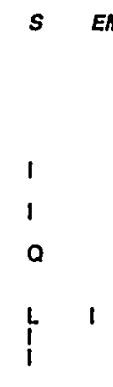

$\begin{array}{cl}\text { EMS } & \text { SQL } \\ & 200 \\ & 100 \\ & 1.00 \\ & 1.00 \\ 1.00 \\ & 200 \\ 10.0 \\ 10.0 \\ & 0.500 \\ & 100 \\ & 1.00 \\ 1 & 1.00 \\ 1.00 \\ & 7.50 E \cdot 10 \\ & 1.47 E\end{array}$

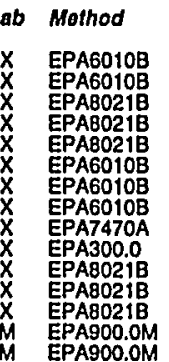

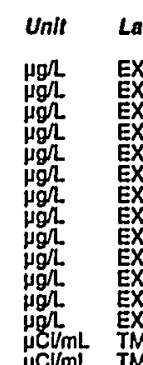

WELL TRW 3

MEASUREMENTS CONDUCTED IN THE FIELD

Sample date: $06 / 01 / 99$
Depth to waler: $67.65 \mathrm{ft}(20.62 \mathrm{~m})$ below TOC

Water elevation: $86.85 \mathrm{ft}(26.47 \mathrm{~m}) \mathrm{ms}$ |

SH: 5.8 conductance: $54 \mu \mathrm{S} / \mathrm{cm}$

The well was continuously pumping

ANALYSES

$F$ Analyto

Result

: Aluminum, total recoverab

O Coron, lotal recoverab

Chloroform

O Iron, itatal recoverable

Manganese, total recoverable

Tetrachloroethylene

T.1,1-Trichloroethane

o Goss alpha

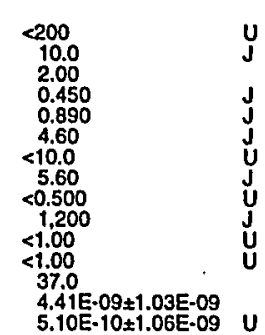

WELL TRW 4

MEASUREMENTS CONDUCTED IN THE FIEL.D

Sample date: 04/22/99

Depth to waler: $64.4 \mathrm{H}(19.63 \mathrm{~m})$ below TOC Waler elevation: $86.5 \mathrm{H}$ (26.37
Hp: 4.8
Sp. conductance: $84 \mu \mathrm{S} / \mathrm{cm}$

Waler evacuated from the well prior to sampling: $1 \mathrm{gal}$

ANAL.YSES

$F$ Analyte

Result
$<200$
10.1
$<1.00$
$<5.00$
$<1.00$
$<5.00$
1.47
$<5.00$
867
$<100$
$<10.0$
17.5
$<0.500$
4.630
$<1.00$
$<5.00$
$<1.00$
$<5.00$
137
210
2.10
$3.45-09 \pm 8.80 E-10$
$3.45 E-09 \pm 1.16 E-09$

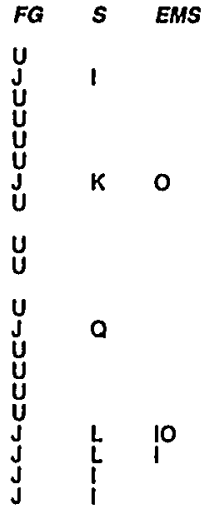

Time: 9:35

Air temperature: $213^{\circ} \mathrm{C}{ }^{\circ} \mathrm{C}$

Total alkalinity (as CaCO3): $6 \mathrm{mg} /$
Phenolphithalein alkalinity: 0 mg

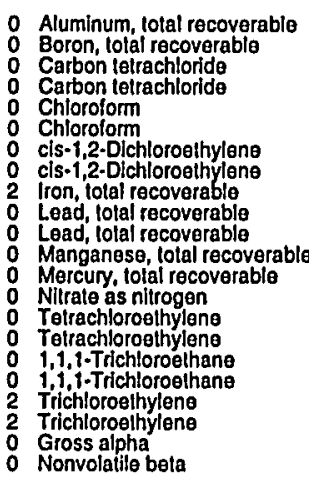

3.45E-09+1.
Time: 9:15

$241.3^{\circ}$

Total alkalinity (as CaCo3): $9 \mathrm{mg} /$
Phenolphthalein alkalinity: $0 \mathrm{mg}$ 
ANALYTICAL RESULTS

\section{WELL TRW 4}

MEASUREMENTS CONDUCTED IN THE FIELD

Sample date: 05/17/99

below TOC

Waler elevation: $86.41 \mathrm{ft}(26.34 \mathrm{~m}) \mathrm{msl}$

Sp: 5.4 conductance: $85 \mu \mathrm{S} / \mathrm{cm}$

The well was continuousiy pumping.

ANALYSES

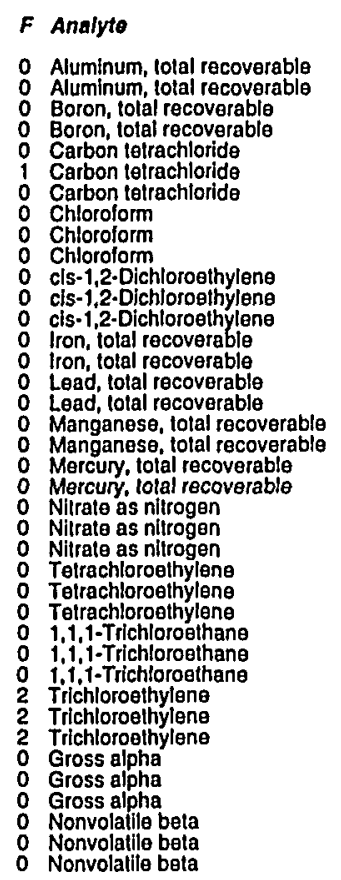

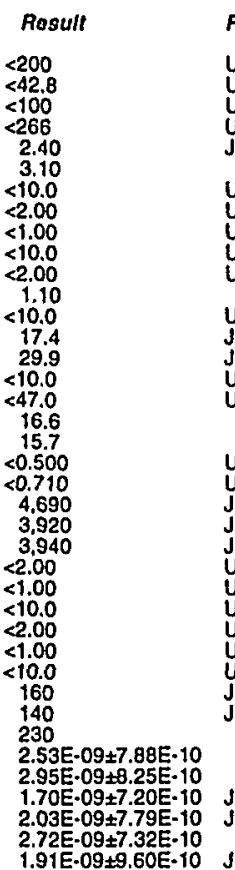

\section{WELL TRW 4 Replicate}

MEASUREMENTS CONDUCTED IN THE FIELD

Sample date: 05/17/99

Depth to water: $64.49 \mathrm{ft}(19.66 \mathrm{~m})$ below TOC

Water elevalion: $86.41 \mathrm{ft}(26.34 \mathrm{~m}) \mathrm{msl}$

: 5 .

p. conductance: $85 \mu \mathrm{S} / \mathrm{cm}$

The well was continuously pumping

ANALYSES .

\begin{tabular}{|c|c|}
\hline Analyte & Result \\
\hline 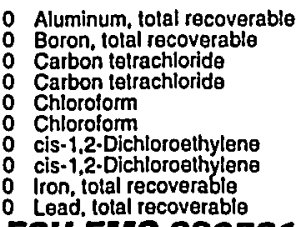 & $\begin{array}{l}<200 \\
<100 \\
<2.00 \\
<1.00 \\
<.00 \\
<1.00 \\
<1.00 \\
<1.00 \\
73.7 \\
<10.0\end{array}$ \\
\hline
\end{tabular}

Woll TRW 4 collected on 05/17/99 (cont.)

\begin{tabular}{|c|c|c|c|c|c|c|c|c|c|}
\hline $\boldsymbol{F}$ & Analyto & Result & $\boldsymbol{F G}$ & $\boldsymbol{s}$ & EMS & SOL. & Untt & Lab & Mothod \\
\hline & 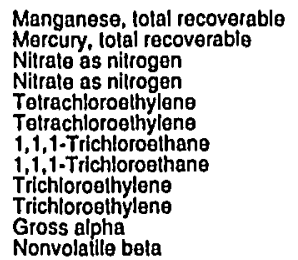 & $\begin{aligned} & 17.2 \\
&<<.02 \\
& 4.650 \\
& 4.750 \\
&<2.00 \\
&<1.00 \\
&<2.00 \\
&<1.00 \\
& 170 \\
& 140 \\
& 1.32 \mathrm{E}-09_{ \pm 7.20 E}-10 \\
& 1.73 \mathrm{E} \cdot 09 \pm 1.25 \mathrm{E} \cdot 09\end{aligned}$ & $\begin{array}{l}\breve{u} \\
\end{array}$ & L & io & $\begin{array}{l}10.0 \\
0.500 \\
200 \\
200 \\
2.00 \\
1.00 \\
2.00 \\
1.00 \\
2.00 \\
1.00 \\
1.00 \mathrm{E} \cdot 09 \\
2.05 \mathrm{E} \cdot 09\end{array}$ & 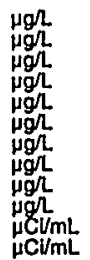 & $\begin{array}{l}\text { EX } \\
\text { EX } \\
\text { EX } \\
\text { EX } \\
\text { EX } \\
\text { EX } \\
\text { EX } \\
\text { EX } \\
\text { EX } \\
\text { EX } \\
\text { TM } \\
\text { TM }\end{array}$ & $\begin{array}{l}\text { EPA6010B } \\
\text { EPA7470A } \\
\text { EPA300.0 } \\
\text { EPA300.0 } \\
\text { EPABO21B } \\
\text { EPABO21B } \\
\text { EPABO21B } \\
\text { EPA8021B } \\
\text { EPABO21B } \\
\text { EPAB021B } \\
\text { EPA900.0M } \\
\text { EPA900.0M }\end{array}$ \\
\hline
\end{tabular}

Time: 9:45

Tir $21.6^{\circ} \mathrm{C}$ Total alkalinity (as CaCO3): $5 \mathrm{mgl}$.
Phenolphthalein alkalinity: $0 \mathrm{mg}$.

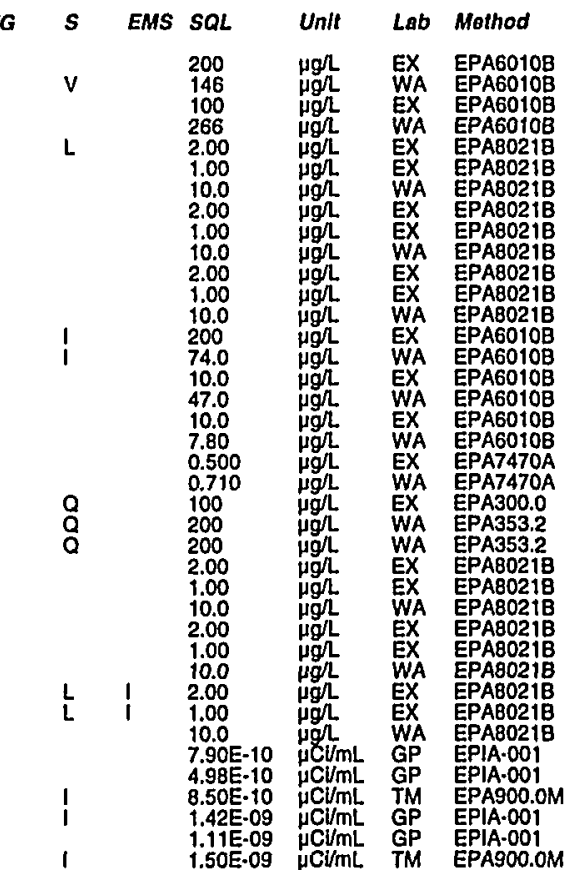

Time: 9:45

ir temporature: $21.6^{\circ} \mathrm{C}$ Total alkalinily (as CaCO3): $5 \mathrm{mg} / \mathrm{L}$ Penolphthalein alkalinity: $0 \mathrm{mg}$

\begin{tabular}{|c|c|c|c|}
\hline & & De & \\
\hline $\begin{array}{l}200 \\
100 \\
2.00 \\
1.00 \\
2.00 \\
1.00 \\
2.00 \\
1.00 \\
200 \\
10.0\end{array}$ & $\begin{array}{l}\mu g \Omega \\
\mu g \Omega \\
\mu g \Omega \\
\mu g \Omega \\
\mu g \Omega \\
\mu g \Omega \\
\mu g \Omega \\
\mu g h \\
\mu g \Omega \\
\mu g \Omega\end{array}$ & $\begin{array}{l}\text { EX } \\
\text { EX } \\
\text { EX } \\
\text { EX } \\
\text { EX } \\
\text { EX } \\
\text { EX } \\
\text { EX } \\
\text { EX } \\
\text { EX } \\
\text { EX }\end{array}$ & 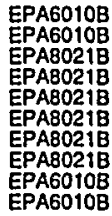 \\
\hline
\end{tabular}

\section{WELL TRW 4}

MEASUREMENTS CONDUCTED IN THE FIELD

Sample date: 06/01/99

Depth to water: 62.92 H $(19.18 \mathrm{~m})$ below TOC

Water elevali:

. conductance: $87 \mu \mathrm{S} / \mathrm{cm}$

The well was continuously pumping.

ANALYSES

\section{F Analyte}

- Aluminum, total recoverabl

Carbon letrachlorid

Chloroform

cis-1.2. Dichloroethylene

cls-1,2-Dichloroethylen

Lead, total recoverable

Manganese, lotal recoverable

Mercury, total recoverable

Nitrale as nitrogen

Tetrachlorosthylene

1,1,1-Trichlorosthan

Trichloroethylene

Gross alpha

Nonvolatile beta

\section{WELL XSB $1 A$}

MEASUREMENTS CONDUCTED IN THE FIELD

Sample date: $05 / 04 / 99$

aater elevation: $95.05 \mathrm{ft}(28.97 \mathrm{~m}) \mathrm{ms}$

. conductance: $71 \mu \mathrm{S} / \mathrm{cm}$

Water ovacuated from the well prior to sampling: $84 \mathrm{gal}$

ANALYSES

\begin{tabular}{|c|c|}
\hline alyte & ost \\
\hline 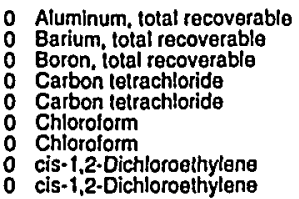 & $\begin{array}{l}<200 \\
19.0 \\
580 \\
<1.00 \\
<1.00 \\
<1.00 \\
<1.00 \\
<1.00 \\
<1.00\end{array}$ \\
\hline
\end{tabular}

\begin{tabular}{|c|c|c|c|c|c|c|c|}
\hline Result & $F G$ & & EMS & SaL & In/t & Lab & Sethod \\
\hline $\begin{array}{l}<200 \\
11.0 \\
3.20 \\
<10.0 \\
<1.00 \\
<10.0 \\
0.970 \\
<10.0 \\
33.0 \\
<10.0 \\
17.0 \\
<0.500 \\
4.600 \\
<1.00 \\
<10.0 \\
<1.00 \\
<10.0 \\
120 \\
240 \\
3.58 E-09 \pm 9.90 E-10 \\
1.711 .09+100\end{array}$ & $\begin{array}{l}\mathbf{U} \\
\mathbf{J} \\
\mathbf{J} \\
\mathbf{U} \\
\mathbf{U} \\
\mathbf{J} \\
\mathbf{U} \\
\mathbf{J}\end{array}$ & $\begin{array}{l}\text { IL. } \\
\text { I }\end{array}$ & 0 & $\begin{array}{l}200 \\
100 \\
1.00 \\
10.0 \\
1.00 \\
10.0 \\
1.00 \\
10.0 \\
200 \\
100 \\
10.0 \\
0.500 \\
100 \\
1.00 \\
10.0 \\
1.00 \\
10.0 \\
1.00 \\
10.0 \\
5.90 E-10 \\
1.94 E-09\end{array}$ & 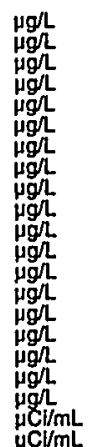 & $\begin{array}{l}\text { EX } \\
\text { EX } \\
\text { EX } \\
\text { EX } \\
\text { EX } \\
\text { EX } \\
\text { EX } \\
\text { EX } \\
\text { EX } \\
\text { EX } \\
\text { EX } \\
\text { EX } \\
\text { EX } \\
\text { EX } \\
\text { EX } \\
\text { EX } \\
\text { EX } \\
\text { EX } \\
\text { EX } \\
T M \\
T M\end{array}$ & 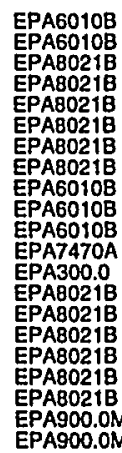 \\
\hline
\end{tabular}

Time: 13:12

Air temperalure: $22.9^{\circ} \mathrm{C}$

Total alkalinily (as CaCO3): $2 \mathrm{mg} / \mathrm{h}$ Fhenolphthalein alkalinity: $0 \mathrm{mgl}$

Waler temperature: $21.8^{\circ} \mathrm{C}$ Total afkalinity (as CaCO3): $11 \mathrm{mg} / \mathrm{L}$
Phenolphthalein alkalinity: $0 \mathrm{mg} / \mathrm{L}$
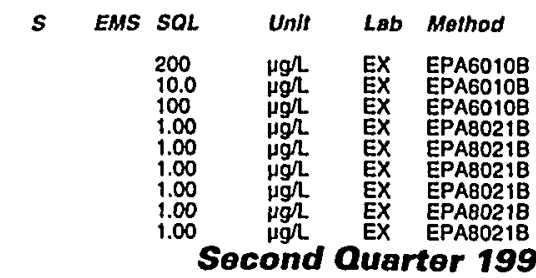
Well XSB iA collected on 05/04/99 (cont.)

\begin{tabular}{|c|c|c|c|c|c|c|c|c|}
\hline Analyto & Result & $F G$ & $s$ & EMS & SOL & Unit & Lab & Mothod \\
\hline 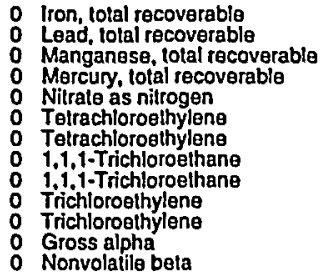 & $\begin{array}{l}<200 \\
<10.0 \\
15.0 \\
<0.500 \\
1.940 \\
<1.00 \\
<1.00 \\
<1.00 \\
<1.00 \\
<1.00 \\
<1.00 \\
1.126-09+7.60 \mathrm{E}-10 \\
3.30 \mathrm{E} \cdot 09 \pm 1.06 \mathrm{E}-09\end{array}$ & 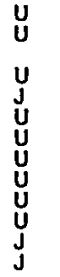 & $Q$ & & $\begin{array}{l}200 \\
10.0 \\
10.0 \\
0.500 \\
100 \\
1.00 \\
1.00 \\
1.00 \\
1.00 \\
1.00 \\
1.00 \\
1.05 E-09 \\
1.51 E .09\end{array}$ & 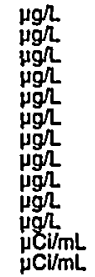 & $\begin{array}{l}\text { EX } \\
\text { EX } \\
\text { EX } \\
\text { EX } \\
\text { EX } \\
\text { EX } \\
\text { EX } \\
\text { EX } \\
\text { EX } \\
\text { EX } \\
\text { EX } \\
\text { TM } \\
\text { TM }\end{array}$ & 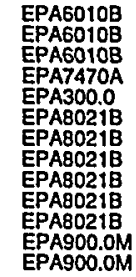 \\
\hline
\end{tabular}

\section{WELL XSB 1B}

MEASUREMENTS CONDUCTED IN THE FIELD

Sample date: 05/04/99

Daler: $55.85 \mathrm{ft}(17.02 \mathrm{~m})$ below TOC

What 5

. conductance: $30 \mu \mathrm{S} / \mathrm{cm}$

Water evacuated from the well prior to sampling: $160 \mathrm{gal}$

ANALYSES

F Analyte

$\begin{array}{ll}0 & \text { Aluminum, tolal recoverable } \\ 0 & 200 \\ 0 \text { Barium, total recoverable } & 25.0 \\ \text { Well XSB iB collectod on 05/04/99 (cont) }\end{array}$

$\boldsymbol{F}$ Analyte

o Boron, total recoverable

Carbon lefrachlorida

Chlorolorm

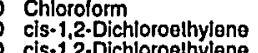

lron, lotal recoverable
Lead, tolal recoverable

Manganeso, lotal recoverab

Nitrate as nitrogen

Tetrachloroethylene

i.1.1. Trichloroethane

Trichloroethylene

O Trichloroethylen

WELL XSB 1D

MEASUREMENTS CONDUCTED IN THE FIELD

Sample date: 05/04/99

Depth to water: $60.94 \mathrm{H}(18.57 \mathrm{~m})$ below TOC

Water e

p. conductance: $62 \mu \mathrm{S} / \mathrm{cm}$

Waler evacuated from the well prior to sampling: $\mathbf{3 0} \mathrm{gal}$

ANALYSES

$F$ Analyte

Rosult
72.0
9.20
58.0
$<1.00$
$<5.00$

Result

FG

Time: 14:38 Total alkalinity (as CaCo3): $3 \mathrm{mg} /$ Phenolphthalein alkalinity: $0 \mathrm{mgh}$

EMS SQL Unit Lab Mothod

$\begin{array}{llll}200 & \mu g h & \text { EX } & \text { EPA60108 } \\ 10.0 & \text { Hgh } & \text { EX } & \text { EPA6010B }\end{array}$

9.40
$<1.00$
$<1.00$
0.430
0.430
$<1.00$
$<1.00$
870
$<10.0$
17.0
$<0.500$
$<100$
$<1.00$
$<1.00$
$<1.00$
$<1.00$
$<1.00$
$<1.00$
$1.24 E-09 \pm 6.60 E-10$
$2.47 \mathrm{E}-09 \pm 1.05 \mathrm{E}-09$

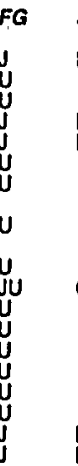

Q

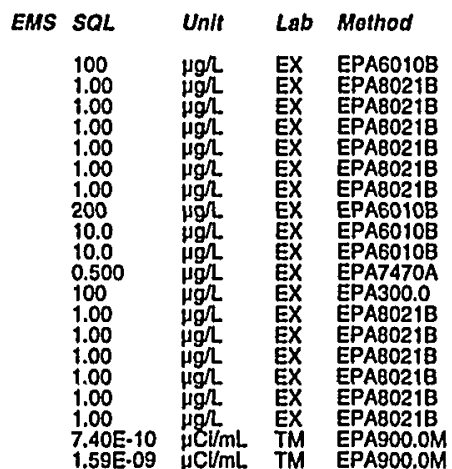

Time: 12:10

Air temperature: $32.7^{\circ}$

Total alladinity (as Caco3): $0 \mathrm{mgh}$

Phenolphthalein alkalinity: 0 mgl
Field Qualifier(s): $\mathrm{S}$

\begin{tabular}{|c|c|c|c|}
\hline$F G$ & $s$ & EMS & $S Q L$ \\
\hline J & i & & $\begin{array}{l}200 \\
10.0 \\
100 \\
1.00 \\
5.00\end{array}$ \\
\hline
\end{tabular}

Unit

Lab Method

\begin{tabular}{ll} 
EX & EPA6010B \\
EX & EPA6010B \\
EX & EPA6010B \\
EX & EPAB021B \\
\hline$X$ & EPABO21日
\end{tabular}
Air tempererature: $22.3^{\circ} \mathrm{C}$
Well XSB 1D collected on 05/04/99 (cont.)

$F$ Analyte Result

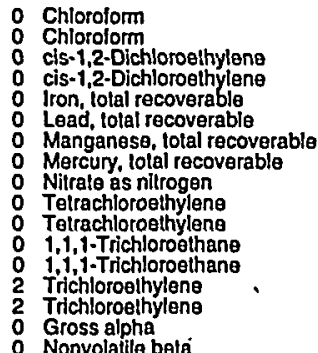

$<1.00$
$<5.00$
$<1.00$
$<5.00$
$<2.0$
$<10.0$
9.40
$<0.500$
4.050
$<1.00$
$<5.00$
$<1.00$
$<5.00$
140
170

O Nonvolatile beta

$1.77 \mathrm{E}-09 \pm 7.00 \mathrm{E}-10$
$2.17 \mathrm{E}-09 \pm 9.40 \mathrm{E}-10$

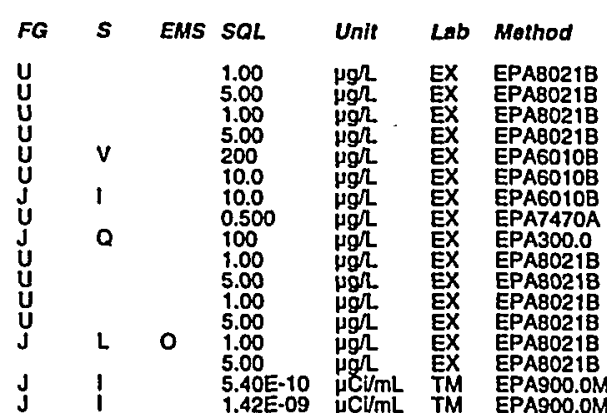

MEASUREMENTS CONDUCTEO IN THE FIELD

Sample date: 05/07/99

Water elevation: 95.02 if $(28.96 \mathrm{~m}) \mathrm{ms}$

: 5.2

conductance: $150 \mu \mathrm{S} / \mathrm{cm}$

Water evacuated from the well prior to sampling: 22 gal

ANALYSES

$F$ Analyto

Rosult
$<200$
733
$<1.00$
$<1.00$
$<1.00$
21.0
4.41
17.8
$<0.500$
8.010
$<1.00$
$<1.00$
10.0
$3.586 .09 \pm 1.14 E-09$
$5.14 E \cdot 09+1.11 E \cdot 09$

FG $s$

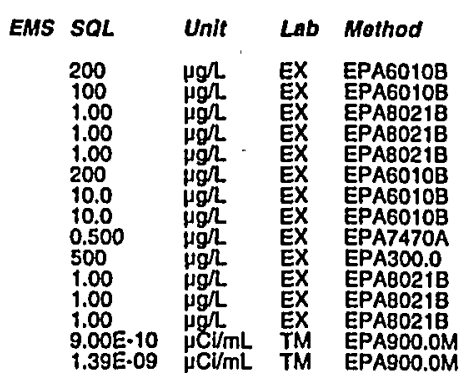

Time: 8:20

Air $23.3^{\circ} \mathrm{C}$

Total alkainily (as CaCO3): $5 \mathrm{mgh}$

Phenolphnatein alkalinity: $0 \mathrm{mgl}$

A Aluminum, total recoverable

Carbon telrachioride

cis $+1,2$ - Dichloroathylen

Lead, total recoverable (n)

Nitrate as niltrogen

1.1.1-Trichloroethane

Gross alpha
Nonvolatile bela

WELL XSB 3A

MEASUREMENTS CONDUCTED IN THE FIELLD

Sample dalo: 05/05/99

Wepth to water: Nol available

H: 4.9

. conductance: $140 \mu \mathrm{S} / \mathrm{cm}$

Water evacuated from the well prior to sampling: $35 \mathrm{ga}$

ANALYSES

F Analyto

Result

Aluminum total recoverable

Carbon tetrachioride

cis-1,2-Dichlorosthytene

o lron, total recoverable

Manganese, total recoverable

Manganese, tolal recoverable
Mercury, lotal recoverable

Nitrale as nitrogen
Telrachloroethylene

B-223

$<200$
451
$<1.00$
$<1.00$
$<1.00$
4.24
4.40
11.8
0.270
3.380
$<1.00$
$\times 1.00$

Time: 9:16

alure: $21.5^{\circ} \mathrm{C}$

Total alkalinity (as CaCO3): $4 \mathrm{mg} / \mathrm{h}$

Phenolphthalein alkalinity: $0 \mathrm{mg} L$
Field Qualifier(s): $S$

$\begin{array}{llr}\text { FG } & \text { S } & \text { EMS SOL } \\ U & & 200 \\ U & & 100 \\ U & & 1.00 \\ U & & 1.00 \\ J & 1 & 200 \\ J & 1 & 10.0 \\ J & 1 & 10.0 \\ J & 1 & 0.500 \\ J & 0 & 100 \\ U & & 1.00\end{array}$

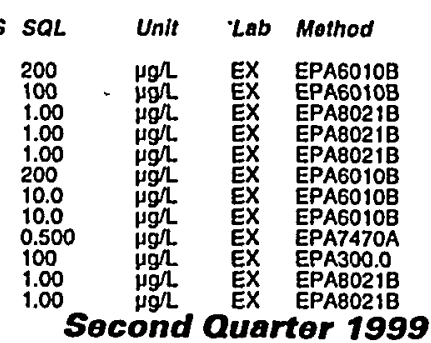


Well XSB 3A collected on 05/05/99 (cont.)
$F$ Analyto
Result
2 Trichloroethylene
O Gross alpha
7.00
$2.89 \mathrm{E}-09 \pm 9.40 \mathrm{E}-10$
$1.47 \mathrm{E}-09 \pm 1.15 \mathrm{E}-09$
G EMS SQL Unit Lab Mothod

\section{WELL XSB 4D}

MEASUREMENTS CONDUCTED IN THE FIELD

Sample date: $05 / 05 / 99$
Depth to water: $59.58 \mathrm{ft}(18.16 \mathrm{~m})$ below TOC
Waler elevalion: $95.32 \mathrm{ft}(29.05 \mathrm{~m}) \mathrm{msl}$
WH:

Sp. conductance: $120 \mu \mathrm{S} / \mathrm{cm}$

Turbidity: 1 NTU

ANALYSES

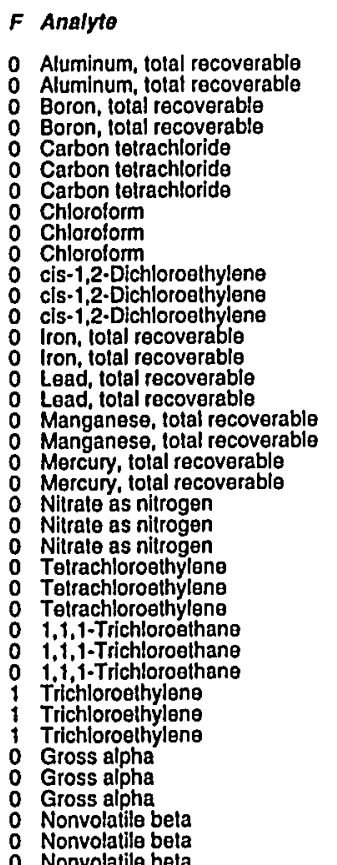

\begin{tabular}{|c|c|c|c|c|c|c|c|}
\hline sult & $F G$ & 5 & EMS & SQL & Unit & 600 & Mernoa \\
\hline 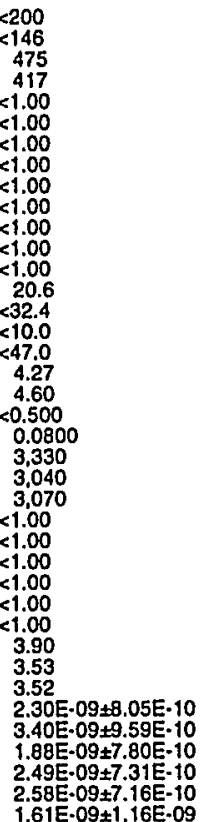 & 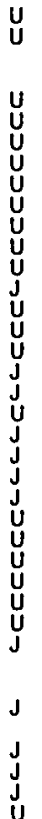 & $v$ & 0 & $\begin{array}{l}200 \\
146 \\
100 \\
266 \\
1.00 \\
1.00 \\
1.00 \\
1.00 \\
1.00 \\
1.00 \\
1.00 \\
1.00 \\
1.00 \\
700 \\
1.0 \\
1.0 \\
47.0 \\
100 \\
7.80 \\
0.500 \\
0.710 \\
100 \\
200 \\
200 \\
1.00 \\
1.00 \\
1.00 \\
1.00 \\
1.00 \\
1.00 \\
1.00 \\
1.00 \\
1.00 \\
6.96 E-10 \\
5.43 E-10 \\
6.70 E \\
1.23=09 \\
1.16 E-09 \\
1.09\end{array}$ & 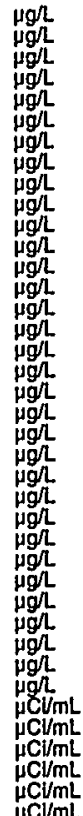 & 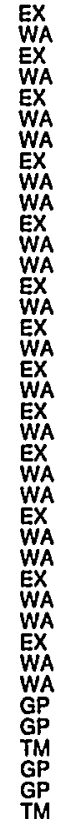 & 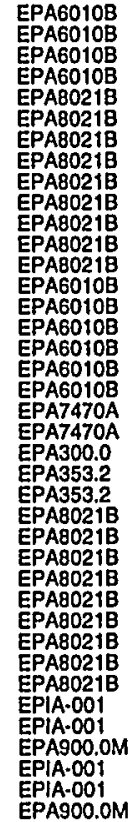 \\
\hline
\end{tabular}

\section{WELL XSB 4D Replicate}

MEASUREMENTS CONDUCTED IN THE FIELD

Sample date: 05/05/99

Deph to waler: $59.58 \mathrm{ft}(18.16 \mathrm{~m})$ below TOC

$\mathrm{gH}$ : 5.6 conductance: $120 \mu \mathrm{S} / \mathrm{cm}$

Waler evacuated from the well prior to sampling: $35 \mathrm{gal}$

ANALYSES

$F$ Analyto

Result

FG

: Aluminum, total recoverable $\quad<200$

ESH-EMS-990521

\section{Time: 9:42 \\ Waler lemperature: $20.8^{\circ} \mathrm{C}$ \\ Total alkalinity (as CaCO3): $5 \mathrm{mg} / \mathrm{L}$}

Time: 9:42

Water temperature: $20.8^{\circ} \mathrm{C}$

Total alkalinity (as CaCOO3): $5 \mathrm{mg} /$

EMS SOL Unlt Lab Mathod

$\begin{array}{llll}200 & \mu g / 2 & \text { EX } & \text { EPA60108 } \\ 100 & \mu g h & \text { EX } & \text { EPA6010B }\end{array}$
1.89E.09 $\mu \mathrm{C} V \mathrm{~mL}$ TM EPA9O0.OM

$u$
Well XSB 4D collected on 05/05/99 (cont.)

\begin{tabular}{|c|c|c|c|c|c|c|c|c|}
\hline Analyto & Rosult & $\boldsymbol{F G}$ & $s$ & $E M S$ & SQL & Unit & Lab & Mothod \\
\hline 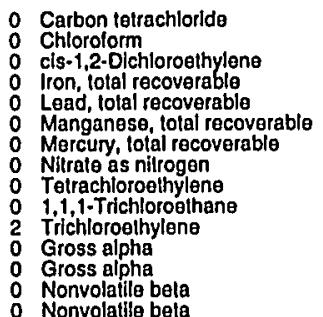 & $\begin{array}{l}<1.00 \\
<1.00 \\
<1.00 \\
21.0 \\
<10.0 \\
3.95 \\
0.200 \\
3.450 \\
<1.00 \\
<1.00 \\
45.0 \\
2.57 E-09 \pm 9.10 E-10 \\
2.15 E-09 \pm 8.40-10 \\
1.10 E-09 \pm 1.14 E-09 \\
9.30 E-10 \pm 1.13 E-09\end{array}$ & $\begin{array}{l}\mathbf{U} \\
\mathbf{U} \\
\mathbf{J} \\
\mathbf{U} \\
\mathbf{J} \\
\mathbf{J} \\
\mathbf{U} \\
\mathbf{U}\end{array}$ & $a$ & 0 & $\begin{array}{l}1.00 \\
1.00 \\
1.00 \\
200 \\
100 \\
10.0 \\
0.500 \\
100 \\
1.00 \\
1.00 \\
1.00 \\
6.70 E-10 \\
6.80 E-10 \\
1.89 E-09 \\
1.90 E-09\end{array}$ & 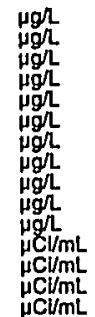 & $\begin{array}{l}\text { EX } \\
\text { EX } \\
\text { EX } \\
\text { EX } \\
\text { EX } \\
\text { EX } \\
\text { EX } \\
\text { EX } \\
\text { EX } \\
\text { EX } \\
\text { EX } \\
\text { IM } \\
\text { IM } \\
\text { IM } \\
\text { IM }\end{array}$ & 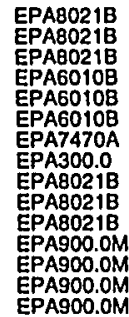 \\
\hline
\end{tabular}

\section{WELL XSB 5A}

MEASUREMENTS CONDUCTED IN THE FIELD

Sample date: 05/05/99

(7) $17.1 \mathrm{ft}$ ( m) below TOC

H:5.4

conductance: $130 \mu \mathrm{s} / \mathrm{cm}$

Water evacuated from the well prior to sampling: $37 \mathrm{gal}$

ANALYSES

$F$ Analyte

Time: 13:56

Total alkalinity (as CaCO3): 3 mg/l

Phenolphthalein alkalinity: $0 \mathrm{mg}$

- Aluminum, total recoverable

Carbon tetrachlorida

Chloroform

1.1.1-Trichloroethane

WELL YSB 1A

MEASUREMENTS CONDUCTED IN THE FIELD

Water olevation: $26.8 \mathrm{ft}(8.17 \mathrm{~m})$ below TOC
We. $18.7(36.18 \mathrm{~m}) \mathrm{ms}$

Water evacualed from the well prior to sampling: $50 \mathrm{gat}$

ANALYSES

$\begin{array}{llc}\text { F } & \text { Analyte } & \text { Result } \\ 0 & \text { Aluminum, lotal recoverable } & <200 \\ 0 & \text { Boron, total recoverable } & 7.36 \\ 0 & \text { Iron lotal recoverable } & 69.0 \\ 0 & \text { Lead, total recoverable } & <10.0 \\ 0 & \text { Manganese tolal recoverable } & 1.29 \\ 0 & \text { Mercury, lotal recoverable } & <0.500\end{array}$

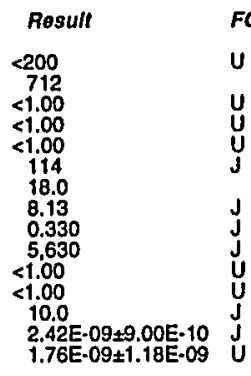

Iron,

Manganess, lotal recovera

(ang

Tirichloroethylene

Sample date: 05/05/99

p. conductance: $32 \mu \mathrm{S} / \mathrm{cm}$

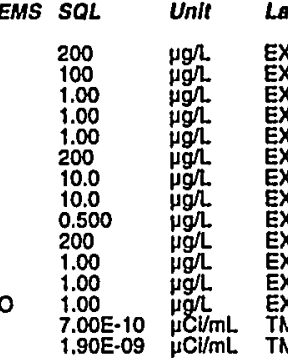

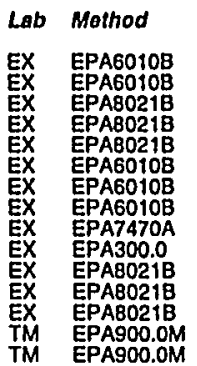

ime: 13:30

Water $20.5^{\circ} \mathrm{C}$ Total alkalinily (as CaCo3): $4 \mathrm{mg} /$ Phenolphithalein alkalinity: $0 \mathrm{mgl}$

Mercury, total recoverablo $\quad 1.29$
EMS SQL
$\begin{array}{ll}200 & \mu g h \\ 100 & \mu g h \\ 200 & \mu g \mu \\ 10.0 & \mu g g \\ 10.0 & \mu g h \\ 0.500 & \mu g h\end{array}$
EX EPA6010B
EX EPAG0010
EPAG010B



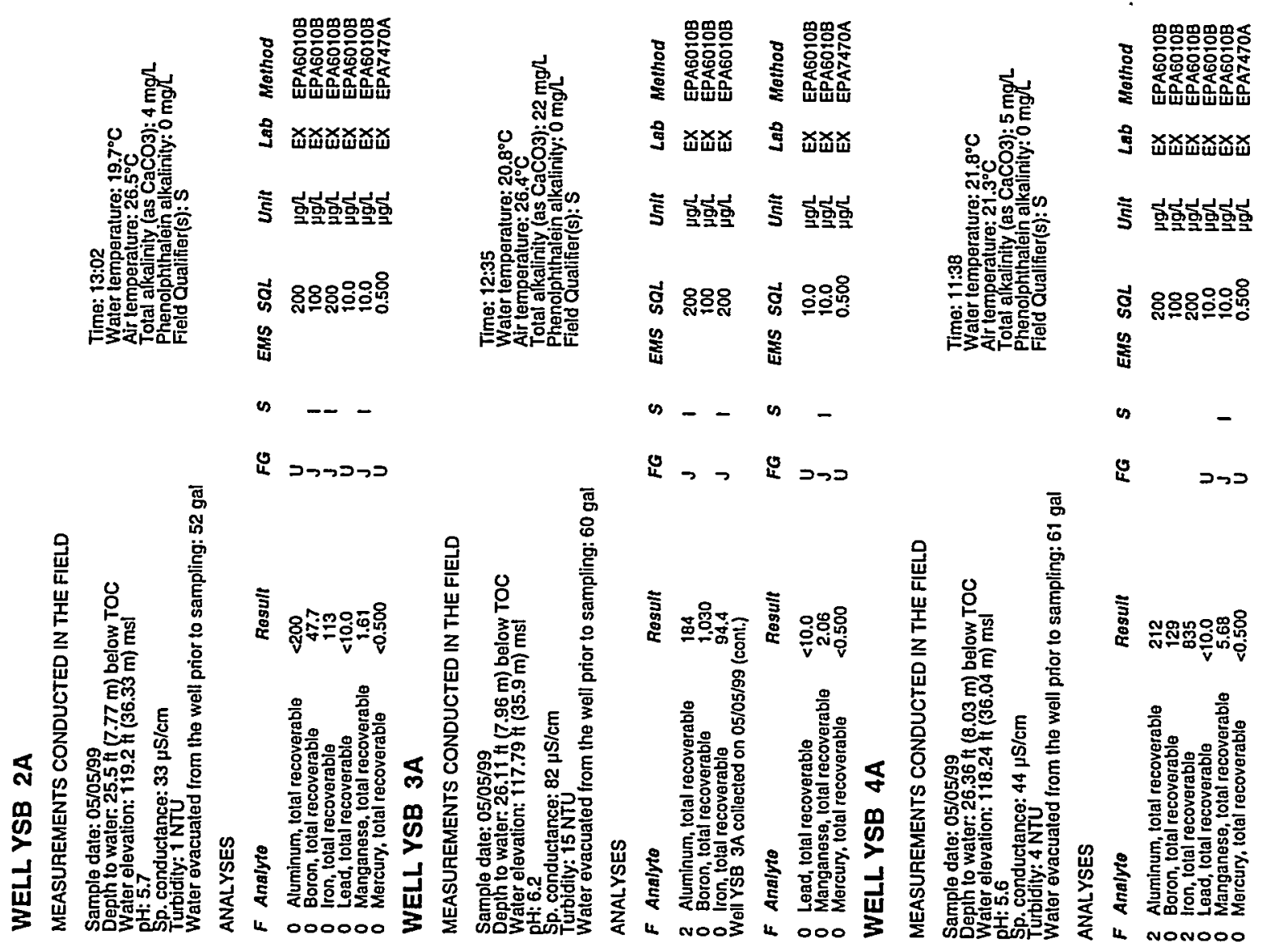

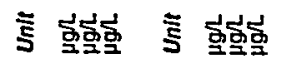

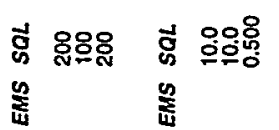

ฟ్

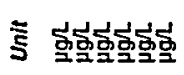

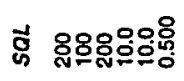

言

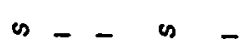

as

L, 2 S D

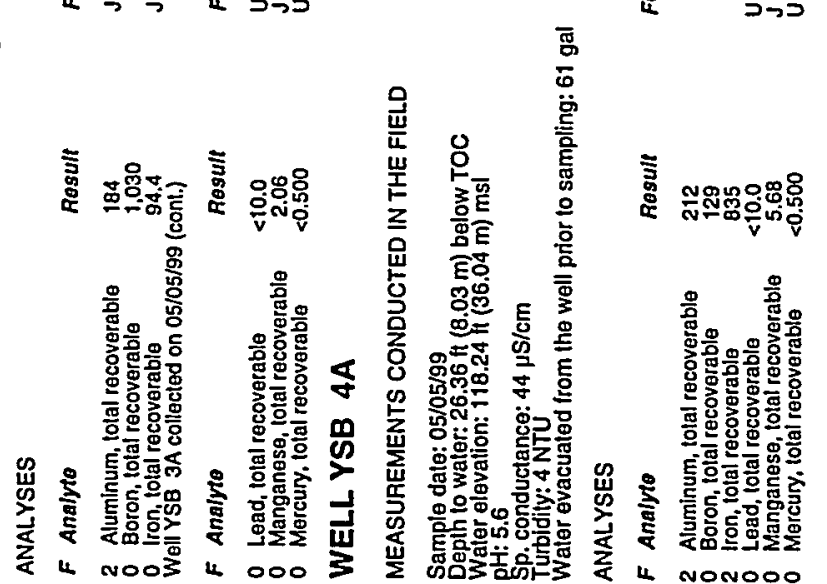


1

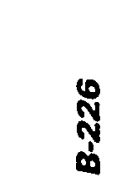

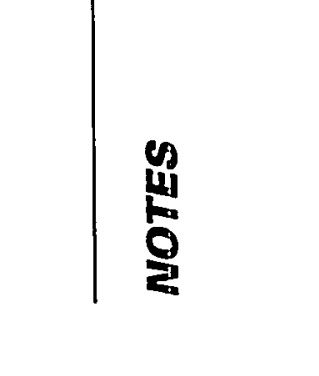

1 


\section{Appendix C. Sampling Blanks Results}

This section presents the analytical results for sampling blanks analyzed during second quarter 1999. 
NOTES 


\section{WELL QA 2B}

MEASUREMENTS CONDUCTED IN THE FIELD

Sample date: 04/05/99 $\mathrm{ft}(42.1 \mathrm{~m})$ below TOC Air temperature: $24.3^{\circ} \mathrm{C}$ PP.conductance: $2 \mu \mathrm{S} / \mathrm{cm}$

ANALYSES

\begin{tabular}{|c|c|c|c|c|c|c|c|c|}
\hline Analyte & Result & $F G$ & $s$ & EMS & SQL & Unit & Lab & Method \\
\hline 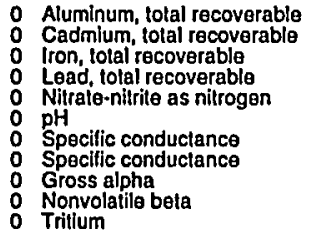 & $\begin{array}{l}<15.0 \\
<1.00 \\
<25.0 \\
<2.00 \\
10.0 \\
5.84 \\
1.18 \\
1.15 \\
-7.30 E-11 \pm 2.24 E-10 \\
-8.53 E-11 \pm 5.35 E-10 \\
-1.11 E-07 \pm 3.16 E-07\end{array}$ & 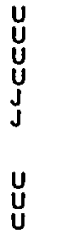 & a & 6 & $\begin{array}{l}15.0 \\
1.00 \\
25.0 \\
2.00 \\
500 \\
0.100 \\
1.00 \\
1.00 \\
6.23 E-10 \\
1.222-09 \\
5.62 E-07\end{array}$ & 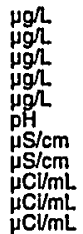 & $\begin{array}{l}\mathrm{GE} \\
\mathrm{GE} \\
\mathrm{GE} \\
\mathrm{GE} \\
\mathrm{GE} \\
\mathrm{GE} \\
\mathrm{GE} \\
\mathrm{GE} \\
\mathrm{GP} \\
\mathrm{GP} \\
\mathrm{GP}\end{array}$ & $\begin{array}{l}\text { EPA6020 } \\
\text { EPA6020 } \\
\text { EPA6020 } \\
\text { EPA6020 } \\
\text { EPA353.1 } \\
\text { EPA90408 } \\
\text { EPA9050A } \\
\text { EPA9050A } \\
\text { EPIA-001 } \\
\text { EPIA.001 } \\
\text { EPIA.002 }\end{array}$ \\
\hline
\end{tabular}

\section{WELL QA 4B}

MEASUREMENTS CONDUCTED IN THE FIELD

Sample date: 04/15/99
Depth to water: $: 118.03 \mathrm{ft}(35.98 \mathrm{~m})$ below TOC Air temperature: $18.5^{\circ} \mathrm{C}$ Sp. conductance: $1 \mu \mathrm{S} / \mathrm{cm}$

ANALYSES

\begin{tabular}{|c|c|c|c|c|c|c|c|c|}
\hline Analyto & Rosult & $F G$ & $s$ & EMS & SQL & Untt & Lab & ithod \\
\hline 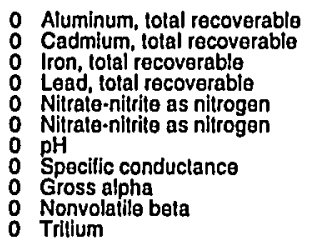 & $\begin{array}{l}<15.0 \\
<1.00 \\
31.6 \\
<0.371 \\
<50.0 \\
<50.0 \\
5.83 \\
1.20 \\
-7.25 \mathrm{E}-11 \pm 3.25 \mathrm{E}-1 \\
-1.28 \mathrm{E}-10 \pm 6.10 \mathrm{E}-1 \\
-2.03 \mathrm{E} \cdot 07 \pm 3.07 \mathrm{E} \cdot 0\end{array}$ & 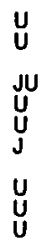 & a & $\begin{array}{l}6 \\
46\end{array}$ & $\begin{array}{l}15.0 \\
1.00 \\
25.0 \\
2.00 \\
50.0 \\
50.0 \\
0.100 \\
1.00 \\
9.03 E-10 \\
1.43 E .09 \\
5.54 E .07\end{array}$ & 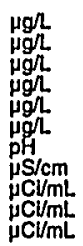 & $\begin{array}{l}\mathrm{GE} \\
\mathrm{GE} \\
\mathrm{GE} \\
\mathrm{GE} \\
\mathrm{GE} \\
\mathrm{GE} \\
\mathrm{GE} \\
\mathrm{GE} \\
\mathrm{GP} \\
\mathrm{GP} \\
\mathrm{GP}\end{array}$ & $\begin{array}{l}\text { EPA6020 } \\
\text { EPA6020 } \\
\text { EPA6020 } \\
\text { EPA6020 } \\
\text { EPA353.1 } \\
\text { EPA353.1 } \\
\text { EPA9040B } \\
\text { EPA9050A } \\
\text { EPIA.001 } \\
\text { EPIA.001 } \\
\text { EPIA.002 }\end{array}$ \\
\hline
\end{tabular}

\section{WELL QA $6 B$}

MEASUREMENTS CONDUCTED IN THE FIELD

Sample date: 04/06/99

Depth to water: $133.4 \mathrm{Ht}(40.66 \mathrm{~m})$ below TOC

Air remperature: $24^{\circ} \mathrm{C}$

Sp. conductance: $2 \mu \mathrm{S} / \mathrm{cm}$
Turbidity: 1 NTU

Time: 13:46

Total alkalinity (as CaCO3): $1 \mathrm{mg} /$
Phenolphthalein alkalinity: $0 \mathrm{mg}$ L

ANALYSES
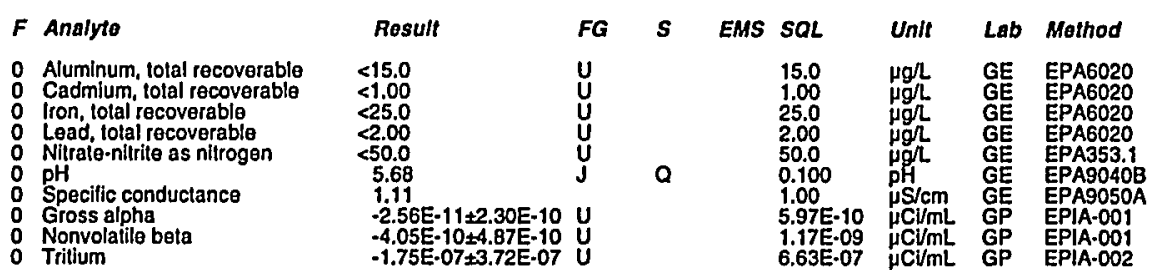

WELL QA 8B

MEASUREMENTS CONDUCTED IN THE FIELD

Depth to water; $67.5 \mathrm{At}(20.57 \mathrm{~m})$ below TOC

Air temp

Sp. conductance: $2 \mu \mathrm{S} / \mathrm{cm}$

ANALYSES

\section{$F$ Analyto \\ Aluminum. 1otal recoverable \\ Iron, lotal recoverable \\ Nitrate-nitrite as nitrogen \\ $\mathrm{pH}$ \\ Specillc conductance
Specific conductance \\ Nonvolatile beta}

\section{WELL QA 10B}

MEASUREMENTS CONDUCTED IN THE FIELD

Sample date: $04 / 15 / 99$
Depth to waier: $132.26 \mathrm{fl}(40.31 \mathrm{~m})$ below TOC
Air temperature: $17.6^{\circ} \mathrm{C}$

pir temp 4.9

Sp. conductance: $1 \mu \mathrm{S} / \mathrm{cm}$

ANALYSES

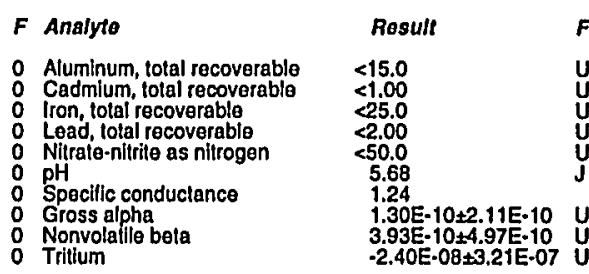

\section{WELL QA $12 B$}

MEASUREMENTS CONDUCTED IN THE FIELD

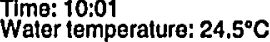

Total alkallnity (as CaCO3): $1 \mathrm{mg} / \mathrm{L}$

Sample date: 04/19/99

Depth to water: 63.65 ft $(19.4 \mathrm{~m})$ below TOC

Air temperature: $24.1^{\circ} \mathrm{C}$

Sp. conductance: $4 \mu \mathrm{S} / \mathrm{cm}$

ANALYSES

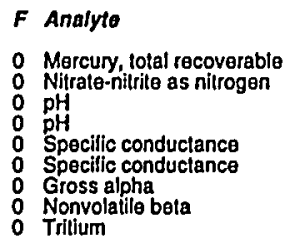

Time: 13:06

Water temperature: $24.5^{\circ} \mathrm{C}$

Tolal alkalinity (as Caco3): $1 \mathrm{mg} /$

$\begin{array}{ll}<15.0 & U \\ <0.314 & J U \\ <25.0 & U .417\end{array}$

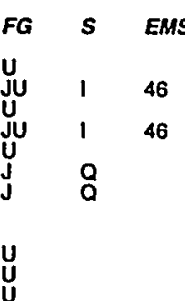

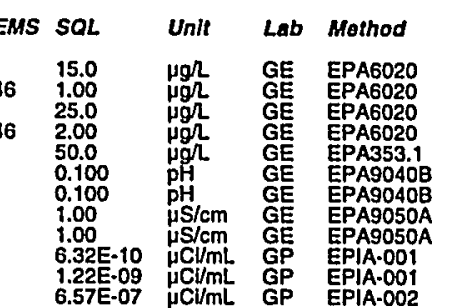

Time: 8:43

Total alkalinity (as CaCO3): $1 \mathrm{mg} / \mathrm{L}$
Phenolphthalein alkalinity: $0 \mathrm{mg} / \mathrm{L}$

\begin{tabular}{|c|c|c|c|}
\hline$S Q L$ & Unit & Lab & Method \\
\hline $\begin{array}{l}15.0 \\
1.00 \\
25.0 \\
2.00 \\
50.0 \\
0.100 \\
1.00 \\
4.41 \mathrm{E}-10 \\
1.05 \mathrm{E} \cdot 09 \\
5.63 \mathrm{E} .07\end{array}$ & 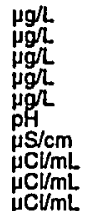 & $\begin{array}{l}G E \\
G E \\
G G E \\
G E \\
G E \\
G E \\
G G \\
G E \\
G E \\
G E \\
G P \\
G P \\
G P\end{array}$ & $\begin{array}{l}\text { EPA6020 } \\
\text { EPAG020 } \\
\text { EPA6020 } \\
\text { EPAG020 } \\
\text { EPA353.1 } \\
\text { EPA9040B } \\
\text { EPA9050A } \\
\text { EPIA.001 } \\
\text { EPIA.001 } \\
\text { EPIA.002 }\end{array}$ \\
\hline
\end{tabular}

Time: 14:40

Tolal alkalinity (as CaCO3): $1 \mathrm{mg} \Omega$
Phenolphthalein alkalinity: $0 \mathrm{mg} \mathrm{m}^{-}$

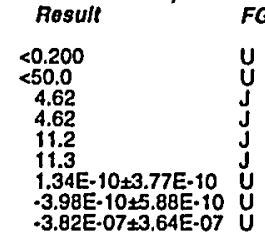

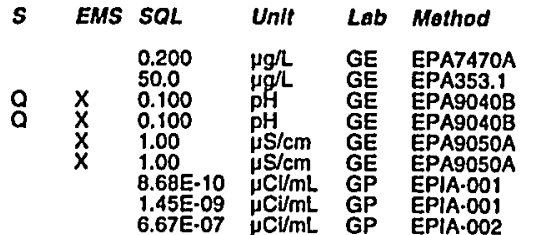




\section{WELL QA 14B}

MEASUREMENTS CONDUCTED IN THE FIELD

Sample date: 04/16/99
Depth to water: 43.7 th (13.32 m) below TOC
Airt tomperature: $17.4^{\circ} \mathrm{C}$

H: 4,4

Sp.conductance: $1 \mu \mathrm{S} / \mathrm{cm}$

ANALYSES

$\begin{array}{ll}\text { F } & \text { Analyto } \\ 0 & \text { Mercury, total recoverable } \\ 0 & \text { Nilrate-nitrite as nitrogen } \\ 0 & \text { pH } \\ 0 & \text { pH } \\ 0 & \text { Specillc conductance } \\ 0 & \text { Specific conductance } \\ 0 & \text { Gross alpha } \\ 0 & \text { Nonvolatile bela } \\ 2 & \text { Trilium }\end{array}$

\section{WELL QA 16B}

MEASUREMENTS CONDUCTED IN THE FIELD

Sample date: $04 / 22 / 99$
Depth to water: $79.25 \mathrm{H}(24.16 \mathrm{~m})$ below TOC
Air temperature: $14.7^{\circ} \mathrm{C}$

$\mathrm{AH}: 5.1$

Sp. conductance: $7 \mu \mathrm{S} / \mathrm{cm}$

ANALYSES

$F$ Analyto

Mercury, total recoverable
0 Nitrate-nitrite as nittrogen

$\mathrm{pH}$

Specilic conductance
Specilic conductance

Gross alpha

Tritium

\section{WELL QA 18B}

MEASUREMENTS CONDUCTED IN THE FIELD

Sample date: 04/23/99

AH: 5.4

p. conductance: $1 \mu \mathrm{S} / \mathrm{cm}$

ANALYSES

$F$ Analyto

Mercury, total recoverable
N Nitrale-nitrite as nitrogen

$\mathrm{pH}$

Gross alpha
0 Nonvolatila beta
0

\begin{tabular}{|c|c|c|c|c|c|c|c|}
\hline Result & $F G$ & $s$ & EMS & SQL & Unit & Lab & Mothod \\
\hline $\begin{array}{l}<0.200 \\
<10.0 \\
5.56 \\
5.55 \\
1.67 \\
1.73 \\
5.41 \mathrm{E}-12+2.38 E-10 \\
.7 .98 \mathrm{~g}-11 \pm 6.04 \mathrm{E}-10 \\
2.81 \mathrm{E} \cdot 04 \pm 5.54 \mathrm{E} \cdot 06\end{array}$ & $\begin{array}{l}u \\
J \\
J\end{array}$ & $\begin{array}{l}\text { v } \\
\text { Q }\end{array}$ & & $\begin{array}{l}0.200 \\
50.0 \\
0.100 \\
0.100 \\
1.00 \\
1.00 \\
6.43 E-10 \\
1.42 E-09 \\
1.09 E-06\end{array}$ & 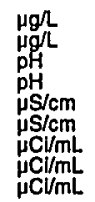 & $\begin{array}{l}G E \\
G E \\
G E \\
G E \\
G E \\
G E \\
G E \\
G P \\
G P \\
G P\end{array}$ & $\begin{array}{l}\text { EPA7470A } \\
\text { EPA353.1 } \\
\text { EPA9040B } \\
\text { EPA9040B } \\
\text { EPA9050A } \\
\text { EPA9050A } \\
\text { EPIA-001 } \\
\text { EPIA.001 } \\
\text { EPIA-002 }\end{array}$ \\
\hline
\end{tabular}

\begin{tabular}{|c|c|c|c|c|c|c|c|}
\hline Result & $F G$ & $s$ & EMS & $S Q L$ & Unit & Lab & Mothod \\
\hline $\begin{array}{l}<0.200 \\
10.0 \\
4.75 \\
4.75 \\
7.68 \\
7.68 \\
-4.77 \mathrm{E}-12 \pm 1.49 \mathrm{E}-10 \\
2.37 \mathrm{E} \cdot 10 \pm .077-10 \\
1.02 \mathrm{E}-08 \pm 3.53 \mathrm{E} \cdot 07\end{array}$ & $\begin{array}{l}U \\
\mathbf{J} \\
\mathbf{J}\end{array}$ & $\begin{array}{l}1 \\
Q \\
0\end{array}$ & 6 & $\begin{array}{l}0.200 \\
50.0 \\
0.100 \\
0.100 \\
1.00 \\
1.00 \\
4.30 \mathrm{E}-10 \\
1.10 \mathrm{E} \cdot 09 \\
6.15 \mathrm{E} \cdot 07\end{array}$ & $\begin{array}{l}\mu g / L \\
\mu g / L \\
\mu H \\
{ }_{p H} \\
\mu \mathrm{SH} / \mathrm{cm} \\
\mu \mathrm{S} / \mathrm{cm} \\
\mu \mathrm{C} / \mathrm{mL} \\
\mu \mathrm{C} / \mathrm{mL} \\
\mu \mathrm{C} / \mathrm{mL}\end{array}$ & $\begin{array}{l}\mathrm{GE} \\
\mathrm{GE} \\
\mathrm{GE} \\
\mathrm{GE} \\
\mathrm{GE} \\
\mathrm{GE} \\
\mathrm{GP} \\
\mathrm{GP} \\
\mathrm{GP}\end{array}$ & $\begin{array}{l}\text { EPA7470A } \\
\text { EPA353.1 } \\
\text { EPA9040B } \\
\text { EPA9040B } \\
\text { EPA9050A } \\
\text { EPA9050A } \\
\text { EPIA.001 } \\
\text { EPIA.001 } \\
\text { EPIA.002 }\end{array}$ \\
\hline
\end{tabular}

Time: 8:34

ature: $19.5^{\circ} \mathrm{C}$

Total alkalinily (as CaCO3): $2 \mathrm{mg} / \mathrm{L}$
Phenolphthalein alkalinity: $0 \mathrm{mg} L$

Time: 11:28

Total alkalinity (as CaCO3): $1 \mathrm{mg} /$
Phenolphthalein alkalinity: $0 \mathrm{mg}$.

\section{Time: $7: 10$ Water temperalure: $21.7^{\circ} \mathrm{C}$}

Total alkalinity (as CaCO3): $2 \mathrm{mg} /$.
Phenolphthalein alkalinity: $0 \mathrm{mg} L$

\begin{tabular}{|c|c|c|c|c|c|c|c|}
\hline Result & $F G$ & $s$ & EMS & SQL & Unit & Lab & Method \\
\hline $\begin{array}{l}<0.200 \\
20.0 \\
5.78 \\
1.23 \\
3.30 \mathrm{E}-10 \pm 3.09 E-10 \\
2.12 E-10 \pm 5.67 E-10 \\
\cdot 2.87 E \cdot 07 \pm 3.40 E-07\end{array}$ & $\begin{array}{l}U \\
\mathbf{J}\end{array}$ & ' & 6 & $\begin{array}{l}0.200 \\
50.0 \\
0.100 \\
1.00 \\
5.58 E-10 \\
1.23 E-09 \\
6.19 E-07\end{array}$ & $\begin{array}{l}\mu g / \\
\mu g / L \\
\mu \mathrm{p} \\
\mu \mathrm{S} / \mathrm{cm} \\
\mu \mathrm{CumL} \\
\mu \mathrm{C} / \mathrm{mL} \\
\mu \mathrm{C} / \mathrm{mL}\end{array}$ & $\begin{array}{l}\mathrm{GE} \\
\mathrm{GE} \\
\mathrm{GE} \\
\mathrm{GE} \\
\mathrm{GEP} \\
\mathrm{GP} \\
\mathrm{GP}\end{array}$ & $\begin{array}{l}\text { EPA7470A } \\
\text { EPA353.1 } \\
\text { EPA9040B } \\
\text { EPA9050A } \\
\text { EPA.001 } \\
\text { EPAA.001 } \\
\text { EPIA.002 }\end{array}$ \\
\hline
\end{tabular}

\section{WELL QA 20B}

MEASUREMENTS CONDUCTED IN THE FIELD

Sample dale: 04/21/99 $\mathrm{H}: 4.9$. p. conductance: $1 \mu \mathrm{S} / \mathrm{cm}$ ANALYSES

\begin{tabular}{|c|c|c|c|c|c|c|c|c|}
\hline Analyte & Result & $F G$ & $s$ & EMS & $S O L$ & Unlt & Lab & Method \\
\hline $\begin{array}{ll}0 & \text { Mercury, total recoverable } \\
0 & \text { Nilrate-nitirite as nlliogen } \\
0 & \text { pH } \\
0 & \text { pH } \\
0 & \text { Specille conductance } \\
0 & \text { Spectic conduclance } \\
0 & \text { Gross alpha } \\
0 & \text { Nonvolatile beta } \\
0 & \text { Trillumm }\end{array}$ & $\begin{array}{l}<0.200 \\
10.0 \\
5.77 \\
5.78 \\
1.25 \\
1.26 \\
-1.51 \mathrm{E}-11 \pm 2.59 \mathrm{E} \cdot 10 \\
3.14 \mathrm{E}-10 \pm 5.36 \mathrm{E}-10 \\
-2.69 \mathrm{E}-07 \pm 3.20 \mathrm{E}-07\end{array}$ & $\begin{array}{l}U \\
\mathbf{J} \\
\mathbf{J}\end{array}$ & $\begin{array}{l}1 \\
Q \\
Q\end{array}$ & 6 & $\begin{array}{l}0.200 \\
50.0 \\
0.100 \\
0.100 \\
1.00 \\
1.00 \\
6.32 E-10 \\
1.15 E-09 \\
5.80 E=07\end{array}$ & $\begin{array}{l}\mu g / 2 \\
\mu g / L \\
\mathrm{pH}^{\prime} \\
\mathrm{pH} \\
\mu \mathrm{S} / \mathrm{cm} \\
\mu \mathrm{S} / \mathrm{cm} \\
\mu \mathrm{C} / \mathrm{mL} \\
\mu \mathrm{Cl/mL} \\
\mu \mathrm{Cl} / \mathrm{mL}\end{array}$ & $\begin{array}{l}G E \\
G E \\
G E \\
G E \\
G E \\
G E \\
G E \\
G P \\
G P \\
G P\end{array}$ & $\begin{array}{l}\text { EPA7470A } \\
\text { EPA353.1 } \\
\text { EPA9040B } \\
\text { EPA9040B } \\
\text { EPA9050A } \\
\text { EPA9050A } \\
\text { EPIA.001 } \\
\text { EPIA.001 } \\
\text { EPIA.002 }\end{array}$ \\
\hline
\end{tabular}

\section{WELL QA 228}

MEASUREMENTS CONDUCTED IN THE FIELD

Sample date: $04 / 23 / 99$

Air temperature: $15.8^{\circ} \mathrm{C}$

Sp. conductance: $1 \mu \mathrm{S} / \mathrm{cm}$

Waler temperature: $22.4^{\circ} \mathrm{C}$

ANALYSES

$F$ Anelyto

Mercury, total recoverablo

Nitrate-nitrite as nirrog

Speeclice conductance

Nonvolatile bet

\section{WELL QA 24B}

MEASUREMENTS CONDUCTED IN THE FIELD

Sample date: 04/23/99

Depth to water: $60.03 \mathrm{ft}(18.3 \mathrm{~m})$ below TOC

Air temperalure: $21.6^{\circ} \mathrm{C}$

Surbidity: 1 NTU: $2 \mu \mathrm{S} / \mathrm{cm}$

$\begin{array}{ll}\text { Result } & F G \\ <0.200 & U \\ 20.0 & J \\ 5.75 & J \\ 1.30 & \text { J } \\ 1.78 E-10+2.59 E-10 & U \\ -6.83 E-11 \pm 4.50 E-10 & U \\ -7.68 E-08 \pm 3.43 E-07 & U\end{array}$

Time: 11:06

$334^{\circ} \mathrm{C}$

Total alkalinity (as $\mathrm{CaCO}$ ): $1 \mathrm{mg} /$
Phenolphthalein alkalinity: $0 \mathrm{mg} L$

ANALYSES

$F$ Analyto

Mercury, total recoverable

Nitrate-nltrite as niltrogen
Nitrate-nitrite as nitrogen

$\mathrm{pH}$

Specilic conduclance

Specifle conductance

Gross alpha
Nonvolatile bota

Nonvolatilia
Result

$<0,200$

10.0
10.0
5.65
$\mathbf{5 . 6 6}$
1.55
1.57

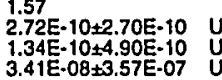

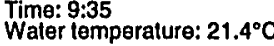

Total alkalinily (as CaCO3): $2 \mathrm{mg} /$

\begin{tabular}{|c|c|c|c|c|c|}
\hline$s$ & $E M S$ & SQL & Unit & Lab & Mothod \\
\hline la & 6 & $\begin{array}{l}0.200 \\
50.0 \\
0.100 \\
1.00 \\
5.17 E-10 \\
1.03 E-09 \\
6.06 E-07\end{array}$ & 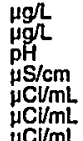 & $\begin{array}{l}G E \\
G E \\
G E \\
G E \\
G P \\
G P \\
G P\end{array}$ & $\begin{array}{l}\text { EPA7470A } \\
\text { EPA353.1 } \\
\text { EPA9000 } \\
\text { EPA9050A } \\
\text { EPIA.001 } \\
\text { EPIA.001 }\end{array}$ \\
\hline
\end{tabular}




\section{WELL QA 26B}

MEASUREMENTS CONDUCTED IN THE FIELD

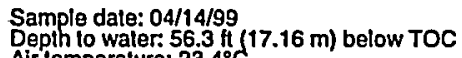

Air temperature: $23.4^{\circ} \mathrm{C}$
pp: $5.4^{-0}$
Turibiductance: $1 \mu \mathrm{S} / \mathrm{cm}$

ANALYSES

$F$ Analyte

O Gross alpha
o Nonvolatile beta

- Nonvolatile beta

\section{WELL QA 28B}

MEASUREMENTS CONDUCTED IN THE FIELD

Sample date: $05 / 17 / 99$
Depph to water: $101.6 \mathrm{ft}(30.97 \mathrm{~m})$ below TOC
Air temperature: $25.7^{\circ} \mathrm{C}$

Air temperature: $25.7^{\circ} \mathrm{C}$

Sp. conduclance: $1 \mu \mathrm{S} / \mathrm{cm}$

ANALYSES

$F$ Analyto

$\begin{array}{ll}0 & \text { Gross alpha } \\ 0 & \text { Nonvolatile beta } \\ 0 & \text { Trillum }\end{array}$

WELL QA 30B

MEASUREMENTS CONDUCTED IN THE FIELD

Sample dale: 06/14/99
Depth to water: 55.28 (1
(16.85 m) below TOC

Airtemp

Sp. conductance: $1 \mu \mathrm{S} / \mathrm{cm}$
Turbidity: O NTU

ANALYSES

$F$ Analyto

0 Gross alpha

O Triflum

WELL QA 38B

MEASUREMENTS CONDUCTED IN THE FIELD

Sample date: 06/03/99

Sp. conductance: $3 . \mu \mathrm{S} / \mathrm{cm}$

ANALYSES

F Anglyto

o Aluminum, total recoverable

Anlimony lolal recoverab

o Barium, total recoverable

- Ceryllium, total recoverable

Chemical oxygen demand

ESH-EMS-990521
Resulh

FG

$-1.30 E-10 \pm 4.00 E-10 U$
$1.80 E-10 \pm 9.80 E-10$
$5.00 E-08+3.20 E-07$

FG

$-7.00 E-11 \pm 4.00 E-10$
$-7.00 E-11 \pm 9.10 E-10$
$0.00 E+00 \pm 3.20 E-07$

Result

$F G \quad S$

erature: $23.7^{\circ} \mathrm{C}$

Total alkalinity (as CaCO3): $0 \mathrm{mg} / \mathrm{L}$
Phenol phthalein alkalinity: $0 \mathrm{mg} / \mathrm{L}$

$\begin{array}{ll}6.10 E-10 \pm 5.50 E-10 & U \\ 1.31 E \cdot 09 \pm 9.80 E \cdot 10 & U \\ 2.90 E \cdot 07 \pm 2.80 E-07 & U\end{array}$

Time: $12: 47$ Water temperature: $24.8^{\circ} \mathrm{C}$

Total alkalinity (as CaCO3): $1 \mathrm{mg} /$
Phenolphthalein alkalinity: $0 \mathrm{mg}$

Water temperature: $21.1^{\circ} \mathrm{C}$

Total alkalinity (as CaCO3): $1 \mathrm{mg} /$
Phenolphthalein alkalinity: $0 \mathrm{mg} /$

\begin{tabular}{|c|c|c|}
\hline $\begin{array}{l}8.50 E-10 \\
1.62 E .09 \\
55.80 E .07\end{array}$ & $\begin{array}{c}\mu \mathrm{C} / \mathrm{mL} \\
\mu \mathrm{CL} / \mathrm{mL} \\
\mathrm{u} C / / \mathrm{mL}\end{array}$ & $\begin{array}{l}\text { TN } \\
\text { TN }\end{array}$ \\
\hline
\end{tabular}

MS SQL Unit Lab Mothod

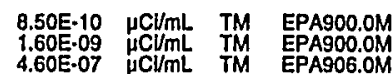

Time: $9: 34$

Total alkalinity (as CaCO3): $0 \mathrm{mg} /$
Phenolphithalein alkalinity: $0 \mathrm{mg} L$

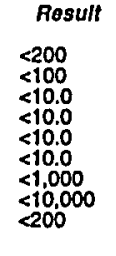

Well QA 38B collected on 06/03/99 (cont)

$F$ Analyte

Result

o Chloride

Cobper, total recocoverable

Cyanide

Lead, total recoverable

Magnesium, tolal recoverable

Mercury, total recoverable

Nitrate-nitirite as niltrogen

$\mathrm{pH}$

Potassium, total recoverable

Selentum, lotal recoverabita

Silver, tolal recoverabla

Sodium, tolal recovera

Sulfar

Thallium, total recoverable

Tolal organic carbon
Total organlc halogens

Z Zanadium, lotal recoverable

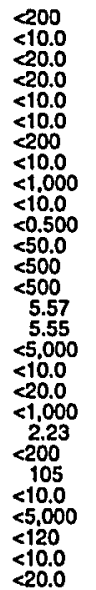

WELL QA $44 B$

MEASUAEMENTS CONDUCTED IN THE FIELD

Sample date: 05/25/99

Depth to water: 142.2 . fit $(43.34 \mathrm{~m})$ below TOC

$\mathrm{pH}: 5$.

Sp.conductance: $3 \mu \mathrm{S} / \mathrm{cm}$

ANALYSES

\section{$F$ Analyto}

- Alkalinity (as $\mathrm{CaCO}$ )

- Aluminum, total recoverab

Antimony, tolal recoverable

Barium, tolai recoverable

Boron tolal recoverable

CCromium, total recoverable

Copper, lotal recoverable

Iron, tolal recoverable

- Mercury, tolal recoverablecoverable

Nickel, total recoverable

Shelenlum, total recoverable

Silver, total recoverable

Tin, lotal recoverable

Tolal dissolved solids

Total organic carbon

Zolal organlc halogens

Carbon-14

Gross alpha

Ravium, lotal alapha-emitting
Radium, lotal alpha-emitling

Radium, lotal
Strontlum 90

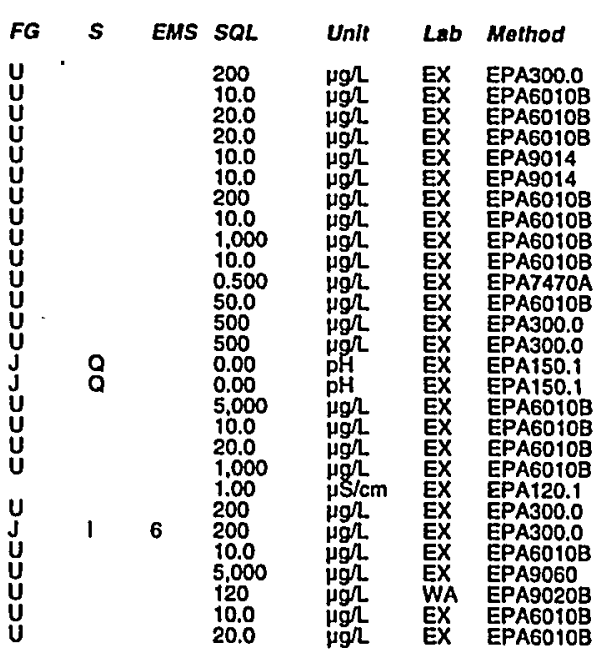

Time: 9:09

Total alkalinity (as CaCO3): $1 \mathrm{mg} /$
Phenolphthalein alkalinity: $0 \mathrm{mg} \Omega$

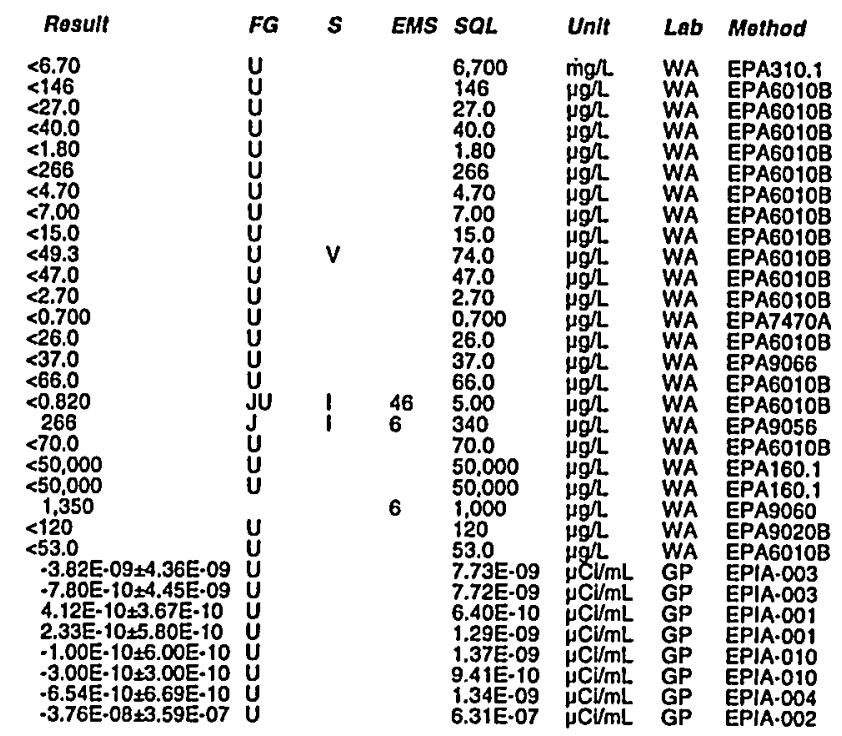

Second Quarter 1999 


\section{WELL QA 46B}

MEASUREMENTS CONDUCTED IN THE FIELD

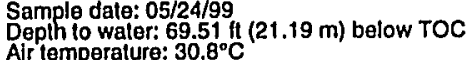

Air temperature: $30.8^{\circ} \mathrm{C}$

SS. conductance: 1 HS/cm
Turbidity: 0 NTU

ANALYSES

F Analyto

: Alkallitity (as $\mathrm{CaCO}_{3}$ )

Aluminum, oolat recoverable

Arsenlc, total recoverablo

Barium, lotal recoverable

Boron, lolal recoverable
Bromodichloromethane

Bromolorm

Cadmlum, total rocoverable

Carbon teltrachlorid
Chilorobenzene

Chloroethane

Chloroesthene (Vinyl chloride)

Chioroform

Chromium, total recoverable

Copper, total recoverablo

1.1.-Dichloroethane

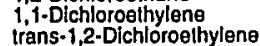

Dichloromethane

cis-1, - Dichloropopopene
itans-1, 3 -Dlchloropropena

Elhylbenzene
Iron, tolat recoverable

Lead, Iotal recoverabla
Lithium, total rocoverabte

Mercury, toal recoverablo

Selenium, total recoverabte

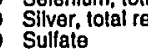

$1,1,2,2$-Tetrachloroethan

Tina, tolal recoverabale

Toland
Tolatissolved sollds
Total dissolved solids

Tolal organic carbon

1,1,1-Trichloroelhane

Trichloroesthylene

Xylenes
Znc, tolal recoverable

Carbon-14

Gross alpha
0 Nonvolatile bela
0

Radium, Iotal alpha.ernitting

Strontium-90

Tritium
0

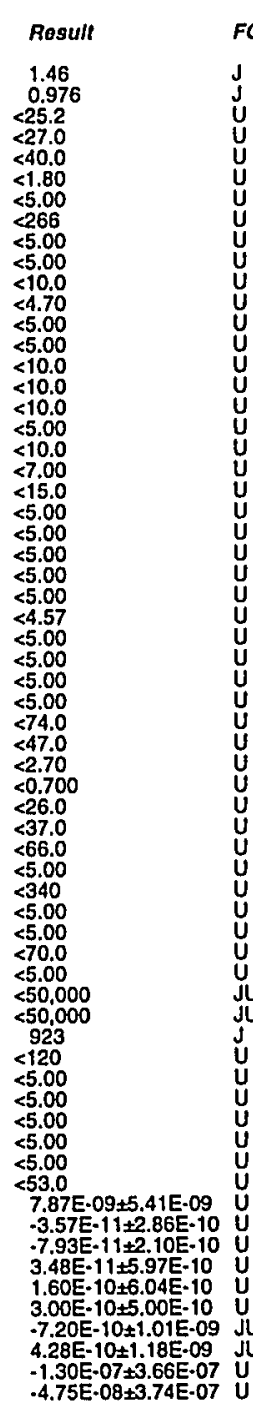

ESH-EMS-990521

\section{WELL QA 48B}

MEASUREMENTS CONDUCTED IN THE FIELD

Time: 13:51

Total alkalinity (as CaCO3): $1 \mathrm{mg} / \mathrm{L}$
Phenolphithalein alkalinity: $0 \mathrm{mgl}$

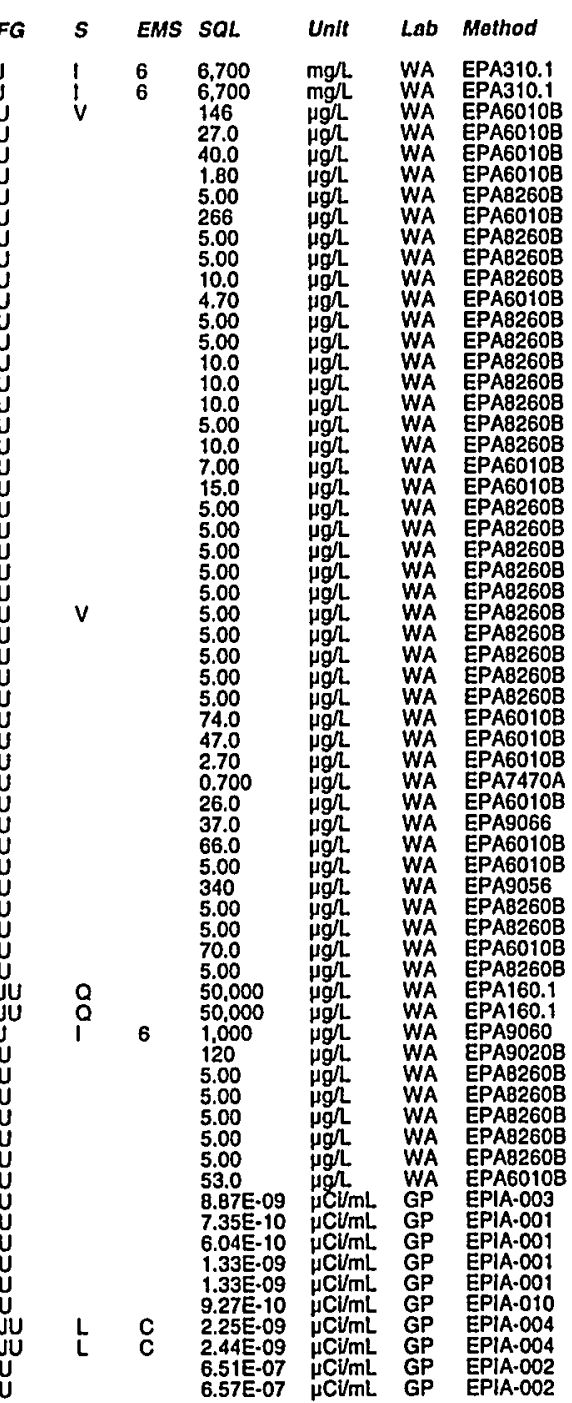

Sample date: 06/03/99
Depph 1o water: $33.31 \mathrm{ht}(9.24 \mathrm{~m})$ below TOC
Air temperalure: $28^{\circ} \mathrm{C} \mathrm{C}$

Air temperature: $28.7^{\circ} \mathrm{C}$
gH: 6
Sp. conduclance: $1 \mu \mathrm{S} / \mathrm{cm}$

ANALYSES

Analyto

- Aluminum, total recoverable

Barium, total recoverable

Chromium, tolal recoverable

Iron, total recoverable

Mercury, lotal recoverable Silver, total recoverable

\section{WELL QA 508}

MEASUREMENTS CONDUCTED IN THE FIELD

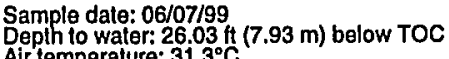

Rosult

$\begin{array}{ll}<200 & \\ <10.0 & U \\ <10.0 & \\ <10.0 & U \\ <10.0 & \\ 19.0 & U \\ <10.0 & J \\ <0.500 & U \\ <10.0 & U \\ <20.0 & U \\ 3.30 E-10 \pm 2.30 E-10 & J \\ -1.30 E \cdot 07 \pm 3.10 E-07 & U\end{array}$

FG

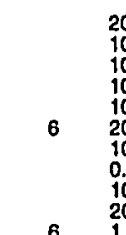

Time: 9:49

Total alkalinity (as CaCO3): $1 \mathrm{mg} / \mathrm{L}$
Phenolphthalein alkalinity: $0 \mathrm{mg} / \mathrm{L}$

$\mathrm{H}: 5.2$

Tp. conductance: $4 \mu \mathrm{S} / \mathrm{cm}$

ANALYSES

$F$ Anglyte

Resurt

- Aluminum, total recoverable

Arsentc, total recoverable

Cadmium, total recoverable

tron, total recoverable

Mercury, lotal recoverable

Selenium, otal recoverable

Thallium, total recoverable

Gross alph

\section{WELL QA 52B}

MEASUREMENTS CONDUCTED IN THE FIELD

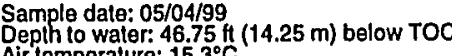

Air temperature: $15.3^{\circ} \mathrm{C}$
pH: 3.6 .
Sp. conductance: $7 \mu \mathrm{S} / \mathrm{cm}$
Turbidity: $0 \mathrm{NTU}$

ANALYSES

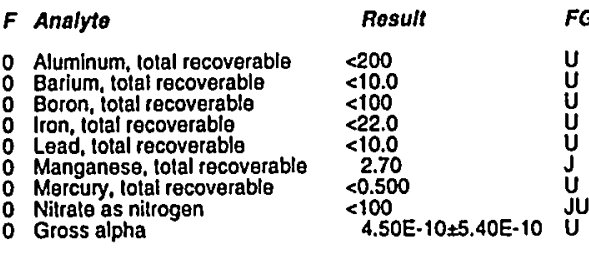

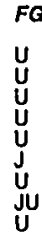

C-6
Time: $10: 55$.

Total alkalinity (as CaCO3): $1 \mathrm{mg} / \mathrm{L}$
Phenolphthalein alkalinity: $0 \mathrm{mgh}$
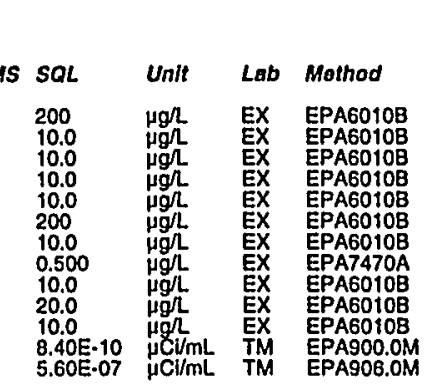

Time: 9:38

Total alkalinity (as $\mathrm{CaCO}$ ): $0 \mathrm{mg} \Omega$
Phenolphthalein alkalinity: $0 \mathrm{mg} L$

200
10.0
100
200
10
10
0.000
100
8.80

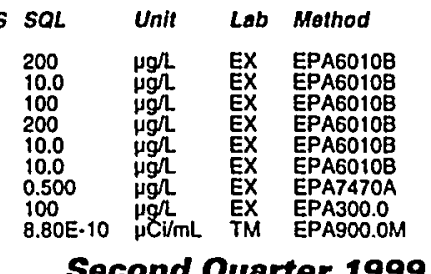


Well OA 528 collected on 05/04/99 (cont)

FG S EMS SQL Unit Lab Mathod

0 Nonvolatile beta

10

WELL QA 54B

MEASUREMENTS CONDUCTED IN THE FIELD

Sample dale: $05 / 17 / 99$
Oepth to water: $64.49 \mathrm{ft}(19.66 \mathrm{~m})$ below TOC
Air temperature: $21.1^{\circ} \mathrm{C}$

Air temp

p. conductance: $1 \mu \mathrm{S} / \mathrm{cm}$

Tuibidity: O

ANALYSES

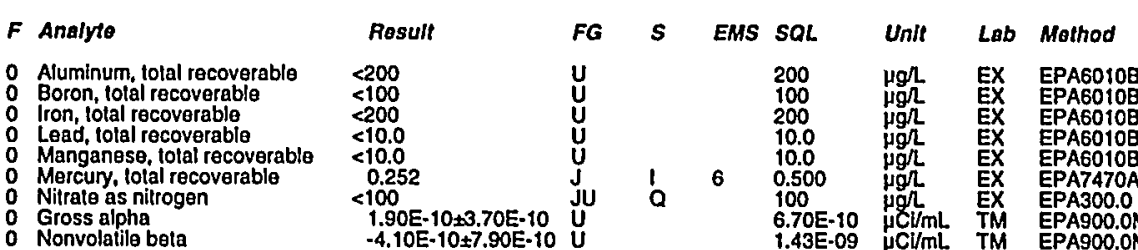

\section{WELL QA 56B}

MEASUREMENTS CONDUCTED IN THE FIELD

Sample date: 05/05/99
Depth to waler: $59.58 \mathrm{ft}(18.16 \mathrm{~m})$ below TOC
Air temperature: $17.6^{\circ} \mathrm{C}$

pir temp 4.9

p. conductance: $7 \mu \mathrm{S} / \mathrm{cm}$

ANALYSES

F Analyto

- Aluminum, total recoverable

Iron, tolal recoverable

Manganese, lotal recoverable

0
0 Nonvo alpha
0

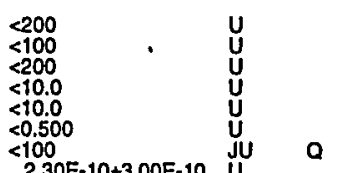

WELL QA 58B

MEASUREMENTS CONDUCTED IN THE FIELD

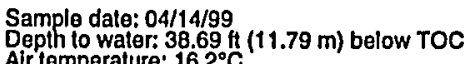

$\mathrm{gH}: 4.4$ conductance: $1 \mu \mathrm{S} / \mathrm{cm}$

ANALYSES

F Anolyte

\& Acenaphthene

Acenaphthylen

- Aluminum, total recoverable

- Anthracene

- Arsenic, total recoverable

B Barium, total recoverable

beta-Benzene hexachloride

ESH-EMS-990521
151E-09 $\mathrm{C}$ CIML TM EPA900.0M

Water temperature: $21.1^{\circ} \mathrm{C}$

Total alkalinity (as CaCO3): $1 \mathrm{mg} / \mathrm{L}$
Phenolphthalein alkalinity: $0 \mathrm{mg} h$

Wait 9:42

Total alkalinity (as CaCO3): $1 \mathrm{mgh}$.
Phenolphthalein alkalinity: $0 \mathrm{mg}{ }^{2}$

Well QA. 588 collected on 04/14/99 (cont.)

$F$ Analyto

0 della-Benzene hexachloride

$<\begin{gathered}<0.0202 \\ <49.5\end{gathered}$

Benzo(a)anthracene

Benzo(i) lluoranthen
Benzocic acid

: Benzo(g,h,l)perylen

o Benzyl alcohol

Beryllium, total recoverable Bis(2-cchloroethyl) ether

Bis( 2-chloroisopropyl) ether 4-Bromophenyy phenyl ether Cadmium, lotal recoverable alpha-Chlordane q.Chma-Chlordan 4-Chloro-m-crosol 2.Chlorophenol Chromlum, total recoverable Cobsall, total recoverable

m/p.Cressl 0 .Cresol (2-Methylphenol) P.p'DpD

P.,

pibenz(a,h)anthracene

Dil-n-butyl phithalate

1,2-Dichlorabenzen

1.4.Dichlorobenzene

2,4 -Dichlorophenol
Diton

Dieltyl phithalalo

Dimethyl phithalate

2,4. - initirololuene

Di.n-octyl phthalate

Endosullan sula

Endosullan it

Endrin aldehydo

Endrin ketone

Time: 8:57

Total alkalinity (as CaCO3): $1 \mathrm{mg} /$
Phenolphthaleln alkalinity: $0 \mathrm{mg} /$

Heptachlor

Heplachlor epoxide

Hexachlorocyclopentadion

Hexachloroethane
Indeno $(1,2,3-c, d)$ pyren

Iron, tolal recoveliben

Lead, tolal recoverable

Magnesium, total recoverablo

Manganese. total recoverablo

Mercury, Lotal recoverable

2-Methyl-4,6-dinitropheno

2.Methylnaphthalene

Nickel, total recoverable

C-7
5 EMS SQL Unit Lab Mothod

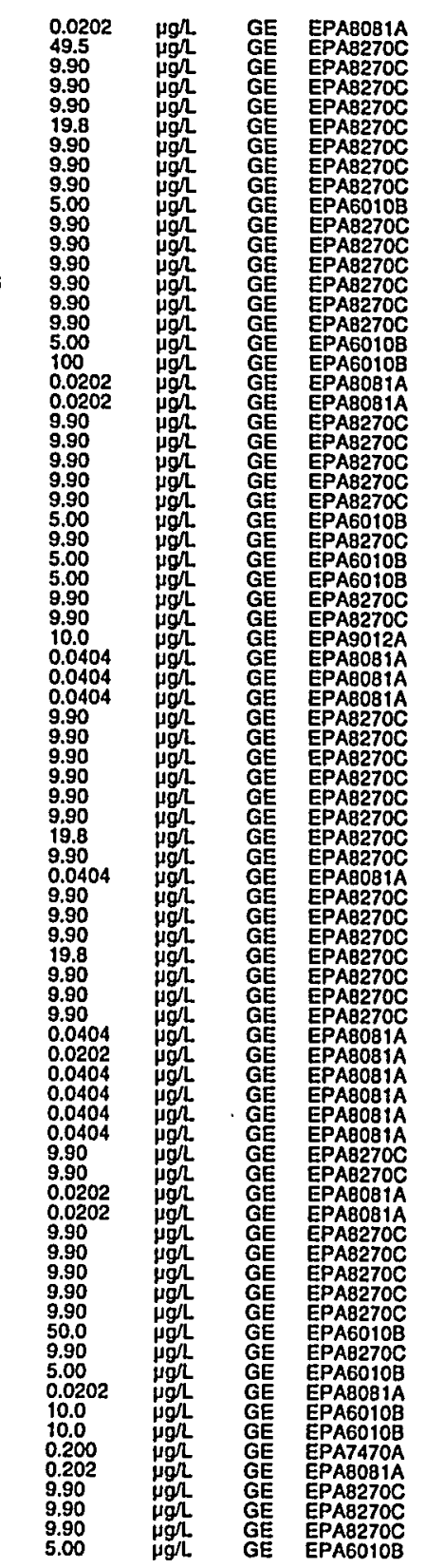

Second Quarter 1999 
Well QA $58 B$ collected on 04/14/99 (cont.)

$F$ Analyte

Result

FG

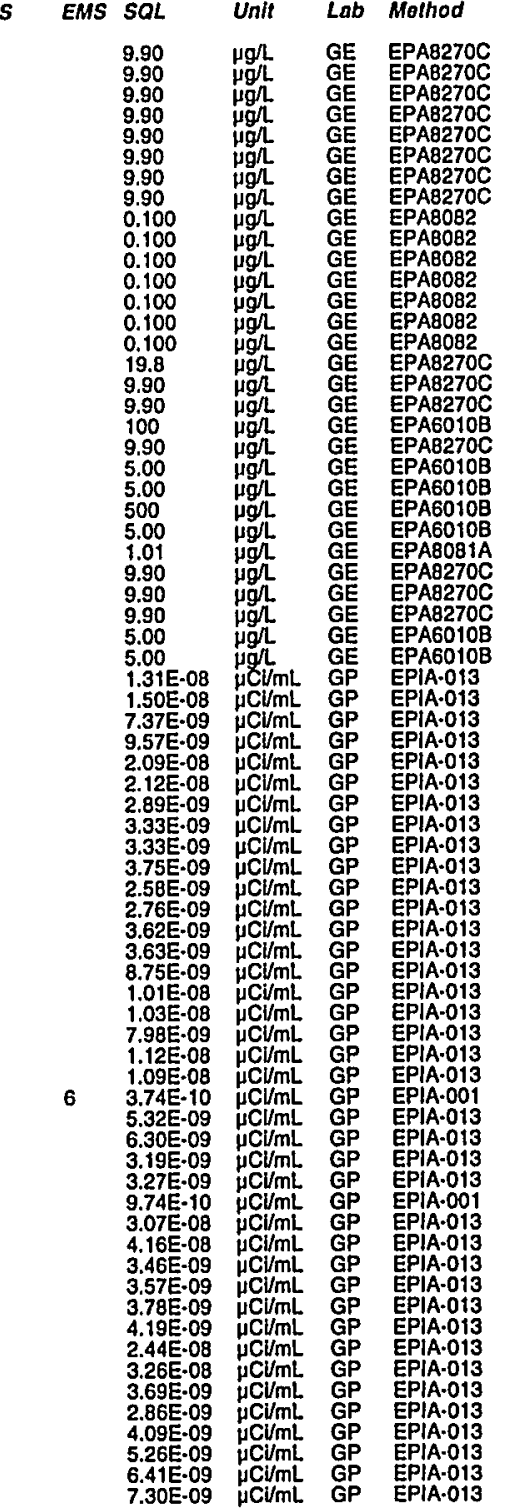

m.Nitroaniline

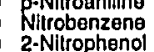

4.Niltrophenol

N-Nitrosodiphenylamin

PCB 1016
PCB 1221

PCB 1242

PCB 1254

Pentachlorophen

Potassium, total recoverable

Selenlum, total recoverable

Thallium, total recoverablecoverable

Toxaphene

2,4,5. Trichioropheno

2,4,6-Trichlorophenol
Vanadium, total recoverablo

Actinium-228

Antimony-125

Cerium: 144

Cesium-134

Cosium-134

Cesium: 137

Eubaplium-152

Europium:-152

Europlum.154

Lead-212

Manganese-54

Manganese-54
Nonvolatile beta

Polassium-40
Potasslum-40

Promelhium-144

Promethium-146

Ruthenium-106
Rulhenium-106

Sodium-22

0
0
0

Zinc-65

\begin{tabular}{|c|c|}
\hline & 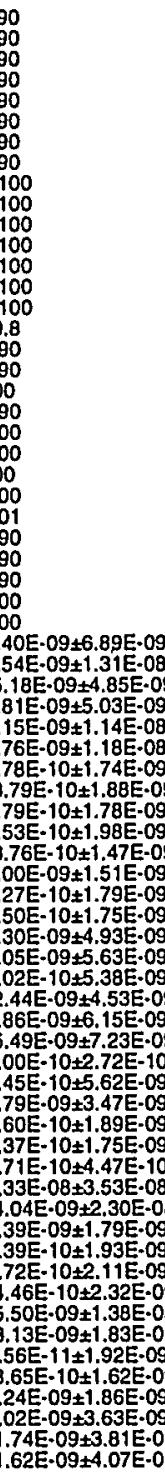 \\
\hline
\end{tabular}

ESH-EMS-990521

\section{WELL QA 62B}

MEASUREMENTS CONDUCTED IN THE FIELD

Sample data: 04/13/99

Hp. 5.4 conductance: $1 \mu \mathrm{S} / \mathrm{cm}$

ANALYSES

$F$ Analyto

: Octachlorodibenzo-p-dioxin

: Acenaphithylene

2. Acetylaminoofluorene
0 Aluminum total recoverable

Aniline

Anthrecene

Arsuite

Benzo (b) Iluoranthene

Benzo(g, hi, perylene

Benzog,apyreng

Benzyl alcohol
Bis(2-chloroolhoxy) mathan

Bis 2-chloroisopropyl) ether

Bis(2-ethylhexyl) phithalate 4. Bromophenyl pheny
Butylbenzyl phthalate

4-Chloroaniline

Chlorobenzillate

4-Chlorophenyl phenyl ether Chrysene

Diallale

Oibenzoluran

$\begin{array}{ll}0 & 1,2 \cdot \text { Dichlorobenzene } \\ 0 & 1,3 \cdot \text { Dichlorobenzene } \\ 0 & 1,4 \cdot \text { Dichlorobenzeng } \\ 0 & 3,3^{\prime} \text {-Dichlorobenzldine }\end{array}$

3,3'-Dichlorobenzlid
Dithyl phihalaile

p.Dimeihylaminoazobonzene

a,a-Dimethyphene
$1,3$. Dinitrobenzena
2.4. Dinitrotoluene

2.4-Dinitrotoluene
2.6-Dinitrotoluene

Di-n.octyl phthala

Diphenylamin

Elthyl methanesulionate

Fluoranthen

Fluorene
Hexachlorobenzena

Hexachlorobutadiene
Hexachlorocyclopentadiene

Hexachlorocyclope
Hexachloroethane

Hexachlorophene

Indeno(1,2,3-c,d)pyrene

Isophorone

Manganese, total recoverable
Methapyrilene

Result

$<3.20$
$<10.2$
$<10.2$

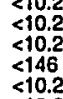

$<10.2$
$<10.2$
$<2.4$
$<40.0$

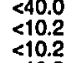

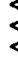

$<10.2$
$<10.2$
$<10.2$
$<10.2$
Time: 9:08

Total alkalinity (as CaCO3): $1 \mathrm{mg} / \mathrm{L}$
Phenolphthalein alkalinity: $0 \mathrm{mg} /$
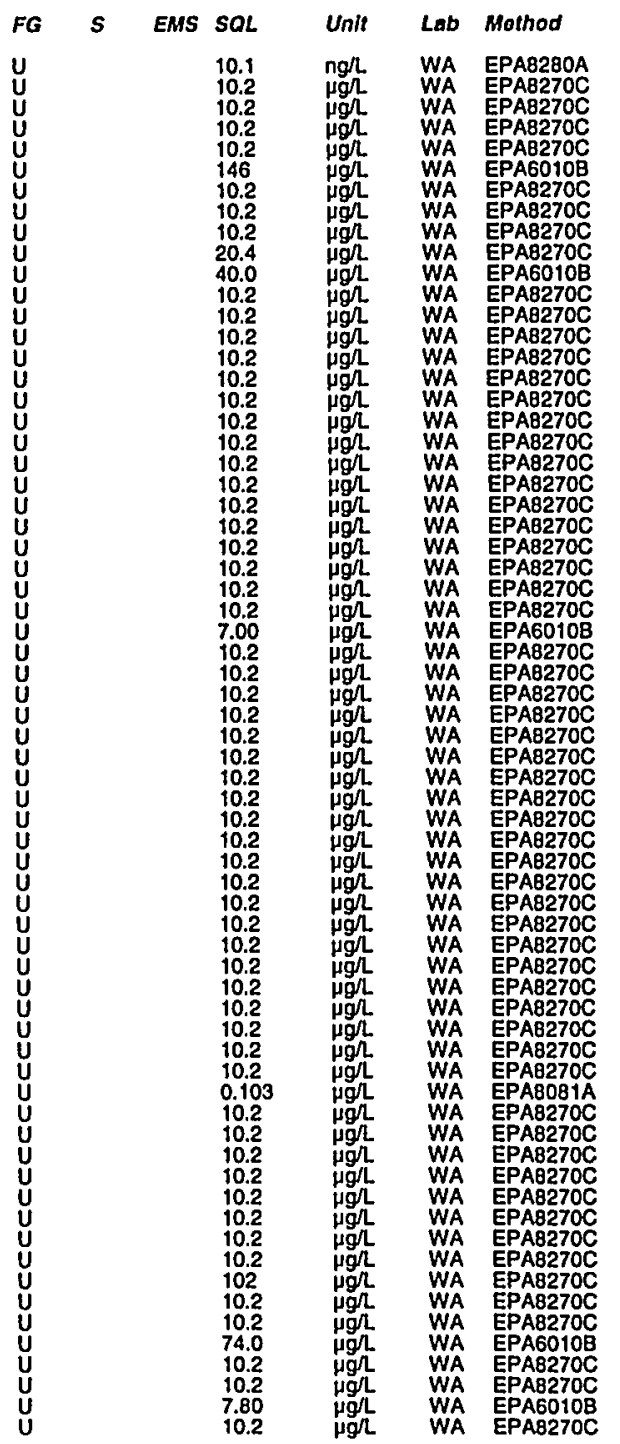

Second Quartor 1999 
Well QA 62B collected on 04/13/99 (cont.)

\begin{tabular}{|c|c|}
\hline$=$ Analyto & Result \\
\hline 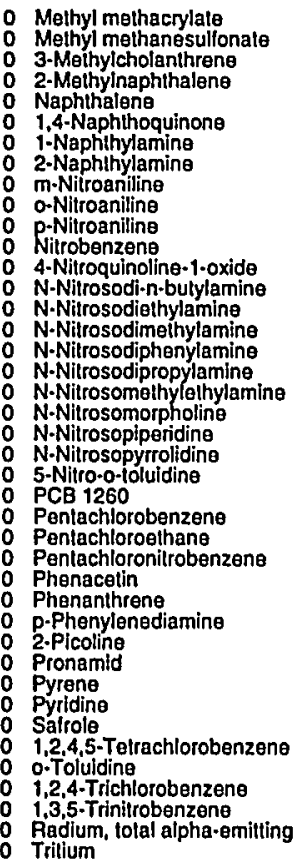 & $\begin{array}{l}<10.2 \\
<10.2 \\
<10.2 \\
<10.2 \\
<10.2 \\
<10.2 \\
<10.2 \\
<10.2 \\
<25.5 \\
<25.5 \\
<25.5 \\
<10.2 \\
<20.4 \\
<10.2 \\
<10.2 \\
<10.2 \\
<10.2 \\
<10.2 \\
<10.2 \\
<10.2 \\
<51.0 \\
<10.2 \\
<10.2 \\
<1.03 \\
<10.2 \\
<10.2 \\
<51.0 \\
<10.2 \\
<10.2 \\
<10.2 \\
<10.2 \\
<10.2 \\
<10.2 \\
<10.2 \\
<10.2 \\
<10.2 \\
<10.2 \\
<10.2 \\
<10.2 \\
3.60 E-10 \pm 5.50 E-10 \\
1.20 E-07 \pm 3.30 E \cdot 07\end{array}$ \\
\hline
\end{tabular}

WELL QA 64B

MEASUREMENTS CONDUCTED IN THE FIELD

Sample date: $05 / 14 / 99$ th $(4.4 \mathrm{~m})$ below TOC Air temperature: $22.1^{\circ} \mathrm{C}$

SH: 3.8 .

Waler evacuated from the well prior to sampling: $1 \mathrm{gal}$

ANALYSES

$F$ Analyto

Rosult

$-2.83 E-09 \pm 4.76 E-09 U$

W Carbon-14

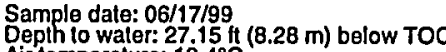

Depth to waler: $27.15 \mathrm{ft}$

Sp. conductance: $40 \mu \mathrm{S} / \mathrm{cm}$
Turbidity: $1 \mathrm{NTU}$

ANALYSES

$F$ Anaiste

Result

$F G$

1.07E-09ะ4.17E-09 U

o Carbon-14
MEASUREMENTS CONDUCTED IN THE FIELD

.

EMS SQL

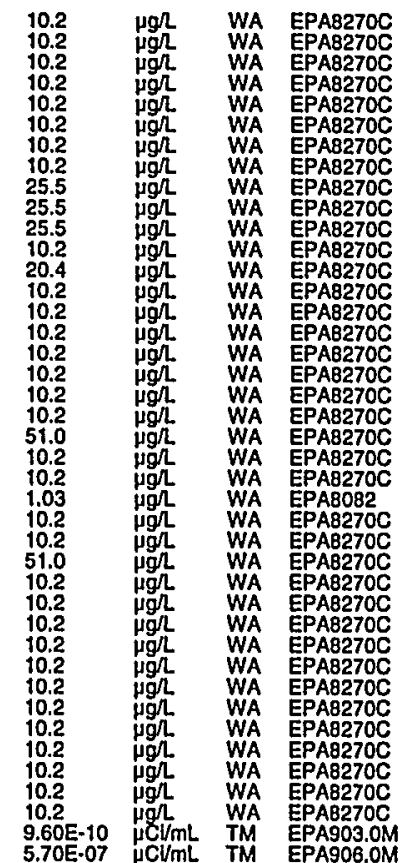

Time: $11: 14$

Total alkalinity (as CaCO3): $0 \mathrm{mg} /$
Phenolphthalein alkalinity: $0 \mathrm{mgh}$

EMS SQL Unit Lab Method 8.39E.09 $\mu \mathrm{Cl} / \mathrm{mL}$ GP EPIA.003

Time: 9:50

Total alkalinity (as CaCO3): $0 \mathrm{mg} / \mathrm{L}$
Phenolphihalein alkalinity: $0 \mathrm{mg} / \mathrm{L}$

ESH-EMS-990521

\section{WELL QA 68B}

MEASUREMENTS CONDUCTED IN THE FIELD

Sample date: 05/12/99

Air temperat

Hp. conductance: $1 \mu \mathrm{S} / \mathrm{cm}$

ANALYSES

$F$ Analyte

o Aluminum, lotal recoverable

Bis(2-ethylhexyl) phthalate

- Chromium, hexavalent

Chromlum, total recoverabl

pH

O Gross alpha

Radium-226
0 Radium-228

Uranium-233/234

- Uranium-235

\section{WELL QA 100A}

MEASUREMENTS CONDUCTED IN THE FIELD

Sample date: 04/09/99

Airth to waler: Not available

gH: 4.8 .

ANALYSES

$F$ Analyto
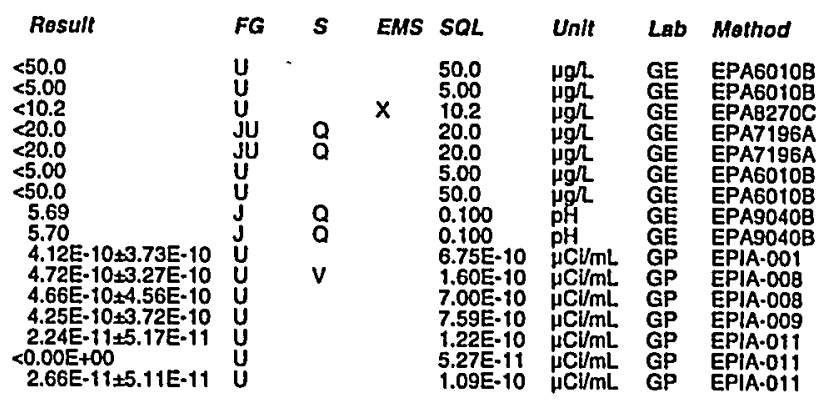

Time: $13: 35$
Water temperature: $23.2^{\circ} \mathrm{C}$

Total alkalinity (as CaCO3): $1 \mathrm{mg} /$
Phenolphthalein alkalinity: $0 \mathrm{mg} L$

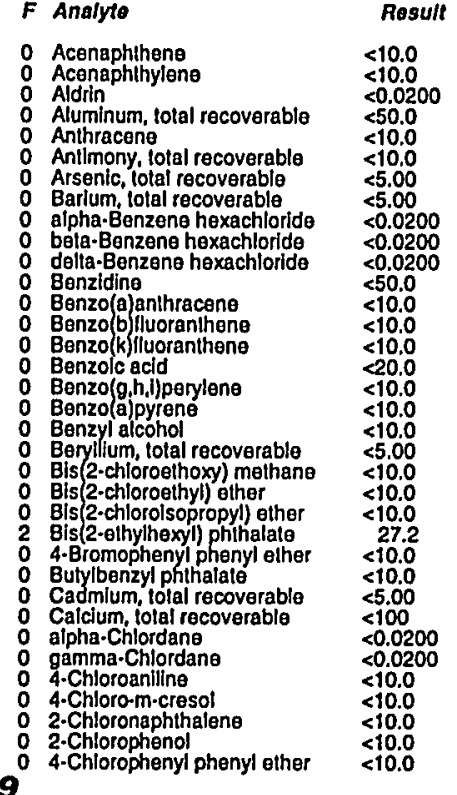

Time: 9:20

Total alkalinity (as CaCO3) $1 \mathrm{mg} /$ L
Phenolphthalein alkalinity: $0 \mathrm{mg} L$

\begin{tabular}{|c|c|c|c|c|c|c|c|}
\hline Result & $F G$ & $s$ & EMS & $S Q L$ & UnIt & Lab & Mothod \\
\hline $\begin{array}{l}<10.0 \\
<10.0 \\
<0.0200 \\
<50.0 \\
<10.0 \\
<10.0 \\
<5.00 \\
<5.00 \\
<0.0200 \\
<0.0200 \\
<0.0200 \\
<50.0 \\
<10.0 \\
<10.0 \\
<10.0 \\
<20.0 \\
<1.0 \\
<10.0 \\
<10.0 \\
<5.00 \\
<10.0 \\
<10.0 \\
<10.0 \\
27.2 \\
<10.0 \\
<1.0 \\
<5.00 \\
<100 \\
<0.0200 \\
<0.0200 \\
<10.0 \\
<10.0 \\
<1.0 \\
<10.0 \\
<10.0\end{array}$ & 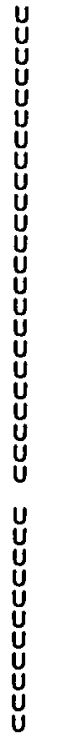 & & 6 & $\begin{array}{l}10.0 \\
10.0 \\
0.0200 \\
50.0 \\
10.0 \\
10.0 \\
5.00 \\
5.00 \\
0.0200 \\
0.0200 \\
0.0200 \\
50.0 \\
10.0 \\
10.0 \\
10.0 \\
20.0 \\
10.0 \\
10.0 \\
10.0 \\
5.00 \\
10.0 \\
10.0 \\
10.0 \\
10.0 \\
10.0 \\
10.0 \\
5.00 \\
100 \\
0.0200 \\
0.0200 \\
10.0 \\
10.0 \\
10.0 \\
10.0 \\
10.0\end{array}$ & 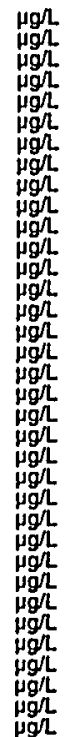 & $\begin{array}{l}\text { GE } \\
G E \\
G E \\
G E \\
G E \\
G E \\
G E \\
G E \\
G E \\
G E \\
G E \\
G E \\
G E \\
G E \\
G E \\
G E \\
G E \\
G E \\
G E \\
G E \\
G E \\
G E \\
G E \\
G E \\
G E \\
G E \\
G E \\
G E \\
G E \\
G E \\
G E \\
G E \\
G E \\
G E \\
G E \\
G E \\
G E \\
G E\end{array}$ & 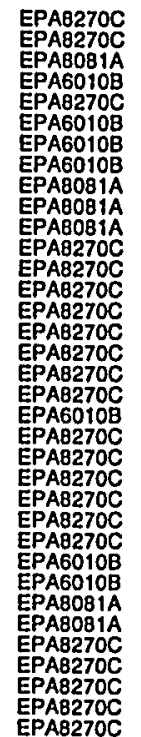 \\
\hline
\end{tabular}


Well QA 100A collected on 04/09/99 (cont.)

$F$ Analyto

o Chromium, total recoverable

Result
$<5.00$
$<10.0$

$\begin{array}{ll}0 & \text { Chrysena } \\ 0 & \text { Coball, total recoverable } \\ 0 & \text { Copper, total recoverable }\end{array}$

m/p.Cresol

o Cyanide

o

Bibenz(a,h)anthracene

Dibenzofuran

$\begin{array}{ll}1,2-D i c h l o r o b e n z e n e \\ 0 & 1,3 \text {.Dichlorobenzene } \\ 0 & 1.4 \text {. Dichlorobenzene }\end{array}$

$1,4 \cdot$ Dichlorobenzene
$3,3 \cdot$ Dichlorobenzldine

Diethyl phthalate

2.4-Dimbihyl pheno

2.4-Onintrophenol

2,6-Dinitrotoluene

Endosuffan sullate

Endosulian

Endrin aldehyde

Endrin kelon

Fluoranthe

Heplachlor
Heplachlor epoxid

Heplachlor epoxide

Hexachlorobutadiene

0 indeno(1,2,3-c,d)pyrene

Isophorone
Lead, total recoverable

Lead, total recoverable
Lindane
Magnesium, tolal recoverab

Manganese, total recoverab

Methoxychlor

2.Methylnaphithalene

Nickel, total recoverable

m-Nitroaniline
o-Nitroaniline

P.Nitroaniline

2-Nitropheno

N-Nitrosodiphenylamine

0 PCB 1016
0 PCB 1221

0 PCB 1242

0 PCB 1254

Phenanthrene

Potassium, total recoverable

Pyrene

Silver, tolal recoverable

ESH-EMS-990521

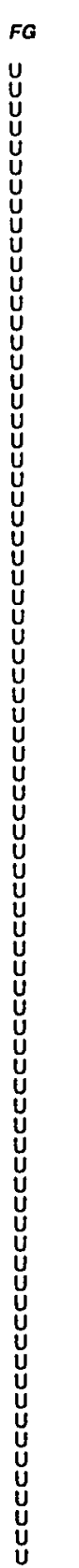

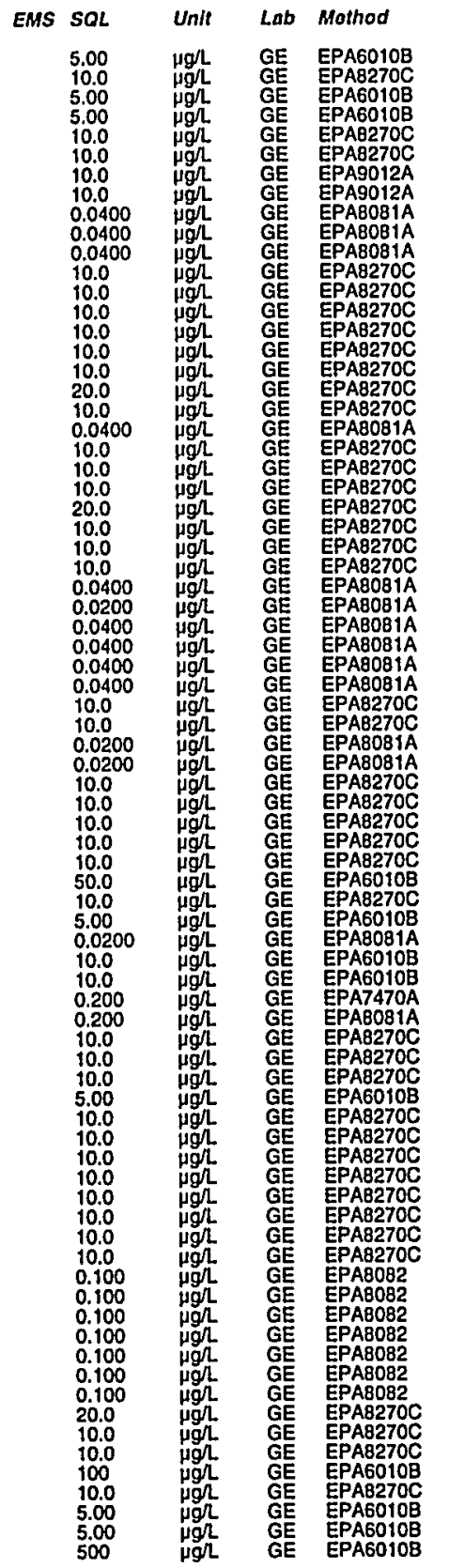

Well QA 100A collected on 04/09/99 (cont.)

$F$ Analyto

Rosult

FG

0 Thallum, total recoverable

Toxaphene

2.4,6-Trichlorophenol

Vanadlum, tolal recoverable

o Actinium-228

Antimony-125

Corium-144

Coball-57

$\begin{array}{ll}0 & \text { Europlum-152 } \\ 0 & \text { Europtum-154 } \\ 0 & \text { Europium-155 }\end{array}$

Gross alpha

$\begin{array}{ll}0 & \text { lodinse-129 } \\ 0 & \text { loding-129 }\end{array}$

0 Lead-212

Nonvolatile beta

Ponvolatlle beta

Promethium-144

O Ruthenlum-10

o Strontlum-90

Technelium-99

$\begin{array}{ll}0 & \text { Trillum } \\ 0 & \text { Yitrlum-88 } \\ 0 & \text { Zinc-65 }\end{array}$

$<5.00$
5.04
$<1.00$

$<10.0$
$<<.0$
$<10.0$

$<5.00$
$<1.99$

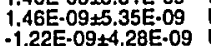
$-5.86 E-10 \pm 1.09 E-08$
$-4.61 E-10 \pm 1.85-09$ $-1.47 E-09 \pm 2.14 E-09$
$-7.32 E-10 \pm 1.41 E-09$ $-2.34 \mathrm{E}-09 \pm 6.17 \mathrm{E}-09$ 2.49E- $10+6.71 \mathrm{E}-09$ - $1.22 \mathrm{E} \cdot .09 \pm 5.39 \mathrm{E}-09 \mathrm{U}$ $7.98 E-11 \pm 3.52 E-10$
$3.51 E-10+7.82 E-10$
$2.62 E-10+5.70 E-10$ 3.24E-09+5.59E-09 $2.94 E-10 \pm 4.58 E-10$
$-5.95 \mathrm{E}-10+5.06 \mathrm{E}-10$ $8.28 \mathrm{E}-09 \pm 3.79 \mathrm{E}-108$ $-1.06 \mathrm{E}-09 \pm 2.59 \mathrm{E}-09 \mathrm{Y}$ $-6.94 E-09 \pm 1.86 E-08$
$1.04-10+2.41 E-09$ $-1.02 E-10 \pm 7.40 E-10$ $-1.57 E-09 \pm 6.37 E-09$ $1.86 E-09+2.63 \mathrm{E}-09$
$-0.18 \mathrm{E}-10 \pm 5.13 \mathrm{E}-09$

\section{WELL TRP100B}

MEASUREMENTS CONDUCTED IN THE FIELD

Sample date: 04/22/99

Air temperature: Not available

$\mathrm{PH}$ : Nol available . conductance: Nol available

Tuibidity: Nol available

ANALYSES

$F$ Analyto

$\begin{array}{ll}0 & \text { Benzene } \\ 0 & \text { Bromodichloromethane } \\ 0 & \text { Bromoform }\end{array}$

Bromomethane

Carbon tetrach

Chloroethane

Chloroethene (Vinyl chloride)

Chlorotorm

Chloromathane
Dibromochloromethan

1.1.Dichloroothan

i, 1 -Dichloroeshylene
irans-1,2-Dichloroethylen

Dichioromethane

cis-1,3-Dichloropropene
trans-1,3-Dichloropropene

Elhylbenzene

Telrachloroethylene

C-10

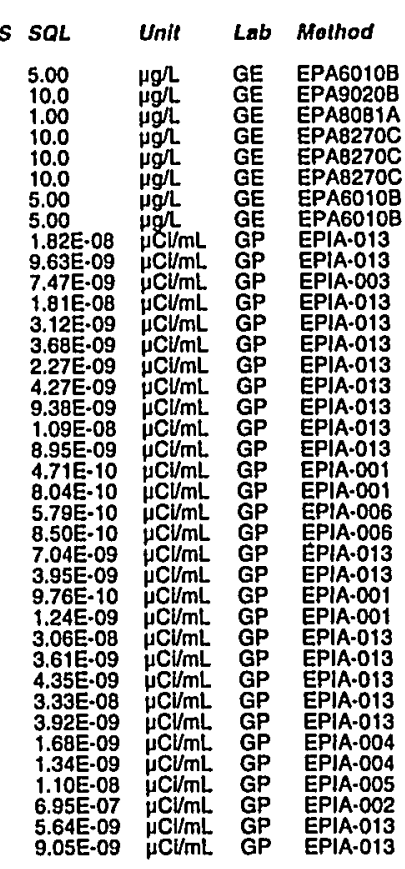

Time: Waler temperature: Not available

Total alkalinity (as CaCO3): Not available

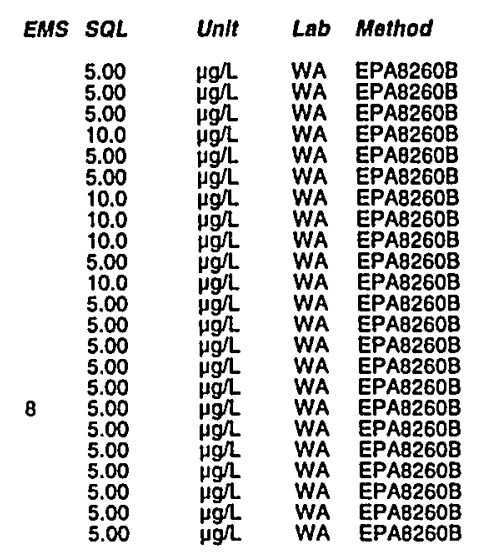

Socond Quartor 1999 
Well TAP100B collected on 04/22/99 (cont.)

$F$ Analyte

Rosult

$\begin{array}{ll}0 & \text { Toluene } \\ 0 & 1,1.1-T \text { Trichloroethane } \\ 0 & 1.1,2-\text { Trichloroethane }\end{array}$

: Trichlorosthylene

$<5.00$
55.00
5.00
55.00
5.00
$\$ 5.00$

\begin{tabular}{|c|c|c|c|c|}
\hline$F \boldsymbol{F}$ & EMS SQL & Unit & Lab & Mothod \\
\hline & $\begin{array}{l}5.00 \\
5.00 \\
55.00 \\
5.00 \\
5.00 \\
5.00\end{array}$ & $\begin{array}{l}\mu g h \\
\mu g h \\
\mu g h \\
\mu g h \\
\mu g h \\
\mu g h\end{array}$ & $\begin{array}{l}\text { WA } \\
\text { WA } \\
\text { WA } \\
\text { WA } \\
\text { WA } \\
\text { WA }\end{array}$ & $\begin{array}{l}\text { EPA8260B } \\
\text { EPAA8260B } \\
\text { EPAB2608 } \\
\text { EPA82608 } \\
\text { EPA82600 } \\
\text { EPA82608 }\end{array}$ \\
\hline
\end{tabular}

\section{WELL TRP101B}

MEASUREMENTS CONDUCTED IN THE FIELD

Sample date: 04/27/99

Depth to water: Not available

Arr emperature: Not avaliable
$\mathrm{g} H$ : Nor availabie
$\mathrm{Sp}$. conductance: Not available

No water was evacuated from the well prior to sampling.

ANALYSES

$F$ Analyte

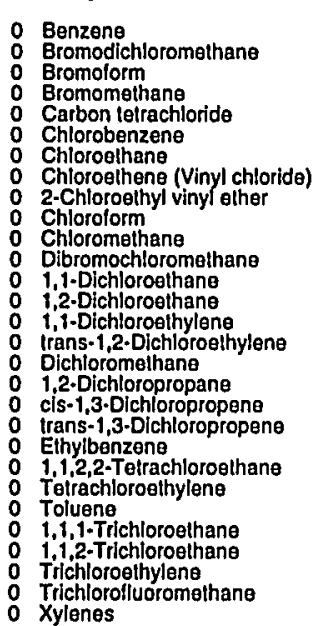

Resuht
55.00
55.00
55.00
510.0
55.00
55.00
10.0
510.0
10.0
55.00
10.0
55.00
55.00
55.00
55.00
55.00
55.00
55.00
55.00
55.00
55.00
55.00
55.00
25.00
55.00
55.00
55.00
55.00
$<5.00$

Time: .

Wher temperature: Not available

Total alkalinity (as CaCO3): Not available
Phenolphthalein alkalinity: Not available

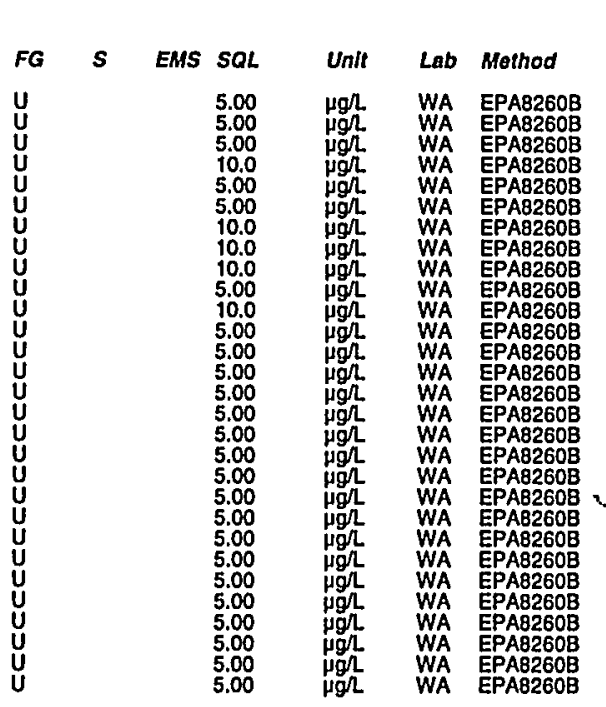

WELL TRP102B

MEASUREMENTS CONDUCTED IN THE FIELD

Sample date: 05/21/99

Deph to water: Nol available

Air temperature: No avaliable

Sp. conductance: Nol available

Turbidity: Not available
No water was evacuated from the well prior to sampling.

ANALYSES

$F$ Angivto

Result

0 Benzene

Bromolorm

Carbon telrachloride

Chlorobenzen

Chloroethene (Vinyl chloride)

ESH-EMS-990521

$<5.00$
$<5.00$
$<5.00$
$<10.0$
$<5.00$
$<5.00$
$<10.0$
$<10.0$
$<10.0$

Time: Waler temperature: Nol available

Total alkalinity (as $\mathrm{CaCO}$ ): Not availablo

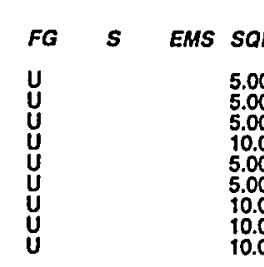

Unit Lab Method

$\begin{array}{ll}5.00 & \mu g \Omega \\ 5.00 & \mu g \Omega \\ 5.00 & \mu g \Omega \\ 10.0 & \mu g \Omega \\ 5.00 & \mu g \Omega \\ 5.00 & \mu g h \\ 10.0 & \mu g \Omega \\ 10.0 & \mu g \Omega \\ 10.0 & \mu g \Omega\end{array}$

WA EPAB260日
WA EPAB260日
WA EPAB260B
WA EPAB260B
WA EPAB260B
WA EPAB260B
WA EPAB260B
WA EPAB2608
WA EPAB260B
Well TRP 102B collected on 05/21/99 (conl.)

\begin{tabular}{|c|c|}
\hline \multicolumn{2}{|l|}{ Analyto } \\
\hline 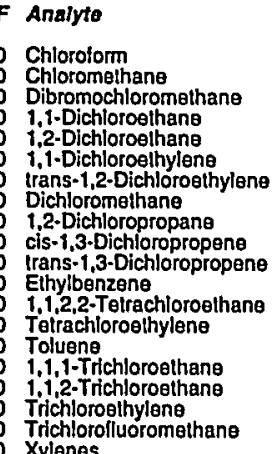 & $\begin{array}{l}<5.00 \\
<10.0 \\
<5.00 \\
<5.00 \\
<5.00 \\
<5.00 \\
<5.00 \\
<6.94 \\
<5.00 \\
<5.00 \\
<5.00 \\
<5.00 \\
<5.00 \\
<5.00 \\
<5.00 \\
<5.00 \\
<5.00 \\
<5.00 \\
<5.00\end{array}$ \\
\hline
\end{tabular}

\begin{tabular}{|c|c|c|c|c|c|}
\hline$F G$ & EMS & SOL & Unit & Lab & Mothod \\
\hline 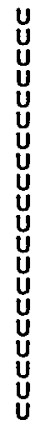 & v & $\begin{array}{l}5.00 \\
10.0 \\
5.00 \\
5.00 \\
5.00 \\
5.00 \\
5.00 \\
5.00 \\
5.00 \\
5.00 \\
5.00 \\
5.00 \\
5.00 \\
5.00 \\
5.00 \\
5.00 \\
5.00 \\
5.00\end{array}$ & $\begin{array}{l}\mu g h \\
\mu g h \\
\mu g h \\
\mu g h \\
\mu g h \\
\mu g h \\
\mu g h \\
\mu g h \\
\mu g h \\
\mu g h \\
\mu g h \\
\mu g h \\
\mu g h \\
\mu g h \\
\mu g h \\
\mu g h \\
\mu g h \\
\mu g h \\
\mu g h \\
\mu g h \\
\mu g h\end{array}$ & $\begin{array}{l}\text { WA } \\
\text { WA } \\
\text { WA } \\
\text { WA } \\
\text { WA } \\
\text { WA } \\
\text { WA } \\
\text { WA } \\
\text { WA } \\
\text { WA } \\
\text { WA } \\
\text { WA } \\
\text { WA } \\
\text { WA } \\
\text { WA } \\
\text { WA } \\
\text { WA } \\
\text { WA } \\
\text { WA } \\
\text { WA }\end{array}$ & 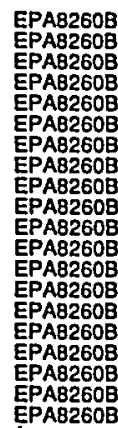 \\
\hline
\end{tabular}

WELL TRP103B

MEASUREMENTS CONDUCTED IN THE FIELD

Sample date: 05/25/99

Air temperature: Not available

$\mathrm{gH}$ : Nor available conductance: Not available

Waler temperature: Not available

No waler was evacuated from the well prior to sampling.

ANALYSES

$F$ Analyto

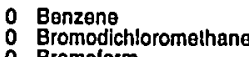

Bromoform

Bromomethane
Carbon letrachloride
Chlorobenzeng

Chlorobenzene
Chloroethane

Chloroothene (Vinyl chloride)

2.Chloroethyl vinyl ether

Chloroform

Dibromochloromethane

i, 2 -Dichloroothane

1,1-Dichloroethylene
0 trans-1,2-Dichloroethylene

Oichioromethane

1,2-Dichloropropane

Elhylbenzene
$1,1,2,2$-Terrachloroethan

Tetrachloroethylene

1,1,1-Trichloroethane

Trichloroethylene

0 xylenes

Resul
$<5.00$
$<5.00$
55.00
$<10.0$
55.00
$<5.00$
$<10$.
$<1.0$
$<10.0$
55.00
$<10.0$
55.00
$<5.00$
55.00
55.00
55.00
$<4.07$
55.00
55.00
55.00
55.00
55.00
55.00
55.00
55.00
55.00
5.00
55.00
55.00
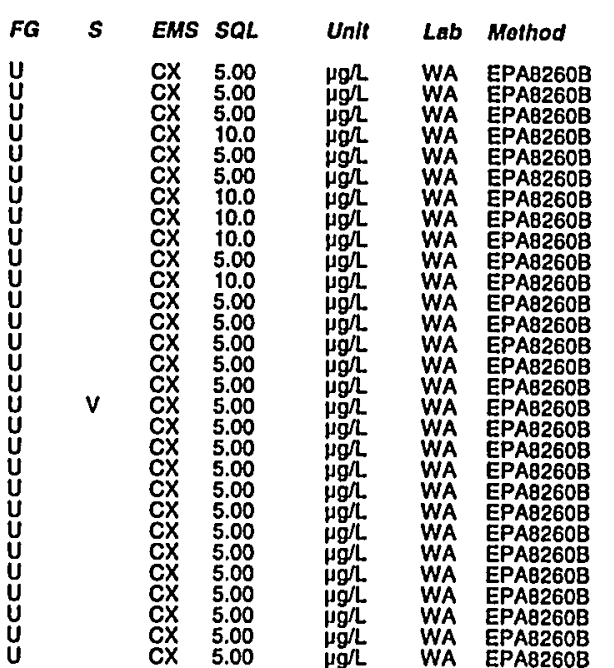

C-11 


\section{WELL TRP104B}

MEASUREMENTS CONDUCTED IN THE FIELD Sample dale: 06/07/99

Depth to water: Not available
Air temperature: Not available

Air temperalure: Not available
$\mathrm{pH}$ : No available

Sp. conduclance: Not available

Turbidity: Not available

ANALYSES

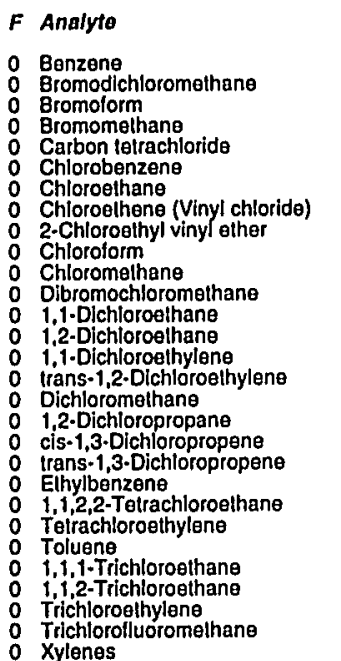

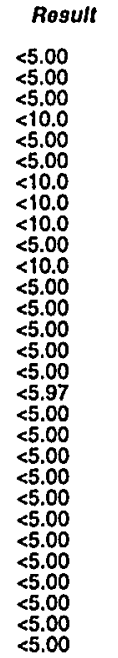

WELL TRP105B

MEASUREMENTS CONDUCTED IN THE FIELD

Sample date: 06/15/99

Ar emperature: Not available

H: Nol avallable

S. conduclance: Not availab

No water was evacuated from the well prior to sampling.

ANALYSES

$F$ Analyto

0 Benzene

Bromotorm

Bromomethane

Chloroethene (Vinyl chloride)

2-Chloroethyl vinyl

Chloromethane

1.1.-Dichloroethane

$1,1 \cdot$ Dichloroethylene
trans-1,2-Dichloroethylene

1,2-Dichloropropan

cis-1,3-Dichloropropene

ESH-EMS-990521

Result
$<5.00$
$<5.00$
$<5.00$
$<10.0$
$<5.00$
$<5.00$
$<10$.
$<10.0$
$<10$.
$<5.00$
$<10.0$
$<5.00$
$<5.00$
$<5.00$
$<5.00$
$<5.00$
$<7.25$
$<5.00$
$<5.00$
$<5.00$

Time: - Waler temperature: Nol available

Total alkalinity (as CaCO3): Not available
Phenolphthalein alkalinity: Not available

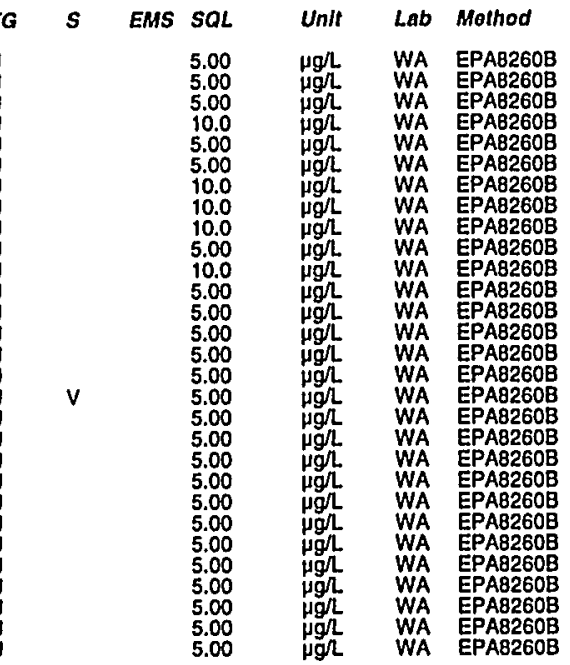

Time: Water temperature: Not available Total alkalinity (as $\mathrm{CaCO}$ ): Not available

Well TRP 105B collected on 06/15/99 (conl)

$f$ Analyto

: Ethylbenzene

o Titirachloroethylene

o Toluene

0 Trichlorolluoromeihan

\section{WELL TRP106B}

MEASUREMENTS CONDUCTED IN THE FIELD

Depth to water: Not available

Air temperature: Not avallable

No water was avalabie from the well prior to sampling. ANALYSES

$F$ Analyto

O Benzene

Bromolorm

Carbon telrachlorid

Chlorobenzene

Chlorosthane
Chloreathena (Vinyl chloride)
2-Chloroethyl vinyl ether

Chlorolorm

Chloromethane
Dibromochloromethan

1.1.-Dlchloroothane
1.2.-Dichloroothane

1,1-Dichloroethylene
trans-1,2-Dichloroethylene

Ditionsoromethane
1.2.-Dichloropropane

cis-1,3-Dichloropropene
trans-1,3-Dichloropropene

Ethylbenzene

Telrachloroethylen

1, 1,1-Trichloroethane
i. -Trichlorothane

$1,1,2.2$ Trichloroethane
Trichloroethylena

Trictiorofluoromethane

Rosult

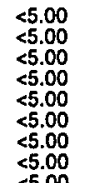

$<5.00$

\section{WELL TRP107B}

MEASUREMENTS CONDUCTED IN THE FIELD

Sample date: 06/22/99

Airth to water: Not availabie

$\mathrm{pH}$ : Nol available $\mathrm{Nol}$ available

Sp. conductance: Nol available

Result

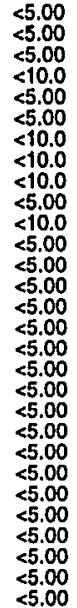

ANALYSES

$F$ Analyte

0 Benzene

0 Bromolorm

Cramomethane

$\begin{array}{ll}\text { Result } & F G \\ <5.00 & U \\ <5.00 & U \\ <5.00 & \\ 510.0 & U \\ <5.00 & U \\ 55.00 & U\end{array}$

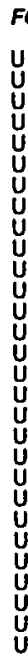

\begin{tabular}{|c|c|c|c|c|c|c|}
\hline$F G$ & $s$ & EMS & SaL & Unit & Lab & Mothod \\
\hline & & $\begin{array}{l}c x \\
c x \\
c x \\
c x \\
c x \\
c x \\
c x \\
c x \\
c x\end{array}$ & $\begin{array}{l}5.00 \\
5.00 \\
5.00 \\
5.00 \\
5.00 \\
5.00 \\
5.00 \\
5.00 \\
5.00\end{array}$ & $\begin{array}{l}\mu g h \\
\mu g h \\
\mu g h \\
\mu g h \\
\mu g h \\
\mu g h \\
\mu g h \\
\mu g \Omega \\
\mu g \Omega\end{array}$ & $\begin{array}{l}\text { WA } \\
\text { WA } \\
\text { WA } \\
\text { WA } \\
\text { WA } \\
\text { WA } \\
\text { WA } \\
\text { WA } \\
\text { WA }\end{array}$ & $\begin{array}{l}\text { EPAB260B } \\
\text { EPA8260B } \\
\text { EPAB260B } \\
\text { EPAB260B } \\
\text { EPAB260B } \\
\text { EPAB260B } \\
\text { EPAB260B } \\
\text { EPAB260B } \\
\text { EPAB260B }\end{array}$ \\
\hline
\end{tabular}

Water temperature: Not available

Total alkalinity (as CaCO3): Not available
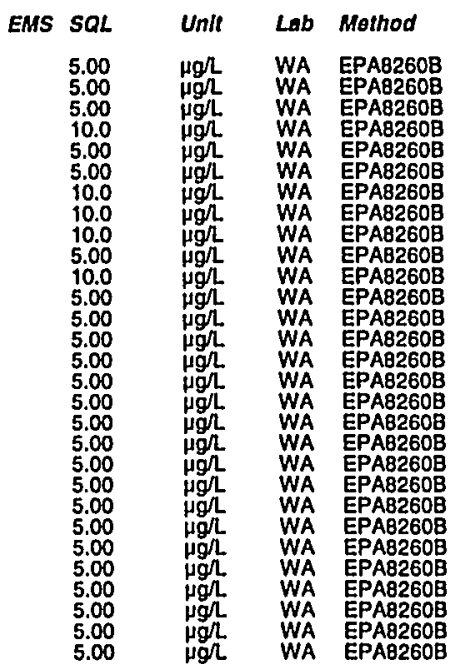

Time: Water temperature: Not available

Total alkalinity (as CaCO3): Not available

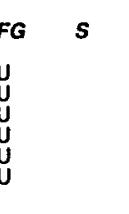

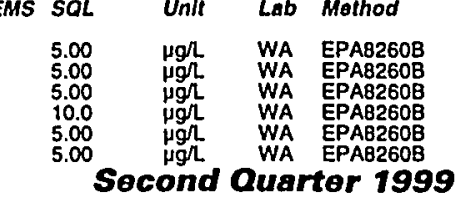


Well TAP1078 collected on 06/22/99 (cont.)

$F$ Analyto

Result

\begin{tabular}{|c|c|}
\hline 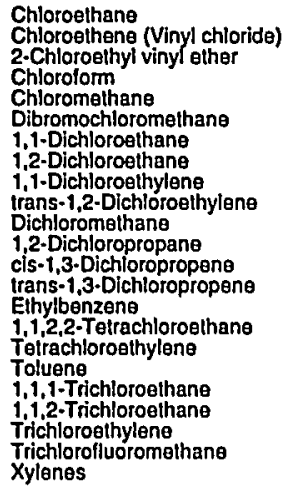 & $\begin{array}{l}<10.0 \\
<10.0 \\
<10.0 \\
<5.00 \\
<10.0 \\
<5.00 \\
<5.00 \\
<5.00 \\
<5.00 \\
<5.00 \\
<5.00 \\
<5.00 \\
<5.00 \\
<5.00 \\
<5.00 \\
<5.00 \\
<5.00 \\
<5.00 \\
<5.00 \\
<5.00 \\
<5.00 \\
<5.00\end{array}$ \\
\hline
\end{tabular}

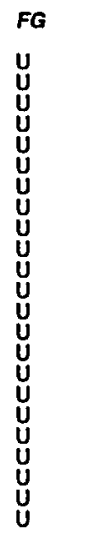

WELL TRP108B

MEASUREMENTS CONDUCTED IN THE FIELD

Sample dale: 06/24/99

Deplh to water: Nol available

$\mathrm{pH}$ : Not availabie . Not available

No water was evacuated from the well prior to sampling.

ANALYSES

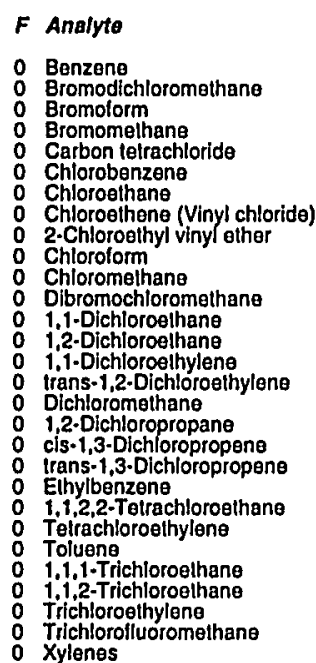

EMS
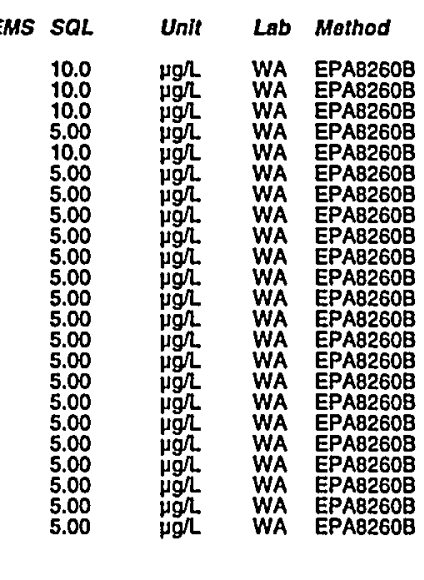

Time: Water iemperature: Not available Total alkalinity (as Caco3): Not available
Phenolphthalein alkalinity: Not available

Rosult
5.00
55.00
55.00
510.0
55.00
55.00
510.0
510.0
510.0
55.00
$<10.0$
55.00
$<5.00$
55.00
$<5.00$
55.00
55.00
55.00
55.00
55.00
55.00
55.00
55.00
$<5.00$
55.00
55.00
55.00
$<5.00$
$<5.00$

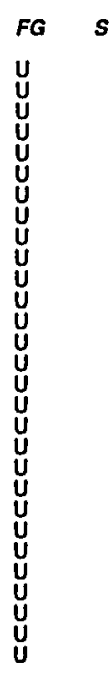

EMS SQL
5.00
5.00
5.00
10.0
5.00
5.00
10.0
10.0
10.0
5.00
10.0
5.00
5.00
5.00
5.00
5.00
5.00
5.00
5.00
5.00
5.00
5.00
5.00
5.00
5.00
5.00
5.00
5.00
5.00

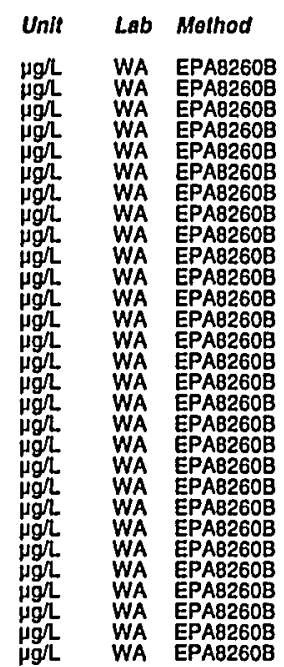

ESH-EMS-990521

\section{WELL TAP115B}

MEASUREMENTS CONDUCTED IN THE FIELD

Sample date: 05/11/99

Air temperature: Not available

Sp: Nol availabie Not available

No water was avacualed from the well prior to sampling.

ANALYSES

$F$ Analyte

: Benzona

O Bromolorm

Carbon letrachloride

Chlorobenzene

Chloroalhene (Vinyl chloride)
2-Chloroethyl vinyl other

0 Chioroform

- Dibromochloromethane

o 1,2-Dichlorotothane

: 1,1-Dichloroethylene

1,2-Dichloropropan

: cis-1,3-Dichloropropene

Eltyylbenzene

Telrachloroethylene

Toluene 1,1, Trichloroethane

Trichloroethylene
Trichlorofluoromethane

\section{WELL TRP116B}

MEASUREMENTS CONDUCTED IN THE FIEL.D

Sample date: 05/13/99

Ar temperature: Not available

$\mathrm{H}$ : Nol available

conductance: Not avallable

No water was evacuated from the well prior to sampling.

Result
55.00
55.00
55.00
55.00
55.00
55.00
510.0
55.00
55.00
55.00
55.00
55.00
55.00
55.00
55.00
55.00
55.00
55.00
55.00
55.00
55.00
55.00
55.00
55.00
55.00
55.00
55.00
55.00

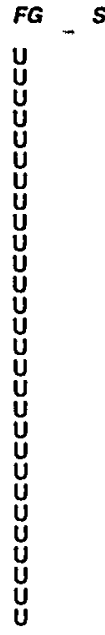

EMS SOL

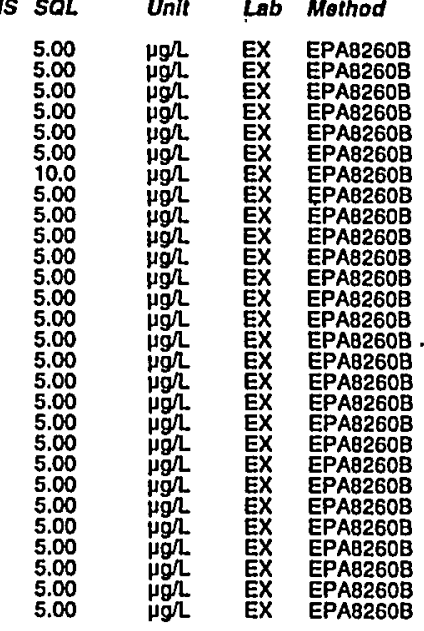

\section{$F$ Analyto}

Benzene

Bromolorm

Carbon tetrachioride

C Chlorobenzene

Chloroethane

Chinyl chloride)

2.Chloroethy

Chloromethane

Dibromochiorometha

1.2-Dichloroethane

$1,1-D i c h l o c o e t h y l e n$
0 trans $-1,2-0$ ichloroethylene

1.2-Dichloropropan

C-13
cis-1,3.Dichloropropene
Irans $1,3 \cdot$ D.chloropropene
Elhylbenzene
Time: Water iemperature: Not available

Total alkalinity (as CaCO3): Nol available
Phenolphthalein alkalinity: Nol available
Time: Water temperature: Not available Total alkainity (as CaCO3); Not available 
Well TRP116B collectod on 05/13/99 (cont.)

$F$ Analyto

Result
55.00
55.00
5.00
55.00
5.00
55.00
55.00

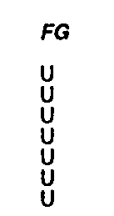

S EMS

\begin{tabular}{|c|c|c|c|}
\hline SQL & Unit & Lab & Method \\
\hline $\begin{array}{l}5.00 \\
5.00 \\
5.00 \\
5.00 \\
5.00 \\
5.00 \\
5.00\end{array}$ & $\begin{array}{l}\mu g / L \\
\mu g / 2 \\
\mu g / \\
\mu g / 2 \\
\mu g / 2 \\
\mu g h \\
\mu g h\end{array}$ & $\begin{array}{l}\text { EX } \\
\text { EX } \\
\text { EX } \\
\text { EX } \\
\text { EX } \\
\text { EX } \\
\text { EX }\end{array}$ & $\begin{array}{l}\text { EPA8260B } \\
\text { EPA8260B } \\
\text { EA9260B } \\
\text { EPA8260B } \\
\text { EPA260B } \\
\text { EPAB260B } \\
\text { EPAB260B }\end{array}$ \\
\hline
\end{tabular}

\section{WELL TRP118B}

MEASUREMENTS CONDUCTED IN THE FIELD

Sample date: 05/19/99

Depth to water: Not available
Air temperature: Not available

$\mathrm{H}$ H.: No gvauilable
$\mathrm{Sp}$. conductance: Not available

Turbidity: Nol available

ANALYSES

\begin{tabular}{|c|c|c|}
\hline & Analyte & Result \\
\hline & 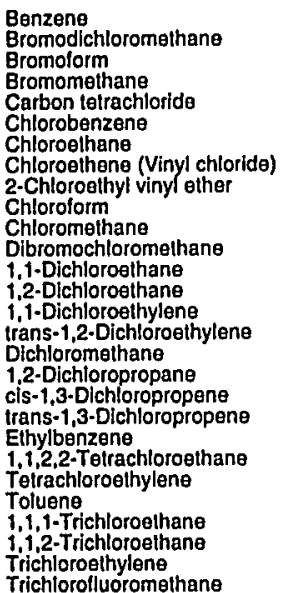 & $\begin{array}{l}<5.00 \\
<5.00 \\
<5.00 \\
<5.00 \\
<5.00 \\
<5.00 \\
<10.0 \\
<5.00 \\
<5.00 \\
<5.00 \\
<5.00 \\
<5.00 \\
<5.00 \\
<5.00 \\
<5.00 \\
<5.00 \\
<5.00 \\
<5.00 \\
<5.00 \\
<5.00 \\
<5.00 \\
<5.00 \\
<5.00 \\
<5.00 \\
<5.00 \\
<5.00 \\
<5.00 \\
<5.00\end{array}$ \\
\hline
\end{tabular}

\section{WELL TRP119B}

MEASUREMENTS CONDUCTED IN THE FIELD

Sample date: $06 / 15 / 99$

Depth to water: Not available

Air temperature: Not available
pH: Nol availabie

Turbidity: Not available

ANALYSES
$F$ Analyte
Resuht

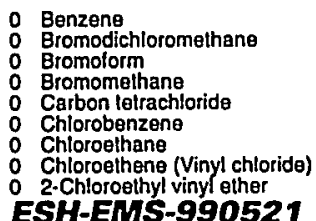

$<5.00$
$<5.00$
$<5.00$
$<5.00$
$<5.00$
$<5.00$
$<10.0$
$<5.00$
$<5.00$

$\begin{array}{lrr}\text { FG } & \text { S } & \text { EMS SQL } \\ \mathbf{U} & & 5.00 \\ \mathbf{U} & & 5.00 \\ \mathbf{U} & & 5.00 \\ \mathbf{U} & & 5.00 \\ \mathbf{U} & & 5.00 \\ \mathbf{U} & & 5.00 \\ \mathbf{U} & & 5.00 \\ \mathbf{U} & & 5.00\end{array}$

Time: Waler temperature: Not available

Total alkalinity (as CaCO3): Not available
Phenolphthalein alkalinity: Not available

ESH-EMS-990521

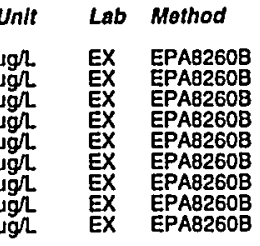

$\begin{array}{lll}\text { Unit } & \text { Lab } & \text { Mothod } \\ \mu g h & \text { EX } & \text { EPAB2608 } \\ \mu g h & \text { EX } & \text { EPAB2608 } \\ \mu g h & \text { EX } & \text { EPAB2608 } \\ \mu g h & \text { EX } & \text { EPAB2608 } \\ \mu g h & \text { EX } & \text { EPAB2608 } \\ \mu g h & \text { EX } & \text { EPAB260B } \\ \mu g h & \text { EX } & \text { EPAB260B } \\ \mu g h & \text { EX } & \text { EPAB260B } \\ \mu g h & \text { EX } & \text { EPAB260B } \\ \mu g h & \text { EX } & \text { EPAB260 }\end{array}$
Well TRP 1 19B collected on 06/15/99 (cont.)

\begin{tabular}{|c|c|}
\hline Analyto & Result \\
\hline 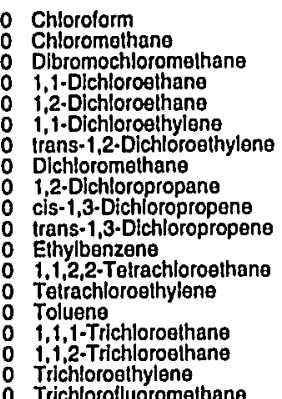 & $\begin{array}{l}<5.00 \\
<5.00 \\
<5.00 \\
<5.00 \\
<5.00 \\
<5.00 \\
<5.00 \\
1.90 \\
<5.00 \\
<5.00 \\
<5.00 \\
<5.00 \\
<5.00 \\
<5.00 \\
<5.00 \\
<5.00 \\
<5.00 \\
<5.00\end{array}$ \\
\hline
\end{tabular}

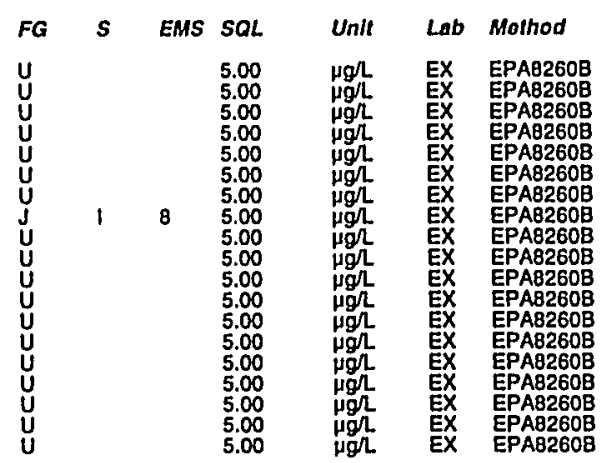

\section{WELL TRP125B}

MEASUREMENTS COHIDUCTED IN THE FIELD

Sample date: 04/15/99

Arr temperature: Not available

$\mathrm{Hp}$ : Nor available $\mathrm{conductance:} \mathrm{Not} \mathrm{available}$

urbidity: Nol avallabla avalt

the well prior to sampling.

\section{ANALYSES}

\section{F Analyte}

$\begin{array}{ll}0 & \text { Acroleln } \\ 0 & \text { Acrylonitrile } \\ 0 & \text { Benzene } \\ 0 & 0\end{array}$

Benzene
Bromodichloromethane
Bromolorm

Bromomethane

Carbon tetrachlorld
Chlorobenzene

Chloroethan

Chloroethene (Vinyl chloride)

Chlorolorm

o Chiloromethane

o 1,2-Dichlorobenzene

1.4-Dichlorobenzene

$\begin{array}{ll}0 & 1,1-D i c h l o r o e t h a n \\ 0 & 1,2-D i c h l o r o e t h a n \\ 0 & 1,1-D i c h l o r o e t h y l e n\end{array}$

$1,1 \cdot D$ ichloroethylene
trans-1,2-Dichloroethylene

Dichioromethane

cis-1,3-Dichloropropene
i crans-1,3-Dichloropropene

O Elhytbenzene

Teirachloroethylen

Toluene

$1,1,2$-Trichloroethan
Trichloroethylene
Time: Water femperature: Not available

Total alkalinity (as CaCO3): Not available
Phenolphthalein alkalinity: Not available

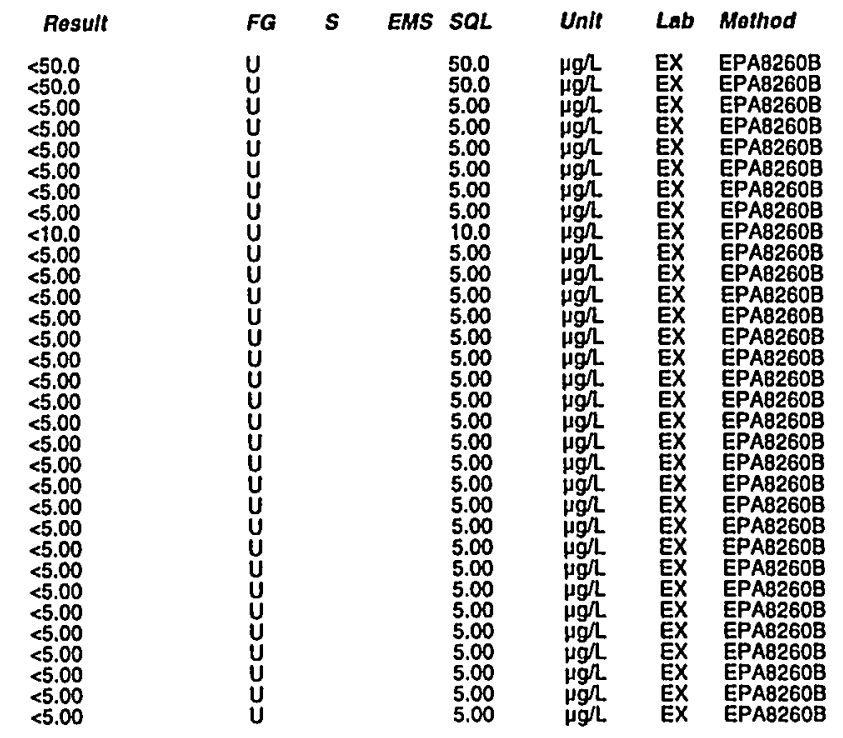


Well TRP132B collecled on 06/23/99 (cont.)

$F$ Analyte

Result

o Chlorolorm

Dibromochloromethane

1,2-Dichloroothane

trans $1,2-$ Dlchloroelhylene

1.2-Dichloropropane

trans-1,3-Dichloropropene

1,1,2,2-Tetrachloroethane

1,1,1-Trichloroethane

Trichloroothylene

\section{WELL TRP135B}

MEASUREMENTS CONDUCTED IN THE FIELD

Sample date: 06/04/99

H: Nol availabile Not available

Sp. conductance: Not available

No water was evacuated from the well prior to sampling

ANALYSES

F Analyto

Result
$<10.0$
$<5.00$
$<5.00$
55.00
$<10.0$
55.00
55.00
5.00
510.0
$<10.0$
55.00
$<10.0$
55.00
55.00
55.00
55.00
5.00
55.00
55.00
55.00
55.00
55.00
$<10.0$
$<10$.
$<10.0$
55.00
55.00
55.00
55.00
5.00
55.00
55.00
$<10.0$
55.00

Vinyl acetate
0 Xylenes

Betone

Bromodichloromethane

Catbon tetrachloride

Chioroethane

Chloromethan

1,2-Dichloroethane

1,2.Dichloroethylen

Dichloromethane

cis-1,3-Dichloropropene
trans-1,3-Dichloropropen

Elhylbenzene

Meithyl alhyl ketone
Methyl isobutyl ketone

1,1,2,2-Tetrachloroethane

Tetrachloroethylene

1,1,1-Trichloroethane

Trichloroethylene
Depth to water: Not available

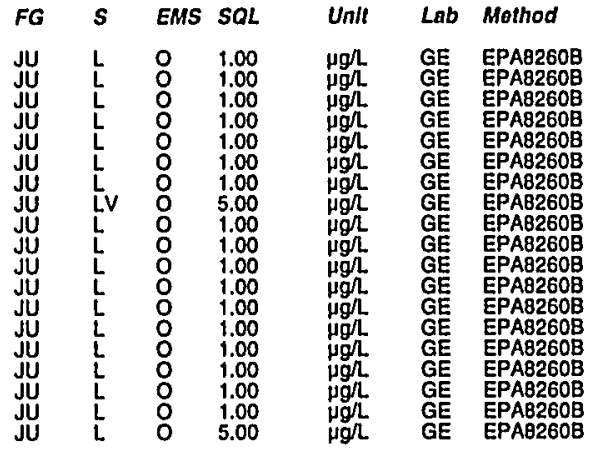

Time: Water Iemperature: Not available

Total alkalinity (as CaCO3): Not available
Phenolphthalein alkalinity: Not available

\section{WELL TRP136B}

MEASUREMENTS CONDUCTED IN THE FIELD

Sample date: 06/03/99

Depth to water: Not avallable

$\mathrm{pH}$ : Nop available

No waler was evacuated from the well prior to sampling.

ANALYSES

$F$ Analyto

0 Aceton日

Benzene
Bromodichloromathane

Bromomethane

Carbon telrachioride

Chloroothane
Chloroethene (Vinyl chloride)

Chloroethe

Chiloromelhane

1,2.Dichloroethane

$1,1.0$ ichloroethylene
$1,2$. Dichloroeshylene

Dichloromathane

cis-1,3-Dichloropropene
trans-1,3-Dichloropropen

2.thexanone

Melhyl ethyl ketone

Styrene 1,2 -Tetrachloroethane

- Tetrachloroethylent

o Toluener $1,1-$ Trichloroethane

Trichloroethylens

0 Vinyl acetate
0 Xylenes

\section{WELL TRP137B}

Rosult
$<10.0$
$<5.00$
$<5.00$
$<5.00$
$<5.00$
$<5.00$
$<5.00$
$<5.00$
$<10.0$
$<5.00$
$<5.00$
$<5.00$
$<5.00$
$<5.00$
$<5.00$
$<5.00$
$<1.00$
$<5.00$
$<5.00$
$<5.00$
$<5.00$
$<5.00$
$<5.00$
$<10.0$
$<5.00$
$<5.00$
$<5.00$
$<5.00$
$<5.00$
$<5.00$
$<5.00$
$<5.00$
$<20.0$
$<10.0$
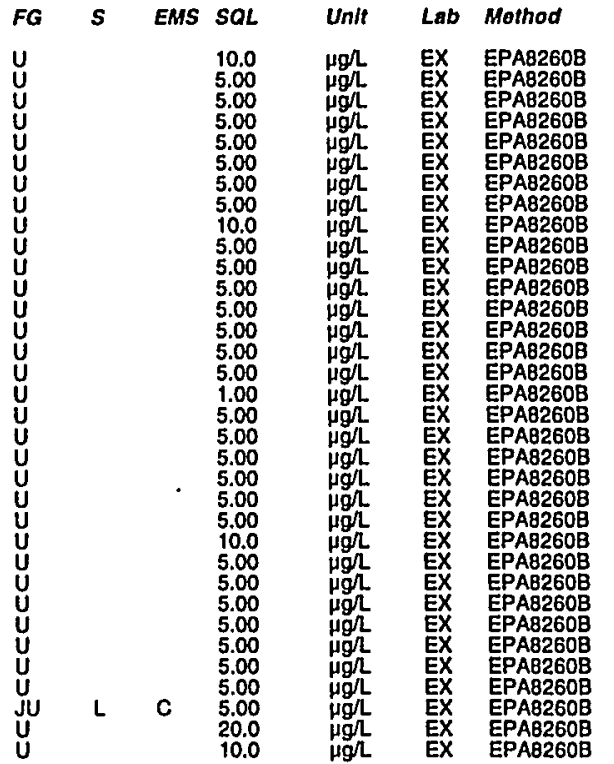

MEASUREMENTS CONDUCTED IN THE FIELD

Sample date: 06/04/99

Depth to water: Not available
Air temperature: Not available

Air temperature: Not available
pH: Nol available

Turbidity: Not available No water was evacuated from the well prior to sampling.

ANALYSES

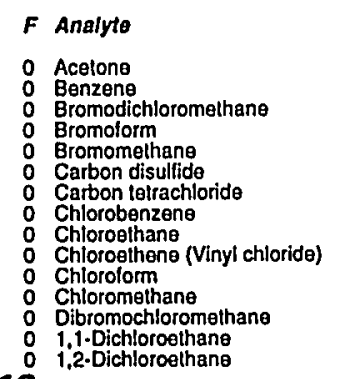

Result
$<10.0$
$<5.00$
$<5.00$
$<5.00$
$<5.00$
$<5.00$
$<5.00$
$<5.00$
$<10.0$
$<5.00$
$<5.00$
$<5.00$
$<5.00$
$<5.00$
$<5.00$

$F G$
$u$
$u$
$u$
$u$
$u$
$u$
$u$
$u$
$u$
$u$
$u$
$u$

Wime: Water temperature: Not available

Total alkalinity (as CaCO3): Nol available
Phenolphthalein alkalinity: Not avallable
Water iemperature: Not available

Total alkalinily (as CaCO3): Not available
Phenolphthalein alkalinity: Not available

EMS SQL
10.0
5.00
5.00
5.00
5.00
5.00
5.00
5.00
10.0
5.00
5.00
5.00
5.00
5.00
5.00

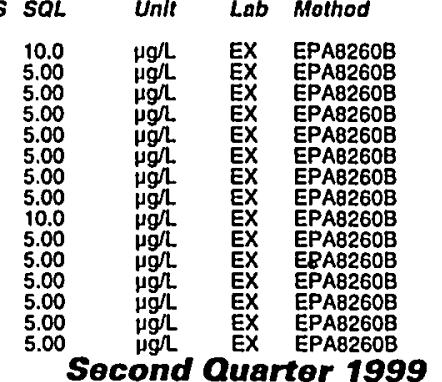




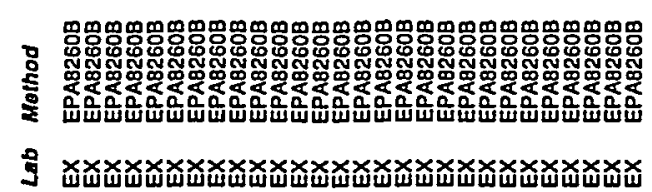

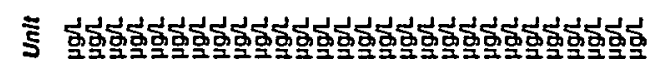

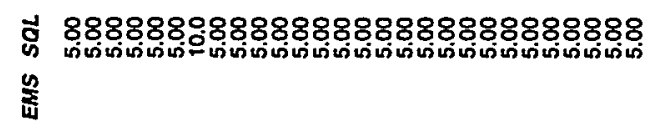

$\infty$

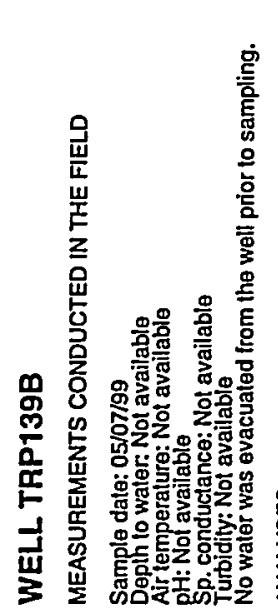

¿

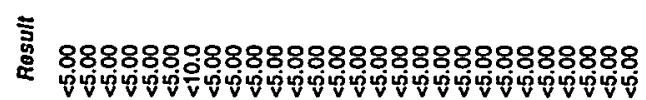

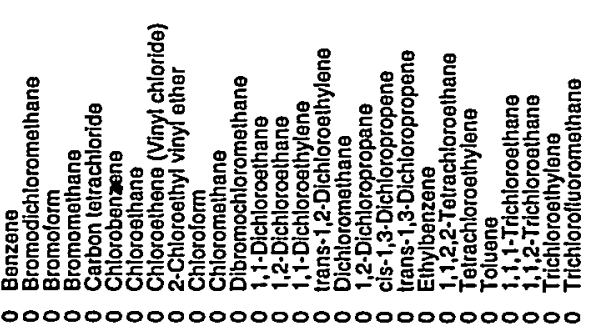

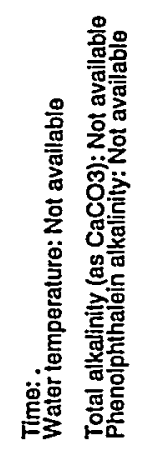

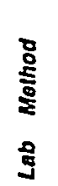

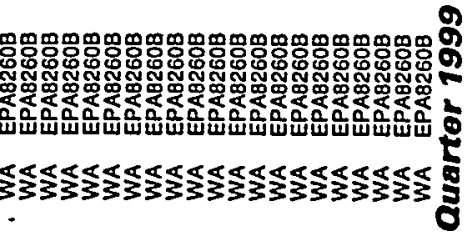

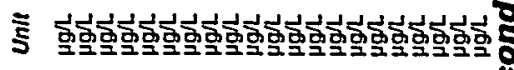

की

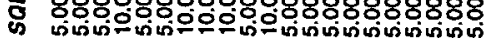

搴

क

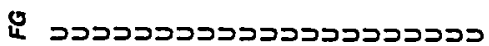

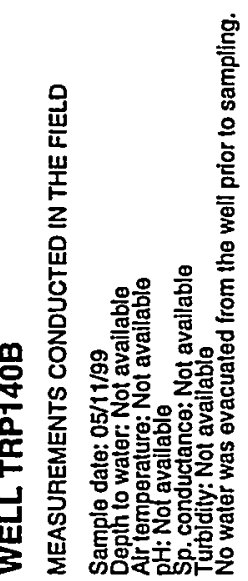

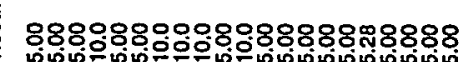

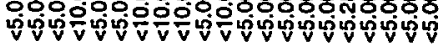

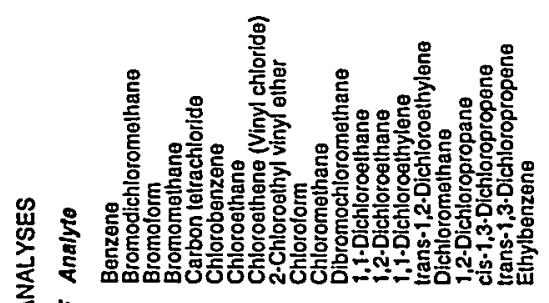

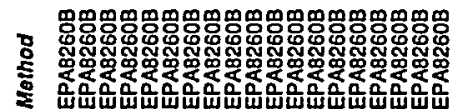

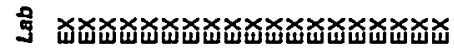

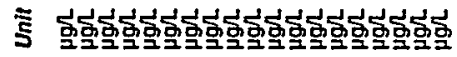

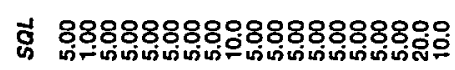
量

0

as

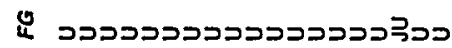

폴

惫

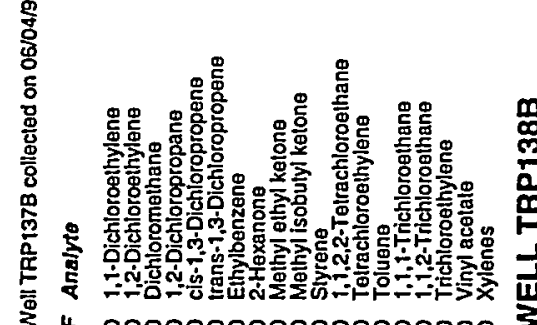

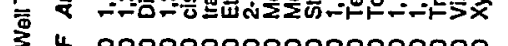
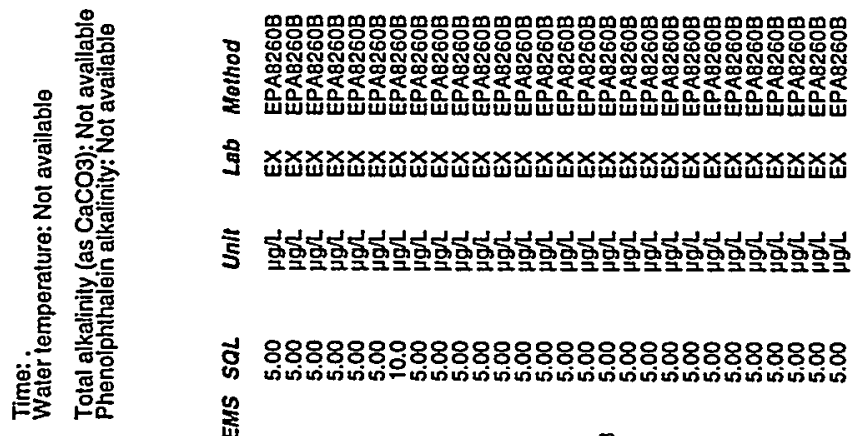

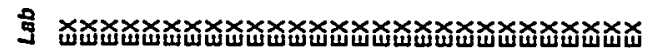

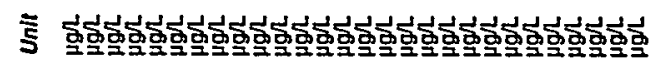

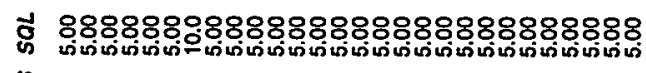
竞

$\infty$

s

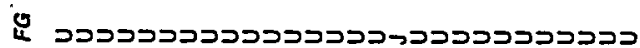
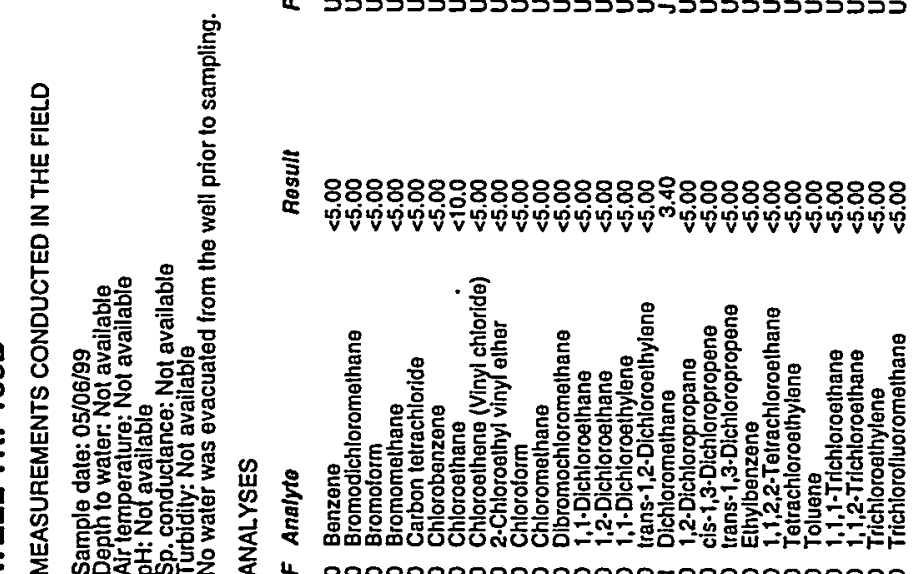

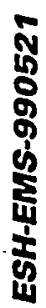


Well TRP140B collected on 05/11/99 (cont.)

o 1,1,2,2-Tetrachloroethane

$\therefore$ Tolrachloroethylen

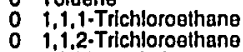

o Trichloroelthylene

o Xylenes

$<5.00$
$<5.00$
$<5.00$
$<5.00$
$<5.00$
$<5.00$
$<5.00$
$<5.00$

WELL TRP141B

MEASUREMENTS CONDUCTED IN THE FIELD

Sample date: 05/07/99

Air temperature: Not available

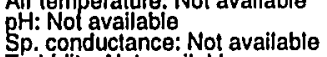

Sp. conductance: Not available
Turbidity: Not available

ANALYSES

\section{$F$ Analyte}

Result

0 Xylenes

$<5.00$
55.00
55.00
10.0
55.00
55.00
510.0
510.0
$<5.0$
55.00
510.0
55.00
55.00
55.00
55.00
55.00
59.45
55.00
55.00
55.00
55.00
55.00
55.00
55.00
55.00
55.00
55.00
55.00
55.00

WELL TRP142B

MEASUREMENTS CONDUCTED IN THE FIELD

Sample date: 05/19/99

Depth to water: Not available
Air temperature: Not available

Air temperature: Not available
gh: No availabbe
Sp. conduclance: Nol available
Turbidity: Not available

No water was evacuated from the well prior to sampling.

ANALYSES

\begin{tabular}{|c|c|}
\hline Analyte & Result \\
\hline $\begin{array}{ll}\text { o } & \text { Benzene } \\
0 & \text { Bromodichloromathane } \\
0 & \text { Bromolorm } \\
0 & \text { Bromomelhane } \\
0 & \text { Carbon tetrachloride } \\
0 & \text { Chlorobenzene } \\
\text { 0 Chloroethane } & \end{array}$ & $\begin{array}{l}<5.00 \\
<5.00 \\
<5.00 \\
<10.0 \\
<5.00 \\
<5.00 \\
<10.0\end{array}$ \\
\hline
\end{tabular}

FG

EMS SQL
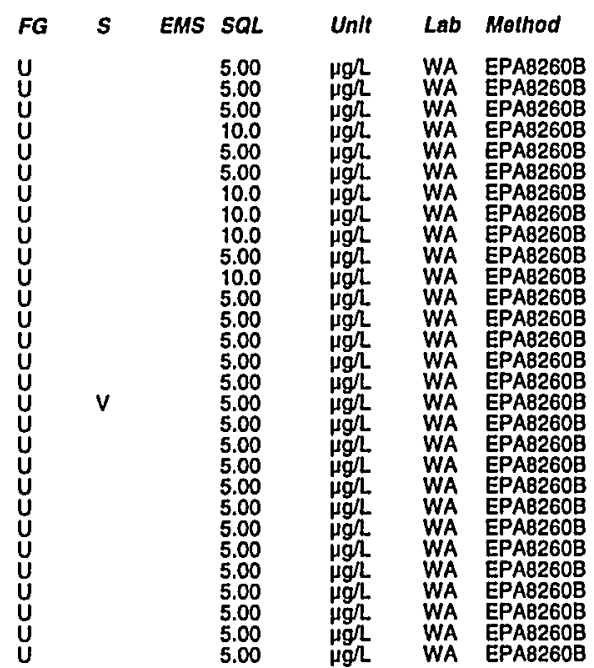

Time: Water temperature: Not available

Total alkalinity (as CacO3): Not available
Phenolphthalein alkalinity: Not avallable

Water temperature: Not available

Total alkalinity (as $\mathrm{CaCO}$ ): Not available
Phenolphthalein alkalinity: Not available

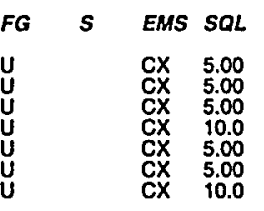

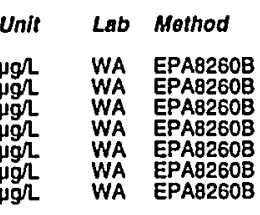

Well TAP 1428 collected on 05/19/99 (cont.)

$F$ Analyto

O Chloroethene (Vinyl chloride)
2-Chloroethyl vinyl ether

0 Chlorolorm

o Chloromelhane

1,2-Dichloroethane

0 1,1-Dichloroellhylene

1,2-Dichloropropan

cis-1,3-Dichloropropene
irans-1,3-Dichloropropene

0 Elhylbenzene

1, 1,2,2-Telrachloroethan
Totrachloroethylena

0 Toluene

o i, i, -ritichloroesthane

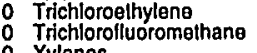

\section{WELL TRP143B}

MEASUREMENTS CONDUCTED IN THE FIELD

Sample date: 05/20/99

Air temperature: Not available

AH: Nol availabie
Sp.conductance: Not available

Wo water was evacuated from the well prior to sampling.

ANALYSES

$F$ Analyte

0 Benzene

Bromoform

Carbon tetrachlorida

Chlorobenzene

Chloroethene (Vinyl chloride)

2.Chloroethyl vinyl ether

Chloroform

Dibromochloromethan

1,1-Dichloroelhane

i,i-Dichloroethylene

o trans-1,2-Dichloroethy

1,2.Dichloropropane
cis- $-1,3$-Dichloropropene

cos. $1,3-D i c h$ oropropene
trans-1,3-Dichloropropene

Eihylbenzene

Tetrachioroethylene

Toluene

Ti, 2-Trichloroethan

Trichloroethylene
Xrichlorofluoromethane

$<10.0$
$<10.0$
$<5.00$
$<10.0$
$<5.00$
$<5.00$
$<5.00$
$<5.00$
$<5.00$
$<10.5$
$<5.00$
$<5.00$
$<5.00$
$<5.00$
$<5.00$
$<5.00$
$<5.00$
$<5.00$
$<5.00$
$<5.00$
$<5.00$
$<5.00$

$\begin{array}{ll}\text { EMS } & S O L \\ C X & 10.0 \\ C X & 10.0 \\ C X & 5.00 \\ C X & 10.0 \\ C X & 5.00 \\ C X & 5.00 \\ C X & 5.00 \\ C X & 5.00 \\ C X & 5.00 \\ C X & 5.00 \\ C X & 5.00 \\ C X & 5.00 \\ C X & 5.00 \\ C X & 5.00 \\ C X & 5.00 \\ C X & 5.00 \\ C X & 5.00 \\ C X & 5.00 \\ C X & 5.00 \\ C X & 5.00 \\ C X & 5.00 \\ C X & 5.00\end{array}$

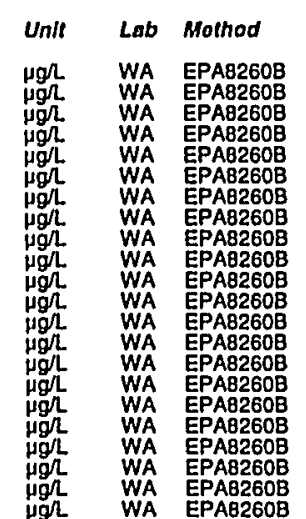

Time: Water Iemperature: Not available

Total alkalinity (as CaCO3): Not available
Phenolphthalein alkalinity: Not available

Rosult
55.00
55.00
55.00
510.0
55.00
55.00
510.0
510.0
510.0
55.00
510.0
55.00
55.00
55.00
55.00
55.00
510.0
55.00
55.00
55.00
55.00
55.00
55.00
55.00
55.00
55.00
5.00
55.00
55.00

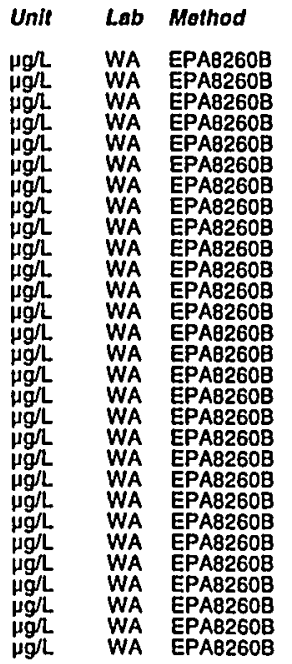


WELL TRP144B

MEASUREMENTS CONDUCTED IN THE FIELD

Sample dale: 05/20/99

Air to water: Not available

$\mathrm{OH}:$ Not available

p. conductance: Not available

Turbidity: Nol available
No water was evacuated from the well prior to sampling

ANALYSES

$F$ Analyte

0 Benzene

Bromolorm

Carbon tetrachioride

Chlorobenzene

O Chloroethene (Vinyl chloride)

Chlorolorm

o Dibromochloromethane

1,1-Dichloroelhane

,i, Dichloroethylene

Dichloromethane
1,2-Dichloropropan

cis-1,3.Dichloropropene

ropene

i, 1,2,2-Tetrachloroethane

Toluene

1.1,1-Trichloroethane

Trichloroethylene

Trichloroltuoromethan

0 Xylenes

\section{WELL TRP145B}

MEASUREMENTS CONDUCTED IN THE FIELD

Sample date: 05/27/99

Air temperature: Not available

$\mathrm{HH}$ : Nol availabie

p. conductance: Not available

No water was evacuated from the well prior to sampling.

ANALYSES

$F$ Analyto

o Benzene

Bromolorm
Bromomethane

Carbon telrachloride

Chloroethane

Chloroethene (Vinyl chloride)

Chlorolorm

Dibromochloromethane

i, 2-Dichloroesthan

$1,1 \cdot 0$ ichloroethylene
trans-1,2-0ichloroethylene

1.2-Dichloropropane

cis-1,3-Dichloropropene

ESH-EMS-990521

\begin{tabular}{|c|c|c|c|c|c|c|c|}
\hline Rosult & $\boldsymbol{F G}$ & $s$ & EMS & SQL & Unit & Lab & Method \\
\hline $\begin{array}{l}<5.00 \\
<5.00 \\
<5.00 \\
<10.0 \\
<5.00 \\
<5.00 \\
<10.0 \\
<10.0 \\
<10.0 \\
<5.00 \\
<10.0 \\
<5.00 \\
<5.00 \\
<5.00 \\
<5.00 \\
<5.00 \\
<5.00 \\
<5.00 \\
<5.00 \\
<5.00 \\
<5.00 \\
<5.00 \\
<5.00 \\
<5.00 \\
<5.00 \\
<5.00 \\
<5.00 \\
<5.00 \\
<5.00\end{array}$ & 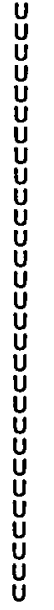 & & $\begin{array}{l}c x \\
c x \\
c x \\
c x \\
c x \\
c x \\
c x \\
c x \\
c x \\
c x \\
c x \\
c x \\
c x \\
c x \\
c x \\
c x \\
c x \\
c x \\
c x \\
c x \\
c x \\
c x \\
c x \\
c x \\
c x \\
c x \\
c x \\
c x \\
c x\end{array}$ & $\begin{array}{l}5.00 \\
5.00 \\
5.00 \\
10.0 \\
5.00 \\
5.00 \\
10.0 \\
10.0 \\
10.0 \\
5.00 \\
10.0 \\
5.00 \\
5.00 \\
5.00 \\
5.00 \\
5.00 \\
5.00 \\
5.00 \\
5.00 \\
5.00 \\
5.00 \\
5.00 \\
5.00 \\
5.00 \\
5.00 \\
5.00 \\
5.00 \\
5.00 \\
5.00\end{array}$ & 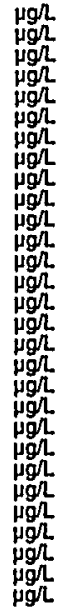 & $\begin{array}{l}\text { WA } \\
\text { WA } \\
\text { WA } \\
\text { WA } \\
\text { WA } \\
\text { WA } \\
\text { WA } \\
\text { WA } \\
\text { WA } \\
\text { WA } \\
\text { WA } \\
\text { WA } \\
\text { WA } \\
\text { WA } \\
\text { WA } \\
\text { WA } \\
\text { WA } \\
\text { WA } \\
\text { WA } \\
\text { WA } \\
\text { WA } \\
\text { WA } \\
\text { WA } \\
\text { WA } \\
\text { WA } \\
\text { WA } \\
\text { WA } \\
\text { WA } \\
\text { WA }\end{array}$ & 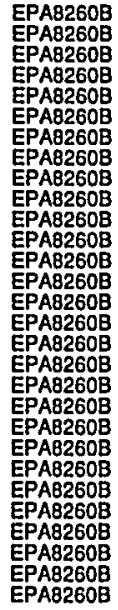 \\
\hline
\end{tabular}

Time: Water temperature: Not avallable

Total alkalinity (as CaCO3): Not available
Phenolphthalein alkalinity: Not available

Time:- Water temperature: Not available

Total alkalinity (as $\mathrm{CaCO}$ ): Not available

$F$ Analyte

Ethylbenzene
$1.1,2,2$-Tetrachloroethan

Toliachloroethylene

1.1. 2 -Trichloroethan

Trichloroelhylene
0 Trichlorolluoromethane

WELL TRP146B

MEASUREMENTS CONDUCTED IN THE FIELD

Sample dato: 06/01/99

Air temperalure: Nol available

Sp: Nol avallable Nonduclance: Not availabl

No water was evacuated from the well prior to sampling

ANALYSES

F Analyto

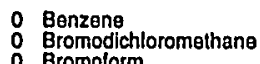

Bromodion
Bromomethane

Carbon tetrachlorid

Chloroethane

Chloroethene (Vinyl chloride)

Chloroform

Dibromochloromethan

1.1.Dichloroethan

i,1-Dichloroethylene

1.chloromethane

$\begin{array}{ll}0 & \text { cis-1,3-Dichloropropene } \\ 0 & \text { trans-1,3-Dlchloropropen }\end{array}$

1,1,2,2-Tetrachloroethane

Tetrachloroethylene

1,1,1-richloroethane

Trichloroothylene

0 Trichlorofluoromethan

\section{WELL TRP147B}

MEASUREMENTS CONDUCTED IN THE FIELD

Sample dale: 06/01/99

Depth to water: Not available

AH: Nol available avaliable

Sp. conductance: Nol available

No waler was evacuated from the well prior to sampling

ANALYSES

$F$ Analyte

Rosult
$<5.00$
$<5.00$
$<5.00$
$<10.0$
$<5.00$
$<5.00$
$<10.0$
$<10.0$
$<10.0$
$<5.00$
$<10.0$
55.00
55.00
55.00
5.00
55.00
$<.51$
$<5.00$
5.00
55.00
5.00
55.00
5.00
55.00
5.00
55.00
5.00
55.00
5.00

Time: Water temperature: Not available

Total alkalinity (as CaCO3): Not available
Phenolphthalein alkalinity: Not available

\begin{tabular}{|c|c|c|c|}
\hline SQL & Unit & Lab & Mothod \\
\hline $\begin{array}{l}5.00 \\
5.00 \\
5.00 \\
5.00 \\
5.00 \\
5.00 \\
5.00\end{array}$ & $\begin{array}{l}\mu g h \\
\mu g h \\
\mu g h \\
\mu g h \\
\mu g h \\
\mu g h \\
\mu g h \\
\mu g h \\
\mu g h \\
\mu g h\end{array}$ & $\begin{array}{l}\text { WA } \\
\text { WA } \\
\text { WA } \\
\text { WA } \\
\text { WA } \\
\text { WA } \\
\text { WA } \\
\text { WA } \\
\text { WA }\end{array}$ & 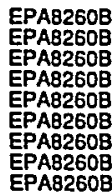 \\
\hline
\end{tabular}

: Benzene

Bromodichlorom

Bromolorm
Bromomethane

Carbon telrachioride

C-19
Rosult

$<5.00$
55.00
5500
510.0
55.00
55.00
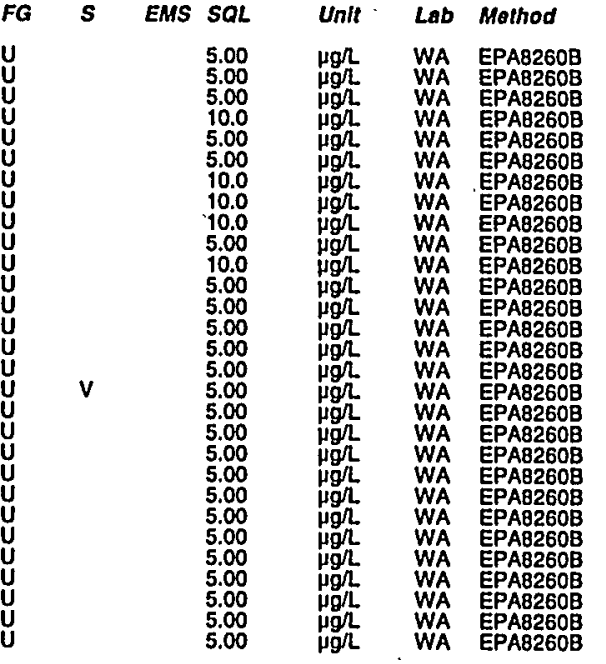

Time: .

perature: Not availablo

Total alkalinily (as CaCO3): Not available

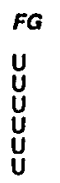

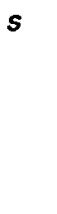


Well TRP 1478 collected on 06/01/99 (cont.)

\begin{tabular}{|c|c|}
\hline Analyto & Rosult \\
\hline 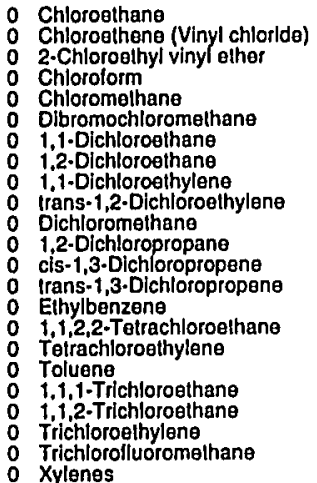 & $\begin{array}{l}<10.0 \\
<10.0 \\
<10.0 \\
<5.00 \\
<10.0 \\
<5.00 \\
<5.00 \\
<5.00 \\
<5.00 \\
<5.00 \\
<4.44 \\
<5.00 \\
<5.00 \\
<5.00 \\
<5.00 \\
<5.00 \\
<5.00 \\
<5.00 \\
<5.00 \\
<5.00 \\
<5.00 \\
<5.00 \\
<5.00\end{array}$ \\
\hline
\end{tabular}

\section{WELL TRP148B}

MEASUREMENTS CONDUCTED IN THE FIELD

Sample date: 05/26/99
Depth to water: Not available
Air temperalure: Not available

pH: Nol available Nol availabl

Turbidity: Not available

Wo water was evacuated from the well prior to sampling.

\section{ANALYSES}

F Analyte

Result

Benzene

Bromoform

Carbon letrachlorid

Chlorosthane

Chloroethene (Vinyl chloride)

Chlorolorm

Dibromochloromethan

1,1-Dichlorosthane

1.2-Dichloroothane

Irans:1,2-Dichloroethylen

1.2-Dichloropropan

ciss-1,3-Dichloropropene Ethylbenzene

Totrachloroethylene

Tiluene

1.1,2-Trichloroelhan

Trichlorofluoromethane

$<1.00$
$<1.00$
$<1.00$
$<1.00$
$<1.00$
$<1.00$
$<1.00$
$<1.00$
$<5.00$
$<1.00$
$<1.00$
$<1.00$
$<1.00$
$<1.00$
$<1.00$
$<1.00$
1.94
$<1.00$
$<1.00$
$<1.00$
$<1.00$
$<1.00$
$<1.00$
$<1.00$
$<1.00$
$<1.00$
$<5.00$

ESH-EMS-990521

\section{WELL TRP149B}

MEASUREMENTS CONDUCTED IN THE FIELD

Sample date: 05/24/99

Airtemperalur: Not avallable

$\mathrm{gH}$ : Nol available $\mathrm{Not}$. conductance: Not available

.

ANALYSES

$F$ Analyto

Result

FG $\quad s$

Water Iemperature: Not available

Total alkalinity (as CaCO3): Nol available
Phenolphthalein alkalinity: Not available

O Benzene

Bromomethane

Carbon tetrachloride

Chlorobenzene

0
0
$2-C h l o r o t h e n e$
0

Chlorotorm

Dibromochloromethane

D.1.Dilchloroethane
$1,2 \cdot$ Dichloroethane

1.1-Dichloroethylene
rians-1,2-Dichloroethylene

Dlchloromelhane

Time: Water temperature: Not available

Total alkalinity (as CaCO3): Not available
Phenolphthalein alkalinity: Not available

cis-1,3-Dichloropropene

Ethybenzene

1,1,2,2-Tetrachloroel

o Toluene

1.1.2. Trichloroelha
Trichloroethylene

- Trichloroethylene

$<1.00$
$<1.00$
41.00
$<1.00$
$<1.00$
$<1.00$
$<1.00$
$<1.00$
$<5.00$
$<1.00$
$<1.00$
41.00
$<1.00$
$<1.00$
$<1.00$
$<1.00$
$<5.00$
$<1.00$
51.00
$<1.00$
$<1.00$
$<1.00$
41.00
$<1.00$
41.00
$<1.00$
$<1.00$
$<5.00$

EMS SQL

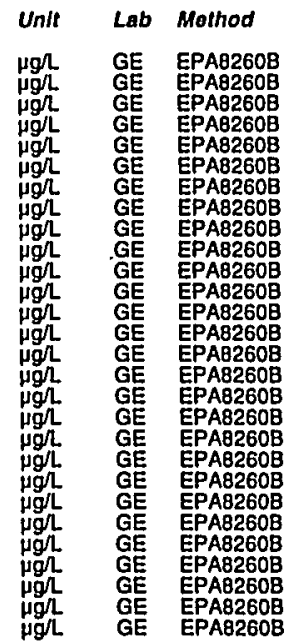

WELL TRP150B

MEASUREMENTS CONDUCTED IN THE FIELD

Sample date: 04/14/99

Airtho warer: Not availablo

pH: Nol available : Not available

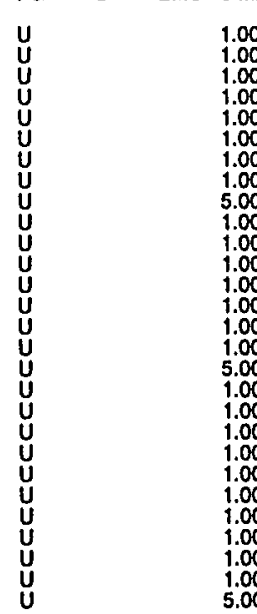

1.00
1.00
1.00
1.00
1.00
1.00
1.00
5.00
1.00
1.00
1.00
1.00
1.00
1.00
5.00
1.00
1.00
1.00
1.00
1.00
1.00
1.00
1.00
1.00
5.00

Time: Water temperature: Not available

Tolal alkalinity (as CaCO3): Not available
Phenolphthalein alkalinity: Not available

ANALYSES

$F$ Analyt?

Result

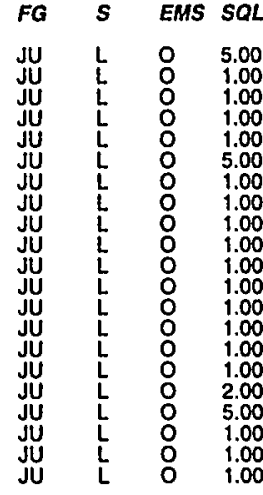

Unit Lab Mathod

$\begin{array}{ll}0 & \text { Acatone } \\ 0 & \text { Benzene } \\ \text { Bromodichloromethane } & \end{array}$

Bromolorm

Carbon disullide

Chlorobenzene

Chloroethane

Chlorolorm

Dibromochloromethan

1,i.2-Dichloroesthane

1,2-Dichloroethylene

1,2-Dichloropropano C-20

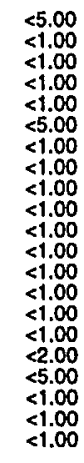


Well TRP150B collected on 04/14/99 (cont.)

$F$ Analyte Result

O Ethyibenzene $<1.00$
$<5.00$
$<10.0$
55.00
51.00
51.00
$<1.00$
41.00
51.00
$<1.00$
41.00
55.00
$<2.00$

\begin{tabular}{|c|c|c|c|}
\hline & & EMS & 5 \\
\hline 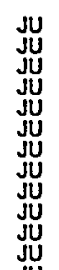 & $L$ & $\begin{array}{l}0 \\
0 \\
0 \\
0 \\
0 \\
0 \\
0 \\
0 \\
10 \\
0 \\
0 \\
0 \\
0\end{array}$ & \\
\hline
\end{tabular}

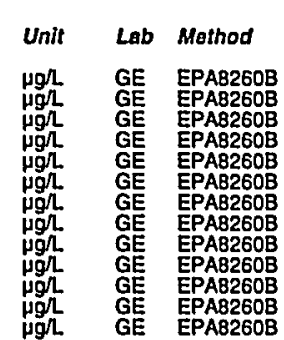
O Vinyl acetate

\section{WELL TRP151B}

MEASUREMENTS CONDUCTED IN THE FIELD

Sample date: 04/15/99

Depth to water: Not available

H: Nol availabie Not available

Sp. conductance: Nol available

Nurbidity: Not available and the well prior to sampling.

ANALYSES

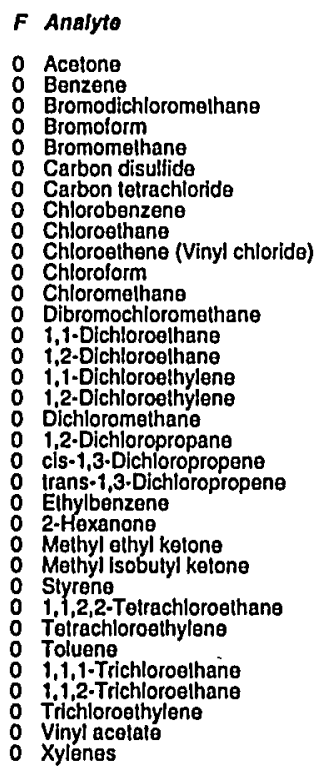

Result
$<5.00$
$<1.00$
$<1.00$
$<1.00$
$<1.00$
$<5.00$
$<1.00$
$<1.00$
$<1.00$
$<1.00$
$<1.00$
$<1.00$
$<1.00$
$<1.00$
$<1.00$
$<1.00$
$<2.00$
1.34
$<1.00$
$<1.00$
$<1.00$
$<1.00$
$<5.00$
$<10.0$
$<5.00$
$<1.00$
$<1.00$
$<1.00$
$<1.00$
$<1.00$
$<1.00$
$<1.00$
$<5.00$
$<2.00$

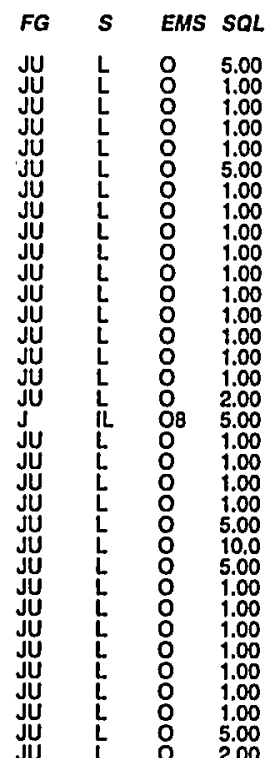

Waim: Wemperature: Not available

Total alkalinity (as CaCO3): Not available
Phenolphthalein alkalinity: Not available

\begin{tabular}{|c|c|c|c|}
\hline & Unit & Lab & Molhod \\
\hline $\begin{array}{l}5.00 \\
1.00 \\
1.00 \\
1.00 \\
1.00 \\
5.00 \\
1.00 \\
1.00 \\
1.00 \\
1.00 \\
1.00 \\
1.00 \\
1.00 \\
1.00 \\
1.00 \\
2.00 \\
1.00 \\
1.00 \\
1.00 \\
1.00 \\
1.00 \\
5.00 \\
1.00 \\
1.00 \\
1.00 \\
1.00 \\
1.00 \\
1.00 \\
1.00\end{array}$ & 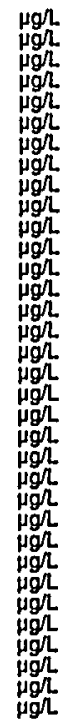 & 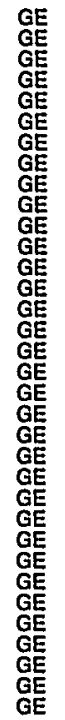 & 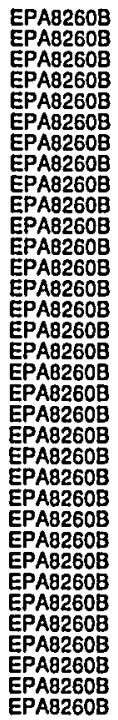 \\
\hline
\end{tabular}

ESH-EMS-990521

\section{WELL TRP152B}

MEASUREMENTS CONDUCTED IN THE FIELD

Sample date: 04/15/99

Aepth to water: Not available

SH: Not available Not available

No water was evacuated from the well prior to sampling

ANALYSES

$F$ Analyto

Resull

0 Acatone

o Benzene

$<10.0$
55.00
55.00
5.00
510.0
55.00
55.00
55.00
510.0
$<10.0$
55.00
510.0
55.00
55.00
55.00
55.00
55.00
6.17
55.00
55.00
55.00
55.00
510.0
$<10.0$
510.0
55.00
55.00
$<5.00$
55.00
55.00
55.00
55.00
10.0
$<5.00$

FG

$\begin{array}{ll}\text { EMS SQL } \\ X & 10.0 \\ X & 5.00 \\ X & 5.00 \\ X & 5.00 \\ X & 10.0 \\ X & 5.00 \\ X & 5.00 \\ X & 5.00 \\ X & 10.0 \\ X & 10.0 \\ X & 5.00 \\ X & 10.0 \\ X & 5.00 \\ X & 5.00 \\ X & 5.00 \\ X & 5.00 \\ X & 5.00 \\ X 8 & 5.00 \\ X & 5.00 \\ X & 5.00 \\ X & 5.00 \\ X & 5.00 \\ X & 10.0 \\ X & 10.0 \\ X & 10.0 \\ X & 5.00 \\ X & 5.00 \\ X & 5.00 \\ X & 5.00 \\ X & 5.00 \\ X & 5.00 \\ X & 5.00 \\ X & 10.0 \\ X & 5.00 \\ X & \end{array}$

Time: Water temperature: Not available

Total alkalinity (as CaCO3): Nol available
Phenolphthalein alkalinity: Not available

Carbon disulfide

Chlorobenzene

Chloroesthene (Vinyl chloride)

Chlorolorm

Dibromochloromethane

1,2-Dichloroethane

0 i, 2 -Dichloroethylene

1,2-Dichloropropane
cis-1,3-Dichloropropene

trans-1,3-Dichloropropene

2.Hexanone

Melhyl elthyl ketone

i,yrena 2,2 Tetrachloroethen

Teirachloroathylene

o $1,1,1$ - Trichloroethane

O Vichloroethylent acetale

WELL TRP153B

MEASUREMENTS CONDUCTED IN THE FIELD

Sample date: 04/14/99

Depth to water: Not available

gh: Nol available . conductance: Not avallable

No water was evacualed from the well prior to sampling

ANALYSES
$F$ Analyto

Benzene
: Bromodichloromelhane
Bromoform

: Bromomethans

: Carbon letrachlorid

o Chloroethana

Chloroethene (Vinyl chloride)

2-Chloroethy

Chlorolorm

Dibromochloromethano

1,1-Dlchloroethane

$-21$
i.i-Dichloroethylene

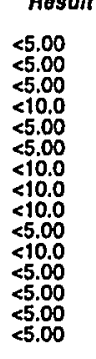

Time: Water temperature: Not available

Total alkalinity (as CaCO3): Not avallable
Phenolphithalein alkalinity: Not avallable

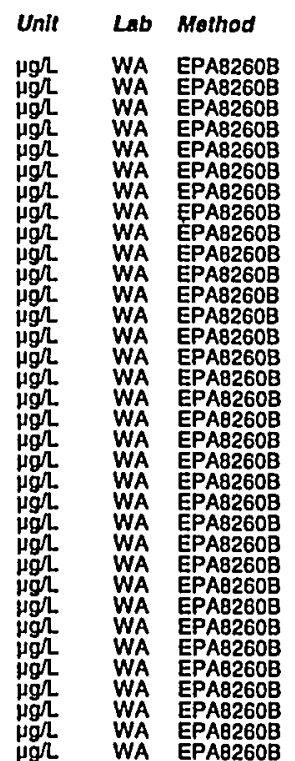


Well TRP153B collected on 04/14/99 (cont.)

$F$ Analyto

Rosult
$<5.00$
$<4.59$
$<5.00$
$<5.00$
$<5.00$
$<5.00$
$<5.00$
$<5.00$
$<5.00$
$<5.00$
$<5.00$
$<5.00$
$<5.00$
$<5.00$

\section{WELL TRP156B}

MEASUREMENTS CONDUCTED IN THE FIELD

Sample date: 06/02/99

Depth to water: Not available

Air temperature: Not available
gH: Nol available
Sp. conductance: Not available

Turbidity: Nol available
No water was evacuated from the well prior to sampling.

ANALYYSES

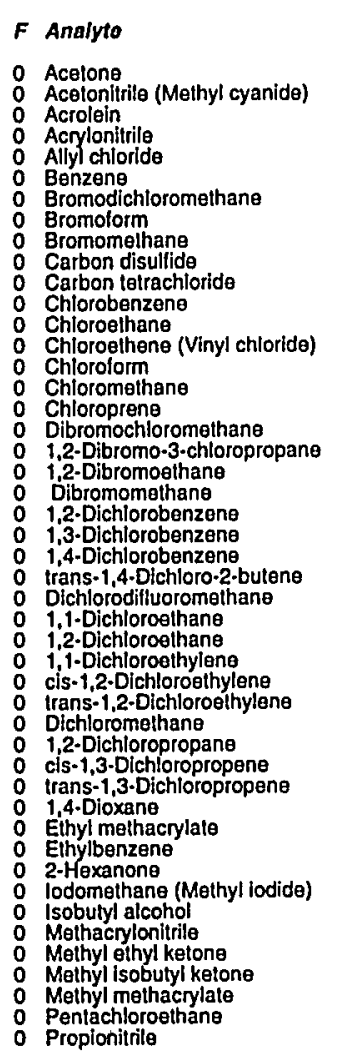

\begin{tabular}{l} 
Result \\
$<10.0$ \\
$<500$ \\
$<50.0$ \\
$<50.0$ \\
$<10.0$ \\
$<5.00$ \\
$<5.00$ \\
$<5.00$ \\
$<5.00$ \\
$<5.00$ \\
$<5.00$ \\
$<5.00$ \\
$<10$. \\
$<5.00$ \\
$<5.00$ \\
$<5.00$ \\
$<50.0$ \\
$<5.00$ \\
$<5.00$ \\
$<5.00$ \\
$<5.00$ \\
$<5.00$ \\
$<5.00$ \\
$<5.00$ \\
$<200$ \\
$<5.0$ \\
$<5.00$ \\
$<5.00$ \\
$<5.00$ \\
$<5.00$ \\
$<5.00$ \\
$<5.00$ \\
$<5.00$ \\
$<5.00$ \\
$<5.00$ \\
$<1.000$ \\
$<5.00$ \\
$<5.00$ \\
$<5.00$ \\
$<5.00$ \\
$<5.500$ \\
$<100$ \\
$<5.00$ \\
$<500$ \\
$<200$ \\
$<500$ \\
\hline 5
\end{tabular}

ESH-EMS-990521

Well TRP 158B collected on 06/02/99 (cont.)

Rosult

0 Styrene

O Totrachloroethylene

Toluene

Trichloroethylene

1,2,3-Trichloromethane

0 Vinyl acetate

WELL TRP157B

MEASUREMENTS CONDUCTED IN THE FIELO

Sample date: 06/08/99

Air temperature: Not available

$\mathrm{pH}$ : Nol availabie . conductance: Not available

No water was evacuated from the well prior to sampling.

ANALYSES

$F$ Analyze

$<5.00$
5.00
55.00
55.00
$<5.00$
55.00
$<5.00$
55.00
$<5.00$
$<5.00$
$<20.0$
$<10.0$

U

EMS SOL

\begin{tabular}{|c|c|}
\hline $\begin{array}{l}5.00 \\
5.00 \\
5.00 \\
5.00 \\
5.00 \\
5.00 \\
5.00 \\
5.00 \\
5.00 \\
5.00 \\
20.0 \\
10.0\end{array}$ & 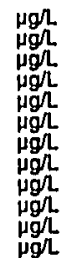 \\
\hline
\end{tabular}

Time: Water iemperalure: Not available Total alkalinity (as CaCO3): Not available

Total alkalinity (as CaCO3): Not avallablo
Phenolphthalein alkalinily: Not availablo

Acetonitrile (Methyl cyanide)

Acrolein
Acrylonitrile
Ally chlorido

Allyl chlorida

Bromodichloromethane

Bromolorm

Carbon disulfidide

Carbon telrachlo

Chloroethane

Chlorolorm

Chloroprene
Dibromochloromethane

1,2-Dibromo-3-chloropropane

1.2.Dibromoethane

1,2-Dichlorobenzene

1,3-Dichlorobenzene

trans-1,4-Dichloro-2-butene

1,1 -Dichloroethane

1,2-Dichloroothane

cisa-1,2-Dichloroethylane
irans-1,2-Dichloroethylen

Dichloromelhane

cis-1,3-Dichloropropene
trans-1,3-Dichloropropen

1.4.Dloxane
Eihyl methacrylate

Ethylbenzene

2-Hexanone
lodomethane (Methyl lodide)

Methacrylonitrilo

Mathyl athyl ketone
Methyl isobutyl ketone

Methyl methacrylate
Pentachloroethane

Propionitrile

Styrena
1.trite

c-22

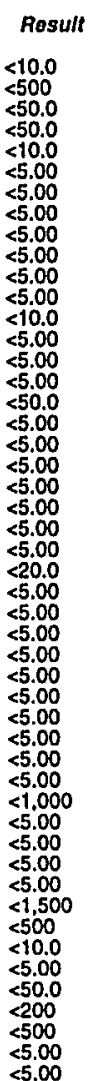

Rosult

FG

EMS SO

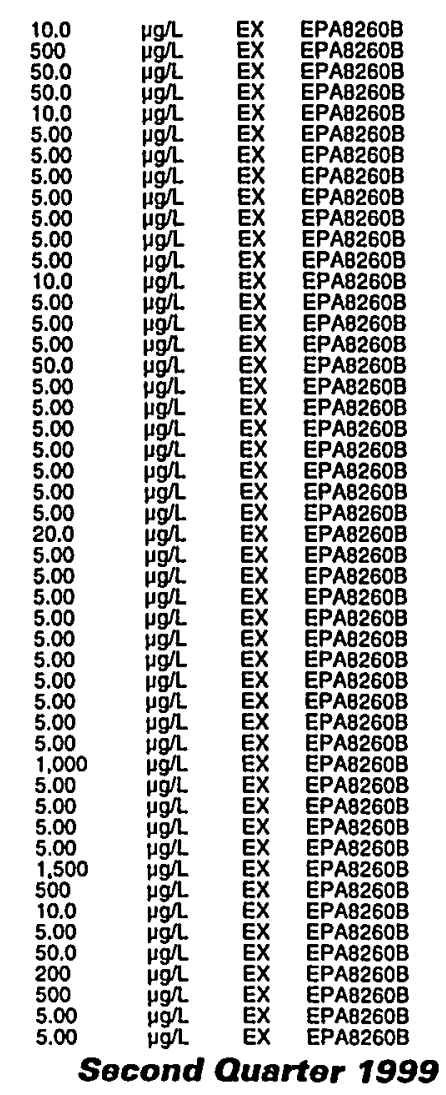


Well TRP157B collected on O6/08/99 (cont.)

$F$ Analyte

0 1.1,2,2-Tetrachloroothane

Tolueno

1.1.1-Trichloroethan

Trichloroethylene

1,2,3-Trichloropropane

0 Xylenes

\section{WELL TRP166B}

MEASUREMENTS CONDUCTED IN THE FIELD

Sample date: 04/23/99

Deph to water: Not avaijable

Air temperature:

Sp. conductance: Not available

No water was evacuated from the well prior to sampling.

ANALYSES

F Analyto

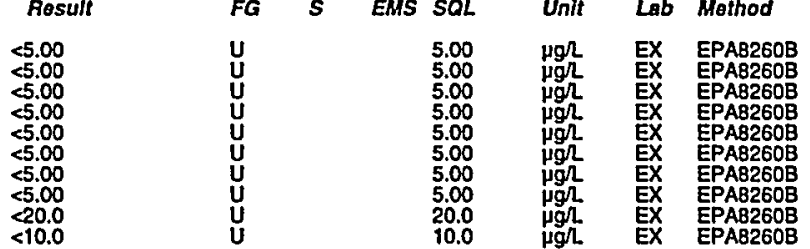

- Carbon tetrachloride

cis- $1,2 \cdot$ Dichloroethylene

Totrachloroethylens

: 1,1,1-Trichloroethane

\section{WELL TRP167B}

MEASUREMENTS CONDUCTED IN THE FIELD

Sample date: 05/04/99

Air temperature: Not available

Sp conduclance: Not availab

No water was evacualed from the well prior to sampling

ANALYSES

\begin{tabular}{|c|c|c|c|c|c|c|c|c|}
\hline Analyto & Rosult & $F G$ & $s$ & $E M S$ & SQL & Unit & Lab & Molhod \\
\hline 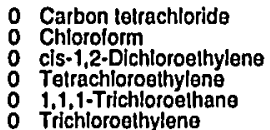 & $\begin{array}{l}<1.00 \\
<1.00 \\
<1.00 \\
<1.00 \\
<1.00 \\
<1.00\end{array}$ & 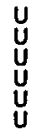 & & & $\begin{array}{l}1.00 \\
1.00 \\
1.00 \\
1.00 \\
1.00 \\
1.00\end{array}$ & $\begin{array}{l}\mu g h \\
\mu g h \\
\mu g h \\
\mu g h \\
\mu g h \\
\mu g h \\
\mu g h\end{array}$ & $\begin{array}{l}\text { EX } \\
\text { EX } \\
\text { EX } \\
\text { EX } \\
\text { EX } \\
\text { EX }\end{array}$ & $\begin{array}{l}\text { EPA8021B } \\
\text { EPAB021日 } \\
\text { EPAB0218 } \\
\text { EPAB0218 } \\
\text { EPA80218 } \\
\text { EPAB0218 }\end{array}$ \\
\hline
\end{tabular}

\section{WELL TRP168B}

MEASUREMENTS CONDUCTED IN THE FIELD

Sample dale: 05/05/99

Air lemperature: Not available

H: No available

p. connuclance: Not available

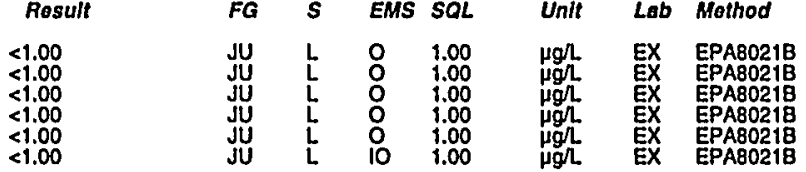

Time: Water temperature: Not available

Total alkalinity (as CaCO3): Not available
Phenolphthalein alkalinity: Not available ANALYSES

$F$ Analyto

Carbon totrachlorlde

cis-1.2-Dichloroothylene
: Telrachloroethylene

ESH-EMS-990521

Time: Water iemperature: Not available

Tolal alkalinity (as CaCO3): Not available

Time: Water temperalure: Not avallable

Total alkalinity (as CaCO3): Not available

$\begin{array}{llll}1.00 & \mu g h & \text { EX } & \text { EPABO21B } \\ 1.00 & \mu g h & \text { EX } & \text { EPABO21B } \\ 1.00 & \mu g / 2 & \text { EX } & \text { EPABO21B } \\ 1.00 & \mu g \Omega & \text { EX } & \text { EPABO21B }\end{array}$

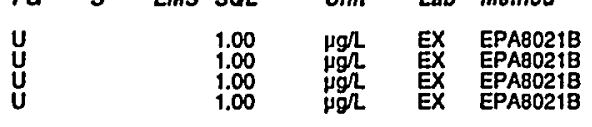

Well TAP168B collected on 05/05/99 (cont.)

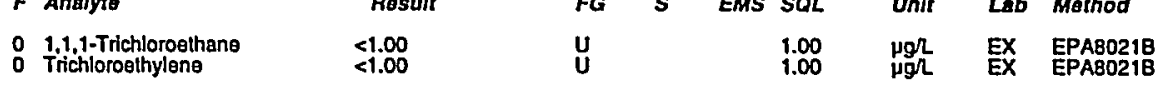

\section{WELLL TRP169B}

MEASUREMENTS CONDUCTED IN THE FIELD

Sample date: 05/07/99

Deph to water: Not available

pH: Not available

. conductance: Nol availab

No watity: Nol avallable

ANALYSES

$F$ Analyto

O Carbon tetrachloride

chlorolorm

Tetrachloroethylene

0 Trichloroethylene

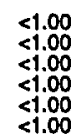

WELL TRP170B

MEASUREMENTS CONDUCTED IN THE FIELD

Sample dale: 05/18/99

Depth to water: Nol available

Air temperature: Not available

Sp. conductance: Not available

No water was evacuated from the well prior to sampling
Notion

ANALYSES

$F$ Analyto

- Carbon telrachloride

o ciss-1,2-Dichloroethylene

Tetrachloroethylene

Trichloroethylane

\section{WELLL TRP173B}

MEASUREMENTS CONDUCTED IN THE FIEL.D

Sample date: 05/05/99

Air temperature: Not available

H: Not available

p. conductance: Nol available

Result

$<1.00$
$<1.00$
$<1.00$
$<1.00$
$<1.00$
$<1.00$

ANALYSES

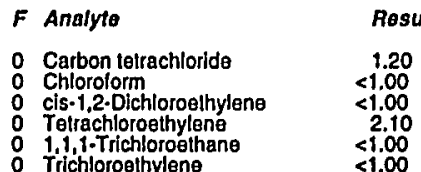

1.20
$<1.00$
$<1.00$
2.10
$<1.00$
$<1.00$

Time: Water temperature: Not available

Total alkalinity (as CaCO3): Not available
Warer temperalure: Not available

Total alkalinity (as CaCO3): Not available

$\begin{array}{llll}\text { SaL } & \text { Unit } & \text { Lab } & \text { Mathod } \\ 1.00 & \mu g h & \text { EX } & \text { EPABO21B } \\ 1.00 & \mu g h & \text { EX } & \text { EPABO21B } \\ 1.00 & \mu g h & \text { EX } & \text { EPABO2jB } \\ 1.00 & \mu g h . & \text { EX EPAB21B } \\ 1.00 & \mu g h & \text { EX } & \text { EPAO021B } \\ 1.00 & \mu g h & \text { EX } & \text { EPABO21B }\end{array}$

Time:

\begin{tabular}{|c|c|c|c|}
\hline SQL & Unit & Lab & Mothod \\
\hline $\begin{array}{l}1.00 \\
1.00 \\
1.00 \\
1.00 \\
1.00 \\
1.00\end{array}$ & $\begin{array}{l}\mu g / \\
\mu g \Omega \\
\mu g / \\
\mu g \Omega \\
\mu g \Omega \\
\mu g h\end{array}$ & $\begin{array}{l}\text { EX } \\
\text { EX } \\
\text { EX } \\
\text { EX } \\
\text { EX } \\
\text { EX }\end{array}$ & $\begin{array}{l}\text { EPAB0218 } \\
\text { EPAB0218 } \\
\text { EPAB021B } \\
\text { EPAB021B } \\
\text { EPABO2 } \\
\text { EPABO21B }\end{array}$ \\
\hline
\end{tabular}

Time: Waler temperature: Not avallable

Total alkalinity (as CaCO3): Not available
Phenolphthalein alkalinity: Not available 


\section{WELL TRP174B}

MEASUREMENTS CONDUCTED IN THE FIELD

Sample date: 05/06/99

Depht to waler: Not available
Air temperalure: Not available
pH: Nol available

ciance: Not avaliable

No water was evacuated from the well prior to sampling

ANALYSES

$F$ Analyto

Rosult
$<1.00$
$<1.00$
$<1.00$
$<1.00$
1.00

Carbon tetrachloride

cis-1,20lchloroethylen

$1,1,1$-Trichloroethan
0 Tilchloroethylene

$<1.00$

\section{WELL TRP175B}

MEASUREMENTS CONDUCTED IN THE FIELD

Sample date: 05/18/99

Air temperature: Not available

H: Nol available

p. conductance: Not available

No water was evacuated from the well prior to sampling.

ANALYSES

$F$ Analyte

Result
$<1.00$
$<1.00$
$<1.00$
$<1.00$
$<1.00$
$<1.00$

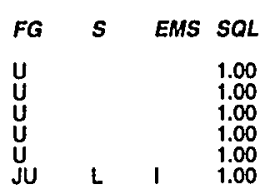

Time: Water temperature: Not available

Total alkalinity (as CaCO3): Not available

Water temperalure: Nol available

Total alkalinity (as CaCO3): Not available

Carbon tetrachloride

cis-1,2-Dichloroethylen

Ti,1-Trichloroethen

\section{WELL TRP178B}

MEASUREMENTS CONDUCTED IN THE FIELD

Sample date: 04/16/99

Depih to waler: Not available

$\mathrm{pH}$ : Not availabie
$\mathrm{Sp}$. conductance: Not available

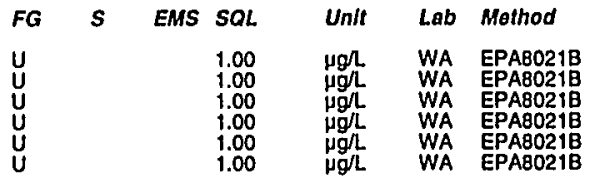

Wo water was evacuated from the well prior to sampling

ANALYSES

$F$ Analyte

0 Acetone

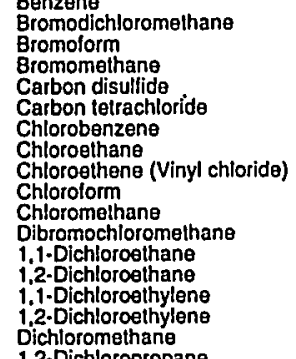

ESH-EMS-99052

Well TAP178B collected on 04/16/99 (cont.)

$F$ Analyto

0 cis-1,3.Dichloropropene

Elhylbenzen

Methyl elhyl ketone

Siyrene

Tetrachloroethylene

o $1,1,1$ - Trichloroethane

Vinyl acotale

0 Xylenes

\section{WELL TRP180B}

MEASUREMENTS CONDUCTED IN THE FIELD

Sample date: 05/10/99

Dir temperature: Nol availlable

$\mathrm{BH}$ : Nol availabie

No water was evacuated from the well prior to sampling.

ANALYSES

$F$ Analyto

0 Acetone

Bromodichloromethane

Bromomethane

Carbon tetrachloride

Chlorobenzene

O Chloroethane

Chloroform

$\begin{array}{ll}\text { O Chloromethane } \\ \text { O Dibromochloromethane } \\ 0 & 1,1 \text {-Dichloroethane }\end{array}$

1,1-Dichloroethane

1:1-Dichloroothylene

Dichloromethane

cis-1,3-Dichloropropene
irans- $-3,3$-Dichloropropene

Ethylbenzen

: Methyl othyl kelone

1,1,2,2-Tetrachloroethane

Teirachioroethylene

o Toluene

1.1.2-Trichloroethane

Virichloroeshylen

0 Xylenes

Rosult
$<1.00$
$<1.00$
$<1.00$
5.00
$<10.0$
5.00
$<1.00$
$<1.00$
$<1.00$
$<1.00$
$<1.00$
$<1.00$
$<1.00$
5.00
$<2.00$

\begin{tabular}{|c|c|c|c|c|c|c|}
\hline$F G$ & $s$ & EMS & SQL & Untt & Lab & Mothod \\
\hline $\begin{array}{l}\mathrm{J} U \\
\mathrm{JU} \\
\mathrm{JU} \\
\mathrm{JU} \\
\mathrm{JU} \\
\mathrm{JU} \\
\mathrm{JU} \\
\mathrm{JU} \\
\mathrm{JU} \\
\mathrm{JU} \\
\mathrm{JU} \\
\mathrm{Ju}\end{array}$ & $\begin{array}{l}L \\
L \\
L \\
L \\
L \\
L \\
L \\
L \\
L \\
L \\
L\end{array}$ & $\begin{array}{l}0 \\
0 \\
0 \\
0 \\
0 \\
0 \\
0 \\
0 \\
0 \\
0 \\
0 \\
0 \\
0 \\
0 \\
0\end{array}$ & $\begin{array}{l}1.00 \\
1.00 \\
1.00 \\
5.00 \\
10.0 \\
5.00 \\
1.00 \\
1.00 \\
1.00 \\
1.00 \\
1.00 \\
1.00 \\
1.00 \\
5.00 \\
2.00\end{array}$ & $\begin{array}{l}\mu g \Omega \\
\mu g h \\
\mu g h \\
\mu g h \\
\mu g h \\
\mu g h \\
\mu g h \\
\mu g h \\
\mu g h \\
\mu g h . \\
\mu g h \\
\mu g h \\
\mu g h \\
\mu g h \\
\mu g h \\
\mu g h\end{array}$ & $\begin{array}{l}\mathrm{GE} \\
\mathrm{GE} \\
\mathrm{GE} \\
\mathrm{GE} \\
\mathrm{GE} \\
\mathrm{GE} \\
\mathrm{GE} \\
\mathrm{GE} \\
\mathrm{GE} \\
\mathrm{GE} \\
\mathrm{GE} \\
\mathrm{GE} \\
\mathrm{GE} \\
\mathrm{GE} \\
\mathrm{GE} \\
\mathrm{GE}\end{array}$ & 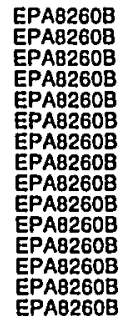 \\
\hline
\end{tabular}

Time: Waler temperature: Not available

Total alkalinity (as CaCO3): Noi available
Phenolphthalein alkalinity: Nol available

\begin{tabular}{|c|c|c|c|c|c|c|c|}
\hline Result & $F G$ & $s$ & EMS & SQL & $U_{n} / t$ & Lab & Method \\
\hline $\begin{array}{l}<5.00 \\
<1.00 \\
<1.00 \\
<1.00 \\
<1.00 \\
<5.00 \\
<1.00 \\
<1.00 \\
<.00 \\
<1.00 \\
<.00 \\
<1.00 \\
<.00 \\
<1.00 \\
<1.00 \\
<1.00 \\
<2.00 \\
2.01 \\
<1.00 \\
<1.00 \\
<1.00 \\
<1.00 \\
<.00 \\
<10.0 \\
<.00 \\
<1.00 \\
<1.00 \\
<1.00 \\
<1.00 \\
<1.00 \\
<1.00 \\
<1.00 \\
<5.00 \\
<2.00\end{array}$ & 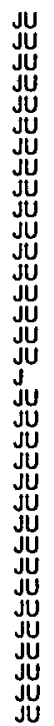 & $\begin{array}{l}L \\
L \\
L \\
L \\
L \\
L \\
L \\
L \\
L \\
L \\
L \\
L \\
L \\
L \\
L \\
L \\
L \\
L \\
L \\
L \\
L \\
L \\
L \\
L\end{array}$ & $\begin{array}{l}0 \\
0 \\
0 \\
0 \\
0 \\
0 \\
0 \\
0 \\
0 \\
0 \\
0 \\
0 \\
0 \\
0 \\
0 \\
0 \\
0 \\
08 \\
0 \\
0 \\
0 \\
0 \\
0 \\
0 \\
0 \\
0 \\
0 \\
0 \\
0 \\
0 \\
0 \\
0 \\
0 \\
0\end{array}$ & $\begin{array}{l}5.00 \\
1.00 \\
1.00 \\
1.00 \\
1.00 \\
5.00 \\
1.00 \\
1.00 \\
1.00 \\
1.00 \\
1.00 \\
1.00 \\
1.00 \\
1.00 \\
1.00 \\
1.00 \\
2.00 \\
1.00 \\
1.00 \\
1.00 \\
1.00 \\
5.00 \\
10.0 \\
5.00 \\
1.00 \\
1.00 \\
1.00 \\
1.00 \\
1.00 \\
1.00 \\
1.00 \\
5.00 \\
2.00\end{array}$ & 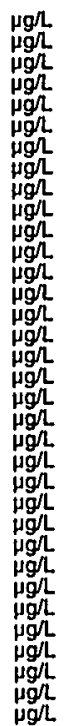 & $\begin{array}{l}G E \\
G E \\
G E \\
G E \\
G E \\
G E \\
G E \\
G E \\
G E \\
G E \\
G E \\
G E \\
G E \\
G E \\
G E \\
G E \\
G E \\
G E \\
G E \\
G E \\
G E \\
G E \\
G E \\
G E \\
G E \\
G E \\
G E \\
G E \\
G E \\
G E \\
G E \\
G E \\
G E \\
G E\end{array}$ & 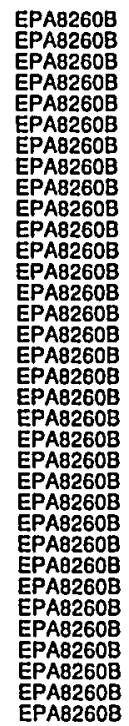 \\
\hline
\end{tabular}


WELL TRP181B

MEASUREMENTS CONDUCTED IN THE FIELD

Air temperalure: Not available

Sp. conduclabe Not available

Nurbidity: Not available
No water was evacualed from the well prior to sampling.

ANALYSES

$F$ Analyto

Result

$<1.00$

FG

s

$\begin{array}{llll} & \text { Untt } & \text { Lab } & \text { Mathod } \\ 1.00 & \mu g \Omega & \text { GE } & \text { EPAB260B }\end{array}$

WELL TRP182B

MEASUREMENTS CONDUCTED IN THE FIELD

Sample date: 05/12/99

Dirth to water: Not available

$\mathrm{pH}$ : Nol available conductance: Not avaliabl

Sp. conductance: Not avallable

No water was evacuated from the well prior to sampling.

ANALYSES

$F$ Analyto

Result

FG

- Trichloroethylene

$<1.00$

WELL TRP184B

MEASUREMENTS CONDUCTED IN THE FIELD

Sample date: 06/07/99

Air temperature: Not avallable

$\mathrm{pH}$ : Nol available

Sp. conductance: Nol available

No water was evacualed from the well prior to sampling.

ANALYSES

F Analyto

Result

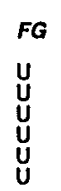

0
0
0

$\begin{array}{ll}0 & \text { Tetrachloroethylene } \\ 0 & 1,1,1-T \text { richloroethane } \\ 0 & \text { Trichloroethylene }\end{array}$

$<1.00$
$<1.00$
$<1.00$
$<1.00$
$<1.00$
$<1.00$

WELL TRP185B

MEASUREMENTS CONDUCTED IN THE FIELD

Sample dale: 06/09/99

Depth to water: Not available

oH: Not avaliabie

Sp. conductance: Not available

No water was evacuated from the well prior to sampling

ANALYSES

$F$ Analyto

- Carbon tetrachsorido

cis-1,2-Dichloroethylene

Tetrachioroethylene

Trichlorichtoetha

ESH-EMS-990521

Time: Water temperature: Not available

Total alkalinity (as CaCO3): Not available

Water lemperature: Not available

Total alkalinity (as CacO3): Not available
Phenolphthalein alkalinity: Not available

Time: Waler temperalure: Not avallable

Total alkalinity (as CaCO3): Not available
Phenolphthalein alkalinity: Not available

Time: Water temperature: Not available

Total alkalinity (as CaCO3): Not available
Phenolphthalein alkalinity: Not available

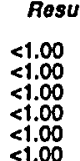

$<1.00$
$<1.00$
$<1.00$
$<1.00$
$<1.00$
$<1.00$

\begin{tabular}{|c|c|c|c|c|}
\hline$s$ & EMS SOL & Unit & Lab & Mothod \\
\hline y & $\begin{array}{l}1.00 \\
1.00 \\
1.00 \\
1.00 \\
1.00 \\
1.00\end{array}$ & $\begin{array}{c}\mu g h \\
\mu g h \\
\mu g h \\
\mu g h \\
\mu g h \\
\mu g h \\
\mu g h\end{array}$ & $\begin{array}{l}\text { WA } \\
\text { WA } \\
\text { WA } \\
\text { WA } \\
\text { WA } \\
\text { WA }\end{array}$ & 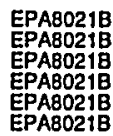 \\
\hline
\end{tabular}

MEASUAEMENTS CONDUCTED IN THE FIELD

Sample date: 06/10/99

ir temperature: Not availab

$\mathrm{H}$ : Not available

water was evalabla

Water iemperature: Not available

Tolal alkalinity (as Caco3): Nol available
Phenolphthalein alkalinity: Nol available ANALYSES

$F$ Analyto

Carbon tetrachlorido

cis-1,2-Dichloroethylene

Ti,1-Trichloroothen

- Trichloroethylene

\section{WELL TRP193B}

MEASUREMENTS CONDUCTED IN THE FIELD

Sample data: 06/11/99

Air temperature: Not available

Sp: col available Notuctance: Not availab

No water was evacuated from the well prior to sampling.

ANALYSES

$F$ Analyte

- Carbon tetrachloride

athylene

Tetrachloroethylene

0 Trichloroethylens

\section{WELL TRP194B}

MEASUREMENTS CONDUCTED IN THE FIELD

Sample date: 06/14/99

Air temperature: Not avallable

$\mathrm{pH}$ : Nol availiable

Sp. conductance: Not available

Whar wo avallable from

ANALYSES

$F$ Analyto

- Carbon tetrachlorido

Rosult
$<1.00$
$<1.00$
$<1.00$
$<1.00$
$<1.00$
$<1.00$

FG

FG $\quad$ s

1.00
1.00
1.00
1.00
1.00
1.00

$\mu g h$
$\mu g h$
$\mu g h$
$\mu g h$
$\mu g h$
$\mu g h$
$\mu g$

Lab Mothod

WA EPAB021B

WA EPABO21B

WA EPABO21B
Time:

temperature: Not available

Total alkalinity (as CaCO3): Not available
Phenolphthalein alkalinily: Not available

EMS SOL

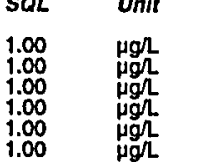

ab Mathod

WA EPABO21B

WA EPAB21

WA EPABO21B

Time: Waler temperature: Not available

Total alkalinity (as CaCO3): Nol available 
WELL TRP195B

MEASUREMENTS CONDUCTED IN THE FIELD

Sample date: 06/15/99

Air temperalure: Not available

$\mathrm{gH}$ : Nor avallable

No waler was evacuated from the well prior to sampling.

ANALYSES

$F$ Analyto

C Carbon tetrachioride

chloroform

Tetrachloroethylene

o 1.1, -Trichloroethane

Rosu
$<1.00$
$<1.00$
$<1.00$
$<1.00$
$<1.00$
$<1.00$

$<1.00$
$<1.00$
$<1.00$
$<1.00$
$<1.00$
$<1.00$

$F G$
$U$
$U$
$U$
$U$
$U$
$U$

$s$ EMS 5

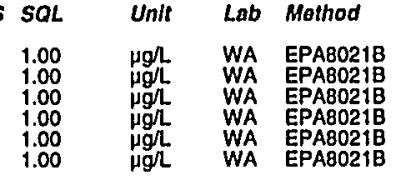

WELL TAP196B

MEASUREMENTS CONDUCTED IN THE FIELD

Sample date: 06/17/99

Air temperature: Not available

$\mathrm{pH}$ : Nol available . conduclance: Not avallable

No water was evacuated from the well prior to sampling.

ANALYSES

$F$ Analyte

$$
\text { Result }
$$

FG

Time:

Not available

Total alkalinity (as CacO3): Nol available
Phenolphthalein alkalinity: Not available

0 Carbon tetrachioride

Tis-1,2.Dichloroethylene

0 T,1,1-Trichloroothan

$<1.00$
$<1.00$
$<1.00$
$<1.00$
$<1.00$
$<1.00$

\section{WELL TRP202B}

MEASUREMENTS CONDUCTED IN THE FIELD

Sample date: 06/30/99

Depth to water: Not avaliable

$\mathrm{pH}$ : Nol availabie
$\mathrm{Sp}$. conductance: Not available

Turbidity: Not available

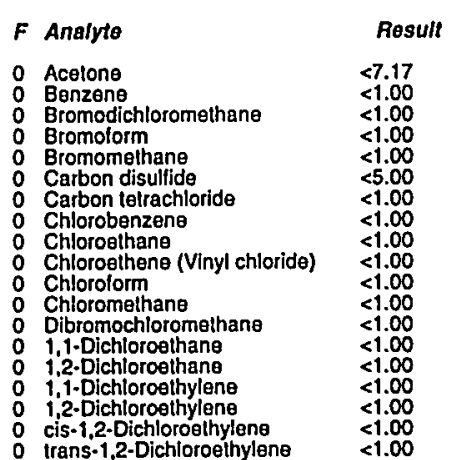

Well TRP202B collecled on 06/03/99 (cont.)

F Analyte

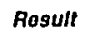

O Dichloromethane

o cis-1,3-Dichloropropene

0 trans-1,3.Dichlorop

$\begin{array}{ll}0 & \text { Ehylbenzene } \\ 0 & \text { 2.Hexanone }\end{array}$

0 Methyl ethyl ketone
0 Methyl Isobutyl ketone

O Styrene 0 - Tetrachloroethane

Toluene

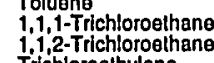

Trichloroethylene

0 Vinyl aceta

$<4.07$
$<1.00$
$<1.00$
$<1.00$
51.00
$<5.00$
$<5.00$
$<5.00$
$<1.00$
$<1.00$
$<1.00$
51.00
$<1.00$
51.00
41.00
55.00
$<1.00$

WELL TRP304A

MEASUREMENTS CONDUCTED IN THE FIELD

Sample dale: 04/12/99

Air temperature: Nol available

H: Not avallable

No water was evacuated from the well prior to sampling.

ANALYSES

$F$ Analyto

0 Acetone

Bromodichloromethane

Bromomethane

Carbon disulfide

Carbon tetrachlo
Chlorobenzene

Chlorobenzene

Chloroethene (Vinyl chloride)

Chlorolorm

o Dibromochloromethane

0 i, -Dichloroethane

1,i.:Dichloroethylens

Dichloromethane
1,2-Dichloropropan

cis-1,3.0lohiloropropene

Elhylbanzene

: 2.Hexanone

Methyl Isobutyl ketone

Styrene

Telrachloroethylene

1,1,1-Trichloroethane

Trichloroethylens

Vinyl acetate
Xylenes

Resul
$<5.00$
$<1.00$
$<1.00$
$<1.00$
$<1.00$
$<5.00$
$<1.00$
$<1.00$
$<1.00$
$<1.00$
$<1.00$
$<1.00$
$<1.00$
$<1.00$
$<1.00$
$<1.00$
$<2.00$
2.46
$<1.00$
$<1.00$
$<1.00$
$<1.00$
25.00
$<10.0$
$<5.00$
$<1.00$
$<1.00$
$<1.00$
1.00
$<1.00$
$<1.00$
$<1.00$
25.00
$<2.00$

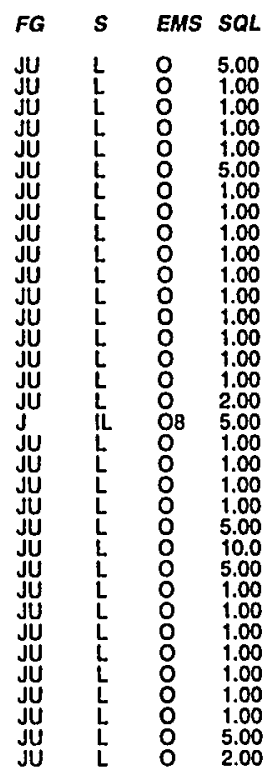

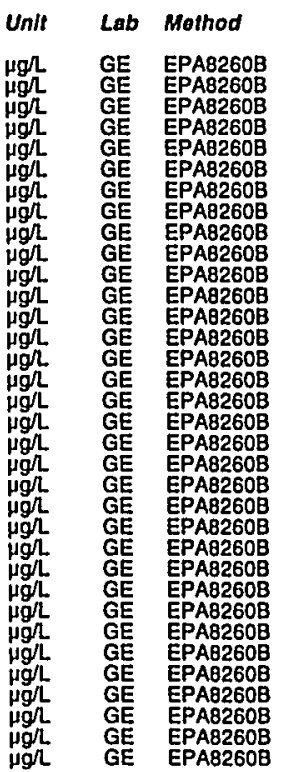

Second Quarter 1999

Time: Water temperature: Not available

Total alkalinity (as CaCO3) Nol available

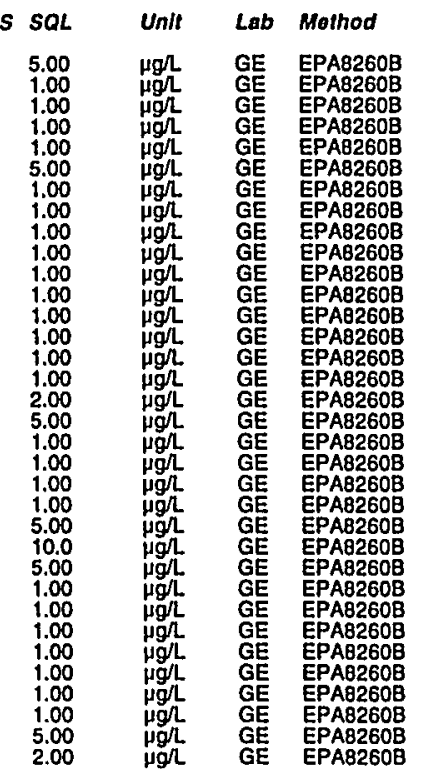




\section{WELL TRP308A}

MEASUREMENTS CONDUCTED IN THE FIELD

Sample date: 04/12/99

Depth to water: Nol available

Time: Water temperature: Not available

gH: Not available

No water was evacuated from the well prior to sampling.

ANALYSES

$F$ Analyto

Rosult

Total alkalinity (as CaCO3): Not available

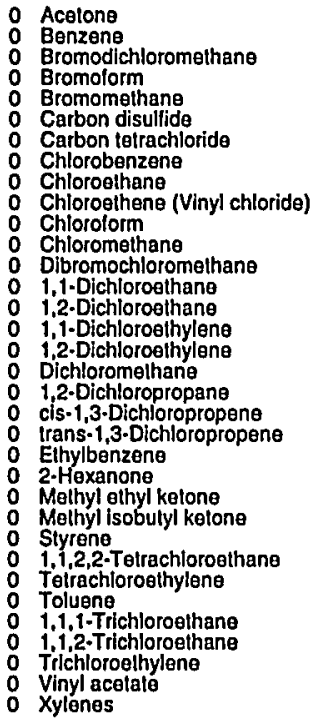

$<10.0$
$<5.00$
55.00
$<5.00$
$<10.0$
$<5.00$
$<5.00$
$<5.00$
$<10.0$
$<10.0$
$<5.00$
510.0
$<5.00$
55.00
$<5.00$
$<5.00$
$<5.00$
$<5.00$
$<5.00$
$<5.00$
$<5.00$
$<5.00$
510.0
$<10.0$
$<10.0$
$<5.00$
$<5.00$
$<5.00$
$<5.00$
55.00
$<5.00$
55.00
$<10.0$
$<5.00$

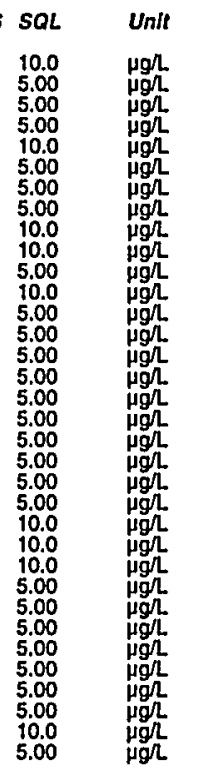

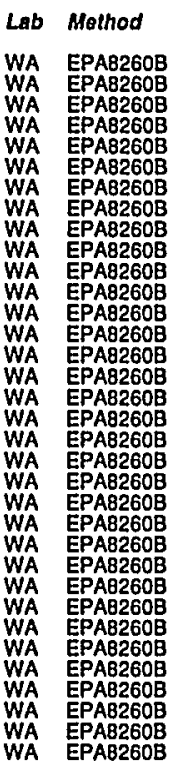



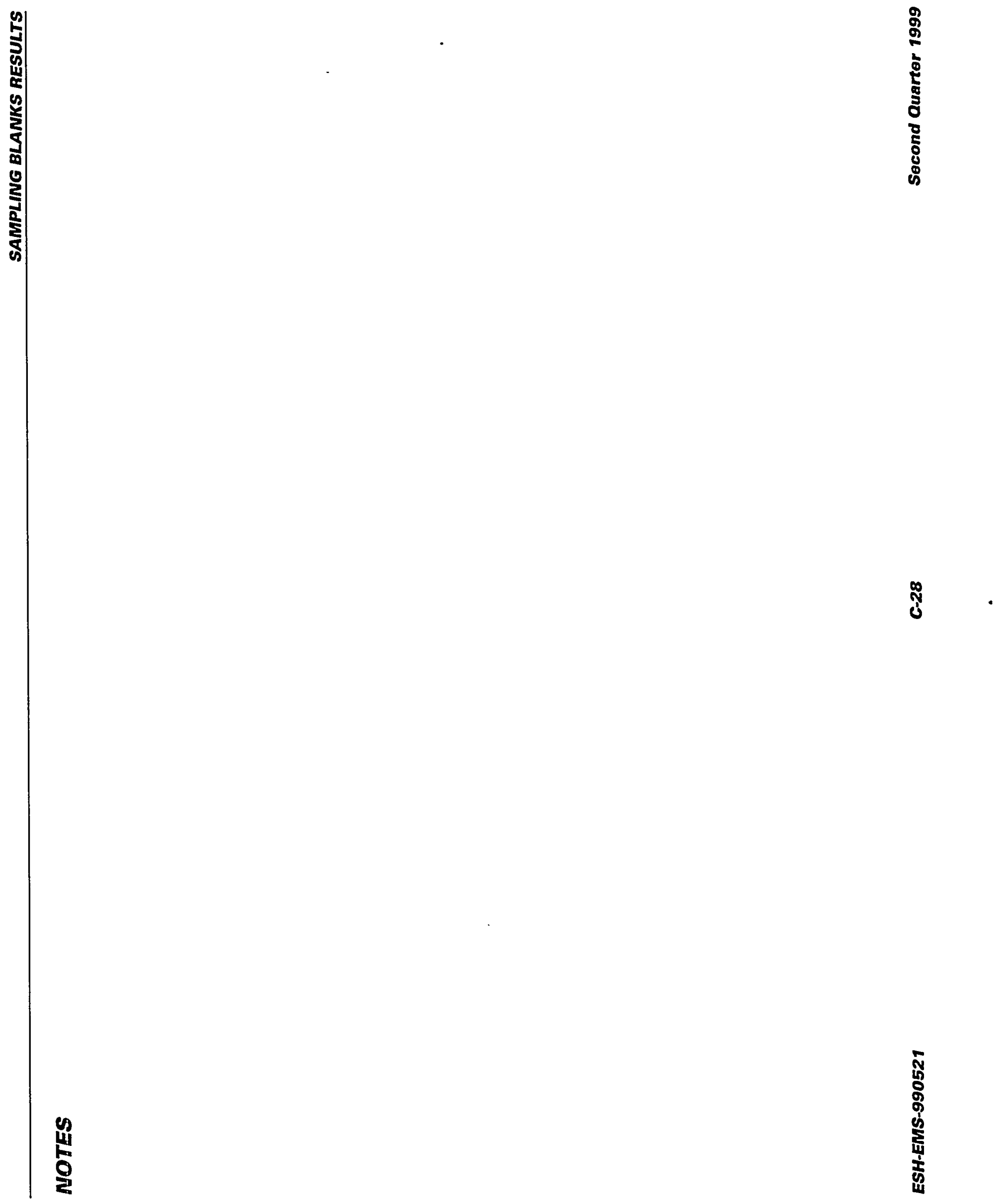

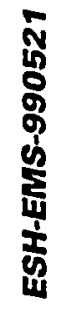




\section{Appendix D. Analytical and Sampling Blanks Results for MSB Wells}

This section presents the field and analytical results for samples from five MSB wells collected during second quarter 1999 as well as the analytical results for sampling blanks analyzed for the project. Data collected from these wells were not subjected to the SRS Groundwater Monitoring Program standard verification and validation processes and are therefore not presented in the Analytical Results table in Appendix B of this report. 
NOTES

Appendix D. Analytical and Sampling Blanks Results for MSB Wells ESH-EMS-990521

Pago 2

Second Quarter 1999 


\section{Analytical Results}

\section{WELL MSB 90C}

MEASUREMENTS CONDUCTED IN THE FIELD

Sample date: 05/05/9

Depth to water: $114.21 \mathrm{ft}(34.81 \mathrm{~m})$ below TOC

Whater ele

Sp conductance: $36 \mu \mathrm{S} / \mathrm{cm}$

Water evacuated from the well prior to sampling: $181 \mathrm{gal}$ ANALYSES

$F$ Analyto

0 Acelone

Eromodichloromethane

Bromomethan

Carbon disulfide

Carbon tetrachlorido

Chloroethane

Chloromethan

Dibromochloromethan

1.2. Dichloroethane

1,i. Dichloroethylens

0 Dichloromethane

cis-1,3.Dichloropropene

Elhylbenzene

Methyl ethyl ketone

Slyrene

1,1,2,2-Tetrachloroeth

1,1,1-Trichloroethane

Trichloroethylene

: Vinyl acetale

WELL MSB 90C

MEASUREMENTS CONDUCTED IN THE FIELD

Sample date: $05 / 14 / 99$ Water elevalion: Not available SH: 5.6 conductance: $32 \mu \mathrm{S} / \mathrm{cm}$

Water evacuated from the well prior to sampling: $191 \mathrm{~g}$ the well was continuously pumping.

ANALYSES

\begin{tabular}{|c|c|c|c|c|c|c|c|c|}
\hline Analyto & Result & $F G$ & $s$ & $E M S$ & SOL & Un/t & Lab & Mothod \\
\hline $\begin{array}{ll}0 & \text { Acelone } \\
0 & \text { Benzene } \\
0 & \text { Bromodichloromethane } \\
0 & \text { Bromolorm } \\
0 & \text { Bromomethane } \\
0 & \text { Carbon disulfide } \\
0 & \text { Carbon telrachloride }\end{array}$ & $\begin{array}{l}<5.00 \\
<1.00 \\
<1.00 \\
<1.00 \\
<1.00 \\
<5.00 \\
<1.00\end{array}$ & $\begin{array}{l}u \\
u \\
u \\
u \\
u \\
u\end{array}$ & & & $\begin{array}{l}5.00 \\
1.00 \\
1.00 \\
1.00 \\
1.00 \\
5.00 \\
1.00\end{array}$ & 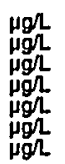 & $\begin{array}{l}M L \\
M L \\
M L \\
M L \\
M L\end{array}$ & $\begin{array}{l}\text { EPAB260B } \\
\text { PPAB2608 } \\
\text { PPAA260B } \\
\text { EPAE260B } \\
\text { EPAB260B } \\
\text { EPAB260B } \\
\text { EPAB260B }\end{array}$ \\
\hline
\end{tabular}

ESH-EMS-990521

Well MSB 90C collected on 05/14/99 (cont)

\begin{tabular}{|c|c|c|c|c|c|c|c|c|}
\hline Analyte & Rosult & FG & $s$ & EMS & $S Q L$ & Unit & Lab & Mothod \\
\hline 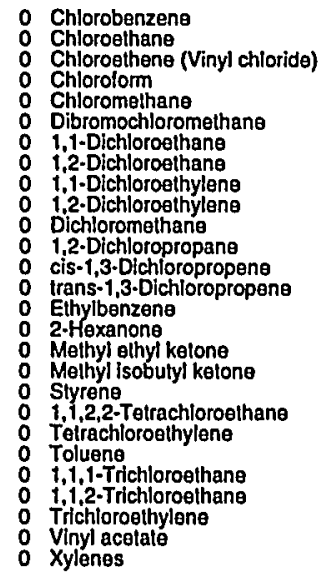 & $\begin{array}{l}<1.00 \\
<1.00 \\
<1.00 \\
<1.00 \\
<1.00 \\
<1.00 \\
<1.00 \\
<1.00 \\
<1.00 \\
<1.00 \\
<2.03 \\
<1.00 \\
<1.00 \\
<1.00 \\
<1.00 \\
<5.00 \\
<5.00 \\
<5.00 \\
<1.00 \\
<1.00 \\
<1.00 \\
<1.00 \\
<1.00 \\
<1.00 \\
<1.00 \\
<5.00 \\
<1.00\end{array}$ & 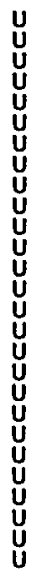 & $v$ & B & $\begin{array}{l}1.00 \\
1.00 \\
1.00 \\
1.00 \\
1.00 \\
1.00 \\
1.00 \\
1.00 \\
1.00 \\
1.00 \\
1.00 \\
1.00 \\
1.00 \\
1.00 \\
5.00 \\
5.00 \\
1.00 \\
1.00 \\
1.00 \\
1.00 \\
1.00 \\
1.00 \\
5.00 \\
1.00\end{array}$ & 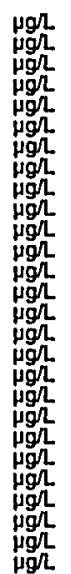 & $\begin{array}{l}M L \\
M L \\
M L \\
M L \\
M L \\
M L \\
M L \\
M L \\
M L \\
M L \\
M L \\
M L \\
M L \\
M L \\
M L \\
M L \\
M L \\
M L \\
M L \\
M L \\
M L \\
M L \\
M L \\
M L \\
M L \\
M L\end{array}$ & 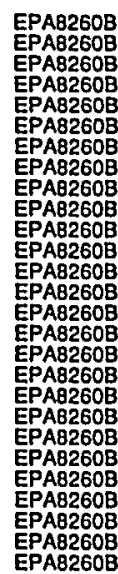 \\
\hline
\end{tabular}

\section{WELL MSB 90C Replicate}

MEASUREMENTS CONDUCTED IN THE FIELD

Sample date: 05/14/99 $(34.81 \mathrm{~m})$ below TOC

Water elevalion: Not availablo

Sp: 5.6 ductance: $32 \mu \mathrm{S} / \mathrm{cm}$

Water evacualed from the well pior to sampling: $191 \mathrm{gal}$

the well was continuously pumping.

ANALYSES

F Analyto

Acelone
0 Benzene
0 Bromodichloromethane

Bromolorm

Carbon disullide

Chlorobenzena

Chloroethene (Vinyl chloside)

Chloromethan

Air temperature: $24.4^{\circ} \mathrm{C}$
Total alkalinity (as CaCO3): $20 \mathrm{mg} /$
Phenolphthalein alkalinity: $0 \mathrm{mg}$

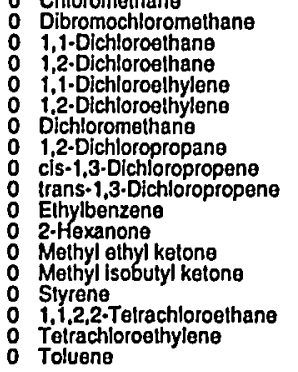

D-3

\begin{tabular}{|c|c|c|c|}
\hline Result & $F G$ & $s$ & EMS \\
\hline $\begin{array}{l}<5.00 \\
<1.00 \\
<1.00 \\
<1.00 \\
<1.00 \\
<5.00 \\
<1.00 \\
<1.00 \\
<1.00 \\
<1.00 \\
<1.00 \\
<1.00 \\
<1.00 \\
<1.00 \\
<1.00 \\
<1.00 \\
<1.00 \\
<2.06 \\
<1.00 \\
<1.00 \\
<1.00 \\
<1.00 \\
<5.00 \\
<5.00 \\
<5.00 \\
<1.00 \\
<1.00 \\
<1.00 \\
<1.00\end{array}$ & 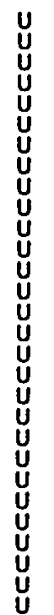 & $v$ & 8 \\
\hline
\end{tabular}

Time: 10:45

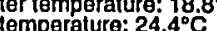

Total alkalinity (as CaCO3): $20 \mathrm{mg} /$
Phenolphthalein alkalinity: $0 \mathrm{mg} /$ 
Well MSB 90C collected on 05/14/99 (cont.)

\begin{tabular}{|c|c|c|c|c|c|c|c|c|}
\hline F Analyto & Rosult & $F G$ & $s$ & EMS & $S Q L$ & Untt & Lab & Method \\
\hline $\begin{array}{ll}0 & 1,1,1-\text { Trichloroethane } \\
0 & 1,1,2-\text { Trichloroethane } \\
0 & \text { Trichloroethylene } \\
0 & \text { Vinhy acetate } \\
0 & \text { Xylenes }\end{array}$ & $\begin{array}{l}<1.00 \\
<1.00 \\
<1.00 \\
<5.00 \\
<1.00\end{array}$ & 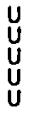 & & & $\begin{array}{l}1.00 \\
1.00 \\
1.00 \\
5.00 \\
1.00\end{array}$ & $\begin{array}{l}\mu g / L \\
\mu g / L \\
\mu g / L \\
\mu g / L \\
\mu g / L\end{array}$ & $\begin{array}{l}M L \\
M L \\
M L \\
M L \\
M L\end{array}$ & $\begin{array}{l}\text { EPA9260B } \\
\text { EPA9260B } \\
\text { EPA8260B } \\
\text { EPA8260B } \\
\text { EPA8260B }\end{array}$ \\
\hline
\end{tabular}

\section{WELL MSB 90TB}

MEASUREMENTS CONDUCTED IN THE FIELD

Sample date: 05/05/99 1 (42.14 m) below TOC Water elevalion: Not available

$\mathrm{pH}$ : 5.6 .6

Water evacuated from the well prior to sampling: $368 \mathrm{gal}$

The well was continuously pumping.

ANALYSES

$F$ Analyte

0 Acelone

Bromodichloromethane

Bromomethane

Carbon telrachlorid

Chlorobenzen

Chloroethene (Vinyl chloride)

Chloromethan

Dibromochloromethane

1.1.D.Dichloroethane

1.1.1-Dichloroethylene

Dichloromethane

cis-1,3-Dichloropropene

Ethylbenzena

o Melhyl ethyl ketone

Methyl isobutyl kelone

i.1,2,2-Tetrachloroethan

Toluene

$\begin{array}{ll}0 & 1,1,1-\text { Trichloroethane } \\ 0 & 1,1,2-T \text { Trichloroethane }\end{array}$

Vinyl acelate

0 Xylenes

WELL MSB 90TB

MEASUREMENTS CONDUCTED IN THE FIELD

Sample date: 05/14/99 $\mathrm{f}(42.07 \mathrm{~m}$ ) below TOC Water elevation: Not available

$\mathrm{gp}$ conductance: $21 \mu \mathrm{S} / \mathrm{cm}$

Water evacuated from the well prior to sampling: $435 \mathrm{gal}$

The well was continuously pumping.

ANALYSES

\begin{tabular}{|c|c|}
\hline F Analyte & Result \\
\hline $\begin{array}{ll}0 & \text { Acetone } \\
0 & \text { Benzene } \\
0 & \text { Bromodichloromethane } \\
\text { ESH-EMSS-990521 }\end{array}$ & $\begin{array}{l}<5.00 \\
<1.00 \\
<1.00\end{array}$ \\
\hline
\end{tabular}

Time: $15: 33$ Water temperature: $20.2^{\circ} \mathrm{C}$

Air temperature: $23.3^{\circ}$ Co 2 ) $24 \mathrm{mg} / \mathrm{L}$
Artemperalure: $20^{\circ} \mathrm{C}$.

$\begin{array}{llll}5.00 & \mu g / & M L & \text { EPAB260B } \\ 1.00 & \mu g / & M L & \text { EPAB260B } \\ 1.00 & \mu g h & M L & \text { EPAB260B }\end{array}$

\begin{tabular}{|c|c|c|c|c|c|c|}
\hline$F G$ & $s$ & EMS & SQL & Unit & $L a b$ & Mothod \\
\hline$\underset{U}{U}$ & & & $\begin{array}{l}5.00 \\
1.00 \\
1.00\end{array}$ & $\begin{array}{l}\mu g / \\
\mu g h \\
\mu g h\end{array}$ & $\begin{array}{l}M L \\
M L \\
M L\end{array}$ & $\begin{array}{l}\text { EPAB2608 } \\
\text { EAB8260 } \\
\text { EPAB260日 }\end{array}$ \\
\hline
\end{tabular}

Well MSB 90TB collected on 05/14/99 (cont.)

\begin{tabular}{|c|c|}
\hline & \\
\hline 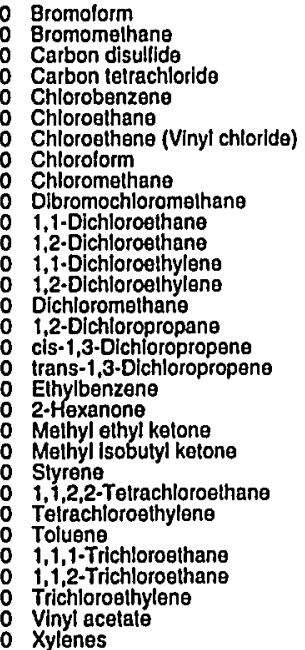 & $\begin{array}{l}<1.00 \\
<1.00 \\
<5.00 \\
<1.00 \\
<1.00 \\
<1.00 \\
<1.00 \\
<1.00 \\
<1.00 \\
<1.00 \\
<1.00 \\
<1.00 \\
<1.00 \\
<1.00 \\
<2.00 \\
<1.00 \\
<1.00 \\
<1.00 \\
<1.00 \\
<5.00 \\
<5.00 \\
<5.00 \\
<1.00 \\
<1.00 \\
<1.00 \\
<1.00 \\
<1.00 \\
<1.00 \\
<1.00 \\
<5.00 \\
<1.00\end{array}$ \\
\hline
\end{tabular}

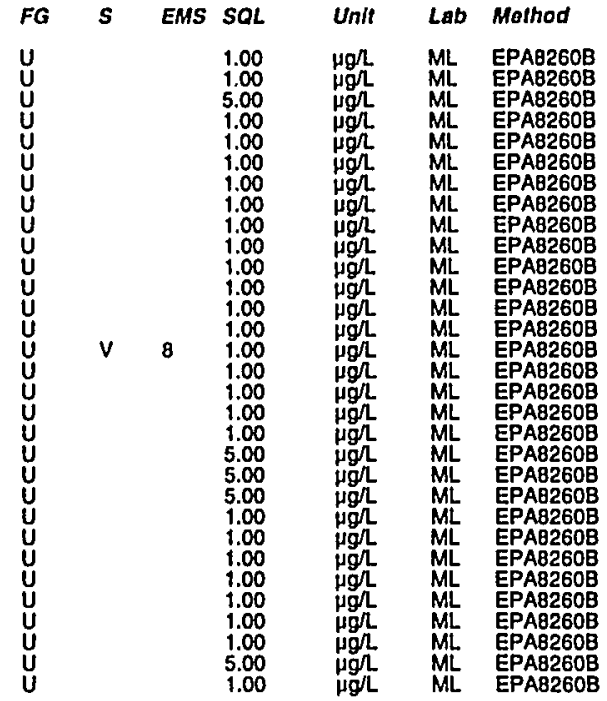

\section{WELL MSB 91C}

MEASUREMENTS CONDUCTED IN THE FIELD

Sample dale: 05/05/99 1 (31.83 m) below TOC

Waler elevation: Not available

$\mathrm{PH}: 5.2$

Sp conductance: $16 \mu \mathrm{S} / \mathrm{cm}$

Water evacuated from the well prior to sampling: $\mathbf{7 3 6} \mathrm{gal}$ The well was continuously pumping.

\section{ANALYSES}

\section{$F$ Analyte}

0 Acelone

Bromodichloromethane

Bromoform

Carbon disullide

Carbon tetrachloride

Chlorobenzene

Chloroethene (Vinyl chloride)

Chloroform

Dibromochloromethan

1.1-Dichloroethane

i, 1. Dichloroethane

$1,1 \cdot$ DIcchloroethylene
$1.2-$ Dichloroethylene

Dichloromethane

1,2-Dichloropropane

0 trans-1,3.Dichlorop

2.Hexanon

Methyl ethyl ketone

S Styrene

Tetrachloroethylene
Time: 12:35

Ar

Total alkalinity (as CaCO3): $32 \mathrm{mg} /$
Phenolphthalein alkalinity: 0 mo $\Omega$

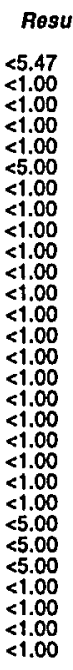

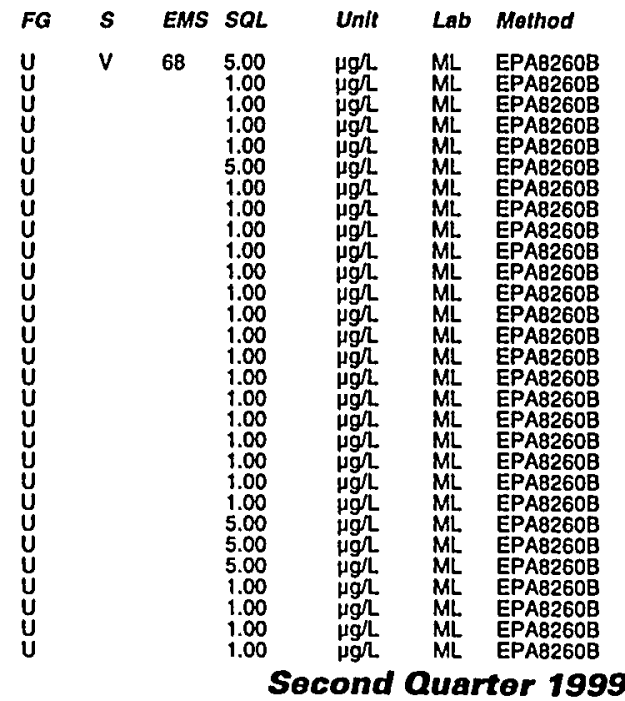




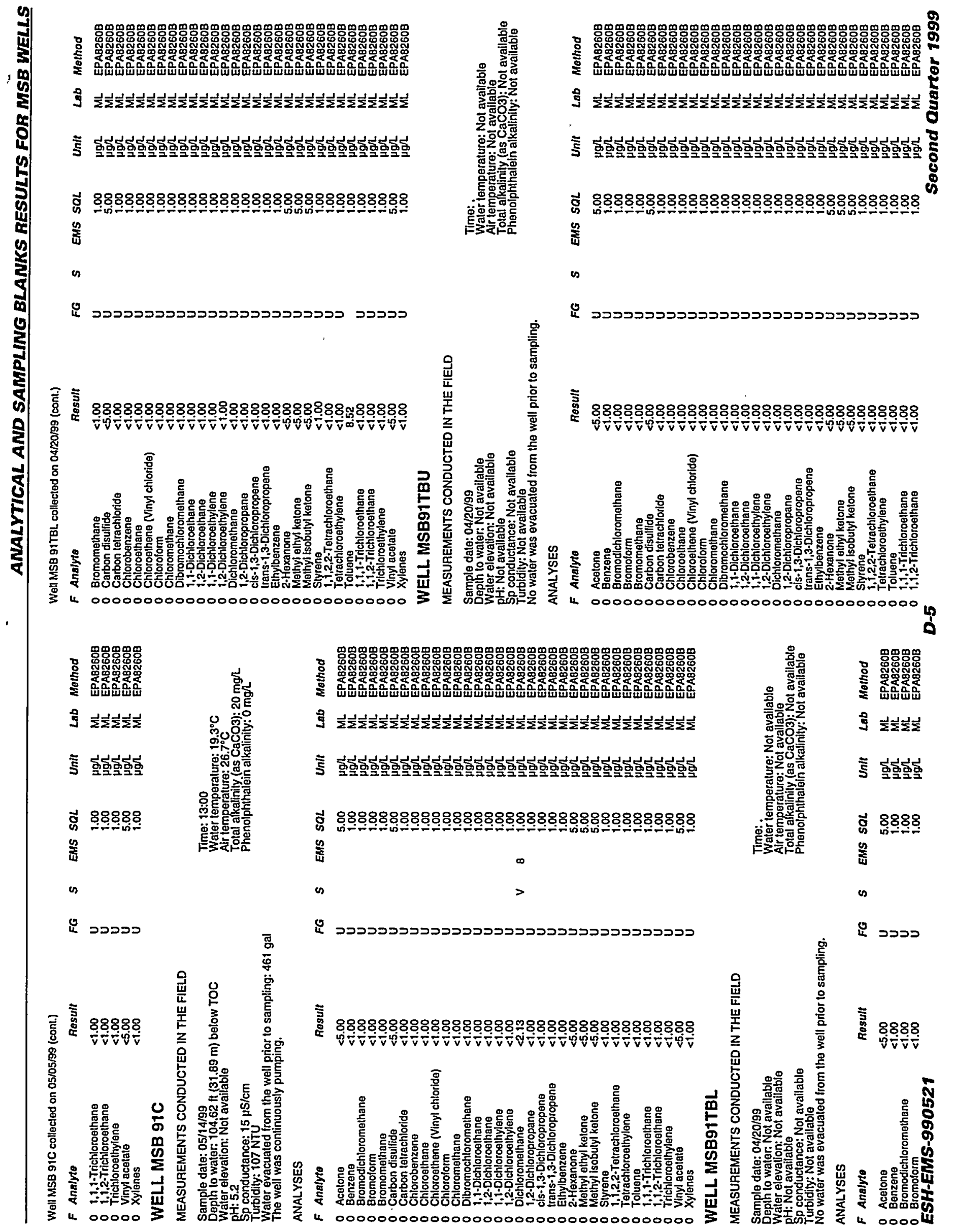


Well MSB91TBU collected on 04/20/99 (conl.)

\section{$F$ Analyto \\ Rosult \\ Trichlorosthylen
0 Vinyl acetate \\ $<\begin{aligned} & <1.00 \\ & <5.00\end{aligned}$ \\ WELL MSB 92C}

MEASUREMENTS CONDUCTED IN THE FIELD

Sample date: $05 / 05 / 99$ ( $33.56 \mathrm{~m}$ ) below TOC Depth to waler: 110.1 it $(33.56$

$\mathrm{pH}: 5.7$

p conductance: $26 \mu \mathrm{S} / \mathrm{cm}$

Waler evacuated from the well prior to sampling: $220 \mathrm{gal}$

The well was conlinuously pumping.

ANALYSES

\begin{tabular}{|c|c|}
\hline \multicolumn{2}{|l|}{ nalyte } \\
\hline $\begin{array}{l}\text { ichloromethane } \\
\text { im } \\
\text { ithane (Methyl bromide) } \\
\text { cisulfide } \\
\text { letrachloride } \\
\text { enzene } \\
\text { inane } \\
\text { thene (Vinyl chloride) } \\
\text { im (Vine (Methyl chloride) } \\
\text { ethane } \\
\text { chloromethane }\end{array}$ & $\begin{array}{l}.15 \\
.00\end{array}$ \\
\hline
\end{tabular}

\section{WELL MSB 92C}

MEASUREMENTS CONDUCTED IN THE FIELD

Sample dale: $05 / 14 / 99 \mathrm{ft}(33.56 \mathrm{~m})$ below TOC Water elevation: Noi available

Sp conductance: $23 \mu \mathrm{S} / \mathrm{cm}$

Water evacuated from the well prior to sampling: $177 \mathrm{gal}$ The well was continuously pumping.

ANALYSES

F Analyte
: Acetone
: Benzene
0 Bromodichloromethane
Bromolorm
O Bromomethan
OCarbon disullide
ESH-EHS-990521

Result
$<5.00$
$<1.00$
$<1.00$
$<1.00$
$<1.00$
$<5.00$

$<5.00$
$<1.00$
$<1.00$
$<1.00$
$<1.00$
$<5.00$
Well MSB 92C collected on 05/14/99 (cont.)

\begin{tabular}{|c|c|}
\hline \multirow[b]{2}{*}{ 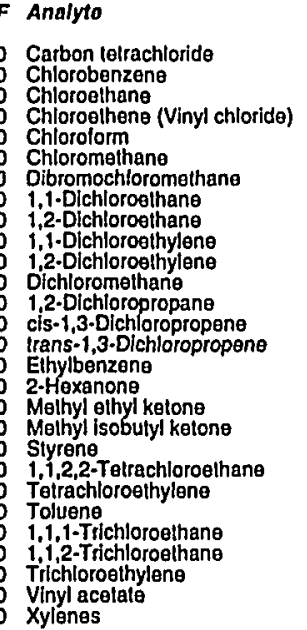 } & $A n d$ \\
\hline & $\begin{array}{l}<1.00 \\
<1.00 \\
<1.00 \\
<1.00 \\
<1.00 \\
<1.00 \\
<1.00 \\
<1.00 \\
<1.00 \\
<1.00 \\
<1.00 \\
<1.00 \\
<1.00 \\
<1.00 \\
<1.00 \\
<5.00 \\
<5.00 \\
<1.00 \\
<1.00 \\
<1.00 \\
<1.00 \\
<1.00 \\
<1.00 \\
<5.00 \\
<1.00\end{array}$ \\
\hline
\end{tabular}

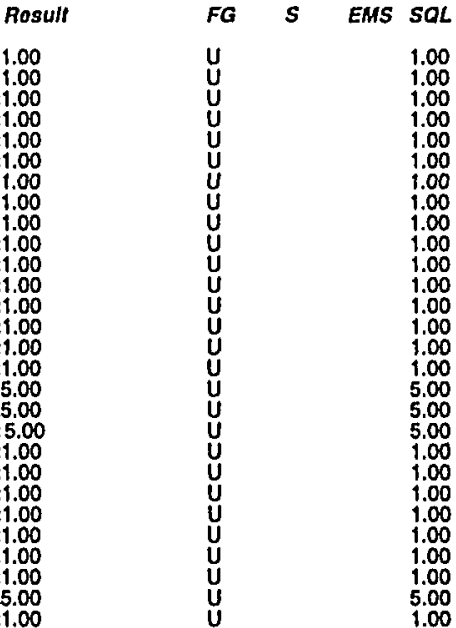

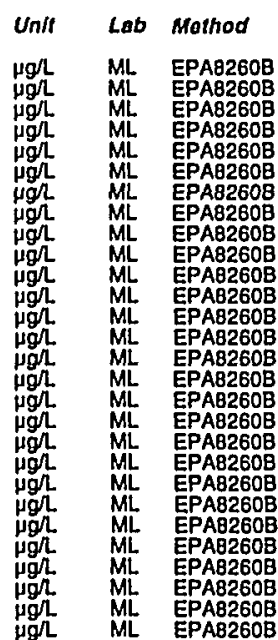

Time: 14:15

Air temperature: $27.8^{\circ} \mathrm{C}$

Total alkalinity (as CaCO3): $12 \mathrm{mg} / \mathrm{L}$

Water temperature: $18.7^{\circ} \mathrm{C}$
Air temperalure: $20.6^{\circ} \mathrm{C} \mathrm{C}$
otal alkalinity (as Caco3): $16 \mathrm{mg} / \mathrm{L}$
Phenolphithalein alkalinily: 0 mg/

\begin{tabular}{|c|c|c|c|c|}
\hline SQL & Unit & Lab & Mathod & utyl ketone \\
\hline $\begin{array}{l}5.00 \\
1.00 \\
1.00 \\
1.00 \\
1.00 \\
5.00 \\
1.00 \\
1.00 \\
1.00\end{array}$ & $\begin{array}{l}\mu g h \\
\mu g h \\
\mu g h \\
\mu g h \\
\mu g h \\
\mu g h \\
\mu g h \\
\mu g h \\
\mu g h\end{array}$ & $\begin{array}{l}M L \\
M L \\
M L \\
M L \\
M L \\
M L \\
M L \\
M L\end{array}$ & $\begin{array}{l}\text { EPAB260B } \\
\text { EPAB260B } \\
\text { EPAB260B } \\
\text { EPAB260B } \\
\text { EPAB260B } \\
\text { EPAB260B } \\
\text { EPA82608 } \\
\text { EPA82608 } \\
\text { EPAB260B }\end{array}$ & $\begin{array}{ll}0 & 1,1,2,2-T e t r a c h l o r o e t h a n e \\
0 & \text { Tetrachloroethylene } \\
0 & \text { Toluene } \\
0 & 1,1,1-\text { Trichloroethane } \\
0 & 1,1,2-T \text { Trichloroethane } \\
0 & \text { Trichloroethylene } \\
0 & \text { Vinyl acetale } \\
0 & \text { Xylenes }\end{array}$ \\
\hline
\end{tabular}

$<1.00$

EMS SOL
5.00
1.00
1.00
1.00
1.00
5.00

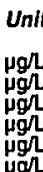

Lab Mothod

$\begin{array}{ll}M L & \text { EPAB260日 } \\ M L & \text { EPAB260日 } \\ \text { ML } & \text { EPAB260B } \\ \text { ML } & \text { EPAB260B } \\ \text { ML } & \text { EPAB260B }\end{array}$
D-6 
Well NS4TBO1 collected on 05/05/99 (cont.)
$F$ Analyto
Rosult
FG
EMS SQL
Unif
Lab Molhod

\section{WELL NS4TBO2}

MEASUREMENTS CONDUCTED IN THE FIELD

Sample date: $05 / 14 / 99$
Depth to water: Not available
Water elevation: Not available

oH: Not available

Sp conductance: Not available

No water was evacuated from the well prior to sampling.

ANALYSES

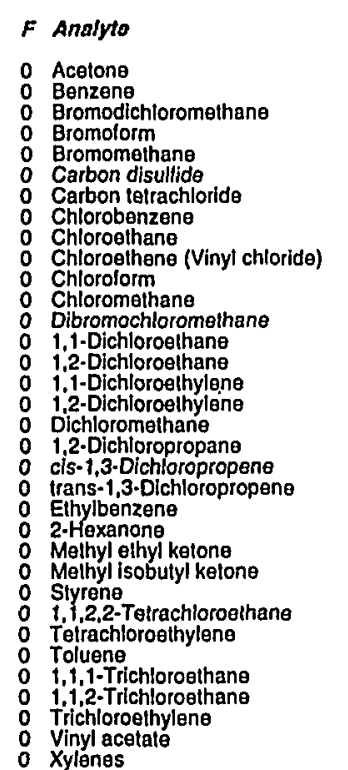

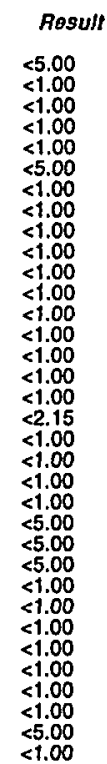

\section{WELL QAMSB91-}

MEASUREMENTS CONDUCTED IN THE FIELD

Sample date: 04/20/99

Wepth to water: Nol available

Hot Notailable

No water was evacuated from the well prior to sampling

ANALYSES

$\begin{array}{ll}\text { F Analyte } & \text { Result } \\ 0 \text { Acelone } & <5.00 \\ 0 \text { Benzene } & <1.00 \\ 0 & <1.00 \\ 0 \text { Bromodichloromethane } & <1.00 \\ 0 \text { Bromolorm } & <1.00 \\ 0 \text { Bromomethane } & <5.00 \\ 0 \text { Carbon disullide } & <1.00 \\ 0 \text { Crrbon terrachioride } & <1.00 \\ 0 \text { C yorobenzene } & <1.00 \\ 0 \text { Chloroethang } & \end{array}$

Wime: Wamperature: Not available Air temperalure: Nol available
Total alkalinity (as CaCO3) Not available
Phenolphihalein alkalinity: Not available

Time: Water temperature: Not available

Air temperature: Not available
Total alkalinity (as CaCO3): Not available
Phenolphthalein alkalinity: Not available

\begin{tabular}{|c|c|c|c|c|c|c|}
\hline$F G$ & $s$ & EMS & SQL & $U_{n i t}$ & Lab & Method \\
\hline $\begin{array}{l}U \\
U\end{array}$ & & & $\begin{array}{l}5.00 \\
1.00 \\
1.00 \\
1.00 \\
1.00 \\
5.00 \\
1.00 \\
1.00 \\
1.00\end{array}$ & $\begin{array}{c}\mu g h \\
\mu g h \\
\mu g h \\
\mu g h \\
\mu g h \\
\mu g h \\
\mu g h \\
\mu g h \\
\mu g h \\
\mu g h\end{array}$ & $\begin{array}{l}M L \\
M L \\
M L \\
M L \\
M L \\
M L \\
M L \\
M L \\
M L\end{array}$ & $\begin{array}{l}\text { EPAB260B } \\
\text { EPAB260B } \\
\text { EPAB260B } \\
\text { EPAB260B } \\
\text { EPA82608 } \\
\text { EPAB2608 } \\
\text { EPAB260B } \\
\text { EPAA2608 } \\
\text { EPAB2608 }\end{array}$ \\
\hline
\end{tabular}

Well QAMSB91 - collected on 05/05/99 (cont.)

$F$ Analyto

: Chlorogthene (Vinyl chloride)

O Cibromochloromethane

: 1,i.Dichloroothane

1,1.Dichloroeshylene

o Dichloromethane

0 1,2-Dichloropropane

: cis-1,3-Dichloropropene

Eihylbenzene

Melhyl elhyl kelon

0 Melhyl isobutyl keton

1, 1,2,2-Tetrachiorcothane

Tolueno

1,1.1.Tichloroethane

0 Trichloroethylene

0 Vinyl acetate

Rosult
$<1.00$
$<1.00$
$<1.00$
$<1.00$
$<1.00$
$<1.00$
$<1.00$
$<1.00$
$<1.00$
$<1.00$
$<1.00$
$<1.00$
$<1.00$
55.00
$<5.00$
$<5.00$
$<1.00$
$<1.00$
$<1.00$
$<1.00$
$<1.00$
$<1.00$
$<1.00$
$<5.00$
$<1.00$

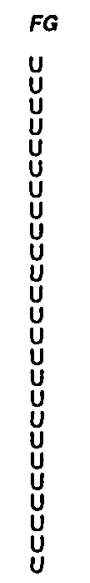

$s$

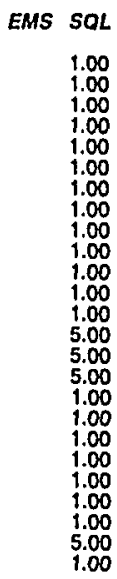

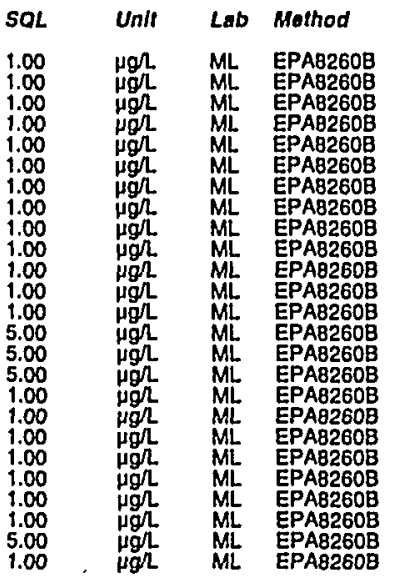

